\title{
THE GAME BIRDS of CALIFORNIA
}

GRINNELL - BRYANT • STORER 


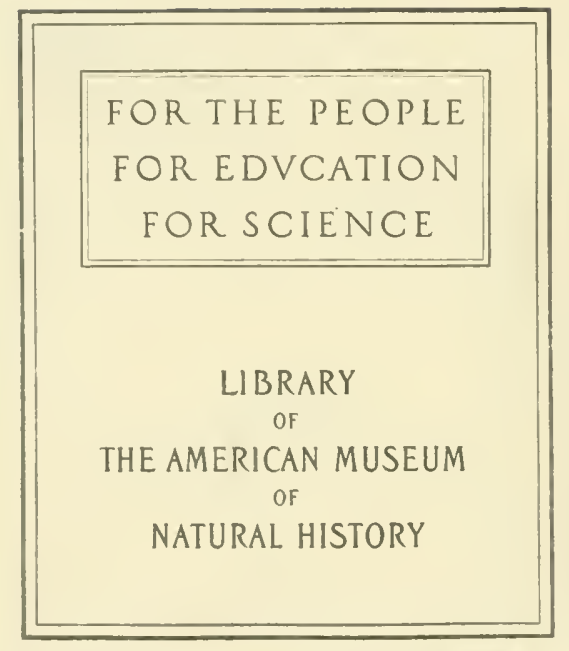






SEMICENTENNIAL PUBLICATIONS

OF THE

UNIVERSITY OF CALIFORNIA

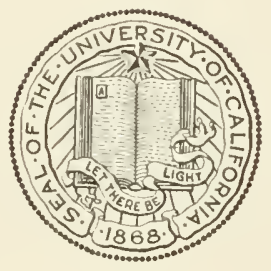

$1868-1918$ 



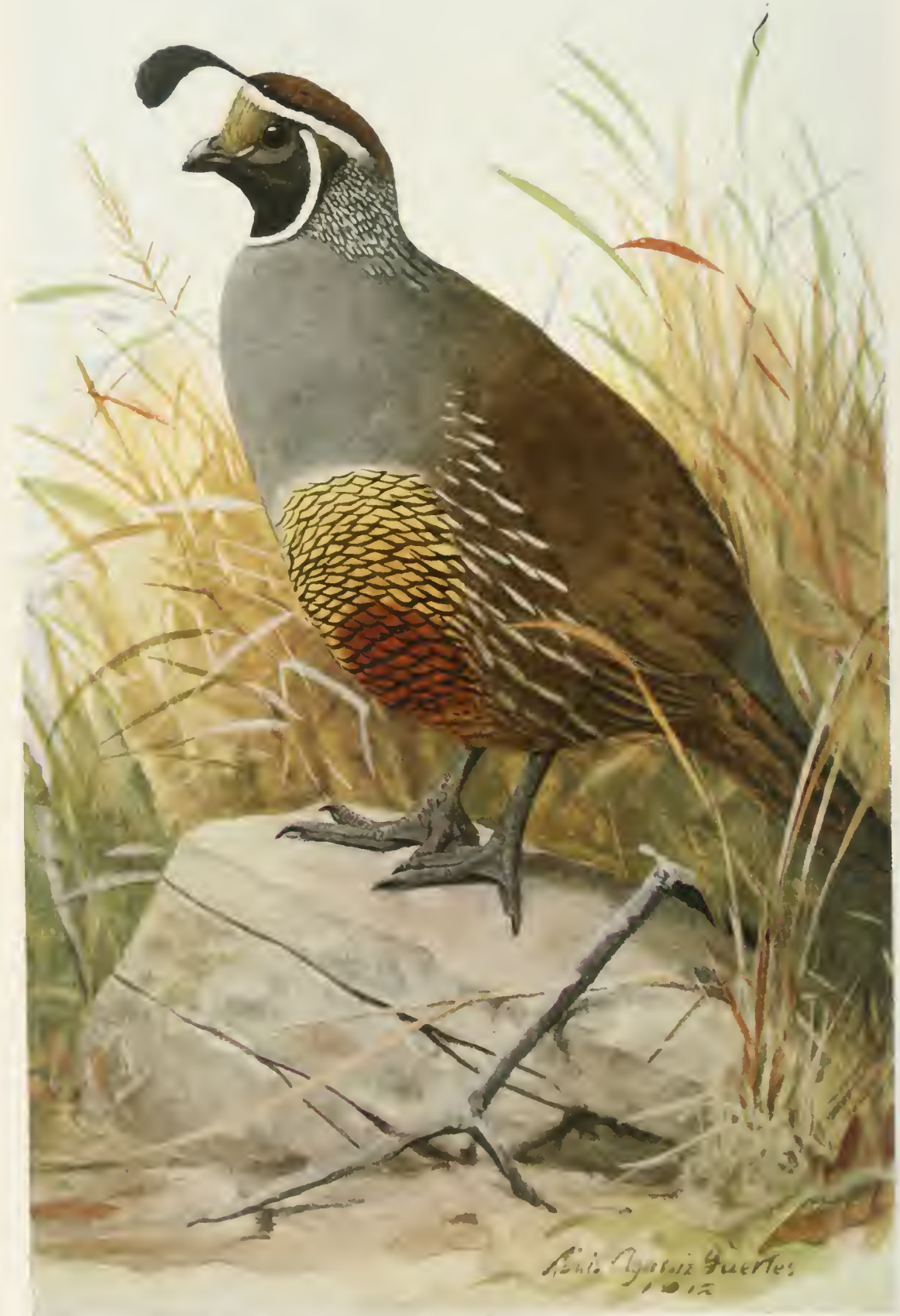

CALIFORNIA QUAIL, MALE 


\title{
THE GAME BIRDS OF CALIFORNIA
}

\author{
CONTRIBUTION FROM THE UNIVERSITY OF CALIFOR.NIA
}

MUSEUM OF VERTEBRATE ZOOLOGY

\author{
BY \\ JOSEPH GRINNELL \\ HAROLD CHILD BRYANT \\ AND \\ TRACY IRIVIN STORER
}

UNIVERSITY OF CALIFORNIA PRESS

BERKELEY

1918 
COPYRIGHT, 1918

$\mathrm{BY}$

J. GRINNELL

11. 1815. July it

ISSUED DECEMBER 28, 1915 


\section{PREFACE}

In the fall of 1912 it was decided that the staft of the California Inuseum of Vertebrate Zoology should begin to apply a portion of its knowledge of the vertebrate natural history of the state along practical lines, more partieularly in an active effort towards conserving the native fauna. In the course of extended field work throughout California we had been foreibly impressed with the rapid depletion everywhere evident among the game birds and mammals, but at the same time we found reason to believe that a earcful study of the situation would reveal some effectual means of retarding this downward trend.

After observing the course of legislation for several months during the season of 1913, and recalling the popular indifference we had eneountered in various parts of the state toward existing game laws, we had come to the conclusion that however numerous or stringent the game laws might be, they of themselves eould not be expeeted to furnish adequate protection. The people at large must be apprized of the facts, and shown the need for, as well as the most effeetive means of, eonscrving our game resources.

About this time our plans became known to a Berkeley gentleman who was already intensely interested in any and all ageneies for the protection of wild life. It was through the financial aid tendered by this man, whose name I am pledged to withhold, that the beginning of our work along economic lines was made possible. The actual task of writing the present book on the status of the game birds of California was begun on June 1, 1913, when Dr. Harold Child Bryant joined the staff of the Mruseum of Vertebrate Zoology under salary provided as above indicated, and, in collaboration with the director of the museum, devoted his time exclusively to this enterprise. Bryant's services formally terminated on August 1, 1914, when he was called to a position as director of education, publicity and research, under the State Fish and Game Commission. He thereby carried the slogan "Game Conservation through Edueation" into a sphere of application the scope of which he has been able steadily to enlarge and perfect.

The work on the game-bird book was immediately taken up where Bryant had left off, by Mr. Traey Irwin Storer, and the latter, under salary at first supplied from the anonymous source above alluded to, and later by Miss Annie MI. Alexander, has, again with the collaboration of the director of the museum, faithfully and unremittingly labored on the book until its completion at the end of 1916 . 
Meanwhile, Bryant's interest in the mndertaking has not flagred, and he has embraeed opportunities in conneetion with his new work under the Fish and Game Commission, to secure information for use in our general chapters, as well as here and there throughout the aceounts of speeies.

It is but just to state liere that the whole game-bird book has been brought to a conelusion only through the opportunities afforded under the auspices of the University of California Museum of Vertebrate Zoology; and the maintenance of this museum in all its funetions has been due to the eontinued financial support furnished in generous measure by Miss Alexander.

The arduons typing and retyping of the manuseript was a necessary labor, done faithfully by Miss Margaret W. Wythe, of the museum staff. Corrections in the plurasing were suggested by $\mathrm{Mr}$. Aubrey Boyd, instructor in English in the University of California. Mr. Albert H. Allen, manager of the University Press, evineed personal interest in the enterprise in many ways during the process of compilation. The line drawings were done by Miss Frieda Imeddemamn, dircetly from museum specimens. Of the sixteen colored plates, nine were done specially for this book by Louis Agassiz Fuertes; three colored drawings, also by Fuertes, were loaned for om use by the California Fish and Game Commission; and the use of four colored drawings done by Allan Brooks was allowed by their owners, two of them by Miss Annie M. Alexander, one by Mr. A. Brazier Howell, and one throngh Mr. W. Leon Dawson, the latter from the stoek of Brooks drawings owned by the Birds of California Publishing Conpany, and intended for use ultimately in Dawson's Birds of California.

I would like to repeat here a prineiple in which I fully believe; namely, that the highest plane of seientifie output ean be aceomplished only through coöperative effort. If the present contribution proves to have reached an unusually satisfactory plane in any respect it will be becanse the attention of sereral workers rather than of a single inclividual has been deroted to it. Where one author working alone would make mistakes unawares, two or, better, three, are able to check one another's output to advantage. The best results, always granting mutually sympathetie interest, will follow organized coöperative toil.

\section{Joseph Grinnela}

Director of the California Muscum of Vertebrate Zoology.

Transmitted November 30, 1916. 


\section{CONTENTS}

Preface

PAGE

Table of contents

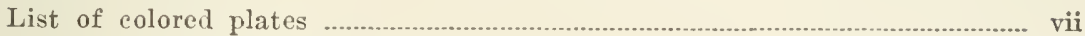

List of figures in the text ................................................................................. vii

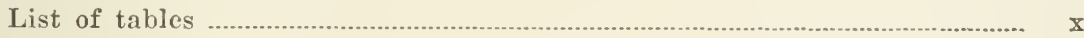

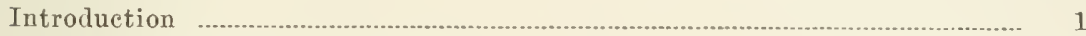

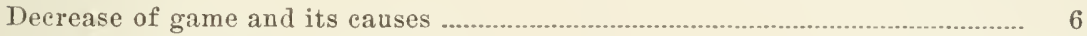

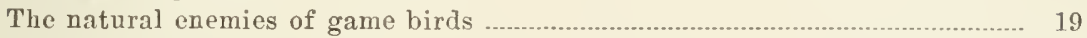

The gun club in California ....................................................................... . 23

History of attempts to introduce non-native game birds into California ........ 29

The propagation of game birds ................................................................ 45

Legislation relating to game birds in California .................................... 55

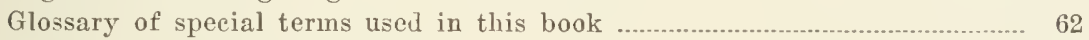

Method of taking measurements ................................................................. 66

Key to the game birds of California ............................................................ 67

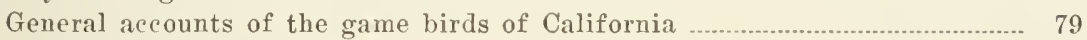

American Merganser …....................................................................... 79

Red-breasted Merganser ............................................................................ 84

Hooded Merganser .............................................................................. 89

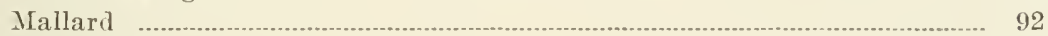

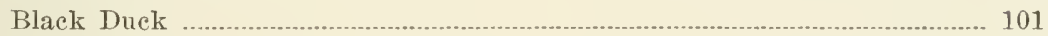

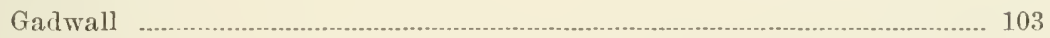

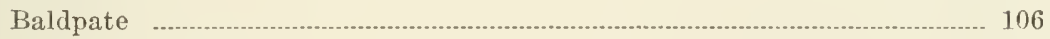

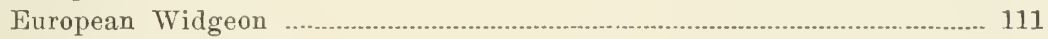

Green-winged Teal ......................................................................................... 113

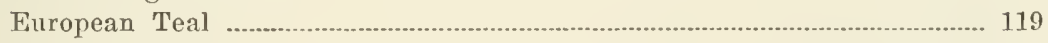

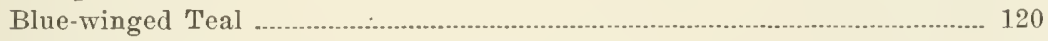

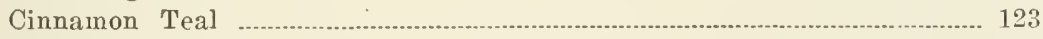

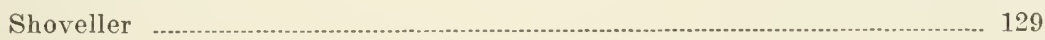

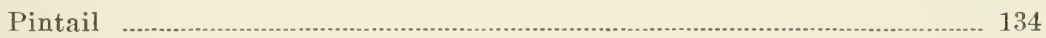

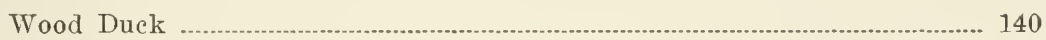

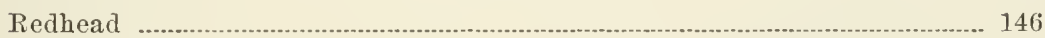

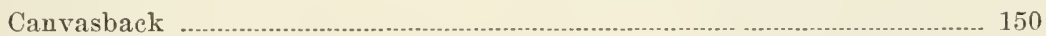

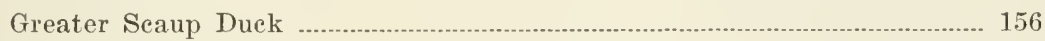

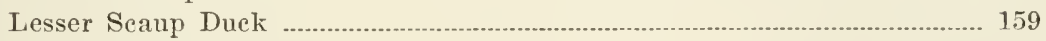

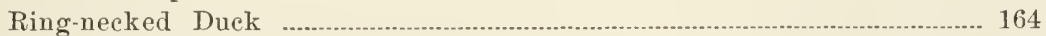

American Golden-eye .................................................................................... 167

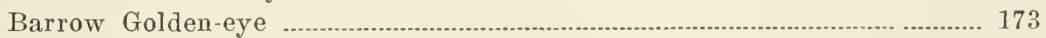

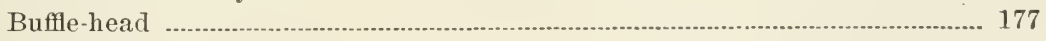

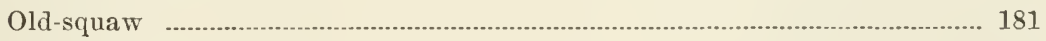

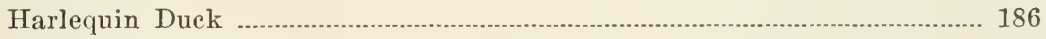

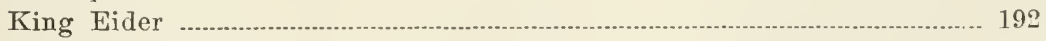

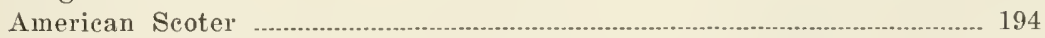

White-winged Scoter _................................................................................... 197

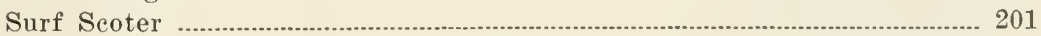




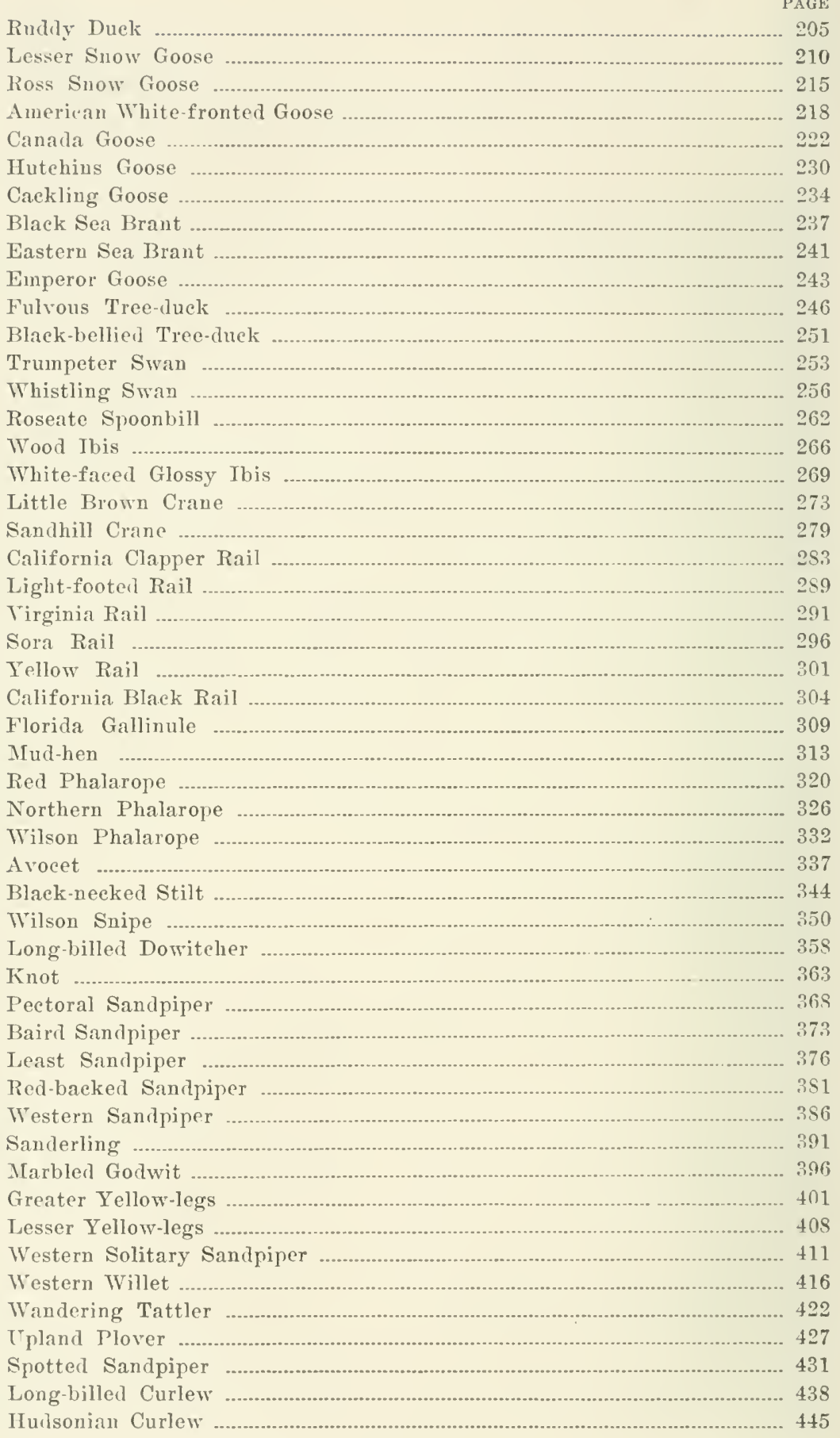




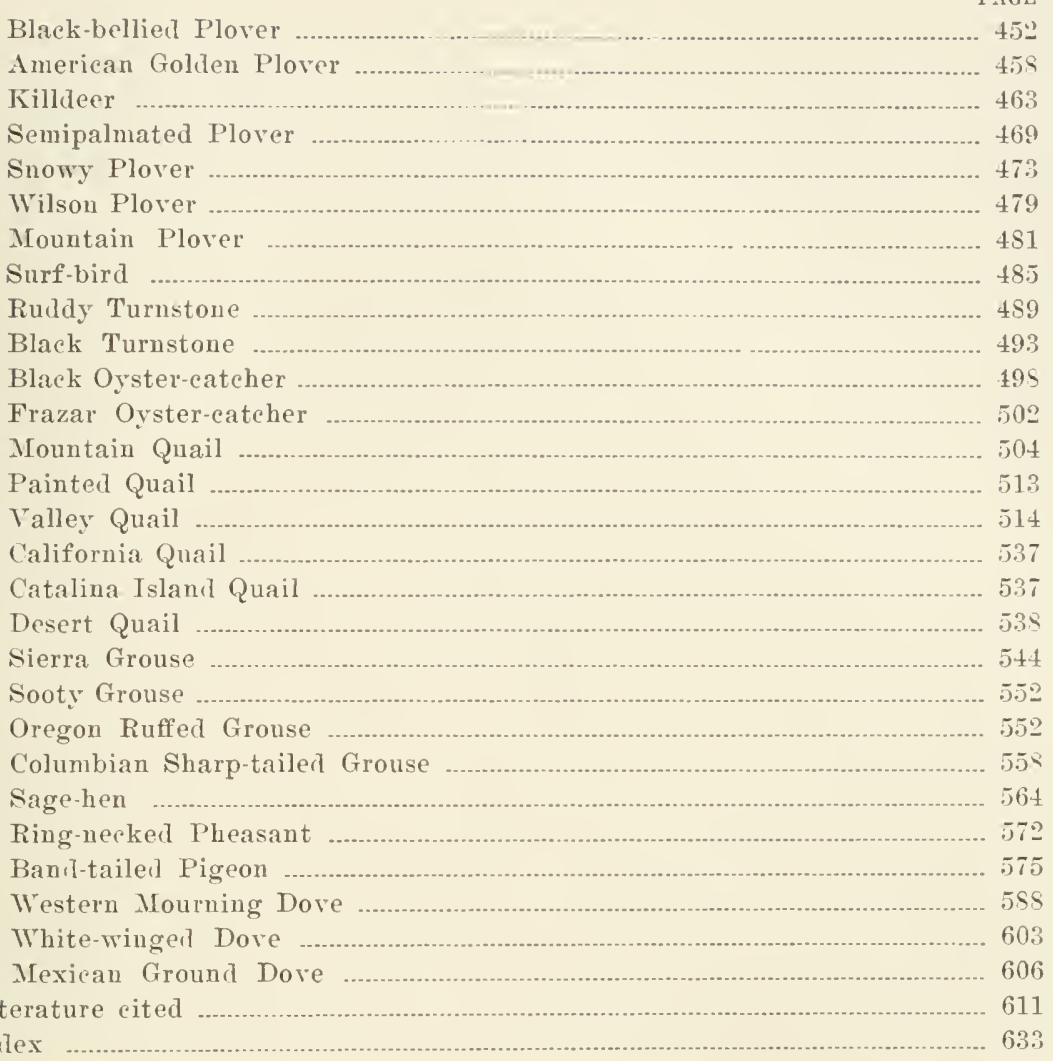

\section{Colored Plates}

1. California Quail (drawn by Louis Agassiz Fuertes)

Frontispiece

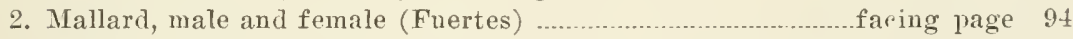

3. Baldpate, male and female; European Widgeon, male (Fuertes)................ 110

4. Cinnamon Teal, male and female (Fuertes) …….................................. 126

5. Canvasback and Lesser Scaup Duck, males and females (Fuertes) .......... 150

6. American White-fronted Goose and Lesser Snow Goose (Fuertes) ............ 214

7. Fulvous Tree-duck (drawn by Allan Brooks) ................................. 246

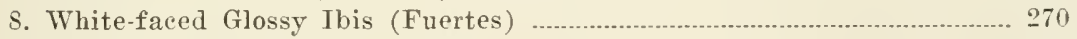

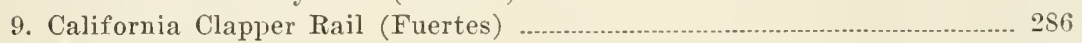

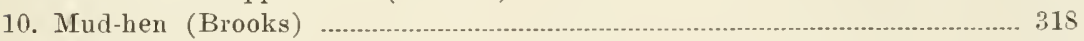

11. Avocet and Black-necked Stilt (Fuertes) …............................................... 342

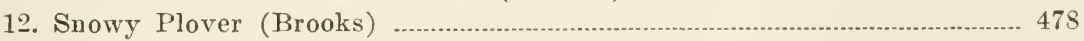

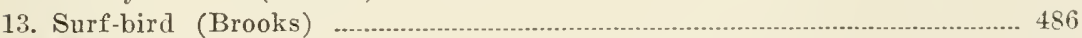

14. Mountain Quail (Fuertes) ............................................................. 510

15. Sierra Grouse, male and female (Fuertes) ….......................................... 550

16. Ring-necked Pheasant (Fuertes) _............................................................... 574 


\section{Text Figures}

Note.-Numbers in parentheses following titles of figures, and usually accompanying the figures in the text, are those of the speeimens in the Museum of Vertebrate Zoology from which the drawings were made; figures drawn from specimens in private collections have numbers followed by initials of owners (e.g., 209 H.S.S.). All figures natural size except as noted.

1. General outline of a Mallard showing names of parts and areas referrer to in describing a game bird; $\times 1 / 4$

PAGE

2. Outer surface of spread wing of Green-winged Teal showing names of regions and feathers enployed in deseriptions (24635); $\times 1 / 2$

3. Under surface of spread wing of Black-bellied Plover showing axillars and lining of wing $(24868) ; \times 1 / 2$

4. Side view of Hudsonian Curlew showing method of taking the measurements used in this book (6940); $\times 1 / 4$

5. Ameriean Merganser, side of bill (21609)

6. Ameriean Merganser, top of bill (21609)

7. Red-breasted Merganser, side of bill (18814)

8. Red-breasted Merganser, top of bill (18814)

9. Mallard, side of bill (21615)

10. Mallard, top of bill (21615)

11. Mallard, side of tarsus and foot (21615)

12. Gadwall, top of bill of female (21643) …............................................. 104

13. Green-winged Teal, side of bill of female (21699) ….......................... 116

14. Cinnamon Teal, side of bill of female (21739) ...................................... 125

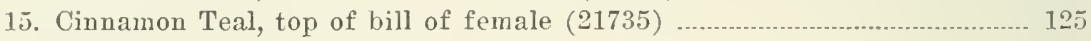

16. Blue-winged Teal, top of bill of female (1647 H.S.S.) ............................ 125

17. Shoveller, side of bill (2176S) ............................................................. 131

15. Shoveller, bill from below (21768) ......................................................... 131

19. Pintail, top of bill of female (21S27) ................................................... 136

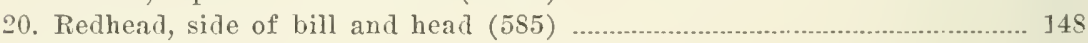

21. Canvasback, side of bill and head (10607) ............................................. 153

2.. Canvasback, side of foot and tarsus (10607) ....................................... 153

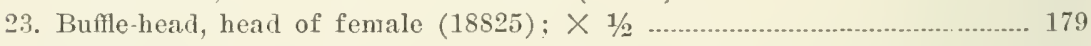

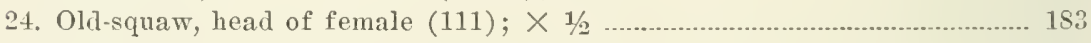

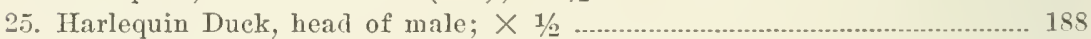

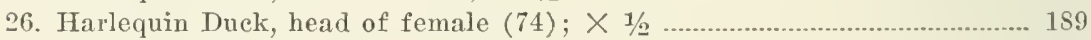

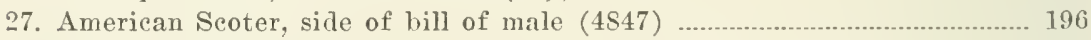

2S. White-winged Scoter, side of bill and head of male (18826) ................. 199

29. Surf Scoter, side of bill of male (113) …...................................... 202

30. Lesser Snow Goose, side of bill (5493) ….............................................. 212

31. Ross Snow Goose, side of bill (21905) ................................................... 216

32. Canada Goose, side of bill (21949) ............................................................. 224

33. Hutehins Goose, side of bill (22001) ................................................... 224

34. Cackling Goose, side of bill (22028) ..................................................... 225

35. Canada Goose, side of tarsus and foot (21949) ................................... 226

36. Hutchins Goose, side of tarsus and foot (22001) ................................... 227

37. Cackling Goose, side of tarsus and foot (22028) …................................ 227

38. Fulvous Tree-rluek, side of tarsus and foot (21573) ............................... 24S

39. Fulvous Tree-duck, side of bill (21573) ............................................. 249

40. Whistling Swan, sirle of bill and head (212S4) .................................... 257 
PAGE

41. Whistling Swan, side of tarsus and foot (21284) ............................ 259

42. Roseate Spoonbill, sicle of bill (23325) …............................................. 265

43. Roseate Spoonbill, top of bill (23325) .................................................. 265

44. White-faced Glossy Ibis, side of bill (6188) ........................................ 271

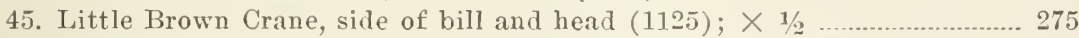

46. Sandhill Crane, side of bill and head (X2067 J. \& J. IV. M.) ; X 1/2 ....... 280

47. California Clapper Rail, side of foot aud tarsus (6995) …..................... 284

4S. California Clapper Rail, side of bill (6995) …....................................... 285

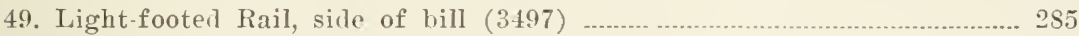

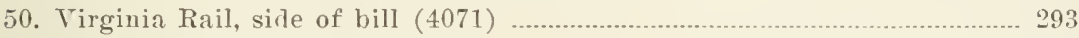

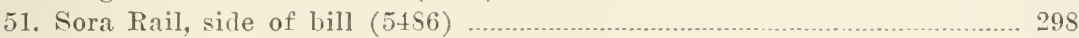

52. Yellow Rail, side of bill (17250) .......................................................... 303

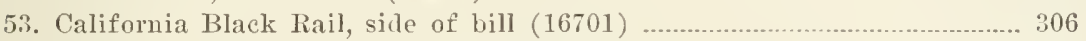

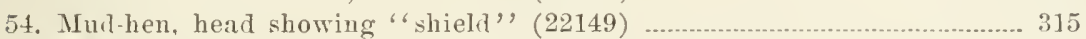

55. Murlhen, top of foot showing lobes on toes (22148) ................................. 316

56. Red Phalarope, tarsus and foot showing webbing and lobes (4804) ....... 322

57. Red Plialarope, side of bill (4804) ........................................................ 322

58. Northern Phalarope, sicle of bill (15932) …......................................... 329

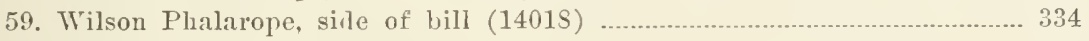

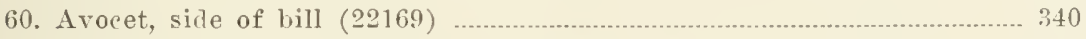

61. Arocet, top of foot showing webs between bases of toes (22169) ......... 341

62. Black-necked Stilt, side of bill (22183) ............................................... 346

63. Black-necked Stilt, top of foot showing practical absence of webs (221S3) 347

64. Wilson Snipe, side of bill of female, with sense pits near tip (1068) ........ 352

65. Long-billed Dowiteher, sirle of bill of female (22232) ........................... 361

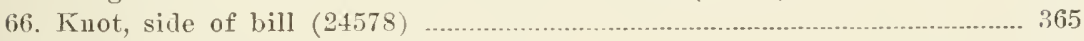

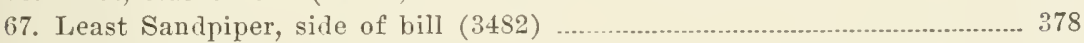

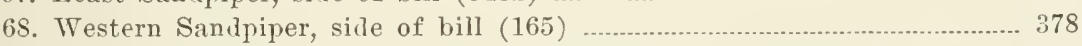

69. Least Sandpiper, top of foot showing absence of webbing (3482) .......... 379

70. Western Sandpiper, top of foot showing webs between bases of toes (165) 379

71. Red-backed Sandpiper, side of bill (9835) .

72. Western Willet, outer surface of spread wing showing color patches

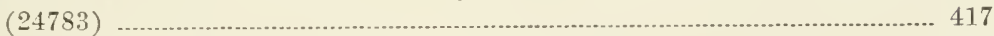

73. Long-billed Curlew, side of bill of female (24867) ................................. 440

74. Hudsonian Curlew, side of bill of female (3997 J. G.) . ......................... 447

75. Black-bellied Plover, side of bill (22342) …................................... 454

76. Black-bellied Plover, side of tarsus and foot, showing presence of small hind toe (22342) ................................................................................. 455

77. Killdeer, side of tarsus and foot, as typical of Plovers (18983) ............... 465

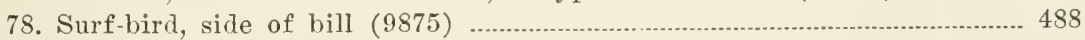

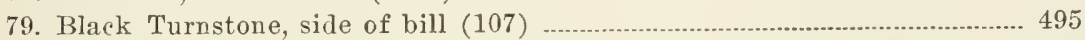

80. Black Oyster-catcher, side of bill (19016) ......................................... 499

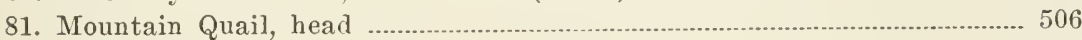

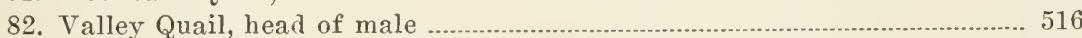

83. Valley Quail, side of tarsus and foot (11955) ........................................ 517

84. Curve showing by half-month periods the time when Valley Quail begin to lay their eggs ............................................................................ 529

85. Sierra Grouse, side of tarsus and foot, showing feathering (14076) ....... 546

86. Band-tailed Pigeon, head (15619) ......................................................... 577

S7. Map showing distribution of the Band-tailed Pigeon in California ....... 578

88. Band-tailed Pigeon, lower surface of tail (238 H.S.S.) ........................... 589 
S9. Western Mourning Dove, lower surface of tail (209 H.S.S.) ................... 589

90. White-winged Dove, lower surface of tail (239 H.S.S.) ......................... 589

91. Western Mourning Dove, head (209 H.S.S.) ....................................... 591

92. Graph showing nesting season of the Western Mourning Dove in California, aceording to opinions of deputies of the California Fish and Game Commission

93. Graply showing ehanges in open season for hunting doves in California, 1880-1915

94. Graph showing open season for hunting doves in states which allow these birels to be shot (1915)

\section{TABLES}

Table 1. Game biris shot on the gromds of the Empire Gun Club (Elkhorn, Monterey County, California) in four seasons between 1905 and 1913

Table 2. Estimates of numbers of ducks soll in the markets, between 1911 and 1916

Table 3. Dueks received by the American Game Transfer Company at San Franeisco in the season of 1910-11

Table 4. Geese receivel by the Independent Game Transfer Company, of San Francisco, during the season of 1909-10

Table 5. Ducks received by the Hunters Game Trausfer Company of San Francisco, during the five seasons, 1906-11 ............................ 14

Tahle 6. Dueks sold on the markets of San Franciseo hy five game transfer companies during the season of 1910-11

Table 7. Showing open seasons for hunting game birds in California, $1 \varsigma^{5}-$ 1915

Table s. Data relative to the nesting of the Mallard in Califormia ......... 96

Table 9. Data relative to the nesting of the Gartwall in California ....... 105

Table 10. Data relative to the nesting of the Cinnamon Teal in California 126

Table 11. Data relative to the nesting of the Ruddy Duek in California 20 -

Table 12. Data relative to the nesting of the Virginia Rail in California 294

Table 13. Data relative to the nesting of the Mountain and Painted quails in California ........................................................................... 507

Table 14. Crop contents of Mountain Quail ............................................. 512

Table 15. Data relating to nesting of Valley and California quails in California

Tahle 16. Sets of eggs of Valley Quail examined by C. S. Sharp in the vicinity of Escondido, Sau Diego County, Califoruia, 18961913

Table 17. Sets of Valley Quail eggs showing more than one type of coloration ................................................................................................. 5 פ

Talle 18. Data relative to the nesting of the Band-tailed Pigeon in Cali-

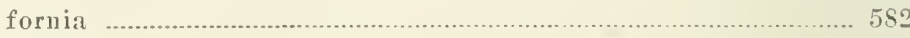

Table 19. Data relative to the nesting of the Western Mourning Dove in California 


\section{INTRODLCTION}

In preparing the present volume the anthors have attempted to meet the requirements of a varied public. The hunter wishes information concerning the haunts and habits of our game birds ; the naturalist wishes to have the completest possible data regarding their life histories; the legislator who appreciates the necessity of judicious game laws wishes to have the facts that are relevant to his purpose presented in concise form : and the conservationist desires that information which will assist him in his efforts to perpetuate our bird life for the ultimate benefit of the greatest number of people. Whether the needs of these various classes have been adequately met in the following pages remains to be proved, but it may at least be stated here that nome of them has been overlooked. To each of the four categories of persons above mentioned, this book is offered as a working manual.

The authors also have appreciated the fact that the literature relating to California game birds is widely scattered, and not accessible for immediate use by the public; an exhanstive review and compilation was necessary to make it easily available. Furthermore, they have realized that many California game birds are rapidly disappearing, and that any postponement of the time of writing the histories of these species might mean losing entirely the opportunity to record much that pertains to them. An effort has been made to organize the material at hand in such a form as to provide a convenient summary of our knowledge of the subject to date. While the book may thus prove of positive value to the active field naturalist, the writers hope that the deficiencies apparent in the data presented will of themselves furnish an incentive to further research. A more thorough observation of the bird life within our boundaries is urgently needed.

In comparison with the Atlantic states California has thus far produced but a small number of careful observers, and many more are needed for the purpose of watching and recording the changes in the population of the birds from year to year, of chronicling their migrations, learning their food habits, and determining their relation both to sport and agriculture. Should the present volume sueceed in enlisting even a few intelligent and active recruits in this work, an excellent end will have been served.

Many game birds in eastern North America had almost or entirely disappeared before their value was realized or any attempts were made to conserve them. Adequate knowledge and forethought would have prolonged the life of these species and perhaps have saved many 
of them for all time. Here in California the situation has not yet become so serions; we are in a somewhat earlier stage of development. We have still an opportunity of studying the cirenmstances, learning the facts, and taking the remedial measures indicated thereby. But the time for action is short; already one species, the Columbian Sharptailed Grouse, is gone, and certain others are threatened. The neecssity of calling attention to this danger is another reason for the publication of this book now.

The authors fully recognize the fact that there are a number of people in this state who by reason of their long experience as hunters possess, in this regard, better qualifications for the anthorship of a book on game birds than the present writers. But these persons are as a rule so engrossed in business that they themselves have not sufficient time to put throngh such a work. Some of them, however, together with certain other interested people, have placed the necessary means at the disposal of the anthors, who, realizing their own shortcomings, have utilized their opportunities to the best of their ability. They have attempted to compensate for their lack of direct knowledge in the field of hunting by conversing and corresponding with sportsmen of experience, and they have each visited hunting grounds at the opening of different shooting seasons, with the object of learning something of the viewpoints, methods, and field-lore of Californian gunners.

As regards the technical handling of the book the authors feel themselves on much surer ground. They have been able to derive first-hand information for almost all of the technical descriptions from museum specimens or from live or freshly killed birds in the field, and they have reviewed the literature of the subject in an exhaustive and discriminating manner. They are accordingly reasonably confident of the accuracy of their descriptions of birds, nests, and eggs, places of nesting, and of the habits of the several species. But with regard to the sportsman's notions and evalnations of the several species, and his preferred methods of hunting them, they have had to rely chiefly on second-hand information.

The authors have been fortunate in having at their disposal a large amount of musemm material. The specimens contained in the California Minseum of Vertebrate Zoology, and in the private collections of J. and .J. W. Mailliard, J. Grinnell, H. S. Swarth, and G. F. Morcom, have provided a basis for almost all assertions, independently of what has been previously published on the subject. When western material failed to supply needed facts, recourse has been had to eastern collections. Among eastern institutions which have granted the use of specimens or given information are the United States National Mrusem and Bureau of Biological Surver, in Washington; the 
Academy of Natural Sciences, Philadelphia; the Jonathan Dwight, Jr., collection in the American Museum of Natural History, New York City; and the Museum of Comparative Zoology, Harvard College, Cambridge. 'To all of these institutions and their officers we express our appreciation of the spirit of cordial coöperation they have shown.

In response to our direct request a great many persons have furnished specific information. Wherever such information has been used it lias been eredited to the individual contributor. Nuch use has been made of Lyman Belding's manuscript Water Birds of the Pacific District, now on deposit in the Bancroft Library of the University of California. The field observations of the three present co-authors and of W. P. Taylor and R. II. Beck have been taken from the note books of these persons on file in the California IIusemm of Tertebrate Zoology. All of these various sources of information are referred to in the text as "MIS."

The hearty coöperation of the California Fish and Game Commission has been of great assistance in assembling data. Much new material has been obtained by means of circular letters to the commission's deputies, as in the cases of the Mourning Dove and Valley Quail. Mr. Ernest Schaeffle, former secretary of the commission, assisted us in a multitude of ways both official and personal.

Finally, Mr. Harry S. Swarth, eurator of birds in the California Museum of Vertebrate Zoology, has read the entire proof of the book, and by reason of his extensive knowledge of western birds has been able to make important corrections and improvements.

It was found necessary arbitrarily to set a date beyond which no new information should be incorporated into our manuscript. This date was fixed at June 30, 1916. Work done subsequently, and up to the time of going to press, consisted solely in revision.

The list of "literature cited" at the end of the book must not be taken as a complete bibliography of the subject; it contains titles only of those articles or books from which material is actually taken either indirectly or by quotation.

Many of our readers will probably disapprove of our frequent use of direct quotations. In defense of this practice we urge the greater accuracy thereby obtained. Experience has taught us that rewording an account often leads unintentionally to a perversion of the original author's exact meaning, and we believe that scientific accuracy of fact should take precedence over smoothness of diction or an appearance of originality. We also recognize the fact that interpolation of citations in the text mars its typographical appearance; but their presence makes verification possible, and, together with the list of articles and books under the heading "literature cited," they serve to assist those readers who are interested in following the sub- 
ject farther. We believe that placing citations in the text rather than in footnotes results in a smaller percentage of error even thongh it somewhat interrupts the smoothness of the printed page.

The order in which the species chapter's follow one another is essentially that used in the Ameriean Ornithologists' Union Check-list of North Ameriean Birds (1910).

The small-type paragraphs at the beginning of each species chapter' are intended primarily for reference purposes, as for example in eomparing two or more speeies, and are eonsequently reduced to essentials. Nany of the points briefly given in these paragraphs are elaborated upon in the general (large-type) account which follows.

Each species ehapter is headed by the most generally accepted common name, followed by the current scientific name and its author. Under "other names" are included, as a rule, only those names by which the species has been ealled in California, either colloquially by sportsmen or naturalists, or more formally in published articles. Mere variations in the spelling of names have not been listed. For a few common or widely distributed species, names used in other parts of North America are included, as a convenience in referring to other books. The word "part" indicates that the name which it follows has also been used for one or more other species in California.

Under "description" are included only details of plumage (color) and size (measurements). Peculiarities in the strueture of feathers, bill and feet are rarely mentioned because if important in diagnosis they are clearly shown in the accompanying illustrations or diseussed in the running account. For each plumage a specimen has always been selected showing typically the particular phase to be described. Many species which oceur in California, such as certain shore birds, are, in migration time, in a mixed transitional state between the winter and summer plumages. Of eourse these, and such additional variants as are produced by wear or fading of the feathers, are not ordinarily mentioned in the description.

Under "marks for field identification" are mentioned such characters as will be of service in long-range observations. In most instances are inelnded eharacters which will separate a species under diseussion from others with which it is likely to be confused. In the rumning account there will usually be found one or more paragraphs disenssing these field character's in greater detail.

A number of our game birds differ slightly in color and measurements in different parts of the country and naturalists are aceustomed to recognize such geographic races as subspecies. In some instances it is known that sueh races exhibit marked differences in behavior, so that we do not feel justified in eiting the habits of eastern races in illustration of the behavior of western birds (e.g., see Oregon Ruffed 
Gronse). However, in the case of certain birds which are represented in California by two or more subspecies, such as the valley and the mountain quails and the "blue" grouses, our knowledge of the birds has led us to believe that there are no important differences in the behavior of the different races, and we have consequently combined the general accounts under that of the more widely distributed race. For example, in the account of the Valley Quail the habits of the California and Catalina Island quails are to be considered as covered.

Whenever a bird in hand cannot be identified by the use of the "key" or does not fit any of the descriptions, the specimen should be sent at once to some natural history museum for identification. Such a bird may be a representative of a rare species or of one new to the state, and so of particular value to science. The California Museum of Vertebrate Zoology stands ready at all times to receive and identify such specimens.

Joseph GrinneLL, Harold C. Bryant, TricY I. STORER.

MUseum of Tertebrate Zoologr, UNIVERSITY OF CALIFORNIA,

Berkeley, September 15, 1916. 


\section{DECREASE OF GAME AND ITS CAUSES}

It is easy to make statements to the effect that game has either increased or decreased; but to find reliable figures with which to substantiate such statements is well-nigh impossible. Yet the material gathered under this heading, even though fragmentary, scems not unworthy of consideration. The evidence we have been able to obtain may be grouped under four headings: the judgments of dependable observer's; the records of the kills of waterfowl on gun-club grounds; the records of market sales and shipments of game; and the toll taken by various agencies, natural as well as artificial.

The decrease in the numbers of game birds in California began to arouse comment more than thirty-five years ago. In 1880 that pioneer ornithologist, Dr. J. G. Cooper, stated (1880, p. 243) that game birds had already "rer'y much diminished" locally. In his opinion this reduction was due to "persecution by the gun," and to poisoned grain intended for "vermin" (probably squirrels and gophers).

In 1913 letters of inquiry on this subject were sent out from the MIuseum of Vertebrate Zoology to responsible observers throughout the State. Questions were asked as to the status of ducks and geese, shore birds, quail, and other game birds. Seventy replies were receired, lepresenting twenty-seven counties of the State. Many of these reports covered periods of ten to forty years, and one observer stated that he had kept track of game conditions for sixty-one years.

A compilation of these reports showed that sixty-eight of the seventy observers had noted a decrease in ducks and geese. The other" two reported that these birds were "holding their own." Not one reported an increase! The estimates of the decrease in ducks ranged from twenty-five per cent to ninety-nine per cent, and arerage elose to fifty per cent. The same observers agreed in reporting the greatest decrease in the ease of geese; six stated that the birds had entirely disappeared from their aceustomed localities, and five said that they were now seldom seen. The percentages of decrease for geese were given as fifty per cent and more, the average being about seventy-five per cent.

Forty-one reports on the status of quail showed a considerably smaller decrease. Thirty-six observers reported a deerease, four stated that the birds were "holding their own," and one reported an increase. Of eleven reports relative to the Mourning Dove, seren indi- 
eated a marked decrease, and four no change. 'The amount of decrease ranged from twenty-five to seventy-five per cent.

A few excepts from the letters reeeived are given here to show the general eharacter of the reports. Mr. Henry Grey, writing of San Diego and vieinity, unler date of Mareh 17, 191:3, says:

Eight anıl nine years ago I could go down to a pond near my house and shoot six Widgeon in twenty minutes. After shooting what I wanted, ducks would come streaming in from the ocean aml the water-hole would soon be so fillerl with dncks while I stood in full view that they hardly had room to flap their wings. . . Now all is changen. . . . A nearby resident declared that in the season of 1911-12 there was only one duck for over 100 seen in the same place four years before, and this season (1912-13) I failed to see even that proportion.

Mr. Sammel Hubbard, Jr., under date of Mareh 12, 1913, writes us:

In 15,6 ,lucks were very plentiful in all the marshes from Sausalito north to Petaluma, Napa and Vallejo. In those days it was easy for a boy to kill from twenty to thirty clucks in a day's shooting and very murh larger bags were obtained by experienced hunters. Torlay, in the region between Sausalito and Novato, I think it is safe to say there is not one luck in the marsh now where there were a hunilred then. Beyond Novato there is still some shooting, but it is mostly confined to baited ponds where the birls are regularly ferl. There are still large flocks of Canvashacks and Bluebills on San Pablo Bay, but nothing like as many as in former years. On Oakland Creek where ducks, rail, curlew, and shore birls were formerly plentiful, they are seldom seen today. I have killerl as many as forty rail on one tille in Oakland Creek but I doubt if there is a single one there today.

The same observer has told us that many Wood Ducks were formerly killed along Oakland Creek. But none has been seen in this vicinity for ten or fifteen rears.

Mr. C. I. Clay, moder date of March 16, 1913, states that the Canala Goose was not uneommon on Humboldt Bay seven to ten years ago. Dnck hunters frequently killed fair-sized bags from their hunting boats. But he has not seen or heard of a Canada Goose being killed on Humboldt Bay within the past five years.

Mr. W. E. Unglish, under date of March 10, 1913, says that geese were onee abundant on the plains between Gilroy and Hollister, San Benito County. Now, althongh the fields are still sown to grain, there are not a dozen geese killed there in a year.

Mr. T. M. Lane writes:

Twenty years ago wild geese came to the grain fields near Reedley, Fresno County, by the thousands. It would be a safe estinate to say we have seen at least five or six acres of ground covered with them. They were so thick they looked like seattered banks of snow with the ground showing through in black streaks. We have seen them covering a strip over a half mile in length. As the country was settled up and put out to fruit they gradually disappeared, but for several years we would see many flocks flying over; today we scarcely ever see or hear any. 
MIr. A. D. Ferguson, also speaking of the Fresno region, states November 30, 1912) that flocks of geese may yet be seen in rertain sections along the San Joaquin River and in some grain ficlds many miles from the river. But ten to twenty years ago the whole san Joaquir: Valley literally swarmed with wild geese fluring miklwinter. From the windows of a moving train myriads of geese were to be observed, reaching as far as the eye conld see on either side of the railroad from Fresmo to Stockton-certainly a thousandfold more geese than ean be seen today along the same ronte.

Some published statements coneerning the decrease of ducks and gerese in the erntral and northern parts of the State may be introlnced here. Tyler $(1913 b$, p. 7 ) says :

It is with regret that we note a gradually diminishing mmber of waterfowl returning to us each fall. . . While it is probably true that gumers are in a large measure responsible for the decrease in numbers of many species, partienlarly of the ducks and geese, yet a changed cuvironment has been a potent factor in bringing about the present conclition. . . . The large grain and stock ranches are being subdivided, reclamation work is steadily reducing the swamp-covered areas, vineyards and orchards are springing up ererywhere with a consequent great increase in population. Even the tule ponds that remain are often unsuitable for a nesting place on accomt of the custom of nsing them as foraging grounds for hanis of hogs.

As early as 1890 the decrease in the mmbers of geese hat begun to attract attention. W. F. Bryant (1890, pp. 291-292) makes the following statements:

There has not, so far as I am aware, been a very marked derrease in the number of geese which annually visit California, but the area over which they now feed is considerably less than in 1850 . In the fall of that year, my father, while going from San Francisco to San José, met with atres of white and gray geese near San Bruno. They were feeding near the roalside. indifferent to the presence of all persons, and in order to see how elose he could alproach he walked directly towards them. When within five or six yards of the nearest ones they stretched up their necks and walked away like lomestic geese: by making demonstration with his arms they were frightened and took wing, flying but a short distance. They seemed to have no idea that they would be harmed, and feared man no more than they did the eattle in the fields. The tameness of the wild geese was more remarkable than of any other biris, but it must he understood that in those days they were but little hunted and probahly none had ever heard the report of a gun and few had seen men. This seems the most plausible accounting for the stupid tameness of the geese, forty years ago. What the wild goose is tolay on the open plains of the large interior valleys of California those who have hunterl them know. By 1953 the geese had beeome wilder and usually flew hefore one could get within shotgun range, if on foot, but in an open buggr or upon horseback there was no difficulty. There was a very marked contrast hetween the stupilly tame geese after their arrival in the fall and the same more wathful and shy hirts hefore the departure in spring of the years 18.52 and $185 \% 3$. 
H. L. Bryant, an early settler in southeru California, has told ns of thousands of geese which formerly fed on the open fields of Los Angeles County and describes the snow-like effect produced there by the herds of white geese. Few feed in the same localities at the present time, and comparatively few can be seen flying overhead.

Mr. Henry Grey, under date of March 17, 1913, states:

There are no geese to be seen in the vicinity of San Diego now. Although fifteen years ago numbers of Black Brant came into San Diego Bay, the numbers are harlly noticeable at the present time.

Additional testimony that certain species of ducks have noticeably decreased is to be found in magazines devoted to field sports, where attention is contimually being called to the lessening numbers of the more desirable speeies. For instance, Himman (1903, p. 179) speaking of marshes in southern California, states that Mallards and "Cans" seem to be getting scarcer every year, and the Redhead is a very rare visitor in that vieinity. P. G. Clark (1905, pp. 110-112) describes the killing of 279 ducks in one morning in a favorable section of the San Joaquin Valley, 179 of which were Mallards. There are many complaints to the effect that Mallards are now scarce in the same vicinity; comparatively few of these birds are taken there each year.

Mr. W. H. Bastian, keeper of the Santa Barbara Gun Club at Guadahupe, Santa Barbara County, wrote in February, 1914, as follows :

I shot here for the market twenty rears ago. Then it was no trouble to kill fifty to seventy-five ducks a day, mostly "Cans," and using no decoys. At present, it is a scratch to kill twenty-five birils per day, and when that loes happen, half are usually Ruddies.

The marked decrease in the Band-tailed Pigeon is indicated by the following statements:

We have harl no pigeons near Gilroy for several years. Formerly we had large flights, and the birds were slaughtered by the thousands (W. E. Unglish, March 10, 1913). The Band-tailed Pigeon is so searce here in Humboldt County that it is hardly worth one's while to try to get a mess for the table. One can see the numbers diminislı alnost year by year (C. I. Clay, March $16,1913)$.

Many other instances of decrease will be found cited under the general accounts of the different game birds, in the chapters following, notably in the cases of the Columbian Sharp-tailed Grouse, the Clapper Rails, and the Wood Duck.

Present conditions are such that they often lead to exaggerated estimates of the relative numbers of birds existing now and formerly. The ducks and geese which were once distributed throughout the state 
are now elowded into the few ponds and marshes which are not yet reelaimed. It now takes a scientifically managed gun-club pond with every attraction that can be offered to wild fowl to bring the birds in large numbers. 'The same numbers of bircls that ean now be seen on baited ponds were present formerly on every small natmal pond in the state. An example of this concentration is to be found in the vicinity of Gridley, Butte County, where geese still congregate anmually in immense numbers; but most of the localities in the San Joaquin and Sacranento valleys which formerly favored the wintering of these hirds, are completely devoid of them now. Many observers. seeing thousants of ducks on a few sections of overflowed land, fail to realize that the same sort of ground once extended far and wide through the valleys, and that these immense areas were then as well populated as are the smaller areas at the present time.

The annually diminishing kills on club grounds also indicate that both waterfowl and mpland game birds have decreased in this state. Although the gradual reduction that has been nade in the bag limit might be expected to favor the maintenance of an adequate supply of ducks, the increase in the efficiency of firearms and methods of attracting waterfowl has nndoubtedly facilitated their capture. The old-timers eontinue to complain of the decreasing number of birds bronght to bag. The following table (no. 1) compiled from the books of the Empire Gun C'lub, one of the best managed clubs in California, will serve to indicate the changes in abundance of the several speeies of game birds visiting those grounds. Of course the figures do not take into aecount the varying number of shooters each year, nor the fewer shooting days from year to year. A noticeable decrease in the

TABLE 1.-Game birls shot on the grounds of the Empire Gun Club (Elkhorn, Monterey County, California) in four seasons between

1905 and 1913

\begin{tabular}{|c|c|c|c|c|}
\hline & $1995-06$ & $1910-11$ & $1911-12$ & $1912-13$ \\
\hline 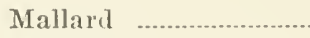 & 106 & 15 & 13 & 22 \\
\hline 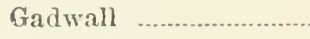 & $\bar{j}$ & $\tau$ & 1 & 10 \\
\hline Widgeon ............................ & 525 & $5:: 7$ & 325 & 227 \\
\hline Teal & 2025 & $4: 36$ & $7 \mathrm{~s} 0$ & 1195 \\
\hline 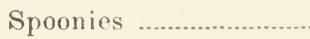 & 905 & 392 & S\&1 & 651 \\
\hline 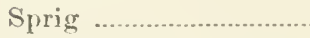 & $4+9$ & $18: 39$ & 1660 & 1645 \\
\hline Canvashack ....... & 251 & s & $S T$ & 23 \\
\hline Jluebill ........................ & 91 & 125 & $4 t$ & 29 \\
\hline 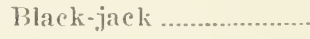 & . ......... & 3s & 5 & 5 \\
\hline 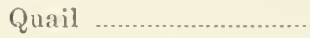 & . $69: 3$ & $7 \pi 6$ & 600 & $: 882$ \\
\hline 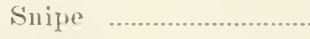 & 117 & 189 & $9 . \overline{1}$ & 24 \\
\hline 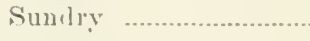 & 96 & :i4 & $\therefore$ & 16 \\
\hline Totals & 5266 & $4: 3: 29$ & 4.5 .32 & 4232 \\
\hline
\end{tabular}


number of large ducks such as Canvasback and Mallard, is, however, indieated. The kill of quail and snipe also shows noticeable decrease.

In 1913 and again in 1914 a questionaire was sent ont by the writers to different gun clubs asking for reports of the kills on the opening day of the season. Among the questions asked were: Number of hunters on hand; number of hunters securing the limit; number of ducks in each bag examined; total number of ducks for the day; kinds represented; and, how the birds were shot. Most of the reports returned, show a preponderance of small ducks such as teal, and also of the less desirable speeies such as the Spoonbill. The larger ducks, especially the Mallard, are relatively few in numbers. It also appears from these reports that although about as many limit bags are proeured as in former years it takes more hours to seenre the full quota of birds, notwithstanding the increased facilities for shooting and the increased efficiency of the firearms used.

Sale of game on the open market has been fundamentally the most important factor in redueing California's supply of game birds. So great has been the depletion from this eause in past years that it has been found necessary to prohibit the sale of all kinds except ducks and geese. These, too, should be removed from the sale list. All our neighboring states now prohibit the sale of all game, as do most of the eastern states. Were it not for eertain San Francisco eafé and hotel men who reap a rich harvest from the retailing of game, California would have done likewise in 1913, when a "no-sale" bill passed the Legislature, but was nullified by referendum. The high prices offered the market hunter usually tempt him to go beyond the legal limit. So long as a market demand exists men will continue to hunt the birds regardless of any law. Government authorities are right in saying that "the free marketing of wild game leads swiftly to extermination." California must prohibit the sale of all game species, if all are to be conserved as natural resourees.

The type of market hunter who in former days took the largest toll of wildfowl used an animal blind in approaching his quarry. This "bull hunter,' as he was called, proceeded to the hunting-ground leading a trained steer or cow. After a good-sized flock of dueks or geese had been located, he proceeded to "walk a shot." Moving along behind the animal, which was easily guided, he approached the birds by a process of "tacking," each tack bringing him nearer his game. A direct approach would have tended to frighten them, but this indirect method rendered them unsuspecting. Throughont the proeess of "working the shot," which required an average period of from two to three hours, an attempt was made to bunch or "bank" the birds as much as possible. When the birds were finally in proper position, the hunter whistled, whereupon the birds would raise their 
heads; then aiming over the baek of the animal with his large-bore gun or automatic, and bracing himself for the recoil, he fired the first shot or shots while the birks were sitting, and the seeond or subsequent shots while they were rising. Formerly a 2-, 4-, or 8-bore gun was used, but most commonly a double-barreled, number 4, muzzle-loader; in more recent years, a 12-gange automatic with an extension magazine carrying from seven to nine loads, has been employed. The resulting slaughter was simply enormous. Mr. M. leeker is authority for the statement that he watehed Siseho, a famous market hunter of Los Baños, Mereed County, with two assistants kill 400 dueks with six shots from number 4 gums. Two shots were fired from the animal blind while the birds were sitting on the ground, and four while the were rising. Mr. Beeker was rewarded with twenty-two dueks for not disturbing the flock before the shot. Mr. Ralph P. Merritt tells us that a single bull hunter in the same vieinity killed 104 dueks with two shots from a number 4, and Mr. J. Walter Scott, president of the Los Baños Gum Club, reports a kill of 108 geese with four shots.

Hunting by means of an animal blind was first discouraged by the establishment of a bag limit of twenty-five birds; but for several years the diffienlty of apprehending the violator and the practical impossibility of proeuring a convietion after his apprehension prevented the elimination of bull hunting. Then, too, the men employing this method of hunting continually threatened the lives of those who attempted to enforee the law. Several shooting frays between game deputies and bull hunters took place near Los Baños, and in 1915 a deputy was killed there while attempting to make an arrest. After the law prohibiting bull hunting for dueks was passed, this sort of hunting was still continned under the guise of hunting for geese. It was not until 1915, when all hunting with animal blinds was prohibited, and the market for birds was largely destroyed by the elimination of the illegally formed game transfer companies in San Francisco, that bull hunting beeame a thing of the past.

The automatic shotgun allowed the market hunter to reap a eopious harvest. IIormaday (1913, p. 148) records the killing of 218 geese in one hour with antomatie guns in Glenn County, and 450 on the same day, by the two men coneerned. The use of the automobile has also reacted against the birds. Some market hunters at Los Baños killed 198 white geese from automobiles in less than an hour in February, 1913.

The sale of gane birds on the market, then, has been a large factor in the general deerease of game. This is well shown by statisties relating to San Franeisco. The figures for the following tables, heretofore unpublished, were seeured by us direet from the reeords of the game transfer eompanies named, and show the magnitude of the business which existed during the period from 1906 to 1912. 
TABLE 2.-Estimates of numbers of lucks sold in the markets, between 1911 and 1916. Data from J. S. Hunter, Assistant Executive Officer,

Cahifornia Fish and Game Commission

$\begin{array}{lrrrrr} & 1911-12 & 1912-13 & 1913-14 & 1914-15 & 1915-16 \\ \text { San Franciseo markets...... } 250,000 & 150,000 & 82,000 & 81,000 & 75,000 \\ \text { All markets in California.... } 350,000 & 200,000 & 160,000 & 150,000 & 125,000\end{array}$

TABLE 3.-Ducks receivel by the American Gane Transfer Company at San Francisco in the season of 1910-11

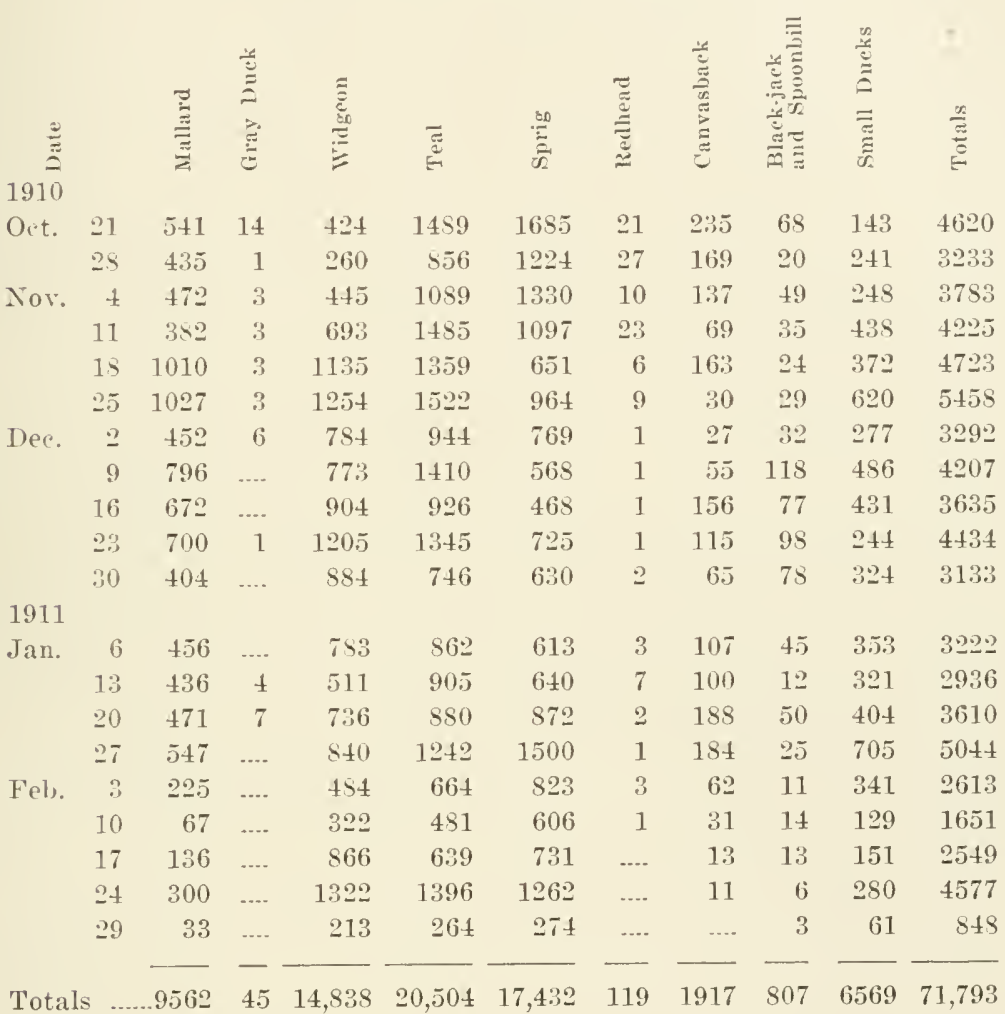

TABLE 4.-Geese receiver by the Independent Game Transfer Company of San Francisco during the season of 1909-10

\begin{tabular}{|c|c|c|c|c|c|}
\hline October & $\begin{array}{l}\text { White } \\
5+3\end{array}$ & $\begin{array}{l}\text { Gray } \\
28 \pm 7\end{array}$ & Honker & $\begin{array}{l}\text { Brant } \\
1142\end{array}$ & $\begin{array}{r}\text { Totals } \\
4832\end{array}$ \\
\hline November ............... & 1002 & 1673 & 19 & 2196 & 4890 \\
\hline December ................. & 529 & 1256 & 125 & 1592 & 3502 \\
\hline January ................... & 667 & 929 & 151 & 1578 & 3325 \\
\hline February …................ & 646 & 1027 & 135 & 1225 & 3033 \\
\hline Mareh 1-5 ............. & 82 & 321 & 5 & 116 & 524 \\
\hline Totals & 3469 & 8053 & 435 & 8149 & 20,106 \\
\hline
\end{tabular}




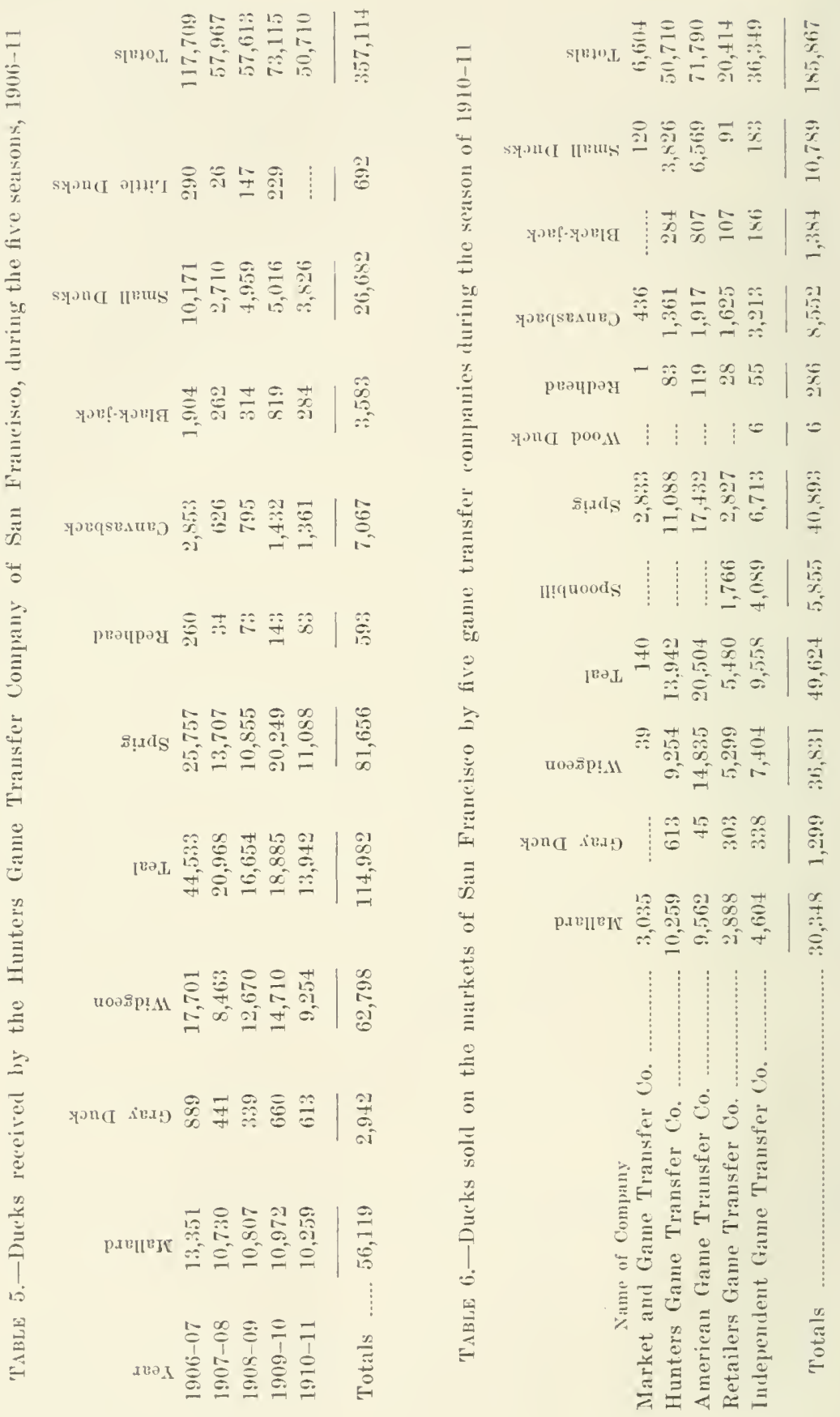


Oceupation and settlement of a country by white men affects game birds in many other ways than through hunting. The reclamation and enltivation of the land not only introduces sueh major disturbances as a deerease in the birds' food, but involves minor clangers to bird life in the form of telegraph wires, oil pools, and so forth. The rapid-flying birds are the most frequent vietims in the former ease, partieularly during seasons of wind and fog. Many birds which do not meet death immediately suffer injury and are later eaught hy predacious animals. Among waterfowl the Mud-hen is the bird which most often meets death by Hying against a barbed wire fence or telegraph wire. In Los Baños marshes it is not uneommon to see a Mudhen still hanging from the barbed wire of the fenee it struck, or lying beneath a telegraph line. There are sereral reeords of the Sora and Virginia rails having met death by striking a wire. Among the shore birds phalaropes are common victims of overhead wires. II. C'. Bryant (MS) found one live Northern Phalarope and two dead ones, each with a wing completely severed from the body, beneath telegraph wires west of Madera, Madera County, May 14, 1915. F. H. Holmes found two or three dozen phalaropes beneath telegraph wires near San José, in November, 1898 (Emer'son, 1904, p. 38). Emer'son (1904, pp. 3738) contributes eonsiderable information in this regard. On September 8,1898 , he found several dead sandpipers and a phalarope with a broken wing under some telegraph wires in a salt marsh near Hayward, Alameda County. Furthermore, several sandpipers were scen to meet death by flying against the same wires. In all, on this one day, forty dead birds were picked up beneath the wires. A trip to the same place the next day revealed thirty dead birds, mostly Northern Phalaropes, and Red-backed. Western and Least sandpipers. Again on Mareh 11, 1903, he found a number of birds of each of the above species at the same plaee. It is apparent that only speeies that fly at heights eorresponding to those of the wires are exposed to this danger. The birds ehiefly affected are speeies also of migratory and gregarious habits. The large number of Mourning Doves reported as found beneath telegraph wires in southern California shows that even this species suffer's in the same way.

Ponds of erude oil, sueh as are eommon in the oil fields and near pumping stations, eonstitute a menace to bird life, and in some loealities the toll exaeted of game birds is considerable. H. C. Bryant (1915d, p. 184), on Mav 11, 1915, found the bodies of more than three hundred birds in an oil pond about 50 by 150 feet in extent, at Brito, Mereed County. Along the shores of the pond there was a winrow made up of bones and feathers of many other birds that had met the same fate. Among the game birds noted were five different speeies of ducks, one goose, several Mud-hens, some Avoeets, Black-neeked Stilts, 
Killdeer and sandpipers. Ducks appeared to have been trapped most frequently. The moment a bird's feet touch the stieky oil its doom is sealed; for each of its successive efforts to free itself with its wings involves these members more completely in the oil. Even if a bird were able to reach shore the adhering oil would prevent flight, and on penctrating into its body would soon cause death. Rescued birds, even when well cared for, die quickly.

The old practice of dumping waste oil into bays and estuaries resulted in the death of many waterfowl. Many birks dead, or dying and unable to fly because of the oil they have collected on their plumage while swimming, have been noted along beaches by different observers. To obviate the danger to fish arising from the dumping of refuse oil into state waters, a law was passed prohibiting this practice. As a result, there will be a saving of fish and also a saving of waterfowl. There still remains a considerable danger to the sea-ducks on the open ocean, where "tankers" (oil ships) are aceustomed to flush out their tanks into the water. Many dead and dying birds, believed to be victims of this practice, are at times cast up along the sea-facing beaches of San Mateo, Marin, and Los Angeles counties.

There are many reports to the effect that nests of upland game birds are broken up by the trampling of cattle or sheep. The scarcity of gronse and sage-hen in eertain closely "sheeped" loealities has been attributed to this cause. There are also here, of course, the factors of reduced food-supply and corer.

On the overflowed pasture lands in the vieinity of Los Baños, Mereed Comty, the herds of eattle do some destruction to nests of ducks and shore birds by trampling (II. C. Bryant, 1914e, p. 237). In this particular locality, also, the raising and lowering of the water accompanying the process of irrigation, alternately inmolates nests and exposes them to discovery by predatory enemies such as racoons and skunks.

Where ducks, quail and pheasants (see p. 33) resort for nesting purposes to grain and alfalfa fields there is plentiful testimony to prove that many nests are broken up when mowing-time coincides with the breeding season of these birts. In some instances the incubating bird has been actually ent to pieces by the knives of the mower.

During the extensive campaigns against the spread of plague by rodents, statements (no doubt considerably exaggerated) lave been given publicity, to the effect that many game birds have fallen victims to the poison used. Monruing Doves and Band-tailed Pigeons in small numbers have been found dead on poisoned gromd. As regards quail, tests made by the United States Public Health Service show that this bird, at least, is not easily susceptible to the action of strychnine. Pieree and Cleger (1916, p. 13) state that poisoned barley as used for 
ground-spuirrel cradication does not cause the death of California Valley Quail under natural feeding conditions.

Game birds are as a rule remarkably free from disease in California. Only one serious point of ontbreak is known to us, and waterfowl alone were here affected. In 1908, an epidemic broke out among the water birds (especially dueks) in and around Tulare Lake, Kings County, and Buena Vista Lake, Kern County (see Clarke, 1913, pp. $214-226$ ), and this has recurred during the summer and fall months of each year since that time. The disease first appear's during the hot summer weather, about August, and has rum its course at the advent of the cooler weather of October. It then rather suddenly abates, and no more sick birds are to be found until the following summer. It has generally, though not always, been confined to areas of stagnant water.

Most of the ducks that die are fat and have the appearance of being in normal condition. The first symptoms of the disease are loss of the power of flight: following this, the ability to walk is lost. Finally in the later stages, the sick birds sit with their breasts on the ground or mud, and after a few days, during which time a diarrhoea develops, they die, apparently of paralysis.

During an investigation in 1913 eareful counts and estimates were made of the numbers of dead ducks on Buena Vista and Tulare lakes. A conservative estimate for the former lake was 15,000 , and 25,000 for the latter. Thus a total loss of over 40,000 ducks was sustained in 1913, in the two counties of Kings and Ker'n, besides many hundreds of other water birds.

Experiments carried out there seemed to prove that the water in Tulare Lake, which is heavily charged with mineral matter, is responsible for the death of the birds. However, during other years many birds have been found dead in this and some other lakes when the water was comparatively fresh. The prace where infection occurred during those years is not definitely known, but is currently supposed to have been near where the birds were found dead.

Investigations by the United States Biological Survey (Wetmore, 1915, pp. 6-7) of a similar disease occurring around Great Salt Lake, Utah, also indicate an alkaline poison, the exact nature of which is yet to be determined. As was the ease in California, a large percentage of affected ducks recovered when placed on fresh water. The increased leaching of the adjacent lands by irrigation may be responsible for all these outbreaks. The only remedy yet suggested is to capture the sick birds and place them on fresh water.

We know of no other instances of game birds dying as a result of disease except quail which in eaptivity often fall victims to a "quail disease." This disease is known technically as coceidiosis. No cure 
is known, but good sanitary surroundings appear to be a preventative. There are no recorded instances of the disease becoming epidemic anong wild birds in this state. Although quail and other game birds are often infested with tape worms and romel woms, these parasites seldom, if ever, cause eleath directly.

The array of evidence above given shows beyond question that waterfowl and mpland game birds have both on the average lecreased by fully one-half within the past forty years. Very likely the rednetion totals much more in many individual species. Obviously, from the nature of the data which we have been able to assemble, aceurate estimates of comparative population are now impossible to give. Certain it is, that one gamo species has totally disappeared from its former range in California-the Colmmbian Sharp-tailed Grouse, in the Nocloc region. The Trumpeter Swan, if it ever ocenred here in sufficient numbers to rank as of game value, must also be set down as vanished. Some other waterfow and shore birds, which are so seriously depleted as to warrant alarm as to their persistence, are the Wood Duck, Ringnecked Duck, Redhead, Mountain Plover, and Long-billed Curlew.

The causes of this decrease are many and diverse, but all are due in last analysis to the settlement of the state by the white man. Some of these factors, such as excessive hunting and sale of game, are subject to control ; but others, such as reclamation of land, and overhead wires, are inevitable. The reduction in natural enemies by man's agency is a factor farorable to some game birds. But this must not be oreremphasized; bminting has intensified the deerease far beyond any balancing compensation from this factor. The game supply of the future must rely upon correct induetions based upon careful study of the entire problem, and final adoption of those means which it is forml feasible to employ. 


\section{THE NATURAL ENEMIES OF GAIIE BIRDS}

Many people have mistaken ideas regarding the general effeet of predacious animals on wild game. It is true that certain hawks and predatory mammals prey extensively upon game, but that they constitute the most important or eritieal faetor in redueing the numbers of individuals of gamt species we believe to be untrue. We need but point to conclitions as they exist in the wild to prove that this idea is erroneous. Where game is abundant predaeious birts and mammals are also abundant; where game is searee (due probably to a laek of food) predaeious birds and mammals are also searee. In other words, the number of predaeious animals is controlled by the supply of game. It can be seen, therefore, that a certain balance exists between wild gane and its enemies. Forbush (1912, p. 5+1) says: "It is the mission of the native natural enemies to help preserve birds, to keep them up to full efficieney and at the same time to prevent their increase in numbers beyond the limit of safety."

Predacious birds and mammals are to be looked upon as eonstitnting but one of many factors which affeet the numbers of game birds and mammals, and eare should always be taken that the importanee of this factor be not overemphasized. No attempt is being made here to unclerestimate the aetual damage to game eaused by any of its enemies, but rather to point out that there is a tendeney among many people at the present time to interpret wrongly the relative importanee of the different eategories of enemies.

However, at times and under more or less artifieial eonditions, control of enemies may be advantageous to game birds. Destruetion of predaeious animals is of value when they have beeome abnormally abundant due to a destruction of their enemies, or to their taking adrantage of the inereased food supply furnished by eultivated erops. The crow in the eastern United States is a ease in point. In Afriea, where numerous game refuges have been established in the Transvaal, it has been found that the systematie destruetion of eertain predacious birds and mammals has been distinetly benefieial in inereasing game.

Destruetion of mountain lions here in California has tended to eliminate one of the ehief factors in the deerease of deer and henee inereased the supply of the latter animals for the use of man. But in most attempts at eontrol, many really, though indireetly, beneficial animals are destroyed, while some of the worst enemies of game go free. The reason for this is that in but few instanees ean friend and foe be so easily distinguished as in the ease of the mountain lion. It is very easy to jump to a eonclusion in regard to the effeet of any 
given preslator on game. But that such a conclusion is the correct one ean be decided only after careful and far-reaching study of the problem. We would urge extreme caution in declaring sweeping lestruction of smpposed enemies of game hirds, except in the few well established eases. It is hoped that the following comments on some of the enemies of game in California may be of help to those who wish to distinguish foe from friend.

'Three typical bird-destroying hawk are mprotected by law in this state. All three of them prey systematically upon. game and inseetivorous birds. The best known of these hawks, and apparently the most destructive, because of its habit of feeding mpon Valley Quail, as well as poultry, is the Cooper Hawk, or "bullet hawk," as it is commonly called. This bird has a dark-barred tail as long or longer than its body, and in silhonette against the sky, in flight, the wings show bluntly romnded at the ends, and the tail also is rounded rather than squarish at the end. The bird flies with a quick darting flight and nsually perches in some nearby tree, or flies along throngh the trees, suddenly darting down and carrying off its prey with lightning speed. It does not as a rule soar abont in plain sight overhead. This is the real "ehicken hawk," and should be carefully distinguished from the larger Red-tailed Hawk. The latter species sails about high in the air like a buzzard, but its food consists almost entirely of ground squirrels. In the hand these two birds ean readily be distinguished hy a comparison of their feet. The Cooper Hawk has very slender legs and feet, whereas the Western Red-tailed Hawk has very heavy legs and feet.

A near relative of the Cooper Hawk, called the Sharp-shimmed Hawk, is elosely similar to it. The main points of difference are the much smaller size of the Sharp-shimned, and its square-ended rather. than rounded tail. In flight as well as in habits the Sharp-shimned is practically a small edition of the Cooper Ilawk. It is to be seen beating along over the brush and trees, especially along streams, and not infrequently alights on the limbs of trees beneath concealing foliage. In these situations the Sharp-shimned Hawk preys upon small birds of every kind and will not infrequently help itself to young gane birds and to ehicks in the barmyart.

The Duek Hawk, a true faleon, is the most powerful of the three species nuprotected by law and is able to attack birds even as larege as dueks. This hawk is said to kill more birds than it ean eat, apparently killing for the pleasure it finds in the sport. The Duck Hawk is not now very common and is found ehiefly abont marshes and along the sea coast where it preys upon water birds. Fairly large size, sharply pointed wings, a slaty back, and black pateles on the face help in identification. At Santa Cruz Island in November, 1907, Linton 
$(1908 b, 1 \% .127)$ olsserved a pair of Duek Hawks eapture a Red Phalarope. Black Turnstones were considered the favorite prey at one locality on the island.

A fourth speeies, the Western Goshawk, which is rare in California except in the extreme northern and northeastern portions of the state, should also be ranked among the harmful speeies. It is similar in form to the Cooper and Sharp-shinned hawks but is of mueh larger size. The adults have bluish gray baeks and gray-and-white breasts, while the immatmre birds have brown backs and streaked bellies. Where it is abundant the Goshawk is known to do serious damage to grouse and quail.

The two members of the cat family found in California, the mountain lion, "puma" or" "cougar," and the wildeat, "bob-eat," or "lynxeat," are both enemies of game. The mountain lion is aeeused on good evidenee of killing an average of at least one deer a week throughont the year. In addition it probably kills the larger game birds. It ean readily be seen, therefore, that the systematie destruetion of the mountain lion means the saving of a large number of deer, and perhaps some game birds. The wildeat feeds habitually mpon birds, and it is doubtful whether the number of rodents eaten compensates for the destruetion of quail and other valuable birds. There is eonsiderable evidenee that the wildeat is, in eertain loealities, a very important enemy of quail. For instance, a wildeat killed at Petaluma, Deeember 29, 1908, eontained a recently eaught California Quail (Dixon, MS).

These, then, are the prineipal undoubted enemies of game birds in California. To the mammals might be added, according to loeal eireumstances and season, the weasel, skmnk, eoyote, and raceoon; but all of these, especially the first two, do considerable good by destroying small rodents and in most instanees probably do more good than harm. Before any of these mammals are killed an attempt should be made to determine whether or not, in the particular locality and as regards other interests than those of the game, they are doing more harm than good. Circumstances sometimes alter eases, however, and the systematic destruction of coyotes in Modoe County in 1916, because of the spread of rabies by them, was to be favored. Also, on occasion, individual animals, as when found destroying dueks' nests, should be destroyed. An acconnt of sneh depredations by a coyote in Sutter County is given by Neale (1916, p. 161). In eertain loealities raccoons rob the nests of ground-nesting birds. The breaking up of the nests of dueks and other water birds in the Los Baños district of the San Joaquin Valley has been attributed to these animals (H. C. Bryant, 1914e, p. 237).

The only bounty paid by the state on any of these animals is twenty dollars each for mountain lions. Several of the counties offer bounties 
on coyotes, and a few also on wildeats. Whether the bounty system is the best means of attacking the problem is still in doubt. It ean be justified only when the animal on which the bounty is paid is individually of great destruetiveness, and at the same time not so aburdant that the paying of bounties is too great a tax on the treasury. When the average hunter becomes able to distinguish between friend and foe there will probably be a large enoingh toll of predacious birds and mammals taken voluntarily by him to enable game to hold its own, without resort to bounties or other special means (see lorbush, 1916, p. 56$)$.

There is danger that some of the introduced game birds may become enemies of native game birds, not so much because of any predacious habits of the former or of their pugnacity, as because of usurpation of food supply. This matter has been covered in our chapter" on "History of attempts to introduce non-native game birds into California" (p. 43). Althongh it has been suggested that the Ring-neckerl Pheasant would not only appropriate the food supply of Valley Quail but also by its pugnacity drive it ont of its habitat, what little evidence is at hand points the other way. The Valley Quail ean apparently hold its own, and it is even said to drive out the pheasants (Neale, 1915, pp. 153-155). What effect the few introduced game birds have actually had on our mative species we are mable to state.

The gromnd-foraging Roadrumner has been aceused of destroying the eggs and young of Valley Quail. An attempt to obtain light on this point brought little positive evidence. The investigation included a review of every published reference to the food of the Roadrunner in California, as well as the analysis of eighty-three stomachs of Roadrumners taken in southern California (H. C. Bryant, 1916). The investigation showed that, although the Roadrumner may oceasionally attack small birds, its bird-eating and egg-eating habits have been exaggerated, and that the killing of this bird as an injurious speeies is wholly unjustified. It is only in very rare eases that young quail are molested. The benefits conferred by the Roadrumner in the lestruction of insect and rodent pests phus its great esthetic value leave a balance greatly in favor of the bird and mark it as a benefieial rather than injurious speeies. Here, again, decisions were jumped at, which subsequent careful study failed to support.

Among reptiles, a few of the snakes are commonly believed to rob the nests of birds. There is no doubt that individual gopher snakes do resort to a diet of (qual 's eggs when opportunity offers. Four wellattested cases of this sort are on record (Hoover, 1899, p. 75). But here, as with most preclators, the normal or usual toll, of the species as a whole, should be taken into aceonnt, and the service of this snake as a rockent destroyer compels favorable consieleration. 


\section{THE GLN CLUB IN CALIFORNIA}

The last twenty years has seen a great change in the attitude of man towarls wild game. In the early days game was so plentiful that no thought was taken for its preservation. As a result it was slanghtered without restriction. Two instances are typical. One is the well known case of the Passenger Pigeon in the East; the other a less known and much more recent one relating to geese in California. Here more than two hundred geese have been killed within a few hours by a single hunter using a large-bore gun.

Now that game birds have become so searce that they cannot be secured with ease in large numbers, a reaction has set in, and the public at large does not countenance such wholesale slanghter. In consequence restrictive laws have been enacted. A further, less formal, step has been taken locally in attempts to attract birds in various ways. These efforts are at present ehiefly confined to so-called gun clubs, and much ingenuity, as well as considerable sums of money, is used to bring about the desired results. 'The process of game extermination is being succeeded on a small scale by game conservation.

There are many problems which must be earefully worked out in determining methods of game conservation. Of first importance are those which bear directly on the survival of the species: market hunting, natural enemies, discase, safety of breeding places, and native food supply. Other problems must be considered from the standpoint of the citizen-public rights to wild game, equable legislation, and the like. There is one important problem that must be looked at from both points of view, for it intimately concerns both the bird and the citizen. This is the problem of the private and club game preserve, best illustrated at the present time by the familiar "duck club." For" a long time the duck preserve has been an object of contention among sportsmen, the outsider maintaining that the preserve curtails his liberties by usurping all the available shooting grounds and hence the birds, and the clubman defending his point of view by pointing out the advantages to the duck population afforded by his preserve. In fact, the gun-club question must take first rank, if the importance of the problem be judged by the amount of protest raised against such preserves.

Every one of the conditions which assail the native game population and which are due to the settlement of the country by man, such as the effacement of breeding, feeding, and loafing grounds for ducks, the replacement of native vegetation by introduced plants, the destruc- 
tion of game, for food or sport, the introduction of exotic birds and mammals, and the introduetion of diseases, are all affected by the preserve. Thus we see that the problem is a complex one and needs careful treatment. The present brief diseussion can be considered as only a very inadequate contribution to the subject.

Preserves are really of three kinds-publie, club. and private. The first, a far different type from the other two, is exemplified in the state game lefuge now being established in different parts of California, and of the utility of this there cam be no question. Let us examine somewhat eritically the elub and private preserves as they 'xist at the present time.

Clul preserves are tracts of land, either rented by groups of men or owned by then for the common advantages they offer for exclusive hunting. Every degree of equipment may be found, from a rented house-boat on some slough at the edge of a bay marsh to an elaborate shooting lodge situated on a valuable traet of land owned jointly by the club members. A representative instance of this last trpe is the Empire Gun Club, which eonsists of about twenty business men of San Francisco, and whose holdings are loeated along the Elkhorn Slough, near Castroville, in Monterey County. The land is largely marsh, such as is suitable for ducks, but some of the adjoining hill land affords favorable ground for quail. The improrements consist of a house for the keeper, who patrols the grounds the year round, and a substantial clubhonse for the aecommodation of the members at shooting time. Expenses are met by dues and assessments.

The most necessary improvements eomeeted with this type of preserve are those eoncerned with the furnishing of attractive places for the ducks. These eonsist eliefly of a number of fresh water ponds made by eonstrueting levees and flooding the enelosed land with fresh water. This water is piped from springs, or pumped in from wells. In a short time the fresh water drives out the salt marsh plants, sueh as "pickle wred," and their place is taken by a better type of regetation. The ponds are kept free from rank or undesirable growtls, and are in other ways made attraetive for the more desirable linds of ducks. An effort is made to keep the ponds deep enongh to attraet Sprig, rather than Spoonbills or other less desirable clncks, which prefer shallower water. The ponds are baited twice a week. Wheat, whole corm, and maize, are used to the amount of a earload and a half each year. The slough itself affords exeellent Canvasback and Bluebill shooting during the latter part of the season, so that the elub is irleally situated from the standpoint of the hunter.

The rules of the elub are few but well observed. Shooting is allowed on two days of each week only-Wednesday and Sunday. The use of pump gums and automaties is prohibited. Trained dogs are 
kept for retrieving. Blinds are chosen by lot, and a regular order followed in rotation throughout the season. Each bag is recorded by species in a ledger, so that the shoot for each year sinee the organization of the elub can be aseertained. It is of interest to note that in the twelve years of this chub's history there has been no marked diminution in the total ammal bag. There has, howerer, been a ehange in the make-mp of the hag in that certain larger dncks are now taken in smaller numbers (see table 1, p. 10).

This partienlar elub is looking forward to the eomplete reelamation of its land in the more or less distant futmre; in other words, the property will sometime be sold for agricultural purposes, so that the initial outlay is looked at in the light of an investment. It is to be observed that the large sums of money now invested in duek preserves, although primarily for sport, are secondarily for the purpose of obtaining land eapable of reelamation. Whenever the growth of the country demands it, these lands will be available for agriculture.

Differing but slightly in the method of operation is the preserve owned by only one individual, or but two or three. Let us take as an example that owned by Mr. W. W. Richards at Cygnus, Solano County, one of twenty or more shooting preserves on the Suism marshes. The equipment is similar in a general way to that of the elub-owned grounds just deseribed. The loeality offers slightly different conditions so that we find the ponds made both by exeavation and by the building of levees, the slightly braekish water being admitted by means of head gates at high tide. A further step is taken to attraet ducks by flooding large areas which are diked off to afford loafing and feeding grounds. In addition to grain, "grit," or crushed quartz, is put ont. L'seless vegetation is burned off and every farorable eonclition maintained for the growth of those native plants which furnish food for dueks. In the ponds thrives the California femel pondweed (Potamogeton pectinatus), sometimes locally known as "nutgrass," which is the best of the natural food plants for many kinds of dueks, both surface feeders and diving ducks. An attempt has been made to introduce Vallisneria, the famous duck food of the Atlantic coast, but this has proven unsuceessful.

The blinds used on the preserves are usually of two kinds, the barrel or box blind eonsisting of a large barrel or box smm nearly to the level of the ground, and the platform blind whieh is a wooden platform surrounded by high brush or tules. These blinds may be elaborately equipped to insure the comfort of the occupant as well as to render his loeation invisible to the game. The hunter wears inconspienous clothing and is careful not to make quick movements or to allow. the sun to shine on his face when dueks are flying overhead. Calling the dueks in by imitating their eall-note is a method eonsidered "unprofessional" on some preserves, but is in common use on others. 
Woolen decoys are always employed. Sometimes they are placed on the pouds previonsly to the day's shoot, at other times put out by the hunter himself when he goes to his blind. The decoys are put out in groups, each species by itself, and each individual decoy is anchored by a leaded string. About half a dozen each of Greenwinged Teal, Sprig, and Wirlgeon are sufficient to attract dneks of these species, but for C'anrasbacks a larger number of decoys is used.

The storm of protest which arises from the unattached hunter tends to place gun clubs in a position which our own investigations fail to substantiate. It is true that the very best hunting grounds are preempted by the gum elubs. Ant, in light of the fact that the game of the state belongs to the people as a whole and not to any one individual or gromp of indiviluals, this would seem radically opposed to the principle of demoeracy. Yet there is something to be said even on this score in defense of the gun chub. One stock argument, and a valid one, that is repeatedly propounded at the present time in eonnection with other natural resources, is applicable here as well. It concerns a fundamental economic relationship. The expenditure of large sums of money for any sort of commodity (commercial or recreative) is considered helpful to the whole social body. The establishment and the npkeep of the preserves requires the employment of large sums of money which would not otherwise be spent in the same field of labor. Invested capital is increased thereby. For instance, on one preserve of which we know, the cost of the bait used in a single year was greater than would have been the cash value that could have been realized if all the ducks shot had been sold at current prices on the market: There is a statement current on the Suisun marshes that the ducks there shot cost their weight in silver. In other words, a duck shot on a preserve is worth vastly more than one shot on open ground, beeause of the expense incident to its killing. Surely this is a point that must in all fairness be considered.

If we stop to think, it seems remarkable that this adverse point of view should be entertained regarding the duck elub, when the same arguments are seldom applied to the roughly analogous ease of the antomobile. We hear little complaint against the man who is able to own an automobile and therefore able to get a disproportionate amount of use out of the good roads which are supported by erely taxpayer. Nor do we find people eritieising the national govermment for maintaining Yosemite Valley as part of a national park in spite of the faet that comparatively few persons ean afford to visit it. We simply have to admit the general truth that some men have superior advantages in many things-aceess to game included.

The following are the factors which are detrimental to, and favorable for, the duck population, and which are concerned with the pre- 
serve as it is being eonducted today. If we look at the problem strictly from the conservation standpoint the evidence is fairly in faror of the preserve.

\section{EFFECTS OF THE GUN CLLB ON OLR DUCK SUPPLI}

\section{DETRIMENTAL}

Concentration.-The best natural hoeation is selected and conditions male still more attractive for ducks. As long as there are any ducks at all, they will concentrate upon such favorable grounds. In other words, the preserve may be looked upon as hastening the decrease of the duck sulply because it lears to a continual concentration of population in a place where regular and heary toll is levied.

Heary toll.-On the preserve there is systematic hunting every favorable shooting day during the season, and under the best devisable conditions. Hence very large annual bags are apuropriated.

Marksmanship. - The highest type of marksmanship is always to be found on the preserve and this makes for limit bags.

Efficiency of fircarms. - The best grades and most expensive guns and ammunition are used.

Personnel.-The highest grade of intelligence is brought to bear on ways and means of procuring the lucks.
FATORABLE

Inereased and better feeding grounds.- These are secured by diking, flooling, and the construction of artificial ponds. Inereaserl breeding and loafing grounds are also furnished.

Maintenance of farorable grounds. Much land is appropriated and retained in the preserve which otherwise woukl be made unfit for ducks through reclamation for agrieultural and frastoral purposes.

Additional food.-Arlitional fool supuly is furnished in the form of bait, and by the enrouragement of native food plants.

Restrieted Inuting.-Hunting is often limited to but two days a week and to relatively few shooters.

Indiscriminate hunting precented.$\mathrm{By}$ a system of posting and patrol of lands undesirable hunting is eliminated. Illegitimate shooting during -losed season is atso prevented.

Refuge for ducks.-During the -losed season, on non-shooting days, and during rough weather, the preserve affords an ideal refuge for the birits.

Cripples not wasted.-The habitual use of trained dogs assures the recovery of practically all cripples, and thus lessens the total number of birils killer.

Most deadly grus not used.-On most preserves use of the pump gun and automatic is prohibited.

In our minds, the most important count against the duck preserve is not so much the preëmption of the most desirable hunting grounds, as the improved conditions offered to the ducks, which cause them to congregate at points where a severe toll is exacted. The mnavoidable concentration due to the reclamation of marsh land is undesirable 
enough; intentional concentration is to be still more deplored when advantage is taken of it, and excessive depletion results. The failure of many persons to appreciate the dininution in duck population is due chiefly to the fact of this concentration of all the ducks which under former conditions wintered over a great extent of territory, within a few localities made favorable to them by artificial means. The other factors concerned, such as the efficiency of the firearms used and the high degree of marksmanship, are really but supplementary to this more fundamental factor.

On the other hand, many conditions are afforded by the preserve which faror the persistence of our duck supply. Some of these serve directly to offset the detrimental effects of concentration. Probably the most important of these is the maintenance of favorable feedinggrounds which otherwise would be much sooner appropriated for agriculture. The provision of a refuge during the closed season and on non-shooting days, and the restrietion of hunting, also detract greatly from the evil effects of concentration. In fact, if we study the problem entirely from the standpoint of the effect on the duck population, we are led to the conclusion that the duck preserve is an institution which at the present time is to be fostered rather than discouraged. With plenty of available natural feeding grounds for ducks this judgment would have to be reversed. But present conditions certainly justify the conclusion.

It would appear that the institution of the well regulated gun club, occurring, as it has, at a critical stage in the adjustment of artificial to natural conditions, is to be looked upon as a propitious rather than as an adverse factor in the conservation of our duck supply. Whether or not, as further changes result from increased human population. this valuation of the preserve will persist, remains to be seen. 


\section{HISTORI OF ATTEMPTS TO INTRODUCE NON-NATIVE GAME BIRDS INTO CALIFORNIA}

Even before our native game birds had become so far reduced in numbers as to alarm greatly those most interested in their maintenance, attempts were made to introduce species from other states and countries. This was done for a variety of reasons. Some persous believed that by increasing the number of kinds of game birds we could increase the total number of individuals; others thought that foreign species would prove more prolific than our native kinds; and some hoped that species "bigger" and finer" than any of our native ones could somehow become established here. But the proponents of these several hypotheses were all doomed to disappointment. The faulty reasoning which underlay these notions will be demonstrated later. First let us review the history of the introduction of alien birds into California.

The first attempts to introduce foreign birds into the United States were made more than a hundred years ago. Since that time, and for one reason and another, efforts to establish exotic species in this country have been numerous. A brief review of some of these attempts shows that there is great contrast in the results obtained in different places. On the one hand stands Oregon's extraordinary success with the Ring-necked Pheasant, a suceess which has stimulated interest in acelimatization throughout the United States; on the other hand we find many failures. For example, Illinois has spent many thousands of dollars in an almost wholly futile attempt to stock the state with pheasants. Between these two extremes there have been all degrees of success and failure.

Neither the large expenditure involved, the danger attendant upon the introdnction of a species which might later prove undesirable (as did the English Sparrow), the possibility of replacement of a native species by a foreign one, nor the possible introduction of diseases fatal to ou native game, seems in any way to have halted the mad rush to introdnce and attempt to establish foreign game birds. State after state has carried on haphazard and poorly managed experiments, in most instances without paying any attention to the experiences of other states. Few seem to have codified the knowledge concerning acclimatization as it applies to game birds, and those who have done so have found the effort an exceedingly difficult one because of the incompleteness and unsatisfactory nature of the records. 
The suceess of Oregon in introducing pheasants, and the similar success which attended the introdnction of exotic fishes into the waters of California have both been incentives to experiment in acelimatization with game birts in this state. Within eight years after shad had been planted in the Sacramento River at Tehama they became so abundant that thousands were caught and sold in the markets of San Franciseo. Carp becane numerous soon after they were planted, and the same was true with blaek bass. It is not to be wondered at that the same sort of results was looked for by those who songht to restock the depleted game covers of our state.

More than a quarter century has passed since the first private attempts were made to introdnce foreign game birds into California, and more than two decades have gone by since the matter was given serions consideration by the State Board of Fish Commissioners, the predecessor of our present Fish and Game Commission. In view of the length of the period which has elapsed since then, and the number and extent of the trials which have been made, it seems that a time has arrived for reviewing the work performed, for judging the results obtained, and for attempting to find ont what will be the best course for the future in this direction. The present chapter aims to do this, and also to place data and materials for studying the problem in more detail than is here possible at the disposal of those who are most interested.

\section{Pheisints}

California's most persistent attempt to bring in and establish a foreign species appears in the case of the Ring-neckel Pheasant (Phasianus torquatus). The earliest efforts to this end were made by private individuals, but unfortmnately the acomnts of these first attempts are incomplete, and it is probable that we have reend of only a small proportion of the total number of importations that were made. The first published statement we have been able to find which pertains to this subject is that made by Belding in 1890 (pp. S-9) in which he says:

Some years ago a flock of English pheasants was put out in the woors of Santa Cruz County, but nothing has been seen nor heard of them simce. Colonel Haymond of San Mateo has a number of these birds, English and Japanese, but he has had no sneress in raising them; when let out they sullenly disappear and nothing is seen or heard of them. Mr. Howard, near by, has experimented with the same bird. A few weeks since he informed me that his foreman told him he had seen a flock of twenty-two birds. The birds mentioned are the only ones experimented with. Certainly thus far the experiments are not a success. In Oregon they have met with great success, with both quail and pheasants. 
The Comntry ('lub of Marin County is known to have introduced "English" Pheasants prior to 1889 , lut the birds soon disappeared. W. E. Gerber, at one time a Fish and Game Commissioner, in 1904 hegan to propagate pheasants of several species on his country place, the Del Paso Ranch, near Sacramento. Ring-necked Pheasants were imported from China and Oregon and placed in charge of a gamekerper. Hundreds were reared and most of them liberated on the ranch, but all subsequently disappeared.

The following statement by Ars. Demmy, wife of Judge O. N. Denny who was instrumental in introdncing the Ring-necked Pheasant into Oregon, indicates that an early semi-official effort was made to obtain birds from China.

Before returning to the I'nited States, my hushand communicater with Mr. Redding [one of the commissioners] of San Francisco, asking him if he would like to have a shipment of game birds sent to California. Mr. Redling was very enthusiastic and maide all arrangements to take care of them on their arrival. He arranged with the Spring Valley Water Company of California, who were also in sympathy with the movement, ant who arranged to have the birds turned out upon their grounds. They sowed buckwheat seed in different places and promised that every facility for the feeling and comfort of the birds would be attended to. Between eighty and ninety birls were shipped, extreme care being taken so that they would reach San Francisco in good condition. The ship arrived at the wharf as the funeral procession of Mr. Redling was taking place. He had dier suddenly and no arrangements had been made to receive the birds. In fact, no one knew anything about it. The birds, of course, had to be taken from the boat, and, no one seeming to know anything about them, the sailors finally gave them away along the waterfront and some of them were sold to the eity markets. California never knew of my husbant's splendit gift, and the state received no benefit from it (Simpson, 1914, pp. 17-18).

The first consistent public effort was begun on March 16, 1889, when an appropriation of $\$ 2000$ was made by the Legislature to purchase foreign game birds for planting within the state and for protecting birds so planted. W. H. Shebley was sent to Oregon to procure Ring-necked Pheasants and obtained from farmers and others who were breeding the birds about 140 at ten dollars a pair. The pheasants were liberated in Monterey, Sacramento, Marin, and Nevada counties, and in some localities in the San Joaquin Valley. This constituted the first plant made by the California Fish Commission.

Further distribution of Ring-necked Pheasants by the Fish Commission took place in the spring of 1894, when sixty-seven of these birds were obtained and distributed in various counties of the state where it was thought they would thrive. The pheasants were placed in charge of citizens who had met the commission's requirements and built suitable aviaries. It was understood that all the birds prodnced 
from this parent stoek were to be liberated on public lands. Owing to the fact that the female pheasants would not incubate their own eggrs and that hatehing had therefore to be done by domestic hens, few birds were reared and liberated. A year or two later a number of imported pheasants were liberated in Santa Clara, Kern, and Tehama connties. In 1897, an agent was again sent to Oregon and 323 Ring-neeked Pheasants were obtained. These were distributed in five-pair lots to many different parts of the state. In 1898, 93 "Mongolian" (= Chinese Ring-neeked) and 150 "English Ringneeked" pheasants were purchased and liberated. Later, favorable reports stating that young birds had been seen eame from Humboldt, Santa Clara, and Flesno counties. Most of the "Mongolian" Pheasants were brought over from Hongkong, China, and were purehased for seventy-five cents each. ${ }^{1}$

During the next few years the commission was unable to secure pheasants from the Orient beeause of the fact that a demand had arisen for pheasants for table use on steamers stopping at Asiatic ports, and the resulting increase in eost was prohibitive. By 1906, interest had centered in the Hungarian Partridge, and attention was for the time withdrawn from pheasants.

When the State Game Farm was established, in 1908, a breeding stoek of Ring-neeked Pheasants was secured, and during the next few years hundreds of pheasants were reared and planted throughout the state. The largest distribution took place in 1912, when 1398 Ringnecked Pheasants were planted in twenty different eounties in the state. $^{2}$ The total number of pheasants liberated by the Fish and Game Commission up to 1916 was approximately five thousand. One or more plants have been made in at least thirty-seven of the fifty-eight eounties of the state.

More than twenty-five years have passed sinee Ring-necked Pheasants were first introdneed into California by private enterprise and more than twenty years sinee they were introdueed by the Fish and Game Commission. In this time the repeated efforts which have been made seem to us to have suffieiently tested the pheasant's ability to become aeclimated to Californian eonditions. The speeies should have become well established thronghont the state; but it has not done so. The birds are now reported as established in about twenty localities, but in seores of places where large plants were marle not a single wild pheasant is to be found at the present time. In certain loealities where at first they thrived, they eventually disappeared. Some have, of course, been killed by uninformed or malicious gunners; but in eom-

1 Calif. Fish Com., 1894, p. 29; ibid., 1896, p. 33; ibid., 1900a. p. 10; ibid., $1900 b$, p. 41 ; ibid, 1902 , p. 44 .

2 Calif. Fish and Game Comm., 1910, pp. 54-55; ibid., 1913, pp. 60-62. 
paratively few, if any, instances ean the total disappearanee of birds be attributed to this eause.

Loealities where Ring-neeked Pheasants are now known to exist in the wild, together with an estimate of the number of birds present in 1916, accorling to figures furnished by deputies of the Fish and Game Commission, are as follows:

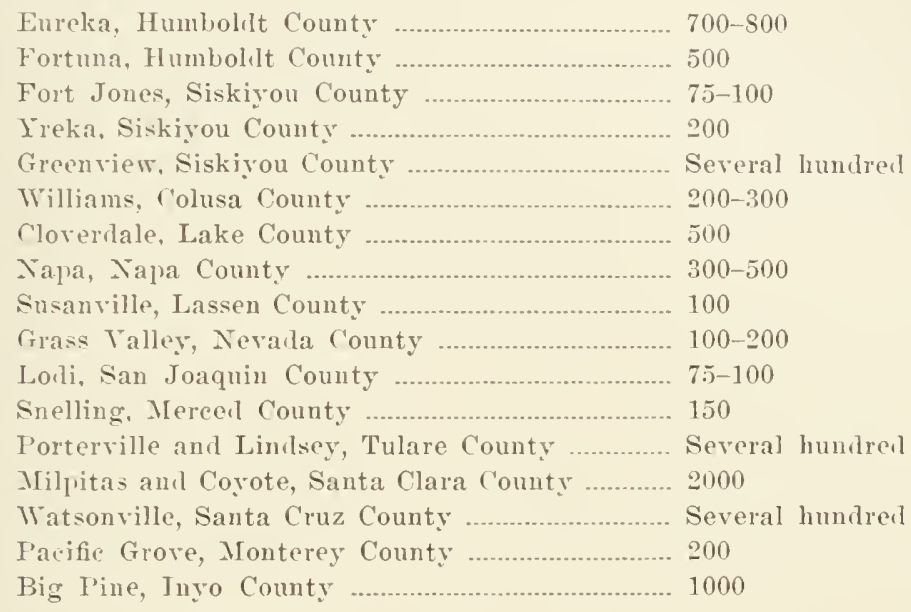

Reviewing their present status in detail, we find that Ring-necked Pheasants are now well scattered over the Santa Clara Valley, especially north of the eity of San José. Deputies I. L. Koppel and J. H. Hill saw about fifteen (not over four together) on or near the road between Alviso and Milpitas on one day in the fall of 1915 . During the previous summer Mr. Koppel saw a flock of between thirty-five and forty pheasants at the Katz place, between Berryessa and Milpitas. In 1912, the same observer saw a flock of at least one hundred and fifty pheasants south of Coyote. They ranged from one-fourth grown to adult birds. In August, 1913, two nests were discovered in a hay field near the same town. The eggs were sent to the Game Farm where they were snceessfully hatehed. In May, June, and July, 1916, no less than a dozen nests of pheasants were discovered near Alviso and San José. Many of these were broken up in the mowing of alfalfa and hay fields. Sixty-three eggs in good condition were taken from these nests and sent to the State Game Farm. Nests and broods of young were also observed near Coyote. The above observations, coupled with the breeding records, show that the Ring-neeked Pheasant may be considered fairly established in the Santa Clara Valley. It was from this same section that the first eneouraging reports were received more than twelve years ago, after fifty birds had been liberated near Coyote Lake. All of the loealities mentioned in this paragraph are in Santa Clara County. 
Mr. J. S. Hunter reports that he saw two hroods of young and several adult pheasants on the Forgeus Ranch near Williams, Colusa County, in Jume, 1916. The birds in this locality appear to be thriving.

The inerease in number of pheasants in Owens Valley, Inyo C'ounty, has been such as even to lead to some eomplaint of depredations in grain fields.

On April 22, 1914, Wall (1915, p. 59) found a wild pheasant 's nest with twelve eggs at the edge of a swamp near San Beruardino.

The Macomber Ranch, at Paicines, San Benito County, has been stocked year by year with hundreds of propagated birds, and pheasants are now reported as abundant throughout the neighborhood of the laneh.

The present writers are frank to say that their own field experience inelines them to the belief that most of the estimates above listed are more or less padded; and it seems to us probable that there are less than 15,000 wild birds all told in the state at the present time. In spite of the favorable nature of the reports, pheasants are nowhere considered to be abundant enough to warrant an open season or even to give promise of the possibility of an open season within the near futme.

Attempts to rear fancy breeds of pheasants, such as the Reeres, Lady Amherst, Swinhoe, Bohemian, and Copper, in California, have mostly met with failure. The Golden and Silver pheasants, alone, have been successfully reared in eaptivity. A few of these, from the State Game Farm, were liberated on Goat Island. San Francisco Bay, in 1915 .

The attempts to acclimatize pheasants in other states have met with varied results. Oregon stands ont as the one state which has been really successful. From twenty-six Ring-necked Pheasants imported from China in 1882, and planted in the Willamette Valley, the whole state west of the Cascades has been stocked (Shaw, 1908, pp. 12-15). By 1892, pheasants had become so abundant that an anmul open season of two and one-half months was declared, and 50,000 birds were reported to have been killed on the opening day. In 1896, 10,000 pheasants were marketed within a single month. A short open season on eock birds still prevails. In Washington and British Columbia the Ring-necked Pheasant is also well establisheel.

On the other hand, many eastern states have had little or no success in establishing any species of pheasant. The ease with which the "English" Pheasant could be procured has led to the importation of this bird for stocking purposes in the East, rather than thr Chinese Ring-necked Pheasant. Illinois has spent many thousands of clollars in attempts to stock the state, but the results to late have been alto- 
gether disappointing. Maine, New York, New Jersey, Ohio, Indiana, and Mimnesota have had similar experiences. Massachusetts imported pheasants from Oregon as early as 1859. The birds established themselves rapidly, an open season being soon deelared; but they failed to maintain their initial vigor. Oklahoma planted thousands of English Pheasants, and between 1910 and 1913 distributed 20,000 pheasant eggs to per'sons who pledged themselves to hateh, rear, and liberate the birds when mature. In spite of this endeavor few, if any, pheasants are now to be foumd in Oklahoma. In practically all eases, promising reports were receivel during the first year after planting; but with the second year reports were less encouraging, and by the third year the birds had disappeared.

It is seen, therefore, that California's experiences with the Ringnecked Pheasant have been somewhat intermediate between the utter' failures of eastern states and the marked snceesses of Oregon, Washington, and British Columbia.

\section{Hengarian Partridge}

In 1905 attention began to foens on the Hungarian, or common European, Partridge (Perdix perdix). For a time attempts to proeure birds for planting here faiłed. Finally W. E. Gerber suceeeded through his personal efforts in purchasing in Hungary and shipping to Cahifornia, fifty-four of these partridges. Half of the birts died in transit; the remainder upon arrival were placed in an aviary on his raneh near Sacramento (Calif. Fish Comm., 1907, pp. 64-65). No success attended the effort to propagate the birds in eaptivity; in fact only two eggs were laid. The birds were finally liberated, but nothing further was heard of them.

In the spring of 1908 the Fish and Game Commission purchased, from eastern game dealers, for stocking purposes, 395 Hungarian Partridges, and in the following year 2,127 more. These birds were planted in lots of 20 to 50 in more than ninety localities in the state, from San Diego County to Siskiyon County and from sea level to high in the mountains. During the same year 65 Hungarian Partridges were received for propagation purposes at the State Game Farm; in 1910, 993 were received there, and in Febrnary, 1912, 24 more. Notwithstanding this large breeding stoek, not a single young bird was reared at the Game Farm. The birds died off rapidly, and by 1914 not one remained. During the first year after planting, broods of young were reported to have been seen in many parts of the state, but such favorable reports soon ceased. As an example of the result of California's attempts to establish the Hungarian Partridge we quote a report from George Neale: "About the year" 
1910 I received a small shipment of Hungarian Partridges from the Fish and Game Commission. I liberated these hirds on the Haggin Grant about eight miles from Sacramento. Abont a month after the liberation I saw one male bird. This was the last scen of any of them." Indeed, in the attempt to establish the Hungarian Partridge, (alifornia has sacrificed over 3,500 birds costing over $\$ 3.50$ each.

A recent experiment under private auspices is that of King Macomber who, in 1914, imported fifty pairs of Hungarian Partridges and confined them on his ranch in San Benito Connty in a large ontdoor aviary extending over abont an aere of natural cover. Small rodents were said to have destroyed the few eggs laid in 1915, but several clntehes of eggs are reported to have been deposited in 1916 .

In contrast with the failure to aeelimatize this speeies in California and also in several eastern states is its apparently suecessful establishment in British Columbia. In 1915 an open season of one month was deelared, and a large number of birds was killed. Despite the toll which is expected to be taken each year, it is thought that the birds will eontinue to increase.

\section{Wild TurkeY}

As long ago as 1877 turkeys (Meleagris galloparo. subspecies?) wer introduced on Santa Cruz Island. This was done at the instance of Judge J. D. Caton. The two male and four female birds which were placed there produeed sixty-one young the first year and 120 the seeond. It was reported that the birds gradually decreased in size until the males which normally weighed eighteen pounds weighed no more than six pounds (Caton, 1887, pp. 350-354). No reeent visitor to Santa Cruz Island has reported the presence of wild turkeys there.

In March, 1908, W. E. Tan Slyke of San Bernardino was detailed by the Fish and Game Commission to proemre from Mexico as many wild turkeys as could be obtained in four montlis. He delivered 22 turkeys and 11 "ehachalaeas" at San Bernardino on June 15, 1908. They were liberated in two places in the San Bernardino Momntains at an altitude of about 4,000 feet. Eneouraging reports were reeeived from these plants, and a shipment of thirty young turkeys which were raised at the State Game Farm was made to the same locality in Angust, 1910 (Calif. Fish and Game Comm., 1910, p. 57). Nevertheless naturalists who visited these mountains in the summers of 1915 and 1916 failed to find any trace of turkeys.

Mr. Van Slyke was engaged again in Oetober, 190s, to proeure additional stock for breeding at the Game Farm. He slipped 26 birds, which eost elose to fifty dollars each. Their high eost prohibited 
further importations. From this stock there were raised at the Game Farm in the spring of 1909 more than one lumdred strong young birds. Of these, 48 were sent to Wawona and liberated in the southern part of the Yosemite National Park. Conditions seemed favorable and the birds were subsequently seen on various oecasions, but 110 increase in thein numbers was noted, and they all finally disappeared.

Thirty-four birds were sent to Sequoia National Park, Tulare County, in November, 1909. In February, 1910, Walter Fry, aeting superintendent of the park, reported finding a nest with five eggs; in Mareh. two nests, one with 11, the other with 16 eggs. On March 21 he reported the wild turkeys to be doing finely. One hen had seven young birds. On May 21, many tracks of young birds were noted. Inder date of July 14, 1910, referring to that season's shipment, he said: "Wild turkers were this day liberated in the Sequoia National Park at the mouth of the Marble Fork of the Kaweah River. They were in gool condition and no losses were sustained."

During the season of 1910 more than two hundred young wild turkeys were leared at the Game Farm. Of these, eighty-five were sent to the Sequoia National Park and ten to citizens of Porterville, Tulare County, who liberated them in a particularly favorable section near there. In 1911, five wild turkeys from Virginia were added to the breeding stoek at the Game Farm, but only a few birds of this Iatter race were reared. Propagation of wild turkeys was finally abandoned in 1913 after the larger part of the breeding stoek had died from blackhead.

There are reports to the effect that when liberated many of the wild turkeys reared at the Game Farm sought some nearby farmyard and there mingled with the domestic stock. Reeent reports from the Sequoia National Park indicate that some of the wild turkeys in the park are semidomestieated; they have become very tame and forage near the camp of the Mount Whitney Power and Electric Company. Another band, which appears to be firmly established near the junction of the Middle and Narble forks of the Kaweah River, is very wild.

From the foregoing accounts of the introduction of turkeys into California there is one outstanding inference to be drawn: the conditions in the localities where the birds were liberated were not suited to the stock used.

\section{Bов-WHite}

Some of the first attempts to introduce non-native game birds into California were made with the eastern quail, the Bob-white (Colinus virginianus).

Mr. Ramon E. Wilson, of the California Sportsman's Association, kindly furnishes the following [information] concerning introduced game birds; date, 
Oetober 12, 1855: "Our efforts in that direction have resultel in failures, except as 1 will state. Mr. Estee, some rears ago, placed two dozen bob-whites on his farm in Napa County. Every precaution was taken to proteet them from hunters, and they were carefully looked after. They all soon disappeared, the theory being that they were destroyed by vermin. I learn that last February some of the same kind of birds were placed on the farms of Mr. Miller, Mr. Samuel Rea, and Mr. J. J. Sargent, along Carmelero Creek, near Gilroy. It is said they have bred the past season, and their numbers materially increased. The experiments, however, from the length of time ean harlly be caller a success. . . . Some bob-whites were placed on General Bidwell's place near Chico, but I understand they have disappeared also. Bob-whites roost on the ground and are therefore unable to proteet themselves from the vermin which is so plentiful everywhere in California" (Belding, 1590, p. 8).

Between 1904 and 1906 fifty dozen Bob-white were brought into the state by the California Fish Commission. Two shipments eame from Miehigan, one from Massachusetts, one from Alabama, and the fouth from Texas. The birds wre liberated in lots of a dozen eaeh in a number of widely separated localities. In only one seetion, the Del Paso Rancho, near Saeramento, did the birds inerease. Fere two dozen were liberated and a speeial effort was marle to protect them by killing off the vermin and establishing a close season of a number of years (Calif. Fish Comm., 1907, pp. 65-66). George Neale reports that during the first few seasons after they were introdneed a number of nests were found. The increase was but temporary, for after four years not a single Bob-white remained in this loeality. Attempts to propagate the Bob-white at the State Game Farm likewise failed.

\section{Chinese Quill}

Beginning about 1900 large numbers of Chinese Quail (Coturnix japonica) were imported for restanrant purposes. Between 1901 and 1903, 16,609 of these quail were brought into the Inited States. Becanse the birds were used as a cloak for the sale of native game, the importation of the birds into ('alifornia was stopped by law. Before this law went into effect, large numbers of the birds were purehased by private breeders and were planted in various parts of the state. None of the birds are known to have survived. In 1903, a number of confiscated Chinese Quail were liberated by the Commission, and these, too, were seen but a short time. In 190t, ten dozen wre confiseated from a Chinese restaurant and liberated in Mendoeino County on a large traet of land where every proteetion was aceorded wild game (Calif. Fish Comm., 1904, p. 67 : ibid.. 1907, p. 65). No eneouraging reports were received, and there is no evidence that the birds here or clsewhere survived the first rear. 


\section{OTHER QLAIL}

Attempts to transplant our native species from place to place have also been made. For instance, the Gambel or Desert Quail (Lophortyx gambeli) found on our southeastern leserts, early proved incapable of withstanding the cooler climate and widely different conditions of the north, as is evidenced hy the following statenent by Belding (1S90. p. 8): "Some years ago some Arizona [D(sert] quail were put out near Folson, but they all soon disappeared, and nothing has been heard of them since." This failure did not prevent further attempts. An editorial in Westem Ficld (Anonymous, 1907, p. 208) reports that a large number of Ganbel Quail obtained in Arizona were liberated on the grounds of the Country ('lub in Marin County, but that in less than two years not one could be seen.

In January, 1912, at the instance of the California Fish and Game Commission. more than 700 Gambel Quail were trapped in Coachella Valley, in sonthern Riverside C'ounty. Three lnmolred were liberated in three different places in Los Angeles Comnty, one hundred in Orange Comity, and a similar number in V'entura and San Benito counties, while another humbleet was sent to the State Game Farm at Haymard.

All of the attempts to introduce the Gambel Quail into northern California have met with failure. Nor did suceess attend the effort to breed this quail at the Game Farm. All but three of the female birds died, most of them when containing eggs ready to be laid.

Early in 1904, Deputy H. T. Payne, of the Fish and Game Commission, was sent to Mexico to secule some of the quail of that country, believing that they wonld be likely to find congenial conditions in our interior valleys. About four dozen Elegant Quail (Lophortyx elegans) were brought from the State of Sonora, and were placed in seemingly suitable localities in California (Calif. Fish Comm., 1904, p. 67). The birds quickly disappeared and nothing was ever heard of them.

Acting on the current popular belief that "new blood" was necessary in order to prevent in-breeding and thus to stimulate increase, efforts were made in 1908-1909 to trap Valley Quail in sections where ther were abundant and distribute them to localities where their numbers had been greatly reduced. In 1908 about 2,000 Valley Quail were thus trausferred. At the same time efforts to obtain quail from Mexico resulted in the trapping of 1,500 birds (Talley Quail?) in Lower California. These birds were retained for a time in a public park in Los Angeles and subsequently liberated (Calif. Fish and Game Comm., 1910, p. 57). This practice has been abandoned of late years. Present knowledge discloses no scientific basis for the belief that in-breeding has any deleterious effect on rate of increase among wild species. 


\section{Ptarmigin}

In 190:3 and again in 1904 and 1905 , attempts were made to seciure ptarmigan from Alaska for planting on Mount Shasta and in the Lake 'Tahoe region. Although fifty pairs at $\$ 10.00$ per pair were contraeted for, not even one pair was fortheoming. From a seientific standpoint the ptarmigan seems to be a species likely to thrive on the high Sierra Nevada above timberline; the conditions there closely resemble those of the ptarmigan's native habitat and no other grouse or quail is present there with which it would have to eompete. The failure to make the trial is therefore partieularly regrettable.

\section{Fictors Concerned in Acchim.tizzition of G.ime Birds}

With the above review of attempts to acelimatize non-native game birds in California before us, let us try to determine what has prerented their suceess. Palmer and Oldys (1904, p. 27) name three factors which seem to them of special importance as obstacles to the introduction of foreign speeies.

Migratory habits, cost, and inadequate protection ... tend to restrict successful acclimatization of game birls. Little, if auy, suceess, has resulted from the introduction of migratory species and even in the ease of resident birds preference for certain kinds of food or cover enter largely into the question of success. Present prices of pheasants . . and of certain kinds of waterfowl are so high that they practically prevent the importation of these biris in large numbers. Most foreign birds require special protective legislation, but many of the laws thus far enacted are unsatisfactory.

Tested by these three factors we must admit that the birds selected for introduction into California show themselves to have been well fitted for the enterprise. The pheasants, quails, and wild turkers were all of non-migratory races, were not unreasonably expensive (with the possible exeeption of the turker), and were given special legislative proteetion. What, then, was at fault?

The inherent ability of a bircl to adapt itself to a new and different wild enviromment is the principal matter for consideration in any attempt to acclimatize it. This ataptability camot be suddenly altered by human effort. Man-controlled factors, such as eost and protection, are of secondary importance. The only remaining factor is that of external environment, and though we camot directly control it, we can do so indirectly by a proper selection of locality. Just as the Caucasian race of man thrives best in a certain restricted climatic belt the workd around, so do animal speeies prosper most under certain limited conditions of temperature and humidity. The most important single factor controlling the distribution of animal life in 
the world is temperature; and this applies fully to game birds. The chief reason why the Gambel Quail of the sontheastern deserts did not thrive in central and northern California was that the temperature conditions diftered from those to which it had been acenstomed in Arizona. The same is true of the Elegant Quail from Mexieo. Almost as great a degree of control is to be observed in the case of humidity as in that of temperature. For example, the Ring-necked Pheasant thrives in western Oregon where the relative humidity is greater than in most of California. But the places where these birds have thriven here, namely swamps and tule thickets, afford conditions of high hmmidity, which eompensate for the lack of general atmospheric moisture. The same factor was also probably associated with temperature in killing off the Gambel Quail which were introdneed into Marin County. Thus climate must be taken seriously into aceount.

Finally there are certain faetors which are inseparably bound up with the habits of the birds. These pertain to the type of eountry whieh the birds inhabit as it relates dircetly to their modes of life. Grimnell (1914b, p. 96) has pointed ont the following three factors in the last named category :

1. Kind of food supply afforded, with regard to the inherent structural powers of each of the animals concerned to make it available.

2. Presence of safe breeding places, adapted to the varying needs of the animals, in other words, depending upon the respective inherent powers of construction, defense and concealment in each species concerned.

3. Presence of places of temporary refuge for individuals, during day time or night time, or while foraging, when hard pressed by prestatory enemies, again correlated with the respective inherent powers of defense and concealment of each species involved.

An examination of the failures that have attended California's experiments in introduction show that these "assoeiational" faetors were probably of much less importanee than were temperature and humidity. Possibly the assoeiational elements counted for most in the cases of the Bob-white and turkey.

Critieism of the trials made in California leads us to two main causes of failure: laek of preliminary investigation of the points just. discussed, and improper methods of introdncing and liberating the birds.

In the introduction of foreign species three methods have been used: the immediate liberation of imported adult birds; the retention of adult birds for a time by responsible parties in aviaries, with subsequent liberation of either the adults or young reared by them; and lastly, the planting of young birds whieh have been reared in captivity on a game farm. Records show that the first named method, which was that originally employed in Oregon, has given the best results. 
A modification of this method, which consists in retaining the birls under semi-wild conditions until they have been partially acelinated, would probably produce still more satisfactory results; but this and many other feasible experiments have not heen systematically tried out.

'The liberation of birds which have been propagated in captivity almost always results in failure. The suecessful maintenance of foreign species in ariaries is no test of their ability to establish and maintain themselves when released in the wild. Unless bircls reared on a game farm ean be brought up under semi-wild conditions nothing but unfavorable results are to be expected when they are liberated. The complete change that ocenrs, in the nature of their food and their method of procuring it, and the presence of enemies which they have not encountered in captivitr, are circumstances which birds that have been propagated nnder artificial conditions camnot be expected to contend with successfully. Failure to recognize these prineiples has made many attempts at acelimatization unsuccessful. A state game farm can be of value to game breeler's as an experiment station for testing the practicability of methods of rearing gane in captivity : but its service as a means of rearing birds suitable for liberation in the wild has yet to be demonstrated in this state or elsewhere.

Here, then, are the factor's of climate, of food, of safe breeding places, and of safe cover from enemies, conditions that must be considered when an attempt to introduce an exotic species is made. These are precisely the same factors which prevent the spread of a species beyond a certain normal boundary, and they affect its persistence in like degree when it is transplanted to a new locality. There are doubtless many foreign speeies that possess an inherent ability to adapt themselves to one of the changed conditions represented among these factors; but the possibility of finding a species which can adapt itself to all of the changed conditions is extremely small. With the increase in the number of limiting factors there is a decrease in the number of species capable of successfully meeting all of them. Few species can ever be considered as candidates for introduction into any one new loeality.

The possibility of failure is not the ouly objection to projects of introducing foreign game birds. Three others are yet to be mentioned: the possibility that the species introcluced may later become undesirable; that it may completely replace some native species; and that it may bring in some infections disease such as will spread to native species. No instance of the introduction of a wholly undesirabie species of game bird is known to us, but the conspicuous eases of the English Sparrow and Starling among small birds should warn us of grave consequences in this comnection. 
As an example uncler the second point, it is well known that the English sparrow and our native Linnet to not get along well together. 'The former is aggressively pugnacious in disposition, and drives the Limnet off the premises by individual combat. In any case it is certain that, since at the scason of minimm food supply, about February and March, the struggle for existence is very keen, hoth because of food shortage and because of persecution by carnivorous enemies, and since the number of birds that can persist through this critical season depends absolutely upon the amount of sustenance then available, the introduction of foreign birds will inevitably bring injury to the native species. Some peculiar atvantage in food-getting power on the part of the introduced birds may increase this peril still further.

Finally, there is the question of diseasc. Parasites and disease organisms are very likely to be bronght in by exotic hirds, and the conditions may prove farorable to their spreat among our native game species. Because of the abmuptness of the exposure, our birds will not have acquired immunity from those parasites and cliseases, and wholesale mortality is likely to result. It is undesirable that the existence of onr native birds should be jeopardized in this mamer for the mere chence of a suceessful introduction of any sort of foreign game. In 1916 quail from Mexico were prohibited entry into the United States because of the prevalence of a "quail disease" in their native country.

\section{STMMARY}

A review of the attempts to acclimatize foreign game birds in California shows that the success attained has not been commensurate with the money and energy expended, and that two of the underlying causes of failure have been the lack of careful preliminary investigation of the factors controlling acclimatization, and the improper method of liberation. Every introduced species must meet certain requirements, the chief of which relate to the climatic conditions of temperature and humidity, the food supply, the safety of breeding places, and the availability of suitable cover for protection from enemies. Not one, but many, limiting conditions must be satisfied; hence the chances that a given species will succeed in a new environment are small, and, also, the number of species possessing the necessary all-around adaptive ability is small. The possibility of establishing a foreign game species has been demonstrated in the case of the pheasant in Oregon, and more carefully planned undertakings here might lead to suceess in the case of other game species. Even thongh a foreign species proves to be desirable, there is always the attendant danger that the introduced bird will wholly supplant some native one, 
an event the full conseguence of which must be earefully weighed. The chances of failure in aechimatizing the immigrant, of introdueing an undesirable bird, of wholly supplanting some native species, and of introducing some contagious disease fatal to native speeies, all emphasize the great need of direeting effort and money toward the conservation of native game birds rather than toward the introduction of foreign ones. Conserve our native speeies! There are none whose qualities are superior; they are part of the natural heritage of our land, and have been serviceable to us in the past; we are responsible for their preservation. 


\section{TIIE PROPAGATION OF GAIE BIRDS}

In several European countries the supply of game hoth for sport and for the table is furnished almost wholly by propagation. In Great Britain, for instance, game corers are systematically restocked with pheasants by breeding these birds in large numbers and then liberating them. Dueks are reared in large numbers and made to furnish sport for the gunners. The consequence of this sort of game administration is that few persons are allowed the privilege of hunting, and no public lands are open to the hunter at large. Even now, in Scotland, the right to hunt is, theoretically at least, reserved to persons who have inherited that unknown quantity, a "plowgate" of land, and in Ireland qualifieations of estate are necessary for killing game and keeping sporting dogs. In Great Britain the right to take or kill wild animals is treated as ineidental to the ownership or occupancy of land on which they are found, and the general publie has not the right to take them on private land or even on a right of way. (For further discussion of conditions abroad, sec Westerfeld, 1916, pp. 1-10.)

In the Cnited States, where all of the people have rights to game, we have administered our game resourees in an entirely different way. Instead of inereasing the breeding stoek by artificial methods or by large game preserves we have heretofore, where anything has been done at all, simply encouraged the breeding of our game birds and mammals under natural eonditions. Little attention has been paid to restocking depleted covers with birds reared in captivity, save as concerned with the introduetion of non-native species (p. 30). It may be that as our supply diminishes we will be foreed to turn seriously toward artificial propagation as one means of replenishing game in the wild. That an increasing number of individuals is becoming interested in this phase of the subject and rearing game for profit or pleasure is evidenced by the growing output of articles and books on game breeding.

California has slowly been awakening to the faet that some measures must be taken to increase her supply of game. Breeding as a means of bettering game conditions has not been altogether overlooked, but as yet very few adequate experiments have been performed to ascertain whether or not the breeding of game in eaptivity would be feasible under the conditions obtaining here. The hitherto adequate supply of game has doubtless been largely responsible for this negleet of an important remedy, and most of the experiments thus far 
tried have given discontaging results, as will be learned from the following paragraphs.

\section{The SThte G.hHe Furu}

Believing that the establishment of a state farn for the learing of game birds in eaptivity, operated along the same lines as fish hatcheries, would be of help in restoring depleted game covers, the Califormia Fish and Came Commission fomded such a farm in september, 1908, at Hayward, Alameda Connty, and has maintained it for some eight years at a total expense of orel $\$ 50,000$. The farm was immediately stocket with Ring-necked Pheasants, Talley Quail, and a few Hungarian Partridges. During the operation of the farm perhaps 3,000 Ring-necked Pheasants have been reared and distributed throughout the state. In most instanees, however, it has been found that the birds become very tame in captivity and that when liberated they seemed to be ineapable of taking care of themselves. In spite of the large numbers planted, there are at the present time but few places in the state where the birds have gained a foothold.

The efforts to propagate quail in eaptivity have for the most part been unsuceessful. In 1915, about 300 young birds were reared. "Quail disease" gave eontimual trouble and large numbers of the hirds died before reaehing maturity. A few Mountain Quail have been kept at the farm but they have not bred. The eggs of a few captive Desert Quail have been hatched in incubators, but none of the ehicks survived. No Hungarian Partridges have been snecessfully reared on the farm and those whieh were purehased and planted in different parts of the state soon disappeared.

In response to requests and suggestions from a number of sportsmen, efforts were made to secure from Virginia and from Mexico some Wild Turkeys, in the hope that propagated birds might establish themselves if given reasonable proteetion. A few were reared at the farm from the stock secured and were planted in different parts of the state. No turkeys are believed to exist in a wholly wild state in California at the present time, although favorable reports were at first receired from the Sequoia National Park, where some wre placed (see p. 37). The breeding stock at Hayward was eonstantly reduend in numbers by blackhead, a disease very fatal to turkeys.

In all the above breeding experiments the birds with the exeeption of the turkeys, were kept in small wire ages. Eggs have been collected and hatehed in a few instances moder hantams but more frequently in ineubators. Most of the young birds have been reared in brooders. Fastern game farms have abandoned the ineubator in favor of bantams, but there seems no good reason why erpual sureess could not be obtained through the use of incubators and brooklers. 
In 1914 a pond at the farm was stoeked with wild ducks in order to determine whether or not these birds could be easily propagated. It was found that pinioned Mallards would breed readily and would successfully rear their broods. But out of the twelve species of ducks kept in captivity, the only ones whieh nested under the artifieial conditions provided were Mallards, Cimmamon Teal (one pair) and Shovellers (one pair), and Ind-hens. No attempts have been made to liberate any of the Mallards thus raised. Attempts to hatch, by means of incubators, egrgs collected in nearby marshes met witl success, but only a part of the lncklings so hatched survived.

In March, 1916, the Fish and Game Commission decided that the game farm was not a paying proposition, and, desiring to retrench in some direction, ordered the farm abolished. It had become evident that the adobe soil on which the farm was sitnated was a constant hindrance to success.

Thongh it seems reasonable to believe that with more experience and better conditions a larger pereentage of birds conld be reared, yet it has everywhere been growing more manifest that birds so reared are not suitable for stocking purposes. The only apparent justification for a state farm is that it may be a useful ground for experiments in the breeding of captive game birds. In furnishing the knowledge thus acquired to game breeders, a state game farm might prove of considerable value.

\section{Private Gide Farms}

Game propagation as earried on by private individuals still appears to be in the experimental stage. Though a number of people have established small game farms, they have usually done so for pleasure rather than for profit. Many people rear a few pheasants each year in their back yards, or in aviaries, but without any idea of making money. Even the offer by hotels in San Francisco of $\$ 2.00$ apiece for Ring-necked Pheasants has not greatly increased the number of pheasant breeders. A possible indication that the rearing of fancy breeds is not fast increasing is evidenced by the fact that breeding birds of certain races still bring the high price of $\$ 10.00$ a pair.

The equipment needed in order to rear pheasants successfully deters many from engaging in their propagation. Wire for pens is expensive. The hen birds do not properly incubate the eggs, and it is necessary to use either incubator's for hatching purposes and brooders for rearing the chicks, or else employ bantam hens. The young need a great deal of insect food and this is difficult to supply. 


\section{The Bowan Liw}

An attempt to encourage the breeding of game in captivity was made in 1913 when the Bowman Law (Stats. 1913, Penal Code, §631d), providing for game farming, was passed by the State Legislature. This law, although not an ideal one, provides for the selling under the tag system of game reared in eaptivity. It had, when passed, the disadvantage of preseribing a large lieense fee-\$25.00. This burdensome eondition has prevented most breeders in the state from availing themselves of the provisions of the law, and unless the lieense fee be redneed, it will eontinue to discourage rather than eneourage game farming.

\section{Proplation of Upland Game Birds}

Of all our native game birds, the Valley Quail has been most widely reared in eaptivity. If the first eggs deposited be removed, the female bird will lay as many as sixty or seventy eggs during a season. 'The first eggs seeured ean be set under bantam hens, and the quail may be allowed to hateh the last fifteen or twenty eggs. No one, so far as we know, has been sueeessful in rearing Mountain Quail. A number of these hirds have been kept in eaptivity by breeders, but in the lower altitudes they show no tendeney to breed. No similar trial of grouse has been attempted. The latter birds are almost impossible to obtain alive, and judging from experiments with Ruffed Grouse in the East, efforts in this direetion would promise only failure. A few persons living in the Sage-hen country have attempted to rear Sagehens, but without sueeess.

The Mourning Dove is kept as an aviary bird and proves prolifie. Mr. L. W. Hammond, of Filhmore, Ventura County, has informed us that this dove breeds readily in eaptivity, rearing at least two broods a year; and Mrs. Elizabeth Grinnell, of Pasadena, has also been suecessful in rearing these birds. Wounded birds eaptured in the shooting season and housed by Mrs. Grimnell in large open eages through the winter bred the following spring. One such pair nested several times from early spring to Oetober and produeed many young, but there were never more than the usual two eggs laid for one setting. The parent birds were sueeessful in raising every squab that was hatehed. It was found possible to transfer young from nests found in the wild to the eare of the eaptive adults, always with favorable results. Squabs found in deserted nests after the opening of the hunting season, and whose parents had probably been shot, were reared on a diet of "chewed-up" nuts and similar material. 
During the stason of 1916 a few attempts have been made to breed the Band-tailed Pigeon. Three men in the San Francisco Bay region have secured birds from Oregon and are experimenting with them. All three men are experienced aviarists and will eertainly meet with success, if success be possible. In the first season a deserted egg was hatched under a domestic pigeon, and one pair of Band-tails themselves successfully incubated a set of eggs.

\section{Propagation of Waterfowl}

Experiments by private individuals have demonstrated the fact that of all the waterforl the Mallard is the easiest to breed in captivity. This might have been expected from the fact that all or most of the breeds of tame ducks are descendants from wild Mallard stock. Wild Mallards have been bred in numbers "ven in eity yards. For example, Mr. Theodore Kytka has for several years reared wild Mallards in his backyard in San Francisco. Better results are obtained as the birds become tamer; those which have been reared in captivity nest more readily than captive wild birds. IIence there is a tendency among breeders to direct their efforts toward the increase of breeding stock rather than toward the rearing of bircls for the purpose of restocking wild lanct. We are not aware of any instance where Pin. tuils, Shovellers, Teal, or other ducks have bcen successfully reared in any numbers under artificial conditions. The sea-ducks, which include the Redhead, Canrasback, Scaups, Golden-eyes and Buffle-head, are very difficult to handle in captivity, in that they require animal food which they are accustomed to obtain only by diving. Pinioned Lesser Scaup Ducks on Stow Lake, Golden Gate Park, San Francisco, have nested and brought off broods, but in every case the young have failed to survive.

Several attempts to rear Canada Geese in captivity have met with success where the birds were kept at high altitudes. Mr. Henry Shook, of Yreka, Siskiyou County, succeeded in rearing six young from a pair of pinioned birds during the first season they were in his possession. Eggs taken from Lake Tahoe marshes have been hatched and the young reared by residents of El Dorado County, and reports have been received to the effect that eggs secured at Honey Lake, in Lassen County, were successfully hatched by residents of the vicinity. On the other hand, decoy geese which have been kept in captivity for many years in the Sacramento Valley have shown no desire to breed. Canada Geese hatched from eggs secured at Lake Tahoe have been bred to a Chinese Horned Goose by Mr. Chase Littlejohn, of Redwood City. The hybrids very closely resemble the Canada Goose. 


\section{The Future of Gane Breeding}

With increasing knowledge of the subject game breeding promises to become a well established industry. Situations ean be found in the different parts of the state which offer ideal conditions for rearing the various types of game birds. The market is continually improving because of the diminishing supply of wild-killed game. Without doubt a few more years will see the passage of a non-sale law, after which any game offered for sale in the markets will necessarily have been reared in captivity. Prices even now are high enough to encourage any resourceful person in starting a game farm.

As more people become interested in the subject many of the problems which now discomage the breeder will probably be solved and the business of rearing game for the market be made easier and more profitable in consequence.

\section{Breeding Under Natural Conditions}

It is difficult to improve on natmre and hence game covers can, as a rule, be restocked more easily by a stimulation of breeding under natural conditions than by propagation in captivity. When an area is set aside and the birds encouraged by being given the best of food and cover, and by aderuate protection from their enemies, a remarkable increase in numbers follows. A knowledge of this fact has led to the inauguration of the preselve system by wealthy land owners, and later to the idea of game refuges. Under the private preserve the birds are usually better cared for than moder the game-refuge system, since in the former case, all their needs are attended to by expert caretakers, and in the latter the only assistance usually given them is protection from hunting. But although in most instances the preserve system is the better metlod of rearing game birds, it has certain drawbacks. The most obvious of these is the difficulty of securing the large area required for the enterprise. Hundreds of acres are needed to rear birds under natural conditions, whereas a few acres are sufficient for a game farm. Noreorer, if the birds are to be marketed or distributed, it is difficult to trap then. In spite of these difficulties; however, there is no doubt but that the restocking of depleted covers can be realized more satisfactorily in this way than through the artificial propagation of the birds on game farms, where ease of living makes them tame and incapable of properly caring for themselves when turned loose in the wild.

There are few places in California where game conclitions are better than on certain large ranches. Here the birds may be given adequate protection withont a radieal change being made in their 
normal conditions of life. On the Naeomber ranch at Paicines, San Benito County, quail have been carefully protected and regularly fed, and as a result are very abundant, two or three hundred of them gathering to feed in front of the ranch house each morning.

Game birds may be attracted to a locality by using appropriate food as an enticement. Quail may be attracted with patches of buekwheat or other grain. Wild fowl may be brought to a pond by planting Egyptian corn around the edges or by seattering wheat or barley on the banks and in the water. Still better for this purpose are sueh natural forage plants as pondweed (Potamogcton sp.), ditch-grass (Ruppia maritima), tule potato (Sagittaria latifolia), bulrush (Scirpus sp.). sedge (C'(1)ex sp.), water-eress (Nasturtium officinale), or knotweed (Polygonum sp.). Seeds or plants of wild riee, wild celery, and other water or bog plants suitable for attracting waterfowl can be purchased from dealers whose addresses ean be seemred throngh the University of California. Although many attempts have been male to grow wild rice and wild celery in this state, the results have so far been negative. Mr. R. W. Skinner of Eureka, Humboldt County, writes us that he was successful in getting wild rice to grow in a small fresh-water pond one foot deep. but that the drying up of the pond the following year unfortunately ended the experiment. He believes that this plant will grow in the Fumboldt Bay section in fresh water that has little current, and is not too deep, and where the soil is rich. Mr. W. W. Richards of Oakland, who has experimented with wild rice in the Suisun marshes, calls attention to the fact that fresh running water such as is suitable for wild rice is seldom found in our duck marshes.

\section{How to Start a Gaue Firi}

UPLand Game Birds.-Prerequisites.-A permit or license from the State Fish and Game Commission. Five or more acres with sandy or loamy soil: movable pens for quail 4 by 8 feet or, better, 10 by 12 feet: for pheasants, large stationary pens, for bantams and chicks, coops about two feet square with removable tops, and each connected with a small pen. Sun and shade, abundant insect life, and well drained soil are necessities.

Breeding Stock.-Should be procured in late fall or early winter, preferably from a locality of similar climate. Quail should be procured in pairs; with pheasants, which are polygamous (excepting the Silver Pheasant), one male to six females is the rule. Purchase birds rather than eggs.

Food.-Adults do well on almost any sort of grain if fed regularly and moderately. Ordinary commercial "chick-feed" is good for quail. 
In addition, green feed is important, and a certain amomnt of animal matter, such as meat-serap preparations, is essential. Newly hatched chicks should be fed four times a tlay on hard-boiled eggs mixerl with finely powdered eracker-crumbs. A constant supply of grit is essential. Water shonld also be furmished. After the fifth clay, flies or fly larvae should be added to the diet. A mash of prepared "pheasant meal," middlings, etc., may take the place of the insect food. After the sixteenth day some "chiek-feed" may be atded to the diet.

Rraring.-Neither quail nor pheasants readily incubate their own eggs; hence it is advisable to use incubators and brooders, or clse bantam lrens. The latter are now consilered preferable. Abont twenty (quail's eggs ean be covered by one hen. The nest should be made from a square of sod, grass-sicle down, hollowed ont, and lined with soft hay. During the period of inembation the hens should be removed regularly each morning for food, drink and exercise. When the chieks are from 24 to 36 homs old they should be removed to a fresh coop and pen. Later, the brood together with their foster parent should be given a larger range.

Discase.-Aceording to Job (1915, p. 37), the prineipal disease of eaptive quail is an acute enteritis, which, once introdneed, becomes epidemic and will spread throngh an entire flock. Formerly this disease was smpposed to be due to a miero-organism fomd only in eertain regions, but it or a elosely similar malady is now known to ocen in quail and other gallinaceons birds in widely separated localities. Erron's in the feeding or housing of captive birds, sueh as that of overfeeding them, or of eonfining them in dirty coops or in yards fouled by poultry, usually result in an ontbreak of this distemper. Moderation in feeding and cleanliness about the yards and houses are the best ways of preventing the disease from getting a start.

WATERFowL-Prerequisites.-A permit or license from the State Fish and Game Commission. A small freshwater pond, or section of a stream, well fenced to exelnde "vermin" (weasels, skmmks, rats, (te.), and capable of being drained and eleaned at intervals. At least two square yards of water shoult be allowed for each duck. The proportion of land to water should be at least two to one. Both meadow and brushy or grass-evered land shonld be inchued.

Brecding Stock.-Procure the progeny of pure wild birds from dealers during late fall or early winter. Mallard dneks cost abont $\$ 5.00$ to $\$ 6.00$ a pair; Pintails, $\$ 7.00$ to $\$ 20.00$. On reecipt, the birds should be given a rest in a dry enclosure for several days before being allowed on water. They should all be pinioned, unless the breeding season is near, in which event they should be merely wing-elipped.

Food.-Grain either once or twice daily, preferably a mixture, in equal parts, of wheat, barley, buckwheat, and Kaffir corn or cracked 
colm. Drop the food in water six inches to a foot in depth. Chopped raw meat or fish should be given oceasionally, as also green vegetable matter of almost any sort, such as grass cuttings and cabbage. Grit, such as marble dust mixed with charcoal, and gromd oyster shells, are indispensable to good health. In early spring a richer food is lequired to stimulate agg-laying. A mash meets this need; for instance, Spratt's duck meal, or a mixture of cormmeal, bran, middlings, and crissel. Ducklings should be given food for the first time when they are one day old. This food should consist of finely ground hard-boiled egg mixed with cracker-crumbs or rolled oats, and a little coarse grit or sand. At first, feeding should be frequent but in small quantities. After the sceond day a "duck-meal," either of the commercial variety or mixed according to an accepted formula should be provided. Tegetable food is important from the first, and insect food of some form should not be omitted.

Rearing.-The eggs of some wild fowl can be latehed by the parents themselves, but in the case of the wilder species better' suceess is attained by hatching them in incubators or under bantams. The eggs of the Mallard should be collected systematically each day; but those of the other species, after the clutch is completed. When the eggs are removed regnlarly, the number produced by the Mallard is increased from about ten, the average clutcli, to about forty. Ducklings should be placed with bantam mothers in small pens on grass and should not be allowed near large bodies of water until they are well feathered, althongh pure water should be available for drinking purposes.

Pinioning.-Wild birds may be rendered incapable of flight either by wing-clipping or pinioning. The former operation consists in merely snipping off the primary flight feathers near their bases, and of course must be repeated after each molt. This method is preferable for females of the less easily tamed species. In pinioning, the operator should be provided with a pair of gardener's pruning shears and some powdered tannic acid or boric acid. Two of the imnermost primary wing quills should be pulled ont, as also the nearby smaller feather's. A cord should be tightly tied around the end joint of the wing well up under the little thumb or "bastard wing." With the shears the bone can then be snipped off cleanly and evenly within a quarter of an inch beyond the ligature. An application of the tannic or boric acid will check the bleeding. After the operation the bird may be liberated at once. The pinioning of ducklings is a simple affair, almost bloodless, and may be done when they are four to seven days old. A bird suceessfully pinioned is permanently flightless. 


\section{Sources of Breeding STOCK}

Diffieulty is likely to be experienced in procuring the proper breeding stock with which to start a game farm. Breeding stock should be seemred in late fall or early winter. It can be obtained in one of three ways: by capturing the birds in the wild under permit from the Fish and Game Commission; by purehase from some one of the large game farms in the East; or by purchase from breeders in this state. Addresses can be secured through enquiry from the Musem of Tertebrate Zoology, University of California.

\section{Information on Methods of G.jue Breeding}

The following works should be consulted for detailed information on game breeding :

Јов, Н. К.

1915a. Propagation of wild birds. (New York, Doubleday, Page \& Co.), xxvii +276 pp., illustrated.

1915b. Propagation of upland game-birds. (New York, National Association of Audubon Societies), Bulletin 2, pp. 33-72, illustraterl.

1915c. Propagation of wild water-fowl. (New York, National Association of Audubon Societies), Bulletin 3, pp. 73-104, illustrated.

QUARles, E. A.

1916a. Anerican pheasant breeding and shooting. (New York, American Game Protective Association), xii $+128+8$ pp., 50 figs. in text. Free on application to publishers.

1916b. The mallard -its breeding, shooting and preserving. (New York, American Game Protective Association), Bulletin 5, no. 1, pp. $4-7,15-19,7$ figs. in text.

Simpson, G. MI.

1914. Pheasant farming. (Salem, Oregon, State Printing Dept.), Oregon Fish and Game Commission, 50 pp., many illustrations.

Hornaday, W. T., and Crandall, I. S.

1912. Breeding mallard dueks for profit. (Albany, New York State Conservation Dept.), 24 pp., $s$ pls.

Crajidal, L. S.

1913. Wild duck farming a new industry. Outdoor World and Recreation, vol. 4S (new series), pp. 265-270, 279-2s0, 4 figs. in text. 


\section{LEGISLATION RELATING TO GANE BIRISS IN}

\section{CALIFORNIA}

The history of game-bird legislation in California has been long and varied. From the time when the first law on this subject was passed at the third meeting of the State Legislature in 18.52, up to the present, hardly a session of that hody has convened without some changes in or arditions to the gane laws, so that they are now numerous and detailed. No constant policy seems to have dictated these amendments and alterations, and the majority of them have shown but little regard for the results of scientific investigation. In carlier. years no appreciable attention was given to the conservation of game birds ; in fact, very few people seem to have urged the economic benefits to be obtained by appropriate protection. The more recent laws, as they finally appear on the statute books, represent compromises between the efforts of the modern conservationists, who would use only the natural surphis over and above a normal breeding stock, and the efforts of the more selfish element among the hunters, who seek only to gratify their own immediate desires, without any regard to the needs or rights of posterity.

The earliest game-bird legislation was more or less local in its application: but in 1880 all counties in the state were brought under uniform treatment. The Connty Govermment Aet of 1897 provided means whereby boards of supervisors could shorten, but not lengthen, the seasons in their respective counties. Considerable use was made of this act up to 1905 ; in that year a decision of the District Court of Appeal rendered county legislation uneonstitutional.

In 1901 an amendment to the State Constitution was proposed for the purpose of enabling the Legislature to divide the state into fish and game districts. This amendment, although soon after adopted, was not made use of until 1911, when six districts were established. In 1913 these districts were altered somewhat, and their total number increased to seven; and a further change was made in 1915, when the state was divided into four major and twenty-five minor districts. All of the above changes were made in response to an increasing recognition of the diverse natural conditions obtaining in different portions of California, and were in the nature of attempts to meet this diversity by providing open seasons appropriate to the several climatic areas of the state. The difficulty has been, and always will be, that the political boundaries made use of in eonnection with the game laws, and the natural boundaries along which districts 
should, ideally, be divided from one another, rarcly coincide. The ideal arrangement would be to give full recognition to the several natural "life-zones" in which the different kinds of game exist.

There has been a gradual increase during the past sixty years in the number of species of game birds protected nuder the laws of California. At first (1852) only the most desirable ones, the quail and Mallard and Wood Duck, received recognition. In 1861 several other "broad-bill" ducks were inchuled, as were also grouse, and in 1866 "prairie chickens" [= Sharp-tailed Gronse] and Sage-hens were given protection in Siskiyon Comnty. The Gadwall, Cimnamon Teal and Redhead were recognized in 1878 , and in 1880 the duck law was made general to include all wild species. From 1883 to 1887 all species of ducks were, for the time being, without protection of any sort. Doves first received protection in 1878, in San Joaquin County, and two years later a state-wide closed scason of six months was extended to these birds. Rails were first protected in the same rear (1880), suipe in 1893, robins (as game, but for two years only) in 1895, ibis, curlew and plover in 1901, and other shore-birds in 1905. Not until 1909 did any geese receive mention, and then only the Black Sea Brant; and only in 1915 were the other species of these big birds given any protection. The Band-tailed Pigeon first received legislative recognition in 1915. The two groups of quails, Talley and Desert, and Mountain, were not treated separately until 1895.

While the whole scheme of closed seasons was, and is, designed directly to enable our game birds to maintain their numbers, other restrictive measures, with a similar purpose, have been applied. Among these the following may be mentioned: Protection of nests and eggs $(1878,1893)$; prohibition of trapping (1880); restriction in bore of gun used (1893); prohibition of sale (1895, 1901, 1913); bag limits (1901); prohibition of extra-state shipment (1895); prohibition of night hunting (1901); and closed terms (grouse, 19071911; Mountain Quail, 1909-1911; Wood Duck and Band-tailed Pigeon, 1915 to date).

The Federal Migratory Bird Law, and the regulations promulgated under it since 1913, assisted materially on points where the citizens and Legislature of California had been too lax. The protection afforded shore-birds, the Wood Duck and the Band-tailed Pigeon by these regulations has probably prevented the extirpation of several of the species concerned.

The chronology of legislation and the table of open seasons which are presented herewith have been compiled chicfly from the statutes and Amendments to the Codes of California, 1850-1915. The annual summaries of game legislation issued since 1901 by the United States Bureau of Biological Survey have also been consulted. 


\section{CHIRONOLOGY OF LEGISLATION RELATING TO GAME BIRTS IN}

CALIFORNIA， 1552-1915

1852. Open season for quail or partridges, mallari duck and wool or sumuer luck, September 20 to March 1 in counties of Contra Costa, Mariu, Monterey, Napa, Sacramento, Sau Francisco, San Joaquin, Santa Clara, Santa Cruz, Solauo, Sonoma, and Yolo; penalty upon conviction of violating law, $\$ 50$, one-half to be paid informer.

1853. Open season: quail or partridge, mallard and wood duck, September 1 to Mareh 20.

1554. Open season: quail, mallard, and wood luck, September 15 to March 1; penalty upon conviction $\$ 25$ for each individual bird, fines to go to county treasurer for school fund. Protection extended to birds named above in Colusa and Tuolumne counties.

1855. Protection extended to birds named above in Shasta and Trinity counties.

1857. Act of 1854 ameniled: one-half of fine to be paid informer, one-half to school fund in county where conviction is had.

1860. Counties of Los Angeles, Mendocino, San Diego, San Luis Obispo, anıl Santa Barbara, exempted from acts of 1854 and 1857.

1561. Open season: all counties except Los Angeles anıl San Bernardino, quail, partricige or grouse, mallari, wool luck, teal, spoon-bill and all other broad-bill dueks, September 15 to March 15; Los Angeles and San Bernarlino counties, August 1 to April 1. Act of 1860 repealed.

1866. Open season: Siskiyou County, grouse, sage-hen, prairie chicken [sharptailed grouse], August 1 to April 1; quail, Oetober 15 to Mareh 15; mallard, wood duck, teal, spoonbill and all other speeies of wild ducks, September 15 to April 15.

1870. Open season: Lassen, Plumas and Sierra counties, mallard, wood duck, teal, spoombill and other broad-bill ducks, August 15 to March 15, Lake Merritt, Oakland, and its shores declared a game preserve.

1872. Huntiug in Butte County on private lands or within 500 yards of dwelling of another person, prohibited. Hunting on enclosed lands in San Francisco County, or in Napa County east of Napa River, prohibited. Hunting in Yolo County, about houses, or in October on eultivated lands, or anywhere in the county during the months of June to October, inelusive, prohibited. Hunting on private lands without permission prohibited in Alameda, Colusa, Contra Costa, Humboldt, Los Angeles, Marin, Nevada, Sacramento, San Bernardino, San Diego, San Luis Obispo, San Mateo, Santa Barbara, and Sonoma counties.

1874. Hunting on private lands without permission prohibited in Mendocino County.

1876. Open seasou: Lassen, Plumas and Sierra counties, quail, partrilge and grouse, September 1 to March 15. Hunting on private lands unlawful in certain counties.

1578. Gadwell or gray duck, redhead, and blue-winged [cinnamou] teal specifically mentioned among species protected during closed season. Doves first protected; open season: San Joaquin County ouly, July 1 to January 1. State Board of Fish Commissioners requirer to provide for distribution and protection of imported game birds. Gathering or destroying eggs of wild ducks prohibited. 
1850. Open season: all counties, quail, partrilge, grouse, all kinds of wild lucks, anl rails or marsh hens, September 15 to Mareh 16 ; doves, all counties, July 1 to January 1. Trapping of (puail, partriılge, or gronse prohibited.

1851. Giving away of trapped quail, partringe, or grouse, prohibited.

1853. Open season: quail, partridge, grouse, and rail, Oetober 1 to March 1; doves, June 1 to January 1. Gathering of quail, partrilge or grouse eggs prohibited. Trafficking in or possession of trapped quail, partridge, or grouse prohibited. No close season on ducks.

18s7. Open season: quail, partridge, grouse, and rail, September 10 to Narch 1.

1859. State Board of Fish Commissioners anthorized to import game biris: wild turkeys, prairie chickens, bob-white quail, pheasants, grouse and skylarks mentioned; $\$ 2,000$ appropriated for the work; closed season for such species as might he introduced until January 1, 1895.

1891. Open season: ducks, October 1 to March 1; doves, July 1 to January 1. County boards of supervisors given right to make game laws for counties and these to superserle state laws.

1893. Open season: quail, bob-white, partridge, grouse, wild luck, snipe, rail, September 1 to March 1; doves, Angust 1 to March 1. Gathering eggs of bob-white, pheasant, or dove prohibited. Innting pheasants or their possession (except for purposes of propagation) prohibited until 1895. Hunting duck, rail, quail, partridge, grouse, or pheasant with shotgun of larger bore than 10-gauge prohibited. Cold storage of quail, partrilge, bob-white, pheasant, grouse, love or will duck during closed season prohibited. Hunting game birls on lanils posterl against. shooting prohibited.

1895. Open season: valley quail, bob-white, partridge, robin, will duck and rail, October 15 to Fehruary 15; mountain quail aud grouse, August 15 to February 15; doves, July 1 to February 15. Possession of game species for propagation under permit made legal. Gathering eggs of robin prohibited. Hunting or possession of pleasants, except for propagation, prohibited until March 27, 1895. Possession or sale of game during elosed season prohibited; sale of quail, bob-white, partriılge, pheasant, grouse, dove or wild luck prohibiterl except between November 15 and January 15. Common carriers prohibited from trausjorting any quail, partrilge, pheasant, grouse, prairie chicken, doves, or wild duck, out of the state except for purposes of propagation ani then only under permit.

1897. Open season: valley quail, bob-white, partridge, wild duck, and rail, Ortober 1 to March 1; mountain quail and grouse, September 1 to February 15; doves, July 15 to Feluruary 15 . Protection for pheasants extended until Nareh 1, 1899. Robin removed from list of game biris. Cold storage of rail prohibited. County boards of supervisors given right to enact county laws for shortening seasons, ete.

1901. Open season: quail, partrilge, grouse, sage-hen, wild ducks, rail, ibis, curlew, and plover, October 1 to Fchruary 1; doves, August 1 to February 1. Constitutional amendment proposed permitting division of the state into fish and game districts. Complete protection for introrncerl speries: Mongolian or English pheasant, English partrirge, eastem or Chinese quail, bob-white. First daily bag limits established: loves or Jucks, 50; quail, partrilge, snipe, ibis, or curlew, 25; rails, 20. Sale of quail, partridge, pheasant, grouse, sage- 
hen, ihis, or plover entirely prohibitel. II unting between one-half lour after sunset and one-half hour before sunrise prohibiterl. Trapping or netting game birds except under permit for scientific purposes or for use in propagation prohibited. Bore of guns used in hunting no longer restricted. Common carriers prohibited from transporting more than one bag limit of game for one person on any one lay: game required to be exposed to view and labeler with name and aldress of shipper. Taking specimens for scientifo purposes allowerl uniler permit.

1903. Open season: valley quail, partrilge, wild duck, rail, curlew, ibis, plover, October 15 to February 15; mountain quail, grouse, or sage-hen, September 1 to February 15; doves, July 1 to February 15.

1905. Shorebiris (Limicolae) other than plover anil eurlew first protected; open season: October 15 to February 15; Wilson snipe, October 15 to April 1. Swan, pheasant, bob-white quail, or any variety of imported quail or partrilge protected at all times. Bag limit: doves reluced to 25; for all slorebirds and rail, set at 25 . Sale of dores and all shorebirls (in ardition to those mentioned in laws of 1901) prohibited. Hunting on private lands without permission prohibited.

1907. Open season: dueks, October 1 to February 15; loves, July 15 to October 15. Closel season on grouse and sage-hen until September 1, 1909. System of annual hunting licenses inaugurater: $\$ 1$ for residents of California; $\$ 10$ for citizens of the Uniter States not residents of California; $\$ 25$ for aliens. Bag limit on ducks recluced to 35 . The following groups mentioned as game birls: Anatillae, Rallidae, Limicolae, Gallinae, and Columbilae. Provision male for registering private holdings as game preserves [refuges] under supervision of Fisl and Game Commission for periods of one to five years.

1909. Open season: wild luck, black sea brant, rail, ibis and all shorebirds (except snipe), October 1 to February 15; iesert ani valley quail, October 1 to February 1; Wilson snipe, October 1 to April 1. Closer season on grouse and sage-hen extended until September 1, 1911, and mountain quail protected until that time. Bag limit on ducks and black sea brant reduced to 25 ; quail, snipe, ibis, rail, shorebirds, and loves reduced to 20 . Use of animal blinds, and bunting from power boats in motion, prohibiter. Pinnacles National Monument made a game refuge. Hunting permitted on navigable waters within any game refuge. Resolution passed to appoint committee to consider dividing state into fish and game districts.

1911. Dealers in wild game required to obtain licenses and to keep record of game received, together with names and addresses of shippers. Use of animal blinds permitted in hunting geese. Rearing of pheasants in captivity permitted, and birds so reared allowed to be sold at any time under permit. State divided into six fish and game districts, viz: 1. Del Norte, Siskiyou, Modoc, Lassen, Shasta, Trinity, Humboldt and Tehama counties. 2. Mendocino, Glenn, Colusa, Lake. Sonoma, Napa, Yolo, Solano and Marin counties. 3. Plumas, Butte, Sierra, Yuba, Sutter, Nevada, Placer, El Dorado, Sacramento, Amador, Alpine, Calaveras, Tuolumne, Mariposa and Mono counties. 4. San Joaquin, Stanislaus, Merced, Madera, Fresno, Kings, Tulare and Kern counties. 5. Contra Costa, Alameda, San Francisco, San Mateo, Santa Clara, Santa Cruz, San Benito, Monterey and San Luis Obispo 
counties. 6. Santa Barbara, Ventura, Los Angeles, Orange, San Diego, Imperial, Riverside, San Beruartino and Inyo counties. Open season: wild lluck, ibis, shore birds (exeept Wilson snipe, plover and eurlew), Districts 2 to 5, Oetober 15 to March 1; Distriets 1 and 6, October 1 to Mareh 1. Black sea brant, District 1 , October 1 to April 1; Districts 2 to 6, November 1 to Marel 15. Wilson snipe, flover, curlew, November 15 to April 30. Desert and valley quail, Districts 1 to 5, October 15 to February 15; District 6, Oetober 15 to November 15. Doves, Districts 1 anil 3, July 15 to October 1; Districts 2 and 5, August 1 to Oetober 15; Districts 4 and 6, September 1 to November 1. Mountain quail, grouse, and sage-hen, September 1 to December 1 . Closed season on rail until November 1, 1912 ; open season after that date, November 1 to December 1 . Bag limits: wild ducks, black sea brant, laily 25; weekly (二 sumrise one Sunday to sumrise the following Sunday) 50; desert or valley quail, Wilson snipe, curlew, ibis, plover, rail, doves, 20; mountain quail 10; grouse and sage-hen 4.

1913. Sale of game prohibitel, except of ducks (during November) and geese at all times; later repealed by refereudum. Hunting in certain parts of Cleveland National Forest prohibited. Provision made for converting private lanis into game preserves (refuges) under control of State Fish and Game Commission for perior of not less than ten years; hunting on navigable waters or on tide lauds not interfered with by this. Provision made for rearing game in captivity and selling same (Bowman Act). Fish and game districts rearranger and a new one added, viz: 1. Siskiyou, Modoc, Lassen, Shasta, Trinity, and Teliama counties, 2. Del Norte, Humboldt, Mendocino, Sonoma, Marin, Glenn, Lake, Colnsa, Napa, Yolo and Solano counties. 3. Plumas, Butte, Sierra, Yuba, Sutter, Nevarla, Placer, Sacramento, El Dorado, San Joaquin, Amalor, Calaveras, Tuolumne and Mariposa counties. 4. Eastern Stanislaus, eastern Merced, Madera, eastern Fresno, eastern Kings, Tulare, and eastern Kern counties. 5. Contra Costa, San Francisco, San Mateo, Alameda, Santa Clara, Santa Cruz, western Stanislans, western Merced, San Benito, Monterey, western Fresno, western Kings, San Luis Obispo, western Kern, anı Santa Barbara counties. 6. Ventura, Los Angeles, Orange, San Diego, San Bernardino, Riverside and Imperial counties. 7. Alpine, Mono and Inyo counties.

1915. Open season: will duck, geese, brant, mud-hen, gallinule, Wilsou snipe, black-breasted or golden plover, yellowlegs, October 15 to February 1; desert or valley quail, October 15 to January 1; mountain quail and grouse, Distriets 2, 3, 4, and all other districts south of the northern hounilary of Menilocino County, October 15 to January 1; mountain quail, grouse, and sage-hen (except as above), September 1 to December 1; doves, September 1 to December 1. Bag limits: honker geese and black sea brant, daily 12; weekly (between sunrise one Sunday ant sunise the following Sunday), 24. Other geese and ducks, daily 25; weekly 50; desert or valley quail, black-breasted or golden plover, jack snipe, yellowlegs, daily 15; weekly (=between sunrise one Sunrlay and sunset the following Sunday), 30; mountain quail, daily 10: weekly 20; grouse and sage-hen, daily 4; weekly 8. Doves, daily, 15; no weekly limit. Indefinite close season on rail, 
Ducks

Mallard and Wood Duck

\section{Rail}

Quail ${ }^{1}$

Grouse

Sage-hen

Dove

1891

Ducks

Wood Duck

Geese

Black Sea Brant

Swan

Ibis

Cranes

Rail

Mud-hen, Gallinule

Wilson Snipe

Yellow-legs

Curlew

Plover

Shorebirds ${ }^{11}$

Quail

\section{Mountain}

Valley and Desert

\section{Grouse}

Sage-hen

Band-tailed Pigeon

Dove

July 1-Jan. 1

1 Including "partridges" and

2 1852-80, close season applied

3 Including all "broad-bill" duch

-1866, close seasons mentioned

5 Including "prairie-chickens"

6 1870, 1876, close seasons men

71878 , close season on doves a

8 1880-1911, close seasons on a

"Including all "will" ducks.

${ }^{10}$ Including "marsh-hens."

11 Other than those specifically $\square$

12 1895-97, including robin.

13 1911-15, for districts see Chr

14 Close season on certain specie

${ }^{15}$ Others, Sept. 1-Dec. 1.
No protection

Oct. 1-Mar. 1

Oct. 1-Mar. 1

Oct. 1-Mar. 1

June 1-Jan. 1

$1911^{13}$

2-5: Oct. 15-Mar. 1 Oct. 15-Feb. 1

1 and $6:$ Oct. 1Mar.1

\section{.............................. \\ 1: Oct. 1-Apr. 1 \\ 2-6 : Nov. 1-Mar.15 Closed \\ 1 and $6:$ Oct. 1- \\ Mar. 1 1912 , then Nov. 1-Dec, 1}

Sept. 10-Mar. 1

Sept. 10-Mar. 1

Sept. 10-Mar. 1

June 1-Jan. 1

$1915^{13}$

Closed ${ }^{14}$

Oct. 15-Feb. 1

Oct. 15-Feb. 1

Closed

2-5 : Oct. 15-Mar. 1 Closed ${ }^{14}$

Closed until Nov. 1, Closed ${ }^{4}$

Nov. 15-Mar. 30

Oct. 15-Feb. 1

Oct. 15-Feb. 1

Oct. 15-Feb. 1

Nov. 15-Mar. $30 \quad$ Closed $^{14}$

Nov. 15-Mar. $30 \quad$ Oct. 15-Feb. 1

2-5: Oct. 15-Mar. 1 Closed ${ }^{14}$

1 and $6:$ Oct. 1-

Mar. 1

Sept. 1-Dec. 1

$2,3,4$, etc.: Oct.

1-5:Oct. 15-Feb. 15 Oct. 15-Jan.1

6: Oct. 15-Nov. 15

Sept. 1-Dec. 1

Sept. 1-Dec. 1

$2,3,4$, etc. : Oct.

oct. 15-Jan.1

Closed $^{16}$

1 and $3:$ July 15-

Oct. 1

2 and 5 : Aug. 1-

Oct. 15

4 and 6 : Sept. 1-

Nov. 1 .

Sept. 1-Dec. 1 
Table 7-Showino Open Seasons for Hunting Game Birds in Californta, 1852-1915

\begin{tabular}{|c|c|c|c|c|c|c|c|c|c|c|c|}
\hline & $1852^{3}$ & 1853 & 1854 & 1851 & $1885^{4}$ & $\begin{array}{c}1870^{\circ} \\
\text { Aug. } 15-\mathrm{Mgr}, 15\end{array}$ & $\begin{array}{c}1878^{\circ} \\
\text { Aug. } 15-\text { Mar. } 15\end{array}$ & $\begin{array}{r}1878 \\
\hdashline-. .\end{array}$ & $\begin{array}{c}1880^{4} \\
\text { Seph. 15-Mar. 15" }\end{array}$ & $\begin{array}{c}1883 \\
\text { No protection }\end{array}$ & $\begin{array}{c}1887 \\
\text { No proteotion }\end{array}$ \\
\hline $\begin{array}{l}\text { Duekn } \\
\text { Mollerd and } \\
\text { Wood Dack }\end{array}$ & Bept. 20-Mar. 1 & Sept. 1-Mar. 20 & Sept. 15-Mar. 1 & 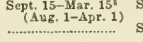 & $\begin{array}{l}\text { Sept. 15-Apr. } 15 \\
\text { Sept. 15-Apr. } 15\end{array}$ & 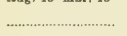 & - & $\ldots$ & 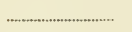 & & ………… \\
\hline Etesll & & & & & & & & & Sept, 15-Mar, $15^{10}$ & Oet. 1-Mat. 1 & Sept. 10-Mar. 1 \\
\hline Qusili & Sept. 20-Mar. 1 & Bepl. 1-Mar. 20 & Sept. 15-Mar. 1 & $\begin{array}{l}\text { Sept. } 15-3 \mathrm{srr} .15 \\
(\text { Ang. 1-Apr. 1) }\end{array}$ & Oct. 15 -Mar. 15 & & Sept. 1-Mar. 15 & 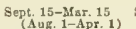 & Sept. 15-Mar. 15 & Oct. 1-Mar. 1 & Sept. 10-Mar. 1 \\
\hline Orauno & 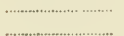 & 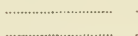 & . & $\begin{array}{c}\text { Sept. 15-Mrs. } 15 \\
\text { (Aug. 1-Apr. 1) }\end{array}$ & $\Delta u g \cdot 1-\Delta p r .1$ & & Sept. 1-Mar. 15 & $\begin{array}{l}\text { Sept 15.Mar. is } \\
\text { (Aug. 1-Apr. } 1 \text { ) }\end{array}$ & Sept. 15-Mar. 15 & Oct. 1-Mar. 1 & 8ept. 10-Mar. 1 \\
\hline $\begin{array}{l}\text { Bsgathen } \\
\text { Dove }\end{array}$ & 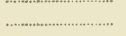 & $\ldots \ldots$ & $\ldots$ & $A$ & Aug. 1-Apr. 1 & $\ldots$ & 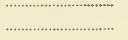 & July 1-Jan. $1^{\prime}$ & July $1-J a a .1$ & June 1-Jan, 1 & June 1-JBn. 1 \\
\hline & 1801 & 1893 & 5895 & 1897 & 1901 & 1803 & 1905 & 1907 & 1809 & $1911^{14}$ & 1915" \\
\hline Wood Duck & Oct. $1-\mathbf{M a r} .1$ & Sept. 1-Mar. 1 & Oct. 15-Fob. 15 & Oct. 1-Mar. 1 & Oct. $\mathbf{I}-\mathrm{Feb}, \mathbf{1}$ & Oct. 15-Feb̀. 15 & Oct. $15-$ Feb. 15 & Oet. 1-Feb, 15 & Oct. 1-Feb. 15 & $\begin{array}{l}2-5: \text { Oct. } 15-\text { Mar. } 1 \\
1 \text { and } 6: \text { Oct. 1- } \\
\text { Mar.1 Oct }\end{array}$ & Oct. 15-Feb. 1 \\
\hline $\begin{array}{l}\text { Wood Duck } \\
\text { Geenes }\end{array}$ & ……… & 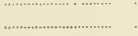 & 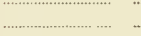 & $-1-1$ & ………............... & . & …-1- & & & $\ldots$ & Oct. 15-Feb. 1 \\
\hline Black Bes Bram & 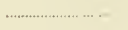 & 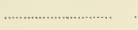 & ………… & 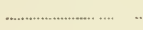 & ……… & $\ldots \ldots \ldots \ldots \ldots$ & $\ldots$ & ………… & Oct. 1-Feb. 15 & 1: Oct. $1-$ Apr. 1 & Oot. 15-Féb. 1 \\
\hline Swan & $\ldots \ldots \ldots-1, \ldots-\ldots$ & & & 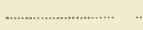 & 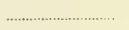 & ․․․․․․ & Closed & Closed & Cloaed & Closed & Closed \\
\hline Cranes & 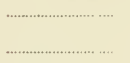 & …………… & 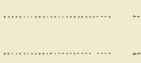 & 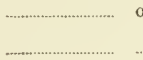 & Oct. 1-Feb. 1 & Oet. 15-Feb. 15 & Oet. $15-$ Feb. 15 & Oet. $15-\mathrm{Feh} .15$ & Oct. 1-Feb. 15 & $\begin{array}{l}2-5: \text { Oot. 15-Mrar, } 1 \\
\text { and } 5: \text { Oct. 1- } \\
\text { Mar. } 1\end{array}$ & Closed" \\
\hline RnIII & Bopt. 10-Mar. 1 & Sept. 1-Mar. 1 & Oct, 15-Feb, 15 & Oet. 1-Mar. 1 & Oct. 1-Feb. 1 & Oct. $15-$ Feb. 15 & Oet. 15-Feb. 15 & Oct, $15-$ Feb. 15 & Oct. 1-Feb. 15 & $\begin{array}{l}\text { Olosed antil Nov, } 1 \text {, } \\
\text { 1912, then Nor. } \\
\text { 1-Dec, } 1\end{array}$ & Ctoned" \\
\hline Mud.ben, Oslinule & 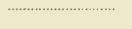 & ....................... & (n) & 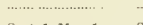 & . & (20) & & Oct. $15-A_{\text {pr. }} 1$ & Oct. $1-\Lambda$ pr. 1 & Nor. $15-\mathrm{Mar}_{1} 80$ & $\begin{array}{l}\text { Oet. } 15 \text {-Feb. } 1 \\
\text { Oct. } 15 \text {-Feb. } 1\end{array}$ \\
\hline $\begin{array}{l}\text { Wilson 8nips } \\
\text { Yellow:logrt }\end{array}$ & …-..- & Sept. 1-Mar. 1 & Bept. 1-Max. 1 & Sept. 1-Mar. 1 & Sept. 1-Mor. 1 & Bept. 1-Mar. I & Oct, $15-\Lambda p r .1$ & Oct. $15-$ Apr. 1 & & & Oct. $16-$ Fob. 1 \\
\hline Curlow & $\ldots \ldots \ldots \ldots \ldots \ldots \ldots$ & .. ………............... & ․․․․…… & ....... & Oct. 1-Feb. 1 & Oet. 15-Feb. 15 & Oct. 15-Feb. 15 & Oct. 15-Feb. 15 & Oet. $15-\mathrm{Feb} .15$ & Nov, 15-Mar. 80 & Olosedit \\
\hline Plover & 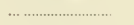 & 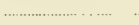 & $\ldots$ & ......................... & Oct. 1-Feb, 1 & Oet. 15-Feb. 15 & Oct. $15-$ Feb. 15 & Oct. $15-F_{e b}$. 15 & Oct. 15-Feb. 15 & Nov, 15-Mar. 80 & Oct. 15-Feb. 1 \\
\hline Ghoroblrdat & ………… & $\ldots$ & 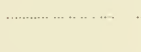 & 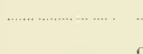 & $\ldots$ & $\ldots$ & Oct. 15-Feb. 15 & Oct. $15-$ Feb. 15 & Oet. 1-Feb. 15 & $\begin{array}{l}\text { 2-5: Oct. 15-Mar. } 1 \\
\text { and } 8: \text { Oct. 1- } \\
\text { Marr. } 1\end{array}$ & Closed" \\
\hline $\begin{array}{l}\text { Quall' } \\
\text { Mountain }\end{array}$ & $\ldots$ & Sept. 1-Mar. 1 & Aug. 15-Feb. 15 & Sept. $1-$ Eeb. 15 & Oct. 1-Feb, I & Sept. 1-Feb. IS & Sept. 1-Feb. 15 & Sept. 1-Feb. 15 & Closed until & Sept. 1-Dec. 1 & $2,8,4$, etc: ${ }_{13}$ Oet. \\
\hline Yolley and Detert & rt & 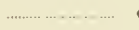 & Oct. $15-$ Feb. $15^{12}$ & Oce. 1-Mar. 1 & 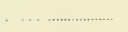 & Oct. $15-\mathrm{Feb}, 15$ & Oct 15-Tob. 15 & Oet. 15-Feb. 15 & Oct. 1.-Feb. 1 & $\begin{array}{l}1-5: \text { Oef. } 15-F e b, 15 \\
8: \text { Oct. } 15-\text { Nov. } 15\end{array}$ & oct. 15- $\operatorname{Jan}^{1}, 1$ \\
\hline Groutso & $-\ldots \ldots \ldots$ & Scpt. 1-Stur. 1 & Aug. 15-Feb. 15 & Sept. 1-Feb. 15 & Oct. 1-Feb. 1 & Sept. 1-Feb, 15 & Sept. 1-Feb. 15 & $\begin{array}{l}\text { Closed uotil } \\
\text { Sept. 1,1909 }\end{array}$ & $\begin{array}{l}\text { Cloged until } \\
\text { Sept. 1, 1911 }\end{array}$ & Bept. 1-Dec. 1 & 2. 8,4 , etc. ${ }_{15-J_{a n} \text { is }}^{\text {Oet. }}$ \\
\hline $\begin{array}{l}\text { Bugrs hen } \\
\text { Bnnd-toiled Pigeon }\end{array}$ & 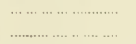 & $\ldots$ & (1) & ㄴ.. & Oct. 1-Feb. I & Sept. 1-Feb. 15 & Sept. 1-Feb, 15 & $\begin{array}{l}\text { Closed untif } \\
\text { Sept 1, 1909 }\end{array}$ & $\begin{array}{l}\text { Cloged until } \\
\text { Sept. 1, } 1911\end{array}$ & Sept. 1-Dec. 1 & $\begin{array}{l}\text { Oct. 15-Jin.1 } \\
\text { Closed } d^{14}\end{array}$ \\
\hline Dove & July 1-Jan 1 & Aug. 1-Mar. 1 & July 1-Feb. 15 & July 15-Feb. 15 & Aug 1-Feb. 1 & July 1-Feb. 15 & July 1-Feb. 15 & July $15-0$ et. 15 & Juty 15-Oet. 15 & 1 and 8: July 15- & Sept. 1-Dec. 1 \\
\hline 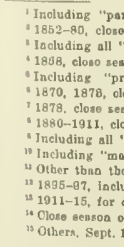 & 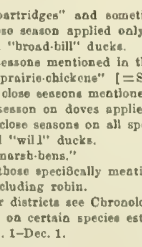 & $\begin{array}{l}\text { ned in there yesra } \\
\text { led only io Sna Jo } \\
\text { pecies mentioned a }\end{array}$ & $\begin{array}{l}\text { pplied only in Lasseo, } \\
\text { quin County. } \\
\text { plied is all counties. }\end{array}$ & Plumper gi: & 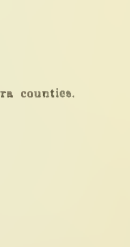 & & & & & $\begin{array}{l}2 \text { and } 5 \text {; Aug. 1- } \\
\text { Oct. } \\
4 \text { snd 8: Sept. 1- } \\
\text { Nov. 1. }\end{array}$ & \\
\hline
\end{tabular}


wook duck, will [banl-tailed] pigeon, shorebirds other than those mentioned above, and sandhill, whooping and little brown cranes. (The above changes were ehietly for the purpose of making the California law conform with the regulations issued unler the fecleral Migratory Bird Law.) Use of animal blinds entirely pro. hibited. Fish and game districts rearrangel and increased in number. Four principal districts: 1. Del Norte, Siskiyon, Morloc, Humboldt, Trinity, Shasta, Lassen, Tehama, Butte, Sutter, Plumas, Yuba, Sierra, Nevada, Placer, Sacramento, El 1)oralo, Amador, Calaveras, Alpine, eastern San Joaquin, eastern Stanislaus, Tuolumne, eastern Mereed, Mariposa, Madera, Mono, eastern Fresno, Kings, Tulare, eastern Kern, aul Inyo counties. 2. Menlocino, Sonoma, Marin, Gleun, Lake, Colusa, Yolo. Napa, and Solano counties. 3. Contra Costa, Alameda, San Franeisco, San Mateo, Santa Cruz, Santa Clara, western San Joaquin, western Stanislaus, western Mercel, Monterey, San Benito, western Fresno, San Luis Obispo, and extreme western Kern counties. 4. Santa Barbara, Ventura, Los Angeles, Orange, San Diego, Sam Bernardino, Riversile, and Imperial counties. Also twenty-five minor districts (numbers 5 to 29 , inclusive), embracing the coast line, the main interior waters, and certain forest areas. All game protecter in minor districts 24 to 29 , inclusire, except that waterfowl may be hunted in District 28. 


\section{GLOSSARY OF SPECIAL TERMS USED IN THIS BOOK}

(See figs, 1-3)

ABDOMEN-SEC BELLY.

Axiluars-A group of feathers situated beneath the wing in the "arm-jit," at the junction of the wing and side of boly; they are usually narrow and often much elongated.

BAck (of body) - The area on the upper surface inclurled between the neck, wings and rump.

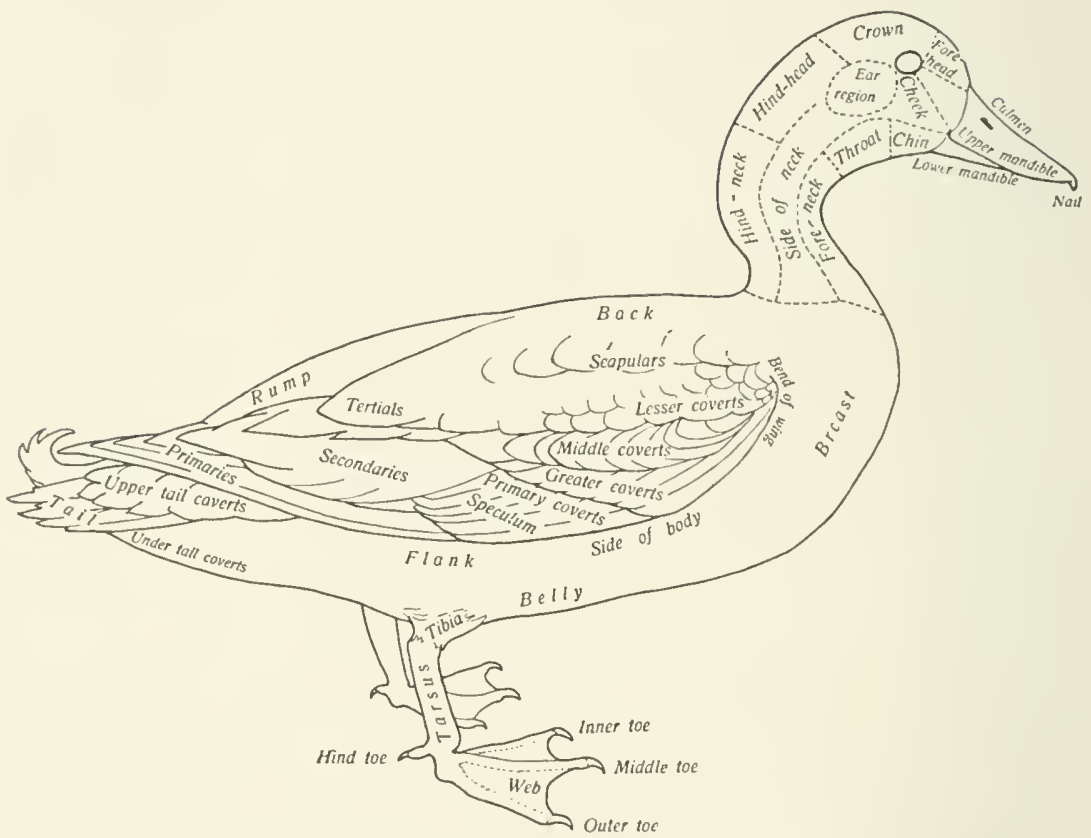

Fig. 1. General ontline of a Mallard showing mames of parts and areas referred to in describing a game bird. One-fourth natural size. See Glossary (1) 62-65) for lefinitions of terms used.

BAR-A narrow transverse mark of color across an indivilual feather, or across wing or tail.

BASE OF BILL-Where the bill is joined to the skull; in most birds, where the feathers of the forehead end.

BELLY - The hinder middle portion of the lower surface of the body, included between the breast, sides and flanks, and vent.

BREAST-An area on the midlle of the under surface of the borly, between the fore-neck and belly; not capable of exact definition.

CERE-The nakel skin at the upper base of the bill, through which the nostrils open. 
('HEEK-The area on the lower side of the head between the eye and throat.

CHEST-The upper part of the breast, just below the fore-neck.

CHIN-The area on the under side of the head included between the branches of the lower mandible or jaw.

CLAw-The horny sheath on the terminal joint of any toe.

CREst-A more or less lengthened tuft or group of feathers on the top of the head, which is either permanently erected (Hooded Merganser, male), or capable of being elevated at will (Mountain Quail).

Crissum-See Lower I AIL Coverts.

Cross-ringes (on bill)-The horny flutings on the sides of the bill in dueks, geese and swans; these are not to be confused with the sharper "teeth" on the opposed surfaces of the mandibles of mergansers.

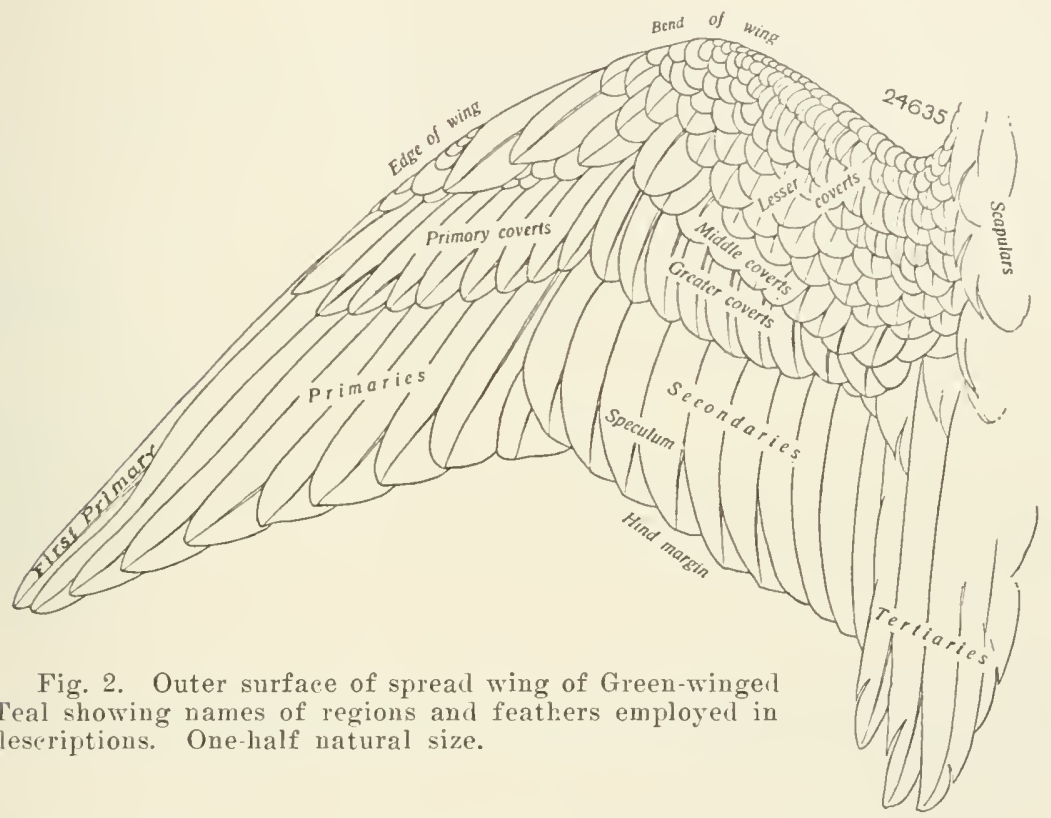

CULMEN-The upper ridge or profile of the bill.

Ear Coverts-See Ear Region.

EAR REgION-The area over which the feathers (ear-coverts) which cover the external ear opening are distributed.

FLANKS-The hindermost feathers on the side of the body, included between the rump and belly, and overlapping the thigh.

ForEHEAD-The area just above the base of the upper mandible of the bill; situated in front of the "top of head."

FORE-NECK-The lower throat, between the throat proper and the breast.

FOREPART of BODX-That part of the body nearest the head; in general, the region forward of the bend of the wing.

Greater (WING) Coverts-The hindmost row of covering feathers on the outer side of the wing, overlying the bases of the secondaries and tertials; the outer margins of these feathers are exposed.

HIND-NECK-The middle of the neck behind. 
HINDPART OF BODY-That part of the body nearest the tail; in general, the region behind the bend of the wing.

LESSER (WING) COVERTS-The several rows of small covering feathers on the onter surface of the wing, from the bend of the wing to the side of the body and forward of the middle coverts; like the greater coverts, the outer margins of the lesser coverts are exposed.

LINING OF WING-The feathers on the under surface of the wing covering the inner bases of the flight feathers.

LOBES (ON TOES) - A series of thin, membrane-like flaps on the sides of the toes (fig. 55).

Lower TAIL CoverTs-The feathers behind the vent and immediately underneath the tail.

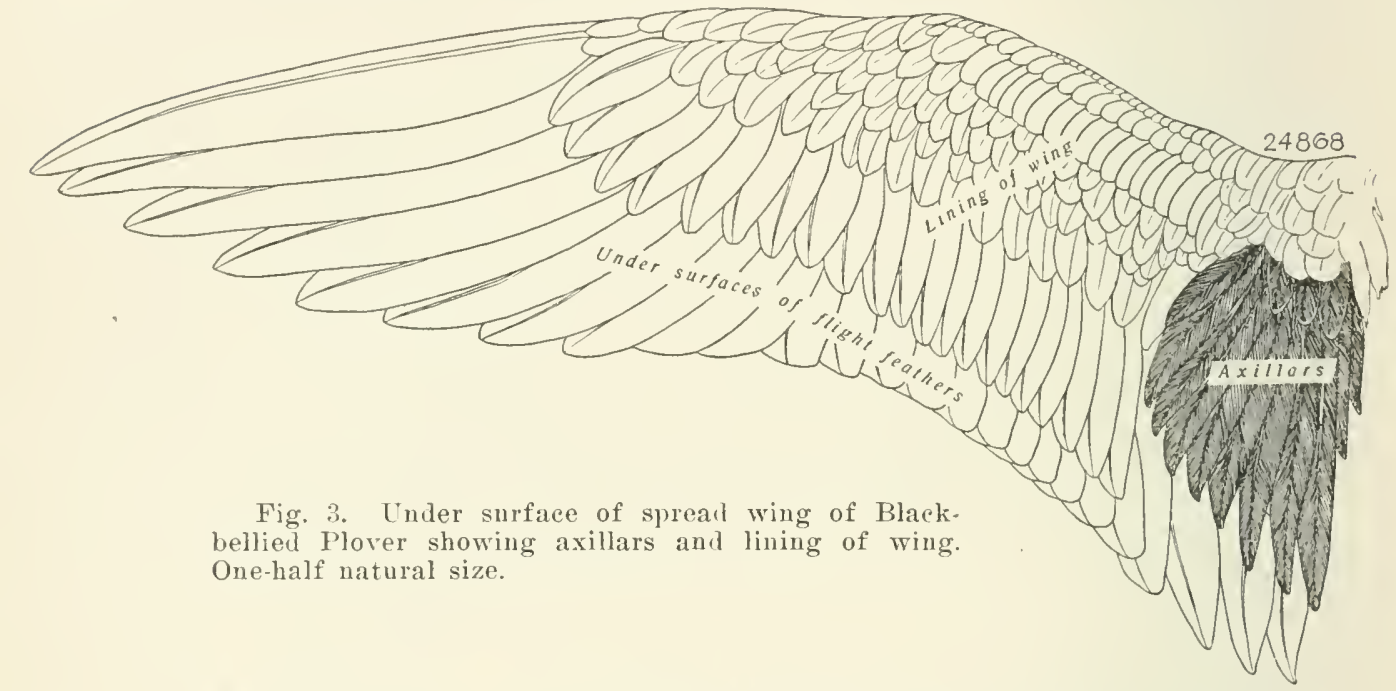

MANDIBLE-Either the upper or the lower half of the bill; the jaw.

MARGIN OF WING-The elge formed by the outermost primary feather and the smaller feathers overlying it, from the benct of the wing backward.

Midde (WING) Coverts-The series of covering feathers lying immediately forwarl of the greater wing coverts on the outer surface of the wing; the middle coverts have their inner margins exposed while both the greater and lesser coverts have their outer margins exposed.

NAIL (OF BILL) - In ducks, the smooth, rounded and slightly raisel portion on the end of the upper mandible.

NAIL (OF TOE) - See CLAW.

NAPE-See HIND-NECK.

OUter Surface of Closed WING-All of the several series of covering feathers on the outer surface of the wing, collectively.

PLUME (ON IIEAD) - A slenter tuft of elongated feathers on the top of the hearl.

PoINTED TAIL-One in which the central pair of feathers are the longest and the outer ones shorter in regular order so that, when spreal, the tail is weigeshaped as seen from above or below.

Primaries-- The outermost and longest series of flight feathers of the wing: the wing "quills" attached to the outermost (the "hanl") of the three "joints" of the wing. 
PRIMRY (WING) COVERTS-The series of rather stiff covering feathers overlying the bases of the primary flight feathers.

REFF-A bunch of elongated feathers on the sirles of the neck, which by reason of their length (and often color) stand out distinctly from the surrounding feathers.

RuMp-That portion of the upper surface of the body lying just forward of the base of the tail between the back and upper tail coverts.

RuMP PATCH-Any contrasted area of color oceurring on the rump, or upper tail coverts, or both.

SCALES-The small horny plates on the tarsus or "leg" of birds; in the duck and shorehird families the shape of these plates is important in classification.

SCAPULARS-The gronp of feathers at either sile of the back, on the "shoulder," just above the wing; they often overlie some of the tertial feathers.

SECONDARIES - The next to the outermost series of flight feathers on the wing; they are attached to the midrle section of the wing (the "forearm") and form a series continuous with that formed by the primaries.

SHAFT (OF A FEATHER) - The quill or mirrib to which the two webs are attached.

SHAFT STREAK-A line or narrow stripe of contrasting color running lengthwise along the midale of a feather.

SIDE (OF BODY) - The area on either' sirle, between the " arm-pit" and flank, and back and belly.

SPECULCגi-A brightly colored area on the terminal portions of the outermost secondary wing feathers of most ducks.

SPLR-A horn-corered projection on the back of the tarsus of the male Ringneck Pheasant and of the male Will Turkey.

SQTARE-EXDED (TAIL) - Said of a tail in which the feathers are of such lengths that when lying parallel they end evenly; not weilge-shapert or pointer.

STREAK

STRIPE Mark of contrasterl color running lengthwise of a feather.

TARStS-The "leg" of a bird; that portion from the heel joint to the base of the toes.

TEETH-The sharp horny projections on the opposeil surfaces of the two mandibles in mergansers.

TERTIALs-The innermost series of flight feathers on the wing, between the secondaries and the body; they are attached to the innermost section of the wing ("upper arm"').

THROAT-The area on the lower sille of the head, between the ehin and foreneck.

UXDER STRFACE (OF BODY) - The whole of the boily below lines drawn along either side from the corner of the mouth to the side of the tail.

UNder, of INNer, Surface of Flight Feathers-The surfaces of the flight feather's which are next to the body when the wing is closed.

UPPER STRFACE (OF BODY) - The whole of the body above lines arawn along either side from the corner of the mouth to the sille of the tail, and, where the tail is of the same color, including the upper surface of it as well.

UPPER TAIL COVERTS-The feathers immediately behind the rump, and covering the upper bases of the tail feathers.

VENT-The anus.

WEB (OF FEATHER) - Either half of the vane of a feather, each side of the shaft.

WEB (BETWEEN TOES) - A membrane-like extension of skin between the front toes in all members of the duck family and in certain other birts. 


\section{ME'TIOD OH TAKING MEASUREMENTS}

As a rule, only adult birds have been used in securing the measurements given in this hook; but in a few cases (which are lesignated) full-grown immature birds have been included. In every instance the region of eapture of the specimens used is indicated. Oceasional individuals are likely to be found which do not eome within the limits of the measurements here given, and of course specimens with tail or wing feathers badly worn or in process of molt will give total lengths and wing lengths below normal.

Wherever measurements were taken by us originally in millimeters, the equivalents in inches and hundredths have been seeured by mechanical conversion, double checked; and the converse is true of measurements taken originally in inches, as well as of all those quoted from published literature.

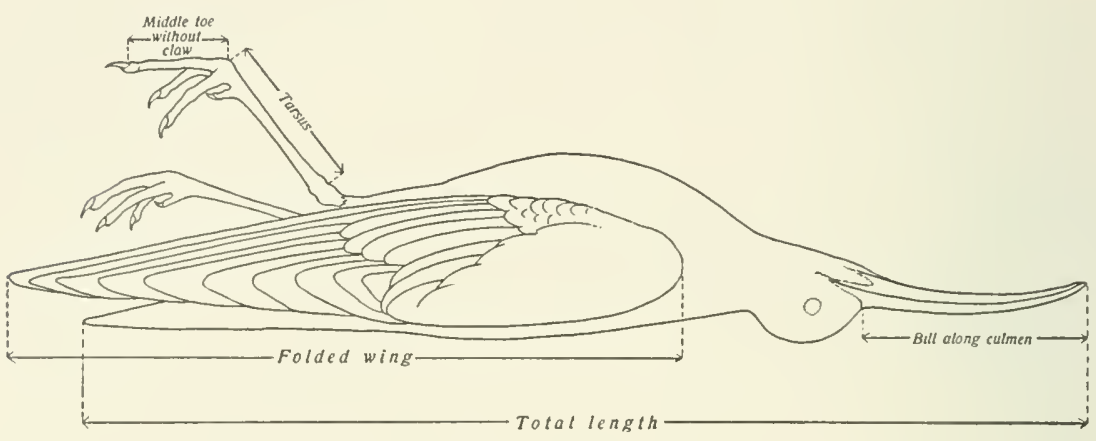

Fig. 4. Side view of Hudsonian Curlew showing method of taking the measurements used in this book. One-fourth natural size.

TOTAL LENGTH-With the bird laid flat on its back, the head straight out, and the neck not unduly stretched, measure from the tip of the bill to the end of the longest tail feather.

FOLDED WING-With the wing folred naturally against the side of the bird, neasure in a straight line from the bend of the wing ("wrist joint") to the tip of the longest primary flight feather.

Bill Along Culmen-Measure in a straight line from the last feathers on the midale of the forehead to the tip of the bill. This is really the "cllord of the culmen,' and does not take into account any irregularity or eurve in the profile of the bill.

TARsus-Measure from the notch in the "hock" or "heel" at the upper end of the tarsus to and over the rounded knob on the front of the lower end of the tarsus at the base of the midale toe.

MIDDLE TOE (without elaw) - With the foot pressed against some flat surface so that the toes are spread out, measure from the angle just below the lower end of the tarsus to the base of the claw.

EGGS-Measured with ealipers; specimens with holes in their ends are likely to fall short of the measurements given for the longer dimension. 


\section{IE TO THE GANE BIRDS OF CALIFORNIA}

It is believed that the following key will prove suffieient for identifying any game bird heretofore found in California. We would warn our reacters, however, not to depend upon it for the determination of species outside of our own state, and to use it only for birds in hand, either freshly killed or stuffed as speeimens. The key is "artifieial," in that it makes use of any serviceable eharacter, whether or not that eharacter be important in a natural elassifieation of birds. If information be desired as to the techniealities of systematic ornithology, then reeourse must be had to other works than the present one.

The kind of key here employed, exeept in two places, is that which is called "dichotomous," that is, it is two-branched, the mombers of a larger gromp bring separated into two lots according as they possess or lack a certain character or group of characters. In determining to which of tro groups a specinen belongs, both headings should be read-that is, read 1 and $1^{\prime}$, and 2 and 2 , even if from first inspection it is certain to which group the bird belongs. Referenee to the figures cited will often assist in deciling doubtful points. If any difficulty be found in identifying a specimen by means of the key, appeal to the deseriptions of speeies will soon settle the question. Measurements have been used in the key only where there were no convenient color or structural features. The methods of taking the measurements used in this key are the same as those mployed in the deseriptions of species (sce page 66 and fig. 4).

A concrete example will best show the manner of using the key. Suppose we have in hand a specimen of one of our commonest upland game birds and wish to identify it. In the "Key to the Main Groups" we read:

1. Feet fully webberl between front toes, ete.

1'. Feet without webs (or else only partly webbed); bill without cross-ridges or "teeth," and never "duck-like"' in shape.

Our specimen has no webs and therefore belongs in group 1'. Proceeding :

2. Legs and feet short, tarsus (leg) never more than one-tenth total length of bird; ends of claws never reaching beyond ends of longest under tail coverts: claw of hind toe reaching to base of claw on outer toe.

2 . Legs and feet longer, tarsus (leg) almays more than one-tenth total length; ends of claws reaching to or beyond ends of longest under tail coverts; elaw of hind toe never reaching to base of claw on outer toe.

Our bird belongs to group 2', as it has longer feet, ete. Continuing:

3. Area between bill and eye and space aronnd eye naked.

3 . Area between bill and eye and space around eye always feathered. 
The specimen in hand has the area between bill and eyc fully feathered and therefore belongs in 3 '. Next:

4. Wing more than $1 \overline{7} .00$ inches (430 $\mathrm{mm}$.) long; bill more than 3.00 ( $76 \mathrm{~mm}$ ).

$4^{\prime}$. Wing less than 13.00 inches (328 mm.) long.

The short wing of our bird places it in group 4'. Then:

5. Bill "'hicken-like," never more than one-third as long as head (except in Ring-neeked I'heasant); tip of upjer mandible curved abruptly downward, covering tip of lower mandible.

Pheasant, Quails, and Grouses.

5'. Bill never "chicken-like," always more than one-third as long as hearl, and tip of lower mandible never covered.

The short bill on the bird being identified, places it in group 5 . Turning to the key for the Pheasant, Quails and Grouses, we proceed, beginning there with 1 and $1^{\prime}$ again:

1. Wing more than 6.00 inclies $(152 \mathrm{~mm}$.) long.

1'. Wing less than 6.00 inches $(152 \mathrm{~mm}$.) long; tarsus never featherer?.

Our specimen has a wing less than 6.00 inches long and an unfeathered tarsus and hence goes muler 1'. Continuing:

7. Head with a straight, slender, tajering plume more than 2.00 inches (51 mm.) long; flanks rich chestunt hrown broadly barred with black and white; throat brown in males.

7'. Head with a short, enrved, broarleniled plume, less than 1.50 inches (3S mm.) long; flanks without black and white barring; throat black in males.

Onr bird belongs under $\tau^{\prime}$, as it has a short plume and black throat. Then :

9. No scale-like markings on belly, ete.

9 . Forepart of belly sealed with narrow blackish cross-bars, ete.

Evidently our bird comes under 9'. Then:

10. Ground rolor of mper surface and flanks deep olive brown.

California Quail.

10'. Ground color of upper surface and flanks grayish brown.

11. Smaller: wing averaging less than 4.35 inches $(110 \mathrm{~mm}$.) long. Nainlanri species.

Vailey Quail.

11'. Larger: wing averaging more than 4.35 inches (110 mm.) long. On Santa Catalina Island only.

Catalina Island Quail.

Our birel shows a grayish rather than olive tinge on the back, so we have a Valley Quail. Such character's as the last (under 10 and 11) are often difficult of determination and in the absence of specimens of both races for comparison depentence must be placed upon the locality of capture of the bird. After finding a name for any specimen by use of the key, reference should always be made to the full description of the species so as to verify the determination. 
1. Feet fully webbed hetween front toes (fig. 1); bill usually broad and PAGE flat (figs. 9 and 10), rarely slender (figs. 7 and $S$ ), and always provilerk either with eross-rilges or "teeth."

Ducks, Geese, and Swans

1'. Feet without wehs (or else only partly mebbed [figs. 56 and 61]); bill without "ross-rilges or "teeth" and never "duck-like" in shape.

2. Legs and feet short, tarsus (leg) never more than one-tenth total length of bird; ends of claws never reaching beyond ends of longest uncer tail coverts; claw of hind toe reaching to base of claw on outer toe.

Pigeons and Doves

2 . Legs and feet longer, tarsus (leg) always more than one-tenth total length; ends of elaws reaching to or beyond ents of longest under tail coverts; claw of hind toe never rearhing base of "law on outer toe.

3. Area between bill and eye and space around cye naked (figs. $42-44)$.

Ibises and Spooubill

3'. Area between bill and eye anil space alound eye alwars feathered (feathers sometimes bristle-like).

4. Wing more than 17.00 inches (430 mm.) long; bill more than 3.00 ( $76 \mathrm{~mm}$.) (fig. 45$)$.

Cranes

4'. Wing less than 13.00 inches (328 $\mathrm{mm}$.) long.

5. Bill "ehicken-like," never more than one-third as long as head (exeept in Ring-necked Pheasant); tip of upper mandible curved abruptly downward, covering tip of lower mandible (fig. 81). Pheasant, Quails, and Grouses

5'. Bill never "chicken-like," always more than one-third as long as head, and tip of lower mandible never covered.

6. Wing less than four times as long as midrle toe without claw.

Rails, Gallinule, and Mud-hen

$6^{\prime}$. Wing unore than four times as long as middle toe without claw.

Shore Birds

$7 \mathrm{~S}$

73

\section{DUCKS, GEESE, AND SWANS}

1. Plumage (including all flight feathers) entirely white; neck as long or longer than boly; area between bill and eye naked (fig. 40).

2. Larger; bill entirely black; hind margin of nostril more than 2.50 inches $(63.5 \mathrm{~mm}$.) from tip of bill.

Trumpeter Swan

2'. Smaller: a yellow spot (in adult) on side of bill in front of eye; hind margin of nostril less than 2.35 inches $(59.7 \mathrm{~mm}$.) from tip of bill (fig. 40).

Whistling Swan

1'. Plumage never entirely white; neek shorter than body; area between bill and eye always feathered.

3. Bill at least three times as long as height at base; no eross-ridges on sides of lower mandible, but "teeth" present (fig. 5).

4. "Teeth" on bill conspicuous, sharp, and inclined backward at tips; wing more than 8.00 inches $(203 \mathrm{~mm}$.) long; head crest various, but never with white. 
Key to California Game Birds-(Contimued)

5. Larger; wing of male more than 10.00 inches $(254 \mathrm{~mm}$.) long, of female more than 9.00 (228 $\mathrm{mm}$.); no reddish brown band on breast of male; nostril (both sexes) nearer middle of bill than base of bill (figs. 5 and 6 ).

American Merganser

5'. Smaller; wing of male less than 10.00 inches $(254 \mathrm{~mm}$.) long, of fenale less than 9.00 (228 $\mathrm{mm}$.) ; breast of male crossed by a broad redlish brown band; nostril (both sexes) nearer base of bill than midale of bill (figs. 7 and 8 ).

Red-breasted Merganser

4'. "Teeth" bhnt and not inclined backward; wing less than 8.00 inches (203 mm.) long; hear of male with a large erect, compressed, b]ack and white crest. Hooded Merganser

3'. Bill never as much as three times as long as lieight at base; the sides of lower mandible cross-ridged or fluted (figs. 9 and 39 ).

6. Wing more than 12.00 inches $(305 \mathrm{~mm}$.) long; tarsus longer

than middle toe without claw (shorter in Canarla Goose).

7. Plumage chiefly white (grayish in immatures), sometimes stained with rusty.

S. Larger; bill more than 1.75 inches ( $44 \mathrm{~mm}$.) long; the margins of the two manilibles wirlely separated and a large black area showing between them (fig. $30)$.

Lesser Snow Goose

$\mathrm{S}^{\prime}$. Smaller; hill less than 1.75 inebes (44 mm.) long; margins of the two mandibles almost meeting, no large black area between them (fig. 31).

Ross Snow Goose

$7^{\prime}$. Plumage various, never predominantly white.

9. Bill and feet never wholly black.

10. Top of hear and hind neck never white though area around base of bill usually white; breast usually marked irregularly with biack.

American White-fronted Goose

$10^{\circ}$. Top of hearl and hind neek white; breast bluish ash, with regular dark bars. Emperor Goose

$9^{\prime}$. Bill and feet entirely black.

11. Broad band across eheeks and throat white (sometimes interruted on throat).

12. Large; bill 1.88-2.31 inches (47.7-58.6 $\mathrm{mm}$.) long; tarsus usually shorter than mitllle toe and claw (figs. 32 and 35 ).

Canada Goose

12'. Medinm; bill 1.3\%-1.80 inches (34.S-45.7 mm.) ; tarsus about as long as midlle toe and claw (figs. 33 and 36 ).

Hutchins Goose

12". Snall; bill 1.04-1.44 inches (26.4-36.6 mm.); tarsus much longer than midlle toe anit claw (figs. 3t auc 37). Cackling Goose 
Kes to Calmorna (iame Birds-(Continued)

11'. Hearl entirely black; no white on cheeks or throat.

13. A series of white streaks on each side of nerk. Eastern Sea Brant

13'. A broarl white collar around middle of neck, incomplete behind.

Black Sea Brant

PAGE

241

237

6'. Wing less than 12.00 inches (305 mm.) long; tarsus shorter than midlle toe without claw.

14. No broad thin lobe on hind toe (compare figs. 11 and 22).

15. Tarsus 2.00 inches $(51 \mathrm{~mm}$.) long or more.

16. Belly black.

Black-bellied Tree-duck

251

16'. Belly hazel brown like breast, not black (pl. 7).

Fulvous Tree-duck

246

15'. Tarsus less than 2.00 inches (51 mm.) long.

17. IIeal cresterl; speeulum deep steel blue.

Wood Duck

17'. Heall not erested; speculmm variously colored.

18. Bill spoon-shaped (fig. 18), abont twice as broar near tip as at base.

Shoveller

18'. Bill nearly straight-sided, never greatly expanderl at tip.

19. Speculum purple or riolet.

20. Speculum pordered with white (pl. 3).

Mallard 92

20'. Speculum without white border.

Black Duck 101

$19^{\prime}$. Speeulum not purple or violet.

21. Speculum white.

Gadwall 103

21'. Speculum not white (though there may be white elsewhere on wing).

22. Larger; folded wing 9.00 inches (225 mm.) long or more.

23. A large white patch on fore part of wing; top of head white or creamcolor in males; bill less than 1.75 inches (44 mm.) long; mirlle tail feathers never greatly elongated.

24. Head of male cinnamon (pl. 3), of female ochre flecked with blackish.

European Widgeon

24'. Hearl not cinnamon, but white flecked with black in both sexes; a streak of green behind eye in male (pl. 3). Baldpate

23'. No light patch on fore part of wing or on top of lead in male; bill more than 1.75 inches (44 mm.) long (fig. 19); middle tail feathers of male in winter very long (pl. $3)$.

Pintail 
Key to California Game Birds-(Continued)

$22^{\prime}$. Smaller; folderl wing less than 8.25 inches (210 mun.) long.

25. No blue patch on wing.

26. A white har on side of breast of male. Green-winged Teal

26'. No white bar on side of breast of

25'. A large blue patch on forepart of

PAGE wing.

27. A crescent-shaped white patch on cheek of male; uniter surface never cinnamon brown; bill usually less than 1.60 inches $(40.5$ mm.) long (fig. 16).

Blue-winged Teal

$27^{\prime}$. No crescentic white pateh on cheek of male; under surface of male chiefly cinuamon brown (pl. 4); bill usually more than 1.60 inches $(40.5 \mathrm{~mm}$.) long (fig. $15)$.

Cinnamon Teal

14'. A broad thin lobe on hind toe (fig. 22),

28. Speeulum gray.

29. Larger; folded wing more than 8.50 inches ( 216 $\mathrm{mm}$.) long.

30. Forehead high and promiment (fig. 20); bill bluish gray, black at tip; iris yellow.

Redhead

$30^{\prime}$. Forehead sloping (fig. 21); bill uniformly colored (pl. 5); iris red.

Canvasback

29'. Smaller; folded wing less than 8.25 inches (210 mm.) long.

Ring-necked Duck

28'. Speculum varions, but never gray.

31. Speculum white.

32. Wing more than 10.00 inehes (254 mm.) long: head of male dull black, never irilescent.

White-winged Scoter

32'. Wing less than 9.50 inches (242 mm.) long; hearl of male more or less iridescent.

33. Bill (viewed from above) broader near tip than towards base.

34. Larger; folded wing more than 8.25 inches $(210 \mathrm{~mm}$.) long; hearl of male glossed with green.

Greater Scaup Duck

34 . Smaller; folded wing less than 8.25 inches (210 $\mathrm{mm}$.) long; hearl of male glossed with purple (pl. 5).

Lesser Scaup Duck

33'. Bill (viewed from above) narrower towarl tip than at base. 
Kex to Califoria Game Birds-(Continucd)

35. No white behind eye; folled wing more than 5.00 inches (203 mm.) long; male with a white patch between bill and eye, female with whole head dull realish brown.

36. Head of male glossed with green; white spot between bill and eye, rounded.

American Golden-eye

36'. Head of male glossed with purple; white spot between bill and eye triangular, higher than wide. Barrow Golden-eye

$355^{\prime}$. A single patch or band of white behind eve (fig. 23); folded wing less than 7.25 inches (1S4 nım.) long; no white spot in front of bill of male.

Buffle-head

31'. Speculum never white (but white patches may be present elsewhere on wing).

37. Wing less than 6.00 inches (152 mm.) long.

Ruddy Duck

37'. Wing more than 6.50 inches (16.5 $\mathrm{mm}$.) long.

38. Lower tail roverts white.

old-squaw

35'. Lorrer tail coverts not white.

39. Wing more than 10.50 inches (266 mm.) long.

King Eider

39'. Wing less than 10.00 inches (25t mm.) long. 40. Feathering at base of bill never extending as far forward as within 0.25 inch (6.3 mm.) from nostril (fig. 27).

American Scoter 194

$40^{\prime}$. Feathering at base of bill approaching to within 0.25 inch $(6.3 \mathrm{~mm}$.) of nostril.

41. Wing more than 8.50 inches (216 mm.) long; bill more than 1.25 inches ( 31.8 mm.) long (fig. 29). Surf Scoter

41'. Wing less than 8.50 inches (216 mm.) long; bill less than 1.25 inches (31.8 nm.) long.

Harlequin Duck

\section{IBISES AND SPOONBILL}

1. Bill not flattened, rather slender anil curved downward toward tip. 2. Plumage chiefly white; larger; bill more than 5.00 inches (203 mm) long; folded wing more than 16.00 inches (406 mm.) long.

Wood Ibis

2'. Plumage chiefly deep brown; smaller; bill less than 6.00 inches (152 mm.) long (fig. 44); folded wing less than 12.00 inches (305 mm.) long.

White-faced Glossy Ibis

1'. Bill straight, flat and broad, much expanded at tip (figs. 42 and 43); plumage pinkish.

Roseate Spoombill 


\section{CRANES}

1. Larger; folled wing more than 21.00 inches (533 $\mathrm{mm}$.) long; bill more than 5.00 (127 $111 \mathrm{~m}$.).

Sandhill Crane

1'. Smaller; folded wing less than 20.50 inches $(520 \mathrm{~mm}$.) long; bill less than 4.50 (114 mm.).

Little Brown Crane

\section{RAIIS, GALLINULE, AND MUD-HEN}

1. No "shiell", on middle of forchead.

2. Bill as long as, or longer than, tarsus.

3. Folded wing more than 5.00 inches (127 mm.) long.

4. Areraging slightly larger; upper surface grayish brown; uniler surface inll cinnamon brown. California Clapper Rail

4'. Areraging slightly smaller; upper surface olive brown; under surface bright einnamon brown.

Light-footed Rail

3'. Folled wing less than 4.50 inches (114 mm.) long. Virginia Rail $2^{\prime}$. Bill not more than three-fourths as long as tarsus.

5. Under surface with little or no black; folded wing more than 3.00 inches (76 mm.) long.

6. Breast gray; no white on wing feathers; folded wing more than 3.75 inches $(95 \mathrm{~mm}$.) long. Sora Rail

6 . Breast yellowish brown; patch on secondary wing feathers white; wing less than 3.75 inches (95 mm.) long.

Yellow Rail

5'. Under surface of borly chiefly blackish; folded wing less than 3.00 inches ( $76 \mathrm{~mm}$.) long.

California Black Rail

1 '. Middle of forehead covered by a horny, shield-like extension of the bill (fig. 54).

7. Toes slender, without any marginal lobes; bill of arlult chiefly red.

Florida Gallinule

7'. Toes with thin, broad, marginal seallop-like lobes (fig. 55); bill whitish.

Mud-hen

\section{SHORE BIRDS}

1. Tarsus more than 3.25 inches ( $82.5 \mathrm{~mm}$.) long; bill black, and more than 2.25 inelhes (57 mm.) long, never curvel ilownward; some solid black in body plumage at all times of year.

2. Top of hearl, nerk and back, black; bill almost straight (fig. 62) : no hind toe; webs between front toes very small (fig. 63); legs pink.

Black-necked Stilt

2'. No black on heal or neck; bill deciledly curved npward (fig. 60); hind toe present; extensive wohs between front toes at hases (fig. 61); legs lolue.

Avocet

1'. Tarsus less than 3.25 inches $(82.5 \mathrm{~mm}$.) long (if more than 3.25 [\$2.5 mm.] then hill eurved downwari); hill various.

3. Front toes with lobes or webs on margins and wobbed at hases; tarsus conspicuously compressed; under surface of bolly nerer streaked or harred.

4. Bill blunt (fig. 57): willer than high at hase; marginal webs on front toes sealloped (fig. 56); uniler surface of borly einnamon red in spring.

Red Phalarope 
Key to California Game Birds-(Contemuct)

4'. Bill slender and needle-like (figs. 58, 59).

PAGE

5. Bill less than 1.00 inch (25.4 mm.) long, not longer than hearl; a white stripe on wing; midkle of rump not white.

Northern Phalarope

5'. Bill more than 1.00 inch (25.4 mm.) long, longer than head: no white stripe on wing; upper tail coverts chiefly white.

Wilson Phalarope

$3^{\prime}$. Front toes without lobes on margins (but sometimes with webs between bases); tarsus never conspicuonsly compressed; under surface of body often streaked or barred.

6. Hind toe present (very small in Black-bellied Plover).

7. Axillar feathers solilly black.

8. Bill less than 1.50 inches ( $58 \mathrm{~mm}$.) long; hind toe very small (less than .10 inch [2.5 $\mathrm{mm}$.] long). Black-bellied Plover $\mathrm{S}^{\prime}$. Bill more than 2.00 inches $(51 \mathrm{~mm}$.) long; hind toe more than 0.25 inch $(6.3 \mathrm{~mm}$.) long.

Western Willet

$\tau^{\prime}$. Axillar feathers never solidly black.

9. Upper tail coverts solidly white, or black and white in solisl patches, never barred; bill less than 1.25 inches $(31.9 \mathrm{~mm}$. ) long.

10. A single pateh of solicl white on upper tail "overts.

Surf-bird

10'. Two solid patches of white, separaterl by black, on rump ancl upper tail coverts.

11. Throat and breast entirely black. Black Turnstone

11'. Throat and breast of mixed pattern. Ruddy Turnstone

9 . Upper tail coverts never solidly black or white, often barred.

12. Bill curred decidedly downward toward end, and more than 2.50 inches $(63 \mathrm{~mm}$.) long.

13. Larger; bill more than 4.50 inches $(114 \mathrm{~mm}$.) long; top of hear of mixed pattern like back.

Long-billed Curlew

13'. Smaller; bill less than 4.00 inches (102 mn.) long; top of head blackish brown with middle stripe of lighter color.

Hudsonian Curlew

12'. Bill straight or slightly curved upward (if curved slightly downward at tip then bill less than 2.00 inches [51 mm.] long).

14. Bill more than 2.00 inches (51 $\mathrm{mm}$.) long.

15. Bill stout, curved slightly upward, and more than 3.50 inches ( $89 \mathrm{~mm}$.) long. Marbled Godwit

15'. Bill never curved upward, and never more than 3.00 inches (76 mm.) long.

16. Bill tapered from base to tip and smooth; a whitish area on upper tail coverts. Greater Yellow-legs

16'. Tip of bill slightly enlarged and pitted (fig. 64); upper tail coverts completely barred.

17. Head and back with conspicuous longitudinal streaks of buffy yellow; upper tail coverts barred with buffy yellow.

Wilson Snipe 
Key to Califoria Game Birds-(Continued)

17'. Hearl and back without longitudinal streaks; upper tail eoverts barred with white.

Long-billed Dowitcher

$1 t^{\prime}$. Bill less than 1.75 inches $(4 t \mathrm{~mm}$.) long.

18. Tail feathers barred.

19. Breast white, unstreaked, but marked in summer with rounied black spots. Spotted Sandpiper

$19^{\prime}$. Breast variously streakerl, on buffy or gray grouni.

20. Wing more than 5.70 inches $(1+5 \mathrm{~mm}$.) long.

21. No white in tail barring.

Upland Plover

21'. Tail barring with considerable white.

Lesser Yellow-legs

20. Wing less than 5.60 inches (142 mm.) long.

Western Solitary Sandpiper

$8^{\prime}$. Tail feathers not barred.

22. Whole upper surface from head to tail, uniform grayish brown, without trace of streaking.

Wandering Tattler

22. Upper surface of bolly never colored uniformly.

23. Bill more than 1.30 inches $(33 \mathrm{~mm}$.) long.

24. Axillars and upper tail coverts both barred; bill not bent downward near tip (fig. 66).

Knot

24'. Axillars white; upper tail eoverts like back, not harres; bill bent slightly downward near tip (fig. 71).

Red-backed Sandpiper

23'. Bill less than 1.30 inches ( $33 \mathrm{~mm}$.) long.

25. Front toes webbed at bases (fig. 70).

Western Sandpiper

25'. Front toes not webbed at bases (fig. 69).

26. Wing less than 3.75 inches $(95 \mathrm{~mm}$.) long.

Least Sandpiper

26'. Wing more than 4.25 inches (108 mm.) long.

27. Feet greenish; tarsus and bill both more than 0.95 incle $(24 \mathrm{~mm}$.) long.

Pectoral Sandpiper

bill both less than

27 . Feet black; tarsus and bill
0.95 inch (24 mm.) long.

Baird Sandpiper

6'. Hind toe ahsent (see note under no. 6).

28. Bill less than 1.25 inches $(31.8 \mathrm{~mm}$.) long; never red.

29. Axillar feathers gray; belly black in spring.

American Golden Plover $45 \mathrm{~s}$

29'. Axillar feathers white.

30. Breast crossed by two hackish bands; rump tawny.

Killdeer 463

$30^{\prime}$. Breast with one or no black band; rumj, never tawny.

31. Breast erossed by a single black band.

32. Bill orange at base; forehead black. 
Key to Californa Game Birds-(Continued)

32'. Bill entirely black; forelsead white. Wilson Plover

PAGE

31'. Breast never erossed by a complete black band.

32. Larger; folled wing more than 5.25 inches $(133 \mathrm{~mm}$.) long. Mountain Plover

33'. Smaller; folled wing less than 5.25 inches (133 mm.) long.

34. Neek eneircled behind by a white collar; folded wing less than 4.25 inches (108 mm.) long; bill less than 0.75 (19 mm.). Snowy Plover

2t'. No white collar around hind neek; folded wing more than 4.25 inches ( $105 \mathrm{~mm}$.) long; bill more than 0.75 (19 $\mathrm{mm}$.). Sanderling 25'. Bill red, more than 2.25 inches (57 mm.) long.

35. Whole belly and base of tail white. Frazar Oyster-catcher 35'. Whole plumage browu or blackish appearing; no white markings anywhere.

Black Oyster-catcher

479

481

498

\section{PHEASANT, QUAILS, AND GROUSES}

1. Wing more than 6.00 inches ( $152 \mathrm{~mm}$.) long.

2. Tarsus altogether unfeatherel; toes never with horny fringes; male with spur on tarsus.

Ring-necked Pheasant

2'. Tarsus (at least the upper half) feathered; toes (in winter at least) with horny fringes; no spur on tarsus of male.

3. Middle of belly solidly black; feathers of tail conspicuously pointed: tail longer than wing; wing over 9.75 inches (2 48 mim.).

Sage-hen

3'. Middle of belly not black, but of same color as most of under surface; feathers of tail not pointed; tail shorter than wing; folded wing less than 9.75 inches ( $248 \mathrm{~mm}$.).

4. Tail not square-ended, midlle pair of tail feather's longer than the rest: middle of belly solidly white.

Columbian Sharp-tailed Grouse

4'. Tail square-ended; belly not pure white.

5. Each side of neck with a "ruff" of black or copper-colored feathers; lower third of tarsus naked; tail crossed by a broal lark band near end; plumage mostly redilish brown in both sexes.

Oregon Ruffed Grouse

5 '. Silles of neck without ruffs; tarsus completely feathered; end of tail crossed by a broad light band; body plumage (of male) chiefly dark bluish gray.

6. Alult male darker colored; less white on chin and throat.

Sooty Grouse

6'. Adult male lighter; more white on chin and throat.

Sierra Grouse

572

564

1'. Wing less than 6.00 inches (152 mm.) long; tarsus never feathered. 7. Head with a straight slender tapering plume more than 2.00 inches (51 mm.) long; flanks rich chestnut brown, broadly barred with black and white; throat brown in both sexes.

S. Darker; back and tail deep olive brown.

Painted Quail 
Key to California Game Birds-(Contimued)

$S^{\prime}$. Lighter; back and tail grayish brown.

Mountain Quail

PAGE

7'. Head with a short, eurvell, broad-ended plume, less than 1.50 inches

(35 mm.) long (fig. 82 ); flanks without black and white barring: throat black in males (pl. 1).

9. No scale-like markings on belly; flanks streaker with cinnamon and white; males with back of heal cinnamon colored, and with a black area on middle of belly.

Desert Quail

9'. Forepart of belly scaled with narrow blackish cross-bars; no cinnamon streaks on flanks; males with back of hearl grayish brown, and with a cinnamon colored area on middle of belly.

10. Ground color of upper surface and flanks deep olive brown.

California Quail

10'. Ground color of upper surface and flanks grayish brown.

11. Smaller; wing averaging less than 4.35 inches (110 mm.) long. Mainland species. Valley Quail

11'. Larger; wing averaging more than 4.35 inches (110 mm.) long. On Santa Catalina Island only.

Catalina Island Quail

\section{PIGEONS AND DOVES}

1. Tail pointei (fig. 89 ).

Western Mourning Dove $5 S S$

1'. 'Tail square-ended.

2. Tail crossed by a blackish hand near midnle lut not white at enıl (fig. 8.); total length of hiri over 13.00 inches $(330 \mathrm{~mm})$.

Band-tailed Pigeon 2'. Tail white-ended (fig. 90); wing with a large white patch; total length of birl under 13.00 inches $(330 \mathrm{~mm}$.). White-winged Dove

2". Tail without either lark cross band or white end; total length of bird under 7.00 inches ( $17 \mathrm{~S}$ mm.).

Mexican Ground Dove 


\title{
GENERAL ACCOLNTS OF THE GAME BIRDS OF CALIFORNIA
}

\section{American Merganser}

\author{
llergus americanus Cassin
}

OTHER xAMES-Fish Duck, part; Sawbill, part; Goosander; Sheldrake: Mergus merganser americanus ; Merganser americanus.

Description- ldult male: A single short erest on top and back of head; head and crest metallic greenish black; chin and throat dull black; bill reit, ridge and tip black and provided with backward-projecting, sharp-pointer, tooth-like serrations on opposed surfaces of the two mandibles; nostrils nearel middle of bill than base (figs. 5 and 6 ); iris carmine; back black: rump, upper tail coverts and tail ashy gray; outer surface of closed wing mostly white, crossed by a single bar of black; flight feathers kull brownish black; speculum white; axillars and lining of wing white; hind neek, and whole lower surface of hody, including sicles, creamy white to salmon buff; feet deep red. Total length “25.00-27.00"' inches (635-685 mm.) (Ridgway, 1900, p. ss) ; folded wing 10.1510.75 (25S-273); bill along culmen 2.06-2.25 (52.4-5..0); tarsus 1.56-2.09 (47.353.2) (six specimens). Adult female: Slender feathers of heal crest longer than in male; whole head reddish brown except for chin and throat which are white; upper surface of boly ashy gray; outer surface of closed wing chiefly gray like back; speculum white, outlined with sooty brown and crossed by a single bar of dusky; flight feathers blackish brown; axillars and lining of wing white; under surface of body ereamy white to salmon buff; hind neck, sides, and upper breast indistinctly barred with gray and white; iris and feet red as in male, but paler. Total length " $21.00-24.00$ " inches (533-609 mm.) (Rirlgway, 1900, p. 89) ; folded ming 9.22-10.12 (234-257) ; bill along cuimen 1.742.05 (44.3-53.0); tarsus 1.S0-1.95 (45.7-49.5) (five specimens); all from Pacific Coast, California to Alaska. Juvenile plumage of male: Similar to that of adult female. Natal plumage: Whole top of head reddish brown; stripe from base of bill to below eye, white; beneath this a deep brown stripe from angle of mouth, joining head-color behind eye; this stripe contrasts markedly with the white of chin and throat; the reddish brown of head and hind neck fades into riunamon where it meets white of throat; upper parts elove brown reliever by four white spots, one at hind border of each wing and one on each side of rump; whole lower surface white.

MARKS FOR FIELD IDENTIFICATION-The slender, cylindrical, "toothed", bill, with its sharp-edged and hooked tip, distinguishes mergansers from all other ducks. At a distance male mergansers appear black and white and both sexes show white on the wing when in flight. American Merganser is distinguished from Red-breasted by somewhat larger size, a head crest with but one point, by lack of reddish brown collar on breast (of male), and (in hand) by the nostril being nearer middle than base of bill (see figs. 5 to 8 ).

Voice-Of female: a coarse masculine "quack", (Law, 1912b, p. 42).

NEST-Usually in hollow trees along wooded streams, less frequently on the ground; made of twigs, grass, lichens, ete., lined with down. 
EgGs--10 to 16, ovate in shape, measuring in inches, 2.50 to $2.50 \mathrm{by}^{*} 1.70$ to 1.50 (in millimeters, 63.5 to 71 by 43.2 to 45.7 ); pale buff in color (Davie, 1900 , p. 76 and autliors).

General distribution-North America. Breeds from southern Alaska, southern Iukon, central Keewatin, southern Ungava and Newfoundland south to eentral Oregon, southern South 1)akota, northern New York and Maine, and in the mountains to central California, central Arizona and northern New Mexico. Winters from Aleutian Islands, British Columbia, northern Colorado, southern Ontario and New Brusswick, south to northern Lower California, northern Mexico ant the Gulf states (modifiel from A. O. U. Check-list, 1910, p. 66).

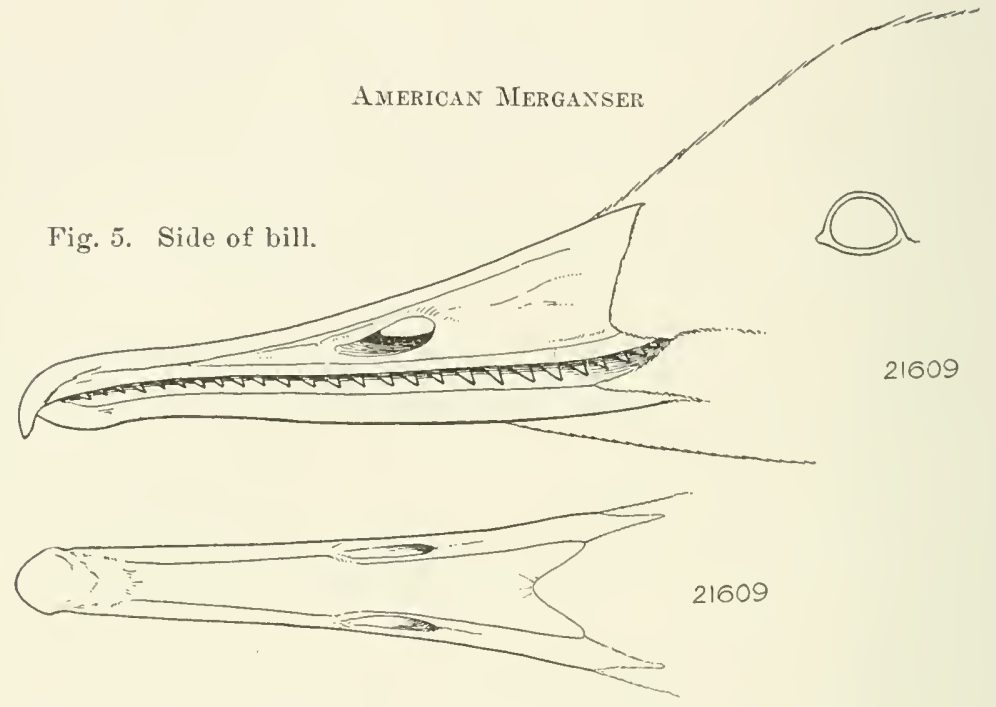

Fig. 6. Top of bill. Both drawings natural size.

Note slender outline (length more than three times height at base), sharp "teeth", absence of cross-ridges on sides (compare with figs. 9 and 17 ), and situation of nostrils rela tively far from base (

Distribution IN CALIFORNIA-Fairly common winter visitant to interior valleys and the entire coast region; partial to the vicinity of fresh water. Oceurs in summer and breels about lakes and along streams of the Sierra Nevada from the McCloud River, in Shasta County, south to the upper Kern River in Tulare County; also in the Humbolut Bay district.

The American Merganser, sometimes referred to as the handsomest of swimming birds, is to be looked for during the winter in pairs or small flocks along rivers, in lakes and with less certainty on the ocean or on salt marshes. It is oceasionally found summering abont lakes and along streams in the high momtains. At no time or place in California can it be said to be actually common as compared with other dueks, unless at Lake Tahoe, as deseribed beyond. 
The narrow bill with its sharp horny "tecth" and hooked tip, and the erest on the back of the head, help to distinguish the mergansers from other linds of ducks. The Ameriean Merganser, about the size of the Mallard, is the largest of the fish ducks or sawbills. It can be distinguished from the Red-breasted Merganser, the only one with which it is likely to be confused, by the position of the nostrils, which are nearer the middle of the bill than the base (see figs. 5 to 8 ). In the field the male American can be distinguished by the shorter, single crest and the absence of a reddish brown band across the breast. The frmales and young of the two species are diffieult to tell apart at any great distance.

The sawbills ar excellent swimmers and divers, and are able not only to pursue their prey under water but to remain beneath the surface for consiclerable periods of time, even as nuch as one or two minutes. When wounded, they have been known to dive to the bottom and cling to the grass. Eaton (1910, p. 179) states: "On one occasion [in New York] I fired into a flock of sambills at chose range, bringing down four of the birels, but all of them plunged into the water like so many stones, and only one of then ever so mueh as gave me a glimpse of himself again." The small mark which the birds present when swimming and their ability in diving makes them hard to shoot, and, like the grebes, they are popularly said to be able to "see the shot coming." When rising from the water they, like the mud-hens, patter along the surface with their feet for some distance before gaining sufficient impetus to rise in the air. Once well started they are swift flier's.

Most of the migrant birds of this species foumd in California breed in the far north, in British Colnmbia and Alaska, although some have been found breeding along the larger streams and lakes of the Sierras. C. H. Townsend (1887, p. 193) says. "This sheldrake breeds regularly on the lower MeCloud [Shasta County], where it is present the year round. Young birds in the down were obtained on May 21, and several flocks of young were seen on Eagle Lake [Lassen County]. late in June. Fish ducks were not observed elsewhere than on the larger mountain streams and lakes." Sheldon (1907, p. 185) records having seen two or three broods at Eagle Lake, Lassen County, and a young one was eollected in June, 1905. Law (1912b, p. 42) reports this bird as nesting commonly at Lake Tahoe. A female followed by eighteen or twenty young was noted there on June 24, 1911, and several pairs and a female with six young on June 28. A. K. Fisher $(1893 a$, p. 15) says: "A flock of a dozen or more sheldrakes was seen at Soda Springs (locally known as Kern River Lakes), in the Sierra Nevada the first week in September, and a specimen [was] shot there by Mr. Bailey August 15. . . "' Evidence obtained by a 
field party from the California Museum of Vertebrate Zoology indicates the breeding of this bird in small numbers in the same general loeality, namely, on the upper Kern River, in Tulare County. According to Wilder $(1916, p .127)$, this species is to be found at all seasons on the river's of Humboldt County. Ioung as yet unable to fly have been observed there in summer.

The courtship of the American Merganser as observecl in Massachusetts has been carcfully deseribed by (. W. Townsend (1916, pp. 10-12). The essential fratures ale as follows:

The courtship of the Merganser . . . is fairly spectacnlar and differs widely from that of its red-breasted cousin, $\boldsymbol{M}$. serrator. . . A group of five or six male Mergansers may be seen swimming energetieally back and forth by three or four passive females. Sometimes the drakes swim in a compact mass or in a fite for six or seven yards or even farther, and then each turus abruptly and swims back. Again they swim in and out among each other, and every now ant then one with swelling breast and slightly raised wings spurts ahead at great speed by himself or in the pursuit of a rival. . . They frequently strike at each other with their bills, and I have seen two splendid drakes rise up in the water breast to breast, and, amid a great splashing, during which it was impossible to see details, fight like game-coeks. The pursuit is varied by sudden, momentary dives and mueh splashing of water.

The smooth irideseent green heads, the brilliant earmine bills tipped with black nails, the snowy white of flanks and wing patches and the red feet, which flash ont in the dive, make a wonderful color effect, contrasting well with the lark water and white ice. The snaller females with their shaggy hrown heads, their neat white throat-bibs, their quaker houegray backs and modest wing patches, which are generally hidden, are fitting foils to their mates. The male frequently raises himself up almost on his tail and displays the beautiful salmon yellow tint on the whole under surface of his hody. Most of the time he keeps his tail cocked up and spread, so that it shows from hehind a white centre and blue border. Every now and then he points his head and elosed bill np at an angle of forty-five degrees or to the zenith. Again he bows or bols his hearl nervously and often at the same time tilts up the front of his breast from which flashes out the salmon tint. From time to time he emits a quiekly repeated purring note, dorr-dorr or krr-kirr.

The most surprising part of the performanee is the spurt of water fully three or four feet long which every now and then is sent backwards into the air by the powerful kick of the drake's foot. . . .

During all this time the fenale swims about unconcernedly, merely keeping ont of the way of the ardent and belligerent males, although she sometimes joins in the dance and bohs in a mild way. At last she suceumbs to the eaptivating display and submerges herself so that only a small part of her borly with a bit of the erest appear above the water, and she swims slowly lesinle or after her mate, sometimes even touching lim with her hill. Later she remains motionless, flattens herself still more, the erest disappears and she sinks so that only a line ... is seen. ... The drake slowly swims around her several times, twitehes his head and neek, pieks at the water, at his own feathers and at her before he mounts and completely submerges her, holding tightly with his lill to her neek meanwhile. Then she bathes herself, washes the water vigorously through her feathers and flaps her wings; the drake stretehes himself and flaps his wings likewise. 
Jutging from observations made elsewhere in North Aneriea, the nest is usually placed in a hollow tree or stub. Dawson (1909, p. 759) records one as having bern found at the top of a stub one hundred feet high and suggests that the roung in such cases are carried to the water in their mother's bill. Other observer's state that the young tumble from the nests into the water ten or fifteen feet below without injury to themselves. The ten to sixteen pale buft-colored eggs are protectre by a lining of down plueked by the female from her own breast. The young are especially good swimmers and the oarsman who succereds in catching them must be an expert. Their speed in eluding a pursuer is often greatly increased by flapping along the surface, something which they are able to do when but a few days old. When pursuert, the mother is said to allow the more fatigned ones to ride on her baek. An instance in point is recorded by Law $(1912 b, \mathrm{p} .42)$ as follows:

Several times the mother raised ahmost out of the water and dashed quickly along for fifty feet or so, every ehick rising and skipping after her, flapping their little wings and pallling the surface of the water with their little feet. After three of these spurts the youngsters seemed to tire, and one elimherl on its mother's back, and soon several hat hone so, aud roile securely there as long as they were in sight.

Swarth (1911, pl). 39-40) recorts an interesting methor of obtaining food as observert in Alaska, which has also been reorted for the Ret-breasted Merganser (C. W. Townsend, 1911, p. 343). The former writes :

I was concealed in the shrubbery at the water's ellge examining a large flock of ducks for possib) le rarities, when a lzozen or more mergansers ( $M$. americanus and $M$. serrator) began swimming back and forth but a very short distance from my blinil. They swam slowly, with neck outstretehed, and with the bill held just at the surface of the water, and at a slight angle, so that the head was submerged about to the level of the eyes. The water was evidently filtered through the bill, as a slight "gabbling" noise was quite audible, and obviously something was being retained as food, though just what it was I could not tell.

As one of its vernacular names (fish duck) signifies, the regular diet of the Ameriean Merganser is made up chiefly of fish, which it devours in great quantities. The gullet of an individual killed at Los Baños, Merced County, February 19, 1912, contained five carp about four inches in length. If earp were the only kind of fish eaten this would be considered a useful bird; but the merganser is also known to eat salmon and trout fry. Mr. W. H. Shebley, superintendent of hateheries for the California State Fish and Game Commission, (in letter) says: "The sawbill or fish duck is very destructive to trout and other fish. I have killed individuals on our trout ponds gorged with trout so that they were unable to swallow another one. We consider them one of the worst of the fish-eating birds." 
This bird is usually considered poor food, as it is pronounced tough, and at most seasons, has an mnpleasant fishy taste. When properly prepared, however, its "gamy" flavor ean be appreciated with the aid of a hearty appetite. But the skill needed to bring it to bag, therefore forms its chief claim to being classed as a game bird.

American Mergansers have been oeeasionally seen on the market in San Franciseo and Sacramento along with other ducks, and hunters are sometimes seen carrying them. No information regarding their comparative numbers now and formerly has been obtainable. But as the hunter often passes them by, and as they are wary and diffieult to shoot, it seems probable that there has been no marked decrease in their numbers.

\title{
Red-breasted Merganser
}

\section{Morgus serrator (Linnaeus)}

\begin{abstract}
OTHER NAMES-Fish Duck, part; Sawbill, part; Rerlbreaster Shelliake; Mergenser serrator.
\end{abstract}

Description-Adult male: Head with much elongated, double-pointed crest of very slender feathers; whole head black, dully so on throat aud "lown, but with strong metallic green wash on sides of head behind eye: a conspicuous white collar completely encircling neck save for black stripe town himl neck, connecting black of head with that of back; bill red, dusky along top, and with tooth-like serrations, sharp pointed, backward projecting and claw-like; iris red; whole back together with flight feathers black; rump, upper tail corerts and tail feathers brownish gray; rump raried with finely broken narrow black bars; outer surface of closed wing white, crossed diagonally br two black bars, and with white feathers of hinder portion of speculum outwardly eilger with black; a tuft of broal feathers on sides of breast overhanging beni of closed wing, these feathers being white with wide black borders; sides other. wise finely and irregularly barred with black and white; uniler surface white except for broad band across chest separated from black of heail by white collar; this band is reddish brown mottled with black; feet reil; uostril relatively small, located near base of bill (see figs 7 and 8 ). There is in the adult male in midsummer a brief-liver "eclipse" plumage in which the hear becomes dull brown and the breast dull gray (Stome, 1900, pp. 15-16). The total length (both sexes): "20.00-25.00" inches (507-635 mm.) (Rillgway. 1900, p. 89). Males: folderl wing 8.75-9.55 (222-242); bill along enlmen 2.13-2.32 (54-59); tarsus 1.73-1.81 (4t-46) (nine specinens from California). drult female: Sides of head and neck cinnamon brown, grading into whitish on ehin and throat, and into dark brown on top of head and crest; bill and iris red (Eaton, 1910, p. 179); whole upper surface including rump and tail ashy brown, the feathers having darker centers; flight feathers dull black; "losed wing gray like back; speculum white, crossed by one diagonal bar; lower surface white, the brown of hear fading gradually over the fore neek througly a faintly mottled area; sides and flanks dull grayish brown; feet dull red. Foliled wing S.25-S.80 inclies (209-224 nmm.); bill along culmen 1.93-2.13 (49-5t); tarsus 1.62-1.69 (41-43) (four specimens from California). Juvenile plumage of male: Similar to that of adult female but tuft of black-and-white-marked plumes in 
evidence on side near bend of wing, and rump and sides showing traces of fine irregular barring. Natal plumage: Top of heal elove brown; a white stripe below eye to base of bill; beneath this a cinnamon stripe from angle of inouth to side of neek, where it broalens; chin, throat and breast, white; upjer surface clove brown relieved by four white spots, one at hind borler of each wing, and one on each sile of rump. Downy young of the American and Red-breasted Mergansers are indistinguishable save for the position of the nostril.

MARKS FOR FIELD IDENTIFICATION-Smaller than American Merganser (for general characters of mergansers see that species). Male: Reddish brown hand across breast, and two black bars across speculum. Female: Cinnamon brown of neck not abruptly ended and back brown-tinged rather than bluegray. Both sexes have hearl crest of two points, one behind the other, and nostril nearer base of bill than mirlle (see figs. 5 to 8 ).

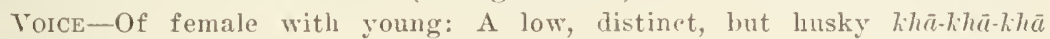
(Nelson, 1887, p. 67).

NEST-On marshy land in the vicinity of salt water, usually muler the shelter of a rock, bank, or braneh of a tree. A simple structure of leaves anil grasses, lined with down from the breast of the female parent.

EGGS-6 to 12, wate in shape, measuring in inches 2.45 to $2.65 \mathrm{by} 1.70$ to 1.85 (in millimeters, 62.2 to 67.2 by 43.2 to 47.0 ); color cream, buff, or greenisls buff (Baird, Brewer and Riılgway, 1884, 11, pp. 118-120; anil autlors).

General distributiox-Northern portion of Northern Hemisphere. In North America breeds from Aretic coast of Alaska, northern Mackenzie, Cumberland Sound, and Greenland (lat. $73^{\circ} \mathrm{N}$ ), south to southern British Columbia, and extreme northern Unitel States; winters from southern British Columbia anıl northern Unitel States, south to southern Lower California, Louisiana and Florida, and also in Greenlanıl and the Commander Islands (morlified from A. O. U. Check-list, 1910, p. 67).

Distribution IN CALIFORNiA-Common winter visitant along the entire sea. coast, oceurring both on the open ocean about rocky headlands and islands, anil on bays and salt lagoons; less numerous interiorly where it occurs at times on the larger bodies of water, as on Lake Tahoe and Owens Lake.

In California the Red-breasted Merganser is a better known "fishduck" than its larger relative, the American Merganser, for it is found plentifully on hunting grounds adjacent to the sea coast and occasionally on the larger bodies of water in the interior. To the north, in southern Alaska, the species is very abundant. At the base of the Alaska Peninsula, Osgood (1904, p. 55) states that this merganser is outnumbered among water birds only by the larger gulls. In California the bird associates in flocks of from a dozen to a hundred individuals.

At Monterey the first antumnal appearance of the species in 1896 was on October 9 (Cooke, 1906, p. 21) ; from abont that time on, it is common on the larger bays and lagoons and about rocky headlands on the ocean shore. In 1911 birds of this species were present at Monterey until April 10 (Mus. Vert. Zool), and at other points along the coast individuals have been seen in May. At Saint Michaels, Alaska, the species arrives about the middle of May and leaves by 
the first week in Oetolser' (Nelson, 1887, pp. 66-67). 'The birds wintering in California probably nest in British Columbia and Alaska; and the instances reeorded of nesting in Washington and Oregon (Dawson, 1909, p. 762; Cooke, 1906, p. 20) may also pertain to mergansers which winter in our state.

In addition to a considerable difference in size, there are other charaeters which enable one to distinguish the American and Redbreasted mergansers. The most useful of these is the presence in the male Red-breasted Merganser of a reddish brown breast band streaked witl black, and of a donble rather than single head erest. Of less utility for field identifieation is the color of the haek and the presenee

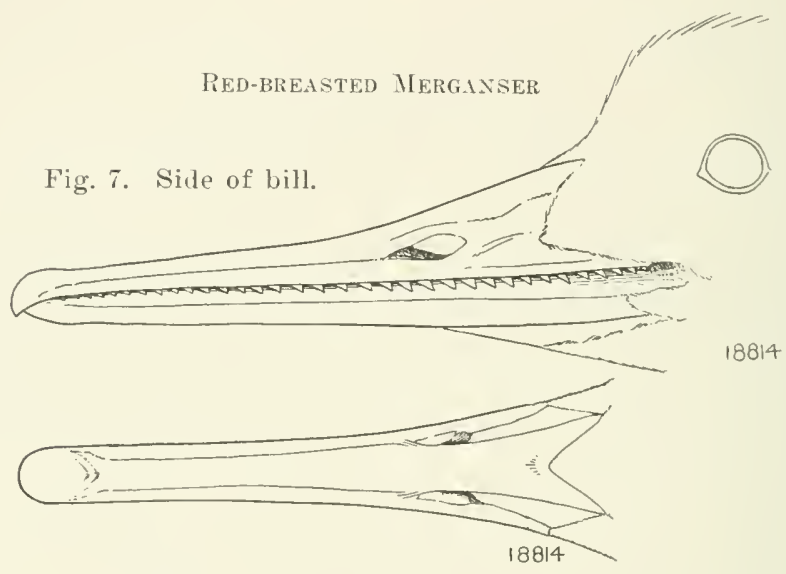

Fig. S. Top of bill. Natural size.

Note slender outline (length more than three times height at base), sharp "teeth", absence of cross-ridges on sides (compare with figs. 9 aud 17 ), and situation of nostrils relatively near to base (compare with figs. 5 and 6 ).

of two dark bars in the speenlum of the wing. In the hand the nostrils lying closer to the base of the bill than the middle easily identifies either sex of this speeies (figs. 5 to 8 ).

Althongh lacking the brighter eolor's of the Ameriean Merganser, the Red-breasted also presents a beautiful appearance. Graceful as a swimmer, it is strikingly adept as a diver. In diving it disappears below the water instantly and almost withont rippling the surface. After returning to the surface some distance away the bird often flaps its wings as if to streteh itself, or more probably to shake its plumage free from water and to readjust its feathers. Individuals of this speeies have been seen to dive repeatedly through advaneing waves during rough weather. On land this merganser is said to progress on its feet more rapidly than the diving dueks. On the 
wing it is swift and umusually silent. When closely pursued while swimming it secures partial concealment by lying low in the water with only its bill and head showing. A woumed bird nearly always use's this ruse.

The contship of the Rech-hreasted Merganser as observed on the New England coast has been described by C. W. Townsend (1911, pp. 3+1-343) as follows:

The nuptial performanee is always at its best when several drakes are displaying their charms of movement, voice and plumage, before a single duck, and each ries with the other in the ardor of the courtship. The drake begins by stretching up his long neck so that the white ring is much broadened, and the metallic green head, with its long erest and its narrow red bill, makes a conspicuons ol,jert. At once the bill is opened wide and the whole biril stiffly bobs or teters as if on a pirot, in such a way that the breast and the lower part of the neck are immersed, while the tail and posterior part of the body swing upward. . . All of the motions are stiffy executed, and suggest a formal but ungraceful courtesy.

The muptial "song." which is emitted while the bill is open, is a lond, rough and purring, slightly doubled note resembling the syllables $d a-a h$.

... The female merganser . . sometimes responds by a hobbing which is similar to that of the male, but of considerably less range. . . She emits a single note at this time, which is somewhat louder . . . and is of a different quality as it is decidedly rasping. . . . When the female responils in this manner she appears to be very exeited, and the ardor of the drakes is correspondingly increased.... Every now and then she darts out her neck and dashes at the ring of suitors. . . D During the courtship actions the tail [of the male] is elevated at an angle of forty-five degrees. . . This bobbing courtship of the males, although sometimes directed toward the female, is as often directer towards another male or even the empty water. The males not infrequently rush at one another with powerful leg-strokes making the water foam about their elevated breasts. Sometimes they raise their wings slightly or splash along violently using both wings and feet for propulsion. Now and then a male pursues a female, and she, to avoid capture, may dive and is at once followed by the male. In flight the female generally precerles by a short interval the male.

The habit of lying flat in the water and of rising up and flapping the wings is indnlged in at all times of the year.

In Alaska the Red-breasted Merganser breeds from Sitka and Kodiak Island north to Icy Cape and perhaps to Point Barrow (Nelson, $1887, \mathrm{p} .66$ ). The nests are as a usual thing carefully concealed under dead leaves or in grass, and sheltered by a log or bank. A nest observed by Girinnell (1900, p. 14) on Chamisso Island, Alaska, was situated on an exposed sea wall about fifty feet above the surf and hidden among clımps of tall grass. The nest often consists largely of down, and the eggs are usually covered over by the female when 
she leaves the nest, provided she is not routed ont too suddenly. The eggs number from six to ten in a set and are laid early in Junc. Downy young are most commonly seen during July. The incubation period is 26 to 28 days (Strong, 1912, p. 482). The male takes no part in the duties of incubation, and it is doubtful whether le assumes any of the care of the young.

Concerning the behavior of the females and young. Grinnell (1900, p. 15) says:

At Cape Blossom on August 1, 1899, I emcountered a brood of six downy young with the female parent. They were ont in the middle of a lake, and the juveniles swam in a close humch. The parent kept diving at short intervals, and whenever she reappeared, which might be at a considerable distance from where she dove, the band of young with one accord scramblerl over the water towards her, with flapping arms, and almost ruming on the surface. The foremost chick, probably always the hungriest of the lot, was apparently the one to obtain the prey which in all cases observerl was a small fish.

Dawson (1909, p. 762) states that a female when surprised with her brood played dead as a ruse to deceive her pursuers.

The food of this duck consists almost entirely of fish. In Alaska, according to Nelson (188T, p. 67), “. . . in the brackish ponds and tide creeks of the marshes they find an abmuance of food in the myriads of sticklebacks which swarm in these water's." In the East it is said that the birds also eat crustaceans and shellfish. Mr. F. A. Shebley, of the Brookdale Hatchery, Monterey Countr, California, says he has shot fish ducks along the stream so gorged with fish that by holding them up by the feet, the fish would fall from their mouths. He states further that birds of this species stay mostly in the lower conrses of the streams, and in the lagoons of his vicinity. Linton (1908b, p. 126) saw them frequently feeding in tide pools in the vicinity of Northwest Harbor, Santa Cruz Island. The stomach of a bird taken there December 2, 1907, contained nine "rock bass and one spotted shark," each two to four inches long.

This duck cannot be considered an important game bird (a statement which applies also to the American Merganser) as the fish taint in its flesh caused by the fish diet makes it undesirable for food. However, during the season of 1895-96, 217 "sheldrakes" were sold in the markets of San Francisco and Los Angeles (Calif. Fish Comm., 1896, p. 40). Since then, birls of this species have rarely been seen in the markets of San Francisco and Sacramento. As this merganser is shy and liard to approach it is only obtained with difficulty. Consequently there seems to be no immediate danger of its extermination. And yet the very fact that it is difficult to shoot gives it a certain value in the eyes of the hunter. The increasing efficiency of firearms, will also have some effect on the numbers of this species. 


\section{Hooded Merganser}

\section{Lophodytes cucullatus (Limaeus)}

OTHER NAMES-Hooled Shelilake; Oyster Duck (Napa County); Mergus curnllatus.

DESCRIPTIOx-Aclult male: IIearl and neck chiefly black; conspicuous, vertical, compressed crest of hair-like feathers; this crest chiefly white but set in black, giving the effect of a hlack-bordered white fan; feathers arounl base of bill lark brown blended into black of rest of head; bill short, black, with nostrils near base, and with "teeth", short, obliquely set, and not claw-like; iris yellow; fore back, black, continuously so with hind neck; lower back, rump ancl tail dark lrown; forepart of rlosed wing dark grayish brown and gray; speculum white, margined in front by black bar, and crossed centrally by a similar bar; jrimary flight feathers dark brown; secondary flight feathers black, each with a sharply lefined central white stripe; silles and flanks (innamon brown finely barrel with black; breast and under surface white; sides in frout of wing with two black half-creseents originating from the black of the back ancl extending diagonally downwarls and forwards; legs and feet "yellowish-browu," webs "Alusky" (Aulubon, 1843, VI, p. 406). Total length (both sexes) "17.25-19.25", inches (4.38 to $4.99 \mathrm{~mm}$ ) (Ridgway, 1900 , p. 89). Nale: folled wing 7.90 (198); bill along eulmen 1.54 (39.1) ; tarsus 1.24 (31.5) (one specimen from California). Adult femalc: Heat, neck, chest and whole npper surface grayish brown; throat paling to whitish on chin; top of head clove brown shading to reddisls hair browu on crest; crest of looser textmre than in male and less conspicuous; bill black with base of lower mandible orange; iris hazel; wings and tail dark brownish; speculum white, with two bars of black as in male; lower surface white, with siles, flanks and unler tail coverts clouled with brown; legs anil feet dusky. Folded wing 6.85-7.40 inches (174-1S. mu.) ; bill along culmen 1.49-1.64 (37.741.6); tarsus 1.22-1.31 (31.0-33.2) (five specimens from California and British Columbia). Jurenile plumage: Similar to that of adult female but with erest poorly developed and under tail coverts more distinctly brown (Ridgway, loc. eit.). Natal plumage: Top and sides of head brown, paling to cinnamon color on cheeks; chin and throat white; upper mandible blackish, its tip and the whole lower mandible yellow; upper surface of boly dark brown; five pairs of small spots on back, rmmp, and wings, white; band across foreneck, pinkish brown; rest of under surface white.

MARKS FOR FIELD IDENTIFICATION-Small size (for a duck), slender short bill (shorter than hearl), narrow, erect, black-bordered white-patched head crest (in the male), and brown sides. Distinguished from other mergansers by much smaller size, and from all other ducks by the size and shape of bill.

ToICE-"A hoarse croak", (Forbush, 1912, p. 68); "a variety of guttural, chattering notes", (Bowles, in Dawson, 1909, p. 763).

NEST-In hollows of trees high above ground and near or over water; built of grasses and weeds and lined with down from the breast of the female.

EGgs-5 to 12, nearly globular in shape, measuring in inches, 2.05 to 2.15 by 1.70 to 1.75 (in millimeters, 52.0 to 54.6 by 43.2 to 44.5 ); in color pure ivory white (Baird, Brewer and Ridgway, 1884, II, p. 124; and authors).

General Distribution-North Ameriea. Breeds on the north from central British Columbia, Great Slave Lake, central Keewatin, central Ungava, and Newfoundland, south to southern Oregon, northern New Mexico, southern Louisiana, and central Florida; winters on the north from southern British 
Columbia, Utah, Colorado, Nebraska, 1llinois, Indiana, Pennsylvania, and Massachusetts, soutl to Lower California, Mexico and the Gulf States; rare in the northeastern part of its range; casual in Alaska, Bermuda and Europe (A. O. U. Cheek-list, 1910, p. 67).

Distribltion IN CALIForNiA-Rather rare fall, winter and spring visitant to salt marslies along the seacoast, and on the lakes and slower streams of the interior.

The Hooded Merganser is at the present time the rarest of the three mergansers belonging to Califormia. The other two are typically northern species, whereas the IIooded is sonthern, breeding largely south of the Canadian boundary. It is a notable circumstance that the Hooded Merganser and the Wood Duck appear to frequent the same type of locality. In California during the fall, winter and spring the former speeies oceurs sparsely in the salt marshes along the eoast and on the lakes and streams of the interior. In southern California it has been stated to arrive in November and to leave by February (Grimnell, 1898, p. 10). It is evident that musem colleetor's have rarely eneountered the species in the field as but few specimens have been available for study.

The following are all the definite records for the state known to the authors: Inmmoldt Bay, MeClond and Pit rivers (C. H. Townsend, 188T, p. 193) ; Mark West Creek, Sonoma County (Mailliard, MS); Snisun Marsh and Putah (reek, Solano County (Mus. Vert. Zool.); San Franeiseo (Newberry, 1557, 1). 104); San Franeiseo Bay (Mus. Yert. Zool.) ; Marysville, Yuba County (Belding, 1879, p. 447) : Paicines, San Benito County (J. Mailliard, 1902b, p. 46); Ventura Comnty (Evermann, 1856, p. 89) ; Fillmore, Ventura County (Willett, 1912a, p. 22) ; Del Rey, Los Angeles County (Chambers, 1914, p. 92) : Alamitos Bay, Los Angeles County (Grinnell, 1898, p. 10); Westminster', Orange County (Grey, 1915, p. 59); vicinity of Los Angeles (Willett, loe. cit.) ; San Diego (Belding, IIS).

It is impossible to confuse the male of this duck with that of any other speeies. Aside from the small size of the bird, its vertieal, eonpressed, black and white erest, eomposed of hair-like feathers, serves to immediately distinguish it. This fan-like erest is freguently raised and lowered as if to display the umusually conspicuons ornament. The Hooded Merganser almost equals that handsomest of the ducks, the Wood I)uck, in its splenclid coloration. It can always be separated from the other merganser's by its bill which is eliefly blaek in eolor, and shorter than the head. The female can be recognized by her short bill and clark grayish brown ehest.

Although no deseription of an eclipse plumage has been located by us, and no birds in such a plumage are to be found in available collections, yet the following quotation from Widnam (1895, p. 351) suggests that there is such a plumage in this speeies as is the ease 
with most other lucks: "At this season [June, in southeastern Missomi] the beauty of the male s dress and coiffure is entirely gone; both parents resemble each other so much that they are generally mistak'n for female. Wood Incks, which are also very common brecters in these swamps."

Little is known of the life histor'y of the Hooded Nererans'r on the P'acific Coast. It is said to begin nesting in Washington in April (Bowles, in Dawson, 1909, p. 763). The nests are located high in hollow trees orer or near water and are composed of weeds and grasses, and lined with down. The eggs are variously reported as numbering from 5 to 12 ; they are ivory white in color, and more nearly globular in form than those of other ducks. The following notes on the nesting hahits of this hird are recorded by Spreadborough (in Macoun and Nacoun, 1909, p. 77): "A pair has built in an elm stub for foul years, at about thirty feet from the gromel, at the mouth of Sharp Creek, Bracehridge, Ontario. The stub is on the bank of a stream. The old bird carries her young from the tree to the water in her bill. At first the young are rather helpless and are very easy to eatch, but in a few days they are well able to take eare of themselves." As is the case with the other melganser's, the male leaves the duties of incubation and the rearing of the young entirely to the female. Flocks of male's are generally the first to be seen in the fall migration.

Hooded Mergansers are swift Hier's and make less nois? with their wings than almost any other duck. Bowles (loe. eit.) says: "Its flight is rery swift and eccentric, resembling greatly that of the Greenwinged Teal, for which the bird is easily mistaken in the faint light of early morning or evening."

Instead of frequenting swiftly ruming streams as is the case with the American Merganser, the Hooded prefer's the quieter streams, sloughs and small ponds. In such places it is said to feed upon tadpoles, small fish and water insects, even taking some vegetable food.

'The smaller size of the bill of this mergansel', as well as its habitat, would seem to indieate that it is not so destructive of valuable fish as the other two mergansers. Its diet also makes it more palatable, and in the middle west wherever it is plentiful, it is used for food.

All the evidence at hand points to a great reduction in the numbers of this species during recent years. Henshaw (1876, p. 275) says that at the time of his travels through California in the early serenties the Hooded Merganser occurred "in fall in large numbers as a migrant." No recent observer has offered a like statement. In former years (1870-1885) this merganser was oeeasionally seen along the creeks of Marin County and along Mark West Creek, Sonoma County, but it has long since been shot out of this region ( $\mathrm{J}$. and $\mathrm{J}$. W. Mailliard, MS). 


\section{Mallard}

\section{Anas platyrhynchos Jimnaeus}

OTHER NAMES-Greenhear; Wild Duek; Gray Mallard (female); Anas boschas.

DESCRIPTION-Adult male: Hearl and neek brilliant metallic green, with purple reflections at certain angles; forehead and crown overlaid with black; green of head suceeded by a narrow white ring around lower neck interrupted behind; bill ehiefly greenish yellow; iris brown; midale of back between shoulders brownish gray with paler feather edgings; sides of baek silvery white minutely barred with lusky; back, rump and upper tail coverts black, with steely blue reflections; tail feathers mostly white with the two middle feathers black and slightly curled upwards, and the two longest upper tail coverts conspicuously eurled up; outer surface of closed wing in general brownish gray; axillars and lining of wing white; speculum metallic violet approaching purple, borderes in front and behind with black and white feathers, a black and white bar being thus formed at both front and hinil margins: breast lark ehestnut; siles and rest of under surface silvery gray undulated with lusky; under tail coverts black; feet orange red, nails dusky. Total length 23.50-25.25 inches (596-640 $\mathrm{mm}$.) (four specimens); folded wing 10.55-11.55 (276-293); bill along culmen 2.13-2.44 (54-62); tarsus 1.62-1.83 $(41-46.5)$ (seven specimens). Adult female: Head and whole upper surface chiefly deep brown, but variegated with abruptly paler feather edgings; gen. eral tone of head paler, with finer, more streaky pattern than on baek; top of head darkest, sides of head lighter with dusky streak through eye; throat very light brownish white scantily or not at all streaked; wings mueh as in male; ground color of under surface brownish white, deepest in tone on breast, but black feather centers giving a streaked or mottled appearanee; sides and chest most heavily marked, belly lightest. Total length 22.25-23.25 inches (565-590 mm.) (two specimens); folded wing 9.95-10.80 (252-274); bill along culmen 1.89-2.27 (48.0-57.5); tarsus 1.63-1.77 (41.4-45.0) (ten specimens); all from California. Eclipse plumage of male (assumed in July and August): Closely resembles dress of female but darker; lacks green of head. In full eclipse plumage male and female can be distinguished only with difficulty: In partial eclipse or post eclipse enough old or new feathers are present on wings to identify the male. Juvenile plumage (at least of female): Similar to that of adult female but dusky mottlings and streaks duller, less clearly defined; those on breast simple shaft streaks instearl of horseshoe-shaped figures as in adult female; wing markings same as in adult. Natal plumage: Whole back and top of heal dark brownish green fading to lighter color on forehead; side of head light yellowish brown, stripe through eye, and spot on cheek dusky; brown of baek reliever hy two pairs of yellowish spots, one at hind border of each wing and one on each side of rump; under surface yellowish buff; sirles shading to gray and invarled by two brown patches of same color as bark.

MARKS FOR FIELD IDENTIFICATION-The large size (total leugth over 22 inclies [558 mm.]), metallic green heal, white ring around neek, and violet-colored speculmm identify the male. The violet or purple speculum borlered along loth elges with black and white distinguishes both sexes in all plumages (pl. 2), except, of course, the natal. In flight the white umbr wing coverts show forth. The female can be distinguished from the Black Duck, a near relative, ly its much lighter color. 
Vorck-Of female: a loul, oft repeated "quack," like that of the rlomestic duck. Of male: similar but much sotter, more wheezy.

NEsT-Generally on ground near water, hidilen in clumps of willows, weeds, tules, but more often in tall grass; erudely male of leaves and grasses but warmly and copiously lined with lown; about seven inches in insicle diameter.

EGGS-5 to 14 , bluntly ovate, measuring in inches, 2.06 to 2.55 by 1.50 to 1.80 (in millimeters, 52.3 to 64.7 by 35.0 to 45.7 ); in color vellowish drals or pale greenish white (Bairl, Brewer and Ridgway, 1S54, I, 1. 499; and one set from Alaska). Eggs of the Mallard resemble those of the Gadwall enough for the two to be confused. Mallard eggs average slightly larger, and have a greenish rather than buffy tone of coloration.

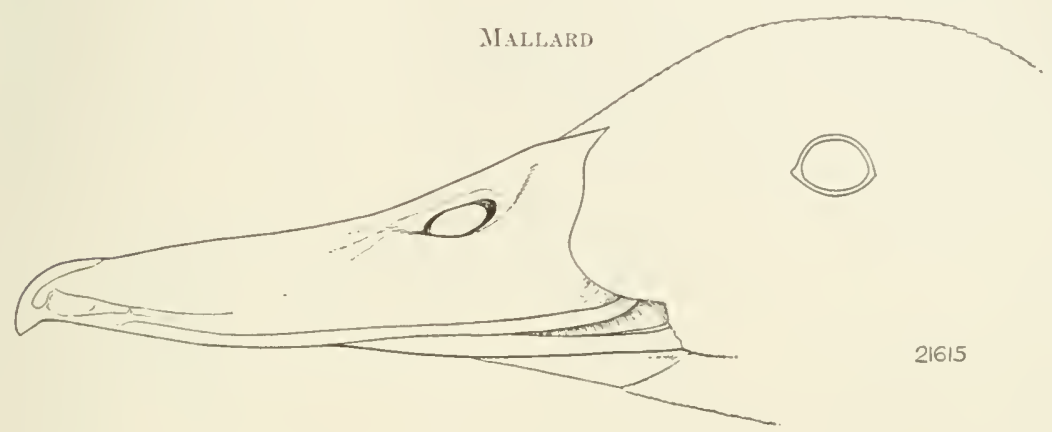

Fig. 9. Sirle of bill.

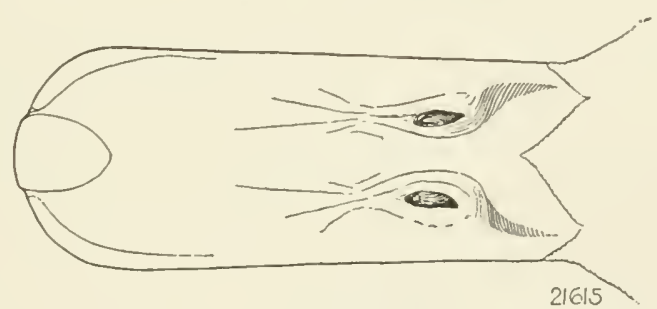

Fig. 10. Top of bill. Natural size.

Note broad outline (height at base more than one-third total length), and presence of cross-ridges on silles of lower mandible as showing near base (compare with figs. 5-8).

GeNERAl Distributiox-The Northern Hemisphere generally. In North America breels from western Alaska, east through Canala to Hudson Bay, and in Greenland; thence south through the United States to Lower California, southern Kansas, southern Indiana, and (rarely) Maryland; winters from Alaska (sparingly), and the northern United States, south to Mexico and Panama; casual in Bermula and Hawaii. In the Old World also migratory, wintering south to northern Africa and Inclia (modified from A. O. U. Checklist, 1910 , p. 68).

DistribUtion in CALIFORNIA-Common resirlent in suitable localities throughout the state, but much more abundant in winter than in summer. A typical fresh-water duck, oceurring but sparingly on salt water. Most abunilant around fresh-water ponds and streams in the interior valleys. Breeding stations numerous and widely distributed. 
The Mallard is the largest and most highly prized of the resident ducks in California, and is widely distributed throughout the state. A typical river duck, it is seldom found on salt water and only sparingly on the marshes along the seacoast. It is most abundant on the rivers, lakes and ponds of the interior, heing partial to the freshest water. A large number of Mallards hreed within the state, but their numbers are greatly augmented during the winter season by migrants from the north. This is a common breecling bird in Oregon, Washington, British Columbia and sontheastern Alaska; in each of these regions the species ocens in varying numbers in winter also, but in northern and western Alaska it appears merely as a summer resident and even then only in limited numbers. It is also one of the commonest ducks of the middle west but is only a straggler in the

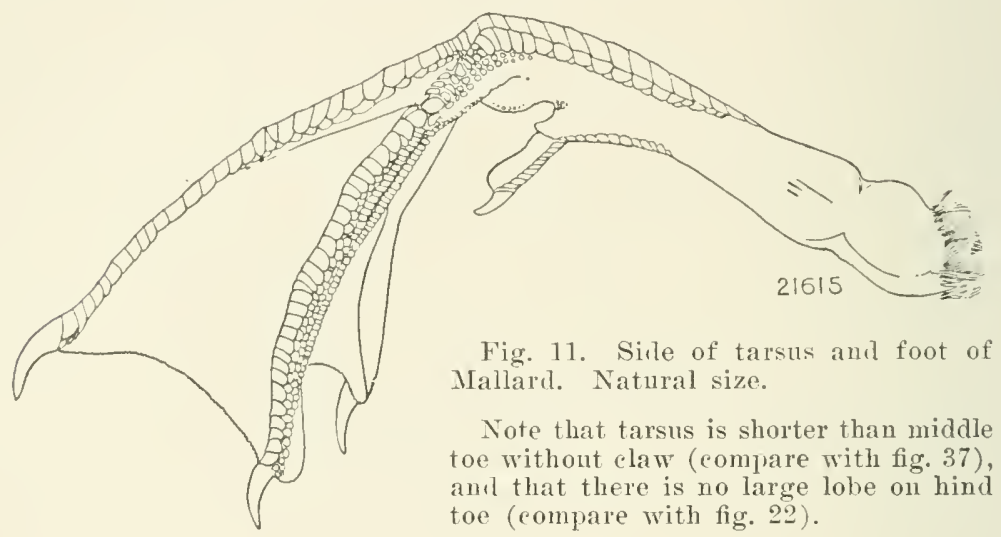

states of the Atlantic Coast where its place is taken by the Black Duek (Anas rubripes).

For the majority of the people of the state the Gremhead or Mallard is the duck most easily recognized, and it has been domesticated to such an extent that it is familiar to many people who have never seen it in the wild. The green head and white ring around the neck easily identifies the male, while the large size together with the violet wing-speenlum bordered on both sides by black and white, are sufficient to distinguish either sex of the Mallard from all other (hrreks (pl. 2). In flight the white under surface of the wing often helps in identification. When flushed at close range the white of the spread tail in the male shows as a white hand. Not only do the plainer body rolor's of the female easily separate this sex' from the male, but its much louder call is by conmon testimony a noticeable trait. The female Mallard when flushed in the open ean be readily distinguished from the female Pintail by its larger size, shorter neck and white under surface of wing. At close range the conspicuous violet speculum 


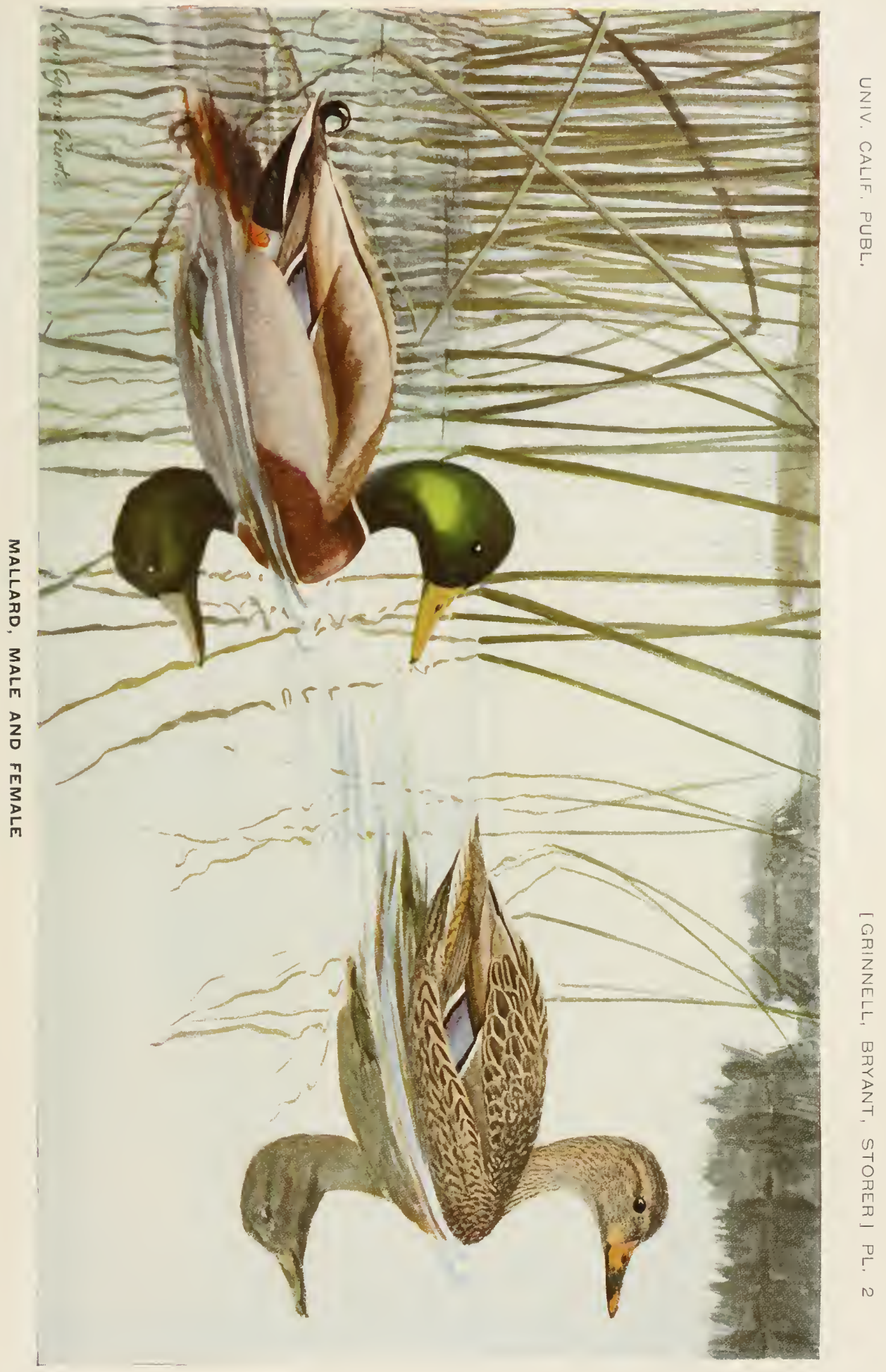



of the Mallard contrasts markedly with the dull brownish speculum of the Pintail. The Mallard's nearest relative, the Black Duck, is of very late occurrence in California ; it is easily distinguishable from the Mallard by its much darker general color in both sexes and by the lack of the metallie green on the hearl in the male.

As a general rule this duck is monoganous in its native estate, although some authorities contend that polygamy oceurs where there is a dearth of males. The eomrting anties of the wilet Mallard in California have never been described; but they are doubtless of the same type as observed by C. W. Townsend in Massachusetts. According to that author the drake swins restlessly about following or sidling up to a duck. She may lead him a long chase before he is able to press his attentions elosely. He then begins a continual howing to her, bobbing his head np and down in nervous jerlis so that the yellow bill dips into the water for a quarter of its length and comes up dripping. II also rears himself up in the water and from time to time displays his breast. The female shows little concern at first, but oceasionally turns her head to one side and calelessly dabbles her bill in the water. " . . . Sooner or later, if all goes well, she begins to bow also, less vigorously at first-not touching the water at alland to the empty space in front of her. Suddenly she turus and the pair bow to each other in the same energetic nervous jerks, and, unless a rival appears to spoil the situation, the drake las won his suit" (C. W. Townsend, 1916, p. 13).

The Mallard is one of the earliest dueks to breed. "By February nearly all have selected their partners for the nesting season. They still travel in large companies; but watch a flock of them after they have settled down in the open water. At once they separate into pairs, every handsome 'Greenhead' swimming in close attendance wherever his modestly garbed mate shall lead. Should one of the pair be killed, the other will not mate again that season. . .' (Bowles, in Dawson, 1909, p. 767).

In California Mallards breed wherever suitable conditions are afforded. There does not seem to be in the lowland districts any difference in the time of nesting which can be correlated with differences in latitude. The earliest record is that by Belding (IIS) who found eggs at Gridley, Butte County, Mareh 25, 1890. In Los Angeles County, Grinnell (1898, p. 10) gives the nesting season as extending from the first of April to the end of June, and this probably would apply to other portions of the state as well. The latest report, seasonally, is that by A. K. Fisher (1893a, p. 15) who records downy young at Walker Basin, Kern County, July 13, 1891.

The data brought together in the accompanying table (no. 8) are all that have been found by the authors as applying to California. 
TABLE S.-Data relative to the nesting of the Mallard in Califoruia

LOCALITV

Gridley, Butte Co. I.os Angeles Co.

Lake Nereed. San Francisco Co. San Diego

Hueneme, Tentura Co. Near San José, Santa Clara Co. Olancha, Inyo Co.

Wheeler Island, Solano Co.

Alvarado, Alameda $\mathrm{Co}$ Alvarado, Alameda Co. Stockton, San Joaquin Co.

Hayward, Alameda Co. Los Baũos, Merced Co.

Los Baños, Merced Co.

Gridley, Butte Co.

San Diego

Merced Co.

Merced Co.

Gridley, Butte Co.

Gridley, Butte Co.

Gridley, Butte Co.

Lake Tahoe

I ake Valley, Lake Tahoe

Los Baños, Merced Co.

Stow Lake, San Francisco

Willow Creek, Lower Klamath Lake

Willow Creek, Lower Klamath Lake

Lake Tahoe

Bear Talley reservoir, San Bernardino Co.

Rowlands Marsh, Lake Tahoe

Tulare Lake, Kings Co.

Kern Valley, Kern Co. Clowehilla, Merced Co.

Fresno district

Eagle I,ake, Lassen Co. June 27, 1884 8 eggs

Walker Basin, Kern Co. July 13, 1891 Broods of downy young Bakersfield, Kern Co. July 19, 1891 Brood of young neariy

Escondido, San Diego __ _ 1896 One nest foumi Co.

Santa Barbara

Santa Cruz grown

Mar. 25, 1890 Fggs

First of April Breeding to last of

Apr. 28, $191510 \mathrm{eggs} \mathrm{(7} \mathrm{on} \mathrm{Apr.} \mathrm{22)}$

Apr. 24, 1862 Female witl egg nearly

May 1, 191011 eggs, partly incubated

May 1, 189311 eggs

$\underset{1891}{\operatorname{May}} \mathbf{6 1}$

May 8, 1914 Four broods about one week old

May $9,1914 \quad 11$ eggs

May 9,191414 eggs

May 9, 1878 A brood of young

May 11, 1884 Half-grown young seen

May 12, 1914 Brood of half-grown young

May 19, — Young a month old

May 19, 1897 Eggs

May 19, 18969 eggs, fresh

May 19, $1896 \quad 8$ eggs

May 25, 1914 Brood of young 10 inches

May 26, 1914 Nest found from which young had hatehed

May 27, 1914 Brood of young 7 inches

May _-, 1901 Nest; eggs hatched later

May Bred in this month

June 1, 19159 eggs, incubation various

June 5, 191570 roung seen with 66 adults

June 6, 19145 eggs, bird sitting

June 7, 19149 eggs, ineubated

June $9,19119 \mathrm{eggs}$, half incubated

June 14, 18868 eggs, fresh

June 16, 19037 eggs, practically fresh

June 18-July Large young 12,1907

22, 1891 Present

June 24, 1900 Young 3 days old

26, 1906 Female with brood (or later)

Breeds on estuary, 6 iniles away

Eggs found
A UTHORITY

Belding, MS.

Grinnell, 1898, 1. 10

Squiles, 1915, p. 234

Cooper, 1880, p. 251

Willett, $1912 a$, p. 22

Barlow, 1893 , p. 38

A. K. Fisher, $1893 a$, 1. 15

Fair, MS.

Dirks, MS.

Dirks, MS.

Belding, 1879 , p. 416

Emerson, in Belding. MS.

H. C. Bryant, $191 \mathrm{te}$, p. 219

H. C. Bryant, $1914 e$, p. 219

Belding, MS.

Reed, 1904, p. 70

Mailliard coll.

Mailliard, MS.

H. C. Bryant, $1914 \rho$. p. 227

H. C. Bryant, $1914 e$, p. 227

H. C. Bryant, $1914 e$, p. 227

Ray, 1901, p. 116

Ray, 1903, pp. 48-49

Mailliard coll

Squires, 1915, p. 234

H. C. Bryant, 1914e p. 231

H. C. Bryant, 1914e, p. 231

Carriger coll.

Stephens, MS.

Ray, 1905, p. 367

Goldman, 1908b, p. 201

A. K. Fisher, $1893 a$, p. 15 Mailliard coll.

Tyler, $1913 \mathrm{~b}$, pp. 15-16 Sheldon, 1907 , p. 186

C. II. Townsend, 1887, p. 193

A. K. Fisher, $1893 a$, p. 15

A. K. Fisher, $1893 a$, p. 15

Sharp, 1907, p. 86

Streator, 1886, p. 90

Skirm, 1884, p. 150 
The table suggests that the height of the nesting season is in April, perhaps the latter part of the month. Many of the nests which are found after this time probably represent instances of second laying where the first ehteh was destroyed.

The Mallard nests with equal freedom in the marsh lands surrounling our bays, the rivers and ponds of the great interior valleys, and the mountain lakes of the Sierra Nevada even as high as Lake Tahoe, elevation 6,225 feet. A seeluded spot, usually not far from water, is most often seleeted for the nest site. Advantage is taken of any shelter sueh as willows, tules, weeds or tall grass in whieh the structure can be concealed. At Lake Tahoe, Ray (1903, pp. 48-49) found Mallard nests in the wiry grass wheh grew on sandspits, and about Lower Klamath Lake, Siskiyon County, II. C. Bryant (1914c. p. 2:31) found the species nesting on dry flats covered with sage brush, though not far from water. More rarely nests are loeated in grain fields and may then be some distance from water. In many instances marsh nests are on such damp gromul that the eggs may be stained by contact with the moist nest materials. About Stow Lake, in Golden Gate Park. San Francisco, nests are hidden in the shrubbery which lines the inner shore of the lake. The nest itself is eonstrueted of plant materials of various sorts sueh as fresh and dried grasses and elover, and to these is added a warm lining of down feathers from the breast of the female. The structure is large; one found by Barlow (1893, p. 38) near San Jose, Santa ('lara County, measured eighteen inches in diameter.

The eggs in a eomplete set number from five to fonrteen. The clata at hand do not permit of obtaining a satisfaetory statistieal average, but our impression is that the average number in a set is abont nine or ten.

The female alone ineubates the eggs. She guards them very solieitously, seldom leaving the nest voluntarily exeept under cover of darkness and then only after carefully eovering the eggs with down. When on the nest she will even cover herself with leaves and grasses to assure better coneealment, though her own dull mottled plumage would seem alone suffieient for this purpose. Oeeasionally a female will sit so elosely that she will allow herself to be taken on the nest, or the eggs to be removed from beneath her. On being flushed from the nest or when with young, the female nearly always employs the ruse of lameness or of a broken wing to lead the intruder away. The period of ineubation is four weeks. During ineubation the male can usually be found in the near vieinity of the nest, but he takes no part in the duties of ineubation or of rearing the young. It is during this period that he begins the molt into the eelipse plumage. The Mallard returns to the same loeality to nest year after year. 
Toung Mallards are found in greatest abmondace in May. They are led to water by the mother soon after hatching. The mother carefully tends the youmg, and aids them in obtaining fool so that they soon learn to find their own provender. As far as know under normal circumstanees but one brood is raised rach year. The broors of young as a rule keep themselves well concealer among the tules and grass. When surprised in open water the ducklings seurry to cover and conceal themselves so artfully that they are very difficult to find. Aftel diving, a young bird either elings motionless to the reeds on the bottom or swims for a long distance under water. When coming to the surface the bill alone is exposed above the water. For this reason a whole broot may disappear as if by magic and the closest seareh result only in failure. Unlike the adult, the young Mallard is said to obtain much of its food by diving. This habit would be of value also as a means of escape from enemies during the consiterable period of time before tlight becomes possible.

Mallards in Califormia seldom gather in large flocks as do many of the other ducks. As a rule, they are fommd in pairs or at best in small flocks. Their ability to walk on land is far superior to that of most other ducks. In flight they progress by continuous rapid strokes of the wing, no sailing being evident. The wing beats are accompanied by a distinet whistling somnd. A speed of nearly a hundred miles an hour is said to be attained (Bairel, Brewer and Ridgway. 1884, I, p. 498).

Among most male ducks a remarkable change in plumage takes place during the stummer months. Beeause this plumage overshadows the brighter plumage of the spring months it is known as the "eelipse" plumage. In such a bright colored bird as is the drake Mallard in spring, the change to the eclinse plumage is particularly noticeable. The change is first to be noted in Jume; a few birds seen on Lower Klamath Lake, June 5, 1914, were already assmming the eclipse plumage. The old feathers of the head and hreast gradually drop out and new ones take their places. By Angust first the green of the head has been entirely replaced by brownish feathers and the bird looks at a little distance very much like the female, except that it is darker.

Drring Angust the regular annual molt takes place and the sombre brown of the eclipse plumage in turn gives place to the brighter colors of the plumage worn throughout winter and spring. There are thus two molts during the year, and two plumages, one of which is worn for only a fer weeks in the late smmmer. During the late summer molt, which involves the entire plumage, the Mallard hides away in lank regetation, concealing itself so well that it is seldom seen. The flight feathers are among the last to be molted. Since the bird loses 
the power of Hight ly the almost simultaneous molt of the wing frathers, its only means of protection rests in its ability to hicle or to escape notice because of its dull coloration. Thus the dull eelipse plumage is supposerlly for protective purposes.

The following interesting note on the nse of protective coloration by the Mallard is recorlexl from Alaska by Osgood (190t, p. 56):

Expecting the birl to rise at any moment, we paldled on but were hegin ning to feel haflesl, when just before the canoe touched the bank, we found our game giving a very pretty exhibition of its confidence in protective coloration. It was a female Mlallarl, and lay ou the brown mud lank, strewn with dearl grass and hecaying matter, which blended perfectly with the markings of its back. It was not merely "rouching, but lay prostrated to the last degree, its wings rlosely follesl, its neek stretched straight out in front of it, with throat and unler mandible laiıl out straight, and even its short tail pressesl flatly into the mull. The only sign of life came from its bright little eyes, which nervonsly looked at us in a half hopeful, half iesperate manner. When a pardle was lifted, with which it rould almost be reathed, the hiru started up and was allowel to escape with its well-eamed life.

Most of the food of the Mallard is obtained in shallow water. but the bird often forages on shore and even at some distance inland when desirable fool is obtainable there. When feeding in shallow water it not only skims the surface of the water but rerer now and then turns tail up and searehes the hottom. The latter mode of food getting is sometimes called "tilting," and the Mallard, like the other river and pond ducks which often feed in this manner, is called a "tip-np": the adult bird seldom dives, however. It discovers its food by means of touch rather than sight, so that it can feed erfually as well at night as by day (Baird, Brewer and Ridgway, 1854, I, p. 497). The food consists largely of vegtable matter in the form of grass, aquatic plants, weed seeds, and grain. So fond is this bird of grain that in some localities the loss it oecasions the grain grower is no small one. Nevertheless, the Mallard can be said to be fairly ommivorous, for it also feeds on larvae of aquatic insects, worms, grasshoppers, small molluses and crustaceans. A. K. Fisher (1893a. p. 15) records that a jurenile Mallard taken at Walker Basin, Kern County, July 19, 1891, and still in the down, had its stomach distended with grasshoppers, insects which were aburdant at that time in the neighborhood of the sloughs. W. E. Bryant (1893a, p. 55) reports the following from the stomachs of four specimens secured in the Suisun marshes: “ $a$. Small univalve shells in gullet. $b$. Bearded barley and barley heads. $c$. Small sprouted seeds. $d$. Half a teacupful of barnacles in the gullet." MeAtee (19116, pp. 1, 2) states that the Mallard eats a larger percentage $(17.13 \%)$ of wild rice than any other duck, the Black Duck and Wood Duck ranking next. Wild 
celery was found to make up $2.48 \%$ and pond weeds $12.67 \%$ of the food for the rear, in the 209 stomachs examined from all over the Tnited States.

Its large size and delicious flavor make this the most valuable game bird of its kind in the state. While feeding on grain it becomes excessively fat, attaining a weight of over three pounds. Its palatability also increases at this time and it then brings the highest price in the market, even the famed Canvashack taking second rank. In the season of 1895-96 there were 47,565 Mallards sold in the markets of San Franciseo at twenty-five cents apiece (Calif. Fish Comm., 1896, p. 42). During the season 1911-12 the markets paid an average price of fifty cents apiece for them, and at one time as high as eighty eents.

Owing to its habit of foraging far from water the Mallard affords ideal "pass shooting." In addition it is rasily decoyed. Thus it has every requisite of a fine game hird and is consequently the farorite of the sportsman.

The Mallard breeds readily in eaptivity and for that reason has been widely domesticated. A pond, sechsion, and plenty of weeds and grass are the chief needs. On the State Game Farm at Marward. Alameda County, Mallards rear broods each year. Several fancier's have also been suceessful in raising the bird in this state. There is every indication that this species ean be propagated for the market on a large seale. The increasing prices obtainable from year to rear point towards this as a profitable industry.

In England Mallards have been raised regularly in eaptivity and made to fly in a straight line over guns to afford sport.

Both in the wild state and in captivity this bird readily hybridizes with other near-related species. A highly esteemed variety of harnyard duck is a hybrid between the Mallard and Muscory Duck. Hrbrids also occur between the Mallard, and the Pintail. Gadwall, Shoveller, and Black Duck, respeetively.

In 1889 A. M. Shields (Davie, 1889, p. 62) stated that, (luring the summer, the Mallard was, "perhaps, the most eommon of the ducks in the vicinity of Los Angeles." But of recent rear's according to H. .J. Lelande (in letter), very few if any breed in Los Angeles Comnty. A hrood was known to have been reared in 1904 at Little Elizabetl Take. Filling-in of swamps and close settlement of the territory has its inevitable effects on hirds of this class. In the San Joanuin Talley the Mallard is eertainly outnumbered in summer by the cinnamon Teal. But whereas the latter may be found plentifully about both alkaline and fresh water ponts and marshes, the Mallard shows a decided preference for fresh water.

That the numbers of Mallards have been greatly rednced is evident. Anyone conversant with game enditions will name this speeies as one 
of those which have been most noticeably leduced. As the supply of Mallarels in California is probably dependent to a large extent on the birds raised within the state, it is only natural that the anmal toll taken by the hunter has eaused a very noticeable decrease. Compared with suel ducks as the Redhead and Wood Durk, however, the drecrease in the number of Mallards has been slight.

Two things, at least, give hope that this duck will continue to exist in large enough mumbers to supply the demands of the sportsman, if these demands are reasonable. One is the fact that this duek soon learns to keep ont of gumshot and the other the fact that the bird will content itself with a small anomt of water and will even nest where the only water is an irrigation ditch some distance away. This latter. point suggests that the increase of agrieulture, with the attendant development of irrigation, may not have so deleterions an effect on the Mallard as would at first be supposed, especially if the birds are not molested during the breeding season. Although the Mallard is in no immediate danger of extermination in this state, yet the present annual toll taken is too great to be maintained very many rears without endangering the existence of the species. By relucing the bag limit and shortening the season it should be possible as with other game to adjust the anmul toll to the rate of production.

\section{Black Duck}

\section{Anes rubripes Brewster}

OtHer NAMES-Black Mallare; Dusky Duck: Anas obscura.

DESCRIPTION-Adults, both scxes: Whole head and upper surface dusky bromn, varjegated with pale rusty brown feather edgings; top of hear larker than sides and throat, the latter narrowly streaked with dnsky on a pale brownish gray ground; a dusky stripe back from eye; iris brown; bill yellowish green; outer surface of closed wing like back but with a faint gray tinge; flight feathers blackish; speculum changeably steel blue and violet, framer in black; under surface of wing mostly white; under surface of boly like back but paler, due to wider edgings of dusky on feathers; feet orange red, webs darker. Total length " $21.00-24.50$ ", inches (533-622 mun.) (Ridgway, 1900, p. 91.) Female: folded wing 10.60 (269); bill along culmen 2.02 (51.3); tarsus 1.63 (41.4) (one specimen from California). Juvenile plumagc: "Similar to adult, with bill more of a greenish lne and streaked with dnsky', (Sanford, Bishop and Van Dyke, 1903, p. 79). Natal plumage: Whole top of head dark brown, with a yellow cast on forehead; side of head, chin and throat, brownish white; stripe from side of bill through eye to above ear region, brownish black; above this a stripe of pale yellowish brown; rest of upper surface, brown; hind margin of wing yellowish white, as also a pair of spots on back behind wings and another pair on each side of rump; foreneck pale yellowish brown; rest of under surface dull white. 
MARKS FOR FIELD IDENTIFICATION-Both sexes resemble female Mallard but are darker in coloration; the general blackish coloration, the white wing lining, and violet speculum framed in black are distinctive.

ToICE-A loul resonant " "quack", like that of the Mallari (Chapman, 1912 , P. 193).

NEST-On the ground; constructed of weeds, grass, and feathers (authors).

Egas - 8 to 12, ovate to elongate ovate in shape, measuring in inches, 2.22 to $2.44 \mathrm{by} 1.63$ to 1.83 (in millimeters, 56.5 to 62 by 41.5 to 46.5 ), and averaging 2.36 by 1.69 (60 by 43 ) ( 28 eggs in U. S. National Museum); in color white or creamy white; the shell having an oily texture.

General distribution-Eastern North America. Breeds from central Keewatin and northern Ungava south to northern Wisconsin, northern Indiana, and southern Maryland; winters from Nova Scotia south to southern Louisiana and Colorarlo; west in migration to Nebraska and central Kansas; casual in Bermula, Jamaica and California (molified from A. O. U. Check-list, 1910, p. 68$)$.

Distribution in California-One instance of oceurrence: A single biril, presumably a female, taken at Willows, Glenn County, February 1, 1911 (now no. 17198 Mus. Vert. Zool.).

The Black Duck, a near relative of the Mallard, is a speeies of the eastern and middle western Inited States, and eastern Canada. In the North Atlantie States it entirely replaces the Mallard as a breeding species. There is but one record of its oeeurrenee in California. A bird, evidently a female, although the sex was not determined by dissection, was taken by a hunter at Willows, Glenn County, February 1, 1911. 'This individual was mounted by Vernon Shepherd, a San Franciseo taxidermist, and later presented to the Museum of Vertebrate Zoology. This bird was evidently a straggler; and the Black Dnek camnot be eonsidered of more than accidental occurrence in California.

"The Black Duek breeds so early that young have been found at Old Saybrook, Conn., May 5, and eggs at Rehoboth, Mass., April 30" (Cooke, 1906, p. 25).

" It is more common in the Atlantie Coast States than inland, and when molested will sometimes pass the day at sea returning at night to feed in the ponds and marshes" (Chapman, 1912, p. 193).

"Like the Mallard, the Blaek, or Dusky Duek, feeds on wild rice, bnekwheat, weed seeds and nearly all manner of vegetable substances, also devonring suails, frogs and other aquatic animals with a gluttonous greed, especially in the springtime" (Eaton, 1910, p. 186).

The Black Duck resembles the Mallard in general habits and it is to be looked for in situations frequented by the latter bird. Loveland, Colorato, is the nearest place where this typieally eastern speeies has been previously reeorded and it is not probable that any great number of individuals will ever wander so far west as California. Additional instances of oeenrence should be reported for their seientific value. 


\section{Gadwall}

\section{("haulelasmus streperus (Limaeus)}

OTher NAMEs-Gray Duck; Galwell; Anas strepera.

DESCRIPTION-Adult male: Whole head and neck pale brown finely mottled with black, the brown being darkest on tol of heal with less distinct spotting; throat very pale brownish gray minutely flerked with dusky; bill bluish black; iris reddish hazel; baek and sides witl fine undulating, transverse bars of brownish black and white; outer surface of elosed wing ashy brown with a chestuut patch on middle wing coverts followed belind by a black bar; speculum pure white; rump dull slate color; upper and lower tail coverts velvety black; tail drab gray faintly elgerl with whitish; whole breast mottled in intricate pattern witl erescentic bars of black and white, with a suffusion of pale brown; rest of under surface pure white, save for faint lusky barring in the region of the vent; sometimes a strong suffusion of rusty over whole lower surface; feet dull orange yellow with dusky webs. Total length "19.25-21.75", inches (4\$9-553 mm.) (Rilgway, 1900, 1. 95); folılel wing $9.75-10.90$ (248-27 $)$; bill along eulmen 1.63-1.78 (41.4-45.3); tarsus 1.53-1.67 (35.8-42.4) (ten sperimens). Alult female: Heal and neck coloreal as in male, but otherwise lecidedly different; upper surface and sides coarsely and irregularly barred and mottled with dark brown and dull white; wing as in male but with markings less clean and chestnut entirely lacking; rump and upper and under tail coverts brown, the latter mottled with dull white like flanks; breast heavily mottles with black on a rusty lrown ground: lower breast and ablomen white often more or less obseured with rustr. Total length "about 18 " inches (457 mm.) (Ridgray, loc. eit) ; folded wing 9.6210.12 (244-25i) ; bill along culmen 1.52-1.70 (38.6-43.2) ; talsus 1.42-1.58 (36.140.2) (nine specimens) ; all from California. Eclipse plumage of male: Top of hearl hrownish black with a greenish tinge; indistinct dark brown streak through eye; rest of head and neck dull brownish white markel with blackish brown as in regular plumage; back, rump and upper tail coverts, blackish brown, each feather margined with rusty red; wings and tail as in regular plumage; breast dull rusty red with central black spot on each feather; flanks lark brown broadly marked and margined with dull rusty brown; rest of uniler surface dull white with a hlackish brown spot in center of each feather (see Sharpe and Dresser, in Baird, Brewer and Ridgway, 1884, I, p. 506). Jucenile plumage (both sexes): Closely resembles that of adult female. Natul plumage: Top of head and line from bill through eye, lull brown; sides of learl and neck, dull creamy buff; spot over ear, dusky; upler surface of body dark brown; paired spots on hind margin of wing and sides of rump, light buff; throat and foreneck pale buff; under surface of borly buffy white; band across chest buff.

MARKS FOR FIELD IDENTIFICATION-Slender appearance, long pointed wings, general gray coloration, and pure white speculum (the only river duck so marked). Uniler tail coverts black in male.

VoICE-In flight, an oft repeated "quack,' resembling that of the Mallari, though higher pitched and less in volume (Eaton, 1910, p. 189).

Nest - In grass on dry ground but usually close to rater; composel of grasses and tules and lined with down; resembles that of Mallard.

EGGS - 7 to 13 , bluntly ovate, or nearly oval, measuring in inches 2.02 to 2.18 by 1.48 to 1.57 (in millimeters, 51.5 to 55.5 by 37.5 to 40.0 ), and averaging 
2.11 hy 1.53 (53.5 hy 39.0) (18 eggs in U. S. National Museum); color creany white.

(iExfral Distributiox-Amost throughout the Northern Hemisphere. In North America breesls from southern British Columbia and central Keewatin soutl to southern California and rast to southern Wisconsin; winters from soutlern British Columbia and the rentral-eastem Uniterl States south to southern Lower Cahifornia, central Mexico and Florida; rare in migration on Atlantic Coast, and of casual oecurrence in Bermuda, Cuba and Jamaica (A. O. I. Check-list, 1910 , p. 69).

DISTRIBUTION IN (ALIFORNIA-Fairly common resident in fresh water tule swamps particularly of the great interior valleys. More numeroms in winter when the numbers are augmenter by migrants from the north. Recorrel as breeding, west of the Sierras, from the Sacramento Valley south to San Jacinto Lake, Riversirle County.

The Gadwall or Gray Duek is essentially a river or freshwater duck and is to be foumd in many parts of the interior of California.

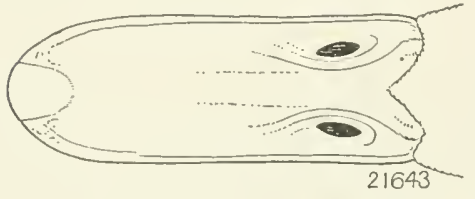

Fig. 12, Top of bill of female Garlwall. Natural size.

Note slender ontline as compared with bill of female Pintail (fig. 19). It exists in greatest numbers about those ponds, lakes and rivers where there are plenty of tules and weeds. It is seldom, if ever, found on salt water or on alkali ponds and lakes. Praetically all of the Gadwalls sold on the markets have been procured in the Saeramento and San Joaquin valleys.

This duck, like the Mallard and Cimnamon Teal, breeds regularly within the state. Although there are not many records of its nesting, yet it is commonly understood among hunters that the supply of Gadwalls is largely dependent upon the birds raised in California. The fact that this duek is usually seen in pairs or in small flocks even in winter also lends support to the belief that it breeds in the immediate neighborhood. The species of ducks which breed in the far north usually gather in large flocks during migrations and in the winter. Nevertheless, the considerable increase in the numbers of the Gadwall found here in winter is certainly the result of an influx of birds which breed farther to the north. If the number of these dueks sold in the markets of San Franeiseo is a criterion, the Gadwall is only one-twentieth as numerous as the Mallard. But as the former is less sought after as a table bird, this is not perhaps a fair basis of eomparison.

In liabits the Gadwall resembles the Mallarel. But it is distinguished from the latter by its smaller size and gray coloration, and by its more slender outline when on the wing. In the hand, the Gadwall ean be distinguished in all its plumages from all other dneks 
by the pure white of its speculum. The females of the Gadwall and baldpate lesemble each other very closely, but the former is clarker on the back and mump and does not show the conspienons white patehes on the wings which mark the Baldpate in flight. The female Gadwall and Pintail are closely similar and may be confused, espercially on the wing. 'The Pintail has a longer neck and is lighter colored beneath; in hand its green speenlum and relatively broat bill (spe figs. 12 and 1!) make iclentifieation easy.

(hapman (1912, p). 194) describes the comrtship flight of the Gadwall in the East as follows: "The male pursues the femalr often high in the air and for some time, on a conlse as elratic as that of a Barn Swallow:" sechuled places in fresh-water marshes are nsmally selected as nesting sites. The nest is placed on the gromnd, sometimes in a depression, and usmally in grass in relatively dry situations though close to watel. The structure is composed of any avalable vegetable material such as grass and tules, fincly shreddol, and is lined with very dark-colored down. The aggs, mumbering seren to thirteen in a sot, and averagring about ten, are bluntly orate or almost oval in shape. They are of a pale ereamy white tint. Eggs of the Cactwall cosely resemble those of the Baldpate. From the latter's eggs those of the Garlwall may usually be distingmished by their shorter length and more oval shape and by their paler, less deeply cream color: but the identifieation camot always be made with certainty. As compared with egos of the Mallard those of the Gadwall are smaller and less ovate in shape. The nest down of the Gadwall is darker than that of the Baldpate. As with the Mallard the female alone cares for the young. The downy young of the Gadwall are stated to be among the palest colored of our river dncks. The aeeompanying table (no. 9) gives reeords of nests whieh have been reported in California.

TABLE 9.-Data relative to the nesting of the Gallwall in California

\begin{tabular}{|c|c|c|c|}
\hline LOCALITY & DATE & Contexts of Nest & ALTHORITY \\
\hline Near Los Angeles & April $16, \ldots \ldots$ & $\begin{array}{l}11 \text { eggs, considerably } \\
\text { ineubated }\end{array}$ & Davie, 1900, p. 79 \\
\hline Los Baños. Merced Co. & Jay 12, 1914 & 9 eggs & $\begin{array}{l}\text { H. C. Bryant, 1914e, } \\
\text { p. } 222\end{array}$ \\
\hline Los Baños. Merced Co. & Jay 16,1914 & $\begin{array}{l}12 \text { eggs, slightly in. } \\
\text { cubated }\end{array}$ & $\begin{array}{l}\text { H. C. Bryant, 1914e, } \\
\text { p. } 222\end{array}$ \\
\hline $\begin{array}{l}\text { San Jacinto Lake, } \\
\text { Riverside Co. }\end{array}$ & June 8,1897 & $\begin{array}{l}12 \text { eggs, incubation eom- } \\
\text { menced }\end{array}$ & Ingersoll coll. \\
\hline $\begin{array}{l}\text { Chowchilla, Merced Co. } \\
\text { San Pedro, } \\
\text { Los Angeles Co. }\end{array}$ & $\begin{array}{l}\text { June } 24, \quad 1901 \\
\text { July } 20, \ldots \ldots \ldots\end{array}$ & $\begin{array}{l}8 \text { eggs, incubation begun } \\
9 \text { eggs }\end{array}$ & $\begin{array}{l}\text { Mailliard coll. } \\
\text { Baird, Brewer and Ridg. } \\
\text { way, } 1884 \text {, I, p. } 508\end{array}$ \\
\hline
\end{tabular}

The Gadwall is a shy speeies, hiding away in the tules and weeds during the daytime and even when foraging for food remaining elose to cover. Its long pointed wings give it rapid powers of flight; and 
a whistling somd, not so loud as that made by the Baldpate, is to be heard under favorable conditions. When flushed it is said to rise into the air almost perpendieularly.

Its food is made up largely of the seeds, leaves, buds and roots of water plants. These it obtains along the shores of ponds, lakes and rivers by "standing on its head," or "tilting," and searehing the bottom as does the Mallard. MeAtee (1911b, p. 1) states that an examination of stomachs has shown that the food comprises a lesser number of seeds but a larger per eent of pond weeds than that of other dneks. W. E. Bryant (1893a, p. 55) found small seeds and sand in a stomach which he examined.

Although usually considered an execllent bird for the table, Belding (MS) agrees with Bendire that its flesh is at times very inferior. He says: "I have known it to be so oily and have such a fishy taste that I could not eat it [even when] nicely roasted.' If this be true the small numbers sold in the market (671 in season 1895-1896) (Calif. Fish Comm., 1896, p. 42) might be attributed to this fact rather than to actual numbers of the species obtainable. The wellnigh exclusive vegetable diet of the Gadwall, on the other hand, would appear to recommend it as a desirable bird for food.

Almost as many Gadwalls were sold in the season 1911-1912 by one game transfer company in San Franeiseo as were sold in all of the markets of San Franciseo and Los Angeles in the season 18951896. If this be at all indicative, there ean not have been a very great diminution in their numbers during the last fifteeen year's. The greater decrease in more desirable ducks, however, will in time increase the demand for the Gadwall and so inerease the ammal kill.

\section{Baldpate}

\section{Mareca americana (Gmelin)}

OTHER NAMES-American Widgeon: Widgeon; Anas americana; Mareca penelope, part.

DEScRIPTION-Adult male: Broad streak from forehear over top of heal, white; rest of heal and neek thickly speekled with black on a white ground; streak behind each eye metallic green, the two often joining on hind neck; bill light bluish ash, the tip, extreme base, and lower mankible, black; iris hazel; back pale pinkish brown, delicately undulated with black; rump ashy brown, sometimes ninutely undulated with white; mildle upper tail coverts pale ashy, the basal ones finely undulated with dusky; lateral ones velvety black contrasting conspiruously witl white pateh at side of base of tail; tail slaty black above, ashy beneath; large area on forepart of wing pure white, edger in front and above with ashy brown; speeulum metallic green, bordered in front by a uarrow black bar and shading behind into a broad area of velvety black; tertials black, narrowly elged with white; rest of flight feathers slaty brown; axilars 
white; lining of wing pale ashy gray; breast, sides and flanks, pinkish brown. the breast washel with ashy and the sides and flanks irregularly barred with blackish; lower tail coverts velvety black; rest of under surface pure white, sometimes suffused with rusty; legs and feet greenish slate, claws and joints Ilusky. Males: Total length 19.30-20.4t inches (490-520 mm.) (two specimens); folded wing 9.55-10.35 (250-263); bill along culmen 1.36-1.57 (34.7-40.0); tarsus 1.41-1.55 (35.8-40.2) (ten specimens); weight 22.65-23.20 0\%. (641-656 gm.) (two specimens). Adult female: Whole upper surface dull gravish brown; barrel with yellowish brown; hearl and neck thickly mottlen with blackish on a whitish ground; rump and upper and under tail coverts dark brown, with whitish feather margins and the coverts pervaded with reddish brown; wing as in male but white area chiefly replaced by white-edged ashy brown feathers; sleculum dull black, oceasionally with a small patch of metallic green; sicles and flanks deep redllish brown; breast dull brown, mottled with blackish and tingel with ashy; rest of under surface white, sometimes tinged with rusty. Folderl wing 9.00-9.80 inches (228-249 mm.) bill along culmen 1.22-1.55 (31.139.4 ) ; tarsus $1.37-1.5 .5$ (34.9-39.4) (ten specimens); all from California. Juvenile plnmage: Similar to that of adult female but colors more pronounced, and the pattern better lefined, especially on the wing (Bairl, Brewer and Rilgway, 1554, J, p. 521). Tatal plumage: Top of head anıl stripe down hind neck, dark sepia brown: sides of head and neck cinuamon buff; back light brown; pair of spots at base of tail, white; hind margin of wing pinkish buff; throat creamy buff; rest of under surface dull creamy buff, suffused with cinnamon buff on chest.

MARKS FOR FIELD IDENTIFICATION-Medium size, white axillars, and more or less white on forepart of wing. Males have top of head white, sirles of hearl mixerl blark and white, a green pateh behind eye, green speculum, white flank latch, and black under tail coverts. Both sexes listinguished from European Wilgeon by pure white rather than grayish axillars, and male by lack of reddish brown on head (1) 3). The wings make a whistling noise when the birls are in flight.

VoICE-Of male: a mewing whistle resembling the syllables $u h e u$ uhe ; of female: a loud kaon, kaon, or hue, me, hue, with a strong accent on the seronil note (Eaton, 1910, p. 191; Nordhoff, 1902, p. 213).

NEST-Csually on high dry ground, and often a consirlerable distance from water; a slight depression well lined with dry grass and weed stems and abundantly supplied with light gray down (Bent, 1901, p. 335).

EGGS-6 to 12, elliptical ovate in shape, measuring in inches, 2.00 to 2.37 1,y 1.42 to 1.60 (in millimeters, 51.0 to 60.1 by 36.2 to 40.1 ), and averaging 2.17 by $1.5 \%$ (55.1 by 38.9) : color leep cream to nearly white (Bent, 1901, pp. 335-336; anı fifty-four eggs in U. S. National Museum).

Gexeral distributiox-North America. Breeds from northwestern Alaska, northern Mackenzie and central Keewatin south to Oregon, Coloralo, Kansas, and northern Indiana; winters from southern British Columbia, southern Illinois, and Maryland south to southern Lower California, the West Indies and Costa Rica; rare in migration in maritime provinces of Canarla, and casual in Hawaii, Bermuda and Europe (A. O. U. Check-list, 1910, p. 70).

Distributiox IN CAIIfORNIA-Common winter visitant to suitable localities throughout the state, chiefly on fresh water, but occurs occasionally along the coast, especially in the shoal waters of Humboldt, Tomales and San Franeiseo hays. Recorded as breeding on Davis Creek, Molloc County. 
'The Balelpate, or Anerican Widgeon, is one of the best known and most numerous of the river ducks in C'alifornia during the winter season. It begins to arrive in numbers in October, and leaves again for the north in the early part of March. From the numbers sold on the market in California, one might judge the species to be most abmolant in Norember. Although preferring the fresh water lakes, ponds, rivers, and sloughs of the interior, the Baldpate is sometimes found in consiclerable numbers on the shallow water of the bays. Often the latter location is used as a loafing ground, at least during the day. The species is "very common along the coast from Creseent City sonthward during Oetober. Widgeons nsually [form]. . the largest part of every duek hunter's bag. They often spend the day in the open ocean and return to the marshes to feed at night" (Ferry, 1908, p). 38-39).

A large area of white on the top of the head of the male has given this duck its common name of Baldpate (pl. 3). This white pateh together with a broad metallic green streak behind the eye helps to distinguish this duck from others. The large amount of white on the fore part of the wing, especially in the male, the white axillats, and the conspienous white under surface of the body also aid in identification. The speculnm is peculiar, that of the male being green, bordered in front and behind with velvety black, while that of the female is usually altogether dull black. In most dncks it is the same in both sexes. The lighter color of the lower surface and the white axillars and dark speculum serve to distinguish the female Baldpate from the female Gadwall, our only other duck of comparable size and coloration. Were it not for the gray under surface of the wing in the female Ballpate, visible in Hight, she might be mistaken for a female Nallard: but the latter bird has a pure white under wing lining, and no patel of white on the outer surface of the wing.

The Baldpate breeds later than most other ducks, as it apparently does not begin laying until late Nay or early June in Alaska. According to Nelson (1887, p. 68) small dneklings are to be sexen there at rarious times in July, and young only half-grown as late as the middle of Angust. There is only one reeord of this duck nesting in california: Dawson (1916, p. 24) says that it was "bleceding commonly at I)avis Creek in Mlodoc County," where lie found a set of nine fresh rggs on . June 20, 1912, and another of eleven, adranced in ineubation, Jume 24 of the same year. Birds seen by him at Eagleville, surprise Valley, in the same comnty, July 12, 1912, were thought to be breeding. Belding (IIS) saw a pair of Baldpates at Stockton, San Joa(nuin County, as late as May 28 (1878), but foumd no definite eridenes that they were breeding there. 
For its mest the Baldpate usmally selects al plater on high, dry gromul often some distance from water. Sometimes the nest is plaeed at the foot of a tree or shmb; at other times it is situaterl in weeds, grasses or bushes. In either event there is little or no attempt at conerahnent. The nest is lined with dry grass and weed stoms, and is abundantly smpplied with light gray clown by the female parent. In Alaska the place selected for nesting is saicl to be exactly like that chosen by the Pintail.

No complete aceomt of the comrtship of the Baldpate has yet beren published. ( . W. Townsend $(1916$, p. 15) says of the male bird in Massachusetts :

In his courting he continually emits gentle but eager whistling notes, and with neck extended and heal low, bill wide open and wings elerated behind so that the tips are pointed uj at an angle of forty-five legrees, he swims rapidly over the water beside or behind the duck. Ocrasionally he peeks playfully at the side of her heal, anil now anil then in his excitement jumps rear of the water ambl flies for two or three rarts.

Eviclently the female alone performs the chutes of inconbation. The males remain in the vieinity for some time after the mates begin to sit, but when the time of moulting arrives they retire to grassy marshes and edges of lakes for concealment and there for the time being lead solitary lives. If the female be smprised white on the nest she usually rises silently into the air and flies to the nearest water, although sometimes she will alight on the gromed only a short elistance from the nest.

The young, before they are able to fly, seek the shelter of grassbordered lakes. But as soon as they can fly they repair to rivershores and other open feeding-places, where they obtain aquatie insects, small shells, and seeds and roots of varionis plants. The broods often separate before leaving for the sonth in September (Baird, Brewer and Ridgway, 1884, I, p. 524).

Nelson (1887, p. 68) gives the following facts regarding the behavior of a female Baldpate and her young in Alaska. He came suddenly upon a bird, with her brood of ten or a dozen little dueklings, in a small pond. As he approached, the parent nttered several low, guttural notes and suddenly fluttered across the water and fell heavily at his feet. Meanwhile the young swam to the opposite side of the pond and began to scramble out into the grass. Wishing to observe the old bird's manoenvers, he poked at her with his gun as she fluttered abont at his feet, but she always managed to elude his strokes and, just as the last of her brood elimbed ont of the water, she slyly edged off, and suddenly took flight to another pond some distance away. As quickly as possible he ran to the point where the ducklings had left the water; yet, though but a few moments had 
elapsed, the young had concealed themselves so effectually in the grass which was only three or four inches high that a half hour's search was mnavailing.

Powles (in Dawson, 1909, p. 772) says that "their principal call is a lisping, throaty whistle, repeated three times in quick succession. It is surprisingly light in character for the size of the bird and serves to confirm the bird's position on the list next to the Teals. . . The only other note I have heard them utter is a low, short chattering, somewhat resembling that of the Pintail, but greatly reduced in volume. Their quacks, or squawks, of alarm also express the limit of terror, but are still pathetically inadequate in comparison with those, say, of a hen Mallard.',

While the Canvasback and the Scaups dive and pull up by the roots the vallisneria or eel grass, the Baldpate manages to obtain a large share indirectly through theft, and at times succeeds in robbing them of all they bring up. In Chesapeake Bay, Maryland, the Baldpate is said to be the constant companion of the Canvasback, the latter possessing great superiority in its diving powers (Baird, Brewer and Ridgway, 1884, I, p. 524). To what extent they are similarly parasitic in California is not known to us. Here, Baldpates are oceasionally found in company with Pintails.

"Almost strictly a vegetarian as to diet, their food in fall and winter consists of seeds, water-weeds, soft roots, and an occasional insect, thus making them more desirable as table birds than the average duck. In late January and February, however, they confine their feeding largely to the water-soaked fields, digging up the young grass with their bills and eating roots and all" (Bowles, in Dawson, 1909, p. 771). Near Los Baños, Merced County, Beck (MS) says the Baldpates were feeding in close companies upon green grass near sloughs. Although the grass was less than an inch high, it was pulled off close to the ground. Feeding is done chiefly at night. Stomach examination by us has shown that the Baldpate eats a larger percentage of grass than any other California duck.

"In wing shooting it [the Baldpate] is regarded by the hunters as a great nuisance. It is not only so shy that it avoids the points of land, but by its whistling and confused manner of flight it alarms the other species", (Baird, Brewer and Ridgway, loc. cit.). Howcver, it may be decoyed within gunshot by imitating its notes or with well-placed wooden decoys. Its euriosity as well as its sociability cause it to return again and again to decoy ponds.

In California the Baldpate is considered as inferior game in spite of the fact that large numbers have been anmully sold on the market. Nevertheless, when in good condition, its flesh is hard to distinguish from that of the Canrasback. Over 52,000 Balelpates were sold in the 


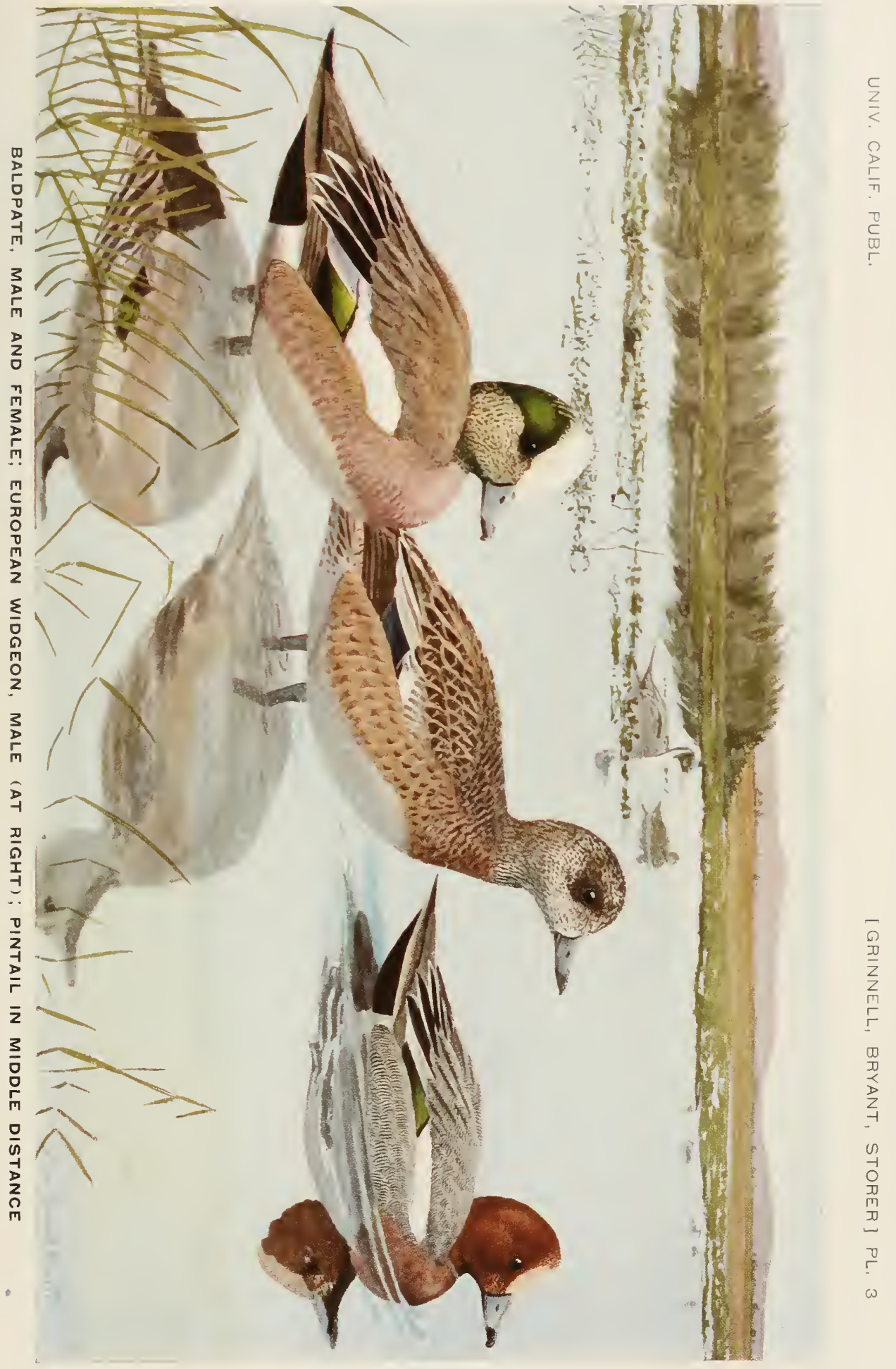



markets of San Franciseo and Los Angeles during the season 18951896 (Calif. Fish Comm., 1896, p. 40). In San Franciseo nearly 15,000 were sold by one game transfer company in 1909-1910, while but 9,25t were reported as sold in 1911-1912. The deerease here shown would seem to indieate that there has been a marked decrease in the general abundance of this duck during the two years speeified. The species has held its own to a greater degree than some other ducks in spite of the large number killed anmually. Nevertheless it needs adequate protection such as would be afforded by a no-sale law, shorter season, and smaller bag limit, to assure its preservation as a game bird.

\section{European Widgeon}

\section{Mareca penclope (Limmacus)}

OTHER NAMES-Rerl-heallerl Wilgeon; Anas penelope.

DESCRIPTION-Adult male: Head and neck bright rufous red, except erown and forehead which are creany white; lower eyelicl white, upper black; numerous minute black or irilescent flecks on sicles of hearl; chin and narrow line lown throat dull black; bill " "light grayish bluc, with the tip... black','; iris “' 'hazel brown',' (Bairl, Brewer and Ridgway, 1894, I, p. 518); back undulaterl with fine zig-zag bars of black and white, resulting in a general gray cast: base of rump grayish brown; midlle upper tail coverts like back, but lighter: lateral upper aud whole under tail coverts black; tail feathers above blackish, beneath ashy; outer surface of closed wing mostly white but edged anteriorly with ashy hrown, and the tertials black elgerl with white; flight featliers plain asly brown; speculum metallic green borlered both in front and behind with velvety black; umler surface of wing shining ashy gray; lower surfare largely pure white; broarl area on chest extencling high on the shoulders pinkish brown; legs and feet " "light grayish blue"," (Baird, Brewer and Rilgway, loc. cit.). Total length (both sexes): “18.00-20.00”, inches (458-508 mim.) (Ridgway, 1900, p. 96) ; male: folded wing 10.00 (254); bill along culmen 1.47 (37.3); tarsus 1.62 ( 41.2$)$ (one specimen in Grinnell coll., in Mus. Vert. Zool.). Adult female: Hearl and upper neck vellowish red with small greenish black spots most numerous on the upper part of head; upper surface lusky brown, each feather elged with brownish red or whitish, giving a barred appearance; bill and iris as in male; outer surface of closer wing dusky gray, the white feathers of male being replacel by dusky gray ones tipperl with white; ouly an indication of a dark terminal bar on secondary coverts, aurl black of inner secondaries as found in male replaced by dark gray; tail feathers brownish gray elger with lighter; under tail coverts white barrerl with brown; siles and fore part of chest obscurely barred with redclish brown and brownish gray; breast and belly white. Folded wing 10.00 inches (254 mm.); bill along culmen 1.50 (38.2); tarsus 1.50 (38.2) (Baird, Brewer and Rilgway, 1S54, I, p. 518). Juvenile plumage: “Head, neck, jugulum [foreneck], sides anıl flanks, umber brown, varying to a cinnamon shade, the head and neck thickly streakel with black, and the feathers of the jugulum, sicles, etc., centered with dusky. Back and scapulars lusky, the feathers broadly borlerel with dull fulvous; crissum [under tail coverts] irregularly streakerl and spotted with dusky; rump and upper tail coverts slaty brown, bordered 
with dnll whitish. Wing as in the adult, except that the coverts are dull einereous broadly bordered with white. Lower parts except as described, pure white" (Baird, Brewer and Ridgway, lor. cit.). Nalal plumage: Top of hear brownish black; foreheal, sides of head, and hind neck, light cinnamon hrown; whole back brown, with a spot of straw yellow on each sille near base of tail, and one of light tawny on hind borler of each wing; lower surface of borly dull straw yellow, with an obseure wash of light einnamon brown across foreneck.

Marks For Field idEATIFICATION-Similar to those for Baldpate. In hand the male European Widgeon can be identified by the bright rufous red instear of white and black speekled head, by lack of a green patch behiml eye, by grayish rather than pinkish brown tone of back, and by entire absence of hrown on sides of body (pl. 3). Both sexes possess gray axillar feathers; in the Baldpate these are white.

VoICE-"The call note of the male is a shrill, whistling whee-you, whence the local names 'Whew-Duck' and 'Whewer'; but the female utters a low furr or eroak" (Saunders, 1899, p. 428).

NEST-On ground near water; built of grasses and dead plants and well concealed.

EGGS- 5 to 10 , pointedly ovate in shape, measuring in inches, 2.13 to $2.30 \mathrm{by}$ 1.50 to 1.53 (in millimeters, 54.3 to 58.4 by 35.2 to 35.8 ); in color buffy white (authors).

GENeral DISTRIBUTION-Northern part of the Eastern Hemisphere. Oicurs oceasionally in winter and in migration in North America, from Wisconsin, Michigan, New York, Nova Scotia, Newfoundland, and Greenlanil south to Nelraska, Missouri, Indiana, Ohio, North Carolina and Florida, ant in Alaska, British Columbia and California (A. O. U. Check-list, 1910, pp. 69-70).

Distribition in Falifornia-A not infrequent winter visitant. Definite records known to the writers, of its oceurrence within the state are: Rio Vista, Solano County, two specimens (Belding, MS): San Francisco market, several specimens (Cooper, 1868, p. 9; W. E. Bryant, 1886, p. 426; Ridgway, 1850, p. 231): Eureka, Humbolit County (C. H. Townsenl, 18s6, p. 491): Humbolit Bay, Humbollt County, two specimens (F. J. Smith, MS); Bixbr, Los Angeles County (Griunell, 1904b, Pl. 383-384).

The European Widgeon is one of the fer species which really belong to the Eastern Hemisphere but of which straggler's occasionally reach America. There are no records of its bresting within the United States or anywhere else in North Ameriea. (Cooke (1906, p. 28) points out that most of the California records are in February, those in British C'olumbia from December 25 to February 9. and the two Alaska dates Oetober 12 and May 27. Our bilds probably come from (astern Siberia.

All the California recorils are from near the eoast. MIr. F. J. Smith of Euleka writes ns that thee Red-headed Widgeons have leeen taken on Humboldt Bay. One is an adult male in the collection of birds momted by Mr. Chas. Fiebig and now in the publie library at Enreka. This is doubtless the specimen recoleled by C. II. Townsemel (1886, p. 491). A seeond adult male in faldel plumage was taken 
about 1905 amel is in the collection of 1)r. F. H. Ottmer. The thire specimen was taken by an expert humter. Alden Trott, from a flock of Balulpates on Areata Bay, Oetober 20. 1911. Mr. ('hase Littlejohn has told us that when his brother was hmonting for the market in the eighties, Red-hraded Widgeons were frequently secured on sonth Sam Franciseo Bay.

There is a considerable difference in eoloration betwern the male Emropean Wielgeon and onr Baldpate, so that there is no need of confusing the two, at least when in hand. The male Emopean Widgeon "an always be distinguished by the rieh bown color of the head and neck, and hoth sexes by the gray instead of white axillary feathers. In the full plumaged male bird the head and neck are almost uniform lufous red in color, there is no brown on the sieles, and the back lacks the pinkish brown tone to be observed in the Baldpate. The top of the hearl is ereamy white, slightly rusty on the forepart. The throat is largely hackish, while minute flecks of black dot the checks and loral region. Barek of the eye the chestmut gromel-color is overlated by numbers flecess of metallic green. A speecimen procured in Los Angeles comnty was taken for a hybrid betwen a Redhead and Baklpate by local sportsmen.

In all its habits the Emopean Widgeon is said by competant authorities to resemble elosely the Ameriean Wilgeon, or Pialdpate.

It has been suggesterl that probably many instances of occurrence of this species have been overlooked by sportsmen and market hunters, who usually make no attempt to pick ont umsual hirds unless the difference is very noticeable. Owing to the rarity of its occurrence the Emropean Widgeon ean hardly be reckoned upon as one of California s regular game ducks.

\section{Green-winged Teal}

\section{Nrttion carolinense (Gmelin)}

Other xAmes-Green-wing; Common Teal; American Green-wingerl Teal; Aluas carolinensis; Querquedula carolinensis.

DESCRIPTION-Adult male: Heal anit upper neck rhiefly rich chestnut brown, darkest on forehearl; a broal patch of metallic green on each side of hear extenting from exe to hind neck, shaling into black under eye and borlerert below by a buffy white line; on back of hear the two green patches are separater by a black patch, the latter involving the hiniler part of a short crest which is otherwise chestunt brown in continuation with same color on top of hear; chin and upper throat dull black; bill black; iris dark brown; upper surface of body, a narrow collar around foreneck, sides, and flanks, finely and irregularly undulated (cross-barred) with black and white; rump slate brown; upper tail coverts dull black with ashy ertgings which have a suggestion of fine black and white undulation; tail slaty brown; outer surface of closed wing (including elongated tertials) slate brown; speculum bright 
metallic green, appearing violet at certain angles, borlered in front by a vertical bar of buffy brown and above and below by horizontal black bars; a conspicuous transverse bar of white on each sile of body near bend of wing; breast pinkish brown, distinctly spotted with black; middle under tail coverts and patches at siles of vent, black; lateral under tail coverts creamy white; under surface of tail ashy; rest of under surface dull white often more or less obscured by rusty; legs and feet olive gray, larker at joints; webs brownish black. Total length 14.75-15.75 inches (375-400 $\mathrm{mm}$.) (six specimens); folded wing $6.90-7.50(175-190)$; bill along culmen $1.40-1.48$ (35.6-37.6); tarsus $1.11-$ 1.26 (28.2-32.0) (ten specimeus); weight, $12.5 \mathrm{oz} .(355.5 \mathrm{gm}$. ) (one specimen). Adult female: Top of head and upper surface dark brown, the feathers edged with pale ashy brown giving a barred or mottled appearance; top of heal more nearly uniform brown, the narrow light feather elgings giving an effect of fine streaking; sides of head buffy white closely flecked with dusky; stripe through eye dusky; chin, throat and lower eyelid dull white, more or less speckled with dusky; iris yellow; outer surface of closed wing nearly as in male but slate brown feathers edged with ashy; sides, breast, and flanks similar to back, but of lighter general tone; rest of under surface as in male except that the indistinct spotting of the breast sometimes extends onto belly; under tail coverts like sides and back but still lighter. Total length 14.5015.25 inches (368-387 mm.) (three specimens); folder wing 6.62-7.00 (168178 ); bill along culmen 1.35-1.49 (34.3-37.8); tarsus 1.07-1.18 (27.2-30.0) (ten specimens); all from California. Juvenile plumage: Similar to that of adult female, but lower surface lighter, and spotting on belly very faint or absent. Natal plumage: Top of head and hind neak, line from bill through eye, and spot on ear, dark brown; silies of head dull yellow; back brown, with four spots of straw yellow, one on each side at base of tail and one on each side near wing.

MARKS FOR FIELD IDENTIFICATION-Very small size (for a duck); male, chestnut brown head with green patch back of eye, white bar across side of breast and bright green speeuhm bordered above and below by black. Dis. tinguished from the rare European Teal by presence of white bar across sicle of breast, and from Cinnamon and Blue-winged teals by absence of blue on wing. Flanks of female and young Green-wing more heavily marker than in Blue-winged Teal.

VOICE-Of male: a short mellow whistle; of female: a high pitehed and oft repeated "quack" of slight volume (Eaton, 1910, P. 193; Bowles, in Dawson, 1909 , p. 774).

NEST-On the ground near water; constructed of grass and feathers placed in a thick growth of grass.

EGGs-5 to 12 , bluntly ovate in shape, measuring in inches 1.60 to 1.83 by 1.22 to 1.34 (in millimeters, 40.7 to 46.5 by 31.0 to 34.0 ), and averaging 1.72 by 1.27 (43.7 to 32.2) (fourteen eggs from Arctic America and one set, seven eggs, from California, all in U. S. National Museum); pale olive or greenish buff in color.

General distribution-North America. Breels from northwestern Alaska, central Keewatin, and Newfounlland south to California, northern Nebraska and New Brunswick; winters from the Aleutian Islanls, British Columbia, Nevala, northern Indiana and western New York south to southern Lower California, Honduras and the West Indies (modifiel from A. O. U. Check-list, 1910 , pl. $70-71)$. 
Distribution in CAlmoRNA- Abundant winter visitant throughont the state, ehiefly on fresh water. Summers in small numbers locally; has been recorled as breeding only in Ventura County (Evernann, 1856, p. 89); at Tulare Lake, Kings County (Goldman, 190Sa, p. 129); in Sierra Valley, Plumas County (Belding, MS); and near Alvarado, Alameda County (Dirks, 1916, p. 46).

The Green-winged Teal is probably the commonest and most widely distributed duck in western North America, and during the winter season is one of the most abundant species in the sonthwestern United States. Along the Atlantie Coast it is now exceeded in numbers by the Bluc-winged Teal, but in former year's Green-wings were fairly abundant there. The general breeding range of the Greenwing extends from the central United States to Alaska and Newfoundland, but it is not common in summer south of the Canadian boundary. Most of the birds nest in west-central Canada, from Manitoba to Lake Athabasca. The winter range is very cxtensive, reaching from British Columbia and New York to Mexico and even Central America. As with certain other ducks it is probable that the individuals of this species wintering in California breed in British Columbia and Alaska.

The Green-winged Teal is among the earliest migrant ducks to arrive here in the fall and also one of the last to depart in the spring. On Angust 12, 1905, a flock was flushed at Cushenbury Springs, San Bernardino County (Grinnell, 1908, p. 53), and as early as September 15 it has been noted at Stockton (Belding, IIS). On the Pacific slope of southern California it arrives in late September or in Oetober and leaves in March (Willett, 1912a. p. 23). It occurs in greatest abundance here during November and December, to judge from the numbers to be seen in the city markets.

This teal prefers the smaller bodies of fresh water to the larger lakes and rivers. The Green-wing is the species which so often drops into temporary ponds, irrigation ditches, small evanescent desert pools and the innumerable little lakes that form during wet weather in the hill country, and is the duek most often shot on the small meadow ponds of the interior. In the coastal lowlands, and marshes adjacent to the lower reaches of the large rivers, it is also abundant. As a rule it avoids salt water, but oceasionally, during the daytime, it is to be seen rafted with other species on the smooth water of the ocean just outside the surf.

Among the smallest of our dueks, and eonsidered by many to be the fastest of them in flight, the Green-winged Teal is still an easy bird to recognize. Its small size, and in the male the chestnut brown head relieved by green patches behind the eyes, the white bar in front of each wing and the bright green speculum together with the absenee of a large blue patch on the wing make identification easy. Both the 
Cimmanon and Blue-winged teals, in addition to their green speenlums, have lange patehes of light blue on the wing, while the rare European Teal lacks the white bar across each sicle of the breast. The small body size, close flock formation, and erratic flight serve as good field marks in separating teal from other ducks.

Green-winged T'eal are known to nest in small numbers within the state. Goldman (1908u, p. 129) found a nest with seven eggs at Thulare Lake, lings County, July 7, 1907, and several other birels of this speeies were also present in the vicinity. There is also a report of two sets of Green-winged Teal eggs secmed at Tulare Lake in June, 1910, which were sent to Judge F. W. IJenshaw and hatehed out on his place at Redwood City. This additional instance strengthens a surmise which Goldman makes that there is a breeding eolony in the vicinity of Tulare Lake. Evermann (1886, p. 89 ) states that a few bred in Ventura county in former years. Belding (MIS) states that

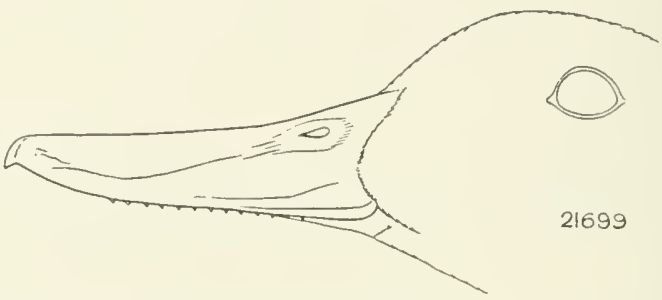

Fig. 13. Side of bill of female Green-winged Teal. Natural size. Compare with bill of Cinnamon Teal (fig. 14).

he found a few nesting in Sierra Talley, Plumas County, in June, 1885. This was after a dry winter. Residents told him that in seasons following abundant rainfall many more representatives of the speeies nested there.

In eastern Oregon during the breeding season this teal is saicl to prefer the smaller momtain streams to the larger boties of water (Baird, Brewer and Ridgway, 1884, II, p. 4). The nests of this duek resemble those of other species. One found by W. P. Taylor (1912, p. 357) in northwestern Nevada at Quinn River Crossing, Humboldt County, on Jume 4, 1909, “. . . was loeated in a depression on moist ground, and surrounded by the tall grasses of the marsh. The nest was eomposed of willow twigs and grass stems so loosely felted together that the structure eould not be pieked up intact. The eavity measured $127 \mathrm{~mm}$. (5) inches) in diancter and $70 \mathrm{~mm}$. (23/4 inches) deep. Four eggs were found in the nest, and one other on the gromud at a distance. . Strangely enough, no down feathers were noted anywhere in the ricinity." MeGregor (1906, p. 119) deseribes a nest from the Aleutian Islands, Alaska, as being ". . . on the ground beneath the overhanging trunk of a twisted willow; it was 
thinly furnished with elown about the top and the eggs rested on the gromel." The insile dimensions of this nest were about 51\% by $31 / 2$ inches. Farther north, at the month of the Yukon River, Alaska, Nelson (188T, 1. 6!) ) says the nests are placed on dry knolls near small ponds, and arr composed of grass stems and foather's. The seven egas referred to above as collected by Coldman at Tulare Lake are bluntly ovate in shape, and deciderlly smaller than those of the Cimmamon Teal. In color they are pate olive butf. They measure in inches 1.60 to 1.69 by 1.22 to 1.26 and average 1.65 by 1.24 (set now in L. S. National Musemun).

The only description we have of the behavior of the female when with a broou is that by Bent (1902, p. 1) who (anne npon a parent bird with eight ducklings in a rnsh-bortered pond in North Dakota. The female made a considerable demonstration, flapping and dragging helself about as long as the observer remained. 'The young meanwhile sought safery in the atjacent rushes. In Alaska, according to Nelson (Ioce cit.), the old and young may be found feeding together by the last of Angust. They then forage in the mul at the edge of small sechuled ticle ereeks or in the grass-covered margins of pools in the marsh land. The downy young of the Green-winged Teal, as compared with those of related species, exhibit one feature by which they ean be distinguished even if color characters camnot be remembered. The bill is notably long and parallel-sided, giving an effect of extreme slenderness.

The Green-winged Teal is distinetly a gregarious species anrl, during the winter season, flocks have been observed, of as many as several hundred individuals. In fact this has been referred to as the most gregarious of ducks. Another striking feature of this bird's behavior is its extremely high rate of speed on the wing. Bowles (in Dawson, 1909, p. 773) says:

Moring at a rate of certainly not less than one hundred miles an hour, the evolutions of a large flock of these birds are truly startling. They fly in such close order that one would think their wings must interfere, even on a straight course; yet of a sudden the whole flock will turn at a right angle, or wheel and twist as if it were one bird. The looker-on ean only wonder what the signal may be which is given and obeyed to such perfection, for the least hesitation or mistake on the part of a single bird would result in death or a broken wing to a score.

When flushed from the ground or water these teal usually ascend to a considerable elevation before flying off. When not disturbed they like to spend a large share of their time on land and seem to enjoy this "loafing" more than the great majority of wild ducks. The Green-wing is a rapid swimmer, but it seldom dives except when wounded. 
Ordinarily Green-winged 'T'eal feed during the daytime, but if molested they forage chiefly at night. Their favorite feeding ground is along the shore of a pond where they search about the mud (that is, "puddle") for insects and seeds. Like the Mallard and other pond and river ducks, the Green-winged Teal feeds in shallow water, searching the bottom by "standing on its head" and sifting out the seeds and other food materials from the mud and water. While thus "tilting" a bird often kicks the water vigorously to help it in maintaining the desired balance. Occasionally it may be seen wandering about on the grass-grown banks searching for insects. In fact the Green-wing is almost as omnivorous a feeder as the Mallard; for it will take aquatic plants, snails, crustaceans and all sorts of insects along with the commonest element of its food-weed seeds.

Some persons consider the Green-winged Teal the most desirable duck as far as flavor is concerned. Its tender juicy flesh is certainly of a sort to be relished by anyone. This duck is also very attractive from a sportsman's standpoint; indeed many hunters consider it their "best" duck. It is both fast flying and wary and this makes it difficult to hit. A long lead and a quick shot are necessary to bring it to bag. However, it is fond of company and in consequence is easily attracted by the decoys. Even when it has been shot at several times this desire for company will cause the birds to return repeatedly to the same pond. The close formation is maintained both when in the air and on the water, thus affording opportunity for "pot shots."

In this state, the numbers of Green-winged Teal shot each year exceed those of any other single species of duck. This is because of its greater abundance and also its desirability as a table bird. In 1909-1910 each of the game transfer companies of San Francisco handled from 5,000 to 20,000 "teal," while in 1895-1896 more than 82,000 were sold in the markets of San Francisco and Los Angeles (Calif. Fish Comm., 1896, p. 40). There were probably some Cimamon Teal in these lots, but by far the greater number were Green-wings. In 1886 several species of ducks on the San Francisco market sold for the following prices per dozen: Canvasback, $\$ 3.50$ per dozen; Mallards, $\$ 2.50$ and $\$ 3.00$; Sprigs, $\$ 1.50$ and $\$ 2.00$; Widgeon, $\$ 1.25$; Teal, $\$ 1.50$ to $\$ 1.75$; “small ducks," $\$ 1.00$ (Belding, MS). Thus it will be seen that, taking size into account, teal were greatly preferred. As long as the breeding grounds in the far north are well protected, and the toll taken each year is not too great, we can expect this duck to continue to visit us in numbers. 'That the toll is now in fact too great is the contention of many hunters in this state, who maintain that the numbers of this bird are steadily decreasing from rear to vear. 


\section{European Teal}

\section{Nettion crecca (Limnaeus)}

OTHER NAME-Allas crécer.

Descriptiox-Adult male: "Similar to .. [the Green-wingerl Teal] but no white bar on sicle of breast, black and whitish undulations of sirles, etr., much coarser, inner webs of outermost scapulars wholly, and onter webs partly, white, the exposel portion of outer wels mostly hlack . . " (Rilgway, 1887, p. 94). Total Iength "about 14.00" inches (356 mm.); follerl wing "7.00-7.30", (178-186); bill along culmen " $1.45-1.50$ ", (36.8-38.2); tarsus "1.10-1.25," (25.0-31.8) (Bairl, Brewer ant Rilgway, 18.4, II, p. 7). Adult female: "Not distinguishable with certainty from that of [Green-winged Teal] $N$. carolinensis?", (Bairl, Brewer and Rislgway, loe, eit.). "Females and young of this teal can scarcely be letermined unless by careful comparison with authentic specimens, but seem to be browner and less finely variegaterl than the Ameriean birl', (Faton, 1910, p. 191). Natul plumage: See Green-winged Teal.

MARKS FOR FIELD IDENTIFICATION-Adult male: as for Green-winger Teal but white bar on side of breast lacking. Female cannot be listinguisher from that of Green-winged Teal (Chapman, 1912, p. 195).

Torce-Like that of Green-winged Teal.

Nest-In bogs and marshes in grassy fields; formed of grasses and reeds, warmly lined with feathers (Davie, 1889, p. 64).

EGGS-8 to 10 , sometimes 15 , oval in shape, measuring in inches 1.75 by 1.30 (in millimeters, 44.5 by 33.0 ); color yellowish white (Davie, loc. cit.).

Gexeral distribution-Northern part of Eastern Hemisphere. Occasional in North America; recorded from the Aleutian Islands, California, Greenland, Labrador, Nova Scotia, Maine, New York, Massachusetts, Connectient and Tirginia (A. O. U. Cheek-list, 1910, p. 70 ).

Distribution in CALIforxia-Known chiefly from Cooper's statement (1886, P. 125) that in his time it hall been "found not rarely in California."

The Enropean Teal is widely distributed over the Old World, breeding thronghont Europe and Asia. The records of its oceurrence in North America are very few. Specimens have been taken along the Atlantic Coast from Labrador to the District of Columbia ; several have been found in the markets of New York City. On the Pacific Coast but two records are known, one for the Aleutian Islands, Alaska, and the other for California. The latter record, as far as we are aware, is unfortunately not substantiated by specimens in any collection. The dates of capture elsewhere in America are for every month of the year, except January, August, and October; those from the United States range from November to April (Cooke, 1906, p. 30). This teal is known to be abundant on the eastern coast of Asia as far north as Kamchatka and Bering Island.

Althongh Cooper (1886, p. 125) records the European Teal as having been "found not rarely in California," no other record of its occurrence within the state is known to us. Belding (MS) thought 
that individuals of this speeies bred in the marshes near Stockton. But since this belief was based on sight determination, it can hardly be given weight as conchsive evidence. This duck eertainly camnot be eonsidered as more than an extremely rare straggler within the borders of the state, if it now oceurs here at all.

In liabits the European Teal doubtless so nearly resembles the Green-winged Teal that the aceomt of the latter will serve to give a fair idea of the former. One of the peculiar habits for whieh the European Teal is espeeially noted in England may be mentioned however. When startled it flies up alınost perpendieularly to a considerable height, then starts off in a straight line, afterwards returning at a great height. When abont to alight the birds dive down almost perpendienlarly from overhead. Their speed in flight is said to be remarkable, and has been estimated at over a hundred miles an hour. Millais $(1902$, p. 82$)$ says: "Whilst on the wing the male oceasionally utter's his low double whistle, but Teal are silent birds at all times, and the female rarely ealls nuless frightened, such as when the brood is threatened, when she emits a subdued little quack."

\section{Blue-winged Teal}

\section{Querquedula discors (Linnaeus)}

OTHER NAMES-White-faced Teal: Anas discors.

Description-Adult male: Head and neck dull learl color, slightly glossed with purplish on the sirles; top of head from base of bill to hind neck, black: conspicuous erescent on side of head extending from above eye around in front of eye and downwards and backwards past chin, white, bordered with hlackish; chin hlack; bill "bluish-black"; iris "dark hazel" (Andubon, 1842, TI, p. 291); upper surface dark brown, the feathers lighter-edged, and those of back and seapulars variegated with horseshoe-shaped markings of light rusty brown; rump ani tail nearly uniform dark brown, but with pale feather erlgings; forepart of outer surface of closenl wing pale blue; flight feathers dark brown; tertials long and narrow and striped with light rusty brown and lblack: speculum metallic green, bordered in front by a white bar, ahove by a blackish stripe, and behind by a very narrow white border; most of lining of wing, and axillars, pure white; mnler surface of bolly and sides, reddish brown, spotted with black; unler tail roverts brownish black; spot at base of tail on each sile, white; unler surface of tail feathers, ashy; feet "dull yellow," wehs "'lusky," claws "brownish black", (Audubon, loe. eit.). Total length (both sexes): "14.50-16.00", inches (368-407 mm.) (Riılgway, 1900, p. 92). Males: folderl wing 7.50 (190) (adult), 7.00 (17S) (immature); bill along ("ulmen 1.5.) ( 39.4 ) (arlult), 1.52 (38.6) (immature); tarsus 1.22 (31.0) (arlult), 1.17 (29.7) (immature); one sperimen of each from California. Adult female: Cpper surface dark brom, with dull buff feather edgings; sicles of heal anit nerk finely streakel with same eolor; stripe before and behimd eye, dusky: rest of head and neck pale brownish white; rhin and throat almost pure white; hill, iris, anl outer surface of elosed wing as in alult male, but green of sperulum muh duller and tertials colored like bakt under surface of borly 
lull white, with grayish brown feather centers, giving a spotted or mottlea apprearance, coarsest on sides of body and least distinct on belly. Folıled wing 6.s3-6.5 inches (174-175 mm.); bill along culmen 1.48-1.51 (37.6-38.4); tarsus 1.16-1.24 (29.4-31.5) (two sperinens from California). Juxenile plumage: Similar to that of alult female but wing like that of arlult male. Natal plumage: "Top of head and upper" parts, brown; buff spots in front of wing, arross wing. and at sinle of rump; forehead, line to eye and lower parts, pals buff; silles of heal and hind neck, ochraceous buff', (Sanford, Bishop and I'an Dyke, 1903, p. 99). Adult males at close of breeding season assume an "erlipse" plumage resembling plumage of female.

MARKS FOR FIELD IDENTIFICATION-Small size. Male has large blue pateh on forerast of wing, green sperulum, white crescent on cheek and no leej eimnmon rolor on under surface. Female distinguished with kiffieulty from female C'imamon Teal: chin anl throat much lighter, no rusty on whest or sirles. and heal and neck more heavily speckled.

Vurce-nf male: a whistling "peep," repeatel five or six times; of female: similar to "quack" of Green-winged Teal (Waton, 1910, p. 195).

NEsT-I'sually on dry ground near fresh wated, and hidelen in tall grass; male of grass or reels and linel with down.

Figs-6 to 12, bluntly ovate in shape, measnring in inehes, 1.71 to 1.93 by 1.26 to 1.36 (in millimeters, 43.5 to 49.0 by 32.0 to 34.5 ), and averaging 1.51 by 1.30 (46.0 by 33.0); in eolor pale olive buff (forty-one eggs in U. S. Nationai Museum).

Gexeril DISTRIBUTION-Western Hemisphere, lut most mumerous in the eastern portion of North America. Breels from eentral British Columbia and Newfomdland south to northern Nevada, southern Tndiana and Maine, but most abmulantly between the Rocky Mountains and Great Lakes. Winters from southern British Columbia, Arizona, southern Illinois. and Delaware south to central America and northeru South America (motified from A. O. $T$. Check-list, 1910, p. 71).

DISTRIBTTON IN CALIFORNIA-Rare transient and winter visitant, oecurring exclusively on fresh water. The following are the ouly records from California known to the writers: Napa, Napa County (WV. E. Bryant, 1891, 1. 128 ); Storkton, San Joaruin County, San Diego, and Agua Caliente [= Palm Springs], Riverside County (Belling, 1591, p. 97); Weaverville, Trinity County (Salvalori, 1595, p. 299); Tallejo, Solano County (Kolbé, in Bailey, 1902, J. xlix); Little Owens Lake, lnyo County (A. K. Fisher, 1893a, p. 16); Santa Barbara (Torrey, 1909a, IP. 173-174; Dawson, 1916, P. 24); El Monte and Los Angeles, Los Angeles County (Grinnell, 189S, p. 11; Swarth, 1910, p. 107); Los Angeles County (Willett, 1911, 1. 76); Bolsa Beach, Orange County (Grinuell collection); National City, San Diego County (Willett, 1912a, p 23); Colorado River, Riverside County, opposite Ehrenberg, Arizona (Stephens, $1902, \mathrm{p}, 76)$.

The Blue-winged Teal, although a common duck of the east and still more common in the middle west, is a rare species on the Pacific Coast. Its breeding range includes the northern United States and extends northward to eentral Canada. It is to be found breeding most abundantly in south-central Canada and in the middle western states between the Rocky Mountains and the Great Lakes. It is rare in British Columbia and has been reeorded but onee from Alaska. Dur- 
ing the winter it is distributed from the south-central states to northern South Ameriea. Consequently it must be classed along with the Cimmamon Teal as a southern duck which comes north through the United States for the summer.

The Blue-winged Teal has been taken but comparatively few times in California and the majority of the records are from south of Tehachapi. Of twenty individual specimens recorded, three are of Jamury date, one of February, eight are of "spring", dates (March to May, inelusive), the other' eight of "fall" dates (August to October, inelusive). From these faets it would appear that the Blue-winged Teal oceurs in California as a transient, and casually as a midwinter visitant.

The adult male is distinetive among American dueks by reason of the erescent-shaped patehes of white on the sides of its head, and this feature gives it the name of White-faeed Teal. The large area of light blue on the wing will separate the Blne-winged Teal from all other dueks of similar size exeept the Cinnamon Teal. The males of these two speeies are readily distinguished because of the bright cimmamon, almost ehestnut color, of the Cimmamon Teal. The females and young, however, are very similar. Those of the Blue-winged Teal have a slenderer bill (compare figs. 15 and 16), constrieted at the base, and they lack the slight tinge of chestnut to be noted on the sides of the breast in the Cinnamon 'Teal. The feathers of the breast of the Cinnamon Teal are commonly marked with horseshoe-shaped markings of pale rufous, whereas those of the Blne-winged Teal are simply edged with ashy.

Aceording to Davie $(1889$, p. 65) the nest is made on the ground, in a thick pateh or tussoek of grass, usually in meadows, the border's of ponds, or streams, and swampy places. It is composed of soft pieces of grass and weeds and lined with down and feathers from the breast of the bird. The eggs are six to twelve in number, bluntly ovate in shape, and are lighter in tint than those of the Green-winged Teal; they are distinguishable from those of the Cimmamon only by their slightly smaller size. In the middle west this duek is said to nest in thickly settled loealities and even on embankments beside railroad traeks.

Like the Green-winged Teal, the Blue-wing flies with great speed and in elose flocks. On approaching a pond it drops quickly into the water or into the reeds mueh as do some of the shorebirds.

The habits of the Blue-winged Teal are almost identieal with those of the Green-winged Teal. Individuals found in California have nearly always been mixed in with floeks of Green-winged Teal and have not been reeognized until shot. 
Where abumlant this chek affords the same sport as does the Green-wing and makes just as diffienlt a mark. Like the latter bird the Blue-wing readily decoys, and it is just as desirable as the Greenwing for the table.

It is not probable that the Blue-winged Teal will ever become common in California. Certainly the reeords lo not show that it is beeoming more abundant at the present time. An increase in the number of recorts at some future time might result from an increase in the number of people who are able to reeognize the speeies, and from a keener watch being kept for unusual oceurrences among the ducks killed in the state.

\section{Cinnamon Teal}

\section{Querquedula cyanoptera (Tieillot)}

OTHER NAMES-Rell-breasted Teal; Western Blue-wingel Teal; A mas cyanoptera; Pteroeyanca coeruleata; Pterosyanea discors.

DESCRIPTION-Adult male: Hearl rich chestnut, washerl with black on rown aul chin: iris orange; bill black, margiu of uppor manclible and whole of lower mandible tingel with pink; back brownish black with $\mathbf{U}$-shaperl bars and feather-edgings of chestnut; rump and midlle upjer tail coverts dark brown edged with lighter hrown; lateral upper tail coverts and upper surface of tail brownish black: forepart of outer surface of closel wing and outer webs of scapulars, elear light blue; flight feathers slate brown; speculum metallic green, separated from blue area by a white bar and horlereil above by brownish black; tertials striped with buff; axillars white; lining of wing white and ilull brown; whole uniler surface of borly rich chestnut, washed with blackish on belly; under tail coverts black: under surface of tail feathers ashy; feet greenish orange, joints, webs and claws lusky. Total length 15.9.516.20 inches (405-412 mm.) (three specimens); folled wing $7.25-8.00$ (18t203); bill along culmen 1.67-1.Ss (42.4-47.7); tarsus 1.21-1.32 (30.7-33.5) (ten specimeus); weight $10.3-11.3$ ounces (290-320 gm.) (three specimens). Adult female: Top of heal blackish brown, each feather narrowly edged with brown; rest of head ashy eiunamon, finely streaked with dark brown; chin sometimes unstreaked; whole upper surface blackish brown, with buffy or ashy feather edgings; iris hazel; outer surface of closed wing as in male, but speculum dull black, showing only a trace of green, and white bar reduced or absent; scapulars dark brown streaked and elged with paler brown; lining of wing and axillars as in male; breast buffy, heavily mottled with blackish and more or less suffused with light einnamon brown; rest of under surface like breast, but less heavily mottled and ground color paler sometimes almost white on middle of belly; feet dull green, webs and elaws dusky. Total length 15.75 inches (400 $\mathrm{mm}$.) (one specimen); folled wing 6.90-7.45 (175-189); bill along culmen 1.63-1.85 (41.4-47.0); tarsus 1.21-1.26 (30.7-32.0) (ten specimens); weight 10.8 oz. (305.7 gm.) (one specimen); all from California. Juvenile plumage: Similar to that of adult female, but under surface of body less suffused with cinnamon brown, and markings narrower, giving more of a streaked appearance. Juvenile males can be distinguished from females by the green speculum and white wing bar being as in adult males. Females have speeulum dull black with faintest trace of green and white bar but brokenly indicated. Natal plumage: Top of 
head dark olive; sieles of head, chin and throat, yellowish buff; strije from base of bill near nostril to eye and two streaks back of eye, dark brown; upper surface of body dark olive; spot on each side of back and one on each sicle at base of tail, vellow; whole under surface yellowish buff.

MARKS FOR FIELD IDENTIFICATION-Small size (lut large for a teal), and large blue patch on wing in front of green or blackish speculum. Male distinguished from all other ducks by rich chestmut brown body color (pl. 4). Female and young can only be separated from those of Blue-winged Teal in haul and then only with difficulty; the Cinnamon has heart and rhin more speckled, and distinct diffusion of light cinuamon brown and $C^{\top}$-shapen markings on hreast.

Vorce-Similar to that of other teal; a miniature "quack," given by the female.

NEST-Situated in grassy fields or among tules, sometimes above shallow water but more often above damp grount, at times some little listance from water; made of grasses or tules compactly woven together anil ileeply saucershaped.

EGGS-6 to 12 , ovate or elongate ovate in shape; measuring in inches 1.7 .3 to 2.09 by 1.18 to 1.35 (in millimeters, 44.0 to 53.0 by 30.0 to 35.0 ), and averaging 1.87 by 1.36 (47.5 by 34.5) (seventy eggs in U. S. National Musemu); in color (reamy white or pale buff.

General distribution-North and South America. Breels in North America from southern British Columbia, southwestern Alberta, southeastern Wroming, and western Kansas south to northern Lower California, northern Chihuahua. southern New Mexico, and southwestern Texas; winters from southern California, central New Mexico, and southem Texas south to southern Lower California and central Mexico. Oceurs in Sonth America from Peru and Brazil south to the Falkland Islands (molified from A. O. U. Check-list, 1910, P. 71).

Distribution IN CALIFORNiA-Abunlant spring, summer and fall visitant throughout the state, breeling throughout its summer range; restricter to the vicinity of fresh water. Scattered individuals winter in the central and sonthern portions of the state, the following lefinite instances of occurrence heing known: Vallejo, Solano County (Kobbé in Bailer, 1902, p. xlix): Los Baños, Mercen County, November to Fehruary, inchsive, 1911-1912 (twelve specimens in Mus. Yert. Zool.); Riverdale, Fresno County, January 10, 1912, a dozen (Tyler, 1913b, p. 16); Tulare Lake, Kings County (Cooke, 1906, 13. 35): . Newport Slough, Orange County, Decenber and January, 1884 (Beling, MS); and near Salton Sea, Imperial County, December 16, 1910, one (Tan Rossen, 1911, p. 130). The spring migration begins about the first of Mar.h and the southwarl movement commenues in september, the breeling grounds being almost leserted by mirl-Ortober (Cooke, loc. eit.).

The bright coloration of this duck has attracted much popular attention and has been the basis for its several vernacular names. The chestmut or cimmamon eolor of the under surface has giren rise to its aecepted remacular name, Cinmamon Teal, also a common hunter's name, Reil-breasted Teal; while the large patch of blue on the wing is responsible for its being ealled Blue-winged Teal. Use of the latter name, however, is eonfusing, as a related bird abundant in raster'n North America, and even reaching California, has proper claim to this name (see preceding aceount). 
The chest nut rolor of the lower surfater serves to easily distinguish the male Cinmamon 'Teal from all other dueks (pl. 4). The females and young closely resemble those of the eastern Blne-winged Teal. The heavier speckling on the hear and chin, the strong suffusion of rusty or einnamon on the breast. and the $\mathrm{I}^{\mathrm{T}}$-shaped markings of pale rusty brown are never present in the Blne-winged Teal. c'lose examination of the bills will show that of the Blue-wing to be smaller, although relatively broader at the base (figs.

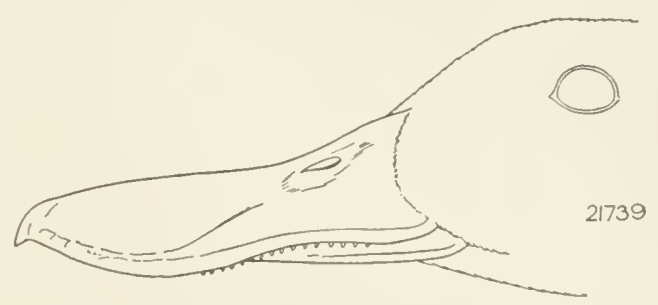

Fig. 14. Side of bill of female Cinnamon Trall. Natural sime.

15 and 16). From the Green-winged Teal the Cimnamon Teal may be distinguished in hand by the larger size of the latter, longer bill and neck, darker color, presence of blue on forepart of wing and, in flight,

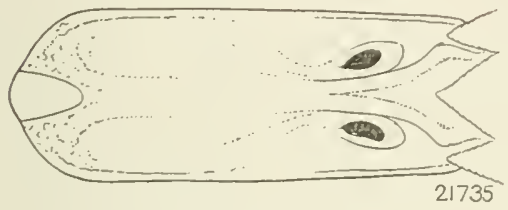

Fig. 15. Cinnamon Teal.

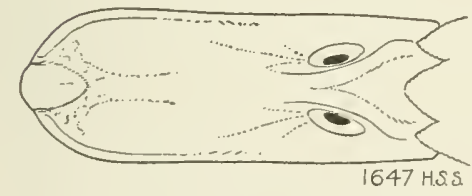

Fig. 16. Blue-winger Teal. Tops of bills. Both females, natural size. The differences in outline shown will serve to separate the two species when coloration fails.

by the last named character and also by the less rapid beating of the wings.

The Cinnamon Teal must be considered the commonest brecding duck as regards the whole of California, although the Pintail or Mallard may possibly outnumber it in certain localities. In sonthern Califormia there is hardly a ranch of any size offering suitable conditions where a pair or more of these binds is not to be observed at the proper season. It is the Cimnamon Teal which is the usual duck forme nesting in the marshes of the San Joaquin and Sacramento valleys. The artifieial ponds in the form of reservoirs, found so commonly throughout the state, often furnish a home for it.

In California the nesting season of the Cinnamon Teal extends from April into July. The bulk of the nesting oecurs in May and June, chiefly the former month. There is no difference in time of nesting eorrelative with latitude, but nesting at high altitudes occurs later than in the lowlands. The aecompanying table (no. 10) gives all the data known to the anthors relative to the nesting of the species in California.

While Cinnamon Teal have been found nesting in sueh widely 
TABLE 10.-Data relative to the nesting of the Cinnamon Teal in California

LOCALITY

D. 1 Th:

Stockton, San Joaquin Co.Apr. 13, 1878

Escondido, San Diego Co. Apr. 18 to

May 13

Newport Bay, Orange Co. Apr. 20, 1897

Newport Bay, Orange Co. Apr. 20, 1897

Near College Park, Apr. 29, 1893 Santa Clara Co.

Near College Park, Santa Clara Co.

Near College Park, Santa Clara Co.

Near College Park. Santa Clara Co.

ricinity of Los Angeles First week in

Compton, Los Angeles Co. May 7, 1895

Wheeler Island. Solano Co.

Fort Crook (near Pitt- May 9, $186 \mathrm{I}$ ville), Shasta Co.

Sierra Valley, Plumas Co. May 9, 1891

Los Baños, Merced Co. May 10-14, 1915

Los Baños, Merced Co. May 11-24. 1914

Near College Park, Santa Clara Co.

Los Angeles Co.

Merced Co.

Buena Tista Lake. Kern Co.

Apr. 29, 1893

Apr. 29, 1893

May 13,1893

Mid-May

May 20, 1896

May $20-30$ 1907

Lathrop, San , Toaquin Co, May 22, 1911

Dos Palos. Merced Co. May 22, 1912

Los Baños, Merced Co. May 22, 1911

Nigger Slough, Los Angeles Co.

Gridley, Butte Co.

May 25, 1911

May 25, 1914

Sugar Hill, Modoc Co. May 28, 1910

Merced, Merced Co.

Tule [ = Rhett] Lake, Siskiyou Co.

Lower Klamath Lake. Siskiyou Co.

San Jacinto Lake. Riverside Co.

Lake Tahoe

May 30,1898

June 1, 1914

June 6,1914

June โ. 1897

June 14, 1915

Tulure Lake, Kings Co, Tune 18, 1907

Lake Valley, near Lake Tahoe

Chowchilla, Merced Co. Jume 21, 1901

Chowchilla, Merced Co. Jume 21, 1901

San Luis Rey, [San Diego Co.?]

Fagle Lake, Lassen Co. June 26, 1905

Rowlands Marsh, Lake Tahoe

Palo Verde, Imperial Co. July 14, 1916

Bear Lake, San Bernardino Mts.
11 eges

eggs, fresl

9 eggs, fresl

8 eggs, fresli

\section{Nest Contexts axd} CONDITION

ATTHORITY

Belding, 1879 , p. 446 Sharp, 1907, p, 86

Grinnell, 1898, p. 11

Grinnell, 1898, p. II

Schneider, 1893, p. 21

Schneider, 1893, pp. 2122

Schneider, 1893, p. 21

Schneider, 1893, p. 21

Davie, 1889 , p. 66

Grinnell, 1898, p. 11

Fair. MS

12 eggs, fresh

Newly hatched brood

3 eggs (set incomplete?)

3 eggs (set incomplete?)

1 egg (set incomplete)

23 nests found and 4 broods of downy young seen

11 eggs, deserted

Young birds seen by this time

9 eggs, fresh

Fresh eggs and young

6 eggs

11 eggs, nearly fresh

11 eggs, fresli

5 eggs (set incomplete)

9 eggs, fresh

10 eggs, incubated

8 eggs

9 eggs, female sitting

Brood of 5 or 6 downy young

11 eggs, incubation com. menced

I1 eggs, incubation commenced

Sesting completed; many broods: some nearly full grown

4 eggs (set incomplete?)

9 eggs, fresh

et in U. S. National Museum

Set in U. S. National Museum

H. C. Bryant, 1915e, p. 193

H. C. Brrant, 1914 , pp. $222-223$

Schneider, 1893, p. 21

Willett, $1912 a$, pp. $23-21$

Mailliard coll.

Linton, $1908 c$, p. 196

H. C. Bryant, MS.

Carriger coll.

Mus, Vert. Zool.

Willett, $1912 a$, p. 24

H. C. Bryant, 1914e. p. 227

W. P. Taylor, MS, in Mus. Tert. Zool.

MIus. Tert. Zool.

H. C. Bryant, $1914 \mathrm{p}$, p. 230

H. C. Bryant, 1914 , p. 231

Ingersoll coll.

Carriger coll.

Goldman, 1908b, p. 202

Ray. 1903 , p. 49

Mailliard coll.

I0 eggs, incubation begun Mailliard coll.

Female with matured egg Cooper, 1880, p. 251

7 eggs, 8 eggs, 10. eggs

Sheldon, 1907, pp. $186-187$

10 eggs, practically fresh Ray, 1905, p. 370

7 eggs, liatched on this Wiley, MS. date

Sull young seen

Grinnell, 1908, p. 53 


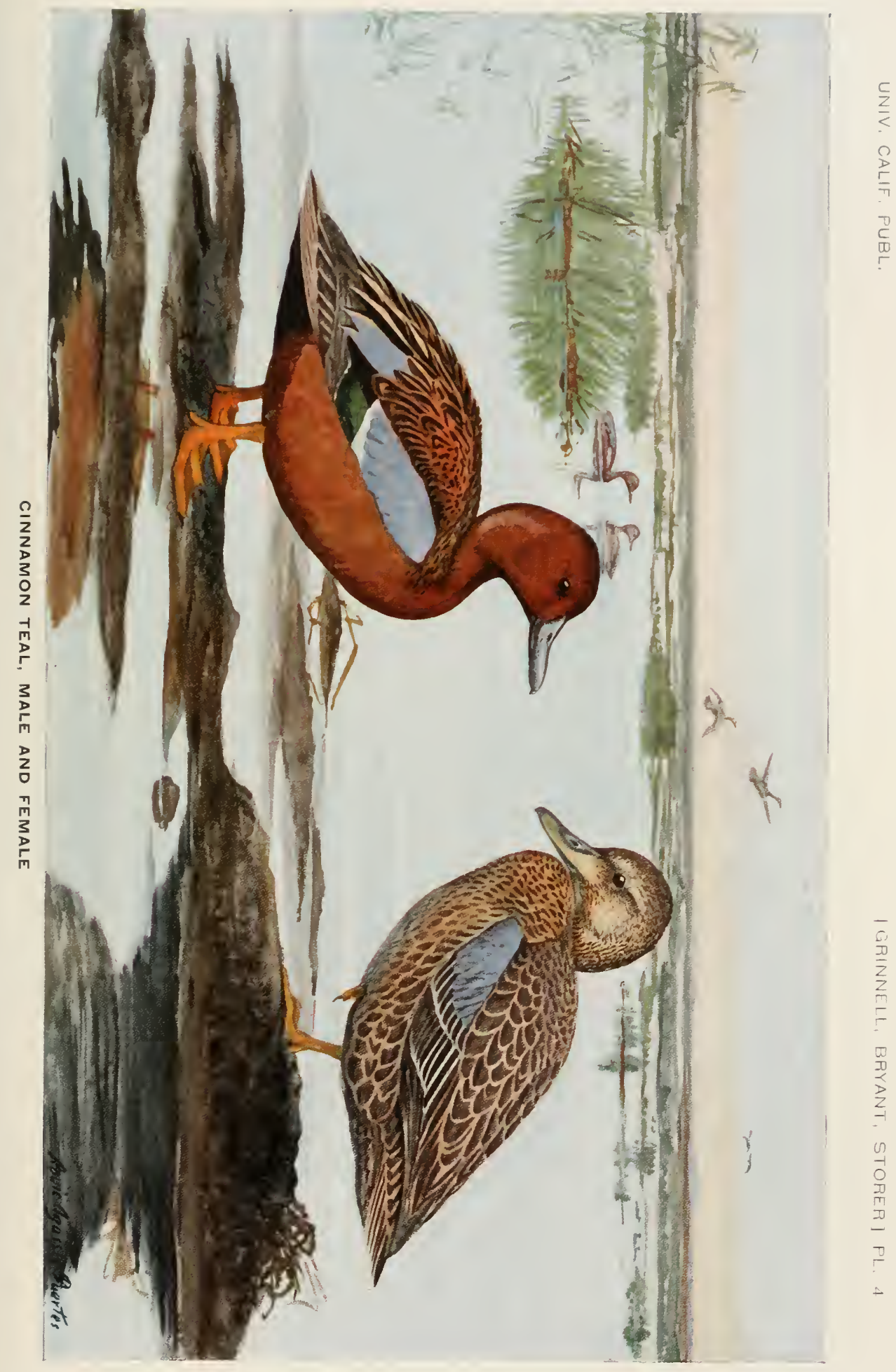



separated and direrse localities as Lake Tahoe, the San Joaquin Valley, and the coastal marshes of southern California, the site ehosen for the nest is always in the vieinity of fresh water. On salt marshes, fresh water oases are sought out. The immediate site chosen differs markedly in the numerous instanees reeorded. Sometimes the nest is placed in grass land or a grain field a hundred rards or so from water; more commonly, it is in a clamp situation, as in tules or marsh land, and at the edge of some small pond or stream. The nest itself is usually a compaet strueture made of grass stems and weeds and, less often, tules; but oecasionally it is nothing more than a slight hollow in the ground. After the full complement of six to thirteen eggs is laid. the nest is always well lined with down of a dark gray hne: as a rule, until the set is eomplete, little or no down is to be found in the nest. While sitting, the female is secretive, and only flushes when an intruder is elose to the nest. A nest found by II. C. Bryant (MS) near Lathrop, San Joaquin ('ounty, May 22, 1911, from which the female had departed before his approach, was found to have the eggs eovered and completely concealed by the down. Speaking of the Cimmanon Teal in the nesting season at Los Baños, Chapman (1908, p. 290) says that "the drake was always within a few feet of the duck, when she was off the nest, and invariably sprang into the air a foot or two behind her when she took wing. Wr made this habit a subject of speeial observation without ever seeing the male bircl fly first."

At Los Baños, Mereed County, in May, 1914, I. C. Bryant (1914r. p. 2.2.) found no less than twenty-three nests of this species. Of these, eighteen showed evidence of destruction of the eggs by some predaeious animal, and from three others the young had already hatched. A nest which when first found contained but a single egg, four days later held five eggs, showing that one egg was laid each dar. Concerning nests found at this locality the same author sars:

The inconspicuousness of a nest when covereil with its blanket of down was significantly impressed upon us on returning to a nesting site we harl previously marked. Although we went directly to the small islet on which the nest was situated and looked carefully for the nest it took several minutes to descry it, and when found was in exactly the position we had pictures it in our minds. The dusky-hued lown of the Cinnamon Teal harmonizes woniterfully with the damp black earth on which the nest is most often directly placerl (H. C. Bryant, 1914e, pp. 222-223).

The method most frequently used in loeating nests of this and other species of ducks is for two persons to drag a long rope over an area in which nests are to be expeeted. As the rope, passing over the grass, approaches a sitting bird she will usually flush directly and thus give a elue to the exact location of her nest. 
As is shown by the accompanying table (no. 10) the number of egess in a eomplete set ranges from 6 to 13 , the average being between 9 and 10 . The eggs are orate or clongate-orate in shape, and measure in inehes 1.73 to 2.08 by 1.18 to 1.38 , averaging 1.87 by 1.36 . The color is ereany white or pale buff. 'The eggs of the Green-winged 'Teal are deeidedly smaller, but similar in tone of color. Those of the Pintail, Gadwall and Shoveller are mueh larger.

A. M. Shields (in Sehneider, 1893, p. 22) has given the following notes as to the habits of the young:

After being hatched, the wother duck (joined by her mate) escorts the young brool to the nearest body of water and manifests the greatest solicitude for the well-fare of the little fellows, giving a signal upon the slightest approach of danger, which is followed by the almost instant disappearance of the entire brood, as if by magic.

If on the shore, they disappear in the grass; if in the water, they dive, and that is generally the last seen of them, for the time being at least, as they swim nnder water for great distances until reaching the edge of the stream or pond, when they imperceptibly secrete themselves among the water moss or grass.

I once watched a little fellow as he marle his way under the clear water. He went straight for a little bunch of floating moss, and by gazing intently I could just distinguish the least possible little swelling of the moss; a small hump, as it were, about the size of a narble. He had come to the surface (as intended) under the patch of moss, and his hearl and bill were responsible for the little hump in the moss.

Possibly one thing more than anything else helps the little fellows to misappear in such marvelously quick time and before you can realize it. The old duck flutters and falls around you just out of your reach and most suceessfully imitates a fowl badly winged, hardly able to rise from the grounl.

Her actions are bound to more or less avert your attention for a moment at least, and it is just that moment that the little fellows disappear, as the mother Duck undoubtedly intended.

After a short time, when the little ones are all securely hidden, the mother, feeling no further anxiety, gracefully recovers from her crippled rondition, flies off a few hundred yarts, and there awaits your departure. when she leturns to her family, who soon gather around ber one by one till they are all assembled and everything goes on as though nothing had happener-mutil the next intruder appears, when "presto! change!", and the same aetions are repeated.

Writing of the Cimmamon Teal at Los Baños, Merced County, Chapman (1908, p. 290) says that the agility of the "freshly hatehed ducklings was remarkable. Almost on emerging from the egg they took to the water, swimming and diving frecly.",

The Cimnamon Teal is one of the tamest of the ducks and ean often be approached to within a few yards. The species often associates with other dueks, especially with the Creen-winged Teal, but withont appearing to be as soeiable as the latter and never gathering in such large flocks. After nesting time, family parties are the rule, 
but mon first arrival in the spring and when leaving in the fall larger flocks are common. It is, however, to be observed that even in Hocks the indivichals consociate in pairs.

The food of the Cimmamon 'Teal, as well as its method of feeding, is like that of other teals. In the shallow water along the borders of ponds it may" be seen "tilting" in its attempt to obtain insects and seeds from the mul on the bottom. It is often seen searehing for food in the grass on shorc.

The Cimnamon 'Teal is usually rated as inferior to other tral as a table duck. Howerer this may be, this bird was, in the eary days, killed in mmbers for the market. Its flesh is said to be sweet and full of blood (like a dove's), but its keeping qualities are poor. As the Cimmamon Teal migrates south in September and October, being almost altogether gone before the opening of the shooting season, it receives a much greater degree of protection than in the ease of resident or wintering ducks. So long as snitable breeding places are furnished this dnck, and so long as conditions in its winter home remain favorable, it will, therefore, eontinue to be a eommon species. The great amomnt of land reclamation which is now being carried on would seemingly tend to rednce the appropriate nesting grounds to a minimmm, so that the breeding species of dncks might either be driven elsewhere or might be correspondingly rednced in numbers. On the other hand the construction of irrigation canals and reservoirs, with their overflow seepages, monst to a considerable extent counter'balance the above tendency. The Cimnamon Teal can be eredited with an esthetic vahne, because of its natmral tameness and beantiful plumage; and it is to be hoped that its existence as a regular member of our avifama will never be endangered.

\section{Shoveller}

\section{Spatula clypeata (Limnaens)}

OTHER NAMES-Spoonbill; Spoonie; Rynchaspis clypeata.

DESCRIPTION-Adult male: Whole head and neek metallic greeu with violet reflections at certain angles; top of heard, throat and area about base of bill approaching dull black or brown and showing least of metallic lustre; bill almost black, lower mandible paler; iris yellow; middle of back slate l.rown, each feather eilged with white or light brown; rump and upper tail coverts black, with metallic green lustre; tail feathers brown, conspicuously edged with white; front portion of outer surface of closer wing clear light blue; primaries slate brown; speeulum brilliant metallie green bordered in front by white bar which separates speculum from blue area; innermost secondaries black, tinged with metallic green and each with a streak of white towards tip; scapulars long, and streaked with white and black or brown; under surface of wing and axillars mostly pure white; whole breast pure white, sometimes obscured by a brownish stain and not infrequently showing black spottings; this broad white area almost completely encircling the body as a 
wide collar; rest of lower surface rieh cinnamon; a white spot on each sicle at base of tail; area behind vent finely barred with biack and white, tinged with brownish; uniler tail coverts black with metallic green lustre; under surface of tail white; legs and feet orange red. Total length (both sexes): "17.0021.00 ' inehes (432-533 mm.) (Ridgway, 1900, p. 97). Males: folded wing 9.56-9.95 (243-252); bill along eulmell 2.48-2.69 (63.0-68.4); tarsus 1.46-1.54 (37.2-39.2) (ten specimens). Adult female: Whole head and upper surface of body brown, each feather edged with ashy, and those of back with irregular light bars; bill olive gray, edges of lower mandible orange, its under surface pale gray; tail feathers grayish brown edged with white, siles of head grayish, finely streaked with dusky; ehin nearly white; throat minutely streaked with dark brown; outer surface of elosed wing as in male but duller colored; speculum with much less metallic green, and bounded behind by a white line; breast, sides and area behind vent grayish brown, each feather with a lighter edging, giving a spotted or mottled appearance; belly less prominently or not at all marked, but usually obscured by a more or less deep suffusion of rusty; under surface of tail ashy white. Folded wing 8.78-9.32 inches (223$236 \mathrm{~mm}$. ); bill along culmen 2.30-2.51 (58.4-63.8); tarsus 1.38-1.47 (35.1-37.4) (ten specimens); all from California. Eclipse plumage (of male): Mueh like plumage of adult female but enongh of wing pattern and pateh of white on breast remain to make identification certain. Juvenile plumage-Male: Similar to that of adult female but lighter in tone and breast usually tinged with ehestmit. Female: Wing dull slate eolor instead of blue; speculun dusky, with very little metallie green, and bordered behind by a faint white line. Natal plumage: Top and baek of head dark brown; stripe from base of bill over eye, and side of head below eye, pale buffy brown; stripe from bill through eye, brownish black; ehin and throat buffy white; rest of upper surface brown; spot on side of back, stripe across hind border of wing, and spot at side of rump, white; under surface of boty grayish white; breast tinged with brown.

MARKS FOR FIELD IDENTIFICATION--Broal spoon-shaped bill (figs. 17 and 18), much wider near tip than at base (whence the names "spoonie"' and shoveller"), ehnnky head, short neek and blue pateh on wing. Male distinguished by dark green head and einnamon colored belly bounded in front by a white breast pateh.

VoICE-A feeble quack (Forbush, 1912, p. 100); in breeding season note resembles the syllables took, took. Notes of any kind are seldom uttered.

Nest-Usually on dry ground, sometimes at a considerable distance from water; constructed of grass and weed stems, and sometimes lined with down.

EgGS-9 to 14, ovate in shape, measuring in inches, 2.00 to 2.28 by 1.38 to 1.50 (in millimeters, 51.0 to 58.0 by 35.0 to 38.0 ), and averaging 2.18 by 1.46 (5.5.5 by 37.0) (twenty eggs in U. S. National Museum); in color pale olive buff or greenish gray. The shells are comparatively thin, with but a slight surface gloss (authors).

General Distribution-Northern Hemisphere. In North America breels from northwestern Alaska, northwestern Mackenzie, and southern Keewatin south to southern Catifornia, central New Mexico, northern Texas, northern Missouri, and northern Indiana; winters from southern British Columbia, Arizona, New Mexico, sonthern Missouri, southern Illinois, Maryland, and Delaware sonth to the West Indies, Colombia, and Hawaii (A. O. U. Cheeklist, 1910, P. 72 ).

Distribution in California-Abundant winter visitant, ehiefly on fresh water, thronghout the state. In some years the spring migration does not 
begin until late May. Remains through the summer in small numbers locally, and has been found breeding at the following localities: Gorman Station, Los Angeles County (A. K. Fisher, 1893a, p. 17); near Los Angeles (Willett, 1912a, p. 24); Tulare Lake, Kings County (Goldman, 1908b. p. 202); near Jamison, Fresuo County (Ingersoll coll.); near Chowehilla, Merced County (Mailliard, MS); near Hayward, Alameda County (Emerson, 1901, p. 116); and Wheeler Island, Solano County (Fair, MS).

The Shoveller, or Spoonbill Duck, the "Spoonie" of hunters, has the widest distribution of any of the ducks so far treated, for it is found throughout Europe and Asia and parts of Africa as well as
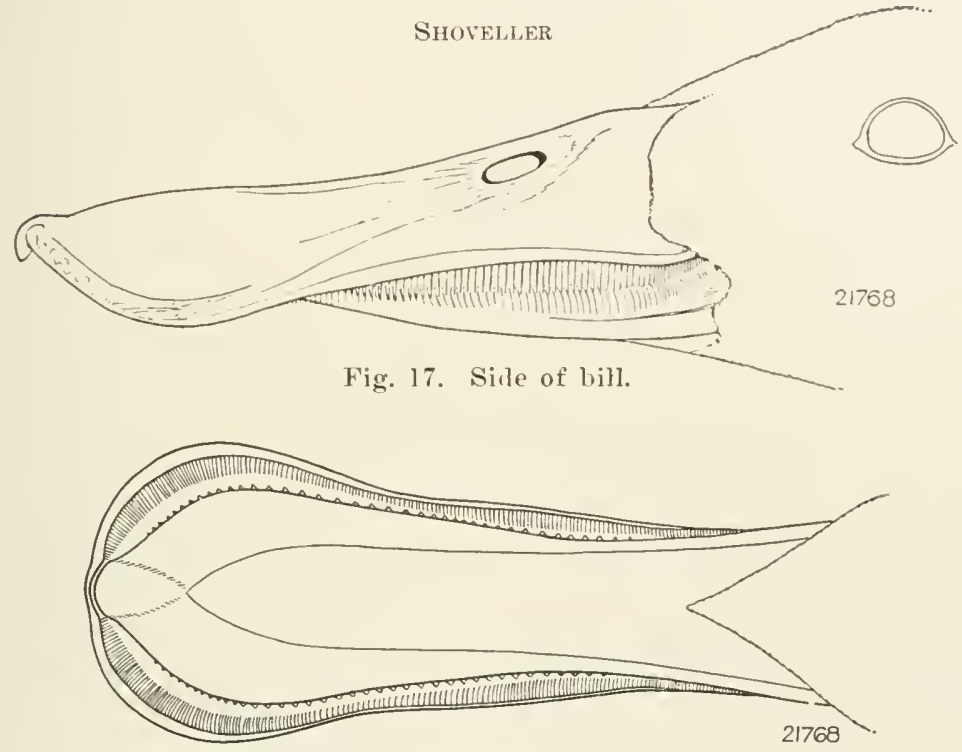

Fig. 18. Bill from below. Natural size.

Note broad, spoon-like end, whence the name "'Spoonbill,' and the cross-ridges or "strainers"' on sides of mandibles.

throughout North America and portions of Central America. In North America the principal breeding home of the Shoveller is in the prairie region of the interior from the northern United States to Saskatchewan. Along the Pacific Coast this duck is an abundant winter visitant from central British Columbia to Panama and parts of Central America. Large numbers also winter in the Hawaiian Islands. The spring migration into the Mackenzie region begins about the second week in May, and October 16 to 18 are some dates for the fall migration into Mexico (Cooke, 1906, p. 37). In California it is common from the first of October till late in April, and even until the first part of May, after other species of migratory ducks have all gone north. 
Shovellers "are usually found in pairs or suall flocks, sitting on banks or puclding in shallow water close to shore, skimming flies and laurae from the surface with their spoon-like bills, or with head and neek moler water, sifting seeds, mollusks and erustaceans from the muddy bottom" ( $\mathrm{Y}$. Bailey in Bailey, 1902, p. 54).

The male shoveller, with its bright green head, pure white breast, deep cinnamon belly and light blue patches on the wings, is, to say the least, a strikingly marked bird. The additional charaeter of a broarl, spoon-shaped bill (see figs. 17 and 18), makes it one of the casiest of the ducks to recognize. The female and young, althongh roughly similar in coloration to the Blue-winged and Cinnamon teals, especially in the possession of blue patches on the wing, are easily separated from the teals by larger size, and still better, by the shape of the bill. On the wing the comparatively luge bill, thick head and short neck, make good field marks. The flight of the Shoveller is something like that of the teal but is less direct, more of a hesitating, hovering sort.

In California the nesting season of the Shoveller eommences in April. Emerson (1901, p. 116) found two nests near Hayrard, Alameda Comnty, one on April 25, 1901, with fourteen eggs, and another (number of eggs not stated) on March 28, 1886. On Wheeler Island, Solano County, Fair (MS) found a nest with eleven eggs on May \&, 1914. In the Inger'soll collection there are two sets, of nine and ten eggs, respectively, with incubation begun in both eases: both were taken near Jamison, Fresno County, May 21, 1916. Farther south, at Tulare Lake, Kings County, Goldman (1908b. p. 202) found small young hetween Jume 18 and 24 (1907), at Chowchilla, Merced County, two downy young were found June 25, 1900 (Mailliard coll.), and near Gorman Station, Los Angeles County, the species has been reported as breeding during the "last of Jump" (A. K. Fisher, $1893 a$, p. 17).

The nest, eonstructed of dried grasses and reeds, with an oceasional lining of down, is usually plaeed on dry ground, and often at some distance from water. Emerson (loe. eit.) describes the nest found near Iayward, Alameda County, April 25, 1901, as being on the bare gromnd among salt weed. "It was not oror four inches off the ground and . . Was eomposed of dry stems of the salt-reed, lined with down and a few feathers from the parent bird, and measured fourteen inches across the top with a depth of five inches." Another nest discovered on March 28, 1856, by the same writer and in the same general locality, was placed mucler a low bush, 1.50 yards baek from the bay shore and was of similar construetion to the one just described. 
The exgs of the Shoveller are similar in eolor to those of the Mallard and Pintail, being usually pale olive buft or pale greenish gray, and have thin shells with very little Iustre. They are smaller in size. lowever, and slightly different in shape. They are distinguishable from the eggs of the Mallard by their paler tint as well as by their smalle' size (Bent, 1902, p. 4).

The downy young eamnot be readily distinguished from other ducks in that stage, for the bill at first shows little indication of the broad spoon-like form which it takes on gradnally as the birel approaches full size.

The molt into the breeding plumage is slow. Beck (MIS) states that as late as January 2, 1911, Shovellers collected at Los Baños, Hercel C'omnty, were still molting on the head and that but few were in perfeet feather. Young males often show enrions eombinations of the juvenile and achlt patterns of coloration.

Shovellers are swift Hiers and make a noticeable flapping noise with their wings when rising flom the water's surface. During certain seasons they are restless and spend mueh of the time on the wing.

Nordhoff (1902, p. 213) states that on Elsinore Jalke, Riverside County, Shovellers were much tamer than other speeies of dneks, sometimes allowing approach to within twenty or.thirty yads. They do not gather into large flocks consisting purely of their own kind, but both forage and travel in pairs or small companies, often associating with other speeies of dueks.

As is evidenced by the character of the bill the Shoveller obtains much of its food by skimming the water. The comb-like fringes along the edges of the sensitive upper mandible, sometimes called lamellae, are especially well dereloped and enable the bird by skimming the surfaee to strain out plants and animals of very small size. The birds can often be seen swimming with their heads partially submerged, "gabbling" or sifting the water as they go, and seldom raising the head mless some large object is captured. In addition to the insect food obtained on the surface of the water, the Shoveller feeds on aquatic plants, grasses, and seeds whieh it procures in the mud near shore. At Owens Lake, Inyo Comnty, Nelson (in A. K. Fisher, 1893a, p. 17) found the Shoveller feeding extensively on the larvae and pupae of a small fly (Ephydra hians) which abounded at the time in the lake.

As a general rule this duck does not aequire much fat. When it does, however, it makes as fine a table bird as exists in the state, and by some is even considered superior to the Mallard. Its food insures a good flavor as a rule, and the birds are usually niee and juiey at least at the begimning of the hunting season. As the season advances it is said to beeome somewhat poorer in flesh and in flavor. Its small 
size is one of the things that rates it as a second-elass duck on the markets.

The Shoveller falls an easy prey to the market hunter, for it comes readily to deeoys and is not so wary as most other speeies. In most parts of the state, it is always to be seen in any good bag and rery often is the principal species represented. Two transfer companies in San Franciseo which recorded the number of Shovellers sold during the season 1910-1911, disposed of 5,855 of these ducks. Although considerably reduced during the past few year's, Shoveller's continue to appear in large numbers during the winter season. The toll upon this species taken by the hunter is determined by the supply of more desirable ducks. As the more valuable table ducks become reduced in numbers, the Shoveller tends to rise in popularity.

\section{Pintail}

\section{Dafila acuta (Limnaeus)}

OTHER NAMEs-Sprig; Sprigtail; Dafila caudacuta.

Description-Adult male: Head hister brown, larkest on top, each feather. black centrally with pale tip, the whole giving a faintly sealed apjearance; a similar but more finely sealed effect on cheeks and throat; feathers of hind neck black, washed with metallic green and separated from brown of bead on either sisle by a conspicuous white stripe which extends upwarl and forward from white of breast; feathers on sides of hind neck washef with metallic pink: iris dark brown; bill blackish gray on "ulmen, nail and lower manclible, lead color at sides; upper surface and side of bolly with fine irregular, wavy bars of black and white; longer seapulars velvety black erlgerl with ashy white; rmm nearly miform ashy brown; upper tail roverts blackish hown, elged with white, lateral ones having outer webs deep black; tail feathers blackish brown edgen with white, the central elongated ones black; outer surface of closel wing clear brownish gray: primary flight feathers larker brownish gray; tertials long and black, broally eilged with ashy gray: speculum iridescent, varying from green to bronzy furple at afferent angles; speeulum edged in front by a har of pale rusty brow, behind by a har of hlack followerl by a bar of white, and above by a broal band of hlack; unier surface of wing grayish brown; axillars dull white, finely mottled with ilusky; under surface of horly pure white save for belly which is faintly and dully harrefl with dusky; lower surface often discolored with rusty; a conspicuous white patch at base of tail on each sisle; muler tail coverts hlark, the outermost ones outwarlly elged with white; feet olive gray, lusky at joints. Total length " $26.00-30.00 \%$, inches (660-762 $\mathrm{mm}$.$) (Rilgway, 1900, p. 97); folılerl$ wing 10.30-10.80 (262-274); bill along enlmen 1.93-2.16 (49.0-54.8); tarsus 1.59-1.74 (40.3-44.2) (ten specimens). Adult female: Top of hear reddish brown, narrowly streaked with black; sides of heal and whole nerk lighter buffy brown and more finely streaked with hlack; whin and throat white; rest of upper surface and sides, dark brown, each feather marked with U-shaperl bars of light reldish hrown anil with whitish marks on outer margin; uljer tail coverts more broally erged with white: tail feathers dark brown irregularly harrel with light rusty brown: wing as in male except that 
speenlum is dull brown, showing hut faint green or pmple reflections, ant with bars of color adjoining speculum less contrasted; tertials and scapulars dull brown, like flight feathers; under surface of wing and axillars as in male; unler surface of body dingy white, often stained with rusty; feathers of foreneck with U-shaped hrown markings and those of rest of under surface with grayisl eenters, giving a more or less mottled aplearance; muler tail coverts white with browuish centers. Total length " $21.00-23.50$ ', inches (.533-597 mm.) (Ridgway, lor. eit.) ; folded wing 9.64-10.42 (24t-265); bill along culmen $1.83-1.96$ (46.5-49.5); tarsus $1.56-1.67$ (39.6-42.4) (ten sperimens); all from California. Juvenile plumage: "Young male, similar to the female, hut markings on upper parts more bar-like, and lower parta sometiues nearly wholly streaked", (Bairl, Brewer and Rilgway, 185t, 1, p. 512). Natal plumage: Top of heasl brown, palest on forehead; stripe over eye, lower part of cheek, and chin, dull white: strije hehind eve running around back of hearl, and patch on ear region, light hrown; neck white save for narrow brown stripe hown hind neek; rest of upjer surface light brown; streak down side of baek, and large patch aeross end of wing, white; under surface of boly white, tinged more or less with brownish.

MARKS FOR FIELD IDENTIFICATION-Large size (at least as to length), warrow hear and long slender neck. The long central tail feathers, dark brown head with white neek stripes, and white uniler surface easily identify the male.

VoIce-Of male: a lourl qua, qua, uttererl in flight; also a mellow whistle. Of female: a hoarse muffled quack; and several low notes (authors).

NEST-ITsually in tall grass on dry ground hut near water: a crulle structure of dry grasses lined witlı lown.

EgGs-; to 12, ordinarily 6 to 8 , elongate ovate in shape. measuring in inches. 2.06 to 2.26 by 1.39 to 1.59 (in millimeters, 52.3 to 57.4 by 35.3 to 40.3 ), and averaging $2.18 \mathrm{lyy} 1.51$ (55.4 by 38.3$)$; in color dull grayish olive or pale olive green, often liscolores with clay-toned markings (Grinuell, 1900, p. 15; and authors).

Gexeral distributiox-Northern Hemispllere. In North Ameriea breeis from Aretic Coast of Alaska to Keewatin, and south to southern California, northern Nebraska and northern llinois; wintej's from southern British Columbia, Nevada, southern Wisconsin, southern Ohio and Delaware, south to Porto Rieo and Panama, and in Hawaii (morified from A. O. U. Check-list, 1910, P. 73 ).

Distribution in CALIFORNia-Common winter visitant throughout the state, but more abundant in the southern portion. Migrants from the north begin to arrive in September and usually leave in March. An inhabitant of fresh water and found but rarely in salt water situations. Small numbers remain throughout the summer and breed in suitable localities; the following are the only definite records of nesting known to the writers: Pennington, Sutter County (H. C. Bryant, 1914e, p. 223); Hayward, Alameda County (Mailliari coll.); Los Baños, Merced County (H. C. Bryant, 1914e, p. 220; Carriger eoll.); Tulare Lake, Kings County (Goldman, 1908b, p. 202); Buena Tista Lake, Kern County (Linton, 1908a, p. 50); Los Angeles (Davie, 1859, p. 66); Alamitos, Los Angeles County (Cooke, 1906, p. 38); Bear Lake, San Bernardino County (Willett, $1912 a$, P. 24); and San Jacinto Lake, Riversile County (Willett and Jay, 1911, 1. 158).

The Pintail or Sprig is usually one of the commonest ducks in the hunter's bag and it is always to be found on the market during 
the open season. Even during the severest winter weather this duck is found in numbers on any sizable body of fresh water. Only rarely is it found "rafted" on the bays along the coast. Bailey (1902, p. 55) states that at Point Reyes large flocks of Pintails were seen by J. A. Loring lying out in the bay. As soon as the tide covered the salt grass flats the Pintails would follow in and commence feeding. Pintails in the north begin to move south in August. but they do not appear in great numbers in California until well along in September, and the full quota does not arrive until the latter part of Oetober. By the end of March most of the migrants have left for the north.

Whether resting on the water or in flight the Pintail may be recognized by its considerable size and by its slender head and long, graceful neek. If it is disturbed while feeding in the grass its long neck stretehed almost straight upward is an easy mark of identification. The long middle tail feathers,

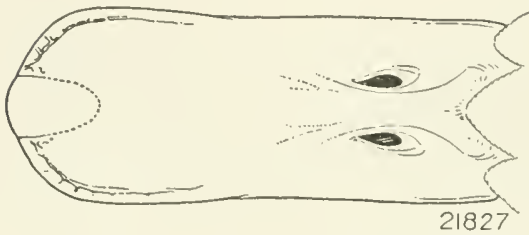

Fig. 19. Top of bill of female Pintail. Natural size.

Note breadth as compared with bill of female Gadwall (fig. 12). dark brown head, white stripe on neek, pale rusty wing bar and pure white under surface are excellent distinguishing charaeters in the male (pl. 3). The female, although much like the female Mallard, is readily distinguished by her slender form, dull brownish speculum, more pointed tail, and long neck. (See also figs. 19 and 10.) The mellow whistle of the drake and the hoarse muffled "quaek" of the duek are so rarely given that the voice is seldom useful for field identification. According to Brooks (1899a, p. 19) the note of the male, generally heard only in spring, is a soft rolling whistle, exactly like that of the Green-winged Teal, but in a lower key. The same author says that while feeding with Mallards, Widgeon or Teal, the Pintail does not turn tail uppermost as these dueks do, its longer neek ordinarily enabling it to reach the bottom when sitting flat on the water. The eye of this duck is smaller in proportion than that of any other surface-feeding duck exeept the Shoveller. 'The habit of "slanting in" to a pond with wings set, is a field mark used by almost every hunter.

Although the favorite breeding grounds of the Pintail lie far to the north of California, yet some individuals of this species remain and breed within the state. It is one of the earliest of our ducks to breed, for usually it lays its five to twelve eggs in late April or early May. A set of eight eggs, partly inenbated, was collected by Wr. O. Emerson near Hayward, Alameda County, as early as April 
18 (1909) (Mailliard coll.), and from a set of eight collected April 21, 1916, on the Alvarado marshes, seven were hatched on April 26 (Dirks, MS). Willett amd Jay (1911, p. 158) record laving seen a female with young at San Jacinto Lake, Riverside County, on May 2s, 1911, and Linton (1908c, p. 197) records a brood as hatehing on June 4, 1908, at Buena Vista lake, Kern County. Gollman (1908b, p. 202) found the Pintail the commonest breeding duek in the vicinity of Tulare Lake in 1907. A female shot there June 21 contained an egg leady to be laid. On the same date several adults with young large enough to make short Hights were seen.

The following deseription of mating bohavior as observed in Mlaska is given by Nelson (1857. p. 70) :

On May 17, while sitting overlooking a series of small ponds, a pair of Pintails arose and started off, the male in full chase after the female. Back and fortl they passel at a marvelously swift rate of speerl, with frequent quick turns and evolutions. At one moment they were almost out of view high overhearl, and the next saw them skimming along the gromul in an involved course very diflivult to follow with the eye. Ere long a second male joined in the chase, then a third, and so on until six males ried with each other in the pursuit. The original pursuer appeared to be the only one capable of keeping rlose to the eoy female, and owing to her dextrous tums and curves he was able to draw near only at intervals. Whenever he did suceed he always passed under the female, and kept so elose to her that their wings elattered together with a noise like a watchman's rattle, and aulible a long distanee. The ehase lasted half an hour, and after five of the pursuers had dropped off one by one the pair remaining (and I think the male was the same that originated the pursuit) settled in one of the ponds.

The nest is nearly always placed on dry gromd, more often near the edge of a pond or lake, but oceasionally at some distance from water. The nest itself is seldom more than a hollow in the ground scantily lined with a mixture of dry grass and down, and is ordinarily not so well concealed as the nests of other ducks. In Alaska bodies of water with a broad margin of marsh grass are usually selected as the rendezvous for the future brood. In the Kowak Delta, Pintail's nests were found far ont on the bare, mossy tundra, in two cases fully 400 yards from the nearest pond (Grinmell, 1900, p. 14). The first brood of downy young in this locality was noted June 23.

The eggs are pale olive green or dull gravish olive in color and vary in shape from ovate to elongate ovate. They measure, in inehes, 2.06 to 2.26 by 1.39 to 1.59 , and average 2.18 by 1.51 . They are similar to the eggs of the Mallard in color but are smaller, more elongated and a little more glossy. Davie (1889, p. 67) states that in the far north as many as twelve eggs are to be found in a single nest, but six or eight seems to be nearer the average number. It is also 
stated that if the eggs are taken, the bird will immediately deposit a seeond set which is seldom more than five or six in number.

"As the young are hatehed they are led to the small creeks and rivulets, where the birds remain until the young take wing, after whieh all pass to the great marshes, where they grow fat feeding upon the roots of the horsetails (Equisetmm)" (Nelson, 1887, p. 70). The young take wing early in Angust, before those of any of the other species. Grimnell (1900, p. 15) says of a female with a brood of downy young which he found at the edge of a pond in northern Alaska: "The old bird tumbled away through the grass in frantic efforts to distraet my attention, [while] the brood of young with one accord scurried aeross the water to a small islet, and in a moment were scattered through the short grass and completely hidden from view."

Cones $(1874$, p. 562) found the males mable to fly during the molt in July in the northern parts of Montana. Nany were killed with stieks or captured by hand at this time. Brooks (1899a. p. 19) says that like the Shoveller, the male Pintails seldom get into really perfect plumage before Jamuary, the bulk of the males shot in the fall being in "female" (eelipse) plumage or changing, with the long central tail feather's not yet developed. Old females sometimes acquire tails of considerable length. Their plumage then partakes a good deal of the eharaeter of that of the males, the mnder parts being spotless and the upper surface having a gool deal of whitish fleeking.

Cones (1874, p. 563) says that hybrids of this speeies with the Mallard are of eomparatively frequent ocenrence and that in at least one instanee sueh hybrids have proved fertile intrr so. There is a stuffed speeimen of a lyybrid of this origin colleeted at Los Baños, Mereed County, and now in the Los Baños Hotel.

Pintails fly very fast, at a great height, and usually in T-formation. When "slanting in" to a pond, the distinct noise mare by the wings ean be heard at quite a distance. The habit of sailing long distanees with wings set and curved downwards is a notable characteristie of the speeies. The birds gather in flocks of as many as fifty individuals, and when flushed erowd close together thus offering good "pot shots." 'They spend much time on shore preening their feathers. On the water they sit high and are graeeful swimmers. While the Pintail does not resort to diving as a method of seenring food. it will when wounded in such a way that the wings aro uscless, submerge itself readily and travel beneath the surface of the water for a long distance.

The food of the Pintail is largely regetable. Beek (MSS) speaks of this duck as feeding on snails and weed and grass seeds at Los 
Baños. Mrepeed ('omity, during the winter of 1911. Jike the Mallared, l'intails glean in the grain fields, and in the midelle west they feed lalregely on wild ricr. In Alaska, Grimell (1900, p. 1t) reeords them as feeding exchusively in the fall on the seeds of a kind of grass which borlereel the slonghs and ponds; and Baird, Brewer and Rirlgray (1Sst, I, p. j1t) state that they feed on the roots of the horsetail rush.

As a table Anck the P'intail ranks with the Mallard and ('anvasback, both as regards size and Havor. Consequently it is widely sought after. A wary birel, flying ligh and with great speed, this speeies makes an icleal game bird. It is a favorite not only with the hunter who shoots over decoys but with the pass shooter as well. [n southern California it is often eonsidered the "best " bird. for rery soon after the opruing of the season it is in prime eontition. This is ane to the fact that immediately mon their arrival from the north the hirds resort at night to the stubble fields and soon lereme grain-fattenerl. A crain and seed eater by choice, the sprig is uniformly fat and delieious. Certain sportsmen adrocate allowing drawn birds to hang for several days before cooking. The concensus of opinion among epicures is that young drakes are superior to roung ducks. The former can be selected from the bag by the mottled color of their plumage and becanse the pin-feathers are just bursting out into the ragged pateles of their winter color (Hedderly. 1912a, p. 490). Belding (MS') alone, considers it an inferior table duck. He says that its Hesh often has an arthy taste aecuired by feeding in mukldy ponds. This may be true locally.

The numbers of Pintails sold in the market (over 40,000 in San Franciseo alone in 1910-1911) sugrgests that this is one of the species which eammot long exist in numbers if something is not done at once to conserve the breeding stock. Sportsmen have noted a distinct decrease in its numbers luring the past ten years. In spite of the faet that most of the Pintails killed breed ontsicle of the state, yet the fact that there is a constant dimimution of its numbers from year to year sliows that the hreeding stoek of the north is being seriously depleted. Te believe that the report of relatively large numbers of Pintails from some loealities in late years is due to the disproportionately greater rate of reduction of one or two other species more popular with the sportsman. Our three best table dueks, the Mallard, Canvastuack and Pintail, are all regularly diminishing in numbers and their survival as game birds ean only be assured by a more rigid protertion than they now receive, to the end that the annual toll taken in hunting and the normal rate of reprodnction may strike a somewhat closer balance. 


\section{Wood Duck}

\section{Aix sponsa (Linnaeus)}

OTHER NAME-Summer Duck.

Description-Adult male: Top of head and front of crest metallic green; tip of crest metallic violet; cheeks black tinged with violet; region around eye and base of crest metallic reddish purple; chin, throat and foreneck, pure white, from which area two crescentic bars of the same color extend upwards on each side, one onto side of head just behind eye, the other onto hind neck; a narrow white line on each side of forehead extends from base of bill back over eye along each side of crown to tip of crest; a similar stripe begins a short distance behind eye and extends along lower edge of crest to its tip; iris "bright orange red"'; eyelids "deep vermillion" (Baird, Brewer and Ridgway, 1884, II, p. 12); bill pinkish white, lake red at base; ridge, tip and lower mandible, black; upper surface of body sooty brown, lustrous with bronzy green, most vivid on rump and tail; a vertical crescent of enlarged black and white feathers in front of wing; outer surface of closed wing dark brown with more or less steel blue iridescence particularly on greater and middle coverts, these latter also narrowly tipped with black; flight feathers slaty brown with exposed inner webs steel blue and outer webs becoming silvery gray toward tips; feathers of speculum steel blue narrowly tipped with white, bordered ahove by a broad black band which pertains to the much expanded innermost secondaries and scapulars; lining of wing and axillars irregularly barred with brown and white; sides and flanks pale buff, minutely undulated (eross-barred) with black; terminal feathers of flank expanded at tips, and marked with conspicuous bars of black and white; breast rich purplish chestnut, the forepart with a purple gloss, and marked with arrowpoints of white; rest of under surface pure white; a patch of metallic purple on each side at base of tail; lateral upper tail coverts marked with narrow central stripes of light brown; under surface of tail and lower tail coverts dark brown, the latter with iridescent green toward tips; legs and feet orange brown, webs olive black, nails black. Total length " $19.00-20.50$ ", inches (482-520 mm.) (Ridgway, 1900, p. 99); folder wing 8.75-9.40 (222-238); bill along culmen 1.28-1.50 (32.5-38.1); tarsus 1.34-1.44 (34.0-36.5) (three specimens from California and Oregon). Folded wing 8.05 (204); culmen 1.27 (32.2); tarsus 1.38 (35.0) (inmature male no. 3739 Mailliard coll.). Adult female: Top of head and small erest dark gray, glossed with metallic violet; sides of head and whole neck ashy gray; chin and throat white; a white ring around eye, continuous with a white patch behind eye; eyelids yellow: bill "dark lear color," nail "black" (Sanford, Bishop and Van Dyke, 1903, p. 114); back, rump and upper tail coverts brown, slightly glossed with bronze and reddish purple; tail brown, glossed with greenish bronze; outer surface of closed wing as in male but secondaries more widely tipped with white, and the four upper greater coverts rich metallic reddish purple, more bluish toward the centers, bronzy toward edges, and narrowly tipped with velvety black; fore breast dark brown, each feather with a shaft streak of brownish white; sides and flanks brown; rest of uniler surface white, the feathers centererl coarsely with light brown or whitish; legs and feet "yellowish brown" (Baird, Brewer and Ridgway, loc. cit.). Total length " $17.00-19.50$ " inches (432-495 mm.) (Ridgway, loc. eit.); folded wing 8.35-8.90 (212-226); bill along culmen 1.15-1.30 (29.2-33.0); tarsus 1.25-1.52 (31.7-38.6) (three specimens 
from California). Jucenile plumage: Top of head lark hrown: stripe over eye, eyelil, and area between bill and eye, dull white; sile of heall otherwise brown; chin, throat and foreneek, white; upper surface of louly brown; forepart of breast mottled with yellowish brown and lark brown; rest of unler surface dull white, mottled with lusky feather centers. Natal plumage: Top of head (from base of bill), hind neck and whole upjer surface of boly, brown, palest on foreheal and wings; bill (lriel) blackish, nail horn-color, lower mandible yellow; stripe behind eye, side of head, spots at sicle of rmmp and below wing, and whole lower surface of body, dull yellowish white; feet (dried) blackish.

MARKS FOR FIELD IDENTIFICATION-The most heautiful and lorightly marked American duck. Medium size, consuicuously erested head, mottled breast, and pure white unler surface of hody. Plumage of male variegated, heal and erest green, chin and throat white, creseents in front of wing white and black, spreculum dark blue. Female duller colorel, with conspicuous white eye-ring and stripe behind eye.

Volce-Of male: a wateh-note hoe-čk. rarely utteren. Of female with brool: a low, soft, prolonged pe-te. pe-it. Of lowny young: a mellow pee. pee, pee-e, often and rapilly repeated (Ambulion in Coues, 1874, p11. 572-573).

NEST-In a hollow il a tree usually over or near water, but oceasionally some distance from it: composel of twigrs, grasses and leaves, and lined with down.

EgGs - S to 12, or nore, short elliptical in shape, measuring in inches 2.01 to 2.19 by 1.50 to 1.61 ( in millimeters, 51.0 to 55.5 by 39.0 to 41.0 ), anil averaging 2.05 by 1.59 (52.0 by 40.0) (twenty-nine eggs in U. S. National Mruseum); in color ereany white, with a glossy surface; nore globular than those of most other ducks.

General Distribetion-Temperate North America. Breeds from southern British Columbia, central Saskatchewan, northern Ontario, New Brunswick and Nova Scotia south to central Califomia, southern Texas, Florida and Cuba; winters chiefly in the United States, from sontlern British Columbia, Kansas, Indiana, and New Jersey, south to southern California and the Gulf

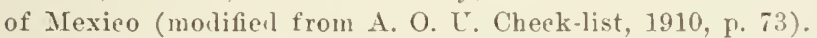

Distribution IN CALIFORNiA-Resident in suitable localities throughout the state but ehiefly in cential and northern portions. Formerly common and widely distributed west of the Sierras, but now rare anywhere in its range. A few adilional migrants appear in the fall (October). Sonthermmost record station at any season: Ramona, San Diego County (Sharp, 1906, p. 75). The following are all the breeding records known to the writers: Tentura County (Cooke, 1906, p. 40); near Lathrop, San Joaquin County (Wheeler, MS); Forest Lake, San Joaquin County (Sampson, 1901, p. 95); Isleton, Sacramento County (Wheeler in H. R. Taylor, 1897, p. 110); Gallinas Creek, Marin County (Mailliard, MS); Lake Tahoe (Ray, 1901, p. 116).

It is universally accepted that the Wood Duck is the handsomest of all the American ducks. Its near relative, the Mandarin Duck of Asia, is its only near competitor for honors, and so far as brilliancy of coloration is concerned even that species must be given second place. The Wood Duck's habit of making special display of its bright colors but adds to its ever evident beauty and grace when on the water. 
This species is found only in temperate North America and indeed is more nearly restricted to the United States than any other single duck. There is but one instance of its oceurrence in Mexico (at Mazatlan). In California the Wood Duek was formerly well distributed throughout the low country west of the Sierras. Now it is a rare local resident of the Sacramento and San Joaquin valleys and westward to the coast, frequenting the secluded, slow-flowing, timber bordered streams and fresh water sloughs, especially in the oak belt. Although permanently resident within the state the speeies appears to be to a slight extent migratory, moving toward the north in April and southward in October. It is rare in southern California where conditions favoring its existence are now lacking. The southernmost reeord station for any season is Ramona, San Diego County.

So conspicuously and distinetively colored is the male of this duck that field marks are scarcely necessary, even for the novice. The green crested head relieved by white stripes, the pure white under surface and chin, the chestnut colored breast, and blue speculum, easily identify the male. Although lacking the bright coloration of her mate, the female displays more color than the females of most other species: in addition she can be recognized by the white eye-ring and streak behind the eye.

Wood Ducks seldom stray away from the secluded, wooded streams and sloughs which constitute their habitat. "A mossy $\log$ in a pond is a farorite resting place for the dueks, but as you walk through the woods in spring a pair will often fly from a branch overhead, uttering their shrill, plaintive ery as they dart through the trees" (Bailey, 1902 , pp. 55-56).

Writing of his observations in Massachusetts, C. W. Townsend (1916, pp. 15-16) says:

The courtship of the Wood Duck (Aix sponsa) is a pretty sight. The gorgeously colored drake swims close to his modest little wife who is dresserl in quaker gray and wears large white spectacles. If she swims too fast for him he is apt to touch her head with his bill, and when she stops he jerks his hearl up and down in an abbreriated bow. At the same time he whistles in a low sweet way as if he were drawing in rather than blowing out his breath. The feathers of his erest and head are at the same time erecterl.

Most ducks nest on the ground, but this species selects hollows in trees which may be either living or dead. Often the nest is situated orer water but sometimes is at a considerable distance from it. Oceasionally the entrance to the nesting cavity is forty or fifty feet above the ground, and the nest itself may be several feet below the entrance to the hollow. Twios, grass and leaves are used as building materials, with down feathers for lining. The hollow end of a broken-off branch is said to be frequentiy selected, and oceasionally nse is made of a 
desereted woodpectier's nest enlarged through decay. Sampson (1901. p. 95) found a Wood Duek's nest loeated in the deserterl home of a Red-shafted Flicker abont twenty-five feet above the ground in a valley oak tree at Forest Lake, San Joaquin ('ounty, April 29, 1900. The nest contained twenty-one eggs. A difference in size and coloriltion was noticeable in these eggs. so that it semens probable that the set had been laid by two females.

Messirs. Wheeler and sampson fomm a set of fifteen eggs of this speeies in 1896 at a point on the San Joaquin River a short distanee above Lathrop, San .Joaquin Compy. The nest was in a hollow tree close to the overtlow from the river, and the tree was infested with ants, which, however, did not appear to have in any degree disturbed the ducks. Wheeler (in H. R. Taylor, 1897, p. 110) lias also reported the nesting of a parr of Wood Ducks in a harn on the Sacramento River. near Isleton, Sacramento County. The birds entered the barn through a hole in the boards and built their nest in the hay. The farmer who owned the hay guarded the nest and allowed the eggs to hateh.

Mr. Joseph Mailliard tells us of having found in 1872 or 1873 a nest of the Wood Duek in a hole in a dead tree on the bank of Gallinas Creek, Marin County. One of the parents was frightened from the nesting eavity. The nest contained not less than pight eggs, though no aceurate record was kept of the cireumstances.

This duck returns to the same nesting site year after year. Incubation lasts for a period of four weeks. The female alone attends to this duty, the male usually being found standing gnard on a near-by limb. Some oloservers say that the male deserts the female during this period. The roung either tumble out of the nest and are led to water, or are carried to the water one hy one in the bill of the mother (Sandr's, 1902, pp. 166-167; and others).

We have no good general aeeonnt of the habits of the Wood Duek since the days of the famous naturalist-artist. Audubon. Writing of observations made in the southern states he says:

No sooner has the female completed her set of eggs than she is abanilonerl by her mate. who now joins others, which form themselves into considerable flocks, and thus remain apart until the young are able to fly, when old and roung of both sexes come together, and so remain until the commencement of the next breeding season. In all the nests I have examinerl, I have been rather surprised to find a quantity of feathers belonging to birds of other species, even those of the domestic fowl, and particularly the Wild Goose and Will Turkey. On coming upon a nest with eggs when the birl was absent in search of fool, $T$ have always found the eggs corered over with feathers and down, although quite out of sight, in the depth of a . . hole. ... If the nest is placerl immediately over the water, the young, the moment they are hatched. scramble to the mouth of the hole, launch into the air with 
their little wings and feet spread out, and drop into their favourite element; but whenever their birth-place is at some distance from it, the mother carries them to it one by one in her bill... On several oceasions, however, when the hole was thirty... or more yards from... water, I observed that the mother suffered the young to fall on the grasses and dried leaves beneath the tree, and afterwards led them directly to the nearest edge of the next pool or creek (Audubon, 1843, VI, p. 273).

"The Wood Duek is eonspienous for the swiftness. ease and elegance of its flight. It can pass throngh woods, and among the branches of trees, with as much facility as the Wild Pigeon. While flying it is rarely ever heard to utter any ery" (Baird, Brewer and Ridgway, 1884, II, p. 14). This speeies is to be found in pairs or at most in small flocks.

The Wood Dnek does not limit itself to the aquatic insects and plants found along the stream near its regular abode, but often forages about the woods in seareh of other food. Belding (MS) says that on the Feather River he found it feeding in eorn and wheat fields after harvest and also on wild grapes and acorns. J. Mailliard saw quite a number feeding on aeorns at Paieines, San Benito County. Oetober 13, 1900. The stomach of a female taken near Laytonville, Mendoeino County, in November, 1913, contained a large number of aeorns, as also that of one taken near Santa Rosa, Sonoma County. Aeorns would appear therefore to form a very general artiele in its diet. Stomachs of eastern Wood Ducks examined by the United States Biological Survey (NeAtee, 1911b, p. 1) showed that over fifteen per cent of the food is made up of wild riee and eelery and over six per cent of pondweeds.

At the present time the Wood Duek exists in such small numbers that it should not properly be eonsidered a game bird of the state. Yet, as its flesh is deelared to be delieions, and sinee it has proven itself readily domestieated, there secms no good reason why it cannot be raised in eaptivity as a commercial proposition and sold on the market. At present there is a brisk demand from breeders and pleasure parks for this, the handsomest of the truek tribe.

Early writers report the Wood Duck as common in California. C. H. Townsend (1887, p. 194) says that it was ohserved on the lower MeCloud River at various times from Oetober 1 until Mareh 1, often in quite large eompanies, and was seen in April and May at Red Bluff, where it frequented the slonghs in the timber belts along the Sacramento River. Heermann $(1859$, p. 68) gives it as "abundant, hreeding in the hollow trees bordering the streams of California." .T. Mailliard (1911, p. 49) says that as late as twenty-five years ago it was no uneommon thing to see Wood Dueks seattered in small groups along such a stream as the Paper Mill or Lagunitas Creek, 
Marin County, or anywhere along Laguna de Santa Rosa, Sonoma County, even where quite a number of people lived in the vicinity and where there was a good deal of travel along the streams. Often the ducks were found in small tributaries and dimimutive ponds along these waterways. The last one killed in this ricinity was taken on Oetober 23, 1898. Mr. A. Jackson reports that a limit of Wood Ducks could often be obtained fifteen years ago along the Napa River, but that now not a single Woor Duck is to be seen there.

George Neale reports (October 1, 1914) that he used to hunt Wood Dueks on Elk Slough, Yolo County, where he has bagged thirty or forty in an afternoon. A few are still to be found there. W. W. Richards states (October 15, 1913) that Wood Ducks were formerly common on Sherman Island, Sacramento River, where "as many as a hundred" were shot in a single day. 'The last one killed there was shot about 1908. Streator $(1886$, p. 90) records the species as rare near Santa Barbara but says that birds were occasionally met with beyoud the Santa Ynez Mountains about ten miles from that eity.

Practically no Wood Dueks are to be found in these old haunts at the present time. An inclividual is occasionally reported as being seen in the locality above mentioned by Mailliard, and in the vieinity of Gridley, Butte County ; but beyond these, and an oecasional one reported by a collector or market hunter, the species is now almost unknown. Dr. W. F. Badé reports that he saw numbers of Wood Dueks on the Sacramento River on a trip from Tehama to Chieo in 1905. When the same trip was taken in 1911 not more than six were seen. The more recent records of its occurrence are as follows: Ramona, San Diego County, November, 1905 (Sharp, 1906, p. 75) ; Redlands, San Bernardino County, Oetober 2, 1909 (Willett, 1912a, p. 24) ; Banning, Riverside County, April, 1907 (Willett, loc. cit.); Oxmard, Ventura County, November 6, 1905 (Grinnell, 1906b, p. 29) ; Reedley, Fresno County, April, 1910 (Tyler, 1913b, p. 17); Stanislaus County, fall of 1910 (J. Mailliard, 1911, p. 49); Live Oak, Sutter County, November 28, 1914 (specimen in Mus. Vert. Zool.); near Castroville, Monterey County, October 20, 1908 (Silliman, 1915b, p. 207) ; near Laytonville, Mendocino County, November, 1913 (F. C. Clarke, MS). Mr. J. S. Hunter, Assistant, State Fish and Game Commission, has stated to us that whereas this species came to the market in considerable numbers several years ago, not more than two or three have been seen during the past few years. Four hundred and forty Wood Ducks were recorded as sold in the markets of San Franciseo and Los Angeles in the season 1895-1896 (Calif. Fish Comm., 1896, p. 40). The records of sale in the markets of San Franciseo during the season 1910-1911 show a total of six birds. 
From the foregoing evidence it ean be seen that the Woor Duck, although existing in California in considerable numbers in the early lays, is now nearly extinct. A number of the eastern states have found it necessary to give it complete and permanent protection in order to save it. California s's only hope of saving this species is to do likewise. Although the Wood Duek is migratory in most states, it remains with us throughout the year and so gives us an added responsibility. The federal regulations regarding migratory birds which went into effect in the fall of 1913 placed a elosed season of five years on the Wood Duck. At the end of this period a renewal of total proteetion will be necessary.

\section{Redhead}

\section{Marila americana. (Eyton)}

OTHER NAMES-Red-headed Duck; Pochard; Aythya amcricana: Aythya erythroccphala; Nyroea americana; Nyroea ferina; Nyroea erythroeephala; Fuligula ferina americana.

DESCRIPTION-Adult male: Whole head anil upper neck rich reddish chestnut, glossed with reddish purple; bill bluish gray, nail black; iris lemon yellow; lower neck and forepart of upper surface of body, black; rest of back and rump ashy brown; middle of back finely cross-barred with dull white; upper tail coverts and tail lull black, facling into dull white at tip of tail; outer surface of elosed wing lead gray; seapulars vermieulated with irregular white and black bars, those of black widest; flight feathers slate gray; speculum pale bluish gray, borlered behind narrowly with white, the three upper feathers elgel with black on onter webs; axillars pure white; rest of uniler surface of wing gray; lower neck and breast blackish, with ashy featherellgings giving a mottled appearance; forepart of belly pure white; sides, flanks and hinder portion of belly, dusky, with white vermicnlations as on scapulars; muler tail coverts blackish brown; legs and feet bluish gray, darker at joints; webs blackish. Total length $19.87-21.00$ inches (506-533 mm.) (three specimeus); folded wing 8.50-9.33 (216-237); bill along culmen 1.89-2.05 (48.0-52.0): tarsns 1.61-1.66 (40.8-42.2) (four specimens). Adult female: Top of head and whole upper surface, brown, larkest on crown; sides of head and area at base of bill, much lighter in tone; chin white; bill lead color, tip black: upper tail coverts dusky brown; terminal portion of tail dull white; wing as in male: scapulars like back, lacking vermieulations, but each feather broadly tipper with ashy; breast much as in male but of lighter tone, the feathers being more extensively tipped with redish brown and ashy. Total length (both sexes): “17.00 21.00”, inches (432-533 mm.) (Tidgway, 1900, 1) 101); folitel wing 9.00 (22s); hill along rulmen 1.77 (14.9); tarsus 1.57 (39.S) (one speeimen): all from California. Jucenile plumage: Not kuown to us. Natal plumage: Whole npper surface olive hrown; spot back of hase of each wing, one on hind borter of each wing, ant one on each sille of rump, yellow; silte of hearl and whole lowel surface deel' buff yellow, paler am less rellow behind; no distinet streaks on side of hearl although a buffy line above and below eye is to be noter on rlose inspertion; hill anil feet (driel), light brown. 
MARKS FOR FIELD IDEXTIFICATION-large size, abruptly elevater foreheal and, in the male, relılish hear. 1)istinguished from Canvasback by high instearl of sloping forehearl (see figs. 20 and 21), darker coloration, smaller general size, and yellow iris. Female Relhear can be separated from female Canvasback by the high foreheal, smaller bill (about one-third shorter), and absence of barring on featlers of back; from female Scaup by gray on speeulum ani smaller amount of white aromnıl bill; from female Ring-nerked Duck by larger size (wing $\$ .50$ inches, $216 \mathrm{~mm}$., or more in Redhead) : from female Gollen-eye by absence of white patch on wing.

Torce-Of male: in spring (and rarely in fall) a peculiar quï-quua. Of female a quack of distinctive tone and quality (Eaton, 1910, p. 2033).

Nest-On ground among thiek weeds or grass, or in mishes and over water; ronstructed of weerls, grasses or rushes.

EGGs-10 to 16, oval to elliptical in shape, measuring in inches, 2.30 to 2.58 by 1.67 to 1.73 (in millimeters, 58.5 to 65.5 by 42.5 to 44.0 ), and averaging 2.40 by 1.71 (61.0 by 43.5) (twenty-seven eggs in U. S. National Museum); color greenish drab or light buff.

Gexeral distributios - North America. Breeds from southern British Columbia, eentral Alberta, eentral Saskatchewan and southwestern Keewatin soutl to southern California, southern Sonth Dakota and southern Wisconsin; winters from southern British Columbia, Utah, Kansas, lllinois, and Delaware south to eentral Mexico and Floricla (A. O. U. ('heek-list, 1910, p. 7t).

Distributox IN CALIFORNIA-Fairly common resident in suitable localities throughout the state; more numeroms in winter than in summer anil formerly more abundant than at present. Inhabits both salt and fresh water. Breeding stations known to the writers are as follows: Lower Klamath and Tule lakes, on Oregon line (H. C. Bryant, 1914e, pp. 229, 231); Sacramento Valley (Heermann, 1859, p. 70); Sacramento (Cooper and Ridgway, 1856, p. 403); Alvarado, Alameda County (H. C. Bryant, MS); Buena Vista Lake, Kern County (Linton, 190Sc, p. 197): Tentura County (Evermann, 18\$6, p. S.9); Los Angeles (Davie, 18s9, 1) 65); Nigger Slough, Los Angeles County (Willett, 1912a, 1. 24): San Jacinto Lake, Riversise County (Willet and Jay, 1911, 1\% 158; Ingersoll coll.).

The Redhead, although classed as a typical sea duck, becanse of the large lobe or flap on the hind toe (the presence of which distinguishes the sea ducks from the fresh water ducks), differs from the others of its relatives in that it is chiefly an inhabitant of fresh water. It is, however, found also in considerable numbers on salt water along the sea coast. In early spring numerous Redheads can be seen mixed in with the great numbers of Canvasbacks which dot the shallow waters of San Francisco and San Pablo bays. In the interior it prefers the deeper bodies of fresh water. Althongh most abundant here during the winter months, this is nevertheless a resident species, for a certain proportion remain during the summer and breed in suitable localities thronghout the state.

Like the Cinnamon Teal, the Redhead is essentially sonthern in its distribution. The only record of its occurrence on the Pacific Coast north of Tancouver Island is of a stray taken in 1896 on Kodiak Island, 
Alaska. 'The greater number of Redheads summer in a restricted area in west-eentral Canada. It is less common on the Paeific slope locally from Lae la Maehe, British Columbia, south to southern California ( V'entura and Los Angeles comties) and east to Ruby Lake, Nevada, and Rush Lake, Utah. The prineipal winter home of the Redhead extends from Texas, along the Gulf and Atlantic coasts to Chesapeake Bay; a few winter on Long Island, while in the west it winters north to New Mexieo, Arizona, Utah (rarely), Nevada, and southern British Columbia, which is almost as far north as it breeds. The Redhead is not uneommon in winter in the Valley of Mexico, but is quite rare on the west eoast of Mexico where it has been found south to Manzanillo and southern Lower California (Cooke, 1906, p. 42).

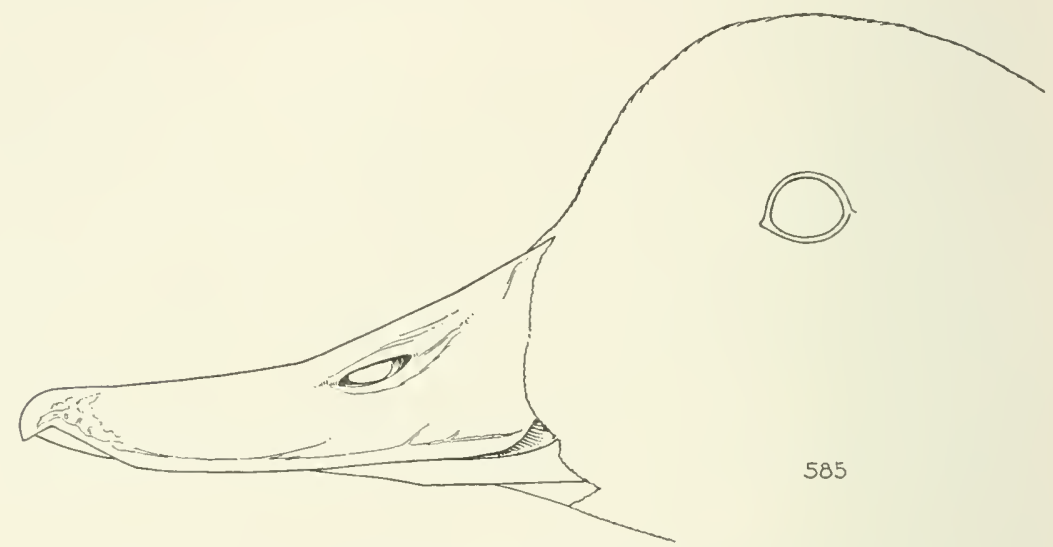

Fig. 20. Side of bill and head of Redhead. Natural size.

Note high forehead. Compare with sloping forehear of Canvasback (fig. 21, p. 153).

The Redhead is very similar in strueture and appearance to the famed Canvasback. The most dependable method of distinguishing the two species is by the profile of the forehead. The Canvasbaek's forehead is low and slopes backward in line with the top of its bill, while the forehead of the Redhead is high and meets the bill at a eonsiderable angle (see figs. 20 and 21). Other characters of the Redhead are the smaller size, yellow instead of red eye, darker color, and higher extension of blaek on the neek. The female Redhead and the Ring-necked Duck are rather easy to confuse, but may be distinguished by the difference in wing length, the Redhead having a folded wing more than 8.50 inehes long while that of the Ring-neek is 8.25 or less in length; also by the former having a relatively broader bill, darker throat, and lighter baek. 'The only other sea dueks with reddish heads are the male Canvasback and the female golden-eyes. 
The female Redhead resembles a female Scaup Duck but has less white on the face and about the bill.

The Redlead breeds in fresh-water marshes, often in company with Mallards and Canrasbacks. In fact it is well known that elsewhere than in California eggs of the latter have been taken in nests of Redheads. The nest is built either on the ground in thick grass or weeds, or in tules or grass above water, and is lined with white down taken from the breast of the female bird. In the former ease it is composed of reeds and grasses, whereas in the latter case it is often built of tules and looks something like a Ind-hen's nest. Bowles (in Dawson, 1909. p. 791) describes the Redhead's nest as being a deep basket of rushes, placed in the thickest sort of growth, cither upon a small muddy island left by the receding water, or built up anong the flags upon the matted dead stems which corer the surfare of the water in farorable places.

Ten to sixteen greenish drab or light buff eggs are laid. "The (ags of the Redhead can gen'rally be distinguisled from those of any other species, as they are usually quite different in color, size and texture. The sleell is extremely hard and flinty, with a smooth, slightly glossy surface, and quite thick: . . I In shape they vary from a somewhat rounden to a considerably elongated elliptical ovate, sometimes nearly oral. . . The eggs are entirely different in color from those of the Canvasback, which builds a somewhat similar nest and in similar situations, but lines it with gray down" (Bent, 1902, p. 9$)$.

Willett and Jay (1911, P. 158) found the Redlead breeding very commonly at San Jaeinto Lake, Riverside County, on May 28, 1911. Four nests found contained respectively, fifteen, seventeen, eighteen and twenty-seven eggs. The last set was undoubtedly the product of two females, as there were seventeen eggs of one type and ten of another. At the same place A. M. Ingersoll took a set of twenty-one eggs advanced in incubation on Jume 7, 1897. Shields (1899, p. 9) found a nest in central California on Juse 25, 1898, containing twelve Redhead eggs and three of the Fulvous 'Tree-duck. A Redhead's nest was found by H. C. Bryant (MS) in some tules at the end of a pond near Alvarado. Alameda County, April 23, 1915. Tall tules had blown over a fence making a dark sheltered nook beneath, and here the nest was placed. Twelve well-incubated eggs and a little whitish down were contained in the nest. The eggs were hatched out at the State Game Farm four days later, and the appearance of the downy young made the identification complete.

The Redhead is so similar to the Canvasback both in coloration and habits that it is often mistaken for it. "Its flight is hurried, the bird rising from the water in a confused manner, but being able 
to continue long on the wing" (Baird, Brewer and Ridgway, 1884, II, p. 39). It travels in $\mathrm{V}$-shaped flocks like geese and flies with great rapidity. A loud whistling or roaring noise is prodneed by the wings in flight.

The Redhead is an expert at diving and gains most of its food in this mammer. It is naturally a deep water species, rarely found along the margins of ponds or streams; yet individuals may occasionally be seen dabbling about in the num of the shallower pools. This duck is said to subsist largely on vegetable food such as the various kinds of aquatic plants; small mollusks, crustaceans, fish, frogs, and water newts are also taken. Where available it feeds extensively on wild celery, eating the blades of the plant when the roots are not obtainable.

As a game duck the Redluead ranks with the Canvasback. Since it has similar food preferences, there is very little choice between the birds for table use. On the markets Redheads when separately specified, are listed as cheaper than "Cans"; but they are commonly sold under the name of the more desirable bird and then, of course, bring the same price.

Redheads have been greatly rednced in numbers drring the past ten years. H. J. Lelande (MS) says of this duck in southern California: "The Redhead, once fairly common during the breeding season, is now seldom seen at any time of the year." Judging from the progressively smaller numbers sold on the market, as well as from direct observation, we are justified in stating that this duck next to the Wood Duck demands absolute protection to save it from the fate of total extermination. The great decrease in its numbers can be partly accounted for by the ease with which it is killed. It is sometimes called "Fool Duck" by sportsmen because of its fearlessness or apparent indifference to their approach. As with the Mallard, we have here a resident duck much hunted for the market. The number of migrants coming in during the winter is small and the annual kill lias depleted the local breeding stock. Hence the Redhead is rapidly decreasing in numbers, and the critical point as regards its survival has already been reached.

\section{Canvasback}

\section{Marila valisineria (Wilson)}

Other xames-Can: Aythya callisneria: Nyroea valisneria: Fuligula rallisneria.

Description-Adult male: Whole heal and neck lark redilish rhestnut, shading to almost black around hase of bill aud on top of hearl; bill black, tinged with green; iris bright carmine: base of neck completely encircled by broarl black collar; back and scapulars white, with fine, irregular, dusky harrings; rump black; upper tail coverts anil tail blackish slate; outer surface 


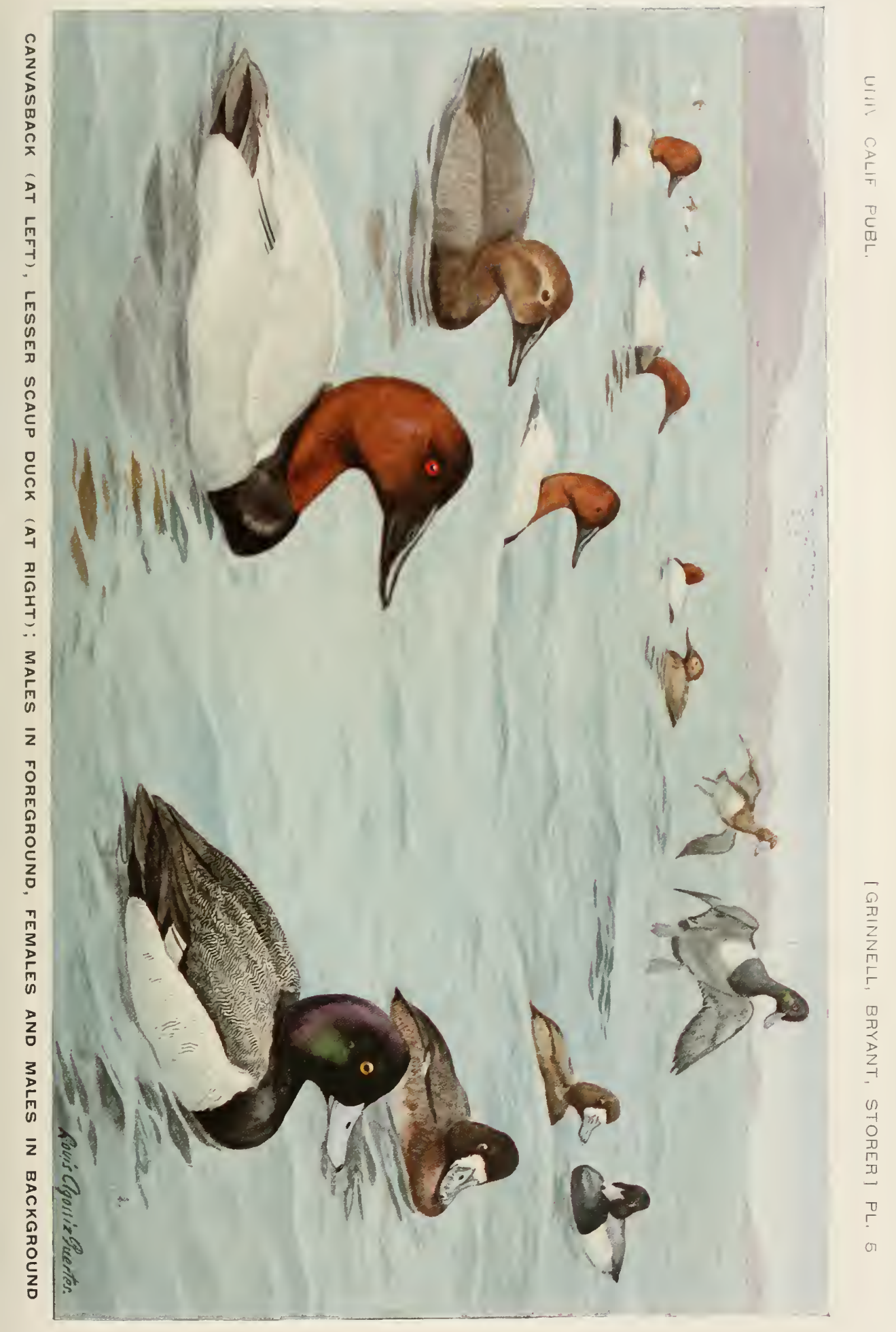



of elosel wing gray, with minute white dots or vermiculations; flight feathers slaty brown; speeulum pale bluish gray borlered hehind by a bar of white, and uppermost two or three feathers narrowly eilged with black; axilars white; lining of wing pale gray; sides, flanks and lielly like back but more nearly white; unler surface otherwise pure white or with faint suggestion of dusky vermiculation; unler tail coverts hlarkish; feet "grevish-blue" tinged with "yellow", (Aululon, 1843, VI, J. 309). Total length (lioth sexes): “20.00-23.50", inehes (507-596 num.) (Ridgway, 1900, p. 102). Males: Folded wing S.9S-9.50 (2.2S-241); bill along culmen $2.36-2.47$ (59.9-62.7); tarsus $1.70-$ 1.81 (43.2-46.1) (four speeimens from California). Ldult frmale: Tearl, neok and breast dull redlish brown, darker on top of hear, aml lighter, almost white, on chin and throat; an indistinct whitish spot behind eye: back and seapulars slaty brown, with traees of white vermiculations; rump blackish; upper tail coverts and tail dusky brown; outer surface of eloserl wing uniform slate gray without vermiculations; flight feathers, speeulum and unier surface of wing as in male; whole under surface of lody dnll white, mottled with grayish brown; siles with meagre white and dusky rermioulations. Folded wing 8.50 (216); bill along eulmen 2.36 (59.9); tarsus 1.64 (41.6) (one speeimen from California). Jurenile plumagr: Like that of arult female. Natal phumage: Top of heal, stripe hown hind nerk, and most of loark, greenish brown; side of head deep straw yellow, washed with dusky; paired spots on back at base of tail, behind wing, and on hinder margin of wing. hright straw yellow; whole lower surface deep yellow.

MARKS FOR FIELD IDENTIFICATION-Large size, reldish brown heal aml neek, canvas-eolored back and low foreheal sloping lown to long slenter bill (see 11. 5 aud figs. 20 amd 21). Distinguished from Rerlhead by larger size, especially of hear, hlackish coloration around base of hill, red iris, and sloping forehead and hill (which meet withont evilent angle between the two).

Torce-Of male: "a peeping or growling note." Of females: a lom quack and, when startled, a screaming nurr-row (Liton, 1910, p. 205).

NEsT-In a elump of reels or tules in a shallow poul or slough but generally near a larger body of water; a large structure of reels or tules well lineil with gray lown (Bent, 1902, pp. 11-12).

EGGS-6 to I0, ovate to elliptical ovate in shape, measuring in inches 2.36 to $2.57 \mathrm{by} 1.68$ to 1.50 (in millimeters, 59.9 to $65.3 \mathrm{by} 42.6$ to 45.7 ), and averaging 2.45 by 1.75 (62.5 by 44.4); color rirh grayish olive or greenish irab (Bent, loc. cit.).

Gexeral distribution-North America. Breels from central British Columbia, Fort Iukon, Great Slave Lake and southwestern Keewatin south to Oregon, northern Nevala, Colorado (rarely), Nebraska anı southern Minnesota; winters from southern British Columbia, Nevata, Colorarlo, Illinois, Pennsylvania and western New Iork, south to eentral Mexico and the Gulf coast (A. O. U. Cheek-list, 1910 , p. 74).

Distribution IN CALIforia-Common winter visitant (Ortober to Mareh) both interiorly and along the searoast. Most numerous about salt water bays and coastal sloughs and marshes, seeming to prefer the deeper waters to the muldy margins. The marshes about San Francisco and San Pablo bays constitute a feeling ground for great numbers of this speries. No lefinite breening records are known for California.

The Canvasback, the far-famed " Can"' of the hunter, is probably the best known of all American ducks, not excepting even the Mallard. 
This reputation has largely been built up in eastern North America where, by reason of its regetable diet and the consequent fine flavor of its flesh, it is very highly prized as a table bird. In California the Canvasback is strictly a migrant, arriving during October and usually departing by the end of March. 'The earliest fall record is from Stockton, San Joaquin County, October 6, 1881 (Belding, MS) ; southern California is usually reached about October 20 (Cooke, 1906, p. 44). Observations made by E. W. Gifford (MS) over a term of years on the arrival and departure of dncks about San Francisco Bay yielded the following dates for Canvasbacks : 1903-1904, last seen April 4; 1904 1905, first seen December 8, last seen May 6; 1906-1907, first seen December 26, last scen April 14; 1907-1908, first seen January 18, last seen April 22; 1908-1909, first seen November 11, last secn April 3; 1909-1910, first seen, October 27, last seen, February 28. Most of the Canvasbacks to be found in California are on the bays and coastal marshes, from which places the bulk of the market supply, which is at a maximum during November and December, is secured.

The close similarity between the Canvasback and the Redhead sometimes leads to confusion in distinguishing these two ducks. No better worded diagnosis is known to us than that of Coues (1874, pp. $575-576)$ :

Some persons experience diffieulty in diseriminating between the Canvasback and Red-head, but there is no accasion for this, at least in the case of males. In the Red-head, the whole head is clear chestnut red, with coppery or bronzy reflections, and the bill is elear pale grayish blue, with a dark tip. In the Canvas-back, nearly all the head is obscured with blackish-brown, and the bill is dusky throughout. There is also a marked difference in the shape of the hearl and bill; in the Red-head, the head is puffy and globose, sloping abruptly down to the base of the bill; in the Canvas-back, the head is longer and narrower, and slopes gradually down to the bill, which rises high on the forehead [pl. 5 and figs. 20 and 21]. These distinctions of form hold with the females, though less evident in that sex. In the Canvas-back, moreover, the back has much more light than dark color, instead of an equal amount, or less, the fine black lines being very narrow aud mostly broken up into minute dots.

Althongh reported as brecting rarely in Oregon and Nevada (Cooke, 1906, p. 43), there is no record of the nesting of this duck within our own state. Brooks (1903, p. 278) records it as breeding commonly in British Cohumbia. He describes the nests as being bulky platforms of reeds, similar to those of Coots, and to be found generally on small swampy ponds, away from the larger lakes where the males associate in flocks. Bent (1902, pp. 11-12), in North Dakota, found the nests of Canvasbacks almost invariably located in isolated chumps of reeds surrounded by water in large, deep sloughs. He deseribes one nest as being built upon a bulky mass of wet dead reeds, measuring eighteen by twenty inches in outside diameter, the rim 
being built up six inches above the water, and the inner cavity being about eight inches across by four deep. It ean be seen, therefore, that the C'anvasback is mlike the Mallard, 'Teal, and other fresh water ducks, in that it chooses growths of reeds rather than grass as locations for nests. Gray down is used to line the nest.

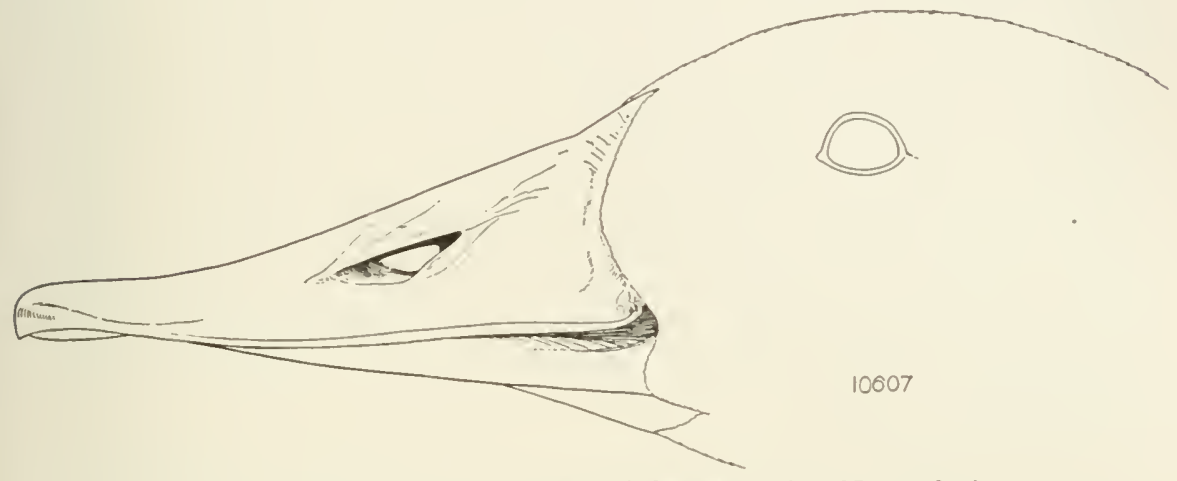

Fig. 21. Side of bill ant heal of Canrasbark. Natural size.

Note low, sloping forehead. Compare with high forcheal of Redhead (fig. 20).

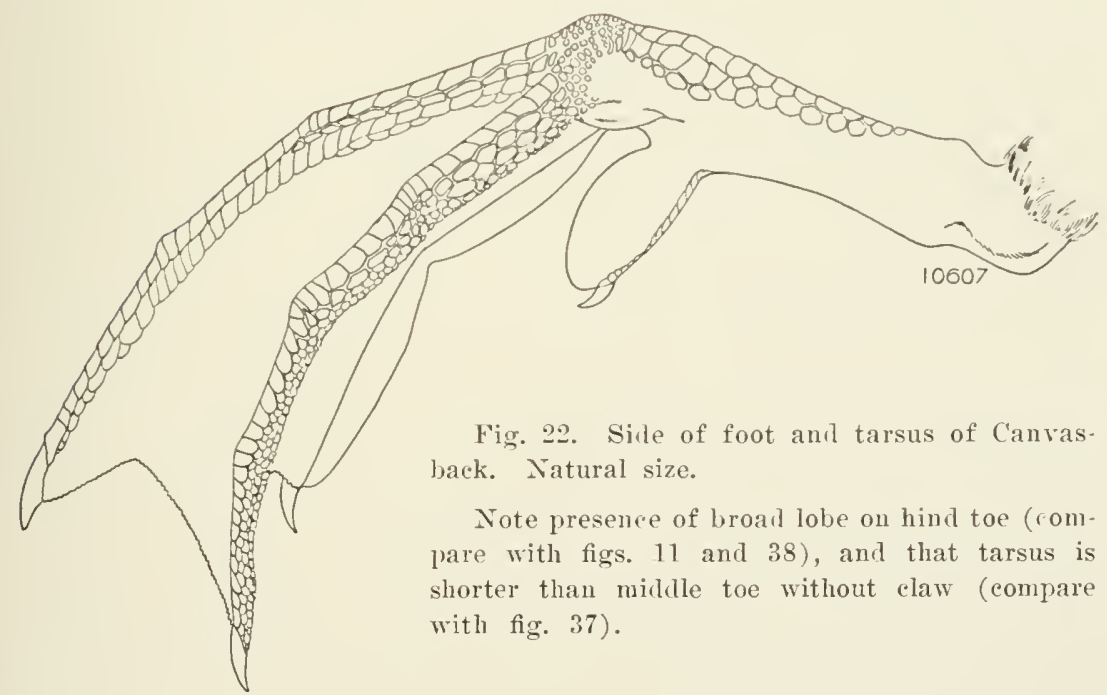

The finding of the cggs of other ducks in the nests of the Canvasback appears to be of common experience. Bent (loc. cit.) found one or more eggs of the Ruddy Duck or of the Redhead in every Canvasback nest examined by him, but did not find the eggs of the Canvas- 
back in the nest of any other species. The eggs number six to ten. They are grayish olive or greenish drab in color, of a darker shade than the eggs of other spceies of ducks, and measure in inches, 2.36 to 2.57 by 1.68 to 1.80 and average 2.48 by 1.75 .

The Canvasback is an exeellent diver, often descending to a deptlı of twenty or thirty feet to obtain its food, and is said to use its wings for propnlsion when beneath the water. This speeies gathers in large flocks on the bays where it slecps during the day on open water, moving nearer the shore when wishing to feed. The Canrasback is a strong, swift flier and makes a lond noise with its wings which is clearly noticeable when a flock passes immediately overhead. The estimated speed of the Canvasback is greater than that of any other duck-130 to 150 feet per second (Askins, 1911, pp. 556-560). When coming to decoys in a pond the birds arrive with a rush of sound like that made by the wind and they settle into the water with great splashing.

Canvasbacks deeoy very readily. On the open water they are usually wary and hard to approach. On the decoy pond, howerer, they are said to be more easily obtained than teal or Mallard. By carefully choosing the last one to dive each time, a whole flock can sometimes be brought to hag. This duck is often hunted not only from blinds on the marshes but also from brush blinds built up over the shallow waters of the bays, and from brush-covered boats semlled near the birds when they are at rest on the open water.

In the east the Canvasbaek feeds almost exelusively on a plant known as Vallisneria, often called wild eelery or eel grass, hence the specific name of the bird-ralisinerit. Stomach examination has shown that over twenty-three per cent of its food is made up of the roots, leaves and seeds of this plant (McAtee, $1911 b$, p. 1). A much larger per cent of pondweels is also taken by this speeies than by any other duck. It is also said to feed on fish, tadpoles. leeches. mollusks, and insects, when these are available. In California the Canrasback partakes of more animal food, for wild eelery does not grow in this state. On the shallow waters of the tidelands and marshes. it feeds extensively on erustaceans and shellfish, thereby aequiring a "fishy" taste and thus beeoming undesirable as a table bird. The stomachs of some Canvasbacks eollected on San Pablo Bay eontained clams ( My ya (remoria), and snails (Odostomia sp.) : one stomach from Tia Jnana slongh, near San Diego, eontained periwinkles (rerithiden crifornica), and mother from the same place eontained grass-blades, stems and roots. A stomach from Guadalupe, San Luis Obispo County, was filled with barley, thele heing twenty-two whole kernels and many hulls; but there is a possibility that this was hat put ont by hunters. 
In the east the Canvasback is the most highly prized of all the ducks: for its habit of feeding on wild celery makes it of prime Havor. Large? because of its eastern reputation it is also eonsidered the best of the game ducks almost everywhere in the west. The hunter with a bag of ('anvasbacks is always the hero of the day. As a matter of fact the west coast Canrasback does not ordinarily surpass the Mallard, and is sometimes less desirable. A few days diet on shellfish makes an inferior table bird of cither duck. When killed in the interior or on momntain lakes, however, the Canvasback is invariably reported to be of fine flavor. Its large size compled with its aristocratic reputation makes it bring the highest price on the market. In early days many were netted by ltalian fishermen and the drowned dueks were sold in the markets for twenty-five cents a pair. In the season of 1910-1911 the price paid by market men of San Franciseo for this duck ranged from four to nine dollars a dozen, averaging about six dollars. The Mallarel brought about the same price. Hecrmann (1559, p. 70) reports having seen a single ('anvasback solel for twrelve dollars in the "boom" times of 1849 .

The Canrasback is a much hunted duck throughout its winter range. On ('hesapeake Bay, Maryland, where it used to congregate in vast numbers it has been deeimated by excessive shooting. Now it seldom appears in any quantity on this borly of water. In California. also, the numbers on onr waters have conspicnonsly dwindled of late vear's. In times past "Cans" were killed in rery large numbers on the Sonoma marshes. There is one record of two hmolred and sixtyeight drake Canvasbacks to a double-barreled gun in one day (Beitch, 1912, p. 13). Occasionally, at the present time, one will hear of a limit $(2.5)$ killed at the rate of a bird a minute, such being reported as recently as 1912. This is the exception, however, though the rarity of the occurrence gives the report such wide circulation that people are led to believe it common.

The numbers appearing in the state vary greatly from year to rear, as this is a bird which shifts its movements according to the abundance of food supply. A common saying among sportsmen is to the effect that every fourth year is a good "Can' year. A typical migrant, passing throngh two states before reaching California, and hunted everympre it goes, the Canrasback is subjected to a considerable depletion in its ranks before retmrning to its northern breeding gromds. The danger of great depletion in the numbers of this species lies in its popularity as a table bird, and in its consequent high market value. Where there is sale of game the rate of destruction for any game species is largely determined by the market demand for it. 


\section{Greater Scaup Duck}

\section{Marila marila (Linnaeus)}

OTHER NAMES-Scaup; Big Black-head; Greater Black-head; Big Blue-bill; Broad-hill; Shuffler; Black-jack, part; Raft Ruck; Aythya marila; Aythya marila nearctica; Fuligula marila; Fulix marila.

DESCRIPTION-Adult male: Whole of head, neek, breast, and fore part of back black; sides of head and neck with metallic green reflections; iris lemon yellow; bill pale bluish gray, nail black; back and scapular region white with zig-zag barrings of black; rump, upper tail coverts and tail dull black; outer surface of elosed wing slate brown mottled sparsely with fine white dots; flight feathers slate brown; speeulum pure white; sides and long feathers of flanks pure white, in some specimens showing faint dusky unlulations; hind part of belly, black; rest of under surface white, faintly unlulated with dusky behind; legs and feet "plumbeous" (lear gray) (Sanford, Bishop and Van Dyke, 1903, p. 134). Total length $18.50-20.00$ inches (470-508 mm.) (Faton, 1910, p. 206); folded wing 8.35-8.95 (212-227); bill along culmen $1.70-1.90$ (43.2-48.3); tarsus 1.50-1.57 (38.1-39.8) (nine sperimens from Alaska and California). Adult female: Whole of head, neck, breast and fore portion of back dusky reddish brown; a dull white area about base of bill; outer scapulars show faint traces of whitish undulations; back, rump, upper tail coverts, and tail, blackish brown; onter surface of closesl wing plain slate brown; flight feathers dusky browu; speculum pure white; sides, flanks, and under tail coverts coarsely mottled with light and dark reddish brown; rest of under surface pure white shading behind into color of under tail coverts. Total length 17.00-18.12 inches (432-460 mm.) (Eaton, loe. cit., and two speeimens from California); folded wing 8.27-8.53 (210-217); bill along culmen 1.64-1.82 (41.6-46.2); tarsus 1.47-1.53 (37.3-38.8) (six specimens from Alaska and California). Juvenile plumage: Similar to that of ardult female, but wing of young male like that of adult male and with head darker than the female. Natal plumage: "Crown, nape [=hind neck], aud upper parts uniform dark olive-brown; throat, sides of the head, and fore part of the neck, rellowish white; a dull grayish band crosses the lower neck, rest of the under parts dull yellowish, the flanks grayish yellow' (Dresser)." (Ridgway, 1900, p. 102).

MARKS FOR FIELD IDENTIFICATION-Medium size, stout build, lark-colored head and neek, broad "blue" bill, conspicuous white speculum, and white under surface. Male Greater Seaul Mistinguished from male Lesser Scaup in hand by larger size, greenish instearl of purplish gloss on hearl, anil by tendency to white on outer webs of innermost primaries. Female Greater Scaup separable from all other ducks (save Lesser Scaup and Ring-neck) by conspicuous white area encireling hase of bill. Female Greater Scaup distinguished from female Lesser Scaup only in hand, by larger size and by tendency to white on outer webs of innermost primaries; from Ring-neck by greater size and by gray instead of white speculum.

TOICE-A soft purring whistle; also, when excited, a loud discordant scaup (Eaton, 1910, p. 206).

NeST-In tall grass on dry ground, usually not far from water; made of grass and weeds, and well lined with down.

EGGS-6 to 11, elongate ovate or elliptical in shape, measuring in inches, 2.26 to 2.70 by 1.69 to 1.73 (in millimeters, 57.5 to 68.5 by 43.0 to 44.0 ), and averaging 2.46 by 1.72 ( 62.5 by 43.5 ) (twenty-seven eggs in U. S. National Museum); in color olive buff (authors). 
Gexeral nistribltox-Northern part of Northern Hemisphere. In North America breeds from northwestern Alaska, Great Slave Lake. and eentral Keewatin south to southern British Columbia and northern North Dakota; winters from Maine to Florida and from the Alentian Islands. Nevarla and Colorado south to southern California and southern Texas (molified from A. O. U. Cheek-list, 1910, p. 75).

DISTRIBLTION IN CALIFORNA - Fairly common winter visitant loeally and irregularly on salt and brackish water along the sea roast. Recoried south to the vicinity of San Diego (Willett, 1912a. 1. 25). Rare inlant, as at Stockton, San Joaquin County, anıl northward in central California (Belıling, 1s79, p. 446; and Belding, MS).

The Scaup Ducks, or Blue-bills, ale among the commonest of the sea ducks. The Greater Scanp, however, is not so plentiful in most parts of the lnited States as is the lesser seaup 1)uck, for the former has a more northerly winter rangr. This statement holds for California, for whereas the Greater Scaup is but oceasionally met with, the Lesser Scaup is found abundanty in winter on all of the coastal hays and marshes, and often in the interior. Doubtless the Greater Scaup is a commoner bird than is indicated hy the comparatively few records; its habit of congregating with the smaller species, from which it differs very slightly except for size, makes it easy to confuse with the latter species. Records of the Greater Scaup in California are limited to the midwinter season save for a single bird taken at Stockton, San Joaquin County, April 1, 1878 (Belding, 1879, p. 446), though there are general statements to the effect that it oceurs from Oetober until April.

The black head with a slaty blue bill, the white belly and mantle, and pure white speenhm, conspicuous in flight, enable one to distinguish the male Greater scaup from all other ducks except the Lesser Scaup. In addition to a considerable difference in size, the Greater Scaup ean be separated from the Lesser by the metallie green reflections on the sides of the head instead of the purplish ones to be found in the Lesser Scaup Duck. The white mask formed by patehes of white abont the base of the bill in the female separates her from all other ducks exeept the female Lesser Seaup and Ring-neeked. Greater size alone is usually suffieient to separate her from either of these two near-related species. In common with the male, her contrastedly dark head, and white belly and speenlum, distinguish her from most other ducks.

The following deseription of the nesting site and nest of the Greater Seaup in Alaska is given by Nelson (1887, p. 71).

The nesting sites chosen are such as the Pintail and most other ducks choose-a dry, grassy tussock or knoll elose to some pond--the only difference being that the present species appears to desire a position nearer water, ... and the nest is frequently at the point of some small jutting cape and so near the water that the parent can swim to and from the nest. The nest is eom- 
posed of grass stems, gathered close at hant, and a large fluffy bed of down plucked from the parent's breast.

Three nests found in the delta of the Kowak River, Alaska, are thus deseribed by Grinnell (1900, p. 15):

The nest was on a high dry hummock, about ten yards from the eilge of a lake. It was almost hidden from view by tall, dead grass of the previous year's growth. The eggs rested on a bed of finely broken grass stems, while the rim of the nest was indicated by a narrow margin of down. This nest contained eleven fresh eggs. A secont set of ten fresh eggs was taken on the same day (June 14, 1899). The nest was similar in eonstruction, but was out on the tundra between two lakes, and fully a quarter of a mile from either. A set of seven fresh eggs taken on the 15th was quite differently situated. The nest was almost withont feathers or down, and consisted of a neat saucer of matted dry grass-blarles, supported among standing marsh grass anil about four inches above the water. It was in a broad marshy swale about thirty feet from a small pond of open water.

The following paragraph provides facts as to the summer habits of the Greater Seaup in the Norton Sound region of Alaska:

The first days of Jume is the time usually chosen for depositing the first eggs, and some are not laid until nearly a month later. On Augnst 16, 1878, several broods of young, from one-half to two-thirds grown, were seen, and on August 30, half-grown young were found in company with the female, whose primaries and secondaries were just starting after her summer moult. In the north as in the sonth these birds show a predilection for the larger boilies of water, and at once after the young are hatched they are marshalled off to the largest pond in the vicinity, so that it is a common occurrence to find a pond with six or eight broods of these ducks united in a large flock, whereas the other fresh water lucks keep in smaller pools and more than a single brood in a pond is the exception (Nelson, 1887, 1). 71).

The eggs of the Greater Scaup Duck, in common with those of its lesser relative, can be easily identified in comparison with those of other ducks, by their darker and rieher color which may be described as rich olive buff (Bent, 1902, p. 165). Sets taken in northern Alaska by the senior anthor are uniform deep olive buff. Twenty-one eggs average in size 2.46 by 1.73 inches.

In flying the Greater Seaup Duek rarely utters any note, but when swimming leisurely about in calm weather it is said to give utteranee to a quick rattling or rolling sound (Baird, Brewer and Ridgway, 1884, II, p. 21). Eaton (1910, p. 206) says that ducks of this species utter a soft purring whistle when excited or when calling to their mates, and rarely the discordant scaup, which when given is screamed out in an exceptionally harsh, coarse voice. He ards: "On two or three occasions I have heard a flock of seaups giring utterance to these notes and the effect was the loudest and most discordant chorms of bird notes to which I ever listened, coming as it did from seores of voices over the silent water." 
1) 1 e to its habit of "rafting," or resting on the water in close flocks during the daytime, this duck has sometimes been termed "Raft Duck." It is a good diver and obtains practically all of its food in this way. When woumded it seeks safety in diving or skulking under overhanging rocks or banks. When a Hock is flushed the birds immediately scatter so that a "pot-shot" is seldom possible.

Greater Scaup Ducks are saicl to feed almost exclusively at night. Crustaceans, shellfish and the like form the principal part of their fool, but pondweeds are not altogether negleeted. In the east these ducks, like many of the other species which dive, feed to a large pxtent on wild celery the roots of which can be torn loose only by the more expert divers among the ducks. Threc stomachs of Greatcr Seaup Ducks shot by San IIubbari on San Pablo Bay, December 5, 1913, contained many shells, mostly broken, of a small clam (Mya arenaria). A stomach obtained by W. Toms on Tia Juana Slough, below Sam Diego, December 7,1913 , contained over 450 seeds of ditch-grass (Ruppia maritima).

The Seaups are among the less desirable ducks for table use, as their flesh is usually tainted by their shell-fish diet. On the market both the Greater and Lesser Scaup Ducks are known as "Blue-bills" and are sometimes classified with certain other inferior speeies, as "small dueks," and sold wholesale for $\$ 1.00$ to $\$ 2.00$ a dozen. The Lesser, being alumdant on the bays and marshes near. San Franciseo, ean always be found on the market, ant the Greater has been at times recognized among them. The rare appearance of the Greater Scaup' on the market, as compared with the Lesser, is probably due to the fact that it affects more open and inacessible waters. But it ranks equally with the Lesser Scaup from the sportsman's point of view.

The Greater Scaup Duck is, with us, preëminently a maritime species. It is a bird which evidently winters chiefly north of us. Hence its preservation is not a partieularly urgent problem to Californians. It will probahly never be an important game bird in this state for two reasons: first, it appears in but small number's, irregularly and in inaccessible places: and second, it is not in great demand as a table duck, but is used merely as a makeshift when other more desirable species are not proeurable.

\section{Lesser Scaup Duck}

\section{Marila affinis (Eyton)}

OTHER NAMEs-Bluebill; Little Black-head; Black-jack, part; Broarl-bill; Aythya affinis; Fulix affinis; Fuligula affuis; Fuligula mariloides.

Description-Adult male: Whole of head, neck, breast and fore part of back black (some specinens show a dull brownish ring arouml the lower neck, but not of the chestnut color seen in the Ring-neckerl Duck); sirles of hear 
and neck with purplish reflections predominating; iris yellow; bill clear bluish gray, nail black; back and scapular region white with coarse zig-zag barrings of black; rump, upper tail-coverts and tail dull black; outer surface of closed wing slaty brown, mottled sparsely with fine white dots; flight feathers slaty brown; speculum pure white; sides and long feathers of flanks white, the latter finely vermiculated with dusky; hind part of belly blackish brown, finely barred with whitish; under tail coverts black; rest of under surface pure white, this sharply contrasting with the black on breast; legs and feet (dried) slaty black. Total length 16.50-18.00 inches (418-457 mm.) (Eaton, 1910, p. 207), and two specimens from California; folded wing 7.608.20 (193-208); bill along culmen 1.55-1.73 (39.4-43.9); tarsus 1.35-1.40 (34.335.6) (seven specimens). Adult female: Whole head, neck, breast, and fore back, dusky reddish brown; a conspicuous area (sometimes called a mask) arouni base of bill, white; lower back, rump and tail dark brown; scapulars finely peppered with white dots, this taking the place of the zig-zag barrings in the male; outer surface of closed wing and flight feathers plain slate brown; speculum pure white; sides, flanks, lower belly and under tail coverts more or less deeply brownish, with bere and there traces of whitish vermiculation; rest of under surface white, not so abruptly marked off from brown of breast as in male. Total length " $16.00-16.75$ ", inches (406-425 mm.) (Eaton, loc. cit.); folded wing 7.42-8.00 (188-203); bill along culmen 1.56-1.65 (39.6-41.8); tarsus 1.27-1.40 (32.3-35.6) (nine specimens); all from Alaska and California. Juvenile plumage: Not known to us. Natal plumage: "Upper parts. dark brown, with buff spots on side of back and rump; lower parts, buff; forehearl and sire of head, brownish buff; narrow brown ring across neck in front connecting with brown of upper parts', (Sanford, Bishop and Van Dyke, 1903, pp. 137-138).

MARKS FOR FIELD IDENTIFICATION-Not distinguishable from Greater Scaup at gunshot range. In hand, or within a few yards, the smaller size, purplish instead of greenish gloss on the head, somewhat coarser or more distinct black undulations on back and flauks, and lack of whitish on outer webs of innermost primaries identify the male Lesser Scaup (pl.5). Females can be Refinitely distinguished only by size differences. The Lesser Scaup averages uearly two inches shorter than the Greater Scaup and is proportionally smaller throughout.

VoICE-Same as that of Greater Scaup Duck.

Nest-Concealed in grass near water; composed of dry grass stems and lined with down.

EGGS-6 to 11, elongate ovate or elliptical in shape, measuring in inches 1.97 to 2.38 by 1.40 to 1.62 (in millimeters, 50.0 to 60.5 by 35.5 to 41.0 ), and averaging 2.22 by 1.56 (56.5 by 39.5 ) (fifty-two eggs in U. S. National Museum); color plain olive buff.

General distribution-North America. Breels, chiefly in the interior, from the Yukon Valley, Alaska, and Fort Auderson, Mackenzie, south to central British Columbia, southern Montana, and northern Indiana: winters from southern British Columbia, Colorado, Lake Erie and New Jersey south to Panama, but chiefly within the United States. Non-breeding birls summer far south of the breeding range (modified from A. O. U. Check-list, 1910, p. 75).

Distribution in CALIFORNIA-Common transient and winter visitant practically throughout the state wherever farorable conditions ohtain. The coastwise records are largely in the fall and winter and the interior ones in spring. A few non-breeders summer along the sea coast, as at Santa Barbara (Torrey, $1910 b$, p. 204): has hred on lakes of San Francisco County (Squires, 1915, p. 234; J. Mailliard, 1915, ]. 235). 
The Lesser Scaup Duck or Little Blue-bill is the commonest duck found on the salt water bays and marshes along the coast during the winter season. Rafts of Lesser Scaups are always to be found on San Francisco and San Pablo bays from October to April, ant this is the duck most commonly secn resting on the water near the ferry moles or diving for mussels about the piling. Non-breeders are oceasionally seen in California during the summer. They have been noted in June at Santa Barbara (Torrey, 1910b. p. 204). Even as far south as San Diego large flocks have been known to remain unt the first of May and individuals were seen there as late as May $\vec{\imath}$. 1885 (Belding, MS). In 1881 Lesser Seaups were seen in the markets of Stockton as early as October 6. On San Franciseo Bay F. W. Gifford (MIS) has record of "Blue-bills" as follows: 190t-1905: first seen. November 23 ; last seen, May 13; 1906-1907: first seen. November 29; last seen, April 14: 1907-1908 : last seen, May 20: 1908-1909 : first seen, December 25; last seen, March 21 ; 1909-1910: first seen, November 7 ; last seen, February 28. They apparently follow the coast more generally in their southward migration, and the interior in their northward migration; practically all of the records from the interior are in the spring. Inland this duck is found chiefly on the larger bodies of water.

The breeding range of the Lesser Scaup is a little more sontherly than that of the Greater Scaup, as Nelson and others have not found it in northern Alaska. The southern limit of its summer range is certainly far south of that of the Greater Scaup. The great interior plains region, from northern North Dakota and northern Montana to the elge of the timber near the Aretic coast in the Anderson and Mackenzie river regions, contains the principal breeding grounds. The migration carries most of these breeders sontheast to the south Atlantic states and even to the Bahamas and Mexico. The birks found along the Pacific coast are thought to breed mostly in the interior of British Columbia, Alaska, and Yukon territory.

As has been noted in the discussion of the Greater Scaup Duck the Lesser Scaup is practically indistinguishable from it at a distance of more than a few yards in spite of the fact that some observers claim to have noticed differences in habits. A Scaup is readily recognized from other ducks by the combination of black head, blue bill, white or light mantle and white speculum and belly (pl. 5). On close examination the male Lesser Scaup can be identified and separated from the Greater Scaup by the presence of a purplish instead of greenish gloss on the head, by lack of whitish on outer webs of innermost primaries, and by heavier markings on the scapulars and flanks. But size is the main distinguishing feature, and females can nearly always be separated by this character if by no other. The Lesser Scaup averages nearly two inches less in total length and the folded wing is about an inch shorter. 
On the Pacific slope, save for the instance noted below, this duck has not bcen found breeding south of British Columbia. In the latter place Brooks (1903, pp. 278-279) found it breeding much later than the Canvasback or Ring-neck. The nests were usually placed in coarse grass, with a path to watcr, generally a muskrat's rumway, connecting with the nearest open watcr. The first eggs were taken on Jume 21 and the clutches varied from seven to eleven in number. A nest with ten eggs found by Chase Littlejohn at Glacier Bay, Alaska, July 16. 1907, was placed within a heavy growth of grass about a foot from the water's edge and consisted of grass stems lined with a little down from the parent's breast (Grimmell, 1909b, p. 195). Nests found in North Dakota by Bent (1902, p. 165) were "all placed on dry gromd but never more than fifty yards from the water. They were generally rathel poorly concealed in the prairie grass, but in some cases, where the grass grew thick and high, they were fairly well hidden. The nest consisted of a hollow scooped in the ground, profusely lined with very dark colored, almost black, down, mingled with a little dry grass and occasionally a white feather from the breast of the bird.' Evidence was obtained that the Lesser Scaup sometimes lays eggs in the nests of other ducks.

On Lake Mereed, San Franciseo County, Squires (1915, p. 234) observed a pair of Lesser. Scaups in July, 1915, with three young not yet able to fly, and J. Mailliard (1915, p. 235) reports that two or three families of "scamps" with young only a few days old had been seen on Stow Lake in Golden Gate Park, San Francisco, in the same month. So far as could be learned these broods were not reared to maturity. There is likelihood that these breeding birds had been crippled or pinioned and were thus prevented from undertaking the usual migration.

Eggs taken in southeastern Alaska are plain olive buff and average 2.34 by 1.58. Twenty-six eggs from North Dakota areraged 2.26 by 1.59. "The lightest types approach somewhat the darkest types of the Mallard's eggs, and the darkest types are rich dark buff or coffeecolored" (Bent, 1902. p. 165). The male Blue-bills flock together during the nesting season as is the habit in many other species of dincks.

In habits the Lesser Scaup is almost identical with the Greater Scaup except that the former appear's to be a little less restricted to salt water. It is nearly always found in large flocks and resorts to the larger bodies of open water. "Rafts" (large dense flocks) of these ducks can often be seen during the day on the surface of open water, with their heads tneked under their wings, sleeping. In spite of their semning obliviousness to their surroundings they are difficult to approach, and only a boat well concealed by brush or tules will enable 
the lumter to approaeh within gunshot. On San Franeisco Bay Bluebills are often seren feeding about the moles and wharves where they ohtain a fair living hy diving for mussels which are attached to the piles. On Stow Lake, Golden Gate Park, and on Lake Merritt, Oakland, Blue-bills become very tame and one can often approach to within a few feet of them. When flying over the larger bodies of water they usually move elose to the surface. On San Pablo Bay Scaups and Canvasbacks are commonly observed assoeiating together on their feeding gromels in February and March.

The food of the Lesser Scaup, like that of its larger consin, is made up almost entirely of shellfish, "rustaceans, aquatic insects, and pondweeds, oltained hy diving. Plue-hills can stay moler water for some time and often remain above the surface for a few seconds only, before diving again for some other delectable morsel which they have previously sighted. Eight stomachs of this duck. from birds taken by W. Toms on Tia Juana Slough, near San Diego. containul (quantities of thr seeds of ditch-grass (Ruppin maritima); two of these stomachs also held parts of mollusk sluells, and one coutained over two hundred small water bugs (Notonectislae).

The shellfish diet obtainerl along the coast often makes this duck undesirable for fool. One man has tescribed a scaul) as tasting after a few weeks of shellfish liet like a pint of eute oil! When feeding on the lakes of the interior where fresh-water food is available it is said to make a more acceptable addition to the bill of fare.

In spite of its inferiority this is a common duck on the market, where it is sold as "small duck." The average wholesale price on the markets of San Franciseo during the season 1911-1912 was $\$ 1.00$ to $\$ 2.00$ per dozen. Because of its numbers it affords more sport than any other bay duck. It comes readily to decors and is shot in great numbers from blinds built in the shoal waters of the bays along the coast. When taking flight the flock immediately seatters so that "potshots" are difficult.

A diminution in the nmmbers of this less-sought-for duck has not been particularly noted on the west eoast as has been the case on the east coast. Nevertheless hunters with years of experience say that the numbers now appearing in California do not compare with the thonsands which flocked to our shores formerly.

There is no better example of the results to be expected from protection than is afforded by a visit to Lake Merritt, Oakland, where ducks, including great numbers of Blue-bills, congregate by the thousands even though the lake is situated near the heart of a great city. The species is also found in some numbers on Stow Lake, Golden Gate Park, San Francisco, showing that by protection and the use of a few pinioned ducks a small reservoir ean be made to teem with waterfowl even though it be in the midst of eivilization. 


\section{Ring-necked Duck}

\section{Marila collaris (Donovan)}

OTHer NAMES-Ring-bill; Black-jack, part; Black-head; Aythya collaris; Fulix collaris; Fuligula collaris.

DESCRIPTION-Adult male: Whole of head, neck, breast and upper surface black, except for a triangular patch of pure white on the chin and a more or less distinct half-collar of chestnut brown around fore part of lower neck; sides of head faintly glossed with violet; low erest on head shiny black with faint greenish iridescence; iris yellow; bill lead color, with a narrow basal anil broad subterminal band of bluish white, the end black; outer surface of closed wing and flight feathers slaty brown; speculum pearl grav, bordered above by blackish feathers with slight greenish reflections, and behind by a narrow margin of white; axillars and most of lining of wing pure white; tail slate brown; sides and flanks white, delicately undulated with dusky; under surface, including crescent-shaped extension upwards on each side in front of wing, satiny white changing behind through an undulated area like the sides and flanks to the black of the under tail coverts; legs and feet "'greyish-blue," webs "brownish-black" (Andubon, 1843, VI, p. 323). Total length 17.20-17.37 inehes (437-441 mm.) (two specimens); folded wing 7.75-8.15 (197-207); bill along culmen 1.75-1.86 (44.4-47.2); tarsus 1.36-1.42 (34.5-36.0) (six specimens). Adult female: Top of head dark brown; sides of head lighter brown more or less mottled with whitish; an area at base of bill, chin, and throat dull white; bill usually showing evidence of a light cross-bar; hind neek and whole of back dark reddish brown shading into the black of rump; outer surface of elosed wing exactly as in male; breast, sides and flanks reddish brown, each feather edged with lighter brown giving a somewhat mottled appearance; lower surface otherwise white, shading into brown on the lower belly and under tail coverts; longest under tail coverts whitish. Total length 16.75 inches (425 mm.) (two specimens); folded wing 7.26-7.62 (184-193); bill along culmen 1.73-1.90 (43.8-48.2); tarsus 1.27-1.40 (32.3-35.6) (eight specimens); all from California. Juvenile plumage: Male: Similar to that of adult female (authors). Natal plumage: Forehead straw yellow; top and back of head and most of upper surface of body, warm brown; sides of head and neck, and throat, straw yellow, palest below; chin yellowish white; iris hazel; bill leadcolored above, flesli-colored below; short narrow streak in middle of back and large patches on sides of back and rump, pale straw yellow; under surface of body, pale straw yellow, darkening on flanks and lower belly where some grayish brown down shows through; feet lead colored, toes tinged with yellowish.

Marks for field identification-Resembles Lesser Scaup but speculum bluish gray instead of white. Back of male black instead of whitish, and white of under surface extending upwards on each side to form a crescent-shaped mark in front of wing. At close range the combination of narrower dark bill with light cross-band near end, the light (chestnut) collar, and triangular white spot on chin is diagnostic. Female has white around base of bill less sharply defined than in Lesser Scanp, chin and throat continuously whitish, but lower surface of body darker, and sperulum bluish gray instead of white. Female Ring-neck distinguished from female Redhear by smaller size, shorter wing, narrower bill, whiter throat, and darker back.

Vorce-Said to resemble that of Greater Seaup Duck. 
NEST-In grass of marslı land, over or near water; małe of grass stems au! sparingly lined witl down.

EgGS-6 to 12 , elliptical in shape, measuring in inches 2.25 to $2.30 \mathrm{by} 1.60$ to 1.65 (in millimeters, 57.2 to 58.3 by 40.6 to 41.8 ) (Davie, 1889 , p. 70 ); eolor varying from greenish or grayish white to buff.

CENeral DIsTribetios-North Ameriea. Breeis from North Dakota ani Minnesota north to Atlabasea Lake, and less abunlantly west of the Rockies from Lassen County, California, to southern British Columbia. Winters from southern British Columbia, northern Texas and New Jersey south to Porto Rieo and Guatemala (nodifiel from A. O. U. Check-list, 1910, P. 75).

DISTRIBLTION IN CALIFORNIA-Rather rare winter visitant, mainly in the west. central and southern parts of the state, and chiefly on fresh water. Southermmost record station: San Diego (Belding, MS). One breeding record: Lagle Lake, Lassen County (Sheldon, 1907, p. 187).

The Ring-necked or Ring-bill Duck is the rarest of the RedheadCanvasback-Scaup group occurring in California. Beeause of this fact ornithologists have taken especial interest in reporting instances of its ocenrence, with the result that there are now more than fifteen definite reeorls. It has been taken at least four times on San Franciseo Bay and there are other records from west-central California. It has been found at Eagle Lake, Lassen County, and at Lake Tahoe and also at several plaees in southern California, even as far south as San Diego. Bekling (MS) states that in his experience the Ringnecked Duck was a winter visitor "in unknown quantity" south to San Diego and that it was a fairly common species in central California where he shot speeimens repeatedly and saw it in the markets. As an instance of nmusual occurrence, W. K. Fisher (190t, p. 25) secured a specimen from the ridge back of Black Mountain, nine miles west of Stanford University, on November 26, 1903. The species seems to prefer the vicinity of fresh water, in this state at least. Its principal winter home is the Gulf Coast from Texas to Florida where it is said to be the most abundant duck present (Cooke, 1906, p. 48).

In general appearance the Ring-nceked Duek resembles the Scaups. However, the speculum is bluish gray rather than white, and in the male the back is black and the white of the under surface extends upwards on each side to form a creseent-shaped bar in front of the wing. At elose range, or in hand, the male may be known by the narrower bill, dark in color and with a light cross band near the end, by the light ehestnut-colored collar, and the triangular spot of white on the chin. Females have white around the base of the bill as does the same sex in the Scaups; but the Ring-neck has this white less sharply restricted, the chin and throat are continuously whitish, the back is darker, the brown sides and flanks lack undulated markings, and the lower surface of the body is less whitish. The female Ringneck can be distinguished from the female Redhead by smaller size, darker body colos, whiter throat and narrower bill. 
The summel home of the Ring-necked Dnck seems to comprise two general areas on opposite sides of the Rocky Momntains. The majority of the birds breed in the interior plains region from North Dakota and Mimnesota north to Athabasca Lake and the western side of Lake Winnipeg. West of the Rockies the species nests from Eagle Lake, Lassen County, California, north to the Cariboo district of British Columbia (Cooke, loc. eit.).

At Eagle Lake, Lassen County, Sheldon records (1907, p. 187) that he found many Ring-necked Ducks in pairs, or old with young. This observation suggests that the species must nest locally about other large lakes in the northeastern part of the state. It is known to have nested in the vicinity of Fort Klamath, Oregon (Merrill, 1888, p. 142), and Brooks (1903, p. 279) has found it breeding in British Columbia. The latter anthor says: "I was able to take only one set of eggs, evidently a second laying as there was no down. This was on the 27 th of June. The nest was in a tussock of grass, in eight inches of water; it was composed of coarse green grass and arched orer with the drooping blades of the tussock. The nine eggs contained small embryos. Young broods of this species were observed before the Lesser Scaup) (1. affinis) had started to lay. The roung in town are very light colored, resembling the young of the Canvasback and Redhead, and quite different from the dusky, unspotted young of the Lesser Scaup." Roberts (1880, p. 61) describes a nest of the Ring-necked Duck found on .June 1, 1876, in southeastern Minnesota, as follows:

The situation chosen for the nest was a narrow strip of marsh borlering a large shallow pond or slough. About half way between the shore and the edge of the open water was a mass of sunken debris, probably the remmants of an old muskrat house, which reached nearly or quite to the surface of the water, here about eight inches deep. On this foundation was the nest, a rather compact, bulky structure built mainly of fine grass with a little moss intermingled. Outside the grass is long and circularly disposer, while the bottom, inside, is composed of short broken pieces, and the insile rim of fine grass bent and loosely tangled together with consiclerable tow among it. Measurements were not taken before remoring the nest, but in its present condition the walls and base are two and a half inches thiok, the diametco inside six inches, and the depth of the ravity thee inches. The cluteh was nine eggs which contained small embryos. The eggs were yerfectly smooth, and of a light greenish-white rolor, wholly unmarkeil.

Seren of the eggs out of the set just described measured 2.19 to 2.27 by 1.58 to 1.62 and averaged 2.23 by 1.60 inches. According to Baild, Berwer and Rilgway (1884, II, 1). 28) the eggs of this speecies ar" graysh ivory white. but sometimes the glay tinge is replaced by $1,11 f f$. 
At Eagle Lake, Lassen Comnty, California, Sheldon (loce cit.) found Ring-necked Ducks less shy than other ducks. They were always close to shore, usually where dead trees lay in the water, and often perched on limbs of dead pines which rose above water.

As a rule hirds of this species are seen singly or in pairs, and they do not resort to open water as much as their relatives, the Seanp, Ducks. Brooks (1899b, p. 350) says: The Ring-neck "generally frequents smaller ponds and more rushy localities than the seamps, but I have seen both species of S'caups, Ringbils, Redheads and Canvasbacks (all five species of the genus Aythya foumd in America) in one enormous flock. Jike the [other] members of this gemus the Ringbill is a swift flyer. In fact I shonld class it as the fastest flying duck in Ameriea." The swift motion of the wings produces a whistling sonnd as the birds pass overhead. In flight, too, the general behavior is like that of Seaups, in that the member's of a band of Ringrecks spread out and do not afford opportunities for "pot-shots." The feeding halits of the Ring-neek are similar to those of its nearest of kin. It dives easily and is able to stay meler water for a consilerable period of time. It eats snails, aquatic insects, and seeds.

Beleling (IIS) says that the Ring-neck takes low rank anong food dueks. It is too rare a duck to be of importance as a game bird. If it conld be readily distinguished in the field it would be well to afford it special protection along with the Wood Duck and Redhead; but its similarity to the Scanp Duck prechudes such a course. Better protection in the states lying to the north, where it is found more abundantly, will favor its persistence withm our own state.

\section{American Golden-eye}

\section{Clangula clangula americana Bonaparte}

OTHER NAMES- Whistler; Whistle-wing; Copperhear (female only); Bucephala americana: Clangula americana: Buccphala clangula; Clangula glancion americana: Glancionetta clangula americana: Bucephala clangula var. americana.

DESCRIPTION-ddult male: Whole head, including moderately developed crest, and upper part of neck, black, glosserl (except on throat) with dark metallic green changeable to violet at certain angles; a nearly circular spot of white (measuring about five-eighths by one inch) at base of bill on each side; iris "bright yellow", (Audubon, 1S43, VI, p. 367); bill deep black; pure white of breast and lower surface continuons clear around neck, contrasting abruptly with black of hearl; inner scapulars black, outer ones white with black erlges; back, rump and tail, solidly black; outer surface of closerl wing black and white; bend and edge of wing blackish, secondaries, greater and middle coverts (including speculum), pure white; primaries and tail blackish slate; sides pure white; elongated flank feathers, white, edged sharply with black; under tail coverts white; under side of tail ashy brown; feet "orange," webs "'lusky,' claws "'black', (Aurlubon, loc. cit.). Total length "18.50- 
23.00" inches (470-554 mm.) (Rilgway, 1900, 1. 105); folled wing 9.12 (232); bill along culmen 1.45 (36.8); tarsus 1.59 (40.2) (one specimen from Alaska). drlult female: Whole hoar, including morlerately developer crest, and hinil neck continuously light brown (no circular white spot at base of bill); bill with parallel erlges, symmetrically lounderl at tip, and "dusky," "dull yellowish orange' toward ends of both mandibles (Audubon, loc. cit.) ; hroad collar around fore neck, white, incomplete behind; upper surface of body ashy brown, the feathers with blackish centers; ruml black; tail ashy brown both ahove and below; onter surface of alosed wing incluling flight feathers slaty black, many of the lesser and midlle coverts with white tippings; secondaries and broal ends of greater coverts (including speculum) pure white; under surface of wing ant axillars blackish brown; band arross breast ashy gray, couspicuously outlinel above by a white collar, and behind by the white of rest of uncler surface; silles and elongated flank feathers slate brown, narrowly tipperl with white. Total length "abont 16.50 ", inches (418 mm.) (Rirlgway, lor. cit.); folled wing 5.12 (206); hill along culmen 1.28 (32.5); tarsus 1.37 (34.8) (one sperimen from California). Juvenile plumage: Male: Like that of adult female but has white spot before eye more or less indicated, while gray hand across chest is less conspieuous (authors). Natal plumage: Whole top of head to level of bill, and hind neck, very dark brown; throat white; back and sides dark brown, with paired spots of gravish white as follows: on hind margin of wing, behind wing, on flank, and at base of tail; whole lower surface of boly white; band across forenerk light brown; iris brownish; bill blackish, tip of lower mandible flesh-color; feet olive ochre.

MARKS FOR FIELD IDENTIFICATION-Medium size, storky build, yellow eye, fluffy hear, and uotable whistling souml produced by wings in flight. Male: Black and white plumage, and conspicuons rounded white spot on side of head at base of bill. Female: Combination of general characters given above together with white speculum, abruptly and solilly brown hearl, and white collar, separate her from other lucks except the Barrow Golden-eye. From the female of the latter she differs slightly by paler head, shallower and broader bill at tip, lack of yellowish band across bill near tip, light band across chest, and lack of blackish bar across white of wing.

Volce-Of male: In courting, a short flat vibrant paaap (Brewster, 1911, p. 25). Of female: When startled or lost a sharp cur-r-rcw; in nesting season (at least) a low pitoher quack (Eaton, 1910, pl. 209-210; and authors).

NEST-In ravities in trees over water; a lining of down on the resirlual rotten wood or other lebris.

EGGS-5 to 15, or more, rounded-osal in shape, measuring in inches 2.30 to 2.55 by 1.70 to 1.78 (in millimeters, 58.4 to 64.7 by 43.2 to 45.2 ) : color ashy green; thin-shelled with a glossy surface (neasurements from Davie, 1ss9, p. 71 ).

General nistributiox-North America. Breesls from southem British Columbia, southern Montana, northern North Dakota and northern New England north to central Alaska, central Keewatin and Newfoundland; winters ehiefly in the Uniter States from Utah, Nebraska, Minnesota and Maine sonth to sonthern California, central Mexiro anil Florida (modified from A. O. U. Cheek-list, 1910, 1. 76).

Distribution IN CALIFORIA-Fairly common winter visitant, rhiefly in the northern half of the state; most numerous on roastal bays and salt marshes, owasionally straggling to the interior. Several instances of ocenrence in sonthern California (Willett, 1912a. p. 25), the southernmost being at San 
Diego (Belding, MNi). Some inlaul record stations are: near Daggett, San Beruadino County (Lamb, 1912, p. 34); Loue l’ine, Inyo County (A. K. Fisher, 1s93a, p. 1s); and lower Mecloud River, Shasta County (C. II. 'Townsemi, 1447, p. 195). Other inland revorils nearer the coast.

The American Goldentere or Whistler is to be numbered anong the less common ducks in California. Serelal early writers give it as a common winter visitant, but recent leeorits especially in sonthern California have been for. Littlejohn (1912, p. 41) says that it is often plentiful during the fall migration on the salt marshes of San Franciseo Bay near Rectwoot City. From Oregon northward th is duck is reported as regularly common in winter. It is witlo us found alnost exchnsively on salt water along the coast, but there have been sereral recorls of its occurrence interiorly, for example, "central California in winter, but rare" (Brlding, MS'). 'The numbers decrease rapilly sonth of Monterey Bay.

'Tlue medium size, stocky build, strongly contrasted black and white coloration, and large-appearing heal of the male Golden-ere make him easily distinguishable from otler trakes in the field, either when flying or at leest on the water. At close range or in the ladul, the ronndish white spot at the base of the bill on each siste and the bright yellow eyos make identification eertain. The extraordinary whistling somel made by the wings marks this birl in flight. On otler black and white dureks witl which it is sometimes confused by the incxperienced observer are the sawbils and the Bufflehead: but the longer body and slender beak of the mereansers give them an rntirely difforent appearan.e, while the linfllehear is a much smaller bird and the head, thongh fluffy, has a large white patcl behind the eye. The female Golden-eyes are mole difficult to recognize than the males, as the head is brown instead of black, the upper surface is gray in color and there is no white spot at the base of the bill on each side. The stocky build, bright rellow eye, and whistling noise in flight still remain. however, and together with the white specnlum, abruptly and solidly brown head, and white collar, combine to distinguish them from other female ducks.

Males of the American Golden-eye can be separated from those of the Barrow Golden-eye by the roundish white spot at the base of the bill instead of the narrowy triangular patch found in the same place in the latter species. Females and young of these two species are so similar in appearance that they are diffienlt to distinguish even in the hand. The decided reduction in the width of the bill near its tip in the Barrow Golden-eye is the most dependable character available for discrimination. Other diagnostic characters of the American are the paler head, paler band across ehest, lack of yellowish band aeross bill near tip, and lack of blackish bar across the white area on the wing. 
The Golden-eye has not been found breeding in California. Being a distinctly cold-loving species, in summer as well as in winter, it nests almost entirely in the far north. As it requires hollow trees for nesting sites, its breeding range is of course limited to those areas where trees are found. It breeds commonly in the interior of Alaska, but is very rarely seen along the coast. The Golden-eye has been found breeding in southern British Columbia so close to the Ameriean line that it probably will be found to breed in northern Washington (Cooke, 1906, p. 49). Brooks (1903, p. 279) states that in the Cariboo district, British Columbia, it is seen during migrations but has not been found to nest there. The principal breeding grounds are in central Canada, but it has also been found nesting in the extreme north-eentral and northeastern United States, as far south as northern New York.

More has been written on the life-history of the Golden-eye than on that of many of the commoner dueks. Unfortunately, lowerer, little or none of this information pertains to the Pacific Coast. We can only infer a general similarity in behavior on the part of our birds.

The Whistler is noted for its extraordinary mating anties. (. W. Townsend (1910, pp. 177-178) deseribes the typieal courtship of this duck, as seen in Massachusetts, as follows:

One or more males swim restlessly back and forth and around a female. The feathers of the cheeks and crest of the male are so erecterl that the head looks large and rouni, the neck correspondingly small. As he swins along the head is thrust out in front close to the water, occasionally dabbing at it. Suddenly he springs forward, elevating his breast, and at the same time he enters on the most typical and essential part of the performance. The neck is stretched straight up, and the bill, pointing to the zenith, is openerl to emit a harsh, rasping double-note, zzee-at, vibratory and searching in character. The head is then quickly snapped back until the ocriput touches the rump, whence it is brought forward again with a jerk to the normal position. As the head is returned to its place the birl often springs forwarl kicking the water in a spurt out behinı, and wisplaying like a flash of flame the orange-colored legs.

Brewster (1911, pp. 22-30) has noted no less than six trpical poses which are suceessively assumed while the males are displaring themselves before the females. The love note is deseribed as a short, flat, vibrant putup. aceompanied by an upward kiek of the feet which sends np a slender slower of water behind. There were often as many as nine males courting one female and yet the msual jealousy to be noted among males of other species of dneks appeared to be wholly lacking.

Brewster has mate an extensive study of the nesting habits of the Golken-eye at Lake Tmbagng, Maine. In the course of his admirable aceount, he states (1900, pp. 208-209): 
All the Whistlers nests which I have examinel [in Maine] have been placel over water at heights varying from six or eight to fifty or sixty feet and in eavities in the trunks of large liarlwool trees such as elms, maples, and yellow or canoe birches. As the supply of such ravities is limiter, even where dead or deeaying trees abound, and as the birls have no means of enlarging or otherwise improving them they are not fastidious in their ehoice, but readily make use of any opening which can be marle to serve their purpose. Thus it happens that the nest is sometimes placed at the bottom of a hollow trunk, six, ten, or even fifteen feet below the hole at which the biril enters, at others on a level with and scarce a foot back from the entrance, which is usually rounded, and from six to fifteen inches in diameter, but oceasionally is so small and irregular that the Whistler must have diffieulty in forcing its bulky l’oky through. ...

The eggs are laid on the rotten wood or whatever other debris there may be at the bottom of the eavity. When the set is complete (never before, so far as I have observed) the bird places umler, arounil, anl even over the eggs, down pluckel from her breast. The quantity of lown varies greatly in different nests. The lown is very light gray, each down feather having a slightly paler eenter.

The number of eggs in a completed set varies greatly. Oceasionally there are but fire or six, oftener from eight to ten, not infrequently as many as twelve or fifteen, while I once found nineteen, all of which almost certainly belongerl to one bird... The whole bottom of the nesting eavity, be it large or small, is usually covered with eggs, and they are often piled in two layers or set on end, and prekel so elosely that it is as diffieult to remove the first as to take a book from a tightly filled shelf.

An occupied nesting eavity can usually be located by the presence of white down on the eclges of the aperture or on near-by limbs.

Bent (1902, p. 170) describes the eggs as different from other ducks eggs in that they vary from a clear pale malachite green in the lighter specimens to a more olivaceous or pale chromium green in the darker specimens. Serenteen eggs from North Dakota measure in inches 2.37 to 2.58 by 1.66 to 1.77 , and average 2.46 by 1.71 .

The ducklings are easily separated from those of other species. "The dorny young have the upper parts, as well as a band across the breast and the sides and thighs, dark sooty brown, marked with several white spots; ehin, throat, and checks pure white; belly gravish white" (Eaton, 1910, p. 210). Unlike the Wood Duck, the young apparently often tumble from the nest instead of being carried to water in the bill of the parent, for Brewster ( loc. cit.) tells of seeing the young tumble out of a nest into the water after being called by their mother. All used their tiny wings freely, beating them continuonsly as they descended so that they struck the water with very little force. On the other hand George A. Boardman (in Forbush, 1912 , p. 131) states that in Maine he saw a female Whistler pick up two of her dncklings and carry them, one at a time, across a lake, and he was told by his companion that the mother birds often took their 
young from one lake to another when they thought the little ones were in danger. Boardman's eompanion also told him that the young were usually earried from the nest to the water in the bill of the parent, but to go any distance the feet were used in earrying them. Bailey (1916a. p. 55) says that at Stmmp Lake, North Dakota, parent ducks have been seen to fly down from nest holes with young birds on their backs, the dueklings steadying themselves by bolding onto the mother's feathers by their bills.

Golden-eyes are generally found in small flocks on large bays, lakes or rivers. In flight this duck makes more of a noise with its wings than does any other duck. This peenliarity has given it the common name of "Whistler." It seems to be otherwise perfectly silent in California during the winter, making no noise, exeept that produced by the whistling of the wings in flight. In a seattered company mixed with other speeies this duck is usually one of the first to give the alarm, for it is nearly always shy and diffient to approaeh ; but on oceasion, apparently trusting to its dexterity in diving, it will allow a near approach. Both when swimming and in flight it is a very active bird.

The male Whistler floats lightly on the water. The female, bowever, sits much lower in the water. Prewster (1911, p. 29) states that in diving the wings of this species are kept tightly closed whereas the tail is usually spread to the utmost width possible. As a rule the downward plunge is made without much apparent effort, the bird simply immersing its head and then vanishing with surprising if not mysterious quickness. Oceasionally it springs upward and forward in the manner of a grebe or merganser, sometimes showing not only the entire outline of the lower parts of the body above the surface but also the whole of the legs and feet. This species dives so very quiekly (at the flash of the powder) that, aecording to testimony, it could not be shot with the old-fashioned flintloek gnn. The flight of the Whistler is powerful, rapid, and protracted. On rising from the water it proceeds at first very low, and does not aseend to its usual height until it has gone a considerable distanee.

Lamb (1912, p. 34) has recorded the following notes on a pair seen November 17, 1910, feeding in a small pond on the Mohave Desert. "At this place the water" was about four feet deep. They would dive and stay moler the water possibly forty-five seeonds, and when coming up I conll hear them hreathe so plainly, it sounded to me as lout as a full grown man after a harel rum. The birds remained on the smefaee, apparently to recover their breath, abont half again as long as they stayed mucter water." Bailey (1916a, p. 55) observed a female (living and feeding in Stump Lake. Nortl Dakota. As the hirel rose above the surface with a morsel of foor she would throw her head up as she swallowed it. 
The food is made up largely of mussels and other shellfish olstained by diving. The stomach of a hiret taken on San Pablo Bay, December 5, 1913, by samuel Hubbard, Jr., eontained only hroken elam shells (Mya arenaria). Some anthors state that the Golden-eye also foeds on small fisls. In the interior it is said to feed on aqnatio insects and even such regetable matter as grasses and roots.

Like other's of the rarer ducks the Golden-ere cannot be considered an important game hird. From the sportsman's point of view it is almost negligible, for it seldom eomes well to decoys. It has rarely been seen on the markets of San Francisco. As a table bird it is inferior, taking rank below even the Blne-bill. The young. however, are said to be fairly tender and well flarored.

'This lover of the far north will probably always be more or less of a rare duck in California. The size of the eontingent reaching us will alwars be dependent on enditions obtaining fartler to the north. Thus the numbers to be expected each rear are variable. Dnring mild winters in the north, the continued presenee of open water makes it unnecessary for the birds to travel farther south.

\section{Barrow Golden-eye}

\section{C'langula islantica (Gmelin)}

OTHER xAMES--Rorky Mountain Gollen-eye; Rorky Mountain Garrot; Whistler; Buccphala islandira: Glaucionetta islandira.

Descriptiox--Adult male: Heal, inuluding well developel crest extending to hind neck, and upper half of nock, black, strongly glosserl, exrept on forehearl and throat, witl steely blue showing riolet reflections at certain angles; extreme point of chin flecked with white; an approximately wedge-shaper patch of white on each side of hearl hetween eye and bill, bordering wiole lateral base of bill; upper part of this white patch forms an acute angle on each side of the forehead, the lower part broadest and rounded: bill goose-like, color "black"; iris "yellow", (Sanford, Bishop and Tan Tyke, 1903, p. 147); upper surface of body velvety black, with a faint steely gloss on scapulars; onter row of scapulars on each sire white, with outer elge of outer web of each feather black and produced into an abruptly elongated spike; the mass effect of this seapular white is of a longitudinal series of roundish or oblong spots; onter surface of closed wing chiefly black; middle wing coverts white, together producing a broad white bar; exposed terminal half of greater coverts, and whole of exposed portion of five or six inmer secondaries, white, forming a large patch, which includes speculum; black bases of greater coverts form a diagonal black bar separating the two above designated patches of white on wing; axillars and under surface of wing blackish brown; sides and flanks chiefly white, continuous with same color on lower surface, but upper feather edges widely hordered with deep black, and flank feathers also broadly terminated with black; thighs and marginal under tail coverts blackish brown; lower half of neck all around, and entire lower surface of bory, except as above, pure satiny white; legs and feet "pale orange", (Sanford, Bishop and Tan Dyke, loc. cit.). Total length “ $21.00-23.00$ ”' inches (533-584 mm.) (Ridg- 
way, 1900 , p. 105); folled wing 8.95 (227); bill along culmen 1.37 (34.8); tarsus 1.62 (41.2) (one specimen, in Mailliard collection, from California). Adult female: Whole of head, including moderately developer crest, and upper neck, continnously dark brown; collar around neck white, interrupted behind by light brown, continuous with color of back; bill conspicuously high at base, narrow at tip, with large black nail, and mostly black with usually a yellow patch across each mandible near tip; npper surface of body ashy brown, with blackish feather centers; seapulars larker; rump dull black; tail ashy brown both above and below; outer surface of elosed wing including flight feathers, slaty black; speculum pure white, bordered in front by a blackish bar formed by the tips of the greater coverts which are otherwise white on their exposed portions; many of lesser coverts also mottled with white; lining of wing and axillars, blackish brown; broad band across breast ashy brown, conspicuously outlined by the white collar above, and behind by the white on rest of lower surface; sides aud elongated flank feathers slaty brown, tipped with ashy; under tail coverts pure white. Folded wing $8.25-8.65$ inches (210-220 mm.); bill along culmen 1.27-1.50 (32.2-38.1); tarsus $1.43-1.60 \quad(36.3-40.6)$ (two specimens from California and Alaska). Juvenile plumage: Not known to us. Natal plumage: Whole top of head, sides of head to level of bill, and hind neck, uniform very dark brown; throat white; iris brownish; bill blackish, tip of lower mandible flesh color; upper surface of boily and sides, dark brown, with paired white spots as follows: on hind margin of wing, on flanks, behind wing, and at base of tail; whole lower surface white, with band across foreneek light brown; feet olive ochre.

MARKS FOR FIELD IDENTIFICATION-Similar to those for American Golden-eye from which not readily distinguishable except at close range or in hand. Male Barrow Golden-eye has white patch on cheek sharply triangular instead of rounded, head glossed with steel-blue instead of green, scapulars spotted instear of striped, black band across white wing patch, and bill deeper and narrower. Female Barrow Golden-eye, as compared with the American, has heall darker brown, bill more goose-like and with yellowish band near tip, chest band darker, white collar narrower, and white wing pateh usually erossed by a dusky bar.

VOICE-No description foumd by us.

NEST-In hollows in trees; built of grass, sticks and other debris, and usually lined with white down.

EGGS-6 to 10, rouncled oval in shape, measuring in inches, 2.40 to 2.60 by 1.60 to 1.85 (in millimeters, 61.0 to 66.0 by 40.6 to 47.0 ), and averaging 2.48 by 1.71 (63.0 by 43.4) (fifteen eggs); in color "grayish pea-green", or "bright seagreen', (Brewer, 1879, pp. 151, 152).

Gexeral distribution-Northern North America. Breeils from south-central Alaska and northwestern Mackenzie south to southern Oregon and southern Colorarlo; also from northern Ungava to central Quebee. Winters from southeastern Alaska, central Montana, the Great Lakes and Gulf of St. Lawrence south to central California, southern Coloraro, Nebraska and New Englanil (A. O. U. Cheek-list, 1910, p. 76).

Distribution in CaLifornia-Rare winter visitant to northern half of the state. The following definite instances of oceurrence are known: Gridley, Butte County (Belding, MS); at or near (?) Nicasio, Marin County (Beling, MS); Ross Landing and Point San Pedro, Marin County shore of San Francisco Bay (J. Mailliard, 1904, p. 15); Stege, Contra Costa County (Mus. Vert. Zool.); San Francisco markets (Henshaw, 1576, p. 274); San Franeiseo Bay (Kobbé, in Bailey, 1902, p. xlix); San Franeiseo Bay near Rerlwoor City, San Mateo County (Littlejohn, 1912, p. 41). 
Previous to 1876 the Barrow Golden-eye was supposed to have a general far northern distribution. In that year the nest and eggs of this sprecies were first found in the mountains of Colorado. Sinee that time it has been found breeding on a number of the sequestered monntain lakes of the Rockies from sonthern Colorado almost to the Aretic Coast although breeding records north of the United States are rare. On the northwest the breeding range extends to the base of the Alaska Peninsula and to Iceland on the east. The species also breeds about the mountain lakes of Oregon, Washington, and British Columbia. The cold of the winter season forees it but little south of its summer range. By frequenting water that is too deep or too rapid to freeze it is able to remain all the year as far north as Minnesota and the Great Lakes.

Along the Pacifie Coast the Barrow Golden-eye is to be found during the winter season from Alaska south to eentral California. In California it has never been taken south of San Franciseo Bay and even to the north of this place it is a relatively rare bird. In all, less than a dozen specimens have been recorded from the state, all but one being from the vieinity of San Franciseo Bay. This one, recorded $h$ Belding (MS), was eaptured far from the seacoast-at Gridley, Butte County, February 26, 1895, where it accompanied two or three others in a flock of Ameriean Golden-eyes. This speeies apparently frequents salt water during its magrations and is to be fomnd, at least sometimes, in company with the mole common American Golden-eye. In Washington it is said to keep to the open lakes and river's.

The most reecnt specimens taken within the state were seeured by Littlejohn (1912, p. 41) under the following cirenmstances: "After" examining hundreds of speeimens of Golden-eyes for many rears past, I at last sueceeded in securing a roung male in immature plumage on November 19, 1908, and a female on November 28, 1910 ; all other's were of the common, or American Golden-eye, which are quite plentiful during the fall migration on the Redwood City salt marshes.'

The white patch in front of the eye is sufficient for telling the males of either species of Golden-eye from other ducks; but to separate the Barrow from the American Golden-eye is somewhat more difficult, especially in the open. In flight the two are practically indistinguishable and when on the water a close view must be afforded in order that the shape of the white patch in front of the eye be made of use as a distinguishing character. By examination of specimens in the hand the male Barrow Golden-eye ean be recognized by the following points: the vertical, upward pointing, wedge-shaped pateh in front of the eye; the color of the head, on which the reflections are chiefly steely blue, the better developed erest, the more goose-like bill, 
the spotted instead of striped scapulars, and the black wing bar. Females are even more difficnlt to distinguish, as the general coloration of the two species is the same. The Barrow Golden-eye, however, has the white wing patch crossed by a blackish band formed by the dark tips of the greater wing coverts, the head is darker brown, the white collar narrower, the gray band across breast darker, and the bill usually shows a yellowish har near the tip. The bill is relatively shorter and higher at the base and distinctly narrower towards the tip; the "nail" is larger and more hooked at tip.

Althongh never found nesting in California, the Barrow Goldeneye has been found to breed at Pauline and Diamond lakes, Crook and Douglas counties, Oregon (Cooke, 1906, p. 51). It is possible, therefore, that this species may breed about the higher momntain lakes of northern California. Carter (in Brewer, 1879, p. 150), who first discovered a nest of this species in Colorado, states that this, like the American Golden-eye, nests in hollow trees and that it is surprising to see to what small cavities, in some instances, they can accommodate themselves.

Brewer (1879, pp. 151-152) states that in Tceland the nest of the Barrow Golden-eye cannot be mistaken for that of any other duck, because of the pure white down with which the nest is lined. The female sits so closely that she can usmally be captured upon the nest. The eggs, from nine to twelve in number, resemble those of the American Golden-eye but are slightly larger.

Brooks (1903, p. 279) has found this a rather scarce breeding duck in British Columbia in the neighborhood of 158-Mile Honse, but more common in La Hâche Valley. "One set of eggs was taken from a hole in a dead Douglas fir, fifty feet from the ground, probably the deserted nest of a flying squirrel. The tree stood about four hundred yards from the nearest water. The eggs (seven) at this date (17th June) contained large cmlryos." From another nesting hole which Brooks was mnable to reach, a female brought out fourteen roung.

IIolböll (in Brewer, 1879, p. 151) says that the Barrow Goldeneye is the most wary of all water-fowl and that it is with the greatest difficulty that one can approach even within gunshot of it. Collectors have had to station themselves in places where this bird feeds on moonlight nights in orker to obtain specimens. In general habits it resembles the Ameriean Golden-eye but is said to be a less expert diver.

As a game duck the Barrow Golden-eye must be considered along with the American Golden-eye; its extreme rarity in California makes it of even less importance. The one or two records of its oceurrence in the markets of San Francisco are so exceptional as to have merited particular comment. In fact, its classification in California as a game species is hardly more than technical. 


\section{Buffle-head}

\section{('haritometta albcola (Limnaens)}

OTnE: xayes-Buterball; King Butterball (male); Spirit Durk; Clangula albeola: Buecpliala albeolu.

1)Escriptox- fllult male: J'lumage of heal copious and flufiy forming a distinct erest of even outline; heal anl upler ne"k, black, glossel vivilly with metallic green, violet-jurple, and an intermeliate greenish bronze, the green being most apparent alout fare and on hind neck, the violetpurple on crown and siles of heal and nerk: a large patel of white extends backwarl from immeliately heneath rye ancl meets its fellow on hark of hearl iris "dark hrown"; bill "slite," nail "lblack", (Sanfurl, Bishop and Tau Dyke, 1903, 1. 150); back and rump blakk, separated from dark wolor of head and upper neck hy a broal white collar; upjer tail coverts and tail light gray; forepart ot outer surface of closel wing ahiefly white; flight feathers and inmer seapulars black: outer scapulars white eilgerl narrowly on outer margins witl black: axillars aml lining of wing mottled Insky and white; loreast, sisles, uniler tail coverts and expaniled flank feathers pure white, the last narrowly borlereal along "pper elges with black; belly plain pale ashy gray. blending into white of hreast; white of hreast runs up on foreneck into an $\mathrm{A}$-shaped invasion upon the lark hearl; legs and feet "flesh color" (Sinford, Bishop anıl Van lyye, loc. eit.). Total length " $14.25-15.25$ ", inules (362-3ऽ7 mm.) (Riılgway, 1900 , p. 106); folded wing 6.50-6.97 (165-177); bill along vulmen 1.061.17 ( $26.9-29.7)$; tarsus $1.27-1.36(32.2-34.5)$ (nine specimens from California anıl Alaska). Adult female: Hearl (less puffy than in male), neck, and whole upper surface of boly, lark grayisly brown, approathing lulack on wown, midile of back, and rump: throat amb whole nerk lightest in tone; a white pateh on each side of hrad hehind and helow level of eye (these patehes much smaller and less sharply defined than in male, and not meeting on hind neck); iris dark brown; bill bluish gray; tail above anl below grayish lrown; outer surface of closed wing and fliglit feathers, slaty black; small, sharply contrasted area on wing, including speculum, pure white, crossel by a black bar; breast, sides, flanks, under tail coverts and hinder part of belly, grayisl, blending with the dull white of rest of uniler surface; legs and fect "slate"'; mebs "dusky", (Sanforl, Bishop anil Van Drke, loc. eit.). Total length “12.25-13.50", inches (311-343 mm.) (Rilgway, loc. rit.); folderl wing 5.956.50 (151-165); bill along culmen 0.96-1.08 (24.4-27.4); tarsus 1.11-1.27 (28.232.2) (seven specimens from California and Alaska). Juernile and natal plumages: Not known to us.

MARKS FOR FIELd IDENTIFJCATION-Small size, chunky buill, relatively large head, short bill, black (or dark) and white coloration, white pateh on sile of hearl, and white speculum, separate either sex from other ducks. Female slightly smaller than male, with much of black replacel by blackish brown; distinguished by white patch on side of head behind eye, and white wing patch crossed by a black bar.

VoICE-Resembles quack of Golden-eye but feebler; on the wing a deep guttural note (Baird, Brewer and Ridgway, 1884, II, pp. 50, 51).

NEST-In hollow stump or tree, near water; lined with down.

EGGS-2 to 9, averaging 8 , nearly elliptical in shape, measuring in inches 1.75 to 2.11 by 1.32 to 1.50 (in millimeters, 44.5 to 53.5 by 33.5 to 38.0 ), and averaging 1.99 by 1.44 (50.5 by 36.5 ); color creamy white or old ivory (measurements 
from eighteen eggs in U. S. National Museum, deseription from various authors).

General distribution-North America. Breeds from Upper Yukon Valley, Alaska, Great Slave Lake and central Keewatin south to British Columbia, northern Montana, and central Ontario. Winters from Aleutian Islands, British Columbia, Colorado, Missouri, southern Michigan, western New York and New Brunswick, south to northern Lower California, central Mexico and Florida (modified from A. O. U. Check-list, 1910, p. 77).

Distribution in CALIFORNIA-Common winter visitant along entire seacoast; less numerous away from salt or brackish water. Interior records pertain chiefly to lakes and sloughs at low altitudes. Some record stations away from the seacoast are: Salton Sea, Imperial County (Van Rossem, 1911, p. 134); near Daggett, San Bernardino County (Lamb, 1912, p. 34); Lone Pine, Inyo County (A. K. Fisher, 1893a, p. 18); Los Baños, Merced County (Mus. Vert. Zool.); Stockton, San Joaquin County, and Marysville, Yuba County (Belding, 1879, p. 447); and Fort Crook, Shasta County (C. H. Townsend, 1887, p. 195). Arrives in Oetober and remains as late as April 20 (San Diego: Cooper in Baird, Brewer and Rirlgway, 18s4, II, p. 49). Not known to nest within the state.

The Buffle-head, or Butterball as it is usually called, is one of the handsomest of the ducks to be found in California. It is commonly to be seen in pairs or small flocks on salt water bays and brackish sloughs, less frequently on fresh water in the interior valleys. Its stay in California is limited to the winter months from October to April. During the nesting season the Buffle-head is confined almost entirely to Canada and the extreme northern United States. It is a common breeder from Manitoba westward to British Columbia, thence north to the limit of trees. Most of the California birds probably breed in the western portion of this region, although some may breed farther south as for instance about the mountain lakes of Oregon and Washington.

The small size, big head, conspicnous black and white plumage, with white patches on the sides of the head and body make the male Buffle-head casy to distinguish from all other ducks. The long brightly glossed feathers of the head form a sort of enveloping hood and contrast strongly with the short white feathering of the lower neek. The female is slightly smaller and browner than the male, and lacks entirely the glossy sheen on the head; the white pateh on her wing is smaller and is crossed by a black bar. The Hooded Merganser is the only duck with which the Buffle-head is likely to be confused. The male Hooded Merganser has a somewhat similar white pateh on the head when the crest is raised, but the Buffle-head can be distinguished by the short, stubby bill and by the lower neck which is conspicuously pure white all the way around. The female Buffle-head can be distinguished from the female Ruddy Duck, the only speeies which it at all elosely resembles, by the white spot on the side of the head behind the eye, the white speenlum, and the very much smaller bill. 
The eonting beharior of the Bufte-head in California has been only imperfectly deseribed, but (C. W. Townsend (1916, pp. 16-17) from observations in llassachusetts, writes of it in detail as follows:

A group of thirty-five or forty of these birds with sexes ationt equally liviled may have been autively feerling, swimning together in a compart Hork all pointing the same way. They dive within a few secomls of earh other and stay under water 14 to 20 seconds and repeat the living at frequent intervals. Sullenly a male swims vigorously at another with flapping wings, making the water boil, and soon each male is ariently courting. He sprearls and cocks his tail, juffs out the frathers of his loan and rheeks, extends his bill straight out in front elose to the water and every now and then throws $j$ back with a loo in a sort of reversed bow. All the time he swims rapinly, and, whereas in feeling the groul were all swimming the same way in an orierly manner, the drakes are now uervously swimming hack and forth and in and ont through the crowl. Every now and then there is a rommotion in the water as one or more irakes live with a splashing of water only to eome ul again in pursuit or retreat. As the excitement grows a rlake flaps his wings frequently and then jumps from the water and flies low with outstreteherl neek towarils a linek who has listlessly strayed from the group. He alights heside her preeipitately, sliding along on his tail, his breast and head elevated to their utmost extent and helil ereet. He bobs nervously. And so it goes.

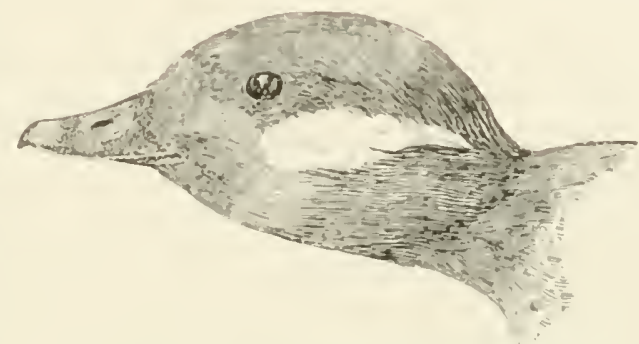

Fig. 23. Hearl of female Buftle-hear. One-half natural size.

Note single white pateh below and be himil eve (complare with figs. 24 and 26 ).

Swarth (1911, r. 43) says that in southeastern Alaska during April and May the preponderance of males was rery noticeable. He further states: "The drakes were constantly exhibiting their plumage and competing for the faror of the females; sometimes when several were fighting together furiously the single female of the flock would quietly fly away and leave them, to be presently followed by the whole gathering as soon as her defection was discorered."

Brooks (1903, p. 279), who had excellent opportunity to study the nesting habits of this species in British Columbia, says that:

Almost every lake has one or more pairs of these charming little ducks. The nests, unlike those of Barrow's Golden-eye, were always in trees elose to or but a short distance away from water. These nests were invariably the deserted nesting sites of fliekers, and in most instances had been usel several vears in suecession by the ducks. The holes were in aspen trees from five to twenty feet from the ground, and the entrance [in each ease] was not more than three and a quarter inches in diameter. The number of eggs ranged 
from two to nine, eight being the average; in color they resemble old ivory, without any tinge of green. I have several times seen the eggs of this duek described as "dusky green," but these have evidently been the eggs of some speries of teal. The female Bufle-henl is a very close sitter, never leaving the nest until the hole was sawed out, and in most cases I had to lift the bird and throw her up in the air, when she wonld make a bee-line for the nearest lake, where her mate wonll be slowly swimming up and down unconscious of the violation of his home. In many eases the eggs harl fine cracks, evidently made ly the compression of the bird's borly when entering the small aperture.

It is said that some nests have no other lining than down feathers from the fomale parent.

The Buffle-head flies with notable speed, viluating its wings with great rapidity, and usually travels elose to the water. When alighting on the water it does so with a big splash, eonsidering the size of the bird, and ploughs through the water for some little distance before its momentum is completely arrested. It associates in pairs or flocks of small size. Floeks do not fly in regular formation as is the habit with some dueks, but the individual members bunch elosely together each disregarding the position of its companion. A deep gnttural note is sometimes given when on the wing, but more often the birds fly without uttering any sound whatsoever.

Next to its fatness, whence the name Butterball, the Buffle-head is famed for its expertness in diving. It is said to dive at the flash of the gun and consequently is difficult to hit when resting on the water. Although usually shy and not easily aproached it sometimes depends for its safety entirely upon its agility in diving and will then permit close approach. When wounded or pursued it swims great distanees moler water and upon rising to the surface will immediately dive again if danger is still near.

So expert a diver is the Buffle-head that it ean eatch small fish easily, and this sort of food is said to be taken regularly. Like many other sea dueks, the Buffle-head varies its food with locality. Along the seacoast, it feeds upon small fish, shrimps and other crustaceans, and shellfish; in fresh water, erawfish, leeches and snails, and grasses and other water plants, are taken (Baird, Brewer and Ridgway, 1884, II, p. 51).

Despito its fatness the Buffle-head is not considered a rory desirable tahle bird becanse its flesh is usually ill-flavored. Birds taken in the interior have been reported as palatable, and young birds taken along the coast are relished by people who know how to cook them. But as a general rule Buftle-heads taken along the sea coast have been subsisting on a shellfish diet so long that it las made their flesh taste "fishy." This speeies is only ineidentally sought for by the gumner, its small size, poor flaror, and its usual inaceessibility giving it low rank 
as a game bird. But for the bird student or eamera hunter, no more interesting or handsome duck can be found.

Little need here be said as to the probable futme status of this duck in California. It must simply be numbered with other migratory salt-water species which have shown some decrease in numbers. On the Atlantic coast, aceording to Forbush (1912, p. 138), the diminution has been deplorably rapid. That there has not been a greater decrease here is due to its slight lemand for table use, and also to its elusive habits. Nevertheless, the market hunter has sent regular quotas of these birds to the market each year. During the season 1895-96, 325 Buffle-heads were solel on the markets of San Franciseo and Los Angeles (C'alif. Fish ('omm., 1896, p. 42). In more reeent seasons this species has been classified along with other species as "small clucks," so that the exact mmber sold on the markets is not known.

\section{Old-squaw}

\section{Harclda hycmalis (Linnaeus)}

(OTHER NAMES-Long-tailed Duck; South Southerly; Clangula hyemalis; Harelda ylacialis.

DEscription-Adult male in winter: Head and neck mostly white; rheeks ashy; a blackish browu patch on side of head and neck, and a blackish stripe from ridge of bill up over crown of head; eyeliss white; iris "bright carmine"': bill relatively small, narrowed towards tip, with well-developed nail, basal half "black," "orange yellow" near end, nail "bluish-grey" (Audubon, 1843, VT, p. 383); upper part of breast and back, white, continuous with white of heacl; rest of upper surface sooty brown; onter surface of closed wing blackish brown, the speculum a little more warmly brown; lining of wing and axillars dusky; elongated and pointed scapulars pearl gray, some with dusky centers; breast and forepart of belly solidly blackish brown; sides, flanks, rest of belly and under tail coverts, white; middle tail feathers greatly narrowed and elongated ( 8.50 to 10.00 inches, 216 to $254 \mathrm{~mm}$., long) and blackish brown in color, others white with dusky centers; legs and feet "pale slate," webs "dusky" (Sanford, Bishop and Van Dyke, 1903, p. 153). Adult male in summer: Pateh on side of head from bill to behind ear, encircling eye, ashy; area immediately around and behind eye more purely white; bill as in winter; rest of liead and neck blackish brown except for patches of white on back of head (made up of long feathers probably remnants of winter plumage); back blackish brown, save for transverse area of reddish brown dark-centered feathers across shoulders, and for elongated scapulars which are reddish brown with blackish centers; outer surface of closed wing sooty brown; speculum more brownish and not well defined; lining of wing and axillars dusky; breast and forepart of belly solinly sooty brown continuous with same color on head; sides, flauks, lower part of belly and under tail coverts, white; elongated tail feathers as in adult winter plumage. Total length " $20.75-23.00$ ', inches (527-5s4 mm.) (Ridgway, 1900, p. 106); folded wing 8.53-9.40 (217-235); bill along culmen 1.04-1.14 (26.4-2S.9); tarsus 1.35-1.48 (34.3-37.6) (seren specimens from Alaska). Adult female in winter: Most of head and neck 
white, but crown and sides of head and neck usually sooty brown; iris "yellow"; bill "dusky-green" (Audubon, 1843, VI, p. 384); entire uprer surface of boily dusky brown, many of the feathers with broad pale eilgings; outer surface of elosel wing dusky brown; some of wing eoverts anil scapulars with broad ashy endings, these wearing off towarls smmmer; lining of wing anil axillars, dnsky; tail ashy brown; tail feathers pointed hut not elongaterl; fore breast dull grayish brown; entire under surface white, tinged on forepart with gray; feet "dusky-green", (Audubon, loe. eit.). Alult female in summer: Head and neck dark grayish brown; large area containing eye, and another on side of neek, grayish white, the latter with extensions forwart to each sicle of ehin; upper surface as in winter plumage, but forepart of back and seapulars variegated with light brown. Total length ' $15.00-16.00$ '" inehes (381-406 mm.) (Ridgway, loe. eit.); folderl wing 7.90-5.35 (200-212); bill along eulmen 0.92-1.04 (23.4-26.4); tarsus 1.22-1.38 (31.0-35.0) (four specimens from Alaska). Juvenile plumage (both sexes): Somewhat similar to that of summer female, but nearly uniform above; head and neek light lrownish gray, darkest on crown, and more or less indistinetly whitish between bill and eye, behind eye, and on side of neck; bill wholly lusky; back and outer surface of elosed wing, blackish brown; seapulars and speculum slightly more brownish; tail, lining of wing and axillars dnsky; tail blunt-enderl; lower surface inelurling under tail coverts, white; fore breast and sirles light grayish brown. Natal plumage: Top and sides of head, hind neck and whole back, llackish brown, with many lighter hair-like yellowish brown lines; hanl arouml foreneck light brown; small spots above and below eye, lower cheek, chin, throat and rest of lower surface (except band on foreneck), white, clearest on ehin and dullest on belly.

MARKS FOR FIELD IDENTIFICATION-Stoeky build (about size of Shoveller, but with small bill), no white or bright markings on wing, and in winter murh white on head, neek, and under surface. Adult male with two mindle tail feathers greatly elongated (8.50-9.50 inches, 216-241 mm.) and with scapulars eonspicuously pearly white, strongly contrasting with blackish brown of back. Ailult female and all immatures in winter strikingly similar to female Harlequin Duck but with unler surface ineluding flanks aml under tail coverts extensively white instead of deep brown, and white patehes on side of hear less conspienous (see figs. 23 and 26).

Vorce-Resembles the syllables south south southerly or old south smuthrly (Elliot in Forbush, 1912, p. 140); or $\hat{a}-l e \bar{e} d l e-\hat{a}$, $\hat{a}-l^{\prime} \bar{e}^{-} l l e-\hat{a}$, frequently repeater in deep reerlike tones (Nelson, 1887, ]. 73). Mellow call-note of male is aptly imitated by the native name $\ddot{A}$-h- $\bar{i}^{\prime}-70 \mathrm{ok}$ (Grinnell, 1900, 1). 16).

NEST-On ground near water, built of grass and lined with rark-colored down.

EGGS-6 to 10 , nearly elliptical in shape, measuring in inches, 1.93 to 2.36 hy 1.42 to 1.54 (in millimeters, 49.0 to 60.0 by 36.0 to 39.0 ), and a veraging 2.09 by 1.46 (53.0 by 37.0) (139 eggs in U. S. National Museum); color ilull grayish pea-green to dull light olive buff (Davie, 1889, 1. 72).

General distribution-Northern Hemisphere. In North America lireels from islands of Bering Sea and Arotie roast of Alaska to northern Greenlanu, south to Aleutian Islands, easterentral Markenzie, northern Hudson Bay and southeastern Ungava. Winters from the Alentian Islands sonth regularly to Waslington, rarely to southern Califoruia, aud from Gulf of St. Lawrence south to Great lakes and North Carolina; rarely farther south (morlifien from A. O. U. Cheok-list, 1910, p. 77). 
Distribution IN CaLiforNiA-Rare millwinter visitant on hays along the coast as far south as San Diego. The kuown record statious are: Humbolit Bay, Humbolit County (T. S. Palmer, 1589, P. S8); Suisun Marshes, Solano County (J. W. Mailliarl, 1916, p. 85); Point Reyes, Marin County (W. E. Bryant, 1693b, p. 363) ; Marin County (J. Mailliard, 1902b, p. 46) : Sau Francisco (Newberry, 1857, 1. 104; Loomis, 1901, 1. 105); San Francisco Bay near Redwool City, San Mateo County (Littlejohn, 1912, 1. 41); Monterey Bay, Monterey County (Beck,.1907, p. 5S); Santa Barbara (Henshaw, 1576, 1. 274); Los Angeles County (Willett, 1912a, l'. 26); Newport, Orange Connty (Daggett, 1901, 1. 15); San Diego Bay (Belding, MS; Anthony, 1s96, 1. 172).

The Old-squaw has an exceptionally wide general distribution. It is found throughout the Aretic regions of the OId World as well as the new. In North America it breeds most commonly along the Aretic coast from Hudson Bay to extreme western Alaska ant the

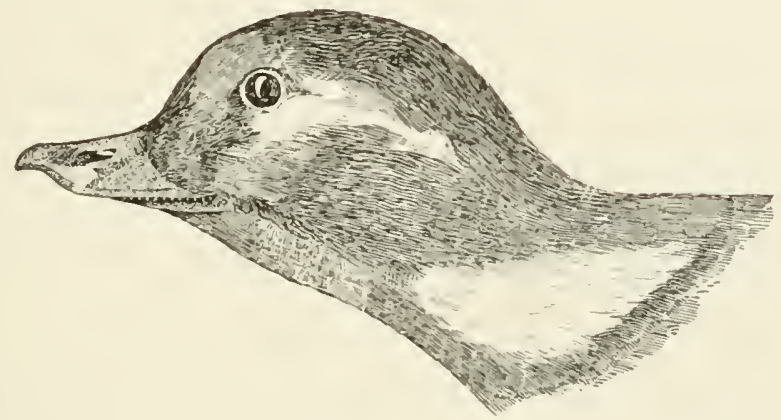

Fig. 24. Head of female Old-squaw. One-half natural size.

Note white area behind eve and another on sile of neck (compare with figs. 23 and 26 ).

nearby islands. Along the coast of Alaska from the Aleutian Islands to Point Barrow this is one of the commonest ducks in summer. The Old-squaw is a hardy species, wintering from the Aleutian Islauds southeast along the coast of southern Alaska to British Columbia and Washington. It is less frequent farther south on the Pacific coast, and the southernmost record station is San Diego Bay. Of the dozen or so records from California all except one (probably of a disabled bird) are of late fall and midwinter dates and all are from along or near the sea-coast. Newberry (1857, p. 104) offers the suggestion that the Old-squaws appearing on our coast are driven this far south by bad weather, for he says that they are only found on San Francisco Bay during the "severest weather." Certain it is that they are not regularly observed within the state, some years furnishing no record whatever. It is possible that they occur more regularly on the open sea and reach the inner bays only during severe storms. 
The mate Old-squaw may be known from all other ducks by its stocky bnild, white and blackish coloration, extremely long and narrow middle tail feathers, and the orange-colored band across its bill. In both sexes the bill is small and narrowed towards the tip, there are no white or bright color markings on the wings, and, during the winter', the head is more or less white. 'The female is quite similar to the frmale Harlequin Duck, but has a much more extensively white under surface, though less conspicnously contrasted white patches on the sides of its head (figs. 24 and 26). Its peculiar, organ-like eallnotes are specially good field eharacters, for the Old-squaw even in winter is a noisy duck.

The phumage changes of this duck seem to be different from those of many other species, for no eclipse plumage is acquired during the late summer molt of the flight feathers (Stone, 1900, p. 20). On the other hand there is every imaginable gradation between the winter and summer phmmage, with frequent so-called "arrested" stages.

The courting anties of this species in southern Alaska are thus commented upon by Dixon (in Grimnell, 1909b, p. 196):

They [the males] were all intonating "auck-quan-tlee" to their utmost capacity and the one that holloed the loulest seemed to stand the best chance, so there was considerable competition. There seemed always to be about three males to one female.

\section{Nelson (1887, p. 73) gives the following deseription:}

The male is often seen swimming rapidly about the female, his long tailfeathers raised to an angle of about 75 degrees and vibrating rapidly from side to side as he passes before the female, uttering the love note at short intervals. If he becomes too pressing in his suit, the female suddenly dives and is instantly followed by her partner, and then a moment later they appear and take wing, and a playful chase ensues, the two living at full speed and flying ahore or below in rapid succession until they are tired. It is common for two or three males to join in this follow-the-lealer kind of game after the female, and in the end the latter usually flies to some secluded pool with her choice, while the discomfited suitors move off in searcl of some easier prize.

In western Alaska nesting begins early in June and young are to be seen by the end of the same month. W. Pahmer (1899, p. 378) found nests on the Pribilof Islands placed almost anywhere on the flat gromed near ponds, but usually on some small rise. They were built of grass and lined with hackish down.

From the Jukon delta along the coast in earh direction their nests are almost invariably placed in close proximity to a poni or tile ereek-the sloping grassy hank of the ponds being a favorable loration. The parents always keep in the immediate neighborhool and swim anxionsly about in the nearest pond when the nest is approached. An numsual amount of dry grass stems and down plucked from the parent's breast composes the nest, and if the eggs are left they are carefully hidlen in the loose matrial. 
The young are fomm the millle of Augrist about the ponds and marshy lakes, some only a week or so from the shell and others alreaty trying their wings. As fill approarhes young and old are most common along the shores of the inner bays and among the tide-ereeks (Nelson, 1Ss7, p. 73).

The Olel-squaw seenss well adapted to its northern home, in which, rinter and summer, it is exposed to extremes of rigolous weather. In its main winter habitat far to the north of us, it is most often found in gool-sizul flocks and sometimes bands together in rery targe flocks. esperially when there is little open water. Flocks may often be seen resting on calkes of ice. It is an "xtromely noisy anck, for besides the musical notes it keeps up a constant "gabbling," especially at night. Arctic explorels welcome the Ohl-syuaw, for, with the approate of summer. its notes ale anong the first to break the monotony of the nortleen solitudes.

In Hight the Old-sfluaw moves its wings with short, rapid strokes. Indivinluals of this speeies often eirele high in the air, apparenty in play, a habit whieh is called "tomering." So erratic is there flight on such occasions that birds have ben shot in the back when flying overherad: "As spring approaches, whole flocks of Old-squaws may be seren to leave the water and "tower" to the regions of the upper air, swinging in wide eireles, smrmounting leight after height, until almost lost to view, when they turn and plunge downward, hurtling through the air in arrowy flight, sometimes straight downurd, sometimes zig-zagging willly, until they rest again on the surface of the sea " (Forbush, 1912, p. 14:3). The manner of alighting on the water by suddenly dropping in with a great splash is very characteristic of the species. Not only is the Old-squaw noted for its swift flight, but also for its diving ability. So quickly does it dive at the flash of the gun that it is considered one of the most difficult of ducks to kill on the water. Its diving propensities are further evidenced by the fact thit it has been taken in gill nets set in deep water eighteen and twenty fathoms below the surface. At Erie, Pemnsylvania, eight hundred of these ducks are said to have bern netted in a single hanl (Bacon, 1892, p. 45).

As is the ease with other ducks, the food of the Old-squaw varies with the feeding grounds. "In shallow water near the coast it collects mollusca, crustacea, fish, and marine insects. In a few instances the remains of the common mussel and shrimp are found. In the summer its stomach is usually filled with fresh-water insects" (Baird, Brewer and Ridgway, 18s4, II, p. 61). In the interior (Akron, Ohio), angleworms and insect larvae have been found in stomachs (Haynes, 1900, pp. 12-13). Certain marine plants are also taken as fool.

The flesh of the Old-squaw is tough and of very poor flavor. Tet in the eastern states, because of its abmulance and the sport afforded 
in bagging the bird, it is loeally considered a good game speeies. Its flesh is so lark and rank that shooters sometimes do not tronble thenselves to pick up the dead birds. Its down is said to be of excellent quality, but little inferior to that of the eider.

Even if the Old-squaw were more nmmerous in California it would not be eonsidered a desirable game bird because of its almost total unfitness for table use. This is espeeially true in this state, where many more desirable speeies yet remain. As it is, the status of this duek within the state has probably remained unaffeeted, for, as far as we know, it has never oecurred in large enough numbers to attract the particnlar attention of the hunter.

\section{Harlequin Duck}

\section{Histrionicus histrionicus (Limnaeus)}

OTHER NAMES - Histrionieus torquatus; Histrionicus mimutus; Cosmonetta histrionica.

Description-Adult male: Head and neck, dark slate blue, relieverl by various conspicuous markings; stripe from base of bill over milllle of crowll to back of heal, black, forming a low ridge ou tol of hear; stripe on ear.h side from above eye to back of head, reddish brown, the two almost meeting to form a $\mathrm{T}$-shaper borler about hinder portion of rentral black stripe; large triangular patch at side of bill in front of eve, straight-bordered behind, and narrow stripe from upper corner of triangular patch to above eye, both white; rounded spot below and behind eye, and oblique stripe on side of ueck, white; all white markings black-bordererl; throat sooty black; iris "hazel"; bill "bluish-black," tip "bluish horn-color", (Nelson, 1887, p. 74); collar arounl lower neck, divided on breast and hind neek, white, horlered above by broad band of black with steel blue sheen and below hy narrow band of dull black; rump black with steel blue sheen; tail rather long, conspicuously pointed and blackish slate in color; onter surface of closer wing leep slate; flight feathers blackish brown; two small roundish white spots on wing in front of speculum, one on greater and one on mildle coverts, the latter often concealed; speculum dark metallic blue with violet reflections, hordered above by feathers having their expanded outer webs white, outwardly edged with black; axillars and under surface of wing lusky brown; feathers of seapular area centrally white, together forming a white stripe on either side of back; conspicuous transverse white bar on each sile just in front of bend of wing, borlered in front and behind with paralleling black bands; sides behind bend of wing. and flanks, rich redilish brown; whole lower surface slaty brown, becoming lusky on belly, and clearer slaty blue on breast; under tail coverts black with steely reflections and with a small roundish white spot on each side neal hase of tail; legs and feet "dark olivaceous brown," webs "black", (Nelson, loc. eit.). Ectipse plumage: Conspicnous hear markings absent or replaced by duller colors. Similar to adult female, but general color of hear llarker; cheeks and crown approaching slaty black; whole back, rump and seapulars, clark brownish slate; wing, however, as in summer plumage, lint raggel from wear and molt; new flight feathers almost black; whole lower surface slaty brown; white transverse bar across sile of chest in front of wing and chestnnt-colored area 
on sile earli representel by few feathers. Total length 17.75 inches ( $451 \mathrm{~mm}$.) (one specimen from Alaska); folded wing $7.62-8.27$ (193.5-210.0); bill along culmen $1.0+1.15(26.4-30.0)$; tarsus $1.45-1.52(36.5-35.6)$ (ten specimens from Alaska). Adult femule: Extremely somber-hued: Head and neck ehiefly olive brown, larkest on erown, lightest on ehin and throat; spot above and in front of eye, another below and behiud eye, and broall area on cheek between base of bill ani eye, dull white, more or less flecked with brown: whole of upper surface, wings, tail, silles, chest, and uniler tail coverts almost uniform olive brown; lower surface grayish brown, whitish towarls mill-line, and usually with a mottlel pattern lue to hroal white feather ends. Total length 15.50 inches ( $34+\mathrm{mm}$.) (two specimens from Alaska); folded wing 7.00-7.5.5 (17s$192)$; bill along culmen $0.95-1.04$ (24.1-26.4); tarsus $1.34-1.39$ (34.0-35.0) (five specimens from Alaska). Juvenile plumage: Male: Similar to that of alult male but with markings less distinet, white not well defined and blue-black absent; speculum dull gray without gloss; unler surfare grayish white, each feather markel with a transverse spot of gravish brown; silles amil flanks grayish brown, without cliestunt color; "ollar around lower neck imperfect. Female: Similar to that of alult female but upper surface larker anil lower surface more hrowntinged (Sanforil, Bishop and Van Dyke, 1903, 1). 157). Natal plumaye: "Top of heal and upper parts, blackish brown: face and neek, white; unier parts and a spot on each wing aml thigh, white" (Sanford, Bisholl and Van Dyke, 1903, p. 158).

MARKS FOR FIELD IDENTIFICATJON-Size merlium (about that of a Scaup), bill very small, tail short and pointed, general coloration very dark, below as well as ahove. Male has several conspicuous white patehes on silles of hearl (fig. 25) and boly, as also a white collar around hind neck, a white bar across sille of chest, anil a white pateh on wing. Female dull brown with dull white spots on hear, the most conspicuous one below and hehind eye; no white on wing. Females of both Buffle-head and Old-squaw have white streak directly behind eye (compare figs. 23,24 and 26 ).

Vorce-Sellom heard; in flocks: "a confusion of low gabbling and chattering notes" (Nelson, 18s7, p. 74).

NEST-On ground under logs, driftwood or rocks, sometimes in stump near water, and lined with town.

EGGS-5 to 10, roumlerl oval in shape, and averaging in inches 2.30 by 1.62 (in millimeters, 58.5 by 41.1 ) ; color yellowish buff or greenish yellow (Davie, 1889, p. 73 ; and authors).

Gexeral distribution-Northern North America and eastern Asia. In North America breeds from the Kowak and Yukon rivers, Alaska, the Aretie coast, and Greenland, south to southwestern British Columbia, central Mackenzie, northern Ungava and Newfoundland, and, in the mountains, south to central California anil southwestern Colorato. Summers in flocks near Aleutian Islands and along coast of Washington. Winters on Pacific coast from Aleutian Islanis to central California, in the interior to Colorarlo, and on Atlantic coast from Gulf of St. Lawrence to Maine, rarely farther south (morifiel from A. O. U. Check-list, 1910, pp. 77-78).

DISTRIBTTION IN CALIFORNIA-Irregular winter visitant coastwise in northern and central portions of the state. Known instances of oceurrence are: Humbolit Bay (F. J. Smith, MS); Bollega Bay (Belding, 1891, p. 98); Tomales Bay, abundant in fall (Mailliard, MS); Point Reyes, Marin County, flocks in June (J. Mailliard, 1904, p. 15); Monterey (Loomis, 1895, p. 222; 1900, p. 362); Point Carmel, Monterey County (Beck, 1910, p. 69). Breeds sparingly along 
secluded streams of the Sierra Nevada in central California: on Stanislaus and Tuolumne rivers (Belding, 1891, p. 97); Griswolel Creek, tributary to Stanislaus River, Tuolumne County (Beliling, MS); South Fork of Tuolumne River, near Crockers, 20 miles northwest of Yosemite Valley (Belding, 1891, 1. 97). Rejorted to have lored in Yosemite Valley (C. C. Bull, MS).

No other duck has such an odd dress and few have snch an extraoldinary mode of life as the Harlequin Duck. Its rarity emplasizes its miqueness to such an extent that it is a bird much songht after by the collector of game trophies.

The breeding range of the Harlextuin Duck is usually given in general terms as northern North America and eastern Asia; ret it is notably discontinnons. Records of breeding are known from such widely separated points as the Kowak and Yukon rivers, Alaska,

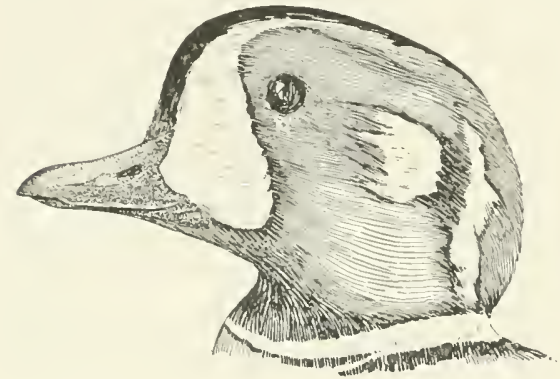

Fig. 25. Hear of male Harlequin Dnek. One-half natural size. Greenland and leeland, soutlwestern British Columbia, eentral Mackenzie, norther'n T'ngava, and Newfoundland, and the monntains of cuntral C'alifornia and southwestern c'olorado. Bircls believed to be non-breeder's have been reported during the smmmer season from the Pribilof and Alentian islands, the Sitkan distriet of Alaska, and the coasts of Washington and California. This duck winters along the Atlantic coast chiefly from the Gulf of St. Lawrence to Taine, and in the interior in Colorado and Missouri, and on Lake Michigan. On the Pacific coast it winter's from the Aleutian Islands to Monterey Bay, California. Along the Asiatic eoast it is to be foumd as fal sonth as Japan, but it is of only accidental oecurrence in Europe.

The Harlequin is apparently a resident species in California. During the winter season it oceul's only along the seacoast, about rocky headlands as far south as Monterey Bay, and a few birds. probably non-breeders, are seen in these same hamts in summer. Many of our winter contingent of Harlecquins probably migrate north of the Canadian boundary to breed. but a certain number pepair for the smmmer to the swift-flowing momtain streams in the Sierra Nevarla in the vicinity of which they nest.

So distinctive is the make Harlequin in its eolomation that after once being identified it is one of the easiest of our ducks to l'erognize, exen at a distance. The general dark coloration. wholly blackish slate ahove and slaty brown beneath, with irregular and conspienous lines and patches of white on the head, wings, and side of hody, imme- 
diately separate this from all other ducks. The small bill, sharply pointed tail, and bright hazel brown sides, are also characteristic. The female and young are ineonspienous birds of plain eoloration. The very small and short bill, pointed tail, lack of any sort of white markings on wing, and the two whitish spots on each side of head, are the only definite markings which distinguish the female. As compared with the Seoter's the Harlequin when swimming is much more buoyant, its body appearing to sit higher out of the water.

The seeker of rare birds eggs might well bend his endeavors to the discovery of a nest of the Harlequin Duck; up to the present time no one has found the eggs within this state, and indeed, sets taken anywhere are rare in collections. Belding (MS) says of the Harlequin in California :

I have noticed many of these ducks on the juincipal streams of Calaveras and Stanislaus counties in sum. ner in each of the past six or seven years and sent a juvenile to the Smithsonian [Institution] which I shot luere in 1879 or 1850 . I find young broods from about 4,000 feet upward, the earliest apparently hatehen about the first of June or earlier, and have often surprised

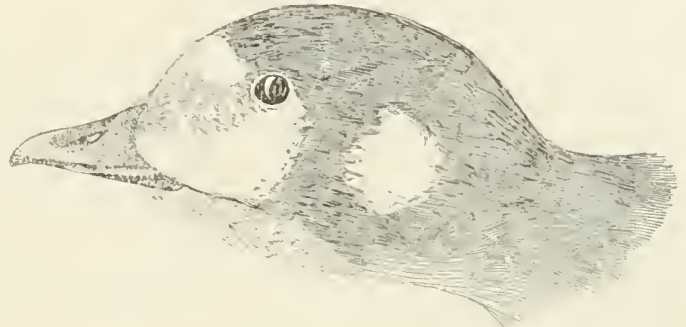

Fig. 26. Heal of female Harlequin Duck. One-half natural size.

Note white between bill and eve and white patch in region of ear.

the mother ducks with their

broods when hidden in Saxifrage ( $S$. peltata) which grows profusely in parts of the mountain streams, sometimes approaching within a few feet of the brood ere I alarmed it, when all would hurriedly swim from me. vigorously using botll feet and wings to propel themselves against or with the rapid currents, not hesitating to tumble over a moderate sized cataract when auxious to escape from danger, or, even, when following the streams without such impetus.

Dr. Huse saw a female Harlequin with a broor of ducklings on Griswold Creek [Tuolumue County] in 1881 or 1882, and J. Clarence Sperry and Horace Pillsbury caught a juvenile from a flock of the same, which coull not fly, on the same creek, in the summer of 1589. The most southern point where it has been captured in California is the south fork of the Tuolomne River, where I got . . a male and female-May 15, 1891 (Belding, 1891, 1. 98).

Belding (MS) thinks the California birds breed among the rocks. Kaeding states that he knew of two pairs of Harlequin dueks nesting in 1896 in Tuolumne County at an altitude of 4,600 feet. The nest site for the previous year was found but he was unable to locate the site of the 1896 nest. Later he found that at least one of these pairs had brought off a brood. On a mountain journey of a hundred miles 
the same year only three pairs were seen and these at widely separated loealities. They frequent the iey, turbulent mountain streams, seeming to share with the Ouzels a love for the noisiest parts of the rivers. During the breeling season they are rery shy and retiring, being seldom seen in pairs, the male and female remaiming separated and frequenting different parts of the stream (Kaeding, 1898b, p. 77 ).

Raine (in Maeoun and Maeoun, 1909, p. 106) describes a nest found on the Mackenzie River as being ". . . built on a high bank near some ice-floes, muder stieks piled up by the overflow water in the spring." 'The eggs are deseribed as being similar to those of the Gadwall and Baldpate, but are of a deeper buff tint and average larger. All aceounts seem to agree that this duck nests as a rule on the ground near swiftly-rumning streams; yet in Newfomdland nests have been found in hollow trees.

The Harlequin Duck is rare enough in the United States to excite keen interest, especially when found on its breeding grounds. A little flock of the richly barred and spotted beauties fishing in a foaming mountain stream, diving, bobbing on the rough surface, drifting or darting down over the rapids, and then gathering in a bunch below to fly back up stream for another descent, suggests a lot of schoolboys on a coasting party rather than a flock of birds engaged in the serious business of getting breakfast. They seem to enjoy the icy water and their power to dare and buffet its torrents (V. Bailey in Bailey, 1902, p. 62).

Belding (1891, p. 9S) deseribes his first sight of this rare duck in California, diseovered while hunting with a companion in the Sierras in 1879, as follows: "While we were separated, a strange duek which he had probably frightened, but did not see, flew down the camyon and alighted within twenty yards of me, bent its neek forward elose to the water, lifted its wings and uttered a seream I had never heart." Belding states further that he has often seen this duek sinee that time on the Stanislaus River, and has oceasionally seen it on other neighboring streams but that of late vears it has become rare owing to its destruetion by fishermen, who shoot the birds on sight.

Mailliard (MS) states that in the fall of 1913 humdreds of young Harlequin Ducks were to be seen in seattered flocks on Tomales Bay, Marin County. At the same time adult males were noted on the open oeean off Tomales l'oint. In Jume, 1880, many were seen on the water just outside the surf at Point Reyes.

A further irlea of their habits when found along the seaeoast ean be had from the following quotations, which apply to Alaska: "At Coronation Istand many were seen feeding among the rocks at the water"s edge, and were very tame and easily approaehed. . . . At 
this time, Jume 9 to 14 , they were all in pairs, but usually two or three pairs seemed to stay together" (Swarth, 1911, p. 44). "They spend much time out on the open water with other speeies of ducks, but frequently leave their company to visit the months of small streams or to aseend them for eonsiderable distanees. When slightly startled on a stream they do not $f y$, but keep at a safe distance from danger by allowing the current to carry them down stream, unconcernedly passing through riffles and rapids and deftly avoiding, without apparent effort, the roeks and whirlpools"' (Osgood, 190t, p. 58). "Mr. Elliott found them common on and around the shores of the Fur Seal Islands. There they were in the labit of 'idly floating amid the surf in flocks of fifty or sixty, or basking and preening on the beaches and outlying rocks" "(Nelson, 1887, pp. 74-75).

The Harlequin Duek is an expert swimmer and diver. It is even said to dive from the wing into the water and to emerge Hying. Most observers testify to its being a playful duck, its every action betokening the greatest enjoyment. Harlequins are more buyant than many of the other dueks and eonsequently sit higher in the water.

Belding (MS) states that when inland the fool consists chiefly of aquatic insects, to judge from the few stomachs he examined. IIe does not believe Harlequins eat many trout, if they consume these fish at all. Along the coast this duck feeds largely on mussels and other shellfish obtained by diving. But other marine animals are apparently obtained in the surf. Grimnell (1909b, p. 196) says that at Chichagof Island, Alaska, this speeies was found to feed extensively on isopod crustaceans which were gathered at high tide from under stones on the beach.

Young Harlequin Dueks taken in the high mountains are said to be very palatable. Adults are rarely so because of their marine fare throngh the winter months. Neither is the speeies eonsidered seriously as game-but this is because of its rarity here. The bird's chief claim for interest lies in its striking coloration, and, with nature lovers and naturalists, in the peculiarities of its distribution in the state.

The testimony of Belding, who knows most about this duck as a breeding bird of California, is to the effect that it has been greatly reduced in numbers. Present conditions favor still greater reduction so that the early extinetion of the native contingent within the state seems almost a certainty. It is probable that a part, at least, of the coastwise representatives are migrants from the north, and these are more likely to hold their own. An absolnte elose season for a term of years might aid the Harlequin in recouping its number's. Certainly no huntsman would have his sport greatly restricted by the establishment of such a season for this species. 


\section{King Eider}

\section{Somateria spectabilis (Limnaeus)}

DESCRIPTION- Llult male: 'Top of head uniform pearl gray, slightly desper tonel on hind neek; lorder along swollen base of upjer mandible glossy blark; iris "bright yellow", bill "flesh-colourea," sides of upper mandible and swellings on each sile of forehead "bright yellow" (Autubon, 1843, V1, 1. 348); theeks pale sea-green; eyelid, small spot under eye, and V-shaped forward. pointing mark on throat, black; rest of head, neck, upper back and fore breast creamy white, the last named area tinged with buff; lower back, scapulars, and sides and under surface of bodr black: large patch on each side of rump white; wings and tail blackish brown; large patch on forepart of onter surface of closed wing white; feet "dull orange," webs "dusky," claws "brownish-black" (Auclubon, loc. cit.). Total length 22.25-24.00 inches (565-609 mm.) (ten specimens in Acad. Nat. Sci. Philadelphia); folded wing 11.15 (283); bill along culmen 1.40 (35.6); tarsus 1.77 (44.9) (one specimen from Alaska). ddult female: Whole head and neck, cinnamon buff, finely streaked with black, most thickly on top of hearl; iris "Anll yellow"; bill "pale greenish-grey", (Audubon, ]oe. cit.); back brownish black, with conspicuous feather edgings and tiplings of ochraceous tawny and cinnamon buff; rump, cinnamon buff with U-shapel narkings of black; onter surface of closed wing browish black, with conspicuous feather edgings and tiplings of ochraceous tawny and cimnamon buff; flight feathers and speculum blackish brown, the latter outliner in front and behind with hars of white; tertials broadly edged on onter margins with eimmamon; axillars and part of lining of wing, white; rest of unier surface of wing, brown; breast and sides and under tail coverts, cimnamon buff, with U-shaped markings of black; belly, sepia brown; feet "dull ochre", (Aukubon, loc. cit.). Total length 20.75-22.25 inches (527-565 mm.) (six specimens); wing 10.75 (273); culmen 1.25 (31.7); tarsus 1.75 (44.4) (one specimen); all in Acad. Nat. Sci. Philadelphia, from Alaska. Jurenile plumage: Somewhat like that of adult female, but with head and neck pale gray clnlly streaked, axillars and area on lining of wing grayish white, and rump and whole lower surface obseurely barred with blackish brown and inll buff, the pattern finest on belly. Natal phmage: Whole upper surface, leaden brown; lower surface, a paler tone of same color, lightest (almost white) on lower breast and belly.

MARKS FOR FIELD IDENTIFICATION-Large stout horly (resembling Sicoters); male with chiefly whitish foreparts, the rest of hody hlack, with white areas on wing and side of rmmp. Female with no white whatever, brown-toner, finely streaked on bead and barred elsewhere.

VoleE-(?)

Nest-On ground among rocks or shrubs, usually close to salt water; 1.omposed wholly of down.

EgGs-6 to 10, elongate ovate in shape, measming in inches 2.77 to 3.08 lox 1.Ss to 2.07 (in millimeters, 70.3 to 78 . 3 by 47.7 to 52.5 ), and averaging 2.94 ly 1.95 (74.6 by 49.6); color light olive gray to grayish green (one set, six eggs, in Mns. Vert. Zool.).

General distribution-Northern part of Northern Hemisphere. In North Ameriea, breeds along Aretic coast from ley Cape east to Melville Islanil, Wellington Chamnel, northern Greenland, northwestern Hudson Bay, and northern Ungava. Winters on Paeific poast from Alentian Islands to Kouliak Islanu, 
in the interior rarely to the Great Lakes: and on Atlantic coast from southern Greenland and Gulf of St..Lawrence south regularly to long Islanil, rarely to Georgia. Accilental in California and Iowa (mollifiel from A. O. IT. Checklist, 1910, p. So).

DISTRIBUTIUA IN CALIFORNIA- Very rare winter visitant roastwise. Two definite recorts: One taken off Black Point, San Francisco, in winter of 1s79-s0 (IIenshaw, 18s0a, p. 189) ; and female taken on Suisun Marshes, Solano County, between October 15, 1902, and February 1, 1903 (Loomis, Ms).

The Ting Eider is of but extremely rare ocenrenee in California, appearing here only as a straggler from the far north. Its breeding gromnds are in the Aretie regions and south into Bering Sea. It winters abundantly among the Alentian Islands south to the Shumagin Islands and Kodiak Island, and in smaller number's to sontheastern Alaska.

There are but two definite records of the King Eider for California, the first of a specinen taken by 1). S. Bryant, off lilack l'oint, San Franciseo, in the winter of 1879-80 (Henshaw, 1ss0a. 1. 189). The second and more reeent instanee, is of a female said to have been brought in from the Suisum marshes, Solano County, in the winter of 1902-03. The bird was mounted and was on exhibition in foleher Brothers'store, San Franciseo, until the fire of 1906 (Isoomis, MS). A further rumor is at hand of an Eider of some species having been seenred in Jammary of February, 1910, off the heads west of Sansalito, Marin County. This was a male, and was mounted and reported to have been deposited in the Golden Gate Park Musenu.

Eider's are large, heavily built ducks, recalling the Scoters. The male King Eider has the fore part of the body (hearl, neck, upper back and breast) wholly white appearing, and there is a large white area on each wing and on each side of the rump. The rest of the plumage is black. The female and young are without conspicuous markings, and have a finely streaked pattern on the head and a barred pattern elsewhere. In hand, the King Eider in any plumage may be distinguished from other eiders by the extension of feather's on the eulmen as far forward as the nostrils, while on the sides of the bill the feathering goes only about half way to the nostrils.

The following description of the peculiar head of the male is given by Forbush (1912, p. 152): "The raised frontal processes at the base of the bill, which adorn the head, develop immensely in the breeding season, bulging high above the rest of the bill. These processes are soft, and are supported upon a mass of fatty substance. They shrink and become more depressed in winter, when the general formation of the beak is not much different from that of other eiders."

MacFarlane (Baird, Brewer and Ridgway, 1884, II, pp. 87-88) found the King Eider nesting near the beach in the neighborhood of 
Franklin Bay on the Aretic coast. The nest was a mere depression in the ground fifty yards from the beach and composed entirely of down.

It [the King Eider] is a deep water luck and feerls mostly on mussels which it is able to procure, it is said, in water upward of 150 feet in depth, and oceasionally is caught like the Old-squaw in the deep water gill nets of the lake fishermen. In the breeding season the males go into the "eclipse" plumage and flock together on the open sea. The female lines her nest with down as do the other species of eider, thus furnishing the famous eider down of commerce, which is gathered by the natives of Iceland, Greenland and Norway. This is taken chiefly from the Greenland and European eiters, each nest yielding about five ounces of down in a season (Eaton, 1910, p. 220).

The King Eider even in the far north is of little value as a game bird, so its extreme rarity within our state is of small consequence to hunters. Oceurrenees as far south as California are of interest ehiefly because they are out of the ordinary. No economic importance can be ascribed to a bird of such rarity.

\section{American Scoter}

\section{Oidemia americana. Swainson}

OTHER NAME-Black Scoter.

Description-Adult male: Entire plumage glossy black; wing and tail feathers becoming sooty brown with wear; swollen base of upper manilible to front of nostrils "bright orange," rest of bill black; iris "brown" (Aulubon, 1843 , VI, p. 345); legs and feet dull black. Total length (both sexes) " 17.00 21.50 "' inches (432-545 mn.) (Ridgway, 1900, p. 111); folled wing 9.20 (233); bill along culmen 1.65 ( $\$ 1.8$ ); tarsus 1.77 ( 14.9 ) (one specimen from Alaska). diult female: Top and back of head, hind neck, and upper surface of body, dark brown, larkest on top of head and on tips of primary wing feathers; bill hlack; sides of hearl and neek and whole lower surface of boily, mottled light brown and grayish white, lightest on head and neck aud darkest on chest and uniler tail roverts, this pattern produced by feathers being brown at base with tips broally dull white. Total length 18.75 inches ( $476 \mathrm{~mm}$.) (one specimen); folked wing 8.30-8.87 (211-2.25); bill along culnen 1.60-1.62 (40.6-41.2); tarsus 1.64-1.6s (41.7-42.7) (two specimens, one from California). Juvenile plumage: "Upper parts, jugulum [=foreneck], sides, and flanks, uniform dark grayish brown; siles of liead and neck, chin and throat, dirty whitish, tinged with brownish gray, quite abruptly defined against the dark brown of the pileum and nape [=top of head and back of neck]; abdomen whitish, each feather marked with a lusky grayish brown bar just beneath the surface, some of these bars exposed; aual region and arissum [=uniter tail coverts] grayish brown, the feathers tipped with white. Bill anl feet black", (Baird, Prewer and Rirlgway, 1854, 11, p. s9). Natal plumagc: "Lpper parts and hreast dark brown; lower parts, lighter lrown; throat, white", (Sanforl, Bishop' and Van Dyke, 1903, p. 175).

MARKS FOR FIELD IDENTIFICATION-For Scoters in general: Large size and black or very lark eoloration. For American Seoter: Male wholly black, and bill black with orange-colored base; female very dark brown above, without 
white on wing or side of hear, and unler surface of boly (inclurling eheeks and chin) coutinuously pale colored, not broken into patches.

VoICE-"A musical whistle of one prolonged note"' (Mackay, 1591b, p. 284).

NEsT-On ground, sometimes hidlen in eliffs or in hollows of steep banks; male of dry leaves, grass, feathers and down.

EgGS-6 to 10 , orate to elliptical ovate, measuring in inches 2.42 to $2.68 \mathrm{by}$ 1.79 to 1.81 (in millimeters, 61.5 to 68.0 by 45.5 to 46.0 ), and averaging 2.5 .5 by 1.80 (64.9 by 45.7 ) (five eggs in U. S. National Museum); eolor pale ivory yellow; surface smooth but not glossy.

General distribution-Northern North Ameriea and eastern Asia. In North Ameriea breeds from Kotzebue Sound, Alaska, south to the Aleutian Islands and also on west shore of Hudson Bay, in Ungava and Newfoundland, but unknown in the distriet from Yukon Territory to IIulson Bay. Winters on the Pacific coast from Bering Sea south to southern California; in the interior sparingly on the Great Lakes and easually south to Louisiana; amd on the Atlantic coast from Newfoundland to Florida. Non-breeding birds may remain during the summer as far south as Rhole Island and eentral California (modified from A. O. U. Check-list, 1910, 1) S1; Cooke, 1906, pp. 59-60).

Distribution IN CALIFORNA-Rare winter visitant roastwise. Restricted to salt water. The following instances of oceurrence are kuown: Areata Bay, Humbolit County, February, 1914 (F. J. Smith, MS) anul December 24, 1915 (Mus. Vert. Zool.); San Franeisco (Newherry, 1557, p. 104); San Francisco Bay near Redwool City, San Mateo County, January 17, 1909 (Littlejohn, 1912, p. 41); off Point Pinos, Monterey County, November 1 and 4, 1909 (Beck, 1910, p. 69) and Octoher 27, 1910 (Beck, MS); Norro Bay, San Luis Obispo County ( A. K. Fisher, 1893a, p. 18); San Luis Obispo, spring, 1566 (Richmoni, 1916, P. 83) ; Santa Barbara (Cooper, 1887, F. 87); coast of Los Angeles County and Santa Catalina Island (Grinnell, 1898, p. 12).

The American Scoter is a bird of the subarctic sea coasts and even in those regions is abundant only locally. On the Pacific coast it breeds from the Aleutian Islands north to Kotzebue Sound and northeastern Alaska. The American Scoter is the least common of the three species found in carly spring in sontheastern Alaska (Swarth, 1911 , p. 44). During the winter it migrates southward in small number's as far as Califormia. Non-breeding birds are occasionally recorded from the winter range during the summer. First spring arrivals have been noted at St. Michael, Alaska, on May 16, and at Kotzebue Sonnd on June 3. On the coast of California records are too infrequent to warrant statements as to times of migration. There are no interior records for this state.

Scoters really deserve the name of "black ducks" for they are certainly the blackest of their tribe. From their habits they are often called "Scooters." Typical sea ducks, they are to be found almost entirely on salt water. All three species associate together more or less, and are of about the same size and general behavior, so that they would be difficult to distinguish were it not for certain prominent field marks that make identification of the males fairly easy. The male 
American Scoter is the only one which lacks any sort of white patch on its miformly black plumage. The female and young of this species can be separated from those of the White-winged Scoter by the lack of white on the wing, and from the Surf Scoter by their dingy cheeks and throat instead of the whitish-patehed ones found in the latter species. With specimens in hant, of any age, the squarely restricted feathering at the base of the bill is a good distinguishing feature of this species.

In western Alaska ... a nesting site [is] "hosen on the border of some pond. The spot is artfuly bidden in the standing grass, and the eggs, if left Jy the parent, are carefully covered with grass and moss. As the set of eggs is completerl, the male grailually loses interest in the female, and soon deserts ler to join great flocks of his kind along the seashore, usually keeping in the vicinity of a bay, inlet, or the mouth of some large stream. These flocks are

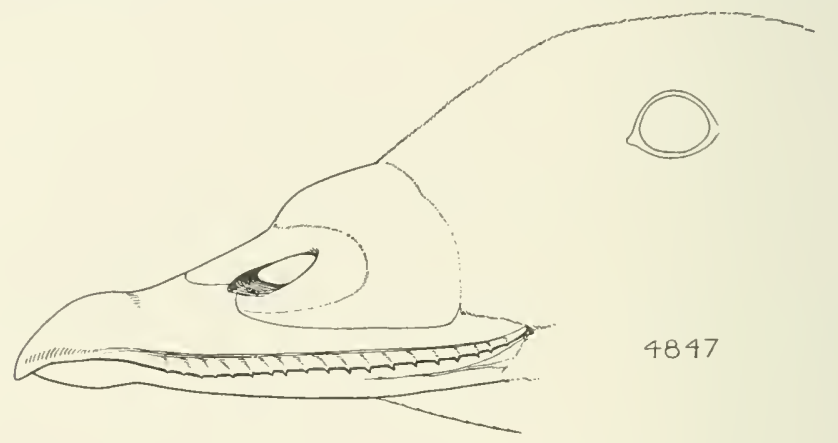

Fig. 27. Sitle of bill of male American Scoter. Natural size.

formed early in June and "ontinue to grow larger until the fall migration occurs... At the Yukon mouth Dall found a nest of this species on June 17. The nest contained two white and rather large eggs, and was in a bunch of willows on a small island, and was well lined with dry grass, leaves, moss and feathers (Nelson, 1887, p. S0).

At St. Michael, Alaska, a set of fresh eggs was taken on Angust 3, and a brood of downy young was obtained on September 9.

Tutil the young are about half grown the female usually keeps them in some large poul near the nesting place, but as August passes they gradually work their way to the const and are found, like the eiders of the same age, along the reefs and ahout the shores of the inner bays until able to fly (Nelsou, 1587, p. 81).

Scotens feed almost entirely on mussels, and fishermen are said sometimes to locate beds of shellfish by searching ont places where Seoters congregate. The birds are excellent divers and can forage in water forty feet in depth. "When wounded and elosely pursued, 
they will frepuently dive to the bottom (always using their wings as well as feet at snch times in swimming muler water) and retain hold of the rock-weed with the bill until drowned. . . I I have also seen all three species [of scoters] when womnled dive from the air, entering the watel withont any splash" (Nackay, 1891b, pp. 282$283)$

Sicotris may be realily deeoyed, and were it not for their oily, strongly flavored flesh, they might be considered desirable game. But their unfitness for use as a table birt makes them of ordinary interest only in so far as they afford a mark for the gumner. As the American seoter does not appear in any numbers on the California coast, it is negligible here from an economic standpoint.

\section{White-winged Scoter}

\section{Oidemia deglandi Bonaparte}

Otner Xines-White-wingerl ('oot; Black Surf burk; Vehret 1)urk; Klondike Mallaril: Oidemia fused: Melenetlu volvetinu.

DESCRIPTION-Adult male: Iniformly blark, tingerl with brown on siles and belly; wings black, speculum ahruptly jure white; crescentic spot immediately below and behind eye, pure white: iris "bright yellow"': silles of upper nuandible featheref almost to nostrils: prominent knob at base of rulnen, ancl margius of both mandibles, black; silles of upper manlible rerl, sharling to orange on culnen and hase; uail "flesh-colour"; lower mandille black; feet "orange-rerl," webs "grevish-black", (Audubon, 1543, YI, J. 336). Total length (loth sexes) " $19.75-23.00$ ", inches (501-58.3 mm.) (Rillgway, 1900, p. 112). Males: follerl wing $10.75-11.10$ (273-282); bill from tip to limit of feathers on vulmen 1.54-1.66 (39.1-42.2); tarsus 1.96-2.05 (49.5-52.2) (five specimens). Adult female: Heal hownish black without any conspicuous white spots; rest of plumage dusky brown, lighter on lower surface; speculum pure white: bill dull black; iris "dark"; legs anı feet "brownish red"; wels "lusky" (Sanford, Bishop and Tan Dyke, 1903, 1. 178). Folled wing 10.4010.75 inches (264-273 mm.); bill from tij to limit of feathers on culmen $1.41-$ $1.55(35.5-40.2)$; tarsus $1.75-1.51$ (45.2-45.9) (three sperimens); all from California. Jurenile plumage: Dark sooty brown, becoming black on top of hear and back, and lightest on rentral part of lower surface llue to narow feathererlgings of dull white there; iris brown; speculum white as in adults; legs and feet (aried) dull blark. Natal plumage: Black, chin white (Bairl, Brener and Ridgway, 1s\$4, II, p. 96). Note.-By wear, juveniles become ashy white on lower surface of body and also locally on sides of hear. At post-juvenal molt males assume only a partially black plumage, some of the old, worn, palecolorer, plumage persisting in irregular patches on lower surface of body. The bill gradually accuires adult form lluring the first year. Tear-old birls in incomplete arlult plumage are the ones most often found in California luring the summer season.

MARKS FOR FIELD IDENTIFICATION-Large size, thick body, short stout hear ant nerk, black or black-appearing coloration, white patelies on wings, anct absence of white on back of hearl. Sits rery low when resting on water. 
VoICE-None, so far as lefinitely known; said to utter a low quack (Mackay, $1891 b$, p. 284).

NEST-On ground concealed by shrubs, and usually near fresh water; constructed of "rubbish" and lown (Bent, 1902, p. 171).

EGGS-6 to 14, ovate in shape, measuring in inches 2.60 to 2.86 by 1.69 to 1.85 (in millimeters, 66.0 to 72.5 by 43.0 to 47.0 ), ant averaging 2.72 by 1.81 (69.0 by 46.0 ) (twenty-one eggs in U. S. National Museum); color pale salnon buff or flesh-color (Bent, loc. eit.).

General Distribution-North America and eastern Asia. Breeils from northeastern Siberia along Aretic coast of America to northern Ungava, and south to central British Columbia, northern North Dakota and southern Quebec; winters on slores of Pacific Ocean from Aleutian Islands south to China aurl to southern Lower California, in the interior on Great Lakes, aud on Atlantic coast from Gulf of St. Lawrence south to Florida (rarely). Non-breeding birds summer as far south as Rhode Island and southern California (modified from A. O. U. Cheek-list, 1910, p. 81).

Distribution in CALIFORNia-Common winter visitant along entire searoast. Restricted to salt water. Arrives in September and October and leaves in latter part of April. Non-breeders often remain here throughout the sumner months, and have been recorled as far south as San Miguel Islanil (Willett, 1910, p. 173) and Santa Barbara (Torrey, 1910b, p. 204).

The White-winged Seoter or Telvet Duck is an abundant winter visitant along the whole coast of California. It has a wide general winter range on the Pacific coast as it is found from the Aleutian Islands south to Lower California. In California it oeeurs in greatest numbers on San Franciseo and Monterey bays and on the waters about the Santa Barbara Islands, but small numbers are to be found in almost every little coastal bay. While called winter visitants these birds arrive here as early as the last of Angust and remain until the end of April, and some individuals even remain thronghont the summer. These latter are non-breeders and most of them are thought to be immatures, less than two years old.

The birds which winter in California probably come from two breeding centers, in Alaska and in central Canada. In the latter case the migration, which is thonght to take place at night, must have a decidedly westward trend and extend over land for a considerable distance.

Among the big sea ducks the White-winged Scoter is the only one exhibiting a white speculum. This distinctive character shows well in flight or when the birds are at rest on the water and is possessed by all ages and both sexes. In the adult male the otherwise wholly black phumage, relieved only by a small white pateh bolow the eve, is an additional character. At close range the hill is seen to be swollen at the npper base and the feathers extend forward on the sides of the upper mandible almost to the nostrils.

While the White-winged Seoter is a salt water species during the 
winter months, it sereks fresh water situations for nesting. Near Fort Anderson and on the Barren Gromnds of Aretie Canada, MaeFarlane found this seoter breeding in numbers, in both opren and wooded situations. The nests were always near fresh water. They were placed in depressions in the ground at the bases of small trees and contained no other lining than feathers and down. Five to eight eggs eonstituted a set in the nests examined. Nests with eggs were found on varions dates between June 14 and July 3 (Baird, Brewer and Ridgway, 1884, II, p). 96-97).

Bent (1902, 1. 17]) and Jol, (1899, pp. 16:3-164) have both found White-winged Seoters nesting in North Dakota. The nests were placed on small islands and were admirably eonceated, usually under

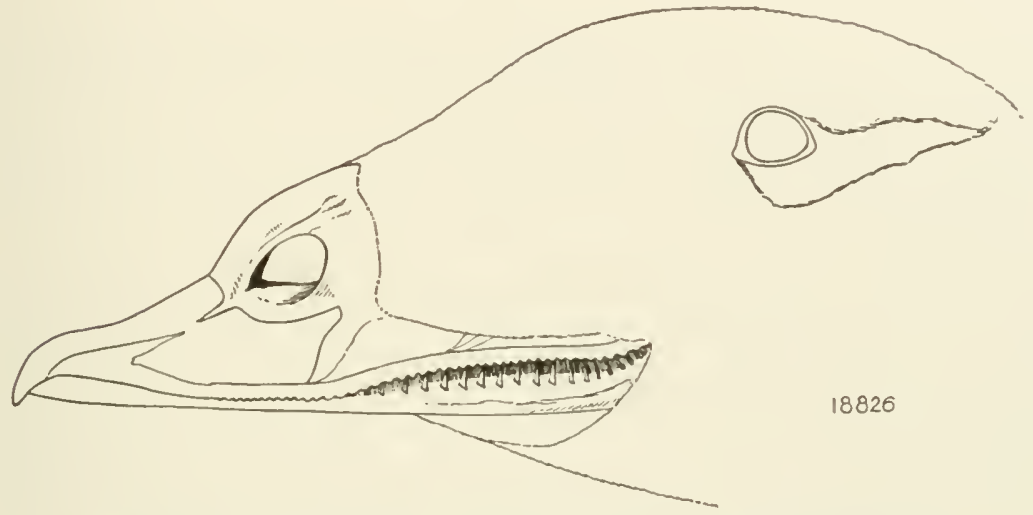

Fig. 2s. Sirle of bill and hearl of male White-wingerl Sroter. Natural size. Location of white sjot behind eye is inclicaterl.

small bushes. The nests were lined with dry leaves, sticks, soil, and other available material, but on the whole were the poorest in construetion of any duek nests which they examined. No down seemed to be added until the sets were complete. Eight nests found by Job (loc. cit.) on June 27 (1898) contained 14, 13, 10. 10, 7, 6, 1, and 0 eggs, respectively, and all the eggs wore fresh, which shows that the breeding season of this species is about the latest of all the ducks. There is an earlier record of downy young found near Fort Yukon, Alaska, on June 23 (1866) (Cooke, 1906, p. 61).

In California the White-winged Scoter is exelusively a salt water duck. It frequents the open bays and water's adjacent to the outer beaches, but we know of no instance of its appearing on fresh water here, even on ponds but a short distance from the beach. All species of scoters are probably most active at night, for during the day they often lie floating out in the eenter of a bay and remain asleep there for hours. At such times they may be closely approached, but usually 
they are vigilant, soon putting themselves out of gunshot range by flight or by diving repeatedly and swimming rapidly away under water. Even by this second method they can easily ontdistance a row-boat. The White-winged Seoter appears to be a perfectly silent bird, save for the flapping or whizzing sound produced by its wings as it rises heavily from the water.

This species usually flies low over the water, but during migrations it attains considerable heights. It often exhibits euriosity and may be attracted within gunshot by the hunter waving some object in the air or eren by firing off his gun. Baird, Brewer and Ridgway (1884, II, p. 94) say that "Hunter's often resort to the expedient of shooting, in order to alarm the tlock. This often has the desired effect; the foolish birds, alarmed at the unusual noise, make a sudden plunge in the direction of the water, as if that element alone could give them safety, and in their deseent present the opportunity desired by the hunter." This habit is peculiar to the White-winged Seoter. On Nonteley Bay, August 29, 1910, Beck (ISS) saw a number of Whitewinged Seoters in molt. The birds had lost their wing quills and were unable to fly.

The food of the White-winged Scoter consists of small fish, mollusks, crabs, and the like (Baird, Brewer and Ridgway, 1884. II, P. 96). On San Franciseo Bar the birds are often to be seen around the wharves diving for the mussels which eling to the piles. Many of the people who daily cross the bay note these flocks of worthless scoters near the ferry moles, and some of them make covetous remarks about the availability of "roast duck." A little elose observation would show these people that the seoters are foraging for a diet which is not conducive to a delicate flavor. A stomach from Monterey contained only the shells of univalve mollusks; one of the shells contained a hermit erab. The mollusks represented were 1 Olivella biplicata, $t$ Olivella intorta. 1 Nessa perpinguis and 1 Mangilia variogata. Another stomach contained several small "sand-dollars" (Echinoidea). Stomachs of this duck from Massachusetts examined by the Cnited States Biologieal Survey eontained $4 t$ per cent mussels, 22 per eent quahogs (a kind of elam), 19 per cent periwinkles, 9 per eent hermit crabs, and smaller pereentages of algae and other vegetable matter (Forbush, 1912, p. 162).

The Indians of the far north relish this scoter as an article of food, along with practically all other kinds of sea fowl. But to the white man it has the strongest and most disagreealule taste of any of the ducks. Some hmuters have told us that by skimning the birds before they are cooked much of this disagreeable flavor can be eliminated. Even a poor shot can hit this elumsy duck and as the birds decoy easily the "sport" aftorded in shooting the White-ringed Seoter 
attralets a few anateur gummers in places where the species is abundant, or. where more desirable birels a re larking.

The comparative present and past status of the White-winged Seoter in California is not known. Apparently it is maintaining its mumbers. $A$ s it usually remains on open water and is there difficult to approach, and as it is a wery poor oflering for the table, this scoter is not greatly sought after by the hunter, and so at the present time its persistence seems assured. Also, its fool-supply is not being rechecel by encroaching civilization as in the case with the fresh-water duckis.

\section{Surf Scoter}

\section{Oidemia porspicillate (Linnaeus)}

OTHER XAIES-Surf Duck; Sea Coot; OEdemia perspicillata vatr troubrillgei; I'elimetla perspicillata; Pelionetta troubriduci.

DEsCRIPTION-Anult mule: Whole plumage deep black above and hrownish black beneath, execpt for two triangular white patches, one across forehearl in front of eyes, the other on bark of hearl; top of lill feathered forwarl to nostrils; large squarish or rounded spot on swollen sille of upper mandible near base, black, hounded behind by "corange," top of bill to above nostrils " "leep rechish-orange," nail " "dingy greyish-yellow," bill otherwise "bhish-white, yellow" or "flesh-eolourerl"; iris "yellowish-white"'; legs anıl feet "orangerell," webs and joints "dusky," claws "blark" (Auclubon, 1543, VI, p. 341). Total length "about 20.00-22.00"' inches (509-55s mm.) (Riılgway, 1900, 1. $112)$; fohled wing $9.25-9.60(2.35-244)$; hill from tip to linit of feathers on eulmen 1.32-1.55 (33.j-39.3); tarsus 1.66-1.51 (42.2-45.9) (eight specimens from Alaska and Califoruia). Adult female: Tol of heal black; rest of plumage blackish brown, except for indistinct light areas on thin and letween bill and eye, and two small white patches below and behind eye and on back of hearl; iris "brown"'; bill "black, witl greenish or brownish tinge', legs anıl feet "lorown," webs "black', (Sanford, Bishop and Van Dyke, 1903, 1) 1S2). Total length "about 15.00-19.00" inches ( $457-483 \mathrm{~mm}$.) (Rirgway, loc. cit.); follerl wing 9.00-9.05 (225-231): bill from tip to limit of feathers on eulmen 1.49-1.63 (37.5-41.3) ; tarsus 1.61-1.71 (40.9-43.4) (three specimens from California). Jurenile plumage: Similar to that of adult female, but lighter in tone, aplroaching dull white on midille of lower surface of boly; whole plumage of softer texture. Natal plumage: Not known to us.

MARKS FOR FIELD IDENTIFICATION-Large size, stout buil, short head and neek. black or black alpearing coloration, presence of white patch on back of head in male (whence the name "skunk-hear"), and absence of white patch on wing. In hand the presence of feathers on top of bill (culmen) extending forward to nostrils easily identifies all ages of both sexes.

TOICE- "A low guttural croak like the clucking of a hen" (Mackay, 1891b. P. 284); in mating season a clear whistle (Nelson, 1887, p. 82).

NEST-On ground near water, well concealed, usually built of grasses and linell with dark-colored down.

EgGs -5 to 8 , ovate to elliptical ovate, measuring in inches, 2.25 to $2.30 \mathrm{by}$ 1.60 (in millimeters, 57.0 to 58.4 by 40.6); color ivory white to pale buff (authors). 
General distribution-North America. Breels from Sitka to Kotzebue Sound, Alaska, and from Great Slave Lake and northern Quebee north to the Aretic coast; winters on Pacifie coast from Aleutian Islands south to Lower California, interiorly on the Great Lakes, and on Atlantic coast from Nova Scotia to North Carolina, rarely to Florida. Non-breeders oceur in summer far south of the breeding range (molified from A. O. U. Check-list, 1910, p. 82).

Distribution IN CALIFORNiA-Abumlant winter visitant along entire searoast, exclusively on salt water. Migrants arrive in numbers during October and November and leave in March and April. Some non-lireeders remain liere during the summer months.

The Surf Scoter is the most abundant of the three species of black sea dncks which visit California during the winter season. From October until April it is fount in considerable numbers on all of our

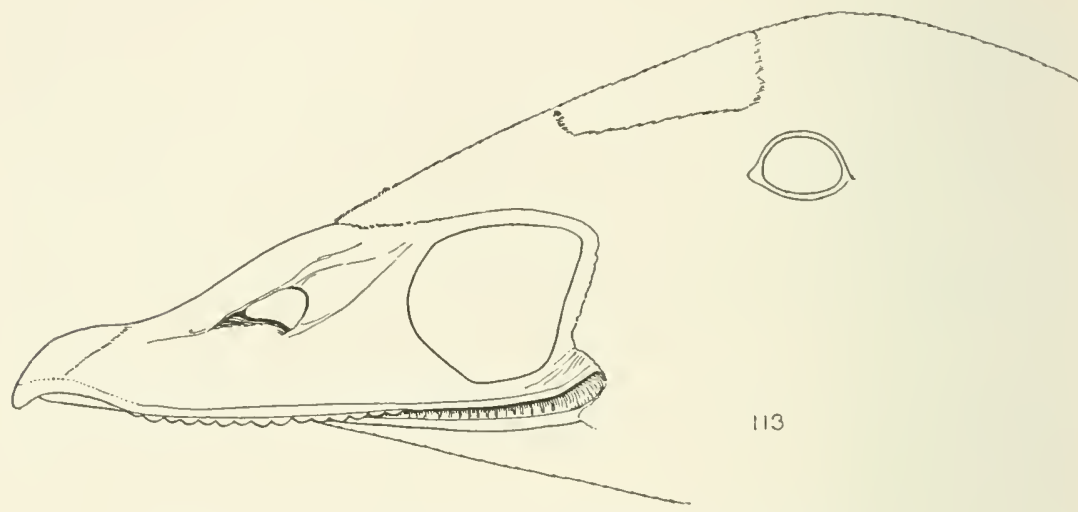

Fig. 29. Sicle of bill of male Surf Scoter. Natural size.

bays and also on the adjacent ocean either inside or outside the surf. In the summer most of the birds of this species repair to their breeding ground in the far north in the northern portions of Alaska and Canada; but some non-breeling individuals, which are believed to be birds less than two years old, remain here thronghout the season. During its sojourn here the Surf Scoter is restricted to salt water and has not been reported from any fresh water situation within the state.

The general black plumage relieved by patehes of pure white on the forehead and back of the head easily identify the male even at a distanee. The white iris and the swollen black-and-orange-marked bill, which can be seen at moderate range, both add to its striking apprearance. The female is less conspicuously marked and to her general brownish black coloration there are added only a few whitish patches on the head and chin. Her feet and bill are hotli black, and lack the brilliant colors displayed in her mate. In any phumage the absence of a white patch on the wing easily separates this species 
from the White-winged Scoter. In hand the presence of feathers on top of the bill extenting nearly to the nostrils is the best character for positive identification. "The neck pateh of the male makes a striking field character, as do the two white spots at the side of the heat in the young: while the female, lacking the ear pateh, can be told by elimination" (Bailey, 1916b, p. 108).

For the nesting season this scoter seeks the vicinity of fresh water as does its white-winged relative. A nest of this species found by MacFarlane in the neighborhood of Fort Anderson, Canada, was sitnated on a ridge of gromud at the foot of a dry stunted pine, where it was entirely hidden by the lower branches of the tree. It was constructed of dark-colored down. 'The nest is said to be indistinguishable from that of the White-winged Scoter (Bairk, Brewer and Ridgway, 188t, 11, p. 10²).

The Surf Scoter is appropriately named as it appears to be thoronghy at home in the roughest surf of our ocean shore. For rest or sleep the birds resort to the smoother water outside the surf, and sometimes they come insile onto the beach, where they stand and preen their feathers. During the day time these birds are often to be seen sleeping on the quiet waters of San Franciseo Bay in company with White-winged Scoters. When taking flight they rise heavily from the water, with apparent difficulty, rumning or kicking along the surface for some distance before gaining sufficient impetus to enable them to rise clear of the water. Once in flight they are able to travel with considerable speed.

During an extended visit to the beaches of sonthern California Florence Merriam Bailey studied the habits of the Surf Scoter in some detail. The following paragraphs are excerpted from her account.

One of the big sea birds . . did actually go through the breaking surf prow on, but ... none of his fellows ever did. . . . It was a pretty sight when, uniler a gray sky, the beautiful long green rolls of surf rose and combed over and the Surf Scoters came in from the green swells behind to feed in front of the surf and do skillful diving stunts to escape being pounded by the white water-falls. As the green wall ridged up over their heads they would sit unmover, but just as the white line of foam began to appear along the erest they would dive, staying under till the surf had broken and the water was level again. ...

A flock of about twenty-five Surf Scoters ... swimming Indian file, on reaching a certain point disappeared one after the other, doubtless going down to a streamer of kelp under the surface. They were past masters in timing the breaking of the rollers, again and again riding over one the instant before the crest broke into foam. When feeding far out from the shore a few of the sea birds would sometimes get widely separated from the rest of the flock and after rising up to look over the water would swim or, if too far, fly across to rejoin their companions. 
One drizzly morning . . the Scoters were in near shore... The surf was rolling in, sea after sea, anul the great birls rode the green rollers. . . When a squal were down in front of the surf line and the foaming water-fall came, it was laughable to see the row of tails disappear below. . . When diving through the green rollers near shore the black bodies of the Scoters, parliling feet and all, showed as plainly as beetles in yellow amber (Bailey, 1916b, 1)l. 109-110).

According to Cooper (in Baird, Brewer and Ridgway, loc. cit.) this species is but little humed, and has but few natural enemies. Many individuals escape the usual dangers that beset birds, and, lingering along our southern coast finally die solely from old age. The long rainy seasons are said to be fatal to some decrepit individuals. as at such times the birds seem to be peculiarly subject to unfavorable influences. At the time of assuming their spring plumage, many become very thin, and even blind, and swim, unconscions of danger, near the wharves and shores, or after storms are found weak and dying along the beaches.

When feeding, Surf Scoters dive so constantly that but few of the members of a flock are to be seen at the surface at any one time. They keep popping up and disappearing so that the observer sometimes finds it impossible to count them. Swarth $(1911, p .45)$ found this species at Kuin Island, sontheastem Alaska, feeding close to the shore, in the shallow water. The drakes were constantly on the move, flying for a few rarts and then sliding for eight or ten feet upon the surface of the water, with the wings held stiffly extended above the body.

The food of the Surf Scoter is made up almost entirely of shellfish obtained by diving. Stomachs examined by the United States Biological Survey contained 79.6 per cent of mussels, 13.8 per cent of periwinkles, and 6.6 per cent of algae and eel-grass (Forbush, 1912, p. 165). This species is also said to eat fish. The gullet of one shot near the edge of a California marsh, was so filled with small crabs that they fell from its mouth when the bird was picked up. In this state, small crabs and mussels form a considerable portion of the food of this species (W. E. Bryant, $1893 a$, p. 55).

The Surf Scoter is seldom shot for food as its flesh has a strong, fishy flavor that to most people is very disagreeable. It is said to be readily decoyed within gumshot by imitating its call-note from a blind, so that it is sometimes killed for sport. The surf-riding propensities of this duck, which ordinarily keep it ont of reach, and its poor food value render it of slight importance as a game bircl, and in consequence its number's are likely to remain muchanged by hmman influenee. 


\section{Ruddy Duck}

\section{Eismatura jemaicensis (Gmelin)}

OTHer xames-Wiretail; Sprig-tail; Pin-tail, part; Diplerr 1)uck: Spratterer; Apatter; Erismatura rubilu: Erismatura dominicensis.

DEscRHPTIOx-Adut male in spring and carly summer: Top and side of head to helow eye, and hind nerk, glossy black, abruptly outlined; large conspicuous patch on each side of heal from hase of bill to behind ear, pure white, the two patches joined by" narrow Land of white aeross chin; iris "hazel" (Audubon, 1A43, VI, P. 327); bill slaty blue; whole neck. silles of lueast, luack aml upper tail coverts rich redilish chestuut: rump lusky brown; upler tail coverts very short, learing the narrow tail feathers exposel nearly to their bases; tail blackish brown; outer surface of closed wing dull dark brown, the coverts finely "peppered", with light brown; flight feathers blackish brown; lining of wing and axillars white, marked with grayish hrown; unler surface of flight feathers pale brown; siles of boly (beneath wings), and flanks, deep ehestnut; unier surface of boly grayish brown with broas feather tippings of silvery white, the whole giving an effect of light silvery gray; breast often tingerl with pale rusty brown: uncler tail "overts pure white: feet " lull grevish-blue,", webs "dusky", (Aulubon, loc, eit.). Adult male in uinter: Top and side of heal to below eye, and himl neck, blarkish brown, minutely flecked with asliy brown; patch on side of hear white, as in summer: whole upper surface of borly dark hrown, minutely peppered with ashy gray and ehestult: tail and wings and lower surface as in summer; throat and broad eollar aromn neek, ashy brown. In any plumage wings and tail may he pale ashy due to wear and fadiug. Total length (both sexes) "alout $13.50-16.00$ ", inches (343-406 mm.) (Riıtgway, 1900, 1. 113); folitel wing 5.65-5.92 (14.3.5-150.0); bill along culmen 1.4S-1.6s (37.6-42.7); tarsus 1.27-1.36 (32.2-34.5) (ten sprecimens). Adult female at all seusons: Top and sile of heal to below ere, hackish lirown, narrowly barrel with redlish brown; rest of heal gravish white except for dusky stripe from corner of mouth to hind neck, paralleling margin of dark area on top of head; bill slaty black; chin white; upper surface of body brownish black, finely variegated with ashy or buffy brown; tail hrownish black; outer surface of elosed wing dark brown; lining of wing and axillars as in male; forenerk grayish brown; breast indistinctly harrer with dnll black and yellowish brown, sometimes appearing rusty; feathers of lower surface ashy brown at bases, tipper with silvery white, the former color sometimes showing through and giving a barred effect; midlle of belly lightest; under tail roverts white. Folded wing 5.50-5.75 inches (139.5-146 mm.); bill along (oulmen 1.57-1.6s (39.5-42.7); tarsus 1.20-1.31 (30.4-33.2) (ten specimens); all from California. Jucenile plumage: Similar to that of arlult female. Natal plumage: Top and siles of hear, whole upper surface of body, silles, flanks, foreneek, and upper breast blackish brown, darkest on top of head and lightest on foreneck; stripe from side of bill below eye to ear region, lower part of eheeks, and ehin, dull white; patch on side of back behind wing dull white; belly grayish white; bill and feet (dried) black.

MARKS FOR FIELD IDENTIFICATION-Small size (slightly larger than a teal), stout ehunky buill, flat hear, short neck, broad flat hill, conspicuously white eheek patehes, short, exposed, "wire-like" tail, earried almost perpendicularly to back, and absence of contrasted pateh of white or color on wing.

Vorce-None (?) 
NEST-Always close to water, above or sometimes floating upon it, and usually concealed in tules; constructed of dry tules and lined with dull whitish down.

EgGs-5 to 11, more in exceptional cases, short or elongate ovate in shape, measuring in inches, 2.44 to 2.62 by 1.75 to 1.89 (in millimeters, 62.0 to $\mathbf{6 6 . 5}$ by 44.4 to 48.0 ), and averaging 2.52 by 1.82 (64.0 by 46.2 ); color grayish white, surface rough (twenty eggs from California).

General distribution - North America. Breeds from central British Columbia, southern Keewatin and northern Ungava, south to northern Lower California, northern New Mexico, sonthern Minuesota and Maine, rarely south to Guatemala and Cuba. Winters from southern British Columbia, Arizona, southern Illinois and Maine south to Lesser Antilles and Central America (modifiel from A. O. U. Cheek-list, 1910, p. 82).

Distribition in CALIForNia-Common resident throughout the state, chiefly on fresh water. Occurs on San Francisco and Tomales bays in winter. Breeis from San Franciseo (Squires, 1915, pp. 234-235), south to Mission Valley, San Diego County (Belding, MS), but most abundantly in southern California and in the San Joaquin Valley; breeds also about Tule [= Rhett] Lake, Morloc County (H. C. Bryant, 1914e, p. 230).

The Ruddy Duck is strictly a North American species and has not been taken, even as a straggler, in the Old World. East of the Alleghany Mountains it is a comparatively rare bird, but in the west and southwest it is locally abundant. The main breeding range is in the north-central Cnited States and central Canada, but there are many isolated colonies far south of this area. In the western part of the Mississippi Talley it is found breeding in sonthern Minnesota and northwestern Nebraska. From here the sonthern boundary of the nesting range extends southwestwardly through the mountains of Colorado and northern New Mexico, to central Arizona and northern Lower California. Indeed there are records of nesting birds from localities as far south as the V'alley of Mexico, Guatemala and Cuba. As a species, this duck does not perform any very extensive migration, the center of the breeding range lying but slightly north of the center of abundance in winter.

The Ruddy Duck, the "Wire-tail" or "Spatterer" of the hunter, is one of the most widely distributed of our California ducks. In any one place it is never found in large mumbers, as are some other species, but each little body of fresh water is apt to have from one to a dozen pairs of the birds. In general the Ruddy Duck is an inhabitant of fresh water. It may in winter occasionally be found on salt water in company with such species as the Canvasback and Scaups, but this is not a common thing.

When resting on the water the Ruddy Duck may be recognized by its moderate size, "squat" appearance, short thick head and neck, erect tail, and in the male, by the white area on each cheek. The wings lack contrasted markings of any sort. On close examination a num- 
bere of othere distinctive claracters can be seen. The upper tail coverts are extremely short and leave the eighteen stiff, narrow-webbed and pointerl tail feather's almost witlout covering. The bill is broad and shighty tumed mpwarl toward tip and bears a conspicuous "nail." It is not longer than the heat. In spring and early smmmer the males have the whole neck and back a miform chestnut or reddish brown, a distinctive feature. The brightly plumaged males in spring carry on various eomplex conrting antics, in which the spread tail figures conspicuonsly. Brooks (1903, p. 280) records that while watching the curious anties of the male, through a binocular at very close range, he was struck with the peculiar formation of the head, there being distinct elevations over each eye resembling those on a frog's head. These were evidently cansed by inflation from inside the skin. The breeding season of the Ruthy Duck extents from the first of May to the enel of July" or "ren latele (see table 11).

TABLE 11.-Data relative to the nesting of the Rudily Duck in California

\section{LOCALITY}

Nigger slough. Los Angeles, Co. Niles, Alameda $\mathrm{Co}$

Mission Vallev, San I)iego ('o.

Los Buños, Merced Co. Orange, Orange $\mathrm{Co}$.

San Jacinto Itake, Riverside Co.

Near Los Angeles

Bear Valley lakes, San Bernardino $\mathrm{Co}$

Santa Cruz

Tule [=Rhett] Lake. Modoc C'o.

Nigger Slongh,

Los Angeles Co.

Santa Cruz

San Pasqual. San Diego Co.

San Jacinto Lake Riverside Co.

Wilmington, Los Angeles Co.

Tulare Lake, Kings Co.

Near Los Angeles

Santa Cruz

Santa Cruz

Tulare Lake, Kings Co.

Santa Cruz

Point Pinos, Ionterey Co.

Seaside, Monterey Co.

\section{1).1T:}$$
\text { M }
$$$$
\text { 1, } 1910
$$$$
\text { IIay 8, } 1904
$$$$
\text { May 20, }
$$$$
\text { May 22, } 1914
$$$$
\text { Iily 28, - . }
$$$$
\text { May 28, } 1911
$$$$
\text { Last of May, }
$$$$
\text { June, } 1 \text {.886 }
$$

Aug. 19. 1914

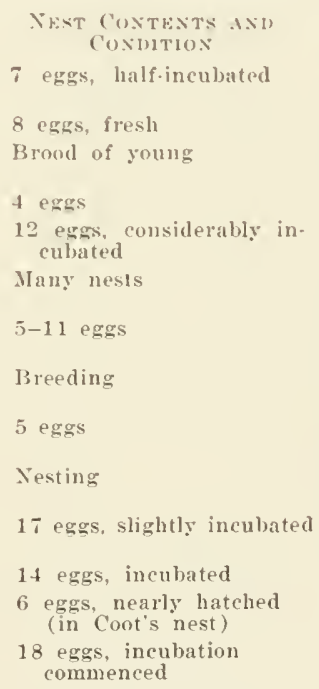

A L THORITY

Willett, 1912a, p. 26

Inilliard coll.

Belding, MS.

Bryant, 1914e, p. 224

Grinnell, 1898 , p. 12

Willett and Jay, 1911. p. 158

Davie, 1889 , p. 77

Morcom, 1887, p. 38

Ingersoll, 1884, p. 15

Bryant, 1914 , p. 230

Willett, 1912a, p. 26

Mailliard coll.

Sharp, 1907 , p. 86

Ingersoll coll.

Willett, 1912a, p. 26

Goldman, $1908 b$, p. 202

Davie, 1889 , p. 77

Ingersoll, 1884, p. 15

Ingersoll, 1884, p. 15

Goldman, $1908 b$, p. 202

Ingersoll, 1884, p. 15

Squires, MS.

Squires, MS. 
The nest, which in California is usually composed of tules, is placed near the water's edge or, more often, directly ahove the water of some deep, sluggish stream, lake or pond. Shichls (in Davie, 1889, pp. 77-78) says there is evidence that this duck prefer's the abandoned nests of Coots for nesting purposes, to those constructed by itself. In sereral instances he took eggs of this species from what appeared to be rehabilitated Coots' nests. In one case seven eggs of the Rutidy Dnek were found in a coot's nest from which, a few weeks previously, a set of eggs of the Coot had been obtained. Shar') (1907, p. 86) found six nearly hatched eggs of the Rudily Duck in a Coot's nest near Escondido, San Diego County, June 5, 1906.

Ingersoll (1884, p. 15) tells of a number of nests which he found near Santa Cruz:

The nests were usually built near the center of the tules, and just above the water, which was two or three feet ieep, and were inaccessible except by wading, as the tules were too thick to allow a hoat to pass through them. The nests were all coustrurted of hry tules; those forming the lining were picked into fine shreds and slightly mixesl with down of the prarents. Nests were from eight to fifteen inches high, and ten to twelve in diameter. The cavity varied in size as much as the nests, but not in proportion to them, as the highest and most firmly built of any I saw had a ravity that was only large enough to hold two eggs in the first laver, and so shallow that the three other eggs it contained were above the level of the nest. This nest also varied from the others in having a slight covering of tules over the egurs.

Two other nests foumd by Ingersoll on June "26 contained nineteen eggs each. The eggs in these nests were arranged in three layers. Nests of the Ruddy Duck are but sparingly lined with down and sometimes it is lacking entirely. The aggs of the Ruddy Duck are always recognizable. They are extremely large for the size of the bird, more rounded than most other dnek's eggs, and of a uniform dull white color. The thick, rough-surfaced shell is peeuliar to the eggs of this duck. The shape varies somewhat from short orate to elongate ovate. Twenty speeimens from Califomia average 2.52 by 1.82 inches.

According to Brooks (1903, p. 280) the young are very precocious and dive for their food soon after hatching, a habit not foum in the young of other sucks, which take their food from the surface of the water for several weeks. Ingersoll (loc. eit.) surprised several families away from the tules, in which the parents invariably songht shelter. leaving the young to look out for themselves. The young were unable to fly but could dive and swim well.

During the winter Rudily Ducks are sometimes seen in small flocks numbering up to ten or twelve individuals, these forming a compact company. But more often they are to be seen singly or in 
pairs. They can often be elosely approached, for they depend upon diving rather than Hight for safety. If plenty of tules are at hand in which to hide, gunshots will not frighten them away from their favorite haunts. Their ability to dive and hicle under water or beneath some floating object with only the head above water is mexcelled by any other duck; in this respect they resemble the grebes. When wounded, they invarialily try to escape in this way, and very often succeed. During the breeding season the female is said to be the shyest of all the ducks and it is almost impossible to surprise her on the nest.

On the watel at a distance the Ruddy looks like a floating bloek of wood, so stockily is it built and so low does it sit in the water. It rises with considerable difficulty, paddling along on the surface for some distance before getting clear of the water. It flies close to the surface of the water and its rapidly beating wings make a whirring sound. When well started the speed of this duck is great. hut as it is slow getting under way this speed is not often evident.

The food of the Rudly, as reported hy varions ohserver's, consists of seeds, roots, plant stems and shellfish. The stomach of a bird from Guadalupe, Santa Barbara County, California, was found by us to contain twenty-fire seeds of diteh-grass (Ruppia maritima) and some green algae. Thres other stomachs contained firely ground vegetable materials.

The Ruddy Duck is so snill and has such strange habits that it is not always considered a game bird by the sportsman. On many of the gun club grounds these birds are not counted in the limits, or else are killed only as a makeshift to complete the bag. Nevertheless the Ruddy is very good eating unless it has subsisted on shellfish for a long time. Many people do not use it for food simply because they do not know how to remove the feathers, an operation which is very difficult for the minitiated. Experts dip the bird in boiling water, and withdraw it almost immediately, before the grease starts; then it is wrapped in newspaper soaked in hot water. The steam loosens the feathers and the bird is then easily picked (Hedderly, 1912b, pp. 50-51). When properly dressed the Ruddy makes an excellent table bird. It is fat and has a mild flavor. "Roasted Indian fashion in the fire with feathers on, its meat is juicy, tender and of delicions flavor ..." (V. Bailey, in Bailey, 1902, p. 65).

As a mark for the gumner this species takes second rank, for it is not regularly on the wing and is very difficult to kill on the water becanse of its thick plumage and its expertness in diving. But as the more desirable ducks become reduced in numbers there is no doubt that the Ruddy will be one of the first to take a respected place in the hunter's bag. 
When ummolested this duck is likely to nest in any suitable locality, be it even a pond in a city park. Consequently the maintenanee of a breeding stoek and the regulation of the annmal supply by this means would probably prove a simple matter. The Ruddy still exists in goolly numbers espeeially in southern California and ean be expeeted to continue to hold its own until considerably greater numbers are taken by the hunter, or until the available breeding grounds are greatly reduced through reclamation or other causes.

\section{Lesser Snow Goose}

\section{Chen hyperboreus hyperboreus (Pallas)}

Other Names-White Brant; White Goose; Anser hyperborens; Chen albatus: Anser albatus; Chen hyperboreus nicalis.

DeSCRIPTION-Adults, both sexes: Whole plumage (except as mentioned below) snowy white; primaries black, becoming ashy at bases; primary coverts gray, with dusky shafts; lower surface of body often tinged with light yellowish brown; iris dark brown; bill lake red, nails whitish; edges of mandibles (forming "grinning patch") black; feet (lusky lake red; claws brownish black. Total length (both sexes) " about 23.00-28.00"' inches (583-711 mm.) (Ridgway, 1900, p. 115). Males: folled wing 16.65-17.12 (423-435); bill along culmen 2.19-2.40 (55.5-60.9); tarsus $3.07-3.38$ (77.9-85.8) (six specimens). Females: folded wing 15.20-16.65 (386-423); bill along culmen 2.00-2.26 (50.8-57.3); tarsus 3.01-3.32 (76.5-84.3) (eight specimens); all from California. Juvenile plumage: Heal, neck, back and seapulars, pale gray with brownish feather edgings; top of head darkest; primary flight feathers black; outer surface of closed wing pale ashy brown with broad white feather edgings; secondaries mottled darkly with drab, and margined with white; rump, upper tail coverts, tail and lower surface, white, the tail and breast faintly tinged with ashy; head and lower surface usually more or less strongly tinged with bright yellowish browu. Winter birds from California are mostly in more or less mixerl transitional plumage from juvenile to adult. Natal plumage: No specimen or description available.

MARKS FOR FIELD IDENTIFICATION-Large size, pure white body plumage, black flight feathers, and redlish bill and feet (pl. 6). Distinguished from.Ross Goose by larger size, longer, smoother bill, and large black area ("grinning patch"') exposed between edges of mandibles (compare figs. 30 and 31). Immature birds also appear white at a distance.

Vóıс-Iu flight, a shrill houk (Baird, Brewer and Rilgway, 1884, I, p. 441).

NesT-On wet ground; made of grasses, mosses and down (Eifrig, 1905, 1. 237 ).

EGGS-5 to 8 , ovate in shape, measuring in inches, 3.00 to 3.47 by 2.09 to 2.19 (in millimeters, 76.0 to 88.0 by 53.0 to 55.5 ), and averaging 3.17 by 2.13 ( 80.5 by 54.0) (nine eggs in U. S. National Museum); color creamy white (Eifrig. lor. eit.; Davie, 1889, p. 79).

Gexeral distribution-North Ameriea. Breeds only along Aretic coast from mouth of Mackenzie River to Hulson Bay. Winters from southern British Columbia, southern Colorado, and southern Illinois south to worthern Lower California, central Mexico and the Gulf States; rare on Atlantic coast (morlified from A. O. L. Cheek-list, 1910, p. \$.3). 
Distribution in CAliforNia-Abumlant winter visitant to the interior valleys; less frequent near the seacoast. Recorded south to San Diego (Belling, MS), aurl southeast to the Coloralo River below Needles (Grinuell, 1914b, p. 116). Arrives soon after the first of Ortober and leaves in March and early $A_{p}$ ril.

California probably surpasses any other state in the Union in the number and variety of geese which winter within its borders. The winter ranges of at least three speeies center within its confines, and as many as five different species have been taken in a single day, in 1913, at Los Baños, Mereed Comnty. To many people the geese are the most conspicuous examples of birds which migrate regularly with the changes of the seasons.

The Lesser Snow Goose, often ealled White Brant, and oecasionally by the Eskimo name. White " Wary," is among the commonest of geese to be seen in the Pacific region. For instance, on December 9, 1911, in the vicinity of Los Baños, Beck (MS) observed approximately 5,000 White-fronted Geese, 300 Canada Geese, and 50,000 white (Lesser Snow and Ross) geese. On December 29 of the same year he estimated that he saw 1,000 White-fronted, 100 Canada, and 50,000 white geese.

In migration the Lesser snow Goose occurs more or less abundantly along the whole Pacific coast from Alaska to Lower California, but during the winter months almost the entire population concentrates in central and western California. These geese are most often seen passing overhead in long diagonal lines or $\mathrm{V}$-shaped flocks: but on open level country, such as the plains of the Sacramento-San Joacpuin Valley, it is not an uncommon thing, during the winter season, to see the ground fairly whitened with them as they rest or feed.

So far as we know only two species of white geese ocem in California. The Greater Snow Goose of the Atlantic coast has never been recorded from this state, and specimens which were first reported as instancing the occurrence of the Blue Goose here have since been shown to be young of the Lesser Snow Goose (Swarth, 1913a, p. 43).

The Lesser Snow Goose differ's from the Ross Goose, the other white species oceurring in California, by its much larger size, longer and smoother bill, and by the presence of a large black area ("grinning patch") exposed between the two closed mandibles of the bill (compare figs. 30 and 31). The voice of the Lesser Snow Goose is more sonorous than that of the Ross Goose.

Although the Lesser. Snow Goose has been found breeding along the Arctic coast east of the Mackenzie River, yet great nmmbers of the birds have been seen to pass still farther north, to breeding grounds as yet unknown. Nelson $(1887$, p. 83$)$ states that this species finds a nesting ground along the course of the lower Anderson River and the neighboring region along the Aretic coast; and Raine (in 
Macoun and Macoun, 1909, p. 120) records several sets of eggs colleeted in Mackenzie Bay, in the middle of June, 1905, and says that this goose serapes a hole in the sand and lines it with down and frathers. Eifrig (1905, p. 2:37) states that on Southampton Island, Hndson Bay, Lesser Snow Geese were found breeding in 1904. On Jume 22 a set of seven eggs was taken there. The nests which are six to eight inehes high, are on wet ground and construeted of grass and moss and lined with down. The young are said to be able to fly by the middle of Angust and to keep in separate flocks. Many individuals retain the grayish tinted (juvenile) plumage nearly throughout the winter, thus giving rise to the belief that this species does not attain its full snowy white plumage mutil at least the second year.

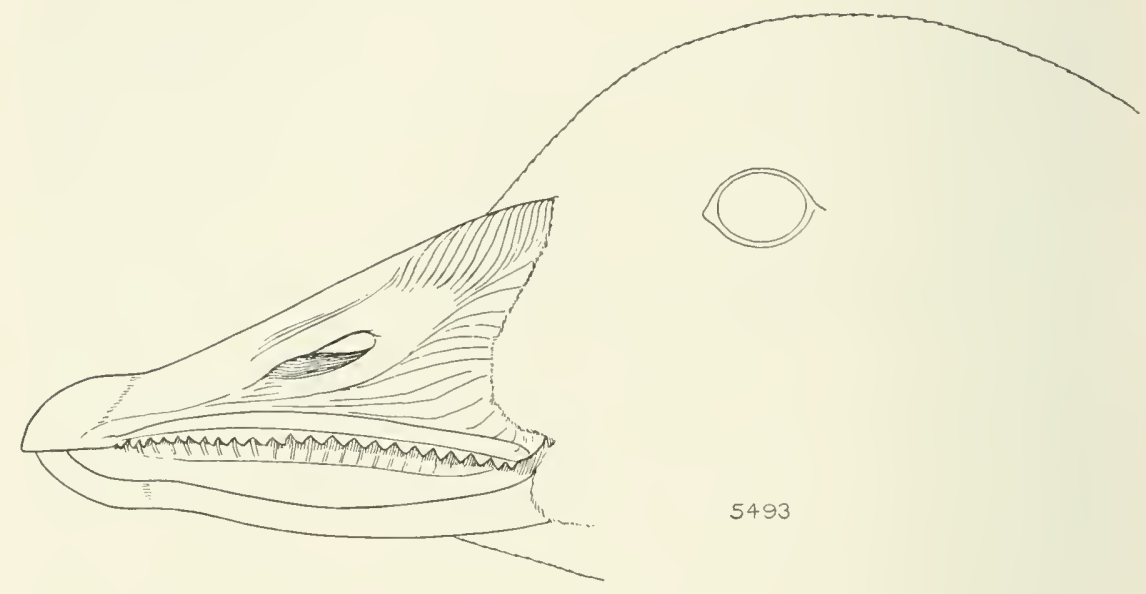

Fig. 30. Sile of bill of Lesser Snow Goose. Natural size.

Note "grinuing patch" exposed between the bowed rims of the two mandibles (compare with fig. 31).

The Lesser Snow Goose is not averse to associating with other kinds and it is not an unusual sight to see some of them mixed in with a flock of "gray" geese. C. H. Townsend (1887, p. 195) reeords having seen at Red Bluff, Tehama Comnty, a triangle of Canada Geese headed by a single Lesser. Snow Goose, the two waving lines of clark forms converging to a snow-white point.

Between California and their breeding gromuds Lesser Snow Geese appear to take the most direct ronte; they are seldom found in numbers along the coast of Alaska, but are abundant during. migration in the vicinity of Fort Simpson on the Mackenzie River. Althongh some of these geese may migrate across the northern border of the state from or into Oregon, yet a great many are known to cross eastward 
or Westward over the Sierra Nevala. Belding (MS) noted flocks of this spereses at Summit, Placer ('ounty, on Oetober 5 and 10, 1885. They were flying ahove the highest peaks westward from Nevada toward California. They were again noter at the same place on Octoler 6. 1 S96, flying high and going toward the Saeramento Valley. On April 8 and 16, 1886 . thonsands of white geese were noted by the same olserver, at Murphy's, Calaveras County, Hying eastward over the Sierras in the diretion of Nevada. The earliest arrivals of this speceies in west-central california, as noted by Belding, are: Stockton, San Joaquin County, September 28, 1886, September 29, 1881, and October 9, 1883: Gridley. Butte ('omnty. September 30, 1884. The first flock seen at San Diego in the winter of 18s:3-8t was on February 17. The latest records are: Stockton, April 30, 1880; Gridley, April 28, 1sst; Chieo, Butte ('ounty, A pril 2̄i, 188t; Gridley, Mayr 1, 1896.

Writing from the vicinity of Fresno, Trler (1913b, p. 1S) makes the following statements: "White geese swarm by thousands on the westside plains. No record has been obtained of their date of arrival in the fall, but as late as April 7 (1906) they were congregated in large nimmbers on several humberl acres of grassy pastmre near the Artesian Lake. Just before sumdown, as I drove past, the ground was white alnost as far as one could see and the noise was deafening. I have not had an opportunity of measuring any of these geese, but there appears to be a great variation in size. During January large flocks of snow Geese move restlessly about, flying at a great height, and generally traveling toward the north."

The Lesser Snow Goose feeds largely in grain fields and pastures at night, spending the middle of the day on the sea or on some open body of water. Beck (IIS) says that in the ricinity of Los Baños this goose leaves for the grain fields early in the morning, returning between ten and eleven o clock, and spends the rest of the day in wet marshy places. One bird shot after returning from feeding in the fields contained 1,581 grains of barley. On March 25, 1912, in the same locality, Lesser Snow Geese were seen feeding on the stalks of "filaree." They bit off the tops and ate the roots as well. One killed had 500 of the stalks in its gullet (Beck, MS).

Various kinds of ordinary grass form a large part of this bird's food, at least during their winter residence in the United States. . . They alight upon a meadow or plain, and pass over the ground in broken array, cropping on either side as they go, with the peculiar tweak of the bill and quick jerk of the neck familiar to all who have watched the barnyard birds when similarly engaged (Coues, 1874, p. 552).

While in California, this goose appears to feed largely on grass. Coues (loc. eit.) says that the short turfy grasses are highly relished 
and that the bulbons roots and soft sueculent eulms of aquatic plants are also eaten. The depredations of this and other geese in grain fields in California until very recently has prevented the placing of a closed season on these birds. In the north, their food in the smmmer consists of rushes and insects, and in the autumn, of berries particularly those of Empetrum nigrum (Baird, Brewer and Ridgway, 1884, I, p. 441).

In former years in the far north this speeies during the fall migration was killed and salted in great numbers for winter consumption, it being almost miversally regarded as good eating. It has always been the commonest goose on the markets in California. Whether this is beeause it is more abundaut, more easily deeoved, or because it is most desirable for the table is not known. During the season 1895-96, 10,251 "white" geese were sold in the markets of San Franeiseo and Los Angeles (Calif. Fish Comm., 1896, p. 41). A total of 3,649 were handled by one transfer eompany alone in San Franciseo, in the season of 1906-07, and 3,800 similarly in 1910-11. In the season of 1910-11 the markets in San Francisco paid one to three dollars a dozen for them. During the season of 1913-14, they could be purehased regularly for seventy-five cents a pair retail. The young of this species are eonsidered very good eating in spite of the fact that their meat is eomparatively dry and dark and of a rather strong flavor. But our impression is that the other species of geese are held in somewhat greater esteem for table use.

There has been a more eonspienous deerease in the numbers of geese than in any other game birds in the state. Many observers testify that there is only one goose now for each hundred that visited the state twenty vears ago, and some persons aver that in eertain localities there is not more than one to every thonsand which formerly oecurred here. Not only have these birds been slanghtered for the market, but gangs of men have been paid to destroy them where they were feeling in grain fields. Until 1915 they were afforded no proteetion whatever and as a natural result their ranks have been so often deeimated that, comparatively speaking, only a remnant now remains (see pp. 7-12).

In former years, when passing throngh the Sacramento or San Joaquin valleys by train, great floeks of white geese in company with other, dlark-eolored species were often to be seen settling on the grain fields or pasture lands almost within gunshot of the ears.

The days are past and gone when a man has to drive geese from his grain field. In many places where formerly the ground was so covered with white geese as to look snow elad, not a single goose is now to be observed feeding and but few flying overhead. In spite of the extreme shyness and watehfuhness of these geese, the ingenuity 


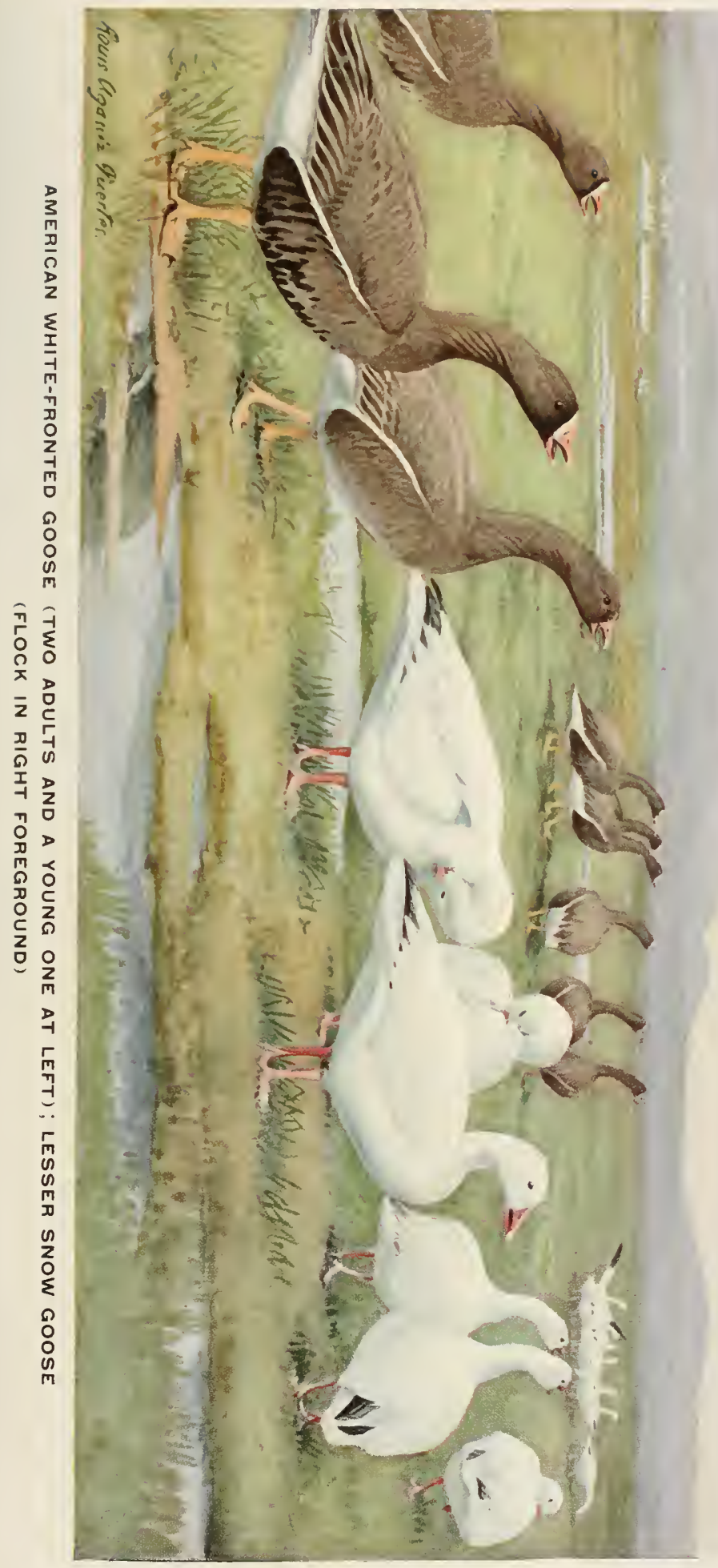

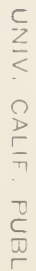

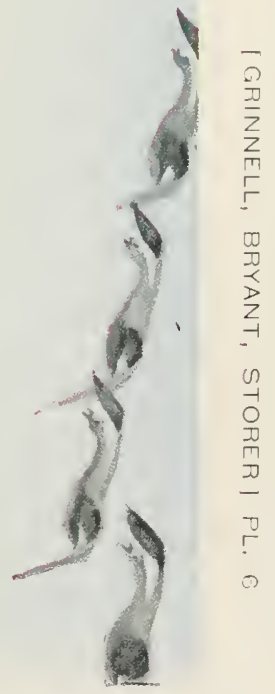



of the hunter and the increased efficiency of firearms has so far overbalanced the natural protection thus afforded that the birds are now actually threatened with extinction. Lnless the protection now furnished proves adequate in the very near future, this state, which at one time appeared to have an inexhaustible supply of geese, will have entirely lost this valuable game resomree.

There is no reason why, with proper regard for the natural rate of increase, a certain toll might not be levied ammally on the influx of geese from the far north. In their summer home they are doubtless largely free from human interference, so that the winter resort, which with snow geese lies chiefly within our own state, constitutes the eritical area. It is in such cases as this that we are most favorably situated for putting into effect a system of regulation upon a sound economie and biological basis, so that we will seeure the maximum returns.

\section{Ross Snow Goose}

\section{('hen rossi (Cassin)}

OTHer xaMes-China Goose: Alser rossi.

Description-Idults, both sexes: Entire plumage snowy white except for primary flight feathers and their eoverts; prinaries black, becoming ashy basally; primary coverts gray, with dusky" shafts; hill " "lull reddish,' nail "white" (Bairl, Brewer and Rilgway, 1s84, I, p. 44t), lasal portion of upper mandible often wrinkled anıl warty; feet "dull redlish" (Bairı, Brewer and Rirlgway, loe. eit.). Total length (hoth sexes) " $20.00-26.00$ ", inches (580-660 mm.) (Rirlgway, 1900, p. 115). Males: foldel wing 13.60-15.00 (345-381); bill along culmen 1.43-1.66 (36.3-42.2); talsus 2.57-2.87 (65.2-72.5) (seven specimens). Fenales: folled wing 13.35-14.45 (339-367); bill along culnen $1.42-1.55$ (36.1-39.3); tarsus 2.38-2.6s (60.4-68.0) (nine specimens); all from California. Juxenile plumage: White, tinged with gravish on head and foreback; wing as in adult but seronlaries with blackish eenters; bill and feet "'lusky", (Bairl, Brewer and Ridgway, loe. cit.). Natal plumage: Not known.

MARKS FOR FIELD IDENTIFICATION-Small size for a goose (but little larger than a Mallard), white plumage relieved by hlack primaries, and redish bill anıl feet. Distinguished from Lesser. Snow Goose by smaller size (abont half the bulk of that species), and by much shorter bill, which is also more corrugated on surface and lacks broad black area between edges of closed mandilyles (eompare figs. 30 and 31 ).

YoICE-Resembles that of the Cackling Goose (Belling, MS).

NEST AND EGGS-Unknown.

Gexeral distribution-Western North Ameriea. Breeding range unknown but probably north of Mackenzie, Canacla; winters in California. In migration occurs from Kent Peninsula, and Anderson River, on Arctic coast of Canada, south to Manitoba and Oregon (modified from A. O. U. Cheek-list, 1910, p. 84).

Distribution IN CALIFORNiA-Abundant winter visitant; most numerous in Sacramento-San Joaquin Valley and about Los Angeles. Southernmost reeord station: Newport, Orange County (Daggett, 1901a, p. 15). 
The Ross or China Goose is the smallest, and one of the least known of our North American geese. Its winter range, so far as known, is restricted to central and western California, in which area it often associates with its larger relative the Lesser Snow Goose. The species arrives in mid-fall, as shown by the following dates for Stockton: October 6, 1880; October 6, 1881; October 26, 1896 (Belding, MIS). At Grayson, Stanislaus County, one was taken October 29, 1908 (Mus. Vert. Zool.). In the winter of 1911-12 specimens were secured at Los Baños, Merced County, from November 30 to March 16, and the species was present there until April 2. During November and December, 191:), this goose was often seen by ns in the markets of San Francisco. Belding (MIS) states that in the winter of 1880-81 Ross Geese were found in equal numbers with Lesser Snow Geese in the Stockton markets, and in 1896 exceeded the numbers of the latter

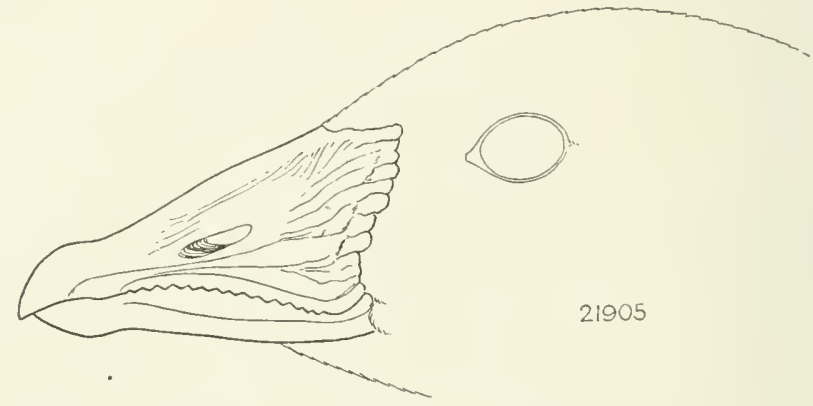

Fig. 31. Sille of bill of Ross Snow Goose. Natural size.

Note roumled rorugations on sile of upper mamible at its base (compare with fig. 30 ).

species. Most of the birds secured at Los Baños in 1911-12 were birds of the year, while in 1908 hunters reported that the birds then killed were mostly adults.

The much smaller size of the Ross Coose readily separates it from the Lesser Snow Goose. When drawn, the Ross Goose seldom weighs mole than two and one-half pounds. The comparatively short bill, only an inch and a half in length, with a warty appearance at the base in the adult, is a good character for identifieation when the bird is in the hand (see fig. 31). Youmg birds are distingnishable from aduits by lack of the warty protuberances and by the presence of gray feathers on the head, neek and foreback. In flight the small size and the peenliar note, whieh is much like that of the Cackling Goose, arr chalacters whieh help in identification. Belding (MS) says that the rusty color so generally found on the Snow Goose is nearly always lacking on the Ross Goose, but the speeimens in the Museum of Terte. 
brate Zoology do not confirm this statement, as many of them are suthused with rusty.

The breeding aremels of this goose have not been definitely determined, but apparenty lie near the Aretic coast north of the region bounded by fort Anderson on the west and IIndson Bay on the east. "The path of migration of this goose seems to be different from that of any other spereses. It is a fair presmmption that the principal route coincieles with the districts in which the species is most common. The greater number pass from the brexling gromeds to Great slave Lake and Lalke Athabasca, eontinme sonth to central and wester'n Montana, and them tum sonthwest, "woss the Roeky Momentans, and pass to central and sonthern California. . . The average date at which the last nue was sem in central Mlontana is April 2t," and "the areage date of arrival at columbia Falls, Montana, is Oetober 15)" (cooke, 1906, pp. 6!)-70). Thus, instead of tuming to the sontheast, to wintere on the Gulf roast with the other eastern geese and ducks which have been its traveling companions, the Ross Goose palts company with them at the national bommary line, and goes southwest across the Rock! Momutains to California.

The food and feeding habits of the Ross Cioose are believed to be very much like those of the Lesser. suow Goose, hut no detailed acounts are avilable to us.

bulding (MS') says that the Ross Goose has comparatively lightcolomed flesh and makes very delieate, palatable food. During the proper season it has been found commonly in the markets of San Francisco, Sacrannento, Stockton, and Los Angeles.

A spereies with a restricted breecling range like that of the Ross Goose, and one which roncentrates in a comparatively small area during the winter, is in an umsual position for total extermination at the hands of man. The one saving circumstance in the case of this bird appears to be its choice of hrescling grounds, so remote as to have thus far escaped discovery by civilized man. In smmmer the species probably enjoys total immmity from human interference. But in winter it is fully exposed to the destructive agencies directed against it by man. The numbers sold in the markets of California are alone enongh to arouse the fear that the depletion of the species will. if much longer continued, shortly reach the danger point. As has been the case so often before, the realization of the danger of extermination may come too late. Some people hold to the riew that as long as there are some birds left, the species will persist, forgetting the prineiple that when the breeding stock is lepleted below a certain point further reduction ensues at an increasing rate, so that total disappearance comes rather abruptly. The citizens of California are almost wholly responsible for the preservation of this speeies. 


\section{American White-fronted Goose}

\section{Anser albifrons gambeli Hartlaub}

OTHER NAMES-Speckle-breast; Speckle-belly; Checker-breast; Checker-belly; Laughing Goose; Gray Goose, part; Yellow-legs; Anser erythropus ; Anser albifrons; Anser gambeli; Berniela gambeli.

Description-ddults, both sexes: Heal, neck and chest grayish brown; blackish-bordered area at base of bill, extending one-half to one inch up the foreheal, and chin, white (in other worls, a white border of varying width completely surrounds base of bill); iris and eyelid brown; bill yellow or orange, nail whitish; back lark brown, each feather tipped with ashy; rump slaty brown; upper tail coverts white; tail slate brown tippen with white; outer surface of closerl wing slate gray; greater wing coverts tipper with white; secondaries blackish; primaries lark slate; mnder surface of wiug and axillars slate gray; feathers of silles and flanks like back but with narrow white line along upper margin; breast and belly grayish white with irregular patches of lark brown or blackish, these varying greatly in extent from mere traces to a condition where lower surface is almost wholly black; under tail coverts white; unler surface of tail feathers light slate color, tipped with white; feet redilish yellow. Females average less in extent of black markings on under surface. Total length (both sexes) $27.00-29.00$ inches (655-736 mm.) (five specimens). Males: folled wing 15.80-17.00 (402-432); bill along eulmen 1.76-2.04 (44.6-51.7); tarsus 2.67-3.12 (67.8-79.3) (ten specimens). Females: folder wing 15.20-16.40 (386-416); bill along eulmen 1.73-1.97 (43.8-50.0); tarsus 2.55-2.88 (64.7-73.0) (ten specimens); all from California. Juvenile plumage: Similar to that of adults, but region around bill wholly dark brown like rest of head, insteal of white; wing coverts more brownish; no black blotches on uniler surface; nail of bill dusky. Natal plumage: Top of hearl and back olive brown; forehead, sides of head, hind-neck, chin, throat and whole under surface greenish yellow, yellowest on belly; stripe from base of bill through eye dusky; two yellowish spots on each side of back, one at hinder borler of wing and one at side of rump.

MARKS FOR FIELD IDENTIFICATION-Large size, white forehead, black speckled belly, remlish feet, light colored bill and general gray borly color (pl. 6).

VoICE-A loud, harsh $w a h, w a h, w a h$, somewhat like the langh of a man.

NEST-On the gromnd, near water, often in wooded listricts; malle of grass and feathers and lined with dowu.

EGGS-6 to 7 , ovate to elongate ovate in shape, measuring in inches, 2.93 to 3.41 by 1.99 to 2.25 (in millimeters, 74.5 to 86.5 by 50.5 to 56.5 ), and averaging 3.21 hy 2.13 ( 81.5 by 54.0 ) (thirty-two eggs in U. S. National Museum); color lull white, with yellowish liscolorations.

General distribution-North America and eastern Asia. In North America breels on Bering Sea and Aretic coasts from mouth of the Yukon River, Alaska, north and east to northeastern Mackenzie. Winters chiefly from sonthern British Columbia to sonthern Lower Califormia and Jalisco, Mexico: and less commonly east of the Rocky Mountains from southern Illinois and New Jersey south to northeastern Mexico, southern Texas, and Cuba (morlified from A. O. U. Check-list, 1910, p. 85).

DISTRIBUTION IN CALIFORNIA-Common winter visitant to suitable localities throughout the state, on both the plains and swanyy lowlanils; most alumlant 
in the San Joaquin-sacramento Valley. Arrives in early September and leaves in April.*

The American White-fronter Goose is a common winter visitant in California, and is much prized here as a game bird. While it occurs ahnost everywhere in the lowland portions of the state the center of abundance is on the plains and marshes of the sacramentoSan Joapnin Valley. This species is the first of its tribe to arrive in the fall and the last to leave in the spring. Beleling (MS) noted its arrival at Stockton, San Joapuin Connty, on September 7, 1878, and September 8, 1881. At the same place they were last seen by him April 27, 1879, May 2. 1880, and April 29, 1896. His latest date of spring aecurence is May 3. At Los Baños, Nereed Countyr, Beck (MS) fomd this goose still present on April 22, 1912. The early arrival of this species from the north has donbtless been the basis for many of the predietions of an early winter which are sent to newspapers by local "weather prophets."

The irregular black markings on the breast and belly of this birel have given rise to such names as Speckle-belly and Checker-breast, while its general gray tone of coloration has suggested the name Gray Goose in contradistinction to the white snow Gerese and black-hradeel Canada Geese and Brant. The white area about the bill is the basis of the accepted common name, White-frontecl Goose. The black blotched breast, gray hack, and white ring on the face, together with the large size, and light colorect bill and feet, make this goose rery easy to identify (pl. 6). The snow and Ross geese are chiefly white, the Canada geese and Brant have black heads, necks and feet, and the rather rare Emperor Goose has the whole top of the head white. The lond harsh call-note of the White-fronted is sair by hunters to be distinctive.

The American White-fronted Goose nests in northern and western Alaska and eastward along the Arctic coast of British America to

* Since the above chapter on the White-fronted Goose was set in type, the discovery has been made that two subspecies of Anser albifrons occur in winter in California (see Swarth and Bryant, Univ. Calif. Publ. Zool. vol. 17, October 19, 1917 p0. 209-222, pl. 13). The most abundant of the two is exactly as described above but its name should be $d$ nser albifrons most abundant of the two is exactly as described above but its mame should be Anser albifrons
albifrons. The newly distinguished and relatively" rare bird, the "Tule Goose," properly bears albifrons. The newly distinguished

The differences existing between the two subspecies may be summarized as follows:

Alser albifrons albifrons

Size small: wing $15.12-16.62$ inches $(384-422 \mathrm{~mm}$ ) ; bill small : culmen $1.73-2.05$ (44-52); weight 3 lbs. $140 z$ to $5 \mathrm{lbs}$. $8 \mathrm{oz}$. (five specimens); tail feathers, sixteen: coloration in general paler, head and neck grayish; naked skin at edge of eyelid, grayish brown.

Anser albifrons gambeli

Size large: wing $16.54-13.73$ inches (420-475 mm.); bill large; culmen 2.08-2.45 (53-62); weight 5 lbs. $5 \mathrm{oz}$. to $7 \mathrm{lbs} .8 \mathrm{oz}$. (ten specimens): coloration in general darker, neck dark brown, head blackich; tail feathers, male eighteen, female sixteen; naked skin at edge of eyelid, yellow or orange.

The Tule Goose has been reported only from the upper Sacramento Talley where, in the ricinity of Butte Creek, it frequents ponds and sloughs surrounded by tules and willows. It flocks separately from its smaller relative, and is often seen only sirgly or in pairs. Its notes are said to be pecnliar. The summer home of the Tule Goose is unknown but is conjectured to lie in Arctic America somewhere east of Alaska. 
Maekenzie; also to some extent on the Asiatic coast bordering Bering Sea. Nelson (1887, p. 83) found eggs near the month of the Yukon River as early as May 27 (1879). From this time on mitil the middle of June, fresh eggs were to be found: but very soon after the latter date, downy young began to appear. 'These geese choose for a nesting site the grassy border of a lakelet, a knoll grown over with moss and grass, or even a flat, sparingly covered with grass. Along the Yukon, Dall found them breeding in colonies, the eggs being deposited in hollows scooped out in the sand. At the Yukon mouth and around St. Michaels they were foumd breeding in scattered pairs orer the flat country.

Every one of the nests examinerl by me in these places harl a slight lining of grass or moss, gatheres by the parent, and nyon this the first egg was laid; as the complement of eggs is approachert the female always plucks down and feathers from her breast until the eggs rest in a soft warm bed, when incubation commences. The eggs vary considerably in shape anml size. . . In color they are of a dull white, but ordinarily present a dirty brown appearance from being stained in the nest (Nelson, loe. (-it.).

The maximum number of eggs in a set appears to be seven. Seren eggs at hand from western Alaska are dull white, discolored somewhat to a yellowish tone, and measme in inehes from 2.83 to 3.06 by 1.86 to 1.98 , averaging 2.94 by 1.93 .

Grimmell (1900, pp. 17-18) says that in northern Alaska flocks of from six to twenty are found in the fall up to September 12 on the grassy margins of lakes and on wind swept sand-bars along rivers. When they first arrive, about May 10, they are very quiet but later they become noisy.

The following also coneerns the habits of the White-frontel Goose in Alaska, whence probably cone on winter visitants:

All through September, oht and young, which have been on the wing since Angust, gather in larger flocks, and as the sharp frosts toward the emd of September warn them of approaching winter, commence moving south. The marshes [in the vicinity of St. Michaels] resound with their cries, and after some days of ehattering, flying back and forth, and a general hustle, they suddenly start off in considerable flocks, and the few laggaris which remain get away by the 7 th or 8 th of October (Nelson, 1887, 1. 54).

Indians imitate the eall of this goose by patting the month with the hand while pronouncing the syllable wh (Baird, Brewer and Ridgway, 1884, I, p. 452). The notes of this goose are said to resemble the langh of a man, and the species has been called, locally, the "langhing goose", on this account.

Van Dyke (1904, p. 670) describes the mamner in which the different species of geese come into a pond as follows: 
Coming from afia in a hig white "lowl, the snow geose betore rearhing the elge of the pond mass smblenly up in a longr column inclined some forty legrees from the rertiual. Fvery blark-tippel wing is thrown outwarl and lownwarl and rigilly set. with the axis of the boly about corresponiling to the axis of the whole rolumn. Anything like sailing is thus impossible and the whole descent is a slow settling or srifting lownwarl, almost as gently as the fall of a gossamer skein on the still air of lnclian smmmer. . . The White-fronted Goose swings orel it high in air as if he enjoyed the play. He is reasonably silent about it as he floats a thonsand feet or more alove the water, where he lines up for the great junge. Then the eilge of the line lreaks, and as if struck subleuly hy the thunlerholt, yet with every throat tuned to concert pitch, the birds dive, tmuble, and gyrate sidewise, upside down, rolling over in the air in every imaginable way, a catarat of whirling life, lown to within a few feet of the water. There the grand go-as yon please mareli sullenly ends, the will rlamor of every throat is stilled, earh goose rights itself in a twinkling, drifts into an orderly line, and floats a tew yarus along the surface of the wator, then lrojs its feet, raises its neek and heal, and throwing lack its wings s]ifles into the water as crently as the reflertion of the tleery elourls alove it. Canada geese lescend in long emrling lines, as if the birls were leswending an invisible flight of winding stairs with erery wing stifly set anl every white-collaref throat silent as the grave.

This species of goose is said to be more exclusive than other species, staying more largely in separate or ummixed flocks. They usually frequent low mashy ground when loafing, but during hours of feecting may be seen in stubble fields or on the open plains far from water.

White-fronted Geese usually loaf on or near some borly of water during the midlle of the day, doing their feeding early in the morming, in the evening, or dhing the night. Northoff (1902, p. 213) found that, at Elsinore Lake. Riverside County, they made four regular flights daily to the grain fields, ten miles away, never varying the time of arrival and departure more than fifteen minutes. "During periods of stormy weather they often fiy orer in large flocks, apparently with no definite object in view other than a change of feeding grounds. Their cry is often heard at night, especially during moonlight evenings" (Tyler, 1913b, p. 18).

The food of the White-fronted Goose consists almost entirely of grass. Heermann (1859, p. 68) says that this goose is consiclered the most delicate for the table, as it feeds almost exclusively on the young herbage growing on the highlands and abont the fresh water ponds. In years past this species, along with other geese, has been responsible for considerable damage to grain.

The White-fronted Goose is one of the commonest geese on the market. "Gray geese" (under which term this species and perhaps also the Hutchins Goose is ineluded) to the number of 19,419 were sold in the markets of San Francisco and Los Angeles in the season of 1895-96. The total amount paid hunter's for these birds was $\$ 4,042.30$, 
or about twenty cents apice (Calif. Fish. Comm., 1896, pp.41, 42). In 1909-10 (Oetober 2 to March 5) one company handled 8,053 of the birds. In 1910-11 the prices paid ranged from $\$ 1.50$ to $\$ 7.00$ per dozen. In 1912-13 these geese sold for 65 cents to $\$ 1.00$ per pair on the Los Angeles markets (E. J. Fischer in letter). In 1850 these geese sold at $\$ 1.00$ to $\$ 1.50$ per pair (Newberry, 1857, p. 102) which, considering the high prices prevailing during the gold rush, suggests that these birds were then very easily obtained.

This species is said to be easily approached by the gumner, and so is readily procured. Nevertheless some ruse, such as hiding behind a grazing steer, has usually been resorted to in order to make a big killing. This method of approach, known as "bull-hunting," was formerly widely employed by market hunters in procuring geese. It is now prohibited by law. Pits dug in the ground in localities over which the birds are known to fly regularly, are most often used as blinds in hunting geese.

A brisk market demand as well as ease of eapture has been instrumental in greatly reducing the numbers of this goose visiting California. There is probably not now more than one bird to a hundred that used to be found in the state. With no protection whatever until 1915, it is no wonder that we have lost the greater proportion of these valuable game birds. It remains to be seen whether our present laws will be sufficient to enable the species to maintain itself or increase toward its former abundance.

\section{Canada Goose}

\section{Branta canadensis canadensis (Limnaeus)}

OTHER NAMES-Honker; Hunter; Mexican Goose; Big Mexican Goose; Whitecheekell Goose; Bernicla canadensis; Branta canadensis occidentalis.

DESCRIPTION-Adults, both sexes: Whole heal and neck shiny black, except for large white patch on each cheek which usually meets its fellow across the throat; chin usually blackish; iris brown; bill black; general rolor of upjer surface hrownish gray, each feather narrowly tipped with gray or whitish; rump black; upper tail coverts white; tail black; outer surface of closed wing brownish gray, with pale feather elgings like back; primary flight feathers and inner webs of secondaries blackish; muler surface of wing aud axillars light grayish brown; umler surface of boly pale ashy gray, with whitish feather tippings giving an effect of obseure barring; flanks clarkest colores, more brownish; lower helly and uniler tail roverts white; feet black. Total length (both sexes) "about 35.00-43.00', iuches ( $885-1093$ mm.) (Rillgway, 1900 , p. 117). Males: folled wing 16.50-20.75 (418-527); bill along culmen $1.88-2.31$ (47.7-58.6); tarsus 3.00-3.88 (76.2-98.5) (ten specimens). Females: folderl wing 17.60-19.65 (447-499); bill along culmen 1.89-2.06 (47.9-52.4); tarsus 3.26-3.58 (82.7-90.8) (ten specimens); all from California. Jucenile plumage: Similar to that of adult but with colors duller and white cheek 
liatches speckled with l, lark. Natul plumage: Top of hearl old gold; forehearl, silles of heall, throat, anıl whole neck, leep straw yellow; back old golıl, witl, patch of straw yellow hehind each wing; wings and tail, light brownish olive; lower surface of bolly ilull iream eolor.

MARKS FOR FIELD IDENTIFICATION-Very large size (largest of all our geese), black heal, neck, hill anl feet. white theek patches, and uniform aplearing gray holy. Distinguishell from Hutchins and Caekling geese by larger size, and from sea Brant loy presence of white patches on cheeks (see figs. 32-37). Recognizahle in flight by abruptly black head anı neck, gray boly plumage, lonl trumpet-like "honks,", and slow wing strokes.

Volce-A hoarse, sonorous houk.

Nest-Csually in swampy situation, but on lry groumi, more rarely on a stump or in a tree in an olil nest of some other birl; construeterl of twigs, weerls, grasses or reals, with abundant lining of lown.

Eigs-5 to 7 , ovite to elongate ovate in shape, measuring in inehes 3.06 to $3.71 \mathrm{by} 2.15$ to 2.34 (in millimeters, 77.5 to 94.2 by 54.6 to 59.4 ), and averaging 3.37 by 2.25 (\$5.6 by 57.2) (Ray, 1912a, pl). 6s-69); color dull yellowish white.

Gexeral Distribction-Interior North America. Breels from limit of trees in lower Yukon Valley, Alaska, east to northwestern Markenzie anul eentral Keewatin, and thenre south to Incliana, northern Coloralo, and north-eentral Califoruia. Winters from southern British Columbia, southern Colorarlo, soutl. ern Wisconsin and New Jersey south to southeru California, Texas and Florila (morlifiel from A. O. C. Check-list, 1910, p. sif).

DISTRIBLTION IN CALIFORAIA-C'ommon winter visitant throughout the lowlauls but chiefly to interior valleys; southermmost recori station, San Diego (Belıing, 1s92 $\bullet$, p 100)). Farrly common in summer in lake region nortl and east of the Sierra Nevala. Has heen recorled as breenling at the following localities: Lower Klamath Lake (Newherry, 1857, 1. 100; H. C. Bryant, 1914 . p. 229.2): Eagle Lake (Shellon, 1907, p. 187); Honey Lake (Carly, MS); and Lake Tahoe (Belıing, loc. cit.; Ray, 1912a, p. 72).

The migrating V'shaped flocks of the Canada Goose, or Honker, together with the somorous call-notes while on the wing, are familiar to almost everyone, so that it is safe to say that this is the best known of American geese. It is the most widely distributed speeies in North America and is the one which is here most often brought into domestication. Of the geese occurring in California it is the largest, but at the present time is least common of all, save for the rare Emperor Goose. In winter it is found in suitable localities almost throughout the state, but those birds which remain for the summer to nest within onr boundaries betake themselves to the vicinity of the large lakes in northeastern California east of the Sierra-Cascade divide.

The Canada Goose is about the last of the wintering geese to arrive in California. It seldom puts in an appearance before the middle of November, or at least until unfavorable conditions drive it south from its breeding home. Belding (1892a, p. 100) noted the first birds of this species in the Stockton market on November 11 (1880), and November 23 (1881). In 1896 the first flock seen by him at Stockton was observed on November 27. At Gridley, Butte County, this goose 
was fir'st seen on December 2, 1885, November 24, 1890, and November 5, 1892 (Belding, MS ). It is also among the first to leave for the north. As early as Felmuary 22, 1887, Belding (MS) saw flocks of Canada Geese going east over the snow-elad Sierras of Calaveras County, and at Stockton he saw them going north on February 12 , 1896. Beek (IIS) reports seeing two flocks February 23, 1911, at Los Baños, Merced County, but says that hunters maintained that

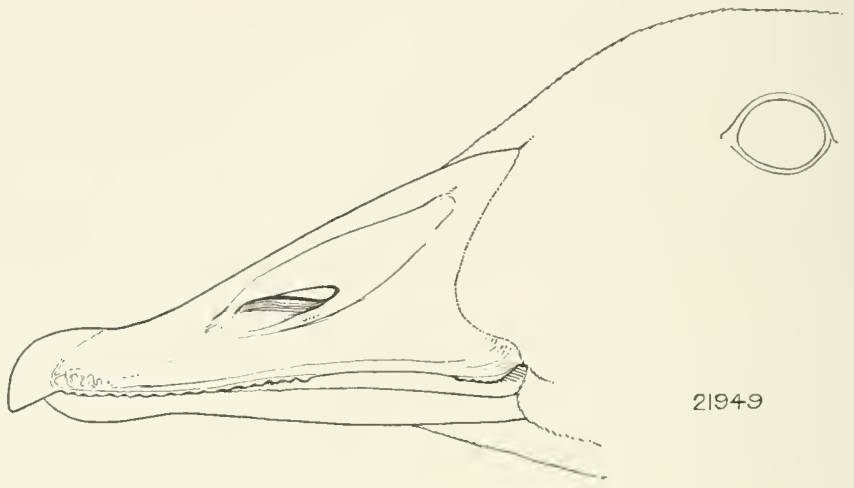

Fig. 32. Canada Goose.

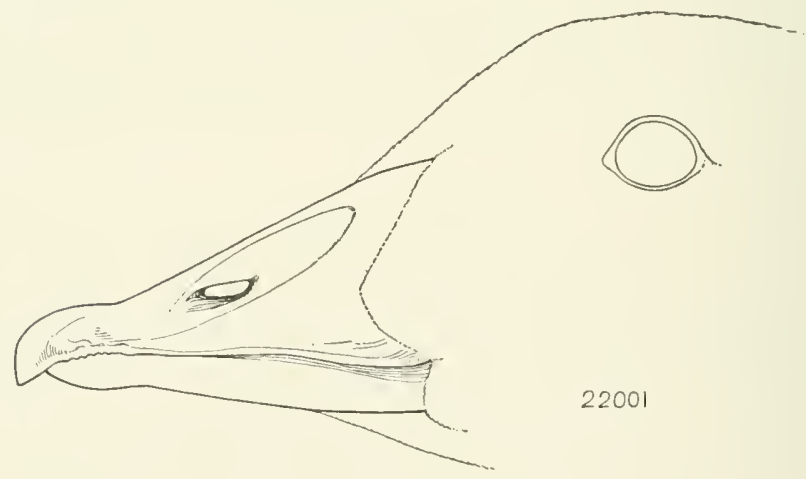

Fig. 3.3. Hutrhins Goose.

most of the Canada Geese had already left. The latest spring record is April 11, 1893, when five individuals were seen in a grain field at Gridley, Butte County (Belding, MS).

The Canada Goose is easily separated from geese belonging to other groups by its abruptly black head and neck, white cheek patches, and black bill and feet. The three subspecies or varieties of "whitecheeked" geese (Canada, Hutchins and Cackling) inter'grade with one another, and individuals are occasionally found which cannot be sat isfactorily referred to one or the other of these races. As a rule, however, they can be separated on the basis of the length of the bill, which, 
of comrese is an index of the genelal size. The famala Goose has a bill 1.5. 2.31 inches long: that of the IIutehins (ioose is $1.37-1.80$ inches, and that of tho ('ackling Goose, 1.04-1.4t inches. In flieght the C'anala fioose "an be recognized hy its large size, its peculiar pattern of coloration, its slow, measmeel wing beats, and its sonorons honk, houli.

Swath (1913b, pp. 8-9) has recently shown that, contrary to the statements found in pratically all ornithological books dealing in any way with the subject, the true White-checked Goose (Brentu canadrasis occidentulis) does not ocene in (alifornia. The many references in literatmere to this goose really apply to the Canala Goose (Branle cannde msis cenade nsis). The White-chenked Goose is a large clark-colored northwestern bace which ocenpies the immediate vicinity

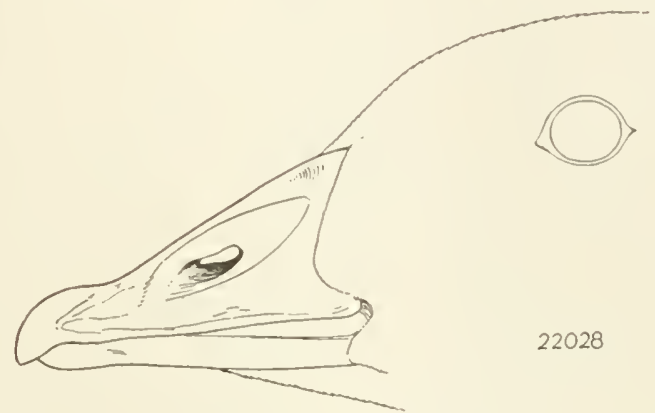

Fig. 34. Carkling Goose.

Figs. 32 to 34 are natmral size and serve to show the lifferences in the size ant proportions of the bill which characterize average specimens of each rare.

of the seacoast, from Washington at least to Prinee William Sound, Alaska, and which in summer probably does not ocenr farther sonth than the southern boundary of British Columbia.

The Canada Goose is definitely known to breed in at least three localities in northeastern California-Lake Tahoe, Eagle Lake, anc Lower Klamath Lake. The first record of nesting in California is that by Newber'y (1857, p. 100) and pertains to Lower Klamath Lake. Belding ( $1892 a$, p. 100$)$ states that, previonsly to 1892 , this goose bred sparingly in a large marsh at Tallae Point, at the sonth end of Lake Tahoe. Numerous nests were found in the same neighborhood in 1909, 1910 and 1911 by Ray (1912a, pp. 67-71), and an old-time settler in Lake Talley told the last named author that this speeies had nested there almost every spring for the past thirty years. In all but one of the instances observed by Ray, the nest was composed entirely of dry marsh grass and down. In the exceptional ease tules were used. One nest measured twenty-two inches over all, but the 
cavity in it was only eleven inches across and three inches deep. Five nests were found on May 15, 1911, while snow was still on the ground. The number of eggs in the nests observed at Lake Tahoe, ranged from five to seven. In a number of instances eggs of the Canada Goose gathered at Lake Tahoe have been sent elsewhere and successfully hatched. Judge F. W. Henshaw has several adult Canada Geese on his place near Redwood City, San Nateo County, which were hatched from eggs collected at Lake Tahoe. Many halfgrown broods of Canada Geese were seen by Sheldon (1907, p. 187) at Eagle Lake in June, 1905. Farther north this goose does not lay until June (Cooke, 1906, p. 76).

H. C. Bryant (1914c, p. 232 ), during a visit to Lower Klamath Lake in 1914, found on June 6 a band of at least ten half-grown young Canada Geese accompanied by one adult. Probably two broods were represented. On June 7 two other broods were seen near the mouth of Willow Creek, one containing four young and the other five or six. Ranchers of the vicinity reported that every spring

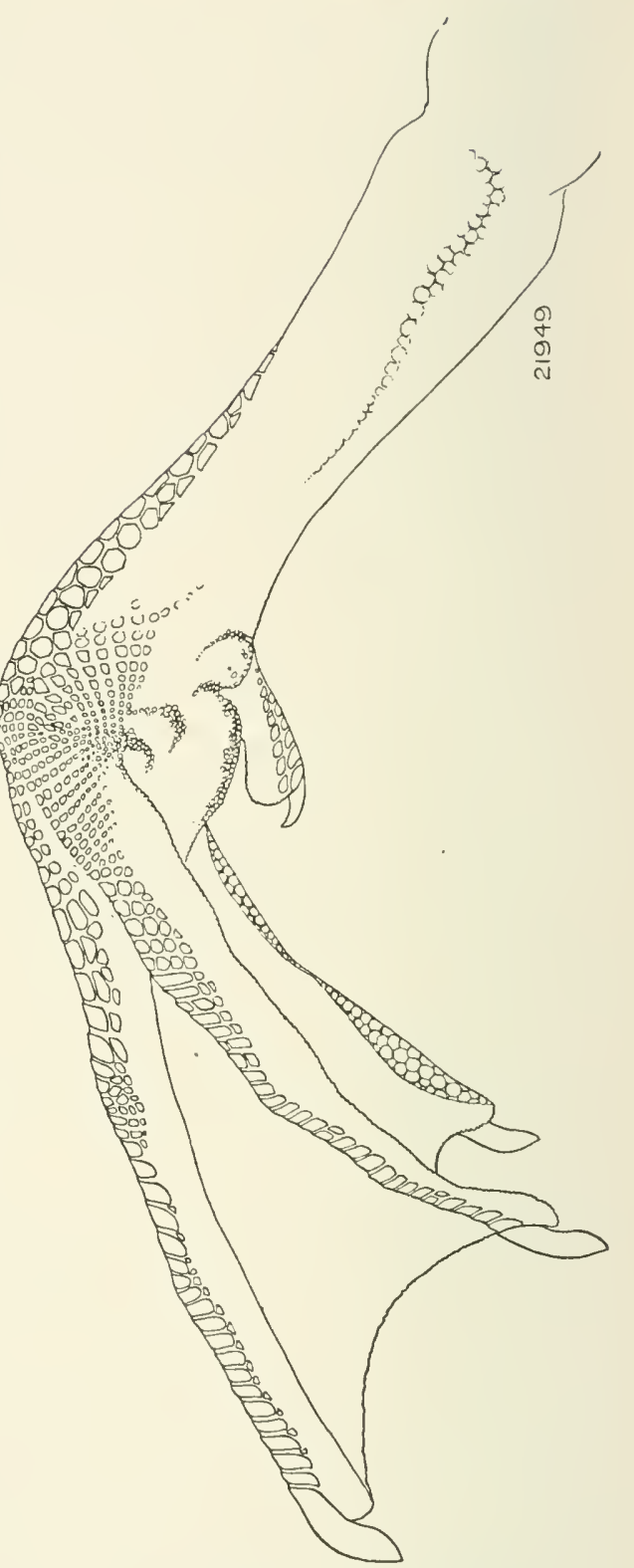

Fig. 35. Canarla Goose. Honkers nest in the tules bordering the lake, and that they are the first of the water birds to nest.

Ray (1912a, p. 68) recounts that while rowing up a slough on Rowlands Marsh, Lake Tahoe, May 23, 1910, a goose "rose from her nest, took a short run, and rising with heavy flight and loud eries, flew 


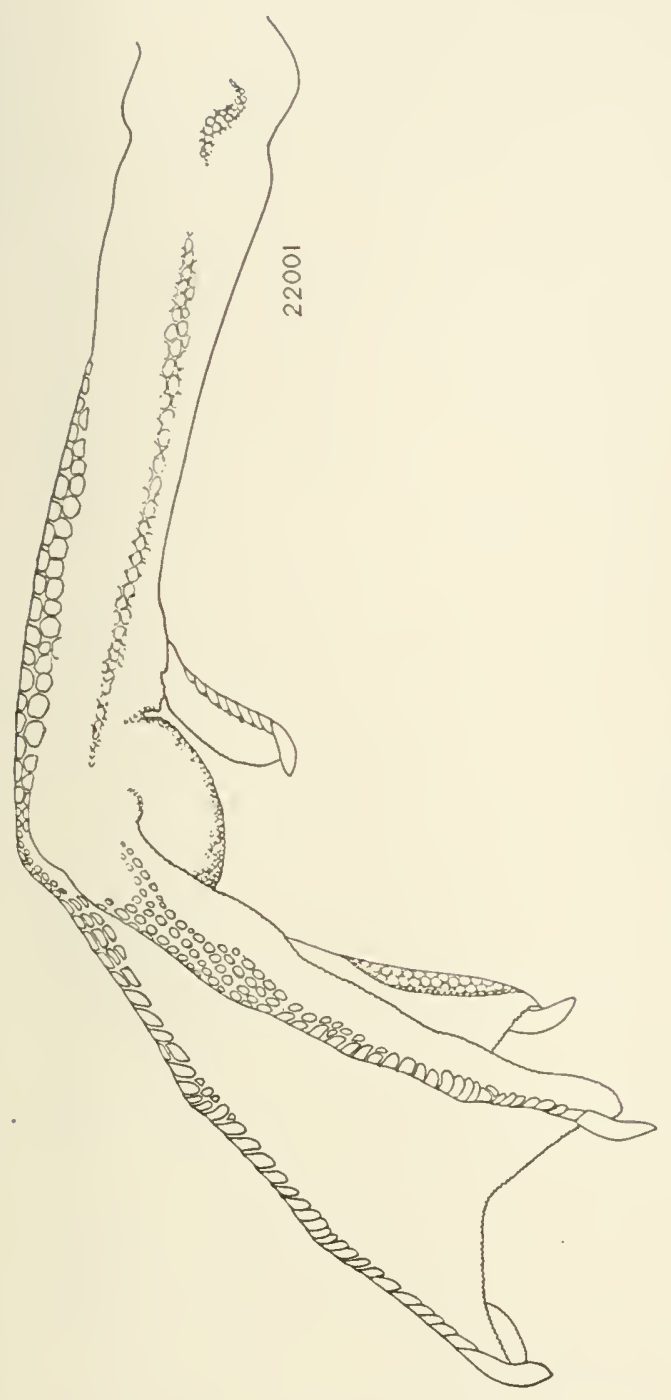

Fig. 36. Hutehins Goose.

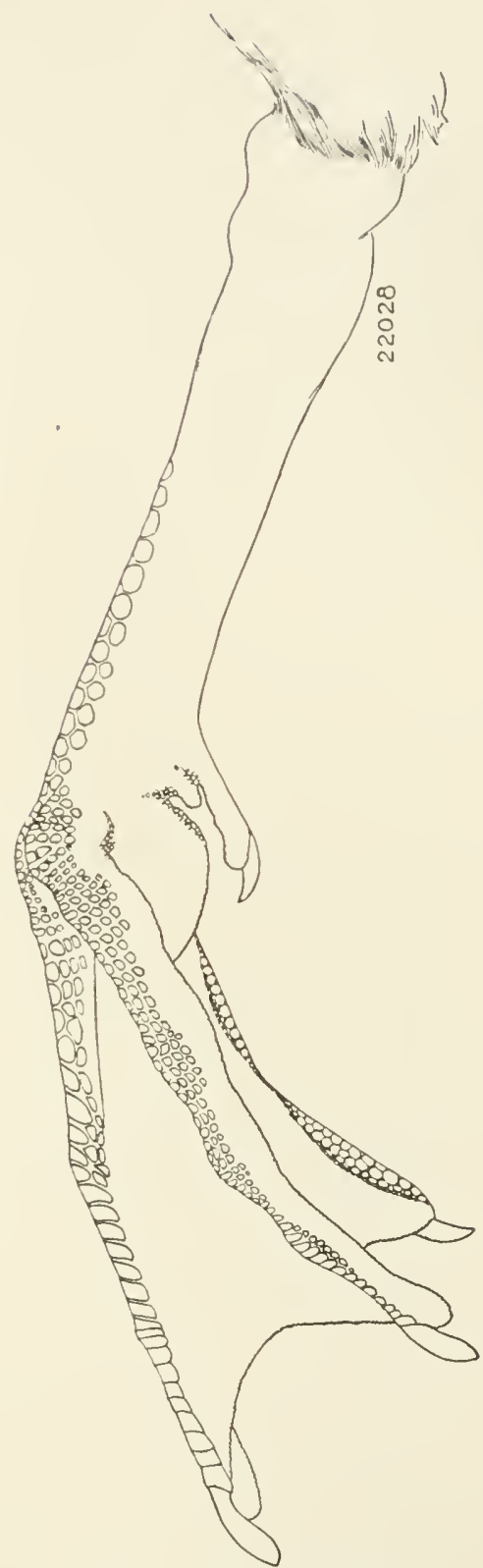

Fig. 37. Cackling Goose.

Figs. 35 to 37 are natural size and serve to show the relative length of tarsus to middle toe which characterizes average specimens of each race.

out to open water, where she was joined by her mate. The cries of the pair echoed so loudly over the marsh that it seemed the whole region must be awakened." The nest of this pair was situated on 
the gromnd at the base of a willow growing on a small island in the marsh.

In the north the Canada Goose does not always build its nest on the gromel. Several instances have been recored where it has ntilized stumps of trees and even deserted nests of birds of prey ( Мacoun and Macoun, 1909, p. 126).

In California during the mid-winter months these geese inhabit the interior valleys rather than the neighborhood of the seashore. Their favorite resorts are the large open grain fields near some big river or other large body of water. Here they feed evening and morning, spending the middle of the day and the night on the water itself. At Los Baños, Míerced County, they leave the marshrs for the evening flight to the grain fields about two, three or four o'clock in the afternoon, and return about dark (Beck, MS).

The flight of this species is firm, rapil, and protracted, the birl moving with great stearliness and regularity. Before rising it usually runs a few feet with outspread wings, but when surprised can rise with a sullen spring. In its migratious it is liable to be thrown into confusion ly passing into a fogbank, or over a city or place where there is much shipping. . . Both keenness of sight and quickness of hearing are remarkable in this bird, and it is always vigilant and suspicious; so that it is with great difficulty taken by surprise (Baird, Brewer and Rirlgway, 1884, I, 1. 463).

"Few wild bird notes are more inspiring than the honk, honk. ha lath, homk, of a long line of Canada Geese flying with apparent deliberation but with really terrific speed overhead, calling as they go in notes that carry for a mile over marsh, lake, and prairie. The big strong wings whish londly overhead far out of shotgun range, and often a low conversational gabble can be heard under the loud honking" ( $\mathrm{T}$. Bailey, in Bailey, 1902, pp. 67-68). It is believed to be always an old gander that forms the apex of the V-shaped flocks. Befor alighting a flock circles several times to investigate. While feeding there appear to be several inclividnals who keep wateh, thus making close approach in an open field almost impossible. In fact this goose has earned a well-deserved reputation for wariness.

Mnch of the food of the Canada Goose is made 11 p of grain gleaned from stublule fields or sprouting grain fields. Grass, especially the roots, also forms a staple article of diet, and a clean-cropped swath, like that made by shere, is left where these geese have been feeding. Doring the summen they vary their vegetable eliet with small animals to be found in their favorite marshes, such as snails, tatpoles anel minnows.

loth as an object of sport and as a contribution to the table the Canada Goose, as a rule, surpasses all other geese. The young of this species are a real hoxury, the flesh being very tender and sweet. 
The weight of a f'anala Goose is said to valy from eight to twelver poumks. A lean fremale, taken in late spring at Lake 'Tahoe, weighed right amel three-quarter pommels.

The amateme humter is likely to shoot behind his first geese, for the birls appear to be moving slowly. In reality they move very fast, and a long leat is resumed. Therir hahit of resorting to fields to fred morning and erening makes it feasible to use a blind beneath a regular line of Hight known to have been established by the birels. On the open plains a pit dong in the gromed is nset as a hlind, and the birds are decoyed by live domesticated geese ol by decoys. As soon as some birds are killed they ale "stooled," that is, propped up with wires so as to appear life-like. In early days these greese were humted from wagons which were driven along on the windward sicle of feeding birds mutil quite neis when a tash would be marle for them and the hunter would fire into the Hock, the members of which had of necessity to rise into the wind. The call is initaterl hy giving a nasal promunciation to the sillahle " wonk."

At the present time the Camada foose must be considered the least common of the "encay geese" fommel in califormia. In many places where it was formerly abmelant it has not been seen for years.

During the season of 1895-96, 2,411 Honker Gerese were sold on the markets of san Franciseo and los Angeles (Calif. Fish Comm., 1896, 1). 41). Eleven years later (season 1906-07) there were sold on the markets of San Francisco by one transfer company 15t Honkers, and in the season of 1909-10 the sane company handled 416. Probably not more than this last number were sold in all the markets of the state doring the season of 1912-13. Even taking into account the shorter season which came into effect in 191:), the decrease has been serions. With the incentive of a high price offered (75 cents each in many (ases) the malket hunter does his ntmost to procule this species of goose. Consequently the numbers sold on the market each year do not acemately inclicate the comparative numbers of Honkers remaining from verar to yrar.

Among all the geese this is the one which most needs protection if it is to continue to exist as a game bird. It is the most sonthern breeding species, and in fact does not retire at anr season altogether beyond the outposts of human habitation. The wariness of the Honker will help it to persist longer than some other species; but the demand for it as a game bird compled with the ingenuity of man and the increased efficiency of firearms more than counterbalances the natural instincts which make for the preservation of the species. If people conld only be bronght to a realization of the true status of this species. more rigid protection would be fortheoming voluntarily, on economic giroumels alone. 


\section{Hutchins Goose}

\section{Branta canadensis hutchinsi (Richardson)}

Other NAMES-Gray Goose, part; Brant; Lesser Canarla Goose; Merliumsizer Honker; Little Honker; Auser hutchinsi; Bernicla hutchinsi.

Description-Adults, both sexes: Practically the same as Canada Goose but size smaller. Under surface usually darker, varying from pale gray to lark brown; a black line down throat separating white cheek patches, and a narrow white collar at base of black neck may or may not be present. Total length (both sexes) "ahout 25.00-34.00" inches (635-863 mm.) (Ridgway, 1900, p. 117). Males: folłed wing 15.36-17.93 (390-455); bill along culmen 1.37-1.80 (34.8-45.7); tarsus 2.68-3.40 (68.0-86.3) (ten specimens). Females: folited wing 15.25-16.60 (387-422); bill along eulmen 1.46-1.58 (37.1-40.2); tarsus 2.78-3.00 (70.5-76.2) (six specimens); all from California. Juvenile and natal plumages: Not known to differ from those of Canalla Goose.

MARKS FOR FIEl.D IDENTIFICATION-Similar to those for Canada Goose but size slightly smaller: total length 25 to 34 inches $(635-863 \mathrm{~mm}$.), weight 3 to 4 pounds (1360 to $1812 \mathrm{gm}$.). On close examination the coloration is seen to be darker, the mildle toe with elaw about equals the tarsus in length, and the bill measures 1.37-1.80 inches (34.8-45.7 mm.) (compare figs. 32-37).

Vorce-Closely resembles that of Canarla Goose but not so deep' and sonorous; said to be distinguishable by experienced persons.

Nest-On ground near water; composed of weeds, grasses or reesls, and profusely lined with down.

EGGS-4 to 6 , in shape ovate to elongate ovate, measuring in inches, 2.84-3.27 by 2.05 to 2.21 (in millimeters, 72.0 to 83.0 by 52.0 to 56.0 ), and areraging 3.12 by 2.10 (79.0 by 53.5) (fifty-six eggs in U. S. National Mnseum); color white (Davie, 1889, p. 81).

General distribution-Western North America. Breels in far north, west in Alaska to Kowak Valley, and east along Aretic shores and islands to Hudson Bay. Winters from British Columbia, Nevarla, Colorarlo, and Missouri south to Lower California, Texas and Louisiana; in migration rare east of Mississippi Valley, although recoriled on Atlantic coast from Maine to Virginia (A. O. U. Check-list, 1910, 1). 86).

Distribution IN CALIFORNIA-Common winter visitant to suitable localities throughout the state. Most plentiful in the Sacramento and San Joaquin valleys. Recorded east to Owens and Death valleys (A. K. Fisher, 1593a, 1. 19) and south to San Diego (Heermann, 1859, p. 67).

Three varieties of Canada or "white-cheekel" geese are found in California during the winter months and of these the Hutehins or Medium-sized Honker is the most abumdant. It arrives from the north about the second week in Oetober and departs about the third week in April. The earliest fall record is for Gridley, Butte County, where the species was seen on October 9, 1884, and the latest spring occurrence, April 26, 1896, is for the same locality (Belding, MS). In Alaska, in the Kowak Talley, the first Hutchins Goose in the spring was seen on May 14, 1899, while the last in the fall of 1898, was observed on September 14 (Grimnell, 1900, p. 18). The species is 
found in very large mumber's in the marshes of the great eentral valley of California, as for example at Los Baños, Nereed County : and it also oeenrs abundantly abont certain of the lakes of high elevation such as Lower Klamath Lake (Ferry, 1908, p. 39).

The Hutehins Goose is simply a slightly smaller "edition" of the Canada Goose, and the ficld marks of the latter species, except for size and weight, will apply equally well to the subject of the present accomnt. A Hutchins Goose measures about six inehes less in total length than a C'anada Goose and weighs only about half as much. In hand the bill is found to measure 1.37 to 1.80 inehes, and the almost equal lengths of tar'sus and middle toe with claw also eharaeterize the present race. 'The Cackling Goose is still smaller than the Hutehins, but has the same general eolor pattern. Oecasional individual birds are found which cannot be satisfactorily elassified with any of these three races (see figs. 32-37).

Despite the fact that the Intehins Goose nests over a wide extent of teritory, from northwestern Alaska east to Hudson Bay, little has been published concerning its breeding habits. Nests are usually placed on the gromd, in slight hollows lined with leaves, grasses and down. Of fifty nests found by MacFarlane $(1891$, p. 424) on the Lower Anderson River, Aretie ('anada, all but one were on the ground and were composed of "hay, feathers, and lown." The exeeption was where a female had deposited her four eggs and was ineubating them in an old crow or hawk's nest nine feest above the ground in a pine tree. In the other nests six was the usual eomplement of eggs. In Alaska these geese sometimes choose hill tops for nest sites, but most generally sandy beaches and grassy situations near fresh-water lakes are ehosen. Eggs were taken by Dall on June 15 and downy young on July 10 (Nelson, 1887, p. 85). MaeFarlane secured eggs on June 10 and June 14, 1864-65 (Cooke, 1906, 1. 78).

Grinnell (1900, p. 18) found this a common goose in the Kowak Valley, Alaska, but did not see it along the seacoast. In the fall, flocks were to be found on the same feeding gromds as the Whitefronted Goose, but eompanies of the two species did not intermingle. In the spring they had become very numerous by the latter part of May and had spread out in pairs among the tundra lakes. The natives of the Kowak Valley have a method of trapping geese, which is surer than shooting. Ineonspicuous fences of willow saplings are built aeross a mud-flat known to be a favorite resort of the birds. Gaps are left in these fences and in these openings ordinary steel traps are set.

Heermann $(1859$, p. 67) says of this speeies in California:

Whilst hunting during a space of two months in Suisun Valley, I observed then, with other species of geese, at dawn, high in the air, winging their way 
towards the prairies and hilly slopes, where the tender young wild oats and grapes offerenl a tempting pasturage. This early flight lasterl about two hours, and as far as the eye could reach the sky was spotterl with flock after flock, closely following in each other's wake, until it seemerl as though all the geese of California had given rendezvous at this particular point. Between ten and eleven oclock they wouk leave the prairies, first in small squarts, then in large masses, settling in the marshes and collecting around the ponds and sloughs thickly erlgerl with heavy reerls. Here, swimming on the water, bath. ing and pluming themselves, they keep up a continued but not unmusical clatter. This proves the most propitious time of the lay for the hunter, who, nniler cover of the tall reeds, and guiled by their continual cackling, approaches closely enough to deal havo among them. Discharging one loal as they sit on the water and the other as they rise, I have thus seen twenty-three geese gathered from two shots, while many more, wounded and maimed, fluttered away and were lost. At about one o'clock they leave the marshes and return to feed on the prairies, flying low and affording the sportsman again an opportunity to stop' their career. In the afternoon, about five o'clock, they finally leave the prairies, and rising high in the air wem their way to the roosting places whence they came in the morning. These were often at a great distance, as I have followed them in their evening flight mtil they were lost to view. Many, however, roost in the marshes. Our boat, sailing one night down the sloughs learling to Suisun Bay, having come among them, the noise made as they arose in advance of us, emitting their cry of alarm (their disordered masses being so serried that we could hear their pinions strike each other as they flew), impressed us with the idea that we must have disturherl thousands. Such are the habits of the geese during the winter. Towaris spring they separate into smaller flocks and gradually lisappear from the country, some few only remaining, probably crippler and unable to follow the more vigorous in their northern migration.

"During the rainy season in California the plains and valleys, before brown and try, beeome elothed in rich verdure, and the nourishing grasses afford sustenance to incredible numbers of these and other geese. Three kinds, the Snow, White-fronted and the present species, have almost preeisely the same habits and the same food during their stay with us, and associate so intimately together that many, if not most, of the floeks contain representatives of all three" (Cones, 1874, pp. 555-556). Although the different species may fred together, other observers have noted that on being disturbed they immediately divide into floeks of their own kind.

Speeimens of this speeies eolleeted at Los Baños, Mereed County, in November, 1911, had been feeding entirely on grain. The gullet and gizzard of one shot from a flock returning from foraging at 10:30 A.M. contained 1,147 grains of barley by actual count; another 1,076 grains of barley (Beck, MS). Thus it ean be seen that where geese colleet by thousands on newly planted grain fields the depredations are serious. Near Windfall Harbor, Alaska, the natives say that this species of goose stops in large numbers, for a short time, to feed on 
the herring spawn which is found allerejug to rocks along the heaches which beseme axposed at low tide (Grimell, 19096, p. 198).

The Ilutehins (foose, although not quite so desirable a bird for the table as ale some other speecies, is the goose which has afforterl the greatest amount of sport for the hunter because of its abundance. It has usually been a common goose on the market, where it is known as the "Brant." In 1909-10 one transfer company in San Flancisco sold the following numbers of Brant: October, 1,442; November, 2,196: December, 1,5!): Jammary, 1,47!): February, 1,226: March, 251. Cackling as well as Hutehins Geese are probably included in these mmbers. This makes a total of over 8,000 geese of only two varieties sold hy the one transfer compang. That season the same company solel mone than 20.000 geese of all kinds. In 1906-07 it solel only $7,4: 31$. In 1,5.7 96 there were sold on the markets of San Firanciseo and Los Angeles 48,400 geese of which 16,319 were Brant (Calif. Fish ('omm., 1896, p. 42). There is little womlere that geese have deereased in numbers more than most other game birels. The markets of San Franeisco during 1910-11 paid from \$2.50 to \$8.00 a dozen for gaese other than the snow Geese. On the Los Angeles markets during 1!112-1:3 the same greese sold at from sixty-five cents to one dollar a pair.

Two things make gerese less desirable than ducks for the table. One is the relatively strong thavor and the other is the drymess of the meat. Certain people in the state have diseorerel a way of making a goose palatable no matter how tough it may be or how strong its Havor. The hind is prepared by skimning, as much of the strong taste comes from the skin. The flesh is then ground up with fresh pork, and a game sausage is made. A few pieces of bacon laid over a goose while roasting also serves to remove some of the strong taste and add flavor to the meat.

The following extract from one of the many letters which we have received gives a good idea of the immense decrease of this and other geese in different parts of the state.

Where years ago there would be "settings", of geese covering as much as 200 acres, and where the farmers around wouk furnish a man with horse, board, ammunition, and $\$ 20$ a month to keep geese off of his grain, it is now rare to see more than 10 to 15 per cent of the former numbers (H. F. Duprey, Dixon, California, March 11, 1913).

Tyler (1913b, p. 19) says:

Ten years ago when much of the country northeast of Fresno was given over to grain ranches these geese were seen very often and were sometimes noted in large numbers during late Narch when the spring migrations began; but during the last four or five years I have not seen half a tozen flocks anywhere east of the tity. 
In December, 1912, fourteen men worked contimuously for two weeks in the Sacramento Valley to obtain 1,500 geese for a famous "goose-stew" served at Sacramento. Twenty year's previously, according to local statements, the same number of geese could have been procured in less than a day and by an even smaller number of men.

Such, then, has been the history of this and other geese. At the present rate of decrease it will only be a few years before the occurrence of the Hutchins Goose, once one of the most numerous of all the geese, will be noted with as much interest as is the occurrence of the Emperor Goose at the present time. The only hope of saving our geese lies in rigorous protection for a term of years.

\section{Cackling Goose}

\section{Branta canadensis minima Rilgway}

OTHER NAMES-Cackler; Yelper; Little Squeaking Goose; Brown Brant; Bermicla leucoparia; Branta hutchinsi var. leucoparia; Branta minima

Description-Adults, both sexes: Similar to Canada and Hntchins geese but tone of coloration usually much larker ani size much smaller. Pattern of head and neck markings extremely variable; cheek patches often wholly separated by black on throat; white collar at base of black neck often conspicuons, though sometimes wanting. Total length (both sexes) "23.00-25.00", inches (58.635 mm.) (Ridgway, 1900, p. 117). Males: folded wing 13.2716.60 (337-422); bill along culmen 1.04-1.44 (26.4-36.6); tarsus 2.38-3.18 (60.t80.7) (ten specimens). Females: folded wing 14.50-15.65 (368-398); bill along culmen 1.18-1.36 (30.0-34.6); tarsus 2.57-2.98 (65.2-75.6) (ten specimens); all from California. Juvenile plumage: "... Dull gravish umber-brown; the head and neck almost uniform with the rest of the body and without any trace of the white cheek-patches. ... Feathers of head, neck, and much of the rest of the body are bordered with a lighter shade than the main part of the feathers"' (Nelson, 1887, p. 87). Natal plumage: Not known to us; probably similar to that of Canarla Goose.

MARKS FOR FIELD IDENTIFICATION-Similar to those for Canarla Goose but size considerably smaller (total length 23 to 25 inches [583 to $635 \mathrm{~mm}$.]), and coloration darker. In hand the tarsus is seen to be much longer than the middle toe with claw, while the bill is less than 1.44 inches long $(36.6 \mathrm{~mm}$.) (figs. 32-37). The high-pitcher call-note (whence the name Cackling Goose) is easily distinguished from the notes of the Canarla and Hutchins geese.

VoICE-An oft-repeated luk-luk (Belding, 1892a, p. 101).

NEST-On grassy border of a pond; a slight depression, sparsely lined with grass and down (Nelson, 1887, p. 86).

EGGS-4 to 9, ovate in shape, measuring in inches, 2.86 to 3.35 by 1.89 to 2.17 (in millimeters, 72.5 to 85.0 by 48.0 to 55.0 ), and averaging 2.99 by 2.01 (76.0 by 51.0 ) (twenty-nine eggs in U. S. National Museum); color buffy white.

General distribution-Western North America. Breeds only in Alaska, on Aleutian Islands and along coast of Bering Sea. Winters along Pacific coast from British Columbia south to sonthern California (modified from A. O. U. Check-list, 1910, p. 86). 
DISTRIBUTION IN CALIFORNIA-Common winter visitant to interior localities, espreailly in the Sacramento and San Joaquin valleys; oceurs also as far south as San Diego County (A. O. U. Check-list, loe. eit.). Arrives about mirlOetolier anil leaves about the millle of April.

The ('ackling Goose is believed to be about as abumdant a winter visitant to California as the Hutehins Goose. Belding (MS) states that, on Butte C'reek, Butte and Sutter eounties, a favorite resort for these greese espeeially when they first arrive from the north, he has seen a half million of them in a single day. But this was over twentyfive vears ago. At the present time, although reduced at least ninety per cent, this is to be still eonsidered a eommon species of goose in favorable parts of California. The Cackling Goose appears to arrive before the IIutehins Goose; for Belding (MS) states that at Gridley, Butte County, October 12, 1592, the former was abundant though the Hutchins Goose had not arrived, and at Stockton, San Joaquin County, November 25, 1881, the Cackling was eommon whereas the Hutchins Goose had not yet appeared. The earliest records of arrival for the ('ackling Goose are Griclley, October 1, 188t; Gridley, October 12, 1892: Stockton, Oetober 10, 1894 (heard at night): Stockton, Oetober 12 (rear not specified). For spring a late record is April 25, at Stockton (Belding, MS). A specimen was taken at Los Baños, Mereed ('ounty, on March 21, 1911 (Mus. Vert. \%ool.).

Tlu Cackling Goose is the smallest of the geese belonging to the Canada group, and it is but slightly larger than even the Ross Goose. The high pitch of its eall-note, which resembles the syllables luk-luk, is about the best character to use in the field after reeognizing the bird to be of the Canada type. In the hand, measurements, partieularly of bill and of tarsus, the latter being generally longer than the middle toe and claw, are the only satisfactory characters to use in separating this from the Hutchins Goose (compare figs. 32-37). As a rule, the Cackling is decidedly darker-colored than either the Canada or Hutehins.

During the breeding season the Cackling Goose is confined to western Alaska. It breeds abundantly on the Bering Sea eoast, from the Seward Peninsula to the north side of the Alaska Peninsula, and has also been reported from the Aleutian Islands. Nelson (1887, p. 86) says that many of these geese are already mated when they return north to the Yukon mouth in the spring. Others appear to be still ummated and such males fight hard and long for the possession of the unmated females. Of these combats he says:

The females kept to one side and dozed, or dabbled their bills in the muct; the males were seattered about, and kept moving uneasily from side to side, making a great outery. This would last but a few minutes, when two of the warriors would eross each other's path, and then began the battle. They would 
seize one another by the hill, and then turn and twist each other abont, their wings hanging loosely by their sides meanwhile. Suldenly they would rlose up and each wonld belahor lis rival with the bend of the wing, until the sound conld be heard two or three lundrea yards. The wing-strokes were always warled off hy the other bird's wing, so but little lamage was done, but it usually ended in the weaker birl breaking loose and ruming away. Just before the males seize each other they usually utter a series of peruliar low growling or grunting notes.

From the seashore its breeling ground extends along the courses of the great rivers far into the interior. . . While rescending the Yukon, Dall found their eggs laid upon the bare sand-banks, as were those of the Whitefrontel speries.

The last of May furls many of these birds alrearly depositing their eggs. Upon the grassy borders of ponds, in the midst of a lunch of grass, or on a small knoll, these hirds find a spot where they make a slight ilepression and perhaps line it with a scanty layer of grasses, after which the eggs are lail, numbering from five to eight. These eggs, like the birls, average smaller than those of the other geese.... As the eggs are lepositerl the female gratually lines the nest with feathers plucked from her hreast until they rest in a hed of lown. When first laia the eggs are white, but by the time inruhation begins all are soiled and dingy. The fenale usnally crouches low on her nest until an intruler comes within a hundred yarls or so, when she sknlks off through the grass or flies silently away, close to the gromm, and only raises a note of alarm when well away from the nest. When the eggs are alout hathing, or the roung are ont, both parents frequently hecome perfectly reckless in the fare of clanger. The young are hatched from the mirlike of Jume until the midlle of July (Nelson, 1887, p). 86-87).

In habits the Cackling Goose so nearly resembles the Hutehins Goose, that no one has been able to point ont differences. As with the latter species, the Cackling Goose feeds largely on grass and grain during its stay in California. Along with other geese this species used to Ho muel damage to young wheat in Colusa, Butte, Sutter and Yuba counties. But the ranks of the birds are so thinmed at the present time, that the injury they inflict now is negligible.

On the market this species is nsually classified along with the Hntchins Goose as "Brant." Tery large numbers of Cackling Geese are to be found at times in the markets of our larger cities.

The Cackling Goose, once just as mumprous, if not more so, than the Hutchins Goose, is like the Intchins, rapidly decreasing in numbers from rear to year. Old resiclents in some parts of the sacramento Valley say that now there is "not more than one of these Geese present where formerly there were hunclreds." To the work of the market humter can be attributed much of this decrease. for this goose is one which is easily procured, and which finds a ready sale on the market. While still rated as common in restricted portions of the state, this goose is in a fair way to disappear completely moless enongh of the bircls are left each winter to guarantere the return of an adequate stock in the spring to the breeding grounds in the north. 


\section{Black Sea Brant}

\section{Brontı nigricans (Lawrence)}

OTHER NAMEs- Sea Brant; Black Brant; Eskimo Goose; Bernicla nigriruls; Iirnicla brenta.

DESCRIPTION-Adults, both seres: Whole foreprart of boly incluiling hear, neck, breast and forepart of hack, solilly l,ack, except for incomplete white collar at base of neck; small narrow streaks of white run forwari from this rollar onto front and silles of nerk; iris llark brown; bill blark; lark brown, abruptly clefined against black in front, and each feather narrowly elgel witl lighter brown; milllle of rump, lilarkish brown; silles of rump and longer ulper tail coverts pure white; tail hlack; outer surface of rlosel wing like back: flight feathers ilull black; umler surface of wing aml axillars, brown; mmler surface of borly slaty brown, feathers of silles and flanks broally tippel with dull white; area in front of and behind vent, and uncler tail coverts, pure white; legs and feet black. Mlales: total length $23.75-25.50$ inches (604-647 mn.) (ten specimens); folder wing 12.41)-13.40 (31.j-340); bill along rumen 1.25-1.41 (31.\$-35.7); tarsus 2.14-2.44 (54.4-63.0) (nine sprecimens from California anil Alaska). Females: total length 2.2.50-24.00 (572-610) (nine sprecimens from (alifornia and Alaska); fohlerl wing 11.90-12.65) (302-321); bill along culmen 1.20-1.3.3 (30.4-33.9); tarsus 2.16-2.46 (54.7-62.4) (eight specimens from ('alifornia). Jucenile plumuge: Similar to that of allults but with white collar entirely lacking; general tone of roloration more grayish, supecially on larker parts; secondaries, sapulars, and wing coverts tipped with dull white; feathers of lower surface faintly tipperl with lighter color. Nutal pluma!n: General tone of color light leaten brown, darkest on top of heal ambl back and lightest (nearly white) on throat and millle of belly; a lark baml across hreast anil light collar arouml himl neck at level of throat; entirely lacks any of the greenish or yellowish tinge found in other American species of geese.

MARKS FOR FIELD IDENTIFICATIOx-Morlerately small size (for a goose), with very lark coloration. Heal anı neck black, with white collar about frout of neck; siles of rump white, hill and feet black. Flies in unlulating rourse, elose to water.

Volce-A low guttural $g r-\gamma_{-}-\gamma-\gamma$, utterel when at rest or in flight (Nelson, 1887, P. 8. ) ; a mellow crouk, cronk, cronk: (Dawson, 1909, p. 836).

NEST-On marshy ground; a simple depression, abundautly linet with down.

Eigs-4 to $s$, elongate orate in shape, measuring in inches, 2.64 to $3.09 \mathrm{by} 1.75$ to 1.97 (in millimeters, 67.0 to 75.5 by 44.5 to 50.0 ), and averaging 2. by 1.5 .5 ( 71.5 by 47.0$)$ (fifty eggs in U. S. National Museum); color grayish white (Reerl, 1904, p. 86).

Gexeral distributiox- Western North America anı eastern Asia. In North America breeds on Arctic coast and islands from Point Barrow east to near mouth of Anclerson River, north probably to Melville [slani]; winters on Pacific coast from British Columbia south to San Quintin Bay, Lower Califormia (morlified from A. O. U. Check-list, 1910, p. 87).

Distribution in CALIForsia-Abunlant winter visitant in former vears to Humboldt, Borlega, Tomales, San Francisco, Morro, and San Diego bays. Now occurs in numbers only on Humbolit ani Tomales bays. Oceasionally reporterl at other places along the coast such as: Point Pinos, Monterey County (Beck, 1910, p. 69); and San Perlro, Los Angeles County, and near Nerrport. Orange 
County (Willett, 1912a, p. 28). Has been fouml in the interior on Klamath River near Beswick, Siskiyou County (Ferry, 1908, p. 39); and near Los Baños, Merced County (specimen taken January 3, 1912, now in Mus. Vert. Zool.).

The Black Sea Brant is notable for being the most maritime of all the species of geese which visit California. It does not occur along our whole seacoast, as do so many sea-faring birds, but restricts itsclf to certain coastal bays, especially those north of San Francisco. It is a wary species, difficult to shoot, it has peculiar habits, and in the opinion of many persons its succulent flesh renders it the most desirable of all the geese for table use; hence it has been extensively sought after in past years, with the usual result that its numbers have been greatly reduced.

In earlier years the Black Sea Brant visited all of our large coastal bays from the Oregon line south to San Diego, but more recently it has been found in mumbers only on Humboldt and Tomales bays. Its close adherence to bay waters suggests that only in such situations can it find the food materials which it likes best. This Brant is strictly a winter visitant arriving in October and leaving in April. At San Diego, Cooper (in Baird, Brewer and Ridgway, 1884, I, p. 473) saw it first, in 1861, during October, and it left there by April 20 of the following year. The same writer saw the species on the watcr outside San Francisco Bay on April 24, 1863. Belding (MS) states that it was last seen at San Diego, in 1884, on April 15, and in 1885, on April 7. A few years ago a flock of abont twenty-five of these birds was seen on San Francisco Bay near Redwood City-but this is the only recent instance of occurrence on this bay of which we have knowledge. A few straggling individuals are found rarely on interior bodies of water, as on Klamath River near Beswick, Siskiyou Connty, and at Los Baños, Merced County.

The Black Sea Brant is a small goose, resembling the Ross Snow Goose in bulk. When at rest on the water it has a general blackish appearance. The solidly black coloration of the fore part of the body as well as of the bill and feet, and the white neck collar, are noticeable features. From all the several varieties of "Canada" Geese the Black Brant is best distinguished by the absence of white cheek patches, and from the Canada and Hutchins geese by its size. Its call-note, which has been described as a guttural croak, wah-ook or $g r^{r}-r^{r}-r$, and its habit of flying in flocks abreast close to the water in undulating lines, are both useful field characters.

This Brant breeds along the extreme Aretic coast west of Hudson Bay. The following meager nesting notes are the only ones available: "It was seen breeding abundantly by Mr. MacFarlane near the Arctic Ocean. Some of the nests were found on small islets in fresh- 
water ponds; others on islands in the Anderson, near its mouth; and many others either on the shore or on islands in Franklin Bay, or other parts of the Aretic Sea. In some cases the nest was nothing more than a mere depression lined with down; but in some the quantity of down was quite large. 'The number of eggs in a nest was generally five; but in one ease as many as seven were seen, and in six or seren instanees six" (Baird, Brewer and Ridgway, 1884, I, p. 474$)$.

Writing from western Alaska, Nelson (1881, pp. 134-136) says:

The tlight of this species is peculiar among North American geese and bears a close resemblance to that of the Filler and other species of heavyboulien short-winged Sea Dueks. It has a parallel in the flight of the Emperor Goose exvept that the latter is a far heavier bird and, in consequence, the wing strokes are less rapill. In $B$. nigricans the strokes are short, energetic, and repeatel with great rajility, earrying the hird with a velocity far greater than that attainen by any other [American] Goose. . .

The flocks.. . liave a protean ability to rhange their form without ever breaking the array or eausing confusion. They are rery gregarious and two flocks almost invariably coalesce when they draw near each other. This frequently oceurs, until... it results in a single flock numbering between four hundrerl and five hundred birls. The usual size is considerably less, generally comprising from twenty to fifty or more, and it is rare to see less than ten or fifteen in a party. At times four or five individuals become detached and until they can unite with a stronger party they fly irregularly about as though bewilıleren, continually uttering their harsh notes, and hurry eagerly away to join the first flock that romes in view. The orler of flight is invariably a single rank, the birls moving sille by sile in a line at right angles to their course so that the entire strength of a flock is to be seen at a glance along its front, which, at times, covers several hundrel yarks. There is barely room enough between the individuals to allow a free wing-stroke. Thus ranger the flock seems governed by a single inpulse, which sends it glicling along parallel and close to the grouni, then, apparently without reason, careering thirty or forty yaris overhear only to descend to its former level as suillenly as it was left; now it sways to one side and then to the other, while at short intervals swift undulations seen to run from one end of the line to the other. These movements are repeatelly taking place...

The entire flock, consisting of perhaps over a hunclred birds arranged in single line, is hurrying on, straight as an arrow, towaris its destination when, without warning, it suddenly makes a wide curving letour of several hundred yards, then resumes its original course only to frequently repeat the manoenvre, but always with such unison that the elosest scrutiny fails to reveal the least break or irregularity in the line; nor does the front of the flock swerve, excepting an occasional slight obliquity which is correcter in a few seconds.

In aldition to this horizontal movement is a still more interesting vertical one which often occurs at the same time as the other but generally by itself. A birl at either end of the flock rises or descends a few inches or several feet, as the case may be, and the movement is instantly followed in succession by every one of its companions till the extreme bird is reached and the entire flock is on the new level; or, it may be that a bird near the middle of the line 
(hanges its position when the motion extends in two lirections at once. These latter changes are made so regularly and with such rapidity that the distance between the birds foes not appear altered in the least, while a motion exactly like a graceful undulation runs the length of the flock lifting or depressing it to the level of the originator of the movement. These changes present to one's eye as the flocks approach, keeping close to the groumi, the appearance of a series of regular and swift waving motions such as pass along a pennant in a slight breeze.

The Black Brant never wings its way far up in the sky, as many other geese have the labit of loing, but keeps, as a rule, between ten and thirty yards ahove the ground, with more flocks below these limits than above them.

The Black Brant "rafts" far out on the sea during mueh of the day. Here the members of a flock keep up a constant gabble which is said to resemble somewhat the croaking of frogs. At eertain changes of the tide the birds fly to the kelp-beds to feed.

During the winter resilence of this Brant upon the shore of California it is noted for its pertinacity in following the outline of the coast as it passes from place to place. In the north this hahit still chings to them, and although they frequently pass over broad, marshy flats, yet a low ridge, but a few yarls high above the general level, is sufficient to turn their course and send them skimming along its base and around the obstacle rather than over it (Nelson, 1887$, p. 8.8$)$.

The food of the Black Brant is made up largely of marine plants for which it often dives as well as dips. The kelp berls off-shore offer. the most attractive feeding gromuds. In addition to the vegetable food, marine erustacea are probably eaten when available. Cooper (in Baird, Brewer and Ridgway, 1884, I, p. 473) says that in San Diego Bay the Brant fed almost exchnsively on the leaves and roots of eel grass (Zostcra marina). In Tomales Bay the birds also feed largely on this grass. A nmmber of speeinens from Humboldt Bay examined by W. E. Bryant (1893a. p. 55) had been feeding entirely on eel grass.

Aeeording to Sanford, Bishop and Van Drke (1903, p. 5 44 ) this is the most "gamy" of all our waterfowl and generally the finest flavored. The slight marine flavor, is far from being mpleasantly fishy, and resembles that of the oyster.

The Black Brant evades the deviees of the lumter better than any other duek or goose. In very early days on San Diego Bay it was never seen to alight on the shore or near it. By 1875 it was ahmost impossible to obtain a shot at the bird from a boat, and even with a box sunk in the mud and coneealed by sea-weed a good bag was secured with difficulty. In 1883 a floating battery with plenty of deenys alone would enable a hmuter to obtain this much prized bird. A few years later many of the birds failed to put in an appearance at all off San Diego, probably going farther sonth, along the Mexican coast. 
Bereanse of its hahit of oecasionally cutting across low samelspits to aroill a long detone in its Hight, most of the humting has been done from blinds situated beneath such a line of Hight. ()n Tomales Bay limeters have saibel down on Horks with "blind-boats," when the birels were at rest doring a fog, their whereabouts heing clisclosed by their " gabbling" noises.

The Black sea lirant has not been solel on the malkets to any extent for a good many years. About twenty years ago consigmments were shippeel to sam Franciseo from Inmbolelt Bay and the birels solel for as little as 25 cents warh. Even the high price that the birel would bring at the present time does not attract it to the marliet beeanse of the lifferenlty now attached to obtaining it.

There has been a marked decrease in the number of Black Brant visiting the coast of california in the last twenty-five reans. They have alparenty been driven away entirely from sam Diego bay and most of the other bays south of sam Franciseo. California is muipue in the possession of this bird during the wintel season so that the survival of the species depends ahmost entirely on the amomit of clestruction aceoteded it while it is within the state. Its extreme warinexs together with its attachment to the open ocean has always been, and will continue to he, its chief protection, but we should supplenent this with adeyuate legistation properly anforeed.

\section{Eastern Sea Brant}

\section{Pranta brrnicla glancogastra (Brelum)}

DESCRIPTION-Adults, both scres: Heal, nerk, whole lieast anl foreprart of body entirely aircled by solid hlack except for restricteri areas of white oblique lines on each side of uerk in a collar-like arrangement which, however, is broatly interrupter both in front and behind; bill black; iris "brown', (Sanford, Bishop and Van Dyke, 1903, p. 244); baık lrown, abruptly defined in front, each feather tipper with lighter brown; siles of rump and upper tail coverts pure white; tail black; outer surface of rloserl wing like back; flight feathers black; uncler surface of wing anı axillars brown; under surface of boily ashy brown, sharply contrasterl with black of fore-breast, anıl paling grailually behinil into pure white of belly and uniler tail coverts: feathers of sides anil flanks broally tipperl with white; legs and feet black. Male: total length 26.31 inches (667 mm.); folded wing 13.37 (339); bill along culmen 1.36 (34.6); tarsus 2.37 (60.2) (one specimen from California). Juvenile plumage: Like arlults but with ". . Wing-coverts and secondaries broally tipper with pure white, forning very conspicuous bars. Lower parts paler and more uniform; white on milllle of the nerk rerlucerl to small specks", (Bairl, Brewer anl Rilgway, 1854, I, p. 468). Tatrl plumage: Not known to us.

MARKS FOR FIELD IDEXTIFICATION-Similar to those for the Black Sea Brant (which see). Distinguisher from Black Sea Brant by much lighter color of under surface, more abrupt line of contrast between black of ehest and light 
gray of under surface, and smaller amount of white on neck collar which consists merely of a restricted patch at each side.

VoIce-A guttural car-r-rup, or $r$-r-r-ronk; ruk-ruk (Forbush, 1912, p. 183).

NEST AND EGGS-Like those of Black Sea Brant.

General Distribution-Northern Hemisphere. Breeds on Arctic islands north of latitude 74 degrees and west to about longitude 100 degrees, and on the whole west coast of Greenland; winters on the Atlantic coast from Massachusetts south to North Carolina, rarely to Florida; has been recorded in the interior from Manitoba, Ontario, Colorado, Nebraska, Wisconsin, Michigan, Indiana, and Louisiana; accidental in British Columbia, California and Barbadoes (molified from A. O. U. Check-list, 1910, p. 87).

Distribution in California-One known instance of occurrence: A specimen taken on Arcata Bay, Humboldt County, January 30, 1914 (H. C. Bryant, $1914 d$, p. 183).

The Eastern Sea Brant is a common bird along the Atlantic Coast of North America but it has been recorded only once from California. Mr. West Dean of Eureka, while hunting near Bird Island, Humboldt County, on January 30, 1914, shot an adult male of this species from a flock of Black Sea Brant (Branta nigricans). It was prepared as a study skin by Mr. Franklin J. Smith, a taxidermist of Eureka, and then presented by the owner, Mr. Otto Feudner of Oakland, to the California Musem of Vertebrate Zoology.

The Eastern Sea Brant closely resembles its western relative, the Black Sea Brant, but can be distinguished from the latter by its lighter-colored under surface which contrasts strongly with the black breast, and by the white neck collar which is incomplete both in front and behind. The lower surface of the body of the Black Sea Brant is much darker and the collar is continuous across the front of the neck.

The habits of this eastern bird are similar to those of its western congener.

The Eastern Sea Brant is of no importance here other than for the general interest which attaches to a rare straggler. It is possible that individuals of this species have found their way to California previously and even that they have been shot by hunters, but, not being recognized, no record of their occurrence has been kept. Hunters will do well to keep a lookout for the species, especially when hunting Black Sea Brant, as instances of the occurrence of the eastern bird are of interest to science. We believe that there is no likelihood of the Eastern Sea Brant ever becoming numerous enough here to be classed as more than a rare visitant. 


\section{Emperor Goose}

\section{Philacte canagica (Sevastianofi')}

OTHER xames-White-heallell Goose; Beach Goose.

DEscription-Aslults, both sexes: Whole head (except throat) and himl neek, white, forming an extensive hool, often stainel with rusty; chin, throat aul foreneck blackish brown, abruptly outlinell; iris "liazel'; membrane about nostrils " livil hlue," rest of upper mandible "pale purplisll or fleshy white," nail "white," its elges "lark horn color"'; lower manlible "lark horn. color," spot on each sile “white', (Nelson, 1887, p. 91); back, sides anıl breast bluish ash, each feather with a subterminal lar of blaek or blackish brown followerl by a narrower tipping of white, the whole giving a conspiruously scaled effect; rump, belly and under tail coverts barrel with very jale brown; tail slate color at base, with termiual thirl white; outer surface of closer wing similar to lack; terminal portions of primary and secondary flight feathers slaty black; legs ami feet bright "orange-vellow" (Nelson, loe. eit.) Males: Total length $26.00-29.00$ inehes (660-710 mm.) (Nelsou, loe. cit.); folderl wing 13.50-15.50 (34.3-394); bill along eulmen 1.42-1.60 (36.1-40.6); tarsus 2.50-2.98 (63.5-75.7) (four specimens from Alaska and California). Females: total length 25.60-27.50 (650-695) (Nelson, loe. eit.); follerl wing $14.75-$ 15.45 (375-392); bill along culmen 1.45 (36.8); tarsus $2.71-2.97$ (65.7-72.5) (two specimens from Alaska). Juvenile plumage: Similar to that of alult but white hood sprinkled with spots of ilusky or blaek, barring on baek aml breast dull brown rather than black, bill duller colored, and legs and feet lighter colored. Natal plumage: No deseription available.

MARKS FOR FIELD IDENTIFICATION-Melium size (for a goose) amil short neak. Hearl and neek (exeept throat) white, plumage asly blue barrel with blaek, tail white tipped, bill and feet light colored.

NEsT-On the ground, usually in salt marshes and often among fragments of driftwood; made of grass, leaves and feathers (Nelson, 1857, p. 90).

EGGS-3 to 8 , ovate to elongate ovate in shape, measuring in inches, 2.72 to 3.14 by 1.91 to 2.09 (in millimeters, 69.0 to 79.7 by 48.5 to 53.0 ), and averaging 2.93 by 2.00 (74.3 by 50.8); eolor white, but usually more or less stained with yellow (twenty eggs from Yukon Delta, Alaska).

General distribution-Northwestern North America and extreme eastern Siberia. In North America breels in Alaska from nortl of Cape Prinee of Wales south to mouth of Kuskokwin River and on St. Lawrence Island. Wiuters in southern Alaska from Bristol Bay to Sitka, but ehiefly in the Aleutian Islands; casual or rare in British Columbia, California, and Hawaii (modified from A. O. U. Check-list, 1910, p. S8).

Distribution IN CALIFornia-Rather rare winter visitant to fresh-water situations in northwestern half of the state. Recorded instances of occurrence are: Humboldt Bay, winter of 1884 (C. H. Townseni, 1886, p. 491); Colusa, November, 1912; Dixon, Solano County, three specimens; Ingomar, Merced County, December, 1912; and near Modesto, Stanislaus County, November 15, 1913 (H. C. Bryant, 1914b, p. 92); Gridley, Butte County, fall of 1895 (Loomis, 1901, p. 105) and November 1, 1915 (C. S. Muller, 1916, p. 32); Rio Vista, Solano County, November 3, 1910 (Littlejohn, 1912, p. 41); near Davis, Yolo County, December, 1906 (H. C. Bryant, 1915a, pp. 5S-59); and San Francisco markets, October 8, 1900 (Loomis, loc. cit.). Each record is of a single specimen except as noted. 
The principal winter home of the Emperor Goose is on the seacoast of sonthwestern Alaska, ant only straggler's reach California. But it is probable that if all of the Emperor Geese ever observed in California had been recorded, it would be found that ahmost every year one or two of the birets had made their way within our borders. At least ten definite instances of the ocenrence of the Emperor Goose in this state are known. In spite of the fact that this is a marine species most of the records are from the interior valleys. Mr. Vernon Shepherd, a taxidermist of San Franciseo, informs us that he has known of the capture of at least a dozen speeimens of this goose since 1906. There is also an unconfirmed statrment current to the effect that two Emperor Geese were taken from a small flock in the Alamitos marshes of Los Angeles ('ounty about twenty years ago (Payne, 1908, p. 770$)$.

Nelson (1887, p. 90) says that Emperor Geese may be distinguished at long distances by their heary bodies, short necks, and hy their short, quick wing-strokes, which very much resemble those of the Black Sea Brant. Althongh not as agile on the wing as the latter birds, or, in fact, as any of the other geese, they are swift fliers when under way. The bluish ash color of the plumage with scaling of black, the extensively white hood abruptly contrasted with black on the throat and foreneek, the white-ended tail, and the bright-colored bill and feet, easily distinguish this goose from all other's. Its note is said to be shriller and clearer than that of other geese.

Regarding the nesting of the Emperor Goose in Alaska Nelson (1887, 1).90) writes:

Soon after their arrival they began to pair, and were seen flying about in conples, keeping close to the grount, rarely flying over 20 or 30 yards high, and often barely keeping clear of the surface. The males are extremely jealous and pugnacious, never allowing one of their kinl to approach within a number of yarits without making an onslaught npon the intruller. The same belligerent spirit is shown to the other speeies of geese shoull one of them chance to draw too near.

While a pair is feeling the male keep moving restlessly about, with eyes constantly on the alert, and at the first alarm they draw near together and just before they take wing both utter a deep, ringing $\hat{u}$-lugh, $\hat{\imath-h} g h$. As in the ease of the call-note, this has a peculiar. leep hoarseness, impossible to describe.

The first of June they began tepositing their eggs on the flat, marshy islands bordering the sea. At low tille the broal mul-flats on the shore were thronged with them, and after feeding until satisfied they congregated on bars until the incoming water foreed them to lisperse. They nested most abunilantly on the salt marshes adjacent to these feeding groumis, ant the eggs were often placed among fragments of drift-wool helow the mark of the highest tilles. Stray pairs were found nesting further inland on the marshy mealows, also frequented by the other speeies of geese, but on the salt flats, near tide water, the Emperor Geese hell undisputerl possession. 
On June is a female was found setting upon her eggrs on a little knoll, with a small fragment of bleached drift-wood within a few yarls of her, and as she lay with extended neck, although the gromnd was aluost bare, my. Eskimo and I jassel within a few feet of her on either sisle, without seeing her. We were abont 20 steps heyond when she left the nest with a startled cry, thus frawing our notice. The three eggs were in full view when we turnel. They rested in a lepression with no sign of a lining. The same ruse “aused us to fass other nests, but the birks betrayed them each time by flying off with a loul outery almost as soon as our backs were presented.

The majority of the nests fomd by Nelson contained from three to five rgg's, but the full complement usually ranges from five to eight. A series of egges in the Musenm of Vertebrate Zoologr taken in the Yukon Delta alr elosely similar to those of the White-fronted Croose. and vary widely in size and shape. Some are moch elongated. while others are obtusely priform. In eolor they are white, but all are more or less nest-stained with brownish. Twenty eggrs measmed by the witers showed length in inches from 2.72 to 3.14 and short diameter's from 1.91 to 2.09 , the averages being 2.93 by 2.01. Nelson (188T, p). 90-91) funthey states that “as the complement of eggs approachel completion, the parent made a soft beel of fime grass, leaves, and feathers phuked from her own breast. As a rule, when driven from her eggs, the female flew straight away and alighted at some distance, sometimes half a mile from the nest, showing very little concern. The male was rarely seren in the vicinity of the nest. The young are hatehed the last of June or first of July, and the adult birds melergo the summer moult from the last of July to the middle of Angust."

The Emperor Goose Hies in pairs or in small Hocks of four or five. A jurenile killed at Gridler, Butte County, was alone, being the second in a flock of White-fronted Geese. One taken near Modesto, Stanislaus County, came to the blind alone. Another taken near Davis, Yolo County, had been noted alone in the same pond for three weeks previous to capture. This species is said to be shyer than any other goose except the Black Sea Brant.

In Alaska the Emperor Goose remains on its breeding grounds longer in the fall than any other species, lingering until the whole seacoast is fringed with ice before going to the slightly less rigorous Alentian shores but a few hundred miles to the southward. In the north it feeds chiefly on shellfish, though at times it resorts to heathberries which are available on the tundras elosely adjacent to the seashore.

As a game bird this goose is not highly prized, for its flesh has a disagreeably strong taste. It is said, however, that much of this taste is due to the skin and that the flesh proves palatable if the skin is carefully removed first and the bird well cooked. 
To our knowledge there has been no marked diminution in the numbers of Emperor Geese either in their northern home or in California. Those taken in this state in the past are in the category of mere stragglers, and it is reasonable to expect that such wanderers will continue to make their appearance from year to year within our boundaries.

\section{Fulvous Tree-duck}

\section{Dendrocygna bicolor (Vieillot)}

Other Names-Mexican Duck; Squealer; Fulvous-bellied Tree-duck; Brown Tree-duck; Spanish Cavalier; Dendrocygna fulva.

DESCRIPTION-Adults, both sexes: Top of head reddish brown, running into a black stripe down hind neck; sides of head yellowish brown, paling to yellowish white on throat; iris dark reldish brown; bill bluish slate; broad collar around base of neck, incomplete behind, dull white streaked with brownish black; general color of rest of upper surface including tail, brownish black, feathers of back and seapular region broadly tipped with redlish brown; rump black; upper tail coverts creamy white; both outer and under surface of wing deep blackish brown, except for lesser (upper) coverts which are deep chestnut brown; under surface of body bright hazel brown becoming paler on breast and belly; elongated feathers of sides and flanks cinnamon brown, each with central stripe of creamy white bordered by narrow dusky lines; under tail coverts ereamy white; legs and feet heavy and long, extending far beyond end of tail, in color deep bluish gray. Total length (both sexes): "about 20.00-21.00" inches (508-533 mm.) (Ridgway, 1900, p. 119). Males: folded wing 8.00-8.60 (203-218); bill along culmen 1.71-1.84 (43.4-46.7); tarsus 2.03-2.21 (51.6-56.2) (five specimens). Females: folded wing 8.00-8.30 (203-211); bill along eulmen 1.82-1.86 (46.2-47.2); tarsus 2.052.16 (52.0-54.8) (two speeimens); all from California. Jucenile plumage: "Similar to allult, but with little or no chestnut color on wing-coverts; under parts paler; the upper tail-coverts tipped with brown', (Sanford, Bishop and Van Dyke, 1903, p. 256). Natal plumage: Top of hear clove brown; chin, throat and sides of head dull white, a streak of the same color extending around back of head on each sicle and meeting its fellow on hind head; a short, dull white streak on each side of head from side of bill to above eye; bill (dried) dusky brown with prominent yellowish nail; hind neck clove brown, a streak of same color invarting side of head below streak of white which encircles head; rest of upper surface of body uniform bister brown; whole under surface of borly dull white; feet (dried) grayish yellow.

IIARKS FOR FIELD IDENTIFICATION-Medium size (about that of Pintail), long, slim neck, extremely long legs (see fig. 38) reaching far beyond end of tail, einnamon colored under surface, black-appearing back, and absence of any light markings on wings (pl. 7). Distinguisherl from Black-bellied Tree-duek by absence of black on belly and of white on wings. The squealing whistle, and down-curved pose of head and neck in flight, are characteristic.

Vorce-A long-drawn, squealing whistle (Chapman, 1908, p. 292).

NEST-Usually on gromml in marsh or near water, well built and often well concealed; reported as occasionally situated in hollow trees; built of grass and sparsely lined with down and feathers.

EGGS-Normally 12 to 17 , elliptical ovate in shape, and measuring in inches, 

UNIV CALIF. PUBL

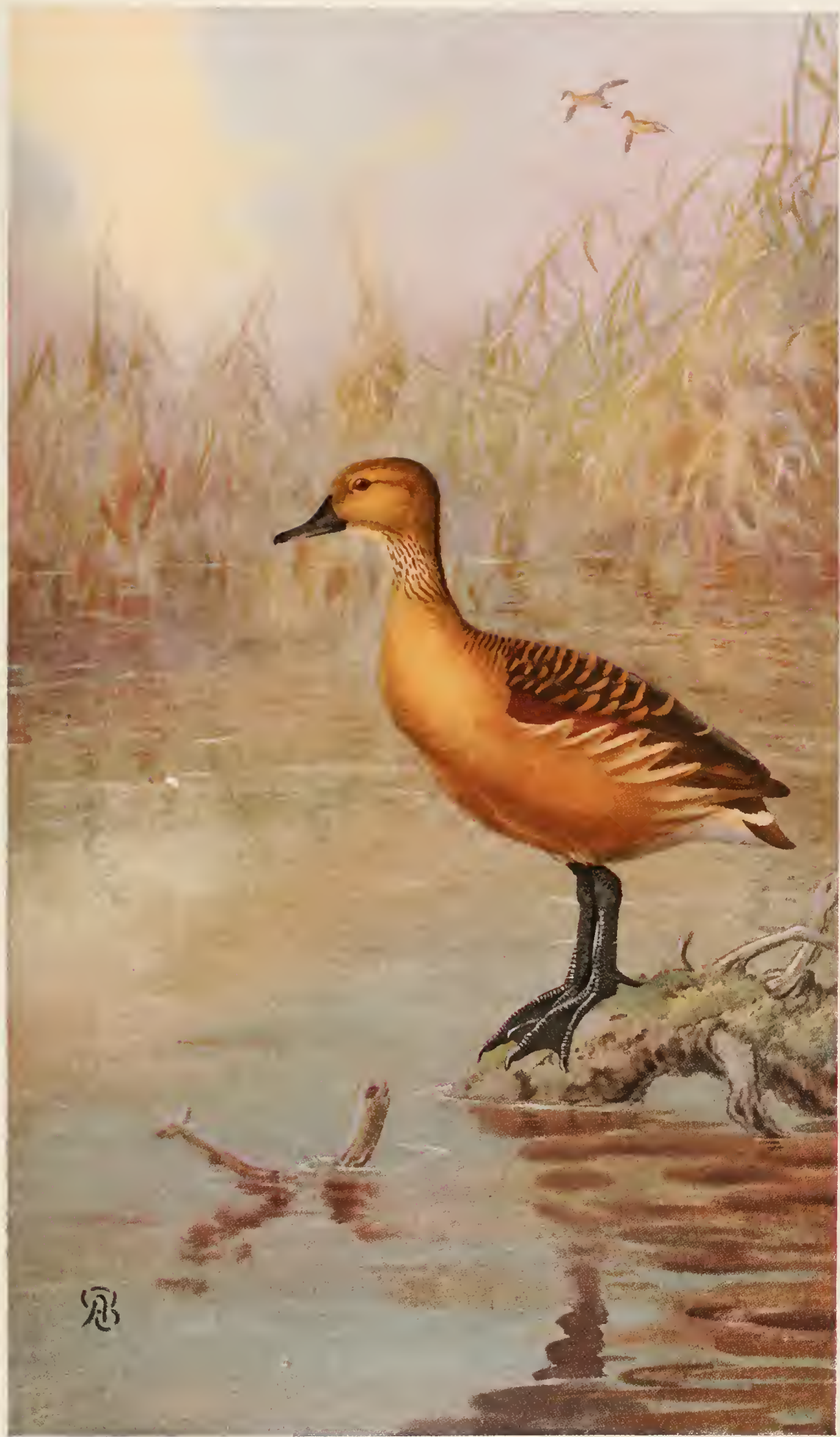



1.35 to 1.65 by 1.95 to 2.20 (in millimeters, 34.3 to 41.8 by 50.3 to 55.8 ); color ivory white, surfare texture rather rough (Shields, 1899, Pp. 10-11).

(iExeral DISTRIBUTIN-Mexico and southwestern United States; also southern Cruguay am Argentina, South Africa and India. In Nortlı America breeds from rentral California and central Texas south to Valley of Mexico; winters from central California (rarely) and central Texas to southern Mexico (molifiel from A. O. U. Cheek-list, 1910, p. \&S).

Distribltion IN CALIFORNia-Common summer visitant to interior tule marshes in the sonthern coastal district and central portion of the state; breeds in Sin Joaquin Valley north to Los Baños, Mereed County (Barnhart, 1901, p. 67; and authors), and in a few suitable places in Los Angeles County (Willett, 1912a, p. 28). Nortlernmost reeorls at any season: Mariu County (J. Mailliard, 1904, p. 15); Marysville, Yuba County (Belding, 1879, p. 445); and Owens Valley (A. K. Fisher, 1593a, p. 19). Several instances of oceurrence on or near central seacoast: Carmel liver, Monterey County (Beek, 1910, p. 69); Elkhorn, Monterey County (H. C. Bryant, MS); Salinas, Monterey County (Silliman, 1915b, p. 207); and Santa Barbara (Dawson, 1916, 1). 25). A few oceur in various parts of the summer range during the winter months.

The trom tree-duck, as applied to the Fulvous Tree-duck, seems to be an almost complete misuomer for the hircl. As regards structure this species seems to be more closely related to the geese than to the lueks, and, at last in ('alifornia, it seldom nests in trees but thooses the extensive tule marshes of our interior valleys. Birds apparently belonging to the same species of Tree-luck that ocenrs in this state are found in South America, in southern Uruguay and Argentina, and also in South Africa and in India-a very striking case of what is known as interrupted or discontinuons distribution. In North America the chief brexling ground of the species is in Mexico, but a considerable number of birds breed in the southwestern United States. The latter contingent is migratory, moving south for the winter season.

In California, Fulvous Tree-ducks are most widely distributed in spring and fall, but are always found in fresh water situations. Some reeords of spring migrants are: Mecea, Riverside County, April 5, 1908 (Mus. Tert. Zool) ; Los Angeles, April 18, 1898 (Swarth, 1900, p. 14) ; Los Baños, Mereed County, April 24, 1912 (Beck, MS); and Stockton, San Joaquin County, April 1 (Belding, MS). On May 5, 6 and 7,1879 , Belding (1905, p. 112) witnessed a remarkable flight of these birds over a slough near Stockton. They were moving north and all followed the same general "fly-line."

Most of these ducks have finished nesting and have gone south before the opening of the duck season on October 15. A late record, which may possibly be for wintering birds, is November 1 , on which date two immature birds of this species were found in the markets of Stockton. Thus it will be seen that the Fulvous Tree-duck is a rather late arrival in the spring and that it departs sonth comparatively early in the fall. 


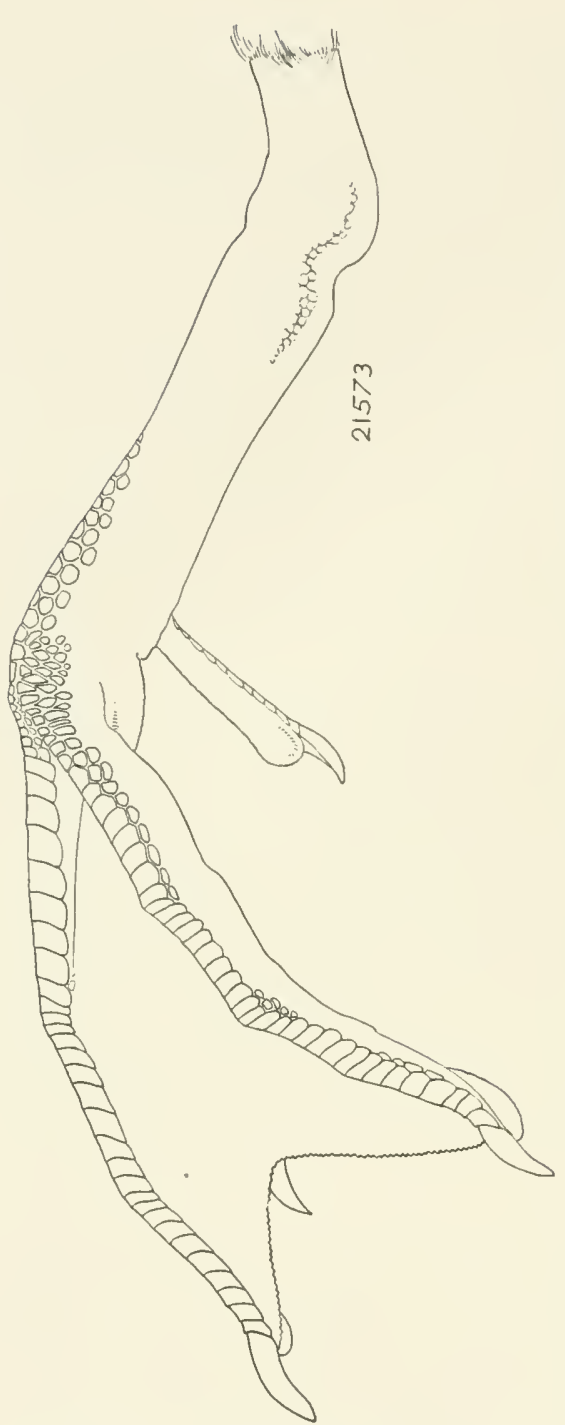

Fig. 35. Sille of tarsus and foot of Fulvous Tree-luck. Natural size.

Note large size of tarsus and foot, and long hind toe without lobe (compare with figs. 11 and 22 ).
While the bulk of the species is migratory, a few individuals may remain throughout the year in parts of the summer range. Thus there is a reeord from Marysville, Yuba County (Belding, 1879, p. 445) of a bird taken in winter and this is, euriously enough, the northernmost record for the state at any season. East of the Sierras a pair was taken at Little Owens Lake, Inyo County, May 8, 1891 (A. K. Fisher, 1893a, p. 19) and one was seen over the Colorado River near Potholes on Jamuary 17, 1913 (Howell and Van Rossem, 1915, p. 232). The speeies is a common transient in the Imperial Valley.

The Fulvous Tree-duek is so very m-dneklike in many respeets that it has been variously elassified, usually as a nember of the goose tribe. Its long bill, with the large, sharply downeurved nail (fig. 39), the long slim neek, the rery long legs (fig. 38), reaching far beyond the tail, and the reddish brown color (pl. 7), without white markings on head or wings, make identifieation easy. The ereet pose when on the ground is goose-like, and in flight the head and neek are bent downward in a mamner characteristie of geese.

'The following notes quoted from W. Otto Emerson would seem to show that the Fulvous Treeduck oceasionally, at least, nests in trees in California, and so rightly deserves its emrent name: "On May 23, 1882, while eolleeting with Wm. C. Flint at Lillie's raneh near Thlare Lake I noticed a Fnlvous Tree-duck sitting in the entranee hole of a large white oak near one 
of the ditehes, but it was out of the question to reach it. Again on May 26 another was located sitting on the edge of a hole high up in a white oak. Lillie's ranch is nine miles from Wildflower, Tulare Countr, and four or five miles sontheast of the lake" (in Shields, 1899. p. 11).

Howeres, the prevalent habit of this bird in California is to nest much as other ducks do, on marsh lands. Shields found a number of nests of the Fulvous Tree-duck in central California during June, 1898. He states (1899, pp. 10-11):

The nests were in main constructed of wire grass anil sparsely lined with down and feathers; the eggs were invariably leposited in two layers and are of a pure white color, anl as eompared with the eggs of other lucks, possess a rather rough shell, sometimes even apjroaching a rhalky apjearance and being frefuently slightly priform in shape. The measurements vary from $1.35 \times 1.95$ to $1.65 \times 2.20$ inches, the majority of eggs being a mean average

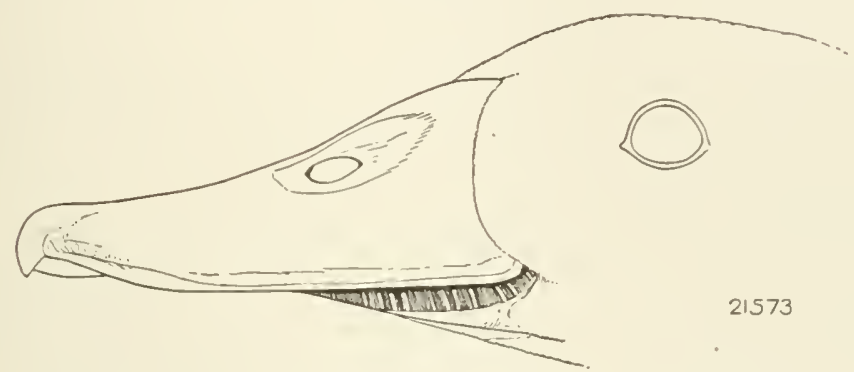

Fig. 39. Side of bill of Fulvous Tree-cluek. Natural size.

of these extremes. The eggs partake of the characteristics of both those of the goose and duek. . .

Shields also found that this species often laid its eggs in the nests of other ducks, for of six or eight nests of Redhead and Ruddy Duck which he discovered, more than half contained one or more eggs of the Fulrous Tree-duck.

In all, Shields found about a dozen nests of the Fulvous Treeduck, all similarly situated and most of them eontaining from 17 to 28 , and some even 30,31 and 32 eggs. The smallest sets found were of 9 and 11 eggs respectively, both of which were apparently incomplete. Such large sets are certainly unusual among ducks and as yet have not been satisfaetorily explained. Either this particular species possesses a greater fecundity than other's, or more than one female lays in the same nest. The latter is the more probable explanation; for in one case (Dawson, IIS) a daily addition of three eggs was noted in a single nest. 
According to common report the Fulvous Tree-duck formerly nested in eolonies, and from 30 to 100 eggs arranged in layers were found in a single nest (Barnhart, 1901, p. 67.). There is no recent instance or verification of such an extraordinary oceurrence. Such reports are doubtless exaggerations, though they must have had some basis in fact.

Sets of eggs have been eollected at Los Baños as early as April 28 and May 5 (Barnhart, 1901, p. 68). A nest found in the same locality by W. L. Dawson June 4, 1914, eontained nineteen eggs.

"Antonin Jay found a nest containing fourteen fresh eggs at Nigger Slough, Los Angeles County, May 30, 1903, and found another nest June 7, the same year, which contained thirteen eggs, ineubation commenced" (Willett, 1912a, p. 28). A downy young specimen was collected at this same locality, July 8, 1903 (Moreom coll.). P. J. Fair found the species breeding plentifully at Los Baños, Merced County, during the summer of 1912. In 1914 the same locality showed a slight apparent decrease in breeding birds.

The downy young of this Tree-duck is readily distinguished from the same stage in other California breeding ducks by the uniformly colored upper surface, without any light spots, by the rery large nail on the bill, and by the long legs and large feet.

The Fulvous Tree-duck forages chiefly at night, and is equally at home in an alfalfa patch or on a body of water. It will even seek an oak grove if not far from the breeding ground, where individuals are said to assemble in numbers to feed on acorns (Shields, 1899, p. 11).

The Fulvous Tree-duck is more easily approached than many other waterfowl, but nevertheless is often diffieult to find as it congregates among the dense tules or far out on the marshy ponds. On oecasion a flock has been easily approached and a number killed at one shot. Sometimes, when Tree-ducks are surprised on grassy ground, they simply stand rigidly with their heads and long neeks held straight up in the air, and at a distance, look more like stakes than birds. When wounded they are said to escape not only by diving but also by rumning at great speed and hiding in the grass, and thus often baffle entirely the hunter's efforts to recover them.

The Fulvous Tree-dnek feeds largely on the seeds of grasses and weeds. In Mexico and Texas it is said to visit the corn fields at night where it finds palatable provender. When feeding in muddy or marshy situations the birds thrust their bills deep in the soft mud on both sides and in front of them as they walk along (Brown, 1906, p. 218). The stomach of an individual obtained at Los Baños, Mereed County, in May, 1914, and examined by us, contained finely ent up grass and other vegetable matter. 
The Hesh of the Fulrous 'There-tuck is light-eolored and juicer, and also free from the rank flavor possessed by sea-faring ducks and geese. On their arrival in california the birds are fat and eminently fit for the table; but since they are here in greatest numbers during the close season, they largely esuape the slangliter levied on other wild fowl. The mumbers of this species are, at best, small in eomparison with many other ducks and gerese. They eould ill afford a heary toll by the hunter during the period of their stay here. Any levy upon them during the actual breeling sidson would be contrary to all recognized principles of gane conservation and lumanity. As it is, but a few 'Tree-ducks are to be shot each year at the opening of the season, Oetober 15. Those who are anxious to hunt the Fulvous Tree-duck in mumbers must go to Mrexico where the birds are to be found regularly in winter and where a certain toll may be levied with safety.

There is a possibility that, instead of having to point to a drecrease in the numbers of Fulvous 'Tres-alucks in California, we shall actually be able to recorel an incerase. Barnhart (1901, p. 67) has pointed out that it is only of recent rears that yomng Tree-dueks have been noted in the vicinity of Los Baños. Mreed County ; in other wolds, since the extensive systen of irligation has been established there. Sinee that time they have eontimally increased in mumbers in that vicinity. Mr. II. Wanzer, chief engineer for the Miller and Lux Company, first noted this thek there in .June, 1895. It did not appear to increase notably in numbers until 1898 , but since that time it has increased with rapidity, so that the biris are now common smmmer residents in the irrigated districts aroumel Los Baños.

\section{Black-bellied Tree-duck}

\section{Dindrocygna autumulis (Limnaens)}

OTHER XANE-Long-legged Duek.

Descriptiox-diults, both sexes: Structurally like Fulvous Tree-duck; top of heal, neck, back, scapulars, and breast, bright einnamon brown; forehead paler, and top of head darker, passing behind into black, which is continued as a narrow stripe down hind neck; narrow eye-ring ashy white; head and neck otherwise, pale ashy brown; iris "brown"'; bill "coral-rer, orange above," nail "bluish", (Merrill, 1S78, p. 170); rump, npper tail coverts and tail black: outer surface of elosed wing pale brown on lesser coverts paling to ashy white on greater coverts anil secondaries; ends of primaries and secondaries deep black; basal parts of primaries and secondaries white, continuous with the white on greater coverts; an alditional whitish patch on onter webs of primaries near ends; axillars and under surface of wing black; belly and flanks, black, abruptly and squarely defined against cinnamon of breast; .under tail coverts white, spotted toward bases with black; legs and feet "pinkish-white", (Merrill, loc. cit.). Total length (both sexes): "19.7524.00 ", inches (502-609 mm.) (Ridgway, 1900, p. 119); folded wing "9.20- 
9.70" (233-246); culmen " $1.90-2.15$ " (48.3-54.5); tarsus " $2.25-2.60$ " (57.266.0) (Baird, Brewer and Ridgway, 1884, I, p. 482). Juvenile plumage: Much like that of adults, but with pattern less distinct and colors dnller; cimnamon replaced by dingy gray, more or less tinged with rusty ochraceous; belly, flanks, and under tail coverts grayish white, tinged with deeper gray; bill dusky; feet dark reddish (Baird, Brewer and Ridgway, loe. cit.). Natal plumage: "Upper parts, blackish brown, with patches of buff on sile of back and on each side of rump; a bright buff stripe over the cheeks and one from cheeks ... [running backwards], blackish brown; unler parts, pale buff; belly, white" (Sanford, Bishop and Van Dyke, 1903, p. 253).

MARKS FOR FIELD IDENTIFICATION-Similar to those for Fulvous Tree-duck (which see), but lower half of belly black, and patehes on wings white.

Vorce-A peculiar whistle: pe-ehe-che-ne (Baird, Brewer and Ridgway, 1884, I, p. 483).

NEST-Usually in hollow trees, often at a consilerable distance from water; lining, if any, seant, consisting of feathers and down (Reer, 1904, p. 87).

EGGS-10 to 16, bluntly elliptical in shape, measuring in inches, 2.05 to 2.24 by 1.50 to 1.63 (in millimeters, 52.0 to 57.0 by 38.0 to 41.5 ), anit averaging 2.15 by 1.53 (54.5 by 39.0 ) (twenty-one eggs in U. S. National Museum); color white (authors).

General distribution - Sonthern Texas, Mexico, anıl Central America. Breeds from Corpus Christi, Texas, to Mazatlan, Mexico, and Panama; winters from central Mexico to Panama; aceilental in sonthern California, Arizona and Jamaica (modified from A. O. U. Check-list, 1910, p. 88).

Distribution In CALIFORNiA-Rare and sporadic visitant to extreme southeastern portion of the state. One definite instance of ofenrence: a bird obtained from bag of ducks sent from Imperial County to San Franciseo market; now mounted and in collection of Vernon Shepheril, San Francisco (H. C. Bryant, 1914c, p. 94). The alleged record by Xantus for Fort Tejon is of doubtful authenticity.

The Black-bellied Tree-dnck is a resident of Mexico and Central America, and in only one state of the Union is it to be found in numbers, namely in Texas. The fact that wanderers have been taken in Arizona (Brown, 1906, p. 218) and in extreme northern Mexico makes it seem quite possible that stragglers may occasionally reach California. A very doubtful record by Xantus of the ocenrence of this species at Fort Tejon has often been quoted to substantiate the placing of this bird on the California list. A more dependable record has recently come to light. In the collection of Mr. Vernon Shepherd, a taxidermist of San Francisco, there is a mounted male specimen of the Black-bellied Tree-duck which was obtained from a sack of ducks sent to L. Scatena and Company from Tmperial Valley in the early part of the season of 1912 . This is just the region in which we would expeet this species to ocemr as a straggler from beyond our southern limits.

Both of the Tree-ducks are of molerately small size. hare long necks, short tails, and very long legs, and so are easily distinguished from ordinary ducks and geese. From the Fulvous Tree-duck the 
black-bellied is easily separated by its black belly, which contrasts abruptly with the cimamon-brown of the breast, and by the presence of conspirinous white patches on the wings.

The following habit notes are quoted from Baird, Brewer and Rilgway (1884, I, P. 483):

This duck perches with facility on the branches of trees, and when in the eorn-fields, upon the stalks, in order to reach the ears of corn. Large flocks spend the day on the bank of some secluded lagoon, ilensely bortered with wools or water-flags, also sitting amongst the branches of trees, not often feeding or stirring about during the day. When upon the wing this birl constantly utters its peruliar whistle of pe-che-che-ne, from which its native name is derived. Colonel Grayson noticed that it seldom alights in deef water, always preferring the shallow edges or the ground; the cause of this may be the fear of the numerous alligators that usually infest the lagoons.

It nests in the hollows of large trees, laying from twelve to fifteen egess and is said to carry the young to the gromed in the hill.

Nothing nexel be said as to the status of the Black-bellied Treeduck in california further than that straggler's may be expected to appear oecasionally in the extreme sonthern part of the state. It will probably never be of importance exeept as a enriosity.

\section{Trumpeter Swan}

\section{Olor buccinator. (Richardson)}

OTHER NAME-Cyguus buecinator.

DEscriptios-Alults, both sexes: Pure white; heal and sometimes also the meck, or even the entire lower surface, tinged with rusty. Bill, legs and feet, leep "black"'; iris "brown" (Sanforl, Bishop and Van Dyke, 1903, p. 265). Young: "In winter the young has the bill black, with the millle portion of the rilge, to the length of an inch and a half [38 mm.], light flesh-colour, and a large elongater patch of light lull purple on each sile; the erlge of the lower mandible and the tongue dull yellowish flesh-colour. The eye is lark brown. The feet dull yellowish hrown, tinged with olive; the elaws brownishblack, the webs blackish-brown. The upper part of the heal and the eheeks are light redlish-brown, each feather having towark its extremity a small oblong whitish spot, narrowly margined with dusky; the throat nearly white, as well as the elge of the lower eyelid. The general colour of the other parts is greyish-white, slightly tinged with yellow; the upper part of the neck marked with spots similar to those on the heal', (Audubon, 1843, VI, p. 225). Total length " 68.00 ", inches (1.725 mm.) (Audubon, loe. cit.); height, standing 44.00 (1,117); folłled wing 22.00-26.00 (559-660); bill along culmen (calculated) 4.26 (108.0); tarsus 4.00-4.50 (101.7-114.3); weight 20-31 pounds (about 9-14 kilograms) (Coale, 1915, p. 87).

MARKS FOR FIEL.D IDENTIFICATION-Similar to the white swans common in parks, but never with any knob on bill. Extremely large size, long neck (as long as boity) and pure white plumage. Distinguishable from Whistling Swan by larger size, and upon close examination, by wholly black bill, longer and narrower-tipped bill and situation of nostrils farther bark (hind margin more than 2.50 inches $[63.5 \mathrm{~mm}$.] from the tip of bill). 
VoIce-Very sonorous, resembling notes of a French horn (Baird, Brewer and Ridgway, 1884, I, p. 431).

NEST-Placed near water; large, composed of hay, down and feathers intermixed, or of sod, grass and rushes lined with feathers and down (Macoun and Macoun, 1909, p. 135).

EgGS-2 to 6 , elliptical in shape, measuring in inches, 4.03 to 4.50 by 2.50 to 2.76 (in millimeters, 102.5 to 114.3 by 63.5 to 70.0 ); color chalky white, and with a rough surface (Davie, 1889, p. 85).

General Distribution-Interior and westem North America. Breeding range formerly extended from Rocky Mountains to western shore of Hurlson Bay and from about latitude $60^{\circ} \mathrm{N}$, to the Arctic Ocean; south in northern United States to Indiana and Idaho; winter range extended from southern Indiana and southern Illinois south to Texas, and from southern British Columbia south to southern California; now very rare anywhere within its former range or else extinct (A. O. U. Check-list, 1910, pp. 89-90; Cooke, 1906, l'p. 86-87).

Distribution in CALifornia-Of regular occurrence, formerly, south through the interior vallevs and southern coastal district. Some more or less definite records are: California (Newberry, 1857, p. 100); northern California (C. H. Towusend, 1887, p. 196); Suisun and Sacramento valleys (Heermann, 1859, p. 68); general interior (Baird, Brewer and Ridgway, 1884, I, p. 431); Stockton, San Joaquin County (Belding, MS); Ventura County (Evermann, 1886, p. 91); Los Angeles County (Griunell, 1898, p. 13). No records of occurrence within the state since 1898 .

The Trumpeter Swan is the largest of the water birds known to have existed in California. It claims additional interest in that it must be numbered with those birds which have been exterminated within the lifetime of most of the eitizens of the state.

The breeding range of this swan was limited to the interior of the British possessions, in the distriet between the Rocky Momntains and Hndson Bay and chiefly north of the sixtieth parallel. During the winter season it was distributed sonth from the limit of open water through the western United States to Texas and southern California. On the Pacific coast it was formerly considered common from eentral British Columbia to southern California though less abundant than the Whistling Swan. Cooper (in Baird, Brewer and Ridgway, 1S84, T, p. 431) states that in California it was fonmd in his day only during the winter, and in small numbers, and that it frequented the inland fresh-water lakes and ponds. C. H. Townsend (1887, p. 196) records it as "rare," though possibly only on the authority of Newberry. Heermann (1859, p. 68) states that he saw the species in the Snisun and Sacramento valleys, as well as frequently in the San Franeiseo markets; but since the Whistling Swan is not listed by him at all, this record may be open to query. Newberry (1857, p. 100) gives both swans, designating the Trumpeter as the least common, and as rare compared with the myriads of the other waterfowl which visited this state and Oregon in his time. Salvadori (1895, p. 35) lists a jurenal specimen from "California" as contained in the British 
Musemon; this specinen cance by presentation from J. Richards, Essq. Evermann (1886, p. 91) records the Trumpeter swan as a winter visitant in Ventura County, "more common" than the Whistling. Grinnell (1s98, r. 13) reeords two specimens as having been taken in Los Angules County by A. M. Shields; but these were subsecquently destroved by fire and the identification has been questioned (Willett, 1912a, p. 110), Belling (Ms') identified three individuals "by description" in the markets of stockton sometime previous to 1890. Lansing Kellogeg has reported to us that a flock of Trumpeter Swans was noted by lim on Buena Vista Lake. l)erember "2.2, 1893. Dawson (1909, p. s+1) says that there has been 110 elefinite record for the state of Washington for a number of years.

In addition to the citations above given, there are a good many merely nominal ascriptions of the species to California. Actual specimens from ('alifornia do not appear to exist in any Ameriean musemm. It is quite possible that some of the records may really refer to the Whistling swan whieh is still to be found in sull numbers within the state: but that all of the lereols for ('alifornia should have been at fault is scarcely possible. The 'Trumpeter was once a member of ond avifauna, but is now gont.

In flight the 'Trumpeter Swan was recognized by its sonorous note. saicl to have been like a Freneh horn in fullness of tone, as compared with the more whistle-like note of the Whistling Swan. In the hand this sprecies may be identified by its large size (20 to 30 pounds, aceording to IIntington, 1911, p. 145), and by the entirely black color of the long and proportionally narrow bill.

The Trmupeter Swan is recorded as breeding largely inside the Aretic Circle although it formerly bred mueh farther south. Macfarlane (in Maeoun and Macoun, 1909, p. 135) found several nests of this species " in the Barren Grounds, on islands in Franklin bay, and on the beach one was taken which contained six eggs." Raine (in Macoun and Macoun, loc. cit.) describes a mest found on Buffalo Lake, Alberta, April 7. 1891, as being a large strueture, three feet in diameter, composed of sods, grass and rushes and lined with feathers and down. During the molting season in August adult birds are mable to fly.

In habits the Trumpeter Swan is said to be similar to the Whistling Swan. However, it appears to frequent the fresh waters of the interior to a larger extent than does the latter species, which may indicate a dislike for salt water similar to that shown by certain ducks which breed in the interior. The food consists of the roots, leaves, and seeds of various water plants, and the bird is said to occasionally take aquatic insects, snails and small reptiles, when this type of food is available. 
Young birds are said to be decidedly palatable. Adults are also reported to have made exeellent food when they had "hung" the proper length of time, this depending on the weather. The Indians in the far north formerly used the eggs for food.

As above indieated, definite instanees of the occurrence of the Trumpeter Swan in California are rare, although the concensus of evidence indieates that it was a more or less common bird in the 50 's. There is no record of the occurrence of this species within the state cluring the past seventeen years. Hence we must point to it as one which, like the Columbian Sharp-tailed Grouse, has been obliterated simultaneously with the settlement of the state by white men.

Nor ean we say that this speeies has simply been driven somewhere else. Coale (1915, pp. 82-90) has summarized the records of occurrenee of this swan down to date throughout its entire range. He finds that "of the great multitudes of Trumpeter Swans which traversed the central and western portion of North America sixty years ago, there are [but] sixteen specimens preserved in musemms which have authentic data. These were eollected between the rears 1856 and 1909." It would appear that the speeies is now nearly if not quite extinct. It is probable that destruetion of the birds on their breeding grounds had as much or more to do with their disappearance as had the hunter in the winter home of the species. For, aceording to MacFarlane (1905, p. 754), between 1853 and 1877, the Hudson's Bay Company sold a total of 17,671 swan skins. The number sold annually ranged from 1,312 in 1854 to 122 in 1877. The bulk of these are believed to have been 'Trumpeter' Swans.

Here, then, is a species the disappearance of which must be charged to commereialization. At any rate, the Trumpeter Swan is a vanished member of our original endowment of game species, though the eiremmstanees indieate that citizens of California have not been largely responsible. This irreparable loss shoult teach us to aroid such a calamity with other game speeies in the future. Apparently the loss of entire sprcirs is necessary to wake us up to our duty toward the wild life, just as the lives of many people had to be saerificed before we conle realize our duty with regard to the social order.

\section{Whistling Swan}

\section{Olor columbianus (Ord)}

Other NAMES-American Swan; Cygmes americamus.

DESCRIPTION-Adults, both sexes: Entire plumage pure white often discolored at tips of feathers with rusty; iris "brown" (Audnhon, 1843, VI, 1. 292); bill black; an oblong spot of yellow or orange on each side of npper mandible near base; legs and feet black. Males: Total length 51.00-53.40 inehes (1,295- 
$1,360 \mathrm{~mm}$.) ; spreat of wings -.5. . . 1$55.00(2,160-2,235)$; weight 14-16; llis. (6.3.4-7.25 kg.) (thres specinens); fohlen wing $20.75-22.50$ inches (527-572 mm.): bill along :uluen $3.80-4.06 \quad(96.5-10.3 .0)$; tarsus 4.1 $4-4.54$ (106.3-115.3) (five spreimens). Females: Total length $45.25-51.50$ inches $(1,225-1,308$ mun.); spreal of wings 78.17 $\$ 3.00(1.955-2,105)$; weight $121 / 2$ los. ( $5.67 \mathrm{~kg}$.) (two speciurns); folled wing 20.35-21.60 inclies (517-5.45 mun.); bill aloug eulmen $3.60-4.49(91.4-114.0)$; tarsis 3.s0 4.52 (96.5-114.7) (five speecimens); all from California. Jureni? plumage: Jale dull gray, nearly white beneatl; head, neek and thighs larkest, approaching leaıl-color; heal tinged with reldish brown; lower surface with more or less lusty fouther-tipping: hill "relllish flesh-colour,' ti]” " lusky.", feet " "lull yellowish flesh-eolour", (Auilubon, loe. eit.). Sutal plumage: Not known to us.

MARKS FOR FIELD IDENTIFICATrox-Similar to lomestieated white swans. Very large size, Jong nerk (as long as bouly), and pure white plumage. Distinguishel from aclult Trumpeter Swan at close range by smaller size, shorter, hroailer tippel bill, presence of yellowish spots on each side of liase of bill in front of eye, and position of nostril (hind border less than 2.35 inches, $59.7 \mathrm{~mm}$., from tip of bill; fig: 40). When on water neek meets boily at distinct augle so that profile of bird resembles the figure \& (reversed) rather than the letter $S$. The latter profile is characteristic of certain foreign swans eommonly domesticated.

ToIce - A high flageolet-like note; varied murmurings from high to low (Forbush, 1912, p. 194).

NEST-Situated near water; a heap of rubbish gathered from the immediate vieinity, comprising grass, moss, and dearl leaves (Nelson, 1887, p. 92); sometimes lined with down.

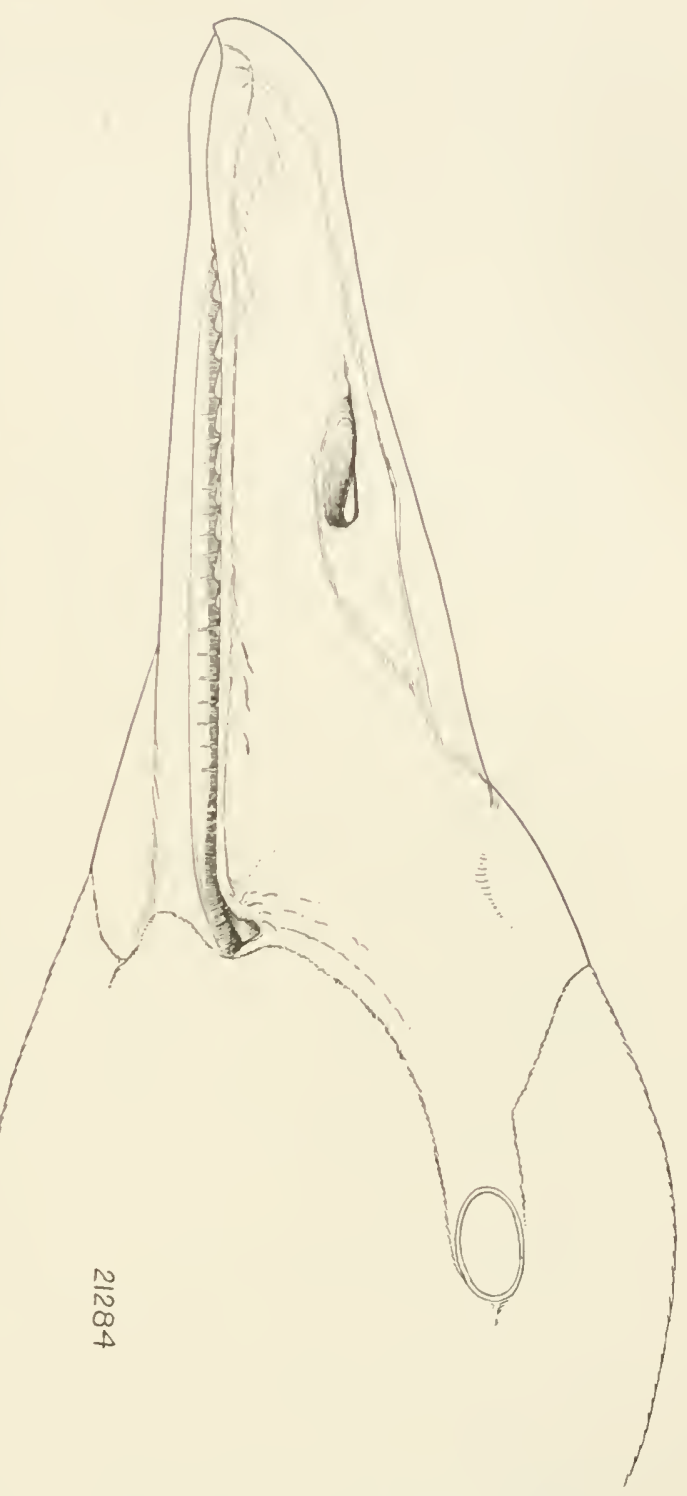

Fig. 40. Side of bill and hear of adult male Thistling Swan. Natural size.

Note area between bill and eye, where feathers are wanting, and that hind margin of nostril is less than 2.35 inches from tip of bill. 
EGGS-2 to 7, elongate ovate to elliptieal in shape, measuring in inches, 4.08 to 4.48 by 2.58 to 2.83 (in millimeters, 103.7 to 113.9 by 65.5 to 71.8 ), and averaging 4.26 by 2.68 (108.2 by 68.0 ); color dull white, usually stained with clay color, and surface of shell pitted (twenty eggs from Alaska).

General distribution-North America. Breeds from northern Alaska south to Alaska Peninsula, and on Arctie islanils from about latitude $74^{\circ}$ south to northern Mackenzie and northwestern Hulson Bay. In migration occurs west to Bering Island. Winters regularly on Paeific eoast from southern British Colnubia to southern California, and oceasionally in Lower California and Mexico; also on Atlantic coast from Delaware to South Carolina, rarely to Massachusetts and Florida; rare in interior of United States. Non-breeling birls have been known to remain through the summer on Lake Malheur, Oregon (modified from A. O. U. Check-list, 1910, p. 89; Cooke, 1906, pp. 84-85).

DISTRIBUTION IN CALIFORNIA-Fairly common winter visitant to suitable localities (usually large fresh-water lakes and brackish hearwaters of bays) south through the state at least to Orange County (Grinnell coll.). Numerous recent records and specimens from west-eentral Califoruia (Mus. Vert. Zool.), and sonthern California in vicinity of Los Angeles (Willett, 1912a, P. 28).

The swans are the largest of all our waterfowl, and by some persons are thought to be also the most beantiful and graceful. Two species of wild swans have been known to oceur within the State of California, both during the winter season. The smaller of these, and that which has probably always been the more abundant of the two, is the Whistling Swan.

This species is still fairly plentifnl as a winter visitant, arriving in late fall or early winter, usually in November or December, and leaving by the first of April or earlier. The larger lakes and ponds are chosen for feeding and loafing grounds. Some of the more recent and conspicuons California records are as follows: A flock of fifteen to twenty Whistling Swans wintered on the Alameda Gun Club grounds in Sonoma County in 1905 (Bolander, 1906, p. 75). A number were regularly to be seen near Los Baños, Merced County, from February 15 to March 11, 1912, but by the latter date most of them had left for the north (Beck, MS). A flock numbering on one oceasion thirty-one individuals, remained on Laguna Blanca, Santa Barbara, from December 22, 1908, to January 29, 1909 (Torrey, 1.913 , pp. 80-91). And in 1909 a flock of about forty birds wintered on Humboldt Bay (C. I. Clay, MS'). In December, 1914, Foster (1915, p. 132) saw sereral flocks on Cache Slough and "Grizzly Bay." One of these flocks numbered fifty birds and another between twenty and thirty.

The resemblance of wild swans to the domesticated varieties found on ponds and lakes in on public parks makes general identification of the wild birds easy. Swans may be recognized in flight by their pure white plumage (no black on wing-tips), their large size, and their long

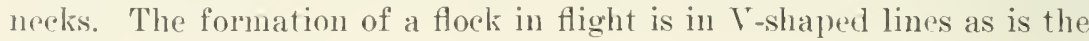
case with most geese. 


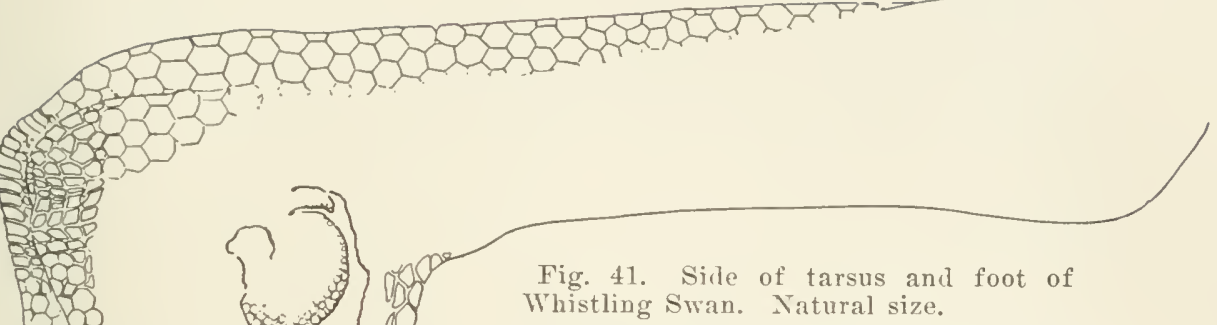

Fig. 41. Side of tarsus and foot of

atural size.

Note that tarsus is shorter than milile toe without elaw.

Three characters are serviceable in distinguishing the adult Whistling Swan from the Trumpeter Swan, the other species which was once found within the state, but is now thought to be extinct. The Whistling Swan is smaller, it has a yellowish spot at the base of the upper mandible on each side, just in front of the eye, and the bill is shorter, and broader, particularly towards the end (fig. 40). Birds of the year may be readily distinguishect from adults even in flight and at considerable distance by the readen cast of

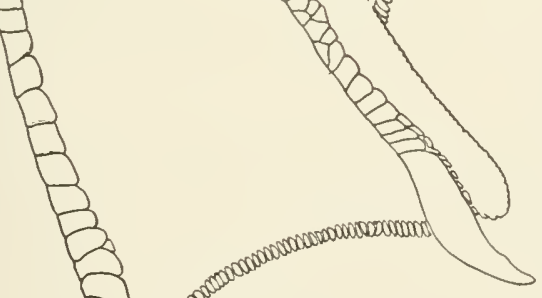
their coloration which contrasts strongly with the snowy white plumage of the adults. In all the speeimens at hand, of all ages, however, there is more or less rusty over-wash on the feathers, probably acquired from something in the water in which the birds almost completely immerse themselves when feeding.

In Alaska the Whistling Swan frequents forest-bordered lakes in the interior as well as the open lakes which dot the lowlands of the delta country. The nest is a bulky affair constructed of grass and moss, about three feet in diameter at the base and about 18 inches high (Macoun and Macoun, 1909, p. 134). Nelson 
(1887, p. 92) says that in Alaska the nest is usually built upon some small island in some secluded lakelet, or on a rounded bank close to the border of a pond. The eggs are deposited in a depression made in a heap of rubbish gathered by the birds from the immediate vicinity. The young are hatched the last of June or the first of July, and soon afterwards the parents lead them to some large lake or stream. There also the old birds molt and while growing their new quill feathers are unable to fly.

In moving from their aretic homes in autumn the Swans seemingly divide their forces; part going toward the Pacifie coast, part southeastwart toward the south Atlantic states and part south through the region of the Mississippi valley. They seem to fly undeviatingly across the country, erossing river valleys or mountain ranges, steering a course straight for their distant goal. When they arrive at their destination they pay little attention to decoys, but busy themselves by plunging their heads to the bottom in shallow water and digging up the hottom grass with their beaks. When they find the favorite morsels they often dig large holes in the bottom. The Swan does not dive, but can readily reach bottom in about three feet of water by standing on its heal on the bottom and padlling with its feet to keep its balance. When unlisturbed it is a noisy birl, though silent when alarmed. When a flock is at ease, their wierd, high-keyed calls and deeper tones may be heard in rhorus (Forbush, 1912, p. 200).

The first comers are in small flocks, composed of a few old birds with their cygnets [young]; these are augmented by others, and soon large numbers congregate. Their iestination is often reached at night; discordant cries announce the arrival and tell the satisfaction of a long, tiresome journey ended. Few sights are more imposing than the lines of white, and the swan drifting majestically along the surface of quiet water is deservedly the emblem of beauty and grace. From afar the appearance is of a snowbank. If disturbed, and not hard-pressed, they swim off rather than take to wing. The flight is started with considerable effort; the bird rising heavily against the wind quickly mounts to an altitude far out of range, when the wings seem almost motionless and the white line sails through the air in striking distinction to the flapping flight of geese (Sanford, Bishop and Van Dyke, 1903, pp. 262-263).

Torrey (1913, pp. 86-87) describes as follows the habits of some Whistling Swans which were present on Laguna Blanca near Santa Barbara during the winter of 1908 :

As they fed, holling their heals under water for a surprisingly long time, a number of Aucks collecterl in the virinity, diving dirertly beside them, almost or quite umier them, in fact, as if-what I doubter not was true-the longnecked creatures were stirring up the muldy bottom with a thoroughness which the ducks foumd highly to their alvantage. ... The swans made not the least objection to the ducks' persistent aml rather meddlesome looking activities,... but now and then they indulged in what seemed like slight fallings-out among themselves.

When they had fed thus for some time, they proceeded to bathe: after dinner the finger-bowl. Anl a lively performance it was, with a deal of 
noisy splashing as they threw themselves heavily aml rather elumsily first on one sille and then on the other. . . One of the alults (known for such by his clear white heal) male a larticularly brave show in lrying himself, stretching up to his full height, and shaking his wings and tail in a most vigorous manner.

In calling... they holi the hearl straight ul, and then at the moment of utterance raise it a little higher still with a surlden jerk. Their loud calls soumil human.

The Whistling swan always feeds in comparatively shallow water, using its long neck to tear loose the various aquatic grasses and roots of which it is fond. Along the Columbia River swans are said to feed on the wapato ol swamp potato (Sagittaria latifolia and S. arifolia) (McAtee, 1914, p. 5). Bendire (in Belding, Ms) found the Whistling Swan feeding on bulbous roots on the shores of Malheur Lake, Oregon. The stomach of one killed at the same place eontained twenty small shells. Belding (MS) says that in the winter of 1894-95 flocks of forty or fifty fed in grain fields near Gridley, Butte County, where they proved very destructive. One shot had a rank taste, not very different from geese which have been living on growing wheat or grass.

Old birds are tough and not particularly attractive for the table, but the young are considered a delicacy. In spite of the fact that they are difficult to shoot, heary loads and large shot being required to kill them, numbers of swans were sold on the markets, before they were protected by law. During the season of 1895-96 there were sold on the markets of San Franciseo and Los Angeles 518 swans, most of them probably of this species (Calif. Fish Commı, 1896, p. 42). Five individuals received at the Museum of Vertebrate Zoology in 1912 were carefully weighed and gave the following results: Two females each, 121/2 pounds; three miales, 14, 15, and 16 pounds, respectively. A full-grown juvenile hird received in 1916 weighed 81/5 pounds.

It is the height of the ambition of most hunters to kill a wild swan. Increased desirability seems to aceompany the bigness of the quarry no matter what the actual worth of the game as food may be. Even admitting that the swan comes under the strict definition of a game bird, ret its increasing rarity and its beanty rightly places it among those species whieh are now protected throughout the year. Its main enemy is the man who must shoot at something, law or no law, and who takes chances on making an extraordinary bag about which he can brag.

The heary drain on the swan population is due to the high estimate in which swans are held as game, and because of their value for feathers and down. This has brought one species, the Trumpeter Swan, near or quite to extermination: while the other, the Whistling Swan, is alarmingly scarce as compared with its former numbers. In many favorable places where swans regularly wintered in years past there are none at all to be seen at the present time. 
As an example of the persecution to which these birds have been subjected, we may cite the following: "Swans were common winter" visitors on Humboldt Bay up to three years ago when a flock of about forty birds lingered here until all but about six or eight were shot by market hunters. I saw eighteen of these birds in the hands of a local taxidermist, all of which were shot within a period of less than two weeks. He had bought them cheaply, expecting to mount them, and sell them at a fancy price, but they were poorly mounted and most of them went to ruin right in his shop" (C. I. Clay, in letter of March 16, 1912). It is to be observed that all of these hirds were killed illegally.

The Whistling Swan is now far from common in most parts of California, and it will certainly suffer the same fate as the now practically extinct 'Trumpeter Swan, if the rigid protection now accorded it is not enforced both here and in the other states and regions through which it migrates. Data accumulated since 1913 indicate that the Whistling Swan is holding its own and is appearing in even increasing numbers in west-central California. Such a gratifying situation is doubtless a result of the total protection given to swans in California beginning in 1905, and also of the aid extended them under the Federal Migratory Bird Law, and goes to show the effectiveness of such laws, especially when they are supported by popular sentiment.

\section{Roseate Spoonbill}

\section{Ajaia ajaja (Limnaeus)}

Other NAMEs-Pink Curlew; Ajaja rosea; Platea mexicana; Platalea ajaja.

DESCRIPTION-Adults, both sexes: Head yellowish green; space around eye and throat sac yellowish orange; band from lower mandible to back of head, black; bill yellowish gray at base, mottled with brownish black, otherwise pale greenish blue, light on margins; base of margin of lower mandible greenish yellow; iris bright carmine; neck white; back and wings rose color, deeper on under surface, wing, and hinder portion of body; shafts of scapulars and flight feathers light carmine; patch on each side of lower part of neck pale ochre; tail roseate at base, otherwise ochre-yellow, shafts carmine; feet pale lake, claws brownish black. Male: Total length 30.75 inches (7S0 mm.); folded wing 15.25 (387); bill 7.00 (177.5); tarsus 4.00 (101.5); weight 4 pounds 2 ounces (1.37 kg.). Female: Total length 28.00 (711 mm.); weight 3 pounds (1.36 kg.) (Audubon, 1843, VI, p. 77). Jucenile plumage: Head feathered except around base of bill; general color white, more or less tinged with pink on wing, tail, and belly; outer margin of wing narrowly dark brown; more white and rosy the second year; full plumage acquired in third year (authors). Natal plumage: Not known to us.

MARKS FOR FIELD IDENTIFICATION-Heron-like bnild, pink color, evirent even at a distance, and conspicuonsly flat paddle-shaped bill (figs. 42 and 43 ). Mnch like ibises in general habits. In flight the neck and feet are fully extended, and the wing-strokes are regular. 
VOICE-( ?)

Nest-ln colonies in tropical swamps; a platform of sticks placed in a tree or shrub.

EgGs-C'sually 3, nearly elliptical in shape, measuring in inches, $2.4 t$ to 2.92 by 1.63 to 1.71 (in millimeters, 62.0 to 71.5 by 41.5 to 43.5 ), and averag. ing 2.56 by 1.67 (6.5.0 $\mathrm{hy}+2.5)$ (twenty eggs in U. S. National Museum) ; color dull white or pale greenish blue with various brown narkings (Reel, 1904. p. 90$)$.

Gexeral distribltiox-North and South Ameriea, from Texas, Louisiana, Florida, and Georgia south to Patagonia and the Falkland Islands; formerly easual north to Penusylvania and the lower Ohio Valley (Indiana and Illinois); more rarely to California. Colorallo, Kansas, anil Wisconsin (A. O. U. Checklist, 1910, P. 91).

DISTRIBLTION IN CALIFORNIA-Very rare summer visitant from the south. Has heen definitely reportel as follows: Several times as far north as San Francisco (Gambel, 1549, p. 2202); one seen near San Bernarilino, June 20, 1903, anr one seen tlying overheal at Riverside, in 1902 (Stephens, 1904, p. 139); along Coloralo River mear l'alo Verile, Imperial County, ifuring summer montls: of 1913 (Leo Wiley, in letter); but no California-taken sperimens are known. Rumors are eurrent of its presence in the Imperial Valley in the summer of 190\%.

The Roseate spombill is typically a far southerm bird, breeding in abundance in portions of Mexico, Central and south America. In the United sitates it is to be foumel as a resident in the Gulf region only. In summer, straggrler's have oecurred as far north as Pennstrania, Wisconsin, Kansals, Colorado, and C'alifornia.

For some time the Roseate spoonbill in California was known only from the statement of Gambel (1849, p. 2.2.2), that "small Hocks of this beantiful bind have several times extenderl mp the coast even as far as San Francisco.' Althongh Cooper (1877, p. 95) has expressed misgivings as to Gambul's ilentification, more recent confirmatory evidence to a degree tends to substantiate it.

The following notes by Stephens (1904, p. 139) are to our knowledge the only published records of the Roseate Spoonbill in California within late years:

Mr. R. B. Herron tells me that he saw a Roseate Spoonbill standing in a pond about four miles south of San Bernardino on June 20, 1903. It was feeding in the pond near the road and pail no attention as he drove past within gunshot. At first he thought it was a Wood Ibis (Tantalus loculator) but on coming near he saw the pink tinge of the plumage and the spatulate bill. On his return the next morning he brought a gun, but the birl was gone. On mentioning the matter to Mr. H. E. Wilder he told me that about a year previously (1902), when in Riverside, he saw a bird fly over that he felt sure was a Roseate Spoonbill.

Roseate Spoonbills were reported to us informally from the Imperial Talley in 1909; and Leo Wiley has written us that he finds this species appearing along the banks of the lower Colorado River in the vicinity of Palo Verde during the hot months of the summer season. 
It evidently comes north along with various herons and the Wood lbis after the elose of its breeding season in the sonth.

In the field as well as in the hand the Roseate Spoonbill is easily recognized. The pink color of its phumage may be seen at a eonsiderable distance, and the thin, flat, broad-ended bill (figs. 42 and 43) is totally different from that of any other bird found in the state. The flight is stated to be somewhat ibis-like, the neck being fully extended. The wing-strokes are, however, continuous, and not interrupted by short intervals of gliding. Spoombills frequent the shores of ponds and streams, and in Mexico are also found along the seacoast.

The breeding season appears to be exceedingly variable and greatly extended. There are reeords of eggs in Florida and Cuba from January to Angust and young have been seen in the nest in December (Cooke, 1913, pp. 13-14). The following aceount of the breeding habits of this bird is given by Davic (1889, p. 86):

Marshy or muddy borders of estuaries, the mouths of rivers, shrubby jslands of tropical seas, or some dense marsh, are the favorite breeding resorts.

Mr. R. E. Rachford visited a small colony of these birds in Southwestern Louisiana, June 2, 1856. The birds were foumd nesting in a clump of cypress trees in a low marshy place fully twenty miles from habitation. Here also nested the Snowy, Louisiana and Little Blue Herons and the Snake Bird.

The nests of the Spoonbills were placed from eight to eighteen feet from the ground, and the usual number of eggs found in the nests was three or four; although from one nest seven eggs were taken, and five or six from several others. The nests were platforms of sticks, and for the most part were built close to the trunks of the trees; they were usually more massive than the Herons nests.

The general shape of the eggs is ovate: and their color is white, or buffywhite, blotched, spotted and stained with various shades of brown; sometimes a pure white egg is found in a nest with spotted or marked examples.

The general habits of the Roseate Spoonbill are evidently mueh like those of the ibises. Its mamer of feeding, however, is different, for the bird immerses the bill and swings it from side to side to sift the food out of the mud (Chapman, 1912, p. 217). It is said to feed on inseets and shellfish, and to forage almost entirely at night.

Like the several speeies of ibises this bird is said sometimes to take wing withont apparent provocation, and then aseend gradually, in a spiral manner, to a great height. It is often found in the eompany of herons, and it often happens that these, by their own natural vigilance, are able to warn it of the approach of danger. The Roseate Spoonbill can alight on a tree and walk on the branehes with all the facility of a heron (Baird, Brewer and Ridgway, 1884, I, pp. 105-106).

The Roseate Spoonbill is not a true game bird, for it is a near relative of the herons. It ehanees to be included among the game 

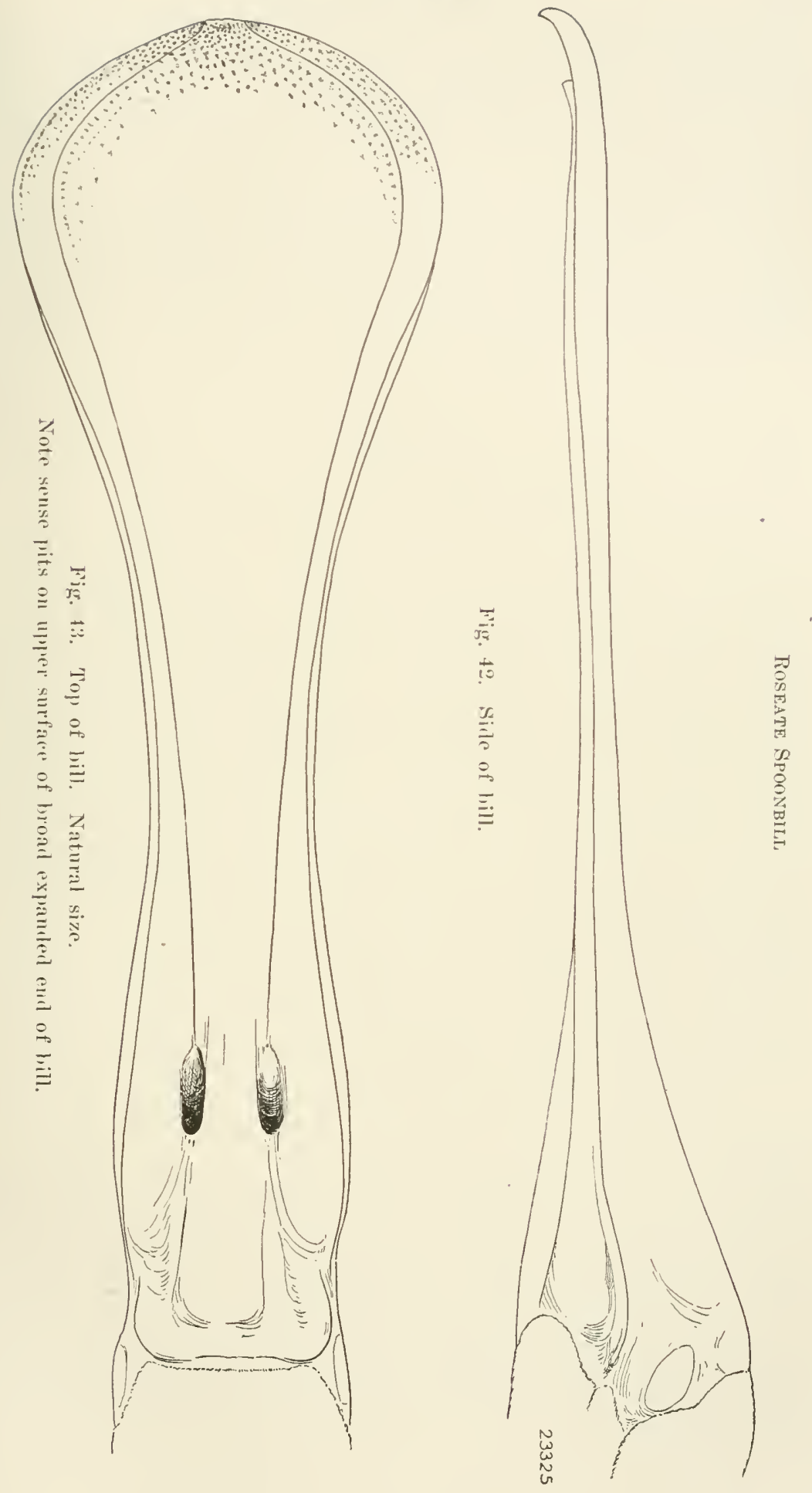
birds of our state beeause it belongs to the same order of birds as the White-faced Glossy Ihis which has in California been ranked as a game species. 'The extraordinary appealance of this bird naturally attracts attention, but does not warrant the destruetion of the speeies hy the hunter.

In many parts of its general range the Roseate Spoonbill has been almost exterminated by plume hunters. But in California it never ocenred in conspicuous numbers, and the probability is that it will always remain one of the rarest birds accredited to the state-a natural curiosity that should be conserved as such.

\section{Wood Ibis}

\section{Mycteria americana Limaeus}

OTHER NAMES-Water Turkey; Tantalus loculator.

DESCRIPTION-Adults, both sexes: Whole head and upper neck devoil of feathers (save for a few small scattering ones on fore and hind neck), anil covered with a hard, scurfy skin of a dusky blnish color; top of head covered with a horuy shield about one and three-quarters inches square; iris "deep brown" (Audubon, 1843, VI, p. 70); bill stont, tapering, and curved downwards at end, dull yellowish brown in color, edges and tip greenish yellow; whole of phumage white except for flight feathers, primary wing coverts, and tail feathers, which are black with metallic green and purple iridescence; legs bluish black; toes yellowish; claws black. Total length (both sexes) " 35.00 45.00 " inches (888-1,143 mm.) (Rillgway, 1900, p. 125); folled wing 19.0019.35 (483-492); bill along cuhmen 9.00-9.12 (225-231.5); tarsus 8.25-8.50 (209-216) (two specimens from Imperial County, California). Jucenile plumage: Head and neck feathered, save for region about base of bill in front of eyes, and top of heal between eyes, which are continuonsly naked; feathers of head and neck grayish brown, approaching brownish black on hind neck and siles of neek; otherwise as in adult, but with black portions of plumage showing less of metallic sheen. Natal plumage: Not known to us.

MARKS FOR FIELD IDENTIFICATION-Large size (over three feet tall when standing), white plumage, black tail and wing tips, bare forehead, heary bill down-curved towards tip, and long stout legs.

Vorce-Usually silent: call-note: croak, croak, croak (Coues, 1874, p. 515). Utters a "rough guttural eroaking note", when frightened (Baird, Brewer and Ridgway, 1884, I, p. 84).

NEST-ln tall trees in dense eypress swamps; a platform of sticks loosely arranged and lined with moss.

EGGS-3, clongate or elliptical ovate in shape, measuring in inches, 2.57 to 3.12 by 1.77 to 1.92 (in millimeters, 65.2 to 79.3 by 45.0 to 48.7 ), and averaging 2.75 by 1.84 (69.9 by 46.7); color white, withont surface gloss (nine eggs in U. S. National Museum from Florida).

General distribution-Temperate and tropical America from southem California, Arizona, Texas, Ohio Valley, and Sonth Carolina south to Argentina: casual north to Montana, Wiseonsin, New York, anıl Vermont (A. O. U. Checklist, 1910, p. 93). 
DISTRIBUTION IN CALIFORNIA-Regular and common summer visitant along lower Colorado River: irregular and less common visitant in midsummer through southern California. Recorded by Cooper (1887, p. 90) as having been seen north to San Francisco Bay and the San Joaquin Valley. No authentie instance of breeding on the Pacific slope north of the Mexican line.

The Wrood Ibis is a tropical species of wide distribution in Central and South America. In the United States it is eommon only in Florida and along the Gulf Coast to sonthern Texas. After the breeding season, and when the roung are fully grown, both old and young are in the habit of moving northward to the swamps along the Mississippi River, partienlarly in southeastern Missouri and southern Illinois, whieh at this season of the year swarm with their farorite food. In similar fashion the breeding birds of the coast of western Mexico work northward in summer after the nesting season. They are espeeially common in the valley of the lower Colorado River, and also appear, though irregularly, throughout southern California (Cooke, 1913, pp. 22-24).

The Woad Ibis is the only member of the family of true storks to be found in California. Along the lower course of the Colorado River it is regularly found during the summer season, but in other sonthern parts of the state it is more or less of a straggler. The most recent reeords of its occurrence within the state are: Daggett, San Bernardino County (Lamb, 1912, p. 34); near Long Beach, Los Angeles County (Law, 1912a, p. 41) ; and near Los Angeles (Willett, $1912 b, p p .191-195)$. The earliest scasonal record within the state is for May 18, and the latest August 5. The northernmost record stations are on San Francisco Bay (Cooper, 1S87, p. 90).

The Wood Ibis eammot be confused with any other bird found in California; for no other large erane-like bird has a bald head, white plumage, and black-tipped wings and tail. The extremely long bill, stout at base and slightly curved downwards toward the tip, is likewise diagnostic. This bird stands over three feet in height and thus presents a conspieuous figure about the open margins of shallow ponds and on marshy land and the shores of streams, where it forages.

Nests of the Wood Ibis have never been found in California, the speeies apparently requiring a warmer and moister climate than ours during the brecding season. In the Gulf states the Wood Ibis like the herons selects dense cypress swamps for its breeding grounds, and nests in eolonies. The nest is built of sticks and is placed in the tallest of trees. The eavity is deep and usually lined with moss. Eggs have been found in Florida as early as December $S$ and January 5 . Consequently this speeies must be considered one of the earliest of birds to breed (Cooke, 1913, p. 24). According to Audubon (1843, YI, pp. 68-69, 70) the young are entirely dusky gray, with brownish 
blaek wings and bill. The head is at first covered, but becomes partially bare after the first moult. Four years are said to be required for the bird to attain its full plumage.

Wood Ibises seen by Stephens (1903, p. 76) along the Colorado River near Needles, in June, were not shy and were feeding in the shallower parts of the lagoons, wading about where the water was a few inches deep. Eight birds under observation by Feudge (1903, p. 79) in San Bernardino County midway between San Bernardino and Highlands, in the summer of 1901, and three seen in the same loeality on Jume 5, 1902, were foraging in damp fields and in the creek bottoms, but were oecasionally seen eireling high in the air. Law (1912a, p. 41) deseribes the manner in which a Wood Ibis was feeding at Dominguez Station, near Long Beach, on July 2, 1911, in the following words: "It was standing almost knee deep in the muddy water, and would insert its bill almost up to the eyes and then, standing on one foot, would seem to be stirring up the water with the other foot." The farmers in this vicinity stated that half a dozen of the birds had visited the slongh almost every day for a month. "One was shot some years sinee at San Leandro... [Alameda County] having incantionsly alighted on a shade tree by the roadside" (Cooper, 1887, p. 90).

The carriage of the Wood Ibis is firm and sedate, almost stately; each leg is slowly lifted and planted with deliberate precision, before the other is moved, when the birds walk unsuspicious of dauger. I never saw one run rapidly, since on all the occasions when I have been the cause of alarm, the bird took wing directly. It springs powerfully from the ground, bending low to gather strength, and for a little distance flaps hurriedly with dangling legs, as if it was much exertion to lift so heavy a borly. But fairly on wing, clear of all obstacles, the flight is firm, strong, and direct, performed with continuous morlerately rapid beats of the wing, except when the birds are sailing in circles as above noted. When proceeding in a straight line the feet are stretched horizontally backward, but the heal is not drawn elosely in upon the breast, as is the case with Herons, so that the bird presents what may be called a top-heavy appearance, increased by the thick, large bill (Coues, 1874 , p. 516).

The Wood Tbis... feeds entirely on fish and aquatic reptiles, of which it destroys an enormons quantity, in fact more than it eats; for if they have been killing fish for a half an hour and have gorged themselves, they suffer the rest to lie on the water mtonched, when it becomes food for Alligators, Crows and Vultures.... To procure its fool, the Woor Ibis walks through shallow mudily lakes or bayous in numbers. As soon as they have discovered a place abounding in fish, they dance as it were all through it, until the water becomes thick with the mul stirred from the bottom by their feet. The fishes, on rising to the surface, are instantly struck by the beaks of the Ibises, and on being deprived of life, they turn over and so remain. In the course of ten or fifteen minutes, hundreds of fishes, frogs, young alligators, and water-snakes cover the surface, and the birds greedily swallow them until they are completely 
gorgen, after which they walk to the nearest margins, place themselves in long rows, with their breasts all turned toward the sun, in the manner of I'elieans and Tultures, and thus remain for an lour or so (Aulubon, 1843, Vl, p. 65).

The crop of a Wood Ibis taken at Bixby, Los Angeles County, Angust 2:3, 1901, and examined by Daggett (1903, p. 19) was filled with aruatie insects. Leo Wiley (in letter of February 19, 1915) states that three Wood Ibises which were examined by him at Palo Verde, Imperial Connty, showed stomach contents as follows: three talpoles, four "pumpkin-seed" beetles (water beetles), two padtle bugs, and moss and slime; (2) nine tadpoles, one pumpkinseed beetle, nine dragon-fly larvae, and one fish (a carp); (3) one water-ericket, ten carp, one eatfish, and two hony-tails (a kind of fish).

There seems to be a difference of opinion as to the value of the Wood Ibis as a bird for the table. Along the ('olorado River, where it is known as the "Water Turkey," it has been eaten with relish; but as a rule, north of Mexico it is elassified along with the herons as being beneath the dignity of a game species. As far as California is eoncerned the Wood Ibis should be protected as a birt whose rarity makes it a subject of interest rather than an object of sport.

\section{White-faced Glossy Ibis}

\section{Plegadis guarauna (Linnaens)}

OTher xames-Bronze Curlew; Black curlew; Falcinellus eatunensis; Ib is ordi; Ibis mexicanus; Ib is thalassinus.

Descriptiox-Adults, both sexes: Hearl, neck, ant boly in general, leep cinnamon brow; a narrow area abont base of bill and extending back around each eve, white; bare naked skin about hase of bill and including area about eye, reshlish purple; iris blool resl; bill slate-colorent, slender, curverl townward like that of a curlew; top of hearl, lower back, wiugs and tail giving metallie reflections of purple, pinkish bronze, aud green; longer seapulars and outer surface of closed wing with purplish and greenish reflections predominating; shorter seapulars and lesser wing coverts rich ehestnut; primaries iridescent green; secondaries mostly bronze; sides of bolly, axillars, and under surface of wing, bronze, purple and green according to angle of view; rump and tail mixed green and purple; lower tail coverts with steel blue and purple reflections; legs and feet varying from grayish brown to dark redtlish purple. Males: Total length $23.75-24.00$ inches $(603-610 \mathrm{~mm}$.) (two specimens); folded wing 10.40-10.75 (264-273); bill along culmen 5.25-5.67 (133-144); tarsus 3.904.15 (99-105.5) (six specimens). Females: Folded wing 9.45-9.75 (240-248); bill along culmen 4.30-4.55 (109-115.5); tarsus 3.35-3.40 (85-86.4) (two specimens); weight $13.6 \mathrm{oz}$. (386 gm.) (one specimen); all from California. Juvenile plumage: Cinnamon and chestnut hues wholly lacking; heal, neck and lower surface, dull grayish brown, the head and upper part of neck streaked narrowly with white; back grayish brown, with green and steel blue reflections; onter sur- 
face of closerl wing, and flight feathers, dusky, with green and steel blue reflections, hut bronze and purple iridescence of adults lacking. Second-ycar (or winter?) plumage: Like juvenal in boly plumage (that is, with grayish brown body and white-streaked heal), but with lower back, wings and tail, more as in arult, differing only in lesser amount of rich chestunt, and purplish pink reflections. Natal plumage: "Uniforn blackish ... bill whitish, with dusky base"' (Rilgway, 1900, p. 124).

MARKS FOR FIELD IDENTIFICATION-Curlew-like profile, bright iridescent chestuut-colored plumage appearing black at a distance (whence the name Black Curlew), down-curved curlew-like bill about fire inches in length (fig. 44), and long legs. Fly in orderly diagonal lines, earh bird with legs and neck extended (pl. 8).

Vorce-A hoarse $k \bar{a}-\check{o} n k$, several times repeated (Grinnell, MS); a jerky, squawking cry of three syllables, rapilly repeated when disturbed (Shields, 1894, p. 108); a nasal ooh-ick-ooh-ick (Chapman, 1908, p. 292).

NEST-In colonies in marshes, compactly built of dry tules, placer on a foundation of bent-over growing tules a foot or more above the water.

EGGS-3 to 4, rarely 5, elongate ovate and rather pointed, measuring in inches, 1.81 to 2.16 by 1.40 to 1.46 (in millimeters, 46.0 to 55.0 by 35.5 to 37.0 ), and averaging 2.03 by 1.42 (51.5 by 36.0 ) (forty-six eggs in U. S. National Museum); color dark blue fading to lighter blue during incubation.

General distribution - Temperate and tropical America from southern Oregon, Arizona, Texas, and Florida south through Mexico: also in southern South America; migratory in the northern portion of its range: casual north to British Columbia, Wyoming, and Nebraska (A. O. U. Check-list, 1910, p. 92).

Distribution in CaLifornia-Common summer visitant interiorly to southern and central portions of the state. Breeds in suitable swampy areas. Some northern recorl statious are: Lower Klamath Lake, Siskiyou County (H. C. Bryant, 1914e, 1. 232); Sutter County (Beliling, 1879, 1. 443); Owens Valley (A. K. Fisher, 1893a, p. 19) ; casual on Farallon Islands (W. E. Bryant, 18ss, p. 42). Some breeding stations are: Escondido, San Diego County (Sliarp, 1907, p. 91); San Jacinto Lake, Riverside County (Willett and Jar, 1911, p. 159); Los Baños, Merced County (Mailliard coll.; H. C. Bryant, MS). Winters occasionally in the southern coastal district, and in vicinity of Los Baños (Mus. Tert. Zool.) and Stockton (Belding, MS).

Like the Cinnamon Teal, the White-faced Glossy Ibis fumishes a good example of discontinnous or interrupted distribution. Although found in both North and South America there is a great extent of country in Central and northern South America where it is not found. The two ranges are separated by $22^{\circ}$ of longitude and $30^{\circ}$ of latitude and there is but one record of the occurrence of even a straggler in this intervening territory (Cooke, 1913, pp. 19-21).

In North America the White-faced Glossy Ibis is to be found from central Mexico north to Louisiana, Utah and Oregon, and oceasionally as far north as Minnesota, Wroming, Idaho and southern British Columbia. Its winter and summer ranges overlap to some extent. but most birds of the species winter south of the United States. 'There are records of its occurrence in winter at Tombstone, Arizona, and in San Diego, Los Angeles, Mereed and San Joaquin counties, California. 


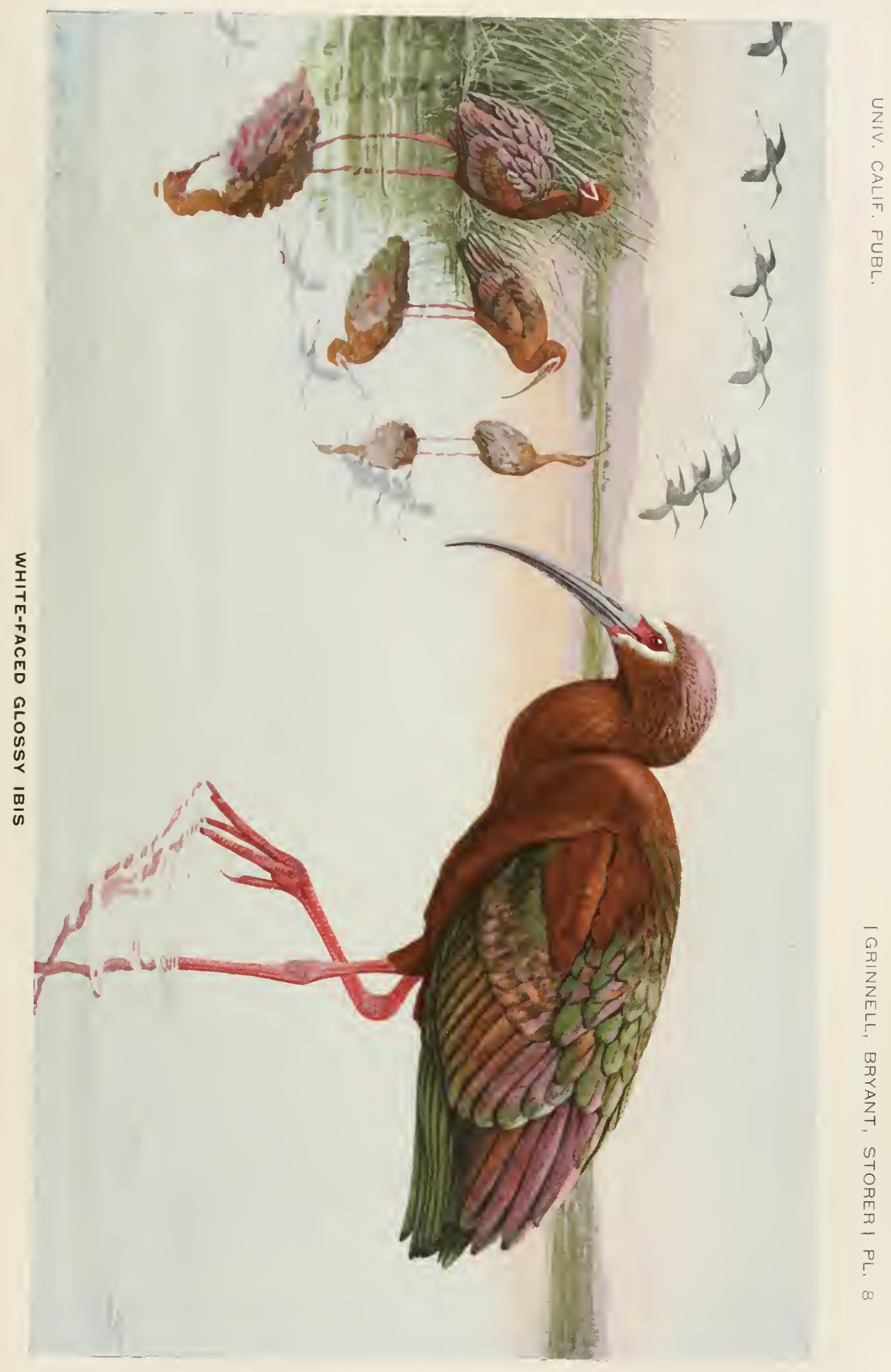



In California this is a common summer visitant and breeder in the San Joaquin Talley. One or two colonies have heen found in southern California. Elsewhere in the state the reeords pertain as far as known to birds in migration or on foraging expeditions. Thus the northermmost records of oceurrenee in ('alifornia are probably of birds in transit to or from the known breeding colonies in eastern Oregon.

Beck (MS) noted the first of these Ibises at Los Baños, Mereed County, in 1912, on April 22, when lie saw two bands of about twenty each flying north. Lamb (1912, p. 34) noted the species as late as September 10 and 24 at an oasis on the Mohave desert. A remarkable flight of White-faced Glossy Ibises was noted by Belding (1905, p. 112) at "Stockton on May 5, 6, 7, 1879, during a gale from the northwest which lasted for three lays. During this time from 4,000 to 5,000 of these birds flew north. They followed the eastern edge of the tule marsh as nearly as the strong wind would allow them to, going hy simmous flight up and down, to the right and left, with few wing strokes.'

J. S. Hunter (MS) saw about 200 Ibises in one flock near Los Baños on October 30. 1914. This is an exceptionally late date in this latitude for more than oceasional stragglers. There are in the Musenm of Vertebrate Zoology three specimens taken in the same locality on November 25 and December 4 and 23,1911 . One of these was plainly a cripple, and all were immature. But Belding (IIS) saw a flock of more than a hundred feeding in a pasture near Stockton on February 9, 1586 , and several dozen were seen by him in the markets of Stockton during the winter of 1855. Small floeks were observed in the winter of 1885 (Jannary 1, etc.) near San

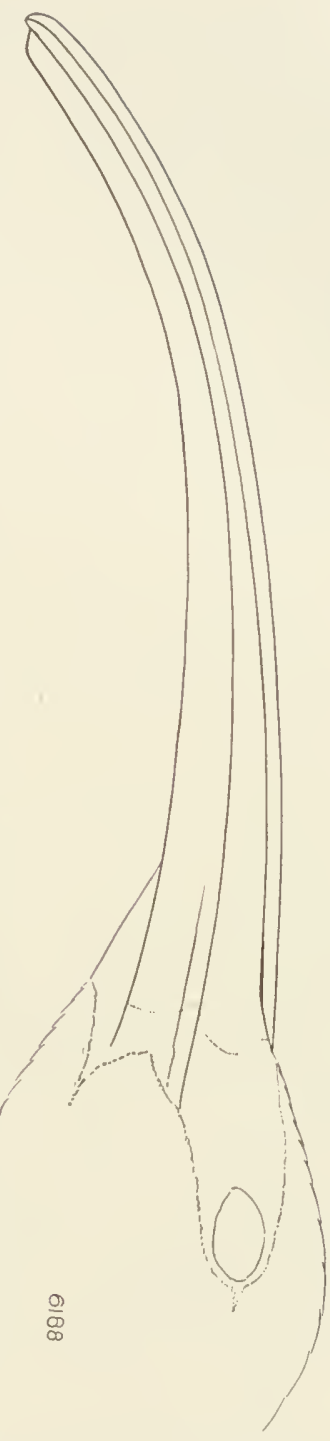

Fig. 44. Side of bill of White-faced Glossy Ibis. Natural size.

Note down-eurved tip and naked area between bill and eye (compare with figs. 73 and 74$)$. Diego (Holterhoff, 1885 , p. 312), and there are other reports of oceasional winter oceurences in the sonthern coastal district; but the species cannot be eonsidered as regularly present in winter north of the Mexican line. 
The White-faeed Glossy Ibis chooses dense tule thiekets for its breeding grounds. The nests are built in colonies and are composed of dry tules and often lined with marsh grass. They are placed on broken-down growing tules one to six feet above the water. In "northern San I)iego County," Shields (1894, pp. 108-109) found new nests and eompleted sets slightly incubated on May 29, 1893. The Mailliard eollection contains a number of sets of two to four eggs taken in Merced County on Jnly 4 and 12, 1913. These eggs varied from fresh to slightly inenbated. The nests varied in height above the water from one foot to eighteen inches.

Willett and Jay (1911, p. 159) give the following account of the nesting of the White-faced Glossy Ibis at San Jaeinto Lake, Riverside County, as observed there May 28, 1911:

In nearly every patch of tules was a nest or two of this species, and in the patch farthest west which covered about a half acre, there must have been at least two hundred nests. They were built on bent-down tules, and were composed of tule stalks and lined with marsh grass. They were situated from two to six feet above the water, the average height being about four feet. About half the nests examined containerl young and most of the others held badly incubated eggs. A very few fresh sets were found but the height of the nesting season was past. The sets almost invariably consisted of three or four eggs. In one or two instances sets of two incubated eggs were noterl, and three nests contained five eggs each, two nests six eggs each, and one nest had seven. It is probable that sets numbering more than five eggs were deposited by more than one bird. In fact they invariably showed two different types of eggs. The color of the eggs evidently farles with incubation, as the heavily incubated eggs are much lighter blue than the freshly laid ones. This is probably the largest breeding colony of these birds in southern California west of the mountains.

The White-faced Glossy Ibis is usually to be found in or near marshes. It is ordinarily seen in small floeks wading in shallow water, probing into the soft muddy ground with its long sickle-shaped bill, or eireling overhead with slow wing-beats and an oecasional soaring flight. While on the ground, Ibises have the dignified pose of herons, but while on the wing more nearly resemble cranes.

The White-fared Glossy Ibis performs interesting aerial evolutions. Chapman (1908, p. 292) describes this habit as wituessed near Los Baños, Mereed County, in the following worls:

In ".lose formation, they soared skyward in a broad spiral, mounting higher and higher until, in this leisurely ani graceful manner, they had reached an elevation of at least 500 feet. Then, without a moment's pause and with thrilling speed, they dived earthward. Sometimes they went together as one bird, at others each birl steered its own conrse, when the air seemed full of j)lunging, darting, crazy lbises. When about fifty feet from the gronnd, their reckless dash was checked, and, on bowed wings, they turnerl abruptly and shot upward. Shortly after, like the rush of a gust of wind, we heard the 
humming souml caused by the swift passage through the air of their stiffened pinions.

The food of this Ibis is composed of inseets, worms, snails, crustaeea, small fish, and frogs. Most of its food is apparently obtained by probing in the mud. Belling (MS) states that the stomach of a birel shot in some tules near Stockton March 18, 1856, was full of fragments of an aquatic plant among which were the legs of a beetle.

The resemblance of this bird to a curlew has doubtless led people to suppose it related to the shore-birds, and hence of desirable table qualities. But judging from the food of the White-faced Glossy Hhis, which appears to be of similar nature to that of the lerons, one would not expect to find the Ibis particnlarly palatable as an article of fool. Belding (MS) states that he never knew of anyone eating Ibis in Califonia excepting Chinese. Tet this speries has been marketed in the langer cities with apparent regularity for many vears, as witness Heermann 's report of its being sold lere during the fifties (1859, P. 63).

Califormia is the only state in the Union that has ever ranked the White-faced Glossy lbis as a game bird, and provided an open season for it. In three states. Nevada, Kansas, and New Mexico, the bird is morotected, but in all other states where it is found it is protected by law the year round. The open season in Califomia was from October 15 to March 1 in the northern part of the state, and from October 1 to March 1 in southern California. The bag limit was twenty birds. Even with this open season there was little drain on the numbers, for, as a matter of fact. because of the marked migratory habit of this species, but few are to be found as a rule within the state during the open season. In 1915 ibis were removed from the list of game birds and thereby came under the laws protecting non-game birds. Large numbers of White-faced Glossy Ibis continue to nest in the larger fresh-water marshes, and the greatest danger to the species lies in the possible reclamation of these breeding grounds.

\section{Little Brown Crane}

\section{Grus canadensis (Linnaeus)}

Other JaMes-Sandhill Crane, part; Grus mexicana part.

DESCRIPTION-Adults, both sexes: Large area on top of hearl to level of eyes, and including space between bill and eye, bald, with but scattering black "hairs" (hair-like feathers); the granulated skin of this area is "dull livid red", in life (Nelson, 1857, p. 96), and the feathers on hind heall extend forwarl into it in the form of a werlge; bill black; iris "orange yellow", (Nelson, loc. cit.); whole of plumage light leaden. gray, except for primary wing feathers which are brownish black with dull white shafts; gray clearest 
on neck and chest, while cheeks and throat are usually lighter, sometimes alnost white; a rusty brown wash often covers parts of plumage; legs and feet black. Males: Total length $35.50-39.50$ inches $(901-1,003 \mathrm{~mm}$.) (three speeimens from Alaska); folded wing 17.40-20.20 (442-513); bill along euhmen 3.223.98 (81.8-101.0); tarsus 6.58-8.35 (167-212) (nine specimens from California and Alaska). Females: Total length 33.70 (856) (one specimen from California); folded wing 17.90-19.12 (455-486); bill along eulmen 3.66-3.78 (92.896.0 ) ; tarsns 7.20-8.45 (183-215) (three specimens from California). Juvenile plumage: Similar to that of adult, but hear entirely gray-featheresl; back of head and neck with a rusty brown rateh, and same tone conspicuous on feather margins of back and wing coverts. Natal plumage: Not known to us.

MARKS FOR FIELD IDENTIFICATION-Large size, standing about three feet, long neck and black legs, and general bluish gray coloration, without any contrasted markings; forehead unfeathered in adults (fig. 45); neck straight out in flight, not drawn in or "erooked" as with Herons. With us in winter usually in flocks, rather than singly. The only distinguishing mark between the Little Brown and Sandhill cranes is size; see measurements of latter beyond.

VoICE-“"A loul, hard, lolling k-r-roo kr-r-r-roo, kû-kr-r-roo" (Nelson, 1887, p. 94).

Nest-A slight hollow in ground sprinkled with grass or twigs.

EGgS-2, elongately ovate in shape, measuring in inches, 3.29 to 3.88 by 2.10 to 2.34 (in millimeters, 83.6 to 98.4 by 53.3 to 59.4 ), and averaging 3.62 by 2.25 (91.9 by 57.2) (nineteen eggs from Alaska); color light buffy or olive brown, spotted and blotched, most thickly at large end, with reddish brown, grayish brown, and lavender; these markings have a distinctly longitudinal trend.

General distribution-North America. Breeds from northern and western Alaska east to Baffin Land and central Keewatin; migrates south along the Pacific coast and through the interior of the United States, wintering from California and Texas south to Jalisco, Mexico. Has been recorder in summer from eastern Siberia (Cooke, 1914, pp. 7-9).

Distribution in CAlifornia-Common migrant through interior portions of the state. Remains throughout winter in varying numbers north at least through San Joaquin Valley. Does not as a rule visit seacoast or affect vicinity of alkali lakes, preferring open plains or vicinity of fresh water.

The cranes are among the largest of the long-legged game birds occurring in California. Their well-known rolling cries as they pass to and fro in migration most often bring them to popular notice. Because of their extreme shyness and habit of foraging far out on open plains they are usually successful in eluding the hunter. and, in spite of the good quality of their flesh, have come nearer maintaining their numbers than many smaller species. Among the near relatives of the Little Brown Crane only the closely similar Sandhill Crane can lay proper claim to a place among California birds. It is true that the Whooping Crane (Grus amcricana), of much larger size and chicfly white plumage, was thought by Belling (1891, p. 99; also MS ) to have been seen by lim on two or more oceasions, in flight, in Butte and Sutter comties. But no specimens of this species from any where west of the Rocky Nomntains are preserved in any museum. 
The Little Brown and sandhill eranes are identieal in proportions ant coloration, differing only in the deeidedly greater size of the latter (see measmements). Neither of them should be eonfused with amy of the herons, to which, especially the Great Bhe Heron, they bear some genelal resemblance. The eranes have no sharply contrasted white or black markings, in the alult their heads are bald (down to the level of the eyes), their necks are hald out straight in flight (not drawn in or "erooked"), and their sonorons rolling cries are totally" different from the gruttural squawks of the herons.

Writing from Montana, Cannoron (1907, p. 251) says: “If undisturbed the eranes fed in the morning and evening. strongly recalling turkeys in general behavior: their stately manmer of walking and

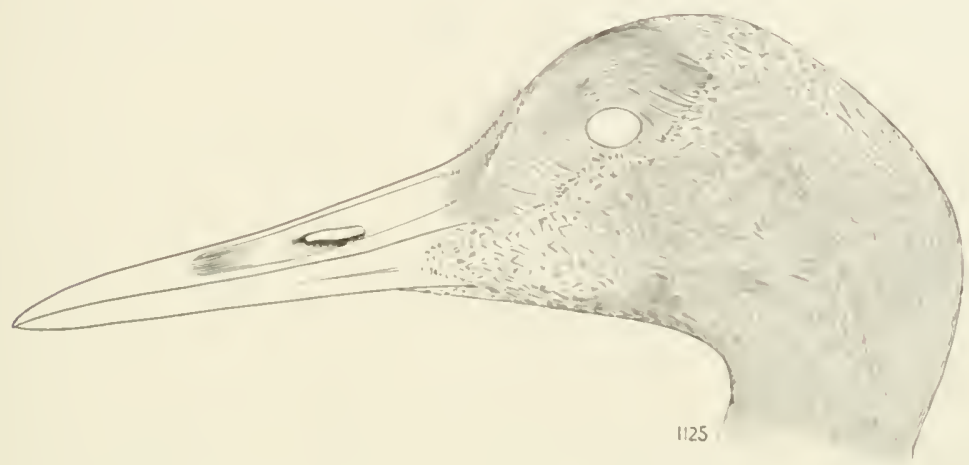

Fig. 45. Side of bill and heal of Little Brown Crane. One-half natural size.

Note hair-like feathers on foreheal and smaller size as compared with sandhill Crane (fig. 46 ).

drooping tertiary plumes eausing them to present a striking appearance."

During the breeding season the Little Brown Crane is confined to northern North America from the rieinity of Hudson Bay to Alaska, where it inhabits the great treeless tundras. It migrates through Canada and the western Lnited States, wintering from California and Texas southward into Mexico. In California this crane is most abundant during the season of migration, but considerable numbers remain throngh the winter in the San Joaquin Valley and on suitable parts of the coastal slope of southern California. As judged from the size of migrating flocks each rear, there has been some diminution in numbers, though estimates are difficult to make. Formerly the term "thousands" was often applied to the migrating hosts.

James A. MacDonald, Jr., of Lathrop, San Joaquin County, states (IIS) that five flocks of cranes were seen feeding in that ricinity on February 4, 1914. In one flock which flew overhead 149 birds were 
comnted, and it was estimated that at least 800 birds were seen inside of forty-five minutes. Persons in the neighborhood reported that flocks of crancs had been feeding in that vicinity for the two or three months previous to this observation. Six speeimens now in the Museum of Vertebrate Zoology were eollected at Los Baños, Merced Connty, February 6, 1912. The following migration data gathered by Belding (MS), althongh attributed to the Sandhill Crane, probably, in the light of omr present knowledge, refer chiefly or altogether to the Little Brown Crane. The earliest fall records for Stockton, San Joaquin Comnty, are: September 18, 1880, and September 23, 1881, when cranes were seen flying south. At Campo, San Diego County, many flocks have been seen passing high overhead in a southeasterly direction which would have led them to the head of the Gulf of California where the species is known to winter abundantly. In early spring flocks have been noted traversing the same conrse in reverse direction. In the vicinity of Tolean Momntain, San Diego County, eranes were seen going north or northwest in flocks March 16 and 20. At Tehachapi Pass, Kern County, April 4, 1889, many flocks were seen by Belding going west to the San Joaquin Valley, the flight eontimning interruptedly for several days. They were first seen at Marysville, Yuba Comnty, in 1884, on March 6, but the bulk did not arrive until May 1. The same year large number's were seen going north at Chico, Butte County, on May 2 ; the last were seen on May 20. At Gridley, Butte County, large flocks were seen going north on May 10, 1884.

The Little Brown Crane resorts to a far inorthern summer home where it can raise its young in safety from most of its enemies and where suitable food is to be found in abundance. The rast open tundras of western and northern Alaska and extreme northern British America afford these conditions. Because of the prolonged winters, the cranes do not arrive on their breeding grounds until some time in May, and this may accomnt for the lateness of their departure from California. The carliest arrivals at Saint Michael, Alaska, have been noted on May 7 (Nelson, 1887, p. 94) ; farther nortl, on the Kowak River, Alaska, the first birds in 1899 appeared on May 14 (Grimnell, 1900, p. 19).

Recording his experiences with the Little Brown Crane at St. Michael, Nelson (loc. eit.) says: "They come from the south toward the Lower Yukon, and on mild, pleasant days it is a common sight to see the cranes advaneing high overhead in wide eircnits, poised on motionless wings, and moving with a grace nnexpected in such awkwardly formed birds. . . . The air is filled with the lond, hard,

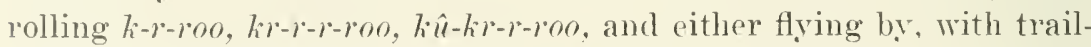
ing legs, or moving gravely from place to place, they do much to render the monotonous landscape animate." 
Immediately upon their arrival courtship begins. The mating anties of this species are thus described by Nelson $(1857$, p. 95). On May 1s, while lying in a hunting blind, le witnessed the performances of two cranes which alighted near by:

The first comer remained alone but a short time, when a seeond liril "ame along, uttering his loud note at short intervals, until he espied the hird ou the ground, when he made a slight eireuit, and dropped elose hy. Both birds then joined in a series of loud rolling eries in quiek sureession. Sullenly the new-comer, which appeared to be a male, wheeler his back toward the female and male a low bow, his head nearly touching the gromu, and ending by a quick leap into the air; another pirouette lorings him facing his eharmer, whom he greets with a still deeper how, his wings menwhile hanging loosely by his silles. She replies by an answering bow and hop, and then each tries to outslo the other in a series of spasmodic hops and starts, mixel with a set of comieally grave and ceremonions bows. The pair stool for some moments howing right and left, when their legs appented to berome envious of the large share taken in the performance hy the neek, and then would ensue a series of stilted hops and skips. . . Frequently others join and the dance keeps uj until all are exhausted.

The site for the nest is usually on the grassy flats, where the llier portions or the slight knolls afforl them suitable plares. The spot usually has an unobstructed view on all sides, and it is common to see the female's long neck raised suspliciously at the appearance in the distance of anything unusual. If one approarhes, the head sinks lower and lower to avoid heing seen, bnt if the person, even though 150 or 200 yards away, should stop and look towarl the hirl, she will generally rise and skulk away, her neck elose to the gromul, wings hanging loosely by the sides, and legs bent, so as to avoil being seen. When she is 100 yaris or more from the nest she straightens up and stalks anxiously about, uttering her loud eall-note incessantly, and is generally joinel by the male; but it is rarely that either ean, even then, be approachen within gunshot... The nest is frequently a mere hollow in the groumd, aurl is commonly lined with more or less coarse grass-stems and straws. In one instance a nest was found on a bare flat, and was lined with a layer of straws an inch deep, all of which must have been brought for some varis; this is unusual, however.

The breeding season is necessarily of brief duration. Eggs, partly incubated, have been found at Saint Michael as early as May 27 (1879), and in the Kowak Delta, well-incubated eggs were found on Jume 14 and 15, 1899 (Grimuell, 1900, p. 20). The number laid is always two. They are elongate ovate in shape, and average in inches, $3.62 \mathrm{by} 2.25$. In color the eggs are buffy or olive brown spotted and blotched with reddish brown, grayish brown and lavender. These markings are thickest at the large ends and have a decidedly longitudinal trend, reminding one in this respect of the pattern of markings on the eggs of the Ash-throated Fly-catcher.

In the north the Little Brown Crane feeds on berries and grasses, with some insects. On this diet the birds become fat and are esteemed excellent eating, surpassing every other game bird there except ptarmigan. 
The stomach of a erane taken at Ash Meadows, on the NevadaCalifornia line, March 10, 1891, eontained small bulbous roots, foliage of young plants, and a quantity of barley, which latter had been picked up from a place where horses had been fed (A. K. Fisher, $1893 a$, pp. 20-21). The gullet of one killed at Los Baños, Mereed County. was found to be filled with large barley grains probably obtained from sowed ground (Beck, MS). When feeding on the plains or in stubble fields these birds dig up the ground with their bills in such a way that it looks as though a pick had been used. In the tule country near Stoekton Belding (IIS) states that they used to feed extensively on sagittaria bulbs. In the Imperial Valley Van Rossem (1911, p. 129) observed cranes visiting the grain fields to forage, going and coming from Salton Sea morning and evening as regularly as though timed by a clock. In 1901 it was reported that eranes were so numerous in the wheat fields west of Tulare that they had to be scared away. The birds were seeking the newly sprouted grain, but no detailed account of the kind or amomnt of damage done has been obtained.

"In the early settlement of California by Americans, when turkeys were yet scarce, I have known a Sandhill Crane to command from sixteen to twenty dollars in the San Franeisco market for the purpose of replacing, on the Christmas dinner table, that almost indispensable feature of this particular festival' (Heermann, 1859, p. 62). More recently cranes were of regular appearance in the markets of San Francisco and Los Angeles. In the season of 1895-96, 385 eranes were sold, bringing to the hunter about 50 cents each, considerably more than any of the geese (Calif. Fish Comm., 1896, p. 42). All testimony agrees as to the edible quality of the flesh of the crane, and this is to be expected from its chiefly vegetable diet.

As illustrating the eraftiness of the Little Brown Crane, by which it insures its safety from even long-range molestation, there may be eited the experience of one of the present writers (Grinnell, MS). On March 10, 1910, camp was pitched on the Califormia bank of the Colorado River about twenty-five miles below Needles. A large floek of cranes arrived at early dusk and took possession of a sand bar directly opposite camp. This bar was about midway from one wooded shore to the other, and fully three hundred yards from either. It was thus impossible to approach the birds under cover from any direction. They were evidently on their guard all night; every now and then something would disturb them, and a chorus of sonorous calls and wing-flappings would ensue for some minutes before quiet again reigned. At dawn they were up and off.

There are a few of our game birds whieh, because of their extreme wariness, may be expected to survive in spite of the increased effi- 
ciency of firralus and the increasing number of hunters. The Litte brown and samlhill cranes are to be included in this category. It is nowalays only by mere chance that the shotgun can bring one of these hirds to bag. To get within range with a rifle, even, takes eonsiderable ingenuity. This, with the protection afforded them by our closed seasons, should suffice to maintain the cranes inclefinitely, as far as (alifornia is concerned.

\section{Sandhill Crane}

\section{Grus mexicana (Miiller)}

OTHER XAMES-Grus conculeusis, part; Grus ennalensis mexicana.

DESCRIPTIN-Inentical in coloration, as far as known, with the Little Brown ('rane (which see). Size larger; bulk probably rlose to twice that of Little Brown Crane. Alults (both sexes): Total length "40.00-49.00" inches (1,015-1,220 mm.) (Rilgway, 1900, 1). 135); folled wiug 21.30-22.00 (540-555); bill along culmen $5.33-6.46$ (135.4-164); tarsus 9.14-9.5s (23:2-243) (four specimens from California in Mailliaril coll.).

MARKS FOR FIELD IDENTIFICATION-SeC Little Brown ('rane.

Vorce-F'robably not much different from Little Brown Crane; a rancons, resoumling note (Forbush, 1912, p. 485); a prolongerl bugle-like ery (Bailey, 1902, p. 79).

Nest-On ground in marshy places, usually surrounled by open water; marle of grasses, weerls, moss or rushes (authors).

EGGS-2, elongate ovate in shape, measuring in inclies, 3.56 to $3.70 \mathrm{hy} 2.35$ to 2.41 (in millimeters, 90.3 to 93.5 by 59.7 to 61.2 ); ground color pale buff, spotted irregularly with light brown, most numerously about the larger end: leeper markings of pale lavender (two eggs from lowa in Mailliarl roll.).

General distribution-Mildle latitucles in North America, ranging from southern Canarla south to Florida, Cuba and Mexico. Breels from southern British Columbia, southern Saskatchewan and southern Alberta, south to California, northern Arizona, Colorallo, lowa, and northern Indiana; also in a letached area inclurling Cuba, Florila, and the Gulf roast of Louisiana. Winters in California, the Gulf states, Cuba, ancl Mexico to the latitule of Yucatan. Most of intervening area covered during migration (modifiel from Cooke, 1914, pp. 10-13).

DISTRIBUTION IN CALIFORNIA-At one time doubtless common in summer in northern and interior parts of the state, more particularly about elevateil meadows east of the Sierran rrest; now rare. A few are thought to winter in the San Joaquin Valley and southern California coastal district. Definite knowlertge is wanting, because of confusion of this species with Little Brown Crane.

The Sandhill Crane is the southern representative of the Little Brown Crane, supplanting the latter as a breeding bird in the United States and extreme southern Canada. For a long time the Little Brown and Sandhill cranes have been confused in western literature; much of the published information attributed to the Sandhill Crane, we now believe refers to the Little Brown Crane. In coloration the 
two speeies are identical; and there remain only dimensions to furnish constant eharacter's (see measurements of both). The Sandhill seems to bulk about twiee as large as the Little Brown. While the breeding ranges of the two speeies are distinet, both oeeur during migrations and probably also in winter on the same ground. The Sandhill Crane, in its general range, formerly existed mueh more widely than it does today; in a number of the middle-western states where it was formerly found in numbers it is now extirpated. The Sandhill, with a sonthern breeding ground, has suffered largely through human oceupancy of the country.

In southeastern Oregon in the middle seventies, Bendire (1878, p. 143) found this a eommon summer resident, breeding abundantly on

Fig. 46. Side of bill and head of Sandhill Crane. One-half natural size.

Note much larger size as comparer with Little Brown Crane (fig. 45).

the lowlands as well as in the highest mountain valleys. Its hoarse cries conld be heard almost everywhere in the vieinity of water so long as the loeality remained undisturbed. Each pair appeared to own a certain district during the breeding season, and two pairs were never found nesting within half a mile of each other. In 1887, Merrill (1888, p. 144) fonnd this erane breeding in the vicinity of Fort Klamath, Oregon.

In California the Sandhill Crane was formerly notably numerous in summer on the elevated meadows lying ehiefly northeast of the Sierran crest. Henshaw (1880b, p. 323), writing of his explorations in 1877 and 1878 in northern California and adjacent states, eonsidered Sandhill Cranes to have been so often met with as not to require speeific mention of loeality. "They bresed in many of the sub-alpine valleys where are found meadows of suffieient extent." 'Two partly grown young taken by Henshaw at Camp [Fort] Bidwell, Modoe County, July 29, 1878 , are contained in the National Mnseum collection in Washington. C. H. Townsend (1857, p. 197) reports seeing a erane on a mountain meadow east of Mount Lassen in June. 
Cones (187t, p. 5i34) records egge from Fort Crook, in northeastern Shasta County. In the San Joaquin Valley eranes have been observed during the summer months, and there is a chance that they may breed there, or at least have once done so. Goldman (1908b, r. 2020) saw three at Tulare Lake, July 8, 1907. L. Tevis (Grimell, IIS) reports their presence in the neighborhool of Buttonwillow, Kes'n ('ounty, all through the summer season; a pair watehed on A pril 30, 1912, behaved as if nesting.

In winter the Sandhills breeding in California may or may not move south out of the state. In either case it is probable that some birds come into ('alifornia from the Pacific ('oast district to the northward, as far as the linit of the summer range in southern British Columbia. Again we have to point to the confusion which has prevailed in separating the Sandhill and Little Brown eranes. Tyle $(19136$, p. 22) says that the birds he has examined in the Fresno district have all been sindhill cranes, and he believes that the majority of the cranes visiting that locality are Sandhils. Four specimens purchased in a San Francisco market, January 20, 1898, and thought to have been slot in the vieinity of Los Baños, Mercecl comnty, are in the Mailliard collection (J. Mailliard, 1911, p. 50). There is a skin of the Sandhill ('rane in the United States National Insemm (no. 11927) taken by Lt. J. (. Ives, probably in 1857 or 1858 , on the Colorado River, though whether or not in California is not elearly stated. The measurements of this bird are: wing 21.75 inches: tarsus 10.60 ; eulmen 5.40 .

In flight the Sandhill Crane flaps along heavily, as though the wings were hardly ahle to lift the large body. Exeept when launched for a long-distance journey these birds fly close to the ground. In migration they fly very high, and in lines somewhat like those of ducks and geese. The legs and neck are held stretehed ont to full extent.

On the big unfencerl prairies and the treeless expanse of marsh where there is nothing to hide a hurking foe, you find the Sandhill Cranes, sometimes in small migrating flocks but usually in pairs, stalking about in dignifier but ever watchful manner, stretehing up to nearly a man's height to survey the surrounding country, then stooping to probe the earth for worms, catch a distant grasshopper, or spear a luckless frog or minnow. Let an enemy appear in the distance, and the long necks are up, and one of the most powerful, farreaching of bird-notes rings out with its alarm challenge, a prolonged buglelike ery, deeper and heavier than the loon's, and often hearl a mile away. With a quick run the splendid birds mount on the wing, the bugle-notes resounding rhythmically with only the space of an inspiration between as they fly; and though their calls mellow in the distance, the cranes vanish as specks in the air before the sound of their magnificent voices is entirely lost ( $V$. Bailey, in Bailey, 1902, p. 79). 
Like the Little Brown Crane, this larger cousin is noted for its strange anties during the mating season which resemble a "war dance" of some sort. The ground selected for nesting is usually some extensive meadow, with small lakes here and there. The birds demand a broad outlook on all sides, and a slight elevation is often chosen for the nest, usually nearly or quite surrounded by water. The nest proper is a simple affair, of grass and other vegetation gathered together on the ground to form a shallow mat. The time of egg-laying in the west is indicated by the following data: Camp Harney, Hamey County, Oregon, April 14 (1878) to May 2 (1875) ; Gumnison County, Colorado, June 5 (1903) (Cooke, 1914, p. 12). The two young birds in the United States National Museum, with down still adhering to the plumage, taken by Henshaw near Fort Bidwell, Modoc County, July 29, 1878, would indicate a nesting date comparable with the instances just eited.

Judging from descriptions, the eggs of the Sandhill Crane closely lesemble those of the Little Brown, differing only in somewhat larger average size. CHapman (1912, p. 230) gives 3.90 by 2.40 inches for the Sandhill, while Davie $(1900$, p. 122) gives the averages as 3.98 by 2.44. Compare these figures with our average for the Little Brown Crane, of 3.52 by 2.24 .

The food of the Sandhill Crane is doubtless in all respects similar to that of the Little Brown. Both prefer vegetable substances, particularly certain bulbous roots. In the lowlands of Kern County a kind of "little tule," or "tulito," is selected.

The bill is an efficient tool in obtaining food, and also a powerful wrapon of defense. A quick thrust of this long sharp beak will make a serious wound, and the hunter should take eare in approaching a wounded bird.

There is reason to believe that the Sandhill Crane exists today in but a small fraction of the numbers once present in the interior valleys and plains. Its breeding grounds have been almost altogether taken up for farms and stock-ranching, and in consequence the species as a breeding bird in California is nearly or quite gone. It is likely that some still come to us regularly in the fall either as transients or to pass the winter within our boundaries. So seldom are specimens of cranes secured, that uncertainty obtains as to the actual numbers. relatively, of our two species. 


\section{California Clapper Rail}

\section{Rallus obsoletus Ridgway}

Other Names-San Mateo Rail; Water-hen; Marsh-hen; Salt-water Marshlen; Mut-hen, part: King Rail: Rallus clegans; Rillus clegans var. obsolctus.

DEscriptiox-dlults, both sfres: Top and silles of heal blackish brown; top of heal with black, bristle-like feather tips; streak of eimmmon from base of bill directly backwarls over eye; whin and throat white, bordered along siles and behind with light rinnamon, the latter blending with the duller tones of eolor elsewhere; iris dark brown or orange brown; bill redulish orange at base of lower mandible ant along edge of ulyer, otherwise dusky olive brown; rest of npher surface incluling rump and tail grayish olive brown, streakel broally with blackish as formed by larker centers of feathers; onter surfare of elosed wing rhiefly cinnamon brown; inner secondaries like lack, and rest of flight feathers dark hrown; axillars and lining of wing brown, harred narrowly aml irregularly with white; foremeek anıl breast clear light rinnamon, falling to pale luffy on helly; siles and lanks dark grayish brown harrel sharply with white; lower tail eoverts like flanks, except for outermost feathers which are white; legs and feet lull orange brown, darkest at joints. Measurements:-Males: Total length 15.\$7-16.62 inelies (403-42.2 mm.) (three speeimens); folled wing $6.04-6.90$ (153-175); bill along "ulmen 2.222.5t (56.4-64.4); tarsus 2.17-2.42 (55.0-61.5) (ten specimens). Females: Total length 15.12-15.62 (354-397) (three specimens); folled wing 5.75-6.01 (146154); bill along culmen 2.17-2.32 (55.0-5.5.9); tarsus 2.10-2.24 (53.3-56.8) (eight speeimens). Juvenile plumage: similar to that of alult, lut with streaking on back tluller, less strikingly contrasted, lower surface very much lighter, more buffy in tone, ant liarring on sinles and flanks seareely or not at all in evilenee. Natal plumage: Black with a slight greenish iridescence except on helly; lill yellow; feet (dried) redlish brown.

MARKS FOR FIELD IDENTIFICATION-Of rails in general: Narrow (compresserl) bolly, small heal, slender hill, long neck and legs, short rounder wings, and extremely short tail. Of California Clapjer Rail: Large size (largest rail in (alifornia), light eimmmon breast, and dark-tonel, brown and black streaked back (pl. 9 and figs. 47 and 49 ). Skulks through marsh vegetation and when flushed rises nearly vertically several feet before flying off. Distinguished from Virginia Rail by much larger size; from Light-footed Rail of sonthern California by slightly larger size and lighter eolor.

Volce-Often spoken of as a harsh eackle; a rlattering, churk, chuck, chuck, chuck, or a cheek-a-cheek-a-chcek, ete., rapidly uttered.

NEsT-In salt marshes; usually of piekle-weed (Salicomia ambigua), loosely laid together, and concealed in the same sort of vegetation or beneath some small shrub.

EGGS-6 to 12, usually 8 to 9, ovate to elongate ovate in shape, measuring in inches, 1.61 to 1.82 by 1.17 to 1.30 (in millimeters, 40.8 to 46.5 by 29.7 to 33.0 ), and averaging 1.72 by 1.23 (43.7 by 31.2) (Einerson, 1885, p. 143); color light ereamy buff, spotted or blotched rather seatteringly with reddish brown and lavender.

General distribution-Resident on salt marshes adjacent to San Francisco and Monterey bays, California; casual elsewhere along the Pacifie coast north to Humbollt Bay, and even, possibly, to Gray's Harbor, Washington.

Distribution in California-Common resirlent on salt marshes bordering 
southern arm of San Francisco Bay (Alameda, San Mateo and Santa Clara counties). Formerly occurred also on bay shores of Marin and Sonoma counties, but no records from there within past 25 years (Mailliarl, MS). Resident in small numbers in marshes bordering Monterey Bay near Elkhorn, Monterey County (Silliman, 1915a, p. 201). Recorded once from Tomales Bay (Storer, 1915 , p. 98) and twice from Humboldt Bay (Suckley, in Cooper and Suckley, 1859, p 246; Storer, loc. eit.). Casual on Farallon Islands (W. E. Bryant, 1888, P. 42).

No other game bird in California has so limited a distribution as has the California Clapper Rail. The salt marshes bordering the southern arm of San Francisco Bay and a few smaller nearby areas of the same character alone seem to afford the proper kinds of food and shelter necessary for its existence. It is found in small numbers

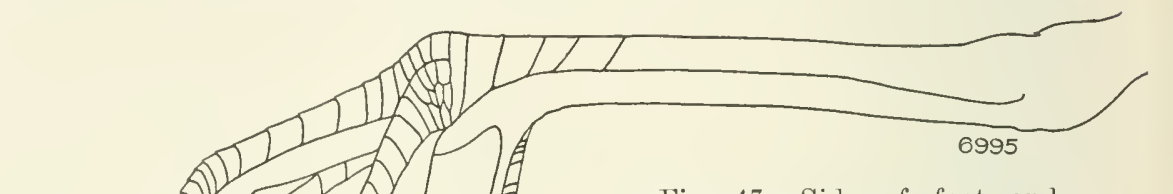

Fig. 47. Sirle of foot and tarsus of California Clapper Rail. Natural size.

Note slender form of all toes and entire absence of webs or lobes.

on the marshes of Monterey Bay near Elkhorn, Monterey County, and individuals have been recolded from Tomales Bay and Humboldt Bay. A single straggler was taken on the Farallon Islands, November 18, 1886 (W. E. Bryant, 1888, p. 42). Newberry (1857, p. 96) states that this species was common in his day around San Pablo Bay, and was particularly numerous at Petahuma. Also Messrs. J. and J. W. Mailliard have told us that Clapper Rails oceurred on the bay marshes of Marin and Sonoma counties up to about twenty-five years ago. But there have been no recent records from these places.

Rails in general are to be recognized by their narrow, compressed bodies, rather long bills, small heads, long necks and legs, large feet, slender toes, and small rounded wings. The present species is the largest of its kind ocenrring in California. In flight it may be recognized by its long bill (nearly two inches in length) (fig. 48), its long legs (fig. 47) (which dangle when the birt first starts in flight), its cinnamon-colored under surface and streaked back (pl.9). In coloration the California Clapper Rail is practically identical with the Tirginia Rail but is mucl larger in size (see measurements of both). 
The California C'apper Rail makes its permanent home on the salt marshes where the regetation eonsists chiefly of pickle-weed (Salicornia ambigua) and an evergreen shrub (Grindelin cuncifolia). Here it may easily be found at any time of the year skulking along the banks of the small mudely sloughs which penetrate the marsh in every direction.

Its rely long and unwebbed toes make large chicken-like tracks spaced abont ten inches apart in the soft mud of the slongh banks and these are very easy to recognize. The voice, too, is characteristie. It is a har'sh, mechanical cackling-chuch, chuch. chuch, chuck, or chert-e-chest-u-check-uttered rapidly for sereral seconds and sound-

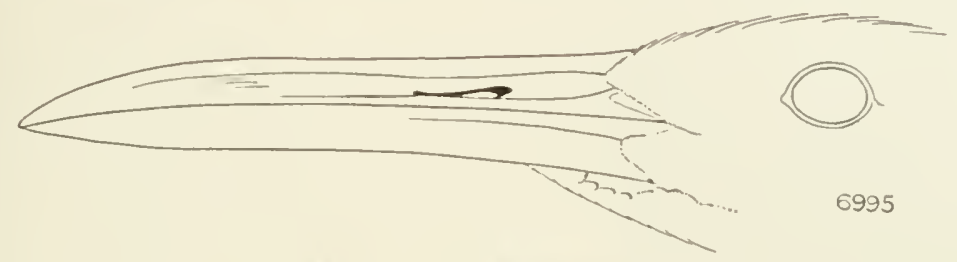

Fig. 45. California Clapper Rail.

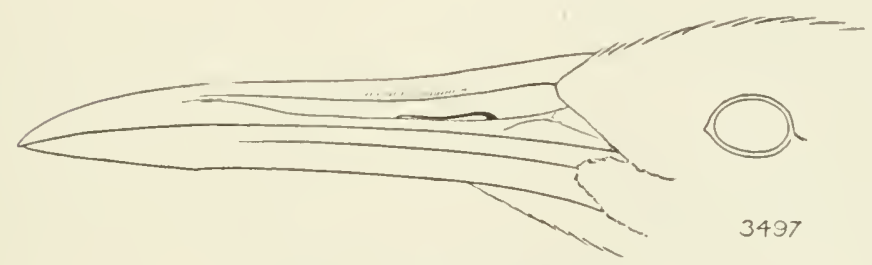

Fig. 49. Light-footerl Rail.

Both drawings are natural size and the two serve to show the ditferences in size of bill between these two elosely similar species.

ing as if two or more birds rather than a single one were participating in its production. When flushed this Rail jumps almost straight up into the air for six or eight feet and then flies off in a chmsy manner, its short narrow wings moving at the rate of two or three beats per second. These flights are usually short, the bird soon dropping down again into the protection of the marsh vegetation.

Rails in general begin to nest rather early in the year. The breeding season of the California Clapper Rail commences about the middle of March, and by the first of April full sets of eggs are to be found. On Mareh 31, 1912, H. W. Carriger (MS) found three sets of nine eggs each, all fresh, on the marshes near Redwood City, San Mateo County. On April 3, 1915, the writers found two fresh sets of nine eggs each on Bay Farm Island, Alameda County. April 18, 1885, Emerson discovered five nests near Hayward, Alameda County, two 
of which contained eight and nine eggs respectively. On May 11, 1884, Emerson (1885, p. 142) found nine nests from which the young had hatehed and departed, while on May 4, 1885, three nests of eight eggs each were found by him. On June 3, 1883, he found a nest of seven eggs on the point of hatching. The latest date of which we have record is Jume 29, 1894, when a set of six eggs with incubation commenced was found by H. R. Taylor in the Alameda County marshes (Mailliard coll.). Thus it will be seen that the breeding season extends from the middle of March to the end of June, but that the bulk of the birds nest between the middle of April and the middle of May.

A high piece of marsh ground, usually on the bank of a slough, is selected for a nesting site. The nest may be concealed in salt grass or pickle-weed, or under a small bush. It is a platform built up three to six inches above the ground, and measures about ten inches across with a cavity in the center one and one-half inches deep. Grasses or dead and living stems of pickle-weed are used for building material. A well-marked trail leading off through the adjacent vegetation is usually discernible. A nest examined by the author's on May 7, 1914, was composed of closely matted Salicornia stems, some of the stems being bent over from the growing plants surrounding it. The structure was well-saucered, the cavity containing the eggs being five and one-half inches across and one and one-half inches deep. The rim was two and one-half inches above the ground which was still wet from a recent high tide. The nearest slough was twenty feet away.

Eight or nine eggs constitute a full set; these are of a light creamy buff color, spotted, often blotehed, with reddish brown and lavender markings, the latter appearing as if beneath the shell. These markings are rather evenly distributed over the egg surface, perhaps a trifle more numerous on the larger end. The eggs are shaped like hen's eggs, possibly slightly more pointed on the average; forty-one measured by Emer'son (1885, p. 143) ranged in inches from 1.61 to 1.82 by 1.17 to 1.30 and averaged 1.72 by 1.23 .

Like some other rails this one sometimes builds nests which it never uses. Three or four new nests, often uncompleted, apparently possessing all the advantages of the one used, are occasionally to be found in the near vicinity of an ocenpied nest. Nor is this bird averse to adopting places out of the ordinary for building its nest. Nests have been found in old barrels, and one was found on a pile of hay near a salt marsh (H. R. Taylor, 1894, p. 154). Adams (1900, p. 32) states that both parents are often seen about the nest and that it is certain that the male assists in incubation. The female is a very close sitter and will sometimes remain on the nest until the intruder is within two feet of her. She will then jump from the nest and either fly away, or glide swiftly through the grass or along the edge of a shough. 


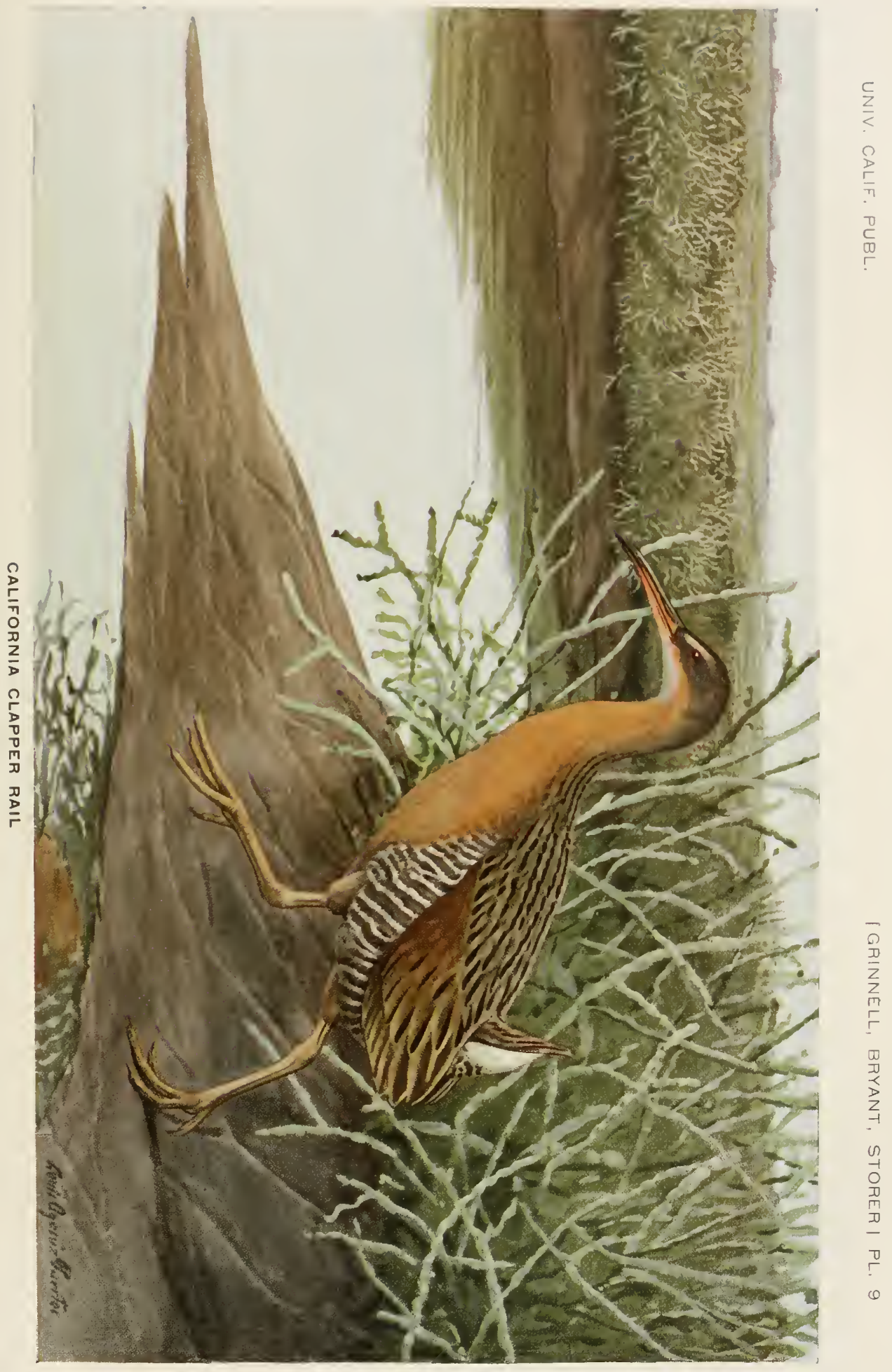



II. R. Taylor (1894, p. 153) states that one he flushed from her nest fluttered and limped along. as if to lead him away.

The following description of the downy young is given by Enerson $(1885$, p. 142):

One nest of seven glossy jet black rhieks was foum, seemingly just out of the shell, one not quite dry. All hut this one would hold their long neaks ont, moving them from sille to sille, and calling in a low plaintive tone pe-ee-ep, pe-ecep, very mueh like a weak young chicken.... On skinning one I noticed a small claw sticking out from the second joint of each wing, not more than a sixteenth part of an inch long, claw part turning lown, of a light horn eolor and comparing only to a little kitten's elaw; it was fouml on all the chicks.

Writing in 1880, W. E. Bryant (p. 124) said of the ('alifornia Clapper Rail:

I have found these birds abundant, at all seasons of the year, on the salt marshes of Oakland, San Irateo, and other marshes that are jartially rovered by the highest tides. At such times they may be shot hy the dozen, as they sit upon floating drift-wool, the deal body of an animal, a fenee, or, in one instance, a railroal bridge, from which they would not fly until nearly run into by an approaching train. Their tameness at all times, especially during the high tides, is remarkable. If obliged to fly, they start from either land or water as readily as a Duck. They swim well; but when wounded and elosely pursued, they dive, and hold on to the marsh grass beneath the water to keep from rising.

The birls are elose sitters, and not easily flushed; but when once started, they seem to fly as long as they have the power, sometimes alighting in the mildle of a slough, as though unable to reach the opposite bank. The only note that I have known them to utter is a harsh caekle, frequently heard at night.

Like all rails the Clapper Rail is, when need be, very skillful at keeping out of sight. Sometimes individuals appear shy, flushing at a distance, or rumning toward the denser vegetation at great speed, with lowered head and elusive mien: at other times they walk out into the open in bottoms of sloughs at close range and view the intruder seemingly with perfect equanimity. They have a long rumning stride, and the body is held close to the ground. The narrowly compressed body enables them to slip easily between the rigid upright stems of a sort of rush which grows in thick beds along the larger salt sloughs. If not thoroughly alarmed rails will sometimes stop or hesitate on open ground, when the peculiar twitching movement of the tail may be clearly seen. This member is held vertically and the twitching of it is rendered conspicuous because of the white color flashed from the under tail coverts. When walking, the head and tail twitch formard in unison with each stride. When thoroughly alarmed this Rail will take to water and swim considerable distances, as, in one observed instance, across a thirty-foot slough. 
"In walking along the slough banks at low tide quietly, they can be seen wading through the soft mud, probing here and there for worms and inseets, which mostly compose their food. I have also seen them come out of the long salt grass along the shore, feeding here and there at the edge of tide drifts"' (Emerson, 1885, p. 142). The food is made up almost entirely of animal matter-worms, crustaceans, and the like, as afforded on the salt marshes. In the gullet of a bird shot on a salt marsh, near an artesian well, W. E. Bryant (1893a, p. 55) found a good-sized frog. Several stomachs from birds taken at Bay Farm Island, Alameda County, were found by us to contain only parts of crabs (Hemigrapsus oregonensis).

The California Clapper Rail has long been considered an excellent bird for the table, and formerly great numbers were sold on the markets of San Francisco. Kemmerly (1859, p. 34) says that in his day it was one of the most numerous of the water birds found in those markets. So also says Suckley (in Cooper and Suckley, 1859, p. 246). The weight of an adult bird, freshly taken by the authors, was threefourths of a pound ( $310 \mathrm{grams}$ ) ; so that the food value of a Clapper Rail as regards size is not ineonsiderable.

The sport furnished in hunting Clapper Rails is of a rather tame sort: for the birds are ordinarily not wild, and, owing to their slow, or sluggish, straight-away flight, are easy to hit on the wing. Unlike many other game birds this one seems to be but slightly endowed with effective means of self-preservation. When pursued, a Clapper Rail is said to sometimes hide its head, ostrich-like, in a tuft of grass : and it is not an uncommon thing for dogs to catch the birds alive. For these reasons, as well as for the fact that they are eonsidered by many to be exeellent eating, these rails have been slanghtered in great numbers.

Few game birds in this state were more surely on the road to total extinetion than was this species just previous to the passage of the Federal Migratory Bird Law. The reclaiming of mueh of their former breeding grounds was concentrating them into smaller and smaller areas, where they were still more easily sought out and killed. Ray (1902, p. 24), speaking of the abundance of this birc in San Mateo County, says: "As late as 1889, I remember sportsmen returning with as many as 200 Clapper Rails while now one would find it exceedingly hard to bag a dozen ...". H. R. Taylor in 1894 (p. 153) reported that an old market hunter of Alameda told him that rails were beeoming very searce at that time in the Alameda marshes. Where they had formerly nested in numbers it was difficult to flush a single bird. This was believed to be due to persistent hunting throughout the year. (Since then a summer elosed season was estab)lished.) Mr. Samuel Hubbard, Jr., of Oakland, has stated to us 
that formerly during high tides as many as forty ('lapper Rail could easily be killeel along Oakland creek. None of these birds are to be fomd in that loeality at the present time. Aeeomts generally agree that the California Clapper Rail is mueh less abmetant now than it once was. Even the extended ammual elose season, in foree for a few years and now replaeed hy total proteetion, was not sufficient to proteet this bird: for its hannts are so readily aceessible to the bay eities that hunting remained exeessive. In 1913, the Federal Migratory Bird Law was passed, and within two rears a marked inerease was ohservable loeally on the Alameda County marshes: proof that atequate protection long enongh eontinued will restore the speeies. The worst enemy of the rail now remaining is the Norway rat which infests many parts of the salt marshes, and whose lepredations during the nesting season have come to our personal notice.

The California clapper Rail is truly a native of the Golden State, being found nowhere else in the world. It deserves protertion on esthetic gromuls, if not on economic ones. It is entirely within possihility that at the expiration of the present closed term of years, hunting can again be safely allowed-with of course, a small bag limit and short season.

\section{Light-footed Rail}

\section{Rallus le riprs bangs}

Other xames-Soutlern California C'lapper Rail; C'lapper Rail, part; Bangs Rail; Rallus obsoletus, part.

DESCRIPTION-Adults. both sexes: Similar to California clapper Rail, but with bark larker and more olive in tone, breast a rieher tone of cinnamon, and size slightly smaller. Top anıl siles of hearl blarkish brown; top of hearl with black, bristle-like feather-tips; streak of light einnamon or lull white from base of lill backwarls over eye; chin and throat white, borlered along sides and behind with cimnamon, the latter blending with the larker tones of sides of hearl and neck; iris dark brown; bill brownish orange at base, dusky along rilge and at tip; rest of upper surface incluling rump and tail, olive brown broadly striped with blackish; outer surface of closed wing chiefly cinnamon brown; inner secondaries like back, and rest of flight feathers dark brown; axillars and uniler surface of wing brown barred narrowly witl white; foreneck and breast deep cinnamon, falling to buffy white on belly; siles and flanks dark grayish brown barred sharply with white; lower tail coverts like flanks, except for outermost feathers which are white; legs and feet dull orange brown, darkest at joints. Males: Total length 15.00-16.44 inches (391-417 mm.); folded wing 6.05-6.27 (155-160); bill along culmen 2.22-2.37 (56.4-60.2); tarsus 2.24-2.35 (57.0-59.7) (six specimens). Females: Total length 14.7515.19 (375-386) (four specimens); folded wing 5.48-5.87 (139-149); bill along culmen 2.05-2.14 (52.2-54.3); tarsus 1.98-2.14 (50.3-54.3) (six specimens). Juvenile plumage: Probably similar to that of California Clapper Rail (which see). Natal phumage: Wholly uniform glossy black; bill dusky, with yellowish white band near end, and yellow spot about nostril; feet (dried) blackish. 
MARKS FOR FIELd IDentification-Same as for California Clapper Rail. In hand may be distinguished from that species by olive brown rather than grayish brown tone on upper surface, deeper cinnamou color of breast, and whitish instead of rusty stripe from bill over eye; also by smaller size, espeeially of foot and bill (compare figs. 48 and 49 ).

VorCE-Like that of California Clapper Rail.

NEST-In salt marshes (usually) along the seacoast; constructed of stems of marsh vegetation.

EgGS-6 to 9, ovate to elongate ovate in shape, measuring in inches, 1.69 to 1.77 by 1.21 to 1.26 (in millimeters, 42.8 to 45.0 by 30.8 to 32.0 ), and averaging 1.72 by 1.23 (43.7 by 31.3 ); color creamy white, evenly and rather sparsely spotted and blotched with umber brown and lavender (one set, seven eggs, in Mins. Vert. Zool.).

General distribution-Coastal region of southern Califormia, and of Lower California south to San Quintin Bay. Casual at Yuma, Arizona.

Distribution in CALIFORNiA-Common resident on salt marshes of southern seacoast, from Santa Barbara to and including San Diego Bay.

The Light-footed Rail, which inhabits the coastal marshes of southern California and Lower California, is so elosely similar to the California Clapper Rail that it might be considered merely a southern race of the latter. Neither of them is migratory, and there is a strip of coast nearly two hundred miles in extent between the southern limit of the California Clapper Rail and the northernmost station for the Light-footed Rail. Practically all of the coastal marshes from the vicinity of Santa Barbara south to and including the vieinity of San Diego Bay are inhabited by the present speeies, and it is also found along the eoast of northern Lower California.

The Light-footed Rail is slightly smaller than the California Clapper Rail, is somewhat darker colored on the baek and breast, and the light stripe from the bill over the eye is whitish instead of rusty. Sinee the ranges are so distinctly separated, these two species are most easily identified by locality, after they have once been determined as Clapper Rails.

There are no essential differenees in the general habits of the two species. The Light-footed Rail, however, has been found breeding in an inland brackish marsh, though, to be sure, this was not far from the seacoast. Willett $(1906$, p. 151) found a nest in some reeds at the elge of Nigger Slough, Los Angeles County, on May 29, 1906. The nest was a very loose affair, the foundation being composed of decayed tules and reeds, and the upper part, eontaining the cavity, of broken bits of tule stalks. When first found, the nest contained three fresh egg's, and when reëxamined on June 14 it held nine eggs partially inenbated. The eggs were creamy white, spotted and blotehed with umber and lavender, prineipally around the large ent, the laventer markings having the appearance of being beneath the surface of the shell. The eggs measured 1.56 to 1.61 inches long by 1.12 to 1.16 broad. 
A set of seven half-inenbated eggs in the Musem of Vrertebrate Zoology was taken by F. Stephens on False Bay, near San Diego, April 10. 1908. The nest was composed of rotting stems of piekle-weed, and was situated on the ground in a thick growth of the same plant at the exlge of the salt malsh. The male bird was flushed from the nest. These egess measure 1.69 to 1.78 inches by 1.22 to 1.26 , and average 1.24 by 1.73 , being thus decidedy larger than the set deseribed above. Two other sets of seven eggs each were found on the same day (Stephrus, MIS). Eggs have also been reported as follows: Ballona, Los Angeles ('omnty, May 16, 1894, set of six slightly incubated eggs (Grimmell, 1898, I. 15) ; Bay ('ity, Orange Comty, March 19. 1910, set of nine fresh eggss (Willett, 1912 (1. p. 32) : San l)iego, April 16, 1895, and April $S$ to 10,1900 , sets in Thayer collection (Cooke. 1914, p. 18). Three small young (in Mus. Vert. Zool.), in the eurious black natal dress, were taken near National C'ity, San Diego County, June 11, 1908: these were part of a brood seen swimming just outside the massh vecuetation at the edge of the bay (Stephens, MS).

Henshaw (1s76, p. 273) states that, in 1875 , in the vicinity of Santa barbara, this rail was common, and that by the first of July the young were ont and able to aecompany their parents in search of fook. They began to be aetive aloont sunset.

Willett (1912a, p. 32) says that at extreme high tieles the clapper Rail swims on the water after the fashion of c'oots, and, as the Rails are at sueh times asily approached, they are killed in large numbers ly the hunters. This pertained, of course. to the time before the enactment of the Federal law providing a fire-year elose season. In many of the marshes in sonthern California where this rail was formerly common, as for instance around Santa Barbara, it has been practically exterminated. Like the California Clapper Rail this southern race should be accorded absolute protection until such tine as its numbers return to normal, after which shooting might be allowed under conditions of moderation insuring the safety of the species.

\section{Virginia Rail}

\section{Rallus virginianus Limnaeus}

OTHER NAME-Sweetwater Rail.

DESCRIPTION-Adults, both sexes: Top of head aud hind neek blackish, uarrowly streaked with olive brown; sirles of hearl uniform learl color; patch between base of bill and eye blackish; above this patch a streak of brownish white; chin white, blending into eiunamon of throat and breast; iris " bright red', (Aurbbon, 1842, V, p. 178); bill dark brown, the lower mandible ancl eilges of upper maulible more yellowish brown; back, scapulars, rump, upper tail coverts, and tail, olive brown, broadly striped with black; outer surface of closed wing chestuut brown; flight feathers dusky brown; axillars dusky 
brown barred with white; under surface of wing plain lusky brown; breast and under surface cinnamon lrown faling to lighter on belly; flanks blackish; barred narrowly with white; lower tail eoverts mixed blackish, white, and einnamon: legs and feet yellowish brown. Males: Total length 10.00-10.50 inches (254-267 mm.) (two specimens from California); folded wing 4.14$4.33(105-110)$; hill along eulmen $1.53-1.71$ (39.0-43.4); tarsus 1.40-1.49 (35.637.6) (nine specimens from (alifornia and Tancouver Tsland). Females: Total length $9.31-10.00$ (236-254) (three specimens from California); foliter wing 3.76-4.17 (95.3-106.0); bill along eulmen 1.39-1.59 (35.0-40.3): tarsus 1.30-1.45 (33.1-36.8) (ten specimens from California). Jucenile plumage: Top) of head, hind neck, fore-back, and rumb, dull black with traces of buffy feather-elgings; ehin and throat extensively white; heal otherwise as in adult; wings and tail as in adult; lower surface mixed black and white, the latter predominating down mildle of breast and on belly; lower tail coverts dull cinnamou. Natal plumage: Entirely black, with greenish and steel blue reflections; bill searlet or orange-red exeept for black hand across upper mandible and black basal part of lower mandille.

MARKS FOR FIELD IDENTIFICATION-Medium size (about that of a Killleer), long. slender, brownish bill (fig. 50), einnamon-colored breast, and olive brown hack hroadly streakel with black. Closely resembles Clapper Rail in proportions and coloration, but of less than one-third the bulk of that bird. Distinguisher from Sora by mueh longer and slenlerer bill (eomprare fig. 51), lack of black on face, and presence of bright cinnamon on lower surface; listinguished from Yellow Rail by mueh larger size, longer bill, and absenee of narrow white bars on baek and wing coverts.

ToIce-Cut, cut, cutta-cutta-cutta; during the breeding season a rapil succession of low, yet penetrating grunts not mlike those of a hungry pig (Brewster, 1902b, p. 47).

Nest-Of dead grasses, seiges, or tules gathered in a heap, with a shallow depression on top; usually well concealed in dense regetation.

EGGS -5 to 12 , rounded oval in shape, measuring in inches, 1.18 to 1.36 by 0.83 to 1.00 (in millimeters, 30.1 to 34.5 by 21.2 to 25.3 ), and averaging 1.28 hy 0.93 (32.5 hy 23.7) (eighteen eggs from Utah); ground color pale buffy gray, with superficial spots and dots of reldish brown, ehiefly around larger end, and deeper ones of lavender.

General distribution-North America. Breeds from British Colmmbia, soutl. ern Saskatehewan, southern Keewatin. Ontario, southern Queber, and New Brunswick south to southern California, Utah, Kansas, Missouri, lllinois, New Jersey, and eastern North Carolina, and in the Toluca Valley, near the City of Mexico; winters from British Columbia, Washington, Oregon, Ctah. and Colnralo, to Lower California and Guatemala, also in the lower Mississipli states, and from North Carolina ("asually Massachusetts) to Florida (A. O. U. Cheeklist, 1910, p. 103; Cooke, 1914, P1. 23-24).

Distribution IN CALIFORNIA-Common in smmmer throughout the state, chiefly in fresh-water marshes. Breels south to Escomlido, San Diego County (Sharp, 1907, p. 86). Also fairly common in winter, ow both fresh water and salt marshes, west of the Sierras, nortl at least to Suisun Marshes. Solano County (Mus. Vert. Zool.), and Tomales Bay, Marin (ounty (Mailliarl, MS).

Rails are so rechusive in their habits and frequent such dense marshy growths that most people know very little about them. In fact, people often live within a stone's throw of the habitat of these 
birds without being aware of their presence. Of the six species of rails occurring in this state the Virginia has the widest general range; it is found almost everywhere throughout Califomia and in most other parts of North Ameriea as well. Even though it is a scemingly poor flyer it migrates south during the winter months and spends the cold season south of its breeding grounds. During the nesting season it is found as far north on the Pacifie coast as British Columbia, but in winter it does not usually remain north of the latitude of central California. During the summer months it may be found nesting in almost any portion of the state where proper conditions ofter. It frequents both fresh and salt water marshes althongh chiefly the former.

As regards proportions of boly and pattern of coloration the "irginia Rail is almost a duplicate of the California Clapper Rail, but it is much smaller, being of about the bulk of a Killdeer. From marshinhabiting birds other than rails it may be distinguished by its long, slender. brownish bill (fig. 50), bright red eye, short tail (which is usually held in a vertical position), eimamon-colored under surface, and olive brown baek. The flanks are blackish. barred

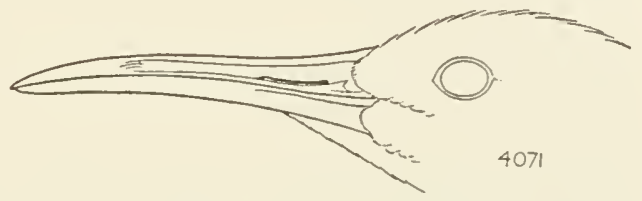

Fig. 50. Side of bill of Tirginia Rail. Natural size.

Note slender form (compare with fig. 51) and small size (compare with figs. 49 and 49 ).

with white. From the Sora Rail, a bird of about the same size as the Virginia and to be found in the same situations, the latter speeies may be known by its mueh longer and slenderer bill, by the lack of black on its face, and by the presence of eimmamon rather than gray on the under surface of its body. The Yellow Rail is much smaller than the Virginia, and has a shorter bill and narrow white bars on the upper surface of its body.

The breeding range of the Virginia Rail in California extends almost the entire length of the state. Eggs were taken at Fort Crook, Shasta County, May 13, 1861 (Cooke, 1914, p. 24); and the species is known to have nested at San Pasqual, San Diego Connty (Sharp, 1907 , p. 86). As to altitude, it has nested from sea level, as at Newport, Orange County (Willett, 1912a, p. 32), up to at least 4,000 feet in Papoose Valley, Lassen County (Sheldon, 1907, p. 187). The nesting season extends from early April-April 13 in one instance (Willett, loc. cit.) - to late Jume (Sheldon, loc. eit.). The records at hand as shown in the aceompanying table (no. 12) indicate that the height of the nesting season is between the middle of May and the first week in June. 
TABLE 12-Data relative to the nesting of the Virginia Rail in California

LOCALITY

DATE

Ballona, Los Angeles Co. Apr. 13, 1902 Alvarado, Alameda Co. Apr. 23, 1915

Fort Crook, Shasta Co. May 13, 1861 Newport, Orange Co.

Los Baños, Merced Co.

Los Baños, Merced Co.

Ramona, San Diego Co.

Near Coulterville, IIariposa Co.

Sespe, Ventura Co.

Papoose Talley,

Lassen Co.

Olema, Marin Co.

Woodland, Tolo Co.

San Pasqual, San Diego Co.

Nest Contexts AxD
Condirox
Eggs, 2 sets, fresh
1 egg; flesh-water
marsh
Eggs
6 eggs
10 eggs, fresh
8 eggs, fresh
Young seen
10 eggs, fresh
2 young and 1 egg
Nesting
About a dozen nests,
5 to 9 eggs
A nest
Nested

AUTHORITY

Willett, $1912 a$, p. 32 H. C. Bryant, $1915 c$, p. 194

Cooke, 1914, p. 24

Willett, 1912a, p. 32

Fair, MS.

Fair, MS.

Willett, $1912 a$, p. 33

Melean, MS.

Willett, $1912 a$, p. 32

Sheldon, 1907, p. 187

Ingersoll, in Belding, MS.

Belding, MS.

Sharp, 1907 , p. 86

Ordinarily the Yirginia Rail chooses drier ground on which to build its nest than does the Sora. Usually a pile of broken-down tules is used as a foundation, and on this the nest itself, which is often constructed of the same material, or of dry grasses, is placed. Usually the nest is well concealed, even though its foundation may raise it a foot or more from the ground. A typical nest found by Sheldon (1907, p. 187) in Papoose Valley, Lassen County, was made of the dry husks of tule stems and placed among low tules.

As reported by different observers the eggs number from five to twelve in a complete set. In shape they are roundedly oval, while in size they arerage 1.28 by 0.93 inches. The ground-eolor is pale buffy gray, with superficial spots of reddish brown and deeper ones of lavender. The markings are rather sparsely distributed except at the larger end of the egg. The eggs of the Virginia differ from those of the Sora in having a lighter ground color and more reddish markings. Sets of eggs of the Virginia Rail usually number less than those of the Sora.

Coneerning the voice of the V'irginia Rail, Brewster (1902b, pp. $47-48)$, writing from Massachusetts, says:

About the midale of April we begin to hear in our marshes, usually in the early morning, late afternoon or during elouly weather, and coming from some briary thicket $0 r^{\circ}$ bed of matted reeds, a guttural cut, cut, cutta-cutta-cutta repeater at brief intervals, often for hours in snecession. This is occasionally interrupted or closely followed by a rapid succession of low yet penetrating grunts not unlike those of a lungry pig. The Virginia Rail is the author of both these sounds, the former appearing to be peculiar to the male and, no doubt, his love song. When heard very near at hand it has a peeuliar vibrant quality and seems to issue from the ground directly beneath one's feet. The grunting notes are given by both sexes, but, with rare exceptions, only during the breeding season. The female when anxious about her eggs or young also calls $k \cdot i-k i-k i$ and sometimes $k i u$ like a Flicker. 
In a small fresh-water malsh near Coulterville, Mariposa County, Donalet MeLean (MS) discovered and watched a nest of the Tirginia Rail during the season of 1916. It was a tower-like structure about eight inches in height and the same in dianeter, and was composed of that marsh grasses. On June 5 the nest held ten egges which were just beginning to he inenbated. Whenever anyone approached the vieinity of the nest the ineulating bire (female?) would utter low clucking sommls. Sometimes she would slip ynietly off and stand nearhy in the marsh grass; again she splashed theugh the water as she departed. Nothing was heart or seen of the male until Jume 18 when he made his presence known ly an ear-piesering whistle which the female answered in a lower tone. IL was more wary than she and did not come near the mest. On June 19 there were six eoal black young in the nest. They hat black-ringed pink hills and very large feet. With the hatehing of the young, the demeanor of the female rhanged. Now she beeame quite fearless and would walk ont to within three feet of an olsserver, fluffing out her fortlers after the manner of a domestic len, and nttering many chucks anel whistles. The male answereel these calls but would not show himself except momentarily. By the aftrmoon of the twentieth the last rog har hatehed and the next morning the whole family had departed.

Bowles (1893, p. 115) states that in Massachusetts he has fomd a Tirginia Rail elestroving her ages after they were disturber in her absence. In one instance when he returned to a nest which he har discorered a few minutes previously he found one of the parents driving her bill through the pags in cuick succession, and later be found another nest which gave evilence of the same sort of treatment. That this is a general trait seems doubtful.

The Virginia Rail kerps well to cover, and like its allies is more often heard than sern. lint if the observer will remain quiet for a short time the lirel will sometimes become inquisitive and approach withm a few feet. When frightened it seldom takes wing. but prefers to slip away through the close-growing marsh vegetation. Small stretehes of olem water form no serions barrier. for the birt is able to swim easily. It flies close to the ground, even in migration, and is consecpuently one of the birds which commonly meets death by Hying against wire fences and telegraph lines.

Rails are partially at least, nocturnal in hahits, and feed at night as well as in the daytime. Their food is made up almost entirely of small animals such as earthworms, snails, caterpillars, and insects, mostly beetles. Some regetable matter, principally weed seeds, is probably taken when the supply of insects rums low (Forbush, 1912, p. 209). The stomach of a Virginia Rail taken at Los Baños, Merced County, May 22, 1914, and examined by us, eontained nothing but beetles (3 Carabids, 2 sphenophorus sp., 1 Hydrophyllid). 
By some, the Yirginia Rail is adjudged a delicious bird for the table, but it is of small size, not nearly as big as a Valley Quail. Where this species is abumdant no skill whatever is required to kill a large number. For both these reasons it camnot be considered as important a game bird from the sportsman's point of view as its larger relative, the Clapper Rail. Snipe shooters often get a ehance to shoot Virginia Rails, but seldom do so, and there are few men in this state who purposely pursue these birds either for food or for sport.

This Rail has seldom been seen in the markets of California cities, and the small amount of shooting it has received has permitted it pretty well to hold its own. Even if hunted to a greater extent in the future than at present, the speeies would have a good ehanee to survive in numbers because of its generally seclusive habits.

\section{Sora Rail}

\section{Porzana carolina (Linnaeus)}

Other names-Common Rail; Carolina Rail.

Description-Adults, both sexes: Top of heal olive brown, with median stripe of black; sides of head and neek, with extension above eye to forehead, lead color; whole face (that is, area between eye and bill, continuous across forehead) and a longitudival stripe down chin, throat, and foreneek, black; iris "brown"; bill "greenish yellow (more orange, especially at base in summer allults)" (Bairl, Brewer and Ridgway, 1884, I, p. 370); upper surface olive brown, continuous up hind neek to top of head; back streaked broadly with black, and narrowly lined with. white; outer upper tail coverts narrowly barred, black and white; tail feathers black, broadly margined with olive brown; outer surface of closed wing and flight feathers, nearly uniform olive brown, but with innermost secondaries and tertials showing white lines like back; breast lead color; sides, flanks, axillars, and under surface of wing conspicuously barred with brownish slate ant white; belly and central under tail coverts creamy white; under tail coverts otherwise pale buff; legs and feet greenish. Males: Total length 8.50-9.37 inches (216-237 mm.) (seven specimens from California and eastern states); folded wing 3.97-4.42 (101.0112.4); bill along eulmen 0.75-0.89 (19.0-22.7); tarsus 1.24-1.44 (31.6-36.7) (ten specimens from California). Females: Total leugth S.00-\$.97 (203-22S) (four specimens from eastern states); folded wing 3.90-4.10 (99.0-104.2); bill along eulmen $0.71-0.73(18.0-18.7)$; tarsus $1.18-1.29$ (30.0-32.8) (three specimens from California); weight $1.7 \mathrm{oz}$. (4S gm.) (one specimen from Califoruia). Juvenile plumage: Similar to that of adult, but with black and slaty areas on head and throat nearly or quite wanting; sides of head and forehear dull buffy brown; top of head duller olive brown, with narrow or interrupted blark stripe; chin and throat whitish; rest of neek, and breast, light buffy brown. Natal plumage: "IBill short, . . . high at base, rapidly tapering, the tip deflecterl. The whole body densely eovered with dull black down, beyond which are produced abundant long, glossy, black hair-like filaments. Upon the throat is a tuft of stiff, coarse, bristle-like feathers of a bright orange-eolor. These are directed forward, and give the bird a most singular appearance", (Brewster, 1879, p. 46). 
MARKs FuR FELD IDEXTIFICATION-Morlerately small size (less than that of Filldeer), of usual rail aspect and habits; short, chicken-like greenish yellow bill (fig. 51), black throat, ant slaty tone of muler surface. Distinguished from Virginia Rail by somewhat smaller size, ancl much shorter bill (compare fig. 50). Both the Yellow and Black rails are much smaller.

Vorce-A clear whistled her-uce, now and then interrupted by a highpitcherl rolling whinny which, like a call of alarm, is taken up anıl repeaterl by different birls all over the marsh (Chapman, 1912, p. 23t).

Nest-Marle of iry grass, weels, or rushes, placed on wet gromm, or often supported upon vegetation above water, and usually well concealed in growing regetation.

EgGs -4 to 15 , orate in sliape, measuring in inches, $1.1 \pm$ to $1.29 \mathrm{by} 0.56$ to 0.92 (in millimeters, 29.0 to $\$ 2.7$ by 21.9 to 23.3 ), and averaging 1.24 by 0.59 (30.6 by 22.5); ground color buffy drab marked seatteringly with spots of reddish hrown and dull purplisli gray (two sets, twenty-four eggs, from California and Tevada).

Geseral nistributiox - North Ameria. Breeds from central British Columbia, sonthern Markenzie, central Keewatin, and Gulf of St. Lawrence south to southern California, Ľtah. Colorado, Kansas, Illinois, and Penusylvania: winters from northern California, lllinois and South Carolina through the West Indies and Central Ameriea to Venezuela and Peru (A. O. U. Cheek-list, 1910, p. 104).

Distribltios IN CALIFORAil-Common in smmmer in appropriate localities thronghont the state; southermmost breeding station, Escondido, San Diego County (Sharp, $1907,1 \%$. 86). Fairly common in winter in interior valleys west of the Sierras, north at least to Butte County: northermost winter record, mouth of Mad River, Humboldt Connty (C. H. Townsend, 1Sis, p. 197). Once reporteil from Farallon Islanis (Keeler, 1592, p. 16t).

Throughout California the Sora is one of the commonest of the rails. It is most abundant in fresh-rater marshes but it also ocenrs at times on the salt marshes. In summer it is apparently more abundant and widespread than in winter, and this fact has given rise to the belief that most of the birds of this speeies move southward ont of the state during the winter months. During the spring and fall migrations Soras appear in many isolated loealities where they are not known to breed and this but strengthens the idea that they pass out of the state for the winter. The speeies is eommon in Mexico and Central America during the winter months and at the same season is found in small numbers as far north as the Saeramento Valley and Humboldt County. California. Belding (IIS) found it at Stoekton as late as Oetober, 1880, and said that it wintered in fair numbers on suitable ground near San Diego. Winter speeimens are in the Museum of Vertebrate Zoology from the following loealities: Los Baños, Mereed County : Modesto, Stanislaus County ; Martinez, Contra Costa County ; and the Suisun Marshes, Solano County.

This rail is hardly as large as a robin and this faet alone will serve to distinguish it from either of our Clapper Rails. The short, chieken- 
like bill (fig. 51), the slaty tone of the under surface and the presence of black on the face and throat are enongh to distinguish the Sora from the slightly larger Virginia Rail. From both the Yellow and likarek rails the Sora is separable by its larger size, as well as different coloration. In habits this species elosely resembles the Tirginia Rail.

From records at haud. April and May seem to be the months when most birds of this species nest. In California the earliest date for eggs is April 18, and the latest Jume 10. These extremes are, in part. however, accounted for by differences in altitude, the early date being for Whittier, in the lowlands of Los Angeles Connty, and the late one for Lake Tahoe.

The nest of the Sora is usmally built on the ground and well concraled in tules or tall grass. One found by H. C. Bryant (1915c, p. 194 , and MS) in a small fresh-water marsh near Alvarado, Alameda County, on April 2:3, 1915, was sitmated in a clump of pickle-weed (Nulicornit), and consisted of a large

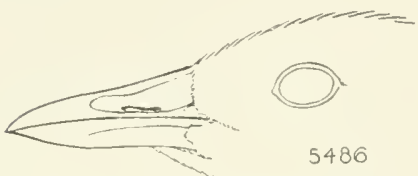

Fic. 51. Sille of bill of Sorat Rail. Natural size.

Note relatively stont form (compare with fig. 50 ). mass of dry sedge stems and grass hlades, the latter chietly composing the lining. The nest proper rested on a mass of regetation which raised it fully six inches above the gromnd. Externally it was approximately seven inches in diameter and three and one-half inches high. The sancer-shaped depression holding the eggs was ahout fonr inelies across and two and one-half deep. The fourteen eggs which this nest contained were arranged in a single layer except for one eg't which topped the rest. The ineubation of these eggs ranged from quite fresh to far advanced, showing either that some of the egros had failed of sufficient warmth to carry on incubation, or that the hirds had conmeneed to sit as soon as the first few eggs hat been deposited. The latter smmise is more probably the eorreet one.

Ray (1913, p). 112-114) records the discovery of a nest among tall garss in Bijom meadow at lake Tahoe, June 4, 1909. It held the momsually small complement of fortr eggs, and strange to say two of these were pipped while two were infertile. A second nest found at Al-Tahor malsh, Jume 10, consisted of diy tules "lateed to tules abore water three feet deep." This entained thirteen eggs in varying stages of incoubation. 'The same anthor (Ray, 1912b, p. 145) fomm a nest at Rowland's, Take 'Tahoe, May 31, 1910, also with thirteen egogs. Six sets of from seren to fourteen eggs, were taken by A. M. Shlibels in a marsh neal Tos Angeles in 1886 (Davie. 1889, p. 102). A set of six slightly incubated eggs was found near Whittior, April 18, 1s!6, 
and another set of six eggs was found at Nigger Slough, also in Los Angeles ('ounty, May 13, 1911 (Willett. 1912a, p. 33).

Merrill (188s, p. 14t) writing from Fort Klamath. Oregon, in 18sT, says: "A nest found May $2 T$ was anong water grass near the edge of a shallow pool, and was supported by the stalks of the grass; the egos were raised about six inclies above the water, but the foumdation of the nest was wet; it was composed entirely of the dead stalks and hlarks of the grass. and was rudely arehed over with growing blades of the same. It contained twelve eggs flom which the young would have soon appeared ...." Another nest similarly loeated and containing nine nearly fresh eggs was found in the same loeality, Jume 15 .

W. P' 'Taylor (1912, p. 35s) describes the nest of a Sora Rail found on Quimn River, Ilumboldt County, Nevada, May 22, 1909, as being built in an open bunch of marsh grass, with the hottom of the nest so near the water that it was damp. Marsh grass was its principal structural constituent, some of the stems being still green. The fragments incorporated into the lining were smaller than those in the main boly of the nest. The whole structure was seeurely interworen among the grass-stalks which partly supported it. It was overshadowed and effectively concealed by a frail canopy of broken-down stems. Ten eggs constituted the set.

As indieated by the instances eited above, full sets of eggs number from four to fourteen; but ten or twelve would seem to be the average number' per' set. 'The eggs are of ordinary orate shape, and measure, in inches, 1.14 to 1.29 by 0.86 to 0.92 , averaging 1.20 by 0.88 (twentyfour eggs in Mus. Vert. Zool., from California and Nevada). The ground-color is notably dark, being deep eream or drab decidedly darker than that on the eggs of the Virginia Rail, and the sparsely distributed markings are of reddish brown and dull purplish gray.

The young, like those of other rails, are of a general black color, and are capable of taking eare of themselves soon after leaving the shell.

The Sora contributes importantly to the medley of sounds which issues from the average marsh. The following two quoted paragraphs pertaining to Massachusetts afford the best description available to us, of the notes of this rail:

In the more open, grassy stretches of meadow, as well as among the beds of cat-tail flags, but seldom, if ever, in thickets of bushes, we also hear, after the middle of April, mingling with the notes of Virginia Rails and the din of countless frogs, the love song of the Carolina Rail, a sweet, plaintive er'-e given with a rising inflection and suggesting one of the "scatter calls" of the Quail. Such, at least, is its general effect at distances of from fifty to two or three hmudred yards, but very near at hand it develops a somewhat harsh 
or strident quality and sounds more like $k \dot{a}-\epsilon$, while at the extreme limits of ear range one of the syllables is lost and tha other might be easily mistaken for the peep of a Pickering's hyla [a species of tree-toal]. This note, repeaterl at short, regular intervals, many times in succession, is one of the most frequent as well as pleasing roices of the marsh in the early morning and just after sunset. It is also given intermittently at all hours of the dar, especially in cloudy weather, while it is often continued, practically without cessation, through the entire night.

Equally characteristic of this season and even more attractive in quality is what has been termed the "whinuy" of the Carolina Rail. It consists of a dozen or fifteen short whistles as sweet and clear in tome as a silver bell. The first eight or ten are nttered very rapidiy in an evenly descending scale, the remaining ones more deliberately and in a uniorm key. The whole series is often followed by a varying number of harsher, more drawling notes given at rather wide intervals. Although it is probable that the "whinny" is made by both sexes I have actually traced it only to the female. She uses it apparently, chiefly as a call to her mate, but I iave also repeateilly heard her give it just after I had left the immediate neighbon hool of her nest, seemingly as an expressiour of triumph or rejoicing at the discovery that her eggs had not been molester. When especially anxious for their safety and circling elose about the human intruder she often utters a low whining murmur closely resembling that which the Muskrat makes while Imrsuing his mate and sometimes a cut-cut-cutta not milike the song of the Virginia Rail, but lecidedly less loud and ribrant. In adlition to all these notes both sexes have a rariety of short, slarp cries which they give when startled by any sudien noise (Brewster, 1902l, p. 48).

The flight of the Sora Rail among the reeds is usually low, and, shelter being abundant, is rarely extended to more than fifty or a hundred yards. When winged, and uninjured in its legs, it dives and swims with great rapidity, and is seldom seen again. On such oceasions it has been found elinging with its feet to the reeds, under the water, or skulking under the floating regetation with its bill just above the surface. This bird is apparently weak and delicate in everything except its legs; but these possess great vigor; and its body being remarkably thin, it is able to pass rearlily between the reeds. Though its flight seems feeble, yet it oceasionally rises to a consilerable height, stretches its legs out behind it, and flies rapidly across the Delaware where it is more than a mile wide (Baird, Brewer and Ridgway, 1884, I, P. 373).

"To avoid flying, when their field is being mowed they will often stay in the fast narrowing strip of green until they must go or meet the sharp teeth of the sickle, when perhaps a dozen will rise one after another and fly to fresh cover", ( $\mathrm{T}$. Bailey in Bailey, 190.2, p. 81). Ranchers have stated to us that these birds are often driven in like manner from California alfalfa fields. Soras are said to answer a clapping of the hands with a mocking, cackling langh. In the marshes they are noisy birds espeeially towards sunset. "They seem so absorbed by their mnsieal devotions that even when calling contimuously it requires endless patience and keen eyes to see the dullcolored, motionless forms in places where one would not suppose there was sufficient growtl to conceal them" (Chapman, 1912, pl. 234-235). 
The flight of the Sora is so slow and labored and the bird seems so reluctant to use its wings that some writers have supposed that it was unable to fly long distances and that its migration was therefore a series of short flights or even performed on foot. As a matter of fact the Sora is among the long. chistance migrants, the most northern breeders traveling not less than 2,500 miles to the nearest winter home; and those wintering sonth of the equator being at least 3,000 miles from the nearest breeding grounds. Thousands make the hundred-mile flight between Florida and Cuba, and there is reason to believe that many individuals easily achieve the 500-mile passage from Florila to Yucatan, and the equally long journey from the West ludies across the Caribbean Sea to South America (Cooke, 1914, p. 4).

The food of the Sora consists mainly of insects, but snails and other aquatic animals are taken. In the eastern states it is known to be fond of wild riee, and donbtless here, too, vegetable matter forms a good part of its food at certain times of the rear.

In the east thousands of Sora Rails were formerly killed by sportsmen and market hunters during the fall migration. when the birds eoneentrated in the coastal marshes. Although easy to shoot, this bird has been highly prized by eastern sportsmen on accomnt of its attractiveness for the table. In California this rail is so scattered in its distribution as not to have attracted concentrated attention from hunters, and its number's here do not seem to have been much affected except as a result of the reclamation of marsh land.

This species like the Tirginia Rail seems to be pretty well able to take care of itself, and muless more aggressive means are taken for its destruction it may well be expected to persist in fair numbers within our state. There is no data at hand which will allow of a statement as to the exact status of the Sora Rail in California at the present time. The rapid rate of reproduction, as indicated by the large arerage complement of eggs laid, would seem to guarantee a large annual crop of Soras, if breeding conditions were favorable over extensive areas.

\section{Yellow Rail}

\section{Coturnicops noucboracensis (Gmelin)}

OTHER NAME-Ortygops noveboracensis.

DeSCRIPTION-Adults, both sexes: Top of head and whole of upper surface including tail, blackish, broadly streaked with yellowish brown (as feather margins), and barred narrowly with pure white; the bars are sparsest, or even wanting, on top of head, and most distinct and widest separated on lower back; sides of head and neck, continuous with breast, yellowish brown, with regions immediately below eye and between eye and bill, dusky; chin white or buffy white; iris brown; bill "greenish-black, with the base dull rellowisll-orange", (Audubon, 1842, V, p. 159); onter surface of closed wing like back; flight feathers slaty brown except for white patch formed by white 
ends of secondaries; axillars and lining of wing, white or mixed white and dusky; breast yellowish brown; belly white; sides and flanks blackish or dusky brown, narrowly barrel witl white; unler tail eoverts chestnut brown; legs and feet light brown. Some specimens have white bars on top of head broken into spots and oceasionally extending down onto sides of head and even around onto breast. Whether this condition is a mark of old age or of immaturity is not apparent. Males: Total length 7.50 inches $(190 \mathrm{~mm}$.) (one specimen); follerl wing 3.34-3.53 (84.8-89.5); bill along eulmen $0.63-0.66$ (16.016.8): tarsus 0.91-1.02 (23.1-25.9) (five specimens). Females: Total length 6.50 (165) (one speeimen); folded wing 3.20-3.36 (81.3-85.3); bill along culmen $0.58-0.64(14.7-16.3)$; tarsus $0.91-0.92$ (23.0-23.4) (three specimens); all from California. Jucenile and natal plumages: Not known to us.

MARKS FOR FIELD IDENTIFICATION-Rail characters of form, small size, yellowish brown east of coloration, and presence of narrow white cross-bars which contrast conspicuously with the otherwise streaked upjer surface, and white patch on wing shown in flight. In all our other rails, exeept the dark-colores Black Rail, the back markings run lengthwise.

Vorce-Not definitely known; thought to be similar to that of the Black Rail (Eaton, 1910, pp. 281, 282).

NEST-Seems to be not yet described, but probably situated on the ground and similar to the nests of other rails.

EgGS-5 (?), ovate in shape, measuring in inches, about 1.06 to $1.16 \mathrm{by}$ 0.81 to 0.8 .5 (in millimeters, 27.0 to 29.5 by 20.5 to 21.5 ), and averaging 1.11 by $0 . \$ 3(28.2-21.0)$; ground color pinkish buff; a small dense cap of fine dots of orange cinnamon, mikado brown and vinareous drab on large end; dots more sparingly distributed elsewhere on surface (5 eggs, a set?, in U. S. National Museum, taken in Illinois).

General distribution-North Ameriea from central Canala to the Gulf Coast. Oceurs in summer from southern Mackenzie, central Keewatin, anıl Quebec south to North Dakota, Minnesota, Illinois, and Maine; winters in the Gulf states and California, visiting more rarely New York, North Carolina, Bermula, Oregon, and Arizona (Cooke, 1914, p. 32).

Distribution in California-Rather rare winter visitant to marshes of westcentral California: Martinez, Contra Costa County (Cooper, 1868, p. 8): Alvarado, Alameda County (W. E. Bryant, 1856, 1. 426); Alameda County (Kaelling, 1998a , 1. 70); Sonoma County (Carriger, 1899, p. 72); Rineon Valley, Sonoma County (Mus. Vert. Zool.); Suisun Marshes, Solano County (Mus. Vert. Zool.): Los Baños, Mereed County (Mus. Vert. Zool.); Marin County (J. Mail. liard, 1901, p. 16); San Mateo County and Berryessa, Santa Clara County (Cooke, 1914, p. 32). Also recoriled from Humbollt Bay (C. H. Townsend, 1886, p. 491); Newport Bay, Orange County (Osburn, 1911b. p. 108); and Corona, Riversille (Pierce, 1914, P. 192).

The Yellow Rail in California must be classed purely as a winter visitant. Like errtain geese and the Mountain Plover it seems to have a diagonal ronte of migration from the north-eentral portion of the continent. Its breeding grounds appear to lie mostly north of the Inited States in central and eastern Canada. Not all of the birds of this species winter on the Paeific eoast, howerer, for a large contingent moves directly southward and spends the colder months in the Gulf states. West of the Rockies the species has been found only in Cali- 
fornia, Oregon, and Nevada, and in but one instance in each of the lattru two states. Even in California, the Yellow Rail is of extremely local ocenrrence, and at best cammot be considered eommon. 'The center' of abmulanee herr appears to be in the San Franciseo Bay region, for it has been reeorded but once north of this region and but twice from southern ('alifornia. Not more than twenty specinens taken in C'alifornia are known to be in collections, and as far as we know all of these were secmerd on fresh-water marshes.

The Yellow Rail is of small size, being eonsiderably smaller than a Virginia or Sora, and but slightly larger than the California Black Rail. Its general yellowish eolor, sharp, narrow, white transverse bars on the hack, and white pateh on the secontary wing feathes's, showing during flight. are "haracters which not only distinguish the Tellow Rail from the liack, but from all our other rails.

This bird has proven more difficult to find and flush than almost any other hirel of the marsh. Most of those eaptured have been foumd mintentionally: only a trained dog and prolomgerl search at the proper season will be likely to reveal this will-o-the-wisp.

Eges of the Yollow Rail have been taken at Wimmebago, Illinois, May 17, 1863, and near Devils Lake. North Dakota, June 4, 1901, Jume \&, 190\%, and .Jume 9, 1910 (Cooke, 1914,

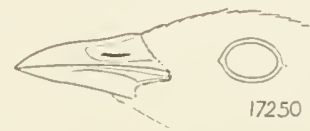

Fig. 52. Sirle of bill of Yellow Rail. Natural size. 1. $: 2)$. The first of the latter three finds is referred to by Reed (1904, 1). 105) as follows: "Their rogs are of a rich buff color, speckleel in the form of a wreath about the large end. with reddish brown. 'They are rleatively narrower than those of other rails. Size $1.10 \times 0.80$ [inches]." 'The set consisted of ten eggs. The eggs of the set taken in Illinois and now in the United States National Musem have a pinkish buff ground color. At the large end of eaeh egg there is a small dense crown of minute dots of orangecimmamon, mikado brown, and vinaceons-drab; elsewhere on the surface there are scattering dots of similar color.

Andubon (in Baird, Brewer and Ridgway, 1884, I, pp. 376-377) observed the habits of this rail along the margins of lakes and swampy bayous in eastern Florida. He noticed that the birds were accustomed to follow the margins of the muddy shores with measured steps, mutil attracted by some object. The tail would then be suddenly jerked upward, followed by the disappearance of the bird for the moment. Each bird proved as a rule so unsuspicious that at times it could be approached within a few yards, when it would only rise more electly, gaze at the observer for a moment, and then resume its ocenpation. The best way to obtain a shot at this bird was to lie concealed near an opening, and call it out of cover by imitating its notes, when, 
being very pugnacions, it wonld come to the open space and be easily shot. Its flight is said to be swift and more protracted than that of most rails, but it can seldom be driven to take refuge in flight.

On December 28, 1883, W. E. Bryant secured a speeimen of the Yellow Rail at Alvarado, Alameda County. Of this hird it was stated that it was pointed by a dog and picked up in the hand, whereupon it made a noise something like a young elicken (Belding, MS). One of the specimens in the Musem of Tertebrate Zoology from the Suisun marshes was eaptured by a house cat.

The stomaeh of a Yellow Rail eollected by A. C. Shelton in Rineon Talley, Sonoma County, November 17, 1912, contained eighteen elover seeds (Trifolium sp.) and a quantity of grass (H. C. Bryant, 1913, p. 92). This is of course insufficient evidence to show that this rail subsists entirely or ehiefly upon a regetable diet. The scareity of inseets at this time of ycar was probably responsible for the laek of animal matter in this partieular stomach.

The only reason why the Yellow Rail is classed by law as a game hird is because it belongs in the same family with the larger rails whieh are legitimate objeets of pursuit for food and sport. It is altogether too rare and too small properly to take rank as a game bird in this state. As the reader has doubtless already inferred, this bird is so sechusive in its habits that, as ret, very little is known of its life history.

\section{California Black Rail}

\section{(reciscus coturniculus (Ridgway)}

Other NAMes-Farallon Rail; Porzana jamaicensis; Creciscus jamaicensís: Porzana jamaicensis coturniculus; Porzana coturniculus.

DESCRIPTION-Adult malc: Whole head, foreneck, and most of under surface, hlackish slate, darkest on top of head; iris red; bill blackish; hind neck and back dark chestnut, brightest on hind neck and deepening to black ou rump and tail; middle of back, rump, tail and outer surface of closed wing with small sharp dots and short irregular cross-bars of white; scapnlars and onter surface of closed wing blackish brown; flight feathers lusky brown sparsely dotted with white; axillars, under surface of wing, and flanks, slaty brown, harred narrowly with white; belly pale slate barrel with whitish; under tail coverts slate gray barred with white and more or less tinged with light einnamon brown; legs and feet "bright yellowish green", (Aulubon, 1942, V, p. 158). Total length 5.37 inches (136 mm.) (one specimen) ; folled wing 2.562.81 (65.0-71.3); bill along culmen $0.55-0.60$ (14.0-15.3) ; tarsus 0.76-0.55 (19.321.6) (ten specinens). Adult female: Similar to male, lont duller colored on back, and lower surface somewhat lighter in tone, particularly on throat and belly. Folded wing 2.56-2.68 (65.0-68.1); bill along culnen 0.52-0.55 (13.214.0 ) ; tarsus 0.76-0.83 (19.3-21.1) (ten specimens); all from Califoruia. Juvenile plumage: Somewhat lighter in general tone of colosation than that of alults. Vatal plumage: Probably as in the Eastern Black Rail which is "entirely bluish blark", according to Baird, Cassin and Lawence (1858, p. 750). 
MARKS FUR FIELD IDENTIFICATION-Tery small size (our smallest rail, abont the lulk of a Least Sandpiper), black bill, and black-appearing plumage with small white lots. loung rails of all species are, as far as known to us, soliclly llack, without any white spots.

Torce-Clec-rle, cleé-ec (acrent falling on first syllable of last word) uttered rhiefly during ear]y mating season, and also in protest against intruders (Huey, 1916, P). 5S-59).

NEsT-On salt marsh, composel of stems of pickle-weed (Salicornia) loosely laid together and situated on ground, or more often on a platform of matted jickle-weed a few inches above the ground, and usually concealed by arching stems of the same and other plants (1ngersoll, 1909, p. 124).

EgGs-4 to S, bluntly orate to almost elliptical in shape, measuring in inches, 0.87 to 1.06 by 0.69 to 0.75 (in millimeters, 22.1 to 27.0 by 17.5 to 19.0 ), and averaging 0.96 by 0.72 ( 24.4 by 18.3 ) (three sets, and one single, fourteen eggs, from San Diego County, California); groma color white with a searcely perceptible tinge of pink, with surface spots of redlish brown and deeper ones of lavender.

Gexeral distribution-Pacifie Coast of the United States from Puget Sonnd to northern Lower California. Only known breeding ground on salt marshes in vicinity of San Diego Bar, California (Cooke, 1914, Pp. 35-36).

Distribetion IN CALIForsia-Fairly common fall and winter visitant to the salt marshes on the San Francisco Bay shores of San Mateo and Alameda counties, ancl at head of Tomales Bay, Marin County (many sperimens). Also in smaller numbers interiorly: Nartinez, Contra Costa County (Cooper, 1S6s, p. S); Stockton, San Joaquin County (Belling. 1879, p. 443), anı Suisun marshes. Solano County (Mus. Vert. Zool.); anıl southerly: Santa Cruz (Emerson, 1904, p. 35); Hueneme, Ventura County (Willett, 1912a, p. 33); Orange, Orange County, and Ballona, Los Angeles County (Grinnell, 1898, p. 15); and Riverside (L. Miller, 1893, p. 104). Twice taken on the Farallon Islands (Brewster, 1907, p. 205; MIus. Vert. Zool.). Fairly common throughout the year and breeds regularly on the salt marshes adjacent to San Diego Bay (Steplens, 1909, pp. 47-4S; Ingersoll, 1909, p. 123; Cooke, 1914, p. 36; Huey, 1916, p. 59 ).

The California Black Rail is the smallest species of the rail family fonnd in the United States. and differs but slightly from the Black Rail of the eastern states. Neither of these small species appears to be abundant, but as their habits are rery sechusive their actual numbers are probably greater than is generally believed. The range of the California Black Rail is limited to the Pacific coast and is separated from that of its eastern relative by a broad interval comprising the Rocky Mountain region. The present species has been recorded as a winter visitant from varions points within this state. At San Diego it is evidently present thronghout the year.

The small size, dark coloration, white-dotted back, and black bill constitute a sufficient number of field marks to identify this rail under favorable circumstances of observation. But it keeps so to cover and is so seldom flushed, that a full view of it is rarely obtained, even when a person is making a special search for the bird. It frequents 
low-growing vegetation and at first glanee is likely to be taken for a mouse.

The only known breeding ground of the California Black Rail is a limited area on the salt marshes of San Diego Bay between National City and Chula Vista. There, A. M. Ingersoll succeeded in finding three occupied nests of this species. But this much success was attained only by twenty-five trips to the locality. There are few birds the nests of which are so hard to locate. In regard to his finds, Ingersoll (1909, pp. 124-126) says:

The salt weeds of this marsh are of an evergreen character and perennial, varying little from season to season. Olil clumps of Salicornia [pickle-weed] become more or less matted down, forming an ileal retreat for this secretive little biri. A favorite nesting site is one formed by an old top-heavy weed falling over a growth of previous years in such a way as to leave a shelf-like space between the layers of stems and foliage. Away from the glaring sum on such a platform, is concealed a flimsy nest of fine dry weel stems. These weeds are too brittle to admit of weaving, and fall apart on being lifted from the sustaining platform....

The whitish eggs have a scarcely perceptible tinge of pink. They are finely speckled with bright reflish-brown and obseure lilae dots. The average

Fig. 53. Sisle of bill of California Black Rail. Natural size. measimement of the eggs is $.95 \times .71$ inches. The eggs exhibit great variations in size and shape but are rather uniformly marked. I believe the eggs of this species could not be mistaken for those of any other bird. The shells are of close-grained hard texture. They possess greater durability than any eggs of similar size that I know of. One year's exposure to the elements is not enough to destroy the shell. In 1908, there were many eggs of the Califormia Black Rail floated out of the nests by the high tides, probably by those of March 30 and 31. I examined upwards of thirty "floaters"' during May of that year. They were then rotten and partially dried 11). Fourteen "floaters", that were whole and perfectly dry were picked up during the present season; most of them were bleacht entirely free of markings. A few that had lodged beneath the vegetation were still speckled. These dry eggs were at least ten months old; possibly the salt water acted as a preservative. Sixteen old nests were found in the immediate vicinity of "floaters." On several oceasions, eggs were found lorged in weeds at a higher elevation than the nest from which they had floated. About one-third of the nests were built on or within two inches of the ground. I am informed of one nest being placed at a height of eighteen inches.

An accurate estimate of the number of birds in this rolony is of course impossible; but judging from the number of floaters and old nests, I should say that in 1908, thirty pairs of birds resided there at that time.

Huey (1916, p. 59) who has had considerable experience with this species on the marshes bordering San Diego Bay gives March 24 (1912) for the earliest nesting date, a complete set of five eggs having been then secured. His latest record is for May 25 (1909) when a 
set of fom partly incubated "runt" eggs was secmerl. This set meas-

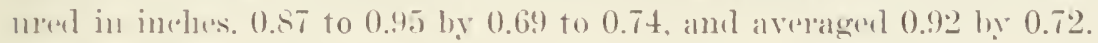
II" satys that nomal egers arelage 1.02 by 0.90 . The smaller size and litte date on whieh these coges were fomm sugerests that the set may have been of a serond laying, the first having heen destroyed of the

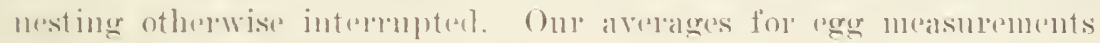
are 0.96 by 0.72 , as based on lluey set, one in the carrigere collection, a set taken by A. M. Ingersoll and presented by him to the Mlusemm of Vertelurate Koology, and a "single" in the same musemum, fourtern regres in all.

Cooke (1914, p. 36) gives April T (1910) as the earliest nesting date known to him: while Willott (1912\%. p. 33: silys that the eagelaying period falls betweren April 1 and 10 . Downy goung of the Black Rail have not yeet been reported from ('alifornia, but they are probahly wotirely black like the young of the eastem libalk hail.

The call aceoreling to 11 uey (1916, ple. j8-59) somels like the

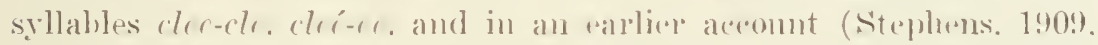
p. 48 ) it is said to be a sort of elicking somel. 'T'his aceolels with the' nature of the roice of the eastern Black Rail as reported ly Premstere $(19026,1)$ int).

A birel which lngersoll (loc. cit.) flushed from neal a nest rose and Hew olf feebly for thirty or forty feet, hovered, and then returned to within sixteen feet of the nest. Entil it hoverest the legs were loft Aangling in the air, and as it alighted in the vegetation they were again dropper below the horly. This speedes is receedingly secertive in its lahits, although it does not display any great amome of frar in the puesence of homman beings. It will erouch and almost allow itself to be stepped on before it will thush. A dog can easily capture one of the hirds and individuals have (xen been picked up in the hand.

The shymess of this rail is reffeeted in the regrularity with which it abandons nests which lave been discovered, even in the most casual manner, by a human observer. Huey $(1916,1) .60)$ says he bas never ret found a nest of this species that did not on a later visit prove to have been abandoned, even when the nest and surrounding regetation had been left entirely umlisturbed.

A Black Rail which Huey (1916, pp.61-62) captured was confined on a sereened porch with a Sora Rail. ". . . The two birds proved quite eompanionable. They ate freely of the food offered them.... The Blaek Rail . . se semed rather vicious at all times, pecking angrily at anything offered her-stieks, fingers and all." In attempting to photograph these birds, "a small, round clump of salieornia, perhaps three feet in diameter, was selected for the baekground. . . . The little rail proved the more elusive of the two. She wonld dive into the dense mass, exactly as a duck dives in water, and would then erouch 
motionless, as if hiding. The walking positions of the two species were noticeably different. The little Black was always prond, with head erect and no jerky movements while walking, but the Carolina [Sora] was a typical rail, head down, tail erect, and forever sneaking off sideways as though he were ashamed of himself."

H. R. Taylor (1898, p. 79) says that in San Mateo County

The Black Rail we saw would fly up . . . with others and several alighted for refuge, after cireling in irregular flight, in bunches of bushy weeds, being still within range. They are sellom if ever shot at by hunters and are very uususpecting little creatures, allowing the boat to approach within a lialf an oar's length from where they are hiding. In this way I struck the one I eaptured with the blade of the oar, and stmnning it but for a moment, took it alive. This bird was kept in captivity where it was observed to he alert to see things and active with its bill. However, all its movements were notably delilerate. It marle no attempt to escape anil acterl as though it har always known a prison.

When the Black Rail is asleep he is no longer a rail. He has become simply a ball of feathers as big and almost as round as an orange, and coming upon one in such a position you would more rearlily believe it were some strange animal [mammal] than a bird. There is a gradual ruffing of the feathers until they are fluffed out all over the body and the rail is more than twice his usual proportions. Now the short wings are not noticeable and the little tail shows but slightly. The head is twisted about by slow degrees until like a flash it disappears. It has gone into that ball of feathers, but where? of course, it is under the wing, but looking at the transformation you would never know. Where the neck was lost in the ball there is a circle which reminds you of the end of a lady's muff, only the brown has harmonizerl beautifully with the black of the body and its dainty flecking of white. We touched the little fellow once while he was thus fluffed up. Ont came his hear but it was quickly popped into place again (H. R. Taylor, 1895, pp. 79-80).

The bird held captive by H. R. Taylor was fed eight earthworms for one meal. Several stomachs of Black Rails taken by Huey (1916, p. 60) in San Diego County contained remains of Isopod erustaceans belonging to the species called Alloniscus mirabilis. A captive individual was fed upon bread crumbs, some of these errustaceans, and some "garden bugs."

This is another of the marsh birds which meets death to some extent by aceident. There are two instances of the sort on record. A bird was found on the main street of Santa Cruz in September, 1903, which had been killed by flying against a wire (Emerson, 1904, p. 38); and one was picked up Angust 4, 1876, beneath where it had been killed by flying against the Point Loma light, near San Diego (Belding, MIS).

The California Black Rail, like many another of the rarer birds really merits but a casual place on any list of game birds. Probablynot more than ten sportsmen in a thousand have ever seen this bird, 
and of these ten surely not one would raise his gum against such a mite of a bird, muless needed for a seientific specimen. To ornithologists the sprecies is of interest beeause of its restricted range and elusiveness. It secms probable that the reclamation of the marshes where it makes its home will be the only factor having to do with any change in its status in the future.

\section{Florida Gallinule}

\section{Gallimula galcula (Lichtenstein)}

Other xades-Red-billed Mruilhen: Gallinula chloropus galcata.

DesCrIPTION-Adults, both sexes: Heal and neck dull black, darkest abore: iris "bright red", (Audubon, 1S42, V, p. 136); large frontal shielil above hase of bill bright suarlet; bill bright rell excent for tip which is greenish vellow: whole of upper surface dark sepia brown, larkest on rump anil upper tail coverts; erlge of wing white; outer surface of elosed wing scpia brown at base, otherwise slaty: flight fleathers blackish brown; axillars and under surface of wing ashy brown, witl mottlings of white on former; under surface of body blackish slate: feathers of flanks elongated and with white shaft streaks; belly chiefly kull white; lower tail coverts white, the millle and basal feathers black; legs and feet greenish yellow, joints ashy blue; naked part of legs above leel joint, rel: toes slemler and without lobes. Males: Total length 14.75 inches $(375 \mathrm{~mm}$.); folled wing 7.25 (185); bill along culmen (to top of shield) 1.53 (38.9); tarsus 2.25 (57.1) (one specimen from Califoruia). Females: Total length 14.00-14.50 (356-36s) (three sperimens); folled wing 6.91 (176); bill along culmen (to top) of shield) 1.32 (33.6); tarsus 2.16 (55.0) (one suecimen from California). Jurenile plumase: Top and sides of hearl sooty black, paler on siles where also sparingly flecked with white; chin and throat white, fleckerl with slate gray; whole neck dull black; rest of upper surface brown, red-toned on back, more blackish from rump backward; breast and sides of boly pale slate gray, many of the feathers extensively tipperl with white; middle of belly white; flanks and rest of uniler surface pale brown; feet proportionately large, as in adults. Natal plumage: Black, the upper surface with a greenish east, under surface with a brownish tinge; a few slender feathers on cheeks and chin, white-tipped; bill straw yellow, dark-banded across middle; legs and feet (dried) reddish.

MARKS FOR FIELD IDEÑTIFICATION-Dark coloration, white under tail coverts, and flaming red frontal shield. Distinguished from the Mud-hen, which is of similar size, general coloratiou and habits, by red instead of white bill, white stripes on flanks, greenish legs (red above "heel'), absence of white on wings, and entire absence of lobes on sides of toes.

VoIce-A loud, discordant, hoarse, hen-like cuck, repeated slowly but in a connected series (Brewster, 1902b, p. 51).

NEST-In dense tule thickets in marshes, usually placed over water; constructed of tules on a platform of the same material.

EGGS-6 to 13, elongate ovate in shape, measuring in inches, 1.54 to 1.95 by 1.10 to 1.30 (in millimeters, 39.0 to 49.5 by 28.0 to 33.0 ), and averaging 1.73 by 1.22 (44.0 by 31.0) (105 eggs in U. S. National Museum); ground color deep pinkish buff, with surface spots of chocolate and redilish brown, and deeper ones of grayish lavender. 
General distribution - Tropical and temperate America. Breeds from central California, Arizona, Nebraska, Minnesota, Ontario, New York, and Vermont south through the West Indies and Mexico to Chile and Argentina, and in the Galapagos and Bermuda islands; winters from southern California, Arizona, Texas and Georgia sonthward; easual in Colorado, Quebee, Nova Scotia, New Brunswick and Maine (A. O. U. Check-list, 1910, Pp. 105-106).

Distribution IN CALIForNia-Fairly common summer visitant to fresh-water marshes in sonthern fortion of the state west of the desert divides from Santa Barbara southeastward; also in the San Joaquin-Sacramento Valley north to Sutter County (Belling, MS). Several recorled breeding stations within these areas. Winters sparingly in sonthern coastal district, as at Los Angeles (Swarth, 1900, p. 15) ; possibly also in the vicinity of Fresno (Tyler, 19136, 1. 23).

Althongh the Florida Gallinule is a bird of wide distribution in both North and South America, it does not exist in great numbers anywhere in the western I'nited States. Along the Atlantic coast it lias been found breeding as far north as Penusylvania and New York, but on the lacific coast the northernmost station of record is Sutter Connty, California. South of the latter place, in the sreat interior valleys, and on the marshes of sonthern California from Santa Barbara southeastward. the species breeds regularly, and in the extreme sonth some individuals remain thronghont the winter season. There is but one coastal record for the species north of Santa Barbara. This is for San Franciseo (Newberry, 1857, p. 96), and might lave been of a bird brought from some interior locality to the markets. The favorite hamuts of this bird are the dense tnle thickets to be foumd in fresh-water marshes. From these shelters it seldom ventures out into the open as does its relative, the Mud-hen.

There is no definite midwinter record for the Gallinule north of Tehachapi, but Trler (1913b, p. 23) saw two individuals near Fresno on Normber 26, 1907, and a single one near Clovis, Fresno Connty, Mareh $\overline{7}, 1908$, which led him to suggest that the species may be a permanent resident in that district. At Los Baños, Merced Comnty, the first spring arrivals in 1912 were seen on April 22 (Beck, MS'). At Los Angeles, Swarth (1900, p. 15) says that "the young remain until late in the fall, when they nearly all disappear. Esually one or two remain thromply the winter."

No other California hird has a flaming red shield on the forehead such as is possessed by the Florida Gallimule. This shield is so conspiconous, exon at a distance, that there is usmally no difficulty in perognizing the bird hy this feature alone. The Gallinule lesembles the Muth-hen in general huild, eolor of plumage and habits, but can he readily distinguished from the latter birt by the lack of white on the wings. hy the alsener of lobes on the toes, by the reet on the legs ahove the "heep" joint, loy the presener of white streaks on the flanks, anel by the reed instead of white bill. The Gallinule has a rail-like 
mannerism of spasmodically jerking its tail upwards. This results in the white under tail coverts being intermittently flashed forth in a conspicuous mamner. No account of the courting antics of the Florida Gallimule has been published from California, but Brewster has recorded the behavior of a pair of these birts seen near Cambridge, Massachusetts. After they had been under observation for some time a great ontery was suddenly heard one afternoon,

... and soon our pair of Gallinules appeared; the fentale, who was much the plainer-colored in every respect, swimming swiftly, her tail lowered ant about in line with the back; the male flapping his wings on the water in his eagerness to overtake her. This he soon succeeled in loing, but just as he clutched at her with open bill.. she eluded him by a sudden rlever turn. He then swam round her in a narrow circle, carrying his tail wide-sprear and erect, his neck arched, his scarlet front fairly blazing and ajparently much enlarged and inflated.

During the chase one of the birds, presmmably the male, nttered a series of eries which sonnded like ticket, ticket, repeated six or eight times in succession. This cry was evidently a wooing note as it was heard on no other occasion (Brewster, 1891, p. 4).

Information concerning the nesting of the Floricla Gallimule in California is rather meager. Wicks (1893, p. 363) records the finding of a nest with nine eggs near Los Angeles, April 27. 1890. The nest was situated in a clump of tules and composed of the same material. At Nigger Slongh, Los Angeles County, Antonin Jay collected a set of eight fresh eggs on May 5, 1901, and a set of five with incnbation commenced, Jume 30, 1895 (Willett, 1912a, p. 33). A. MI. Ingersoll took a set of six partly incubated eggs at Lakeside, San Diego County, on May 15, 1895, and another of nine eggs heavily incubated at San Jacinto Lake, Riverside County, June 7, 1897 (Ingersoll coll.). There is but one instance of nesting in the Central Valley of California of which we know. At Dos Palos, Merced County, a set of ten slightly incubated eggs was taken May 22, 1912 (Carriger coll.).

The nest of the l-lorida Gallinule is always placed in a fresh-water marsh, sometimes on small islands but usually on a mass of dead tules and over standing water two or three feet deep. As elsewhere described (Brewster, 1891, p. 6), it is a bulky affair for the size of the bird, measuring 13 to 20 inches in diameter, and eight inches high. The central carity which contains the eggs was found to be $23 / 8$ inches deep by seven in diameter. As with the Mud-hen an approach or "gang-way" of tules leads from the surface of the water to the nest. In the east, incubation is said to commence with the deposition of the first eggs, so that completed sets comprise eggs in all stages of incubation from fresh to nearly hatching (Brewster, loc. eit.). 
Brewster (1891, p. 4) says that the calls of these Gallinules were valied and complex. Sometimes they gave four or five loud harsh screams, again a series of sounds resembling tlose made by a brooding hen when disturbed, then a number of querulous complaining eries intermingled with subdued clucking.

Again ... something which sounded like this: hr-r-r-r-r, hruc-kruc, hrar-r, hih-hih-hh-lik-kea-kea, delivered rapidly and falling in pitch toward the end. Shorter notes were a single, abrupt, explosive kup, very like the cry given by a startled frog just as he jumps into the water, and a low klöc-klóc or kilócklŏc-klocc. Speaking generally, the notes were all loud, harsh, and discordant, and nearly all curiously hen-like.... In the early morning and late afternoon their calls were frequent and at times nearly incessant. They ceased almost entirely after nightfall, for the Florida Gallinule is apparently much less nocturnal than any of the Rails. ...

Of the general liabits of the Florida Gallinule in Massachusetts. Brewster (1891, pp. 3-4) says :

His manner of swimming and of feeding from the surface of the water was very like that of a Coot. He sat high and accompanied the strokes of the feet with a forward-and-backward nodding motion of the head and neck, aceentuated at times as he reached out to sieze some tempting morsel. On land lie walked like a Rail, treading his way deftly among the stems of the bushes and tall rushes, stepping daintily, lifting and putting down his feet slowly, and almost incessantly jerking up his tail with a quick, nervous motion which eaused the under coverts to flash like the sudilen flirt of a hanlkerchief. As he pieked his food from the vegetation at his feet, the liead and neek were shot forward and downward at intervals of about a second, with a peeuliarly vivid, eager motion. His manner of walking and feeding also suggested that of the Guineahen, the body being carried low and in a erouching attitude, while the movements of the head partook of that furtive swiftuess which is so characteristic of this barnyard fowl.

Onr Gallinule at most times, whetlee in action or repose, was a birr of slender shape and graceful ontline, his carriage light yet firm, the play of the body lithe and strong. While preening his feathers, however, his attitude was often stiff and awkwarl, and the ruffling of his plumage made him appear nearly as portly as a duck. Again, the motion of flight was ludicrously awkwarl and uncoutl. When, frightenei by a glimpse of... [the observers], he rose and flew with legs langing down, wing-beats feeble and labored, the whole bearing was indicative of strain and exhaustion, which receiver an added emphasis from the abrupt reckless drop into the bushes which ended the flight.

Almost every time the birds which Brewster was observing came to a small ditch in the marsh they would stop to bathe. The male would stand at the water's edge where

With a quick plunge and upward fling of the head he scattered the drops over his bark in a shining shower, opening and trembling his wings as the water fell. After repeating this performance five or six times in rapil succession, lie rested a moment, and then went through it once more. After his 
plunage beeame thoroughly soaked, he proceeded to dress it, running each feather separately through his bill. This elaborate toilet oceupied a cousiderable time, often lasting as long as fifteen minutes. When it was completed to his satisfaction, he would start off to feed again.

This Gallimule frequents tule-bordered ponds and streams and may oeeasionally be seen feeding along with Mnd-hens. Although the Gallinule is partially gregarious, it and the Mud-hen are never seen together in any numbers, usually not more than a few pairs of the former frequenting any one marsh in this state.

Aquatic and other insects form the larger part of the food of the Florida Gallinule: but eertain water plants and seeds are also taken. The stomach of a speeimen taken in Nebraska contained seven grasshoppers, twenty-nine other insects, some seeds and other vegetable matter (Barrows. 1912, p. 162). The birds forage more largely on the shores of ponds and among the vegetation, and less on the open water, than does the Mud-hen.

Where known to sportsmen Gallinules are considered fine birds for the table, and were they more numerous here more would doubtless find places in hunter's bags. But in California they are present in sueh small numbers as to be considered euriosities, and it is this faet which most often leads to their being shot.

Near Philadelphia. Pennsylvania, Florida Gallinules have inereased during recent rears, and there is a possibility that by eareful proteetion their numbers might be made to inerease in our own state. We have not been able to find a basis for any judgment as to comparative abundance here, now and formerly, though it seems evident that they have never been notably mmerons in California sinee natural history records began to acemmulate.

\section{Mud-hen}

\section{Fulica americana Gmelin}

OTHER NAMES-Coot; Chinese Mallard.

DESCRIPTION-Adults, both sexes: Whole heal and neck, black; iris bright red; frontal shield chocolate brown; bill whitish. with a brownish or blackish spot on both mandibles near tip; rest of upper and under surface of body including wings and tail, dark slate, blending into black on neck; edge of wing narrowly white; secondaries tipped broadly with white; lower back tinged with olive brown; feathers of belly tipped more or less with white; longer under tail coverts white, forming a $\mathrm{V}$ enclosing the shorter black feathers; front toes broadly lobed (see fig. 55); legs and feet greenish yellow. Males: Total length 15.00 inches $(381 \mathrm{~mm}$.) (one specimen); folded wing $7.40-7.90$ (188-200); bill along culmen (to top of shiell) 1.62-1.84 (41.1-46.7); tarsus 2.21-2.36 (56.2-60.0) (ten specimens). Females: Total length 14.00-14.62 (356372 ) (two specimens); folded wing 6.70-7.45 (170-189); bill along culmen 
(to top of shield) 1.53-1.85 (38.9-47.0); tarsus 1.86-2.19 (47.3-55.7) (ten specimens); all from California. Juenile plumage: Similar to that of adults lut lower surface generally more suffused with whitish, frontal shielil less developed, bill lighter in color and lacking blarkish spots, and iris brown insteall of bright rell. Natal plumage: General color blackish slate; throat, rheeks, neek, wings and back covered with elongatel, rrinkled, bristly feathertips of orange; top of hear almost ball, but with a few blark hair-like feathers; bill orange red, black at tip; legs and feet blackish.

MARKS FOR FIELD IDENTIFICATION-Of small duck size aud actions. Dark slate-colored plumage with whitish bill and white $V$ under tail (pl. 10). Distinguisher in flight by labored efforts in leaving water, large feet extenting lulkily beyond tail, and white patch on hind margin of wing. Walks and swims with listinct fore and aft movement of hearl at stroke of each foot. In hand the broad thin lobes on the front toes are diagnostic (fig. 55). Separable from Florida Gallinule by whitish instearl of red bill (fig. 54), presence of lobes on toes, presence of white on secondaries, and absence of streaking on flanks.

Vorce-An explosive, cackling, mlque, pulque, pulque. or plop, with a hollow intonation.

Nest-Of tules, reeds, or selges, most often floating on tlie water, or built up in tules; seldom well concealed in thick growth. Often several nests are found close together.

EGGS-6 to 15, pointedly ovate in shape, measuring in inches, 1.76 to 2.05 by 1.25 to 1.36 (in millimeters, 44.8 to 52.0 by 31.7 to 34.7 ), and averaging 1.96 by 1.30 (49.8 by 33.1) (thirty eggs from California); ground color creamy white, spotted and speckled in fine patteru with dark brown or blackish.

General distribution-North America. Breeds from central British Columbia, southern Mackenzie, Manitoba, Quebee, and New Brunswick south to northern Lower California, Texas, Tennessee, and New Jersey, anı also in southeru Mexico, southern West Inries, aud Guatemala; winters from southern Britisly Columbia, Nevarla, Utah, the Ohio Valley, and Virginia, south to Panama; rasual at Fort Yukon and Sitka, Alaska, and in Greenland, Labrador and Bermusla (A. O. U. Cheek-list, 1910, p. 106; Cooke, 1914, p. 43).

DistribITION IN CALIFORNIA - Abundant resident of suitable localities throughout the state, breeling at very many points, both east and west of the Sierras. Distinet local migrations, which may he altitudinal rather than latiturimal, are often in evilence; at the higher stations there are local increases in numbers in spring and corresponding lecreases in fall.

The Mnuthen, commonly known in booklore as the Coot. ranges over much of the North American continent. It breeds as far north as British Columbia and southern Mackeinze and has been taken twice in Alaska. It is perhaps more common in the west than in the east, but there is hardly a farolable marsh in the whole comntry that does not support a few birds of this species at least during the summer season. In Lower California it has been found breeding as far south as Purisina (Cooke, 1914, p. 43).

In most places in ('alifornia the Mud-hen nests in far greater mumbers than does any native species of duck. Although remaining within the state during the whole year, a partial migratory movement 
is to be noted. It may be that this migration is more largely altitudinal than latitudinal; in other words that bodies of water above the winter snow line are largely deserted in the fall. Along with the fall migrants of the dnek tribe, Mnd-hens appear in the lowlands in very great numbers. In certain places in sonthern California they are much more abundant in winter than in summer. Belding (XIS) says that in the tule districts of eentral California the Coot does not migrate, in the accepted significance of this term, but that in winter when deep and often muddy water covers their feeding grounds they

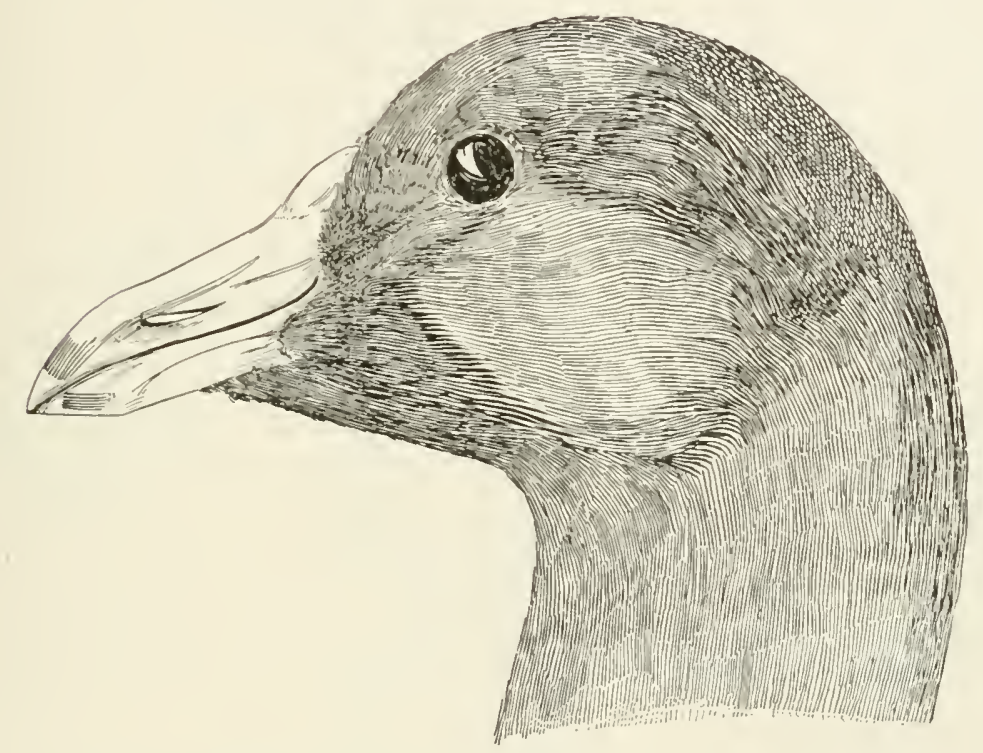

Fig. 54. Hearl of Murthen showing "shield" on forehear. Natural size (no. 22149 ).

spread out into the cultivated fields and cause some damage by eating sprouted grain. Tyler (1913b, p. 24) found a stray or migrant in a peach orchard two or three miles from the nearest water. It was so confused that it was easily captured, but when released flew away.

To the average boy in California the Mut-hen is more familiar than any species of duck. And any person with even the slightest possible knowledge of waterfowl can distinguish the bird, aside from its general duck-like appearance, by a single character-the short whitish bill. The plumage is of a dark slate color shading into black on the head and neck (pl. 10). In flight a white patch on the hind margin of each wing shows conspicuonsly, and the large feet protrude clumsily beyond the end of the tail. In the hand the flat lobes of skin 
along the joints of the toes make identification certain (fig. 55). At a clistance the bird may be distinguished from ducks by the fore-and-aft bobbing motion of the head, in unison with that of the feet. This is observable when walking on land or when swimming in the water.

Almost any large or small marsh, or a pond with more or less of a border of tall grass or tules, may be selected by the Muthen as a

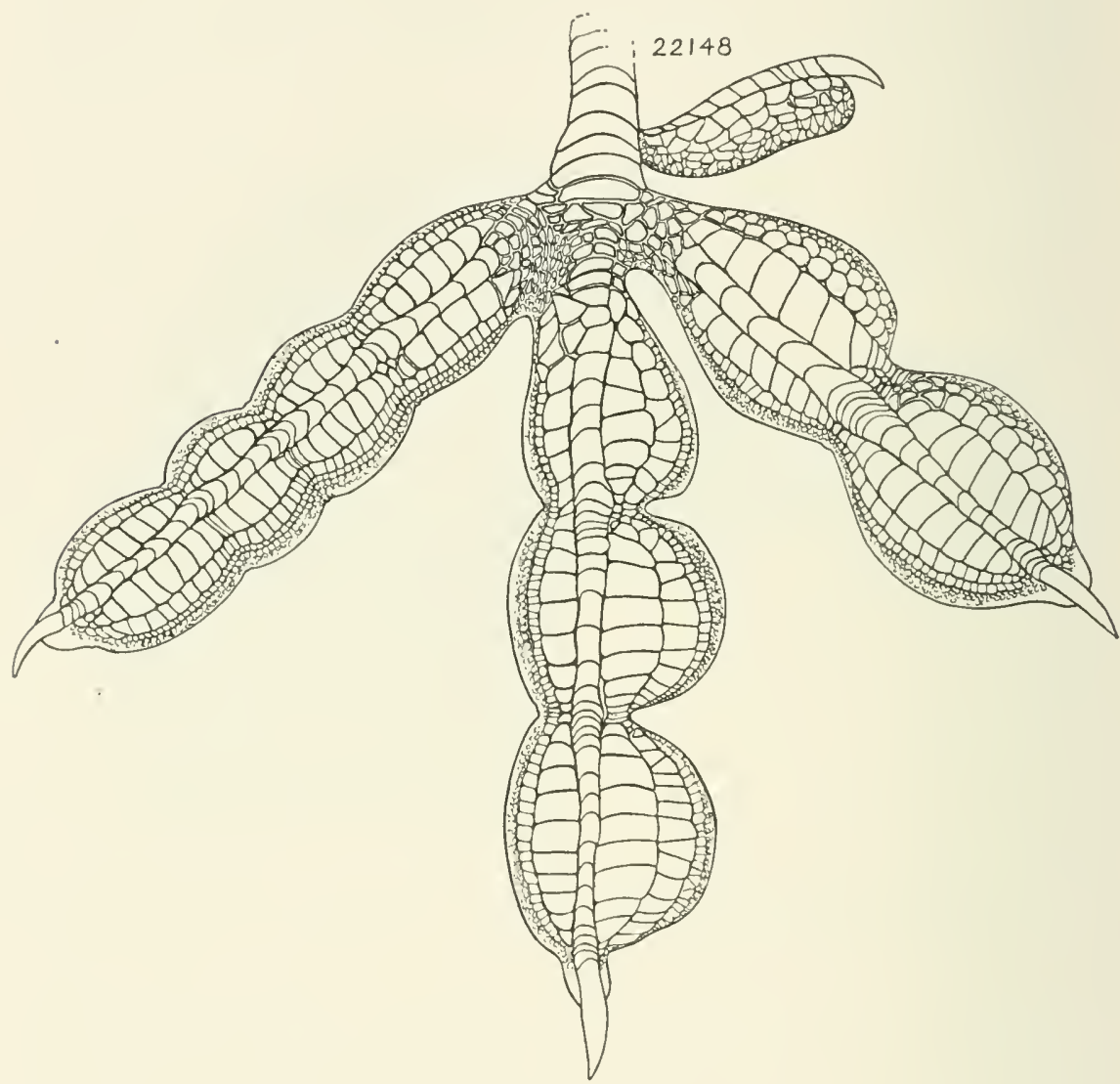

Fig. 55. Top of foot of Mud-hen. Natural size.

Note broad lobes on sides of toes (compare with figs. 11 and 47 ).

nesting site. The Mud-hen is a gregarious species and frepuently nests in eolonies, the nests being placed eren as close as ten feet from each other. Davie (1889, p. 105) says that five humeleed Coot eggs were taken from a single marsh near Los Angeles. At Los Baños. Merced County, nests ale so common that it would be a comparatively easy matter to obtain even a larger number of eggs in a single season. Courtship is evidenced by persistent pursuit of the female hy the male, 
and this is as often earried on under water as above it. The female appears to be able to elude the pursuer just as long as she wishes to do so.

The nest nearly always consists of a platform of vegetation, "floating'" in the sense that the mass of broken-down reeds upon whieh it rests lies in the water; but it is oceasionally situated high and dry on a sedge-covered island, though always near the water. Perhaps the most common nesting site in California is in the edge of a tule thicket. Often the nest is in such an exposed situation that the sitting bird may be seen at a considerable distance. The usual material entering into the eomposition of the nest proper, is the green stems of tules or sedges, the smaller stems often forming the semblance of a lining. These are sometimes woven into a fim, deeply-enpped or basket-shaped structure. The drying out of the fresh stems during ineubation has led to the popular idea that the birds use dry stalks in constructing their nests. There is usually a sort of gangway, eomposed of bent-orer tules, leading to the nest, and the parent bird enters and leaves the nest by this one ronte.

Six to fifteen eggs are laid. Moreom (1887, p. 39) records a nest found in Bear Valley, San Bernardino Connty, which eontained twenty-two eggs; but doubtless this was the product of more than one female. The eggs are creany white in color, finely and uniformly speekled with dark brown or blackish. In shape they are mueh like hens' eggs but usually more pointed at the small end. As compared with eggs of the Florida Gallimule those of the Mud-hen are slightly larger and have a less reddish tone of coloration. The eggs of the Mud-hen are oecasionally used for food, but they are less palatable than those of domestie fowls.

Inembation often begins as soon as the first few eggs are laid and consequently the last egg hatehes several days after the first one. Broods have been seen as early as the first week in April. In the lower eountry the birds usually nest from April 15 to June 15; at high altitudes the season is later. Eggs were found at Lake Mereed, San Francisco County, July 23, 1911 (Carriger coll.), and at Bear Lake, San Bernardino Comnty, altitude 6,750 feet, as late as July 27 (Grimmell, 1908, p. 54).

The young take to the water within a few minutes after hatching. Here they seem to be perfeetly at ease as they swim and dive with agility and are expert in hiding in the vegetation. Their ability to remain beneath the surface of the water for a long period of time is remarkable. In two instances youngsters not more than a day old were observed to remain under water nearly three minutes, as timed by a wateh. They could be seen elinging to regetation beneath the 
surface until apparently forced to come up for air (H. C. Bryant, MS).

In contrast to the sombre hue of the adult the downy young is a most brightly colored bird. The general color is shiny black, but on the throat, neek, wings and back there are patehes of crinkled fuzzy feathers with hair-like terminations whieh are of a chinese orange shate, brightening to orange vermillion on the head. The bill is a bright vermillion exeept for the tip, which is black. The top of the head is at first bare exeept for a few short black bristles.

A quite significant and interesting fact was noted in that the feet of the young grew far more rapilly in proportion than the rest of their body. A half-grown Mud-hen has astonishingly large feet, and after observing the ease with which the youngsters swam and dived (apparently just as well as the arlults), the relative importance of those members to the early suecess of the individual seemed plain. The young of a family near camp returned with both parents to the old nest each evening at dusk, but much squabbling anit jostling, accompanied by various toots, grunts, and cries, took place before they were all finally settled for the night (Grinnell, 1908, 1p. 54-55).

Rich (1907, p. 247) writes eoneerning the Mud-hen in the East: "In summer the separate families keep by themselves, but when in the fall the young are fully fledged and ready for business flocks of eonsiderable size are formed preparatory to migrating." The same is true of Cahifornia birds.

Coots are noisy birds and their explosive caekling notes are the commonest sounds emanating from our tule swamps. The usual eallnote is a pulque, pulque, pulque, often with a peeuliar resonant quality. When alarmed a flock breaks ont into a great ehorus of these eackling notes, and this seems to aet as a warning, as most of the birds in the vieinity at once semry for eover.

The Coot is an excellent swimmer and spends much of its time on the water. It prefers the margins of shallow lakes and ponds. however, and often wanders about on the shore. Safety is more often songht by swimming than by flight. When foreed to fly a bird "rums" along on top of the water for some distance before gaining headway enough to rise from the surface. Both wings and feet make the water fly in every direction, prodneing a characteristic somml and wake. Even when well started, the flight is labored, and as soon as fairly out of danger's way, the bird usually drops back into the water with an appearance of complete exhausion. Tet it must be remembered that in parts of its range the Coot midertakes extensive anmual migrations. Rich (1907, p. 247) states that it swims well under water", "using its wings in eonjunction with its long, lobed feet, which are a most serviceable pair of paddles." Coues (1874, p. 543) says of a flock on open water: "They swam with ease and graeefully; 


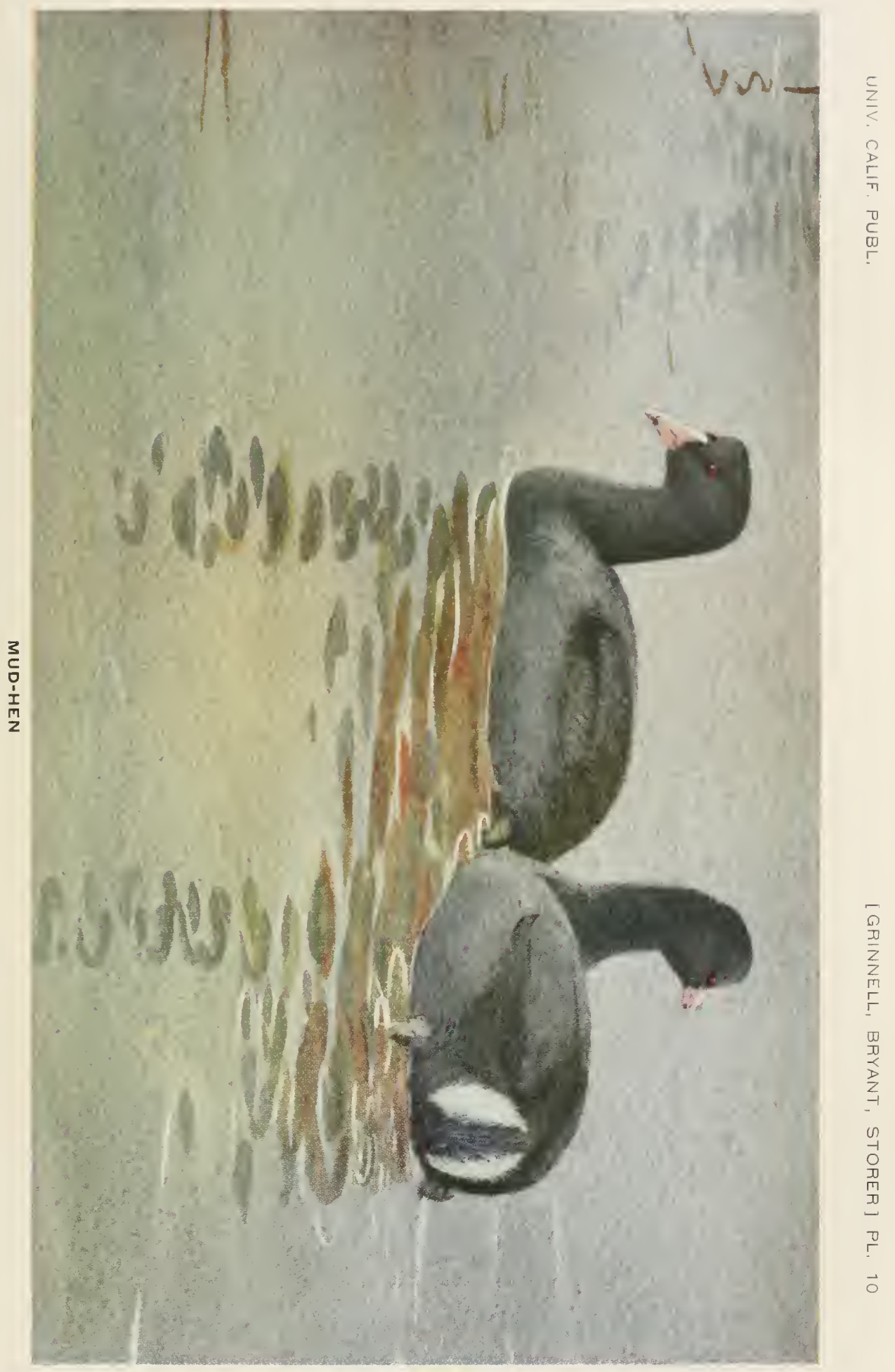



the had now drawn back and held upright orer their plump bodies, that floated lightly and ehanged their comse at a movement of their broad paddles, now stretched out to full length as the birds hurried about, throwing off the ripples from their half-submerged breasts, crossing and reerossing each other's path, in wanton sport, or attracted by some delicaty Hoating at a little distance."

The barled-wire fence has introdneed a new element of danger into the lives of these low-flying birds, and it is not an meommon thing to ser one or more individnals hung on the barbs (Chapman, 1908, 1). 29:3).

The coot is a splendid diver and obtains much of its food from mudre the smrface. The hird is almost ommivorous and althongh it feeds most retensively on serels and aquatic plants, it is not averse to taking insects, tadpoles; or ren, on oecasion, to eating dead ducks. Pondweed (Potumogrton) is a favorite food in most loealities. Anderson and Jenkins (1903, p. 154) found ('oots feeding on green grass near shore on a lagoon in San Mateo County. Grain is relished when obtainable.

Many gun-clubs eonsider the Mud-hen an enemy, because it destroys both the natural and artificially supplied food on the preserves. In some localities clubs hold a "Mud-hen shoot" at the beginning of the season so as to ricl their grounds of these so-called pests and as many as 5,000 Coots har been killed in a day on one preserve in Merced ('ounty (Tyler, 1!)1:3b. p. 2:3). Some far'-seeing sportsmen, however, are averse to these harsh measures, for they are inclined to think that at some not far distant day, when the supply of ducks is exhansted, our sportsmen will of necessity turn to this less desirable game bird as has been done in certain rastern localities.

Many people think as little of the Mud-hen as an article of food as they do of a erow. On the other hand we have heard it asserted that young C'oots, skimed and fried, or even old ones parboiled, are quite as delicious as most dueks. The story is enrent that this bird has for many years been sold by the hotels of San Franeisco and other large cities as "duck."

At present the Mud-hen is very tame and is an easy mark for the gunner. Whether inereased attention would make it a wary bird is problematical.

As far as we can find ont there has been little or no diminntion. in the numbers of Mnd-hens. Through the decrease of more desirable birds it is possible that it will be more largely shot as a game bird. and in that event we may expect this speeies to decrease just as the ducks have done, unless the shooting be judieiously regulated. 


\section{Red Phalarope}

\section{Phalaropus fulicarius (Limnaeus)}

\section{OTher Names-Gray Phalarope; Sea Goose; Whale-bird; Bow-fin Bird; Crymophitus fulicarius.}

DESCRIPTION-Adult male in spring and early. summer: Top of heal, hind neck and back, sooty black with broal feather marginings of buffy brown, giving a streaked appearance; region around eye dull or buffy white, most extensive below and behind eye; area about base of bill, and cbin, mixed reddish white and black, white predominating on chin; bill dull yellow at base, brownish black at tip and about nostrils; iris "brown" (Audubon, 1842, T, p. 293); rump slate-colored; upper tail coverts tawuy, with some dark shaft streaks; tail above sooty brown, the feathers with narrow tawny or whitish margins; outer surface of closed wing brownish slate; edges of coverts white, those of greater coverts extensively so, forming a conspicuous white band, this being continued along tips of secondaries; flight feathers sooty brown, shafts of primaries and bases and shafts of secondaries, white; tertials margined with dull tawny; under surface of wing and axillars white; margin of wing at and below bend, mottled white and dusky; under surface of flight feathers dusky, becoming lrownish toward tips; sides of neck and under surface dull cinnamon red with more or less white scattered along middle of belly; feathers of sides and flanks with dusky shaft streaks; under tail coverts like under surface, but with some of the feathers white; feet lark brown, darker at joints, webs lighter. Total length 7.90 inches $(200 \mathrm{~mm}$.) (two specimens from California); folded wing 4.77-5.18 (121.7-131.8); bill along culmen $0.82-0.95(20.8-24.3)$; tarsus $0.83-0.90(21.1-22.9)$ (ten specimens from California and Alaska). Adult female in spring and early summer: Top of hear, chin, and area about bill, deep brownish black, darker above than below; area around eye, white, more extensive below and behind eye; hind neck and hack dull black; feathers of back extensively margined with light buffy or jale tawny; rump slate colored; middle upper tail coverts pale buffy with hrownish black shaft streaks; outer tail coverts elear einnamon red; inner tail feathers brownish black with narrow light brown elgings, outer ones lighter with whiter edgings; wing as in male; side of neck, and whole under surface including sides, flanks and under tail coverts, uniform deep cinnamon red, approaching ehestnut, with a very few white feathers on belly. Total length 7.96-9.00 inehes (202-228 mm.) (seven speeimens from California anit Alaska): folded wing 5.06-5.48 (128.4-138.6); bill along eulmen 0.S2-0.96 (20.8-24.5); tarsus $0.79-0.89$ (20.0-22.6) (ten specimens from California). Adults, both sexes, in late fall and winter: Head white, except for blackish area almost encircling eye and extending backwards over ear region; back of head and hind neck blackish; back and seapulars pearl gray with narrow white feather tippings; rump dusky brown; midlle upper tail coverts blackish, with buffy edges, lateral ones white with gray shaft-streaks; tail and wing as in summer except that lighter margins are lost or reduced by wear: sides of chest, sides of boty, and flanks, grayisli; whole lower surface otherwise white. Jurenile plumage: Toj of heal mixes black and tawny; cheek and stripe from sile of hill running over eye, buffy white; chin white; back and tail, black with hroad feather margins of tawny; rump gray; outer surface of closed wing largely dull grayish brown; greater coverts and secondaries broadly tipped with white, forming a broal bar across wing; hreast pale brown: rest of under 
surface white, washel with brownish on flanks. Natal plumagc: Ground color of head buff, larkest and most reddish on foreheal and erown; narrow stripe from bill to eye, and broal stripe on pach sicle of crown black; eye region whitish; bill yellowish, dark at tip; back a mixel flattern of llack, rerlish buff and white; elin, throat and breast buff; belly whitish; flanks washed with luff; legs and feet (dried) yellowish brown.

MARKS FOR FIELD IDENTIFICATION-Small size, chunky form, absence of spot. ting, streaking or barring on under surface, white bar across wing, under surface chiefly redlish brown in spring, with white rheek-pateh, mixed white and dull red in fall, and pure white in winter; nerk short and thick (thirker than in Northern Phalarope); wings not markelly different in color from back; spenils much of time swimming on water, anil, within our borlers, is rarely if at all, found feeding on shore; "spins", about rapidly from time to time while feeding on surface of water.

VoICE-A low and musical clink, clink (Nelson, 1887, 1. 97).

Nest-Close to or in near vicinity of small fresh or brackish jools; commonly only a mollerate depression in damp ground, without lining, or else a rather leep depression sunk in the top of mossy hummoek, with a thin lining of dry grasses (Nelson, loc. cit., and Grinnell, 1900, p. 20).

EgGS-3 to 4 , pear-shajerl, measuring in inches, 1.07 to $1.33 \mathrm{ly} 0.55$ to 0.90 (in millimeters, 27.2 to 33.8 by 21.6 to 22.8): grounil-color greenish olive, light or dark buff, or cven a grayish olive with large or small markings of dark brown, sometimes aggregaterl about the larger end forming a zone of lark color, or else rather evenly distributed over the whole egg; thffer from eggs of Northern Phalarope only by slightly larger average size (authors).

Gexerai, distribution-Almost worli-wide. Breeding range circumpolar; in North America extenils north to Ellesmere Land, Melville Island, anit Point Barrow, and south to St. Michael, Alaska, central Mackenzie, rentra] Keewatin, Hudson Strait, and southeru Greenland. Winters in Eastern Hemisphere south to Moroceo, India, China and New Zealand. In Western Hemisphere probably winters in large part on southern oceans. Common offshore in both migrations on Atlantic eoast from Newfoundland to vicinity of Massachusetts, but not known between that region and coast of Argentina. Common at times, chiefly during migration, on Pacific roast from Alaska to southern end of Lower California, and again off coast of Chile (Cooke, 1910, pp. 14-16).

Distribution IN CALIFORNiA-Abundant transient along the seacoast during both migrations. Northward spring migration lasts from late April to early June. Southward migration lasts from first of August to late November or early December. A few stragglers have been taken near Monterey in December and January (Beck, 1910, p. 70), and some probably winter around the Santa Barbara Islands and off the coast near San Diego. Recorded inland only at Stockton, one specimen, October 10, 1590 (Belding, MSS), Pasarlena (Grinnell, 1895, p. 16), and Los Angeles (Willett, 1912a, p. 34).

The Red, or Gray, Phalarope is the most maritime of the three species of phalaropes and for that reason comes under observation of fewer persons. The migrating flocks begin to pass northward about the last of April, and from that time to the first of June (in two cases June 3 ), the species is abundant in the bays along our coast and on the adjacent ocean. The return migration sets in early in Angust (earliest instance Angust 2) and lasts at least throngh 
October. The November and December records of this species probably indicate that some individuals winter on the ocean off the southern California coast and even as far north as Tomales Bay. The colleetion of the California Aeademy of

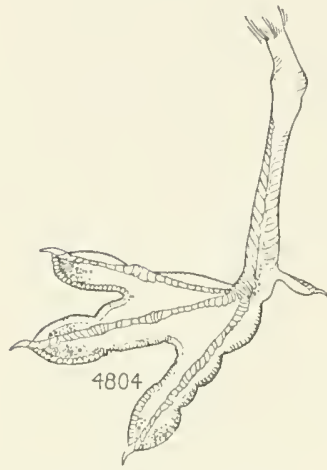

Fig. 56. Side of tarsus and top of foot of Red Phalarope. Natural size.

Note webs between hases of toes anil lobes on margins of toes. Sciences contains fifteen specimens taken at Monterey during December and January (Beck, 1910, p. 70). In this respect the Red Phalarope differs markedly from the Northerr. At the height of the migrating season the former species is exceedingly abundant offshore, sometimes oecurring in flocks believed to number thousands of individnals.

In breeding plumage the Red Phalarope can be easily identified by the uniform dull cimnamon red of its under surface, and the eonspicuous white patches on the sides of its head: but in the fall identification is not so easy. From the Northern Phalarope the Red may then be distinguished at a distance only with some difficulty, by its thicker neck, heavier bill (fig. 57), and chmokier appearance. From many of the shore birds it may be told by its small size and dense duck-like plumage, and from other's by its rather thick head and neck, tawny upper tail coverts, and by lack of streaks, bars or spots on the under surface. Often,

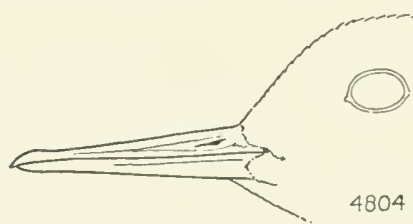

Fig. 57. Side of bill of Rerl Phalarope. Natural size.

Note somewhat stouter form as rompared with bills of other Phalaropes (eompare with figs. 58 anil 59$)$. especially early in the fall migration, the plumage of the under surface is mixed red and white, but never with a definite pattern.

The note is described as a low and musical rlink, clink, sounding very much like the noise made by lightly tapping together two small hars of steel. When the birds are disturbed the note is repeated oftener and becomes harder and louder (Nelson, 1887, p. 97).

In our latitude this species is noted most commonly on the surface of the water, nsually on the ocean, eithes resting quietly or else actively whirling ahont and dabbing the bill rapidly into the water from sicle to side after the small forms of animal life on which the birds feed. On rongh water the birks often take wing to avoid eurling waves, alighting immediately on smoother water. Streator (188s, p. 5t) saw numbers of these Phalaropes standing on floating kelp near San Nicolas Island; and individnals are not infrequently seen 
stancling or Walking on mul flats or the seabeach close to the smrf. Dawson says (1911, p. 178) that when feeding, they work at the rate of 300 dabs per mimute and that the exerement is voided at two or three minnte intervals when so feeding.

Mc(iregor (1898, pp. 87, 88) says coneerning the habits of the species as a visitant along the coast of ('alifornia:

... I have repeatedly seen them in deep water feeling and swimming. ... Near San Diego the Rel Phalarope remains all winter at times and swims about on the "ticle slicks" feeding . . [and] swimming nervously here and there with a peeuliar jerky movement [of the hear] ... [At Santa ('ruz it was] busily feedling, gathering as I afterwarls found, small erustacea from the surface of the water. As 1 attempted to approach them the whole flock arose and circling rapilly for a few seconds lit again a long way off. Another time, apparently forgetting my presence, they would light only a few feet from their starting place. ... The hearl moved as if on a spiral spring and foorl was serured by quick labs at the surface of the water. I found their time was spent either at the elge of the salt water, or, as likely in swimming on small brackish lagoons, just baek of the sand beaches. . . In the Bay of San Diego they are often seen, and a flock of eight or nine Red Phalaropes was seen in Lower California on a fresh water lagoon some twelve miles from the roast. This was the midlle of April and several showed real blotches on the white plumage...

The Phalaropes usually feed near the water's erlge when they are not actually in the water. Not a moment is lost as they run hurrielly back and forth, now following a reserling wave to eateh a helated II ippa and again industriously turning over leraying algae in order to capture the small crustaceans (Orchestia) which are... lurking there.... They feerl on minute particles of animal matter. .. . [One] may approach to within a few feet of a feeding flock, perhaps, but crymophilus $[=$ Phalaropus $]$ is notional and if you get too near, away goes the whole flock as a single bird, with no warning that we cau detect. A killed or erippled Phalarope is almost sure to decoy the remainder of the flock. ... Whether on the wing or running along stretches of white sand beach or whether rapidly paddling over the water, the Phalarope is always neat anil careful of its snowy feathers.

In northeastern Greenland, Mammiche (1910, pp. 152-159) improved an excellent opportunity to leam something of the habits of this Phalarope. Of a pair seen June 19, 1907, he says:

At first they were entirely occupied in searehing for food. Swimming on the water and going amongst the tufts they eagerly hunted for gnats and larvae... They caught the larvae by swimming swiftly with the neck stretched out towards the selected prey. They would often keep the bill vertically and-recomoitring the water just in front of them-pick up the prey ... with the greatest dexterity. Between the tufts the Phalaropes would especially hunt flying insects. [They were evidently afraid of the larger shore birds such as, for instance, Knots.] Several times I saw them rush together in terror and lie motionless on the water with their heads pressed down to their backs until the supposed danger-a passing Knot-was past. ... 
When the Red Phalarope first arrives on its breeding grounds in the far north, during the latter part of May or the first few days of June, floeks of fifty or more individuals are the rule. A little later the birds pair off, but are still to be found associated together and feeding in scattering companies on the slightly flooded grassy flats. A vivid deseription of their behavior at this season was secured by Nelson (1887, p. 97) in western Alaska, and is as follows:

A little later in the day, as their hunger became satisfied, they began to unite into parties until fifteen or twenty birds would rise and pursue an erratic course over the flat. As they passed swiftly along stray individuals and pairs might be seen to spring up and join the flock. Other floeks would rise and the smaller coalesee with the larger until from two to three or even four hundred birds were gatheres in a single flock. As the size of the flock increased, its movements became more and more irregular. At one moment they would glisle straight along the ground, then change to a wayward flight, back and forth, twisting about with such rapidity that it was diffieult to follow them with the eye. Sudilenly their course would change, and the compact flock, as if animaterl by a single impulse, would rise high overhearl, and, after a series of graceful and swift evolutions, come sweeping down with a louil, rushing sound to resume their playful course near the ground. During all their motions the entire flock moves in such unison that the alternate flashing of the under sides of their wings and the dark color of the back, like the play of light and shade, makes a beautiful spectacle. When wearier of their sport the flork dishands and the birds again resume their feeding.

The nesting habits of all the Phalaropes are peculiar in that the male performs most of the duties in other birds alloted to the female. In complementary fashion it is the female that does the conrting. From his observation of the Red Phalarope in northeastern Greenland, Manniche (1910, pp. 153-154) writes:

When the male had been eagerly searching fool for some twenty minutes, often standing on his hearl in the water like a iluck to fish or pick up something from the bottom, he would lie down on a tuft stretehing out his one leg and his one wing as if he would fully enjoy the rest after his exertions. The female for some moments was lying quietly and nutely in the midile of the pool; sudrlenly she began with increasing rapidity to whirl around on the surface of the water always in the same little circle, the diameter of which was some $10 \mathrm{~cm}$. [21/2 inehes]. As the male seemed to pay no attention to her alluring movements she flew rapilly up to him-proilueing as she left the water a peculiar whirling sound with her wings and uttering short angry cries-pushed him with her bill, and then she returned to the water and took up her swimming dance. Now the male eame out to her and the two birds whirled around for some moments equally eager and with increasing rapidity. Uttering a short eall the female again flew to a tuft surrounded by water and waited some sceonds in vain for the male: again she flew to the water to induce him with eager pushes anl thumps to accompany her. They again whirlerl violently around, whereafter she, uttering a strong alhining sound flew back to the tuft this time arcompanied by the male-and the pairing immediately took place. 
While the Red Phalarope remains in northern latitudes for a longer period than does the Northern, usually from late May to the middle of Oetober, the nesting period is quite restrieted. Nelson (loe. eit) found that the bulk of the speeies nested at St. Mielael during the first two weeks of June, while Grinnell (1900, p. 20), just north of Cape Prinee of Wales, found slightly ineubated eggs on June 27 and 28 .

The species varies somewhat in its nesting habits, aceording to Nelson and Grimmell, the nests sometimes being situated elose to bodies of water and at other times at eonsiderable distances from water. The nest itself is a slight depression in the top of a grassy hmmmock or on the surface of the bare ground, usually with a sparse lining of dry grasses or leares. In some cases the nest is rather well eoneealed behind drooping grasses or willows.

Manniche (1910, Pr. 15t-155) says that in northeastern Greenland

... the nest hnilding was executed by the male. He was busy in build. ing the nest on a low bank covered with short grass, while ... [his mate] paid no attention to his lahour, but swam around the beach searching food.

The male shaped a nest-hollow hy turning romm his horly against the ground on the place selected, laving first by aid of the feet scraped away and trampled down the longest and most troublesome straws. He diligently used feet and bill at the same time to arrange the shorter fine straws, which are carefully bent into the nest hollow and form the lining of this. The nest was much smaller than that of Tringa alpina and contained one egg the next day.

A brooding "Phalarope will lie motionless with his head pressed deep down against his back. He is almost fully covered by straws, which surround the nest, as he with the bill bends these over himself; besides he is so similar to the surroundings, that no human eye is able to distinguish him from these, if the spot is not known beforehand" (Mamniche, loe. eit.). If disturbed, the male will perform the broken-wing ruse used by females of other species in decoving an intruder from the vieinity of the nest.

Three or four pear-shaped eggs comprise a full set in the Red Phalarope. They measure in inehes from 1.07 to 1.33 by 0.85 to 0.90 . The ground-color is a greenish olive, light or dark buff, or even a gravish olive. The markings consist of large or small spots of dark brown, sometimes equally erowded over the entire surface. They are to be distinguished from those of the Northern Phalarope only by slightly larger average size.

The period of incubation is not known but probably is about three weeks, as Nelson (1887, p. 98) states that ". . . toward the end of June most of the young are hatehed and, by the mitdle of July, are on the wing." The young, when they are able to fly, form floeks in 
company with the adults. Whether these mixed flocks break up during migration is not known; but the extensive series of this species obtained by Mr. R. H. Beck for the Museum of Tertebrate Zoology at Monterey in Angust, 1910, does not contain a single immature bird. So far as we can determine all are adults, and the males and females are about evenly divided as to numbers.

Some of the food of this species has been indicated in the foregoing account, as quoted from MeGregor. Beck found the birds at Monterey in 1910 feeding, as he supposed, upon small jellyfish which were numerous along "slicks." This is unusual as most of the food of the species is probably made up of small crustacea. The forage grounds include brackish ponds, as well as the kelp beds and tide slicks ("whale grease") of the open ocean.

This phalarope, as in the case of some of the other smaller shore birds, has been killed in considerable numbers by flying against telegraph wires where strung out across a marsh. For instance, near Alameda, May 15, 1896, fonteen individuals were found dead, having been killed in this manner (Cohen, 1896, p. 15).

The Red Phalarope, being a more maritime species than either of the other two, and than most of the shore birds, has probably suffered but little diminution in its numbers. The fact that its breeding range is in the extreme north, farther toward the pole than either of the other two species, has probably also contributed to its protection. It is a small species, not worth the shot of the hunter, important neither as a game bird nor economically.

\section{Northern Phalarope}

\section{Lobipes lobatus (Limnaeus)}

Other Nayes-Mono Lake Pigeon; Lohefoot; Sea-goose; Phalaropus lobatus: Phalarouus hyperboreas; Lobipes hyperboreus.

Description-Adult male in spring and rarly summer: Top of hear and hind neck, dull sooty brown, the feathers with or without whitish or brownish tips; spot in front of eve, whitish; uper and lower eyelids white; sometimes a dull whitish spot behind eye; chin and npler throat pure white; bill black; iris "darkbrown" (Aububon, 1842, Y, p. 298); pateh on each sirte of neek bright rusty brown; bark sooty brown, feathers widely margined with light luffy brown, and extreme elges white until lost by wear; upler tail coverts lull lark brown or blackish with narrow light brown erlgings: tail feathers blackish, lateral ones lighter and margined with white; onter surface of -losel wing sooty hrown, except for tips of greater coverts and hases of secondaries, which are white; in unworn condition there are slight white tippings on rest of eoverts; shafts of outer primaries light luff to white; elongated tertials more brown in tone than rest of wing: axillars and most of lining of wing white; bend of wing heneath mottleal with dusky; under surface of flight feathers lusky, shafts white; lower throat and breast grayish 
brown with feathers more or less white tipped and central portion of the area more or less suffused with rusty brown; rest of under surface white; feathers of sides and flanks with dusky shaft streaks; feet dusky with pale webs. Total length $6.40-7.75$ inches $(163-197 \mathrm{~mm}$.) (ten specimens from California); folded wing 4.04-4.35 (102.8-110.5); bill along culmen 0.79-0.93 (20.023.7) ; tarsus 0.75-0.84 (19.7-21.5) (ten specimens from California and Alaska). Adult female in spring and early summer: Like adult male in correspouding plumage but with bright rusty brown on sides of throat deeper in tone and more extensive, reaching farther around toward middle of ehest, and running down outer edge of scapulars as a duller streak; top of head, hind neck and back, nearly uniform slate, with a longitudinal buffy brown stripe on scapulars of each side; rump and upper tail coverts nearly black; general color of wing blackislı. Total length $7.37-8.00$ inches $(187-203 \mathrm{~mm}$.) (ten specimens from California); folded wing 3.91-4.29 (99.2-109.0); bill along culuen $0.84-0.96$ (21.4-24.4); tarsus $0.76-0.86$ (19.2-21.8) (ten specimens from California and Alaska). Adults, both sexes, in fall and winter: Head and whole lower surface white, except for spot of dusky just below and behiml eye; lack and seapulars pearl gray with broar white feather margins; wings as in summer, save as modified by wear. Most late summer birds observed in Califormia are in mixed, transitional plumage, from summer to winter. Juenile plumage: Similar to summer plumage of adult male but with hrown of nerk and throat wanting, grayish brown of chest and sides replacel by lale drab, and edgings of seapulars and tertials bright rusty brown. Natal plumage: Ground color of upper surface, sides and chin, tawny, paler on lower bark and chin; white spot over eye; stripe from sirle of bill to eye, dusky; top of hearl striper with black and tawny; ear region, millle of hind neck and side of neck, black; a median stripe, and two lateral ones on each side of bark, black; throat suffused with tawny, fading to dull white on unler surface, which is in turn replacer by drab in the region of the vent; feet (dried) yellowish.

MARKS FOR FIELD IDENTIFICATION-Small size, neelle-like bill (fig. 58), slenter head and neck, white under surface, and, in summer plumage, absence of conspicuous streaking or baring on back of head and back, and redish sides of meck. Frequents open water, either salt or fresh; swims gracefully ancl with quick movements. Among Phalaropes, distinguished by smaller size, short, slender bill, dark rump, and in summer plumage by blackish bearl and back. The phalarope most commonly met with on inland waters.

Vorce-A plaintive "pē-èt, pē-ēt," or "pleep, pleep,", or "wit, wit." As the birds take wing from the water, these notes may be uttered at intervals of one or two seconds.

NEsT-On banks of sloughs or near shores of small lakes; a depression moliled in grassy sol and situater on top of a small lrummock; sometimes a small collection of marsh grass, but arranged with little care.

EgGs-3 to 4, pear-shaped, measuring in inches, 1.10 to 1.30 by 0.75 to 0.85 (in millimeters, 28.0 to 33.0 by 19.1 to 21.6), and averaging 1.20 by 0.82 (30.5 by 20.8); ground color greenish-olive, light or dark buffy, or even gravish olive, with either large or small markings of dark brown, sometimes aggregated around larger end to form a dark zone, or else rather evenly distributed over the whole egg (authors). Slightly smaller and less coarsely or deeply marked than those of the Red Phalarope.

General distribution-Both hemispheres. In North America breeds from northern Alaska, Melville Island and central Greenland, south to the Aleutian Islands, valley of the upper Yukon, northern Mackenzie, central Keewatin, 
and northern Ungara; in the Olil World from the limit of tree growth north to the Arctic coast. Winter range in Western Hemisphere unknown, but probably on ocean south of equator; in Eastern Hemisphere winters in northern tropics. During migration oceurs in almost all localities between breeling and winter ranges (Cooke, 1910, pp. 16-18; A. O. U. Check-list, 1910, pp. 107108).

Distribution in CALiforaia-Spring and fall migrant coastwise, less common in the interior. Occurs abundantly both in northward migration in May (extreme dates May 1 and June 19), and in southward migration from late July (earliest, the 11th, at Monterey) to late October (November 16, latest at Santa Barbara). Stragglers may winter within the state, as suggested by the records from Humbolit Bay (C. H. Townsend, 1887, 1. 198); Stockton, in January (Belding, MS); and San Diego (McGregor, 1895, p. SS). Interiorly, in spring migration seems to keep to west side of San Joaquin Talley (east to Fresno), but in fall migrates lown Sierras (Lake Tahoe) to southern San Joaquin Valley and western sille of Mohave Desert.

Among the shore birds there are none more dainty, more unsuspicions and more entertaining than the Phalaropes, of which the Northern is the smallest and most widely known. With its nesting range eentering almost on the Aretic Cirele and its winter home somewhere in the vast expanse of the Southern IIemisphere, the Northern Phalarope presents one of the most interesting problems in migration. Among the fishermen of the North Pacific Oeean these birds together with the Reel Plialaropes are known as "Bow-head Birds" by reason of their feeding on the same small marine animals as the bow-head or right whale. They are also known in these regions as "Sea Geese" because of the ereet posture of their head and neek while they are on the water. East of the Sierras in the region of Mono Lake they have been ealled "Mono Lake Pigeons." Writers have also referred to them as "Lobe-foots," a name which ther might appropriately share with the other two phalaropes.

Northern Phalaropes begin to appear off our eoast by the first day of May, becoming abundant by late May or early . June from whieh time on they rapidly deerease in number's until about the middle of the month when they disappear. Dawson $(1916$, p. 25) records seeing five on Goose Lake, Modoe County, June 24, 1912. As with many other shore birds the breeding season of the Northern Phalarope is exeeetingly short, the great bulk of the individuals beginning to nest within a fer days of one another. This aecounts for the fact that barely five or six weeks elapse between the time that the last of the north-bound migrants disappear in June, and the time when the advance guard of the south-bound host reaches our latitude in the latter part of July. From this time on, the speeies increases in abundanee; its numbers are maintained during August and September, after which time it again beeomes rare. The last of the birds disappear' by late Oetober or early November. The few records of birds having 
been seen within our bonntaries during the winter season are probably cases of stragglers that have been drached from the migrating floeks. The winter' home of the species is not definitely known but it is believed to be the open oeean south of the equator and the birds are thonght to feed and sleep on the water during the winter months (Coolie, 1910, p. 16).

The Phalaropes as a group may be distinguished as the only wading hirds which habitually swim or rest on the smrface of the water. 'This, coupled with the prenliar whing motion, characteristic at least of the Red and Northern, will serve to identify them on the water. In flight their small size, direet comse, and eolor markings must be depended mpon. The Northern Plualarope may be distinguished from the Wilson by its smaller size, and, in the breecting season, by the relatively larger amount of redish on the neck and throat. From the Red it may be distinguished in the breeding season, of comrse. by the restrietion of recldish to the neck and throat. but in the fall and winter phmage chiefly by its smaller head and extremely slender neck (Torrey, 1913, pp. 52, 53).

The Northern Phalarope is at nearly all times of the rear a gregarions species especially in feeding and migrating. Even

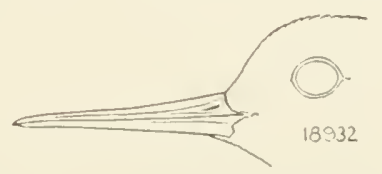

Fig. 5s. Sille of lill of Northern P'lalarope. Natural size.

Note slender form, and length uniler 1.00 inch (compare with figs. 57 and 59$)$. when nesting, pairs remain in the near neighborhood of one another. While it resorts to the shores of inland ponds or streams to nest and may sometimes be found in such loealities at other seasons of the year, it spends the greater part of the year in the vicinity of or on salt water. At times this bird associates with the Red Phalarope, oeeasionally in large numbers, especially while out on the ocean, as for example near Monterey. It may also join with some of the sandpipers in feeding, but the speeies is more commonly found in floeks eontaining only those of its own kind. The eall-note of the adult Northern Phalarope may be deseribed as a plaintive pleet, plert, or pert, pect. It is also credited with a note resembling wit, wit, wit (Samnders, 1899, p. 568).

During the breeding season and to a less extent during migration the Northern Phalarope feeds along beaehes or in muddy creeks at low tide, but it spends most of its time on the water, either while resting or feeding. When on the water the birds have a habit of whirling about rapidly. On this aeeount they have been given the name of "whirligig birds." This movement is evidently for the purpose of bringing to the surface some of the minute animal life which serves as food, and the movement is used most effectively in shallow 
water where the rotating motion produced by alternate movement of the lobed feet creates a little whirlpool. This whirling is maintained at a rapid rate, and from three to forty revolutions may be made without stopping. As a bird rotates, the bill is rapidly dabbed down into the water, at a rate in some eases of 150 dabs per minute. Evidently the suceess of this method depends upon the light eonditions because little or no "whirling" is noted on clondy days (Bowles and Howell, 1912, p. 67). On their breeding grounds these birds have been obselved to dart in zigzag fashion along the margins of the pools in their seareh for food (Nelson, 1887, p. 99).

The nesting season of the Northern Phalarope is exceedingly short, a point which was mentioned in eomection with their reappearance in Jume and July along the California coast. Extreme nesting dates available are June 11, 1908 (Dixon. MS), and June 30, 1899 (Grinnell, 1900, p. 21). Nelson (1887, p. 99) states that fresh eggs are rarely found after June 20.

In North Ameriea this species nests throughout most of the northern half of Canada and Alaska on the banks of ponds or streams near either fresh or salt water, seeming however to prefer the former. The nest itself may eonsist of a small collection of marsh grass, sometimes arranged on the top of a tussock of moss, or more eommonly on the level surface. Little or no eare is shown by the birds in constructing the nest. Grinnell (loe. eit.) deseribes nests in the Kotzebue Sound region as being ". . neatly moulded depressions in the grassy sod, usually on a hummoek at the side of a pool of water. There was no lining exeept that formed by the broken-down grasses underlying the nesting eavity."

The eggs of the Northern Phalarope usually number three or four, sets of the latter number being much the more common. Turner (in Macom and Macom, 1909, P. 159) is authority for the statement that five eggs sometimes eomprise a set. "The ground [color"] raries from dark greenish-olive or brownish-olive, through various lighter drabtints, nearly to a buffy-brown, and in one instance to a light grayishdrab. The markings are usually very bold and heary, eonsisting of large spots and the still larger splashes produced by their confluenee, mingled with dots and seratehes in interminable eonfusion. The markings are, in general, pretty evenly distributed, sometimes aggregated about the butt, and in rarer instanees forming a complete, definite circle. In a few instances all the markings are mere dots. In general, the heaviness and size of the markings bear some proportion to the intensity of the gromul-eolor. The color of the markings is łark bistre, chocolate, and sometimes still lighter brown" (Coues, 1874$, p. 471$)$. The eggs measure in inches 1.10 to 1.30 by 0.75 to 0.85 , and average $1.20 \mathrm{by} 0.82$. The eggs of the Northeru are said to be 
indistinguishable from those of the Red Phalarope, save that the latter arerage slightly the larger.

When a person approaches the nest of a Northern Phalarope, the sitting bird slips quietly from the nest while the intruder is twenty yards or more away, and flies to the surface of a nearby pond where it commences feeding unconeernedly, giving the impression that there is no nest in the vieinity. At other times the bird will employ the broken-wing ruse and other taeties common to nesting birds. During the nesting period the adults remain elose around the nest site; when foraging they follow one another about attentively. Aecording to different authors the male of this speeies does half or all of the work of ineubation. Indeel, exeept for the primary function of laying eggs, the male performs all or most of the duties assumed by the female in other speeies of birds. As a result of the low swampy nature of the ground chosen for the nesting site many of the nests are at times immolated by high tides and the eggs destroyed (Grimnell, loe. eit.). By the latter part of July (20th to 27 th $)$ the young are fully fledged and on the wing, feeding with the adults.

The fall molt seems to extend through a eonsiderable portion of the period from July to September. At least among the many specimens taken in the fall along our coast varying conditions of the plumage are shown, though not one is in full winter plumage.

While often appearing in great numbers on the ocean during migration, the flocks are smaller on fresh water inland, perhaps thirty individuals being the average number found in a flock. The flight is usually quite direet, withont the zig-zag movements of the sandpipers, but at times it is erratic.

Heary winds on the ocean sometimes prove disastrons to the migrating hosts of Northern Phalaropes. Chapman (1905, p. 273) records finding many bodies of this speeies in the tide pools of the Farallon Islands. A heary northwest wind had been blowing along the coast for the previous two weeks and many of the birds had resorted to inland pools of water. The emaciated eondition of the birds at the Farallones was probably due to their inability to procure food while on the open ocean in migration. Forbush (1912, p. 228) records numbers of these birds as being killed on the Atlantic coast by dashing against lighthouses at night. In the Cape Region of Lower California, Brewster (1902a, p. 59) found that "most of the birds examined had lost one or mole toes, and two or three an entire foot, and part of the tarsus, also, while others showed gaping wounds on the breast. These mutilations were probably caused by the bites of fishes." Emerson (1904, pp. 37, 38) reeords finding several of these birds killed by flying against the telephone wires strung across the salt ponds on the marshes west of Hayward, and says that very many of this and other speeies of birds are killed in this manner. 
The Northern Phalarope feeds chiefly, although not exclusirely, on aquatic forms of animal life: Aquatic worms (including Nevis. the oyster-worm), crustaeea, such as small shrimps. larvae of aquatic insects, flies, especially those species which inhabit the surface of water, salt-marsh mosquitoes, crane flies. grasshoppers, clover-root cureulios, wireworms, elick beetles, and water bectles (Dytiscidae) (McAtee, 1911a).

It is a mistake to refer to the Norther"n Phalarope as a "game hird." Its small size, if nothing else, shonld remove it from the list of sprecies reckoned as objects of pursuit for food or sport. This, compled with the fact that its food habits, when it resorts to nonaryuatic forms of life, make it beneficial to our agrienltural interests, should be suffieient ground for placing it in the category of permanmitly protected shore birds.

\section{Wilson Phalarope}

\section{strganopus tricolor Vieillot}

Other Names-Needle-billed Snipe; Phalaropus tricolor; Phalaromus wilsoni.

DEscrIPTION-Adult male in spring and summer: Top of heal anl stripe from base of bill throngh eve to ear region, dull blackish brown; forehcad sometimes suffused with grayish white; stripe over eye, lower eyelir, spot on hind neck, chin, upler throat and lower portion of cheek, white; area behind ear region black, sometimes suffusel with rendish; bill black; iris brown; upper surface except rump and upper tail coverts ilull dark brown, mans of the feathers with lighter margins, and some marker with rusty; feathers of hind neck slightly washed with white; rump feathers drab, tipper with white; upper tail coverts with light drab shaft streaks and white shafts and margins; outer surface of closed wing uniform dnll dark brown; primaries blackish, sliaft of outermost one white; bend of wing mottled white and light brown; inner surfaces of flight feathers light grayish brown, shafts white: lining of wing and axillars, white; sides of hind neck dull redilish; throat and fore-chest abruptly light buffy, more whitish near milline and farling to light drab on lower chest; sides and flanks pale drab, many of the feathers with rlusky shaft streaks and dull whitish tips; rest of lower smrface white: legs and feet black. Total length " $8.25-9.00$ ", inches (210-228 mm.) (Ridgway, 1900, p. 145); foliled wing 4.60-4.92 (117-125); bill along almen 1.08-1.22 (27.5-31.1); tarsus 1.171.29 (29.7-32.5) (seven specimens from California and Nevala). Adult female in spring and early summer: Top of head forwart to uluer base of bill pearl gray: conspicuons stripe through eye and continuing more broally down sicle of hind neck, black; short, black-bordered stripe above and in front of eye white; lower cyelic, chin, upper throat and lower portion of cheek, white; bill black: iris brown; miltle of hind neck light grarish or white; sile of hind neck behind black stripe, and onter margins of seapnlars, deep cinnamon red: back otherwise shading from light gray on hind neck through deeper slate gray to dull brown on lower back and rmmp: upler tail coverts white, the longer feathers irregularly marked with dusky: middle tail feathers light drab with white tippings, lateral ones light drab with increasing amonnts of white 
irregularly distributed; onter surface of elosed wing uniform dull dark brown; primaries blaekish; shaft of ontermost primary white, of the rest light brown; some of secondaries narrowly margined with white; axillars and lining of wing white; benil of wing mottled white aml light brown; under surfaces of tlight feathers light gravish brown with white shafts; lower throat and upper part of ehest abrujtly tawny, darkest toned at silles, naling on hreast, siles aul flanks; rest of under surface white; feet and legs black. Total length " $9.40-10.00$ ', inches (239-254 mm.) (Rilgwar, loe. eit.); folderl wing 4.97-" 5.29 (126.6-124.3); bill along eulmen 1.25-1.39 (31.\$-35.2); tarsus 1.19-1.32 (30.1-33.6) (ten specimens from California and Nevada). Adults and birds of the ycar, both sexes, in late summer, fall and winter: Forehead, side of head, stripe above eye, and whole under surface, white; top of heal, stripe through eye, hind neck, and whole back, brownish gray with minute white feather tippings; upper tail coverts ehiefly white: wings and tail as in adult in spring; sicles of throat, chest anıl boly, faintly washel with light gray. Jucenile plumage: Upper parts blackish, the feathers extensively margined with light rusty, giving a streakel effeet; rhin anil area around eve, whitish; bill black, rellowish at base of lower mandible; iris light brown; throat anil siles of chest washed with ilull buffy; siıles bufly, olsseurely streakel with blackish; rest of under surface dull white; legs flesh-color: feet rellow; nails black. Natal plumage: "Prevailing eolor bright tawny fulvous, paler beneath, the ablomen nearly white; oceiput anil nape with a distinct median streak of black, on the former branching laterally into two narrower, somewhat zig-zag lines; lower back and rump with three broal black stripes; flanks with a black spot, and eandal region erossed by a wide subterminal har of same" (lBairl, Brewer and Rilgway, 1884, I, p. 336).

MARKS FOR FIEID IDENTIFICATIOX-Morlerate size, sleniler neck, long neellelike bill (fig. 59), and white upjer tail coverts; no spotting, streaking or barring on under surface, no white on bark, aml no white bar or pateh on wing. The other two Phalaropes have white on hack, and white bar or patch on wing. An inland species rarely if ever found along the sencoast.

Vorce--A nasal oit, oit, oit (W. P. Taylor, 1912, p. 359), or soft trumpeting yйa, yйa (Chapman, in Forbush, 1912, 1. 229).

NEST-In marslyy or grassy land at varying distances from water; a small aggregation of grass or selge with a slight depression in the eenter, or else merely a slight depression in the surface of the ground with a sparse lining of grass blades.

EGgS-3 to 4, pear-shaped. measuring in inches, 1.25 to 1.33 by 0.92 to 0.94 (in millimeters, 31.7 to 33.7 by 23.4 to 23.8 ), and averaging $1.28 \mathrm{ly} 0.93$ (32.6 by 23.6) (two sets, seven eggs, from Nevada and Colorado); groundcolor light buff to very light drab; superficial markings dark brown or brownish hark, deep ones pale olive or light brown; markings chiefly spots, the larger ones aggregated about larger eni of egg, smaller ones profusely sprinkled over whole surface.

General Distribution- North and South Ameriea. Breeds from northern Washington (and probably southern British Columbia), eentral Alberta, eentral Saskatchewan and northern Nanitoba, east to northwestern Indiana (and jrobably eastern Wiseonsin), and south to central Iowa, southern Kansas, sonthern Coloralo, and northeastern California. In fall migration reaches the Atlantie coast casually from Maine to New Jersey, and Pacific coast from southern Britisl, Columbia to Lower California. Winters in South Ameriea from central Chile and eentral Argentina sonth to the Falkland Islands (A. O. U. Check-list, 1910, p. 108). 
DISTRIBUTION IN CALIFORNIA-Fairly common summer visitant and breerler in suitable localities in the northeastern section of the state, east of the Sierran divide, from Lake Tahoe northward, and westward to lıower Klamath Lake on the Oregon line. In spring migration has been observen at various inland points north to vicinity of Los Baños, Merced County; also on the coast at Santa Barbara. In fall migration oceurs sparingly on coast from Sau Francisco southward, but more commonly inlanı.

The Wilson Phalarope, or Needle-billed Snipe as it has been ealled in parts of the east, is the non-maritime representative of the phalaropes, and is the only strictly Ameriean member of its family. It is a distinctly fresh water species in its habits and is seen but rarely even near the seacoast. In the spring migration it has been observed inland at Salton Sea (April 21), Los Baños (May 11 and June 19), Death and Owens valleys (June 19

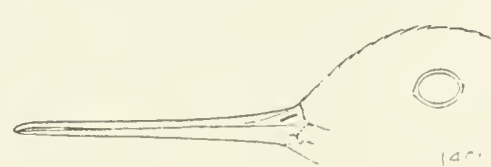

Fig. 59. Side of bill of Wilson Phalarope. Natural size.

Note extremely slender form (whence the name "Needle-billed Snipe"), and length over 1.00 inch (rompare with figs. 57 and 58). and 27), and, on the coast, at Santa Barbara (April 30 to May 20). In the fall it has been taken at Cemeteries, San Mateo Comnty (September 9 ), and has been noted at Santa Barbara (July 22 to September 8), and, in the southern mountain ranges, at Buar Lake, San Bernardino Monntains (July 28 to August 2), and Hemet Lake, San Jaeinto Mountains (August 11). One speeimen is reported as having been taken at Riverside in the "winter of 1891 " (Heller, 1901, p. 100). It is possible that the speeies breeds in the San Joaruin Valley, as at Los Baños (Chapman, MS; Mailliard, MS), and at Tulare lake (Goldman, 1908b, p. 203).

After the breeding season this bird wanders abont extensively, and the records on the Atlantic coast are doubtless dne to this propensity to wander. It is eertainly nowhere sueh an abundant speeies as the two maritime members of the gromp. Wnlike the other two speeies of plalaropes the Wilson rarely associates in large flocks, and when nesting only a few pairs are ordinarily to be found in a given locality.

From the other two phalaropes the Wilson may be distinguished by its large size, long neek, long needle-like bill (fig. 59), white upper tail coverts, and by the absenee of white on its back and wings in all plumages. From other shore birds it may be distinguished by the combination of its swimming propensity and moderate size, with straight and extremely slencler bill, slender head and neck, nmmarked under surface, and absence of a white bar or pateh on its wing.

The call-note of the Wilson Plalarope has been varionsly described by different authors. Forbush (1912, p. 229, eiting Chapman) 
deseribes it as a soft, trumpeting yñ, yna, and Chapman (1912, p. 241 ) gives it as a soft qua or quok. W. P. Taylor (1912, p. 359), who observed the species in northwestern Nevada, describes the note as a nasal oit, oit, oit, somewhat resembling the croak of a toad during the breeding season. "At the instant of utterance of the note the birel which is ealling raises its head somewhat, pauses momentarily in its flight and its throat bulges slightly. The females ... evidently uttered most of the call-notes" (W. P. Taylor, loe. cit.).

This phalarope differs from the other two speeies in spending less time swimming upon the surface and more of its time wading along the shores or banks of pools and streams where it gleans its food in much the same manner as the non-swimming shore birds. Beeanse of this, individuals of the species have been mistaken for Western Solitary Sandpipers. Wilson Plualaropes are usually quite tame and will allow themselves to be closely approached. At times they swim buoyantly upon the surface of the water, but seldom for a long time or very far from the shore. They rarely if ever dive, and when frightened eseape by flight. Therir flight is strong and takes a zig-zag course when they are alarmeel, but in the absenee of danger it is stower and more direct (Goss, 1891, p. 151). When feeding on the surface of the water they have been oceasionally observet to whil and bob up and down much as do the ofher phalaropes. They have also been sem to stalk and capture insects on a muddy flat (W. E. Bryant, $1893(a$. p. 55).

In California the Wilson Phalarope breeds during the month of June, and as far as is now known, only in the platean region east of the erest of the Sierra Nevada and northward from the vieinity of Lake Tahoe. Its reporter breeding in the San Joaquin Valley (Los Baños) has not been substantiated by the discovery of either eggs or downy young there. It lias been found (Ray, 1912b, p. 145) nesting at Lake Tahoe as early as . June 4 (set of four, one-third ineubated). H. C. Bryant (1914, p. 2:32) found a nest on Jıne 8 at Lower Klamath Lake, containing egg-shells from which the young had already hatehed. Ray (1913, p. 113) found a nest at Lake Tahoe on June 6 containing a single fresh egg. By Jume 19 this nest held four eggs in whieh ineubation was well advaneed. Bliss (1893, p. 226) found a nest in the same loeality on June 16, 1889, with eggs on the point of hatching, while H. W. Carriger has a set taken there June 17, 1911, which eonsists of four fresh eggs. Sheldon (1907, p. 187) took a chiek in down near Eagle Lake, Lassen County, on July 1; this would indieate hatehing during the last week of June. It is thus probably safe to say that the nesting period extends from late May to the end of June.

The nesting site is usually in grassy meadows or marshes, where the nest will be well eoneealed, and may be either in the near vicinity 
of a body of water or removed a considerable distance from it. W. P. Taylor and Ray have found the nests only in damp situations. The first nests and sets of eggs are sometimes destroyed through inundation. This has the effect of extending the breeding season. The nest itself is a simple affair eonsisting of dried grasses or sedges loosely put together into a small circular and flattened mass with a slight depression in the center. Again there may be no foundation but merely a slight depression in the ground with a sparse lining of grass. W. P. Taylor (1912, loc. eit) describes a typieal nest as measuring in surface dimensions about 2.25 by 3 inches and being about 0.75 inches in depth of material at the center where the eggs rested.

The eggs of the Wilson Phalarope average 1.28 by 0.93 inches and are of the usual pear-shape. The ground-color is light buff to very light drab, often varying considerably within a single set. The superficial markings are dark brown or brownish black and consist of spots of various sizes, the largest rarely over a fourth of an inch in diameter. The larger spots are more abundant abont the larger end of the egg while the smalker ones are sprinkled abundantly orer the whole surface. The deep markings are pale olive or light brown. The excessive sprinkling of small spots results in a conspicuously dark general tone of color, and this, in conjunction with size. is usually sufficient to distinguish the eggs of this species from those of any other wader nesting in California.

The following account of breeding habits as observed in northern Illinois (where the species is now rare or altogether gone) is condensed from Nelson (1877, pp. 38-43). The approach of the breeding season is indicated by the breaking up of the flocks into small groups of two or three pairs. Mating commences about the middle of May and is evidenced by the increasing solicitude which the members of the two sexes show for each other's welfare. During the mating period a solemn bowing of the head is indulged in by both sexes at times, and again one of the birds [female?] will sometimes run back and forth in front of the other [male?]. Mating accomplished, the male proceeds to the construction of the nest. The eggs having heen deposited by the female, the male then begins the work of incubation. That the male does all of the work of incubation is inclieated by the fact that it is only the breast and ablomen of this sex which shows the worn feathers and wrinkled skin indicative of an incubating bird.

Generally a nmmber of pairs nest in the same vieinity, and as many as fifty have been counted within the ratius of a mile. During the incrbating period the females form small flocks of six or eight, remaining in the vicinity of the nesting grounts. If the breeding gromend is approached at this time the birds fly to meet the intruder and hover orer his head nttering a weak nasal note. After the first 
alarm the birds nesting at a distance leave the flock while those laving nests in the immediate vieinity remain and fly about in long ellipses, with the objeret of concern at the center. If the intruker still remains and approaches eloser to the nest the males join with the females. If the intruler persists in his approach to the nest the length of the clliptic flight is gradually lessened mitil the birds are flying about almost within reach. A ruse of the species is for a nesting bird to lover at some point apart from its nest. If suecessful, it is repeated at a still greater distance from the nest. At times the males employ the well known broken-wing ruse to lead intruders from the immediate vicinity of the nest.

The young birts have a fine wiry "peeps," inamdible beyond a few feet (Nelson, $187 T$, p. 4:3). They are escorterl to the exlge of the water and ferel there, sometimes drifting out on the surface (Sanforel, Bishop and Van Dyke, 1903, p. 329). Until they are fully Hedged their time is spent in marshy land. Ahout three weeks aftre hatehing they are able to fly (Nelson, 1877, p. 42).

The molt is witently accomplished early in the suson in California, as an apparently achlt female taken at Bear Lake. San Bernarkino Mountains, on July 2s, 1905, is in the full gray winter plumage. The spring molt into the bright nuptial plumage is entiredy eompleted hy the time the birkls arrive within our territory.

The food of the Wilson Phalarope differs markedly from that of the other two speeies, becanse of the inland habitat which the bird frequents. It does not eonfine itself to aquatic forms, such as snails, but eats a great variety of insects, inclueling many terrestrial forms (Barrows, 1912, p. 168). Mosquitoes, erane-fly larvae, leaf beetles, water beetles (Dytiscidae), and hill-bugs (Calandrilae) have been found in stomachs of this species (McAtee, 1911 $\iota$ ).

The Wilson Phalarope, although widely distributed, is. with us, by no means a common speeies. Its limited area of summer distribution in California affeets a region but sparsely settled, and there is no evidence to show that its number's have bern reduced. The small size of the bird and the fact that it is a forager upon insects, in many cases frequenting eultirated fields, would seem to justify its permanent exchusion from the eategory of true game birds.

\section{Avocet}

\section{Recurvirostra americana Gmelin}

Other NAMEs-American Aroset; California Arocet; Yellow Snipe; Irish Snipe; Blue-stocking; White Curlew; Recurrirostra occidcntalis.

DESCRIPTION-Adults, both sexes, in late spring and summer: Area arounil base of bill and around eye, whitish, not sharply defined; rest of head, neek, 
upper part of back, throat and breast, dull rusty, darker on top and sides of head and hind neck, paler below and behind, gradually giving way to white on back and under surface; bill black; often pale at base below; iris "bright carmine", (Aurlubon, 1843, VT, p. 29); mildle of back white, becoming very pale gray on rump, upper tail coverts and tail; inner scapulars brownish black, outer ones white, forming on back a dark V set in white; outer surface of closed wing brownish black; primaries black; secondaries extensively white at tips; tertials pale drab; margin and most of under lining of wing, and axillars, white; hindmost under wing coverts, dusky; under surface of primaries black; whole lower surface of body backwards from breast, including sides, flanks, and lower tail coverts, white; hind toe small, feet extensively webbed; legs and feet clear, pale blue, "edges of webs flesh-coloured", (Audubon, 1843, VI, p. 29), drying blackish. Males: Total length 17.61-19.10 inches (447-486 mm.) (five specimens from California and Lower California); folded wing 8.75-9.17 (222-233); bill along eulmen 3.46-4.00 (88.0-101.8); tarsus 3.79-4.00 (96.3-101.7) (ten specimens from California). Females: Total length 16.75-17.90 (426-454) (ten specimens from California and Lower California); folded wing 8.66-9.30 (220-236); bill along culmen 3.22-3.71 (81.694.1) ; tarsus 3.27-3.92 (83.0-99.5) (ten specimens from California). Adults and immatures, both sexes, in fall (?) and winter: As in summer, except that rusty coloration is wholly wanting, being replaced on upper surface of head, neek and back by pale gray, and below by dull white. The spring molt takes place in March. Juvenile plumage: "Primaries slightly tipped with whitish; seapulars and feathers of back tipped or transversely mottled with pale fulvous or buff. Crown dull grayish; nape tinged with light rufous" (Bair', Brewer and Ridgway, 1884, I, p. 341). Natal plumage: Top and side of hearl, mixed black, white anı dull rusty; side of neek, hind neck and upper part of back similar but with more rusty; area above base of upper mandible, and middle of chin, whitish; bill black; rest of upper surface dull blackish, with much white-tipped down and some rusty color; lower back and outer surface of closed wing grayish; under surface dull white; legs pale blue.

MARKS FOR FIELd IDENTIFICATION-Large size, slender build, long, sleniler, upcurved black bill (fig. 60), rusty or white head, white, unstreaked under surface, and long bluish legs (pl. 11). Differs from Black-necked Stilt in having white on scapnlars and in entire lack of black on head or neck at all seasons.

VoICE-A lond sharp' "plee-eek, plee-eek."

NEST-Either on bare ground or in grass near alkaline ponds: varies greatly in construction, being sometimes a well-male platform of grasses as much as two inches in height; again only a rim of grasses, though fairly well put together, the eggs being leposited on the surface of the ground within the rim.

EGgs-Usually 4, pear-shaper, measuring in inches, 1.82 to 2.07 by 1.34 to 1.40 (in millimeters, 46.2 to 52.6 by 34.1 to 35.5 ), and averaging 1.93 by 1.38 (48.9 by 34.9) (two sets, eight eggs, from California and Utah); ground-color ‘ull buff or clay; markings of dark brown or black and lavender or light gray.

General distribution-North Ameriea, chiefly the western part. Breels from eastern Oregon, central Alberta, and southern Manitoba (rarely north to Great Slave Lake), south to southern California, southern New Mexico, northwestern Texas, northern Towa and rentral Wisconsin; winters from southern Califormia and southern Texas soutl to southern Guatemala; of rare or casual oceurrence east of Mississippi River (and now only in migration), but formerly breal there in small numbers (molified from A. O. U. Check-list, 1910, p. 108; Cooke, 1910, 1). 19-20). 
Distribution IN CALiforNia-Common summer visitant in the Moloe (platean) region northeast of the Sierras, in the Sacramento-San Joaquin Valley, and in the coastal district of sonthern California from Santa Barlara southeastward. Breels from Lower Klamath Lake, Siskiyou Connty, on Oregon line (H. C. Bryant, 1914e, p. 233) south to Santa Ana, Orange County (Grinmell, 1898, p. 16). In migration oecurs west to "oast at San Francisco and from that latitude southward throughout the state both east and west of the Sierras. Winters in fair numbers in coastal district from Santa Barhara southeastward, anil casually as far north as Novato, Marin County, near the coast (Mailliarl coll.), and at Stockton, San Joaquin County, in the interior (Belling, MS).

The Avocet is a typical inland species and shows marked preference for the more arid parts of the country. It seems to have a strong liking, at least in the western part of its range, for alkaline depressions, and chooses such places for both forage and nesting grounds, even when fresh water is also available. Pools on which a surface scum has collected are often chosen, probably because of the particular kind of insect life there afforded. During the early summer the species is present and breeds locally in restricted localities, chiefly in the San Joaquin-Sacramento Valley and in the Hodoc region. A few breed also in the vicinity of Los Angeles. Later in the year it is more widespread, occurring west to the coast from San Francisco southward, as well as elsewhere inland. During August it has been seen at Webber Lake, Sierra Comnty (Belding, 1890, p. 267), and at Hemet Lake in the San Jacinto Mountains (Grimnell and Swarth, 1913, p. 226). In the San Joaquin Valley the species arrives in force at Los Baños in Mareh, and continues to be numerous in the valley until October. Stragglers have been taken in December at Los Baños, Mereed County (one specimen, Mus. Vert. Zool.), at Stockton, San Joaquin County (three specimens, Belding. MS), and, east of the Sierras, at Lone Pine, Inyo County, in the same month (A. K. Fisher, $1893 a$, p. 22); while near the coast it has been observed at Novato, Marin County, in January (specimen in Mailliard coll.), and Berkeley, December 26, 1884 (Belding, MS). A flock of sereral humdred individuals was noted by Emerson (1900, p. 34) on the salt ponds near Hayward, Alameda County, November 17 to 24, 1899. In certain years the species winters in considerable numbers in the coastal district of southern California. In the spring and fall migrations it has been seen on the coast at Santa Barbara, March 18 and May 20, and September 20 to November 1 (Bowles and Howell, 1912 , p. 7), and at Santa Cruz, June 10 (Sharpe, 1896, p. 333). As indicated in the preceding paragraph the species may be found in numbers ranging from solitary birds to flocks of several hundred individuals, but flocks of a dozen to thirty birds are by far the commonest. 
The Arocet is one of the easiest birds to recognize. The long, more or less up-curved, black bill (fig. 60) (whenee the name Recurvirostra), and the still longer bluish legs, the rusty red head and neck, the contrasted black and white wings, and the black, white-margined $\checkmark$ on the middle of the back are all diagnostic features (pl. 11). In flight the rather small wings, and long bill, neck and legs, are also useful as recognition marks. The only species with which the Arocet could be confused is the Black-necked Stilt; but the latter has a shorter, nearly straight bill, and pinkish legs, and the top of its head, hind neck and wings are pure black withont any white interruptions. Also the Stilt entirely lacks any decided reddish in its coloration at any season. In fall and winter the reddish coloration on the head and neck of the Avocet is replaced by gray or whitish, but the other distinctive markings remain as in summer.

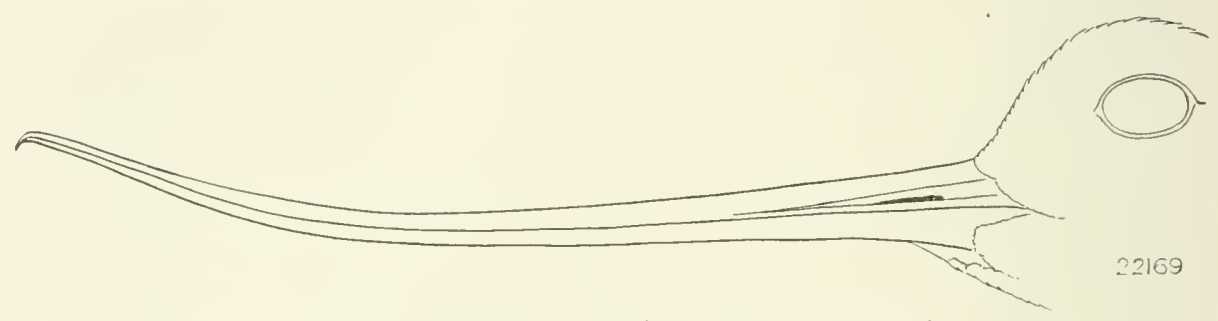

Fig. 60. Side of bill of Arocet. Natural size.

The up-turned end is characteristic (compare with fig. 62).

Together with the Black-neeked Stilt, this bird is sometimes known as the "lawyer bird" because of its long bill and its oft repeated vociferations: The call-note is a loud, not ummusical plee-cek, pleecrk. When not molested by man and when not caring for nests or young, the Avocet becomes quite tame and will permit a close approach; but when it has been persistently lunted or when rearing young, it grows much more wary, and at the same time more noisy and demonstrative.

Avocets spend most of their time on open ground where they ean see and be seen for long distances. Their foraging is carried on along muder shores, often in the water. When on shore they walk with a swinging motion of the body, mueh like that of a person who is mowing with a seythe, and the head is bobbed up and down at almost (2very change in posture. They sometimes rum after and capture the larger insects, and while so engaged hold their wings partly expanded. In the water they wade about and sweep their bills from sicle to side, searehing for insects or other forms of aquatic life. While thus engaged they sometimes keep their wings partly expanded and held vertically above the body. If they happen to wade in heyond their 
depth they can swim off easily. Chapman (1912, p. 242) thus describes their feeding when in the water: ". . . Their peculiar reeurved bill is used in a most interesting manner. Dropping it beneath the surface of the water mint its convexity touches the bottom, they move rapidy formard, and with every step) swing their bill from side to side, as a mower dors his seythe. In this way they seener food which the muddy water would prevent them from seeing." When the water is deep they immerse the whole head and neck minder the surface. Cones (1574, 1. 461) deseribes the actions of the birds as follows:

When afproached too eloseIr, they rose lightly from the water, uttering their peculiar (eries, flappert leisurely to a little rlistance, aml again alighter? to pursue their peaceful seareh for fool, forgetting, or at least not heeling, their recent alarm. As they rose from the water, their singular, long legs were suffered to dangle for a few moments, lut were afterwarils stretehed stiffly backwaris, as a comnterpoise to their long necks... When about to re-alight, they sailed without flapping for a little distance, just elearing the water, llecir legs again hanging loose. ly: as they tomched the ground, their long wings were helil almost upright for an instant, then deliberately folded and settled in place with a few slight anotions.

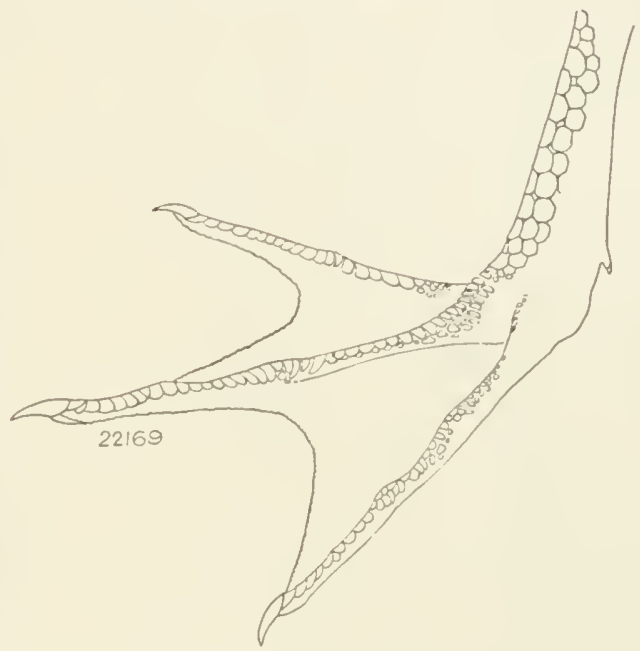
size.

Fig. 61. Top of foot of Aroret. Natural

Note extensive wels between bases of front toes and preseuce of small hind toe (compare with fig. 63).

II. ('. Bryant (IIS) states that he has seen the Arocet alight from the wing in deep water.

During the breeding season, if the vieinity of a nesting colony is approached, the birds often $\mathrm{fl}_{\mathrm{y}}$ to meet the intruder at a considerable distance from the nests. Chapman (1908, pp. 288, 289) says of the birds at Los Baños: "The Arocets were searcely less demonstrative [than the Stilts]. but their method of defending their eggs or young was less by the strategy of aetions to make themselves the center of attraction, than by the most reckless attempts to drive the intruder from the field. Rapidly uttering their loud ples-cek, they eharged one with a directness and apparent determination which threatened to drive their needle-pointed bill in to the base, swerving to right or left when only a few feet away, and repeating the performanee almost im- 
mediately. They claimed dominion over so wide a territory, and appeared so anxious to guard it all equally, that it was difficult to locate their nests from their actions."

In southwestern Saskatchewan, Bent (1907b, p. 425) says that "While conducting their courtships, in May, the Avocets were always amusing and often grotesque in their movements, as they danced along the shore or waded in the shallow water holding their wings fully extended, tipping from side to side, as if balancing themselves. Sometimes they would run rapidly along, crouching close to the groumd, frequently nodding or bowing and sometimes they would lie flat on the water or ground, with wings outstretched as if in agony. At such times they were very tame, apparently oblivious of all else, and could be easily approached.'

In California, the Avocet nests chiefly during the months of May and Jume. The earliest seasonal record of nesting known to us is that by Tyler (MS) who found an adult and four young about onefourth grown at Hehm, Fresno County, April 20, 1914. In sonthern California the species has been recorded as nesting from May 3 to July 6, at Santa Ana, Orange County (Grimnell, 1898, p. 16). In the San Joaquin Valley it was nesting at Mendota, Fresno County, May 27, 1911, and near Firebaugh, Fresno County, May 30, 1912 (Tyler, 1913b, pp. 24, 25), at Los Baños, Merced Comuty, April 26, 1912 (Beck, MS), and May 23, 1914 (H. C. Bryant, 1914r, p. 226). At Lower Klamath Lake, Arocets were nesting at the time of a visit June 2 to 9, 1914 (H. C. Bryant, 1914e, p. 233).

Nests are usually placed on the bare ground in the vicinity of the alkaline ponds where the birds feed, or upon muddy islands in such ponds or lakes; they have also been noted in tall grass at a considerable distance from water. The nest is at best a crude affair, composed of a small aggregation of grasses or weed stems which constitutes a platform containing a slight depression in which the eggs rest. Tyler (1913b, p. 25) describes the nests in the Fresno district as follows:

The typical nest is little more than a shallow depression in the earth with no lining whatever under the eggs but with quite a substantial rim around them so that it may be said to resemble a large, loosely built, and much flattened blackbird's nest with the hottom removed. One is given the impression that this nest might have been hastily woven together, earrier for some distance and set down over the four large pointed eggs with the idea of fencing them in rather than of affording a comfortable nest for the roung.

An exceptional condition of affairs was observed by Lamb and Howell (1913, p. 117) at Buena Vista Lake, Kem County, where Avocets and Stilts were nesting on common ground. Nests of the Avocets were noted containing from five to eight eggs, probably the result of two or more females laying in the same nest; indeed, some mests contained eggs of both species. 


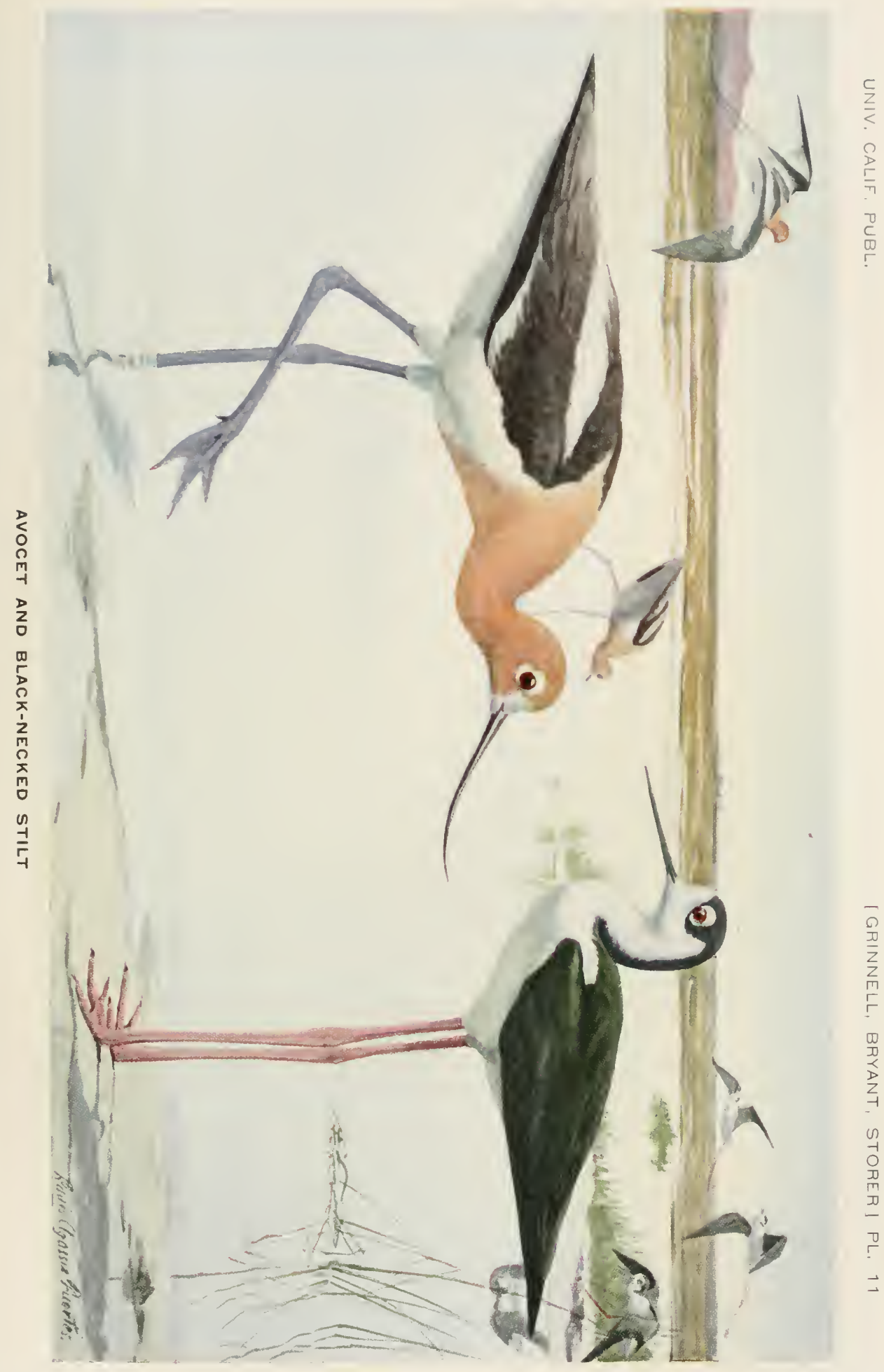



The eggs of the Avocet are usually four in number, sometimes but three, and are pear-shaped. They measure in inches 1.82 to 1.97 by 1.34 to 1.40 , and average 1.93 by 1.37 . 'The ground-color is a dull buff or clay with superfieial markings of reddish brown, brownish black or black, and deeper markings of laventer or gray. The superficial markings are more numerous than the deeper ones, are rather evenly distributed over the surface, and rarely exceed 0.08 inches in diameter. The eggs of the Aroeet differ from those of the Black-necked Stilt in larger transverse diameter, slightly greater length, slightly duller surface, and smaller and less numerous spots.

"The little ehicks take readily to the water and are as much at home as dueklings, swimming and diving if oceasion require" (Sanford, Bishop and Van Drke, 1903, p. 333). A downy youngster several days old observed by H. C. Bryant (1914e. p. 226) at Gadwall, May 21, 1914, was swimming in a shallow pond and tumning tail up as it tried to reach something on the bottom. The young are fully fledged and on the wing by the first of August ; for Belding (1890, p. 267 ) records birds of the year at Webber Lake in the north eentral Sierras on August 3, 1889.

The stomach of the downy young specimen mentioned by H. C. Bryant (loc. eit.) contained eight or more small water beetles (Dytiseidae), 1 Jerusalem ericket (Stenopelmatus), 1 dragon-fly larva, 1 small bug (Pentatomidae), and one eentipede (Scolopendra). At Mono Lake, W. K. Fisher (1902a, p. 10) found this speeies feeding on a small Phyllopod erustacean which abounded along the shore; and Tyler (1913a.p. 16) thinks that the flies oceurring on the sem covering stagnant pools form an attraction for the Arocet. MeAtee (1911a) reports the speeies as feeding on grasshoppers, bill-bugs and water beetles. In Florida a single individual was found to have eaten sixteen fish under an inch in length (Baird, Brewer and Ridgway, 1884, I, p. 342). On the shores of Santa Cruz Island, Henshaw (1876, p. 271) found the species eating the sea-slugs and small erustaceans which were to be found on the sea beach.

The Avocet was formerly an important game bird in California. There are records of considerable numbers having been offered for sale as food in the markets of Stockton and San Franciseo. Authorities, however, differ as to the value of the flesh of the Avocet as an article of food. Huntington (1911, pp. 317, 318) deelares that "the flesh is fairly good, about equal to that of the other shore birds of the second class, such as the tattlers"; while Sanford, Bishop and Van Dyke (1903, p. 333) say that "the flesh is of a bluish color and hardly palatable.",

Apparently the speeies was more abundant in past years than at present, but it has not suffered the great diminution in numbers that 
has obtained in the ease of more desirable game speeies, such as the curlew. As the Arocet affeets a type of habitat not encroached upon by agricultural development, its breeding and feeding ranges have not been measurably restrieted. The large size of this wader combined with its striking eoloration and its open habitat render it a conspienous object for pursuit, thongh this is offset to some degree by its rapidly aequired wariness when repeatedly molested. It would appear that a brief open season early in the fall and limited bag, for the benefit of those hunters who eare for this bird, might be safely allowed as long as present eonditions remain melranged.

\section{Black-necked Stilt}

\section{Himantopus mexicanus (Mïller)}

Other xanes-Lawyer; Tilt; Jack Snipe (in San Joaquin Valley); Longshanks; Himantopus nigricollis.

Description-Adult male: Front of heal, lower eyelid, spot behind eye, and all of under surface of body, white, save that, in breeding season, forenerk and breast are pervaded with pale pink; vertical line in front of eye, cheek, top and back of head, hind neck, upper back, and outer surface of closed wing, contimnously black, showing a greenish sheen in certain lights; lower back, rump and upper tail coverts, white; inner tail feathers drab, darker toward tips, outer ones lighter; shafts of all tail feathers white; whole under surface of elosed wing dull black; axillars white; iris carmine red; bill black; feet dull old rose color, nails black; hind toe wanting. Total length $13.75-15.00$ inches (349-351 mm.) (fom specimens); folder wing 8.63-9.05 (219-230); bill along culmen 2.49-2.71 (63.2-68.6); tarsus 4.37-4.83 (111.0-122.5) (nine specimens). Adult female: Similar to adult male but never acquiring pinkish tinge on breast, and back, scapulars and tertials dull hrownish black insteall of metallic greenish black. Total length 13.12-17.12 inches (333-434 mm.) (ten specimens); folderl wing 8.30-9.17 (211-233); bill along culmen 2.36-2.64 (60.0-67.0); tarsus 3.81-4.38 (96.8-111.2) (ten specimens); all from California. Juvenile plumage: Similar to that of arlult female, but feathers of the dark upper surface and lining of wing narrowly borlered with buff or dull whitish, giving a faintly scaled effect. Natal plumage: Upler surface mixed tawny and blackish in fine pattern; elongated spot on midllle of back, and stripe along sicle of back, black; uncer surface pale tawn paling to whitish on throat and belly; bill deep monse gray; legs and feet grayish blue.

MARKS FOR FIELD IDENTIFICATION-In fljght: long neek, long legs stretehed out behind, and long slender white boly, strongly contrasted with the black wings; when on ground or walling: the same contrasted color areas, moderately. large size, red legs, and straight black bill (pl. 11 and fig. 62).

VoICE-A sharp ip-ip-ip (Chapman, 1912, p. 242): when courting: a nasal quănk.

Nest-Tariously locatel on dry bare ground, on small muldy islands, or even in water a few iuches leep; structure varies with location, from mere depressions with sparse lining of grass to relatively elahorate platforms of weed, or grass stems, or tules. 
Egas-3 to 4, large, pear-shaperl, measuring in inches, 1.59 to 1.54 by 1.16 to $1.2 \mathrm{fi}$ (in millimeters, 40.3 to $46.6 \mathrm{by} 29.6$ to 32.1 ), and aseraging $1.70 \mathrm{by}$ 1.24 (43.1 by 31.4) (six sets, 2.2 eggs, firom Los Baños, Merreal County); groumicolor medium huff or elay; superficial markings deep rehlish brown, or brownish blark, deeper ones gray or lavemler; surface with slight sheen.

Genkral distributiox - Temperate North Ameriea and northern South America. Breels from central Oregon, northern Ttah, and southern Coloralo, south to the southern houmlary of the United States; also breeds locally in Mexico, in the Bahana Islands and West lndies, and in South America to northern Brazil and Peru. Winters in extreme southern United States amil south through Mexico and northern half of South America.

DISTRIBLTION IN CALIFORXIA-Common summer visitant and breeder in the Sacramento-San Joaquin Valley, and in the southern "oastal distrivt west of the desert diviles, from the latitule of Santa Barbara southeastward. Reported also sparingly from northern California east of the Sierran divide at Goose Lake (Dawon, MS). Arrives from late Mareh to early April and departs ly mid-Ootober. Stragglers have been taken as late as Novemlier 19 , 1891. One winter rerorl: Bixby, Los Angeles County, January 5, 1910 (Willett, 191 $2 a, 1$,. 35$)$.

The Black-necked Stilt, Lawyer, or Long-shanks, as it is variously called, is one of the commonest summer birds along intand bodies of water. Often in company with its nearest relative, the Avocet, it is to be found wading or stalking about the edges of shallow borlies of water. The Stilt, however. seems to have a less decided preference for brackish water or alkaline sinks than does the Arocet.

The Stilt is a regular summer visitant in the interior of California, nswally arriving in numbers by the last of March or in early April and leaving by the middle of Oetober. It is somewhat more southern in its general distribution than the Arocet. In northeastern California it is searce, having been found only at Goose Lake (Dawson, MS) and at Rhett, or Tule, Lake (Newberry, 1857, p. 99). In the Sacramento Valley it is common locally and ocens north at least to Gridley, Butte County, and it is abundant in suitable localities in the San Joaquin Valley. On the eoastal slope of sonthern California it oceurs at Santa Barbara in spring migrations during April and May and is a common summer visitant from the vicinity of Los Angeles south at least to the vicinity of Santa Ana (Willett, 1912 $a$, p. 35). Dnring migrations it appears sparingly west to the coast at San Francisco Bay, and on the deserts of sontheastern California. The date of earliest arrival within the state in 1912 was March 22, at Los Baños (Beck, MS), but in 1914 Tyler (MS) saw five near Fresno, February 11. The second week in April seems to mark the time when the species usually arrives; for the majority of the spring records fall during that period. By late July or early Angust the southward migration has set in, a flock having been seen at Bear Lake, San Bernardino Mountains, July 30, 1905 (Grinnell, 1908, p. 55), and 
a flock and scattered individnals at Hemet Lake, San Jacinto Mountains, on August 6 and 21, respectively, 1908 (Grinnell and Swarth, 1913 , p. 227). Clarke (1913, p. 218) records the birds as common about Tulare Lake when he arrived on September 19, 1913, but says that they gradually decreased in numbers up to October 7 , when he left. One was seen in the market at Stockton, October 18, 1890 (Belding, MS). It has been recorded as a "fall and winter migrant" at Miller, Marin Connty (Kobbé, in Bailey, 1902, p. 1). Willett (1912a, p. 35 ) states that the species leaves the coast of southern California in October. A juvenile was taken at Mt. Eclen, Alameda County, November 17, 1895 (Mailliard coll.); others of the species were noted at Riverdale (San Diego County?), as late as November 19, in 1891 (Cooke, 1910, p. 21); and a specimen was taken at Bixby, Los Angeles County, January 5, 1910 (Willett, 1912a, p. 35). These three records are probably all of stragglers left behind by the migrating flocks.

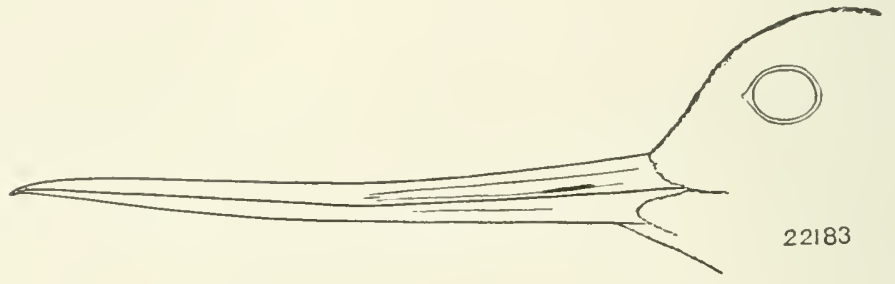

Fig. 62. Side of bill of Black-nerkerl Stilt. Natural size.

The almost straight outline is characteristic (compare with fig. 60).

While Black-necked Stilts and Avocets commonly oeemr together, the first named species is usually much more abundant than the second. H. C. Bryant (1914e, p. 226) found this the case at Los Baños, where the Stilt was the most abundant species of water bird breeding in the vicinity ; and Goldman (1908b, p. 203) and Linton (1908c, p. 197) indicate that the Stilt was the more abundant of the two species on Tulare and Buena Vista lakes, respectively. Tyler (MS) says that in Fresno County Stilts outnumber Aroects 100 to 1, and as the Arocets are decreasing the disparity is increasing.

The Black-necked Stilt is one of the easiest of birds to identify, whether in flight or on the ground, by reason of its sharply contrasted white body and black wings, long neck and long straight black bill (fig. 62) and excessively long reddish legs (pl: 11). The Stilt may always be distinguished from the Avocet by its lesser bulk, by the black on the top of its head and hind neck, the absence of white on its shoulders, its shorter and straighter hill and its longer and dull red, instead of bluish, legs. In the breeding season the Stilt shows no rusty 
red on the head and neck region as does the Avocet, save that males of the former species have a pinkish blush on the throat and breast.

The Black-necked Stilt forages along the grassy or muddy shores of shallow inland poncls and lakes, fresh, brackish and stagnant. It walks about in a sedate fashion, with a deliberate but jerky movement, the long legs being sharply bent at the "heel" and raised far up behind at each step. When standing, the feet are not spread apart as in the case of some waders, the legs being held vertically parallel. A notable mannerism is that of abruptly jerking the head upwards at frequent intervals, with immediate recovery. When chasing insects on land a Stilt will sometimes rmu about swiftly with wings upstretehed, perhaps to aid it in quickly turning and tacking in its cliase. When working in soft mud and probing for food it drives its bill into mud "up to the hilt." When wading about and feeding in mud beneath the surface of the water its body is tilted forward and downward, the legs being used as fulcra. The birds while wading are careful not to get beyond their depth, as they are said to be poor swimmers, not comparing at all in this with Arocets. A fact to be noted here is that the foot of the Avocet is almost completely webbed, while that of the Stilt is practically without webbing, the toes being free (eompare figs. 63 and 61). A Stilt, when wounded, however, and hard pressed, will sometimes resort to swimming. Mortimer (1890, p. 338) tells of a wounded bird that was yet able to use its legs and ran some distance along the shore; but being pressed it took to the river and swam for the opposite bank. In swimming, the Stilt proceeded in a sort of sidling mammer, and rose in the water with each stroke of the feet, continually turning its head from side to side. Tyler (MS) records an instance of the same sort.

The flight of this species is straight and steady, with slow-flapping wings, the individuals in a flock keeping fairly close together and wheeling so that the black and white of the upper and lower surfaces appear alternately (Coues, 1874, p. 465). Their astonishingly long legs stretched out behind give them a peculiarly attenuated outline. 
The voice of the Stilt is described as a shrill ip-ip-ip and may be heard both during the day and at night. On the nesting grounds at the begimning of the breeding season one of a pair is sometimes heard to utter a nasal quăml as it flies up with its mate; on alighting one of the birds continually "squats," as if the legs were too weak to sustain its bolly.

The nesting period of the Stilt extends from the first of April to the end of July. The lieight of the season oeenr's from the middle of May to the midule of June. At Calexico, Imperial County, Murphy (MS) saw three newly hatched Stilts and many adults on April 14, 1915. Sets of eggs have been taken near Santa Ana. Orange County, from the first of May until August (Grinnell, 1898, p. 16). Willett (1912a, p. 35$)$ says that in the coastal district of southern California the Stilt breeds most abundantly from May 15 to .June 15. The species was nesting in colonies at Buena Yista Lake between May 20 and June 16, 1907 (Linton, 1908c, p. 197), and at Tulare Lake between June 23 and July 7 the same year (Goldman, 1908b. p. 20:3). In the Fresno district the Stilt has been found nesting from April 26 to July 1 (Tyler, 1913b. P. 26, and MIS), and farther north, at Los Baños, Merced County, from May 5, 1896, until May 25, 1899 (sets in Mus. Vert. Zool.). It is known to have bred at Woodland, Iolo County (set in Mailliard coll., taken May 23, 1886), but no farther north in the Sacramento Valley. Emerson (Mailliard coll.) has found eggs May 3. 1908, and young June 4, 1911, near Niles, Alameda County. Dawson (MS) thinks the species may nest at Goose Lake, Modoc C'ounty, but no eggs were taken there.

Several different types of surroumdings are selected by Stilts when nesting. The nest may be placed on a dry or grass-covered flat one hundred yards or more from water, on a muddy island in the middle of a pond or lake, or actually in shallow water. The structure of the nest varies with loeation. Frequently, if the nest be placed on a dry flat, it is a mere depression slightly hollowed out to approximately fit the body of the bird and lined with a sparse layer of grasses or weed stems a fourth of an inch in thickness, or even less: sometimes only a few pieces of vegetation are found at the nest site. Again. upon a muddy island, it may be composed of a layer of weed or grass stems, or tules, two or more inches in depth. When so constructed the individnal pieces of regetation eomposing the nest measure about two inches in length. The most elaborate nests constructed by the Stilt are those situated in water several inches in depth. H. C. Bryant, Tyler and some other observers believe that the Stilt is capable of meeting the emergency of rising water hy adeling to the height of the nest sufficiently to keep the eggs above the level of the water. Such uests are begnn on open gromud and added to only when the rising 
water demands it. It is probable that only incubated sets are so cared for (Tyler, MS). A nest of this type found at Los Baños, May 12, 1914, was seven inches in height and composed of piees of tules about two inches in length, the eggs being just at the surface of the water. A trpieal nest measures about seven inches in diameter.

Stilts commonly nest in colonies of five to twenty pairs, and their aggregate numbers in any general area consequently do not seem so great as would be the ease if they all nested in one large eolony. On a small island in Buena Vista Lake, Lamb and Howell (1913, p. 117) found Stilts and Arocets nesting together, and enrously enough cer'tain of the hirds seemed to eonsider themselves members of one large family, as nests were found containing five to eight eggs and some nests held eggs of both species. H. C. Bryant (MIS) found a set at Los Baños which contained five eggs, and Tyler" (MSS) foum a similar set near Fresno.

The eggs of the Stilt number four in a complete set, but in exceptional cases more, as above. The eggs average 1.70 by 1.24 inches, the extremes being 1.59 to 1.84 by 1.16 to 1.26 . The groundcolor is a.medium buff or clay with superficial spots of deep reddish brown or brownish black and deeper ones of gray or lavender. 'The spots are eommonly orer 0.08 inches in diancere, and are usually a little more mumerous about the larger ent where they alre sometimes so thick as to fuse. The eggs of the Stilt differ from those of the Arocet by their smaller transverse diameter, slightly shorter average length, and somewhat darker general toue of eoloration.

Both male and female are said to incubate (Cones. 1874, p. 466). The period of ineubation is not known, but is probably about three weeks or slightly longer. The young are able to run about at birth, but are earefully attended by the parents for some time. Murphy (MS) says that the downy young Stilts seen by him at Calexico, Imperial County, were swimming. Chapman (1908, p. 288) thus describes the behavior of the Stilts at Los Baños:

... The Stilts, berause of their abundance, vociferousness, ant remarkable actions were the most conspicuous and interesting [of all the water biris]. They nesterl on the little islands formed by slightly elevated bits of ground, often selecting a site which, under irrigation, subsequently became submergeda misfortune [which] artificial conditions harl not prepared the birls to anticipate.

On May 23, their eggs were hatching, and in June the Snipe-like young were widely distributen over the marsh. They invariably attempted to escape observation by squatting with neek outstretched, but the parents, whether one approached their eggs or young, expressed their solicitule by a surprising extravagance of motion, all apparently designed to draw attention to them: selves. I was at times surrounded by hopping, fluttering Stilts, all calling londly, waving their wings, bounding into the air to hang there with dangling legs and beating pinions. ... 
The food of the Stilt comprises among other things grasshoppers, bill-bugs, water beetles and other insects, many of whieh are destructive to crops (MeAtee, 1911a). As an element of the inland avifauna the Blaek-nceked Stilt is thus likely to serve in benefieial capacity whenever it frequents agrieultmal lands, and it should accordingly receive protection. Its flesh is comparable to that of the Avocet, in other words, it is of second class. In former years Stilts were sold in the markets to some extent, but so far as known this praetiee has not obtained within recent years. Sportsmen in general pay little or no attention to them. The birds have probably not deereased to any great extent, if at all, sinee the state was first scttled, and the present eondition of agrieulture in the Sacramento-San Joaquin Valley, where farming is dependent upon irrigation, will doubtless provide them for many years to come with the proper kind of surroundings for nesting and feeding.

\section{Wilson Snipe}

\section{Gallinago delicata (Ord)}

Other xames-Jaek Snipe; English Suipe; American Snipe; Gallinago wilsoni; Scolopax wilsoni; Gallinago media; Gallinago media wilsoni.

DESCRIPTION-Adults, both sexes, at all seasons: Top of head velvety black, with a median creamy or whitish longitudinal stripe running back from base of upper mandible, and a similar one running along each side of head above eye; a dark brownish stripe from side of bill (beneath light stripe last mentioned) running to lower eyelid; side of head generally, mixed buffy and whitish, flecked with dusky; a liagonal dark streak on lower cheek beneath ear; chin white or cream-colored; bill "brown," terminal thiri "black"; iris "hazel" (Audubon, 1842, V, p. 345); hind neck and sile of neck streaked blackish and buffy in fine pattern; back and scapulars velvety black, with extensive feather. marginings of pale buffy or whitish, many feathers with irregular spots or bars of tawny; the light markings tend to give the back a lengthwise striped pattern; rump brownish gray, narrowly barred with white; upper tail coverts barred with brownish black and pale buffy brown; tail velvety black with subterminal bar of tawny followed by narrow bars of black, buffy and white, the latter terminal; outer tail feathers lighter, the tawny being replaced by pale drab; outer surface of elosed wing slaty brown, many feathers margined or tipper with white or buffy; outer web of outermost primary white; some of tertials irregularly bander with brownish and pale drab; under surface of wing and axillars barred with blackish brown and white; unier surface of flight feathers dusky; throat and chest buffy drab, the feathers with irregular dusky brown shaft streaks, giving a distinctly mottleil effect; abdomen white; under tail coverts tawny, narrowly barred with dnsky; sides and flanks barred with dusky brown and white; feet olive green. Males: Total length 10.5011.94 inches (266-303 $\mathrm{mm}$.) (three sperimens from California and Alaska); folder wing 4.75-5.06 (120.4-128.5); bill along enlmen 2.44-2.61 (61.9-66.3): tarsus 1.15-1.30 (29.1-33.1) (ten specimens from California). Females: Total length 10.00-10.94 (254-278) (two speeimens from California); folderl wing 
4.53-5.25 (122.4-133.3): bill along culmen 2.48-2.84 (63.0-72.0); tarsus 1.211.33 (30.8-33.9) (ten specimens from California). Weight 3 ounces ( 85 grams) or more (Audubon, 1842, V, p. 344). Jurenile plumage: Top of head black; stripe over middle of crown, pinkish white; stripe from side of bill to eve, black; cheek and chin, mixed white, black and cinnamon; rest of upper surface of body brownish black, with broad feather-margins and markings of cinnamon, buffy brown and dull white; outer surface of closed wing dull brown with broad feather tippings of pinkish buff and white; flight feathers dusky; margin of wing white; throat and breast streaked with pinkish cinnamon and dusky; middle of belly white; sides and flanks barred with white and dark brown. Natal plumage: Bright hazel brown, darkest on upper surface of body where marked irregularly with black and white; forehead at base of bill, black, followerl by white; spot on cheek, white; narrow streak from bill to eye, and spot below angle of mouth, black; chin light buffi.

Marks FOR FIELD IDEXTIFICATION-Medium-small size, long bill( 2.50 inches, $63.5 \mathrm{~mm}$.) (fig. 61), longitudinally striped hear and bask (at all seasons), mottled breast, white belly, dusky rump, erratic flight, sharp grating note, crouching attitude and solitary rather than flocking habits; frequents grassy mearlows rather than open mul-flats or shores.

Torce-A rasping scaipe, scuipe, not loul, and a yuk-yak-yak-yak or ka-kaka-ka-lia of far-reaching quality, the latter two ealls being uttered chiefly or exelusively during the breeling season.

NEST-In semi-moist part of a mearlow, usually placerl in or at the sile of a tuft of grass; a mere lepression lined with a few grasses.

EgGS-3 to 4, pear-shaped, measuring in inches, 1.50 to $1.60 \mathrm{by} 1.05$ to 1.10 (in millimeters, 38.1 to 40.6 by 26.6 to 28.0 ) (Darie, 1889, 1. 110). One set (four eggs) from California measures 1.48 to 1.60 by 1.12 to 1.17 (37.5 to 40.6 by 28.4 to 29.7 ), averaging 1.54 by 1.13 inches ( 39.0 by $28.8 \mathrm{~mm}$.). Color varies "from a grayish-olive to greenish-brown and yellowish-ash, spotted and blotehed with redlish-brown, umber, and sometimes with lines of black; the markings are bold and numerous, particularly on the larger end, usually also sharp scratchy lines of blackish and shell-spots, hardly noticeable" (Darie, loc. cit.).

General distribution-North America and northern South America. Breeds at the north from Newfoundland and northern Ungava to northern Mackenzie, northern Yukon and northwestern Alaska, apparently following closely the limits of tree growth; thence south to New Jersey, northern Indiana, northern Illinois, northern Iowa, southern Colorado, northern Nevala, and south-central California. Winters most abundantly in southern United States and Mexico, althongh winter range extends to Colombia and southern Brazil in South America. Normal northern linit of winter range extends from North Carolina, through Arkansas and New Mexico to northern California, but individuals sometimes winter about springs or streams as far north almost as the Canadian bounilary (Cooke, 1910, pp. 23-24; et al.).

Distribution in CALiforia-Abundant fall, winter and spring visitant throughout lowlands and to a less extent in suitable places in mountainous districts. Occurs in summer and breels in region east of Sierran erest, from latitude of Lake Tahoe northward to the Oregon line andi west to Lower Klamath Lake; also recorded as breeding near Tejon Pass, northern Los Angeles County (J. Mailliard, 1914, p. 261), and may be expected to nest in appropriate places northeast of this station. Occurs in migration over practically the entire state. 
The Wilson Snipe, or Jack Snipe of the hunter, is the game bird suprêne wherever it is found. Its elusive habit of lying close and ftushing suddenly with swift erratie rig-zag flight and its delieaey of Hesh, make this at once the most difficult of pursuit and most highly prized of all our shore birds. Snipe begin to appear in the lowlands west of the Sierras rather late in the fall as eompared with other waders. Dates of first fall appearance in several localities are as follows: Stockton. September 7, 1878 (Beleting. MS) ; Hayward, September 25, 1875 (Belding, MIS) ; Santa Barbara, October 2T, 1911 (Bowles and Howell, 1912, p. 7) ; Los Angeles, Angust 25, 1897 (specimens in Swarth collection); and Hemet Lake, San Jacinto Momntains, August 14, 1908 (Grinnell and Swarth, 1913. p. 227). In the spring it departs rather early, the latest records being: Mecea, Riverside ('omnty, April 26, 1908 (C. H. Richardson, MS) : Los Angeles, April 10, 1899 (Swarth collection); Santa Barbara, April 27, 1911 (Bowles

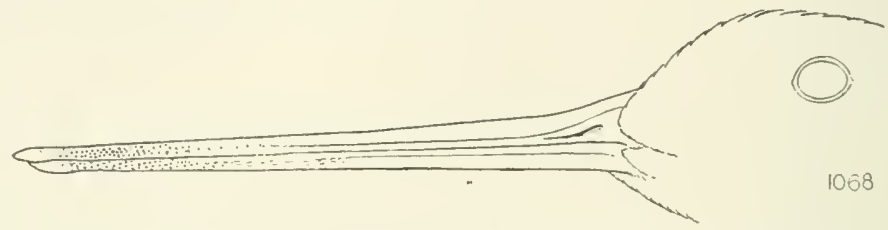

Fig. 64. Sirle of bill of female Wilson Snipe. Natural size.

Note sense pits near tip of bill.

and Howell, 1912, p. 7) : Daggett, San Bernardino County, "through April," 1911 (Lamb, 1912, p. 35) ; Los Baños, Nereed Connty. April 26. 1912 (speeimen in Mus. Yert. Zool.) ; and Gridley, Butte Comnty, April 30, 1893 (Belding, MS). As the species has nested at Tejon Pass, Kern County, hirds seen at Weldon, Kern County, July 5, 1911 (specimens in Mns. Vert. Zool.), and to the east at Little Owens Lake, May 6-11, 1891 (A. K. Fisher, 1893». p. 22), cannot safely be considered as migrants.

In winter the species ocenrs in suitable localities throughout the state below the level of heary snow. Some northern winter records are: Bodega bay. December, 1854 (Baird, Cassin and Lawrence, 18.58. p. 711), Shasta River, Siskiyou County, December, 1912 (specimen in Mus. Hist., Sei. and Art), Nevada ("ity, Nevada County, November 2, 1872 (Nelson, 1875, p. 365) ; Owens Valley, “late Deeember," 1890 (A. K. Fishar, 1893a, p. 22) : Yermo, Mohave Desert, from Oetoher 22.2. 1910, through April, 1911 (Lamb, 1912, p. 35).

From other wader's the Wilson snipe may be distinguished by its combination of moderately small size, long bill (fig. 6t), longitudinally streaked mpuer surface at all seasons and its conspiemously 
white belly set off from the mottled breast. The only species with whieh it might be eonfused is the Long-billed Dowiteher in summer plumage. From the latter species the Snipe differs in the possession of a longitudinally striped rather than irregularly mottled back and by the absence of reddish coloration on its breast. Then, too, the Wilson Snipe is rarely if ever found on the open flats or about salt water, while the Long-billed Dowitcher is found regularly in both of these situations. The sudden and erratic zig-zag flight and the rasping eall-note, uttered as the bird take's wing, are perhaps the best field marks for the sportsman. The harsh, rasping "scaipe, scaipe" is essentially a note of alarm, uttered at the moment the bird flushes and never so far as known while it is on the ground. This note often suffices to start some or all of the other sinipe in the near vieinity. Close view of a bird at rest brings ont an additional character-the large apparent size of the eyes. This is mobably eorelated with its twilight activity.

Although the Wilson Snipe has a wide range within the state and elsewhere, it is sporadic in its local ocenrrence, ontside of the breeding season, appearing in a given loeality in eonsiderable numbers one day and being totally absent on the next, perhaps to reappear on the sueceeding day. Again, territory which seems eminently suited for the support of numerous Snipe may never be visited at all by the birds. Wide reaches along the edges of slow-moving streams, level open marshes, and even upland meadows, when the winter has been very wet, are the preferred haunts of these birds; but at times they oocur in distinetly dry, though grassy, situations. They are rarely if ever found feeding or resting on bare open flats save under cover of darkness. In irrigated sections Snipe are often flushed from the margins of the ditches, where the growths of weeds conceal them completely until they take flight.

Much of the food of the snipe is seeured by probing in soft mud, a practice to which its bill is partieularly adapted. The tip of the upper mandible is flexible and ean be moved independently of the lower one, and the exposed surface toward the tips of both mandil)les is provided with numerous sensitive nerve-endings, each in a little pit. The birds are thus enabled to feel about with the tip of the bill below the surface, a practice not possible for any other wader except the Woodeock of the east and probably the Dowitehers. The bill is thrust perpendieularly into the soft mud and worked about for earthworms and other burrowing forms of animal life without the incessantly repeated probing necessary for waders provided with shorter, mort inflexible, and less sensitive bills; but so numerous are the probings of the Snipe in some places that the whole surface of the ground is literally "drilled with holes." Hunters say that it is useless to look for Snipe in a locality which does not show some of these probings. 
The Snipe's manner of feeding has been deseribed by Galloway (1895, p. 86) essentially as follows: On April 18, 1894, a bird was located at the edge of a pond near Montgomery, Ohio. For a time the bird stood motionless, but before long it relaxed and began dabbing in the mud and water with its long bill. It posed in all sorts of positions, at times standing knee-deep in water and fishing up prey from beneath the surface, again facing the observer with its bill straight down or turned rakishly to one side, an attitude which gave it an air of shrewdness. Presently the bird flew across the pond and alighted among some low clumps of sedge, where it stood at full height in a recess in the bank, eyeing the observer suspiciously. It then climbed up on a elod, stuck its bill over its back and down inside the wing, and went to sleep for two mimutes. Awakening, it dressed the feathers of the breast with the bill, and again relapsed into repose. Returning to the water's edge, and seemingly impressed with something, the bird stood with loosened wings, oscillated for a moment, bent the legs so as to bring its body elose to the ground, and walked very earefully, bowing at every step as though wishing to tread lightly and avoid being seen, till suddenly the head was thrust forward and the bird began pulling an angleworm out from a hole. It would pull and pull until the limit of its height was reached, then take a fresh hold and pull again. The worm must have gone back into its hole each time, else it is inconceivable how so much eontinuous pulling eould have been exerted on one ordinary worm.

In their habits Snipe seem to be affected by elimatic conditions more than other speeies of shore birds. On warm sunny days when little or no breeze is stirring the birds will remain quiet and can be flushed only with difficulty. But cold windy, eloudy, or rainy days seem to excite them, for they then flush wildly, at long range, and zig-zag away at a rapid rate. On sueh days the hunter is apt to start more birds, but they are mueh more diffienlt to shoot. The usual praetice is to hunt against the wind, as the birds when flushed usually labor against the breeze or fly aeross it, in either ease giving the hunter a better chance than if he were pursuing the birds down-wind. Oeeasionally they start off down the wind, and then are so quiekly out of range as to prevent an effective shot. When flushed on clouty or rainy days the birds may move ont of the region to a distant meadow or marsh too far to be pursued, or they may cirele about and return to cover within a few feet of the place from which they were flushed. They also show marked irregularities in behavior as regards flushing. Sometimes the rasping alarm note of the first bird put up will raise the whole population in the vicinity, while at other times the birds will flush one at a time. When they drop into the proteeting grass it is usually to remain in the same spot for a considerable time, so that 
in hunting it is possible to "mark down" the birds which alight and follow them up systematically one after the other. In this manner it is sometimes possible to secure a dozen birds in a relatively small area.

"In taking flight and especially if alarmed the Snipe spreads its tail like a fan and with spasmodic semicircular sweeps . . . swings it from side to side with a peculiar jerky motion. When [the bird is] suddenly frightened into flight, as by a dog or gunner, these sweeps are repeated with amazing rapidity and the result is a series of gyrations ..." (Betten, 1904, p. 265). Faton 's epitome of the habits of the Wilson Snipe is as follows:

When no enemy is near he walks nimbly, carrying the hearl and bocly erect with the bill pointing well downward, but often assumes more the attitude of a Sandpiper and gleans from the surface especially when foraging along the shore of a lake or stream as he often does in the dusk of evening. When his foes appear he erouches so motionless that it is impossible to dis. tinguish him among the grasses, and when too closely pressed springs suddenly into the air with a sharp grating call and makes rapidly off in a "rail-fence", course not far above the ground until well out of danger, when he mounts high in the air and circles about for a few minutes finally to pitch headlong into the swamp again, perhaps into the same position from which he was driven (Eaton, 1910, p. 302).

When flushed the Snipe rises about six feet above the ground before the zig-zag flight is commeneed and this is then kept up for about twenty yards, after which a straight course is pursued. After straightening ont its course it flies on a dead level. In high and scattered brush the birds persist in dodging throngh it, and when among scattered trees they rise without the characteristic short zigzags and fly in wide curves between the trees.

Nesting records of the Wilson Snipe in California are exceedingly rare. The set taken near Tejon Pass, in extreme northern Los Angeles County (J. Mailliard, 1914, p. 261) is the only one as yet definitely recorded from the state. Belding (IIS) states that the species breeds at Webber Lake in the northern Sierra Nevada, and Cooper (in Baird, Brewer and Ridgway, 1884, I, p. 190) was informed that it bred at Lake Tahoe. George Neale reports two small young as found at the north end of Lake Tahoe early in Angust, 1912; and, according to the same person, three young were found in Sierra Valley, Plumas County, September 1, 1899 (H. C. Bryant, 1915b, pp. 76, 77). At Lower Klamath Lake in the first week of June, 1914, H. C. Bryant (1914e, p. 232) saw Snipe in nuptial flight, but did not find other evidences of nesting.

The egg-laying season would appear, from numerous eastern and northern records, to extend from late April through May. The set recorded by Mailliard, in which incubation was nearly complete, and 
two sets from the eastern United States reeorded by Cooke (1910, p. 25), were all taken on April 24 of different years, this being the earliest thate. Belling's reeord (1890, p. 267) of young barely able to fly by the fir'st of Angust, and the above cases recorded by Bryant, rould indieate that nesting in the Sierras proeeeds until August. However, the contention of gane conservationists that the Wilson Snipe is an early nester is borne out by the majority of the reeorded nesting dates, taking the whole of the United States into aecount.

The nest is usually plaeed in a moist meadow in or at the side of a tuft of grass, and is a mere depression lined with a few grass blades. The nest at Tejon Pass was situated in a swampy area and was placed on a tussock of grass about one foot in diameter and two in height. It was “. . . simply a few fine grasses, probably pulled from the stems directly beside the nest, as several bare stalks were noticed',' (.J. Mailliard, loe. cit.). This set eonsisted of four eggs. The ground color was clayey-olive with a faint greenish tinge: the superficial markings were of deep sepia, the deepest ones of varying tints of gray : the markings eonsist of spots, roundish, sometimes elongate, in the aggregate showing a distinetly spiral trend, and the largest being 0.20 ineh in diameter, but usually smaller, 0.08-0.12 inch.

During the breeding season the Wilson Snipe behaves quite differently than at other times of the year. Adults, probably males, are to be seen perehed on fences, stumps or even in the more open parts of trees, a habit mevalent among eertain other shore bircls. Grinnell (1900, p. 22) thus describes the nuptial flight, as observed in the Kowak Valley, Alaska:

I was in a broal, grassy swale studled here and there with scrub spruces and bortered by taller timber, when my attention was attracted by a curious far-off song which puzzled me for some time. Finally I deseried the producer, a Wilson's Snipe, so far overhear as to be scarcely discernible against the clear sky. It was flying slowly in a broarl circle with a diameter of perhays 600 yaris, so that the direction of the sound was ever shifting, thus confusing me until I eaught sight of its author. This lofty flight was not continuously on the same level, but consisted of a series of lengthy undulations or swoops. At the end of each swoop the birl would mount up to its former level. The drop at the beginning of the downward live was with partly closed, quivering wings, but the succeeding rise was accomplished by a sucression of rapil wing-beats. The peculiar resonant song was a rolling series of syllables uttered luring the downwarl swoop; and just before this drop mergel into the following rise, a rumbling or whirring sound became andible, accomprying the latter part of the song and finishing it. This curious songflight was kept up for fifteen minutes, ending with a downward dash. But hefore the birt rearhel the ground, and was yet some twenty yards above it, there was apparently a complete collapse. The birl droppell, as if shot, for several feet, but abruptly recovered itself to fly a short distance further and repeat this new manoenve. By a succession of these collapses, falls, recoveries and short flights, the acrobatically-inclined bird finally reacher the ground, 
alighting in the grass near me. During the last part of this performance another snipe, probably the female, male its appearance, flying low over the ground anl alighting with a weak "ehirp." A little later one of the birls was seen perchen on the top of a spruce, uttering a prolonged series of abrupt, resonant notes, "ka-ka-ka-ka-ka," like the monotonous spring song of the Red-shafterl Flicker.

Concerning flights of the sort deseribed above Henshaw says (18806, pp. 321-322) : "During the mating, and in fact throngh most of the breeling period, and continuing even after the young are hatched, the birels begin these evolutions as soon as dusk comes on, and continue them at irregular intervals mutil about nine o elock. The notes are not heard again until about day-break, and they cease before sun-up. But should the day be cloudy the Snipe may be seen flying in the manner deseribed till late in the morning, often indeed till nearly noon."

"In eonrtship, the male struts with drooping wings and widespread tail aromed his mate, in a most eaptivating manner, often at such times rising spiral-like with quickly beating wings high in air, dropping back in a wary, graceful cirele, uttering at the same time his jarring. cackling low note, which. With the vibration of the rings "1pon the air, makes a rather pleasing sound" (Goss, 1891, 1). 161).

The young run about soon after hatehing. At first they feed on larvae. small insects and snails, but at the end of a fow weeks their bills have hardened sufficiently to enable them to probr in the mul and secure worms as do the adults (Baird, Brewer and Ridgway, 1884, I, p. 192).

Snipe are essentially non-floeking birds, but at times as many as fifteen individuals have been seen in flight in one company. This habit is ehiefly shown during the period of migration. One ohserver noted a flock of hirds eoming into some dnck grounds at nightfall. The flight was not in mison, as in the ease of many shore birds, but the individuality of each member of the flock was apparent. Migration and local movements oeem chiefly at night, and the flights are at lower levels than in the ease of most birds.

As indicated in the preeeding portions of this aceount a large proportion of the fool of the Wilson Snipe consists of earthworms seeured by probing in soft meadow or marsh land. The bird is also reported to take erane-fly larvae, mosquitoes, grasshoppers, wireworms and the adult elick beetles, and water beetles (IcAtee, 1911 $\iota$ ). In adlition, Forbush (1912, p. 252) reports that eutworms and leeehes, seeds of smartweed and other plants, together with roots and other regetable matter have been fornd in the stomachs of these birds.

Eeonomically the Wilson Snipe is a rery important species: in fact it may, by reason of the interest taken in it by hunters, be con- 
sidered onr most important species of shore bird. Its flesh is of excellent flavor, due, perhaps, to the fact that it lives exchusively about clean fresh water. To the hunter it is the game bird por cxcollence. To the farmer it is beneficial by reason of its food habits.

All available accounts go to show that the Wilson Snipe has decreased decidedly in numbers. This is due to several causes: restriction of feeding grounds, encroachments of civilization in other ways, and cxeessive shooting without bag limit for a long period. In the east, in former years, Snipe were not protected at all; shooting continued through the spring and even well into the nesting season. Spring shooting in this state has probably been responsible for much of their decrease on the whole Pacific Coast. Statisties from a gunclub in Monterey County show the following number of Snipe to have been taken during the seasons specified: In 1905-06, 117: 1910-11, 189: 1911-12, 95; and in 1912-13, 24. These figures show an average decrease not to be accounted for even by irregularity of occurrence from year to year.

The five-year elosed season established hy the Federal government in 1913 for many of our shore birds should have been extended to the Wilson Snipe. Such action is necessary if this admirable bird is to continue as a game species. After the end of a closed season of a few years, adequate restrictions conld be provided so that it would continue to exist in fair numbers throughout the state and be a staple feature of the game bag.

\section{Long-billed Dowitcher}

\section{Macrorhamphus griscus scolopacrus (Say)}

OTHER NAMES-Red-breasted Snipe (in summer); Jack Snipe; Gray Snipe (in winter); Scolopax grisea; Scolopax noveboracensis; Macrorhamphus scolopaceus; Macrorhamphus griseus.

DESCRIPTION-Adults, both scxes, in late spring and summer: Top of hearl and hinil neck streakel brownish black and light cinnamon; stripe from upper mandible to above eye, dull whitish; sides of head, mixel white and tawny, flecked with brownish black; chin dull white often finely flecked with ilusky; iris "reddish-hazel"'; bill "dark olive", (Audubon, 1843, VI, p. 13); feathers of back and scapulars black, narrowly margined with pale cimmanon and narrowly tipped with pale gray or white, some with irregular or broken bars of tawny; rump white becoming posteriorly like upper tail coverts, the latter being marked with spots and bars of white and blackish brown; tail feathers ashy brown, irregularly barred with white, and sometimes with pale tawny: outer surface of closed wing brownish gray, lightest on midlle coverts; coverts and secondaries narrowly margined with white, secomlaries more broadly tipped with white; primaries dark brown, quill of outermost one white; mnler lining of wing, and axillars, barred white and blackish brown; under surface of flight feathers lusky, more or less finely marbled with whitish on inner webs; uniler 
surface tawny, the feathers tipped obsemrely with white, and some with small terminal spots or streaks of brownish black; under tail coverts pale tawny or whitish, spotterl and barred with brownish black; feathers of sides and flanks tawny, barred with brownish black; feet with small webs between bases of toes, "light yellowish olive," claws "dusky", (Aurubon, loc. cit.). Males: Total length 10.S1-11.75 inches (274-29S mm.) (two speeimens); folled wing 5.57-5.89 (141.2-149.6); bill along culmen 2.13-2.32 (54.2-58.9); tarsus 1.36-1.47 (34.6-37.4) (ten specimens). Females: Total length 12.00-12.12 (305308) (two specimens); folded wing 5.65-6.10 (143.5-154.7); bill along culmen 2.24-2.s0 (56.9-71.2); tarsus 1.40-1.65 (35.5-41.9) (ten specimens); all from California. Adults, both sexes, in fall and winter: Top of head, hind neck, and back, quite uniform gravish brown, most of the feathers with obseurely darker shafts; eyelids and stripe from upper mandible to eye, white; area between side of upper mandible and eye, grayish brown; lower sile of lead and chin, mixed drab and white in fine pattern; rump white; upper tail coverts and tail, barred with white and brownish black as in summer; wing and coverts as in summer; throat, chest and sides, pale grayish brown, some of the feathers with narrow dark brown shaft streaks; belly white; flanks and lower tail coverts barrel with brown and white. Juvenile plumage: Top of head and back chiefly blackish, with much feather-erlging of clay-color; scapulars and tertials the same; rump and tail as in adults; wing coverts broady outlined with white or dull rlay; "hin whitish finely flecked with dusky; throat, chest and sides, dull buffy brown with obscure dusky spotting; belly dull whitish; flanks dull buffy, barred obseurely with ilusky; lower tail coverts buffy white speckled with dusky. Natal plumage: Top of heal deep chestuut brown, bordered on each sicle by a line of white, the two lines meeting on hind neck; streak down middle of forehead and another from bill to eye, black; sides of head and neck tawny, much obseured with dusky on ear region; hack deep chestnut brown, marbled with black and seatteringly markerl with white espeeially on hind neck and wings; throat buffy white; breast dull orange, paling to buff on belly; flanks like back.

MARKS FOR FIELd IDENTIFICATION-Moderate size (near Wilson Snije), white rump, narrow light bars on wing, long bill (fig. 65) held downward at an angle to boly, swift erratic flight, open flock formation when feeding; in spring and summer, conspicuously tawny breast, in winter nuiform grayish brown upper surface.

ToICE-In fall, a deep guttural chirp; a whistled note (sereral authors). In breeding season a strilent péet-û-wéet; wée-too, wée-too; also péet-peet; pée-ter-úé-too, ete. (Nelson, 1887, p. 101).

NEST-Placed on mossy or bare ground usually in a marshy area; a slight lepression in the ground or in a grassy hummoek, often withont lining of any sort save that formed by dead grasses naturally underlying the spot.

EGGS-4, pear-shapei, measuring in inches, 1.69 to 1.87 by 1.20 to 1.25 (in millimeters, 42.9 to 47.5 by 30.5 to 31.7 ), and averaging 1.75 by 1.22 ( 44.4 by 31.0); grom color clay or grayish, sometimes with a greenish cast; large well defined dark umber brown spots, sparse except abont large end where they are erowiled (Nelson, 1887, p. 101).

General distribution - Western North America and Miłdle America. Breeds from Point Barrow to mouth of the Yukon River, Alaska, and east to northwestern Mackenzie; winters from Louisiana and Florida south into Mexico and the Gulf region. In migration ocenrs over whole Uniter States, but most abundantly in the West, and but sparingly, on eastern coast from 
Massachusetts southward; ocrurs also on eastern coast of Siberia (morlified from A. O. U. Check-list, 1910, p. 111).

Distribution IN CALIFORNiA-Common spring amil fall migrant coastwise and in valleys west of the Sierras. Has occurred as a winter visitant, though irregularly, at San Diego.(Belding, MS); at Santa Ana, Orange County (Grinnell, MS); Wilmington, Los Angeles County (Stephens coll.); and as far north as Los Baños, Merced County, November to March (specimens in Mus. Vert. Zool., and Beck, MS). In migration becomes abundant about second week in April and continues so until about mil-May. In fall first appears about last of July, and is found in varying numbers up to first week in November.

The Long-billed Dowitcher is the "Jaek Snipe" of the seashore. It is a breeding speeies along the northern coast of Alaska and winters in the Gulf region and Mexico. It oeeurs within our confines ehiefly as a migrant, rarely remaining as a winter visitant. Belding (MS) states that it is a rare irregular winter visitant at San Diego, and Grinnell (MIS) has record of its presenee in numbers at Santa Ana, Orange County, January 25, 1893. F. Stephens has one taken at Wilmington, Los Angeles County. December 4, 1879. In the San Joaquin Valley in the vieinity of Los Baños, Mereed Connty, the species was found in varying numbers by Beck throughout the winter of 1911-12, being taken Deeember 9, 1911, Janmary 2 and March 6 and 22, 1912 (specimens in Mus. Vert. Zool.). Lamb (1912, p. 35) took a specimen 9 miles east of Daggett, San Bernardino County, February 24, 1911. Two males were taken at Olema, Marin County, March 9, 1882 (eoll. J. and .J. W. Mailliard). The earliest coastal reeord is for Santa Barbara, March 10, 1910 (Bowles and Howell, 1912, p. 8). It beeomes abundant during the second week in April and continues so until about the first week in May, the last birds being seen about the middle of the month. The latest spring reeord is for May 13 (1914), at Los Baños (H. C. Bryant, MSS). Goldman (1908b, p. 203) noted a floek at Tulare Lake, July 8, 1907; but the birds examined were not in breeding condition, and probably represented early fall migrants. Henshaw (1876, p. 271) noted the species at Kern Lake, Kern County, in Angust. The breeding birds and young from the north appear along the eoast in numbers about the first of September and eontimue to be seen from the latitude of San Franciseo southward until the first or seeond week of November. The numbers of Dowitehers present is probably never very large, although a flock of as many as 200 has been seen at one time. The speeies is more often noted in floeks of six to two dozen individuals.

The Long-billed Dowiteher may be distinguished from other waders by its medium size, long bill (fig. 65), by the absenee of distinet stripes on its bark, by its white rump and wing bars, open flock formation when feeding, and erratie flight. In late spring and summer it may be easily distinguished by the reddish coloration of its under surface; 
in fall and winter by the almost uniform grayish upper surface and unstriped lower parts. The Dowiteher resembles the Wilson snipe in general size and in its very long bill, lut differs notably in the absence of conspienons streaking on the upper surface of its body and in having a white rump and distinet, thongh narrow, white wing bass. In spring plumage the Dowiteher may also be clistinguished from the suipe by its reclish breast. In this plumage the Knot might be eonfused with it, but the latter has a much shorter bill and a dusky lump, and feeds in compat flocks. In antumn the Dowiteler and Wantering 'Tattler' are somewhat similar in plumage, but the Dowiteher may then be distinguished by its mueh longer bill, white rump, barred upper tail coverts, and white wing bars.

The Long-billed Dowiteher fords ont on the open flats, a habit strongly in contrast with that of the Wilson Sinipe, the latter bird slowing exelusive preference for grassy ground. The Dowiteher fre-

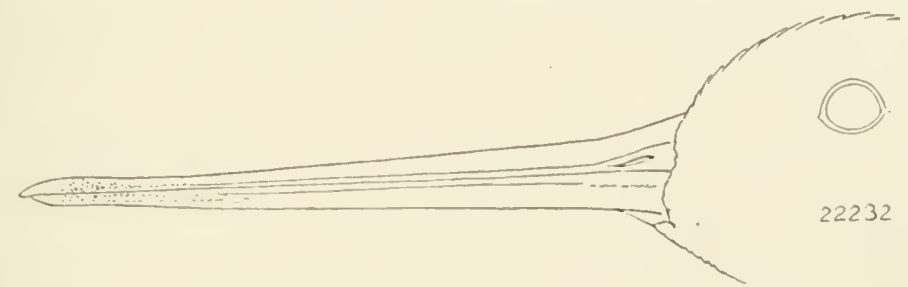

Fig. 6.5. Sille of bill of female Long-billed Dowither. Natural size.

Note similarity to bill of Wilson Suipe (compare with fig. 64 ).

quents the borders of marshes, sand and tide flats, and the edges of inland pools of water, showing but little preference for salt over fresh water. When along salt water the birds retire to higher boggy land during high tike and probe there for worns. The feeding flock usually scatters out over the flat, whieh is in marked eontrast to the method of feeding employed by Knots. The Dowitehers probe industriously, sinking the bill in vertically up to the very base. Often when feeding the birds thrust the bill into the mud, withdraw it, advance a step, again thrust it into the mnd and so on, repeating the process rapidly, so that they remind one of a walking beam. While feeding they keep up a eontimuous run of soft notes (Cones, 1874, p. 479). When alarmed the birds "freeze," with the head down and close in to the body, the long bill pointing downward at an angle of 45 degrees. They frequently wade about in water as deep as the length of their legs will permit, thrusting their long bills through the water into the mderlying mud. If they wander beyond their depth they are able to swim with a fair degree of ease, and the same is true 
when they are wounded. The possession of a slight wobbing at the bases of the toes is probably correlated with this ability in swimming. Dowitchers swim with a bobbing motion of the head and this is accompanied by a corresponding jerking of the tail (Coues, loc. cit.), in much the manner of a Rail. When frightened and forced to take wing, or when moving to a new location, they fly in a small compact flock with quick tuming much like the small Sandpipers. In flight they are usually silent, and the head and long bill are held at an angle (abont $30^{\circ}$ ) to the rest of the body. These character's serve to distinguish the species when only the outline is olservable. Dowitehers frequently associate with other waders and when doing so often lead the flock of which they happen to be members.

The Long-billed Dowitcher nests during the latter part of May and probably throughout the month of June, as eggs have been taken at St. Michael, Alaska, on May 23, 1880, and at Fort Anderson, Maekenzie, Jume 21, 1864, and June 15, 1865; while incubating birds were secured at Point Barrow, Alaska, on Jume 28, 1883 (Cooke, 1910, p. 29). The nest is a simple structure composed at most of a few decayed leaves in a depression in the mossy gromnd (Macfarlane, in Baird, Brewer and Ridgway, 1884, I, p. 199), or may be only ". . . a shallow depression formed by the bird's body in the soft moss and withont a trace of lining." That is to say, there is "no nest, execpt the dead grass naturally fomnd in the place ocempied . . " (Nelson, 1887, p. 101).

The best acconnt of the nesting habits of the Long-billed Dowitcher is that supplicd by Nelson (loc. eit.), who found the birds in the vicinity of Norton Sound, Alaska.

Two or three males start in pursuit of a female and away they go twisting and turning, here and there, over marsh and stream, with marvelous swiftness and dexterity. At short intervals a male eheeks his flight for a moment to utter a strident péet-ûtúet; úé-tōo, uée-too; then on he goes full tilt again. After they have mated, or when a solitary male pays his devotions, they rise 15 or 20 yards from the ground, where, hovering upon quivering wings, the bird pours forth a lisping but energetic and frequently musical song, which ean be very imperfectly expresser by the syllables péet-peet; pée-ter-úé-ton; wée-too; pée-ter-wée-too; pée-ter-uée-too; wée-too; wee-too. This is the complete song, but frequently only fragments are sung, as when the biril is in pursuit of the female.

June 16, while crossing a tussock-eovered hill-top, over a mile from any water, I was surprised to see a female of this speeies flutter from her nest about 6 feet in front of me, and skulk off through the grass with trailing wings and depressed head for some 10 or 15 yarts, then stand nearly roncealed by a tuft of grass and wateh me...

The young are full grown and on the wing with their parents [by] the last of July, and the first of August finds the arlults rapilly changing their hreeding-dress for that of winter, and gathering into flocks. By the first of September they are in perfeet winter dress, and frequent mully flats, the 
elges of tide creeks, and other places, exactly as they do in their passage south or north in midlle latitules. They have the same unsuspicious ways here as there... (Nelson, 1887, p. 101).

Aceording to MeAtee (1911a) the following items have been found in the food of the Dowitcher: Adult and larval horseflies, grasshopper's, and oyster-worms (Nereis). Leeches, worms of various sorts, varions water bugs, and soft mollusks comprise the chief elements of the food inland (Cones, 1874, p. 479).

The Long-billed Dowitcher was probably somewhat more abundant formerly in California than it is at present. 'This is indieated by the faet that Cooper (in Baird, Brewer and Ridgway, 188t, I, p. 200) records their being sold in the markets of Los Angeles in 1865 in bunches as "jack snipe." Nowadays it is usual to see only a small floek of at most two dozen individuals. 'The Dowiteher, along with most of the other shore birds, needs total protection for a considerable period, and should, thereafter, if again placed on the open list, be further guarded by a small bag limit.

\section{Knot}

\section{Tringa canutus. Linnaeus}

()THER XaMes-Robin Snipe; Red-breasted Snipe.

DESCRIPTION-Adult male in spring and summer: Tpper surface of hear, hind neck, and region between base of bill and eye, streaked with pale smoke gray and olive black; dull stripe from base of upper mandible orer eye to above ear, and cheek, ehin, and middle throat, light cinnamon brown, with some whitish feather-tippings; bill black; iris "dark hazel" (Audubon, 1842, V, p. 257); feathers of back with broad irregular centers of olive black, margined with grayish white, some with side spots of pale tawny; feathers of rump light brown, with shafts and margins of darker brown, the extreme tips margined with white; upper tail coverts white with irregular erescentie bars of dark brown; tail drab above, narrowly margined with white; outer surface of elosed wing dull drab near bend, lighter behind; median and lesser coverts margined with light drab; greater coverts margined with white, forming a narrow wing bar.; primaries brownish black, quills of all, and outer margins and tips of inner ones, white; seconlaries anil tertials dark brownish near shaft, lighter toward margin, some edged with white; margin of wing mottled white and dusky; under surface of wing mixed white and light dusky; under surface of primaries drab becoming brownish black at tip; axillars white with irregular narrow bars of light brown; under surface of body (except belly and under tail coverts), bright cinnamon brown, with sparse flecking of white; sires and flanks inconspicuously and irregularly barrel with light brown; belly and under tail coverts white, some of the feathers with darker shaft streaks or spots near tip and pale einnamon wash; feet greenish black. Total length 10.00-10.90 inches (254-277 mm) (two specimens); folder wing 6.53 (165.6); bill along culmen 1.39 (35.2); tarsus 1.27 (32.3) (one specimen). Adult female in spring and early summer: Like arlult male in corresponding plumage but 
generally darkor above, shaft streaks on top of heal wider, white margins of feathers of back less extensive, eross hars on feathers of rmmp. sides ancl flanks broaler and darker: cimmamon eolor beneath, deeper. Folled wing 6.53 inches (165.s mm.): hill along enlmen 1.43 (36.4); tarsus 1.26 (32.1) (one specimen); all from California. Jucnile plumage: Whole head and neck dully streaked with blackish or drab, on a grayish white ground: chin and stripe over eye, nearly unmarked, whitish: back grayish brown with blackish shaftstreaks and narow feather-margins of brownish black horlerel by white, giving a distinetly sealed appearance: rump, upper tail coverts, tail, and wings, as in summer adults: breast and sicles light drab with narrow shaft streaks and spots of liglit brown: rest of under surface white. Fatal pluma!le: "Buff to eream color, markel above with black and rufons, the black markings exceeling the gromnd color on erown, back, and rmup" (Sanfori, Bishop) and Tan Drke, 1903, p. 35s). Iris hack: bill dark olive, tip lark lown; back of legs and soles of feet, greenish yellow: toes hlack (Feillen in Nelson. 1897, p. 102$)$.

MARKS FOR FIELD IDEXTIFICATIOX-Meilim size (slightly larger than Wilson Snipe), ehmoy appearance, short bill (fig. 66) (not muph longer than head), and short legs: feeds along shore in close flocks: in spring distinguishol from all other shore birds of similar size except Dowituher, by its bright rechlish breast, hut the Dowitoher has a very much longer bill. In fall the strutural characters and methou of feeding must be depented upon.

Voce-A soft wah-quoit or whit whit. and a little hom: (Мarkay, 1s93, p. 27: Forbush, 1912, p. 262).

Nest-A sluallow depression on grassy tum hra, lined with a few thry grasses.

Egas-3 (possibly 4), slightly pear-shapel, measuring in inches, 1.64 to 1.97 by 1.14 to 1.33 (in millimeters, 41.7 to t9.5 by 29.1 to 33.5 ), and averaging (6 eggs) 1.74 by 1.21 ( 44.1 by 30.6$)$ : ground-color pale greenish or clay, with superficial spots of rellowish to blackish brown, and deeper ones of pale riolet-gray: markings more numerous abont larger end (Dresser, 1904, pp. 23-233).

Gexeral distribtTiox-Almost world-wide. Breeding rauge cirempolar, northeru Ellesmere Land south to Melville Peninsula and possibly Iceland: also on Taimyr Peninsula, Siberia. Winters sonth in Ameriea to sonthern Patagonia, and from the Mediterranean to South Africa. India, Australia and New Zealand. Casnal on eastern coast of Lnited States in winter. Oceurs in migration over most of the Eastern Hemisplere. on Atlantic coast of North America, and, more rarely in the interior and on the lacifie eoast (A. O. $U$. Check-list, 1910, p. 112).

DistrintTION IA CALIFORAIA-Rather uncommon spring and fall migrant. Recorded in spring only on Alameda Connty shore of San Franciseo Bay, April 27 and 30,1914 (atult male and female in breeling plumage in Mus. Tert. Zool.), and May 10, 1996 (Grimnell, 1902a, p. 25). Fall recoris: Monterey, August 7 and 17,1910 (three males in Mus. Tert. Zool.: Beck, MS): Santa Barbara, August 21 to September 7, 1911 (Bowles and Howell, 1912. p. S); Alamitos Bay, Los Angeles Connty, Septemher 18, 1907, three taken from flock of 30, and Oetober 10, 1907, one taken (Willett, 1912a, p. 36): Anaheim Landing. Orange County, Oetober 3, 1909, one speeimen (Lamh, 1909, 1). 20s); Pacific Beach, San Diego County. September 10 and 16. 1904, two taken from several (Bishop, 1905, p. 141): and Sam Diego, Octoher 7 and 9.1903 , three specimens (Dwight, 1904. pr. $7 \varsigma, 79$ ). 
The Kinot, Red-breasterl sinipe, or Robin Snipe, as this species has been varionsly called, is not abundant when compared with most other shore birds found in California. Indeed the infrequent records of its capture might be intrpreter as showing it to be a rather rare species. During the first half of the last century the speeies was present during the migrations in enormous numbers on the Atlantic coast where it was, and still is, much prized as an article of food. Excessive slaughter and spring shooting have reduced the species to a small fraction of the number's once present there. No such numbers were ever recorded on this coast, and it is probable that the birds were never more abundant here than they are at present. In fact, the keen exes of the collectors risiting Califormia in the davs of the Pacific Railroad surveys failed altogether to detect the Knot within our confines. Eren with the increase of observers of late years, a few compact flocks and some single birds are all that have been seen. But continued observation along the coast in suitable localities during the very few days in spring when the species is passing along our coast will probably show it to be somewhat more abundant than is commonly believed.

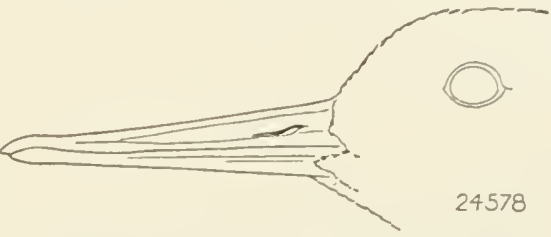

Fig. 66. Sirle of bill of Knot. Natural size.

All oceurrences of the Knot so far recorded for California are for the seacoast. In spring it has been reported only from the shores of San Francisco Bay, where specimens have been taken April 27 and May 10, as noted in the small-type paragraph above. Fall records are more numerous, the earliest being August 7 , and the latest. October 10. The fall migration may thus extend over a period of two months, which indicates a tendency to loiter on the southward journey.

From other shore birds occurring in California the Knot may be distinguished by its medium size (compared with such diverse species as the Godwit and Snowy Plover), chunky proportions, short bill (fig. 66), and short legs. In spring its bright reddish under surface is an important mark of distinetion. Only two other speeies of waders of about the same size oecurring in California show this type of spring eoloration, the Red Phalarope and the Long-billed Dowitcher. From the first of these the Knot may be distinguished by its larger general size and by the absence of white on the sides of its head. The Red Phalarope is somewhat smaller and is usually found swimming and feeding on the surface of water. The Knot is a typical shore bird, and swims only under exceptional cireumstances. From the Long-billed Dowiteher it may be distinguished by the possession of a bill which is little longer than the hearl. That of the Dowitcher 
is at least twice as long as the head. There are also conspienous habit differenees. Knots feed in compact flocks, while Dowitehers spread out when foraging, and in flight the head and bill of the Dowiteher are eonspienously bent downward, while the Knot holds its head and bill in line with the body as do othor speeies of sandpipers. In the fall the Knot is more diffieult of reeognition. Its "ehunky" appearance, the absence of sharply contrasted streaks on its baek and under surface, its short legs and bill (but slightly longer than the head), and its habit of feeding in close flocks, must then be depended upon.

The eall-note of the Knot is a soft wah-quoit, nttered commonly when the bird is coming to decoys, and is said to resemble the rolling note of the American Golden Plover. In addition it has a soft honk (Mackay, 1893, p. 27). Ioffman (in Forbush, 1912, p. 262) renders the note as a soft whit-whit, like the whistle one employs in calling a dog. The birds are said to deeoy to such ealls and to a whistle resembling the eall of the Black-bellied Plover (Mackay, loc. eit.).

The Knot ... frequents the ocean beach, the tidal flat and more rarely the salt marsh. On the beach it plays back and forth, following the receding waves and retreating before their advance. When the surf pounds upon the sandy shore it is the Red-breast's harvest time. Then the surge constantly washes up the sand, bringing small shell-fish to the surface of the beach, as a placer miner washes out gold in his pan, and the birds, nimbly following the recession of the wave, rapidly pick up the exposed shells ere the return of the surge. . . With the flow of the tide, which drives them from the flats or the tide-washed beach, the Knots seek either the beach rilge, some shoal above highwater mark or the salt marsh. They are prone to alight on outer half-tide lelges, where they find small erustaceans and other forms of marine life among the seaweed. They are so attracted to such places and to beaches where seaworms are plentiful that they will return to them again and again in the face of the gunners' fire and this habit accounts in part for their diminution (Forbush, 1912, pp. 266-267).

When the incoming tide drives the Knots from the flats they seek the marshes, or some shoal which is sufficiently elevated to remain uncovered during high water; they also frequent the crest of the beaches. Here they generally remain quiet until the tille has fallen sufficiently to permit them to return again to the flats to feel. When on the marshes during high water they occupy some of the time in feeting, showing they are by no means dependent on the flats for all their foor. They associate and mingle as freely with the Turnstone (Arenaria interpres), Black-bellied Plover (Charadrius sqguatarola), and Red-hacked Sandpiper (Tringa alpina pacifica) as with their own kind. . . They also frequent the flats at night as well as in the laytime... On the ground they are sluggish, and not given to moving ahout much; mnless very much harassed ther are not nearly so vigilant as their companions, the Blackbellied Plover.... In the spring... they sometimes frequent the uplanil on the island in company with the 'Turnstone, never doing so, however, in August or September. . . Knots as a rule are not in the habit of frequenting uplanils as they do the marshes... They are induced... to follow the 
Turnstones where they leal, this birl showing more determination of purpose than the Knots which frequently yield and follow them [the Turnstones]. This is not the case with the Turnstones; they often leave the combined flock rather than be led where they do not care to go. . . (Mackay, 1893, pp. 27-28).

The flocks are much more compact than are those of the Longbilled Dowitcher and this eompany mannerism is usually retained when they take wing on alarm. Because of the feeding habits of the bird the daily period when good shooting ean be enjoyed is rather short-only lasting while the wash of the waves is uncovering new surfaces. Nelson (1S57, p. 102) says that when searehing for food the birds sometimes rum into the water breast ligh.

"When shy, and coming to decoys to alight, they barely touch their fret to the sand before they diseorer their mistake and are off in an instant. They fly quiekly and elosely together and, when coming to decoys, usually pass by them down wind, most of the flock whistling, then suddenly wheeling with heads to the wind, and up to the decoys. At such times many are killed at one discharge" (Mackay, 1893, p. 27).

Information coneerning the nesting habits of the Knot has been very slow in accumulating due to the extreme northern loeation of the summer home of the hird. Nests and downy young were reported as early as 182t, hut no good description of the nests and eggs was published until 1904 (Dresser) and this pertained to the Taimyr Peninsula, in extreme northern Siberia. In 1906-1908, Manniche (1910, pl. 130-136) visited the eastern coast of Greenland north of latitude $76^{\circ}$, and while there had execllent opportmities to observe these birds in the nesting season even though he was unable to discover occupied nests or downy young.

The Knots arrived about the first of June and immediately took up their residence on and about the snow and iee bordered pools of fresh water. Evidently the birds were mated when they arrived on the breeding grounds as they always traveled in pairs even when making long excursions overland. As is the ease with so many other shore birds the male Knot performs a song flight during the breeding season.

The male suddenly gets up from the snowelad ground, and producing the most beautiful flute-like notes, following an oblique line with rapid wing strokes, mounts to an enormous height often so high, that he can not be followed with the naked eye. Up here in the clear frosty air he flies around in large circles on quivering wings and his melodious far sounding notes are heard far and wide over the country bringing joy to other birds of his own kill. The song sounds now more distant now nearer when 3 or 4 males are singing at the same time. Now and then the bird slickes slowly downwards on stiff wings with the tail feathers spread; then again he makes himself invisible in the higher regions of the air mounting on wings quivering even faster than before. ... 
Gradually, as in increasing excitement he executes the convulsive vibrations of his wings, lis song changes to single deeper notes-following quickly after each other-at last to die ont while the bird at the same time drops to the earth on stiff wings strongly bent upward. This fiue pairing song may be heard for more than a month everywhere at the breeding places, and it wonderfully enlivens this generally so desolate and silent nature (Manniche, 1910, p. $132)$.

In the breeding season the male is pugnacious and quarrelsome towards birds of his own and of other species, and will often dive them far from his domain. Both sexes share in the work of incubating the eggs as both show the bare spots on the breast and belly which characterize inenbating birds. But the female does the larger share of this work, the male being much oftener seen off the nest than is his mate. The birds are extremely wary and give absolutely no indication of the location of their nests. Manniche was able to find the nests of many of the other species of birds summering in this region, but was absolutely baffled in his attempts to discover a nest of the Knot. Once, after the young were hatched, he followed a female bird for over four hours and eovered more than two miles of country in a vain endeavor to discover the location of her brood. So far as determinable, the male does not assist in caring for the brood.

The food of the Knot consists of numerous small mollusks, small crustaceans, marine worms, entworms (from the marshes), grasshoppers, diving beetles, caterpillars, and, rarely, parts of plants (MeAtee, 1911a; Mackay, 1893, p. 27 ; Saunders, 1899, p. 596).

The chief interest in the Knot lies in its value as a game bird. Sanford, Bishop and Van Dyke (1903, p. 360) declare that the flesh of this speeies is of fine flavor, to be compared with that of the Golden Plover. The Knot should therefore be carefully conserved. In California its small numbers make it of particular interest from the standpoint of the naturalist.

\section{Pectoral Sandpiper}

\section{Pisobia maculata (Vieillot)}

OTHER NAMES-Tringa maculata: Actodromas maculata.

DescrIPTION-Adults, both sexes, in spring and summer: Top of heail black, the featlers broadly margined with rusty; lower part of forehearl and stripe to and over eye, whitish, many of the feathers with narrow dark brown shaft streaks; below this a dull redlish brown stripe from hill to eye; clin white; (heeks aud throat buffy, finely streaked with blackish brown: bill greenish, rellowish at hase of lower mandible; iris dark brown: hinl neek like top of head but colors paler; upper back and scapulars brownish blark, broadly margined with tawny and tipper with ashy white (as the season proceerls the tawny pales by fading, and the white is worn off): rump and central upper tail coverts, dull brownish black, some of the feathers narrowy tipped with 
pale tamy: outermost upper tail coverts white, streaked with browu; inner tail feathers dull dark brown, lateral ones drab; onter surface of closed wing dull dark brown, most of the feathers dark $n$ 'ar shaft and lighter at margins, even horlerel with whitish; jrimaries brownish black, shaft of outermost one white; margin and under eoverts of wing mottled white and brown; hindmost unter coverts ant unier surface of flight feathers dusky; axillars white; feathers of throat and breast thickly marked with brownish black shaft streaks on whitish or buffy ground; rest of under surface abruptly white: sides with a buffy tinge and dark shafts; flanks white, with narrow slaft stripes; feet greenish. Total length $8.00-9.62$ inches (203-242 mm.) (two specimens, from Alaska and Florida). Males: folded wing 5.37-5.61 (136.5-142.5); bill along r.nImen 1.15-1.20 (29.1-30.5); tarsus 1.09-1.14 (27.8-29.0) (five specimens from California, Alaska and Britisll Columbia). Females: folded wing 4.79-5.05 (121.9-12S.0); bill along eulmen 0.95-1.14 (25.0-29.0): tarsus 1.0.3-1.11 (26.12s.1) (nine specimens from California, Alaska and Britislı Columbia). Adults, both sexes, in fall and winter: "Similar to summer plumage, but the rusty tint above almost or wholly absent, and the black markings less sharply defineit" (Bairl, Brewer and Ridgwar, 18s4, I, p. 233). Jurenile plumage: Similar to that of adults in summer but longer seapulars and other feathers of back margined extensively with bright tawny and white: general buffy tone on breast more intense. Natal plumage: Foreheal and siles of heal, buffy yellow; chin and throat. white: stripes up mildle of foreheal, from bill to eye, from hill to below eye anl from above eye to ear region, black: bill dusky, slightly paler at base; top of head, back and wings. of mixed pattern, the down feathers redllish brown at bases and black near ends and some with buffy white tips; breast buff; belly chiefly white; legs and feet (driel) pale straw rellow; nails blackish.

MARKS FOR FIELD IDENTIFtCATION-Medium small size (slightly smaller than a Killdeer), short bill about as long as head, white chin, buffy foreneek and breast finely streaked with dark brownish (this area constituting a broad, rather abruptly outlined, pectoral band), and blackish rump and upjer tail roverts More common on meadowland and less so on open flats than other sandpipers.

VoICE-A single, rather rasping tweet or kreck: in the breeding season a

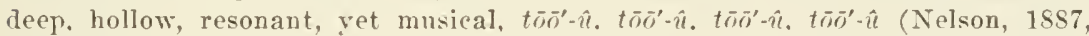
p. 108).

NEST-In grass in dry situations though often in the vicinity of water; a depression lined with a little grass.

EGGS-Usually 4, pointedly pear-shaped, measuring in inches, 1.42 to 1.58 hy 1.02 to 1.11 (in millimeters, 36.1 to 40.2 by 25.9 to 28.2) ; ground-color drab, with a greenish tinge in some specimens, spotted and blotched with umber brown, variously distributed; deeper markings pale purplish gray (Murdoch, 1885, pp. 111, 112).

GeNeral Distribution-North and South Ameriea. Breeds commonly on the Aretic coast of Alaska from the mouth of the Yukon to Point Barrow, rarely in Mackenzie, and probably on the Arctic coast northwest of Hudson Bay. In migration occurs abundantly south to southern Alaska, and throughout the United States east of the Rocky Mountains; in limited numbers on the Pacific coast from British Columbia southward. Winters in central South America in Chile, Bolivia and Argentina, up to 12,000 feet altitude (Cooke, 1910, p. 35 ; et al.).

Distribution in California---Rather rare migrant coastwise; has been recorded from: San Francisco Bay (Cooper, 1868, p. 8); Mill Valley Junction, 
Marin County, a pair, September 14, 1896 (J. Mrailliarl, 1904, p. 15); San Francisco Bay, Oetober 8 (1883) (Kobbé in Bailey, 1902, p. 1); Farallon Islands, September 4, 1884 (Cooke, 1910, p. 36); Santa Barbara, September 9, 1910, one seen April 14, 1910, also seen on seven dates between August 18 and September 20, and one daily from August 20 to September 20, 1911 (Bowles and Howell, 1912, p. 8), three individuals at most, September 17 to 23, 1909 (Torrey, 1910a, pp. 44-45), August 20, 1913; La Patera (near Santa Barbara), August 25, 1915, and Elkhorn, Monterey County, October 11, 1913 (Dawson, 1916, p. 25).

The Pectoral Sandpiper is a rather rare migrant in California. The main migration route of the speeies lies east of the Rocky Mountains and it seems that only a few stragglers, probably birds of the vear, oecur along the Paeifie coast. Borles (1911, pp. 171, 172) states that during a residence of fourteen years in Washington he saw in all only about one hundred birds of this speeies, although he eites the observation of J. M. Edson at Bellingham who saw thirty or forty individuals on one day. This Sandpiper is evidently even less common in California, else the assidnous eollecting which has been carried on along our shores, espeeially in sonthern California, would have vielded more instances of oceurrence.

Cooper (1868, p. 8) thought that the Peetoral Sandpiper oceurred not rarely in his day about San Franeisco Bay in winter, though no corroborative evidenee has been subsequently obtained. Kobbé (in Bailey, 1902, p. 1) lists the speeies from San Franciseo Bay, on the basis of a specimen taken by W. E. Bryant, Oetober 8 (1883). This we believe to be the sane example which was reported by Bryant (18S7a. p. 78) under the name Tringa fuscicollis. A pair of birds was taken September 14, 1896, at Mill Valley Junetion near Sausalito, Marin County (.J. Mailliard. 1904, p. 15). A speeimen was taken on the Farallon Islands, September 4, 1884 (Cooke, 1910, p. 36). Otherwise the speeies has been recorded only at Santa Barbara where a number of observers have noted it. The only spring oecurrence was one individual on April 14, 1910, but in the fall it has been seen on different dates from August 20 to September 2:3, never more than three at one time (Torrey, 1910a, pp. 4t-45; Bowles and Howell, 1912, p. S).

For field identifieation a combination of characters must be depended upon. The moderately small size (somewhat less than that of a Killdeer), the short bill about as long as head, the strongly eontrasted dark area on fore-neck and breast, with its finely streaked pattern on close view, and the blackish rump and upper tail eoverts, are the chief characteristies. The preference of the species for meadow land, and its snipe-like behavior, are two additional eriteria. From the nrarly remated Baird Sandpiper it may be distinguished, though with some difficulty, by its larger size, longer and lighter-eolored bill, paler 
feet, and darker and more conspicuous breast band and streakings. Jureniles of this species as compared with Baird Sandpipers of the same age show a streaked rather than scaled appearance on the back. From the Least and Western sandpipers it may be distinguished chiefly on the basis of size, as it is twice or three times as large as those species. The male Pectoral Sandpiper is distinctly larger than the female, a reversal of size relation obtaining between the male and female of many shore birds.

The Pectoral Sandpiper is ordinarily a rather quiet species. Its call-note is a harsh twect or hrerl:. The latter note has in parts of the East won it the name of "Kreeker." 'This note is ordinarily uttered only onee, but may be replaced by repeated shrill cries when the bird is flushed suddenly.

Torrey (1910a, pp. 44-45) records his brief experience with the Pectoral Sandpiper at Santa Barbara as follows:

On the morning of Septemlier 17, 1909, I found and watchell at my leisule a single bird of this species..., feeding in and abont some small muldy pools. . . The next day it was still there, and after some time another one walked into sight from behind a bunch of reeds... [Ther] allowerl me the closest kind of approarh, in a perfect light, so that all details were abundantly seen: the greenish legs, the parti-colored bill, the black rump, and the immaculate chin... They neither bobbed nor teetered, but lad a plover-like trick of half squatting, or crouching, when startled. ln running, and now and theu when standing still, they assumed a peculiarly erect attitude, which gave them the appearance of being, for sandpipers, uneommonly long necked.

\section{Forbush (1912, p. 272) says of this speeies in Massachusetts:}

The Grass-bird usually comes in the night, in flocks of twenty-five to fifty birds, and scatters in small parties in the salt marshes, particularly those on which the grass has been cut and where little pools of water stand. It seems to prefer the higher portions of the salt marsh, where the "black grass"' grows, and it is sometimes common in the fresh-water meadows near ponds in the interior... The grass pattern and shading of its back furnish such com plete protection from the eye of man that it can conceal itself absolutely by merely squatting in the short grass. Where it has not been shot at or disturbed it becomes exceedingly tame and confiding, but old experienced birds are wild, and fly so swiftly and erratically that some of the hunters call them "Jack Snipe" because of a fancied resemblance in their flight to that of Wilson's Snipe. Sometimes they are found in fresh meadows near the salt marsh, and more rarely on the ocean beach, where they follow the retreating wave like the Sanderling or any other beach bird.

Stearns and Coues (1883, pp. 220, 221) state that "When they arise from the grass to alight again at a little distance, they fly in silence or with a single tweet, holding the wings deeply incurved; but when suddenly startled and much alarmed, they spring quickly, 
with lond, repeated eries, and make off in an irregular manner, mueh like the common Snipe. Sometimes, gaining a eonsiderable elevation, they circle for several mimutes in silence overhear, flying with great velocity, perhaps to pitch down again nearly perpendicularly upon the same spot they sprang from.'

The Peetoral Sandpiper decoys readily as do many other shore birds. When on the ground it walks deliberately, with the bill held downward. Upon alighting, which all the birds in a flock are said to do at the same moment, the wings are raised above the body for an instant and then neatly folded. In flight the birds mass into compact flocks (Sanford. Bishop and Van Dyke, 1903, p. 372).

These birds arrive on the shores of Bering Sea and the Aretic Ocean from the middle to the last of May (Cooke, 1910, p. 36). They linger about the wet spots where green herbage is just beginning to show throngh the tundra, and then pair and seek nesting places.

Nesting probably begins about the first of Jume and continues throughout the month and even into the early part of July, as Nelson (1887, p. 108) observed a male in nuptial flight on May 24, and Nurdoch (1885, p. 112) states that the last eggs which were brought in, on July 12, contained only small embryos. Probably the bulk of the species nests about the middle or latter part of June.

The mating antics of this species have been very fully described by Nelson. The male inflates his throat until it is as large as his body and then ntters a deep, hollow, resonant yet hiquid and musical note, which may be represented by the repetition of the syllables tō'- $\hat{u}$. $t \bar{\partial} \bar{o}^{\prime}-\hat{u} \cdot t_{\bar{o}} \bar{o}^{\prime}-\hat{u}, t_{\overline{0}} \bar{o}^{\prime} \hat{u}$. The air sac gives the resonant quality to the note. The note is nttered under a variety of conditions and at various times during the day or light Aretic night. Apparently the birds fill the esophagus with air only just previous to making the notes.

The skin of the throat and breast becomes very flabby and loose at this season, and its inner surface is covered with small globular masses of fat. When not inflated, the skin loader with this extra weight and with a slight serous suffusion which is present hangs down in a pendulous flap or foll exactly like a dewlap, about an inch and a half wille. The oesophagus is very loose and heromes remarkably soft and distensible, but is easily ruptureal in this state... The [male] bird may frequently be seen runuing along the ground close to the female, its enormous sae inflated, and its hearl drawn back and the bill pointing directly forward, or, filled with spring-time rigor, the bird flits with slow but energetic wing-strokes elose along the ground, its hear raised high over the shonlders and the tail hanging almost directly down. As it thus flies it utters a suceession of the hollow booming notes, which have a strange ventriloquial quality. At times the male rises 20 or 30 rarls in the air and inflating its throat glicles down to the ground with its sar hanging below. ... Again he crosses back and forth in front of the female. puffing his breast out and howing from side to side, running here aud there. as if intoxicated with passion. Whenever he pursues his lore-making, his 
rather low but pervading note swells and dies in musical callences, which form a striking fart of the great bird chorus hearl at this season in the north (Nelson, 1887, lp. 108, 109).

The nest is always built in the grass, with a deciderl preference for high and dry localities like the banks of gullies and streams. It was sometimes placed at the elge of a small pool, but always in grass and in a dry place, never in the black clay and moss. . . The nest ... [is] a depression in the ground lined with a little dry grass. . .

In color anil markings... the eggs closely resemble those of the other small waders. The ground color is drab, sometimes with a greenish tinge, though never so green as in the egg of $P$. alpina americana and sometimes a pale bistre-brown. The markings are blotchings of clear umber brown, varying in intensity, thickest and sometimes confluent around the larger encl, smaller and more seattered at the smaller end. Some of the eggs with brown ground are thickly blotched all over. . . All the eggs have the usual shell markings of pale purplish gray and light neutral tint (Murloch, 1855, pl. 111, 112).

The food of the Pectoral Sandpiper is quite varied. Taking the eastern range of the bird into account, it includes billbugs, water beetles, entworms, corn-leaf beetles, wireworms and elick beetles, clover-root emrénlios, mosquitoes, larvae and adult horsefties, and erane-fly larvae (MeAtee, 1911a) ; worms, minute shellfish, and oceasionally rootlets and buds (Goss. 189)1, p. 170) ; and sea lettuee (Baird, Brewer and Ridgway, 1884, I, p. 235). The flesh of this species is highly prized as an article of food. In fact it is stated (Baird, Brewer and Ridgway, loc. eit.) that "in the antumn its flesh becomes very juicy and finely flavored, and when procured late in the season it is said to be superior to that of any of our shore-birds, and fully equal to any upland game." This is the smallest of the shore birds that can be legitimately called a game species. Thongh the species is obviously highly desirable. the small numbers occurring in California debar it from a prominent place among the game birds of the state.

\section{Baird Sandpiper}

\section{Pisobia bairdi (Cones)}

OTHER NAMES-Tringa bairdi; Actodromas bairdi; Heteropygia bairdi.

DESCRIPTION-Adults both sexes, in spring and early summer: Top of heal and hind neck broadly mottled with blackish brown on pale buffy or creamy white ground; indistinct stripe from base of upper mandible to and behind eye, whitish; below this a dark mottled stripe; eyelids white; chin and throat white, minutely and sparingly flecked with dark brown; sicles of hear and neck, creamy white, flecked with narrow brownish shaft streaks, darkest anil most numerous on ear region; bill black; iris dark brown; feathers of upper back extensively blackish brown, tipped with pale buffy; tertials brownish black, broadly tipped with pale drab and many of the feathers with irregular tawny spots on webs; lower back, rump, central upper tail coverts and middle tail feathers, brown; outermost tail coverts mottled with whitish; outer tail feathers drab; outer surface of closed wing brown, all of the feathers with 
dark brown shafts and some with lighter margins; shaft of outermost primary white; margin of wing mottled with white and light brown; lining of wing white, except hindmost coverts which, like inner surface of flight feathers, are pale dusky; axillars pure white; breast and sides pale buffy, with narrow brown shaft streaks; rest of under surface and flanks, white; legs and feet "dark slate", (Sanford, Bishop and Van Dyke, 1903, p. 376). Total length (both sexes) " $7.00-7.60$ " inches (178-193 mm.) (Ridgway, 1900, p. 157). Males: folded wing 4.43-4.77 (112.6-121.0); bill along culmen 0.74-0.89 (18.9-22.7); tarsus $0.86-0.91$ (21.8-23.0) (nine specimens). Females: folded wing 4.655.00 (118.0-126.8); bill along culmen 0.84-0.92 (21.3-23.4); tarsus 0.86-0.91 (21.9-23.2) (six specimens); all adults and full grown immatures, from Alaska, British Columbia and California. Juvenile plumage (in late summer and fall): Similar to that of adults in spring, but feathers of back and tertials and wing coverts narrowly tipped with white, giving a sealed appearance; tawny spots on webs of tertials lacking, and upper tail coverts narrowly tipped with pale buffy. Natal plumage: Forehead whitish, with a median black line; side of head whitish, with two black lines extending from base of bill towards eye; top of head, to level of eyes, and whole back, mixed tawny and black in coarse pattern, overlaid with a "frosting," the latter consisting of numerous little lown-tippings of white; lower surface of body wholly white.

MARKS FOR Field identificAtion-Small size (not, however, our smallest species), very slender bill (not longer than head), light buffy breast band, dark brown rump, and, in juvenile plumage, scaled pattern on back. Almost impossible to identify positively without specimen in hand.

VoICE-A shrill trilling whistle, peet-peet (Forbush, 1912, p. 277).

Nest-On tundra, always well hidden in grass; a slight depression thinly lined with dried grass (Murdoch, 1885, p. 112).

Egas-Usually 4, pear-shaped, measuring in inches, 1.18 to 1.38 by 0.87 to 0.95 (in millimeters, 30.0 to 35.0 by 22.0 to 24.0 ), and averaging 1.28 by 0.93 (32.5 by 23.5) (36 eggs in U. S. National Museum); ground color buff or clay, with markings of chestnut-brown, usually fine and innumerable, sometimes confluent about larger end (Davie, 1859, p. 114).

General distribution-North and South America. Breeis along Aretic coast from Point Barrow to northern Keewatin. Migrates through Great Basin, Rocky Mountains and Mississippi Valley west of Mississippi River. Oceurs sparingly east to Atlantic coast from Nova Scotia to New Jersey and west to Pacific coast from Alaska to Lower California. Winters chiefly in Chile, but also in Argentina sonth to latitude of Buenos Ayres (A. O. U. Cherk-list. 1910, pp. 114-115; Cooke, 1910, pp. 39-41).

Distribution IN CALIFORNIA-Rather rare fall migrant. The following recorfed occurrences are all that are known within the state: Point Pinos, Monterey County, August 25, 1897, one specimen (J. Mailliard, 1995, p. 51); Santa Barbara, July 25 (1914) (and several other lates) (Dawson, 1912, 1). 224; 1916, p. 25) to September 7 (1911) (Bowles and Howell, 1912, p. S); White's Landing, Santa Catalina Island, September 1, 1907, one specimen taken by H. Wright (Grinnell, 1909a, p. 139); and Pacific Beach, San Diego County, September 8, 1904, one specimen (Bishop, 1905, p. 141). Seen at Santa Barbara, April 27 (1912) to May 7 (1915), four records (Dawson, 1916, p. 25). Three specimens are listed from "California", by Sharpe (1896, p. 573).

The Baird Sandpiper is a rather rare fall migrant through California, although observations at Santa Barbara seem to show that 
it is of fairly regular ocenrence. Bowles and Howell (1912, p. 8) state that at santa Barbara they found it a regular fall migrant. During 1910 but seren individuals were seen, while in 1911 the hirds were "onsidered "common." "Three or foul "onld be found at any time between August 11 and September 4, while at least twelve, of which nine were in one flock, were on the flats September 2." Again, in 1912. Dawson (1912, p. 224) fonnd the species in the same vicinity from August 8 to 22, when the individuals observed were mingling freely with Western santpipers. In 1914 it was observed on July 25 (1)awson, 1916, p. 25). 'The same author has seen the species at Santa Barbara in the spring on fon dates between April 27 and May $\tau$ (Dawson, loc. (eit.). Other localities of reeord are: Point Pinos, near Monterey, Angust 25, 1897. one individual shot from flock of Least Sandpipers (.J. Mailliard, 1898, p. 51): White's Landing, Santa Catalina Islant, one specimen, September 1, 1907 (Grinnell, 1909a, p. 139) : Pacific Brach, near San Diego, one specimen, September 8, $190 t$ (Bishop, 1905, p. 141). Dates of observation have thus covered at least six separate years, and show the species to be of rather regular yet limited presence along the coast.

Compared with the species most closely related to it. the Baird Sandpiper seems to be slightly more numerous than the Pectoral Sandpiper, but in nowise as abundant as the Least Sandpiper. From the Pectoral Sandpiper the Baird may be distingnished by its decidedly smaller size, its blackish feet, by the creamy or grayish rather than tawny cast of its upper surface, as well as by the much less extensive and less sharply streaked breast band. From the Least and Western sandpipers the Baird Sandpiper may be distinguished by its somewhat larger size, the distinctly buffy tone of its breast and back, and the less distinct streaking on its breast.

The Baird Sandpiper, taking its entire range into account, is seldom found singly, but usually in pairs or small flocks of its own kind numbering six to a dozen individuals. It frequently flocks with other species, such as the Least Sandpiper, and at times even with the Turnstone or the Killdeer. When on the beach the birds feed near the upper edge, in the vicinity of tide pools, but this is not their accustomed habitat. They are found more commonly inland, even up to very high altitudes in the monntains. Goss (1891, p. 176) says that he has flushed them on high dry prairie land as much as a mile from the nearest water. Brewster (1881, pp. 60,61) saw this species with the Ring-necked Plover on the beach in Maine. At that place "their motions were slow and sedate and their attitudes cronching. They kept up a low conversational twitter while feeding, and when flushed, flew in that swift, erratic way characteristic of most of the small Waders." 
The Baird Sandpiper is said not to inclulge in the nuptial flights and performances common among other shore birds. The nest and sitting female are both so inconspicuous that it is almost impossible to find them. The only practical way to do so is to withdraw after haring flushed the bird, "mark" the location when she returns, and then proceed directly to the nest (Murdoch, 1885, p. 112).

Murdock (loc. cit.) states that in the vicinity of Point Barrow, Alaska, eggs were obtained only during the last week in June and the first week in July, a trifte later than is the case with other shore birds. "The nest was always well hidden in the grass, and never placed in marshy ground or on the bare black parts of tundra, and consists merely of a slight depression in the ground thinly lined with dried grass." "The eggs are usually four in number; buff or claycolored, spotted and blotehed with varying shades of chestnut-brown; in most instances the markings are fine and innumerable, of indefinite size, irregular in shape and thickness at the greater end, where they are occasionally massed in blotehes"' (Davie, 1889, p. 114).

The food of the Baird Sandpiper comprises among other things mosquitoes, erane-fly larvae, grasshoppers, eutworms and clover-root curculios (McAtee, 1911a) all of which, with the possible exception of the mosquitoes, are to be found in dry inland locations.

The Baird Sandpiper is too small properly to be classed as a game species. Noreover, its numbers migrating through California are too limited to merit it the attention of any persons save nature lovers and ornithologists.

\section{Least Sandpiper}

\section{Pisobia minutilla (Vieillot)}

OTher NAMEs-Peeps, part; Little Sandpiper; Pigmies, part; Jack Snipe (Fresno district); Tringa minutilla; Limonites minutilla; Actodromas minutilla; Tringa vilsonii.

Descripton-ddults, both sexes, in spring and summer: Top of hearl, hind neck, back and scapulars, black, with extensive feather marginings of rusty brown or tawny and lark buffy, some of the feathers narrowly tipped with white (these tippings subject to disappearance through wear); stripe from base of upper mandible to above eye, recurring behind eye, whitish, fleckel with dark browu; stripe beneath this, dark brown flecked with black; cheek buffy, with brownish shaft streaks; chin white, lightly fleeked with dark brown; bill black, yellowish at lower base; iris brown; rump and central upper tail coverts, brownish or velvety black; outermost upper tail coverts brown widely marginer with white; innermost tail feathers black, onter ones drab; outer surface of elosel wing ashy brown, sometimes with seattering feathers in coverts black with l) roall tawny margins; narrow white bar across wing formed by white tips of greater coverts and innermost secondaries; shaft of outermost primary white; margin of wing mottler brown and white; axillars and 
lining of wing white; broad banl across throat and chest, anil siles, pinkish buff, with shaft streaks of blackish brown; belly white; flanks and under tail coverts white with narrow streaks of brown; feet pale olive green. Adults and immatures, both sexes, in fall, winter, and carly spring: Distinguishable from adults in summer chicfly by lack of tawny and buffy markings; top of hearl and most of upper surface ashy brown with darker centers to feathers; sides of head pale ashy brown; ehin white; rump, upper tail coverts, tail, and wing as in summer; broal band across throat, and sides, light ashy gray, narrowly streaked with brown; rest of uniler surface white. Males: Total length $5.50-$ 5.87 inches (139.5-149.0 mm.) (seven specimens); folded wing $3.25-3.45$ ( $82.4-$ 87.5): bill along culmen $0.65-0.73$ (16.5-18.5); tarsus $0.68-0.78$ (17.3-19.7) (ten specimens). Females: Total length 5.50-6.30 (139.5-160) (nine specimens); folderl wing 3.34-3.46 (\$4.6-8९.0); bill along culmen 0.6९-0.78 (17.2-19.S); tarsus $0.72-0.78$ (19.3-19.8) (ten specimens); all from California and Alaska. Jucenile plumage: Similar to that of alult in spring and summer but markings more blenilel; wing coverts throughout marginel with pale tawny; rhin, flanks anıl lower tail eoverts, white, unmarked; breast band obscurely streaked. Natal plumage: Forehearl and sile of heal buffy white; chin and throat white; stripes up middle of forehead and between bill and eye, black; bill black; top and back of head. and rest of upper surface and flanks, of mixed reldish brown and black, with many feather tippings of buffy white, the whole producing a pepper-and-salt effect; under surface white; breast faintly washer with buff: legs and feet (dried) brown.

MARKS FOR FIELD IDENTIFICATION-Yery small size (our smallest sliore biri); slenter hill (fig. 67), not longer than heal; aslyy, lrab or buffy band on breast, narrowly streaked with brown; slender toes, cleft to bases (fig. 69).

VoICE-A plaintive pe-et, peet, or wheet, sometines quavering, when uttered by isolater individuals; faint pecps among members of a foraging flock.

NEST-On marshy ground or damp uplanı, usually a short distance from water; a slight depression in the regetation lined with a few leaves and grass blades (Moore, 1912, p. 211).

EgGS-4. pear-shaped, measuring in inches, 1.04 to 1.18 by 0.79 to 0.57 (in millimeters, 26.5 to 30.0 by 20.0 to 22.0 ), and averaging 1.14 by 0.83 (29.0 to 21.0) (65 eggs in U. S. National Museum); ground color light drab, thinly spotted with sepia brown, grayish brown or ashy; markings more numerous and bigger ahout larger end (Baird, Brewer and Ridgway, 1884, I, 1. 240).

Gexeral Distribution-North and South America. Breeds northward to the Aretic roast from a line through Kotzebue Sound, southern Yukon, southern Mackenzie, central Keewatin, northern Ungava, and Labrador, to northeastern Quebec; also on the Magdelen Islands and Sable Island. Winters from central California, southern Arizona, southern Texas and Georgia south to (northern?) Chile. Peru, and Brazil (south to latitude $7^{\circ} \mathrm{S}$ ). Occurs in migration throughout area between breeding and winter ranges (Cooke, 1910, pp. 41-42).

Distribetios in CAliforsia-Abundant fall and spring migrant thronghout the state; remains through the winter in fair numbers in lowlands from latitude of San Francisco southward. Nigrants arrive from the north inostly during August and September and depart for the north again iluring April and early May. A few non-breeding birds sometimes occur here during June and July.

The Least Sandpiper, or Peep, is, perhaps, the most abundant species of shore bird in North America. During migration it is widely 
distributed, every seabeach and salt marsh, every inland pond and wet meadow being populated by these birds. It is the smallest, the most eonfiding, and the most nnobtrusive of all our wading birds.

While individuals are to be found within our borders at all times of the rear, this species is chiefly a fall and spring migrant; to a less extent it is a winter visitant. The birds occasionally found here during June and July are probably non-breeding individuals. Birds which are undoubtedly migrants arrive from the north late in July or early in August. Two were taken at Berkeley, August 13, 1892 (specimens in Mus. Vert. Zool.) ; large flocks were seen and a specimen taken at Bay Farm Island, Angust 29, 1914 (Storer, MS) ; at Santa Barbara, Bowles and Howell (1912, p. 9) record the earliest migrants July 18, and state that the species had become abundant by the last

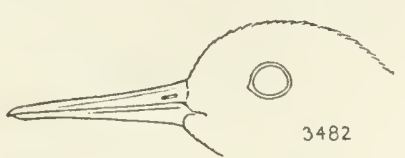

Fig. 67. Least Sandpiper.

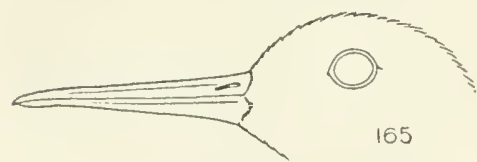

Fig. 65. Western Sandpiper.

Both figures are natural size. Note difference in size of bill, and that in the Western the bill is slightly down-turned at eni. of July; flocks were seen daily at Hemet Lake, San Jacinto Mountains, from Angust 6 to 16, 1908 (Grimell and Swarth, 1913, p. 227) : a flock was seen at Lake Tahoe in August, 1906 (Ray, 1911, p. 108); one bird was taken at Yermo, San Bermardino County, August 28, 1910 (Lamb coll.). Seattered records through the winter proclaim the speeies a winter visitant in fair numbers from the latitude of Stockton (Belding, 1879, p. 441 ), and the shores of San Franciseo Bay, southward. In the spring it has been reeorded at San Diego as late as April 15, 1885 (Belding, MS) ; Mecea, Riverside County, April 19, 1908 (specimen in Mus. Vert. Zool.) ; Los Angeles, April 27, 1900 (speeimen in Swarth eoll.); El Monte, Los Angeles County, May 2, 1896 (specimen in Daggett eoll.); southern Madera County, April 28, 1900 (J. Mailliard, 1900, p. 122); and Los Baños, Merced County, April 22, 1912 (specimen in Mus. Vert. Zool.).

The Least Sandpiper may be distinguished by its extremely small size, slender, short bill (not longer than head), and drab, ashy or buffy breast band, with narrow dark streaks. From the Western Sandpiper (which is nearest in size) it may be distinguished by its shorter and slenderer bill (figs. 67 and 68 ), and the absence of webs between the bases of the toes (fig. 69). From the Snowy Plover it may be distinguished by its less ehmnky build, slender bill and toes, by the presence of a buffy breast band, and by the absence of black or Arab patches on siles of neck and lack of white on the nuter tail feathers. 
When foraging in companies Least Sandpipers utter faint pecps in conversational undertone; in flight the note is more emplatie and raried: whect, wheet, or whect, whect, wher-whr-terr-wheet, of plaintive quality. Lone individuals are more given to calling than members in a flock.

least sandpipers often oecur as single individuals, but mole generally in flocks of varying sizes sometimes numbering several hundred individuals. They frequent with apparent impartiality the sea-beach, tide flat, marshland and rivel bar. Throughout most of the day, and probally well into the night, they are active, attentively rleaning food from the sand or mud at the water's edere. When not persistently hunted they are quite tame and will allow elose apploach. If the observer takes his position on the shore and remains quiet for a time, the hirds will usually feed along almost at his feet. When at work probing for food the bill is rapidy thrust in and out of the sand or mud at the rate of three or four dabs per seeond for as many sereonds: then it is raised entirely free of the surface, and the bird straightens up and moves a fow steps to a n"w location, to continue its search in similar fashion. As the hill goes down the tail gous up. so that the hird appears to teeter up and down, the legs acting as fulcra. When on the ground the birds move with a rapid, direct rum, never trotting as do some of the plovers. Oceasionally an individual will be seen to raise its wings vertically above the body and hold them there for a few seconds before folding them into place again. Once, a bird was seen to do this as it made a deep probe in the mud and at the same time one leg was raised from the gromd and stretched backwards; in this case it seemed as though the wings were raised for the purpose of balancing the body.

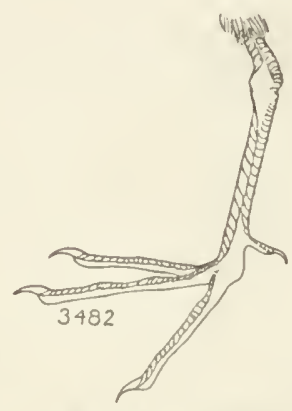

Fig. (69. Tirsus and top of foot of Least Sandpiper. Natural size.

Note absence of any webbing between bases of front toes (romplate with fig. $70)$.

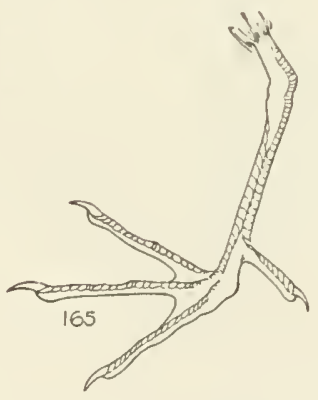

Fig. 70. Tarsus and top of foot of Western Sandpiper. Natural size.

Note partial webs between bases of front toes (compare with fig. 69).

When frightened the birds take to flight suddenly, and look to be traveling at their topmost speed almost immediately. Individuals show more erratic movement in flight than do flocks. The latter pursue a zigzag course, so that one sees first the brown backs and then a flash of white from the under surfaces, and this often, depending upon the backgromnd against which they are seen, eauses the birds to 
appear and then disappear at intervals of a few seconds. So perfectly and in accord do the individuals comprising a flock perform these evolutions, that one is tempted to believe that they are in some way mechanically comnected. That this habit may prove disastrous to individuals is shown by the fact that dead birds have been found beneath telephone wires strung across marshes.

Single individuals seem on the whole to be more wary and apt to take wing at longer distances than birds in flocks. Individuals or small groups of this species sometimes flock with other waders, notably Western and Red-backed sandpiper's; and varions observer's have noted them flocking with, and "rumning about beneath," some of the shore birds of still greater size.

The nesting season of the Least Sandpiper seems to brgin later and to occupy a longer period than that of many of its kindred, this in spite of the fact that the Least often arrives in its breeding area, in the far north, in advance of many of the other species. Sometimes it appears before the ground is anywhere nearly free from snow. The following nesting records given by Macoun and Macom (1909, pp. 176, 177) indicate the extent of the nesting season: Magdalen Islands, June 13. female flushed from nest; Lake Marsh, Jukon, July 2, downy young; Labrador, July 20, nest and eggs : C'ypress Hills, Saskatchewan. August 2, very young birds.

The nest, as found on the Magdalen Tslands, Quebec, is usually placed on grass-corered, water-soaked, hmmmocky gromnd, and consists of a depression lined with dead leaves or grasses so that the eggs are well separated from the damp gromnd beneath. The egors are deposited on consecutive days, and incubation does not commence unt the set is complete. All the eggs, in one obselved case, hatehed rithm a period of twenty-four hours or less (Moore, 1912, pp. 210, 211).

The eggs are usually four in number, pear-shaped, and measure in inches, 1.04 to 1.18 by 0.79 to 0.87 and average 1.14 by 0.83 . The ground color is a light drab, thinly marked with superficial spots of sepia brown and deeper markings of grayish brown or ashy. The markings are more numerous about the larger end of the egg (Baird, Brewer and Ridgway, 1884, I, p. 240).

During the nesting season hirks of this species are to be sem perched on various prominent objects in the near vicinity of the nest, such as rocks, trees, stumps, and even fences. There is a song-flight similar to that of other small sandpipers. After incubation begins, the sitting bird will often crouch down and attempt to escape olserva tion by lemaining quiet on the nest. If this does not avail, the bird will rum fifteen feet or more from the nest, then. if necessary, fly off close to the surface of the ground, with a whirring fight, resembling that of a quail; but the flight sometimes recalls that of a Wilson 
Snipe in being quite erratic. The broken-wing ruse is on occasion attempted, when the nesting Sandpiper is endeavoring to lead an intruder away from the nest; but none of the intimidating tacties employed by larger waders are used by this species.

"'The young are certainly precocious, leaving the' nest at least by the first day after birth, and, thereafter, being able to find their food and take care of themselves. . .." "To protect, to warn, to guide in the seareh for food, these seem to be the chief parental functions at this stage" (Moore, 1912, pp. 212, 213).

The food of the Least Sandpiper consists of insects and minute marine animals found along the shore and on the mud flats. Among the insects eonsumed are mosquitoes and grasshoppers (IcAtee, 1911a), and, at Mono Lake, W. K. Fisher (1902a, p. 9) found these birds feeding in company with other waders upon the flies which swarm in early autumn along the shores of that lake.

The Least Sandpiper never has been considered a legitimate object of pursuit by the better elass of sportsmen. and never should be. Its small size and unsuspecting labits plead for its exelusion from the category of game birds. Along the eastern coast of the United States, Forbush (1912, pp. 278-280) says that in former years it was not humted to any extent, but that with the decrease of larger game the Peeps lave come to be a serious object of sport: many are slaughtered annually, and as a result a marked decrease in their numbers has of late been noticed. Happily other game species in Califormia are ret so numerous that the "Peeps"' have not so far suffered materially from the onslanglits of the hunter. Let us in California conserve the larger species to snch a degree that the day will never come when "peep-pies" will be comntenaneed as legitimate food on our tables.

\section{Red-backed Sandpiper}

\section{Pelidna alpina sathalina (Tieillot)}

OTher NAMes-Dunlin; American Dunlin; Black-bellied Sardpiper; Pelidna americana; Pelidna alpina americana; Tringa alpina; Tringa alpina pacifica; Tringa pacifica; Tringa alpina rar. americana.

DESCRIPTION-Adults, both sexes, in late spring and summer: Top of head streaked with black and rusty; broad stripe from base of upper mandible to ere, and recurring behind eye, white, flecked with dusky; spot at sirle of bill dull buffy; sirle of head otherwise whitish, narrowly streaked with blackish browu; chin white; bill "black"; iris "dark brown", (Audubon, 1842, V, p. 268); hind neck whitish or buffy streaked with dusky; feathers of back and scapulars black centrally, with broad margins of deep tawny red, and narrowly tipped with ashy; rump dull brown; central upper tail coverts black, irregularly marked with tawny red; outermost upper tail coverts white; innermost tail 
feathers blackish brown, onter ones successively lighter, paling to light drab; onter surface of closer wing rull brown, some of the coverts with pale margins; tips of greater coverts and outer margins of inner seconclaries, white, forming a transverse white band on spread wing; flight feathers chiefly blackish brown, with shafts whitish or partially so; imermost secondaries with much white at bases; margin of wing mottled with light brown and white; lining of wing and axillars, white; himlmost under coverts and under surface of flight feathers, dusky; throat, sides of neck, breast and sides, white, narrowly but sharply streaked with black; fore part of belly with a conspicuous squarish black area, some of the feathers narrowly tipped with white; rest of under surface white, with sparse black lines on flanks anl lower tail coverts; feet "black", (Audubon, loc. eit.). Adults and immatures both sexes, in fall, winter, and carly spring: Whole upper surface dull brown, with narrow inconspienous darker shaft streaks; hind neck somewhat lighter, central upper tail coverts and tail slightly darker; eyclids, and stripe to and behind eye, dull whitish; sides of hearl and neck, and whole chest, brownish drab, faintly streaked with dark brown; chin distinctly white; npper tail coverts, tail, and wing as in summer save that wing coverts of immatures are margines with pale buffy; under surface behind chest banı, pure white. Males: Total length 8.12-9.25 inches (206-235 mm.) (cleven specimens from California); folded wing 4.314.67 (109.4-118.S); bill along eulmen 1.38-1.50 (35.0-38.0); tarsus 0.96-1.07 (24.3-27.3) (ten specimens from California and Alaska). Females: Total length $8.62-9.25$ (219-235) (eight specimens from California); folded wing 4.57-4.85 (116.4-123.1); bill along culmen 1.48-1.68 (37.7-42.5); tarsus 1.051.13 (26.6-28.7) (ten specimens from California). Juvenile plumage: Similar to that of atults in summer, but tawny markings on back paler and less sharply contrasted, hearl and chest suffused with buffy and streaking less distinct, and breast anil belly marked with large irregular spots of blackish brown; no continuous black area across lower surface. Natal plumage: Forehead buffy white, with median black line; line from bill to eye dusky; top of hear to level of eyes, mixed amber brown, black and white in fine patteru; side of hearl jervaded with buff; whole hack amber lrown, mixed with black in coarse pattern, with many white lots on tips of down-feathers; under surface white, with a distinct band of pale buff across fore neck.

MARKS FOR FIELD IDENTIFICATION-Moderately small size (smaller than Killeer), bill distinctly longer than hear with slightly lown-eurver tip (fig. 71), and white band across hinder part of wing. In spring and summer: redilish back, and black patch across belly; in fall and winter: brownish back, broad drab rolored breast band, clear white chin and hinder lower surface. Usually moves about in compact flocks.

ToICE-Che-ezp-ezp-ezp-ezp. run together in a rather rasping cheep.

Nest-On slightly elevated ground a short distance from water; a mere depression formed by flattening down the grasses on the surface of the ground.

Egrs - 3 to 4, pear-shaper, measuring in inches, 1.36 to $1.56 \mathrm{by} 0.93$ to 1.06 (in millimeters, 34.5 to 39.5 hy 23.7 to 26.5 ), and averaging 1.44 by 1.02 (36.6 by 25.8) (21 eggs from Alaska); gromul-color clay, buffy or drab, with spots of yellowish brown and varying tints of lavender or pale gray; markings arranged with a spiral trend and nsually most numerous about larger enil of egg.

General distribution-North America and eastern Asia. Breeils on northern coast of Siberia west to mouth of Yenisei River, and in North Ameriea from Point Barrow to mouth of Yukon River and in Boothia and Melville peninsulas. and northern Ungava; winters on Pacific coast from Washington south to 
southern Lower California; and on Atlautic eoast from New Jersey (rarely Massachusetts) soutl to Louisiana anil southern Texas, and in Asia from China and Japan south to the Malay Arehipelago; rare in migration in interior of United States except near southern end of Lake Miehigan (A. O. U. Cheeklist, 1910, 1. 116).

DISTRIBLTION IN C'ALIFORNA-Conmon fall and spring migrant and winter visitant, coastwise; oceurs sparingly inland. Appears most commonly in millle September, and remains in some numbers throughout the winter, departing for the north by late April or early May. Observed far inland only at Los Baños, Merced County, December 9, 1911, to April 26, 1912 (specimens in Mus. Vert. Zool.), in the Sacramento Valley in winter (Belding, MS), and at Salton Sea, Imperial County (U)awson, 1916, p. 25).

The Red-backed sandpiper is more or less plentiful during the migrations along tle seacoast, and remains in considerable numbers through the winter. It is thus one of the better known shore birds. In some parts of its range this speecies is known as the Black-bellied Sandpiper or Black-breasted snipe, beeause of the eonspicuous black band across the belly in the breeding plumage: while the lull appearance of the back in the fall and winter has given it the nane locally of Lead-back. It is also called the Dunlin or American Dumlin, a name borrowed or derived from its European relative.

This species is among the late fall arrivals along our coast, as it usually does not appear until ahout the middle of September. Grimell and Bryant (IIS), however, saw a flock of one hundred at Alvarado, Alameda County, July 28, 1913. In 1914, the speeies was not observed along the Alameda County shore until the last week in September (Storer, MIS). Curiously enough, it seems to appear much later in the northern part of the state, as about San Franciseo Bay, than farther south, this perhaps becanse the first migrants proeeed along the outer seacoast. The earliest fall reeord for San Francisco Bay other than those just given, is Oetober 15 (speeimens in Mailliard eoll. and Mus. Vert. Zool.). Bowles and Howell (1912, p. 9) state that the species first appeared at Santa Barbara in 1910 on September. 9, and Willett (1912a, p. 37) says that it is most abundant along the coast of southern California from September 15 to November 1. Inland it has been taken at Los Baños, Merced County, December 9, 1911 (speeimen in Mus. Tert. Zool.), and individuals were seen there on several dates during the winter of 1911-12 (Beek, MS). Belding (MS) says that it oceurs about ponds in the Sacramento Valley in winter. In the spring it is most abundant along the eoast of southern California from April 10 to May 7, although a specimen was taken and several seen as late as May 19, 1906, at Nigger Slough, Los Angeles County (Willett, loe. eit.). At Santa Barbara it has been noted from Mareh 10 to April 20, and on May 2 and 3 (Bowles and Howell, 1912, p. 7; Howell, MS). It was noted at Bay Farm Island, 
Alameda County, April 30, 1914, by the authors; and Emerson (1904, p. 38) recorded birds of this species at Hayward, May 11, 1903. At Los Baños, Mereed County, it was present in the spring of 1912 up to April 26 (specimens in Mus. Vert. Zool.). It would seem as though the migrants which are seen along the southern coast in the fall and spring and in the interior at Los Baños spend the winter but little farther south, in the vicinity of San Diego (Belding, MS), at Salton Sea, Imperial County (Dawson, 1916, p. 25), and on the coast of Lower California (Brewster, 1902a, p. 63). On the Pacific coast the species is not kuown to oceur soutl of La Paz, Lower California, save in the case of a single straggler taken in Nicaragna (Cooke, 1910, p. 44).

In the springtime the Red-backed Sandpiper is easy to distinguish, with its reddish back and conspicnous black belly; but in the fall less

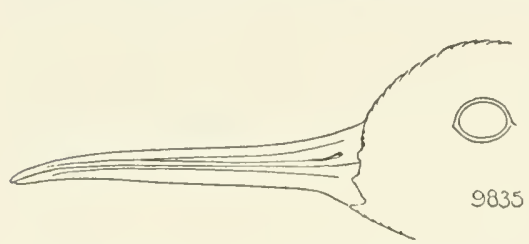

Fig. 71. Side of bill of Redbacked Sandpiper. Natural size.

Note down-curver tip and relatively thick base. conspicuous features must be depended upon : its long bill (fig. 71) which is decidedly longer than its head and eurved slightly downward at the terminal third, its moderately small size (yet conspicuously larger than the Least, Western, and Baird sandpipers), and its plainly marked brown back entirely free from any sealed or prominently streaked appearance such as is possessed by so many species of shore birds. The incessant hobbing up and down of the members of a flock as they probe for food, and the resulting flashes of white and brown as the breasts and backs appear alternately, are additional aids to recognition.

The call-note is a rasping cheep, or chec-czp-ezp-czp-czp. nttered almost as a single syllable. It is much hoarser than that of the Least Sandpiper, a species with which this one sometimes associates.

The Red-backed Sandpiper is a typical beach bird, gleaning its provender by probing along the beaches and adjacent mud flats. In the East it is reported to be something of an upland bird, so that hunters class it with the Snipe rather than with the Sandpipers: but such does not seem to be the rule in California. When feeding the birds probe industriously, but not very long in any one spot. The bill is thrust perpendieularly into the mud; and often when they are feeding on a flat which is partly moder water the whole head may be immersed for a seeond or two. Flocks spread ont immediately upon alighting and rach individual pursues a separate course. This, combined with their rapidity of action, results in the peenliar bobbing appearance referred to above. 
Ordinarily this species is rather tane and will allow close approach, but if flocks are shot at eren a few times they become wary. When frightened, or when taking wing in changing to a new location, the birds bunch together into a compact flock and fly rapidly, sometimes in a direct line at low elevation, sometimes erratically, up and down and zigzag. In the latter instance they partake somewhat of the nature of snipe. As many as 500 have, by estimate, been noted in a single flock. The close-flocking habit of this and most other shore birds is probably of advantage to them in detecting and escaping from enemies under primitive conditions; but the modern hunter with his seatter-gun is able to make large "pot-shots," and there are records of over fifty Red-backs being killed by the discharge of the two barrels of one double-barreled gun into a single flock (Forbush, 1912, p. 28:3).

The breeling area of the Red-backed Sandpipers visiting California lies probably along the western coast of Alaska, where the speeies is known to summer in abundance. The species thus presents an interesting peculiarity as regards its breeding range. There are two distinct areas, corresponding with the divided winter distribution. One is along the coast of Alaska from the mouth of the Yukon to Point Barrow and along the Aretic coast of Siberia, where our Californian birds are thought to nest. The birds found along the eastern coast of North America probably breed in northern Ungava and in the region of Melville Island. Between Melville Island and Point Barrow the species is excecdingly searce or altogether absent.

The nesting season in Alaska extends through the month of June, eggs having been taken at the mouth of the Fukon as early as the 6 th of that month (Cooke, 1910, p. 44), and as late as the 3rd of July (Nelson, 1887, p. 110), while fresh eggs have been taken near Cape Prince of Wales on June 27 and 28 (Grinnell, 1900, p. 24).

The nest is usually located on a slight elevation of the tundra, although as a rule not far from water. It consists of a depression in the top of a grassy or mossy hummoek, lined with a few grass blares; in some cases the surrounding vegetation practically hides the nest.

The eggs number three or four, are notably pear-shaped, and measure in inches, 1.36 to 1.60 by 0.93 to 1.10 , and average 1.46 by 1.01 (21 eggs from Alaska). The ground color is pale olive, buffy, or drab, with light and dark yellowish brown, superficial spots and a few lavender or pale gray deep-lying ones. The spots are usually elongated, measuring on the average, perhaps 0.06 by 0.12 inches, and have a distinctly spiral trend, especially about the larger end. Here they are often so numerous as to form a dark eap. These eggs, hy their combination of pale olive ground color with light brown spirally placed markings, together with their size, can readily be distinguished from those of any other species of shore bird oceurring in western America. 
When the birds reach their breeding grounds in the north some are alrealy paired, but the great majority do not pair until soon after they arrive. The males pursue the females with a quivering flight and often hover over them at a height of 15 or 20 yards, uttering a mellow tinkling song resembling the dropping of water into a partly filled pail. After the eggs are laid this song is no longer heard; the males then assist the females in the duties of ineubation, and apparently spend a good share of their time on the nest (Murdoeh, 1885, p. 113; Nelson, 1887, p. 111).

The young, which are hatehed some time around the first of July (specimens were taken on July 6 in one ease [Cooke, 1910, p. 44]), are on the wing and floeking along the shore by the first of August. From this time until about the last of September the young birds wear the jurenile plumage, but by the first of Oetober the winter plumage, which is similar to that of the adults at the same season, has been assumed. Some of the birds have left before this time, as they appear along our southern eoasts by the middle of September; but the rest linger in the north until about the first of Oetober when a cold snap usually drives all but a few of the most hardy individuals sonthward (Nelson, 1887, pp. 110-111).

Emerson (1904, p. 38) found birds of this species dead on the marshes near Hayward, Alameda County, where they had been killed by flying against telegraph wires strung aeross the marsh, thus meeting a fate eommon to many of the smaller species of shore birds in that vieinity.

Red-baeked Sandpiper's feed on the various forms of animal life found along the seashore. Oyster-worms (Nerris) and water beetles have been found in their stomaehs (MeAtee, 1911a), as well as crustaeea and small shellfish. 'The destruction of the two former' kinds of animals is a distinet benefit, and in return for this the birds should, perhaps, reeeive some eonsideration. They are barely large enongh to be classed as legitimate game. If so eonsidered, the baglimit should be earefully regulated so as to prevent the wholesale slaughter to which the habits of the species subject it. In the fall they are fat and considered exeellent eating. As with all other speeies. spring shooting of these Sandpipers should never be eomtenaneed.

\section{Western Sandpiper}

\section{Ereunetes manri Cabanis}

Other Names-Peeps, part; Pigmies, part; Pups; Ereunetes orcidentalis; Ereunetes pusillus oecidentalis ; Ereunetes pusillus: Ercunetes petrificatus; Tringu semipalmata.

DESCRIPTION-Adults, both sexes, in late spring and summer: Feathers of tol' of head, hind neck, ant back, black centered, conspieuously margined with 
tawny, the latter color often predominating, and all faintly tipped with whitisl or late drab; spot or stripe on each side of forehead, amd one hehind eye, white, usually flecked with dark brown; stripe from side of upper mandib]e ruming below eye to ear region, redlish brown; lower side of head and neck, white, llecked with dark brown, most sparingly on "hin; iris "brown"; bill "black", (Sanford, 13ishop and Van Dyke, 1903, p. 391); rump dull dark brown, many of the feathers lighter at tips; inner upper tail coverts hlackish brown, the shorter ones sometimes tipped with tawny; outermost upler tail coverts white, sometimes marked with brown; inner webs of innermost pair of tail feathers blackish brown, outer webs of these, and rest of tail feathers, drab; onter surface of closed wing dull brown, all of the coverts with blackish shaft streaks, and usually with lighter margins; greater coverts tiphed with white, forming a white bar across wing when expanded; primaries blackish, shaft of outermost one white, others brown toward base becoming white at tip; bend of wing sealed with white and light brown; axillars and lining of wing, white; unler surface of flight feathers, dusky; lower surface chiefy white; throat, chest, sides, and, to a less extent, flanks and outer lower tail eoverts, sharply streakel with lark brown, these markings largest on eliest and sides, where they are somewhat triangular; feet and legs "black" (Sanford, Bishop and Van Dyke, loe. cit.). Adults and immatures, both sexes, in fall, winter and early spring: Whole upper surface ashy brown with blackish shaft streaks and, in fresh plumage, narrow whitis] feather tippings giving a faintly sealed effect; spot in front of eye whitish, often continuing over eye; stripe from side of hill, ruming below eye and broadening on ear region, brownish; ehin white; rump, tail and wing as in summer; band of narrow brown shaft streaks across upler breast; rest of under surface white. Males: Total length 5.75-6.92 inches (147-176 mm.) (ten specimens from Califormia); foliled wing 3.52-3.79 (\$9.4-96.3); bill along eulmen $0.53-0.93(21.2-23.5)$; tarsus $0.82-0.93$ (20.8 23.5) (ten specimens from California and Alaska). Females: Total length 6.00-7.00 (152-178) (ten specimens from California); folded wing 3.67-3.\$9 (93.4-95.7); bill along culmen 0.58-1.16 (22.5-29.4); tarsus 0.85-0.98 (21.6-25.0) (ten specimens from California and Alaska). Juvenile plumage: Resembles that of adults in summer save that colors on upper surface are duller and feathers of back are broally margined with deep tawny, the wing coverts are tipped with buffy, and the breast is merely washed with buffy, not streaked except faintly at sides. Natal plumage: Crown chestnut; rest of upper surface mixed black anil rusty, speckled with white; forehead pale buffy; black line on center of forebead and two black lines between bill and eye; breast buffy; throat and rest of lower surface, white.

MARKS FOR FIELD IDENTIFICATION-Small size (next to the Least Sanipiper, which is the smallest of our shore birds), bill slightly longer than head (fig. 68), and breast band without buffy ground color. Distinguished from Least Sandpiper only with difficulty by its longer bill. In hand can be separated from that species mueh more easily by presence (in the Western Sandpiper) of webs between bases of front toes (fig. 70).

VOICE-A soft weet-ueet, or to-wheet; in summer: a series of soft trills.

NesT-On drier parts of tundra, often on a slight rise or hummoek, but usually in near vicinity of water; a thin layer of grasses or willow leaves, loosely arranged, or more often merely the trampled down or matted vegetation at nest site.

EGGS-Usually 4, pear-shaper, measuring in inches from 1.11 by 0.82 to 1.30 by 0.92 (in millimeters from 28.2 by 20.8 to 33.0 by 23.4 ); ground tint pale 
clay color, in many instances (espeeially on larger eggs), almost concealed by fine superficial spots and streaks of light reldish brown; other specimens have the spots in larger masses and ground eolor more apparent (Nelson, 1887, p. 114).

General distribution-North Ameriea and northern South America. Breeis on Alaskin coast from mouth of Yukon River to a little north of Cape Prince of Wales. Winters on Atlantie coast from North Carolina to Florida and on Paeific coast from southern California to southern Mexico and Venezuela, and prohably in Lesser Antilles. In migration orenrs along Atlantie eoast north to Massachusetts, and in the West Indies, but is extremely rare in central United States. Abundant along Pacific coast amd to some extent inland (A. O. T. Cheek-list, 1910, 1. 117; Cooke, 1910, 1. 47).

Distribution IN CAlifornia-Abundant spring and fall migrant both coastwise and in the interior; also sparing winter visitant from San Franciseo southwark, but more numerous in southern part of the state. Fall migration begins in late July and lasts through Oetober. Spring migration oceurs from early April until first of June, the species being most abunilant from about April 10 until middle or last of May. Non-breeding individuals may remain within the state throughout the summer months.

The Western Samlpiper, a close relative of the Semipahnated Samdpiper of eastern North Ameriea, is an abundant species along our coast and in the interior during the fall and spring migrations, and is present also during the winter, but then only in limited numbers. This species is one of a number among the shore birds in which eertain apparently barren individuals fail to follow the northbound migrants in the spring and are thus to be fomnd within the state throughont the summer season.

The first molonbted migrants from the north appear along our eoast during the latter part of July or first week in August. Two adult fenales in worn breeding plumage were taken at Markham s, Sonoma County, July 13, 1895 (Mailliard coll.). Emerson (in Belding, MS) records the speejes at Mayward, as "common at once", August 2, 1895, and one was taken in "Alameda County," August 10. 1897 (Mailliard coll.). From this time on, the species becomes increasingly ahoudant and is found within the state in large numbers during August, September and Oetober. The numbers decease during Norember, and during the period from Deecmber to February there ale only a few records of oecurrenee; but these are sufficient to indicate that stragglers remain in winter at least as far north as San Francisco, and that the species winters in fair numbers in the southern portion of the state. Some of these records ale as follows: San Franeisco Bay, Deeember 29, 1897 (font specimens in Mailliard coll.); Monterey, Deermber 13, 1910 (Mus. Vert. Zool.): Santa Barhara. up to Deeember 5, 1909 (Bowles and Howell, 1912, p. 9), ame winter of 1885 (Streator, 1886, p. 89) : Alamitos Bay, Los Angeles ('ounty, Deeember 2 to 26, 1905 (specimens in Richardson coll.); 
Newport Sloughs, Orange County, December, $188+$ (Belding, MIS) ; San Diego Bay, November, 1906, to January, 1907 (Willett, 1912a, p. 37) ; San Clemente Island, December, 1908 (Linton, 1909, p. 194); and Salton Sea, December 10, 1910, to Jannary 14, 1911, quite common (Tan Rossem, 1911, p. 131). The northwarel migration begins as early as February or Mareh, as birds appeared at Santa Barbara, February 28, 1910 (Bowles and Howell, 1912. p. 9), and at Moss, Monterey County, March 23, 1911 (Murs. Vert. Zool.). At Los Baños, Merced County. Beck (MIS) saw the first in 1912 on April 10. The general migration through the state is at its height from about the first of April until the middle or latter part of May. Sereral birds were seen ahout Owens Lake, Inyo County, June 1, 1891, in eompany with Snowy Plover (A. K. Fisher, 1893a, p. 23). There are several July records for the state which probably pertain to barren birds.

The Westrin Samlpiper is next to the smallest of our shore birds, being but slightly larger than the Least Sandpiper. From the great majority of our walle's it is to be distinguished at onee on the basis of size. From the Least sandpiper it can be told at a distance only with difficulty ly its longer bill (compare figs. 67 and 68 ) : but in the hand, it is mmistakahly recognizable by the presenee of rather extensive webbing between the bases of the front toes (fig. 70). In labits these two species resemble one another closely.

'The Western Sandpiper occurs most commonly, if not almost exchusively, in flocks, this bring doubtless, as with many other shore birds, for the common protection thereby afforded. They freed with impartiality on open seashores, tide flats, boggy inland meadows, and the margins of rain-pools, usually keeping in the open. In feeding, the parties seatter out in open formation, but eongregate promptly into massed bodies when frightened, and take flight in elose flocks.

These birds begin to arrive on their breeding grounds in the Norton Sound region of Alaska about the middle of May. The nesting season extends from the latter part of May until the end of Jume. Nelson (1887. p. 113) states that eggs were found by the first of June or earlier. and roung were found in one ease on June 7 , while Grimnell (1900, p. 25) at Cape Prince of Wales north of Bering Strait, Alaska, found fresh eggs June 28, 1898.

The nests are usually placed on the drier parts of the tundra, generally on a mossy hummock or slight swell, although Grinnell (loc. eit.) found a nest on a hummock in marshy ground. Sometimes the nest is a thin laver of grass stems or willow leaves loosely arranged. but more often it consists merely of a mat of crushed-down and flattened regetation such as is to be found at the spot ehosen. The eggs, usually four, are pear-shaped, and measure in inches from 1.11 by 0.82 to 1.30 by 0.92 . "The gromnd is ordinarily pale elay color, 
shading toward pale brownish clay. In many instances, nsually among the larger eggs, the ground color is nearly or quite concealed by fine, light reddish brown spots or specks. The other extreme has the spots gathered mainly about the larger end in large irregular spots and blotehes, and the intermediate ones have the shell about half lidden by markings of chocolate and umber-brown in small spots, a little more dense at the large end. In some eggs the spots are rich chocolate and the light or slightly reddish-brown cast in the markings ('ven of the darkest colored eggs usually serves to readily separate these eggs from .. ." those of any other western shore bird (Nelson, 1887 , p. 114).

While the birds are yet scattered over the tundra, before the actual work of nesting is begun, they are wont to utter a series of low twittering notes. The male rmms back and forth in front of the female trailing his wings and elevating and partly spreading his tail. At other times he flies up ten or fifteen rards above the ground, hovers with rapidly beating wings, and pours forth a trilling song. These notes may be represented by the syllables $t z r-\ell-c-\ell, z r^{\circ}-\rho-\rho-\rho, z r-c-c-\iota$, with a high pitched tone and a fresh impetus at each "z." Then the male arches his wings above his back in the form of a $V$ and glides slowly to earth uttering a deeper more throaty tzur-r-r-r,tzur-r-r-r. The birds also utter a variety of low twitterings when feeding or when the male and female of a pair are together. Females when approached sometimes give a low cherp. The song period ends as soon as the eggs are laid, or shortly after. Different females vary in their actions when their nests are approached. Some move away, apparently with perfect indifference, while other's use the broken-wing ruse and other devices to distract the attention of the intruder (Nelson, 1887, pp. 113-114),

We have at present no definite information concerning the food of the Western Sandpiper, but it probably does not differ markedly from that of other species of similar habits, such as the Least Sandpiper. Baird, Brewer and Ridgway (1884, I, pp. 208, 209) state that, when inland (this species or the Semipalmated?) and feeding on fresh water worms and inseets, the birds become very fat and afford excellent eating. Cooper is reported as saying that this species is "much hunted for the San Francisco market."

If the time ever existed when it was necessary to luunt these "Peeps" as food to be sold in the San Franciseo or any other market, it has passed; and it is to be hoped that we shall never be redueed to the necessity of preying upon such dimimutive creatures as these for food. They should be kept permanently off the list of game speeies in California as well as elsewhere. 


\section{Sanderling}

\section{('alidris Incophaca (Pallas)}

Other Names-Beach Birl; Rudily Plover; Surf Snipe; Sanderling Sanipiler; Calidris arenaria; Tringa arenaria.

DEScRIPTIOx-Adults, both sexes, in late spring and snmmer: Top of heall, hind neek, back, siapulars, some wing coverts, and tertials, black, with broal feather-marginings of briglt rimmamon brown, and more or less extensive white tippings; heal and nerk otherwise einnamon, fleckeri sharply with black; ear region lighter ane to minute white feather tippings; bill black: iris "brown", (Aulubon, 1842, V, y. 289); rump anit millle mper tail roverts black, with feather-margins of pale cinnamon; outer uper tail coverts white; innermost pair of tail feathers longer than rest, their inner wels blackish anl outer webs blarkish brown, marked irregularly with pale cinnamon; rest of tail feathers graling from brown to very pale lrab on outermost ones, anil all narrowly marginel with white; shafts of innermost ones brown, of the others, white; outer surfare of closerl wing: most of roverts like back, others (left-over winter feathers) dull brown with blackish shafts; greater poverts broally tippes with white; primaries and their coverts blackish brown, paler on inner webs, shafts chiefly white; seconclaries chiffly white; margin of wing scaled with pale brown and white; lining of wing and axillars, white; under surface of flight feathers pale clrab; chest and siles like lower surface of head, bright cinnamon, markel sharply with blackish, these markings narrowest near milline; rest of under surface white; feet black; toes only tluree, no hind toe being present. Adults and immatures, both sexes, in latc fall, winter and carly spring: Whole face region pure white: narrow area aronnd eve flecked with brownish; top of heal, himl neck, back and scapular's, fale smoky gray, with dark brown shafts and narrow feather-tippings of ashy or whitish; rmul aml central upper tail eoverts like hark, but larker, more hrownish in tone; outer upper tail coverts, white; tail, outer surface of closed wing and flight feathers, as in summer, but lacking any cinnamon; uncler surface entirely silky white. Males: Total length 7.40-8.62 inches (15. -219 mm.) (ten sperimens); folded wing 4.50-4.77 (114.2-121.0); bill along culmen 0.89-1.06 (22.8-26.9); tarsus 0.94-1.04 (23.5-26.3) (teu specimens). Females: Total length 7.73-8.60 (196218) (ten specimens); fohierl wing 4.62-5.10 (117.3-129.3); bill along culmen 0.91-1.09 (23.0-27.6); tarsus 0.99-1.06 (25.1-27.0) (ten sperimens); all from California. Juvenite plumage: Crown, back and tertials, chiefly black, but with feather-erlgings of white and pate clay color, giving a spotted effert; forehear, sides of head, hind neek, and sides of ehest, buffy white, finely mottlerl with lusky or brownish; indistinct streak from base of bill to and beneath eye, lusky; feathers of rump and central upper tail eoverts, brownish black with broad edgings of cream and narrow blackish tips; outer upper tail coverts and tail as in winter; wing as in winter adults, but coverts roarsely elger with pale clay color; umler surface white, faintly tinged with buff across breast. Natal plumage: Not known to us.

MARKS FOR FIELD IDENTIFICATION-Morlerately small size (elose to that of Red-backed Sandpiper), conspicuous white bar across wing contrasting strongly with blackish primaries; in late spring and summer: mixerl black and einnamon back, and chiefly bright cinnamon throat, neck and breast; in winter: extremely pale tone of coloration, glistening white uniler surface, and pale gravish back: in the hand, lack of hind toe and sandpiper-like bill. Frequents sandy sea- 
beaches, feerling most commonly in dense flocks at erlge of water, advancing and retreating with each wave.

Vorce-“. . A shrill but not unpleasant wick"' (Dresser, 1903, p. 779); a short chit, a rasping note, a peeping uote, or sometimes a sharp grasshopperlike soum (Forbush, 1912, p. 290).

Nest-Either in marshes or on high open grouml; a mere depression lined with leaves of the Arctic willow, or with ratkins and grasses (Feilden, 1877, p. 406 ; and other anthors).

EgGS-Usually 4, pear-shaped, measuring in inches, 1.30 to $1.50 \mathrm{by} 0.95$ to 1.03 (in millimeters, 33.1 to 38.2 by 24.2 to 26.1 ), and averaging about 1.41 by 0.98 (35.9 by 24.9); ground color brownish olive or pale yellowish white, green-tinged, and marked sparsely witl faint blotches and spots of varying sharles of brown, most numerous at larger eml; also leeper markings of light violet-gray (1)resser, 1904, pp. 230-231; and others).

Generai distribution-Almost world-wile. Breens along the Aretie coast of both North America and Eurasia, in the former hemisphere south as far as latitude $55^{\circ} \mathrm{N}$., on shores of Hudson Bay, but chiefly along Arctic coast and islands farther north, including Mielville Island and Grinnell Land; also ou both "oasts of Greenland. Winters from central Argentina and central Chile north regularly on Atlantic coast to North Carolina and on Pacifie roast to central California, and casually to Massachusetts and Washington. In OH World, winters from Japan and the Mediterranean south to southern Africa, Malay Archipelago and Oceania. Oecurs in migration on the sea-coasts of the world, and locally on shores of inland borlies of water (Cooke, 1910, pp. 48-49).

Distributiox IN CALIFORNIA-Common fall and spring migrant and winter visitant; recorded most eommonly on beaches of southern California from Santa Barhara southeastwart. Usually absent from June 1 to August 15. Earliest fall record: Santa Barbara, July 29, 1910 (Bowles and Howell, 1912, p. 9); latest spring recorl: near Santa Barbara, June 5, 1915 (Dawson, 1915, p. 207). Recorled inland only at Salton Sea, April 20 and 30, 1909 (specimens in Mus. Tert. Zool.).

The Sanclerling, or Beach Bird as it has been appropriately called, is, in California, almost exchusively an inhabitant of sandy beaches. being rarely encountered amid any other surroundings. It is a breeding bird of the far north, and cones to us as a transient and winter visitant. It has been found along our coasts during every month in the year, although in summer nearly eight weeks elapse between the disappearance of the last northbound migrants and the arrival of the first fall birds. As barren or non-breeding individuals of this species are thonght sometimes to remain orer in southern latitndes, the period in whieh breeding birds are absent from the state may be still longer. On the coast of sonthern California the birds have been seen as early as July 29, 1910 (Bowles and Howell, 1912. p. 9) and as late as June 5, 1915 (Dawson, 1915, p. 207). Willett (1912a.p. 37 ) states that they are most common as migrants, in spring and fall. There is only one instanee of oeenrence of this speeies from other than a seacoast locality. Frank Steplens found it at the southrast end of Salton Sea, April 20 and 30, 1909 (specmens in 1!us. Vert. Zool.). 
The Sanderling is distinguished by its moderately small size, and conspienous white har across the wing contrasting strongly with the blackish primaries. In late spring and smmmer the mixed black and cinnamon back and the chiefly bright cinnamon throat, neek and breast, and in fall, winter and early spring the pure, even glistening, white muler surface and pale grayish back, combined with the blackish primaries and white wing bar, are distinctive. Structurally, the sandpiper-like bill and absence of a hind toe, together with the presence of square transwerse scales on the front of the tarsus, serve to distinguish this species from all other shore birds. From the Least and Western sandpiper's the sanderling is distinguisherl by its larger size, and from these and the Rexl-backed and Baird sandpipers (which latter two are of about the same size as the Sanderling) by the presence, in spring and summer plumage, of a eimamon-colored breast; in the fall by contimuously pure white undersurface. All of the other species mentioned have a pronounced dull-rolored band across the breast at least in the fall.

The roice of the Sanderling is . . . a shrill but not umpleasant wich" (1)resser, 1903, p. T7!) ; or "a short chit (Hoffmann). A rasping note and a peeping note, sometimes also a sharp gl'asshopperlike somnd. The flight song in spring is a quavering trill' (Forbush, 1912, p. 290). Dresser (1904, p. 2:30) describes the flight song as at harsh trrr-trre-trre.

Sanderlings are preëminently gregarious birds of the sandy seabearh, and show marked preference there for the edge of the surf. They run swiftly back and forth, advancing and retreating before the waves in order to secure the crustaceans and marine worms which happen to be meovered by the wash of the water. If while so engaged a comber threatens to overwhelm them they take wing and rise above it, alighting again as soon as it subsides and eontinuing to forage. If frightened they flush quickly and form into a compact swift-moring flock, which flies in steady conse close over the surface of the water, with pleasing harmony of action. They perform none of the zigzag evolutions that characterize the flight of other sandpipers. Torrey (1913, pp. 25, 26) says that at Santa Barbara, he often saw Sanderlings hopping on one leg, a habit which he did not notiee in any other species of shore bird. The Sanderlings seemed to progress as well on the one leg as on two. It lias been suggested that this habit may be for the purpose of keeping the other foot warm, but why the Sanderling alone among shore birds should be put to the neeessity of such a practice, it is difficult to conceive. After bathing, an operation earried on either in shallow surf or in tide-pools on the beach, Sanderlings have been seen to spring repeatedly into the air " to a height of six or eight inches, shaking themselves vigorously while so doing, 
evidently for the pmrpose of drying their feathers" (Torrey, 1913, p. 24). When wounded, or otherwise foreed to the water for safety, Sanderlings are said to be able to swim quite well.

Isolated individuals or small gromps of this species, as in the case of many other small shore birds, have been seen (Torrey, 1913, pp. 27,28$)$ to band together with individuals or flocks of other small species. The Sanderling is sometimes found about larger inland bodies of water in the East, but as yet in California has been noted inland only at Salton Sea. The extensive collecting earried on by R. H. Beck at Los Baños, Mereed County, for the Musemm of Vertebrate \%oology, failed to indicate the presence of this species at that paradise for water birds.

The nesting season of the Sanderling extends from late June to the midlle of July. A nest found by MacFarlane (1891, p. 427) Jume 29, 1863, on the Barren Grounds abont ten miles west of Franklin Bay, Aretic America, consisted of a small depression in the gromed linet with "withered hay and leaves" and contained fonr" fresh eggs. Feilden (1877, p. 406) records a nest found by him in Grimell Land, June 24, 1876, which was located on a gravel ridge several hundred feet above the sea. “. . The [two] eggs were deposited in a slight depression in the centre of a recumbent plant of aretic willow, the lining of the nest consisting of a few withered leaves and some of the last rear"s eatkins." The eggs are nsually four in number, pear-shaped, and measure in inches 1.30 to $1.50 \mathrm{by}$ 0.95 to 1.03 , averaging 1.41 by 0.98 (fifteen eggs from Aretic coast of Siberia) (Dresser, 1904, p. 230-231). The set of eggs taken by MacFarlane has been deseribed as follows: "Their ground-color is a brownish olive, marked with faint spots and small blotches of bistre. These markings are very generally diffused, but are a little more numerous about the larger end' (Baird, Brewer, and Ridgway, 1884, 1, p. 253).

The nesting luabits of the Sanderling have been reported in an interesting manner by Mamniche (1910, pp. 139-151) who olsserved the species in northeastern Greenland dming the summer seasons of 1907 and 1908. The bird arrives in this region abont the first of Jume, and hy the middle of the month pairing has commenced. In fine weather, especially towad evening, the male would momt to a height of ahout two yards ahove the surface of the ground. and. uttering a "snarling or slightly neighing sound," fly a short distance or in small cirres for several seconds. When excitexl he wonld frequently sit on the top of a lange solitary boulder. with the feathers of his back blown out, his tail spreat and his wings half let down. Soon, however, he would return to the female and try to pair with her. Sonnetimes the male goes through the pairing flight when there is no female in the vieinity. 
The nests of the Sanderling are usually placed on the small "islands" of stones and elay which are seattered over the tundras and moors. The nest itself is a small depression sparsely lined on the bottom with leaves of the aretic willow and other plants growing in the vieinity. Egg-laying begins about June 20, and extends at least until July 15. In cleven nests with eggs and fifty broods of downy young observed by Manniche the complenent was always four. Until laying is completed the males accompany their mates, but when incubation commences they join in small flocks of their own kind or with other shore birds, and have usually left the country by mid-July.

The female is exceedingly wary and will often fly to meet the intruler more than a lundred yards from the nest and then try various deceptions in order to toll him away. At night, or in very cold weather, or when the incubation of the eggs is approaching conpletion, the female is more reluctant to leave, and her anxiety to return often results in diseovery of the nest. Somotimes, if surprised on the nest, the fenale endeavors to escape detection by keeping perfectly still. lneubation lasts for twenty-three or twenty-four days, and the egg shells are pipped as much as three days before the young finally emerge. When the chicks are finally ont the female carries the remuants of the shells away from the nest. All the young rmerge within a few hours of one another, and as soon as the down on all of them is sufficiently dry they quit the nest in company with the mother bird and sometimes go as much as six hundred yards away within a very short time. After the brood is out the female becomes even more solicitous for her charges, and she increases her efforts at distraeting the attention of any intruder when he approaches the vicinity of the brood. Now she will go two or three hundred yards to meet him and attempt to lead him off to one side. Meanwhile the brood lies flat on the ground, and the coloration of their backs is such as to make them very inconspicnous. When the old bird returns and utters a peculiar chirping sound the youngsters become active once more. The young are full grown and able to fly within twelve or fourteen days after they are hatched. Toward the end of July the females desert their broods and begin to migrate south, but the former linger and assemble into larger and larger flocks, then to follow their parents (Mamiche, loc. eit.).

The food of the Sanderling consists of marine worms, minute shellfish, crustaceans of various sorts, and insects; and gravel has been found in some of the stomachs examined. In its summer home it is reprorted to feed upon the buds of the saxifrage (Baird, Brewer and Ridgway, 1854, I, p. 250). When the birds lave become fattened in the fall they are said to be excellent eating. It is not known that they have been shot by sportsmen or market hunters to any extent in 
California. The relatively suall number's which ocem along our coasts, and the extreme northern location of their breeding grounds, make any great future diminution in the number of Sanderlings visiting California improbable.

\section{IIarbled Godwit}

\section{Limose fedou (Linnaens)}

OTHER NAMES-Gorlwit; Great Marbled Godwit; American Bar-tailel Gorlwit: Straight-billed Curlew; Common Marlin; Res Marlin; Spike-bill.

Description-Adults, both sexes, at all seasons: Top of heal and hind neek streaked with brownish black and pale buffy; stripe from upper mandible to above eye, dull white, flecked with blackish brown; area between base of bill and eye densely mottled with brown; sides of heal and whole nerk buffy white, narrowly streaked with brown; ehin white; bill pale yellowish, redlish at base, lrownish black at end; iris brown; feathers of back blackish brown, extensively marked with many irregular spots or incomplete bars of pale tawny or buffy white, the whole prollucing a marbled alpearance; rump, uper tail coverts and tail, irregularly barres with brownish black on a cinnamon or buffy ground, the light color predominating; onter surface of closed wing chiefly einnamon, with irregular markings and flecks of dull brown; lrimary roverts brownish black; primaries brownish black along outer webs, and cinnamon sprinkled with brownish black on inner wels: margin of wing scaled with cinnamon and brownish black; axillars and lining of wing, pale cinnamon, faintly marked with brownish black; quills of primaries whitish lielow, that of outermost one white above; under surface of body pale cinnamon, lightest in region of vent; throat narrowly streaked with blackish brown; breast, sides, flanks and lower tail coverts, marked across nach feather with several narrow way hars of blackish brown; feet lead color or black. Males: Total length 16.56-18.00 inches (423-457 mm.) (seven specinens); folded wing 8.46-8.8.5 (215-225); bill along ('nlmen 3.69-4.42 (93.7-1]2.2); tarsus 2.78-3.0t (70.7-77.1) (seven specimens). Females: Total length 16.95-19.10 (430-455) (seven specimens); folded wing 8.75-9.56 (222-243); bill along culmen 4.95-5.03 (123.0$127.8)$; tarsus $2.87-3.07$ (72.8-78.0) (three specimens); all adults and full grown immatures from California: Juvenile plumage: Similar to that of adult, but markings above less sharply defined, and entire lower surface cinnamon, becoming buffy on throat, sparingly streaked with ilusky on lower neek, anil faintly and narrowly larred with dull brown on flanks. Natul plumage: “... Pinkish buff in rolor, more prononnced on the sines and neck, paler ventrally, and almost white on the throat, chin, and silles of the hear. The occiput, cervix [ =hind neek], back, rump and wings were heavily blotehed witl seal brown, or clouded with hair brown, the latter color shading off gradually into the buff on the sides. . . A narrow loral stripe [hetween bill and eye] . . and a median "rown stripe of seal brown, the latter running from the base of the bill to the oceiput" (Bent, 1907 ", 1.166 ).

MARKS FOR FIELD IDENTIFICATIOA-Large size (among the largest of our shore birds), long straight or slightly un-curred bill, and redlish or cinnamon colored plumage; distinguished from Hudsonian Curlew ly straight or slightly up turned rather than down-wred bill, by distinctly reddish coloration, and hy less clear call-notes; from Long-billed curlew ly smaller size and straightish bill. 
Fonck-Terhit' terwhit, or godwit' godwit'; when disturberl, soumls more like kitrech", heruee-ech", or even her-kor'-koit (Bent, 1907a, 1']. 164, 165).

NEST-In grassy meatlows or marshes usually in the vicinity of water; a leppression formed by treading lown the grass, without the use of any additional material; measures about six by seven inches in lianeter by two in lepith (152 to 177 hy $51 \mathrm{~mm}$.) (Bent, 1907a, ['p. 162-164).

EGGS-3 to 4 , pear-shaped, measuring in inches, 2.14 to 2.37 by 1.50 to 1.61 (in millimeters, 54.3 to 60.2 by 39.1 to 40.8 ), and averaging 2.26 b5 1.56 (57.4 ly 39.6) (eleven eggs, three sets, from southwesteru Saskatehewan); groundcolor of varying tones of buff, with superficial spots of deep brown and unierlying ones of drab or lilac (Bent, loc. (eit.).

Gexeral distribution-North Ameriea. Breels chiefly from northern North Dakota to the valley of the Saskatchewan, formerly south to northern Nebraska, northern Iowa, and Wisconsin. Winters from Georgia, Floriela, Louisinna and southern California south to Guatemala and central British Honiluras. Formerly oceurred in migration on Atlantic coast north to maritime provinces of Canada, but now rare or unknown north of Florida. On Pacifie coast oreurs in migration from Alaska to Lower California (Cooke, 1910, 11. 50-51).

DISTRIBLTION IN CALIFORNIA-Common fall anl spring migrant along the seacoast, and about the larger bodies of water in the Sacramento-San Joaquin Valley; less abunlant now than formerly. In fall and early winter oecurs from late July to December (Willett, 1912a. 1).37), anl in the spring from late March to the last of April. A few have been fouml up to December, even as far north as Humboldt Bay (Cooke, 1910, p. 51), and stragglers have been observed in June, as at Santa Barbara (Torrey, 19106, 1. 204; Dawson, 1915, p. 207).

The Marbled Godwit. Marlin, or Straight-billed curlew, is a rather common fall and spring migrant along the coast of California and also occurs sparingly in the interior. While in more northern latitudes during the breeding season the species is found on meadow land, it here seems to prefer the seacoast and, interiorly, the vicinity of large bodies of water.

Marbled Godwits appear on our coast early in July and remain until December, but the birds are present in numbers chiefly during September and October. The earliest record of arrivals from the north is for Hyperion Beach. Los Angeles Connty, July 13, 1910 (Willett coll.). The latest fall or early winter records known to the author's are: Humboldt Bay, December 7, 1885 (Cooke, 1910, p. 51), Los Baños, Merced Connty, December 4, 1911 (Beck, MS), and San Diego Bay, December 12, 1861 (Mus. Vert. Zool.). Judging from the pancity of records and from the accounts of varions observers this species is not so abundant in the spring migration as in the fall. Nordhoff (1902, p. 214) records finding the remains of a bird of this species at Lake Elsinore. Riverside Comnty, in February, 1902. The earliest bona fide spring record is for Los Baños, Merced County, March 30, 1912 (Beck, MIS), and a late spring one is Alamitos Bay, Los Angeles Connty, May 20, 1905 (specimen in Richardson coll.). 
A bird taken at Los Angeles, June 16, 1875 (Henshaw, 1876, p. 272) is stated to have been a female in worn breeding plumage, and since Cooke (1910, p. 51) reeords eggs taken as early as April 20, it is not altogether impossible that this was an early southbound migrant. Birds which are probably non-breeder's sometimes summer along our coast: records probably of this nature have been made for Santa Barbara, June 4, 1910 (Torrey, 1910b, p. 204) and June 15, 1911 (Bowles and Howell, 1912, p. 9).

From most of the shore birds the Marbled Godwit can be distinguished by its large size and brownish red or eimmamon eoloration; from the IIudsonian Curlew by its slightly larger size, straight or slightly up-curved bill, and reddish rather than brownish coloration; and from the Long-billed Curlew by its decidedly smaller size and much shorter and straight or slightly up-curved bill. The call note is also distinctive, differing markedly from any of the notes of the Curlews, the latter being much louder and elearer. In mixed floeks the female Godwits ean sometimes be distinguished from the males by their larger average size.

The ordinary eall-note of the Godwit, heard while the bird is in California, is a single, or repeated, loud squawking ku-uck, scarcely separated into two syllables; but on the breeding grounds there is a more varied repertoire of notes. Bent (1907a, pp. 16t-165) says:

Its ordinary call-note, when only slightly disturbed, sonnds like teruhit, terwhit, terwhit, or pert-urrit, pert-wurrit, or godwit, godwit, godwit, from which its name is probably derived; these notes are all strongly accented on the last syllable, and are uttered almost constantly while the birds are flying over their breeding grounds. When considerably alarmed these notes are intensified, more rapilly given, and with even more emphasis, kerueck, lierwee-eck, or keerreek, kreck, kreck, kerreck; sometimes they are prolonged into a loud, longdrawn out seream quack, qua-a-ack, or quoick, quoi-i-ick, somewhat between the loudest quacking of an excited duck and the seream of a Rerl-shouldered Hawk. There is also a more musieal, whistling note, less often heard, sounding like the syllables kor-koit, ker-kor-koit, korkoit, the accent being on the kor in each case; this note seens to indicate a more satisfied frame of mind and is much more subdued in tone.

Within our borders Marbled Godwits are birds of the open shore, and are rarely if ever found away from the larger bodies of water. At all times they are exceedingly wary and diffieult of approaeh. 'They frequently assoeiate with other species sueh as the Western Willet and Long-billed curlew, the feeding habits of these three species being similar. Torrey (1913, pl. 45-46) reeords seeing Marbled Godwits and Western Willets in large nmbers "in winter" on San Diego Bay. He says:

- I have seen gorlwits and willets together lining the grassy elge of the flats for a long distance, and so densely massel that I mistook them at 
first for a borler of some kiml of herbage. Thousanis there must have been; anrl when they rose at my approach, they male something like a eloul; gray hirls and brown birils so contrasted in color as to be discriminated beyonil risk of error, even when too far away for the staring white wing-patches of the willets to be longer liscernible.

As a tlock there was no getting near them; l provel the fact to my lissatisfaction more than once: but sitting quietly on the same bay shore I have repeatedly known a single godwit or willet to feed carelessly past me within the listance of a rod or tro.

Lsually taking the precaution to forage at some distance from luman beings and their habitations the Godwits probe in the mud exposed by a receding ticle. Often they will thus probe in the mud when it is still covered by a few inches of water, their long bills and legs making this easily possible. If frightened they take wing and fly with rather slow and short wing beats, the long bill, neck and legs giving the body an extremely attemuted appearance, and thus distinguishing the Godwit from the Culews both of which appear chunkier. In flight, as when feeding. they are often seen in the eompany of other large shore birds such as the Willet and Curlews, and are at times accompanied by such smaller speeies as the long-billed Dowiteher. Beck (MS) mentions seeme a Godwit at Los Baños in company with some Black-neeked Stilts.

Mrs. Bailey (1916b. pp. 101-102) says of the Marbled Godwits seen on the beaches of southern Califormia:

It was amusing to wateh the birls feerl. As a wave rollerl up, comberl over and broke, the white foam would chase them in, anil... if it rame on too fast, ther would pick themselves up,... and scoot in... But the instant the water began to recelle they would right about face and trot back with it. . . As they went their long hills-in the low afternoon sun strikingly coral red except for the black tip-were shoved aheal of them, feeling along through the wet sand. . . ; and if anything good was discovered deeper [they] .. would stop to really probe, sometimes plunging the bill in up to the hilt, on rare oreasions when the tirbit proverl out of reach, actually erowing their hearls down into the sand....

One of the long-legged birds would sometimes stop its work and lift up a foot to scratch its ear, and one that I saw feeliug on the edge of a wave suddenly dropper and went through the motions of sousing itself. . . While the Goilwits were hunting absorbediy, sometimes the white foam of the next wave would flow in over their feet and encircle them, and at other times they would wait until the spray of a breaker was almost on them and have to scurry for it with open wings. When the tide was so low that the waves broke far out on the gently sloping shore, the birds hunted in a more leisurely manner. They often brought up round balls, presumably small erabs or rrustaceans, so big that they hal to gulp them lown, and when tempting morsels were seen in their bills neighborly Gulls often gave chase....

When the big brown birds flew they suggested round-shouhlered Ibises except that their bills were not curvel. In flight they often made a close flock calling, queep, queep, queep, queep, queep.... They soared down hand- 
somely. . and as they alighted held their wings straight over their backs for a moment, the black shoulder strajs showing in strong contrast to the warm cinnamon [of the wing which makes such a good recognition mark].

'The nesting season of the Marbled Godwit begins earlier than with most shore birds. This is in part probably due to the relatively low latitudes of its breeding range. Eggs have been taken as early as April 20, 1878, in Iowa, and young by Jume 8, 1820, in Nebraska (Cooke, 1910, 1). 51) ; while Bent (1907a. pp. 162-166), in southwestern Saskatchewan, found nests on May 29, 1905, and downy young, thonght to have been not over a week old, on June 27, 1906. The nesting season thus extends at least from the middle of April or carly May to the latter part of Jume.

The region chosen by the Godwits for nesting is one of rolling or level prairie covered with short dense grasses and liberally supplicd with small lakes and streams. Here the birds make their nests in the open, withont any attempt at concealment, usually in the near vicinity of water. The nest is formed by treading down the grasses on the selected site, and little or no material is carried in from the outside. A typical nest measures six by seven inches in surface area and about two inches in depth. The eggs have a ground color of deep or pale olive, or ereamy buff, and are either sparingly marked about the larger end with superficial spots and small blotches of pale drab or dark browns and deeper markings of lilac, or else they are heavily spotted with dark brown and lilae gray (Bent, 1907a, pp. 162-164).

While on the nest the demeanor of the birds is in marked contrast to their behavior at other times of the year. They sometimes appear to be quite indifferent to human approach, and one bird studied by Mr. Bent aetnally allowed him to raise her from the nest in order that he might photograph the eggs. When off the nest their behavior is less peculiar.

Like all of the shore hirds, the Marbled Golwit is exceedingly demonstrative on its breeding gromis, flying out to meet the intruler as soon as he appears, making fully as much fuss at a distance from its nest as near it, and giving no clue to its exact location. The eries of one pair of birds often attract others, and I have seen as many as eighteen hirls flying about at one time in an especially favorable locality. It shows no signs of fear at such times, often alighting on the ground within ten or fifteen rards [of the observer], standing for an instant with its beautifully marbled wings poised above it. . . Even while feerling on the shores of the lakes we could frequently walk up to within a few yards of them... (Bent, 1907a, l' 165).

The downy young Godwits are adepts in the art of hiding in the seantiest kind of eover, and by reason of their streaked and mottled coloration it is extremely diffieult to find them. They develop rapidly and soon gather into eompanies. The flocks of adults form as early as June 27, and shortly afterwards begin to depart soutluard, even 
While some of the young birds on the breeding ground are not yet fully fledged (Bent, 1907 $($, pl). 166-167).

The food of the Marbled Godwit consists of crustacea, insects and their larvae, worms (Goss, 1891, 1). 187), leeches (Baird, Brewer and Ridgway, 1884, I, p. 256), and snails (Beck, MS). Belding states (IIS) "I find its Hesh ... excellent food, much preferable to the Curlews." Other authors agree that the Hesh of the Godwit is tender, juicy, and toothsome. The weight of a specimen was found by the authors to be one pound, so that the quantity of nourishnent in a single bird is not inconsiderable.

This species was formerly sold in the markets of San Francisco and Stockton. The limited numbers which ocen here during migration at the present time is probably due in part to market hunting in previous years, and in part to the appropriation by man, of its breeding range for agriculture. In Canada the Godwit appears now to be adequately protected, and with such protection as has been afforded by the close season established under the Federal Migratory Bird Law in the United States, there is gromel for the hope that they may soon return toward former numbers. When the season is again opened, the species should be afforded adequate protection by a short season and small bag-limit in ordes to retain it among the game assets of California.

\section{Greater Yellow-legs}

Totanus molanolrucus (Gunclin)

OTHER NAMES-Tattler; Tell-tale; Tell-tale Tattler; Stone Snipe; Greater Yellow-shanks; Gambetta melanolenca.

DESCRIPTION-Adults, both sexes, in spring and summer: Top and sides of head and whole neck streaked with black and white, the black in excess above; a whitish stripe from upper mandible to above eye; eyelids white; chin white, narrowly flecked with black; bill slaty black, lower mandible slightly brownish at base; iris dark brown; back and scapulars mixed sooty and ashy brown with extensive ashy white feather spottings and tippings, giving a conspicuously mottled appearance; rump feathers dull dark brown, each "rossed near end by a narrow blackish band and tipped with white; upper tail coverts white, most of them barred narrowly with lark brown; tail feathers white or ashy white, barred with brownish black; outer surface of closed wing like back; primaries brownish black; shaft of outer primary almost white; margin and lining of wing, and axillars, white, with irregular brown bars on the feathers; under surface of flight feathers, dusky, marked in fine pattern with a paler tint on inner margins; ground color of whole lower surface white; foreneck and breast streaked with black; lower breast, silles, flanks, and under tail coverts, with broad irregular bars of brown or brownish black; legs and feet straw yellow with a greenish tinge: nails black. Adults and immatures, both sexes, in fall and winter: Top and sides of head and whole neck, dully streaked with ashy brown and white; stripe from bill to above eye, and eyelids, 
white; chin white; whole hark ashy brown with dark shafts and whitish feather tippings; rump, upper tail coverts and tail as in summer; outer surface of closed wing, ashy brown, the feathers having dark shafts and white marginal spots; under surface white, the throat and upper chest pale ashy, narrowly streaked with dnll brown; a few indistinct cross bars of ashy brown on flank feathers and outer muler tail coverts. Males: Total length 13.65-14.60 inches (346-371 mm.) (four specimens from California and Georgia); folded wing 6.97-7.64 (177-194); bill along eulmen 2.00-2.21 (50.8-56.0); tarsus 2.19-2.58 (55.7-65.5) (ten specimens from California). Females: Total length 13.2514.50 (336-368) (foul speeimens from California and Georgia); folded wing 7.37-7.84 (187-199); bill along eulmen 2.03-2.28 (51.6-57.8); tarsus 2.32-2.56 (59.0-65.1) (ten sperimens from California). Juvenile plumage: Similar to that of alults in summer, but upper surface dark brown, with a faint greenish iridescence, and with much less extensive light markings, these being marginal only and tinged with huffy; markings on throat, siles, and lower tail coverts, dull brown. Natal plumage: Not known to us.

MARKS FOR FIELD IDENTIFICATION--Merium large size, slender boily (especially noticeable in flight), long slender bill, mottled back (in summer plumage), white upper tail coverts, and extremely long and slenier yellow legs. Distinguished from Lesser Tellow-legs at a distance only by its large size; in hand minor plumage differences can be discerned, such as presence of fine pale marblings on inner surface of flight feathers, and less extensive barring on miler surface of borly. Voice ummistakable after once learned.

VOICE-A rather penetrating, insistent, yet mellow, whistlea series of notes, all on one pitch, set off in three's and two's: wheu-wheu-wheu, wheu-wheu.

Nest-On ground, near a marsh or on the bank of a stream (Reed, 1904, p. $120)$; "a slight depression in the ground... lined sparsely with grass'" (Elliot, 1895, p. 117).

EGgs-3 to 4 , pear-shaper, measuring in inches, 1.66 to 1.97 by 1.16 to 1.36 (in millimeters, 42.0 to 50.0 by 29.5 to 34.5 ), and averaging 1.84 by 1.28 ( 46.7 by 32.6) (nine eggs, three sets, in U. S. National Museum); color grayish white, bollly splashed with several shades of brown, and with lilac (Reed, 1904, p. 120$)$.

General distribution-Nortl and South America. Breeds in northern North America probably between latitules $50^{\circ}$ and $60^{\circ}$; the only authentic breerling records are said to be from British Columbia as far south as Clinton, and from Ungava; winters from central California, Texas, Louisiana and Georgia south to sonthern end of South America; in migration oceurs throughout the intervening area (Cooke, 1910, pl). 54-55).

Distribution in California - Fairly common spring and fall migrant througlont the state; winter visitant in limiter numbers in the San Joaquin and Imperial valleys, and near the searoast from the vicinity of Monterey Bay southwarl. Recorled from Lone Pine, east of the Sierras, in Derember. Late northwarl uigrants and early southloumd birds almost span the summer, but no breeding records are known.

The Greater Tellow-legs bears an munsually apt name; for it is the langer one of two species of shore hirds which are both easily recognizable hy the yellowish color as well as great length of their legs. On a marsh or elsewhere in the vicinity of water where other birds are present, the Yellow-legs, by their shrill notes, appear to give warning 
when a hunter is espied approaching, and the cries so persistently uttered are usually suffieient to put the more desirable game on its guard or even to cause it to take flight. On account of this habit these two birds are often ealled Tell-tales or Tattlers, the present species being known as the Greater Tell-tale. Many a Yellow-legs has forfeited its life before the barrel of an angry hunter for having given mintinely warning to clueks or other game.

The Greater Yellow-legs is a fairly common spring and fall migrant throughout the state, and also occuls during the winter months in linited numbers in the San Joaquin and Imperial valleys, ant near the coast from the vicinity of Monterey Bay southward. Indivituals, possibly barren or injured, have been observed in the vicinity of Los Angeles in June and July, so that the species may be found within the state during every month of the yar. Birds which were probably migrants from the north were seen near Alrarado, Alameda County, July 28, 1913 (Grimell and Bryant, MS); Bowles and Howell (1912, p. 9) state that the speeies was observed at Santa Barbara on July 18, 1910, while in 1911 a single bird was noted on August 29 and the speeies was not again seen until October 14. Belding (MS) records the birds at Stockton on February 25, 1879, and February 24 and 25, 1880 . Beck (MS) observed limited numbers at Los Baños, Mereed County, almost daily throughout the entire winter of 1911-1912. E. W. Nelson saw a few small flocks about ponds near Lone Pine, Inyo County, in December, 1890 (A. K. Fisher', 1893a, p. 23), and Van Rossem (1911, p. 131) states that the species was common in the grain fields of Imperial Valley, near Salton Sea, December 1 to 25,1910 . Willett $(1912 a$. pp. 37, 38) states that during the winter it is present along the coast of southern California as far north as Santa Barbara. Beck (MS) observed two individuals along a slough near Moss Landing. Monterey County, Jamuary 27. 1911.

The northward migration probably begins about the second week in Nareh, as Beck (MS) records their numbers as increasing at Los Baños about this time, and Belding (MS) states that it was first seen in the spring at Gridley, Butte Comty, on March 14, 1893. A pril probably marks the height of the migration season, as the bulk of the spring records oceur during that month. By the middle or latter part of May most of the birds have left for the north; for instance, Belding (IIS) states that the species was observed at Stockton up to May 23, 1878, while at Santa Barbara, Bowles and Howell (1912, p. 9) saw birds up to May 16, 1910. The species was seen at Nigger Slough, Los Angeles County, June 19, 1597, by G. F. Moreom, and it has been observed during July in the same vicinity by H. S. Swarth (Grimnell, 1898, p. 17). 
The case of the Greater Yellow-legs at Los Baños, Merced County, may be cited as an example of the value of continuous, reeorded observations in one locality. R. H. Beck collected for the California Musem of Tertebrate Zoology at this locality during the winter of 1911-1912, and to judge the status of this speeies from the specimens secured would gire a quite different idea from that obtained by an examination of his field notes. The following table, eompiled from Beek's notebook has added to it memoranda of specinens taken and now in the Nuseum:

\section{1}

Nov. 24 several

Nor. 28 heard and seen

Nor, 30 four seen

Dee. 4 four seen

Dee. 5 seen; two taken

Dee. 9 several; one taken

Dec. 13 several; one taken

Dee. 18 several

Dec. 21 three or four

Dec. 26 several

Der. 28 a few singly or in threes and fours: one taken

\section{2}

Jan. 2 two dozen or so; one taken

Jan. 3 few

Jan. 15 several

Jan. 24 three or four

Feb. 15 several

Feh. 23 two or three taken

Mar. 4 six or eight; one taken

Mar. 6 a half dozen seen

Nar. 11 twelve or more
1912

Nar. 13 sereral

Mar. 16 sereral

Mar. ․ about two dozen: one taken

Mar. 25 three or four seen

Mar. 30 several; five taken

Apr. 2 several; one taken

Apr. 4 not rare

Apr. 5 ene taken

Apr. 6 not rare

Apr. 8 one taken

Apr. 10 four or five: one taken

Apr. 12 one flock of 22; others seen; seven taken

Apr. 15 common; one flock of two Hozen; usually one or two at a time along some water: five taken

Apr. 16 one taken

Apr. 17 eight and several single lirils Apr. 19 two or three; one taken

A 1 r. 22 two dozen or so; one taken

Apr. 24 six taken

Apr. 26 few seen; one taken

Probably more dates would have been recorded in the above table had Mr. Beck spent a part of every day in the field; but a goodly portion of his time was spent in the preparation of speeimens so that sometimes several days would elapse without any extensive observations in the field. The value of such olservations as the above. becomes evident when it is recalled that the information previonsly on record in published literature was inadequate to establish this bird as a regular winter visitant within the state.

The Greater Yellow-legs is to be distinguished from other waders by its moderately large size, general appearance of slenderness, espeeially in flight, slender straight bill, mottled upper surfaee, white upper tail coverts which give the effect of a white rmmp pateh, and especially by its long, slender, yellow legs. From its nearest relative, the Lesser Yellow-legs, it is to be distingnished on the basis of size, 
but in many eases sight identification is not to be depended upon at a distance. In hand, size is absolutely diagnostic, and in addition the fine pattern of paler eolor on inner surface of flight feathers, more extensive area of markings below, and lighter, mixed pattern on top of head, are notiecable. From the Black-neeked stilt it is distinguishable by the mottled pattern of the back, by the presenee of streaking on the throat, and the absence of areas of ummixed blaek and white: from the Hudsonian Curlew by its smaller size, shorter and slenterer, straight bill, and less brown coloration; from the Western Willet hy its smaller size and by the absence of contrasted pateles of black ant white on the wing; and from the Wandering Tattle by its slightly larger size, conspieuous pattern of unarings on the upper surface, and white upper tail coverts.

The roice of the Greater Yellow-legs has been varionsly described; when heard at a distance, a soft musieal "whcu, wheu-uhru-uhcuwhru, whcu, wheu-uheu', (Chapman, 1912, p. 256) ; nearer by, a sharper whistle of the same syllables uttered three at a time, and again "a elear, musical tie-urep. very different from the alarm ery", (Reed, 1912, p. 37). 'T'o our ear's the ordinary notes possess a rather penetrating, insistent, yet mellow quality, and they are griven in separated series, as just indieated.

The Greater Yellow-legs inhabits the shores of inlanel ponds and fresh or salt marshes, rarely the open seabeach; in any of these habitats it is to be fomel wading about in the water often to the full length of its long logrs in seareh of food. At times it will immerse its head in order to reach the bottom of the pond in which it is feeding. When moving about, the earriage of its body is graecful, yet there is a eertain jerkiness or halting element in the gait, this perhaps being due to its excessively long legs.

Greater Y'ellow-legs are found singly, in pairs, or, less eommonly, in flocks of half a dozen or so; larger groups sometimes oeeur. In the latter ease we have not noted the larmony of movement among the constituent individuals so conspicuous in many waders. At times solitary individuals attach themselves to floeks of other waders, suel as of the Long-billed Dowiteher. Sometimes these birds will permit elose approaeh, but not often, a long continued perseention having tanght the lneky survivors of their kind that man is to be avoided. Dawson (1909, pp. 668-669) relates his experience with one of these birds, whieh was so eonfiding as to wade about in a pool at his very feet; but this is to be considered exeeptional. Usually the birds take wing when one is ret a long distance off, and give voice to their shrill notes of alarm which serve as effeetive warning to all other inhabitants of the loeality.

In ordinary flight the wing beats are rather slow, but steady, and 
the bird usually moves in a direct line, although in one case it was seen to dip and dart erratieally when flushed from the banks of a salt water pond. Often, as the hunter is standing on the marsh or seated in a blind, the call-notes of a eompany of this speeies high in the air will reaeh his ear long before the birds themselves become visible. They sweep down with set wings, usually eireling one or more times about the spot on which they have ehosen to alight, as if to make sure that no danger lurks there. Then they settle down, and as soon as their long legs have tonched the ground their wings are extended fulllength above their backs and then deliberately folded. If the flock which thus alights is of any size the individuals composing it spread out over the marsh upon alighting and often mingle with the other shore birds found there. Also when alighting over deeovs they spread out, and this trait saves them from slanghter such as is dealt to speeies that bumch together. When on the gromed and not feeding, they stand motionless save for a rather impressive "mpward bow" at long intervals. This species is easily decoyed by imitating its whistle, and the birds may be ealled from a eonsiderable distance in this way. Even after a floek has been fired at as it flies by, or as it starts to settle among deeoys, it will return in response to the eries of its wounded companions or to another whistle by the hunter, and it seemingly does not lear'n to avoid the danger mutil it has been fired upon several times. Thus does commmity interest or sympathy overcome the native wariness of individuals.

Authentie instances of the nesting of the Greater Yellow-legs are still few in number althongh it is sumised that the breeding range eovers a large territory, approximating that portion of North America between latitudes $50^{\circ}$ and $60^{\circ}$, and from British Columbia or even southeastern Alaska to Ungava. This is not an Aretie speeies; it does not range north as far as the limit of timber. Several breeding instanees have been established for British Cohmbia, notably at Fort George, May 20, 1890, and Fort St. James, May 31, 1889 (Cooke, 1910, p. 5.5) ; and Rhoads (1893, p. 36) found yomg at Clinton, in the same territory; while Brooks (1903, p. 281) reeords finding roung in the Cariboo distriet by June 15 . Reed (1904, p. 120) reeords eggs from Whate River, Ingava, taken .June 10, 1902; "the eggs are generally laid on the gromud. near a marsh or on the bank of a stream, with little or no lining to the nest. They are grayish white, boldly splashed with several shakles of brown, and with lilae."

During the breeding season ". . . both sexes stand sentinel on the tops of trees in the vicinity of the nest, rarely alighting on the ground during the presence of an intruder. The newly fledged young often follow the example of their parents in this respect. From this elerated position the male keeps up an ineessant elamor throughout 
the day. One series of notes, uttered only during periods of fancied security, is peculiar and unquestionably a love song" (Rhoads, 1893, p. 36). The habit of the male of watching from the top of a tall tree, and the disinelination of the other bird to alight in the presence of an intruder, make it extremely difficult and in many instanees impossible to find the nest.

Swarth (1911, p. 53) states that on a wooded island in southeastern Alaska in late April he saw males of this species "going through various courting anties, posing with upraised quivering wings, or r'mming in circles on the sand bars, around the objects of their attention, and incessantly uttering the shrill whistle peculiar to the speeies."

The food of the Greater Yellow-legs so far as known consists of insects and their larvae, snails, erustaceans, worms and small fish. Beck (MS) at Los Baños, found beetles and erickets, respectively, in two stomacls examined, and noted further that in that locality the birds fed principally on ground where the water was fresh. A bird taken on a marsh near Santa Barbara. Angust 29, 1911, was "crammed to the bill with minnows abont one inch long', (Howell, MS).

In the fall Yellow-legs become quite fat and ane esteemed a delicacy by some persons, while others rate them at all times as second elass and much inferior to sueh birds as the Wilson Snipe. Undoubtedly, as Eaton (1910, p. 32t) points out, the flavor of the flesh of any particular indivilual is probably determined by the nature of its food for some time previons: birds which have been freding inland on insects and worms are likely to be of better flavor than those which have been living along the seacoast and enjoving a diet of salt water animal life.

There is no direet evidence to show that the numbers of Greater Yellow-legs oeeuring in California have been noticeably redueed of reeent years; but eonsidering that elsewhere they have helped fill the bag of the market hunter along with other shore birds, and that in previous years, and indeed even until within comparatively recent times, shore birds were sold in the markets of our California cities, it is reasonable to suppose that some diminution in numbers has oceurred. Its rather solitary habits, as contrasted with close-flocking species, prevent wholesale destruetion. The noisy nature of this species may also have proven an important factor in its conservation and also in saving the other wading birds which frequent our shores at the same seasons. Because of this last fact, and also because it is esteemed a table delicacy by some, the Greater Yellow-legs should be so treated that its numbers may be maintained from year to year and possibly augmented, thus serving good economic purpose. 


\section{Lesser Yellow-legs}

\section{Totanus flacipes (Gmelin)}

OTher NAMES-Yellow-legs; Summer Yellow-legs; Little Yellow-legs; Yellowshanks Tattler; Gambetta favipes.

Description-Idults, both sexes, 2 spring and summer: Top and sides of head and whole neck streaked with black and white, the black in excess on top of head; stripe from upper mandible to above eye whitish; eyelids white; chin and throat white, or but narrowly flecked with black; bill black, lower mandible slightly brownish at base; iris dark brown; back and seapulars mixed sooty and ashy brown, with extensive ashy white feather spottings and tippings, giving a mottled appearance; rump feathers dull dark brown, each crossed by a narrow blackish band near the end and tipped with white; upper tail coverts white, mostly barred with dark brown; tail feathers white or ashy white, barred with brownish black; outer surface of elosed wing like back; primaries brownish black; shaft of outer primary nearly white; margin and lining of wing, and axillars, white, with irregular brown bars on the feathers; under surface of flight feathers, Ilusky, ummarked; ground color of whole lower surface white; foreneck and breast streaked with dark brown or blackish; lower breast, sides, flanks, and under tail coverts with sparse irregular bars of brown or brownish black; legs and feet yellow, nails black. Adults, both sexes, in fall and winter: Top and sides of hear, and whole neck, dully streaked with ashy brown and white; stripe from bill to above eye, and eyelids, white: chin white; whole back ashy brown, with lark shafts and whitish feather tippings; rump, upper tail coverts and tail as in summer; outer surface of elosed wing, ashy brown, the feathers with dark shafts and white marginal spots; unler surface white, the throat and npper chest pale ashy, faintly streaked with dull brown; a few indistinct bars of ashy brown on flank feathers and outer under tail coverts (modified from various authors; specimens in winter plumage not seen). Males: Total length 10.50 inches (266 mm.) (one specimen); folded wing 5.80-6.18 (147-157); bill along culmen 1.341.49 (34.0-37.8); tarsus 1.94-2.12 (49.3-53.8) (six specimens). Females: Total length 10.75 (273) (one specimen); folder wing 5.95-6.50 (151-165); bill along eulmen 1.30-1.51 (33.0-38.3); tarsus 2.00-2.13 (50.8-54.0) (five speeimens); all from Alaska. Juenile plumage: Similar to that of adults in summer, but upper surface lighter in tone, the feathers with buff marginal spots; streaking on the throat and upper breast, duller, and on a pale drab ground; rest of lower surface pure white. Natal plumage: "Upper parts and thighs, sealbrown; many of the feathers tipperl with cream-buff; forehearl, sides of hearl and streaks on rump, buffy white; lines on forehear, and from bill through eve to nape, seal-brown; throat and ablomen white; rest of lower parts, buffy white"' (Sanforl, Bishop and Van Dyke, 1903, pp. 412-413).

MARKS FOR FIELD IDENTIFICATION-Moderate size, slenderness of body especially noticeable in flight, long slender bill, mottled baek (in summer plumage), white upper tail coverts, and extremely long and slender yellow legs. Distinguished from Greater Yellow-legs under favorable eircumstances on the basis of size, being about one-half the bulk of that species. In the hand, dimensions are diagnostic: also the Lesser lacks the fine pattern of markings on inner surface of flight feathers, and the markings on lower surface of boly are less extensive.

Vorce-Resemlles that of the Greater. Fellow-legs, hut "learer and not so 
lout: "rommonly following the formula, wheu, wheu-uheu-uheu-uheu, wheuw.иеи, ићи" (Eaton, 1910, 1. 326).

NEsT-Čsually located on lry gromu, but at times in the vieinity of a marsh; a depression in the surface, sometimes at the base of a clump of grass or moler a bush, and, if lined at all, merely with a few withered leaves or grasses (autlors).

Eigs-C'sually 4, pear-shaped, measuring in inches, 1.55 to $1.77 \mathrm{by} 1.10$ to 1.15 (in millimeters, 40.0 to 45.0 by 28.0 to 30.0 ), and averaging 1.65 by 1.14 (42.0 by 29.0) (twenty-seven eggs in U. S. National Museum); ground-color light drab, clay or light brown; superficial markings of chocolate, umber-brown, and blackish. and deeper ones of gray; markings most numerous about the larger end (Davie, 1S59, p. 121).

Gexeral, distributiox-North and South America. Breeds chiefly in British America: north to southern U'ngava, central Keewatiu and nearly to the Aretic "oast of Markenzie, and to the Kotzelue Sound district of Alaska, and soutl probably to southern Alberta, southern Saskatehewan anil northern Quebee. Winters in southern half of South America and sparingly northward as far as coast of southeastern [nited States. Oceurs over the intervening area during nigration (Cooke, 1910, l'p. 56, 57).

Distribition IN CALIFORNiA-Rare spring and fall migrant. The only pul,lished recorts known to the authors are specified in the general account following.

The Lesser, or Summer Yellow-legs, as the species is commonly known in the eastern United States, appears to be a rare migrant within our borders; there are but nine recorded occurrences of the bird in C'alifornia. These are as follows: Gridley, Butte County, April 20, 1896, one shot and another seen (Belding, MS) ; Stockton, San Joaquin County, September 13, 1878, one specimen (Belding, 187!. p. 441): Agua Caliente [= Palm Springs], Riverside County, Mareh 25, 1884, one seen by F. Stephens (Belding, MS) ; San Diego, specimen taken about 1880 "in possession of J. C. Parker" (Belding, MS); Shasta Valley, Siskiyou County, one "heard" September 19, 1898 (C. H. Merriam, 1899, p. 110); Rhett [=Tule] Lake, Modor County, "abundant" (Newberry, 1857, p. 98) ; Humboldt Bay "frcquent" (C. H. Townsend, 1857, p. 198); and Santa Barbara, August 30 , to about September 12, 1912, five individuals seen repeatedly on Estero (Dawson, 1912, p. 224), and August 16 to 30, 1913, eleven individuals seen on Estero (Dawson, 1913b, pp. 20t-205). Heller (1901, p. 100) reported the species as having been observed twice at Riverside during the fall migration, but some doubt has been east upon the correctness of the identification in this last case (Willett, 1912a, p. 111).

So much does the Lesser Yellow-legs resemble its closest relative, the Greater Yellow-legs, that save for size an account of the one might suffice for the other. Practically the same criteria are to be used in field identification, namely, general appearance of slenderness, slender bill, the mottled back (in spring), white upper tail coverts, 
and extremely long and slender yellow legs. The present species is about one-half the bulk of the Greater Yellow-legs. Close examination diseloses slight plumage differences: Absence of paler markings on maler surface of flight feathers, greater extent of ummarked white areas bencath, and darker top of head. From the Peetoral and Solitary sandpipers, the Lesser Yellow-legs may be distinguished by the slightly longer bill, by the much longer bright yellow legs, and by the white upper tail coverts. From the smaller plovers, sandpipers, and the phalaropes, it may be distinguished by the extremely long and slender yellow legs, and, in many eases, by the absence of a white band on the wing.

The eall-notes of the Lesser Yellow-legs are said to be similar to those of the Greater but elearer and not so lond, though longer continned. Eaton (1910, p. 326) represents the usual call as follows: "wheu, wheu-uhcu-uhcu-wheu, wheu-uheu, uheu."

This species is an inhabitant of mud flats, sand bars and marshes, in both fresh and salt water situations, where it wades about and probes for, or gleans from the surface, the materials which comprise its food. It is extremely wary and flies up at the distant approach of any intruder, giving voice to its alarm in a tone that all inhabitants of the marsh ean hear and heed. This habit, which is shared with its larger relative, has earned for it the name of Lesser Tell-tale or Lesser 'Tattl'r', as applied by hunter's when they are desirous of seeuring finer game such as ducks or snipe. If wounded in the wing so that flight is impossible the birds are able to run very fast and can make their escape by lunning and hiding in grass or other marsh growths (Baird, Brewer and Ridgway, 1884, I, p. 276).

Dawson (1913b, pp. 20t-205) records his experience in photographing some Lesser Yellow-legs near Santa Barbara in August, 1913, in part as follows: On Angust 16, “. . . there were eleven of the Lesser Yellow-legs present on our Estero, and they were to be found in varying numbers for about two weeks thereafter. They proved to be rather timorous on all oeeasions but especially so when incited to flight by the Killdeers, which were always bossing them about. In moving to and fro aeross the Estero they usually paid little attention to their own kind and were as ready to join a bevy of Long-billed Dowitehers or Northern Phalaropes or the solitary Greater Yellow-legs . . . as to hunt mp their proper fellows."

The breeding season, in the northern smmmer home of the species, extends throughout the month of Jume aceording to Cooke (1910, p. 58), eggs having been taken in Tukon and Mackenzic on June 1, 15, 16 and 20, and downy youmg on July 1.

'The nest is a simple affair, usmally a mere depression in the surface of the gromnd, sometimes lined with dried lraves or grasses and 
occasionally placed where it will receive the protection of a small bush or "lump of grass. It is plaeed either in a rather dry situation or near or in a marsh in the vieinity of water (Baird, Brewer and Ridgway, 1884, I, p. 277 ).

The eggs are usmally four, pear-shaped, and measure in ineles, 1.65 by 1.14. The ground-color ranges from clay, buff or eream color through light drab to light brown. The superficial markings are bold and heary, consisting of chocolate, muber-brown and blackish and are distributed chiefly abont the larger end of the egg. The grayish deeper markings are also nmmerons and noticeable (Davie, 1889, pp. $120-121)$.

In the Kowak Valley of nortlern Alaska, Grimnell (1900, p. 26) observed the arrival of this speeies May 19, 1899. ". . . As one approaehed their domains the Yellow-legs would fly to meet him, uttering prolonged, monotonous eries. Besides these notes of alarm the males liad a full, melodious warble, sung for minntes at a time as they flew slowly about overhead. Their favorite haunts appeared to be the meadows lying between strips of timber, especially if there was a shallow lake or pond in the vieinity."

Males often pereh in trees during the nesting season, as do Wilson Snipe and Greater Yellow-legs. After the young are hatehed both parents will pass from tree to tree until they are several hundred yards from the nest, in their efforts to lead away an intruder. "The young, even when just hatelied, run and hile in the short grass, so as to make it difficult to find them, the parents, in the meanwhile, flying and screaming in the air above" (Baird, Brewer, and Ridgway, loe. cit.).

The food of the Lesser Yellow-legs eonsists of insects, erustacea, small mollusks, worms, and small fish. Its flesh is considered to be of seeond class among the shore birds, not ranking with that of the Wilson Snipe or Knot as regards flavor. From the limited numbers oceurring in California during the many years in which ornithological work has been earried on, it may be inferred that the speeies never has been and never will be an important game bird within the state.

\section{Western Solitary Sandpiper}

\section{Hclodromas solitarius cinnamomeus (Brewster)}

OTHER NAMES-Solitary Tattler; Totanus solitarius; Totanus solitarius cinnamomeus: Rhyacophilus solitarius.

DESCRIPTION-Adults, both sexes, at all seasons: Top of head and hind nerk dark brown, with sparse streaking of white; sides of head and neck, white, thickly but narrowly streaked with dark brown; eyelids white; chin white: bill "greenish black", iris "brown", (Audubon, 1842, V, p. 312, for the east. 
ern subspecies); back, rump and central npper tail coverts, dark olive brown, with snall spots of buffy or white on margins of feathers; onter upper tail coverts sharply barred with brownish black and white; middle pair of tail feathers, olive brown, outer ones strikingly barred with blackish brown and white; outer surface of closed wing like back; jrimaries brownish black; lining of wing and axillars barred blackish brown and white; under surface of flight feathers dusky brown, that of first primary towards basal and inner elge finely marbled with white; throat and breast, white, narrowly streaked with dark brown; sides brownish, irregularly flecked witl white; flanks and under tail coverts sparsely barred with brown on a white grounis; rest of under surface white; feet "greenish-gray," claws "brownish-black" (Audubon, loc. cit.). Males: Total length 8.50-9.06 inches (216-230 mm.) (three specimens from California); folded wing 5.06-5.48 (128.3-139.0); bill along culmen 1.15-1.26 (29.2-32.0); tarsus 1.23-1.35 (31.3-34.3) (ten specimens from California ant Alaska). Females: Total length 8.48-8.87 (215.5-225) (three specimens from California); folded wing 5.17-5.50 (131.3-139.5); bill along culmen 1.11-1.34 (28.3-33.9); tarsus 1.23-1.37 (31.2-34.8) (ten specimens from (alifornia and Alaska). Juvenile plumage: Like that of arults but with upper surface warmer brown, spotting pale buffy or cinnamon, and streaked pattern on lower surface more diffuse. Natal plumage: Stripes from bill over top of head, from bill to eye, over eye to above ear and patch on ear region, black; ground color of top of heal pinkish brown; cheeks and chin whitish; line below eye pinkish brown; bill dusky, pale at base of lower mandible; back of head, whole back and wings mixed pinkish brown and black in large pattern; under surface white; legs and feet (dried) brown.

MARKS FOR FIELD IDENTIFICATION-Moderately small size, very sleniler bill, conspicuously barred outer tail feathers, general brownish coloration above, and absence of any light bar on wing. Distinguished from Spotted Saniliper by larger size, heavily barred outer tail feathers, absence of white bar on wing, absence of rounded dark spots on clear white under surface, presence of brown streaked or washed area on throat and breast, and habit of frequently raising wings vertically above back.

Torce-A few sharp peeps; on breeding grounds a weak flight song, somewhat resembling the call of the Sparrow Hawk (Grinnell, 1900, 1. 26).

NEST-In trees, the birds using the abandoned nests of other birds.

EGGS-4, pear-shaped, measuring in inches, 1.37 to $1.44 \mathrm{by} 1.01$ to 1.06 (in millimeters, 34.7 to 36.5 by 25.7 to 26.8 ), and averaging 1.41 by 1.04 (35.8 by $26.3)$; ground-color almost white, but with an extremely light yellowish glaucous tinge; superficial markings of warm sepia and verona brown, deeper ones light mouse gray and quaker drab; the spots have a spiral treml and are most numerous about larger ends of eggs (one set, four eggs, in IT. S. National Museum).

Gexerdl distribution- Westem North America and probably Sonth America. Breeding range not definitely known; oceurs in summer from Kotzehne Somni east to Great Slave Lake and south to Washington and Colorarlo, but probably breeds wholly north of the United States. Winter home of the eastern and western subspecies supposed to be on common ground in South Ameriva (Cooke, 1910 , pp. 58, 59).

Distribution in CALIFornia-Fairly common spring and fall migrant throughout that portion of the state which is south of the latitucle of Tehachapi; much rarer in the Sacramento-San Joaquin Valley. Seacoast recoris appear to he exceptional. Not recorded from the roast region north of Santa Barbara. 
The Western Solitary Sandpiper, or Solitary Tattler as it is sometimes called, is not as abundant in Califomia as are most of the gregarious speceies of shore birts nor does it seem to be as numerous here as in some ofler places in North Anerica. The two subspecies of the Solitary sandpiper, the Fastern and Western, are extremely similar in appearance, and as a consequence the ranges of the two are not yet clearly defined. Only the Western is supposed to ocenr west of the longitude of Colorarlo.

One marked feature of the oeemrence of this speceses in California is the great number of reeords from southern ('alifornia south of the latituke of 'Tehachapi Pass, there being more than twiee as many from that region as from all the rest of the state. The earliest spring record for California is from Santa Cruz Island, Narch 17 or 18, 1886 (Streator, $1888, p, 53$ ). The lulk of the migration oceurs during April, especially in the latter part, and by the thirel week in May' the hirds have all passed north, the latest spring recold being from Los Angeles, May 14, 1s.9 (Willett, 1912a. p. 38). The southbound migration sets in cluring late July, as birds were observed at santa Barbara on July 22, 1910 (Bowles and Howell, 1912, p. 9). August seems to mark the height of the fall migration, over half of the reeords within the state having beren made during that month. The species disappears from the state during the latter part of september, the latest record being for Los Angeles, S(rptember 22, 1898 (Willett, loc. cit.). Thus it will be seen that the Solitary Sandpiper is in California strictly a through migrant, tarring but briefly. There are no definite records of its ocemrence here during the winter months or during early summer.

While not strictly solitary, as its name would indicate, this species is nerer found in large flocks. It usually oceurs singly or in pairs, but in the fall after the roung are on the wing, as many as half a dozen. may be found together, probably all members of the same family. The species also differs from many of the other shore birds in frequenting inland habitats almost exclusirely, rarely if ever being found about salt water. From observation at Santa Barbara. Bowles and Howell (1912, p. 9) concluded that "the Solitary Sandpiper, more than any other shore bird, is inclined to restrict itself to the grassy mud flats and wet meadows"; none were ever seen on the seabeach or open flats. As reported by other observers, the birds prefer the shores of inland lakes, or sand bars along streams especially where there is good cover in the form of dense brush along the banks. Only when the water about their favorite sechuded retreats is low, as during the late summer and early fall, do they seek more open forage grounds. 
From the Spotted Sandpiper, whieh the Solitary Sandpiper most closely resembles in choice of surroundings, the latter speeies may be distinguished by the fact that it is about one-third larger in size, that it possesses more sharply barred onter tail feathers and a brown streaked area on the throat, and that it has no rounded dark spots on its white under surface, and no white wing bar. Its very slender bill, the brown, unstreaked back, the lack of a white bar on the wing, and the distinet barring on the onter tail feathers, in combination will serve to distinguish this speeies from such birds as the Pectoral, Baird and Red-backed sandpipers. From all the plovers the Solitary Sandpiper may be distinguished at once by the slender bill.

The following three paragraphs relating to certain mannerisms of the Solitary Sandpiper show some differences of interpretation on the part of the observers, but in the main supplement one another so as to give the reader a correct general conception of the bird.

These birds ... ware about in the mud and water, chasing with open wings, or probing for, and feeding upon the minute mollusks, worms and various forms of aquatic insect life that abound in such places. They have a peculiar way of balaneing the body, by benling the knees, jerking the tail, and bowing the head, much like the Spotted Sandpiper, but in a slower and more dignified manner. . . Notwithstanding they are tattlers by name, [they] differ from the family by being usually silent, seldom uttering their low, whistling notes except when startlerl or about to take wing. . . As a rule the birds are not shy, and, when followed, run in an uneoncerned manner along the shore, or by short flights keep a little ahead, or return to the starting point by circling back close to or over the water (Goss, 1891, p. 193, referring probably to the eastern subspecies).

When flushed it usually flies with unexpected swiftness, rises at a sharp angle to a height of several hundred feet, and then flies willly for a moment or two, and often returns and alights near the place from which it started. Almost invariably it utters a sharp whistle of three or four notes as it rises, not particularly lond, but high-pitehed, penetrating, an i very characteristic. While feering it runs about and bobs its head and tail somewhat like a [Spotted Sandpiper] . ..., but the movements are much more abrupt and jerky, and there is far less of the graceful swinging motion so prettily shown by that bird. Often when standing quietly otherwise it will jerk its hearl and body stiffly upward and back again, precisely as if moved by a hic-cough (Barrows, 1912, pp. 194-195, writing of the eastern subspecies).

In the fall, on its return from the north, it has a habit of wading into the water in stagnant ditehes or ponds, where it advances one foot at a time, and by rapidly moving the forward foot stirs up the vegetation at the bottom ever so slightly. This motion is so swift and delicate that the leg seems to be merely trembling, as if the bird were chilled by contact with the water, but it is done with intent to disturb insects among the algae at the bottom without roiling the water, and the eager bird, leaning forward, plunges in its bill and head, sometimes to the eyes, and eatehes the alarmed water insects as they dart away. I have watched this carefully with a glass while lying in the grass only ten or twelve feet from the bird. It is easy by stirring the bottom slightly with a stick to cause a similar movement of the water 
inserts, but 1 never roull agitate it so clelieately as to avoid (-loulling the water with seliment from the bottom (Forbush, 1912, p. 30.5, relating to the eastern subspecies).

Often when one of these birels alights it will raise its wings to their fullest extent above its back, displaying the beautifully barred pattern of the lining of the wing and axillars. "This speeies, and the Spotted sandpiper also, will sometimes dive and swim under water when wounded, using the wings as propellers in the same manner as do the ducks" (Bowles and Howell. 1912, p. 9) ; and in the East the species has been seen to swim for some distance on the surface when it had waded beyond its depth.

The western race of the solitary sandpipere is believed to brest ehiefly in Alaska. In the Kowak Valley, in the northern part of this Territory, Grimell (1900, p. 26) noted the arrival of the species on the 18th of May, 1899. It soon aftel became common, hamnting in pairs the marerins of secturled ponds surrounded hy dense spruce wooks. In such places one of a pair would usually be seen perehed (quietly at the top of a small tree or fallen branch near the pond, while the other bird foraged through the grass at the edge of the water. If alarmed, the hirds wonld take short flights, giving utterance to a few sharp preps. The song-flight usually occurred during the (arly molning hours. 'This consisted of a slow, eireuitous flight on lapidly beating wings, high over the tree-tops, accompanied by frequent repetition of a weak song somewhat resembling the eall of a Sparrow IIawk. At the close of this song-flight the performer, presumably the male, would alight as if exhausted, and proch silently for some time at the top of the tallest spruce in the vicinity. Meanwhile the other bird would continue feeding as before, to all appearances entirely unmindful of the ecstatic efforts of its mate. Examination of various old nests in trees, such as those of the Taried Thrush, in the attempt to locate eggs or young proved fruitless, though the actions of the sandpipers indicated beyond doubt that nesting was in progress.

We know of but one authentic set of eggs of the Western Solitary Santpiper. In the Tnited States National MIuseum there is a set (no. 33209) of forr eggs from northern Alberta, Canada, taken May 30, 1911, by "E. T. for E. Arnold." The four eggs, which were fresh, were taken from a nest "placed in the crotch of a small spruce tree in a large swamp." 'They are pear-shaped and measure in inches, 1.37 to $1.44 \mathrm{by} 1.01$ to 1.06 and arerage $1.41 \mathrm{by} 1.04$. In color they appear to be unique among the eggs of North American shore birds. The ground-color is almost white but has an extremely light vellowish glancons tinge. The superficial spots are warm sepia and verona brown and the deeper ones light mouse gray and quaker drab. The 
markings all have a spiral trend and are more numerous abont the larger ends of the eggs.

The Solitary Sandpiper (one or the other or both subspecies) feeds on worms, aquatie insects and their larvae, beetles, grasshopper's, caterpillars, spiders, and small mollusks (Forbush, 1912, p. 308; and author's). Its general diet of fresh-water insect life eommends the speeies to man's favor. Its small numbers, in California at least, bar it from serious pursuit as a game species. Furthermore, it migrates through the state ehiefly, if not entirely, during the elosed season. Interest in it lies rightly with the naturalist rather than with the sportsman.

\section{Western Willet}

\section{('atoptrophorus scmipalmatus inornatus (Brewster)}

OTHER NAMES-Willet; Candlestick Plover; Catoptrophorus semipalmatus; Symphemia scmipalmata inornata; Symphemia semipalmata; Totonus semipalmatus; Symphemia semipalmata speculifera.

Descripton-dauls, both sexes, in spring and early summer: Top and sides of head blackish brown, streaked with whitish; cheeks and spot in front of eye lightest in effect; eyelids white; chin white, sparingly fleckerl with dark brown; iris dark brown; bill slaty black, changing to gray at base; hind neck narrowly streaked with dark brown and ashy; back cliefly black with a faint bronzy sheen, and mottled with pale buffy or dull white (many worn ashy brown feathers of the winter plumage usually remain); rump gravish brown; upper tail coverts and bases of tail feathers whitish, with narrow bars or flecks of brownish black; tail feathers pale drab brown, outer ones palest; outer surface of closel wing (coverts only) drab brown or gray; terminal third of primaries and all of primary coverts, black; basal two-thirds of primaries and most of secondaries, white; tertials tike back; margin of wing mottled brownish black and white; lining of wing and axillars deep blackish brown, many of the feathers narrowly tipped with whitish; under surfaces of primaries and secondaries like outer surfaces of same; lower surface, except belly, suffused with buffy; throat streaked, and breast, sides and lower tail roverts irregularly barred, with brown; belly white; legs and feet light olive grav. Adults and immatures, both sexes, in winter: Upper surface uniform grayish brown; a light spot in front of eye; eyelids and chin white; tail coverts, tail, and wing, as in summer arlults; side of heal grayish brown streaked with lark brown; whole neck, breast and sides gravish brown and continuous in tone with color of upper smiface, but gradually fading to white on belly; flanks ancl under tail coverts, sparingly flecked with pale grayish brown. Males: Total length 14.90-15.75 inches (378-400 $\mathrm{mm}$.) (two sprecimens); folderl wing 8.03-8.35 (204212 ) ; bill along culmen 2.23-2.54 (56.6-64.4); tarsus 2.52-2.84 (64.2-72.1) (four specimens). Females: Total length 15.00-16.25 (381-413) (five specimens); folded wing 8.15-8.55 (207-217); bill along eulmen 2.27-2.50 (57.7-63.4); tarsus 2.29-2.80 (58.2-71.1) (five speeimens); all adults and full-grown immatures from California. Jurenile plumage: Like that of adults in winter, but upper surface lacking ashy tinge, it being brownish with buffy and blackish featheredgings and blackish shaft streaks; under surface of bory white, slightly 
suffusel with buft on merk, hreast and sirles, where also finely spotten with pale brown. Natal plumage: Top of head and whole liack mixed bufty white and clove brown in fine pattern, the latter color predominating; forehean and sirles of liead buffy white; stripe lown midlle of foreheal dusky; bold stripe from bill to eye, aud a narrower one hehind eye, clove brow; lower surface of borly dull white, with a faint banl of lusky across upper chest.

MARKS FOR FIELD IDENTIFICATIOA-Large size, straight bill, anil gray general apjearance; strikingly contrasted white band set in l,lack, displayed on wing when spread (fig. 72 ); white "rump jatch" (upper tail roverts anil bases of tail feathers). The shrill ery is listinctive.

Vorce-A shrill, high-pitcherl ke-leć-er: or pill-uill-ullet, w pill-will-willy.

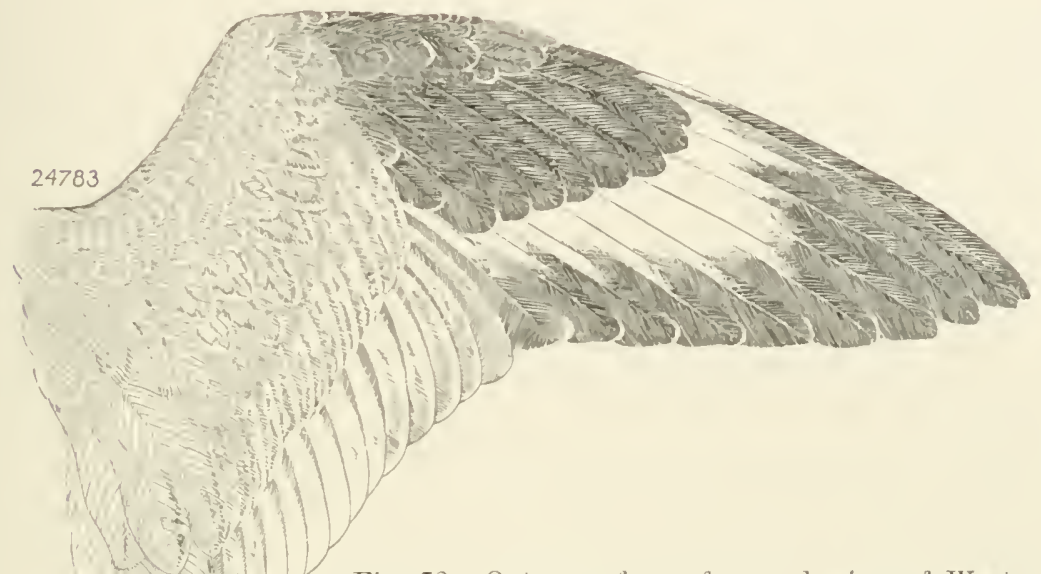

Fig. 72. Outer surface of sprearl wing of Western Willet, showing color patehes.

About two-fifths natural size.

Nest-On ground, usually in grass and in the vicinity of water; a slight depression in the surface sparingly lined with grasses, or a well constructed affair of grasses and other available material, even several inches in height (various authors).

EGgs-3 to 4, bluntly pear-shaperl, measuring in inches, 2.02 to 2.17 hy 1.47 to 1.58 (in millimeters, 51.3 to 55.2 by 37.4 to 40.2 ) : 'ground-color, grayish white, buff or olive, with superficial spots of various shades of brown, and deeper ones of purple gray; spots more numerons about larger enils (Goss, 1591, p. 195).

General distribution-Western North America. Breeds from northern Iowa, southern South Dakota, and northeastern California nortl to eastern Oregon, Alberta, Saskatchewan, and southerı Manitoba; also on roasts of Texas and Lonisiana. Winters on coast of California from Humbolit Bay southward, and on coasts of Texas and Louisiana and Gulf coast of Florida, ranging south into Mexico. In spring migration occurs from Mississippi River west to Pacific coast (in California), and in fall ranges eastward to Atlantic coast (modified from Cooke, 1910, p. 62). 
Distribution IN CALIForNiA-Rather abundant spring and fall migrant, chiefly coastwise; remains through the winter in small numbers along the coast. A few summer regularly in the northeastern corner of the state: breeds at Beckwith, Plumas County (Cooke, 1910, p. 62), and in vicinity of Goose Lake, Modoe County (Mus. Vert. Zool.). Recorded in winter from Humboldt Bay, San Francisco Bay region, and from several localities on coast of southern California from Santa Barbara southward; spring migration, when but few biris are observed, oceurs chiefly during April aud May, and fall migration, which is conspicuous, from latter part of July until late October or early November. Non-breelers are often seen on or near southern seacoast during summer months.

Of the shore birds inhabiting California the Western Willet is one of the largest and most conspicuous. Its shrill call and the flashes of its contrasted black, white, and gray plumage, either in flight or at rest, are among the familiar sights granted persons who frequent the seashore or salt marsh.

Willets are present in California throughout the year although not continuously in the same loealities. The species has been recorded as breeding at Beckwith, Plumas County (Cooke, 1910, p. 62) ; and birds seen about Goose Lake, Modoc County, early in June, 1910, showed evidence of having nests in the ricinity (W. P. Taylor, MS). It has been recorded at Humboldt Bay in November and December (C. H. Townsend, 1887, p. 199) ; about San Francisco Bay on November 4, 1898, and November 17, 1895 (specimens in Mailliard collection), and in December, 1855 (Cassin, 1862, p. 321) : at Carpinteria. Santa Barbara Comnty, December 23, 1911 (Willett, 1912a, p. 38) ; at Newport, Orange County, December 8, 1898 (specimen in Swarth collection): and at and about San Diego, common throngh the winter (Belding, MS). The spring migration occurs during April and May, during which months a few pass through the San Joaquin-Sacramento Valley (Belding, MS) as well as along the seacoast. A few individuals linger behind the northbound migrants, as single birds were seen at Santa Barbara, June 24 and July 8, 1910 (Torrey, 1910b. p. 204), and at Nigger Slough, Los Angeles County, May 17 and 28, June 2 and July 10, 1910 (Willett, $1912 a, p .38$ ). The southward migration is the more conspicuous and commences the latter part of July and continues until the latter part of October or first of November. The early nesting season makes it possible for young birds to appear on the coast as migrants by the latter part of July. Birds-of-the-year which were evidently migrants were observed and collected at Bear Lake, 6,700 feet altitude, San Bernardino Nountains, July 28 to August 2, 1905 (Grimnell. 1908, p. 5.5).

Among the shore birds the Western Willet is exceeded in size only by the Long-billed Curlew, from which it also differs in having a general coloration of gray rather than pinkish brown. From the 
Hudsonian Curlew and Marbled Gorwit, birds of about its own size, the Willet is distinguished by its shorter and straight bill, its gray rather than brownish coloration, the conspicuous black and white pattern on both inner and outer surfaces of its wings (fig. 72) and by the white "lump patch." The striking black and white of the wings, as shown in flight, serves to distinguish the Willet from any of the somewhat smaller Wakers such as the Black-bellied Plover and Greater Yellow-legs. The shrill, ret not unpleasant, eall, pill-uilluill, $t$, is also a very good ficlel character.

Unless hidden by marsh vegetation, as along winding sloughs, the Willet is usually a wary bisk and will not allow close approach. Torrey $(1913$, p. +6$)$ says of a flock that ". . . there was no getting near them: I proved the fact to my dissatisfaction mole than onee : but sitting quietly on the same bay-shore I have repeatedly known a single Goulwit or Wrillet to feed carelessly past me within the listance of a rot or two." Thlese birks commonly flock with inclividuals of other species. 'They may he seen in company with Ciodwits, as mentioned above, also with our two species of ('urlew, Greater Yellowlegs. Turnstones, and long-hilled Dowitchers. and a Willet has even been noted attempting to fy in unison with a flock of Least Sandpipers!

The Willet during miglations and in wintel inhabits seabeaches and salt marshes. serming to prefer sandy or muddy locations to rocky or pebble-strewn shores. Isolated indivichals may be met with at times. but usually there are several in one locality and when restless or not feeding these often gather into fair-sized flocks, numbering up to twenty-five or more individuals. T'orrey (1913, pp. 45, 46) mentions seeing Western Willets and Narbled Godwits near San Diego in such large numbers and so densely massed that he ". . . mistook them at first for a border of some kind of herbage. Thousands there must have been: and when they rose at my approach, they made something like a elond; gray birds and brown birds so contrasted in color as to be discriminated beyond risk of error, even when too far away for the staring white wing-patches of the Willets to be longer discernible."

In its chosen hamnts the Willet stalks abont in search of the aquatic animals which constitute its food, sometimes wading breast deep in the water. Its half-webbed feet allow it to swim easily and this the bird often does when lifted beyond its depth by a wave, or when pursued. On the Atlantic Ocean, Eastern Willets have been seen resting on the water in mid-ocean during their long migration flight from the Canadian maritime provinces to the West Indies (Forbush, 1912, pp. 311,312 ). As suggested in Torrey's account these birds are often more suspicious than most other large shore birds. The Willets do not decoy so readily, and even when passing over decoys the least move- 
ment will frighten them, after whieh no amount of skillful whistling will induce them to return.

A flock of six observed on the Alameda marsh, mpon rising flew in the zigzag manner of sandpipers, but with longer straight flights preceding the changes in direction. When the birds alighted on a sandbar they stood very ereet, and now and then spasmodieally raised the head still higher for an instant in a haughty manner-a baekward bow! During high tide the birds retired inland along the sloughs where they stoor heel deep, preening, and at short intervals they seemingly rinsed their bills (Grimmell and Storer, MS).

The flight of the Willet when well under way is quite direct, with a flat wing beat. The wings rarely rise above the level of the back, aud consequently the upper surface of the body is almost continually in view. The bird sails with set wings only when descending from a higher to a lowel level, or when about to alight. A ehange in the direction of flight is seemingly accomplished by a difference in the intensity of the two wing beats and a rolling of the body. The feet, which extend considerably beyond the tail, probably assist somewhat in steering. During high tide when the feeding grounds of the Willet are covered with water the birds choose some higher situation which will not be inmolated, and there they rest, many of the flock tucking their heads muler their wings as they sleep. 'There is, however, one or more constantly on wateh, and on the approach of danger a shrill ery of alarm is somcled, the flock at once taking wing and rapidly making off to some safer place (Elliot, 1895, p. 130).

On the beaches of southern California, Mrs. Bailey (1916b, p. 102 ) records that

In the flocks of brown Godwits, the few gray Willets looker small. They fed in the same way as the Godwits though their bills were shorter and they could not probe so deep, but they ran their bills ahead of them through the wet sand, probed as far as they could reach, and then trotted back before the oncoming waves. A thoughtless one sat down just at the edge of the water line one day, its back toning in with the sand, its long legs stretched out hefore it: but soon after it was comfortably settler up came the foam and it had to bend forward on its tarsus, raise itself and flee up the beach. I often saw one resting, standing on one leg, or sitting at ease with white rump showing. When stretching, the black of the wings showed effectively as it foes both when the birds fly up and when they alight with wings raised over the back. Willet, willet, they often called as they went.

The Willet may be credited with quite a variety of lond ealls and alarm notes. The ordinary calls consist of full, rounded whistles, nttered either singly or in rapid succession. A notably descending inflection is apparent, though on the whole the effect is a staceato one. In addition there is ". . . an interesting flight song; particularly towarts evening. ..." Duriug the breeding season one of these 
bircls may be seen ". . Hying in large circes high in the air, ponring ont a rapief strean of whistling notes, sommling like pill-uill-willet. repeated over and over again for a period of several mimutes" (Bent, 19076,1 . 427 ).

Althongh the Western Willet is associated in our minds with the sea-coast, its nesting grommls lie, for the most part, far in the interior. In California it has been foumd breeding at Beckwith, Plumas County, at an eleration of about 5,000 feet (Cook', 1910, p. 62), and birds tak'n on Jume 3 and 10, 1910, in the ricinity of 1)aris Creek at the sonthern encl of Goose liake, Modoe Comnty, elevation 4,500 feet, showed by their actions that they had nests in the vicinity (W. P. Taylor, MS'). The speeies hreeds in the north-central United States west through the northern Great Basin, and in sonthern Canada; also locally in a small coastal area in 'Texas and Lonisiana. Eggs have been taken fiom May 2) (partly incubated) until . June 14 (fresh), these dates probably indieating the extent of the brexling season.

The mests may he platerd either on marshland in elose proximity to water or on dry prairies a considerable distance from it. The nest is eonstructed of grasses and such other suitable plant materials as may be at hanc. It is sometimes a mere depression in the grass, with sparse lining. agan a quite hulky affair. The eggs usually number four and measme in inches, 2.02 to 2.17 hy 1.47 to 1.58 . The ground color varies from grayish white to buff and even olive, while the superficial markings, usually more numerous about the larger end, are of varions shades of hrown, the leeper ones of purplish gray (Goss, 1891, p. 195i. They are more bluntly pear-shaped than the eggs of many other shore birels.

The set which forms the basis for Cooke's reeord from Beckwith, Plumas Countr, was collected May 28, 1891, and consisted of three eggs. The eggs measure in inches, 2.08 to $2.16 \mathrm{by} 1.43$ to 1.48 , and average 2.12 by 1.46. In coloration they agree with the deseription given by Cioss (supra cit.). These eggs, which now form set no. 24582 in the United States National Mnseum, were eollected by N. R. Christir, for W. F. Webb of Genera, New York. The data aecompanying this set state that $M r$. C'hristie took three sets of this species all alike in color, ete., "some of four eggs and some of three," all on the same dar. The eggs were fresh. The nest was construeted simply of grass and was situated on swampy ground on a large stock ranch.

During the nesting season Western Willets often perch in low trees as do many of the other larger shore birds (Goss, 1891, p. 195). In Modoc Comnty W. P. Taylor (MS) observed them perehing on fence posts along roads. If the vicinity of the nest be approached by an intruder the birds fly some distance toward him and attempt to divert his attention by eireling about and uttering their shrill calls 
(Bent, 1907b, p. 427). Often several pairs other than those whose nest is threatened will join in the demonstration. At times they hover with quivering wings and at all times while so circling keep up such a elamor that it is impossible to determine when they are near the nest and when away from it.

Forbush states (1912, p. 312) that when inland the Eastern Willet eats grasses and roots and small fish and fish fry, but when along salt water its diet consists of many small mollusks and crabs. Paul J. Fair reports that specimens of the Western Willet taken by him on the marshes near Newark, Alameda County, in April, 1914, eontained clams fully one and one-half inches in length (H. C. Bryant, MS ).

In early days the Western Willet was commonly offered for sale in the markets of San Francisco during the autumm, winter, and spring (Suckley in Cooper and Suckley, 1859, p. 242). Undoubtedly extensive hunting for the market has had its effect upon the numbers of Willets that nowadays oceur within our borders, but to what extent, it is impossible to determine. Despite the rank or fishy flavor of its flesh, the Willet has always been hunted rather extensively, doubtless beeause of its large size. But it is still abundant enongh so that moderate protection will enable it to maintain its numbers and possibly inerease them toward the eomplement of earlier days. The most important factor in the deerease of the species is the gradual restrietion of its breeding range by the advance of agriculture. It does not enjoy the protection afforded the birds which nest in the far north. and should therefore merit more consideration during the winter season.

\section{Wandering Tattler}

\section{IIcteractitis incana (Gmelin)}

OTHER NAMES-Heteroscehus incamus; Totamus ineamus.

DESCRIPTION-Adults, both sexs, in late spring and summer: Entire upper surface including top of head, rump, tail, and outer surface of wing, uniform slaty or dark grayish brown; eyelids white; stripe from bill to eye and spot behind eye, dark grayish brown; stripe from top of bill over eye and sictes of head ani neck, white, finely streaked with dark grayish lorown; rhin and throat white, sparsely spotted with dark grayish brown; iris brown; bill blark, brownish at lower base; margin and lining of wing lusky, with feather-tippings of white; under surface of flight feathers and axillars, uniform slaty brown like ulper surface of boily; whole lower surface inclubing sictes anil unler tail "overts, white, barred closely with dark grayish brown; feut pale "brownish ocher"'; mails "blark", (Bishop, 1900, 1. 69). Adults, and immatures, both sexes, in fall and winter: Entire upper surface, tail and wing, as in summer aclults; eyelids, spot in front of eye and rhin, white; sicles of heal and neck, foreneck, breast and siles of body, light grayish brown, entirely levoid of streaks or bars; belly and flanks pure white; muler tail coverts white harred with grayish brown. Males: Total length 10.87-11.00 inches (276-279 mm.) (three specimens 
from California); folled wing 6.45-6.82 (164-173); bill along eulmen 1.40-1.51 (35.4-38.4); tarsus 1.23-1.38 (31.2-35.0) (nine specimens from California and Alaska). Females: Total length 11.05-11.40 (2s1-290) (three specimens from California); foldel wing 6.51-7.13 (173-181); bill along culmen 1.52-1.5s (38.640.2 ) ; tarsus 1.25-1.39 (32.6-35.2) (five specimens from California and Alaska). Jurenile plumage: Like that of adults and immatures in winter but with feathers of back anl outer surface of wing marked with inconspicuous feathertippings of white and faint subterminal dark bars, with grayish brown of breast and sides faintly barred with dull white, and with nnder tail coverts, like belly, pure white, unbarred. Natal plumage: In its entirety unknown, but as shown by vestiges remaining on a half-grown birl taken July 28, 1908, on Montague Island, Prince Willian Sound, Alaska (no. 1194 Mus. Vert. Zool.), the down on top and sides of heal is lealen gray tipped with white; on the chin, throat and flanks, grayish white; on hind neck leaden gray; a dusky streak extending from bill to eye.

MARKS FOR FIELD IDENTIFICATION-Moderate size (slightly larger than Killdeer), non-contrasted plumage, and uniform slaty color of upper surface at all times of year; no white patches on rump or wing; frequents rocky ocean shores; rarely if ever found on sandy beaches.

Volce-A loud ringing klü, klü, klü̆ (Nelson, 1880, p. 33).

NEST AND EGGS-L'nknown.

General distribetion-Seacoasts and islands of the Pacifie Ocean, interior Alaska, and Yukon Territory. Breeding range thought to be from southcentral Alaska south to Prince William Sound, east to east-central Yukon; occurs west in migration to Norton Sound, Alaska, and to northern Siberia; winters from sonthern California to the Galapagos Islands, and in Hawaii and Oceania (modified from A. O. U. Check-list, 1910, pp. 122-123).

Distribution in CALIForNia-Common spring and fall migrant along the seacoast; small numbers oceur also at various times during the summer, and a few winter on the coast and islands of soutlern California. The spring movement oceurs chiefly in April and the fall migration in August.

Among our shore birds the Wandering Tattler well merits the term wandering. Its distribution covers a large portion of the Pacific Ocean as well as west-central Alaska, and many of the most remote islets are favored by its visits. In spite of its wide range, less is known of the life history of this species than of that of many rarer or less widely distributed species. An element of extreme interest attaching to the bird is the fact that its nest and eggs are as yet undiscovered, it being one of only two or three out of all our shore birds which bear this distinction today. However, the area in which the Tattler nests has been fairly well determined, so that it will probably be a matter of but a few years before full knowledge of its nesting habits is obtained.

Along the coast of California the Wandering Tattler may be considered essentially a migrant, although it has been reported on our sonthern shores during almost every month of the year. The northward migration occurs in April (Willett, 1912 $a$, p. 39) ; some early dates are: Redondo, Los Angeles County, March 1, 1908 (specimen in 
Richardson collection) ; Anacapa Island, March 14, 1911 (Burt, 1911, p. 164) ; San Clemente Island, March 29, 1897 (specimen in Grinnell collection); and Monterey, April 13, 1913 (Howell, MS), and April 20 (Beck, 1910, p. 71). Suall numbers of apparently non-breeding birds are often to be seen during the summer; it is possible that these are late tarriers among the nortlibound migrants, or early arrivals from the morth. The species has been recorded from Santa Barbara, San Nicolas, and San Clemente islands as late as June 12 (Willett, loc. cit.) ; San Miguel Island, June 18, 1910 (Willett, 1910, p. 173); Farallon Islands, June 1, 1911 (Dawson, 1911, p. 180); and Point Reyes, Marin County, June 26, 1880 (Allen, 1881, p. 18). At Monterey, the return migration sets in about the middle of July (Loomis, 1895, p. 223), and by the last of that month the birds are common there. The species was seen on Santa Cruz Island, July 4 to 24, 1887 (Blake, 1887, p. 329), and on Santa Barbara Island, July 3, 1909 (Willett, 1912a, p. 39). The fall migration continues through August. Some birds then remain well along into early winter, late dates being: Santa Monica, Los Angeles County, December 11, 1905 (Willett, loc. cit.) ; and Santa Cruz Island, December 17, 1907 (Linton, 1908b, p. 126). Willett (loc. eit.) states that he has ". . . frequently seen the species on rocky shores of the mainland during the winter months."

The Wandering Tattler is notably an inhabitant of rocky shores and headlands where the surf beats heavily, and is rarely, if ever, found on sandy or muddy beaches. It is therefore much more restricted, as to the localities in which it may be found within our boundaries, than many other shore birds. The word "common" used above was not intended in the same sense as applied. for example, to the Western or Least sandpipers. Even where conditions are most favorable seldom more than two Tattlers are in sight at one time, and ten or a dozen individuals are as many as would be met with in a day's obselvation.

The Wandering Tattler is to be distinguished by its moderate size, which is little greater than that of a Killdeer, its uniform slaty brown upper surface, and its total lack of contrasted white patches at all seasons on either the rump or wings. In hand, the ummottled axillars, and, in spring and summer, the almost completely barred under surface, are distinctive. From the two Yellow-legs, the "tattlers" of inland waters and sandy or muddy flats coastrise, the Wandering "Tattler may be distinguished by the uniform color of its whole upper surface and its much shorter and darker colored legs; from the Turnstones and Surf-bird, with which it is most likely to be associated in life, this species may be distinguished by its slenderer bill, and by the absence of white patches on its rump and wings; from the Plovers it may be told by its more slender build, and proportionally longer and 
slenclerer bill; and from the sandpipers by its dark, uniform-colored upper surface and the absence of white on its rump or wing.

From the more or less extensive notes on the habits of this species made by rarious observers we select the following. Nelson (1857, p. 119) says that while he was walking along the rugged beach on Sanak, one of the eastern Aleutian Islands, Alaska, on May 17, 187t,

... One of these Tattlers was started from its feeding ground on the wave-washel rocks, where, amil the seaweed, it found an abumlance of small erustaceans and mollusks. As I alproached it started off, uttering a loud clear, flute-like tu-tu-tu-tu. This is the common note they utter when startlerl, although they change it at times to a sharper sounl. . . . During their presence on the coast of Norton Sounil they show a decillel preference for the most rugged and rock-bound parts of the shore, rarely or never oceuring elsewhere. They are unsuspicious and gentle, moving grarefully from rock to rock aud running to the ouge of the water, searching for their fool. They are usually solitary. but three or four may be startel sometimes from a small islet on which there is a goou feeling grounil. A gunshot euhoing anong the huge howhlers and eliffs ahout their haunts starts up those near at hand with mellow aries of alarm, but they either fly a short distanee and renew their pursuits, or alight on some jutting point or top of a rook, and stand motionless, like gracefully-poised statuettes. . .

Inenshaw found the Wandering Tattler on Santa Cruz Island, California, on June 4,1875 , and writes (18i6, p. 2072) of it as follows:

They apjear not to be a biril of the sanily shores at all, lut resort exclusively to the rocks eoverel with sea-weel, where they follow the ticle as it ebbs and flows, running back and fortl and picking up the minute worms and marine animals, of which they find a great abunlance. In motions, they simulate exactly the little Spotted Sandpiper, and liave the same curious "tipup', motion of the boly, which they indulge in at moments of rest from feeding or when attentively looking about them. They fly, too, with the same deliberate wing-beats, the pinions being shightly decurver, the tips pointed downwarl. Theil roices are, however, wholly lifferent, and the notes are very loul and harsh when compared with the smooth whistle of the other species. I found them usually solitary and quite watchful and full of distrust, though I found myself once or twice within a few feet of them, and was allowed a most exeellent ehance to waten their motions.

W. E. Bryant (1888, p. 43) observed the speeies on the Farallon Islands in late July, 1S86. Here

At high tide they sat motionless upon the rocks, which they resemble in color, making it difficult to deteet them unless flushed. When the tide was out they fed at the water's edge; following a receling wave they searched hurriedly amongst the kelp for fool, running or making short flights to escape an incoming breaker. Several times a laggard was overtaken and coverei by a breaker; when it receled lie flew to the rocks and after shaking the water from his plumage, returned to feed.

Dawson (1911, p. 180) spent a fortnight, from May 20 to June 3, 1911, on the same islands. He writes: 
During the first week of our stay there were not less than teu biris of this species, well distributed, which quavered and teetered, or fled, as often as we approached the surf line. But their numbers had dwindled to two by June 1st.

Contrary to earlier statements these Tattlors do spend a considerable portion of their time upon the higher ground. The tiny bonlder-strewn meartow surrounling my earlier camp (just east of Franconia beach) was a favorite resting place for them, and I am inclined to think the birds spent the night there, for some were invariably startled upon my first appearance mornings.

Having a common affection for the tide reefs, Wandering Tattlers are not infrequently found in loose association with Black Turnstones; but when put to flight they pay no attention whatever to the fortunes of their chance shipmates, nor to others of their own kinil.

Torrey (1913, pp. 132, 133), after observations on Wandering Tattlers near Monterey, wrote:

.. One of them stool directly before me on the top of a rock, preening its feathers, . . a sandpiper, with something of the look and action of both the spotted and the solitary... Sometimes it nolled in the manner of a plover; oftener it teetered like a spotted sandpiper; while its legs were of a color almost lively enough-but shaling too much to olive-for the bird that we know as "yellowlegs."

A long while it posed there, mucl of the time on one leg. . . Then it flew a short distance... [and] went lown close to the surf, where the rocks were thickly matted with seaweess, and began feeding, jumping into the air at short intervals, as a higher wave than common threatened to carry it away. Once it eaught a fish, or other creature, of considerable size, and seemed not a little exciterl, beating its prize violently against the rock again and again, and finally swallowing it with difficulty, holding its bill open for some time in the operation.

The evidence which is available coneerning the nesting of the Wandering Tattler consists solely of young birds which have been found with the natal down still elinging to them, and of observations of the behavior of adult birds on their presumed breeding gromnds. A notable thing is that this preemminently maritime bird forsakes the seashore at nesting time and repairs to remote mountainous localities inland. Adults observed by Charles Sheldon in the vicinity of Mount MeKinley, Alaska, flew abont solicitonsly on the approach of the hunters, and at intervals lit in nearby willow trees just as do Yellowlegs or Willets when intruders approach their nests (Osgood, 1907, p. 340). In the ligh mountains of east-eentral Inkon Territory, Canada, September 5, 1904, Osgood (1909, p. 86) found a partly grown Tattler, with down still attached to the feathers of its neck. "It seemed strangely out of place, busily engager as it was, rmming hither and thither over the small patches of gravel and stones along the rushing mountain stream.", Other individuals were seen. Joseph Dixon (in Grinnell, 1910, p. 377) seeured an artult Tattler July 23, 
1908, on Montague Island, Prince William Sound, Alaska, under the following eiremustanees :

I found the bird in a park on the mountain side at an altitude of 400 feet. As soon as I appeared on a ridge several hundred yards from him, he flew into a tree and began to "tattle." As I came nearer he flew out to meet me. s.olding as he came. He flew around above me and then went back and lit on the very tip of a tree where he bobbed up and down.

A half-grown young bird was obtained on this same island five days later. The breeding range has been defined upon the basis of such finds as the ones just cited; nests or eggs, if known to white men, have not ret been recorded in current scientific literature.

The food of the Wandering Tattler consists of small animals found along the tide line or in kelp, chiefly crustaceans and small mollusks. It is probable that marine worms and other forms found in such localities are also taken.

In California the Wandering Tattler is relatively safe from the hunter, and its numbers will probably remain unchanged longer than those of most of our other shore birds. This is due to the solitary habits of the species and its tendency to inhabit rocky, more or less inaccessible shores, and especially, the coastal islands. Its breeding grounds, moreover, are far removed from human influences, and are not likely to be eneroached upon by settlement in the near future.

\section{Upland Plover}

\section{Bartramia longicauda (Bechstein)}

\section{OTHER xAMES-Field Plover; Bartramian Sandpiper.}

Descriptiox-Adults, both sexes: Whole upper surface except rump, with mixel pattern of dark, almost blackish, brown, and yelluwish brown; this pattern inclines to streaking on head and neck and to barring on back, wings and tail; sides of head and neck light buff, streaked with blackish; chin white; iris "dark hazel"'; bill "yellowish-green," tip "dusky," edges at base "yellow" (Aulubon, 1842, V, p. 252); rump uniform blackish brown, save that outermost feathers are marked with white; tail feathers (except middle pair) dull buff, broadly tipped with white, and crossed by irregular bars of black; primaries blackish brown, the outermost ones barred with white on inmer webs; secondaries variegated like back, and with white margins; lining of wing and axillars white, sliarply barred with dark brown; edge of wing white; throat and foreneck buff narrowly streaked with lark brown; breast, sides and flanks light buff sharply barred with dark brown; rest of lower surface white; feet and legs " light yellowish-grey," toes " darker," claws " brownish-black", (Audubon, loc. cit.). Total length (both sexes) "11.00-12.75" inches (279$324 \mathrm{~mm}$ ); folded wing "6.50-7.00" (165-178); bill along culmen " $1.10-1.15$, (27.9-29.2); tarsus " 1.90-2.05", (48.3-52.1) (Ridgway, 1900, p. 169). Jurenile plumage: Top and back of head brownish black with a median stripe of pinkish cinnamon; stripe across forehead ruming over eye, patch behind eye, and chin 
and throat, dull white; cheek and siles of neck, lale cimnamon; back lirownish black with feather margins of pinkish buff or white, producing a scaled appearance; rump brownish black, white at sides; tail as in adult: feathers of outer surface of closed wing ehiefly pinkish einnamon, but with brownish black centers and white tips; primaries and lining of wing as in adult; foreneck and upper breast pinkish cinnamon, narrowly streaked with black; rest of breast and belly white; sides pinkish einnamon barred with brownish black. Natal plumage: Upper surface black, white and redlish brown in fine mixed pattern; distinct stripe from base of bill over top of hear, black; side of head and chin, white; bill (dried) yellowish brown, dusky along top of upper mandible; band across chest, yellowish brown; rest of under surface white; legs and feet (dried) dull yellow.

MARKS FOR FIELD IDENTIFICATION--Morlerately large size (decidedly larger than Killdeer), long neck and sleniter bill, general mixed buffy and brown color above, blackish rump, and absence of contrasting white areas; fonnd mainly in pastures and old fields away from water, even when near seashore (Forbush, 1912, p. 315).

ToIсе-"Alarm, quip-ip-ip-ip, quip-ip-ip-ip (Langille). Quitty-quit-it-it (Knight). A soft bubbling whistle; song, a prolonged, meiri, mournful,

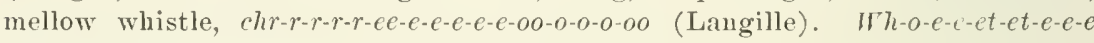
e-e-e-o-o-o-ooo (Richard)', (Forbush, loc. cit.).

NEST-In dry pasture lands or in wet, even boggy, meadows (Barrows, 1912, p. 196); usually a mere depression, sometimes sparingly linel with grasses and usually hidlen by surrounding herbage (several anthors).

EGGS -4, bluntly pear-shaped, measuring in inches, 1.65 to $1.97 \mathrm{by} 1.22$ to 1.34 (in millimeters, 42.0 to 50.0 by 31.0 to 34.0 ), and averaging 1.77 by 1.28 (45.0 by 32.5) (sixty-six eggs in U. S. National Museum); grouni-color pale olive-buff to cinnamon-buff, superficial spots, rounded, snuff brown and chocolate, deeper ones of violet gray and lilac gray; spots more numerons or confluent at larger end.

General Distribution-North and Sonth America. Breeis from north western Alaska, southem Mackenzie, central Keewatin, central Wisconsin, southern Michigan, southern Ontario, and southern Maine, south to southern Oregon, northern Utah, central Oklahoma, southern Missouri, southeru Indiana and northern Virginia; winters on the pampas of South America to Argentina. In migration has occurred north to Newfoundland; casual in California (A. O. U. Check-list, 1910, p. 123).

Distribution IN CALIFORNIA-One instance of occurrence: A single biri taken at Tule [=Rhett] Lake, Modoc County, August 8, 1896 (Cooke, 1910, 1. 65$)$.

The Upland Plover has been recorded but onee from California, a single bird having been taken by Ternon Bailey of the United States Bureau of Biological Survey at Tule [-Rhett] Lake, Modoc County, August 8, 1896 (Cooke, 1910, p. 65). The species is here included in order to complete the list of game birds which have been found within the state, and also to enable persons capturing additional specimens to recognize the bird and so to be apprized of its status. It is not mnlikely that close observation in the northeastern corner of the state would show the regular presence there of this species at certain seasons. 
The Lpland Plover, Field Plover, or Bartranian Sandpiper, as this bird is rariously called in the East, is as its common names inclicate, an inhabitant chiefly of the upland fields and meadows rather than of the seashore, as are so many others of its kin. In various portions of its range it is well known to prefer the drier ground of meadows and prairies. Eaton (1910, p. 333) sars of these birds in New York state: "Their earriage is light and graceful, they run with great swiftness through the rows of stubble to eseape from intrusion, or erouch motionless in the grass until the enemy is dangerously near, when they spring into the air and fly swiftly away, often passing entirely out of sight before alighting, but uttering a mellow whistle as they go. . . " That the birds are extremely wary as indieated in the account just quoted, is the concensus of opinion among recent writer's generally. It would seem that this wariness has been acquired by the species since man first began to hunt it, for its range lies almost altogether in territory that has come under elose settlement and eultivation by man. In earlier days it was not diffieult to get within gun-shot range of them. On the more open prairie land of the middle West a favorite method of hunting nowadays is from a wagon or on horseback; the birls are aceustomed to farm vehicles and do not apprehend any danger when the huntsman approaches in this manner.

Florence Merriam Bailey (1915, p. 177) writes of her experienees in North Dakota as follows:

Another eharacteristic bird of the prairies of whicl I saw all too little was the Upland Plover. One parent whom we lassed when driving stood high in the prairie grass looking at us while just the hear of its young one showed above the grass. Another plover surprised me, standing not on the ground but on top of a telephone pole, its round head and trim body mounted high on its long legs-true wader of meallows! On annther day a guarding parent appeared in the blue sky ahead of us as we drove slowly up a long slope. Down it came toward us, its long wings on the down stroke giving it a curious wishbone figure. Down it came, thongh not concerned with us as it proved, for, passing by, it took a wide sky eircle on fluttering wings-while a Marsh Hawk heedless of its secret went serenely on its way looking for meadow mice. When the plover's liquid note is heard, or the big birds come out of the sky to drop to earth, they give a rare thrill of pleasure. . . . Lovely birds! They go well with the big clean prairie-dividing their time between earth and sky.

The Bartramian Sandpiper in its eastern range, eonceals its nest in the thick grass of a meadow, or under a tussock in a pasture or waste field. The bird is rarely or never seen on the ground in the vicinity of the nest, and will not leave it until almost trodden upon (Eaton, 1910, p. 333). Barrows (1912, p. 196) states that in Michigan it often nests in the drier parts of wet, boggv, snipe-inhabited 
meadows. The nest is a mere depression in the grass, more or less concealed, and lined with grasses. The four eggs, which are bluntly pear-shaped, are, relative to the size of the bird, quite large, their size averaging in inches, 1.78 by 1.28 . The ground-eolor varies from a pale olive buff to cinnamon buff; the superfieial spots, which are more numerous and often eonfluent about the larger end, are sunff brown or choeolate, and the deeper ones are violet gray and lilae gray.

This beantiful bird like most members of the Snipe family executes a peculiar performance in the mating season. The bird mounts high in the air, or alights on a knoll, "a fence, or even a tree, and utters a prolonged mournful mellow whistle, more like the wind than like a bird's voice, which may be heard even in the night, and is one of the most weird and never to be forgotten sounds in nature" ... the notes rapidly rising and swelling, then slowly falling and dying away into a hollow windlike whistle. . . The young follow their parents as soon as hatehed, and the old birds evince considerable distress when the young are molested, often fluttering along the ground, feigning lameness, or a broken wing, after the manner of a Killdeer, to draw the intruder away from the site (Eaton, 1910, pp. 332-333).

This bird is a valuable ally of the farmer. It feeds on locusts, grasshoppers, "utworms, and other enemies of grass and other crops. During the Locust invasions in Nebraska Professor Aughey found this species among the most useful in destroying the insects and saving the crops, for at that time it was abundant and correspondingly useful. It eame in large flocks in spring and did great service on locust-infested farms (Forbush, 1912, p. 319$)$.

MeAtee (1911a) states that the Upland Plover feeds on erane-fly larvae, the cotton worm and cotton cutworm, boll-weevil, elover-leaf weevil, cowpea weevil, elover-root curculio, bill-bugs, wireworms, eornleaf beetle, and grapevine eolaspis.

While this speeies is at present of no importance in California, either agriculturally or from a game standpoint, its capture within our borders has considerable scientifie interest. Hunters seeuring specimens in the future should communicate their finds to some scientific institution or journal, after having made very sure of the identification. As previously intimated, there is some likelihood that the Upland Plover really reaehes with some regularity the elevated northeastern seetion of the state, where the one example was found. Conditions there may even be growing more favorable for the bird as a result of irrigation and the extension of meadow eountry. 


\section{Spotted Sandpiper}

\section{Actitis macularia (Limnaeus)}

OTHER NAMES-Tip-up; Teeter; Teeter-tail; Tringoides macularius; Totanus macularius.

DESCRIPTIOx-Adults, both sexes, in late spring and summer: Whole upper surface, ineluding rump, tail, and outer surfaee of elosed wing, olive brown, with faint greenish irilescence; head indistinctly streaked, and whole back barred and streaked with sooty brown: stripe from upper mandible through eye, and whole lower sille of head, white, fleckel with blackish brown, most sparingly on ehin; eyelids white; bill dull yellow, dusky at tip; iris "hazel", (Audubon, 1842, V, p. 308); outer tail feathers barred with light brown and white; flight feathers dull dark brown, the primaries with white patehes on inner webs near hase and the seeondaries tipped narrowly with white; edge of wing mottled with olive brown and white; forward lining of wing, and axillars, pure white; hindmost under wing coverts and flight feathers, dusky; whole uniler surface of boly white, everywhere marked with rounded spots of brownish black; legs greenish gray; feet and "heel", yellow; nails black. Adults and immatures, both sexes, in late fall, winter and carly spring: Upper surface of same general ('olor as in summer, but without narkings save for blackish shaft lines; unler surface dull white, sides of nerk and ehest suffused with dral, and with larker shaft lines; flanks and lower tail eoverts sometimes faintly spotted. Males: Total length 6.74-7.75 inches (171-197 mm.) (ten specimens); foller wing $3.66-3.96$ (93.0-100.3); bill along eulneu 0.79-1.01 (20.2-25.6): tarsus $0.86-0.98$ (21.8-24.9) (ten speeimens). Females: Total length 7.12-8.40 (181-213) (six sperimens); folled wing 4.00-4.20 (101.5106.7); bill along eulmen 0.89-0.9s (22.5-24.5); tarsus 0.93-0.9s (23.7-25.0) (ten sperimens); all from California. Juvenile plumage: Whole upper surface olive brown with faint greenish irilescence, the feathers tipperl narrowly with buff followed by black, giving a scaled appearanee, and with dark brown shaft lines; evelids and stripe from upper mandible to eye, white; outer surface of elosed wing narrowly but sharply barred with blackish brown and light buffy; rest of wing, and tail, as in adult; sides of neek and chest, washed with drab, and faintly barred with dusky; rest of under surface, white. By wear this plumage becomes nearly indistinguishable from that of arlults during midwinter. Natal plumage: Stripe from top of upper mandible over top of head and down along middle of back to tail, black; top of head at side of black stripe, mixed buffy white and black, in fine pattern; narrow but distinct stripe from side of bill through eye to ear region, black; lower side of head and chin, silky white; rest of upper surface including tail and wing, mixed buffy white and black; whole under surface white; bill greenish yellow.

MARKS FOR FIELD IDENTIFICATION-Small size (but larger than Least or Western Sandpiper), uniform brown upper surface, white streak on wing, and (in spring and summer) sharp rounded blackish spots on white under surface; flies with narrow down-curved wings, rarely raising them above level of back; when on ground teeters almost incessantly. From the Solitary Sandpiper, often found in similar situations, it differs in slightly smaller size, yellowish rather than greenish legs, white bar on wing (shown in flight), white sides and axillars, and (in adults in spring and summer) in the sharp spotting of whole under surface. 
Torce-A clear high-pitcherl wheet, wheet, wheet, utterel six or seven times at half-second intervals, often with descending infleetion; also $p r-r$-r-ret, or ter-r-r-ret.

NEsT-On gravelly ground usually in close vicinity of water, or clse in wet meadow; a slight depression sparsely lined with grasses and plant stems; or altogether lacking any special lining.

Eggs-4, pear-shaped, measuring in inches, 1.24 to 1.37 by 0.87 to 0.97 (in millimeters, 31.5 to 34.7 by 22.2 to 24.8 ), and averaging 1.28 by 0.93 (32.6 by 23.6) (six sets, 24 eggs, from California and Alaska); ground-eolor pale eream or varying shades of buff; superficial spots reddish or blackish brown, varying in size from that of a pin-point to 0.12 inch $(3 \mathrm{~mm}$.) or more in diameter, usually larger and more numerous about larger end where they are often aggregated into blotehes; deeper markings lavender or pale gray ani usually small.

General Distribution-North and South America. Breeds on the north to Newfoundland, northern Ungava, northern Mackenzie and the Kowak Talley, Alaska, and on the south to northern Sonth Carolina, central Alabama, southern Louisiana, central Texas, southern New Mexico, eentral Arizona, ani southcentral California; winters from southern California, Louisiana and South Carolina south to central Peru and southern Brazil (morified from A. O. U. Check-list, 1910, p. 124).

Distribution in CAlifornia-Abundant migrant in suitable localities throughout the state; also winters in moderate numbers along roeky portions of the seacoast and adjacent island shores from Santa Barhara southwarl. Remains through the summer and breeds locally in the Sierras as far south at least as Cottonwood Lakes (11,000 feet altitude), Inyo County (Mus. Tert. Zool.), and in the lake region east of the Sierran divide from Alpine County northward to the Oregon line. Breeds also, but more sparingly and locally, along larger streams of the coast region south as far as Santa Paula, Tentura County (Willett, 1912a, p. 39). Spring migration apparently occurs in late April, May and June, and fall migration from mid-July into September. A few seattered individuals winter in the Sacramento and San Joaquin valleys.

The Spotted Sandpiper is one of the most widely distributed of North American shore birds. Indeed it has a more extensive breeding range than has any other American shore bird, in this respect rivaling the Killdeer. To many people, the Tip-np or Teeter-tail as this well-known bird is often called, is one of the most familiar of water birds. The sandy shores of inland or even mountain streams and lakes, and the rocky seacoast, seem equally to attraet it at rarious times of the year. At times, especially during the sumner, it may be observed in distinctly dry situations such as a meadow, or on freshly plowed gromd, but this is exceptional. From many of its relatives the Spotted Sandpiper differs markedly in being quite solitary. It is found singly or in pairs rather than in flocks, though in the late snmmer and fall while the young are ret dependent, family flocks of at most five or six birds are to be noted.

Throughont most of the lowland areas of California this bird is lut a migrant, but in the coastal district from Santa Barbara southeastward it occurs in limited numbers during the winter months. 
Oceasional individuals winter in the Sacramento-San Joaquin Talley, as at Marysville, Butte County, December 25, 1911 (C. and J. Muller, 1912, p. 43) ; in Amador County, February 2, 1896 ; at Modesto, Stanislaus County, February 12, 1910 (specimens in Mailliard coll.); and at Stockton, November 25 (Belding, IIS). The spring migration probably oceurs during late April, May, and possibly the early part of June, although definite information in this regard is almost entirely lacking. Some dates of first appearance are: Pasadena, April 21, 1897 (Grinnell, 1898, p. 18) ; Monterey, April 16, 1913 (Howell, MS); Mendota, Fresno County, April 4, 1914 (Tyler, MIS); and Ukiah, between April 24 and May 1, 1889 (MeGregor, 1896, p. 129). Belding (IIS) states that it arrives at Stockton about the first of May (April 27, in one instance), while nests with eggs have been found in the Sierras during the last week in May. 'The fall migration probably begins about the middle of July, as Grinnell (1908, p. 56) secured a bird of the year, evidently a migrant, at Dry Lake. San Bernardino Mountains, July 15, 1905; but the bulk of the birds do not leave the breeding grounds until decidedy later, julging by the available nestting tata. Belding (IIS) states that the species usually disappears from the vicinity of Stockton about the first of October. The same observer noted a pair of birds which were possibly summering in the lowlands at Oroville, Butte County, July 1, 1885, and another pair on a sand bar of the Feather River in the same vieinity, July 3, 1885 (Belding, MS ). Along the coast north of Santa Barbara it must be considered a rather rare species, having been observed only three times at Monterey, once at Berkeley, May 9, 185; (T. S. Palmer, in Belding, MS), and at Eureka, August 3, 1910 (Dixon, MIS). About water-holes far out on the desert the Spotted Sandpiper appears as a migrant during both fall and spring. Lamb (1912. p. 35) reports it from near Daggett, San Bernardino County, August 5 and October 11, 1910, and again in numbers for several days after April 16, 1911.

The Spotted Sandpiper can be distinguished from other shore birds by its small size, almost uniformly colored brown upper surface (including rump), the white streak on its spread wing, and the extensively white under surface with (in spring and summer) sharp rounded blackish spots. In flight the wings are distinctly enrved lown toward the tips and rarely raised above the level of the back; while the course pursued is usually semicircular, and there is no undulating or zigzagging as with many sandpipers. The few characters just given will be sufficient to distinguish this species from all other shore birds occurring in California.

The call-note of the Spotted Sandpiper is a clear musieal wheet, uttered six or seven times at half-second intervals, often with a descending infleetion; also, as when exeited, a $p r-r-r-r-r e t$, or ter-r-r-r- 
ret. The notes are usually uttercd when one bird meets another of its kind, as when flying along a stream. The first note may be heard for a distance of half a mile or more and reminds one of the short repeated whistle which a person often uses to call a dog.

When in its most usual habitat, which is on open sand flats or gravel bars adjacent to streams or lakes, the Spotted Sandpiper employs its time searching for the various small insects, other animals, and plants which comprise its food. While gleaning its food or otherwise occupicd it stops for a moment every now and then to "teeter." This movement is described by Stearns and Coues (1883, p. 242) as follows :

As often as the ... [bird] stops in its pursuit of insects, the fore part of the body is lowered a little, the head drawn in, the legs slightly bent, whilst the hinder parts and tail are alternately hoisted with a peculiar jerk, and drawn down again, with the regularity of elock-work. The movement is more conspicuous in the upward than in the downward part of the performance; as if the tail were spring-hinger, in constant danger of flying up, and needed constant presence of mind to keep it down. It is amusing to see an old male in the breeding season busy with this operation. Upon some rock jutting out of the water he stands, swelling with amorous pride and self-sufficiency, puffing out his plumage till he looks twice as big as natural, facing about on his narrow pedestal, and bowing with his hinder parts to all points of the compass.

Another marked peculiarity of the Spotted Sandpiper is its manner of flight. If disturbed from a location on the bank it does not fly directly up or down stream away from the source of danger but indulges in a semicircular flight, skimming out over the water and back to the same bank some distance farther on. If, after the danger is gone, the bird desires to return to its original location it does so over the same cirching course and not by the shortest direct route. Individuals have a tendency to remain in the same locality and even if frightened away will repeatedly return to it.

While it is often seen feeding or mnning about the shore during the day the Spotted Sandpiper would seem to be also somewhat nocturnal. Barrows (1912, p. 203) says: "The Spotted Sandpiper feeds until late in the evening, and possibly is more or less nocturnal, since its notes are frequently heard at night when it cannot be migrating." Belding (1879, p. 441) says: "A bird of this species nightly visited a pond in the rear of the hotel at Murphy's [Calaveras County] in September, 1878. It came about dusk, after the Swallows and Fly-catchers had retired and Bats had taken their places, and circled over the water as if eatching flies, although it never made an abrupt curve or checked its rapid flight. It kept usually about three feet from the water, but went as high as six or cight feet occasionally."' 
Several observers record the ability of this bird to swim when foreed to do so, as is the case with many other shore birds. Indivichals of this speries have also been seen diving miler water. Forbush (1912, p. 323) gives the following aecount of such a performanes: "In September, 1876, I saw a wounded bird of this species when pursued, dive into deep water from the shore of the Charles River [Massachusetts] and fly off under water, using its wings somewhat as a bird would use them in the air. All its plumage was covered with bubbles of air, which eaught the light until the bird appeared as if studded with sparkling gems as it sped away into the depth of the dark river."

Three Spotted Sandpipers were elosely observed by Grimell (MS) along the Mereed River in Yosemite Valley early in June, 1915. They moved about in the shallow water at the elge of the river or on the gravel never farther than a foot or two from the water, walking rapidly a few steps, and then stopping sudklenly to seeure some bits of food sighted among the pebbles. While a bird was thus occupied the hinder portion of the body was eontinually bobhed up and down at regular intervals of a seeond or two, and while it was walking the head underwent a rapid fore-and-aft movement in unison with the trearl of the feet. Two of the birds seemed by their actions to be males, and as this was just at the beginning of the mating scason there was considerable rivalry between them. After much maneuvering, one of these birds pitehed in and drove the other away. Meanwhile the third individual, presumably a female, fed about unconcernedly in the vicinity. After routing his rival the successful suitor approached the female and strutted about her, holding his body in a peculiarly ereet posture and partially spreading his wings and tail. The objeet of his attentions held shyly aloof, with the feathers of her body elosely applessed giving her a smart, trim appearance. She gave no other indieation that his presence or actions were in any way noticed, except that now and then the barred onter feather's of her tail were slightly spread apart.

On their nesting grounds Spotted Sandpipers not infrequently perch on objects well above the ground, such as clods of earth, boulders, and fence posts. Such stations, however, are not long held, as the birds are of a nervous temperament, and must keep moving, especially at this eritical period of the year.

Nesting records of the Spotted Sandpiper in California are fairly numerous. The breeding range extends sonthward at least to Santa Paula, Tentura County, where sets of eggs have been taken in May, 1892 and 1900 (Willett, 1912a, p. 39). Although this species usually nests at considerable altitudes in California there are, in addition to the Santa Paula records, at least two records for altitudes of 2.000 feet or less. Belding (MS) records nesting at Murray Creek, near 
San Andreas, Calaveras County, at 1,000 feet, and Bolander (1907, p. 26) took sets of eggs at Lime Kiln, a little east of Spenceville, Nevada Comnty. From these foothill localities the species ranges up in the Sierras almost to timber line, downy young having been taken at Cottonwood Lakes, Inyo County, August 25, 1911 (specimens in Mus. Vert. Zool.). Most of the recorded nestings have been from the vicinity of Lake Tahoe and northward in the elevated lake region northeast of the Sierran divide. The nesting season extends from May (Willett, loc. eit.) through July, as Belding (MS) found fresh eggs at Summit, Placer County, July 20, 1889; and the young birds (in Mus. Tert. Zool.) taken at Cottonwood Lakes, Inyo County, on A ungust 25, 1911, were but half grown. June, chiefly the latter half of the month, marks the height of the nesting season, as the bulk of the records fall during that period.

Nests of the Spotted Sandpiper occupy a rariety of situations. Rocky or gravelly shores of some mountain or foothill stream, sandy river bar's inland, fresh water marshes, or the drier fields adjacent, may be chosen. Often the eggs are placed in the shelter of a small bunch of grass, or a tree; again they may lie fully exposed among pebbles on the shore. When the latter type of situation is chosen there may be no lining whatever to the nest, but if the nest is in a field or marsh considerable lining material in the form of grasses and weed stems is the rule. Usually a slight surface depression is selected for the site.

The eggs are, so far as known, always four in a complete set, and measure 1.24 to 1.36 inches in length by 0.87 to 0.97 along the shorter axis, the average being 1.28 by 0.93 . The ground-color varies from a pale crean to a rather deep buff, with superficial spots of reddish or blackish brown and deeper ones of pale gray. The superficial spots are usually more numerous and larger about the larger end of the egg, and may sometimes be fused into large blotehes. Deepel purplish gray markings are also noticeable. From the eggs of other shore birds of approximately the same size, and which nest in California, those of the Spotted Sandpiper may be distinguished as follows: from eggs of the Killdeer by their distinctly smaller size, from those of the Wilson Phalarope by less profuse markings and the brownish rather than blackish cast of the superficial spots. Fggs of the Snowy Plover are decidedly smaller in size, much paler in color effect, and less pointedly pear-shaped, than those of the Spotted Sandpiper.

The two sexes participate in the duty of incubation. When flushed from the nest, the bird flutters away as if wounded, uttering feeble peeping notes (L. Kellogg, MS). Tnstances are related of old birds carrying downy young to places of safety by grasping them between their thighs, or in their bills (Bartsch, 1901, pp. 14:ff.). 
The young rum about with remarkable ease and swiftness almost as soon as they are out of their shells. When danger approaches they immediately, upon an alarm signal from their parents, rum and hide themselves, squatting close to the ground, and there remain perfectly immovable, resembling small drab-colored stones, each with a single streak of black down the middle. If a young bird finds itself discovered, and an attempt is made to take it, it runs with great celerity, nttering the most plaintive eries.

At the same time the parents exhibit symptoms of distress and comnterfeit lameness with great skill (Baird, Brewer and Ridgway, 185t, I, p. 304).

A brood of three downy young of this species was observed in the edge of the pine woods at Tenaya Lake. Yosenite National Park, on July 29, 1915. Even at this early age they displayed the bobbing movement of the hincler parts which is so characteristic of the adults, and performed it rery few seconds as they ran throngh the grass; at longer intervals the whole head and fore parts were bobbed abruptly upwards in the manner of a Willet (Storer, MIS).

At Redondo, Los Angeles County, Deecmber T, 1913, Law (1914, p. 93) took tliree spotted Sandpipers all of which had parts of the feet or legs amputated. 'T'his observer suggests that the mutilation may be due to the birls having heen seized by erabs and that the feet were twisted off in their efforts to escape. Of comrse mussels may equally well have been the eause of the trouble.

Insects constitute the chief element of the food of the Spotted Sandpiper when inland. These include beetles, green flies, May flies, grasshoppers, cutworms, army worms. cabbage worms, and ants. The stomach of a downy young examined by Beal contained a small spider, a small caterpillar. 2 tiny wasps, 2 bugs, several aquatic beetles, 7 weevils, and several larval and 10 adult carabid beetles (Judd, 1901, p. 433 ).

While the fact that the Spotted Sandpiper in California rarely visits cultivated grom prevents giving the bird positive credit as a pest-destroyer, it is at least harmless. Neither can it be argued that the species is in danger of extinction; its range is broad, and even in many well settled regions it holds its own. Yet its small size precludes it being considered proper game, either for sport or for the table. Rather should it be given complete protection along with the other diminutive members of its family. Its presence adds a lively tonch to the landscape. 


\section{Long-billed Curlew}

\section{Numenius amcricanus Bechstein}

Other NAMES-Brown Curlew; Sickle-bill; Sickle-billed Curlew; Curve-bill; Daddy-long-legs; Wheu-bird; Numenius americanus americanus; Numenius longirostris.

Description-Adults, both sexes: Top and sides of head and neck, pale cinuamon brown, streaked with blackish brown, most heavily on crown; stripe from base of upper mandible over eye and eyclids, light cinnamon, nearly or quite unstreaked; chin and throat clear pinkish white; bill dusky brown paling to dull flesh color on basal half of lower mandible; iris deep hazel brown; whole back, upper tail coverts, tail, and outer surface of closel wing, coarsely and irregularly barred or spotted with blackish brown on a light pinkish cinnamon ground; outer webs of outer primaries and their coverts, blackish brown; shaft of outermost primary ivory white; inner flight feathers like back but with more cimmamon; under wing coverts and axillars, pinkish cinnamon sparsely flecked with dusky; under surfaces of flight feathers, pale cinnamon, narrowly barred with dusky; ground color of whole under surface of body pinkish cinnamon, lightest on belly; foreneck and chest streaked, and sides and flanks barred, with blackish brown, these markings few and narrow; feet and legs, light olive gray, slightly darker at joints; nails blackish. Males: Total leugth 20.60-22.50 inches (523-572 mm.) (five specimens from Arizona and California); folded wing 9.85-10.48 (250-266); bill along culmen 5.30-5.55 (134.5-140.9); tarsus 3.18-3.21 (80.8-81.5) (two specimens from California). Females: Total length 23.60-25.75 (600-653) (five specimens from New Mexico and California); folled wing 10.71-11.41 (272-290); bill along culmen 5.00-7.12 (127.0-180.5); tarsus 3.11-3.63 (79.0-92.2) (six specimens from California). Juvenile plumage: Similar to that of adults. Natal plumage: Ground-color of upper surface pale ochre yellow, with irregular scattered markings of brownish black; bill about as long as head, dusky; ground color of under surface pale orange yellow, lightest on chin and side of neek; legs and feet (dried) pale greenish brown. Bill notably lown-eurved in adults, but straight in downy young.

MARKS FOR FIELD IDENTIFICATION-Large size (largest shore bird occurring in California), long, down-curved, or sickle-shaped bill (fig. 73), and distimetly pinkish brown coloration without contrasting white or black areas. Distinguished from Hudsonian Curlew by larger size, proportionately longer bill, pinkish tone of coloration, and unbarred under wing coverts and axillars; from Marbler Godwit by larger size and longer, down-eurved instear of up-eurverl bill; from Thite-faced Glossy Ibis ("Black Curlew") by pinkish brown rather than deep redkish brown plumage (so lark as to appear black at a distance).

VOICE-A startling loud cur-lcw', cur-lew', cur-lew' with a harsh quality.

NesT-Usually in dry situations, on open, usually grassy meadow or prairie land; a slight depression lined with dried grasses and weels.

EgGs-Normally 4, pear-shaped, measuring in inches, from 2.42 to 2.70 by 1.82 to 2.00 (in millimeters, 61.5 to 68.5 by 46.3 to 50.8 ) (averages of two sets, eight eggs, from Montana); ground-color varying shaies of light greenish olive; superficial markings of clark umber, chocolate aud blackish (Silloway, 1900 , 1p. 80, S2), with deeper-lying markings.

(ieneral distribttion-North and Mindle America. Breeds morth to central British Columbia, southern Alberta, southern Saskatchewan and soutlern Manitol,a, south to Oklahoma, northwestern Texas, central New Mexico, southern 
Arizona, and northeastern Califormia; winters from South Carolina, Florida, southern Louisiana and Texas, southern Arizona, and central California south to Guatemala (modified from Cooke, 1910, p. 70 ).

Distribltion IN (ALIFORNIA-Common spring and fall migrant over the whole state, except in the northwestern coast district and higher southern Sierras. Winters west of the Sierras from the Mexican line north at least as far as the latitude of San Franciseo and oceasionally to the head of the Sacramento Valley; also east of the Sierras in the vicinity of Owens Lake; breeds in the elevated northeastern portion of the state, west at least to Butte Valley, Siskiyou County; observed in the San Joaquin Valley during June, though such birds have not been shown to be breeding.

The Long-billed Curlew is the largest shore bird found in North Ameriea, and this, together with the faet that its flesh is highly prized by many as an article of food, has made it one of the most sought after speeies of Ameriean game birds. Its large size makes it a conspienous mark for gunners, so that its numbers have been greatly redueed within the past fifty years. In addition, the speeies does not have the protection of a far northern breeding ground as is the case with so many of its kind, its nesting grounds being almost entirely within the area which has been taken up for agrieultural purposes in the northern United States and southern Canada. Because it is a prominent species in any region where it oceurs, the Long-billed Curlew has received many colloquial names. The long eurved bill has given rise to sueh names as Siekle-bill, Sickle-billed Curlew and Curve-bill, while its long legs merit the name Daddy-long-legs, and its prolonged eall-note has given the appellation of Wheu-bird.

Long-billed Curlews are present in California throughout the year, but not eontinually in any one loeality. During the winter the speeies is present in the San Joaquin Valley north to Stockton and oceasionally to the head of the Sacramento Talley (Belding, MS), while along the seaeoast it oeeurs at the same season at least as far north as the latitude of San Franeiseo, and east of the Sierras has been reeorded in December at Owens Lake (A. K. Fisher, 1893a, p. 24). It has not yet been reported in winter from the deserts of southeastern California, although during the same season, it does oecur in fair numbers in the eoastal distriet of southern California west of the mountains.

In sonthern California northward migration oecurs chiefly during April (Willett, 1912a, p. 39). Fall migration sets in during July, as birds of this speeies were observed off Monterey, July 17, 1894 (Loomis, 1895, p. 189) and during the same month at San Pedro (Cooper in Baird, Brewer and Ridgway, 1884, I, p. 312); but they do not seem to reach inland spots sueh as the shores of San Franciseo Bay until Angust or September (W. E. Bryant in Belding, IIS; Grinnell and Storer, MS). Summering individuals have been found in the 
San Joaquin Valley during June (Goldman, 1908b, p. 203; Lamb and Howell, 1913, p. 116; J. Mailliard, 1904, p. 16); there is but one definite nesting record for the speeies in California: Butte Valley, Siskiyou County (Feilner, 1865, p. 423), although birds seen at Goose Lake, Modoc County, June 3, 1910, were probably nesting (W. P. Taylor, IIS).

Size is in itself usually suffieient to distinguish the Long-billed Curlew from other shore birds oecurring in California. In addition the very long, sickle-shaped bill (fig. 73) and distinctly pinkish eimnamon coloration, without conspicuous barring on under wing coverts, the total lack of contrasting black and white, and the startlingly shrill cur-lew', curle $x^{\prime}$ eall-note are useful in field identification. The only species of waders oeeurring in California with which the Long-billed Curlew might be confused are the Hndsonian Curlew. Marbled Godwit, and "Black Curlew" (White-faced Glossy Ibis), all birds of fairly large size. From the first it is distinguished by larger size, much longer bill (compare fig. 74), pinkish rather than grayish eoloration, and monbred mnder wing coverts. From the Godwit it is separable by larger size, and a distinetly down-enrved instead of slightly up-eurved bill. From the This it may be known by its pinkish brown rather than blackappearing eoloration.

Although in structure a typieal shore bird. the Long-billed Curlew seems to be equally at home on the sandy oeean beach, the salt or fresh water marsh, the inland meadow, or the dry prairie of the interior. In any of these habitats at the right season it is to be met with in small floeks of from four or five to a dozen or twenty individuals. Formerly, befor it harl been extensively hunted for the market, larger floeks were commonly nuet with in the winter time, but these are of infrequent occurrence nowatays. Beek (MIS) reeords

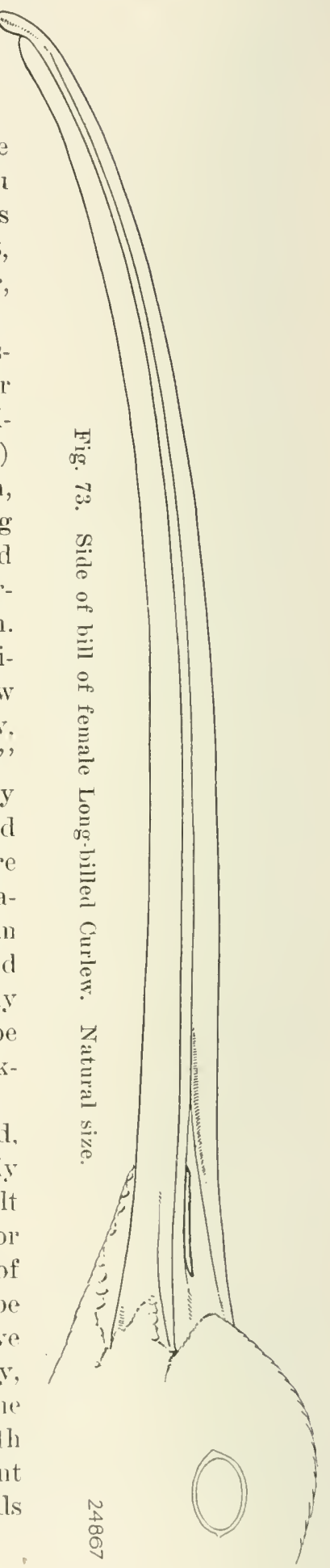


seeing about 500 birds of this species at Los Baños, Mereed County, on Jamury 3, 1912, but does not state whether they were all in one flock; this is the only record known to the writers of large numbers being seen at one loeality in this state during reeent years. On August 5, 1910, near Cedarville, Modoe County, W. P. Taylor (MS) noted about twenty of these birds seattered about over the fields whieh were covered in part with shallow water. The birds flushed at very long range, flying slowly, and contimally uttered their insistent eallnotes.

Newberry (1857, p. 99) relates of this eurlew that in his march through the Sacramento Valley and northward he did not meet with it until he had crossed the main Sierras and had come down into the plains bordering the Pit River above the upper eañon. He says: "Here [the first week of Angust, 1855] we found them in immense numbers, and they formed a valuable addition to our bill of fare. This prairie is entirely covered with water during the wet season, as is proven by the myriads of aquatic shells . . . seattered over the ground in the grass; and as it does not dry up so completely as the other valleys, the curlews apparently pass the summer there."

On the marsh or tide flats the Long-billed Curlew as it probes for food, mingles freely with other shore birds of large and small size. The long bill and legs enable it to work for its food in places covered by several inches of water and give it a larger feeding area along the shore than is available to many of the smaller waders. Birds observed by the authors September 26, 1914, on the Alameda County shores of San Francisco Bay were mingling with Marbled Godwits, Western Willets, and Long-billed Dowitehers. The Long-bills stood viewing us with one eye, and with their bodies always turned sideways, as though keeping in position to fly away should danger threaten. On this date a mixed flock of Godwits, Willets and Long-bills aggregating forty individuals came flying along the beach. One of the curlews being shot the flock swung about and returned, repeating this maneuver twice and keeping up a deafening chorus of calls. The wounded bird attracted the attention of several of the eurlews which flew down and hovered elose above it. This suggests how pot-hunters may have readily deeimated the flocks of earlier days. The flight of the Long-bill is easy and graceful, with slow regular wing-beats.

Heermamn who observed this speeies here during the middle of the last century says (1859, p. 66) :

These birds arrive in flocks in California [in the central valleys] Auring September, resorting to the fields and open prairies, where they find an abundant supply of insects. Wild in their nature, always on the alert, anil the prairie offering no undulations behind which the hunter can approach unseen, they are one of the most difficult game birds to secure. 'Their first 
whistle of alarm startles at onee the whole flock, which, taking to wing, speeds away a long distance before again settling down. Abundant in fall and winter, they migrate to the northern regions in spring for the purposes of incubation.

The following account of the habits of the Long-billed Curlew is eondensed from that by Wiekersham (1902, pp. 353-356) who observed the speeies on the southeastern eoast of the United States and in the southern Mississippi Valley. Along the seacoast these birds spend the day on sandy flats left bare by the reeeding tides and here probe for the worms and other forms of animal life which constitute their food. In the interior their liabits are quite different. Here they live on open prairie land, often far from water. While feeding the birds bob up and down at intervals. As evening approaches they become more restless, bobbing up and down more frequently and more rapidly, feeding is suspended, the birds jump from the ground with a loud whistle and fly to join others, and together they go to some distant marsh or pond. When the resting plaee is approaehed the leader whistles and is answered by the members of the floek; then they all drop, sweeping forward and upward, and with wings almost touehing above and legs ontstretehed, they alight quietly. For perhaps five minutes there is no movement, and then the floek breaks and its members rum about the shore or wade into the water to drink, after which they preen themselves. Then they quiet down, draw one leg up under the body, tuck the head under one wing, neatly fold the other, and thus settle themselves for the night. The return to the feeding grounds is made in the early morning before daylight, except that when the land is eovered with fog they depart at a later hour.

In the fall the birds are, or were, seen in large floeks, sometimes numbering hundreds of individuals; they then seem to be more erratic in their movements and behavior than at any other time of the rear, save perhaps just before the nesting season. In winter these flocks are broken up, two to twenty being most eommonly found together. It is rare that a solitary bird is seen.

The nesting season of the Long-billed Curlew begins quite early. Eggs were taken on April 30, 1876, at Camp Harney, Harney County, Oregon, and from this date the season extends until well into June, young just hatehed having been reeorded on June 23, 1895, at Cody, Nebraska (Cooke, 1910, p. 72). Feilner (1865, pp. 423, 428) reeords finding numerous nests in Butte Talley, in northeastern Siskiyou County, California, May 21, 1860. This is, to date, the sole published breeding reeord for the speeies in California, althongh it is almost eertain that it nests also in portions of Modoe County. Feiner (1865, p. 428) says: “. . In Butte Valley, partienlarly the western por- 
tion of it, which is swampy, they appeared to be numerous, eggs and nests being abundant. The nests are built of dry grass, plaeed in a hollow previously made in the dry ground. The nests usually contain four eggs, nicely arranged, with the pointed end toward the eenter." One nest, with three eggs, was preserved; but it is stated that all the nests when found, contained four eggs. This set of three eggs (now no. 3382 U. S. National Mnseum) measures 2.59 to 2.66 by 1.71 to 1.77 , and averages 2.62 by 1.74 , being thus slightly shorter than the eggs deseribed below. The ground eolor of this set is olive buff, with rather small and well seattered spots and scrawls of dark olive brown and deeper-lying ones of pale mouse gray.

The eggs, whieh in eompleted sets are almost invariably four in number, are pear-shaped and measure in inches, 2.42 to 2.70 by 1.82 to 2.00 (arerage of two sets, eight eggs, from Montana). The groundcolor is light greenish olive of various shades, and the superficial spots are of dark umber, chocolate and blackish (Silloway, 1900, pp. 80, 82): there are also deeper and duller markings. From the eggs of the Willet, which those of the Long-bill most elosely resemble, the latter may be distinguished by larger size, being one-third of an ineh longer, and by their being more pear-shaped, that is, more tapered toward the small end (Davie, 1900, p. 151).

Silloway (1900, pp. 79-82) says of the Long-billed Curlew on its breeding grounds in central Montana:

After their arrival, the curlews inlabit the high, lry prairies, flying restlessly from one portion to another, showing a tendency to associate in I airs, though as couples, these birls are not inseparable. In the mating season, cne of the pair is likely to follow the other in a few moments, when the first bird has flow far over the prairie to a more distant station. At any time the loud, prolonged whistling of these birds, either when on the grouud or a-wing, will call attention to their movements, warning the disturber of their domain that his presence is known and that his actions will be watched with the closest interest.

\section{At times a pair will sail}

.. upward in company a-breast of the wind, moving in perfect accord on wide-spread, motionless pinions curved gently downward, within several feet of each other, then fluttering downward side by side or one in advance of the other, again to sail upward, uttering the characteristic whistles.

This whistle has been eompared to the sqneaking of brakes on a freight train. At times these birds will attaek certain of the hawks and are themselves molested by attaeks from some of the smaller perehing birds.

When an intruder approaches the vieinity of the nest the male will fly directly toward him and swerve upward only in time to prevent a collision. This habit of the male can be nsed to advantage in 
searehing for nests as he will almost invariably "point" away from the nest. The female, squatted close to the ground, will remain on the nest until the observer is quite near (and in exceptional instances can be stroked while on the nest), but therenpon she will flutter away, performing the broken-wing ruse, or run along the ground with lowered head and bill almost touching the surface (Silloway, loc. cit.).

In Siskiyon County, California, Feihner (1865, p. 428) relates that "When driven from the nest by the hunting of the dog it displays great sagacity by leading the dog a cireuitous path from the nest for some distance and then suddenly flying off. At first it hops or flutters along like a young birk, and just when the dog is about to pounce upon it, off it flies, uttering its note, eooi, eooi, sounding like a contraction of go away." Bent (1907b, p. 427) records finding downy young on the prairies of Saskatehewan, June 1, 1905, and June 11, and 18, 1906 :

When large enough to run the downy young are allepts in the art of hilling; they seem to disappear entirely even in the short grass; after hunting carefully, for fully half an hoü, over a limited area where we had seen one ranish, we gave it up and walked away, when we were surprised to see the youngster get up and run away from the very spot [where] we had been hunting hardest. Both parents always showed remarkable derotion and solicitude in utter disregard of their own safety. We saw an interesting exhibition of this one lay which probably succeeded in saving the lives of the young from a prowling coyote. The curlew was decoying the coyote away by feigning lameness, flopping along on the ground a few yards ahead of him, but always managing to barely escape him. We watched them for some time until they finally disappeared over a hill, fully half a mile from where we first saw them.

In Montana. Cameron (1907, pp. 25t-255) says that if the female flutters along the ground it indicates that she has eggs close by, but if she flies about the intruder the young are hatched and in the vicinity. After the young ean fly, at the end of July, old and young begin to gather together, and flocks of as many as one hundreel are formed prior to migration. Their eharacteristic wariness then becomes evident again.

Wickersham (1902, p. 355) states that the food of the Long-billed Curlew in the East consists of crawfish, small crabs, smails, periwinkles, toakls, worms, larvae, grasshoppers, erickets, beetles, caterpillars, and at times spiders, flies and butterflies. Worms ant larrae are pulled ont of the gromul by means of the long bill, the tip of which is thonght by some writers to be sensitive and to be used like that of the suipe in grasping things beneath the surface. Berries of various sorts are picked from low bushes, and flying insects are pursned and captured on the wing. E. R. Kalmbacln (in letter) states that a fow seeds of plants of the mallow family have been foume in stomachs of this birt. He doubts that butterflies are an item of importance in the food of the Long-billed c'urlew. 
When the Curlew first arrive in the fall in their winter home, or when they have been feeding along the seashore, their flesh is not considered to be very palatable; but inland, where they feed on worms, insects and the like, it takes on a very fine flavor and the birds fatten considerably. It was when in this condition that they were mueh sought after in earlier years. The fact that the flesh is dark discounts their value in the estimate of some epicures, but the taste of it leaves nothing to be desired. Two female birds taken on the Alameda marsh weighed 28 and 29 ounces, respectively, so that in quantity of flesh this shore bird compares well with the smaller ducks.

All available accounts place the Long-billed Curlew among the species of shore birds which have suffered great diminution in their numbers. This is due to two causes: First, persistent shooting through too long an open season for a great many years, and with a large or uncontrolled bag limit, and second, restriction of its relatively southern breeding range by the adrances of agriculture and stock raising. Among the more desirable waders the Long-bill is distinetive in being the only one nesting exchsively in the temperate latitudes where man has taken extensive possession of the ground. Its large boly, of a size eomparable with that of a teal, and the excellence of its flesh, which is stated to compare favorably with that of any other shore bird, make it an ideal game bird and entitle it to the most careful consideration. After the present sorely needed closed season preseribed by the federal government has expired, this Curlew should be adequately protected by a short season and small bag limit, so that it may continue in its rôle of benefactor, to hunter, epicure, and nature-lover, in all the rear's to come.

\section{Hudsonian Curlew}

\section{Numenius hudsonicus Latham}

OTHER NAMES-Jack; Jack Curlew; Short-billed Curlew; Curve-billed Snipe.

DESCRIPTION-Adults and immatures, both sexes: Top and back of hearl abruptly dark brown, divided along mid-line by narrow stripe of white or buffy; stripe from side of bill running over eye, whitish, with or without narrow dark brown streaking; another stripe, running from bill througl eye to ear region, below the one just described, dark brown; eyelids white; sicle of head below and behind eye, and whole neck, buff streaked with dark brown; chin and fore part of throat, pure white; bill blackish, shaning to light brownish on basal third of lower mandible; iris brown; back, scapulars, rump, tertials and outer surface of closed wing, mixed light and lark brown, the lighter color appearing as marginal spots on the feathers, and many of the feathers having dark shaft streaks; upper tail coverts and tail, barreil light and ilark brown, in effect not much different from back; outer primaries, blackish brown, outermost one with ivory white shaft; inner ones and secondaries, barred with lighter shades of brown anil buff; under coverts of wing, anil axillars, irre- 
gularly barred with dark brown and pinkish buff; under surface of flight feathers dusky, with triangular cross markings of dull buff; foreneck, breast and sides, streaked rather narrowly with brown on a pale buff, or pinkish buff, ground; middle of under surface pale buff or whitish; flanks and under tail coverts, pinkish buff, coarsely and irregularly barred with brown; feet dark lead color. Males: Total length $16.60-18.50$ inches $(422-470 \mathrm{~mm}$. .) (seven specimens); folded wing 9.22-9.81 (234-249); bill along culmen 2.75-3.38; (69.885.8); tarsus 2.18-2.45 (55.5-62.1) (ten specimens). Females: Total length 17.75-18.75 (452-477) (four specimens); folded wing 9.45-10.30 (240-262); bill along eulmen 3.22-3.87 (81.7-98.3); tarsus 2.24-2.35 (56.8-59.6) (six specimens); all from California. Juvenile plumage: Like that of adults, but the light spots on upper surface are larger and these spots and the whole lower surface are more pervaded with pinkish buff. The immature winter plumage results from faring ani wearing of the juvenile plumage; the annual molt appears to oceur in early spring. Natal plumage: Not known to us.

MARKS FOR FIELD IDENTIFICATION--Large size, long, down-curved bill (fig. 74), grayish brown rather than reddish-appearing general coloration, distinctly barred axillars and under surface of wing, and lack of contrasting white and black areas.

Vorce-Usual call a series of clear penetrating staceato whistles; a low whistled two-note, hur-lew; a rolling note, lasting six or seven seconds (Forbush, 1912, p. 330; Mackay, 1892b, p. 347).

Nest-On tundra, in a low swale, often with water at bases of the grass clumps; a saucer-shaperl depression in the top of a small hummock of grass or moss (Grinnell, 1900, p. 28).

EGGS-4, pear-shaper, measuring in inches, 2.22 to 2.54 by 1.61 to 1.70 (in millimeters, 56.3 to 64.5 by 40.8 to 43.2 ), and averaging 2.36 by 1.64 (60.0 by 41.6); ground color bluish pea-green, olive buff or light olive green, with superficial dots, spots and blotehes of light to dark brown, and deeper ones of drab or lavender; markings most numerous about larger end (Grinnell, loc. cit.).

General distribution-North and South America. Breeds on coast of Alaska from mouth of Yukon River to Kotzebue Sound and on coast of northern Mackenzie; winters chiefly on Pacific coast from Lower California to southern Honduras, and from Ecuador to southern Chile; also on Atlantic coast of South America from British Guiana to mouth of Amazon River; migrates mainly along the Pacific and Atlantic coasts; rare in the interior (A. O. U. Check-list, 1910, p. 125; Cooke, 1910, pp. 72-73).

Distribution in CALifornia-Abundant spring and fall migrant along the seacoast and through Sacramento and San Joaquin valleys. Spring migration occurs from late February to early May, and fall migration from first week in July until well into September or October. One record for November, at Morro Bay, San Luis Obispo County (A. K. Fisher, 1893a, p. 24), and one for December on Santa Cruz Island (Linton, 1908b, p. 126). Not known to winter within our latitudes. Non-breeding birds are occasionally seen here in summer.

The Hudsonian, or Jaek Curlew as this species is popularly known, is, today, by far the most plentiful of the three species of Curlew which formerly abounded in many parts of North Ameriea. The Hudsonian's present superiority in numbers is, however, due to the other two forms having been proportionately much more reduced; the Long-billed has been deeimated, while the Eskimo is now almost, 
if not totally, extinet. With a breeding ground on the Aretic shores of our continent, and a migration route which is chicfly coastal, and a habit of moving about in small flocks, combined with a wary disposition, the Hudsonian has becn able to cope more suceessfully than either of the other two with altering conditions and new dangers.

In California the Hudsonian Curlew is an abundant spring and fall nigrant along the coast and through the Sacramento-San Joaruin Valley. The northward novement begins in late February, as Tyler $(1913 b, 1) .30)$ lats noted the species in the vicinity of Fresno about this time: but the bulk of the birds does not appear until a month or so later. The last birds in the spring usually pass northward along the coast of sonthern California in early May; a flock of twenty-five was seen at Nigger. Slough, Los Angeles County, as late as May 25, 1907 (Willett, 1912a, p. 39). During June small flocks liave been

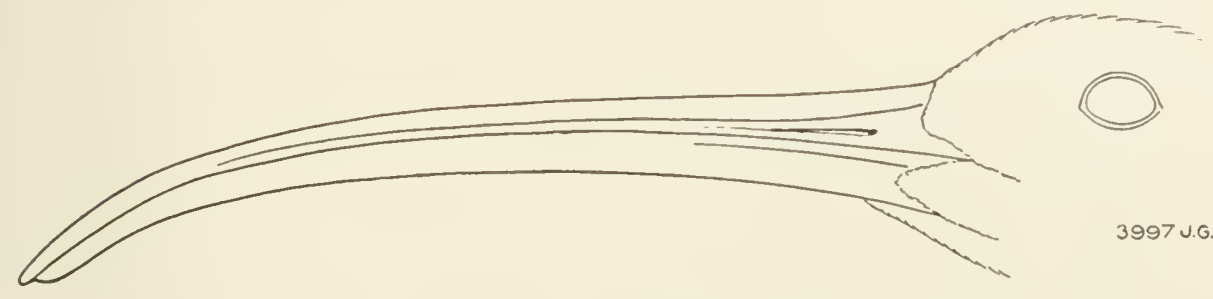

Fig. 74. Sile of bill of female IIdsonian Curlew. Natural size.

Note much smaller size as compared with female Long-billed Curlew (fig. 73 ).

noted near Santa Rarbara on June 2, 4, 9 and 25 (Bowles and Howell, 1912, p. 10; Dawsol1, 1915, p. 207). It is a question whether or not such birds are really enroute to their breeding ground: more likely they are non-breeders lingering here throughout the nesting season, to go back south with the return stream of their fellows.

Migrants, unquestionably southbound, appear early in July, numbers of birds having been observed along the southern California coast by the tenth of that month (Willett, loc. eit.) ; they become common by the middle or latter part of the month. This movement lasts until well along in September by which time the bulk of the species seems to have passed, although some linger until the middle of October, and a flock was seen at Morro Bay, San Luis Obispo County, in November, 1891 (A. K. Fisher, 1893a, p. 24). There is no evidence of the wintering of the species north of the Mexican line, unless the capture of a single bird on Santa Cruz Island, December 8, 1907 (Linton, 1908b, p. 126) is of significance in this regard.

The Eskimo Curlew (Numenius borcalis) has been reported from California three times (Heermann, 1859, p. 66; Holterhoff, 1884, p. 393; Swenk, 1915, p. 31); but the first and second records are cer- 
tainly, and the third very probably, referable to the Hudsonian Curlew. The specimen which was the basis of the second record was examined by Belding (1892c, p. 257) and pronounced by liim to be the Hudsonian, while the third record is based upon sight identification by an eastern hunter.

From most of the other shore birds occurring in California the Hudsonian Curlew may be distinguished by its large size, downeurved bill (fig. 74), grayish brown coloration and by the absence of any striking black or white patches. From the Long-billed Curlew it may be told by its slightly smaller size, shorter, less curved bill, grayish rather than pinkish appearing coloration, and barred axillars and wing lining, and from the Marbled Godwit, a bird of the same size as the IIudsonian Curlew, the latter may be known by its down-curved rather than up-curved bill, grayish rather than cinnamon coloration, and barred under wing lining and axillars. From the Avocet and Stilt the Hudsomian Curlew may be known by its down-curved bill, and by the absence of striking patches of black and white. The elosely related Eskimo Curlew, a species once abundant in migration on the Atlantic coast and Great Plains, and often ronfused with the Hudsonian Curlew, is distinguished by its much smaller size (folded wing only $8.00-8.50$ inches), and shorter bill (culmen only 2.25-2.50) and tarsus (1.70-1.80), and by the wholly umbarred inner webs of its primary wing feathers. The latter character is unfailing. As previously stated, there has never been an anthenticated instance of the ocenrrence of the Eskimo Curlew in California.

The voice of the Hudsonian Curlew is, like that of its relatives, lond and insistent. Mackay (1892b, p. 347) says of these birds on the Atlantic coast:

They make two notes, one a very clear, penetrating, staceato whistle, repeated four or five times in quick succession, and which is very far-reaching. It is given when flying, also when alarmed, and on taking flight. The other consists of two, low, straight whistles or notes, when a flock is alighting. Flocks also make a rolling note lasting as long as it would take to connt six or seven. The sound is similar to that prodnced by a boy's learl bird whistle filled with water. It is nttered when the birds approach, anil are over a marsh or feeiling ground, at an altitnde of sixty or seventy yards. T have never heard of its being marle by single birds.

The Hudsonian Curlew is a bird of the marsh and seashore and is not so often foumd in dry situations as its larger relative. the Longbilled. Like the latter, the Hudsonian is notably wary and at the slightest hint of danger is off on the wing with a lond ery to warn the others of its kind in the vieinity. Along the seacoast the birds resort to the adjacent salt marshes when driven from the open beach o1. mul flats by a rising tide. 
When a tlock of these hirls is on the ground where they lave been feeding, they become swattered, twenty-five or thirty birls covering fifteen or twenty yards' space. At such times they lo not appear to be particularly active, moving about in a rather slow, stately manner, although 1 have once in a while seen them run. During such times I have occasionally noticel one or more birls fly away from the flock, although undisturbed. At other times 1 have seen a single one or a pair pass over the flock which was resting on the ground and neither pay the slightest attention to the other...

When passing to and from their feeling grounds they usually fly at an altitude of abont thirty yards, unless it is quite winly, when they keep within a few feet of the gromul, or water, if they are passing over it. I lave seen them flying only a few feet above the water during their migration south in July. As the season alvances the birds frequent the beach grass near the shore, and at snch times the young birds ean be driven up to with horse and wagon; but rarely, if ever, ean the adult birds be so approached... When on migration they fly similarly to Geese and Ducks at such times. . . I have never seen... young birls in floeks on Nantueket Island [Massachusetts], nor associated with the adults, there usually being not over five or six birls, or even less, together.

.. When noted in the spring it is generally on rery fine, warm, and clear mornings. They are sellom seen in stormy weather, but usually before it. That these hirds are powerful and enduring fliers is evilenced by their long, pointed wings (Mackay, 1\$92b, 1). 348, 349, writing from Massachusetts).

In through flight, the flocks pass high overhead in regular formation, often in the form of a $V$. The individuals show a slow steady beat of the wings. If they wish to drop lower they glide for some distance on set wings.

Tyler (1913b, p. 30) says that in their migration through the Fresno district they arrive in small numbers late in February and become numerous a month later.

Their favorite resorts are large open fielrs where shallow ponis occur, and in such places they often gather in large numbers. I have no definite record of this speeies remaining in spring Jater than May 7 (1912). . .

On the last day of one April I encountered a large flock of curlews in a grain field, part of which was being flooded at the time with irrigation water. .. Approaching to within sixty yards of the big fellows as they stoor hunehed at the water's edge, I concealed myself as best I could. . . . The nervous lisping that at my approach threatened to break into the clamorous, screaming flight calls finally subsided and the birds fed and waded about in the water or preened their feathers while standing stork-like on one leg. Suddenly I was thrilled with a medley of subdued pipings. . . A strange nervous unrest seemed to affect the entire group on the ground. The whistlings became louder and... [presently] a curlew call from over head drew my attention to a flock of new arrivals, nine in number, that were circling preparatory to joining the company at the pond. . . Mere specks they appeared, and yet their melodious eall rang elear and distinct.

Of the Hudsonian Curlew as observed at Santa Barbara, California, in recent years, Torrey (1913, pp. 33-35) says: 
They go about the business as our numerous fishermen do when in search of bait, not looking for it on the surface (though I have seen them doing that also), but probing for it. Down goes their long, sickle-shaped bill into the wet sand, frequently for only a fraction of its length; and often as not you may see it bring up a squirming something that looks like a shrimp or a prawn.

This the bird does not at once swallow, as you might have expected it to do. Instead, it drops its prey upon the sand, picks it up and shakes it, drops it again, and so on, the unfortunate victim all the while struggling to get free, till suddenly a final jerk and a gulp, and it disappears down the long bill. Of the precise reason for all these preliminaries I am ignorant. Possibly the crustacean must be held in a certain position before it can be comfortably swallower. Certainly it is not killed in the process, for it wriggles to the last moment.

I have known a flock of fifteen curlews to take possession of a certain short stretch of the beach, with nothing but a few rods of low sand-hills between them and the noisy asphalt bonlevard, and hold it for the greater part of a day, flying out to sea for a little distance when driven to it by too close a passer-by, and immediately returning. That was a day, no doubt, when the fishing was exceptionally good...

On the other hand, I have seen within the same week a flock of eighty curlews on a lonesome stretch of beach beyond the city limits-and the eity's protection-that would not allow me to approach within two or three gunshots.

A flock of curlews, for example, feeding, heads down, upon the sand, will discover you instantly on the edge of a cliff overlooking the beach, say at an elevation of fifty feet, and be off on the wing almost before you know it, no matter how slow and noiseless your approach may have been; whereas, hall you been walking on the beach itself, in full sight, the chances are that they would have suffered you to come moderately close upou them withont betraying any marked uneasiness. It has become a habit with them, apparently, to keep a sharp lookout upward, perhaps because their more usual enemies come from that quarter (Torrey, 1913, p. 85).

The breeding grounds of the Hudsonian Curlew lie far to the northward, on the tundras which border the Aretie seas. The nesting season extends from about the first of Jume to the first week in July, as Grimnell (1900, p. 28) found a heavily ineubated set in the Kowak River delta, Kotzebue Sound, Alaska, June 14, 1899, and Chapman (1912, p. 262) reports eggs taken east of the Anderson River, Maekenzie, July 4. The nests are, aceording to Grinnell (loe. eit.), always situated in ". . . a wet swale or low place in the tundra, in which the clumps of grass or moss were often surrounded at their bases with water. . . The nest is simply a saneer-shaped depression in the top of a low hummoek of moss or grass." The eggs are fully exposed to view but their coloration is usually suel that they are exeeedingly diffieult to diseover. Twenty eggs measured, in inehes. 2.22 to 2.54 by 1.61 to 1.70 , and averaged 2.36 by 1.64 . The groundcolor is very variable, ranging from a bluish pea-green through olivebuff to light olive-green. The superficial markings consist of dots, 
spots and blotehes of brown with deeper markings of pale lavender and (lrab (Grimmell, 1900, p. 28).

Of their nesting habits in the Kotzebue Sound region of Alaska, Grinnell (1900, pp. 27-28) says:

They were ordinarily met with on the open stretches of tundra, often where these alternate with strips of timber and lakes. Where such perches are afforded, solitary birls on watch would be seen sitting on the tips of isolated dwarfell spruces or even willow bushes. As soon as an intruder entered the lomains of a pair of curlew, the bird on wateh would give the alarm by a louk, ringing eall-note, and soon both birds would fly to meet him. As long as the intruder remains in the vicinity, the pair of birds keep flying restlessly to and fro, now and then alighting on the ground and walking about, but most of the time keeping up their monotonous, rolling whistle. This was the only note 1 heard, except earlier in the season a long, faint whistle like that of a listant locomotive, uttered by the male bird while sailing slowly, on set, motionless wings over the nesting grounds. This is probably their song flight, though it is certainly very simple.

Only by remaining quiet for a considerable period of time at some distanee from the supposed nest site and observing the movements of the parent birds after their fear had subsided, was the collector able definitely to loeate any nest. When the birds liad quieted down for a time, it was usually possible by lushing toward the spot to flush one of them direetly from the nest and thus locate its position. As long as a person is at the nest, the parents fly close about, almost deafening him with their lond, penetrating eries. If anything, the male is the more demonstrative bird of the two.

Mackay states $(1892 b, \mathrm{pp} .347,348$ ) that young birds in the fall are not so wary as adults and are more easily decoyed. The eries of a wing-wounded bird are usually suffieient to recall the other members of a flock and they are then less mindful of danger. Hunters take advantage of this habit and thereby increase their lery on each passing flock.

Along the seashore the Hudsonian Curlew feeds upon fiddler crabs and sand spiders and probably many other marine animals. Inland its diet includes insect larvae, grasshoppers and beetles. Being a more maritime species it is not so important agrieulturally as is the Long-billed Curlew. However, Belding (IIS) states that in April, 1884. flocks foraged on the mesas back from San Diego Bay, where insects were abundant. In the north, during the late summer and early fall months, they feed extensively on various berries which grow on the tundras, and their plumage sometimes shows stains from the berry juice.

The flesh of the Hudsonian Curlew is not so highly prized as is that of the Long-billed, probably because its more maritime habitat results in its taking for food more of the salt-water forms of animal 
life. Nevertheless when fat the Hudsonian is by many people considered a delieacy. But from a sporting standpoint its chief elaim eomes from its wariness and the resulting difficulty of securing a sizable bag. Many of the hunters along the southern California coast use a .22 rifle when after this game, finding that this affords better sport than if a shotgun were used. With either gun, the bag is not liable to be very large, as the birds are well schooled in the art of self-preservation, quiekly learning to avoid dangerous stretehes of the beach. This habit, and the restrieted, seacoast paths of migration, and the remoteness of the breeding grounds, have all doubtless been factors in its preservation. The Hudsonian Curlew will probably remain with us longer than any other of our large shore birds, and, with adequate provisions for protection, may even constitute a permanent game asset.

\section{Black-bellied Plover}

\section{śquatarola squatarola (Linnaens)}

OtHer NAMES-Black-breasted Plover; Beetle-head; Bull-head, part; Whistling Field Plover; Swiss Plover; Charadrius squatarola; Charadrius helvetieus: Squatarola helvetiea.

Description-ddult male in late spring and summer: Forehead, broad stripe over eye, and eyefils, pure white; top of hear and hind neck grayish white, with some nottling of blackish on back of head; sides of head, chin and throat, continuously deep black; bill slate black; iris dark hazel brown; feathers of back, rump and tertials, brownish black broadly tipped with drab or white, giving a conspicuously mottled effect; upper tail coverts and bases of tail feathers, chiefly white; terminal portions of tail feathers barred with varying shades of brown, the latter color lightest on outermost ones; outer surface of closed wing brownish drab, the feathers irregularly nargined with white; primaries and primary coverts brownish black, the former with much white on inner webs toward bases; shafts of primaries white toward tip; edge of wing mottled light brown and white; lining of wing white, except hindmost under coverts which together with much of under surfaces of flight feathers are dusky; axillars solidly black; shoulder region conspicuously white in contiluation with stripe over eye and behind ear; breast, sides, and forepart of belly, solidly black, continuous with that of throat and chin (this black may be interrupted by scattered white feathers which remain over from the winter plumage); rest of under surface white, save that outermost under tail coverts have black spots on their onter edges; feet and legs black. Adult female in late spring and summer: Similar to adult male at same season, but white markings on head and back dingy or replaced by drab, and black of lower surface duller, with brown tinge. Adults and immatures, both sexcs, in late fall, winter and carly spring: Top of hear, hind neck, back and rump, drab brown, the feathers more or less narrowly tipped with white; forehear, stripe to and over eye, and eyelids, dull white, more or less flecked with ashy brown; sides of hearl and foreneck whitish narrowly streakel with ashy brown; chin white: rump, upper and under tail coverts, and tail, as in summer; outer surface of 
-losel wing, drab brown, with rather extensive white feather-tippings anıl elgings; rest of wing inclurling black axillars, as in summer arlult; uniler surface white, with dull and narrow streaking or mottling of ashy brown on breast and sides. Males: Total length 12.00-13.15 inches (305-334 mm.) (eight specimens); folded wing $7.52-5.00$ (191-203); bill along (*ulmen 1.17-1.26 (29.7$32.1)$; tarsus $1.50-2.00(45.6-50.7)$ (ten specimens). Females: Total length $11.57-13.65$ (302-347) (seven speeimens); folded wing 7.28-7.95 (185-202); bill along culmen 1.14-1.25 (2S.9-31.S); tarsus 1.S5-2.04 (47.0-51.7) (ten specimens); all from California. Jurenile plumage: Top of head, hind neck, back, rump and outer surface of elosed wing, dark drab browu, the feathers marginally spotterl at tips with white or pale buffy yellow; side of head and foreneek dingy white, narrowly streaked with ashy brown; chin white; upper tail coverts white tipped with buffy yellow; tail as in summer arlults save for slight buffy tinge on white portions; wing and axillars as in summer adult; breast and sides dingy or buffy white, indistinctly streaked and mottled with light brown; rest of unler surface white; legs and feet lead-colored. Natal plumage: ' C 'pper parts, olive-yellow, spotted with black; hind neck and lower l'arts, white; black lines on side of crown, from bill to eye, and below eye" (Sanforl, Bishop and Van Dyke, 1903, p. 457).

MARKS FOR FIELD IDENTIFIC:TION-Mollerateiy large size (fully twice bulk of Killıleer), big heal, short stout black bill, strikingly black axillars (fig. 3), almost white upjer tail coverts, anl short white band on spreal wing; in allition, in spring, black uniler jarts, except for abrujtly white lower belly ancl uniler tail eoverts, together with absence of any golilen color on upper surface.

Volce-A louel, ringing wher-rell, of a listinctly mellow quality (Grinnell, MS).

Test-On bare grounl or in short grass of tumira: a mere lepression sparingly linel with dried grasses (Mackarlane, IS91, 1. 429; and authors).

Egas -3 to 4 , pear-shaped, measuring in inches, 1.90 to 2.30 by 1.40 to 1.47 (in millimeters, 48.3 to 59.5 by 35.6 to 37.3 ); ground color light greenish or rufous lrab; markings lark umber or bister (Bairl, Brewer and Ridgway, 1854, I, T. 137).

Gexeral distribitiox-Almost cosmopolitan. Breels on Aretie eoast of America from Point Barrow to Melville Peninsula north of Hudson Bay, and on Aretic coast of Eurasia. Winters from California, Louisiana and North Carolina south to Brazil and Peru, and from the Mediterranean to South Africa and in India and Australia. In migration occurs throughout most of the intervening areas, although ordinarily less abundant inland than along the seacoast (A. O. L. Check-list, 1910, p. 127).

DISTRIBLTION IN CALIFORNIA-Fairly abundant spring and fall migrant along the eoast and in linited numbers in the San Joaquin Valley; winter visitant in fair numbers at least as far north as Los Baños, Merced County, and San Franciseo Bay, and once reported in winter from the moath of the Eel River, Humbolit County (C. H. Townsend, 1S57, p. 199). Spring migration oceurs chiefly luring April and May, fall migration from July to October (Willett, $1912 a$, P. 40 ; and authors).

To hunters and naturalists who frequent the seashore no shore bird is better known than the Black-bellied Plover. This is due to its widespread distribution, striking coloration, frequent occurrence in large flocks, and other distinctive features. This extensive recogni- 
tion has given the bird many vernacular names. In California and elsewhere it is known as Bull-head or Beetle-head by reason of the large size of its head; and its clear, far-reaching note has given it the name of Whistling Field Plover. Elsewhere than in California, it is known as Black-breast, while the young in the fall are often called Palc-bellies becanse of the lighter coloration of the under parts.

In California the Black-bellied Plover is a spring and fall migrant, abundant along the coast, and in fair numbers, at least in spring, in the San Joaquin Valley. A few remain throng! the winter, occurring inland at least as far north as Los Baños, Mereed County (Beck, MS: specimens in Mus. Tert. Zool.), and along the coast from the vicinity of San Franciseo Bay southward. C. H. Townsend (1887, p. 199) records the species in

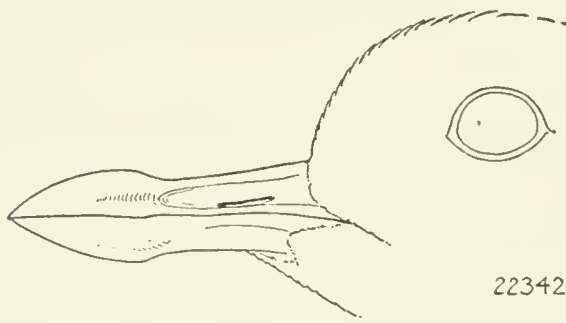

Fig. 75. Side of bill of Blackbellierl Plover. Natural size.

Note stout form and enlarged encl (compare with figs. 64 and 71 ).

December, 1855 , from the mouth of the Eel River, Humboldt County. There are no records at any season for the interior of California north of Stockton. The spring migration probably begins in March, as Beck (MS) at Los Baños, Merced County, heard birds which were evidently in migration on March 6 , 1912 ; but the main body passes throngh during April and May. The last depart from southem California about the middle of May (Willett, 1912a, p. 40) ; later stragglers have twice been noted: San Nicolas Island, June 1, 1910 (Willett, loc. cit.) ; near Santa Barbara, Jume 5, 1915 (Dawson, 1915, p. 207). Observations covering five separate years between 1904 and 1910 showed the dates of last observance of this species in the vicinity of San Franciseo Bay to vary from April 14 to May 23 (Gifford, MS).

In California the fall migration commences in July, birds having been seen on San Francisco Bay, July 9, 1909, and July 13, 1910 (Gifford, IIS). South of San Franciseo the earliest fall dates are: Monterey, July 24 and 30, 1907 (Beck, 1910, p. 71), and August 10, 1910 (specimen in Mus. Vert. Zool.); Santa Barbara, Angust 29, 1911 (Bowles and Howell, 1912, p. 10) ; and Long Beach, Los Angeles County, Angust 17, 1900 (specimen in Grimnell eoll.). Willett (loc. (eit.) says the fall migration in southern California continues until Oetober 20.

From other shore birds occurring in California the Black-bellied Plover in any plumage is easily distinguished by its moderately large 
size (about twice the bulk of the Killdeer) big head, short stout black bill, whitish upper tail coverts, short, white band on spread wing, and black axillars (fig. 3). From the somewhat similar American Golden Plover it is distinguished by its larger size, stonter bill, black axillars, whitish upper tail coverts, ashy rather than golden cast to upper surface, and by the presence of a white band on the spread wing. In spring plumage, when both are extensively black on lower surface, these two plovers may be distinguished by the presence in the Black-bellied of extensive white markings on top of the head, back, and upper tail coverts, and by the clear white on lower belly and under tail coverts. In the fall the Black-bellied Plover is most readily recognizable by the conspicuously contrasting black rather than (lrah)colored axillars. From the Wandering Tattler it is distinguishable by its short, stont bill and by the presence of white on its wings and rmmp, and from the Surf-bird by its white forehead, by the smaller amount of white on its wing and upper tail coverts, by the broken pattern of the upper surface, and by the tarsus being much longer than the bill. This is the only one of om true plovers which has a hind toe, though this digit is quite small.

The note of the Black-bellied Plover is a lond, ringing wherrell, far-reaching and, at a distance, clear and mellow in quality. It has also been described as resembling the syllables lilee-er. sometimes voiced with a quavering effect. These notes may occasionally be heard as the birds are passing overhead at too great an altitude for discermment by the hmman eye.

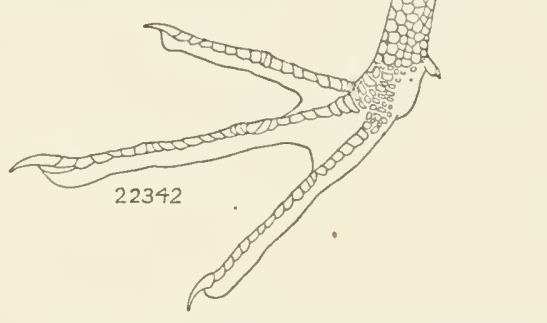

Fig. 76. Side of tarsus and foot of Black-bellierl Plover. Natural size.

Note small hind toe (compare with fig. 77).

While all the larger shore birds exhibit wariness, this trait is developed in the Black-bellied Plover to such a degree that the species may be called the sentinel among its kind, as it seems to warn the less suspicious ones of approaching danger. This extreme wariness is an important reason for the popularity of the Black-bellied as a game bird, lunters prizing it in consequence of the difficnlty in securing a good bag. If the hunter imitates the whistle of the birds they will come to decoys, but with extreme care, usually circling about one or more times before alighting, and making off with great rapidity if they see any suspicions movement. In this respect they resemble curlew but differ from those birds in that the members of a flock do 
not decoy to the cries of a wounded individual. The species is essentially gregarions, being found in flocks ranging in number from a half dozen birds to several humdred; but sometimes lone individuals are seen in company with other shore birds.

"The clear, plaintive note of the blackbreast is the most musical sound of the shore. . . Early Augnst sees the first small flocks, and from Cape Cod to North Carolina they are found" wherever the falling tide leaves exposed extensive sand-flats, and where marshes and wild ocean beaches afford a resting-place at high water. Their whistle, often heard before the flock is seen, warns the gunner to lie low; soon the dark line of birds comes into view, moving close to the water with grace and speed, heading straight for the decoys. One or two on set wings circle within range; but, quick to notice the slightest motion, they are up and off while the hunter may have hesitated a second for a closer shot. With low water the birds avoid the promontories and follow the receding tide until the farthermost bars are exposed; there they feed with the throngs of other shore birds. If this mixed company of foragers is disturbed, the Black-bellied Plover are the first to take alarm and leave. "A little shooting quickly teaches them danger, and few birds become more wary: flying high between stopping places, they keep to the open and avoid everything in the nature of a hlind. . . .' The young upon arrival in the fall are much more easily shot than the adults, as they come readily to decoys and answer if whistled to (Sanford, Bishop and Tan Dyke, 1903, pp. 457-459).

Of the general habits of the Black-bellied Plover as observed for many years on the Massachusetts coast, Mackay (1892a, pp. 146-151) gives the description which follows: 'This

... is in a great degree a tide bird, seeking a large portion of its food on those extensive sand flats left $\mathrm{by}$ the receding waters, which may be adjacent to marshes where the grass is short, and which are interspersed with baren places where there is no grass, also to uplands and fields where the grass is seanty or closely fed down by sheep or cattle. It is to such places that they like to resort when driven from their feeding grounds on the sand flats by the incoming tide. . .

When on the ground they usually run very fast for four or five yards, then stop, elevate the head, and look around. They strike at the object they are going to pick up and eat with a very quick motion. ...

There is something aristocratic in the bearing of the alult birds as you watch them standing on the marsh with their heads erect, their black and white plumage strikingly defined, and their large, dark, liquid eyes erer on the alert for danger. . . .

The Black-bellied Plover fly lower on migration, I think, than do the American Golden Plover, and the flocks string out more, a customary mode of flight being in lines; they also fly like Ducks and Geese at such times. They are apt to $f y$ in lines also when coning from the sand flats to and over the marshes. .. . 
[In migration] when tired at sea they will alight on masses of floating seaweed, and also on the ocean where they sit buoyantly, swimming with ease, experiencing no difieulty in taking wing.

When feeding on the mud flats the Black-bellied Plover walk slowly and ustrally stand with their weight on one foot, the other being held disenganged. Probing is carried on in a more seclate fashion than with the smaller waders, the bill being thrust into the mud but oner in a partieular spot and usually at an angle of about 45 degrees. Oecasionally they bow profoundly, the head almost touching the ground. All the movements are dignified. The flight is swift and direct, with steady wing-heats which seem to eover an are of ahmost 180 deglees so that the black axillars are prominently displayed at (each up-stroke (Grimell and Stoler, MIs).

I Hock of about 150 Black-bellied Plover was seen repeatedly on the beaclu near santa Barbara in the fall of 1911. When first noted, on september i, they were extremely wild, and the most careful stalking would permit of 110 closer approach than 200 yarks. During the succerding two weeks the flook dwindled considerably in munbers but became much tamer. By October 1, the bircls on the beach were so tame that they would allow a person to approach within thirty yards. The diminution in numbers was not due to hunting, but probably to indivituals or small groups withdrawing from the loeality (Bowles and Howell, 1912, p. 11 ; IIowell, MIS).

Flocks of migrants which Beck (MS) eneomitered at Los Baños, Mereed Comnty, during April, 1912, were wont to alight for rest at the margins of large ponds. Oeeasionally they would be found foraging on high ground in the vieinity.

The breeding range of the Black-bellied Plover extends over a considerable portion of the Aretie coasts of Ameriea and Eurasia, but published acconnts of the nesting of the species are few in number. Reed (1904. p. 127) states that eggs were taken at Point Barrow, Alaska, in Jume. 1900; and MacFarlane (1891, p. 429) says that he seeured sets on July 4 and 5, 1864, at Island Point, Franklin Bay, Canada. These, together with the migration data available, indieate that the nesting season oeempies the latter part of Jume and early part of July.

MacFarlane (1891, p. 429) says of the set seeured on July 4, 1864: "The nest contained four eggs and was eomposed of a small quantity of withered grasses placed in a depression on the side or faee of a very gentle eminenee." The eggs taken by MacFarlane measure, in inches. 1.90 to 2.30 by 1.40 to 1.47 . The ground-eolor is light greenish drab or rufous drab, with quite uniformly eolored spots of dark umber or bister and deeper spots of a lighter color. These eggs differ from those of the Golden Plover in being longer and proportionately broader 
(Baird, Brewer and Ridgway, 1884, I, p. 137). "It is probable that ... [ the] parents relieve each other during the process of ineubation, as a male bird was snared on one of the nests" (MacFarlane, loe. eit.).

The food of the Black-bellied Plover comprises small mollusks, earthworms, beetles, grasshoppers, locusts, eutworms and grubs (Forbush, 1912, p. 339; and authors). On the northern tundras in late summer berries are eaten. The stomach of a bird taken on Bay Farm Island, Alameda County, September 26, 1914, contained fourteen small snails, one small bivalve mollusk, and parts of two or more small erabs (Hemigrapsus oregonensis).

When inland and feeding on earthworms and terrestrial or freshwater inseets the flesh of the Black-bellied Plover is fairly palatable, but along the seacoast it partakes of the strong taste common to seafaring birds. The weight of a female taken in Alameda County on September 26, 1914, was eight ounces. The speeies is prized for the diffieulty eomneeted with obtaining a fair-sized bag rather than for the quality of its flesh, which is of distinctly seeond class. In eonsequence of its extreme wariness and failure to deeoy to the ealls of wounded eompanions as do many other speeies, the Black-bellied Plover has suffered a smaller diminution in numbers than have many other shore birds. Its extreme northern breeding range, undisturbed by man, is an added factor in its favor. We ean therefore reasonably expect that it will long remain a prominent member of our avifama. But we should be prepared to afford it appropriate proteetion in case it begins to lose markedly in its contention against adverse conditions.

\section{American Golden Plover}

\section{('haradrius dominicus dominicus Mïller'}

OTHER NAMES-Bull-heal, part; Charadrius virginiacus; Pluvialis rirginiara.

Description-Adult male, in late spring and summer: Top and back of heail and hind neek, black, with a sprinkling of golden yellow and white spots; band across forehead, continuing back over eye and down sille of nerk to expand on side of body near bend of wing, comspicnonsly white; extreme forehear, sides of head, chin, and throat, contimously black; bill black; iris dark brown (Sennett, MS); feathers of back, rump, miper tail coverts, and most of wing coverts, black, with marginal spots of golden yellow and white; tail barred with dark and light brown or whitish; outer surface of elosed wing, mixed dull brown and white, except for scattering new feathers like back; flight feathers blackish hrown, outer ones with shafts white towarl tips; whole under surface of wing and axillars, light aslyy brown, unbarred: whole uniter surface of body from chin to lower tail coverts continuously black, often with more or less mixture of white; sides of lreast just behind white area, mixed black, white and golden yellow; feet "bluish-grey", (Auduhon, 1842, V, p. 206). Adult female, in spring and summer: Like arlult male at same seasons 
but with unler surface distinctly brownish, rather than black, and with greater almixture of white. Adults and immatures, both sexes, in (fall?), winter and early spring: Foreheal, stripe over eye, sides of hear, ehin aud throat, lull white, more or less flerkerl witl light brown; ear region light brown; entire upper surface, wings and tail much as in summer adults but duller and less mottled, apparently as a result of farling and wear; breast and sides, light drab, faintly streaked with larker lrab; rest of unler surface dull white. Males: Total length 10.12-10.75 inches (257-273 mm.) (three specimeus); folileil wing 6.58-7.29 (167-155); bill along eulmen 0.81-0.92 (20.6-23.4); tarsus 1.62-1.77 (4l.0-44.8) (five specimens). Fenales: Total length 10.25-10.37 (260263.5) (two speeimens); folderl wing 6.93-7.17 (176-182); bill along eulmen $0.83-0.93$ (21.0-23.5); tarsus $1.58-1.76$ (40.2-44.7) (four sperimens); all from interior Alaska and Yukon Territory. Juvenile plumage: Upper surface much as in summer adults but ground color brownish black and yellow spotting more extensive, to the exclusion of white; light areas on sile of head suffused with yellowish; wings and tail as in adults, except that lighter markings of tail are strongly yellowish; throat and breast, dull white, with fleckings of pale drab; rest of unler surface ashy white with ohscure brownish bars. Nutal plumage: Top and siles of heal, and whole back, marbled in fine pattern with black upon a pale lemon yellow ground; lower surface and collar around hind neck, white.

MARKS FOR FIELD IDENTIFICATION-Moilerate size (somewhat larger than Killdeer), short llack bill, thick aplearing heal, plain aslyy brown under surface of wing and axillars, and absence of white areas on rump and wings. In spring: black on entire under surface, sharply set off against white band around hearl, combined with spriukling of briglit golden yellow on upver surface.

Vorce-A rear melorlious whistle of three notes: Coorlle, coolle, coorlle (Mackay, $1891 a$, p. 19).

Nest-A mere depression in the ground, generally lined with a few dry leaves (Bairi, Brewer and Rilgway, 1sst, I, p, 143).

EgGS-Usually 4, pear-shaped, measuring in inches, $1.8+$ to $2.00 \mathrm{by} 1.25$ to 1.35 (in millimeters, 46.7 to 50.8 by 31.7 to 34.3 ), and averaging 1.91 by 1.31 (48.3 by 33.2); ground color various sharles of drab; superficial markings deep) umber brown almost black, in well defined spots and seattereil about profusely, slightly the more numerous about larger end (Baird, Brewer and Ridgway, 1884, I, p. 144); deeper-lying markings are also present.

General distribution-North and South America. Breeds on Aretic coast from Kotzebue Sound, Alaska, to Melville Peninsula, north of Huison Bay, and from Melville Island, south to Whale Point at northwestern corner of Hurlson Bay; winters chiefly on lampas of Argentina; fall migration route is from breeding grounds to Labralor, thence to Nova Scotia, thence over the Atlantic Ocean to the Lesser Antilles and northeastern coast of South America and thence to the winter home; in spring the migration route is northward from South America through the Mississippi Valley; some pass southwari through the Mississippi Valley in the fall; a few move south along the Pacific coast (A. O. U. Check-list, 1910, p. 127; Cooke, 1910, pp. 80-85).

Distribution In CALIfornia-Rare migrant. The following specific instances of occurrence are on record: Vallejo, Solano County; Santa Cruz, October 22, 1888; and San Diego near Coronało, January 12, 15, and 20, 1908.

The American Golden Plover is a very rare species in California to judge from the fewness of the records. The main migration route 
in both spring and fall lies so far to the east that the birds which reach Califormia are evidently only infrequent stragglers. The following definite records of occurrence within the state are known: Trallejo, Solano County (Kobbé in Bailey, 1902, p. 1) : Santa Cruz, October 22, 1888 (Cooke, 1910, p. 84); and San Diego Bay near Coronado, one bird seen Jammary 12, 15, and 20, 1908 (Tor'ey, 1909c, p. 207). Newberry (1857, p. 97) thought that it oceurred in the northern part of the state in autumn, and Suckley (in Cooper and Suckley, 1859, p. 230) states that in the San Francisco collections he saw specimens which he supposed had been obtained in the public markets of that eity. Cooper (in Baird, Brewer and Ridgway, 1884, I, p. 143) saw one specimen taken near San Francisco. The record for Menlo Park on the authority of Hornung (Kobbé, loc. cit.) is likely to refer to the Black-bellied Plover; for a skull of the latter species is contained in the collection of the Museum of Tertebrate Zoology, with attached label in Hormung's handwriting bearing the name "Charadrius dominicus | Menlo."

From other shore birds the Golden Plover may be distinguished by its moderate size (somewhat larger than that of Killderer), short, black bill, thick head, ashy brown axillars and wing lining. and by the absence of white areas on its rump and wings. In spring the combination of entire black under surface, sharply set off against the white band around its head, and the yellow-spotted upper surface, render identification easv. From the Black-bellied Plover, the Golden may be distinguished by its somewhat smaller size, slenderer bill, and liglit aslyy brown instead of black axillars. Its note is said to be softer than that of the Black-bellied Plover. The other plovers occurring in California are distinguished from the Golden Plover by the presence of black collars or other transverse bars on head or neck, or of white axillars, or botls.

The habits of the American Golden Plover have been well described by Mackay (1891a, pp. 18-23), who observed the species in Massachusetts and elsewhere on the Atlantic coast. He says:

... they frequent the extensive marshes, .. . the long reach of sandy lills, old fields where the grass is short and the regetation scanty, sand flats left by the receding tide, ploughed fields, and any burnt tracts which are clear of trees and bushes. . . When on the ground they run rapidly and gracefully, and soon seatter on alighting. After running a few yards they suddenly stop, hold the head erect, and look around, all the movements leing very quick. In feeding they seem to strike at the object with a motion that reminls one of a Loon or Grebe commencing to dive.... When scattered over considerable ground, as is usual after they have been any length of time on their feeding ground, every bird apparently on its own hook, if alarmed, a note is sounded; they then rise so as to meet as soon as possible at a common centre, which gained, away they go in a compact body. When high up in the air, flying on 
their migration, I have often noticel the flocks assume shapes that remindel me of the flight of Geese; they also fly in the form of a cluster, with one or nore single lines ont behind; also broadside in long straight lines, with an apyarent velocity of about one and a half miles a minute, measured by the eye as they fass along the headlands. When flying near the ground they course over it at a high rate of speed, in every variety of form, the shape of the flock "onstantly changing, and frequently following every undulation of the surface, stopping suddenly and alighting when a favorable spot is noticel. They are extremely gregarious, and I have had the same flock return to my decoys as many as four times, after some of their number had been shot each time. When approathing the decoys every birl seems to be whistling, or, as I have often expressed it, uttering a note like coodle, coodlc, coodlc. During the midalle of the day they are fond of sceking the margins of ponds where they sit quietly for a long time, if undisturbea. When disturbed they are ahmost certain to return, in a short time, to the same spot from which they have lieen startel, that is, if they have been resting or feeding there any length of time. When suspicious, it is very difficult to alproach, lecoy, or eall them; if not harasser, they are as a rule quite tame, and gentle, and can be easily lriven up to with a horse and wagon. . .

Young birds invariably appear wild and wary, much more so than the old ones. They are also very cratic in their movements and flight when with us. They usually will not pay so much attention to the decoys or (*all-whistle as lo the old birds: and I have seen them when rery shy and after being disturbed, mount up into the air and nearly turn over on their backs while flying with great veloeity. It is a noteworthy fact that when a flock of these young birds is approaching, no dependence "an be placed on their movements. They may sometimes sweep down within a few yarls of the sportsman, passing with great rapidity over his heal, all seattered: or down close to the stand and then up into the air; or they may turn suddenly. . . The older birds rarely indulge in any similar anties. . .

As far as my observation sliows on the Island of Nantueket, the Golden Plover usually seeks land about dusk and luring the first half of the night.

These birds are often heard passing orerhead in migration, but they do not always stop.

Goss sars (1891, p. 210):

In flight they are swift and strong, sweeping over the prairies in a compact, wayy form, at times, skimming close to the ground, then high in air, an ever-changing, circling course, whistling as they go; and on alighting raise their wings until the tips nearly touch, then slowly fold them back, a habit which is quite conmon with them as they move about on the ground.

According to Cooke (1910, p. 83) the American Golden Plover nests during the latter part of June, eggs having been taken on the lower Anderson River, Mackenzie. and at Point Barrow, Alaska, on five dates from June 16 to 24. Reed (1904, p. 127) records a set taken June 1, and some of the sets taken in the Anderson River region by MacFarlane were fresh even as late as July (Baird, Brewer and Ridgway, 1884, I, p. 144). Tery little has been written in regard to the nesting habits of this American race of the Golden Plover. 
According to the observations of MacFarlane in the Anderson River region, near the Aretic coast of Canada, the nests were ". . mere depressions in the soil, generally lined with a few dry leaves, and were difficult to find, as there was nothing to distinguish them from the soil-which the eggs very closely resemble in color....' The eggs are usually four in number, pear-shaped, and measure in inches, 1.84 to 2.00 by 1.25 to 1.35 , averaging 1.91 by 1.31 . Their groundcolor is of varions shades of drab, while the strperficial markings are of deep nmber brown, almost black. These markings are chiefly in the nature of sharply defined spots, and are well seattered over the surface, being perhaps somewhat more numerous about the larger end. These eggs differ from those of the Black-bellied Plover in being slightly smaller and relatively narrower.

When driven from the nest the female ". . runs a certain distance, and if she suceeeds in enticing the party away, will then take to flight. In a few instances, when the bird was surprised by a near approach before she left, she pretended lameness, and fluttered at their feet"' (Baird, Brewer and Ridgway, 1884, I, pp. 143-144).

The American Golden Plover performs an annual migration some 18,000 miles in extent from the time it leaves the breeding ground in the fall to the time when it returns in the following spring. In August the birds leave the breeding grounds on the northwestern shores of America and pass to Labrador where they feed on the erowberries and become exceedingly fat. From this place they pass to and across Nova Seotia whence they take wing and, if the weather is good, pass directly over the ocean to the Lesser Antilles, and to the northeastern coast of South America. Only stormy weather at sea will cause the species to tonch on the Atlantic coast of the United States and then only in the vieinity of New England. Reaching South America, they pass southward into the pampas region of Argentina where they spend the winter. In the spring the flocks move northward and after reaching the United States traverse the entire length of the Mississippi Valley. Thence they move on through Canada to their breeding grounds in the extreme north. Cooke (1910, p. 81), who has worked out the above described ronte of migration, advances the following theory to account for it:

The plover is a bird of treeless regions; it summers on the tumlras and winters on the pampas; an ellormous food supply especially palatable tempts it in the fall to Labrador and furnishes power for the long flight to South America. To attempt to return in spring by the same course would be suicidal, for at that season Labrarlor would furnish seant proveniler. The plover seeks the shortest treeless route overland, and alighting on the coast of Texas travels leisurely over the Mississipui Valley prairies, which are ahumlantly supplied with fook, to the plains of the Saskatchewan and thence to the Aretic coast. 
According to this interpretation, the extraorlinary wanderings of this birt are determined by the factor of food supply.

The Golden Plover feeds upon inseets of various sorts sueh as beetles, eriekuts, grasshoppers, entworms, and some regetable matter (Forbush. 1912, p. 347). In Labrador as before stated, it feeds extensively on crowberies. To the sportsman it is an ideal game species, decoving rather readily, but becoming wary after its suspicions have been aroused. Its flesh is exceedingly palatable and highly prized for the table. The result is that the speeies has been hunted persistently by both sportsman and market hunter, wherever it is found, and eonsequently has greatly decreased in numbers during reeent years. Forbush (1912, pp. 344-347) estimated a 90 per eent decrease on the New England eoast in fifteen years.

Unfortunately the Golden Plover is, and probably always has been, a rare speeies in California: and there is no reason to hope that its numbers here will inerease in the future. It is of immediate interest here only to the scientist and nature-lover. Reports of straggling visitors among our lesser known birds are always of value and should be sent in promptly with full particulars to some seientific institution.

\section{Killdeer}

Oryechus zociferus vociferus (Limnaeus)

OTHER XAMES-Killteer Plover; Killlee; Aegialitis vocifera; Charadrius vociferis.

Description-Alults, both sexes, at all seasons: Top of hear and upper sur face (including siles of breast between two black neck bands) dull brown, with more or less rusty feather-tipping; lower foreheal ("brow"), and stripe above and behind eye, white; stripe from side of bill along each side of hearl to below eve, including ear region, blackish brown; upper part of foreheal black, forming a bar from eye to eye just above the white "hrow'; bill black; iris dark brown, edges of eyelids orange-red; rump and upper tail coverts light rusty brown, or tawny; tail feathers white at extreme bases, the middle ones shading through dull brown to black and ending in light brown; rest of tail feathers berond white bases pale rusty with black subterminal bars and conspicuous tips of white on outermost feathers, and rusty on inner ones; outer surface of closerl wing chiefly like back; flight feathers blackish brown, marked with white on inner webs and near tips; tips of greater coverts and portions of secondaries white, forming a conspicuous bar on expanded wing; axillars and lining of wing white, under surface of flight feathers chiefly rlusky; foreneck and breast crossed by two black bands, separated in front by white (which is usually tingerl with pale brown); the lower black band and the white area between both blend on sides into the dull brown of the back; the upper and broarler black band completely encircles the neck; chin and throat and collar around hind neck above broad black band continuously pure white; rest of under surface of boly white; longer under tail coverts white, spotted with light 
brown; feet and legs dull greenish yellow, dusky at joints. Males: Total length 9.50-10.50 inches (241-267 mm.) (eight specimens); folded wing 6.00-6.50 (152165): bill along eulmen $0.68-0.84$ (17.3-21.3); tarsus $1.32-1.43$ (33.5-36.3) (ten specimens); weight 3 oz. ( $85.5 \mathrm{gm}$.$) (one specimen). Females: Total length$ $10.25-10.50$ (260-267) (five specimens); folded wing 5.97-6.40 (151-162); bill along culmen $0.75-0.83$ (19.0-21.1); tarsus $1.34-1.43$ (34.0-36.3) (seven specimens); all from California. Juvenile plumage: Similar to that of adult, but with black markings on head and neck duller or replaced by dark brown, and feathers of upper surface more extensively tipped with light rusty brown; wisps of natal down often remain adhering to tips of tail feathers. Natal plumage: Lower forehead, chin and throat, and lower surface of boly, white; top of head and upper surface (excepting neck band) mixed light brownish and blackish, sharply ontlined all around by black borders; stripes before and behind eye, single band across throat (complete around neck), and stripe down middle of back, black; white on chin and throat continuous with white collar around hind neck, the latter separating black outlines of crown and back; flanks and area about vent pale rusty; bill blackish; iris brownish; feet more rellowish than in adult.

MARKS FOR FIELD IDENTIFICATION-Moderate size, two black bands across chest, white collar around hind neck, white bar across wing, tawny rump pateh, and white tipped, black banded tail. The shrill call, kill-dee, is distinctive. This is our only shore bird with two black bands across breast.

ToICE-Usually a lond, high-pitched, two-syllabled kill-deer. or hill-dee, rapidly enunciated; oceasionally, as when flushed excitedly from ground, it becomes kill-dee, dee, dee, dec-ey; also when running along ground in alvance of an observer, a softer de-e-e-e-e-et is sometimes uttered.

NEST-On ground, usually near water, in grass or on bare, sandy or pebbly area; a shallow depression with or without a sparse lining of short, dry grass blades, weed stalks, pebbles, or bits of hardened earth.

Eggs-Usually 4, pear-shaped, measuring in inches, 1.46 to 1.56 by 1.02 to 1.10 (in millimeters, 37.0 to 39.5 by 26.0 to 28.0 ), and averaging 1.51 by 1.06 (38.2 by 26.8); ground color light clay or dull eream with bold markings of dark brown, black and dull laventer (four sets, 15 eggs, from California).

General Distribution-North and South America. Breeds from central British Columbia, southern Mackenzie, central Keewatin, and central Quebec, south throngliout the whole United States, and in Mexico to latitude of southern Lower California. Winters from New Jersey, Indiana, Texas, Arizona and central California south to Venezuela and Peru in South America (modified from A. O. U. Check-list, 1910, p. 128).

Distribution in CALIFORNiA-Abundant summer visitant to suitable loealities throughout the state, chiefly in the lowlands, but ranging locally up high in the mountains, even to 8,600 feet altitucle (as on Tuolumne Mearlows. Yosemite National Park). Winters in the valleys west of the Sierras from about the latiturle of San Francisco southward, and, more rarely, east of the Sierras from Owens Valley southwart.

The Killteer is one of the commonest, most widely distributed, and perhaps the best known of all our shore birds. In the East it has been considerably rednced in numbers, hut in the West it has held its place and numbers despite the encroachments of civilization. In the northern half of California the species is chiefly a summer sojourner, 
as there are rery few winter records, but it arrives there early in the spring. From the latitude of San Franciseo southward it is a permanrnt resident in most localities. In smmmer it ranges up in the Sierras to as high as Tnolumne Mradows, Yosemite National Park, altitude 8,600 feet, on the west slope, and to Lake Tahoe, 6,000 feet, and to the head of Owens River, 8,000 fret, on the east slope. In southern California it has been found at Bear Lake, San Bernardino Mountains, at an altitude of nearly 7,000 feet. East of the Sierras it is rhiefly a summer visitant. Numerous records establish it as a breeding species throughout its summer range.

Th. Fildeer is a bird of fresh and brackish water rather than of the salt marsh or seacoast; yct oceasionally it resorts to both of the latter types of country. No hard and fast rule for its oceurener can he laid down, save that it much prefer's fresh water, especially such as is provided along the shores of inland ponds or streams. Fven the seanty sepage water in the bed of an otherwise dry arroyo inill satisfy the neerls of one or more pairs of these birds. While not of solitary habit, the Killdeer is not a typical flocking birel. When flocks do occur, they rarely number more than about thirty members, and their actions

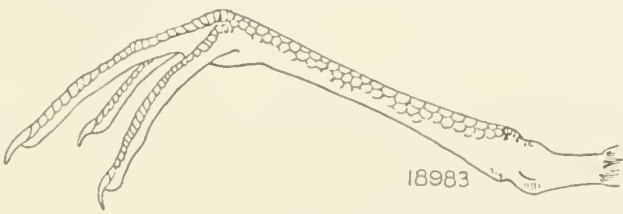

Fig. 77. Sile of tarsus anil foot of Kill deer. Natural size.

Note absence of hind toe, as with all our Plovers except the Black-bellied (compare with figs. 69 and 76 ).

are individual lather than aggregate. In this respeet they differ from some sandpipers, beeause each member pursues a separate course when foraging, in flight, or when danger threatens. Small groups of half a dozen individuals are of most common oeeurrenee. Of course, the breeding season finds the birds in pairs, and more or less sequestered. In the East, and to some extent in California, the Killdeer scatters out over eultivated fields and searehes for inseets or worms. The alfalfa raising districts, of increasing extent in California, evidently offer to this bird the best of forage faeilities.

Of all the shore birds the Killdeer is the easiest to identify. A front view while it is at rest on the ground reveals four transverse blaek bands, two on the head and two on the breast; a side view shows a distinet white collar set off by adjacent black. In flight the ehief eolor markings are the white streak across each wing, the black-banded, white-tipped tail, the tawny rump pateh, and the pure white under surface. The oft-repeated eall, which is uttered in an insistent, eomplaining tone, is by far the best distinguishing eharacter, and when onee learned obviates the neeessity of using other clues. When the 
birds are not frightened the call sounds like til-dee, or kill-deé; but when startled, as by the approach of a human being, the call becomes til-dé-o, or til-de-dé-o, and has a quavering character especially in the initial syllable. After the birds have flown about for some time they resume the call first represented. The eall is usually uttered while the bird is on the wing, but may also be given from the gromnd. The Spanish rendering of the ordinary call is tildeo. Another call, althongh high-pitched, is not so lond and is sometimes given as the bird runs along the ground in front of a person. It may be written $d e-e-e-c-c-e t$.

The Killdeer passes much of its time on the ground, and is able to run with rapidity. It does not, however, maintain a continuous advance, but stops every few feet, for a moment of rigid pose. The body is then tilted slightly forward, the head being held erect. In ruming the head is drawn in and held low, as if to avoid display of the contrasted collar markings. Sonetimes individuals will rm about with wings upstretched, dodging among their companions and uttering a rapid torrent of high-pitehed notes. On the extensive lawns at Stanford University as many as sixty Killdeer have been comnted at one time seattered about foraging silently on the grass or basking beneath the spray of the many sprinklers.

Hunters eomplain that the Killdeer is a great nuisance, as it often flies to meet them, eircling about and uttering its high-pitehed complaining eries which serve as an effective warning to other birds. At all seasons Killdeer aet as if they had nests, and rum before the intruder, apparently trying to excite pity by their melancholy notes and to lure him away from an imaginary object of solicitude. They visit some river bar or lake shore at night and morning to drink and feed and play. Thus there may be a regular flight of Killdeer two or more times a day between the fields and the water. They are greatly given to traveling at night, and their nmmistakable notes often reach the traveler's ear on dark or foggy nights from far overhead, sometimes in the most unexpected localities far from water.

The Killdeer nests in a variety of locations ranging from marsh land to enltivated meadows and dry ereek beds. One ease is on record of eggs being deposited in the middle of a railroad track (Chambers, 1901, p. 105). There are numerous records of Killdeer nesting in moadows and gardens, or in furrows in newly plowed ground, the latter practice in many cases resulting in the eggs being destroyed.

Normally the speeies nests from the latter part of Warch to late June. Although the breeding season thus appears to be extensive, it is doubtful whether more than one brood is reared in a season by any one pair of birds. There is little or no correlation between nesting dates and latitute, as those from San Diego and Lake Tahoe are 
practically the same, the intervening area being noted for early records. Beck (IS) found a nest with two eggs near Los Baños, Merced C'omnty, March 11, 1912. Tyler (1913b. p. 32) records nesting in the Fresno district from March 15 to June 28, and gives one casc of early nesting which would indieate the eommencement of incubation in late February or very early March. The set of two here recorded is quite unusual, and suggests by its rarity that it may not have been complete. "A typical nest throughout the cultivated sections [in the vicinity of Fresno] is composed of a handful of white pebbles about the size of peas and very uniform in size, mixed with an almost equal numbre of dry shells of melon seeds of the previous year. Frequently a few dry, broken-up pieces of melon stems are used also, the whole being spread out over a space the size of a sancer, with the eggs resting in the center. As the result of eoming in contact with a sharp rock that sometimes finds it way into the nest in place of the usual smooth ones the eggs occasionally show small gravel punctures. On the summer-fallow fields only a few dry grass blades line the place where the eggs rest, while around the ponds of the west side the eggs generally lie half covered in the powdered alkali dust without a scrap of nest lining" (Tyler, loc. cit.).

The eggs usually number four, and never more, so far as is known. Sets of smaller number may result from aceidents of various kinds. The ground-color is a light clay or pale dull cream; the superficial markings are numerous and dull dark brown or even blaek, while the deeper ones are dull lavender and less abundant than the superficial ones. The markings consist both of irregular spots and narrow streaks, and in general are more numerous at the larger end, sometimes resulting in the formation of a dark zone about that end. The eggs average in size $1.51 \mathrm{by} 1.05$ inches. On the basis of size alone, the eggs of the Killdeer can be confounded with the eggs of no other shore bird breeding in California, except those of the Wilson Snipe. The much lighter' ground-color would be sufficient in this case, however, to distinguish the eggs of the Killdeer. Tyler (loc. cit.) intimates that the period of incubation is a little over two weeks.

The newly hatched Killdeer are able to run and hide almost on leaving the shell. The color pattern of the back is of excellent service in eoncealing the young birds whether in motion or squatting motionless on the ground. Few little chicks have more devoted parents. The old birds exhaust every resource to lead an enemy far away from the nesting site. The two sexes are equally solicitous concerning the welfare of the eggs or young, and it is probable that they share alike the duties of incubation. There is no means known to us of distinguishing the sexes in the field either by color-marks or behavior. The ineubating bird leaves the nest far in advance of the human 
intruder, insteacl of flushing close at hand, as in the case of less strikingly eolored species. It would appear as though the Killdeer in its combination of conspicuous pattern of coloration and blatant behavior shows a peculiar specialization for distracting attention from its eggs and young.

'The first plumage, of down, is gradually replaced by a juvenile plumage closely similar to that of adults; but shreds of down often remain adhering to the tips of the tail feathers until late fall. The juvenile plumage is retained by the Killdeer through the first winter and on into the spring of the year following that in which it was born. In the fall the young can be distinguished from the adults by the frequent adherence of down to the tips of the juvenile feathers, as just described, by a slightly more rusty tipping of the feathers of the back, and by the white of the neck collar in front being suffused with light brown.

The flight of the Killdeer is quite erratic: the bird frequently dips and dives in a most bewildering mamer, sometimes descending headlong nearly to the ground in almost vertical flight. As already stated, flocks of Killdeer do not show the same compact formation nor do the birds move together in unison as in the ease of many other shore birds.

The Killdeer is, without a doubt, from an agricultural standpoint the most beneficial of our shore birds. This valuation rests upon the nature of its food and upon the eommonness of its oceurrence on cultivated lands. According to McAtee and Beal (1912, pp. 16-18), beetles form 37.06 per cent of its food, other insects 39.54 per cent, and other invertebrates such as centipedes, spiders, ticks, oyster worms (Nercis), earthworms, snails, and erabs and other crustaceans, 21.12 per cent. Some of this food is obtained by probing in muddy places as with other plovers, lout the greater portion of the food is seemed by surface-gleaning. Tegetable matter constitutes only 2.28 per cent of the food and is made up chiefly of weed seeds. Tery many of the species of insects forming the diet of the Killdeer such as grasshoppers, weevils, wireworms, and army worms, are classed as important enemies of various crops. During a plague of grasshoppers in the summer of 1912 at Los Baños, Mereed County, H. C. Bryant (1914a, p. 170) found a single Killdeer's stomach to contain eleven grasshoppers and nothing else.

While it is possible that the Killdeer was a more abundant species in past years than at present, it is obvions that it has not shared with other shore birds the decided dimimution in numbers which they have suffered. The species is abundant in a great many localities in the state, and, with the present farorable attitude on the part of most farmers, will probably continue so inclefinitely. Its wide breeding 
lange is also a farorable element in its maintenance, and we mar cren look to an increase in aggregate numbers. It was formerly recognized to a small extent as a game species, and even sometimes shot as a nuisance by the hunter when stalking game. However, we see no reason why the Killdeer should for a moment be considered a game bird. Its small size and the fact that its flesh is not of the best, being deseribed as fishy or musky in flavor, argue that it had far better be classed among those species which are of marked value to the agriculturalist.

\section{Semipalmated Plover}

\section{Acgiulitis srmipalmatu (Bonaparte)}

OTHER XAses-Semipalmated Ring l'lover; Ring Plover: Acgialeus semipalmatus.

DESCRIPTION- Arlult male: stripe across forehead at base of bill, continuing hackwarls below eye to exprunl somewhat on ear region, blark; bancl aeross milllle of foreheal, white, surmounted ly a broarler trausverse band of black across forepart of crown between eyes; spot on lower eyelid, white; back of heal. brown; chin and whole throat broadly jure white; hind neck crosserl by a white collar connected with white of throat, and below this by a black one continuous witl black chest banel; iris brown; bill orange at base, black on terunal half: upler surface of holy, ucarly uniform brown; outermost upper tail coverts chiefly white: tail feathers brown with tips of inner ones blackish, tips of next outer ones blarkish subterminally with increasing amounts of white, and the outermost pair pure white; outer surface of closed wing brown like back; greater coverts tipped with white, this, together with small white areas on inner llight feathers, forming a narrow bar on expauded wing; flight feathers and primary coverts blackish brown; quills of primaries white on their middle portions; margin of wing mottled white and light brown; lining of wing, chiefly white; axillars, pure white; under surface of flight feathers light drab: whole uniler surface of body white, save for conspicuous single black band across upper chest which joins the narrower one on hind neck forming a complete collar; legs and feet orange. Adult female: Like adult male, but with black bands narrower and brown tinged. Males: Total length 6.878.05 inches $(174-204 \mathrm{~mm}$.) (six specimens from California); folled wing $4.51-$ 4.90 (114.5-124.3); bill along culmen $0.46-0.50$ (11.6-12.7); tarsus $0.89-0.97$ (22.5-24.7) (ten specimeus from Califoruia and Alaska). Females: Total length 6.94-7.57 (176-200) (seren speeimens from California); folded wing 4.43-4.92 (112.7-124.7); bill along eulmen 0.43-0.50 (11.0-12.6); tarsus 0.87-0.96 (22.224.3) (ten specimens from California and Alaska). Juvenile plumage: Like that of adults but with black bands all replaced by dark brown ones, chest band narrowed near mid-line, and feathers of entire upper surface narrowly tipped with pale buffy, giving a faintly scaled appearance. Natal plumage: Top and sirkes of head and whole upper surface of borly (except hind neck) mixed black, yellowish and whitish buff, in fine pattern; broarl collar on neck. white, preceded by a narrow black band at edge of mottled pattern on head: spot between bill and eye, black; whole under surface white; bill black; legs and feet (dried) yellowish brown; nails dusky. 
MARKS FOR FIELD IDENTIFICATION-Small size (much smaller than that of Killdeer), single black or dark brown band across chest, and a white one (black- or brown-bordered) across brow, extremely short bill (much shorter than head), and uniform brown upper surface. Distiuguished from Killdeer by much smaller size, single black or brown breast band, and absence of tawny on rump; from Snowy Plover by larger size, complete band across breast, and absence of dark band from bill to eye; and from Wilson Plover (which is extremely rare iu California) by much shorter bill, orange-colored at base instead of wholly black, and by presence of black on forehear at base of bill.

Volce-A simple sweet plaintive chee-uee (Forbush, 1912, p. 352).

Nest-On pehbly or sandy shores or in short grass, usually but a slight distance from water; a mere depression lined sparingly with leaves and grasses (Macoun and Macoun, 1909, 1. 207; and authors).

EgGs-Usually 4, pear-shaped, measuring in inches, 1.20 to 1.40 by 0.90 to 1.00 (30.5 to 35.5 by 22.8 to 25.4); ground color drab or buff, superficial markings blackish brown, rather few in number and scattered; deeper ones of purplish slate (Baird, Brewer and Ridgway, 1884, I, p. 157; Davie, 1900, p. 155).

General distribution-North and Sonth America. Breeds from Melville Island, Wellington Channel, and Cumberland Sound to valley of the Upper Yukon, southern Mackenzie, southern Keewatin, and Gulf of St. Lawrence; winters from southern California, Lonisiana, and South Carolina, to Patagonia, Chile and the Galapagos Islands; common in migration along Pacific coast and from Nebraska and eastern Texas to the Atlantic coast (modified from A. O. U. Check-list, 1910, p. 128; Cooke, 1910, pp. 8S-90).

Distribution IN CALIFornia-Fairly common spring and fall migrant coastwise, occurring rarely inland. Spring migration chiefly during the latter half of April and first half of May. Fall migration from late August to midile of October. There are two oll records of winter occurrence in southern California.

The Semipalmated Plover is a common migrant along the coast of California. Differing from its nearest relatives, the Killdeer and Snowy Plover, in choosing a more northern nesting ground and a more southern winter home, it spends but limited parts of the year in California and is consequently less known to bird students or hunters in this state. The northward migration commences about April 10 in sonthern California and lasts mntil about the middle of May (Willett, $1912 a$, p. 40). The earliest spring record other than that just given is April 15, 1908 (specimen in Willett coll.), and the latest normal ocenrrence May 16, 1910, at Santa Barbara (Bowles and Howell, 1912, p. 11). Willett (loc. eit.) saw five birds and secured one at Alamitos Bay, Los Angeles County, June 29, 1907. The disposition of this record as concerning spring or fall transients is not now possible.

Southbound birds were first noted at Santa Barbara, July 12, 1910 (Bowles and Howell, loc. cit.), but the species does not become abundant until almost two months later. Along the sonthern coast the migration ocenrs from the midnle of September until about October 10 (Willett, loc. cit.). A specimen was taken at San Pedro, Los Angeles County, October 17, 1894 (Grinnell, 1898, p. 18), and 
it has been reported from Santa Barbara as late as November 1, 1911 (Bowles ancl Howell, loce eit.). Belding (MIS) states that it was tolerably common at sim Diego in winter (year not stated, but probably 1884 or 1855), and ('ooper (1887. p. 91) found it on the coast of Ventura ('ounty "in winter" : but no reeent observer has reported the species from any California locality dnomg the midwinter months. Four instanees of ocemrence away from the seacoast are known, all in the scasons of migration: Webber lake, Sierra Comnty, Angust 5, 1889 (Belding, MS) ; near Caruthers, Fresno Countr, April 21, 1914 (Tyler, MS) ; Salton Sea, Imperial Connty, April 22, 1909 (specimens in Mus. Vert. Zool.) ; and Julian, San Diego ('ounty, April 16, 1884 (Belding, MS). The northermmost coastwise reeord is Bodega Bay, Sonoma Comnty (Bulding, IIS).

From other shore birels occurring in California the semipalmated Plover is easy to distinguish. Its small size, mniform brown-eolored upper surface at all times of the year, the single eouspicuons black or dark brown breast band, black or brown bordered white banel across brow, and extremely short bill, combine to make identification easy. The Killderer differs in its mmeh larger size, two black breast bands, tawny rump, and longer bill; and the Snowy Plover in its slightly smaller size, lighter upper surface, and in the lack of a complete black collar. The Semipalmated Plover differs from the Wilson Plover in having a shorter hill, orange at the hase insteal of wholly black, in having the white brow separated from the bill by black or dark brown, and in the possession of a complete black collar aromd its hind neck. Its very short bill and the presence of a black or brown collar, as well as its small size, distinguish the Semipalmated Plover from the Mountain Plover. The name Ring Plover has been often used for the Semipalmated, with evident propriety : but there is a decidedly different species belonging to Europe and eastern North Ameriea to which this name has been affixed by common usage. The term "semipalmated" refer's to the half webbing of the toes, a feature to be noted with a fresh bird in hand, and distinguishing this species from any other of our plover's.

In California the Semipalmated Plover is most eommon along the shores of the ocean and larger bays. It seems to be equally at home on sandy beaches and on the mud flats of estuaries. Unless too greatly harassed the birds are exeeedingly tame and will allow one to approach very elosely. They may be found singly, in pairs, in small groups of five or ten, or in flocks of forty to fifty ; the companies may either consist entirely of their own kind, or include other small shore birds. When a flock alights on the feeding ground the individuals eomprising it seatter out at considerable distances from one another and theneeforth aet with perfeet independence. Each runs for a short 
distance with such rapid foot movement and even earriage of the body that it seems to fairly glicle over the surface of the sand; then it stops abruptly to dab slantingly into the wet sand for morsels of food. Gromed worked over in this mamner shows a multitude of bill marks. The movements of the birds are, as compared with those of sandpipers, more deliberate; now and then an individual momentarily dips its fore parts, a mannerism shared among several of the plovers. Ordinarily when the bircls are scattered out over a feeding ground they are oblivious to one another's presenee; but, should danger threaten, the signal of one sets all on guard. As they take wing the members of a flock bmneh quickly together and fly off, rapidly, in elose formation, with numerous ntteranees of their clear, two-syllabled call-note. The Semipalmated Plover differs from the Killdeer in being mueh quicter, more gregarious, and in showing a decided preference for maritime forage grounds.

Unlike its near relatives, the Killeer and Snowy Plover, the Semipalunated Plover has seleeted the far north for its breeding ground. Authentic instances of nesting involve the region lying from the Gulf of St. Lawrence northwest to Fort Yukon, Alaska, and north to Melville Island. In this territory, eggs have been taken from June 2 (1862) to June 21 (1875) (Cooke, 1910, p. 90), while eggs just hatehed were seenred July 6, 1899 (Bishop, 1900, p. 70). The nest seems to be usually loeated on sandy or pebbly shores, or in short grass, and in any instance but a short distance from water. It is often a mere shallow depression in the surface withont lining of any sort; at other times a sparse layer of grasses or leaves is provided for the eggs to rest npon. The eggs are usually four in number and measure in inches. 1.20 to 1.40 by 0.90 to 1.00 . The ground eolor is light drab or buff, with rather sparse and seattered superficial markings of blackish brown, and deeper ones of purplisin slate (Baird, Brewer and Ridgway, 1884, I, p. 157 ; IJacoun and Macomn, 1909, p. 207 ; Davie. 1900, p. 155). The Semipalmated Plover seems to be less demonstrative than many others of its kind, although some attention may be paid to an intruder when he first approaches the nest. MacFarlane (1891, p. 430) says of the birls seen in Aretic Aneriea: "When elosely approached, the female usually glided from her nest and ran a short distance before flying, oceasionally drooping her wings and pretending lameness."

Bishop (1900, p. 70) reeords the finding of a pipped egg at Lake Marsh, in southern Yukon Territory, July 2, 1899. He says: "I removed the romng bird from the shell, and within half an hour the down was almost dry, the eyes were open, and it eonld hop about on its "knees'." Bare areas on the slin of the under' side of the body in both parent birds showed that the duties of ineubation are shared hy the two sexes. 
"Its food on the coast consists largely of small erustacea, mollusks, eggs of marine animals, and insects, which it sometimes gleans from ploughed finds. In the interior it feeds on locusts, other Orthoptera, and many other ter'estrial insects" (Forbush, 1912, p. 353).

The Semipalmated Plover is an nnobtrusive member of the great group of shore birds. It occurs in but limited numbers in California and only or chiefly during the migrations, even then rarely away from the ocean. In consequence, it is of indifferent vahne agriculturally. Being of small size and not too good flavor, it seems hardly proper to class it as a game species either. As it is of little import eeonomically, we have left only its esthetic value: the scurrying crowds of plover, advancing and retreating with the surf, constitute an agreeable feature of the seashore scene.

\section{Snowy Plover}

\section{Acyialitis nivosa Cassin}

Other XAMEs-Kentish Plover; Aegialitis alexandrina nivosa; Aegialitis cantiana: Aegialites cantianus nivosus; Charadrius cantianus; Churadrius cantianus nivosus.

DESCRIPTON-Adult male, in spring and summer: Forehead, stripe over eye, collar around hind neck, and whole chin, throat and foreneck, pure white; narrow area from sile of bill to eye, flecked with blackish; band across forepart of crown hetween eyes, and ear region, abruptly black; top and back of liead clay color; bill blackish; iris dark brown; whole back, rump, mirlde upper. tail coverts, and onter surface of closed wing, drab, with faint feather tippings of pale ashy; outermost upper tail coverts, white; tail blackish brown toward tips of millle feathers, lighter, or drab, toward bases and on terminal portions of next outer feathers, the outermost ones pure white; tips of inner primary coverts, of greater coverts (more broadly), and middle portions of secondaries, white, forming a bar on expanded wing; primaries blackish brown, shafts chiefly white; margin and lining of wing, and axillar's, white; unter surface of flight feathers silvery drab; whole under surface of boty white, continuons with that of lower side of head; patch on each side of breast near bend of folled wing, abruptly black; feet dusky. Adult female, in spring and summer: Similar to arult male, but top and back of head drab like back, with little or no clay color, and dark markings on head and sides of breast more restricted, less intensely black, even brownish in color. Adults and immatures, both sexes, in fall and winter: Like adults in summer, save that black or dark brown markings on hear and siles of breast are ashy brown, or drab, of same tone as upper surface or but slightly darker; top of head in both sexes like back. Males: Total length 6.00-7.40 inches (152-188 mm.) (ten specimens); folded wing $3.95-4.18$ $(100.3-106.0)$; bill along culmen $0.52-0.60$ (13.2-15.3); tarsus $0.92-0.98$ (23.425.0) (ten specimens). Females: Total length 6.10-7.00 (155-178) (ten specimens); folled wing 3.76-4.14 (95.5-105.3); bill along enlmen 0.52-0.58 (13.314.8 ) : tarsus $0.92-1.00$ (23.5-25.5) (ten specimens); all from California. Juvenile plumage: Like that of summer adnlt, save that black or brown markings are replaced by drab, like whole upper surface; feathers of upper surface, including 
outer surface of "losed wing, with tippings of ashy white or pale buffy. Natal plumage: Top of head and upjer surface of horly coarsely mottled with black on a buffy white ground; stripe behiml eye black; foreleaı, eheeks, chin and whole under surfare of boly, dull white; bill dusky, pale at tip; legs and feet (dried) dull yellow, claws dusky.

MARKS FOR FIELD IDENTIFICATION-Very small size (smallest of the Plovers and but slightly larger than our smallest shore bird, the Least Samupiper), chunky appearance, short, rather thick bill, white collar alound neck, pure white moler surface, anil dark patrlies on siles of breast (pl. 12). In flight shows white on side of rump and inconspicuous streak on wing.

ToIce-A low guttural trilling or quavering er-r-r-r or pe-e-e-et; in the nesting season relatively loun remonstrative eries are nttered as the nest is approached by an intruter.

NEST-On samrly beaehes of the seacoast and oceasionally on shores of inlant bodies of water; a slight surface depression about two and one-half inehes $(63.5 \mathrm{~mm}$.) in diameter anil one inch $(25.4 \mathrm{~mm}$.) deep, sometimes linel with a few bits of drift naterial, oceasionally with pieces of bright shell.

Egas-2 to 3 , ovate, measuring in inches, 1.15 to $1.22 \mathrm{by} 0.57$ to 0.91 (in millimeters, 29.2 to 31.0 by 22.1 to 23.2 ), and averaging 1.19 by 0.59 (30.2 by 22.7) (three sets, seven eggs, from California): groma color pale buff or eream: superfieial markings brownish black, deeper ones pale grav: markings consist of small spots, elongated streaks, or short serawls, rarely over 0.10 inelies in length; but slightly more numerous about larger eni.

GENERAL Distribition-Southwestern Uniter States to South America. Breels from northern California, northern Utah, and southern Kansas south to northern Lower California and southern Texas; winters from southern California and Texas, south along both eoasts of Mexico and Central America, and on west coast of South Ameriea to Chile (morlifier from A. O. U. Checklist, $1910, \mathrm{p} .129$ ).

Distribution IN CAIIfORNIA-Common resident coastwise, sparingly so in the interior: most numerous in coastal district of southern portion of the state and on aljacent islands; breeds locally along the coast from San Diego at least as far north as Eureka, Humboldt County, and inland at Buena Vista Lake, Kern County. Winters coastwise at least as far north as San Franeisco, lut most abundantly from Santa Barbara southeastward; has oceurred Auring the same season at Owens Lake.

The Snowy Plover is, as regards general distribution, a notably southern species and also the most restrieted in range of the several plovers neemring regularly in California. Indeed, as regards its nesting gromds, it is essentially a bird of the sonthwestern Tnited States. In California it breeds almost exelusively on the seacoast, though in some ofher western states it nests on inland bodies of water. In this respect it is eomplementary to the Killdeer, as the latter bird rarely if ever nests along salt water and usually away from the shores of large lakes or rivers.

Snow Plover are present in many localities in California throughout the year, but there may be a eertain amount of north and south migration; so that as regards certain loealities the birds seen in winter and summer may be different individuals. At Santa Barbara, aceord- 
ing to Bowles and Howell (1912, p. 11) the Snowy Plover, although resident, angments in numbers about the middle of December', when flocks of fifty or more may be seen. In the vieinity of San Francisco the latest known occurrence is November 8, 1889 (specimen in Mus. Vert. Zool.), and as there are no reeords from the San Joaquin-Sacramento Valley in winter it may be that the species leaves the northern half of the state altogether during that season. Numerous instances of occurrence in winter, from the vicinity of Monterey southward, proclaim the species as present thronghout the year on the coast from that point to San Diego. Inland it has been recorded about the shores of Salton Sea, Riverside and Imperial counties, during the spring (March 29, 1908, to May 1, 1909) (Mus. Vert. Zool.) ; at Owens Lake, December 27, 1890, and May 30 to June 4, 1891 (A. K. Fisher, 1893a, pp. 25-26); at Buena Vista Lake, Kern County, June 2, 1907 (Linton, 1908c. r. 197); at Los Baños, Mereed County, April 22, 1912, to May 17. 191t (Mns. Yert. Zool.), and at Goose Lake, Modoe County, in June, 1912 (Dawson, 1916, p. 26). On beaches where the species nests, pairs of Snowy Plover are found to freqnent during the spring or summer comparatively restricted areas and not very many will be fonnd together at any one time; but when foraging on shores where they are not known to nest, as in the early fall when the young of the year are wandering about in search of food, they oceur in flocks $11 \mathrm{~mm}$ bering up to fifty individuals.

The Snowy Plover is readily distinguished from most other shore birds occurring in California, by its very small size (total length 6.00-7.00 inches). It is but slightly larger than our smallest shore bircl, the Least Sandpiper. The chunky appearance, short, thick bill (whieh is shorter than the head), white collar aromd hind neek, uniform pale drab upper surface, pure white under surface, and conspicuous dark brown or black patches at the sides of the breast, are all iseful as aids to recognition (pl. 12). From the Killdeer, and the Semipalmated and Wilson plovers, the Snowy is distinguished by its laek of complete black or dark brown breast band and by its smaller size, and from the Least and Western sandpipers, and from the Sanderling, by its white collar around hind neck, and by the dark patches at the sides of its chest; and, in spring, from the last three named birds, by the absence of mixed coloration on its upper surface.

Snowy Plover are exceptionally quiet birds; but at times a low guttural trilling note, $c r^{-r}-r^{r}-r$ or $p e-e-e-e t$, may be given, and when the vicinity of the nest is invaded the birds give utterance to relatively loud eries.

Sandy seabeaches constitute the preferred habitat of this species, and it is rarely found elsewhere. It frequents as a rule the higher portions of the beach, but may also forage on the wet sand, sometimes 
even at the edge of the waves. Often areas of considerable extent are "plowed up" by these birds in their active probing for the sandinhabiting erustacea and worms which constitute their food. When searehing for food they move about a great deal, with a distinet trot, and on oceasion liave been seen to hop along on one leg as Torrey has observed Sanderlings to do at Santa Barbara. Their morements are rapid and their strides exceedingly long. At Netarts Bay, Oregon, Jewett (1914, pp. 114-115) says that when running fast the strides of one of these birds proved to measure six inches. One of the birds will start, run three or four feet, and stop suddenly, the whole performance oeenpying but a second or two. There is an abrupt upward tilt of the body at intervals, and with the return movement the quavering note is often uttered. In flight the birds may travel in open formation, or closely massed, and the flight may he either direet, or in zigzag eourse as with the small sandpipers. Both in flight, and on the ground, their chunky appearance helps to distinguish them from the small sandpipers. They are quite tame and will usually permit a elose approaeh, preferring apparently to trot along in front of the observer, or off to one side, rather than to take wing:

Torrey (1913, pp. 10-11) says of the Snowy Plover at Santa Barbara:

Every day they are here, and every day it is a pleasure to wateh them; now running about or standing at rest on the gray, dry sand-too close a match in color for even a hawk's eyes, one would think; now squatting singly, here, there, and yonder, in the footprints of horses, hardly more than a head showing, one of their prettiest tricks-you may sometimes see fifty at once cradled in this cozy fashion, for shelter against the wind, or by way of a more comfortable siesta, or, possibly, as affording a measure of concealment; and now seattered in loose order along the edge of the surf, picking up the day's rations. An extraordinarily light repast this would seem to be, or, . . one very easily gathered, seeing how small a share of the day they spent mpon it. Nine times in ten you will find them doing nothing, in what looks like a reposeful after-dinner mood, strikingly unlike the behavior of the common run of birds. ...

As is true of plovers in general, the snowy . . is amazingly sulden and spry in its motions, a sprinter of the first rank, starting at full speer. and scampering before you, hear down, till its legs fairly twinkle, ther more so almost invisibly fast. ...

As a lesult, perhaps, of the temperate elimate of its breeding range the nesting season of the Snowy Plover is very long as compared with those of our other shore birds. Chambers took a set of three eggs well advaneed in inenbation at Ballona, Los Angeles C'omnty, April 15, 1907 (Willett, 1912 , p. 40), and Robertson (1 \$.99, p. 94) records a set far advanced in ineubation at Redondo, Los Angeles County, April 25, 1899. Thompson (1901b. p. 17) reports three serts at Morro, San Tuis Obispo County, August 1 (1900?), all 
of which would have hatclied in a day or two; while Chambers (Willett, loe. cit.) found a single fresh egg at Ballona, August 2, 1903. Extra high tides doubtless destroy many eggs, and this may aceount in part for the prolongation of the nesting season, through repeated egglaying. Willett (loc. eit.) states that in southern California the eggs are usually deposited between May 1 and June 15. From Monterey northward to IImmboldt Bay dates of nesting range from April 16 (Cooke, 1910, p. 93) to Jume 21 (Mailliard coll.).

'The Snowy Plover has been reported nesting at various points along the California seacoast from Eureka, Immboldt County (sets in Mailliard coll.), on the north, to Paeific Beach. San Diego County (Ingersoll, 1895), p. 87) on the south: and it may he expeeted to nest in suitable localities, namely sandy beaches sufficiontly broad and high to live dry upper portions, along our whole neean shore. It lias nested in large numbers on San Francisco Buy at Alvarado, Alameda County (Reynolds, MS'), and onee at Buma Tista Lake, Kern County (Linton, 1908c. p. 197): while A. K. Fisher (1893a, p). 25-26) thinks that the species breeds at Owens Iake, and Dawson (1916, p. 26) surmised the same for Goose Lake, Modoe County.

In coastal localitios the nests are almost invariably situated on the sand, a slight distance above the high tide level, and among debris east up at high water. The nest is a mere depression in the sand, about two and one-half inches in diameter and an inch in depth. Sometimes the cavity is lined with bits of drift wood, fish bones or small pebbles; at other times it is hare of extraneous materials. In an exceptional case, as reported by Henshaw (1876, p. 269), “. . . the owners must have been of an artistie turn of mind, for they had selected from along the shore little bits of pearly nacre, the remnants of broken sea-shells, and upon a smooth lining of this material were placed their treasures. The effect of the richly-eolored eggs as they lay on the eushion of shining nacre was very pleasing."

In the vicinity of the salt works near Alvarado, on the Alameda County shore of San Franciseo Bay, L. R. Reynolds (MS) found that a great many pairs had in the summer of 1914 seleeted nesting sites on the dikes separating the salt ponds. The workmen, in traversing the dikes with wheelbarrows, reported having broken many eggs. The birds were doing most of their foraging at the edges of the salt ponds, hardly at all on the mud flats of the undisturbed salt marshes nearby. It would appear that artificial conditions such as were provided at this place are of a kind to fulfill all the requirements of this Plover.

The eggs in a complete set are two or three, the latter number predominating in the proportion of about three to one. The proportion of two-egg sets is greater towards the end of the nesting season 
(Chambers, 1904, pp. 139-140). They measure in inehes, 1.15 to 1.22 by 0.87 to 0.92 , and average 1.20 by 0.89 (three sets, seven eggs, in Mus. Vert. Zool.). Henshaw (1876, p. 269) gives the measurements of three sets as somewhat larger, ranging from 1.22 to 1.30 by 0.89 to 0.95 . The ground eolor is pale buff or eream with small superfieial spots and lines of brownish blaek, and deeper ones of pale gray. The markings rarely exceed 0.10 inches in length, and are but slightly more numerous about the larger end of the egg than elsewhere. Chambers (loe. eit.) states that the eggs are usually laid at threeday intervals.

Hunshaw (1876, p. 269) gives the following aeeount of the nesting habits of the Snowy Plover at Santa Barbara:

So slight is the contrast between the eggs and the drifted sand about them that they would be difficult enough to find were it not for the tracks about the nest. As the mates came to relieve each other from setting or to bring each other foor, they alighted near the nest, and thus for a little listince ahout each one [there] was a series of tracks converging to a common center, which too surely betraved their seeret. Great was the alarm of the colony as soon as my presence was known, ancl, gathering into little knots, they nervously attenled my steps, following at a distance with low sorrowful cries. The female, when she found her nest was really discovered, hesitated not to fly close by, and used all the arts which birds of this kind know so well how to employ on like occasions. With wings drooping and trailing on the sant, she would move in front till my attention was secured, when she would fall helplessly down, ani burying lier breast in the soft sand, present the very picture of utter helplessness, while the male with the neighboring pairs expressed his sympathy with lond eries.

After the young are fully fledged in the fall, flocks begin to appear in localities where the species is not known to breed. This is probably due to erowding and competition for food in the vieinity of the nest, and may be expeeted to eontinue until the pressure of over-population has been relieved by reduetion in numbers.

The food of the Snowy Plover consists of varions inseets and probably erustacea and other marine organisms. A. K. Fisher (1593a. pp. 25-26) reeorted it as feeding on a fly (Ephydra hians) whieh is present in enormous numbers on the shores of Owens Lake. H. C. Bryant (1914c. p. 226) found more than ten water beetles in the stomach of a bird of this speeies taken at Los Baños, Mereed County. The stomaeh of another bird taken at Los Baños, also eontained beetles (Beek, MS).

The Snowy Plover is elassed as a game species merely beeanse of its near relationships with the larger shore birds, whieh properly are lumter for food or sport. Its insignifieant size from a food standpoint and its confiding habits, ought to justify its release from destrution before the gun of the hunter. The speeies should be accorded complete and continnous protection along with all the other diminutive shore birds whieh oeeur within our boundaries. 


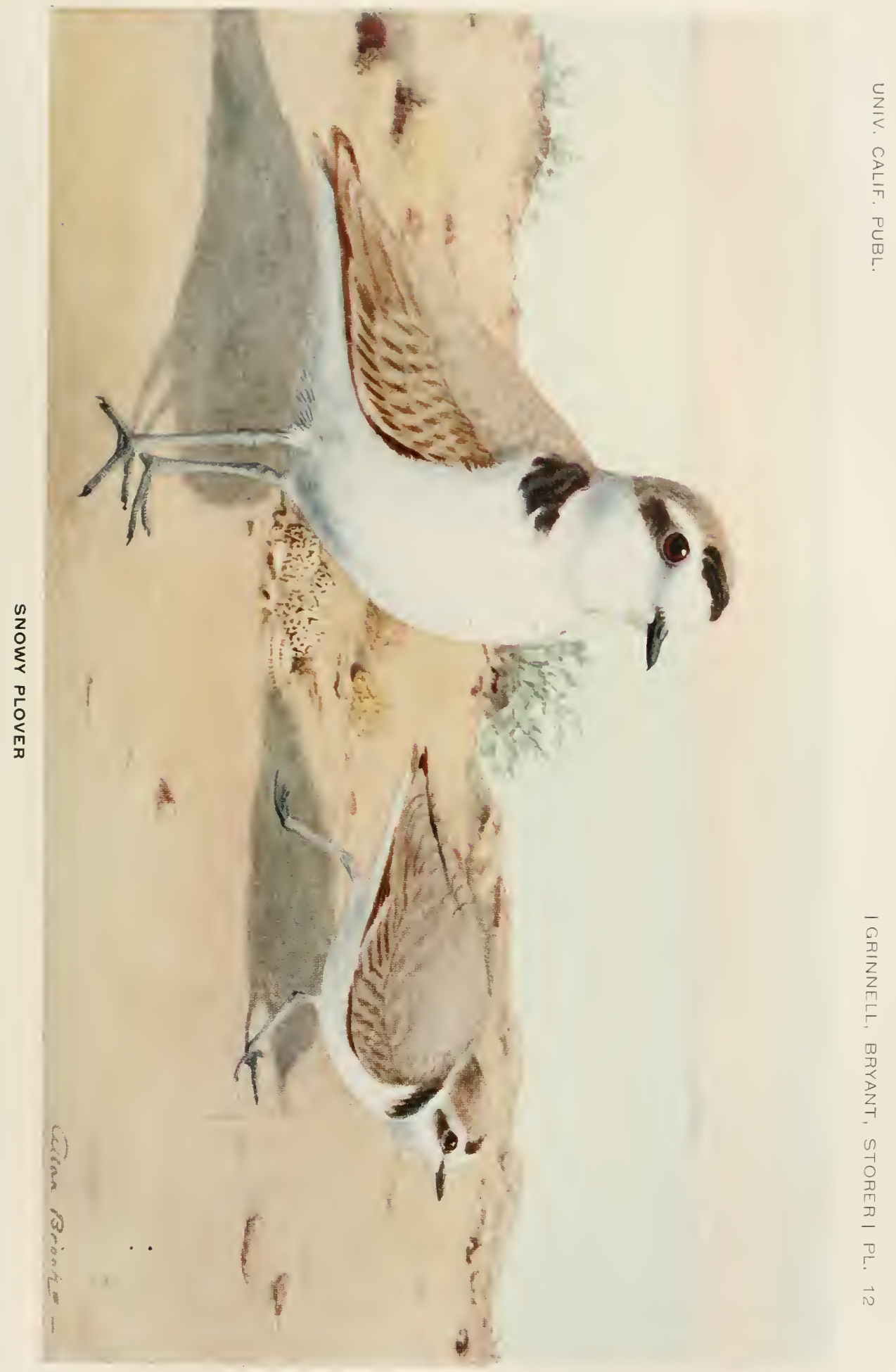





\section{Wilson Plover}

\section{Ochthodromus wilsonius wilsonius (Ord)}

OTHER NANE-Aegialitis wilsonia.

Descriptiox-ddult male: Forehead and line over eye, chin and upper throat, white; forepart of erown and sometimes stripe from bill to eye, black; iris recllish lrown; bill black; ear region, top anl back of hearl, whole back, rump, midlle upper tail coverts and outer surface of closerl wing, ashy brown; back of head tinged witl buff; onter upper tail eoverts and outer tail feathers, white; middle tail feather's dark brown; tips of greater wing coverts white, forming a narrow bar across wing; primaries dark lrown, their shafts ehiefly white, outer one entirely so; margin of wing mottled light brown and white; lining of wing anil axillars, white; miler surface of flight feathers pale duskr; broat band aeross lower throat and upper breast, black; rest of under surface white; feet light flesh color, claws dusky. Adult female: Similar to adult male but with black replacel by brownish; breast hand suffused with light buff. Total length (hoth sexes): "7.50-7.90)" inches (190-200 mm.) (Ridlgway, 1900, f). 175). Male: folled wing 4.25 (108); bill along culmen 0.s.5 (21.6); tarsus 1.16 (29.4) (one specimen from California). Juecnile plumage: Similar to that of adult male but with black replaced by hrown and feathers of mpler surface edged with paler brown. Tatal plumage: Forehead, sirles of hearl, and band aroumd neck, white; stripe through eye black; upper surface grayish buff, mottled with black; last joint of wing and whole lower surface white (leseriptions arlapted from: Sanford, Bislrop' anl Van Drke, 1903, l. 477; Ridgwav, 1900, 1). 175̃; Baird, Brewer and Riılgway, 1984, 1, p. 169; and one specimen from California).

MARKS FOR FIELD IDENTIFICATION-Small size (much smaller tlan Killdeer), chunky appearance, stout, wholly black bill (about as long as hearl), single broad black or dark brown band aeross mpper breast, brow white to base of bill, and miformly grayish brown upper surface of borly.

TOICE-A "slightly rolling" cry"; "half a whistle and half a chirp" (Baird, Brewer and Ridgway, 1884, 1, p. 170).

NEST-Usually on dry open sandy bearlies some distance back from the water; at times in short grass; a mere depression in the bare sand (Coues, 1869, p. 345 ) ; occasionally it is lined with a few bits of drift material.

EgGs-Usually 3, but at times 2, pear-shaper, measuring in inches, 1.22 to $1.45 \mathrm{by} 1.00$ to 1.05 (in millimeters, 31.0 to 36.8 by 25.4 to 26.6 ); ground color pale olive-drab of either a greenish or brownish cast; superficial markings of blackish brown consisting of spots and lines in fine pattern, most numerous about the larger end; leeper markings are also present (Coues, 1869, pp. 348$349)$.

General distributiox-Middle Ameriea and southern North America. Breels on Atlantic coast from southeastern Virginia (formerly from New Jersey) south to the northern Bahamas, and along Gulf Coast west to Texas, and probably on Paeifie eoast from southern Lower California to Guatemala; probably resident on Pacifie side; easual (?) at San Diego, California (modified from Cooke, 1910, pp. 93-94).

Distribution in California-One reeorl: Allult male in worm breerling plumage taken at Pacific Beach, San Diego County, June 29, 1894 (Ingersoll, 1895, p. S7; Grinnell, 1902b, p. 197). 
The Wilson Plover is typically a bird of southern North America. Its admission to a place in the list of California birds is based upon the capture of a single individual in worn breeding plumage at Pacific Beach, San Diego County, June 29, 1894 (Ingersoll, 1895, p. 87; Grimnell, 1902b, p. 197). This individual was first seen, by Mr. A. M. Ingersoll, five dayrs previonsly at the same place, in company with a female Snowy Plover and in the vieinity of the latter's nest. Attention was first attracted to the bird by hearing its ". . . peeuliar alarm ery, quite unlike any note of the usually silent Snowy Plover." It followed the Snowy about, assisting her in remonstrating against invasion of her nesting preeinets. "He was the most talkative Plover I ever met and could not have shown more solicitude had he been the rightful owner of the eggs. ... After I left ... [he] ran ahead eighty or a hmolred feet and kept at about that distance until we had gone up the beach nearly a quarter of a mile. 'Then he took wing and disappeared in opposite direction."

On the date of eapture, June 29, the Wilson Plover was with three Snowies and within a hundred feet of where seen previously. "He ran ahead of me as on former occasion, but only uttered a few notes and did not seem as much disturbed by my presence." After more than three hours continuous observation, Mr. Ingersoll concluded that the hird was mnmated and shot it. The specimen is now in the Grinnell collection, in the Museum of Tertebrate Zoology. As the species may breed along the coast of Lower California not far to the southward, it is not umreasonable to expeet that other individuals will stray over our southern border from time to time, especially in summer.

The Wilson Plover resembles other plovers of its size in general habits. On the sandy beaches and muddy flats of the Carolinas it is to be found in flocks of six to twenty or more. Sometimes the birds stray into the adjacent salt grass meadows in seareh for food. 'They do not rum so fast as other small plovers, and are more given to remaining with their own kind. In flight they pass close to the ground or water.

The nesting season extends from early April (earliest eggs April 8) (Paird, Brewer and Ridgway, 1884, I, p. 171) well into June (fresh eggs Jme 12) (Philipp, 1910, p. 216), but the majority of the eggs are laid during the latter part of May. The nest is a shallow depression in the bare dry sand some distance back from the water; sometimes in a slight grassy growth. Tsually it is without lining of any sort, or it may be supplied with a few bits of drift material. A typical nest measures about four inches across (Cones, 1869, p. 345).

The eggs number three, less commonly two. In size they range from 1.22 to 1.45 by 1.00 to 1.0 5 inches. The grom color is pale olive llab of either a greenish or brownish tone, with blackish brown 
superficial markings and lighter-eolored deeper ones. The markings are more numerous about the larger end of the egg and consist of small spots and lines (Cones, $1869, \mathrm{pp} .348-349$ ). If one intrudes his presence on these birls at their nesting season, the male voices his concern with lond cries. The female, if surprised on the nest, usually slips quietly away for some distance, close to the ground, and then practices various subterfuges to lead the intruder away. Occasionally the members of another pair will join in demonstration with those whose domains have been entered (Cones, 1869, p. 344). Often the birds will squat on the ground at places away from the nest, making discovery of the latter quite difficult (Plilipp, 1910, p. 316). The downy young ". . . can l'un quite eleverly over the sand as soon as fairly dry from the egg ... and are rather diffienlt to find, from their knack of hiding, like their parents, by squatting close on the sand. Their legs seem disproportionately long, like a young colt 's", (Coues, 1869, p. 347).

Sinee this species is kuown in Califormia from but a single instanee, in spite of extensive observations along our southern seacoast, it is improbable that it will ever be found here in numbers. As with several other rare birds of the game category, it is likely to remain of interest only to the scientist and natme-lorer.

\section{Mountain Plover}

\section{Podasocys montanus (Townsend)}

Other NAMEs-Rocky Mountain Plover; Bull-hearl Snipe; Aegialitis asinticus var. montanus; Charadrius montanus; Eudromils montanus; Aegialitis montana.

Description-Adults, both sexes, in late spring and summer: Banil across forehead at base of bill, and extending back as stripe over eye, white; forepart of crown above white band, broally black; stripe from side of bill to eye, black; side of hear immediately below eye whitish, below this and on ear region, buffy; chin and throat, white; bill black; iris dark brown; top of head, hind neck, whole back, rump, central upper tail coverts, and wing coverts, ashy brown, with feather tippings of rusty brown giving a scaled appearance: outer margins of outermost upper tail coverts, white; tail feathers pale drab at base, blackish brown subterminally, and with tips of all ancl outer web of outermost, white; flight feathers and primary coverts chiefly blackish browu; shafts of primaries, and tips of greater coverts, white; lining of wing and axillars, white; under surface of flight feathers pale gray; sides of meck, broad area across chest, and sides of body pale brown, lightest toward mid-line; rest of under surface, white; legs pale brown; feet black. Adults and immatures, both sexes, in fall, winter and early spring: Like adults in summer save that black narkings on head are absent, and feathers of whole upper surface are more or less prominently tipped with light rusty brown; sides of head, chest. and sides of body, strongly suffused with same color. Males: Total length 8.759.50 inches $(222-241 \mathrm{~mm}$.) (four specimens); folder wing 5.55-5.95 (141.0151.2); bill along culmen 0.83-0.89 (21.1-22.5); tarsus 1.54-1.81 (39.0-46.0) 
(ten specimens). Females: Total length 9.00-9.50 (228-241) (six specimens); folled wing 5.44-5.85 (138.2-148.7); bill along culmen 0.78-0.89 (19.8-22.6); tarsus 1.52-1.63 (38.5-41.4) (ten specimens); adults and full-grown immatures, all from California. Juvenile plumage: Like winter plumage of adults but all of lighter feather elgings broaler, and brighter in tone, and lower surface more extensively tinged with pale tawny brown. By fading and wear this becomes the winter plumage. Natal plumage: Forehearl and cheeks pale buff; bill pale brown, lighter at tip; top and back of head and upper surface of body coarsely mottled with black on a pale buff ground; entire under surface of body dull yellowish white; legs and feet (dried) yellowish brown.

MARKS FOR FIELD IDENTIFICATION-Moderate size (about that of Killieer, but chunkier), short bill, uniformity of coloration, white axillars and lining of wing, total lack of black bands or streaking on breast or sirles, and lack of conspicuous white on rump and wing. These features pertain to the winter plumage and hence to the birts thronghont their stay in California; in summer there is black on the forepart of the crown and between the bill and eye.

Vorce-A rather low pleasing whistle (Goss, 1891, p. 218); on breeding grounds, a short shrill whistle, dropping at intervals to a harsh note (Cameron, 1907, P. 256).

Nest-On open prairie or plains of the interior; a mere depression in the surface, sometimes sparingly lined with a few driel grasses (authors).

EGGS-3 to 4, bluntly pear-shaped, measuring in inches, 1.40 to 1.60 by 1.05 to 1.15 (in millimeters, 35.6 to 40.6 by 26.7 to 29.2 ); ground color deep brownish drab, with small rounded spots of blackish brown, a little more numerous about the larger end; leeper-lying markings of grayish are also present (Baird, Brewer and Rılgway, 1884, I, p. 175; Coues, 1874, p. 458; Goss, 1891, p. 218).

General distribution-Western North America. Breeds in the Uniterl States north nearly to the Canadian boundary in Montana, south through western Wyoming and south-central Colorallo to northeastern New Mexico, and east to northwestern Texas, western Kansas and western Nebraska; winters from north-central California, southern Arizona, and south-central Texas, south to central Mexico and southern Lower California (A. O. U. Check-list, 1910, p. 130; Cooke, 1910, p. 94).

Distribution IN CALIFORNiA-Common fall, winter and spring visitant locally to open plains in the Sacramento-San Joaquin Valley, and in the coastal district of southern California from Ventura County to the Mexican line. Has oceurred also in the San Franciseo Bay region and at Monterey. Fall migrants arrive from September to November, and the last spring birds are seen in Narch.

The Mountain Plover, or Prairie Plover as this species has more aptly been called elsewhere, is typically an inland bird. It is rarely, if ever, seen along the seacoast, or indeed anywhere in the vicinity of any water, and in this respect differs markedly from all others of our plovers. It is an exclusively American species and is restricted to the southwestern portion of the continent, nesting in the Rocky Mountain region, and wintering from the southern United States to central Mexico. Much of the winter range lies west of its breeding range, so that an east-and-west course of migration must be the rule.

In California the Mountain Plover is purely a winter visitant. The earliest fall record for numbers is for Montebello, Los Angeles 
('omty, september 15, 1896 (Willett, 1912a. p. 41), when the speeies was recorded as already plentiful. But Dawson (1916, p. 26) saw a single bird on the Santa Barbara beach, August 25. 1915. Belding (IS) states that a flock of about a dozen was seen at Stockton, September 26, 1883, hut that this was earlicr than nsual for its appearance in the central valleys: judging from his and other accounts the average date of arrival is probably some time in October. Thronglont the winter montls the Monntain Plover is present in varying numbers. According to a few reports it has at times been extremely alomilant loeally. The latest known spring oceurrenee for sonthern ('alifornia is February 22, 1888, at Riversicle (specimen in Mus. Vert. Zool.). At Mentota, Fresuo County, three speecimens were serened on Mareh 12. 1912 (Mns. Vert. Zool.). On the coast of central California, it has been recorded only from Montrey, January 24, 1911 (Beck, MS), and in the vicinity of San Franciseo Bay, January 26, 1898 (speeimen in Mailliard eoll.). W. F. l3ryant (in Belding, MSS) reports that the speceses was a rare winter visitant in his day in the vieinity of Oakland. A specimen was taken at ('oncord, C'ontra Costa ('omuty, January 10, 189) (Mus. Yert. Zool.). The northermmost lorality from which the species has been recorded within the state is Marysville, Butte ('ounty (Belding, 1879, p. 440).

The Monntain Plover is to be distinguished by its moderate size (near that of the Killeleer), chunky appearanee, short bill, wniformity of coloration throughont, its white axillars and lining of wing, and the total absence of black bands, patches or streaks on its breast and sides. The dry upland habitat of the bird is also distinetive. From all others of our small or moderate sized plovers the Mountain may be known by the absence of any black band or side-patches on the breast, and from the larger species (Black-bellied and Golden) by the uniformly colored upper surface. white axillars, and, in spring, by the absenee of black on the under surface.

The Momntain Plover is typieally a bird of dry open plains, being rarely if ever found about bodies of water as are most other shore birds. Belding (1879, p. 440) says of this bird in central California: "It frequents the dry plains, but is oftener found in fields that have been prepared for or sown with wheat than any other localities. It sometimes visits the low, rolling gravelly hills to the east of the [Sacramento-San Joaquin] valley, and is often abundant, espeeially previous to the severe rains of winter.', This plover is a floeking speeies found in bands of from fifteen to several hundred individuals. Oceasionally, in years past, they have oecurred in great numbers on the level comtry lying within a few miles of Los Angeles.

This speeies differs from many of its relatives in being somewhat difficult to flush from the ground. When pursued the birds will 
run about, preferring to dodge between bits of regetation, rather than to take flight. When moving about in this manner the head is lowered, but at intervals the birds stop suddenly, straighten up and look around. "When disturbed they have a curious habit of collapsing, or shrinking into themselves, and stretching their bodies to the full height alternately" (Cameron, 1907, p. 255). Often upon alighting, after they have been in flight, the birds will immediately run to some distance so that it is not always possible to follow them up easily as with other shore birds. The flocks fly low over the ground, and are diffienlt to see, exeept when they wheel. As they do this the under surfaces of their wings show momentarily as silvery white flashes.

The nesting season is rather late, especially when considered in relation to the latitude and to the time of departure of the birds in the spring from their winter home. Young about one day out of the shell have been found by May 29 (Warren, 1912, p. 90), and newly hatehed young on .July 28 (Cones, 1874, p. 459), so that the nesting season oeeupies a period of approximately two months.

The Mountain Plover nests on the same kind of dry, half-barren plains which sreve as its preferred habitat at other times of the year. The nests are nothing more than slight depressions in the ground, usually bare but sometimes sparingly lined with dry grass. The eggs number either three or four, are pear-shaped, but much more rounded than those of most other waders, and measure 1.40 to 1.60 by 1.05 to 1.15 inches; the gromd-color is deep brownish drab, with small rounded spots of deep bister or black, a little more numerous about the larger end; deeper-lying grayish markings are also present (Baird, Brewer and Ridgway, 1884. I, p. 175; Cones, 1874, p. 458; Goss, 1891, p. 218).

But little seems to have been placed on record concerning the habits of this species during the nesting season. Cameron (1907, p. 256) describes his experience with a nesting bird in Montana as follows: A pair had been loeated in the eenter of a prairie-dog town and one of them had shown extreme agitation at his approach.

Rumning with a trailing wing she wouk fall over aul lie struggling on the ground, which . . convinced me that she hard young elose by. . . The distracted parent... sought by feints and struggles to engage my attention. All the time she kept up a short, shrill whistle, dropping at intervals to a harsh note and appearing to utter these sounds without opening ler beak. . . By her manoeuvres she assisted me to find her nestlings and I soon saw two little pale yellow birds, spotted with black, together with an egg, on the bare ground, for there was no pretence at a nest.

Warren (1912, p. 90) records the rather eommon occurrence of the Mountain Plover in the brecling season in portions of north-central 
Colorado. On June 11 many partly grown young were seen. One, which was estimated to be a week or ten dars old. was able to run with great speed and did so with its wings ontspread. An adult squatting in the shade of a fence post, and a young one in a similar position, were seen on the same date.

The food of the Momntain Plover, as might be surmised from its ehoice of hamnts, is almost entirely eomposed of inseets; of these, the species which are found in open eountry, such as grasshoppers, erickets and beetles, are most frequently taken. Flies are also eaten (Beek, IIS: MeAtee, 1911a). Belding (IIS) observes interestingly that he often found this Plover in reeently sown grain fields, but was never able to discover a single kernel of wheat in the stomaehs of those shot.

As a possible feature of attrativeness to the hunter may be mentioned this bird's fair size and eonsequent food ralue. In earlier year's number's were sold in the markets at least of Los Angeles. We have, howevel, learned little that would evidence partieular enthusiasm orer this species on the part of the average sportsman. Belding (MIS) says that "during their winter sojourn here the birds beeome fat, and so tame as to afford the lunter but little sport." Also "their flesh has an umpleasant taste not at first noticed."

It may well be said that the Mountain Plover is a mique type among our shore birds. Its upland habitat marks it off sharply from most of our other species. It therefore deserves speeial eonsideration from the game standpoint, as it gives an objeet of pursuit to the plains dweller to whom hunting along the seacoast or in the lowland marshes is denied. Its habit of appearing in great numbers at irregular intervals, as if eoneentrated into a small area, should be taken into aceount and only moderate hunting permitted in order that its numbers may not be too greatly reduced.

\section{Surf-bird}

\section{Aphriza virgata (Gmelin)}

OTHER NAMEs-Townsend's Surf Bird; Strepsilas virgata.

Description-Adults, both sexes, in summer: Whole head and neek streaked black and white, darkest on crown where also suffuserl with pale buff; chin whitest, the markings reducer to flecks; eyelids white; iris dark brown; bill (dried) brownish black, dull yellow on basal haif of lower mandible; feather's of back brownish black, with narrow engings of ashy white, and extensive markings of reddish buff; rump dull dark brown; upper tail coverts abruptly and solidly white; tail pure white on basal half, dull dark brown on terminal half, the onter feathers with narrow white tips; outer surface of closed wing dull brown; bases of primaries, tips of primary coverts and ends of most of secondaries, white, forming a conspicuous band across expanded wing; flight 
feathers brownish black, shafts of outermost ones white; margin of wing scaled white and brown; lining of wing and axillars white; inner surface of flight feathers white toward bases, darkening to pale brown at ends; breast with a mixture of ashy brown feathers, and pure white feathers with crescentshapel bars of blackish near ends; rest of under surface white, marked on ulper belly, sides, flanks and under tail coverts with bold crescents, triangles, or streaks of brownish black; feet " 'olive green; claws black', (Baird, Brewer and Rilgway, 1884, I, p. 127). Adults and immatures, both sexes in winter: Top and sides of hear, whole neck, and breast, back, rump and outer surface of closed wing, continuously blackish brown, the feathers with dull larker shafts or shaft streaks, which are broadest and most noticeable on head; eyelids white; cheeks streaked with dull ashy; chin white, sparingly flecked with brown; rump, upper tail coverts, tail and flight feathers as in summer adults; under surface behind dark breast area, white, sparingly streaked or spotted with dark brown, on upper belly, flanks and under tail coverts. Males: Total length 9.87 inches ( $251 \mathrm{~mm}$.) (two specimens from Alaska); folded wing 6.22-6.62 (158-168); bill along culmen 0.87-0.95 (22.5-24.2); tarsus 1.14-1.25 (29.0-31.8) (ten specimens from Alaska). Females: Total length 10.25 (261) (one specimen from Alaska); folded wing 6.42-6.97 (163177 ); bill along eulmen 0.95-1.02 (24.2-25.8); tarsus 1.22-1.32 (31.0-33.6) (ten specimens from Alaska and California). Jurenile (?) plumage: Like that of adults in winter save that feather's of back are narrowly erlgerl with grayish white, wing coverts are slightly lighter than back and more broadly margined with white, and each ashy brown feather on breast is crossed near end by two narrow white bands; iris dark hazel; bill black at tip, grayish yellow at base; feet and legs yellowish (modified from Nelson, 1887, 1. 128). Natal plumage: Not known to us.

MARKS FOR FIELD IDENTIFICATION-Morlerate size (much larger than that of Killdeer), plump appearance, short bill (fig. 78) and legs, conspicuous white "rump" patch (including upper tail coverts and bases of tail feathers), white land across wing, and heavily marked under surface (pl. 13). Similar in general appearance to the Turnstones, but distinguished from them ly slightly larger size, bolily marked instead of pure white hinder lower surface, and single white patch at base of tail instead of two separated by black interval.

Vorce-A low piping note (Heermann, 1859, p. 64); a wild key- $e^{\prime}-a h$ (Bailey, $1916 b$, p. 103).

NEST AND EGGS-Unknown.

General distribution-Pacific coast of North aud South America. Breeding range unknown but probably in interior of northwestern Alaska; winters in Chile south to Straits of Magellan; in migration occurs from Kowak River, northern Alaska, to southern South America (A. O. U. Check-list, 1910, p. 131; Cooke, 1910, p. 95).

Distribution in California-Spring and fall migrant in moderate numbers on rocky ocean shores; one instance of capture in winter. Recorded from various localities from Bodlega Bay, Sonoma County, sonth to Point Loma, San Diego County.

There remain at the present time but very few birds of regular occurrence in northern North Ameriea whose life histories are not fairly well known. The Surf-bird is one of these elusive species. In winter it is known to occur along the western coast of southeru South 
क्षे

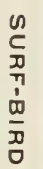

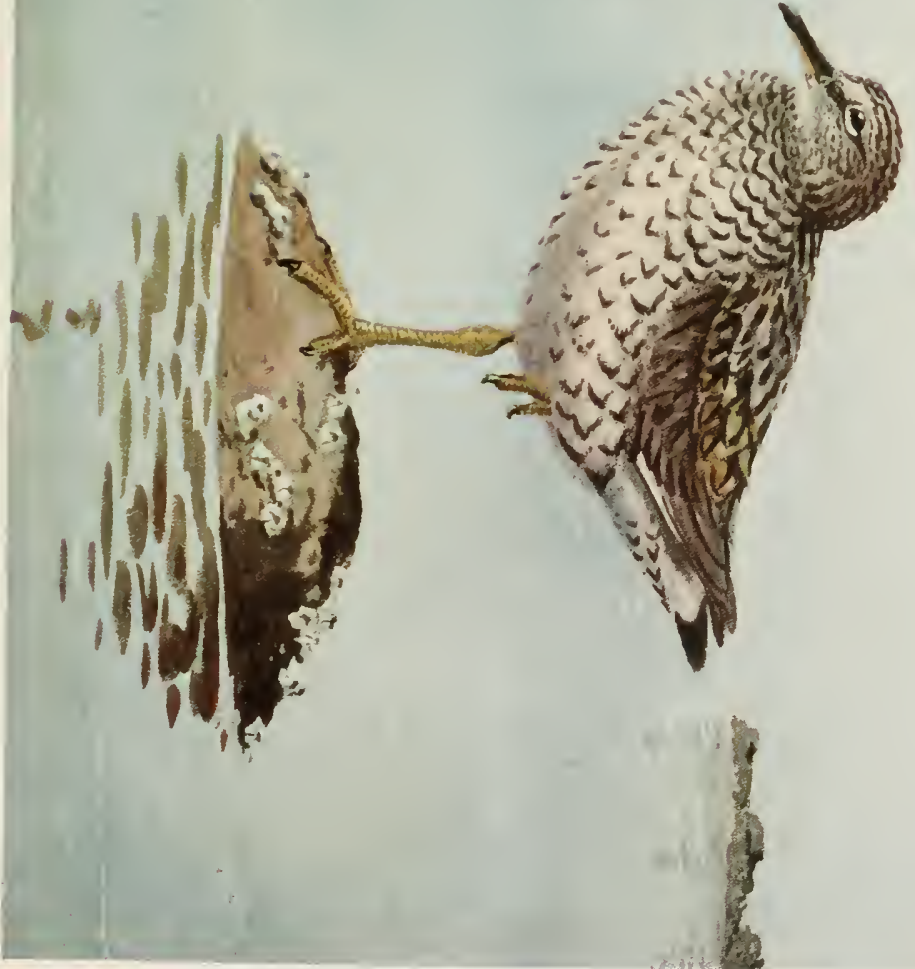

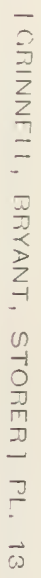



Anrerica, and it migrates along the whole Pacific coast of the two Americas. At the north, in Alaska, it has not been reported between May 29 and July 21; during this interval it vanishes. It is believed that the nesting gromds are in the interior of northwestern Alaska, but this belief rests upon inference coupled with the assertions of Alaskan natives.

In California the Surf-bird is a moderately conmon species in the spring and fall migrations, and it has been observed here once in winter. Definite instances of occurrence, with specific dates, are as follows: Bodega Bay, Mareh 25 or 26, 1885 (Belding, MS) ; Berkeley, October 2t, $188 S$ (Cooke, 1910, p. 95) ; Farallon Islands, June 3, 1903 (Cooke, loc. eit.) ; Santa Cruz, April 22, 1895 (specinen in Mailliard coll.) ; Monterey, August 3, 1894, and other dates in same month (Loomis, 1595, p. 22t) ; Jamuary 12, 1911 (two specimens in Mus. Vert. Zool.); and May 10 and August 5, 1907 (Beck, 1910, p. 71); Santa Barbara, September 16, 1911, flock of five (Bowles and Howell, 1912, p. 11) ; May 3, 1912, flock of twenty-three (Dawson, 1912, p). 224) ; May 1, 1913 (Howell, MS) : and June 4, 1915, two individuals (Dawson, 1915, p. 207) ; San Miguel Island, between Mareh 13 and April 1, 1903 (Willett, 1912a, p. 41) ; San Nicolas Island, May 15, 1909 (Willett, loc. eit.) : Pacific Beach, San Diego County, September 8, 1904 (Bishop, 1905. p. 141) ; and Point Loma, San Diego County, March 19, 1898 (Stephens coll.). It has also beeri reported doubtfully from Santa Barbara Island (Cooper in Baird, Brewer and Ridgway, 1884, I, p. 127), and it was obtained by IIcermann (1859, p. 64) in the markets of San Francisco in the winter of 1849 . The latter author also met with this species on the Farallon Islands in Jume, 1850 .

Summarizing from the above, we find the earliest spring record to be March 19 and the latest June 4; the earliest in the fall August 3 , and the latest October 24 , save for the single January oceurrence. Most of the records are for May and August. Being a species which adheres closely to the rockiest portions of our coasts, it does not come to the attention of the usual visitor to the seashore. Special efforts to find this bird, if made at the proper season and in the proper locality, are quite sure to prove successful.

Among the shore birds occurring in California the Surf-bird may be known by its moderate size (considerably larger than that of the Killdeer), its very plump appearance, short, plover-like bill (fig. 78), very short legs, conspicuous white upper tail coverts and base of tail ("rump" patch), white band across wing, and the bold pattern of markings on its under surface (pl. 13). From our two Turnstones, which it most closely resembles, this bird may be told by its stouter build, somewhat larger size, the boldly marked instead of pure white 
hinder lower surface, and the single white patch instead of two white patches separated by black at the upper base of the tail.

The Surf-bird prefers rocky reefs and outcrops to sandy beaches; in this respect it ahmost duplicates the Wandering Tattler. Indeed the two species are often found in the near vicinity of one another, but the Tattler is solitary while the Surf-bird is of flocking habit. Torrey (1913, pp. 136-137) who observed these two species and others at Santa Barbara says that the Surf-birds ". . . kept persistently close to the water, on what looked at ... [a] distance like bare rocks, not off-shore like those to which the oyster-catchers restricted themselves, nor covered with seaweed like those resorted to by the wandering tattlers. Once . . . they occupied themselves a long time on the face of a rock that inclined seaward, rumning up into sight as the higher waves chased them, and anon hastening down again as the water receded."

The most interesting account of the

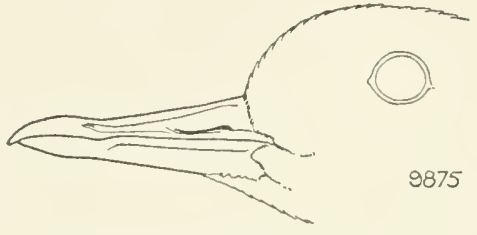

Fig. 78. Side of bill of Surfbird. Natural size. Surf-bird within the state is that furnished by Dawson (1913a, pp. 5-8) who, on May 3, 1912, observed a flock of twenty-three of these birds at La Patera, near Santa Barbara. They were first sighted from a bluff above the beach, and were then feeding in mixed company with some cormorants. A detour and careful approach finally allowed the observer to get within eighteen feet of the waders, from which the cormorants had meanwhile separated. They were feeding along a rocky reef in close leach of the waves. "Now and again the flock shifted, but always they came back, alighting at the extreme tip of the reef where the waves frequently bandied them. For the most part they fed silently, but as often as I made some umusual demonstration or as often as the wave swept about them, a murmur of complaint arose. The flock came to attention, or a few shifted position,. . . but the moment danger was over, work was resumed upon the barnacles." When forced to leave because of the water they took refuge on a near-by sandy area and gleaned like sandpipers; but they seemed to prefer the rocky situation and returned to it at the first possible opportunity. At this time their food consisted exchusively of sessile barnacles from the shells of which, as they were fastened to the rocks, the birds were dexterously extracting the soft parts. ".. . It was interesting to see a bird get a good grip on a reluctant cirriped, then brace and haul him out by main force." The food of the Surf-bircl probably includes other rock-inhabiting marine animals such as mussels, in addition to the barnacles already mentioned. 
being restricted in its occurrence in California, both as to season and locality, and with a breeding ground so sequestered as to have completely eduded man's starch, the Surf-bird seldom comes undel the surveillance of our sportsmen. It is safe to say that it will never be a spereses of importance among the game birds of the state. It is, nevertheless, a noteworthy member of our bird fauna. As Torrey (1913, p. 138) has aptly said with reference to its unknown nesting laabits, "somelow it is impossible not to feel a certain heightened respect for birds that have succeeded in keeping such a secret in despite of man 's insatiable curiosity.'

\section{Ruddy Turnstone}

\section{Arcnaria interpres morinella (Linnaeus)}

OTHER NAses-Calico-back: Checkered Snipe; Relleggen Plover: Arenariu interpres; Lrenaria morinclla; strepsilas interpres.

DESCRIPTION- Llult male, in spring and summer: Stripe aeross forepart of crown and contiuning over eye, around back of heas, and onto car region. white: chin and spot at sille of hill. white; toj of heal. streaked with blark and white; narrow stripe from top of bill running to and below eye, and connecting with strije from lower manilible along side of chin, black; bill "blark"'; iris "hazel" (Andubon, 1942, T, J. 234); neek collar (incomplete behind), blark; lower hind neek, mixel white and brownish; back mixed black and rusty brown in coarse pattern; lower back and longer mper tail coverts, white; shorter upper tail coverts brownish black forming a lark "rump patch" set in white: tail white at base, blackish brown terminally; outer feathers of tail slightly lighter, and outermost ones extensively marked, and all the feathers tipped, with white: outer surface of chosel wing ehiefly rusty brown; tips of greater coverts, lases of primaries, and most of secondaries white, forming a conspicuous band aeross expanted wing; frimaries chiefly blackish brown, shafts largely ivory white; lining of wing and axillars, wholly white; uniler surface of flight feathers white, hecoming pale arab toward tips; foreneck, sirles of ehest, and shoulders, solidly black, abruptly outlined; rest of under surface pure white; feet and legs "deep orange-red," claws "black" (Aurubon, loe. cit.). Adult female. in spring and summer: Similar to adult male at same season, but with eoloration more subdued, bJack areas brown toned, and white areas invaded with dusky (W. Pa]mer, 1599, p. 413). Adults, both sexes, in winter: Similar to adults in summer, but black feathers erlger with white, and rusty brown markings on back less conspicuous (Sanford, Bishop and Van Dyke, 1903, p. 482). Males: Total length 7.75-9.62 inches (197-244 mm.) (four specimens from California and Lower California); folded wing " $5.45-5.95$ "' (138.5151.0 ) ; bill along culmen " $0.56-0.95$ ', (21.8-24.1) ; tarsus " $0.59-1.07$ ", (22.627.2) (twentr specimens from Virginia). Females: Total length 9.40-10.40 (23S-264) (two specimens from California and Lower California); folded wing "5.72-6.08", (145-154); bill along culmen "0.88-0.99", (22.4-25.2); tarsus “0.99-1.07", (25.2-27.2) (eleven specimens from Virginia) (measurements, except of total length, from W. Palmer, 1999, p. 417). Jurenile plumage: 'Top and sides of hearl and neck, dull brown, mottled with pale buff; forehead and areas below and behind eve, dull white, flecked with brownish; chin and throat 
white; back dark brown, with feather margins and tippings of buffy or white; rump, nper tail eoverts, and tail, as in adult, except that tail feathers are narrowly tipped with buff; outer surfaee of elosed wing dark brown, with buffy feather tippings and edgings; rest of wing as in adult; band across throat and large area on side of ehest, continnous with nerk and back, brownish black, finely marked with buffy white; rest of under surface white. Natal plumage: Whole upper surface light buff, profusely marbled with black in fine pattern; sharp stripe between bill and eye, and branch down onto side of jaw, black; center of forehead dark, blending into mottled pattern on top of head; lower surface dull white, with a dusky band across ehest.

MARKS FOR FIELD IDENTIFICATION-Molerately small size (about that of Killdeer), short orange-red legs, conspicuonsly mixed pattern on head and back, double altermation of white and black from lower back to end of tail, broad white band across wing, and black on foreneek and chest.

Volce-A rapidly repeated $k \breve{k} k$, $k \breve{u} k$, $k \breve{k} k$; a loud twittering note; a ehuekling whistle; a clear deep melodions whistle of two or three notes (Forbush, 1912, p). 359, 361).

NEST-On lake, bay or river shores; a slight depression, sometimes lined witl a few grass blades or deall leaves (Reed, 1904, p. 132; Baird, Brewer and Riłgray, 1884, I, p. 124).

EgGs-Usually 4, pear-shaped, measuring in inches, 1.60 to 1.72 by 1.13 to 1.23 (in millimeters, 40.6 to 43.7 by 28.7 to 31.3 ), and averaging 1.66 by 1.18 (42.2 by 30.0); ground-color light olive-brown, eream color, light drab or deep) clay color; superfieial spots light brown in laige bold splashes and spots, most numerous about larger end; deeper nuarkings lilae (of interpres and morinella together?) (Baird, Brewer and Ridgway, loc. cit.).

General distribution-North and South Ameriea. Breeds near Aretic coast of Canada on lower Anderson River and Franklin Bay, and probably at Melville Island, on Melville Peninsula, and at Bellot Strait, north of Boothia Peninsula; winters from South Carolina, Louisiana, Texas and central Califormia sonth to central Chile and southern Brazil; occurs in migration over most of the area between winter and summer ranges (Cooke, 1910, pp. 97-98).

Distribution IN CALIForNia-Rather uneommon spring and fall migrant along the coast; has occurred on San Franciseo Bay in winter, and once ou Santa Barbara Islands in summer. Spring migration evidently takes place during April and early May, and the fall migration from late July to about the first of October.

Among the shore birds occurring in California none are more interesting by reason of specialized habits than the two Turnstones, of which the Ruddy Turnstone, the subject of the present aceount, is the rarer species. Being strictly maritime in its preference, and never, so far as known, even straying inland, this bird comes under the observation of but few persons.

In California the Ruddy Turnstone is a sparing spring and fall migrant, and is apparently more numerous in some years than in others. Stragglers have occurred within our boundaries during both winter and summer. Records of this speeies in the northern half of the state are as follows: Eureka, Humboldt Connty, Angust 28, 1912 (specimen in F. J. Smith coll.) ; Farallon Islands, May 7, 1887, one 
specimen ( W. E. Bryant, 1888, p. 4t) ; San Franciseo Bay, January 28, 1901 (two specimens in Mailliard coll.); Stege, near Berkeley, August 13, 1892 (speeimen in Mus. V'ert. Zool.) ; Bay Farm Island, Alaneda County, September 18, 1914, one individual seen (Grinnell, MS ) ; and vieinity of Monterey, July 1S, 1892, and August 25, 1897. one specimen in eaeh instanee (Loomis, 1895, p. 224; J. Mailliard, 1898, p. 51).

This species is most frequently met with in southern California. Two were seen at Santa Barbara, July ¿6, 1909 (Torrey, 1909b, p. 17t), but none was noted there in 1910. In 1911, however, birds of this species were observed on five dates between August 22 and September 12, in numbers ranging from one to six (Bowles and Howell, 1912, p. 11; Howell, MS). The only record of ocenrence in spring in southern California is for San Nicolas Island, Mareh 30 to May 11. 1910. during which period nineteen specinens were taken (Willett. 1912a. Pp. 41-42). There is one summer record for this region: Santa Cruz Island, July S. 1912, one individual (Wright and Snyder. 1913, p. 91), and a number of fall ones, the latest being for San Miguel Island, Oetober 15, 1910, two seen (Willett, loe. eit.). In all, there are twenty-two records for the state known to the authors, sereral of these being for more than one individual bird.

The Ruddy Turnstone is an easy bird to recognize, by the eombination of moderately small size, short bill, short, orange-red legs, conspicuously mixed pattern on liead and upper surface, white band aeross wing, double alternation of white and black areas from lower back to tip of tail, and black ehest and foreneek. This'speeies differs from the Black Turnstone in being slightly smaller, in having a variegated patter'n of eoloration on the back and a white ehin, and in having less black on its ehest. Its bright reddish legs, heavy black chest area, and the extensive white on its lower back, will distinguish it from the sandpipers and plovers of similar size. Forbush (1912, pp. 360-361) says of the Ruddy Turnstone as observed along the eastern coast of the Inited States:

The bright rariegated plumage of the Turmstone, with its strong contrasts of black. white and chestnut, places it among the most attractive birds of the sea-slore. The flight is rather low and swift at times and then the white of the pluniage is very striking. In flight it often alternates scaling and flapping, and sometimes gives a curious chattering or rattling note as it passes. I have heard, too, the rapidly repeated $k \breve{u} k$, $k \breve{h} k, k \breve{k} k$, which a pair uttered as they flew by overhear, but as a rule I have found them rather silent. . .

[The Turnstone] . . loves the foot of a rocky eliff or a beach with great stones partly submerged by the tide, but is common also on sandy beaches near the pounding surf, and on bars bared by the tirle. Sometimes it is seen in marshes or along the banks of tidal ereeks. It prods the sand with its beak, follows the retreating wave, raises pebbles from their bests, oftentimes squat- 
ting, hearing and working hard to dislodge them. Sometimes it pushes with its breast against a stone or shell in the effort to overturn it, or even digs beneath to undermine it when it is too firmly imbedded to be moved otherwise. It turns over bundles of seaweed, and 'roots' out weeds and sea mosses, as Dr. Townsend says "like a little pig." These labors are undertaken in the hope of finding something eatable beneath such objects, and the little laborer often is rewarded. Dawson states that near the shores of Lake Erie he has seen it on the ploughed lands turning over clods bigger than itself with such force as to roll them a foot or more. This habit of turning objects is not constant, however, with this bird, and is sometimes the exception, as I have watehed it when it seemed to be occupied entirely in probing the sand, or searching for food, like a sandpiper, along the strand.

The Turnstone can swim well at need, and like some other species loves to bathe in the wash of the waves that roll up on the sands, where it shakes off the water like a little dog.

W. A. Bryan (1903, pp. 210-211) tells of an interesting experienee with an individual of the Common Turnstone, a bird closely related to the Ruddy, which came aboard a vessel in the Pacifie Ocean. The bird was plaeed in a eage on shipboard and offered the canned flesh of various animals such as oysters and clams, and also fresh fish. These were all refused. Then some live eockroaehes, the only live insects available, were introduced. The bugs would semry under stones in the bottom of the eage, whereupon the Tumstone would roll eaeh stone to one side and snap up any bug which might be uneorered. Then it would beat the inseet vigorously on the floor several times and finally swallow it.

According to Cooke (1910, p. 97) anthentic records of the nesting of the Ruddy Turnstone are still very rare. The breeding range of the Turnstone of the Eastern Hemisphere extends east into Alaska, and the line dividing the breeding range of this subspecies (interpres) from that of the Ruddy, which nests in boreal America to the eastward, has not yet been clearly marked off. Reed (1904, p. 132) records a set of eggs (of morinella) taken Jume 28, 1900. on the Mackenzie River; while MacFarlane (1891, p. 430) speaks of finding birds at Fort Anderson in Jume, 186t, and of taking eggs on the Lower Anderson River, on a date not speeified.

The nest is said to be usmally plaeed along the shore of a body of water, on a sandy or stony area, and like that of most other waders, is a mere depression in the surface, sometimes lined with a few grasses or dead leaves. The eggs are usually four in number, pearshapel, and measure in inches, 1.60 to 1.72 by 1.13 to 1.23 , averaging 1.66 by 1.18. The ground-color is cream or light drab or deep elay, with superficial markings of light brown, boldly splashed ahout the larger end: there are also deeper-lying lilae markings (Baird, Brewer and Ridgway, 1884, I, p. 124). 
Speaking of the Common and Ruddy tumstones together, Sanford, Bishop and Van Dyke (1903. pp. 485-486) say: "The nest is placed on the ground, sometimes sheltered by a low-growing shrub. In the hrexting season the male gives its alarm note if the nest is approached, and then both birds fly to high grome, perehing on rocks, if such are present, and watch silently, not moring while any one is near. The nests are hollows in the stony beaches near highwater mark.'

Turnstones take, as food, insects, small crustaeca, small mollusks, and worms. Along the Atlantie eoast they feed on the spawn of the horseshoe erab and in northern Florida, according to Audubon, they feed on oysters which have been killed at low tide by the heat of the sun and also on such thin-shelled mollusks as they are able to break open (Forbush. 1912, p. 361).

Considering the small numbers in which Ruddy Turnstones risit California, and also the limited area to which they restriet themselves, they will probably never be well known to any persons save those who frequent the seashore in speeial search for its bird life.

\section{Black Turnstone}

\section{Arenaria melanoerphala (Tigors)}

OTHER XAMES--Strepsilas melanoefphalus.

Description-Adults, both sexes, in late spring and summer: Heall and neck, back, outer surface of eloserl wing, and whole breast, leep brownish black, the back and wings with a faint bronzy iridescence; large spot at sirle of bill, broken stripe over eye, sparse streaking on top and sides of hearl, neck and chest, and margins of scapulars, white; iris "brown; bill, black" (Sanford, Bishop and Tan Dyke, 1903, p. 487); rump white; shorter upper tail coverts solid brownish black, longer upper tail coverts and bases of tail feathers white; terminal half of tail feathers blackish brown, outer ones tipper with white; primaries chiefly brownish black, the shafts white except at tips; tips and inner webs of greater coverts and much of secondaries, white, forming a conspicuous band across expanded wing; under surface of wing anr axillars, pure white, continuous with white of sides, rump and hinder under surface; under surface of flight feathers drab toward tips; under surface of body behind breast, wholly white; legs and feet "yellowish", (Sanford, Bishop and Van Dyke, loc. cit.); nails black. Adults and immatures. both sexes, in fall and winter: Like adults in summer save that white spot at side of bill is absent, and white streaking about hear is less evident. Males: Total length 8.50-9.31 inches (216-236 mm.) (five specimens from California); folded wing 5.52-5.89 (140.0-149.7); bill along culmen 0.86-0.92 (21.8-23.3); tarsus 0.95-1.04 (25.026.4) (ten specimens from California). Females: Total length $8.75-10.20$ (22.225.9) (three specimens from California); folded wing 5.62-6.07 (142.5-154.0); bill along culmen 0.88-0.98 (22.4-24.8); tarsus 1.01-1.10 (25.7-27.8) (ten specimens from California and Alaska). Jurenile plumage: Like that of adults in summer, but white markings on head, neck and sides of 'hest, absent, feathers 
of back and wings lacking iridescence, and feathers of outer surface of wing. back, and breast, narrowly tipped with pale buff. Natal plumage: Not known to us.

MARKS FOR FIELD IDENTIFICATION--Moderate size (near that of Killileer), uniformly blackish upper surface, head and breast, and conspicuous white bar across wing; rump and upper tail coverts largely white, with a middle area of black. Distinguished from Rudily Turnstone by slightly larger size, absence of striking pattern of coloration on liead and upper surface, and extension of blackish farther hack on lower surface; from all other shore birds of similar size it may be known by the extensive area of blackish on forward portion of body both ahove and below.

Volce-A fine elear, peeping ery, wet, weet, too-weet (Nelson, 1887, p. 129).

NEST-On low marshy ground in the vicinity of brackish pools or ou seabeach; a mere depression in the surface (Nelson, loc. cit.; Reed, 1904, p. 132).

EgGS-Isually 4, pear-shaped, measuring in inches, 1.58 to 1.85 by 1.10 to 1.19 (in millimeters, 40.2 to 47.0 by 27.9 to 30.2 ); ground-color light gray or drab with an olive cast, marked (finely?) with light brown and lilae (Reed, loc. cit.; Baird, Brewer and Ridgway, 1884, I, p. 126).

General Distribution-Paeific coast of North America. Breeds in western Alaska from Kotzebue Sound region to Nuslagak, on Bristol Bay; winters from British Columbia and even southeastern Alaska south to Magdalena Bay, Lower California, but mostly in southern half of this area; has occurred casually at Point Barrow, Alaska, on east Asiatic coast, and in India (modified from A. O. U. Cheek-list, 1910, p. 132; Cooke, 1910, 1]).98-99).

Distribution in CALIFornia-Present throughout the year on rocky shores along the seacoast. Nost common as a winter visitant and spring and fall migrant; least abundant during late June and early July when only a few belated migrants or non-breelers are to be found. On coast of sonthem California arrives in numbers chiefly in August, am leaves in April.

The Black Turnstone oceurs in fair numbers along the whole coast of ('alifor'nia during most of the year, but berause of its preference for rocky situations along the ocean shore and about the larger bays, it is met with by but few persons. While not present in such mumbers as certain other speeies of wider habitat preferences the Black Thunstone is ristinetly more numerous than the Wandering Tattler, surf-bird, and Oyster-catchers, which frequent the same restricted sort of territory.

This 'Turustone is present in mumbers along our coast from August to May, the population lessening only during the nesting season. Howerer, straggler's whiel are probably either barren or non-breeding birds, remain through the summer months. Willett (1912 says the main body leaves the coast of soutler'n California in $\Lambda$ pril and returns in August and this apparenty holds true for the northern part of the state as well. In winter the speeies remains at least as far north as San Franciseo Bay (J. Mailliard, 1904, p. 16) while it is particularly abmulant about the islands off the eoast of sonthern California and ocents in fair numbers on the Farallons. Red Rock, on San Francisco Bay, is the farthest point away from the open ocean that the speeies has been recorded within the state. 
The Black Turnstone is an easy bird to recognize. The combination of its moderate size (about that of Killdeer), predominantly blaekish phumage, notably on the forward lower surface, the eonspienons white wing bar, and the alternating brownish black and white from the back to the tip of the tail, insure identification. From the Ruddy Turnstone the present species may be known by its slightly larger size, by the lack of striking pattern on its head and upper surface, and by the farther extension of black on its lower surface. The presence of eontinnous black on the forward half of the lower surface, sharply ent off from the white behind, is sufficient to distingnish the Blaek Turnstone from any of our other shore birds whieh approach it in size.

Black Turnstones are found singly, in small flocks, or in companies numbering $n p$ to forty or more individuals; but they are most frequently observed in flocks of molerate size. In Alaska, on the breeding grounds, these birds frequent pools and marshy land a few miles inland, as well as the seashore, but in California they restrict themselves with notable constancy to the vieinity of the open ocean. Rocky beaches are their prefereed habitat, but they also forage considerably on sandy shores, in either" "ase nsually at the edge of the water. They are quite tame and will often permit a rather close approach, especially if the observer is careful to move slowly.

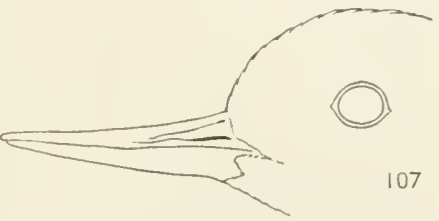

Fig. 79. Sirle of bill of Black Turnstone. Natural size.

Note slight upwaril curve and tapering end.

Torrey (1913, pp. 37-39) records in a vivicl style the feeding habits of the Black Turnstone at Santa Barbara:

They were feeding in three ways. Sometimes they followerl the receding breaker, gleaning from the surface, as it seemed, such edibles as it had washed in. Mostly, however, they busied themselves upon the wet sand just above the last reach of the falling tide.

Once they found a place where the shrimps or prawns were evidently more plentiful than elsewhere, and it was amusing to see how eagerly they worked, each letermined to get its full share of the plunder. . . Thrusting their short, stout bills into the sand, they drew out their squirming prey, dropped it on the sand, picked it up and shook it, and dropped it again, till finally they had it in condition for swallowing. These manoeuvres they repeated, all in desperate competitive haste, till the beach within a circle a few feet in circumference was thickly dotted with minute hillocks of sand, such as I should never have attributed to the work of any birt, had it not been done before my eyes. Then the supply seemer to be exhausted, and . . they moved on in search of another bonanza.

At other times they resorted to patches of seaweed lying here and there a little higher on the beach, turning them bottom side up, or brushing them aside, to feast on such small game as har taken shelter underueath. Their action 
here was like that of a dog when he buries a bone by pushing the earth over it with his nose. They lowered their heads, and with more or less effort according to circumstances accomplished their purpose.

If the obstacle proved too heavy to be moved in this manner, they drew back a little and made a run at it as men do ... in nsing a battering-ram. More than once I saw them gaining the needed momentum by this means. . . .

They quarreled now and then over the business, and once two of them faced each other, bill to bill, like game-cocks, a most unusual proceerling among waders, firing off little fusillades of exclamations meanwhile... The turnstones' disagreements were of the briefest, however, slight ebullitions of temper rather than any actnal belligerency.

"When they take to wing, as they do by a common flock impulse, the transformation in appearance is a delight to the eye. Instead of a row of dull-colored clods, there appears a constant cyclorama of flashing white, set off by variegating blacks'" (Dawson, 1909, p. 694).

Torrey states that one of the birds observed by him rested by dropping its body down on the sand, rather than by standing on one $\mathrm{leg}$ as is the habit of so many other species. This mamnerism is said by Kells (1895, p. 64) also to be evinced if the birds are startled when above the edge of the water.

In an account of the birds of the 1906 cruise of the "Albatross," A. H. Clark (1910, p. 51) says:

On the first day out of San Franciseo, May 4, we saw sereral small flocks of these birds on their way north; each snceeding day they became more abundant until on the afternoon of May 8 we saw them by thousauls, in flocks of from ten or twenty to several hundred. At one time, about 2 o'elock in the afternoon, the whole sea appeared dotted with white, so aburlant were they. All the birds noticer were hearded up the coast, going the same direction as we.

In the mornings these birds were comparatively rare; they began to appear about 11, and increased in numbers until about 2, when they were rery abundant; shortly after 3 there was a falling off until by half past 4 few, if any, were to be seen.... Whether they spent the night and early morning on the neighboring shores or resting on the water I am unahle to say; but all we saw were on the wing; possibly there were other shore birds in these multitudes, but all which came near the ship were of this species.

The Black Turnstone breets rather commonly along a limited stretch of the western eoast of Alaska, from the vicinity of Kotzebue Sound south to Nushagak, on Bristol Bay, and a short distance inland along the lower course of the Yukon River. Strangely, there are but few records of its nesting; descriptions of its eggs are scanty and recorts of downy young are apparently wanting altogether. The nest. which is simply a depression in the surface of the ground, is situated on the seabeach or among near-by brackish pools. The eggs, which ale pear-shaped, are said to number three or fomr, and measure 
in inches 1.58 to 1.85 by 1.10 to 1.19 . The ground-eolor is light gray or drab, with an olive tinge, marked (fincly?) with spots of light brown and lilac (Reed, 1904, p. 132; Baird, Brewer and Ridgway, 1884, I, p. 126).

Nelson (1887, pp. 129-130) says of the Black Turnstone:

It hreeds among the brackish pools on Saint Michaels Island, and is found seattered over the wet flats everywhere. It is one of the commonest birls of this locality, its sharp, elear note breaking the silence wherever one turns his steps among the pools and marshy places. It has a habit of cireling around the intruder, luring the nesting season, with a fuce, clear, peeping ery like the syllables wect, wect, too-uert, as it moves restlessly about; now stopjing a moment on a slight knoll, then running hastily along the edge of a neighboring pool, perhaps picking up a sarap of fool as it rums, and then it mounts on wing again and comes carecning about, evineing the liveliest listress at the invasion of its haunts. When disturbed in the vieinity of its nest it has also a sharp peet, weet, weet, very similar to the well-known note of the Spotted Sandpiper. Let the hunter go where he will on the marshy ground and his ear is greeted by the same remonstrance.

They are found along the course of the Lower Yukon during the summer season and breed wherever found. When the young are able to take wing in July they leave the flats, to a great extent, and frequent the sea-coast, where they keep in small straggling parties searching for food along the tide line.

The food of the Black Turnstone probably eonsists of small marine animals such as are taken by other waders frequenting similar forage gromds; lont we have very little definite information on the subjeet. A specimen taken May 22, 1896, bỵ C. L. Hall at Saint Michaels, Alaska, and now in the collection of the IInseum of Yertebrate Zoology, was feeding on heath berries when secured. This must be considered out of the ordinary-an emergency item of fare. Torrey (1913, p. 37) mentions certain marine crustacea as included in its diet, and Kells (1895, p. 6t) says the Black Turnstone takes small "slugs," while according to Cooper (in Baird, Brewer and Ridgway, 1884, I, p. 125) it feeds on barnacles, as does the Surf-bird.

Locally restricted in its range, and not occurring anywhere in the number's exhilited by most shore birds, this species will never take an important rank among the game species of California. On the coast of Washington, Suckley (in Cooper and Suckley, 1859, p. 234) says that in October he ". . . . found them usually fat, and comparing favorably with the tattlers and sandpipers as articles of food." But there is no evidence that they have ever been made a special object of pursuit by sportsmen in California. No change in their relative abundance has been noted. Like their littoral associates we can but look upon Black Turnstones as essential and attractive figures in the avian life of our seashores. 


\section{Black Oyster-catcher}

\section{IIaematopus bachmani Audubon}

Other NAmes-Bachman Oyster-catcher; Townsend's Oyster-catcher; Haematopus niger; Haematopus ater; Haematopus townsendi.

DESCRIPTION-Adults, both sexes, at all seasons: Whole head, neck and breast, black; rest of plumage dark brown, very slightly paler on under surface, larker on tips of wing and tail; feathers of belly often tipperl narrowly with white; edges of eyelits bright rell; bill "vermillion"'; iris "yellow"; legs and feet "pale flesh color" (Sanford, Bishop and Van Dyke, 1903, p. 494). Males: Total length $16.75-18.40$ inches $(425-467 \mathrm{~mm}$.) (four specimens from California and Lower California); folded wing 9.34-10.05 (237-255); bill along culmen 2.42-2.87 (61.5-72.9); tarsus 1.94-2.15 (49.3-54.6) (ten specimens from California and Alaska). Females: Folded wing 9.56-10.35 (243-263); bill along culmen 2.73-3.01 (69.4-76.5); tarsus 1.97-2.18 (50.1-55.5) (nine specimens from California and Alaska). Juvenile plumage: Like that of adult, but with feathers of back and outer surface of wing sparingly tipped with pale tawny brown; white tippings on feathers of lower abdomen lacking; bill blackish toward tip. Natal plumage: Upper surface mixed light drab and blackish in fine pattern; indistinct streak through eye, two lines down middle of back meeting on rump, and tail, black; unler surface inll grayish, darkest on throat and lightest on midhle of belly; whole plumage presenting a pepperand-salt effect.

MARKS FOR FIEID IDENTIFICATION-Large size (near that of Hudsonian Curlew), long, stout and straight, red bill (fig. S0), wholly blackish-appearing plumage, light colored legs, and entire lack of distinet white markings.

Vorce-A peculiar low whistle (Nelson, 1887, p. 130); harsh, vociferous cries (Henslıaw, 1876, p. 270).

NeST-On small roeky islets, usually but a short distance from a larger island or the mainlani; often but a few feet above the high water mark; a shallow depression in the rock surface or thin soil, with the addition of a few pebbles, bits of shell, or even sharp fragments of rock; no lining of grasses or other vegetable matter.

EgGs - 2 to 3, rarely 4, ovate in shape, and measuring in inches, 2.08 to 2.38 by 1.45 to 1.58 (in millimeters, 52.8 to 60.4 by 36.8 to 40.2 ); ground-color grayish olive to greenish, superficial spots of black and tark brown: (leeperlying markings lavender (Willett, 1909, p. 187).

General, Distributios-Pacific coast of North America. Breeds from Prince William Sound. Alaska, west throughout the Aleutian Islands, and south to central Lower California (Abreojos Point). There are no winter recoris north of southern British Columbia, and there is one winter oecurrence reported from La Paz, extreme southern Lower California, so that a partial migration may prossibly take place (morlified from A. O. U. Cherk-list, 1910, p. 133; W. E. Bryant, 1889, p. 276).

Distribution in California-Common resident locally coastwise, ehiefly on rocky off-shore islets. Recorded north to Trinilad, Humboldt County, but most common on the central part of our coast and around the Santa Barbara Islanis. Recorded as breeding on the latter south to Santa Barbara Island, and to the northward to Seal Rocks near Cypress Point, Monterey County: may be expecterl to breed in suitable localities farther to the northward. 
The Black Oyster-catelur is the representative species of its genus along the coast of California, where it is found locally in linited numbers throughout the year. In the northern part of its general range, that is, from the Aleutian Islands to British Columbia, this species is said to be migratory, but within our borders it is quite certainly resident. It differs from other shore birds whieh ocen in California throughout the year in restricting itself to rocky islets and island shores along the outer seacoast. In consequence of this it is less often met with than most of our other shore birds.

Definite records of the Black Orstei-catcher in Califormia have been established as far north as Trinidad, IIunboldt County (specimen in Mus. Vert. \%ool.), and as far south as San ('lemente lsland (Cooper, 1870b, pp. 79, 81), but it is likely to oceur in all suitable

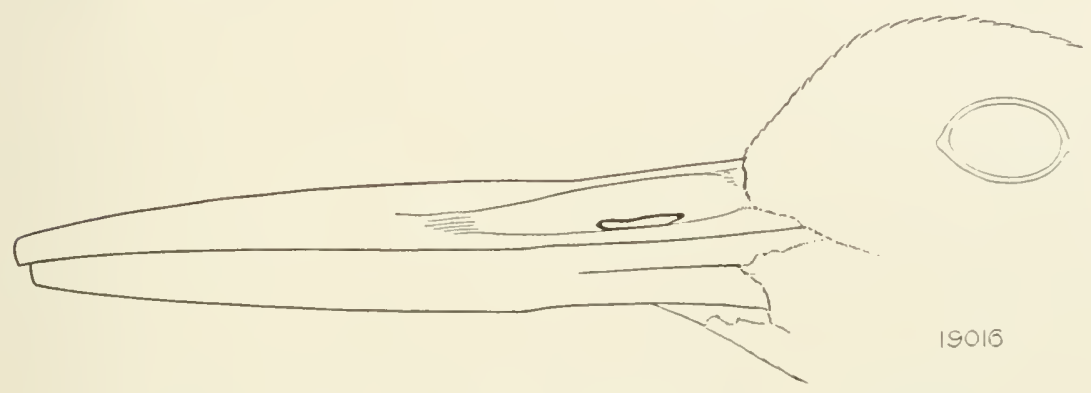

Fig. 80. Side of bill of Black Oyster-catcher. Natural size.

Note stout form aud length over 2.50 inches (compare with figs. 64 and 75 ).

locations along our coast. Present records indicate that it is most abundant on the Santa Barbara group of islands. This species is never found in large numbers in any one locality, each small islet usually harboring but one or a few pairs, according to its size. This limitation in numbers is probably due to the fact that the birds are permanent residents of the territory they occupy and that their full complement is strictly limited by the supply of food obtainable there throughout the year.

From our other shore birds the Black Oyster- catcher is easy to distinguish. Its large size (approaching that of the Hudsonian Curlew), its long, straight, stout, red bill (fig. 80), dark-colored plumage (appearing quite black but a short distance away), lack of any distinct white markings, and pale-colored legs, render recognition certain. From the more southern Frazar Oyster-eatcher it may be easily distinguished by the absence of white on its rump, wings and under surface.

The preferred habitat of the Black Oyster-catcher is a rocky shore, but sometimes the birds forage on a sandy stretch of beach. Their gait 
in walking is said to be clumsy, perhaps because of the disproportion between their large bodies and their short legs. But at times they are quite nimble. When foraging on a beach, they advance and retreat with agility before the wash of the waves. The strong bill, werlge-shaped towards the tip, seems admirably adapted to their peculiar method of gaining a livelihood; and it is put to good use in prying loose from the rocks the various kinds of mollusks which form their' staple diet. They seem to enjoy standing on a partially submerged ledge of rock with their feet now and then awash, and are wont on such occasions to call back and forth to one another with loud curlew-like cries of a quality which carries well above the noise of the surf.

The nesting season of the Black Oyster-eatcher in California extends from the middle of May to the latter part of June (Willett, $1912 \alpha, 1) .42$ ). The earliest nesting is that reeorded by Willett (1909, p. 187) who took a set of half-incubated eggs near Port Harford, San Luis Obispo County, May 14, 1909, and also three other sets on May 15, 16, and 17, and the latest date is for a set of two fresh eggs found at Seal Rocks, near Cypress Point, Monterey County, June 21, 1902 (Grinnell, MS). The recorded instances of nesting range geographically from San Clemente Island (Cooper, 1870b, p. 79), to Seal Rocks, Monterey County (Grinnell, MS), but the species may be expected to nest in suitable localities at many other points farther to the northward.

Black Orster-catchers nest on the same rocky islets that they inhabit at other times of the year. Sometimes they nest in the near neighborhood of such birds as Gulls and Cormorants; again they are the sole inhabitants of these wave-swept spots. The birds seem to prefer the smallest detached rocks to the larger islands, probably beeause of the greater measure of protection afforded by the former. The nests are placed on the bare rocks, sometimes but a short distance above the ligh-water mark, or again at a considerable distance above the reach of the waves. The nest itself is merely a slight natural depression in the rock surface, or in whatever thin eovering of soil there may be. The only lining provided is a number of small pebbles or bits of rock or shell which may be either smooth and rounded, or angular and sharp; no vegetation whatever is included as lining material.

A set of eggs number either two or three, although Cooper (in Baird, Brewer and Ridgway, 1884, I, p. 117) states that he found a nest containing four on Santa Barbara Island, June 3, 1863. The eggs are ovate, and measure 2.08 to 2.38 by 1.45 to 1.58 . The groundrolor varies from gravish olive to greenish, with superficial spots and blotelies of black and dark brown, and deeper-lying ones of lavender (Willett, 1909, p. 187). 
In San Luis Obispo County, Willett (1909, pp. 186-18T) judged that there were in 1909 trelve pairs breeding along fifteen miles of coast. He sars :

The nests are diflicult to locite, and even more diffieult to reach after they are locatei. This bird, like the Killdeer, makes the greatest outery at a point considerably distant from the nest, and the brooding bird will quietly slip from the nest at the first intimation of langer and will appear on a point of rock some distance away, where she will be joined by her mate... The nests are placed on the lea side of a rock or projection sheltered from the prevailing wind, sometimes only a few feet above high water and at other times far above the reach of the flying spray. They are shallow eavities in the rock or thin soil, thickly linerl with sharp chips of rock evidently carried by the birds. Numerous seratehes on the shells of the eggs show that they are frequently turned over by the birils who rely to some extent on the heat of the sun as an assistance in incubation.

\section{Heath (1915, p. 40) says that on Forrester Island, Alaska :}

The freeocial fledglings very early aceompanied their parents on short jomrneys ahout the chiffs, and within a week after hatrhing were observed peeking at limpets, although it is highly probable that for several days thereafter they depended on the old birls for the greater part of their fool supply. During this time the young resemble diminutive ostriches with thick-set legs, big feet amd lluffy phmage, which, it may be arled, harmonizes to a high legree with the surromnlings. Furthermore they have the same habit of hisling the head when it is not possible to conceal the entire body beneath a stone. From the stomach contents of alults, and juiging by the shells seattered about the nests, the foor of the black oystereateher consists wholly of limpets.

The name Oyster-cateher, as applied to these birds is somewhat of a misnomer. They rarely feed upon oysters, as, especially on this coast, they frequent localities where these bivalves are rare or absent, and if they feed elsewhere upon oysters it is only upon the smaller species and not upon the ones of commerce, which live in too deep water to be secured by these birds. Other mollusks including such forms as mussels, chitons, limpets, and young abalones seem to form the principal item of their diet (Beck, IIS; Willett, 1909, p. 187). It is probable that the birds also use other sorts of marine animals for food.

The question of what constitutes a game bird comes up again in the case of the Oyster-catcher. Shall we define as game only the species generally pursued for the excellence of their flesh or the cxcitement afforded in hunting them, or shall we set off eertain natural groups in their entirety (as we do at present), and allow all of their members to be legally pursued? It would seem better to alter the present system somewhat and exclude certain members of our native avifauna from the eategory of game birds. As the Black Oystercatcher is of peculiarly interesting structure and habits, limited in 
numbers and restrieted in distribution, and of little or no value as food, it should eertainly be so treated and removed from :he game eategory. This wonld entail no hardship to the sportsmar, for his quests rarely lead him to the remote haunts of these birds, and even if he captures one he will find it very unpalatable food, if the testimony at hand ean be relied upon.

\section{Frazar Oyster-catcher}

\section{Hacmatopus frazari Brewster}

OTher xames-American Oyster-eatcher; Pied Oyster-eateher; Haematopus palliatus.

DESCRIPTION-Adults, both sexes, at all scasons: Whole head, neck and breast, black; bill vermilion; iris orange; back, rump, and outer surface of closed wing, brown; upper tail coverts chiefly white; tail feathers white at bases, brown on midlle portions, becoming blackish fowarl tips, lateral ones lighter; ends of greater coverts and much of secondaries, white, forming a corrspicuous band across expanded wing; flight feathers blackisl brown; portion of wing lining near edge of wing, mixed white and brown; rest of lining, white in part, in part dusky; axillars solidly white; under surface of flight feathers dusky brown; under surface of body behind breast white, the line of separation not sharp, there being a few feathers of mixed black and white; feet white or whitish. Male: Folded wing 10.10 inches $(256 \mathrm{~mm}$.) ; bill along culmen 2.96 (75.0); tarsus 2.27 (57.6) (one specimen from Los Coronados Islands, Lower California). Females: Total length 18.00-18.50 (457-470); folded wing 9.6010.24 (244-260); bill along culmen 2.83-3.18 (71.8-80.7); tarsus 2.21-2.29 (56.158.2 ) (two specimens from California). Jurenile and natal plumages: Not known to us.

MARKS FOR FIELD IDENTIFICATION-Large size (about that of Huilsonian Curlew but of stouter build), long, straight and thick reddish bill, dark-colored head and back, conspicuous white markings on wing and "rump", and pure white hinder lower surface. Differs from Black Oyster-catcher in the possession of conspicuons white areas.

VorCE--Loud, clear, whistling notes (W. E. Bryant, 18s9, p. 276).

NEST-On rocky islands; probably as with the Black Oyster-cateher a slight depression in the rock surface, lined with a few pebbles.

EgGS-Not known to us.

General distribution-Resident on both coasts of Lower California; formerly ranged north to Ventura Comity, California; and has been reported once from coast of Sinaloa, Mexico (Cooke, 1910, pp. 99-100).

Distribution in CALifornia-Of former occurrence on the coast and islands sonth from Santa Barbara Island to the Mexican line. No thorouglily authentic instance since the eighties.

The Frazar Oyster-eatcher is to be eonsidered at best but a rare straggler in California; it is properly a member of the fauma of Lower California. As it ranges (or did so formerly) north to Ventura County, and south along the whole western eoast of Lower Cali- 
fornia, its range is overlapped by that of the Black Oyster-eateher for several hundred miles. There are but three reeords of this species being found within our borders. These are as follows: Trentura Comnty", "seen oecasionally along the seacoast in summer" (Evermann, 1886, p. 92) : Santa Barbara Island, June 2, 1863, adult female containing an egg ready for extrusion, and San Diego, Mar 16, 1862, adult female (Cooper in Baird, Brewer and Ridgway, 1884, I, pp. 113-114; specimens now in Mus. Vert. Zool.) ; White 's Landing, Santa Catalina lsland, one seen February 12, 1910 (Osburn, 1911a. p. 76). The last eited instance is subject to some loubt.

From other shore birds occurring in California the Frazar Oystercatcher is distinguished by its large size (about that of IIudsonian (urlew but stouter), large, straight and thick, reddish bill, and darkeolored head and back with conspicuous white markings on wing and "rump", and pure white hinder part of under surface. From the Black Oyster-cateher this species may be known by the presence of the conspienous white markings just mentioned.

But little has been placed on record concerning the Frazar Oystereatcher, probably beeause it was for a long time considered identical with the Oyster-eateher of castern North Ameriea, which was already well known, and again because the Frazar oceupies a region not often risited by naturalists. It inhabits by preferener offshore islets, of which there are many along the eoast of Lower California. There it feeds on the various marine animals found on roeks, such as barmacles, other crustacea, and mollusks. Its stout bill is admirably adapted for the work of dislodging such ereatures.

The Frazar Oyster-catcher nests on the same rocky islands that form its forage grounds at all times of the year. Kaeding (1905, p. 111) states that on several islands off the coast of central Lower California eggs of this speeies were taken in various stages of ineubation about June 25, 1897, which would indicate that the nesting season is fully as late or even later than that of the Black Oyster-eatcher (which see). W. E. Bryant $(1889$, p. 276) reeords finding this species common on Santa Margarita Island and vicinity, Lower California, where the birds ". . were mated [that is, in pairs] in January. They were rather shy, running rapidly on the beach, and if approached, taking wing with loud, clear, whistling notes, and after flying some distance, alighting again at the water's edge."

As it has been but seldom observed within our limits, and is not likely to extend its range beyond its present southern habitat, the Frazar Oyster-catcher cannot be looked upon as more than a rarity in California, and the interest which we take in it is almost exclusively scientifie. 


\section{Mountain Quail}

\section{Orcortyx picta plumifera (Gould)}

Other NAMrs-Plumed Quail; Plumed Partridge; San Pedro Quail; Callipepla picta, part; Ortyx picta, part; Ortyx plumifcra; Oreortyx picta, part; Oreortyx picta confinis.

DESCRIPTION-Adults, both sexes: Head, breast and forepart of back clear bluish slaty gray; plume or topknot of two straight narrow black feathers 2.75 to 4.00 inches (70-102 $\mathrm{mm}$.) long when complete; extreme forehead and area between eye and bill whitish; large patch on throat, extending to bill and eyes, bright chestnut brown, bordered above on each siche by a narrow line of black and then by a wider white line; bill black; iris brown; back, outer surface of wing, rump, upper tail coverts, and tail, light olive brown; primary flight feathers ontwarlly edged with ashy; an abrupt white edging along margins of inner webs of secondaries; under surface of wing and axillars plain ashy brown; elongated feathers of sides shiny chestnut brown broarly and strikingly marked with black and white bands; a series of white marks high on each side of the body forming a longitudinal line; flanks light chestnut brown; belly whitish; under tail coverts blackish, more or less streaked narrowly with dark chestuut; legs and feet dusky. The male differs slightly from the female in the greater length of the plume, the clearer gray of hind neck, and the brighter tone of colors on lower surface. Males: Total length 10.6011.75 inches (269-29s mm.) (ten specimens); folled wing 5.10-5.46 (129.513S.5); bill along culmen $0.53-0.57$ (13.4-14.5); $\operatorname{tarsus~} 1.38-1.48$ (35.1-37.6) (ten specimens); weight $7.0-10.3$ oz. (200.0-292.0 gms.) (ten specimens). Females: Total length 10.40-12.12 (264-30s) (nine specimens); folded wing $5.00-5.58$ (127-142); bill along culmen 0.52-0.56 (13.2-14.2); tarsus $1.32-1.46$ (33.5-37.0) (ten specimens). Jucenite plumage: General tone of coloration pale ashy brown; feathers of upper surface, wings and tail minutely flecked with whitish and dusky or blackish, the pattern coarsest on scapulars, and more in the nature of bars on crown of head, wings and tail; two short blackish feathers with narrow light brown bars at tip, form a plune; inner scapulars most strongly tinged with brown; lower surface clearer ashy, the feathers tipped with white; chin, stripe over eye, and cheeks, mostly white; broad patch of blackish varying in extent in different individuals, on lower throat, usually reach. ing to eyes; feathers of sides blackish, broarly borlerel with dingy whitish and showing traces of chestmut brown; flanks and lower tail coverts pale cinnamon brown. Natal plumage: Broad stripe of chestnut brown over top of head and down back to tip of tail, bordered on either side by narrower stripes of black and then of whitish; siles of head and body, and wing, minntely marked with dnsky and? buffy brown; a rark line behind eye; a patch of chestnut brown on shoulder: below yellowish white, palest on chin and belly; flanks and shanks tinged with cinnamon; legs and bill of a pale dull brown.

MARKS FOR FIELD IDENTIFICATION-Large size (as compared with other quail), long slender black plume (fig. 81), and bands of black, white and chestnut on sides of bolly (pl. 14). In hand, distinguished from closely similar Painted Quail (Oreortyx pirta pirta), which inhabits the northern coast region only, by whitish forchead, greater amount of ashy on top of hear and hack, and lesser amount of grayish olive on upper surface of horly generally. Call-note easily distinguisluable from that of Valley Quail.

Volce-Resonant, often turkey-like in quality; of male: a single lourl queerh 
utterel at intervals; note of alarm: ca-ca-ca-ca-cré́-a or gup, gup. gup, qué-ar, queé-ar.

NEST-A depression on the ground lined with leaves, pine needles or grass and usnally coneealed beneath an orerhanging roek, log or bush.

EGGS-5 to 15 , in exceptional cases more; in shape pointedly ovate, occasionally almost pear-shaped, measuriug in inehes 1.27 to $1.46 \mathrm{by} 0.97$ to 1.05 (in millimeters 32.2 to 37.0 by 2.6 to 26.7 ), and averaging 1.33 by 1.00 (33.7 by 25.3 ) (nineteen eggys from California); color plain pale redaish buff.

Generai. Distributiox-Mountainous portions of the Pacifie coast states from west sile of Cascade Range in northwestern Oregon south through the Sierra Nevadia and sonthern coast ranges of California to northern Lower Califormia; east only to extreme western Nevada.

Distribetion is CALfFORNA-Abundant resident at middle altitudes along the major mountain ranges almost throughout the state. In detail: Modoe region of northeastern California from Mount Shasta to the Warner Mountains; west along the Oregon line to the Siskiyou Mountains; south along both slopes of Sierra Nevala to Tehachapi Mountains; desert ranges of the Inyo region; sonthern coast ranges from the Santa Ynez of Santa Barbara County southeast through the San Gabriel, San Bernardino and San .Jacinto ranges to the vieinity of the Mexican line; down onto the desert locally at east base of these ranges. Not in the northern coast ranges nearest the oeean from Humboldt County south to Monterey County, where replaced by a near-related subspecies. A slight rertical migration for the winter down the slopes of the Sierra Nevada.

The Mountain Quail, sometimes known as Mountain Partridge or Plumed Quail, is generally admitted to be the most beautiful of all member's of the quail family found in North America. It is also the largest of the speeies that may be properly termed quail. This bird is found throughout the mountainous distriets of California with the exception of the northwestern coast region, where a darker subspecies (Orcortyr picta picta) is found. No representative of the speeies, however, now oecupies the near vieinity of San Francisco Bay. From the Shasta and Nodoe regions the range of the Mountain Quail extends southward along both slopes of the Sierra Nevada to the Tehachapi momntains, thenee eastward through the higher desert mountains towards Death Valley, and southward through the southern coast ranges from the Santa Ynez Mountains of Santa Barbara County to the Mexiean line in San Diego County. On the eastern bases of the southern California ranges this quail ocenrs about springs well out onto the desert. There are a few places where Mountain Quail and Valley Quail nest on common ground, as for example, in San Gorgonio Pass, Riverside County, and near Walker Pass, Kern Comity. As a rule the Momntain Quail is to be fonnd on brushy hillsides and in wooded eañons between the altitudes of 2,500 and 9,500 feet. In the fall along the Sierra Nevada there is a general dowuward movement, to a belt usually below the snow-line, so that the winter range may be well below the summer range. Thus, in midwinter, the Mountain and Talley quails may be found not infrequently on eommon ground, where in summer only the latter occurs. 
From other quails found in California, the Mountain Quail may be distinguished at onee by its large size, rieh ehestmut throat and sides, the latter broadly banded with black and white, and by the long slender topknot or plume made up of two jet black

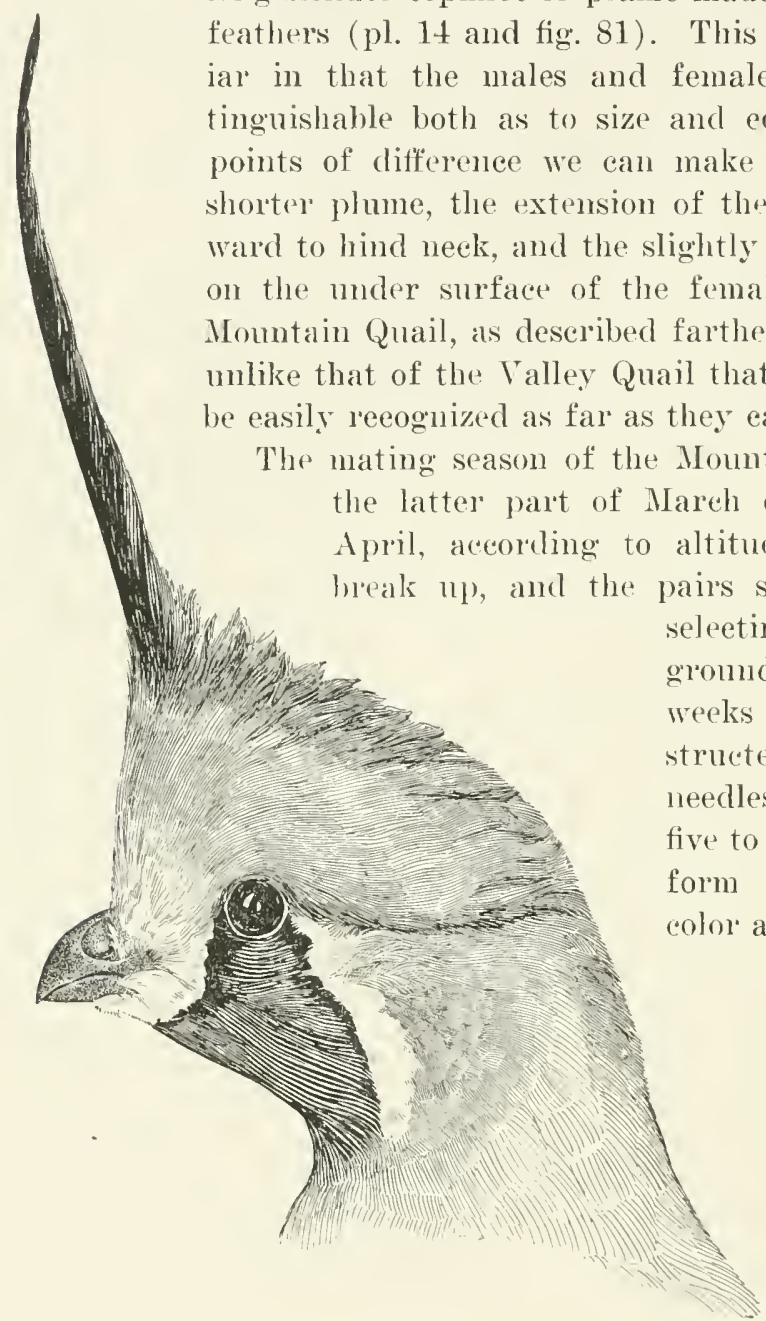

Fig. 81. Hearl of Mountain Quail showing long straight slender plume. Natural size. seleeting favorable nesting. gromuds. Three or forr weeks later a nest is contructed of leares, pine needles, or grass, and from five to fifteen egg's of a uniorm pale reddish buff olor are laid therein. The nest is invariably placed on the ground under the protection of an overhanging rock, log, bush, or elump of grass. An indieation that an incomplete set of eggs is in the near vieinity is said to be the presence of

a pair of Mountain Quail walking sedately along a road or aeross a forest opening, the male leading with plmme erect and the female walking elose behind (Keyes, 1905, p. 14). The earliest nesting date on reeord is April 7 for the southern part of the state, when Mr. Frank Stephens found a "full set" ; the latest date given is August 15, for Shasta County (Bendire, 1892, p. 16). Complete sets are most 
commonly found during the first two weeks of June. The above statements are summarized from the accompanying table (no. 13) which grives details of nesting as far as we have been able to obtain definite data.

TABLE 13-Data Relative to the Nesting of the Mountain and Painted Quails in California

\section{MOLNTAIN QUAIL}

LoCALIT:

"Southern California"

Baird, Shasta Co.

Tolcan Mt. San I)iego (Co.

Linda Vista Hills.

near Pasidena

San Antonio Cañon

Los Angeles Co.

Fyffe, Fidorado Co.

liedding. Sihasta Co.

Fyffe, Eldorado Co.

Fyffe, Eildorado Co.

Downieville, sierra Co.

Bear Valley, Alpine ('o.

Fyffe, Eldorado Co.

\section{Mt. Iassen}

Parker Crepk.

IJotor $\mathrm{Co}$.

Fyffe. Eldoriado Co.

Cisco, Plazer Co.

Palomar IIt. San Diego Co

Near Bloods, Alpine $\mathrm{Co}$.

Near Bloods. Alpine Co.

Near Bloods, Alpine Co.

Baird, Shasta Co.

Southern Sierra Nevada

Mt. Tallac, $8,000 \mathrm{ft}$, alt.

Tuolumne Co. $9,500 \mathrm{ft}$. alt

Big Trees, Calaverns Co.

Baird. Shasta Co.

Big Trees. Calaveras (u.

Big Trees,

Calaveras Co.

"Union Paeific Railroad" (Placer Co.?)

Redding, Shasta Co.

\footnotetext{
Alpine Tralley. Sonoma Co.

Alpine Valley.

Sonoma Co.

Mill Creek. near Ukiah

Monterey
}

$$
\begin{gathered}
\text { NEST CONTEXTS AND } \\
\text { CONDITION }
\end{gathered}
$$

Ipr. 7 .

"Full set"

May 5. 1885

Iay 7,1897

May 11, 1907

II: 13, 1913

Ilay 24, 1886

June 7.1899

June 7. 1899

Iune 7,1866

June $10,18 \times 0$

June 10,1899

June 12, 1884

June 12. 1910

June 16,1899

June 17,1914

June 19, 1897

Iune 19, 190:

dune 20,1903

June 21, 1903

Inne 21 .

June 25, 1906

fuly 2. 1903

July 6, 1890

Tuly, 1878

Alg. 15.

…...... 1879

1880

1886

PAINTED QIAIL.

Mas 15.1914 8 eggs, incubation well begun

May 24, $1913 \quad 6$ eggs, incubation begun

Last of May,

9 eggs, fresh

5 eggs
A UTHORIT

Isendire, 1892 , p. 16

Bendire, 1892 , p. 16

Bendire, 1892, p. 16

Grimmell, 1898, p. 19

Willett, $1912 a, 1,43$

Ray, 1914, p. 59

Bendire, 1892, p. 16

Barlow and Price, 1901 . p. 158

Barlow and Price, 1901 , 1. 158

Bendire, 1892, p. 16

Bendire, 1892, p. 16

Barlow and Price, 1901 , p. 158

C. II. Townsent, 1887 . p. 199

11. C. Bryant, MS.

I3arlow and Price, 1901 p. 158

Carriger coll.

MeGregor, 1899 , p. 67

Keyes, 1905, p. 15

Keyes, 1905, p. 15

Keyes, 1905, p. 15

C. H. Townsend, 1887 , p. 199

Childs coll.

Keyes, 1905, p. 16

Mailliard coll.

Belding, 1879.

pp. $438-439$

Bendire, 1892, p. 16

U. S. National Museum

U. S. National Museum

Bendire. 1892, p. 16

[T. S. National Museum

Carriger coll.

Carriger coll.

Mailliard coll.

U. S. National Museum 
Keyes (1905, pp. 15-16) found several nests of the Mountain Quail in the Sierras while making a trip through the mountains from Sonora to Lake Tahoe. One found on Jume 15 was composed of pine needles and measured eight inches in diameter and three inches in depth at the eenter. It contained seven eggs. An additional egg was found in this nest on the morning of the 17 th, and on the 19 th still another. At eleven o'clock A.M. on the 20th the nest still contained nine eggs, but by one o'cloek P.M. of the same day a tenth had been added.

Another nest found June 15 contained seven eggs. Eight eggs were in the nest when it was visited on the 16th, nine were found on the 18th, ten on the 20th, and eleven on the 21st. These instances would seem to show that the frequent statements that an egg is laid each day mitil the set is complete are not literally true.

Still another nest found by the same observer on June 20 was well construeted of coarse dry grass, a few small twigs, and many breast feathers from the bird, and was well concealed in thiek brush. The remarkable complement of twenty-two eggs was found in it, these being arranged in two layers, the upper of which eontained but three eggs. It was not possible to determine whether so many eggs were the product of two females or of just one, but the former is more likely.

Where the Momtain and Valley quails nest in elose proximity it sometimes happens that eggs may be laid by one speeies in the nest of the other. H. J. Lelande flushed a Mountain Quail from a nest in the Lincla Vista Hills west of Pasadena, May 7,1897 , which contained ten eggs of this quail and four of the Valley Quail. All were fresh (Grimnell, 1898, p. 19). A nest found in Alpine Valley, Sonoma County, held eight eggs of the coast race (picta) of Mountain Quail and two eggs of the California Quail (Carriger, MS).

The eggs of the Valley Quail and Mountain Quail are totally different, the latter bird laying plain, ummarked, buff-tinted eggs, the former conspienously brown-spotted eggs with whitish groundeolor. Nineteen eggs of the Mountain Quail from Ciseo, Placer County, measure in inches, 1.27 to 1.46 by 0.97 to 1.05 , and average 1.33 by 1.00. In shape they vary from elongate ovate with a relatively sharp point at small end to almost pear-shape. Two sets from Sonoma County (and henee probably of the race Oreorlyx picta picta), aggregating fourteen eggs, are similar in shape and color. They measure 1.28 to 1.43 by 1.01 to 1.11 , and average 1.37 by 1.08 .

While general statements ascribe as many as fifteen as the usual complement of eggs for the Mountain Quail (for instance, see Belding. 1879, p. 439), exact data as far as available show an average of only eleven eggs per set. This is decidedly below the average for the 
Valley Quail, so that we may properly infer the reproduetive rate in the Mlountain Quail to be the lower. Beeause of the shorter summer season at the higher altitudes it is less likely that two broods are regularly reared each season. Evidence in this regard is lacking, save for a single statement by a correspondent of Bendire (1892, p. 16) that in Shasta County two broods per season are raised. As against the elaim of two broods, we may offer the following data: Extreme dates for ten just-hatched, downy ehicks (specimens in Mus. V'ert. Zool. and Grinnell coll.), representing as many broods, are June 6 and July 5; the latest date for eggs as shown by our table is August 15, but the next latest is July 6, for incubated eggs. On October 7 , near the Merced River above El Portal, Mariposa County, a covey of two-thirds grown young was flushed from the roadside. But we have no definite knowledge of the rate of growth of this species of quail, so that the late of egg-laying in this case may have been much earlier than some would infer.

During July and Angust the young are very much in evidenee around mountain springs at the heads of ravines. Eight broots were seen by II. C. Bryant (MS) during a ten days stay in the first half of August, 1914, near ('iseo. Placer County. The young birds raried from three inehes in length to half the size of adults. The broods were accompanied by one and often both of the parents. When disturbed the adult bird wonld take some commanding position on a $\log$ or rock, well sheltered by brush, and while watching the intruder, would give voice to the following eall of alarm: r'a-ca-ca-ca, ca-cr$r-r-r c-a, c a-c u-c a-c a, c(t-s)-r-r-r c e-a$. The young are adepts at hiding and a person is likely almost to step upon them before they flush. The half-grown young less often resort to rumning to escape pursuit than in the case of adults, but instead take to trees like grouse where they sit motionless (Grimell and Swarth, 1913, p. 229). Although, as the summer advances, broods of young unite, the resulting aggregations never reach the size of the big autumn flocks of the Valley Quail.

Williams (1902, pp. 65-66) gives the warning note of the Mountain Quail as: cree-auk-crec-auk-crec-auk-a, and the call-note used in keeping the flock together as kow, kow, kow, kow. The alarm notes may be otherwise described as low and turkey-like: gup-gup-gup, que-ar. que-ar. When feeding undisturbed one can hear the birds uttering many faint mellow conversational peeps. When first alarmed perfect quiet may prevail, or only the sound of footfalls as the birds seurry over the earpet of dead leaves, to be followed presently by the startling bur of wings ( $\mathrm{J}$. Grinnell, MS). The male bird gives a solitary far-reaching qué-ark or queerk from some fixed position as on a log. One bird that was timed uttered this note at the following intervals (in seconds) : 7-6-8-5-8-6-7-5-7-9-9 (T. I. Storer, MS). 
J. E. MeClellan says (in Judd, 1905, p. 60) : "Their feeding hours are early in the morning and just before sundown in the evening, when they go to roost in the thiek tops of the scrub live oaks. Their feeding habits are similar to those of the domestic hen. They are vigorous seratchers, and will jump a foot or more from the ground to nip off leaves."

When alarmed the Momtain Quail earries its crest feathers erect, bowing backwards towards the tip but not tilted forward as in the case of the Valley Quail. This action gives the bird an alert attitudeconsistent with its evident anxiety in case there are young about.

Althongh habitually occupying brushy and forested areas, this quail but seldom perehes in trees, and as far as we know the adults never roost in one at night. They stick close to the ground and usually seek safety by rumning beneath cover rather than by flight. For this reason the Momntain Quail is considered an unsatisfactory bird to hunt. When hunted in the brush they generally run some distance before flying, scattering and finally taking wing like as not behind a bush so as to preelude the probability of a suceessful shot.

Lyman Belding (1892b, p. 233), after intimate acquaintance with the Momntain Quail in the central Sierra Nevada wrote of its habits as follows:

The ... Quail ... which are so plentiful in the high mountains in summer, are only summer residents there. They usually spend the winter below the snow line, hut as it is not possible to tell just where that is, or rather where it is going to be, they are sometimes eaught in snow storms, but I have been astonisherl at the correctness of their apparent forecast of different winters. A few birds winter high in the mountains, but I think they are parts of flocks which were nearly annihilated, or young birds which got seattered and lost, and a few that were wounded and survived.

They begin their journey on foot from the summit and east slope to the [western] foothills, a little after the first of September, and by the first of ()etober, when the game law allows them to be shot, they have nearly all eseaped from the mountain hunters to mn the gauntlet of those lower down, on the west slope. In some respects they are very stupid birds, in others, quite the reverse. When they are going from their summer to their winter resorts, birds of a flock can all, or nearly all, be shot if the flock can be turned from its course and seattered. They soon begin to call together and will nearly always respond to a hunter's imitation of their eall. The loud, pleasing call of the male in breeding season is not easily imitated nor described, though apparently consisting of a single note, which is sometimes varied a little.

Barlow and Price (1901, pp. 158-160) say that:

$\mathrm{By}$ the first of September the quail are restless and are beginning their peculiar vertical migration to the west slope of the mountains. Sometimes four to six adults with their young will form a covey of ten to thirty individuals and pursue their way, almost wholly "on foot," along the ridges to a more congenial winter climate. By Oet. 1 the quail have almost abandoned the 


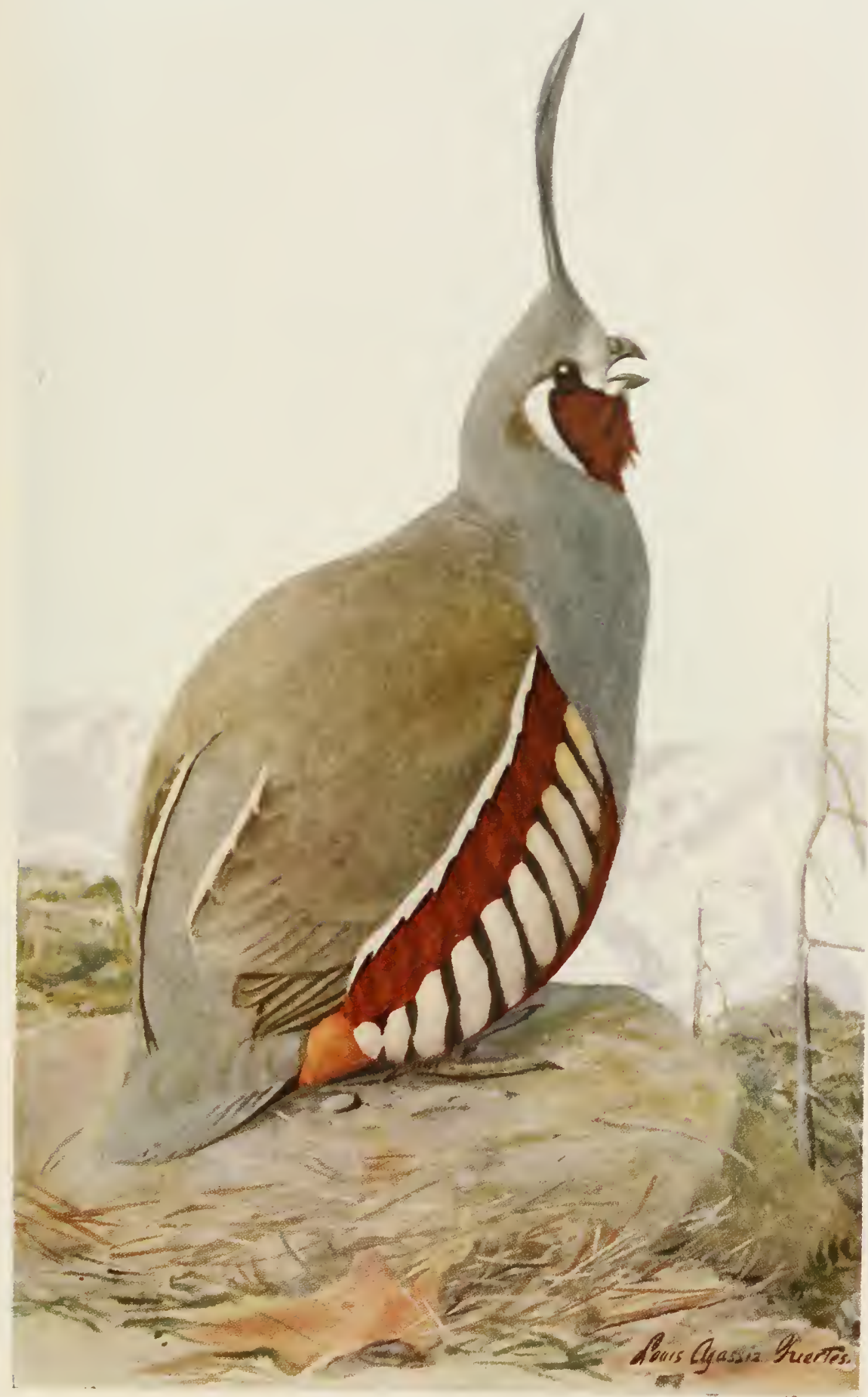

MOUNTAIN QUAIL 

elevations above jo00 feet. In the fall the woodland is full of the disconsolate "peeps" and whistling "all notes of the young who have strayed from their coveys. In the early spring and summer the quail begin their upward journey, not in floeks, but usually in pairs or singly, ascencling as fast as the snow melts from the grounl. At this mating season their rieh, clear whistle is continually heard, though at no time luring the year are they quiet.

Belding (1903, p. 18) has more to say with regard to the migration of Mountain Quail:

The fall migration . . alpears to be influeneed hut little by the food supply or temperature in its summer habitat in the Sierras, which it appears to leave because the proper time has arrived for its anmal tramp down the west slope. The first floeks start ahout the first of September, or sometimes two or three days sooner. At Wehber lake after three cold, eloudy days, they began to move westwarl August 24, 1900. When they are migrating their whistle is frequently hearl, and they th not seek cover for groteetion, but follow a wagon roal, railroall, travel in snow sherls, pass near llwellings, and seem to rare but little for self-jreservation.

A few Momtain (Quail oecur along the east wall of the Sierras in Mono County, and these winter on that side. In severe seasons they come to the ranches around Mono Lake and are said then to mingle freely with the chickens in the stock yards and aromd the haystacks. At such times the quail are welcomed by the people of the region, even the Indians, and are nmmolested

The food of the Mountain Quail has been studied in the laboratory of the United States Biological Survey (see Judd, 1905, pp. 59-60). The stomachs examined, 2:3 in number, were all collected in California. Five were seenred in January, 2 in May, 6 in .June, 3 in July, 3 in Angust, and 6 in November.

The food consister of animal matter, 3 per cent, and vergetalle matter, 97 per cent. The animal fool was male up of grasshopjers, 0.05 per eent; beetles, 0.23 per cent; miscellaneous insects, ineluding ants and lepidopterous pupae, 1.90 per cent; ani centipeles and harvest spiders (Phalangidae), 0.82 per cent. Among the beetles was a speeies of the firefly family (Lampyridae), a ground beetle (Carabidae), and a leaf beetle (Haltica sp.). Vernon Bailey informs the writer that the young eat many ants. The regetable foor consisted of grain, 18.20 per cent; seeds, practically all of weels or other worthless plants, 46.61 per cent; fruit, 8.11 per eent; and miscellaneous vegetable matter, 24.08 per cent. The grain ineluded wheat, corn, barley, and oats. Of the seed element the seeds of grasses formed 7.78 per cent; of legumes, 10.41 per cent; of weeds of the family Euphorbiaceae, 3.16 per cent; of alfilaria (Erodium cicutarium), 2.76 per cent; and of miscellaneous weeds, 22.50 per cent. The legume seeds include seeds of alfalfa, eassia, bush elover, veteh, and lupine. The miscellaneous seeds eome from wild carrot (Daucus carota), tar weed (Madia sativa), Collomia sp., Amsinckia sp., labiate plants, dwarf oak, snowbush (Ceanothus cordulatus), and thistle.

.. This bird is espeeially fond of the leaves of elover and other leguminous plants. It feerls also on flowers, being known to seleet those of Com- 
positae and blue-eyed grass (Sisyrinchium). Flowers, leaves, buds, and other kinds of vegetable matter form the 24.08 per cent marked miscellaneous. The birds probably eat more fruit than these stomach examinations indicate.

Crops of Mountain Quail seeured during field explorations of the Museum of Vertebrate Zoology and examined by the present writers showed contents as indicated in the following table (no. 14):

TABLE 14-Crop Contents of Mountain Quail

LOCALITY

El Portal, Mariposa Co.
DATE

Nov. 21, 1915

Near Coulterville, Mariposa Co. June 6, 1915

$\begin{array}{ccccc}\text { El Portal, Mariposa Co. } & \text { Dec. 1, } 1914 \quad \begin{array}{c}\text { Parts of manzanita berries (Aretostaphylos } \\ \text { mp.) }\end{array} \\ \text { Guerneville, Sonoma Co. } & \text { July 4, } 1913 \text { More than } 575 \text { seeds of turkey mullein (Ere- } \\ \text { mocarpus setigerus) }\end{array}$

* Pertains to the subspecies Oreortyx picta picta.

It must be borne in mind that the above analyses are based upon relatively few stomachs, and give but incomplete evidence as to the food habits of the species taking its entire range into account as well as the entire year. The following field observations supply additional data. Belding says (1892b, pp. 233-234) that:

The service berry is the staple article of their food in fall, but they eat more or less of the different kinds of berries which the grouse eat. I suppose they, as well as the grouse, eat berries of the wild coffee (Rhamnus Californica), but I have no data for a positive opinion. They also eat the acorn of the dwarf oak and seeds of the snow bush (Ccanothus cordulatus), and seeds of many small plants. I do not know that they eat any of the foliage mentioned as the foor of the grouse, but they probably eat leaves of clover early in summer, just as valley quail do in winter. The juveniles eat a great many ants.

Some seasons, when there are no berries and very few seels, they live almost entirely upon the bull, of a species of grass, apparently Mclica bulbosa. which grows at the hear of springs and rivulets. The birds get the hulb hy scratching. Such seasons they start for the foothills sooner than when food is abundant.

In the San Bernardino Mountains, the last of Angust, Grimnell (1908, p. 56) found the Mountain Quail feeding on service berries wherever these were obtainable.

The large size and exquisite coloring of the Monntain Quail combime to make it an attractive game bird. Its flesh is excellent, being 
declared juicier and more finely flavored than that of the Valley Quail. But its comparatively suall numbers, even under normal conditions, the diffeulty attendant upon reaching its habitat, and the fact that it does not lie well to dogs, deter many sportsmen from hunting the species. Exeept when the birds may be ont of their natural habitat, as during their fall migration, it takes stiff hard elimbing and a deal of patience to get a limit of ten.

In former years Monntain Quail were commonly sold on the markets of San Francisco. In some instances they were trapped along the western flanks of the Sierras and sent to the markets alive. Mr. A. E. Skelton, of El Portal, has reported to us that while shooting for the market near Raymond, Madera County, many years ago he averaged about a dozen and a half Mountain Quail a clay. The birds then brought from $\$ 2.50$ to $\$ 4.00$ per dozen. At the present time it is illegal to sell quail of any sort, exeept for propagation and then under permit only. The rapid diminution of Mountain Quail has already given hunters and others considerable concern.

As this quail is a species which inhabits the uncultivated moumtainous distriets of the state it ought to be possible to treat it so that it ean persist in maximum numbers. It would seem that a complete close period for a number of years, so as to allow the species to recuperate, is a measure which could be put in foree every time serious diminution beeomes apparent. In practice such a close period, recurrent every few years, as necessitated, would probably solve the problem to the greatest arlvantage of the hunter.

We may eite as an instance of what could be expceted, the elose season of only two years (1909 to 1911) which was followed by a notable increase of the birds. The fact that the Mountain Quail breeds more slowly than the Valley Quail necessitates different treatment of the two speeies in our laws. In one way this is already met in the difference in bag limit, ten in the case of the Monntain as against fifteen in the Valley Quail.

The reeent establishment (1915) of game refuges in National Forests in several sections of the state is also a wise provision even from the sportsman's viewpoint: for adjacent areas may thus beeme stocked up with minimum diseouragement to the hunter.

\section{Painted Quail}

\section{Orenrtyx picta picta (Douglas)}

OTHER NAMES-Mountain Quail, part; Mountain Partridge; Callipepla picta, part; Oreortyx picta plumifera, part; Ortyx picta, part.

DEscription-Essentially the same as for the Mountain Quail (O.p.plumifera). In adult plumage, a slightly greater lepth of coloration; brown of back 
darker, and, in both sexes, extending farther forward onto hind neck. In juvenile plumage, the differences are more elearly apparent, and consist in a greater amount of brown in the mixed pattern on the upper surface.

MARKs FOR FIELD IDENTIFICATION-See under Mountain Quail.

General distribution-Humid coast belt of Washington and Oregon (west of the Cascades), and of northern California south, more restrictedly, as far as Monterey County.

Distribution IN CALIFORNIA-Common resilent in parts of the narrow humid coast belt, from Humbolat County south to Sonoma County; also sparingly south of San Francisco Bay in the Santa Cruz Mountains (MeGregor, 1901, p. 5), and in the coast ranges of Monterey County south to Big Creek (Jenkins, 1906, p. 125); ranges east at the north as far as Helena, Trinity County (Kellogg, 1911, p. 119). Specinens from the inner coast ranges west of the Sacramento Valley and from Monterey County are apparently intermediate towards the interior race, O. p. plumifera.

General information concerning the Painted Quail has been included under the account of the Mountain Quail.

\section{Valley Quail}

\section{Lophortyx californica vallicola (Ridgway)}

OtIler NAMEs-Valley Partridge; California Partriłge, part; Helmet Quail; Topknot Quail; Crested Quail; Tufted Quąil; Brown-backed Valley Quail; Callipepla californica, part; Ortyx californica, part; Lophortyx californica, part ; Perdix californica; Callipepla californica vallicola.

Description-Adult male: Head with black, forwari-drooping topknot of six overlapning, broad-ended feathers; feathers of forehear buffy yellow with black shafts, this area bounder behind by a double band, of white and of black, the ends of which band continue back on each side of head over eye to a position behind ear; back of head dull brown; chin and throat velvety black, bordered hy a U-shaped band of white which ends on each side just back of eye: feathers of a broad area around hind neck bluish gray, each one margined with a double scallop of black, and many of them with subterminal white spots, the whole giving a scaled appearance; iris dark brown; bill black; back, scapulars and outer surface of closed wing, grayish brown in fall, paling to bluish gray in spring; rump and tail clear bluish gray; buffy white stripe along inner margin of each wing formed by broad edgings on overlapping series of innermost flight feathers; secondaries and coverts narrowly elgerl with buffy white; under surface of wing and axillars grayish brown; a broarl area across breast elear bluish gray; behind this a buffy area, and then one of reddish brown, centrally, white towards silles, the feathers in both these areas being sharply scaled with black; feathers of sides brownish gray, each with a shaft stripe of white; lower belly, flanks anc under tail coverts, light buff, the latter two areas broadly streaked with brown; legs and fcet blackish. Total length 10.25-11.00 inches (260-270 $\mathrm{mm}$.) (ten specimens); folder wing $4.24-4.44$ (107.8-112.7); bill (tip to cere) $0.37-0.43(9.5-10.9)$; tarsus $1.17-1.28$ (29.7-32.4) (ten specimens). Adult fcmale: Somewhat similar to male but lighter in general tone, lacking the conspicuous black and white markings of head, as also the buffy and reddish brown ground-color of under surface; topknot much shorter, and dark brown in color; general color of head light 
brown: throat whitish, with narrow brown streaks. Total length 9.50-10.50 inches (241-266 mm.) (ten specimens); folderl wing 4.05-4.30 (102.8-109.0); bill ( $t$ ip to cere) $0.35-0.44$ (9.6-11.2); tarsus 1.13-1.25 (2S.6-31.8) (ten specimens); all from California. Jutenile plumage. both sexes: Similar to allult female but with topknot still shorter and lighter brown; throat ashy brown, not streaked; feathers of mper surface grayish brown, with white shaft streaks and mottlings of pale brown and black; tail gray, harred interruptedly with blackish and dull white; flight feathers brownish gray, extensively markeil with light brow and tipjed with whitish; lower surface pale ashy brown, the breast with wedge-shapel markings of dull white, and remainder with dull whitish bars; belly almost plain grayish white. Natal phomage: General color above buffy white tingel with rusty, and below dull white; an indistinct lark brown spot over ear; a broal pateh on back of heal, dark brown, hordered with pale buff: two stripes lown back and one on each side beneath wing, black; wing irregularly mottled with dark brown and buffy white: lireast and siles suffusel with buff.

MARKS FOR FIELD IDENTIFICATIOA-The short, blunteenlel black topknot (fig. S2), in assoriation with the scaled pattern of markings arross lower breast, is distinctive. The closely relatel California Quail (Lophortyx californica californica) is distinguishel from the Talley Quail only by slightly darker general roloration, especially on the back and sides, the latter leing a warm brown (1). 1) instear of grayish brown. The Catalina Island Quail (Lophortyx ralifornica catalinensis) is also larker, and in allition is slightly larger especially as regards feet. From the Mountain Quail the valley species is known lyy smaller size, shorter, blunt-ended topknot, and presence of sealing on the belly; and from the Desert (Gambel) Quail, by absenee of rivh rhestmut on sides, and presence of scaled futtern arross lower breast.

VoICE-When listurbed: a sputtering pit-pit-pit, or whit-uhit-uhit; au

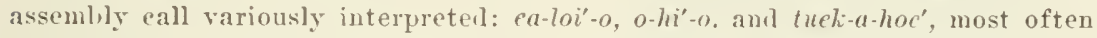
come-right-here, emphasized on the middle syllable. When on guard inring the breeding season the male bird utters a single lous kayrk at intervals.

NEsT-Usually a mere depression in the gromnd, lined sparingly with grass and weed stems; oceasionally a more substantially built affair, though still relatively crude, of the same materials, and placed on a log, stump, or in a brush pile; rarely in trees or otler situations above ground.

EgGs-6 to 2S, usually 13 to 17 , pointedly oval, measuring in inclies, 1.10 to 1.40 by 0.84 to 1.02 (in millimeters, 27.9 to 35.6 by 21.3 to 26.0 ), and averaging 1.24 by 0.95 (31.6 by 24.1) (three sets, 45 eggs, from Nevarla County); ereamy white in color, spotted and blotehed with light golden brown.

General distributiox-Interior valleys and foothills of the Pacifie district, from the vicinity of Klamath Lake, southern Oregon, south throughout California (except the northern coast strip and southeastern desert region) and throughout Lower California to Cape San Lucas; east to extreme western Nevarla. Introducer into many other parts of the West, where now well established.

Distribution IN CALIFORNiA-Abumlant resident of the semi-arid valley and foothill regions, in other words, throughout the state, except in the narrow northwest coast strip (fog belt) from northern San Luis Obispo County to the Oregon line, and the eastern portions of the Mohave and Colorado deserts. Common in the Modoe region of northeastern California aud thence south along the east slope of the Sierra Nevada to Owens Valley and the desert ranges to the eastward towards Death Valley; occurs also out onto the deserts 
east of the southern coast ranges, as in Antelope Valley, Los Angeles County, along the Mohave River at least to Victorville, San Bernardino County, and at Palm Springs, Riverside County. Has been planted in places where it did not exist formerly, as on San Clemente Island, and thriven to a greater or less degree. The Valley Quail reaches the seacoast from San Luis Obispo County southward; north of that county its range meets that of the closely similar California Quail back from the seacoast not more than forty miles, except in the San Francisco Bay region where the line of meeting bends east around Mt. Diablo. The ranges of the Valley and Desert quails overlap in Sau Gorgonio Pass, Riverside County, and doubtless also in other places along the western edge of the desert.

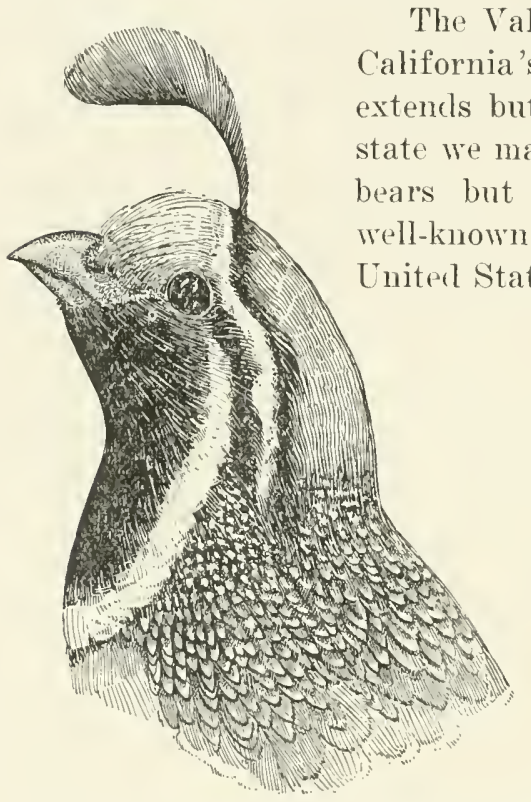

Fig. 82. Head of male Valley Quail showing short, elub-shaped plume. Natural size.

The Valley Quail is usually conceded to be extencls but slightly beyond the limits of this bears but slight resemblance to either the well-known Bobwhite Quail of the eastern Uniterl States or to any of the quails and partridges of other countries. Because of its great popularity as a game bird it has been referred to under a variety of names, as listed at the head of this chapter; but to the great majority of the residents of California this and the closely similar California and Catalina Island quails are known simply as "quail." The liabits of these three races seem to be identical, so that we have deemed it best to combine the general accounts of all three here under one heading.

Under original conditions the Valley Quail ranges north only a short distance into Oregon, and east searcely beyond the Nevada line; but to the sonthward it occurs regularly to the southern end of Lower California. In the state of California it is distributed throughout the lower valleys and foothills from the Oregon boundary (east of the Siskiyon Mountains) to the Mexican line (west of the Colorado Desert). Along the narrow northwestern coast strip (fog belt), from southern Monterey County northward, its place is taken by the closely allied form, the California Quail, but south of San Luis Obispo County the range of the Valley Quail reaches quite to the seacoast. East of the sonthen California coast ranges it oceurs but a little way out onto the desert; beyond, its place is taken on suitable ground 
by the somewhat difterent Desert or Gambel Quail. In mountainous districts it is regularly resident up to 3,500 or 4,000 feet altitude. Less frequently" it has been found up to an altitude of 6,000 feet, as near Fort Tejon, Kern County, where young even have been observed (II mshaw, 1876, p. 266). There are recoris of ocenrence at 6,800 feet on Thomas Mountain in the San Jacinto Range, and at ahmost 8,500 feet altitude on Mount Pinos, Tentura County (Grinnell and Swarth, 1913, P. 230; Grinnell, 1905, p. 382). Belding (1879, p. 439) states that in Calaveras County. Valley Quail spend the summer in the pine forests as high as the Big Trees (5,000 feet), but that they return for the winter to the chaparral belt below. Above the normal altitutinal range of the Valley Quail, the Mountain Quail (Plumed Partridge) holds sway, though the ranges of the two often overlap over a narrow belt. Howerer, the two species are not known to flock togethere. In the San Jacinto Mountains of sonthern California the Valley, Monntain and Deseret quails may be found closely associated, the first and last being sometimos seen in the same flock, and all have been taken in the eourse of a morning's slooting. Gilm a $n$

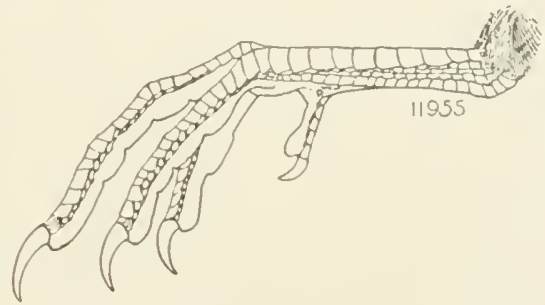

Fig. 53. Sicle of tarsus and foot of Valley Quail. Natural size.

Note stout toes and claws, and absence of feathers on tarsus (compare with figs. 77 and 85$)$.

(1907. p. 149) reports having found all three in certain cañons near Palm Springs. Rirerside County ; and on Piñon Flats, 4,000 feet altitude, fifteen miles south, he saw representatives of all three species drink from the same spring in the course of half an hour.

The Valley Quail has been introdnced on certain of the islands of the Santa Barbara group, notably on San Clemente Island (Grinnell, 1897. pp. 12-13), and on Santa Cruz Island (IFenshaw, 1876, p. 266). On Catalina Island, however, there was originally present a closely similar form, Lophortyx califomica catalinensis (Grinnell, 1906a. pp. 264-265).

Except during the nesting season Valley Quail are to be found in flocks. These range from family assemblages of ten birds or less, up to (in former years) enormous flocks of a thousand or even more; nowadars an average covey is estimated to number from fifteen to forty birds. The tales whieh are told concerning the abundance of quail in early days are almost unbelievable. A. K. Fisher (1893a, p. 28) records that thousands visited a certain spring in the Temploa [Temblor] Mountains; ". . . the ground all about the water was covered by a compact body of quails. . . ,' But such a condition as 
this is entirely passed. The advent of agriculture has had both a beneficial and a deleterious effect on the quail. The removal of brush has reduced the extent of the natural shelter, but on the other hand the planting of vineyards has provided additional refuge. About Fresno, Tyler (1913b, p. 33) states that with the establishment of vineyards quail came down from their natural foothill haunts and, being protected by most vineyardists, have notabły increased in their new haunts: during the same time their numbers in the adjacent hill country have measurably lessened.

Quail have established themselves successfully in the parks and suburbs of several of our cities. In Golden Gate Park, San Francisco, the California Quail is especially abundant, and coveys may be seen feeding in the open places among the shrubbery or scurrying across the paths. On the campus of the University of California, at Berkeley, flocks are seen down among the buildings at times in winter, and young have been hatched out within a few yards of much traveled paths. In southern Califormia, Willett $(1912 a$, p. 43) says Valley Quail are often seen, and that they nest in parks and gardens in the cities.

The Valley Quail has a variety of notes which are used under different conditions and to express various meanings. When anxious or disturbed the members of a floek ntter a soft pit, pit, pit, or whit, whit, whit, in rapid succession, as they run about under the brush or when about to take wing. Then there is a lond call used by the males to assemble the flock when scattered. This has been variously inter-

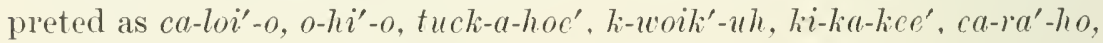
tuck-kie-teu', or more simply as who-ar't-you-ah (Van Dyke, 1908, p. 377 ; Crosby, 1912, p. 311; Bailey, 1902, p. 120). However, the easiest and by far the most usual interpretation is come-right'-here, or come-right'-home, with the accent on the second syllable. Sometimes when excited a bird calls come-right', come-right', come-right'hree. In at least one instance a female bird has been observed to utter this call (J. W. Mailliard, 1912, p. 73). The notes of the Valley Quail are less claborate than those of the Desert Quail, the "crow" lacking the two additional notes which the latter gives at the end; also the Valley Quail lacks much of the conversational twitter of its desert relative (J. Mailliard, in Grimnell, 1904a, p. 41).

Drring the breeding season the male mounts a bush near his brooding mate and utters a single, loud, far-earrying liayr at irregnlar intervals of from one to twelve seconds: an oceasional explosive somnd is given, like one note of a turkey gobbler. After the eggs are hatched and the young are rmming with the adults, the pit, pit, pit motes are used to call the chicks together'. A feeding floek indulges in some low conversational twitter. 
Valley Quail are notably active birds and are nsually busy throughont the daylight hours. They spend the night, not in a eircle on the ground as do the Bobwhite, but in a bush or thiekly foliaged tree, where they are less aecessible to ground-dwelling predators. With the first streak of dawn they are awake, and, Hying down to the ground, usually gather together and go to drink at some near-by pool or stream. This done, the work of gathering the day's rations is commenerd, and while performed in what may seem to be a leisurely fashion, it oecupies them during most of the day. They interrupt it only for the purpose of going again to water, a habit made necessary by the great proportion of hard material in their food, or, in the extreme heat of the day, to rest-in a sort of siesta. In the late afternoon of rainless days they may often be seen in some sumy spot "dustbathing," or preening their fathers. As evening approaches they again seek the shelter from which they departed in the morning. Dixon (1906, p. 95) records that a flock which came to roost in a small elder tree near his eamp in the San Onofe Mountains, San Diego County, arrived with surprising regularity. In eight days they did not vary mole than ten minutes either way from $6: 15$ P.M. "On rainy or clondy days they were seven or eight minutes early" and on bright clear afternoons they were a little late...."

When hunter, the member's of a floek of quail will often wait until the sportsman is almost upon them, whereupon they will spring from the ground, and, with a whir of wings as rapid as it is startling, make off in different directions and drop into the protecting cover of shrubbery. Again on the ground, they make good use of their legs and rmu rapidly off. Hunters state that only when thoroughly frightened will quail erouch and attempt to escape by eoneealment. If flushed in the vieinity of trees they will often take shelter in the thick foliage of these, where they remain quiet and are not to be easily discovered. When exeited they run with surprising rapidity, their topknots down, neeks eraned forward and legs fairly stretehing; but when eoneerned only with their own business they are more sedate, earrying their heads ereet, with the plumes directed upward and forward, in a dignified manner.

Feeding flocks of quail are believed to post sentinels in order that all of the members may not be put to the neeessity of dividing their attention between the seareh for food and guarding against surprise by an enemy. Williams (1903, pp. 146-148) has deseribed this habit as observed by him, in detail, somewhat as follows:

A flock was heard ealling and moving about on a brushy hillside some distanee from the observer, but before eoming into view a single individual preeeded the rest and took his station in the branches of an apple tree, whenee he eould survey the region round about. After 
earefully serutinizing his surroundings for several minutes the kayrk note was uttered several times in a low guttural tone. Soon members of the floek were seen coming down the hill in the same direetion as taken by the sentinel, but their manner of approach was entirely different; he had exereised great eaution and earefully examined the surroundings for possible danger, while they came with their plumed heads held low, searching among the clover roots for seeds and other artieles of food. Some preened and fluffed out their feathers; other's took dust baths. While so occupied they all kept up a succession of low conversational notes. Meanwhile the sentinel remained on his perch and eontinned on the alert even after the flock had moved some distance beyond him. Then a seeond bird mounted a vantage point and took up the sentinel duty and after a few minutes the first relinquished his post. While the flock was still in view, yet a third bird relieved the seeond. It would seem that by this practice, of establishing sentinels on a basis of divided labor, the flock had inereased its individual efficieney in foraging. The same observer also states that he had seen sentinels used when a floek was erossing a road. or when "bathing'" in the roadside dust, and that the practice is made general use of in open areas; but he had never observed the habit when the birds were in tree-eovered loealities. During the breeding season it is known that the male mounts guard while the female is searching for a nesting site, and again when she is incubating the eggs. Sometimes he also performs this guard funetion after the ehieks are out but not fully grown.

The large flocks in which the quail have associated during the winter slowly break up during February and Mareh and individual pairs of birds are then to be seen seeking nesting sites. "In early" seasons they [Valley Quail] begin to pair in the last week of February, but the time varies somewhat according to the season. During this period there is considerable fighting among the males for the favor of the eoveted female. This is kept up until they are suitably mated and the nesting season arrives" (Bendire, 1892, p. 28). Belding (1879, p. 439) recites that he has seen males fighting fiereely, after the manner of turkeys, the other members of the flock "appearing to take great interest in the combat," and making mueh noise.

The Valley Quail seems far from partieular in the ehoice of a nesting site. The grass-lined depression in the gromd whieh usually coustitutes the nest, is commonly hidden under bushes, hedges, brushheaps, and logs. Less eommon sites are haycocks in open fields, or shrubs or vines in gardens, and oceasionally nests of other birts are used. H. R. 'Taylor (1885, p. 142) records the finding of ten fresh California Quail's eggs in a Spurred Towhee s nest in a eypress liedge about four feet from the ground, and also two eggs of this quail in 
a Spurred Towhee's nest on the ground, both in Alameda. Near Los Angeles, Wicks (1897, p. 404) found two eggs of the Valley Quail in a Long-tailed Chat's nest. Several cases of tree-nesting of the California Quail came to the attention of W. E. Bryant (188T, p. 451). The sites which had been chosen were the upright ends of broken or decayed limbs, or the intersections of two large branches. The same observer found a nest in a vine-eovered trellis over a much-used doorway, from which the young later suecessfully reached the ground. Hownll (1915, p. 206) found a nest with three fresh eggs four feet above the ground on top of a bale of hay in the shade of an orange tree at Covina, Los Angeles County.

Several nests found along the bank of the San Joaquin River near Lathrop, San Joaquin county, were hidden under weeds on the levee, the depression in the ground being lined with leaves of the same plants: another nest fomd under a log was lined with decayed wood (H. C. Bryant, MS). Grimell and Swarth (1913, p. 230) found Valley Quail nesting commonly in the shelter of the sage-bushes eovering the floor of Hemet Valley, Riverside County.

While nests of the Valley Quail have been found as early as the mildle of Mareh and as late as the middle of September, the great majority of these birds restriet their nesting to a much shorter period. To judge from the accompanying record of more than one hundred and fifty nests, most of the nesting occurs from the latter part of April to the middle of Jme (see tables 15 and 16 , and fig. 84). Nests found during July and rarly August are likely to represent second layings (that is, instances where the first set was disturbed or (lestroyed), and not neeessarily efforts to rear a second brood. Bendire (18.2, p. 28) records a nest in Butte County as early as Mareh 15, and young about two days old were seen there on April 15. At Haỹward, Alameda County, Emerson (MS) gives extreme nesting dates as April 21, 1883, and July 14, 1905, but Cooper (1880, p. 251) records nesting at the same locality on April 10, 1875. At Selma, Fresno County, Tyler (IIS) flushed a female from a nest containing seven apparently fresh eggs on September 15, 1915. In Los Angeles County the extreme dates are: Claremont, April 4, 1901, thirteen fresh eggs (Willett, 1912a, p. 43), and Oak Knoll, near Pasadena, September 6, 1907, fifteen eggs part of which hatched on September 10 (Grinnell, IIS). At Poway, San Diego County, the last date for fresh eggs in 1884 was August 14 (Belding, 1890, p. 14). Sharp (table 16) has found eggs at Escondido, San Diego County, as late as October 29 (1908), but it is doubtful whether eggs laid so late would have been set upon until hatched.

Our purpose in preparing the tables of nesting data given herewith has been to provide a statistical basis upon which definite state- 
ments concerning the average and extreme times of nesting, and numbers of eggs, can safely be made. Table 16, presenting Sharp's observations (all but two of which pertain to Escondido, San Diego County), includes almost if not all of the nests found by him during the years specified. This table may therefore be taken as exhibiting the numbers of eggs laid by Talley Quail in one locality under the varying conditions encountered during a particnlar series of years. The other table (15), presenting data derived from miscellaneous sources, is of such a nature as to lead to averages different from those actually ocenring in a state of nature. Data cited from sets in collections pertain to selected, often maximum, sets, which are ordinarily preferred by the egg collector. Small sets, of ten eggs or less, are often passed over by collectors and no record kept of them, even thongh they may be complete. Incubation does not commence until a set is nearly. or quite complete, so that in the case of a small set, only by examining the contents of one of the eggs and finding that incubation had actually commenced, would it be safe to assert that the set was complete. It is possible that certain of the small sets listed "fresh" in the tables rere incomplete; if this is true the tendency would be to balance the effect of the extra large sets listed from oological collertions.

Sharp's observations give 13 as the average number in a set of Talley Quail eggs at his locality, while for the whole range of this race within the state the average is 14.6 ; for the California Quail the average is 16.3 , bnt this is based on a considerably smaller number of sets, and is undoubtedly due to selection having been exercised by the collectors, as particularly mentioned in some instances. For both races of quail, taking into account both tables 15 and 16 , the average number of eggs laid is 14.2 .

TABLE 15-Data Relating to Nesting of Talley aurl California Quails in California

\section{VALLEY QUAIL}

Locality
Tentura Co.
Chico, Butte Co.
'Tia Juana Valley.
San Diego Co.
Claremont.
Los Angeles Co.
Escondido, San Diego Co.
Chico, Butte Co.
"Coahuilla Valley." near
Palm Springs. Rirer-
side Co.
Fresno

NEST CONTENTS AND CONDITION: REMARKS Mar. and Apr. Nests found Apr. 1, $1885 \quad 9$ eggs, first nest

Apr. 3, 1885 Two hronds abont a week old; season $\mathrm{nm}$ usually early

Apr. 4. 190113 eggs. fresh

Apr. 12 to Nesting

July 25

[1885? ?

Apr. 17,1886

Apr. 2ก. 1912
First young about two days old

Female with egg ready to lay

$18 \mathrm{eggs}$, incubation begun
AITHORIT Th

Evermann, 18,6, p. 92

Belding. 1890, p. 13

Belding, 1890 , p. 12

Willett. 1912a. p. 43

Sharp. 1907. p. 86

Belding, 1890, p. 13

Noreom, 1887, p. 39

Tyler, 1913a, p. 17 


\section{T.IBLe 1.j-(Continued)}

1. 11 11 เTษ

sian liener

Poway, sian I)ipger ('t).

Santit L'anla, Ventura (cu.

Fresno

Powis. Sian Jjicgn Co.

Santa Paula. Ventura Co.

Sespe. Tentura Con.

Fresno

Caluezon. Riverside Co.

Nenr l"platud.

San 3 exrnardina 1 in.

Fresinn

Fresne

Clareinont.

Los Angelen (in.

San i)ineo

Escondiun, Sin Triegn Con

Fresuo

Fresuo

Fresno

Clareminut.

Los Ingeles $C_{0}$

Santa Paula. Ventura Co.

Tolucir. Los Angulou Co.

Claremont.

Los Ingeles Co.

Claremont.

Los Ingetes $r_{0}$

Ipland,

San Bernardinn $\mathrm{Co}$.

rhien. Butte Co.

Arroyo Seco. Los Angeles Co.

Sunt Pauk. Jentura Co. May 21. 1893

Kenworthy. Rivrride Co. May 23. 1908

Finglits Ferry. Yulo ro.

Clatremnnt

Los Ingeles Co.

Fresno

Snenceville. Nexnda Co.

Sinta Paula, Tentura Co.

Spenceville. Nerada Co.

Santa Paula. Tentura Co.

Trytown, Amador Co.

San Clemente Island

San Dimas.

Los Angeles $C_{0}$

San Dimas.

Ins Angeles Co.

San Dimas, Los Angeles Co.

Tulare Co.

Santa Paula. Tentura Co.

Lathrop, Sian .Toaquin Co.

Lathrop, San Toaquin $\mathrm{C}_{0}$.

Colton.

San Bernardino $\mathrm{Co}$.

Fresno
1).1TE:

Ipr. 20.2.

[1:62?]

1pr. 27. 1884

May 1, 1905

May 2,1907

Misy 5. 1884

May 5. 1910

May 6, 190.5

May (i, 1906

May 7. $190 \alpha$

May $10, \quad 1916$

May 12, 1908

May 12, 1912

Mav 12, 1911

$\mathrm{M}: 1 \mathrm{Y} \quad 13$

[1.881?]

May $13, \quad 1903$

I:1 1 16, 1902

Maly 11;, 1902

May 16, 1912

May 16, 1916

May 17,1909

May 19,1907

May 20, 1916

May 2n, 1916

May 20, 1916

May 21

May 26, 1898

$\operatorname{Mas} 26, \quad 1916$

Mag 27, 1901

Mar 27, 1906

May 27, 1915

May 29, 1906

May 29, 1911

Maỵ 21, 1895

Maỹ 31,1897

May 31, 1916

Way $31, \quad 1916$

Mas (latter part). 1915

May (last week)

May ...., 1908

Trune 1, 1912

Tune 1, 1912

June 1. 1907

June, 2. 1906
NGST CONTEXTS AND CONDITION; RFAARKS

First eges

First set of eggs

1 s eggs, inculbation begun

$1.1 \mathrm{eggs}$, fresli

First young seen

10 pggs, fresh

17 eggs, freslt

5 eggs, fresh

s eogs

$16 \mathrm{eggs}$, all but two

hatched on this date

14 eggs. fresh

1.8 eggs,fresh ; deserted

13 porgs.jurubation two-thirds

First loreod for the season

15 eggs. inculation herun

1.3 eggs, nearly fresh

22 eges. imeulation one-half

10 egcr.fresh

19 eges, all hatched on this date

19 eggs, inculintion nearly eomplete

19 eges, fresh

2.1 eges, fresh

16 eugs, ready to hateh

11 egos, inculation adraneed

22 eggs: all hatehed later

17 eggs

22 egges

10 eges, fresh

8 eggs, incubation begin

20 egrs, incubation

begun

17 eggs, half-incubated

14 eggs

13 eggs, fresh

18 egess

15 eggs, fresh

13 egos, inculation begun

Two broods, scarcely a week old

14 eggs, fresh

14 eggs inculation adranced

13 eggs. inculbation begun

Nest with egg:

25 eggs, incubation

nearly complete

17 eggs

11 eggs. fresh

15 eggs, incubation

advanced

$1+$ eggs, fresh
ITTHORITE

Conper, 1870a. p. 550

Belding, 1890, p. 12

leyton, MS.

Trler, MS.

Belding, 1890, p. $1 . t$

Badger, MS

Peyton, MS

Tyler. MS.

Finncll and Swarth, 1913, p. 231

l'ierce, MS.

Tyler, MIS

Tyler, $1913 a$, p. 17

Pieree, MS.

lielding. 1,290, ․ 12

Law eoll

Tyler, MS.

Tyler, 19136. p. 3.4

Tyles. $1913 a$, 1. 17

pierce, MS.

I3adger, MS

I,aw eoll.

pierce, MS.

l'ierce, MS

Pierce, MS.

Bendire, 1892. p. 28

Law coll.

Badger. MS.

Grinnell and Swarth, 1913. p. 230

Ray coll.

Pierce, MS.

Tyler, MS.

Nus. Tert. Zool.

Barlger, MIS.

Mus. Vert. Znol.

Badger, MS.

Mailliard coll.

Grinnell. 1897. p. 12

Pieree, MIS.

Pierce, MA.

Pierce, MS.

Tudd. 1905. pu, 47-18

Badger. MS:

H. C. Bryant, MS.

H. C. Bryant. MS.

Hanna, 1907, p. 198

Tyler, MA. 


\section{TABLE 15-(Continued)}

LOCALIT:

juesno

l'asadena,

Los Angeles Co.

tresno

lone Pine, Inyo Co.

Chico, Butte Co.

Calaveras Co.

Banning, Riverside Co.

Fresno

Lime Kiln (on Wolf Creek, east of Spenceville),

Nevada Co.

Lime Kiln, Nevada Co.

Claremont.

Los Angeles Co.

Lime Kiln, Nerada Co.

Escondido, San Diego Co.

Chico, Butte Co.

Palomar Mts.,

San Diego $\mathrm{Co}$.

Lime Kiln, Nevada Co.

Tuolumne River, between Chinese Camp and Grove land

Kenworthy, Riverside Co.

Fresno

Six miles east Placerville, in Eldorado Co.

Igo, Siskiyou Co.

Walker Pass, Kern Co.

Sespe, Tentura Co.

Fresno

Fresno

Los Angeles

Poway, San Diego Co.

Fresno distriet

Near Oak Knoll, Pasa. dena, Los Angeles Co.

Selma, Fresno Co.

Poway, San Diego Co.

Haywaud, Alameda Co.

Hayward, Alameda Co.

Palo Alto, Santa Clara Co.

Marin Co.

Hayward, Alameda Co.

Palo Alto, Santa Clara Co.
1) ATE

Nest CONTENTs AND CONDITION; REMARKS

June 2, 1907

June 2,1907

16 eggs, hateling

18 eggs, incubation advanced

June 2,1907

21 eggs, incubatiou one-third

June 4 to 15 , Young just able to fly 1891

Jume 6,1884

June 7,1885

June 8,1908

June 9,1907

First brood

Brood about the size of downy chicken.

8 eggs

12 eggs, ineubation well along

In 10, $1906 \quad 20 \mathrm{cggs}$

June 10, 1906

June 14, 1903

June 15, 1906

June 15, 1901

June 15, 1884

June 16, 1897

June 16，1906

June 16, 1898

13 eggs

15 eggs, incubation begun

14 eggs

15 eggs, incubation begun

Young coming out plentifully

Female with egg in oviduct

10 eggs

11 eggs, ineubation begum

June 23, 1908

8 eggs

June 23, 1906

15 eggs, incubation well begun

June 26, 1896 Young a few days old

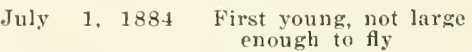

July 1 to 2, Young just hatehed to half grown

11 eggs, ineubation jegun

Nesting begun early but first young not seen unti July 15

July (latter part), 1906

Aug. 9,1897

Aug. 14, 1884

sept. (first

week ), 1912

Sept. 6, 1907

10 eggs, inenbation advanced

9 eggs, fresh

Last fresh eggs

Many half.grown young

15 eggs, incubation ad vanced: part hatched Sept. 10

Sept. 15, 1915

7 eggs, apparently fresh female flushed

Alout Nov. 1 Small quail seen

\section{CALIFORNIA QUAIL}

Apr. 10, 1875 Nesting

Apr. 21, 1883

21 eggs, incubation slight

Apr. 24, 1899

Apr. 27, 1915

Apr. 29, 1877

8 eggs, incubation advaneed

9 eggs, fresh, deserted

Nesting

10 eggs, incubation

just begun
A UTHORITY

Tyler, MS.

Mus. Yert. Zool.

Tyler, $1913 b$, p. 34

A. K. Fisher, 1893a, p. 28

Belding, 1890 , p. 13

Belding, 1890 , p. 14

Girinnell and Swarth, 1913, p. 231

Tyler, MS.

Mus. Vert. Zool.

Mus. Vert. Zool.

law coll

Mus. Vert. Zool.

Law eoll.

Belding, 1890 , p. 13

MeGregor, 1899, p. 67

Mus. Yert. Zool.

Ray coll.

Grinnell and Swarth, 1913 , p. 230

Tyles, MS.

Barlow and Price,

$1901, p, 160$

Belding, 1890 , p. 13

A. K. Fisher, 1893a, p. 28

Peyton, MS.

Tyler, $1913 a$, p. 17

Tyler, MS.

Grinnell, 1898, p. 19

Belding, 1890 , p. 14

Tyler, $1913 a$, p. 17

Grinnell, MS.

Tyler, MS.

Belding. 1890, p. 14

Cooper, 1880, p. 251

Mailliard eoll.

Law coll.

Ray coll.

Cooper, 1880, p. 251

Law coll. 


\section{Table 1.5-(Continued)}

I.OCALIT:

Alaneda, Alameda Co.

\section{Santa Cruz}

San Geronimo,

Marin Co.

Alameda Co.

Hayward, Alameda Co.

San Francisco

san Francisco

Cpper Salinas Talley, Interey $\mathrm{Co}$.

Alameda Co.

Santa Cruz

Berkeley hills,

Alameda $\mathrm{Co}$

Santa Clara Co.

Alameda Co.

Santa Rosa, Sonoma Cu.

Petalnma, Sonoma Co.

Alameda Co.

Santa Rosa, Sonouna Co.

Hayward, Alameda Co. Southern Monterey Co.

Idlewild, Sur, Monterey Co.

Near Middleton,

Lake Co.

Nicasio, Marin Co.

Capitola, Santa Cruz Co.

San Mateo Co.

Santa Clara Co.

Berkeley, Alameda Co.

Oakland, Alameda Co.

Monterey
Test CONTENTs AND CONDITION; REMARKS

21 eggs: 3 fresh. 18 one-half incubated

$\begin{array}{llll}\text { May } & 15, & \ldots . . . . . & \text { Fresh eggs } \\ \text { May } & 16, & 1913 & 14 \text { eggs, fresh }\end{array}$

May 18, 190416 eggs, fresh

May 19, 188118 eggs, fresh

May 23, $1900 \quad 21$ eggs, incubation begun

May 23, 1900

23 eggs, incubation begun

May 23 to

Jun. 3, 1908

May 24, 1901

May 25, ........

Iay 25, 1913

May 26,1898

May 30, 1904

May 31, 1911

June 5, 1886

June 5, 1904

Inne 10, 1911

June 13, 1882

June 14, 1905

June 15, 1900

Iune 15, 1911

June 18, 1894

June 22, 1908

June 24, 1899

June 26, 1889

Tuly 6. 1912

July 18. $187-1$

July 20 ,
Half-grown young abundant

\section{3 eggs, fresh}

Young just hatched

15 eggs, incubation about one-fourth

9 eggs, incubation begun

27 eggs, fresh (laid by two females?

24 eggs, incubation slight

11 eggs, incubation begun

14 eggs, fresh

14 eggs, incubation adranced

18 eggs, fresh

Broods of rery small young begun

22 eggs

14 eggs, incubation slight adranced

12 eggs, incubation one-sixth

Fresh eggs

9 eggs, hatched

Nesting

24 eggs
17 eggs, incubation

$1]$ eggs, incubation
A TTHORITY

Law coll.

MeGregor, 1901, p. 5

Mailliard coll.

Mus. Tert. Zool.

Mailliard coll.

Ray, 1900, p. 126

Ray, 1900 , p. 126

Willett, 1908, p. 137

Mus. Tert. Zool.

Cooper, $1870 a$, pp. 550

$$
551
$$

Carriger coll.

Tan Denburgh, 1899 , p. 158

Mus. Vert. Zool.

Carriger coll.

Law coll.

Mus. Tert. Zool.

Carriger coll.

Mailliard coll.

Jenkins, 1906, p. 126

Ray coll.

Wythe, MS.

Mailliard coll.

Ray coll.

Mus. Tert. Zool.

Tan Denburgh, 1899 , p. 159

Grinnell, $1914 a$, p. 30

Cooper, 1880, p. 251

Gambel, 1849, p. 218

TABLE 16-Sets of Eggs of Talley Quail Examined by C. S. Sharp in the Vicinity of Escondilo, San Diego County, California, 1896-1913

$\begin{array}{cc}\text { Set No. } & \text { DATE } \\ 1 & \text { April 12, 1903 } \\ 2 & \text { April 15, 1903 } \\ 3 & \text { April 16, 1903 } \\ 4 & \text { April 18, 1908 } \\ 5 & \text { April 20, 1908 } \\ 6 & \text { April 21, 1908 } \\ 7 & \text { April 21, 1908 } \\ 8 & \text { April 22, 1903 } \\ 9 & \text { April 24, 1903 } \\ 10 & \text { April 25, 1908 }\end{array}$

Number of Eggs, Condition and Resiarks

12, fresh

14, fresh

18, fresh

21, fresh

19, fresh

15, fresh

17, fresh

19 , fresh

18 , fresh

13, fresh 
SET No.

11

12
DATE

April 30, 1904

May 5, 1908

May 6,1905

May 9,1908

May 9, 1912

May 13,1898

May 13,1902

May 13,1904

Nay 14,1913

May 18,1907

May 20, 1907

Nay 22, 1904

May 25, 1907

May 26, 1912

May 30, 1904

May 30,1904

June 3, 1904

June 3, 1904

June $\quad 6,1896$

June 7, 1904

Jume 11, 1906

June 12, 1908

June 13, 1908

June 14, 1902

Jume 16, 1903

June 18, 1897

Jume 18, 1907

June 18, 1905

June 19, 1903

June 20, 1906

June 20, 1907

June 22, 1905

June 22, 1902

June 22, 1906

June 27, 1903

Jume 30, 1905

July 3, 1905

July 3,1905

July 4, 1908

July 4, 1902

July 6, 1905

July 8, 1906

July \&, 1897

July 10, 1907

July 15, 1902

July 15, 1902

July 21, 1906

July 25, 1903

Oct. 27, 1902

Oet. 29,1902

\section{TABLE 16-(Continued)}

Number of Eggs, Condition and Remarks

15, fresh in 3 ; incubation commenced in 11; broken 1

21 , fresh

17, fresh

18, fresh

17, fresh

11, fresh

14, fresh; 5 eggs May 9

14, fresh

12, fresh

S, incubation commenced

12, inenbation commenced

11, incubation far arlvanced; 2 broken in nest

11, incubation advanced; 4 broken in nest

13, incubation commenced

9 , incubation far arlvanced; 1 broken in nest

19 , incubation commenced

12 , incubation advanced

9 , fresh

7 , fresh

11, incubation commenced

9, fresh

10, fresh

9, fresh

9, fresh; deserted

11, fresh; 6 eggs on .June 11; 14 on .June 15

7, fresh

18, fresh

12, incubation commencer

12. incubation commenced

11, incubation commenced

9 , incubation adranced

9, fresh

13, fresh

16, incubation commenced

10 , fresh

11, fresh

10, incubation advanced

20 , incubation artvancer

7 , ineubation advanced

6 , incubation far adranced

1s, incubation commenced

18, fresh

15, fresh

10, fresh; deserted

8, fresh; leserted

11, fresh: leserter

11, incubation arvancel]

10, incubation arlvincel

s, fresh; deserted

9. fresh: reserter 
Some collectors estimates as to the arerage numbers of egges labl by these birds may he of interest here. For the California Quail, (… Allen (in Bendire, 1892, p. 24) gives 14, and Bendire (1892, p. 25) Says 12 to 16 ; tor the Valley Quail, at Fresno, Tyler (MS) says that first sets, laid from April 20 to May 15, average 18; sets foumd in June, and which may he sereond layings, contain 14 to 15 eggs, while sets foumd from July to September contain but 10 to 12 eggs rach. Grinnell $(1898,1$ ). 19) gives 15 to 17 as the arerage about Los Angeles, and Perton (MS), for Sespe, Tentura County, says 10 to 15. and that sets of 17 are to be considered large. Spealing from experience with both laves of quail, Eaw (MS') thinks that normal sets are not less than 15 in number. It will thus be seen that our arerages from artual statistics ( 13 to 14 ) are below offhand estimates. In any event the size of the set is considerably above that of any other species of game bird oecurring in ('alifornia. As far as observation goes there is gool ground for helieving that yuails' eggs possess a high perentage of fertility : practically all the egars of a set hatch. Mortality comes after the romeng are ont of the nest.

The eggs alle white, or taintly tingerl with cream-color, and abumdantly speekled and olten hlotehed irregularly with golden brown of but slightly valring tone. The markings ale distributed over the egg with fair miformity, there being little or no tendency toward massing the eolor about the larger end as in the rase of the egg's of many shore birels. In shape the egags are short ovate, with the small end notably pointed. They moasure, in incless. 1.10 to 1.40 by 0.84 to 1.01 , and average $1.2+$ hy 0.95 (three sets, of 13,14 and 18 eggs, respectively, from Nevada (ounty).

The eggs of the Talley Quail number from 6 to 28 in a complete set (Sharp. MIS), with an average, as already demonstrated, of about 14. In some instances it is certain that more than one female lays in one nest, and this circumstance might account for some of the larger sets. Tylæ (1913b, p. 34) recites an instance where a nest which was obsirved in the late morning to contain four eggs, upon the afternoon of the same day held six, although from that time on but one ('gg was laid each day. The remarks accompanying Sharp's set no. 17 (table 16) suggest double laying. It is generally believed that a quail deposits one egg a day until the full complement is laid. One instance out of several illustrating this point is provided by M. C. Badger (IIS), who discovered a nest with but four eggs, and thereafter observed that one egg was added each day until there were fifteen; in other words eleven eggs were laid upon eleven successive days. Two or more types of eggs, distinct as to shape, size, or coloration, are not infrequently observable among the eggs contained in one nest. The following table from Sharp (MS) lists the sets which came under 
his observation containing more than one type of egg and therefore believed to be laid by more than one female.

TABLE 17-Sets of Valley Quail Eggs Showing More than One Type of Coloration (All Observed by C. S. Sharp at Escondido, San Diego County).

The Numbers Refer to Sets in Table 16

SET No. Eggs

$6 \quad 15$

$7 \quad 17$

$10 \quad 13$

$15 \quad 17$

20 S

$24 \quad 13$

$37 \quad 18$

419
REMARKS

Two types: 10 and 5 eggs respectively.

Three types: 10, 4 and 2 ; and 1 which probably should go with the 4-egg type.

Three types: 8,3 and 2.

Three types: 8,5 and 4 .

Two types: 5 and 3 .

Two types: 10 and 3 .

Three types: 8,5 and 4 ; and 1 which probably should be added to the 4 -egg type.

Two types: 5 and 4 .

In the early spring, quail often drop eggs at various places anywhere on the ground. Tyler (1913b, pp. 33-34) and Van Denburgh (1899, p. 158) both record the finding of eggs dropped in this manner: and the latter author states that the same propensity was noticed in captive quail. Van Denburgh states further that one of the birds kept in eaptivity by him laid forty-one eggs during one summer, and Cooper (1870a. p. 551) mentions a female kept in eaptivity in San Francisco which laid seventy-nine eggs in one summer season. This bird was provided with an abundance of food and was not allowed to sit.

The statement which is frequently made, that our quail do not nest numerously or even at all in dry years, seems to be fairly well substantiated. Anthony (in Bendire, 1892, p. 27) says that he was told of this phenomenon by the Indians and Mexicans, and that in 1887 he verified it by personal observation. In that year the birds remained in large flocks all smmmer, and only two or three broods of young were noticed. Birds collected during April, May and June showed little development of the sex organs. Cummins (1888, p. 51) states that in 1887 a flock of about one hundred quail remained together on the slopes of Mount Diablo and did not nest. Joseph Dixon (MS) states that he has collected quail for specinens in San Diego County during the summer season of dry years and that upon dissection the sex organs were found to be in a non-functional condition. As evidence from the opposite direction, W. M. Pierce (IIS) declares that sets in 1916 in Los Angeles County, following a winter of heary rainfall, have bren exceptionally large, nine sets averaging between 16 and 17 eggs each. Other persons have also referred to 
this phenomenon. A faet well known to poultry brecders is that quantity and quality of food have a direct effect on egg production and fertility. It is thus not to be wondered at that years of drouth and hence of scanty food supply result in diminishment of the quail crop-not that the quail are able to foresee a shortage of food, but that their bodies have at the beginning of the season of nesting already begun to respond to the unfavorable conditions.

Sportsmen have not infrequently stated that quail rear tro broods in a season, and of course there is plenty of time between April and September for any one pair of birds to rear two, or even three

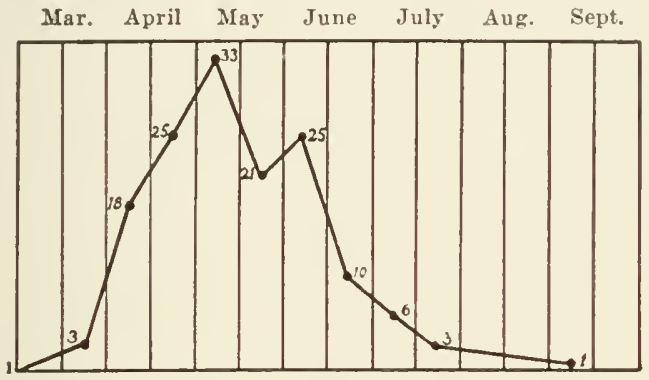

Fig. 84. Curve showing by half-month periols the time when Valley Quail begin to lay their eggs. Calculated from data in tables 15 and 16 by taking account of the number of eggs in the nests when found, their condition as to incubation, and reckoning back to find the dates on which the sets were probably commenced. The numbers in the columns indicate the number of ealculations falling within each half monthly interval. broods; but we have been unable to find any proof of this. In the accompanying diagram (fig. 8t) we have made use of all the pertinent facts contained in tables 15 and 16, grouping the breeding dates by half-montly periods. There will be seen to be two times of maximum egco-laying, one beginning in the first half of May, and the other in the first half of June. However, there are so many complieating factors, such as the destruction of first nests,

that but little significance ean be attached to the double peak of this diagram as indicating two nestings in a season.

The time of incubation is from twenty-one to twenty-three days. The male bird will assume the duties of incubation if the female is made away with, but otherwise seems only to perform the duty of sentinel. The young quail are able to run about so soon after hatehing that it has been said metaphorically that they "run away with part of the shell clinging to their backs." At the State Game Farm newly hatched young have been seen racing about and over eggs in the incubator within fifteen minutes after emerging from the shell. In the wild, when danger threatens the brood, a few notes of warning from one of the parents suffice to cause the young to hide in any available depression or shelter which is handy. Onee so sheltered, their habit of keeping quiet, or "freezing," together with their effectively concealing coloration, makes it almost impossible to rediscover them. About ten days is said to elapse after hatching before the 
young quail are able to fly. John Muir (1901, pp. 223-224) thus describes the nesting of some Califormia Quail on his place at Martinez, Contra Costa County:

One year a pair nested in a straw pile within four or five feet of the stable door, and did not leave the eggs when the men led the horses back and forth within a foot or two. For many seasons a pair nested in a tuft of pampas grass in the garden; another pair in an ivy vine on the cottage roof, and when the young were hatched, it was interesting to see the parents getting the fluffy dots down. They were greatly excited, and their auxious calls and directions to their many babes aftracted our attention. They had no great diffieulty in persuading the young birds to pitch themselves from the man roof to the porch roof among the ivy, but to get them safely down from the latter to the ground, a distance of ten feet, was most distressing. It seemed impossible the frail soft things could avoid being killed. The anxions parents led them to a point above a spiraea bush, that reached nearly to the eaves, which they seemed to know would break the fall. Anyhow, they led their ehicks to this point, and with infinite coaxing and encouragement got them to tumble themselves off. Down they rolled and sifted through the soft lenves and panicles to the pravement, and, strange to say, all got away unhurt exerpt one that lay as if dead for a few minutes. When it revived, the joyful parents with their brood fairly laumehed on the journey of life, proudly led them down the cottage hill. . . .

Even as early as the first of July the different family broods begin to unite into larger assemblages. Sometimes the young composing such a bevy are not all of the same age, but range from ehicks barely fledged to half grown birls (A. K. Fisher, $1893 \%$. p. 2S; and authors). Grinnell and Swarth (1913, p. 2:31) record broods of young at Banning, Riverside County, in jurenile plumage as early as June S (1908), and in the San Jacinto Valley the same writers found fully phunaged roung-of-the-year and half grown young birds together during the first week in September. Both parents assist in rearing their offspring. The male, while spending a considerable portion of his time in sentinel duty, also forages with his brood.

The Valley and California quails are believed to be more exclusively regetarian than any other of om game birds, save those of the pigeon family. The Inited States Bureau of Biological Survey, in an examination of 619 stomachs (representing both subspecies), found (Judd, 1905, pp. 47-56; Beal, 1910, pp. 9-14) that only about 3 per cent of the food consisted of amimal matter. The remaining 97 per cent was regutable material and consisted of 2.3 per cent fruit, 6.4 per cent grain, abont 25 per cent grass and other foliage, and 62.5 per cent serels. The animal food comprised chiefly insects, and of these, ants wre most frequently present. Some beetles, bugs, eaterpillars, grasshopper's, flies, spider's, "thousand-leggers," and snails were also found in the stomachs examined. A ease is eited by Beal (1910, p. 10) of a hrood of young quail feeling extensively on black seale. 
Fruit evidently does not form any important part of the food of the quail, as it was found in only about one-sixtl of the stomachs and then only in very small quantities. Damage is sometimes done to grapes, but this is not shown clearly by examination of stomach contents. Beal (1910, p. 9) mentions two cases where 1,000 and 5,000 quail. respertively, had heen seen feeling upon grapes in vineyards. Ender such circumstances severe loss was undoubtedly sustained; but these are exceptional instances. Florence $A$. Merriam (1896, p. 116) states that on the ranch of Major Merrian at Twin Oaks, San Diego Comnty, quail were in 1889 so abundant as to be a serere pest. For several years previously great flocks of them came lown the eanons to the vineyard, "where they destroyed ammally from twenty to thirty tous of fruit." A report comes from the Fresno district to the effect that grape growers are oceasionally troubled by the birds seattering the drying raisins from the trays.

To elicit funtler information on this subject the present writers addressed letter's to several grape growers in California who by reason of their large holdings would be best able to give evidence on this point. The fonl vineyaldists replying agreed in rharging very little if any damage against the quail. The service of the birds in destroying insect life was recognized by all of them. One man reported that he had found quail aggravating, sometimes, when they picked out certain varieties of grapes which do not bear heavily and which had been left on the vines for more sugar, "for they are great sticklers for a high saceharine content." 'They eat only very ripe grapes and mostly those which are near the ground, and the damage done amounts to only "a fraction of one per cent", (R. Jordan, Jr., San Franciseo). F. T. Bioletti, Professor of Viticulture at the University of California, summarizes his impressions of the Valley Quail as follows (in MS): Tnder certain conditions the birds may be very destructive. One vineyard of fifteen acres in a little mountain valley contained three acres of an early ripening white grape. From fifty to seventy-five per cent of these are taken by the quail every year. The later grapes, which are larger and have tougher skins, are left practically untouched. Damage has also been noted in the case of table grapes in which a few pecked berries on each bunch diminished the value of the whole through the increased cost of trimming and packing. Otherwise, "I am inclined to believe that the quail, as a rule, do very little damage."

It is evidently not the large vineyard that suffers the greatest proportional damage. Rather is it the vineyard of moderate or small size, especially where adjacent to wild lands upon which quail are numerous. Under such circumstances quail have been known to destroy almost the entire crop. But on the whole, the birds cannot 
be considered as seriously affecting either the horticultural or viticultural interests of the state.

The grain secured by quail is evidently picked up casually, no special search being made for it. Only one instance of quail entering a field for grain has been reported (Beal, 1910, p. 11). In no month of the year does grain constitute more than 12.4 per cent of the food for the month. Forage, including under that term grass blades, and leaves of numerous plants, is taken in varying amounts during the year, but most abundantly during the spring months when weed seed is scarcest. Leaves of bur clover, and other clovers including alfalfa and "filaree," are found most commonly; grass blades occur in quite a number of stomachs.

Weed seeds are the staple and most important item in the food of the quail. Seeds of more than seventy species of plants have been identified in the crops and stomachs of these birds. Among those of great economic importance, and most frequently eaten by quail, are seeds of tarweed, maywed, bur thistle, lupine, bur clover, deerweed, vetch, turkey mullein, sumac and poison oak, alfilaria (filaree), geranium, hlack mustard, miner's lettuce, red maids, pigweed, chickweed, catchfly, wire grass, sorrel, sedge, and ray grass. The quantities of these seeds eaten by quail may be conjectured by noting the analyses of material taken from individual birds. One stomach held 83 kernels of barley, 592 seeds of geranimm, 560 of tarweed, 40 of bur thistle, 48 of clover, 80 of alfilaria, 704 of timothy, 32 of catchfly, and 5 of snowberry; 2,144 seeds in all. Another contained 1,696 geranium seeds, 14 of bur thistle, 24 of knotweed, 14 of tarweed, 38 of bur clover, 148 of alfilaria, 12 of ray grass, and two unknown pieces; total 1,944 seeds and one pod (Beal, 1910, pp. 12-13). More rarely quail feed on acorns or on the seeds of the parasite, dodder. The roung quail are more insectivorous in diet and take many ants. After they are about a week old their diet begins to be more like that of the adults.

The enemies of quail are numerous. Wildeats are about the worst enemies of these birds, although certain hawks, and also gray foxes and coyotes figure in varying degrees. Dixon (MS) reports finding the remains of a California Quail in the stomach of a wildeat killed at Petaluma, Sonoma County, December 99, 1908. A Prairic Falcon in the Swarth collection, taken December 13, 1901. at San Fernando, Los Angeles County, contained remains of dove in the crop and of quail in the stomach, hoth organs being entirely filled. J. Grinuell (MS) has shot a Cooper Hawk in the act of eating a Valley (quail. While hunting or tramping about in quail-inhabited country it is not an uneommon thing for a person to find here and there heaps of (pual feathers, each heap indicating where one or another of 
these enemies had captured and devoured a quail. Being a groundnesting speeies, the eggs are loubtless frequently destroyed by predatory manmals and snakes. Four instanees are on reeord (Hoover, 1899, p. 75) of the western gopher snake eating quail's eggs. In one ease, at Stanford University, a female California Quail attracted attention as it fluttered exeitedly in some shrubbery, trying to drive a snake away from the nest. "I earried the snake about fifty yards down the path and put him down. He started off in the direetion of the nest, and when I returned an hour later he was gulping down an egg," and there was already a lump in the snake's body. In another instance a gopher snake was found to have swallowed six quail's eggs.

Bendire (1892, p. 26) states that unusually cold weather has a disastrous effeet on the birks. Thousanels were thought to have been killed by eold in the vienity of Fort Bidwell, Modoe County, in the winter of $188 i-88$. This, however, is at the extreme northern edge of the range of the speeies: over the greater part of its territory cold probably never has any effect except as influencing food supply. Considerable heat is borne without apparent ineonvenienee.

Our quail in the wild appear to be little subjeet to disease, and there are 110 records of epidemies having ocemred among the California speeies. However, intestinal parasites are not uncommon. Thompson (1901a, p. 15) states that while hunting quail in Monterey County about 1898, he found that the intestines of elose to one-third of the birets shot contained tapeworms from $21 / 2$ to 4 inehes long. J. Mailliard states $(1902$. p. 19) that he found so many California Quail similarly parasitized in Marin County that he was led to believe that these birds were partieularly subjeet to such affliction. Ife also found smaller worms in birds eollected in both Marin and San Benito counties. However, neither author found any evidence to show that the presence of these worms had any bearing on the health of the birks. A possible danger to our wild quail eomes from the eustom of rearing native birks in captivity where they may have been brought in contact with foreign speeies harboring disease germs. In such event, by liberation of eaptive birds an epidemic might be started among our wild stoek, with disastrous results.

Our quails have now been introdueed into many loealities where they were not native. As early as 1857 shipments were taken to the state of Washington; and in the neighboring states of Oregon and Nevada the introdueed birds have done so well that unless an observer were told of their introduction he would believe them to be native. They have been established suceessfully in some of the Hawaiian Islands and in other parts of the world. In eastern North America, however, attempts to introduee Valley Quail have been about as unsuccessful as have been the efforts to establish the Bobwhite in California. 
The California Quail (including the races closely related to it) has almost every feature that is desirable in a game bird. It displays exceptional skill in bafling the hunter, and its light-colored flesh is of fine flavor: Easterners often criticise our bird because it does not lie well to dogs; but when they once become acquainted with the western method of hunting the quail, they pronounce our bird superior to their own Bobwhite. Sometimes a dog is used, but the experienced hunter in California is able to pursue a flock suecessfully without such assistance.

Tan Dyke (1892, p. 486), one of the most experienced hnnters of upland game in the state, describes a quail hunt in terms somewhat as follows: At your first advance into the place where the quail last settled in confusion, a dozen or more rise in front of you and as many more on each side anywhere from five to fifty yards away. They burst from the brush with rapid flight and whizzing wing, most of them with a sharp, elear, pit, pit. pit, which apprizes their comracles of the danger and the course of escape taken. Some dart straight away in a lark blue line, making none too plain a mark against the dull background of brush, and vanish in handsome style nuless you are very quick with the gum. Others wheel off on either side, the scaling of their breasts showing in the sunlight as they turn, and making an altogether beantiful mark as they mount above the skyline. Some swing about and pass almost over your head, so that yon can plainly see the black and white around their heads and throats, and the cinmamon shading of their under surfaces.

In the days when the Valley Quail was plentiful far beyond its condition today, it was a common bird on the markets and could be obtained at practically every hotel and restaurant. Records show that during the season 1895-96 as many as 70,370 quail (mostly Valley Quail) were sold on the markets of San Francisco and Los Angeles; while an earlier report states that full 100,000 were disposed of in a single year in the markets of San Franciseo. W. T. Martin of Pomona states that in 1S81-St he and a partner hunted Valley Quail in Los Angeles and San Bermardino comnties for the San Francisco markets. Fight to fonrteen dozen were secured daily, and in the fall of 1883 the two men secured 300 dozen in seventeen days. Martin himself secured 114 birds in one day's hunt. In 1881 and 1882 over 32,000 dozen quail were shipped to San Francisco from Los Angeles and San Bernardino comnties, and brought to the hunters engaged in the business one dollar a dozen. In those days restaurants charged thirty cents for quail-on-toast. By 1885 hunting had become unprofitalle because of the reduction in the numbers of quail.

1. E. Skelton, of El Portal, Mariposa County, tells us (MS) that rears ago when he was hunting for the market in the vieinity of 
Raymoud, Madera County, he areaged about sixty birds per day. By careful handling he was able to seeure better prices than other market hunters. After killing a dozen or fifteen quail, they were drawn, tied three in a bunch, and hung up to eool over night. All the birds which he had thus prepared were on the following day placed in wooden boxes with thin boards between each two layers. They thus reached the cities in beantiful condition and brought him from $\$ 1.50$ to $\$ 2.25$ per dozen, fifty cents more per dozen than quail shipped loosely in sacks, as was the practice of other hunter's.

T. S. Van Dyke (1S90, p. 460) states that market hunter's used to ship 10,000 quail apiece during a single season; daily bags of 200 , made by sporting men shooting the birds singly on the wing, were not unusual. C. H. Shinn (1890, p. 464) says that in eighteen consecutive hunts two hunters at San Diego secured from 47 to 187 quail on each hunt, in addition to other game; six bags of mole than one hundred each were made. Other individual daily bags of six, twelve and twenty-two dozen, respectively, were known to this anthor. In the hills between the soutlern San Joaquin Valley and Carrizo Plains, E. W. Nelson (A. K. Fisher, 1893a. pp. 28-29) found the Talley Quail very numerous.

It was excessively abundant at some of the springs in the hills about the Temploa Mountains and Carrizo Plain. In the week following the expiration of the closed season, two men, pot-lunting for the market, were reported to have killed 8,400 quail at a solitary spring in the Temploa [Temblor] Mountains. The men built a brush blind near the spring, which was the only water within a distance of 20 miles, and as evening approached the quails came to it by thousands. One of Mr. Nelson's informants who saw the birds at this place stated that the ground all about the water was covered by a compact body of quails, so that the hunters mowed them down by the seore at every discharge.

Not only were quail shot for the market, but previous to 1880 , they were regularly trapped in large numbers. In that year the practice was stopped by law. Cooper, writing in 1870 (1870a, p. 551), states that they were constantly exposed for sale alive in San Francisco, where many escaped from their cages to fly from roof to roof, oceasionally descending into eity gardens. MTany trapped birds were shipped east at that time.

Hedderly (1912c, p. 309) gives an aceount of the successful rearing of Valley Quail in captivity by William Schneider of Whittier, Los Angeles County. Starting with six birds in 1905, by 1912 he was able to rear between 400 and 500 young birds, more in fact than he needed for his own table. Some interesting facts, learned in the comrse of his experience with the quail, were: that they are not polygamous, each male selecting one female and remaining with her until the young birds are hatehed, and paying no attention to other females even 
when kept in the same enelosure; that two broods were reared by his birds, in each season, one in February and another in April or May; and that bantam hens were found capable of hatehing the quail's eggs successfully, where the latter had been deserted during the early part of the season. This and other instances suggest the possibility of semidomestication of quail, as on large ranches. In faet there are reports of quail mingling freely with ehiekens; and one ease is on reeord (Henshaw, 1883, pp. 184-185) where a hen with an unusual propensity for sitting, appropriated of her own aceord a nest of quail's eggs somewhere in the neighborhood. In dne time she came off leading in her train a bery of fifteen downy quail. These were suecessfully reared, and remained about the ranch yard where their tameness distinguished them from other quail in the vicinity.

Hunting in one form or another has been the most effective factor in the decrease of the Valley Quail. As with so many of our other game birds, too long an open season, too large bag limits, or none at all, and hunting for the market, have together been instrumental in reducing the numbers of quail; but the last-named factor is undonbtedly the most important one. Twenty years ago a quail hunt for sport involved considerable time and inconvenienee; but today, with the inereased facilities for travel available in the form of railroads, suburban eleetrie lines and automobiles, and the more effieient types of firearms, both of these factors have been greatly redueed. A quail hunt may now occupy but a relatively short time, and the destruction possible with a pump or antomatic shotgun as compared with a double-barrel gun has given the present-day hunter a greatly increased advantage. The ammual destruction of quail has exceded the yearly crop, and in eonsequence the breeding stock has been sadly redured. At present there are many places, notably in southern California, where drastie action must be invoked at once if any birds at all are to be left. Smaller bag limits and shortened seasons, or even an entirely closed season for a few years in eritical localities, are believed to be the only means of affording the birds the protection they need. But even where they hare been redneed, the Valley and California quails may be expected, other conditions being equal, to regain their former numbers more rapidly than any other game speeies. This is another evidence of their fitness as game birds: They can stand the greatest annual toll and yet, beeanse of their high rate of reproduction (providing the optimum breeding stoek be not reduced), safely and easily recoup their numbers from year to year.

It is erroneons to believe that a considerable number of quail eannot be maintained under present eonditions. The birds have demonstrated their ability to exist muler a wide variety of physieal eonditions, and are not averse to the proximity of man, as abundantly 
proved in many instanees. Given the proper protection from excessive hunting, through molerate open season and bag limit, and perhaps further assistanee by the destruetion of their worst natural enemies, and they will remain with us as a joy forever. We ean then say, with Florence Merriam Bailey (1902, p. 121), that they are still the ganne birds of California; ". . . the roads are still patterned with their footprints, and through the valleys they are elosely associated with the charm of the mellow California tays, their melodious who-are-you-ah? eoming from the hillsides in the cool mornings when the high fog is clissolving into blue sky, coming from the chaparral in the warm noonday hours, and echoing softly from the vineyards through the quiet golden sunsets.",

\section{California Quail}

\section{Lophortyx californica californica (Shaw)}

OtIner Nines-California Partridge, part; Lophortyx californica brunnescens: Lophortyx californica vallicola, part; Callipepla californica, part; Tetrao californicus: Ortyx californica, part.

Description-Adults: Similar to Valley Quail (Lophortyx californica vallicola) hut upper surface and sieles of body olive brown (pl. 1) rather than grayish brown, and inner margins of tertial feathers deep buffy or ochraceous rather than pale buffy or whitish. Juvcnile plumage: Like that of Valley Quail, but with tawny suffusion above, and ochraceous tinge below; dark markings everywhere greater in extent.

MARKS FOR FIELD IDENTIFICATION-See under Valley Quail. Probably not distinguishable except in band.

General Distribution-Humid coast region (fog belt) of the Pacific district from southwestern Oregon south to southern Monterey County; introduced into Vancouver Island and Washington.

Distribution in CAlifornia-Abundant resident of the narrow liumid coast strip (fog belt) from the Oregon line south to southern Monterey County. (See Valley Quail.)

For general account, see Talley Quail.

\section{Catalina Island Quail}

\section{Lophortyx californica catalinensis Grinnell}

OTHER XAMES-Lophortyx catalinensis; Lophortyx californica vallicola, part.

Description-Adults: Similar to the Valley Quail (Lophortyx californica vallicola) but averaging about $7 \%$ larger; scaling on lower breast slightly heavier, and shaft streaks on flanks and lower tail coverts broader. Males: folded wing 4.46-4.71 inches (113.5-119.5 mm.) ; bill along culmen 0.40-0.42 (10.2-10.7) ; tarsus 1.18-1.26 (30.0-32.0) (three specimens). Females: folded wing 4.57-4.65 (116118 ) ; bill along eulmen $0.41-0.43$ (10.4-10.9); tarsus 1.18-1.24 (30.0-31.4) (three specimens). 
MARKS FOK FIELD IDENTIFICATION-Sie under Valley Quail; probably not distinguishable exeept in hand.

DISTRIBtTION-Common resident on sinta Catalina Tsland, Los Angeles comity, to which islaud this race is restricted.

It has been rumored that quail from the mainland of California have been introduced on Santa Catalina lsland. But "Captain" James C. Johnston found quail already on the island when he loeated at "Johnston's Harbor"' (of maps) in 1859) (Grinnell, 1906a. pp. 264-265); he and the ofher shere men on the island always considered the birds to be native. If mainland stock has sinee been introduced, we have 110 means of knowing what its effect on the native contingent may have been. It is mulikely that the strangers would survive in competition with the better fit native binds. The eggs of the Catalina Island Quail have been deseribed (Childs, 1907) as differing somewhat from those of other quail in liaving the ground-eolor almost pure white, with "specks and dots of brown, and large conspicnous yellowish-brown blotehes." The eggs described, ten in mumber, were taken at Avalon, July 12, 1907, from a nest on the "ground near enealyptus tree and by a fenee."

The general natural history of the Catalina Island Quail is probably nearly identieal with that of the Valley Quail.

\section{Desert Quail}

\section{Lophorly.r gambeli Gambel}

OTHER NAMes-Gambel Quail; Gambel Partridge: Arizona Quail; Callipepla gambeli; Callipcpla gambeli deserticola.

DESCRIPTION-Adult male: Forehead finely streaked with black and buff, this area bounded behind by a transverse white bar between eves which turns back on each side to continue over the ears to side of neck, this white bar bordered narlowly with solid black; whole hind hearl solid reddish brown; erest with origin just behind white har on top of head, about one and one-half inehes long, and made up of six black cluh-shaped, reeured, closely over-lapping feathers; entire throat jet black, outlined posteriorly by a well defined $U$-shaped borler of white running down each sise of head from eye; ear region, between white bands, blackish brown, opening out onto gray of chest region; bill black; iris lark brown; upper surface of body, iucluding onter surface of rlosed wing, rump and entire tail, pale aslyy brown, beeoming clear gray on lind neek and tail; upper surface also with fine slaft-lines of dusky ; lining and muler suface of wing plan grayish brown; inner webs of tertials and onter wehs of secondaries edged with buffy white; outer wehs of prinaries elgerl with gray; alongated feathers of sides bright chestunt, each with a medial streak of white; fore breast ashy gray continuons with lind neek; feathers of sides of neek and hind neek finely marginel with dnsky and narrowly eentered near tips with reddish brown; a black jateh or spot on fore part of helly, and hetween this and gray ehest area, a broad, elear, buffy band; hinder belly pale buffy white; flanks same eolor, with broad shaft streaks of dull redlish brown; under tail eoverts buff with gravish brown shaft streaks; legs and feet dull greenish gray; claws black. Total length 10.64- 


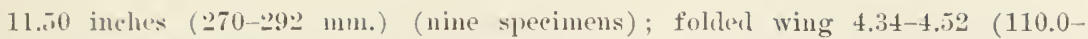
114.7); bill along culmen $0.43-0.47$ (10.5-12.0); tilrsus 1.17-1.28 (29.7-32.4) (ten speeimeus); weight 5.7 oz. (161.8 gm.) (one specimen). Adult female: Head without the white, black and rufous found in the male, ehiefly grayish brown, streaked with dusky on forehead, siles and throat, more rusty brown on back of head; erest about one ineh in l(-ngth, not so broad ended as in male; plumage otherwise much as in male but black spot on belly lacking, and ehestnut of sides paler and less extensive. Total length 10.40-11.44 inches (264-290 mm.); folded wing $4.17-4.49$ (10.5.8-114.0) ; bill along enlmen 0.41-0.45 (10.3-11.5); tarsus, 1.14$1.2+(29.0-31.5)$ (ten speeimens); all from California. Juvenite plumage: Whole of upper surface dull brown, minutely mottled transversely with dusky; scapulars and outer surface of elosed wing with broad whitish shaft-streaks; wing and tail feathers mottled in fine pattern with ashy hrown and buffy white; sides and breast pale ashy brown with whitish bars. Natul plumage: General color dull yellowish; four parallel blackish stripes down back; a dark brown patch on back of liead; breast and sides washed with huffy; wings and flanks matred with dusky.

Marks FOR Field IDENTIFICATION-Similar to Villey Quail, as regards size and erest, but general eoloration much lighter; male with lack of hear bright red. dish brown, and with a elear buffy white band across lower breast, followed by a conspicuous black spot on fore part of belly. Both sexes have the sides rich chestnut, but no seale-like feather-tippings on the under surfare of the body as in the Valley Quail.

Torce-A rapidly uttered series of syllables, each sounding like quoit or oit; call of male: ynk-licie-ja, repented (Bendire, 1592, 1. 31).

Nest-On ground beneath weeds or hrush; a slight depression, usually well lined with grass, weed stems, and leares.

EgGs-10 to 17 , nvate in shape, measuring in inches 1.12 to 1.34 by 0.95 to 1.02 (in millimeters, 28.5 to $34.0 \mathrm{by} 24.0$ to 26.0 ), and averaging 1.24 by 0.95 (31.5 by 24.0) (Benclire, 1592, 1. 34; and anthors); in color white or ereamy white, with dots and irregular spots of dark purplish brown.

General Distributrox-Arid desert regions of southern California, southem Nevada, Arizona, and southwestern Utaln, east to the sonthwestern corner of Colorado; also in southwestern New Mexico to the Rio Grande Valley and the EI Paso region of extreme western Texas; south into northeastern corner of Lower California and to Guaymas, Sonora (A. O. U. Check-list, 1910, p. 137).

Distribution in CALIFORNiA-Abundant resident locally, almost always in the near vieinity of streams or springs, on both the Colorado and Molnave deserts. Recorded north to Amargosa and Death valleys (A. K. Fisher, 1893a, 1. 29); west across the Nohave Desert to Hesperia (Thurber, 1896, p. 265), on the Colorado Desert to the north flank of the Santa Rosa Mountains (Grinnell and Swarth, 1913, p. 232), and through San Gorgonio Pass to Banning, Riverside County (Gilman, 1907, 1. 148). Recorded casually or as a result of escape from eaptivity, from Los Angeles, San Bernardino, and other points on the Pacific slope of sonthern California. Along the western edge of its range, this quail occurs at many points on eommon ground with the Valley Quail, and liybridization is known to oceur.

The distribution of the Desert or Gambel Quail is closely limited to the deserts of the southwest. It is to be found from extreme sonthern Colorado and the western extremity of Texas westward to southern Nevada, southeastern California and northeastern Lower Cali- 
fornia. In California it is an abundant resident locally, always in the near vicinity of streams, on the Mohave and Colorado deserts. It has been taken as far north as the Amargosa Desert and Death Valley, in southern Inyo County, and to the westward it extends to Baming and the north slope of the Santa Rosa Mountains in Riverside County. Along the western border of its range it is often found associated with the Valley Quail. This is especially the ease in some of the low passes, as, for instance, San Gorgonio Pass. Here hybrids between the two species have been taken. Stragglers, possibly escaped from captivity, have been recorded from Los Angeles (Grinnell, 1898, p. 19) and San Bernardino (Wall, 1893, p. 204).

Efforts made to introduce the Desert Quail into northern Califormia have met with failure. Belding (1890, p. 8) records the fact that althongh a number were once liberated near Folsom, Sacramento County, they all soon disappeared. A covey, numbering originally more than a hundred, kept on the State Game Farm at Hayward, slowly diek off until not one was left. The bird seems mable to stand any departure from the warmth and dryness of its native desert territory.

Throughout its range the Desert Quail is a close associate of the mesquite and "quail brush," the latter being a species of Atripler. Althongh individuals often forage up dry washes for a few miles, they keep within reach either of a spring or a stream, since they must go back to water at least twice a day, morning and evening.

In size and general appearance the Desert Quail is much like the Valley Quail. The top of the head, however, is rich reddish brown, there are no seale-like tippings to the feathers of the under surface, and the flanks are chiefly ehestnut in color. A eonspicuons black patch oceupies the center of the lower surface of the body of the male. Being a desert form, the general tone of eolor follows the rule among desert animals and is pale, considerably lighter than it is in the Valley Quail.

Desert Quail usually remain in flocks mutil about the middle of Marel when they begin to pair off. Althongl the height of the nesting season occur's in April, young about two days old. have been seen as late as September 24 (Leo Wiley, MS). The earliest date for eggs is Mareh 19, near Phoenix, Arizona; and near Tueson, April 4 (Bendire, 1892. p. 34). In California, near Salton Sea, Koch (1893, p. 91) foumd fresh eggs on April 5. The nest is a simple structure, often a mere lining, of grasses and weed stems, occupying a depression in the ground surface, and hidden in grass or clumps of weeds. Some instances may here be eited in illustration of nesting habits, exeeptional or oldinary.

Near Tueson, Arizona, on May 25, 1911, Willard (1912. p. 60) found a nest without any protecting eover in a slight depression at 
the foot of a mesquite. It contained twelve fresh eggs. Aceording to Swarth (MIS) the Desert Quail not uneommonly lays its eggs in places other than the usual ground site of quail in general, an abandoned nest of a thrasher or caetus wren in the eholla eactus being sometimes flattened down and used. Bendire (1892, p. 32) found a set of ten eggs near 'Tueson, Arizona, in an old Roadrunner's nest about five feet above the ground in a mesquite tree. Apparently a little additional lining had been contributed by the quail. Breninger $(1897$, p. 122) records the finding of a nest near Phoenix, Arizona, containing six eggs and sitnated in a hollow of a mesquite trunk several feet from the ground and eighteen inches from the opening of the eavity. The cavity was mueh the same as would be ehosen by one of the larger owls.

The eggs of the Desert Qnail resemble those of the Talley Quail in shape, but are decidedly different in coloration. The gromd-eolor' is white or ereamy white, with dots and irregular spots of dark purplish brown (not golden brown). Bendire (1892, p. 34) found the extremes of size in a large number of the eggs of the Desert Quail to be (millimeters changed here to inehes) 1.12 by 0.95 and 1.34 by 1.02 , with an average of $1.2 \pm$ by 0.95 . The complete set contains from ten to seventeen eggs. but the average eomes nearer a dozen. Ineubation is said to last from about 21 to 24 days, and does not begin until all the eggs are laid, these being deposited daily (Bendire, 1592, p. 32). Two broods are thought by some to be reared in one season (Leo Wiley, MS., and Bendire, loe. eit.) ; this, however, is not likely to be the regular thing. Immediately after the breeding season young and old collect into flocks of large size, said to number on oecasion up to 100 or even 500 .

The young are truly preeoeions. Cones (1874, pp. 436-437) says of them:

They rum about as soon as they are hatched, though probably not "with half shell on their backs,' as some one has said. In a few days they become very nimble, and so expert in hiding that it is difficult either to see or catch them. When the mother bird is surprised with her young brood, she gives a sharp warning cry, that is well understood to mean danger, and then generally flies a little distance to some concealed spot, where she cronches, anxiously watching. The fledglings ... instantly scatter in all directions, and squat . . motionless until the reassuring notes of the mother call them together again, with an intimation that the alarm is over. Then they huddle close around her, and she carefully leads them off to some other spot, where she looks for greater security . . . in the enjoyment of her hopes and pleasing cares. As long as they require the parent's attention they keep close together, and are averse to flying. Even after becoming able to use their wings well, they prefer to run and hide, or squat where they may be, when alarmed. If then forced up, the young covey flies off, without separating, to a little distance, often realighting on the lower limbs of trees or in bushes, rather than on the ground. As they grow older and strong of wing, they 
fly further, separate more readily, and more rarely take to trees; and sometimes, before they are fully grown, they are found to have already become wary and difficult of approach. As one draws near where a covey is feeding, a quick, sharp ery from the bird who first notices the approach alarms the whole, and is quickly repeated by the rest, as they start to run, betraying their course by the rustling of dried leaves. Let him step nearer, and they rise with a whirr, seattering in every direction.

"On being suddenly flushed these birds separate very widely, but immediately upon alighting commence their call-note, resembling the soft chirp of a young chicken, which is kept up for some time. The alarm over, and the flock once more remited, they relapse into silence, only broken by an occasional eluck of the male bird. Once seattered they eannot be readily started again, as they lie close in their thick, bushy, and impenetrable coverts"' (Baird, Brewer and Ridgway, 1874, III, p. 484).

This quail has three different notes: a single elear mellow clink with a metallic resonance which is used as a flock call or alarm note, and may be repeated many times; a loud clear whistled killink-killink uttered ehiefly during the pairing season; and an unmusical "lovesong" uttered morning and evening by the male as he sits on some conspicuous pereh near his brooding mate. This last is described as "odd, guttural and energetic," and the bird is said to stretch his neck, dangle his plume and allow his wings to droop while the "song" is being nttered (Baird, Brewer" and Ridgway, 1874, III, p. 485).

As reported by an observer near Palm Springs, Riverside County:

The notes of the desert quail differ from those of the valley quail in variety, and to a certain extent in character, though they have some notes in common. The "crow" of the latter consists of three notes, varying in length and accent according to the eall given, in one case the last note being a falling one. The "crow" of the desert quail, while rather similar to the other, has two additional notes at the end, rentered in a softer tone. Besides the alarm calls the vallev quail has a few twittering or eonversational notes, while the other species has a lot of these, quite varied and often given in a way that seems remarkably loud to one accustomed only to the notes of the former. Another peculiarity of the desert quail is the queer sound that it makes as it rises from the ground on being surprised into thight-the sort of sereching eackle, on a small seale, that a hen makes when frightened from her nest (Mailliard, in Grimell, 1904a, pp. 41-42).

Nelson gives the following account of the habits of the Desert Quail as noted in the Pahrump Talley, Nevada, close to the California line near Deatli Valley :

When a flock of quail came to feed on grain left by the horses, an old male usually mounted the top of a tall bush elose by and remained on guard for ten or fifteen minutes, thien, if everything was quiet, he would fly down among his companions. At the first alarm the flock would take to the bushes, running 
swiftly, or flying when hard pressed. They roosted in the dense bunches of willows and cottonwoods growing along the ditches. . . When feeding they have a series of low elucking and cooing notes which are kept up almost continually (Nelson, in A. K. Fisher, $1893 a$, P . $29-30)$.

The Desert Quail depends for safety very largely upon its legs. It runs with astonishing rapidity and usually seeks to eseape in this manner rather than by flying. Impenetrable thiekets of mesquite, quail brusli, catclaw and ironwood afford safe retreats as long as the use of wings is unnecessary.

Aceording to Judd (1905, p. 57) the food of the Gambel Quail comprises the following elements: insects, 0.45 pel eent; grain. 3.89 per cent; miscellancous seeds, 31.89 per eent: and leaves and plant shoots. 63.74 per eent. Among the insects that have been found in the stomachs of birls examined, are ants, beetles, grasshoppers, leafhoppers and stink bugs. The grain taken includes corn, wheat, and oats, the miscellaneous seeds largely those of leguminous plants such as alfalfa, bur clover and mesquite, and also of alfilaria, mustard, ehiekweed, peppergrass and atriplex. Suceulent foliage and shoots form by far the larger pereentage of the fool. Of this, alfalfa, bur clover, and the foliage of other legumes constitute the greater part. Both the green leaves and pods of alfalfa me freely eaten. In spring this quail shows a fondness for buls, and in some localities its flesh has a distinetly bitter taste due to a diet of willow buds. Certain kinds of fruit are also eaten. Baird, Brewer and Ridgway (1874. III, p. 483) state that during the summer it feeds extensively on the berries of nightshade. Evidence is also at hand that this quail, like many other desert animals, feeds upon the fruit and seeds of eertain kinds of eactus. Stomachs of Gambel Quail collected along the Colorado River in the spring of 1910 contained masses of mistletoe berries, and, at the time the mesquites were first eoming into leaf, quantities of the tender green foliage of this plant (Grimnell, 1914b, p. 122).

The Gambel Quail, like the Valley Quail, is not diffieult to domestieate. In its own habitat this quail may be readily reared in confinement. In but slightly colder elimates, however, breeders have met with little or no suceess.

Gilman (1907, p. 148) gives the following description of the way in which the Gambel Quail often baffles the hunter: "A big floek is seen and pursued. They divide and Nimrod follows the larger portion which again divides and this process of elimination by division continues till the hunter finds he has been up against a vanishing fraction. If near a range the flock immediately takes to the hills and anyone who has once followed them up those sun-burned rocks is ever afterward in the sour grapes elass." Hence, it can be seen that the Desert Quail does not make so attractive a game bird as the 
Talley Quail. Its habitat in the first place is, to many people, forbidding, and its habit of seeking shelter in impenetrable thickets makes it one of the most difficult birds to put up. When once on the wing the flight is excecdingly rapid and vigorous, but as it is nearly always direct, a quick hand ean ensure a successful wing shot.

The Desert Quail has always been numerous in favorable parts of the desert region of sontheastern California. The increase of areas under cultivation in the Coachella and Imperial valleys has resulted in additional supplies of water and food, and in such localities this quail appears to be increasing. In fact, there is some complaint from ranchers that the bird has become so numerous as to do eonsiderable damage locally to newly sprouting grain. Until quite recently the Desert Quail has been hunted but little; but with the decrease of the Valley Quail in the eoast districts of southern California, and the betterment of roads leading out over the desert, sportsmen are directing their attention more and more to the desert species. There is no reason why the Desert Quail should not thrive in large numbers in all suitable places on the southeastern deserts, and, because of its prolific reproductivity and evident responsiveness to new conditions imposed by cultivation of the land, why it may not stand a large anmual levy from the hunter.

\section{Sierra Grouse}

\section{Dendragapus obscurus sierrae Chapman}

Other Nanes-Blue Grouse; Dusky Grouse; Pine Grouse; Sooty Grouse, part ; Dendragapus obscurus: Dendiagapus obscurus fuiginosus, part; Dendragapus fuliginsus; Tctran obscurus; Canace obscura.

Description-Adult male: Head and neck ehiefly dark slaty brown; area between bill and eye, and chin and throat, flecked with white; naked skin above and below eye light orange; iris hazel brown; bill dusky; back, rump, upper tail coverts, and outer surface of closed wing, chiefly brownish black, more or less finely patterned (vermiculated) with pale bluish gray or pale tawny, these vermiculations least conspicunus on middle of back, and most prominent on tertials and onter wehs of inner secondaries; tail ehiefly blaek, brownish at hase, with or without fine light gray vermienlations, and tipped moadly with smoke gray; imner margins of flight feathers dark brown, onter margins paler, marked with buffy or dull white; lining and under surface of wing light slaty brown; axillars white; fore neek deep brownish black; breast slaty brown changing to bluish gray on belly, where also mixed with white; feathers of sides and flanks slaty brown vermienlated with bluish gray, and with white shaft streaks; mder tail coverts dark slate, broadly tipped with white; feathers on tarsus, grayish brown; feet light gray or olive drab, harred with brownish; nails dusky. Adult female: Top of lead, sides of neck, and hind neek, brownish black, barred with pale clay color; side of head, chin and throat, dull white, mottled with brownish black; eselids nearly as in male; hack, rump, upper tail eoverts, middle tail feathers, and outer surface of elosed wing, blackish brown, barred or finely patterned 
(vermiculated) with pale elay color or tawny brown: some of seapulars, with shaft streaks of white; tail chiefly brownish black, with more or less aslyy vermieulation toward hase, and broally tipled with asly aray, this light band sparingly flecked with brownish black; fliglit foathers lorown, marked with buffy white on outer webs; margin and forward lining of wing mixed brown and buffy white; axillars white; moler surface of flight feathers lull hrown; breast dark broma, with broad irregular barring of pald elity eolor or dull white; fore part of belly bluish gray, sparingly marked with white; hinder part of helly mixerl jald bluish gray and dull white; sirles of boly and flanks like onter surfaee of wing: lower tail coverts blackish brown tipped broally witl dull white: feathering of tarsus grayish brown. Males: Total length "alnout 20.00-23.00', inehes (508-584 mm.) (Ridgway, 1900,1 . 19.5) ; folılnd wing $8.8(i-9.52$ (22.5-242); bill along eulmen $0.72-0.58$ (18.4-22.3) ; tarsus, 1.79-1.92 (40.4-48.8) (ten specimens from Califoruia). Females: Total length "17.io-19.00" (444-452) (Rilgway, loe. eit.); folded wing $7.68-5.70$ (195-2.21) ; bill along enlmen 0.65-0.78 (17.419.7 ) ; tarsus $1.54-1.85$ (39.0-47.0) (six specimens from ('alifornia). Weight of a male $23 \%$ pounds (1.25 kilograms) (Mus. Vert. Zool.). Jue'nile plumage: Much like that of adult female, but feathers of upper surface, wings and tail with couspicuous shaft streaks of inll white; no gray bar at enl of tail; gray fratrh on belly lacking; ehin extensively whitish; throat and hreast bale luffy or white, more spottel than barred, with lark brown. Natal plumagr: Upper surface light yellowish hrown, with considerable irregular admixtme of black, especially notiecalle on top and sides of head and middle of back; muler smraee buffy white, palest an throat and belly.

MARKS FOR FIELD IDENTIFTCATION-Large size (next to largest of (mr grouse). general dark bluish gray effeet of eoloration, and light band aeross tip of almost square-ended tail (this often appearing whitish by contrast) (pl. 15).

Torce-Of male in breeding season: a deep, wooden, farearrying, ventriloquial, unt, wunt, wunt', wunt', tw-u'unt', unt. wunt (Storer, MS) ; of female with young: caekling and clueking notes; of both sexes: an alarm note kivk, kuk (BeIding, 1879, 1. 438).

Nest-On dry ground, under slefter of brusl, log or rock; a sliglit drpression sparingly lined with dry grasses, leaves, twigs, and, usually, a few feathers of the female.

EgGs-(In California) $j$ to $\tau$, ordinarily ovate in slape, measuring in inches, 1.98 to 2.14 by 1.34 to 1.46 (in millimeters, 50.4 to 54.2 by 34.1 to 37.2 ), and averaging 2.03 by 1.40 ( 51.6 by 35.5 ) (two sets, twelve eggs, from California). Ground-color pale ereamy buff, with small round spots and dots of redlish brown, usually distributed quite uniformly over the entire surface.

General Distribution-Of the Dusky Grouse and its several subspecies: Roeky Mountain and Paeifie Coast regions from southern Alaska and Yukon Territory south to the mountains of California and eentral Arizona. Of the Sierra Grouse (subspeeies sierrae): upper belt of coniferous trees (upper Transition and Canadian life zones) of mountains from Fort Klamath, Oregon, sonth in the Sierra Nevada of California, to Mount Pinos, Ventura County.

Distribution in California-Common resident of the upper eoniferous belt (upper Transition and Canadian life zones) from Mount Shasta south along the inner eoast ranges at least as far as eentral Lake County, and along the Sierra Nevada south through the Mount Whitney region to Pinte Mountain, Kem County; also on the Warner Mountains, Modoe Connty, on the White Mountains, Inyo County, and on Mount Pinos, Ventura County. 
Two slightly different geographic varieties of Sooty Grouse oecur in California. One, the true Sooty, is restricted to the semi-humid northwestern corner of the state east to central Trinity County and south certainly not farther than Sonoma County near the mouth of the Russian River. The other, and by far the better known race, is the Sierra Grouse, which ranges from Mount Shasta on the north, south along the inner coast ranges to Lake County and along the whole of the Sierra Nevada to Mount I'inos, Ventura County; eastwardly, detached colonies are also found on the Warner Mountains, Modoc County, and on the White Mountains, Inyo County. The differences between these two forms are but slight, and are indicated in the account of the Sooty Grouse (p. 552). Because of its wider and more aceessible range and also becanse practieally all the inform-

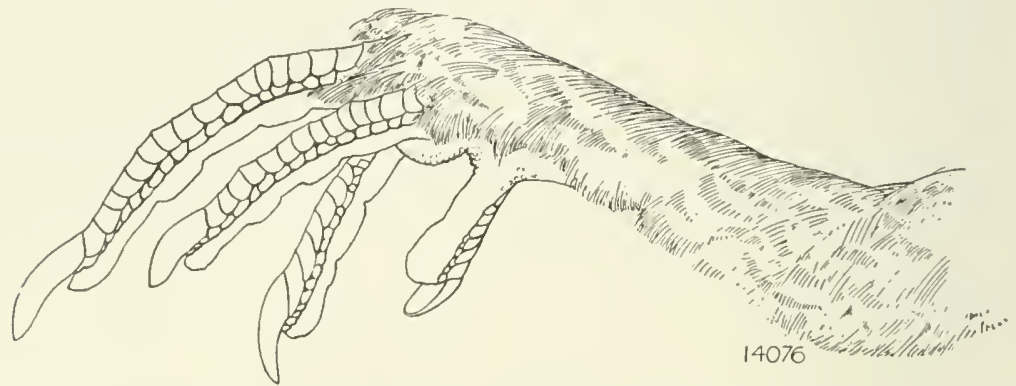

Fig. 85. Sicle of tarsus and foot of Sierra Grouse. Natural size. Note stout toes and claws and presence of feathering on tarsus (compare with fig. 83).

ation we have concerns it, the Sierra Grouse alone is the subject of the following account.

The Sierra Grouse has been called by a variety of names. Blue Grouse, Sooty Grouse, and Dusky Grouse all refer to the dark tone of its coloration (pl. 15) as compared with our other species, while the name Pine Grouse suggests the nature of its preferred habitat. Since throughout much of the Sierra Nevada it is the only species of gronse, hunters there designate it simply as Grous's. In the mountainous districts of California such aceepted place names as Grouse creek or Grouse Lake oceur no less than eight times-a tribute to the prominence of this game bird in the minds of the people.

The metropolis of the Sierra Grouse is to be found in the upper part of the mountain coniferous belt (Canadian zone) among the lodgepole and Jeffrey pines and red firs, but the species also oceurs rather" sparingly, just after the breeding season, still higher up towards timber line, among the monntain and foxtail pines and alpine hemlocks (Hudsonian zone). In autumn it may range to the extreme 
Hpper edge of the forest, and even beyond. This is espeeially true of the old male birds after the close of the nesting season. On the other hand it seems doubtful if this grouse oceurs regularly at lower Nevations than first indieated above, even during the heariest snow's of winter.

In the extreme southern part of its range the Sierra Grouse does not oceur mueh below S,000 feet, as on Mount Pinos, Ventura County (Grimell, 1905, p. 352), and in the Mount Whitney region aroum IIonache Meadows (Mus. Vert. Zool.). Immediately southwest of the Sequoia National Park near Blue Ridge, Tulare County, the two loealities named Grouse Valley and Vpper Gronse Valley, at 3,700 to 4,700 feet altitude suggest low stations for the species: but this needs verifieation by actual observation. In the central Sierras in the vicinity of Yosemite, Grouse do not range much below 7,000 feet (Mus. Vert. Kool.), hut on Mount Shasta they oceur regulary at Wagon Camp, altitule 5,700 feet ((. H. Merriam, 1899, p. 110). However, this decrease in their elevation towards the north is simultaneous with a diminution, in the higher altitudes, of the kinds of coniferous trees which they habitually frequent. These grouse are nowhere found in the same abundanee as quail: as a rule not more than four or five can be started in an hour's walk through the most favorable eountry. Indeed several miles may be covered without seeing or hearing one of the birds, even in the heart of their territory.

The Sierra Grouse is a forest bird. rarely if ever found away from the shelter afforded hy coniferous trees. A faetor in determining its assoeiation with these trees is the dependenee of the gronse on pine and fir needles for food during a portion of the year. While a eertain amount of time is spent regularly on the ground at other times than when nesting or with young, adults probably spend most of their lives in the trees. Not infrequently one may eome upon a grouse feeding on the ground, but when alarmed theme it will almost invariably take refuge well up in a tree.

After a long field experience with this species. John Muir writes (1901, pp. 216-217) :

They like best the heaviest silver-fir woods near garden and meadow openings, where there is but little underbrush to cover the approach of enemies. When a flock... sees a man for the first time... they rise with hurried notes... and alight on the lowest branches of the trees. . . They allow you to approach within a half dozen paces, then quietly hop a few branches higher or fly to the next tree without a thought of concealment.... But in the neighborhood of roads and trails they soon become shy, and when disturbed fly into the highest, leafiest trees, so well do they know how to hide and keep still.... Nor can they be easily dislorged ere they are ready to go. In vain the hunter goes round and round some tall pine or fir into which he has perhaps seen a dozen enter...; not a feather can he see unless his eyes bave been sharpened by long 
experience and knowledge of the blue grouse's habits. Then [suddenly]... they burst forth with a startling whir of wing-beats, and after gaining full speed go skating swiftly away through the forest arehes in a long, silent, wavering slide with wings held steady.

During the summer they are most of the time on the ground, feeding on insects, seeds, berries, ete, around the margins of open spots and rocky moraines, playing and sauntering, taking sun baths and sand baths, and drinking at little pools and rills during the heat of the day. In winter they live mostly in the trees, depending upon buls for food, sheltering beneath dense overlapping branches at night and during storms on the lee side of the trunk, sunning themselves on the southside limbs in fine weather, and sometimes diving into the mealy snow to flutter and wallow, apparently for exereise and fun.

The flight of the Sicrra Grouse is rapid and direct, with fast beating wings. When flushed at short range, the swift movement, and rapid whirring of the wings necessary to lift the bird's heavy body, produce a startling sound, and with a small flock the aggregate noise is most bewildering to an intruder.

It is during the spring and early summer, the courting season, that the voice of the Sicrra Grouse is most frequently heard. Males are in the habit of taking positions near the tops of pines or firs, sixty or seventy feet above the ground, standing close to the trunk on some horizontal limb. Snch a station will be held continuously for hours, and from it the reverberant hooting is heard at varying intervals. The hooting may be described as a deep, wooden, far-carrying, ventriloquial sound. The sequence of notes lias been recorded as: unt, wunt, wunt', wunt', tu-uunt', wunt, u'unt (Storer, MS) ; another rendering is boont, boont, boont', boont', boont, boont, six of these notes seeming to be the average in the case of two birds under observation. In different individnals the series consisted of five to seven notes, in quality of sound likened to beating on a sodden wooden tub, crescendo in volume, diminuendo towards the end of the series (Grinnell, MS). As each note is nttered the tail of the bird is seen to be depressed an inch or two-an index to the effort involved. The separate series of notes in two cases under observation were uttered at intervals of seconds as follows: 40-20-25-45-12-21-29; and again : 10-10-20-26-14-15-17-12-11-15-13-28-17-11 (Storer, MS). The ventriloquial quality comes into evidence when one attempts to loeate the producer, a very difficult feat as a rule. The observer may circle the tree many times with a painfully aching neek and still utterly fail to locate the hird amid the foliage high overhead. The notes are commonly supposed to be produed by inflating and exhausting the glandular sacs on the sides of the neck, which are covered by unfeathered yellow skin. We think it likely that, in fact, these saes serve only as resonators, being kept contimally inflated, while the air producing the sound passes to and from the lungs along the 
regular air passages. Belding (1879, p. 438) says that when alarmed in a tree the birds ntter a note rescmbling the syllables kuk, kul: W. P. Taylor (MS), and other observers, report that females with young ale wont to cluck and cackle, showing anxiety by restless actions, sometimes even flying repeatelly at the intruder.

The nesting season of this species extends from about the middle of May to the latter part of June. The earliest instance of nesting in California as far as known to the authors is \Гay 14, 1902, at Denison Springs, Lake County, six miles north of Clear Lake, where a set of seren slightly ineubated eggs was taken (Mus. Tert. Zool.). A downy roung taken July S, 1911, on the North Fork of Coffee Creek, Trinity County (Mus. Yert. Zool.), altitude 4,500 feet, was not much over a week old, which would indicate that the brood of which it was a member hateled about the first of July. Our present information does not indicate that a great difference in the time of nesting is caused by vatiations in elevation or latitude, although it is possible that the southeru birds nest slightly earlier.

The nest is usually situated in a protected situation on a well drained dry hillside. 'The shelter of a small tree or slightly overhanging rock or $\log$ is often sought. The nest proper consists of a slight depression in the ground, sparingly lined with dry grasses, leaves, twigs, and often with featlers from the female. A nest found by Swarth (Mus. Vert. Zool.) June 9, 1912, in Onion Valley, 8,500 feet altitude, Sierra Nevala, Inyo County, was situated about three hundred feet above the cañon stream, on a hillside covered with manzanita and ehinquapin but destitute of any large timber. It was placed on the bare ground on the north side of a slightly overhanging rock where there was a narrow strip of bare ground between the rock and the nearest brush. The nest eavity was a slight depression. scantily lined with dry twigs and feathers. The nest at Denison Springs, Lake County (see above), was a slight hollow under a young pine shoot and lined only with a few feathers.

The Sierra Gronse lays from five to seven eggs, rather less than its northern relative, the Sooty Grouse, which as Dawson (1909, p. 571) says, usually lays from six to twelve eggs while as many as sixteen have been recorded in a single nest. The eggs of the Sierra Grouse measure, in inches, 1.96 to 2.14 by 1.34 to 1.45 and average 2.03 by 1.39 (two sets, twelve eggs, from California). The ground-color is pale creamy buff, and the surface is marked with dots and round spots of reddish brown, usually very small and uniformly distributed, but at times larger and more unevenly grouped. The large size of the eggs, their fine pattem of markings, and the type of country in which they are found, make their identification easy. There is no other species of bird nesting in similar situations in the Sierras whose 
eggs could be confused with those of the Grouse. Incubation probably lasts abont three weeks, judging from the dates for fresh eggs and newly hatched young.

John Mnir (1901, pp. 217-218) relates that he has sern broods of roung in the Sierras rumning beneath the firs in June.

On the approach of danger, the mother with a peculiar cry warns the lelpless midgets to seatter and hide beneath leares and twigs, and even in plain open places it is almost impossible to discover them. In the meanwhile the mother feigns lameness, throws herself at your fect, kicks and gasps and flutters, to draw your attention from the chicks. The young are gencrally able to fly about the middle of July; but even after they ean fly well they are usually advised to run and hide and lie still, no matter how closely approached, while the mother goes on with her ... acting. . . . Sometimes, however, . . she tells them to take wing; and up and away in a blurry birr and whir they scatter to all points of the compass ... dropping eumingly ont of sight three or four liundred yards off, and keeping quiet until ealled. . . .

While there is no actual migration in the case of the Sierra Grouse, a vertical movement is apparent just following the breeding season, with a complementary return upon the advent of winter. The males work up the mountains toward the timber line rather early and are followed by the females with their broods later on, say after the first of August. Belding (1879, p. 438) says that in late September it is difficult to find the grouse in locations where they are eommon earlier in the year. He attributes this to a vertical migration or in part, perhaps, to their taking to the denser conifers (such as the red fir and alpine hemloek).

The vrgetable food of the Sierra Grouse has been fairly well dotermined by Belding (1892b, pp. 232-233) who dissected many stomachs of specimens shot by him in the eentral Sierra Nevada, more than twenty years ago. The following is a synopsis of his findings with the seientific names of the plants revised to accord with present nomenclature (Hall and Hall, 1912). The thimble berry (Rubus parviflorus) appears to be the favorite article of diet, and next to this the service herry (Amclanchier alnifolia). Several kinds of wikl cmrants and gooseberies (Ribcs) are taken, as well as red mherberry (Sambucus racemosa). green manzanita (Aretostaphylos patula), and dwarf manzanita (A. ncudensis), dwarf twinberry (Lonicrel conjugialis), Sierra bilberry (Taccinium occidentalc), mountain ash (Pirus occidentalis), lupine (Lupinus sp.). false sunflower" (Wryethia mollis), "earaway (Glycosoma)", and mitrewort (Witclla breweri). Acoms of the huckleberry ak (Qucrcus raccinifoliut are sometimes eaten. "After the young grouse are hatehed the mother bird takes them to alder and willow thickets where they find serhusion and whter. Here they also find some insect food (which 


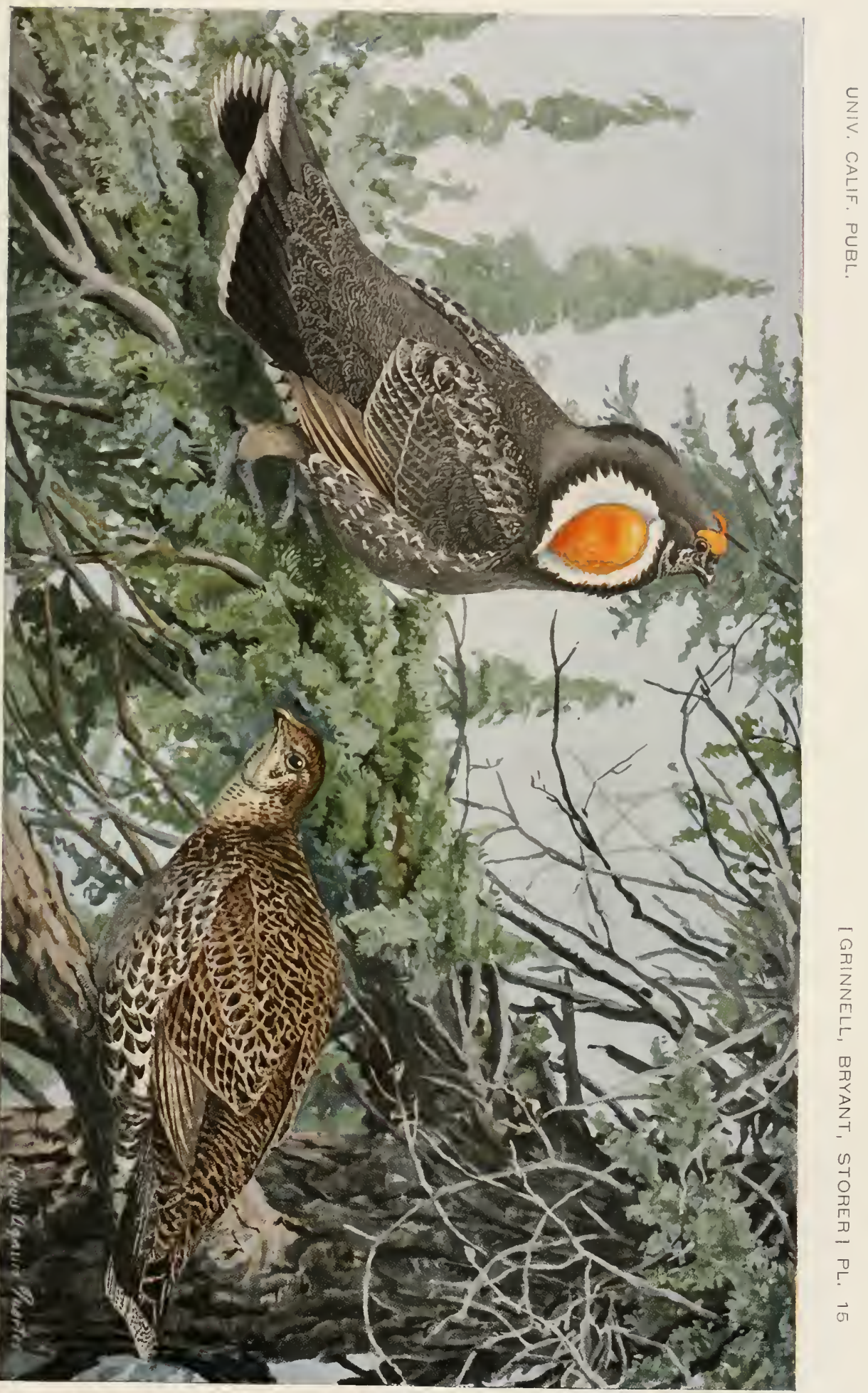



seems to be rely necessary to young birls of most species), and a speeies of native red elover, the green leaves and heads of whieh supply them, for a time, with nearly all the food they require... . About the midlle of August the females, with their broods, begin to ehange their haunts and range higher in the mountains, and then feed partly on the foliage of fir trees (Abics concolor and magnifica) ", and alpine hemloek (Tsuga mertensiana). "the latter being apparently preferred. The old males feed upon the foliage of these eonifer's nearly all the year and during the winter when everything is covered with snow all gronse must subsist upon them....

"Some years, late summer frosts destroy the berry and sced crops and then the grouse are limited to a diet of a few kinds of vegetable fook, grasshoppers and other insects. One such year, during Suptember," they were found "feeding almost exclusively on the fallen dried male flowers of the yellow pine (I'inus ponderosa)."

Belding 's last observation is fully substantiated by our own findings in the Mount Whitney region, where in September, 1911, the grouse at 11,000 feet altitude were found to have fed extensively on the pollen cones of the foxtail pine (Pinus balfouriana). In another instanee the erop of an old male taken near timber line at the head of Warren Fork of leevining Creek, Mono County, September 26, 1915, was found by us to contain 1,520 needle-tips of the lodgepole pine (Pinus murayana). 'The bitten-ofí ends varied from one-fourth to one ineh in length, and there were also a few fragments of very young pistillate cones. The bill of the bird was smeared with pitel. 'The erop of an adult female which had just been killed by some speeies of liawk at Walker Lake, Mono County, September 10, 1915, was found to eontain eleven lipe rose hips, arid the gizzard was filled with the hard seeds of the rose together with quartz grains. Some Sooty Grouse killed near Kuntz, Trinity County, in late September, 1910, eontained madrone berries and fir needles (Dixon, IIS).

Beeause of their high mountain habitat the grouse confliet but little with any agrieultural enterprise of man. Locally, in the mountains of Trinity County, the birds oeeasionally prove destruetive in August when they come down and feed about the edges of elearings. A farmer in that region eomplained that the grouse were so abundant around his raneh as to injure the young grain (Kellogg, 1916, p. 380). In general, however, it may be said that man's ehief interest in the grouse arises from the bird's value to him for sport and food.

The best grouse hunting is afforded when the birds eome out on the edges of clearings in the early morning. Then the hunter who ean shoot quiekly will drop the birds as they rise in their rapid yet straightaway flight. When they take to the trees hunting is more diffieult. C. H. Merriam says (1899, p. 111) that this species, unlike 
other grouse when treed, walks about earefully on the tops of the branches, keeping on the opposite side of the tree to the hunter and making the seeuring of speeimens rather difficult. Cooper (1870a, pp. 526-528) agrees with other writers in stating that gronse as a rule remain perfeetly motionless and that it is only by eareful searching that their post may be discovered. Often when started from trees on ridges, the birds will dash preeipitately down into the cañon far below, glithing on set wings till lost to sight among the forest trees.

By the first of September the young are almost full grown and are then tender of flesh, which is white, and are eonsidered excellent for the table. The flesh of old birds is coarser and liable to be strongly flavored.

Writing in 1870 ('ooper (loc. eit.) said that the grouse were often brought to market (probably meaning San Francisco) from the vieinity of Napa. Doubtless they were also supplied to the dealers from other loealities as well. Now they are, of eomrse, pursued only for the use of the hunter himself. Their limited and rather inaecessible range has probably been the greatest factor in enabling the birds to maintain their numbers in California. Unless conditions change in a way not now eonceivable, the Sierra and Sooty grouse will eontinue for all time to be interesting and important elements in our game resonrees.

\section{Sooty Grouse}

\section{Dendrugapus obscurus fuliginosus (Ridgway)}

DEscription-Essentially the same as the Sierra Grouse (Dendragapus obscurus sicrae), but adult male slightly darker in general tone above and below, and with less white on chin and throat; adult female, jurenile, and natal plumages similar to those in sierrae, but prevalent tone of coloration more warnly brown, approaeling rusty.

MARKS FOR FIELD IDENTIFICATION-See minter Sierra Grouse.

General distribution-Northwest coast region of North Ameriea, from the Sitkan district of southeastern Alaska south into northwestern California.

Distribution IN CALIForNiA-Fairly common resident locally in the semihumid northwestern eorner of the state (chiefly in the Douglas fir belt interiorly from the redwoods), east and south at least as far as Hayfork and Kuntz. Trinity County; probably also to Seaview, near mouth of Russian River, in Sonoma ('ounty (Grimell, 1915, p. 60).

\section{Oregon Ruffed Grouse}

\section{Bunasa umbellus sabini (Dowglas)}

Other NAmes-Oregon Grouse; Wood Plieasant (Del Norte County) ; Bonasa umbellus; Bonasa sabinii; T'etrao sabini.

DESCRIPTION-Adults, both sexes: Top and sides of hear mixed black and brown, with grayish feather tippings; feathers of crown clongated and pointed, 
forming a erest; eyelids yellowish; a series of slender, elongated black and brown feathers ower ear region; sides of chin scaled with black and buffy white; middle of chin, and throat, buff ; bill horn yellow; rest of upper surface, including wings (except primaries) and tail, richly variegated with reddish brown, gray, black, and buffy white, the first named color predoninating; the pattern including bars, stripes, and spots of various shipes, the whole subdued in effect by an extensive remiculation; broad subterminal baud across tail, brownisl black; primary wing feathers blackish brown, onter webs spotted witl buff; lining and under surface of wing eliefly grayish brown; band across mpper breast, deep reddish brow becoming darker at sides; a shiny black (sometimes partly brown) ruff of soft broat feathers on each side of lower neck, overlapping bend of wing: feathers of lower breast and rest of under surfice, buff, marked with bands of brown and tipled with white, the whole producing an interruptedly bared appearane: feathering on lower part of leg (tarsus), ashy brown; feet (dried) yellowish brown and dusky; females differing from males ouly in somewhat lesser development of ruff at siles of neck. Total leugth (both sexes) " $15.50-19.00$ "' inches (394-482 mm.) (Ridgway, 1900, p. 197). Males: Folded wing 6.73-7.52 (171-191); bill along culnen $0.58-0.68$ (14.7-17.3) ; tarsus, $1.66-1.79$ (42.0-45.4) (nine specimens from ('alifornia and Vaneouver Island). Females: Folded wing 7.01-7.29 (178-185); bill along culmen 0.62-0.67 (15.8-17.1) ; tarsus 1.58-1.73 (40.1-44.0) (three specimens from ('alifornia and Vancouver Island). Juvenile plumage: Top of head chiefly brownish black with narrow light brown feather edgings; chin and throat whitish; back, wing eoverts and some of tertials, chicfly blackish, with shaft streaks of buffy yellow, and finely variegated with lark einnamon brown: rump finely barred with dull cinnamon and blackish; tail barred with black, light brown and gray; primaries hlackish hrown edged with dull einnamon; featlers of breast light cimmamon brown with terminal black sjots ancl white shafts: sides and tlanks coarsely marked with black, buft and white; belly barred with blackish brown and dull white; under tail coverts dull buff; leg but seantily elothed with dull white feathers. Natal plumage: Top and sides of head bright cinnamon brown, darkest above; eyelids narrowly, and ear region broadly, marked with black; back chiefly cimnamon brown, darkest along mid-line; under surface yellowish white, with a buffy suffusion across chest.

MARKS FOR FIELD IDENTIFICATION-Moderately large size (smaller than Sierri or Dusky Grouse), general reddish brown coloration, dark band near end of tail, and conspicuous ruff of black or deep brown feathers on either side of neck.

YoIck-(Of eastern subspecies) in adult, a series of rocal clucks and calls; in female with young, squeals, much like those of a rabbit (Forbush, 1912, p. 377 ). There is also a characteristic "Irumming", by the male, caused by rapirl beating of the wings.

Nest-On groumi, often uniler a spruce tree or similar shelter; a slight depression in the surface, lined with grasses, leaves, neelles, and feathers (authors).

EgGs-6 to 13, romdly ovate, measuring in inches, 1.50 to 1.73 by 1.14 to 1.24 (in millimeters, 38.0 to 44.0 by 29.0 to 31.5 ), and averaging 1.62 by 1.20 (41.0 by $30.5)$; ground-color varying from milky white to pinkish buff; some immaculate, but usually marked rather sparingly though uniformly with small rounded dots ranging in color from reddish brown to pale drab (Bendire, 1892, pp. 63, 69, referring to the several races of Rnffed Grouse).

General distribution-Of the Ruffed Grouse and its various subspecies: The wooded regions of Alaska and Canada south to California, Colorado, Kausas, Tennessee, and, in the Alleghenies, to Georgia; of the Oregon Ruffed Grouse (sabini): Coast ranges from Vancouver Island to Humboldt County, California (modified from A. O. U. Check-list, 1910, pp. 139, 140). 
Distrirution in California-Fairly common locally in the denser humid forests of the northwestern corner of the state, south to the vicinity of Humboldt Bay, and east to the Siskiyou Mountains.

The Oregon Ruffed Grouse, a elose relative of the Ruffed Grouse that oceurs in other parts of North Ameriea, is, unfortunately for sportsmen, not widely distributed in California. Naturalists and hunters who know this fine game bird in other parts of the country might well wish that its distribution here were more extensive. The record of sonthermmost ocenrence within the state is for Humboldt Bay (C. H. Townsend, 1886, p. 491), while eastwardly on the Oregon boundary it ranges only to the Siskiyon Mountains (Anderson and Grimnell, 1903, pp. 6-7). So far as known it is non-migratory and breeds throughout its range. In California this grouse is an inhabitant of rather dense coniferous forests, such as often grow in cañon bottoms, but is chiefly a ground dreller, rarely found in the trees themselves. But in the northern part of its range, namely, in Oregon and Washington, it often affects more open eountry.

In size the Oregon Ruffed Grouse most closely resembles the Columbian Sharp-tailed Grouse which formerly ranged into northeastern California. It is decidedly smaller than the Sierra or Dusky Grouse, and the Sage-hen, yet mueh larger than any of our speeies of quail. The complicated pattern of markings, with rich reddish brown eoloration predominating, the black-banded tail, and the blaek or deep brown ruffs of broad feathers on the shoulders are, in combination, eonelusive field marks.

In the Siskiyon Mountains, near the Oregon line, the people of the region elaim that it is to be seen exelusively on the groumd or on logs, usually in groves of small Douglas spruce, sueh as grow near or in the canon bottoms (Anderson and Grimnell, loc cit.). When frightened, it flushes with a rapid, direct flight, almost always taking pains to place as soon as possible some obstaele sueh as a tree between itself and the observer. In some instanees, the birds alight in trees and there, despite the adrantage of their wonderfully protective coloration, they make themselves eonspienous by moving about. The fact that they so often haunt dense woods makes wing shooting ahmost impossible, and one must shoot at them as they move abont after alighting in the trees, or else return with an empty bag.

These gronse are never seen in large bands. In the spring, pairs can be seen together, and later in the year the females with their broods. After the roung are full grown the family is sometimes joined by the male, but the latter is rarely found with his mate when she has eggs or ehicks. Neither do the males hand together as is sometimes the ease with the Sierra Grouse: they are usually found singly. 
The male Ruffed Grouse has no distinctive eall-notes snch as characteriz many of our species of game birds. Instead it has a mechanical method of communication, usually spoken of as "dinmming." 'Tlis sound is most often heard during the late winter and carly spring months, though there is a notable resumption of the performance in the autumn. Its primary use is probably to attract the females, for it is most trequently repeated in the mating season.

The conck Cromse usually selects a mossy log, near some open hedge, elearing, or wools roak, and partly sereened by bushes, where he ean see and not be seen. When abont to drum he ereets his neek feathers, spreads lis tail, and, with drooping wings, steps with a jerking motion along the log for some distance each way from his drunming place, walking back and forth serroll times and looking sharply in every diretion; then, standing erosswise, he strotehes himself to his fullest height and delivers the blows with his wings fully upon lis sides, his wings being several inches clear from the log. After drumming he settles quietly down into a sitting posture, and remains silently listening for five or ten minntes, when, if no canse for alarm is discovered, he repeats the jroeess.

The drumming place is resorted to hy the male from year to year [and may sometimes be worn smooth as a result]. It may be a log, a rock, an old stump, or when snch are not available, a small hillock is made to answer the purpose equally as well. While this drumming can mot be considered a love note, as it may be heard almost every month in the rear, and sometimes in the night as well as in the daytime, yet it must undoubtedly have some attraction for the female, and I think is ferformed as a sign of hodily vigol [and] to notify ler of his whereabonts. Occasionally it eanses a jealous rival to put in an appearance also, when a rough-and-tumble fight ensues. The femile is seldom seen near the drumming place (Bendire, 1892, p. 61, writing of the eastern umbellus).

Dawson (1909. p. 585) says the sound made by a drumming grouse rlosely resembles the syllables bump-bump-bump. bumprrmrr. The wing-beats commence slowly and end in an exeeclingly rapid whirr. The quality of the somnd is such that it carries far and ret gives no notion of exact distance.

During most of the rear the Ruffed Grouse roosts at night in trees, but often during the winter months where there is considerable snow on the ground the birds pass the nights under the snow. They "dive" into the snow from a tree, leaving no track on the surrounding surface. In extremely cold weather they are reluetant to leave such a warm and comfortable shelter and are said sometimes to emerge rather late in the morning, or in the event of severe storms to remain under the surface for a day or more. If a crust forms on the snow as a result of the temperature falling rapidly after a thaw the gronse may be imprisoned and be unable to break through and thereafter die from starvation. But this sort of an accident probably rarely happens in California.

There is but one known record of the nesting of the Oregon Ruffed Grouse in California, although special search in the proper Incalities 
would doubtless bing adequate data. W. K. Fisher (1902b, p. 132) found a brood of downy chicks in heary redwood forest north of Mad River, IImmboldt County, June 11, 1899. In the northern part of its range this race begins to nest about the middle of April and the season eontinues until some time in June. The earliest set recorded was taken on April 14, and a set (probably a seeond laying) was secured June 28, 1876, on Vancourer Island (Bendire, 1892, p. 69$)$.

The nest is usually placed in a shelteres situation, as under a spruce or maple, or at the side of a fallen $\log$ or shightly orerhanging roek. A slight depression is seratched ont and lined with grasses, leaves, needles, or twigs; sometimes a few feathers from the female are added. Dawson (1909, p. 589) says that an average eluteh of eggs numbers eight or ten. Bendire $(1892$, p. 69$)$ states that the eggs number anywhere from seven to thirteen but that the eggs of the set which he thought was of a seeond laying numbered only six. The eggs are roundly ovate, thus proportionately shorter than the eggs of the domestic fowl. They measure in inches, 1.50 to $1.73 \mathrm{by} 1.14$ to 1.24 and average 1.62 by 1.20 (twenty eggs). The gromul color is milky white to pinkish buff, and abont half the eggs are rather sparingly but uniformly marked with small rounded spots varying in color from reddish brown to pale drab (Bendire, 1892, p. 63, referring to the screral races of the Ruffed Grouse). From the eggs of the Sierra and Sooty grouse those of this speeces differ chiefly in size, being decidedly smaller.

After mating, the female alone attends to ineubation and to rearing of the ehieks. Some observers believe this species to be polygamous, one male serving several females and a single mating being suffieient for a clutch. While the set is being laid, any interference with the nest will canse the female to desert, and the same is true during the early part of the period of incubation. Later, however, she is not so easily disturbed. Often, if she be flushed directly from the nest, the surrounding leaves and other debris are swept over the eggs, and, if she has time, she will take pains to cover them herself with material before quitting the vieinity. If a dog or a fox or other predacious animal approaches the nest she will artfully lead away the intruder a sufficient distanee to save the eggs, using the lameness and broken wing ruses most skillfully. When the chicks have hatehed, she will even go ont to meet an intruder, to toll him away from the brood. And in the case of a person she will often fly up toward his body or faee, presenting an altogether forlidding front. An obserration of Swarth's (1912. p. 22) made on Vaneonver Tsland. substantiates the above general statements: "At Beavel Creek broods of downy young hegan to appear during the second week in June, and 
were seen daily thereafter. ... The old birds were fearless in defense of their broods, and often the first intination of the proximity of a grouse family was the sudden onslaught of the perturbed mother, who did not hesitate to hurl herself at any intruder, while her brood effaced themselves in the underbrush. Very young birds usually lay perfectly still when alarmed, and, if visible, suffered themselves to be picked up, but as soon as their wings conld support them they flew to some distance when startled."

The chicks, in observed cases, all hatch ont at practically the same time, and as their feathers dry very rapidly, they are able to run about and forage independently almost from the start. If danger seems imminent a single note of warning from the mother bird causes the chieks to take to the best available shelter', as under leaves; they remain perfectly quiet, and thereby beeome, by reason of their concealing coloration, extremely diffieult to find. For a time the mother broods them at night under her body but the young gain their wing quills rapidly and even when but a week old are able to fly short distances; theneeforth they always roost for the night and seek safety in trees. The brood stays with the mother bird well into, if not through, the first winter. In some instanees the male parent has been known to join his family (Forbush, 1913, pp. 268-271).

Aceording to Judd (1905, pl. 29-38) the fool of the Ruffed Gronse ( the specius as a whole) is quite varied. 'The vegetable material comprises about 89 per cent of the total, and the animal content 11 per eent, the latter being chiefly insects. The regetable material includes about 12 per cent seeds, 28 per eent fruit, and t8 per eent leaves and buds, while the animal food is chiefly grasshoppers, eaterpillars and beetles, the latter being most abundantly represented. On Taneouver Island, Swarth (1912, pp. 22-23) says that the stomaehs and erops examined eontained some berries but were filled for the most part with fern leaves and clover. One young bird had fed entirely on small snails, having swallowed them whole.

A specimen of the Oregon Ruffed Grouse taken near Requa, Del Norte County, November 3, 1915, and now in the eollection of the Musemm of Tertebrate Zoology held the following materials in its erop and gizzard: Berries and seeds of the madrona (Arbutus menziesii), 5 per eent; stems and leaves of thimbleberry (Rubus parviflorus), 65 per eent; stems and leaves of dogwood (Cormus sp.), 20 per cent; unidentified leaf-stems and twigs, 10 per cent. Identifieation of the leaves and stems was made for us by Miss Anna MI. Lute of the U. S. Department of Agrienlture.

The enemies of the Ruffed Grouse are many. Certain hawks and owls, skmnks, mink, wildcats and foxes are the ehief offenders in this respeet, though man himself stands out prominently. A marked 
decrease in the number of Ruffed Grouse occurring in the eastern part of the Enited States in 1907 was attributed by Forbush (1912, pp. 380-382) and other observers to an unusual flight of Goshawks, a raptorial species notably destructive to game birds. Of forty-eight Goshawks dissecter by one firm of taxidermists, twenty-eight had l'emains of Ruffed Cirouse in their stomachs; in another ease thirteen grouse were known to have been destroyed by hawks in one locality. Another important agent in the destruction of Ruffed Grouse is fire, when it sweeps brushy and forested areas. Sitting birds will often remain on the nest until injured or pren killed by the flames.

C. F. Ilodge (Anonymous, 1914) leports marked snccess in artificially rearing Ruffed Grouse. The young hatch readily and can be raised with as much suecess as some domestic fowls. The adult birds have to be kept in separate pens to prevent them from damaging one another, especially at mating time; and the species is, moreover, subject to one or two diseases which may give some trouble. On the whole, artificial propagation in the case of this speeies would seem unusually promising of satisfactory results.

Because of its forest habitat it is probable that the Oregon Ruffed Gronse will not markedly deerease in mumbers within its restricted range in northern California, at least as long as the forests remain. Nevertheless its condition as to numbers should receive careful consideration and any marked reduction be compensated for by closing the luunting season for a period, or by other appropriate means. The matter of its artificial propagation should also be thoroughly investigated and, if feasible mder Californian conditions, encouraged. It would seem much more desirable to increase the numbers and extent of range of our native game birds such as the Ruffed Grouse than to attempt to introduce and acelimatize eastern or foreign species.

\section{Columbian Sharp-tailed Grouse}

\section{Pediocectes phasiancllus columbianus (Ord)}

OTHER NAMEs-Prairie Chicken; Columbia Sharp-tail; Sonthern Sharp-tailed Grouse; Pedivectes columbianus; Tetran phasianellus: Tetrao columbianus.

Description-Autuls, both scxes: Top of head and hind neck, mixed blackish brown, pale elay-colol and ashy white; a pointed crest, rising from crown, brownisl black with buffy feather edgings; broad stripe at side of upper mandible, ruming over eye and car region, buffy white; naked comb over each eye, bright yellow; narrow stripe from enrner of month ruming below eye and through ear legion, brownish black; lower side of head and chin, pale cinnamon or buffy, scatteringly streaked with brown; bill dark olive, basal half of lower mandible pearl gray; iris liglit brown; uples surface of body from hind neek to upper tail corerts, mixed cinnamon, palo buff and brownish black, in an interruptedly barred pattern and somewlint remienlated, the general tone lightest on lower back and 
upper tail enverts; seapulars marked with white wedges; tail sharply pointed, thr millle tail feathers heing ahout an inch longer than the rest am marked with brownish hlack and buffy white; rest of tail teathers chiofly white; outer surface of closed wing irregularly marked with clay color, or pale cinnamon, and brown, mauy of the feathers with sharply contrasted white spots at ents: flight feathers and primary coverts dull brown, spotted with white on outer webs; margin and forwarl lining of wing mixed white and dull brown; rest of lining and axillars, white; under surfaces of fliglit feathers, pale brown; under surface of boly white, with bolk. l-shaped marks of brown plaralleling margins of feathers; markings heaviest on lower breast; chest, silles and flanks, barred with dark brown, clay color and white; belly and lower tail coverts almost or wholly immaculate; feathering of legs and fect grayish brown; toes and horny fringes gray; uails blackish. Total length "15.00-19.00" inches (381-182 $\mathrm{mm}$.) (Rilgway, 1900, p. 203): folked wing 7.68-8.47 (195-215); bill along culmen 0.57-0.68 (14.5) 17.4); tarsus 1.52-1.85 (35.7-47.0) (four sperimens, from British Columbia, Alherta and Colorado). Juvenile plumage: Top of head mixed hlaek and light rust lorown: stripe from side of bill through eye, yellowish white; another stripe below eye, mixed black and yellowish hown; chin and fore-throat, white; whole upper surface largely yellowish brown, with irregular black patches on thr featlers and white shaft streaks: outer surface of closel wing grayish bruwn, spotted with dull white: featlers of breast, sides and fanks, jale yellowish hrown, with small hack spots and white shaft streaks; belly white; feathers on tarsus pale buff. Natal plumage: Cround color of mpper surface straw yellow becoming buffy along midille line, the whole boldly spotted with black; whole lower surface deep straw yellow, without markings; bill horn eolor; feet (dried) yellow.

MIRKS FOR FIELN IDEXTIFCATION-Medium size (Inuch smaller than Sierra Crouse and Sagt-lın!), umbanded, pointed tail (whenes the name Sharp-tail), mixed color pattern, of pale effect, on upper surface, and pure white ground of under surface.

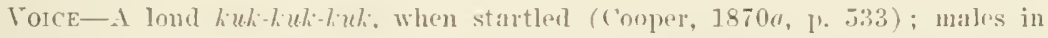
the sprring have a lond eackling note (Vernon Bailey in Bailey, 1902, p. 132).

Nest-On prairie land in tuft of grass nr near a small hillock; a slight depression with sparse lining of grass-stalks and root-fibres (Baire, Brewer and Ridgway, 1874, III, p. 438).

Egas--10 to 1.5, short ovate in shape, measuring in inches, 1.54 to $1.83 \mathrm{by}$ 1.22 to 1.36 (in millimeters, 39.0 to 46.5 by 31.0 to 34.5 ), and averaging $1.70 \mathrm{by}$ 1.26 ( 43.0 by 32.0) : creamy buff to pale olive brown, ummarked, or else finely dotted with realdish brown (Bendire, 1592, p. 101).

Gexeral distribetion-Of all races of the Sliarp-tailed Grouse: Central and westem North America from central Alaska and Ungava south to Illinois and northeasteru California; of the Columbian Sharp-tailed Grouse (subspecies columbiamus): central British Colmmbia and central Alberta, south to northeastern California, Ttah, and central Colorado (A. O. U. Check-list, 1910, p. 144).

Distribt"Tion ix CALifornia-Formerly common in the Modoe region. Recorded from Canoe Creek [near Cassel, northeastern Shasta County] and upper Pit River (Newberry, 1857, p. 94), and Camp Bidwell, Modoc County (Henshaw, 1880b. p. 317). No perfectly authenticated instances of occurrence within late years; probably now nearly or quite extinet within the state.

The history of the Columbian Sharp-tailed Grouse, as far as it concerns California, is like that of a considerable number of North American game and non-game birds, which were once extremely abun- 
dant and are now almost or entirely extirpated. When Newberry, Cooper, Henshaw and other early naturalists were making observations npon the famma of California, previous to 1880 , they found this species mumerous in the plateau region northeast of the erest of the Sierra-Caseade range. Since then, man's ocempancy of that territory, and uncontrolled levy upon its birds for food or sport, has resulted in the apparently complete disappearance of this species.

Writing of the Sharp-tailed Grouse in 1857 (p. 94), Newberry said:

Coming north from San Franciseo, we first found it on a beautiful prairie near Canoe creek [near Cassel, Shasta County], about fifty miles northeast of Fort Reading; subsecuently, after passing the mountain chain which forms the upper caũon of Pit River, we came into a level, grass-covered plain, through which the willow-bordered river flows in a sinuous course like a brook through a meatow [probably near Lookout, Modoc County]. On this plain were great numbers of birds of various kinds, and so many of the sharp-tailed grouse, that, for two or three days, they afforded us fine sport and an abundance of excellent food. We found them again about the Klamath lakes. . .

In 1879 Henshaw (1880b, p. 317) wrote: "Abont Camp Bidwell [Modoc County], Cal., the 'sharp-tails' are sufficiently numerous to afford excellent shooting, and good bags may be made there." Cooper (1870a. p. 533) believed that the species ranged as far sonth as latitude $39^{\circ}$ (Lake Tahoe), but was not certain of this; while Bendire (1892, p. 99) had reeord of its occurrence on the "eastern slopes of the Siskiyou Momntains." Nothing else has to our knowledge been printed concerning this grouse in California. Correspondence was mudertaken by us with local residents of the northeastern section of the state, and some information obtained as to its more recent status.

Mr. Chas. D. Meissner, Assistant Forest Ranger at Alturas, reports (in letter dated Jamnary 18, 1916) that a pair of "Prairie Chickens" was seen hy him during April and Mar, 1915, near Timbered Mountain, central Modoe Comnty. The behavior of the birds indieated that they were nesting. They were always to be found in a certain locality, open grassy country with but little sagebrush. The cock and the hen were both "much smaller" than the Sage Hen and when flushed flew more rapidly and cackled more sharply but sailed the same."

Mr. Clande R. Brown, residing at Lookont, Modoe County. writes us (muder date February 25, 1916) that he harl not seen any "Prairie ('hickens" himself for sereral years. but that a friend had seen two during the fall of 1915 on the ranch of William Kramer about one mile northeast of Lookont. "At one time plentiful, flocks of fifty or more heing often seen, the birds have gradually diminished until almost extincet."

$\mathrm{Mr}$. W. S. Criss, also of I sookont, writes us (monder date February 2.5, 1916) that there were many "little brown Prairje Chickens" on 
his ranch up to abont fifteen years previously. They were at one time "so thick one conld not walk through the fields without scaring up several bunehes." The boys killed them off until finally (about 1901) but one pair was left. Six young were raised that last year, but the entire family was later wiped ont.

1)puty Fish and Game Commissionel Frank P. Cady, of Susanville, writes us (under date February 2, 1916) that "about 15 years ago there were forty or fifty Prairie Chickens" on the ranch of Mr. McKensie "at the month of Juniper Creek, Lassen County." At that time no shooting was allowed on the raneh; but after the death of Mr. Mctiensie, shooting was resumed. 'The birds had all disapleared by about 1906 .

It will be noted from the above testimony that the disappearance of this bird ean be attributed to no other cause than to its ineessant pursuit by man. As long as a single bird renained hunting persisted. Moreover the fact that this grouse prefer's grassy localities, just such as are selected for ranch sites, indieates another of the factor's that led to its extermination.

From other grouse and quail this speeices is distinguishable by medium size, its unbanded, pointed tail (whence the name Sharp-tailed Grouse), its mixed eolor patteru, of pale effect, on the upper surface, and the white under surface of the body with bold V-shaped brown markings. The Oregon Ruffed, Sooty and Sierra grouses, all have square or slightly rounded tails marked with broad bands near the ends; furthermore these speeies all inhalit forested eountry almost exclusively, while the Sharp-tail is essentially a bird of the prairie. The Sage-hen differs strikingly from the Sharp-tail in being of much larger size and in having a large black area on the belly. The present speeies is often called "Prairie Chicken," but that name properly belongs to a bird (Tympanuchus americamus) which does not range west of the eastern border of the Rocky Mountains and which differs from the Sharp-tail in being conspicuonsly barred on the under sulface, and in bearing long blackish tufts of feathers on each side of the neck.

The Sharp-tailed Grouse inhabits dry brushy or buneh-grass prairie land, but it is sometimes found on hillsides and even oeeasionally among small trees, thongh never in heavy timber. At Fort Klamath, Oregon, the speeies was noted by Bendire in rather swampy land, a departure from its usual preference. In winter the birds usually band together wherever they are at all numerous. As many as two hundred have oeeasionally in former years been observed in a single flock. The spring, however, sees them broken into smaller assemblages which then take part in the "daneing" that aceompanies mating. 
Though the grouse usually keep well hidden in summer, in winter when their plumage has beeome dense and their feet and legs rabbit-like, they may be seen crossing the fields on top of the snow or getting their breakfast of buds from the tops of the trees and tall bushes. When the weather is cold and snow deep and soft they often roost under the snow like the ruffed grouse, and come out in the morning fifteen or twenty feet from where they entered the white surface at night (V. Bailey, in Bailey, 1902, p. 132).

Cameron (1907, pp. 256-258) thus deseribes the "dancing" of the Prairie Sharp-tailed Grouse (a subspecies elosely related to the Columbian). On April 18 the ball was opened by a single male making a rum aeross an open space as fast as he could move his legs, the tail being held stiffy raised over the back, while the wings dragged so that a large white area was exposed behind. The vivid yellow fringe above each eye was ereeted and all of the feathers on the neek stood on end so that the inflated, underlying pink-skimned sae was diselosed. At the same time the head was earried so low as almost to toueh the ground, giving the impression (with the raised tail) that the bird was rumning backwards. The bird returned at full speed wherempon another male came forward to meet lim. Both advaneed slowly with vibrating tails. When they met they stood with wing quills quivering, their eyes then being closed. After perhaps a minute one bird wonld take a peep at the other, and seeing him still quiescent would resume an upright and graceful earriage and quictly steal away. The second bird would presently awake-then also quietly depart. Meanwhile the remaining males took up the rumning mutil all were participating. After an hour or so the females commenced to make short rums, but they did not display air saes as did the males. Later on, birds were to be seen at the same moment in all stages of the dance. The end of the dance was, however, the same with each pair. For about twenty minutes two birds would squat flat on the ground with their bills almost touching; after this ther wonld not again enter the danee during that day. While some members of the flock were dancing, others eoncealed in the sagebrush acted the part of spectators, and kept up an incessant coo, coo, con, as if to applaud. The whole affair was quite friendly withont any tendeney toward combat. The dance ended for the day when some bird wnable to find a partner for rumning, nttered a disgusted cluck. After this, as their periods of squatting were completed, the birds would fly seatteringly away.

Byy the end of April the play of the dance was more vigorous. "Drumming" [scraping] with the tail was louder, and crouching more in evidence and prolonged. Also, if squatting pairs were approached by single birds, the latter would be driven away by a typieal rum on the part of one of the squatting pair. If danger in 
the form of a hmman intruler or a hawk threatened, the concealed spectators by warning elucks would cause the performing birds to stop the dance and assume nolmal positions.

This speeies nests more commonly on sheltered and sumy slopes of the grass-covered foothills than in the lower valleys and creek bottoms. The nest is usually placed under the shelter of a bush or clump of grass. althongh the variegated pattern on the back of the female is of a natme to conceal her very offectively even if the mest were situated in the open. A slight depression is usually made in the soil, and this lined with grass. Sometimes the female adds feather's from her own body. The eggs range in number from ten to fifteen, are roundly ovate, and average, in ineles. about 1.70 by 1.26 ; extremes of $72 \mathrm{eggs}: 1.54$ to $1.83 \mathrm{by} 1.2 \mathrm{2}$ to 1.36 . The ground-color is ereamy buff to pale olive brown, and the eggs are either ummarked or else finely dotted with reddish brown. Usually the eggs are in a single layer in the nest. Ineubation lasts about twenty-one dars and is attended to by the female exclusively, neighboring males banding together in groups of three to five while the hens are incubating. Authorities differ on the question of whether or not this species is polygamous. The young are able to run about soon after being hatehed, and for some time their diet is almost exelusively of inseets. Later when the chicks have lrarned to fly they feed with the female parent along ereck bottoms (Bendire, 1892, pp. 99-101).

The food of the adult Sharp-tailed Grouse (all races) is ehiefly regetable, according to the findings of Judd (1905, pp. 21-22). Animal matter (insects) forms only about 10 per ecnt of the total for the year, and comprises chiefly grasshoppers and beetles, although caterpillars have been found in some stomachs. The principal regetable eonstituents are weed seeds, 7 per ecnt; grain, 20 per cent ; fruit, 28 per cent; leares, buds and flowers, 31 per eent. Especially during the winter when other kinds of food are difficult to procure do these birds feed rather extensively on buds and leaves. Their propensity for eating flowers is out of the ordinary, the perecntage taken being greater than in the ease of any other species of North American bird. A half pint of blossoms has been found in a single individual. The wild rose supplies the Sharp-tail with about 17 per cent of its fruit food, the stony-seeded hips being taken in great quantity; in places where gravel is lacking these seeds seem to serve for grinding other materials in the stomach.

The flesh of this species is much like that of the "prairie hen," and, thongh not equal to that of the dusky or ruffed grouse, was always regarded as an acceptable addition to our bill of fare.

The bird lies close, and when flushed flies off, uttering a constantly repeated kuck, kuck, kuck, with a steady flight and considerable swiftness. It is, how- 
ever, tender, and easily killed, No. 4, and even No. 6, shot being, if properly direeted, sure to hring them down when withm moderate range. The young birds, being fat and heary, as they fall on the grassy prairie seatter their feather's about as though tom quite in pieces, giving gratifying evidence of their fitness for the table (Newberry, 1857 , 1. 94).

It is to be hoped that in the history of the Columbian Sharp-tailed Grouse, California has learned a lesson that will result in benefit to every other wild species within the state. Here is a magnificent game bird, completely eliminated from our confines as a result of unrestrained hunting. A modiem of foresight and forbearance would doubtless have preserved the bird as a permanent game species. Now, only very extensive importations, if possible at all, could be expected to replace the species in the territory where once it reigned. This would certainly incur a great deal of expense and probably years of work before hunting could be allowed; but it is worth consideration.

\section{Sage-hen}

\section{C'entrocercus urophasianus (Bonaparte)}

OTher NAMes-Sage Grouse; Sage-eoek; Coek-of-the-plains; Tetrao urophasianus.

Description-Adult male: Whole top of head and hind neek marked in fine transverse pattern with black, pale buff and asliy gray, the latter tone prevalent; line from base of bill over eye, and one beneath eye and ear region, eontinuing around fore neek to meet its fellow in a V, ehiefly white; side of head, ehin, throat and fore neck, mixed white and black in broken pattern, but black predominating; lower neck and fore breast, broadly white, the latter with fine lines of black, eonsisting of the bare shafts of the feathers; the feathers of the breast are notably stiff and stubby; sides of neek ornamented with long slender blaek plumes; bill black; area around nostrils densely feathered; whole of baek, rump, tail and outer surface of elosed wing variegated with black, dull white, and light and dark shades of brown; the pattern on each feather eonsists of wary bars and shaft streaks; primary flight feathers uniform dull brown; axillars and lining of wing white; belly solid black bordered on either side with a white stripe; sides and flanks like back; feathers of lower tail eoverts blackish brown with hroad white ends; tail feathers long and tapering to sharp points, ashy brown beneatl, with fine whitish or buffy markings; legs, feathered to toes, grayish finely barred with brown; toes blackish. Adult female: similar to male, but with hlaek and white areas on head and neek seareely indieated; chin and throat eliefly whitish; whole upper surface, of fine pattern of markings giring a grayish effect: breast soft-feathered, and mottled with white, brownish blaek and grayish brown; black of belly less intense, brownish; primaries mottled along outer edges with dull white in fine pattern; tail feathers shorter than in niale, less slender at ends. Males: Total length " $24.00-33.00$ "' inehes (609-8.37 mm.) (authors): folderl wing 11.50-12.50 (292-317); bill along eulmen 1.34-1.55 (34.0-39.3); tarsus 2.062.55 (52.3-64.7) (nine specimens from California, Nevada and Wyoming). Females: Total length “21.00" (533) (anthors) : folded wing 9.80-10.20 (249$2.59)$ : bill along culmen $1.18-1.26(30.0-32.0)$; talsus $1.77-2.06(4.50-.52 .3)$ (four 
specinens from ('alitoruia and Nevada). Males wrigh as much as seven pounds (3.17 kilograms); females up to five pounds (2.26 kilograms) (Coues, 1874, p. 403). Jux nite plumage: Like that of adult female, but buffy and brown tones prevalent on upper surface and lreast; black feathers of belly narrowly tippeel with white; lower tail coverts largely whitish. Natal plumage: Upper surface mixed buffy white and pale rusty brown, boldly mottled with black; bill black; under surface dull white, marked with pale rusty brown on throat and ehest.

MARKS FOR FIELD IDENTIFICATION-Very large size (larger than any other of our grouse), long tail of slender, pointed feathers, and solinly black belly. The eackle and the loud whir of the wings are characteristic.

Vorce-A rapidly repeated scolding eluck: tuk-a-tuk; a slowly repeated deep guttural $k \breve{u} h$, $k \breve{u} k$, $k \breve{u} h$, uttered as a bird fluslıes from the ground. Males have a meehanical "Arumming" in the spring.

Nest-A mere shallow depression under a sheltering shrub and usually not far from a spring or strean; sometimes linel with grasses and twigs.

EGgs- $i$ to 9 (rarely ul) to 17 ), in shape rather clongate ovate, measuring in inches, 2.04 to 2.35 by 1.41 to 1.60 (in millimeters, 52.7 to 59.7 by 35.8 to 40.6 ), and averaging $2.15 \mathrm{by} 1.50$ (54.6 by 38.1) ; ground-color gravish or greenish drab, thickly spotted and dotterl with reddish brown (Coues, 187f, 1) 406 ; and anthors).

GeNeral distribution-Resident on the sage-brush plains from interior sonthern British Columbia, southern Saskatchewan, and northwestern North Dakota soutl to midrle eastern California, northwestem New Mexieo, and northwestern Nebraska (1. O. U. (7leck-list, 1910, p. 145).

DIstribution IN CaliforxiA-Fairly common resident in the sage-brush comtry of eastern California from vicinity of Lower Klamath Lake, northeastern Siskiyou County (II. C. Bryant, MS), and northern Modoe County (Newbery, 18.57, 1. 95), south along the east base of the Sierra Nevada through Lassen connty (C. H. Townsend, 1857, p. 200), Sierra and Mlpine counties (Belding, 1890, P. 19), to head of Owens River and White Momtaius, in Mono Comty (A. K. Fisher, 1s93a, D. 31), and northern Inyo County (E. H. Ober, MS).

Next to the wild turkey, the Sage-hen, or Sage Grouse as it is often ealled, is the largest of the upland game birds found in the United States. Full-grown males are said frequently to attain a weight of eight pounds and females a weight of five pounds. The species is not widely distributed in North America, it being a resident only of the arid, sage-covered plains of the west, more particularly of the Great Basin. The range of this bird reaches its eastern limit in western North Dakota and Nebraska, and northwestern New Mexico, its western limit in eastern Washington and middle eastern California, and its northern limit in sonthern British Columbia east of the Cascades, and southern Saskatchewan. Within this range the species is to be found only in and near localities where the prevalent vegetation is the true sage-brush (Artemisia tridentata). Thus the bird's name, Sage-hen, has been most aptly chosen.

Within the State of California the Sage-hen also has a distribution nearly coextensive with the arid sage-covered plateau lying east of the Sierra Nevada. The species is, according to reports of local observers, probably most abundant in northeastern Siskiyou County 
and in Modoe County, where in certain areas the birds appear to thrive exceptionally well. From this region southward, Sage-hens are to be found, though less eommonly, in similar situations all along the easter'n base of the Sier'a Nevada, through Lassen, Sierra, and Alpine (at least formerly) comties, to the White Mountains and the head of Owens River valley in Mono and Inyo counties. The single record from the Mohave River, San Bernardino County (Cooper, 1868 , p. 13 , and 1869 , p. 188), if authentic, indicates ocenrence formerly or casually, far out of the present range of the speeies. In the southermmost part of its range the Sage-hen is found at from 6,000 to 11,500 feet altitude, but in more northerly regions from 4,000 to 8,000 feet. A slight vertical migration takes place, but otherwise the birds remain in the same general loeality throughont the year.

The most striking feature of this grouse is its large size. Because of this, the noise of its wings as it rises heavily from the ground is startling even to persons already acquainted with the bird. With the exeeption of the Sharp-tailed Gronse no other member of the family is likely to be found in the same habitat. Confusion as to its identity is in any case practically impossible. Besides numerous other characters the conspicuously black belly will furnish a final clue in making identification certain. The white patehes over the air saes on each sicle of the chest in the male are also often conspicuous (nough to show at a long distance. The males, besides being much larger and heavier than the females, can sometimes be distinguished by the yellow color of the bare skin showing between the parted feathers over the inflated air sacs.

The mating season is said to begin in March and April before the snow is off the ground. Like other grouse the Sage-hen is noted for its peculiar mating anties. The males congregate together in open places, or "courts," and make a great display, obviously to attract the females. The following accomnts of sueh performances by several anthors, although differing in detail, furnish vivid pictures of this extraordinary courting behavior for which the Sage-hen has become famous.

During a long residence in Wyoming and Colorado, Mr. L. E. Burnett became familiar with the habits of the Sage-hen, and he has described the courting of this species as follows:

I have heard them drum as early as December. This performance is most often observed where hundreds of males and females have congregated together, a custom which they have in the fall of the year. By February the males are all drumming, but this is not contimed during bad weather which eloses the session until fair weather retums. By the latter part of the month the males are in full dress. Their protracted meetings last until the first days of May. . . By the 
bahny June days, they laye lost most of their frils, and the breast is dirty and worn from rolling in the dust and stretehing ou the ground in birding. They are credited with soiling the breast while drumming, but I have never observed this to be one of the causes during my entire fifteen years with them. When drumming they stand very erect, holding the wings away from the sides and nearly perpendieularly, while the large loose skin of the neck is worked up, and the head drawn in and out until the white feathers are brought to the chin. At the same time the galls [air-sacs] are filled with air until the birds look as if they were earrying snowballs on their shoulders. Then the skin which lies between the galls is drawn in with a sucking movement, thus bringing the galls together or nearly so. With this action the air is expelled from the throat, producing the noise, which is hard to mimic and which resembles that of an old pump just within hearing distance. The first sound is that of a low " punk," the next "de," followed by the highest, "punk punk," and is made without movement of the wings. After the bird has aceomplished this feat he walks away a few paces either in a straight line or a eircle, with wings down, langing loosely, but not grating on the ground. At times they do drag the wings as they strut along with tail spread and ereet, though not so perpendieular as that of a turkey. Again they will dance about with all the pomp of a male pigeon.

Their courts are generally in very conspicuous places, being either on some barren flat or moraine where they may be seen from a distance. The males, yearlings, and old are social and congregate at these places in bunches comprising from twenty-five to a hundred or more. These birds do not mate, so far as I have becn able to learn, but the females come to these courts from all quarters at about sundom or early in the morning. . . A At the drumming period the males are very jealous and many fights, some of which are quite serious, take place. The fight consists in one bird scizing another by the head, neek, or jacket and pulling and beating with the wings. Its duration is very brief, one or the other giving in (Burnett, 1905, 1. 103).

Cameron (1907, p. 258) speaking of the Sage-hen in Montana, thus describes the conrtship:

During the first half of April the males repair to a regular " playground," but it is a difficult matter to observe their love anties on aceount of the encompassing sage.... They never fought nor threatened each other but strutted or paraded before some leus concealed in the sage bushes, and were entirely oceupied with a most grotesque rivalry. By ruffling up all their feathers, spreading their tails, and dragging their wings along the ground they looked much larger than they really were, while they produced a rattling sound with their quils after the manner of turkey-eocks and peafowl. At the same time they continuously uttered a kind of whistling ehallenge, and distending their necks by means of their air sacs ereeted an enormous white ruff. As the playground was small the eight or nine cocks upon it were in imminent danger of a collision, but for the ten mimutes that we watched them, this did not take place, nor were there any moments of ecstatic oblivion for which some game birds are famous. As will be seen from the above their courtship is rather a display than a "play," thus differing from the performance of the Sharp-tailed Grouse. . . .

Aeeording to Bond (1900, p. 326) the strutting does not involve dragging the wings on the ground. Instead, the air-saes of the neek are inflated until the whole neck and breast has a balloon-like appear- 
ance. Then stooping forward the whole weight of the body is thrown upon the distended portion and the bird slicles along on the bare ground or short grass for some distance, the performance being concluded by the expulsion of the air from the saes with a variety of chuckling, cackling or rumbling sounds. "T'his performance is eontimued probably daily, during the pairing and nesting season, and of course the feather's are worn away by the constant frietion."

Coues $(1874$, p. 406) gives credence to the following aecount:

Small eminences on the banks of streams are the places usually selected for celebrating the weddings, the time generally about sumise. The wings of the male are lowered, buzzing on the gromnd; the rail, spread like a fan, somewhat erect; the bare, yellow oesoplnagus [air-saes] inflated to a prodigious size-fully lialf as large as his body, and, from its soft, membranous substance, being well contrasted with the seale-like feathers below it on the breast, and the flexible, silky feathers on the neck, which on these oecasions stand erect. In this grotesque form le displays, in the presenee of his intended mate, a variety of attitudes. His love-song is a confused, prating, but not offensively disagreeable, tonesomething that we can imitate, but have difficulty in expressing-hurr-hurr-hurr$r-r-r^{*}-h 00$, ending in a deep, hollow tone, not unlike the sound produced by blowing into a large reed.

In Harney County, Oregon, Bendire (1892, p. 109) found Sagehens beginning to nest about the middle of April. One set of nine slightly incubated eggs was taken on April 7, 1877. Fresh eggs were found as late as June 2. But one brood is raised in a season. The nest, as currently deseribed, is always placed on the ground in a slight depression and under the protection of some bush. The location usually selected in California is near some spring or small stream. The depression used, sometimes, at least, scratched out by the bird, is only slightly lined with leaves and twigs, such as might accumulate naturally; not infrequently the eggs rest on the ground itself. Seven to nine eggs are laid, occasionally ten or more, even up to seventeen (Bendire, 1892, p. 111). In color they are light greenish drab or pale olive buff, thickly marked with small roundish spots and dots of reddish brown. In shape they resemble a small egg of the domestic hen. Cones (1874, p. 406) states that the eggs are narrower and more pointed than those of other American grouse. The arerage size of 109 specimens in the United States National Museum is 2.16 by 1.48 inches. The largest egg of the series measures 2.34 by 1.55 , the the smallest 2.04 by 1.41 inches (Bendire, loe. eit.). Other anthor's give the naximum as 2.35 by 1.60 . Bendire (1892, p. 110) states that incubation lasts about twenty-two days and that the males ke(e) to themselves and take 110 part in this work.

The young are able to take care of themselves immediately after hatching, and within a short time are able to fly. Like other members of the family they are adepts at hiding. At night a cover roosts in 
a circle on the ground after the manner of the Bobwhite Quail (Judd, 1905, p. 24). A female when surprised with her brood makes a great demonstration, attempting thereby to distract attention. The chicks when fecling together are said to call constantly to one another with low peeping eries which are andible only for a short distanee.

After the young birds have learned to fly, they descend from the uplands down along the larger eañons, often invading the meadow lands, where small, tender weeds are added to their diet. At sueh places the young birds may gather into large flocks. When approached they erane their neeks and make a weak attempt at eackling. When elosely pressed they run rather than fly. By the last of Angust or early September the roung birds are joined by the old male birds, which eome oft the higher slopes and ridges where they have stayed during the summer, and large floeks become the rule. The rigor of winter eauses a searcity of food and by spring most of the birds are poor in flesh as well as shabby in plumage. The young attain the size of the adults by November (E. II. Ober, MIS, writing from Mouro and Inyo eomnties).

The sage-hen finds flight laborious, and resorts to it only when in great peril. Its vigorous wing-beats on rising from the ground canse a lond whir which has a startling effeet upon the intruder. When once the bird is under way its flight is very swift and is charaetrized by alternate rapid beating of the wings and sailing on set, down-enred wings. If it has been badly frightened it will fly a considerable distance; otherwise it will aliglit again within a few hundred feet.

The call-note most frequently heard is usually deseribed as a short guttural eackle, given when the birds rise from the ground. The sound is like the syllables $k \breve{u} k$, $k \breve{u} k$, kiuk, slowly repeated (Grinnell, MS), or tuk-a-tuk repeated rapidly (Huntington, 1897, p. 17). The "drumming" of the male, which has already been described, is to be heard only during the breeding season.

Newberry (1857, pp. 95-96), the first of the early explorers to record the Sage-hen definitely in this state, gives the following aceount of its habits:

This bird . . belongs to the fauna of the interior basin. . . We first met with it high up on Pit river, at the point where we left it and crossed over to the lakes. . . Following up the little stream toward the spring on the hill-side, a drs, treeless surface with patches of "sage bushes," . . . I was suddenly startled by a great flutter and rush, and a dark bird, that apyeared to me as large as a turkey, rose from the ground near me, and, uttering a hoarse hék, hē off with an irregular, but remarkably well sustained flight. . . But stop he did not. so long as I could see him, now flapping, now sailing, he kept on his comrse till he disappeared behind a hill a mile away.... 
A few days later, on the shores of Wright and Rhett lakes, we found them very abundant, and killed all we eared to. A very fine male which I killed there was passed by nearly the whole party within thirty feet in open ground. I noticed him as soon, perhaps, as he saw us, and waited to watch his movements. As the train approached he sank down on the gromnd, depressing his head, and lying as motionless as a stick or root, which he greatly resembled. After the party had passed, I moved towad him, when he depressed his head till it rested on the gromnd, and evidently made himself as small as possible. The did not move till I had approached to within fifteen feet of him, when he arose and $\mathrm{I}$ shot him. He was in fine plumage, and weighed over five pounds.

.. Its flesh is dark and, particnlarly in old binds, highly flavored with wormwood, which to most persons is no proof of excellence. The young bird, if parhoiled and stewed, is very good; but, as a whole, this is inferior for the table to any other species of American grouse.

During the winter season in the Mono country, according to E. H. Ober (MIS), the Sage-hens find shelter in bad weather by scratching down through the suow to the ground at the bases of the bushes. Sustenance is seenred from the tops of the bushes protruding through the snow and also from the stray leaves and buds which the wind has blown over the surface of the snow. As late as 1896, literally thousands made their homes along the sonthwestern borders of Long Valley some few miles north of the northern boundary of Inyo County. Now there are but a few hundreds in the most farorable tracts.

As is evidenced by the accumulation of droppings to he found in certain favorite localities, Sage-hens roost together on the ground. They are said to return to the same roosting ground night after night, even after foraging a considerable distance for food during the day (Bendire, 1892, p. 110; and authors).

The stomach of a Sage-hen, unlike that of most other upland game birds, is not a museular organ, like a true gizzard, but is a thin-walled reeeptacle. This indicates that the bird is largely herbirorous, feeding upon leaves, buds, and berries, rather than regularly upon grain or hard seeds. As the bird browses rather than seratehes for a living a grinding apparatus would he of small use. Its principal diet throughont the year" "onsists of the leaves of the sage-brush together with leaves and buds of such other shrubs as the wild eherry and deer-brush. together with a small amount of grass and sceds. During the spring and summer, grasshoppers and other inseets are added to the diet. In a large number of speeimens dissected nothing was found but grasshoppers and leaves of the sage-hrush (Baird. Brewer and Ridgway, 1874, III, p. 433).

Stomach examination by the United States Biological Survey of specimens from Itlaho and Wyoming, slows that the Sage-hen, besides eating sage-bunsh leaves, feeds upon the seeds, leaves and flowers of 
lihus, the leaves of aster's and yarrow, and the flowers and buds of Phlor. as well as upon ground beetles, ladybird beetles, fly larvae. moths. ants and grasshoppers. Bendire states that Sage-hens will go a long distance to get a morning feed of wheat, and that erickets and grasshoppers are taken when available. Young birds are more insectivorous than adults. 'The stomach of one young bind ras found to contain over 300 ants (Judı, 1905, pp. 24-25). Birds killed by M. French Gilman at Peliean Lake, Modoe Comnty, in December, 1915. were found to have eaten many leaves and a few young berries of the juniper in addition to leaves of the sage-brush.

This seems to be the only one of our binds that will eat such strongly flavored leaves as those of the sage-brush. Because of this peenliar diet its flesh becomes tainterl, and is usually too strong to be eaten with relish. But at eertain times of the year it makes excellent food. In Modoc County the birds are said to feed in alfalfa fields and therehy cause some damage during the months of July and Angust. In winter, browse is ohtained from the shrubs and bushes that protrude from the snow: At that season the flesh beeomes strongest. Althongh the flesh is dark eolored, and in winter and early spring is often almost bitter, the roung birels in the fall are well Harored and are a delicious acquisition to the table.

The size of this grouse makes it a particularly desirable game bird. In fact the bird is so attractive that neither its comparative inacessibility nor the ease with which it is bagged has prevented its being much sought after by hunters. In Mono County the birds have been greatly redueed in numbers beeause of their acessibility. When Sage-hens are flushed, the hunter marks the places where they alight and usually has no trouble in walking up to within range of the eronching birds. When flusherl again the birds often make a turn just after leaving the ground and eirele back toward their original loeation. thus offering a large and easy target. The erack of the gum seldom starts them from cover, although their wariness varies with circumstances. Sometimes Sage-hens seem to become confused and it is said that in early days vaqueros delighted to ride among the members of a flock and strike them down with a whip or lasso. We have been told that in Modoe County. especially after a rain, when their plumage was wet, Sage-hens have been killed with sticks or knocked over with stones, so diffieult was it for them to take quickly to flight. But at other times it has proven practically impossible to get within range of them.

In most parts of its California range the Sage-hen has been so reduced in numbers that something must be done to afford it better protection. if it is to maintain its place as a gane bird. The automobile has enabled the gumner to enter the heart of the Sage-lien 
country, and little has been done to counteract this added factor in the destruction of the speeies. As a result there is some danger that the Sage-hen, like the Columbian Sharp-tailed Grouse, may soon be numbered among the Californian birds whieh have been nearly or quite exterminated through the agency of man. Even the short season and small bag limit aecorded the bird within the last few vears have not bern sufficient to enable it to hold its own. There is plentiful testimony that its numbers are being redueed each rear. A elose season for a term of years is one remedy that might be applied to good advantage. Although sueh a plan might canse temporary hardship to the lnunter who eonsiders the Sage-hen his favorite game bird, he should be willing to make the sacrifice for the sake of perpetuating the speeies. A close season to allow recuperation, followed by more molerate anmual shooting, should be agreed to by every hunter who values this, the largest and one of the finest of the npland game birds of our state.

\section{Ring-necked Pheasant}

\section{Phasianus torqualus Gmelin}

Other NAMEs-C'hina Pheasant; Denny Pheasant.

DEscription-Adult male: Top and back of head, dull greenish gray; area above lase of bill, iridescent black; stripe from this black patch along side of lead over and behind eve, white; ear region brownish black; above this, a tuft of square-ended, irideseent black feathers; broad area on side of head surrounding eye, extending forward to base of bill, and including most of cheek, almost naked, sparingly flecked with small iridescent black feathers; rest of head and neck, iridescent, greenish blue on fore-neek and sides of neck, purplish below and behind ear, and blnish green on hind neck; broad collar completely encireling base of neck, abruptly white; feathers of npper back buffy yellow, with V-shaped iridescent black markings; middle of back and scapulars, rich chestnut red, each feather with a black line concentric with margin and enclosing a white area which is mottled with drab and black; lower back and rump light grayish green, the marginal featlers washed with blue and with long tips of rusty red, and the middle feathers with ereseentic black, buff and green markings; some of upper tail eoverts reddish brown and drab mixed in fine pattern; tail very loug and pointed, the feathers centrally drab yellow with conspicuous narow bars of black, their murgins luasally pinkish hrow barred with deep chestunt red; onter surface of closed wing chiefly bluish gray; flight featlers light brown mottled with dull white; longer coverts and tertials broadly edged with rich chestunt red; imner surface of wing grayish brown mottled with white; whole breast fiery bronze with a comspicuons metallic sheen, each feather with a W-shaped margin of purplish black, the whole giving a sealed effect; sides and flanks deep buffy yellow with large sharply defined spots of steely blue black; middle of belly steely blue black; area about veut dull yellowish brown; muder tail coverts rich chestnut mottled with hlack: a splu on tarsus: legs and feet (dried) dull dark brown. Adult female: Top and back of head drab brown with extensive brownish black feather centers: area alont ey white. flecked with dusky; ear region yellowish brown; chin and throat uniform yellowish white: 
whole neck rose buff, with narrow feather tippings of black; feathers of upper back with concentric marks of rusty red, black, and pinkish white; feathers of lower back, rump and outer surface of eloserl wing, black-centered, dark yellowish brown near ends, and margined with drab or white; tail long and pointed, barred irregularly with black and pinkish brown ol dull brown; flight feathers broally and irregularly barred with light or dark brewn and dull white; lining of wing dull white and pale brown; under surface of body pale yellowish brown, lightest on middle of belly, the whole finely vermienlated with dusky, heaviest on breast; sides and flanks eoarsely marked with brownish blaek. Male: Total length 33.00 inches ( $838 \mathrm{~mm}$.) ; folled wing 9.00 (228); bill along culmen 1.25 (31.7); tarsus 2.75 (69.7). Female: Total length 20.50 (520); folkled wing 7.56 (192); bill along culmen 1.00 (25.4); tarsus 2.44 (61.9) (one specimen of each). Juvenile plumage: Upper surface brownish black with yellowish brown shaft streaks and feather marginings; feathers on sides of hear and neek, and fore-neck, rellowish white, margined with black; chin and fore-throat white; tail barred with brownish black and reddish brown; wing as in arlult female; breast yellowish brown, tinged with rusty; feathers of sides and flanks marked concentrically with dull white, brownish black and buffy brown; middle of belly yellowish white; thighs and under tail coverts, pals luff. Natal plumage: Upper surface dark yellowish brown with three longitulinal stripes along top of head and baek, the middle one brownish black, the outer ones black; a conspienous blark streak on ear region; bar in front of wing and two others on wing, black; under surface of body sulphury white, bufiy on chest, sirles and flanks; suot on thigh black.

MARKS FOR FIELD IDENTIFICATION-Size of borly between that of a grouse and quail, but with tail feathers greatly elongated. Male with black appearing head, white collar, bronzy breast, black-spotted yellow sides, and with many narrow sharp bars of hack on tail. Female predominantly brown-eolored, slightly sealed on back, but uniformly pale brown on breast (pl. 16).

Vorce-Of male: a sharp, but weak, metallie "crow."

NEST-On ground in sheltered situation in a grain or alfalfa field or wred patell; constructed of leares or grass.

EgGs-7 to 15, ovate in shape, averaging in inches, 1.61 by 1.31 (in millimeters, 40.8 by 33.2) ; color plain buff or greenish buff (Davie, 1900, p. 180).

General distribution-Native in lower Amur, Manchuria, Korea, and eastern Mongolia, south through eastern China to Canton. Introduced and well established in British Columbia, Washington, Oregon, and, locally, in California (modified from Dresser, 1903, p. 666).

Distribution in California-Iutroduced and now established in various loealities in the north coast counties from Mendocino to the Oregon line; also: in the Santa Clara Valley, near San Jose; near Porterville, Tulare County; Bakersfield, Kern County; northern Owens Valley, Inyo County; and possibly sereral other localities (see p. 33).

Since the Ring-necked Pheasant* has been introduced and become established in a number of places in California, we deem it desirable

* The true identity of the "Ring-necked" Pheasants introduced into California is not yet definitelv settled. The name Phasianus torquatus, as the one most commonly used, has been adopted by us tentatively, until such time as California-taken specimens can be compared with Asiatic wild birds. There exist in the Old World several near-related species with white neck rings, any one of which may have been imported. It is also not unlikely that two or more of these races have been bred together in captivity, and mongrel stock, of various origins, imported, at least in part, in the attempts to colonize the state. Our stock may thus not be of any one pure breed. 
to give a short aceount of the life-history and habits of the species. In the ehapter on "History of Attempts to Introdnce Non-native Game Birds into California" there is a fairly comprehensive history of the varions attempts to introduce the speeies into this state (p. 30); and in the ehapter on "The Propagation of Game Birds" directions are given for rearing the species in eaptivity (p. 51). The present aceount will deal with its habits in the wild, ehiefly as reported from California and Oregon.

This pheasant thrives best in and about tracts of rank vegetation in the "fog belt" of the North Coast counties, rather than in the drier areas inluabited by the Talley Quail. In these moist regions the Ringneek finds conditions as to temperature, humidity and rainfall whieh elosely approximate those of its original home in eastern Asia. An examination of rainfall data shows that the IImmboldt Bay distriet of. California has an average annual rainfall of 45.8 inches; Portland, Oregon, where the pheasant thrives as an introdneed speeies, has 45.6 inches: while Shanglıai and Hongkong, China, two localities in its native home, have 43.6 and 84.3 inches, respeetively. So, also, the relative humidity at Eureka arerages $86 \%$, at Portland $75 \%$, and at Shanghai and Hongkong $80 \%$ and $77 \%$. In sueh other parts of California as are inhabited by the pheasant, as the Santa Clara Valley, the birds seek shelter in moist thiekets or swampy places, probably finding there atmospherie conditions whieh parallel those in the north coast district and in eastern China.

No native birel of Califormia is to be confused with the Ring-neeked Pheasant. Its long tail and fowl-like habits easily distinguish it from any of our upland game speeies with which it may be found. The brilliant, variegated plumage of the male, witl blue black head, white neek collar, and fiery-colored breast, is quite distinctive, as is also the long tail of the female together with her uniformly pale brown toned breast. The male, unlike any of our native game birds wears a spur on his leg.

The usual hamnt of the Ring-necked Pheasant is thick eover, but with open spaces nearby where it ean forage. During the greater portion of the year the birds go in flocks, males and females separately. At night many of the birds roost on the ground, in a mamer unlike that of most of our native game birds, and thus they are more than ordinarily subject to ground-dwelling predatory animals or "vermin." In Oregon, in certain places at least, pheasants are reported to roost in trees and on fenees, sometimes more than a hundred together. through the night.

The hen pheasant makes her nest of leaves or try grass in a sheltered situation in a cultivated field or on grassland. Sometimes it is protected by a tussoek of grass, or a shrub or tree. The eggs 


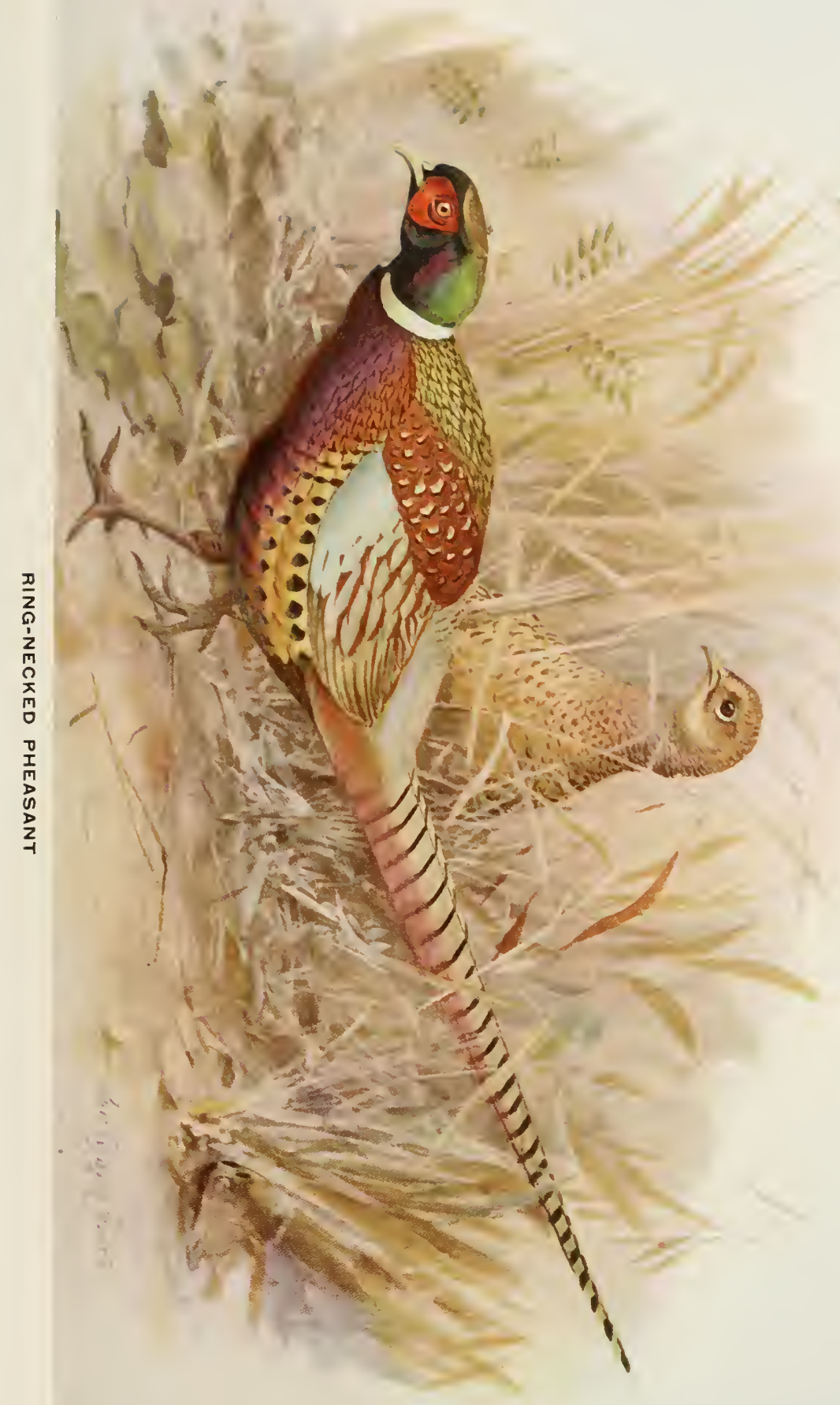

$\frac{c}{2}$
$\vdots$
0
$\frac{8}{7}$
$\frac{7}{7}$
0
0
0
0

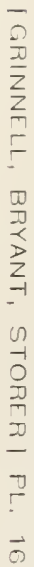



number seren to fifteen in a set, are short ovate in shape and arerage, in inches (different sets) 1.50 by 1.30 and 1.61 by 1.31 . Their color is plain butf or greenish butf without markings of any sort. In Oregon it is said that three broods are reared in a season. Where nests are systematically risited and the eggs regularly removed, hen pheasants will lay from 50 to 80 eggs in a season, and in one recorded instance a bind was known to have laid 108 eggs (Field, Graham and Adams. $1914, \mathrm{p} .3)$. The period of incubation is twenty-two days. In eaptivity when the members of a brood are four to eight weeks old they ean eare for themselves. In autumn, the birds band together in floeks, and remain together through the winter, until the next nesting season.

In this country the Ring-necked Pheasant is an ommivorous feeder, taking almost anything which it can find in the way of food matelials, but it secms to prefer insects, when these are available, to grain and seeds. In certain distriets of Oregon where the species is notably numerous the birds have done damage to truck gardens and eorn patches. On the other hand, three captive pheasants, five weeks old, have been seen to eat between 250 and 300 house flies within one-half hour. In Massachusetts where Ring-necked Pheasants were introdneed from Oregon in about 1894, the birds have been found to eat practically all of the eommon insect pests of the garden. Stomaehs of pheasants shot while supposedly damaging gardens or farm erops showed 2.2 per cent grain (all waste exeept in one instance), 21 per cent tomatoes, 15 per cent inseets, and 23 per eent weed seeds. The halanee was of $n 0$ economic importanee or was not determined (Field, Graham and Adams, 1914, pp. 8, 9).

Here in California this pheasant feeds chiefly in grain fields and grass lands although it also forages in willow thickets and, in some interior countirs, has been formd in thiek manzanita and serub oak brush. In Inyo County pheasants seareh the grain fields for "taboosi" (Brodiaca seed?). They are said also to do some damage to grain fields, vineyards and gardens.

In any event the pheasant is not yet to be reekoned as established in more than a few loealities, its spread will be slow if it eontinues at all, and many years will elapse before the species will be of much importance, from either the hunter's or the farmer's standpoint.

\section{Band-tailed Pigeon}

\section{Columba fasciata fasciata Say}

Other NAmes-Blue Pigeon; Wilä Pigeon; Columba monitis; Chloroenus fasciata fasciata.

DESCRIPTION-Adults, both sexes: Head pinkish brown or vinaceons (exact tint varying greatly among different individuals), darkest and more purplish on top 
and back of head, more ashy on chin and ehceks; base of bill straw yellow, end black; naked eyelids, coril red; narrow collar around hind neck, white, averaging more conspicnous in males; broad area on sides and back of neck (below white collar), irileseent bronzy green; back dark olive brown; rump and bases of tail feathers, dark bluish gray; ill-defined band across mildle of tail, dull black; terminal portions of tail feathers, drab, lightest on outer ones; onter surface of closed wing, chiefly light gray, the coverts narrowly margined with white; flight feathers brownish black; lining of wing and axillars, gray; under surface of flight feathers dull brown; under surface of body pinkish brown or vinaceous, drepest on breast and sides, paling to almost white on belly: under tail corerts white; under surface of terminal portion of tail whitish, distinetly lighter than upper surface of same; feet straw yellow. In some females the tone of eoloration verges towards grayish rather than pinkish brown. Males: Total length 14.1215.81 inches (359-402 mm.) (ten specimens from California and Arizona) ; folded wing 8.20-8.67 (208-220); bill along culmen 0.65-0.71 (16.5-18.0) ; tarsus 1.0J1.09 (26.6-27.6) (eight specimens from California). Females: Total length $13.75-$ 15.75 (349-400) (ten specimens from California and Arizona); folded wing 8.00-8.86 (203-22.5) ; bill along culmen 0.67-0.75 (17.0-19.0); tarsus $0.95-1.11$ (24.0-28.2) (ten specimens from California). Juvenile plumagc: Similar to that of adult, but vinaceous tinge wholly lacking; neek withont white collar or iridescent bronzing; under surface dark brownish, with feather tiplings of lighter color, giving a faintly scaled effect.

MARKS FOR FIELD IDENTIFICATION-Largest of our wild pigeons (about the bulk of a domestic pigeon); general bluish coloration; distinct dark band across middle of square-ended tail (fig. 88); wings without white patches.

Torce-Mnch like that of the domestic pigeon; a deep coó-coo, tuck-oó, or whó-hoc-hoo: occasionally a more spirited hoop-ah-uhoó, or whoó-ugh (Grinnell, 1905, p. 382; Bailey, 1902, p. 139).

NEST-A crude platform of twigs, of very loose constrnction; most often situated on a moderately large horizontal brancl of an oak (less often in a pine), and at heights ranging from eight to thirty feet above ground (authors).

EgGs-Tsualy 1, rarely 2, elongately ovate, white in color, and measuring in inches, 1.08 to 1.15 by 1.5. ) to 1.69 (in millimeters, 27.4 to 29.3 by 39.5 to 43.0 ), and averaging 1.59 by 1.11 ( 10.4 by 28.2 ) (five eggs, four sets, from California: Mns. Vert. Zool., and Sliarp, 1903, p. 16).

General distribution-Western parts of United States and Mexico. Summers from southwestern British Columbia, western Washington, western Oregon, northern Utah, and north-central Colorado, sonth through the southwestern United States and Mexico to Nicaragna, and east to western Texas; winters from northern middle California sonthward (modified from A. O. U. Check-list, 1910, p. 147).

Distribution IN CALifornia-Common but irregular winter visitant below the level of leavy snow, and west of the Sierran divide; oceurs in summer in small numbers, and breeds, in the belts of black oak and golden oak (Transition life zome) in hoth the Sierras ancl Coast Ranges, soutli to Laguna Mountains, southern San Diego County.

The Band-tailed Pigeon is the largest of the fonr members of the pigeon family inhabiting California. Its wide distribution in winter throughout the foothill belt, together with its size and excellently flavoled flesh have eombined to make it an object of pursuit by sportsmen for over half a century. The inevitable result has been that its 
numbers have been greatly diminished. Despite this reduction, especially evident during recent yeals, this pigeon had never received one iota of legal protection from the people of California until the year 1915. But, happily, with the passage of the Federal Migratory Bird Law in 1913, the national government prescribed a five-year elosed season for the species, and the ontlook now is favorable for its persistence.

The range of the Band-tailed Pigeon extends from the Rocky Mountains to the Pacific Coast, and from British Columbia to Niearagua. It is, in a way, complementary to that of the now entirely extinct Passenger Pigeon. But while the latter ocenred over most

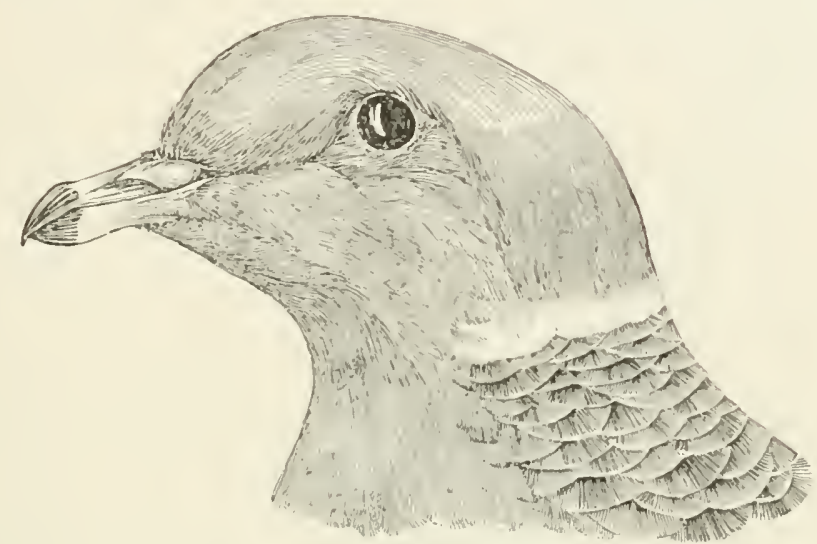

Fig. 86. Head of Band-tailed Pigeon. Natural size (no. 15619).

of the eastern half of the North American continent, the western bird is not found uniformly over all parts of its general range, being most common in the mountains of middle altitude, and absent from the plains and deserts.

In a general way it may be said that in the north and at high altitudes the Band-tailed Pigeon is only a summer visitant. To be more explicit, the speeies summers in the belts of black oak and golden oak (Transition life zone), whether these be in the northern part of its range or at the south. In the latter case the higher altitudes of the mountain ranges resorted to afford temperature conditions similar to those found at lower levels to the northward. In winter the pigeon migrates to more southerly latitudes, or to lower altitudes, whichever may be necessary in order to reach a suitable winter climate. From the data at hand it seems probable that the pigeons of the Rocky Mountain region winter on the Mexiean plateau entirely south of the United States boundary, whence there are many instances of 
ocenrrence during that season. Those pigeons wintering in the foothills and valleys of California come from the adjacent mountains and from the coast district to the north, in Oregon, Washington and British Colmubia.

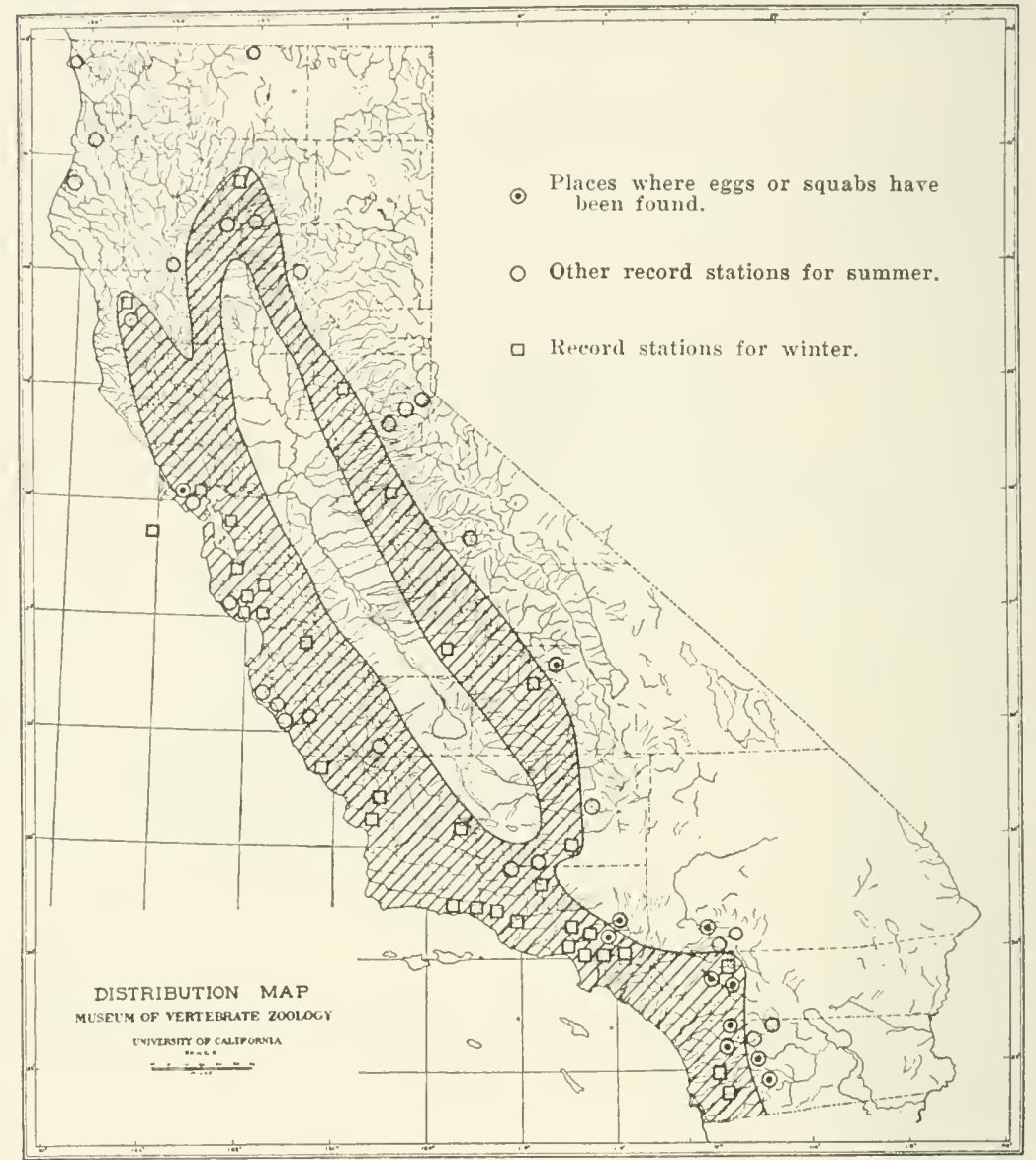

Fig. 87. Map showing distribution of the Band-tailer Pigeon in California. The sladerl area is that in which all the pigeon population of the Pacific states is believed to concentrate for the winter season.

The following facts bear upon the question of the source of at least part of the pigeons wintering in California. The speeies occurs at Blaine, Washington (near the British Columbia bomdary), from May 5 to September 15 (Dawson, 1909, p. 5.55); in southern Washington west of the Cascades from May 15 to the end of September (Cones, 1874. p. 386); and at the month of the Columbia River from May to October (Brindire, 1892, p. 122). In Washington County, 
Oregon, it is common in summer (Bendire, 1892, p. 123) : at 1)ayton, Yamhill County, Oregon, it arrives abont April 20 and leares by the last of Norember (Woolcock, 1902, p. 2S) ; and at Corvallis, Benton C'ounty, Oregon, it occurs from the first of April until the last of S'eptember' (Woodcoek, 1902, pp. 28, 29).

From the above data it will be seen that north of the northern boundary of California the Band-tailed Pigeon is wholly migratory. It seems inevitable that this northern-bred contingent should move south into California for the winter season, and there is, therefore, little reason to doubt the inference that the birds which eoneentrate in winter in west-central and southern California, represent the entire pigeon population of the Pacifie coast region. If this be true it is of course apparent that as far as the whole Pacific coast region is concerned, California alone is, in winter, responsible for the existence of the species.

Band-tailed Pigeons oceur in California throughont the year, but not continuously in the same loealities. In general, the species is found in the mountainous distriets in the summer season and in the foothills and valleys during the winter months. In event of continued farorable weather, the birds will often eontinue in their summer haunts until Oetober or even November, long after other migrant species have departed. probably beeause the supply of acorns and other favored foods is not exhausted until that time. When finally forced to lower altitudes they repair to the foothills where aeorns and berries are still to be found. Only rarely, as when driven by heary storms in the mountains, or by seareity of food in the foothills, do the birds resort to open valleys. They may then forage on the scattered grain of the stubble fields (Gaylord, 1899, p. T). Their spring time return from the lower comntry is also largely controlled by food supply. For example, in 1895 a large flock remained until mid-June at Oak Knoll, near Pasadena, Los Angeles County, feeding on acorns (Grinnell, 1898, p. 20) ; and in earlier years, about the southern end of San Francisco Bay (Palo Alto and Santa Clara Valley) the birds often remained until well into May (Van Denburgh, 1899, p. 159).

The Band-tailed Pigeon may be easily recognized by its large size (being of about the build and bulk of a domestic pigeon), its general bluish eoloration, and its light gray, square-ended tail, erossed by a distinct dark band near the middle. This band is most readily seen just as the bird alights, for then the tail is widely spread. The Mourning Dove, which at times oceurs in the same places as the Band-tailed Pigeon, is at once distinguishable by its smaller size, brownish upper surface, and long, pointed, white-margined tail. The little brownish Mexican Ground Dove is less than one-tenth the bulk of the pigeon, 
while the White-winged Dove of the lower Colorado Valley is also decidedly smaller and has a conspicuous white wing patch.

'The cooing of the Band-tailed P'igeon reminds one of that of the domestic pigeon and is easily distinguishable from the notes of the Mourning Dove. Gimmell (1905, p. 382) describes the notes heard on Mount Pinos as a deep monotonous coó-coo, coó-coo, coó-coo, or tuck-oó, tuck-oó. Elsewhere the notes are deseribed (Bailey, 1902, p. 139) as sometimes a calm whoó-hoo-hoo, whoo-hoo-hoo, at oth('l times a spiriter hoóp-ah-uhoó, and again a two-syllabled whoó-ugh. made up of a short hard hoot and a long coo, as if the breath were sharply expelled for the first note and drawn in for the second.

These pigeons are to be seen in flocks at all times of the year, but the aggregations become larger in the winter months. When foraging flocks visit the foothills and valleys a hundred or more may sometimes be seen together. In earlier years bands of uprards of a thousand were oceasionally observed. The usual assemblage now consists of from one to three dozen birds. Often, even during the height of the nesting season, flocks of a half dozen or more birds may be scen. Apparently these birds, whose nests may be widely seattered throngh the forest, associate together for feeding.

A benefit which accrues from the flocking habit is the individual safety attained through eommunity watchfuhness. This may be considered as in part counterbalancing the possibility of pot-shooting numbers of the birds at one time becanse of their being massed in a flnck. The gregarions habit brings both benefit and danger to the birds: but with the increased deadliness of firearms, it would seem that the flocking habit brings disproportionately greater danger as time goes on. When foraging on the open ground, pigeons show little trepidation, save when elosely approached. In the foliage of trees or bushes, upon the approach of man or beast, the birds usually remain perfectly quiet and thus often elucle observation altogether. If routed out by a too elose approach, they leave their perches abruptly, with a disconcerting elapping of the wings; and, acquiring great velocity with surprising quickness, they are ahmost instantly far beyond reach of the bobeat's spring or even of the hunter's shot. In flight, the flock formation is relatively open, and distantly separated individuals are often to be seen trailing behind the main boty. In passage down a monntain side, the flight is inconceivably swift, the wings being held close in to the sides, beating only at long intervals, and the body vereing slightly from side to side in its arrow-like course. This heallong flight produces a rushing noise as of escaping steam.

Noar Julian, San Diego Comty, early in July, 1910, Hney (1913, p. 152) made observations upon a flock of wild pigeons foraging in 
manzanita thickets on the mountain side. They would arrive daily a little after sumrise and leave between eight and nine o'elock; in the evening they would return about four and depart again at dusk. In feeding in the bushes they often attempted to alight on elusters of brries whose stems were far too weak to support the lieary birds. Eventually. finding a firmer perch from which the berries eould be reached, a pigeon would gorge himself, accompanying his greedy swallowing of the berries with gulping noises. In Arizona similar actions were indulged in by pigeons which Willard (1916, p. 111) saw feeding in oaks. He says: "The anties of these birds were more like the acrobatic stunts of parrots than of pigeons. They would walk out on the slunder branches till they tipped down, then, hanging by their feet, would secure an aeom, and drop off to alight on a branch lower down. In spite of their large size, pigeons are surprisingly inconspicuous when thus engaged in feeding among the leares."

The Band-tailed Pigeon nests in isolated loealities and never in colonies as did its mofortunate eastern relative, the Passenger Pigeon. To this habit it probably owes, in a large clegree. its ability to withstand the heary hunting to which it has been subjected. One authentic report from Arizona states that about thirty-five pairs nested in a "scattered rookery, probably not averaging a nest to every three or four acress at the most thickly populated part " (Fowler, 1903, p. 69) : but such an occurrence has not been recorded from California. The nosts here are widely scattered and extremely difficult to locate. The greatest number of ocmuned nests reported by any Californian observer for a single day s search is two, and about three per season seems to be the limit of one man's discovery. 'The aceompanying table (no. 18, from Grinnell, 1913, with additions and eorrections) gives all the definite nesting data for California known to the writers.

Nearly all authentic reports from California agree in stating that the Band-tailed Pigeon nests in trees- almost invariably in black or golden oaks-at heights ranging from eight to thirty feet above the ground. As exceptions, Littlejohn (MS) found a nest in San Mateo County in a Douglas spruee; and in Marin County, J. Mailliard (1912, p. 194) found a mest in a California lilae (Ccanothus thyrsiforus) overhanging a steep slope. Some early reports from this state have mentioned ground nests, as have several more reeent, but seareely trustworthy, aecounts from Oregon and Washington; but there is no late evidenee of the ground nesting habit in California. In a general way the nest resembles that of the Mourning Dove, save that it is considerably larger, and sometimes proportionately thicker. It is a erude strueture, a mere pile of oak and other twigs, so loosely arranged that attempts to remove the mass often result in its falling to pieces. The average diameter is six or eight inches, while the thick- 
TAmLe 18-Data Relative to the Nesting of the Band-tailed Pigeon in California

\begin{tabular}{|c|c|c|c|c|c|c|}
\hline L,OCAIITJ" & 1) $\mathrm{AT}$ & Tr: & & & Coxthexts of Nest & A匚THORITY \\
\hline $\begin{array}{ll}\text { Tuguna Mts., "20 miles } \\
\text { north of Campo," San } \\
\text { Diego Co. }\end{array}$ & Mar. & 6 & 1877 & 1 & egg (near hatching) & Stephens $(1913,1,129)$ \\
\hline $\begin{array}{l}\text { Pine Mt., } 3,250 \mathrm{ft} . \\
\text { San Diego Co. }\end{array}$ & May & 3 & 1901 & 2 & eggs (fresh) & Shary $(1.903,13.16)$ \\
\hline $\begin{array}{l}\text { Pine Mt.. } 3,250 \mathrm{ft} . \\
\text { San Diego Co. }\end{array}$ & May & 11. & 1902 & 1 & $\begin{array}{l}\text { egg (incubation well } \\
\text { adranced) }\end{array}$ & Sharp $(1903.1) .16)$ \\
\hline $\begin{array}{l}\text { San Jacinto Mts.. at } 6,500 \\
\mathrm{ft.} \text { Ricerside Co. }\end{array}$ & May & 14 & 1897 & 1 & squah (just hatched) & Gilman (1903. p. 134) \\
\hline $\begin{array}{l}\text { San Jacinto Mts., at } 6,500 \\
\mathrm{ft.,} \mathrm{Riverside} \mathrm{Co.}\end{array}$ & May & 14. & 1897 & 1 & sqquab (half-grown) & Gilman (1903.p. 134) \\
\hline $\begin{array}{l}\text { Mt. Wilson, } 5,500 \mathrm{ft} \text {., } \\
\text { Los Angeles Co. }\end{array}$ & May & 23 & 1897 & 1 & $\begin{array}{l}\text { egg (considerably } \\
\text { incubated) }\end{array}$ & Grimell (1898, 1).20) \\
\hline $\begin{array}{l}\text { Cuyamaca Mits, } 4 \text { miles } \\
\text { south of Julian, San } \\
\text { Diego Co. }\end{array}$ & June & & 1896 & & $\begin{array}{l}\text { dult bird on nest, lut } \\
\text { not flushed }\end{array}$ & $\begin{array}{l}\text { Albert M. Iugersoll } \\
\text { (in letter) }\end{array}$ \\
\hline $\begin{array}{l}\text { Palomar Mts., } \\
\text { San Diego Co. }\end{array}$ & June & 21 & 1910 & 1 & egg & Huey $(1913, p .152)$ \\
\hline $\begin{array}{l}\text { Pine Mt.. } 3,250 \mathrm{ft} . \\
\text { San Diego Co. }\end{array}$ & June & 24 & 1902 & & $\begin{array}{l}\text { egg (incub. far adv: } \\
\text { same nest as May } 11 \text {. } \\
1902 \text { ) }\end{array}$ & Sharp (1903. p. 16) \\
\hline $\begin{array}{l}\text { North Peak, Cuyamaca } \\
\text { Mts., San Diego Co. }\end{array}$ & $\begin{array}{l}\text { Iniv } 1 \\
\text { i91 }\end{array}$ & 10 & bout) & 2 & squabs in one nest & Huey (1913, p. 152) \\
\hline $\begin{array}{l}\text { San Jacinto Mis., at Ful- } \\
\text { ler's Mill, } 5,900 \mathrm{ft} \text {., } \\
\text { Riverside Co. }\end{array}$ & July & 1 & 1908 & 1 & $\begin{array}{l}\text { egg (incubation } \\
\text { slight) }\end{array}$ & $\begin{array}{l}\text { Grimnell and Swartl } \\
\quad(1913,13.233)\end{array}$ \\
\hline $\begin{array}{l}\text { Sear Wroodside. } \\
\text { San Mateo Co. }\end{array}$ & July & 3 , & 1914 & 1 & squab & $\begin{array}{l}\text { (Sent to State Gane } \\
\text { Farm. Hayward) }\end{array}$ \\
\hline $\begin{array}{l}\text { MIt. Wilson, } 5,500 \mathrm{ft} \text {, } \\
\text { Los Angeles Co. }\end{array}$ & JuIy & 5 , & 1894 & 1 & $\begin{array}{l}\text { squab (about one } \\
\text { week old) }\end{array}$ & Grinnell $(1 \times 98, n .20)$ \\
\hline Lagunitas, Marin Co. & July & 30 & 1912 & & $\begin{array}{l}\text { egg (incubation } \\
\text { fat advaneed) }\end{array}$ & $\begin{array}{l}\text { J. Mailliard (1912, } \\
\text { p. 194) }\end{array}$ \\
\hline $\begin{array}{l}\text { Barley Flats, } 5,600 \mathrm{ft} . \text {. } \\
\text { Los Angeles Co. }\end{array}$ & $\begin{array}{l}\text { Tast } \\
\qquad 188\end{array}$ & $\begin{array}{l}\text { of } \\
38\end{array}$ & July, & 1 & young (able to fly) & Antonin Jay (in letter) \\
\hline $\begin{array}{l}\text { Barley Flats, } 5,600 \mathrm{ft} . \\
\text { Jos Angeles Co. }\end{array}$ & $\begin{array}{l}\text { Last } \\
\qquad 188\end{array}$ & $\begin{array}{l}\text { of } \\
38\end{array}$ & Tuly. & 1 & young (able to fly) & Antonin .Iay (in letter) \\
\hline $\begin{array}{l}\text { Big Bear Lake, } \\
\text { San Bernardino Mls. }\end{array}$ & Ang. & 11 & 1913 & 1 & egg (nearly fresh) & Pierce (1913, p. 227) \\
\hline $\begin{array}{l}\text { Near Redwood City, } \\
\text { San Mateo Co. }\end{array}$ & Aug. & 23 & 1914 & 1 & ege (half incubated) & $\begin{array}{l}\text { Chase Littlejolin } \\
\text { (in letter) }\end{array}$ \\
\hline
\end{tabular}

ness in two recorded instances was one and fon inches. respectively (Sharp, 1903, p. 16; Grimell, 1913, p. 31). Sometimes as few as 16 $\mathrm{ol}^{2} 18 \mathrm{twigs}$ are all that go to make up the nest (Huer, 1913, p. 152), and again there may be more than a hundred (nest in Mus. T'ert. Zool.). The twigs lange from a sixteenth to a quarter of an inch in diameter and are of varions lengths. They are laid across one another, with little or 110 weaving, forming a platform with numerous interstitial spaces. A slight lining of pine needles was fonnd in one nest (Nharp, 1903, p. 16). As Gilman (1903, p. 134) well says, it is a marvel how an egg can be kept warm enough to hateh while resting on such an airy platform in the cool air of a high altitude. The nest site, which is almost always on top of a large horizontal limb, seems to be so selected that the incubating bird may flush direetly and rapidly from the nest when danger threatens.

Of the actual construction of the nest, Willard. Writing of an observation in Arizona (1916, pp. 110-111). says: 
Nest building was earried on only in the early morning hours, from sumise tiil about 8 o'elock. Both birds were present, but the female alone seemed to be engaged in the aetual construction of the nest, which she went about in a very lackadaisical manner. The pair would sit together on the few sticks already in place for many minutes; at last the female seemed to remember that she was nest building, and Hew ul the mountain side followed hy the male. Considerable time was spent on every trip after material, so very few sticks were added each day, and it was not until six days had elapsed that the flimsy platform was completed and the egg laid.

The birds are close sitters, often flushing when the observer is very near to the nest. However, when once alarmed, they usually leave precipitately, and make off through the trees so swiftly as to be quickly lost to sight. This abrupt flushing of the bird from the nest often leads to discovery of the latter when its location would be otherwise extremely difficult to determine, so closely do the twigs composing the structure resemble the smaller branches of the tree in which it is situated. Only in a few instances lave birds been known to linger in the vieinity of the nest, or to attempt to lead the intruder away.

Two California reports of a definite nature give two eggs as the nest complement; all others specify but a single egg each (see table). Bendire (1892. p. 127) states that the period of incubation is eighteen to twenty days, and that the young birds remain in the nest about a month after hatching. Allowing a week for the construction of the nest, and for laying, about two months time would be necessary for the rearing of one brood. There is no reliable evidence that the pigeon nests more than once eaeh year in California, save when its first nesting is disturbed. In one recorded instance (Sharp, 1903, p. 16) a nest from which an incubated egg had been collected on May 11, contained, on June 24 of the same year (1902), another egg also well advanced in incubation. It is probable that the later nesting dates given in our table refer to instances where the first egg was destroyed, and not to instances of a second successful nesting.

In rate of inerease, the Band-tailed Pigeon is. aceording to the evidence hercwith submitted, by far the slowest of all our game birds. As a rule but one young is hatched each year. Contrast this with ten among quail, eight among ducks, and four among wading bilds. The impressive fact that our wild pigeon does not exceed, in rate of reproduction, the birthrate of deer, antelope and elk, suggests the demand for treatment in game legislation corresponding with that given these large mammals. It is very probable that under primitive conditions the Band-tailed Pigeon was ten times more immune from the fatalities due to predacious animals, and to canses other than old age, than is the quail! 
As already intimated, the amount of food available to the pigeon appears to be the main eontrolling factor in its distribution, aside from the zonal considerations which apply during the breeding season. This is more partienlarly true in winter, though probably to some extent in summer also. As will be observed from the following data, the food consists chiefly of berries and nuts, and the plants which bear these are of intermittent productiveness. A large erop one year in a rertain region is almost sure to be succeded by a poor one the following year. so that the pigeons would fare scantily if dependent altogether on any one loeality. Their proclivity to eirculate over large areas makes available to them abundant crops recurring at different places. The birds are thus able to find support in great numbers somewhere all the time.

Out of twenty-two records mentioning their food, ten give acoms as the chief article of diet. Probably all the species of oaks are patronized by the pigeons. Those specifieally reeorded are: in westcontral and sonthern California, the live oaks (Quercus agrifolia and Q. wislizenii), in the foothill regions, the golden oak (Quereus chrysolepis), and along the Sierra Nerada and on the San Bernardino and San Jacinto mountains, the black oak (Quercus kelloggii). The acorn season lasts well through the autumn months, and under favorable cireumstances even mutil February.

As with all the other articles of food consumed by these birds, the acorns ale swallowed whole, and in snch numbers that at feerling time the erop becomes enomously distended. Here the food is aeted upon by powerful digestive juices, and both shell and kermel rapidly disintegrate and pass on to the stomach and gizzard. There is no disgorgement of hard parts of the food, as with some birds. Considering the apparently small size of its mouth, the pigeon's ability to swallow entire snch relatively huge objects as the acoms of the golden oak is amazing. One dropped hy a bind in flight neasured about one by one and one-half inches (A. M. Ingersoll, in letter). It is reported (Van Rossem, 1914, p. 146) that pigeons have been found in a dying condition, their erops piereed by acorns which they had swallowed.

In the coast region of eentral Califormia the berries of the madrone (Arbutus mrnzicsii) form an attractive food somree in the fall of the year. In certain instances bands of pigeons have been known to stay around tracts of madrones until praetically every berry had been taken. Sometimes the birds feed so largely on these berries that their flesh hecomes discolored thereby (.Jenkins, 1906, p. 126).

When the acorn erop is small or has hecome exhausted, the birds resort to the apple-like fruits of certain species of manzanita (Aretostrphylos), eating them from the time they are first formed and green. until late fall when they are fully ripe. In early October, 1915. large 
numbers of pigeons thronged the brush-eovered slopes of Pinoche Peak, Mariposa Comnty, and literally stripped the manzanita bushes of their berries. In winter the birds often feed on the abmulant fruits of the toron or Christmas berry (IIcteromeles urbutifolia). Earlier in the fall they resolt to the fruit of the coffee berry (Rhummus, several species), and that of the elelerberry (stumbucus glauca) and the chokecherry (I'runus demissu).

Toward the end of winter, the fruit and nut crops become exhansted and then the pigeons subsist on the flower and leaf buds of the same plants that produced their sustenance earlier. Dean (1904, p. 111) says that in Febmary the pigeons in the Sierran foothills at Three Rivers, Tulare ('ounty, feed on manzanita bnds; and in sonthern C'alifornia they have lepeatedly been observed to feed on oak buds. One observer described a bitter taste to the flesh which was thought to have been developed by a diet of oak buts and acoms (Belding, 1879, p. 437).

In southern (alifornia in waly spring the syeanore balls ares frequently eatem. No less than thirty-five of these ball-like flower clusters have been counted in the erop of a single pigeon (Evernamn. 1886, p. 92). Fruits of the Nuttall dogwood, wikl peas, and varions small seeds are known to have been taken. Finally, in two instances, pine seeds have been found in the birds' crops: in Calaveras Connty in July (Belding, 1890, p. 21) ; and on Mount Pinos, Ventura County: June 29 (Grinnell, 1905, p. 382). It is, of eourse, probable in these cases that either the cones were fully ripe and the seales spreat so that the seeds could be readily extracted, or that the seeds were pieked up from the ground beneath the trees where they had fallen.

The above-mentioned articles of diet include only wild fruits, such as are of indifferent value to man. At times. however, pigeons have been fonnd to resort extensively to grain fields. In many eases the birds have repaired to stubble fields where they gleaned the waste grain, wholly worthless of eourse. Thus, near Three Rivers, Tulare County, in July, 1891, pigeons were observed foraging in barley stubble (A. K. Fisher, 1893a, p. 31). In a few instances, newly sown grain has been resorted to, with the result that more or less damage has been inflicted-the only way in which Band-tailed Pigeons are known to affeet man's interests infavorably. At Palo Alto in January, 1901. good sized flocks were observed on newly sown barley fields, and the crop of a bird taken then was crammed with seed barley (Grimnell, MS). A pigeon taken at Creseent City, Del Norte County, May 15, 1916, was found by us to have in its gullet 509 grains of barley, 23 of oats, 6 of corn, and some fragments of acorns. At Santa Monica, in February and Mareh, 1901, flocks were feeding in grain fields. Their depredations were complained of by a rancher who 
attempted to dispose of the birds by putting out poisoned grain, and with some success! Eight killed in this manner were examined by II. S. Swarth (MS). In Marin County, J. Mailliard (1912, p. 194) states that he knows of pigeons picking up stray kernels in ficlds just planted with forage corn.

In Mareh, 1901, great flocks of the pigeons poured into San Gorgonio Pass and fed in the barley fields. For about two weeks there were hundreds of them, but they all left as snddenly as they had appeared. Their method of feeding was peculiar. Instead of spreading ont they kept together, alternately walking and flying. Those behind would fly a few feet ahead of the advance line, alight, and walk along picking up grain until other rear ones wonld fly ahead and it eame their turn again. In this way the flock advanced, some in the air all the time, and ground was covered quite rapidly. The erop of a specimen secured contained 615 grains of barley by actual count (Gihman, 1903, p. 134).

The relative paucity of records of definite damage to grain leads to the eonclusion that the amount of actual loss inflicted by pigeons is very small. If it regularly reached appreciable proportions, we would hear far more frequent complaints. The irregularity in distribution from year to year serves to mitigate such an adverse bearing of the pigeon. Only at long intervals are the burds likely to visit a given locality in just the appropriate season to have any effect on the grain interests.

In Yosemite Valley attempts to destroy gromel squirrels by distributing poisoned grain broadeast have resulted in the death of many pigeons. This method of squirrel poisoning in any locality where pigeons occur, particularly if other food is scarce, is to be disconraged.

The Band-tailed Pigeon seems to be extraordinarily free from natural enemies. Of these we have good record of only two. Willard (1916, p. 111) says that in Arizona "the Prairie Falcon and C'ooper" Hawk take considerable toll from the flocks. These two terror's of the air will dash into a tree and grab a pigeon off a branch, rarely making an unsuccessful raid. The Prairie Falcon is the chief offender." We know of no similar report from California.

The value of the Band-tailed Pigeon as a true game bird is to be coneeded without argument. Its pursuit is of a different type from that offered by any other game species. An anonymous writer in southern California, who signs himself "Stillhunter" (1907, pp. 200202 ), says that the best place for hunting pigeons there is near a dead tree where the birds are known to alight. For such a situation he advises using a 22 or 25-20 rifle; then single birds may be seeured without frightening away others in the flock. For sneaking up on birds a "duck gun" is recommended. Ten pigeons are considered a good day's bag. If the flesh has become "strong" by reason of the birts' acom diet, soaking in brine flavored with vinegar or lemon 
will remove the disagreeable taste. After such treatment the birds should be broiled, or baked in a pot pie.

The remarkably slow rate of increase in the Pigeon was doubtless great enough to maintain its numbers easily under the conditions obtaining before the appearance of the white man and his firearms. We can but marvel at the ability the bird has shown to maintain itself in fair numbers during the last fifty or sixty years, in spite of unrestricted humting. Judging from recorded accounts, it is only at rare intervals that such a slaughter has taken place as that noted in the sonth-central coast counties of this state in the winter of 1911-12 (Chambers, 1912, p. 108). Indeed, as suggested by the writer cited, such unmitigated destruction could not last long without eausing a complete extinetion of the species. C'hambers' account is as follows:

Band-tailed Pigeous... Were abundant the past winter from Paso Robles south to Northoff all through the coast range of mountains. One lumter from Los Olivos slipped over 2,000 birds to the San Franciseo and Los Angeles Irotels. The morning train from San Luis Obispo to Los Olivos on Sundays averaged 100 jassengers who came to hunt pigeons. A prominent hunter [stated]... that these passengers averaged about thity birds apjece per day. This would make this one day's excursion [account for] over 3,000 pigeous. Now!-this is [the record $\left.f^{\prime}\right]$ only one train and one day's lunting. One can hardly ealculate the number of birds killed by luunters in automobiles and by those who started from Los Angeles, San Franciseo, Santa Barbara, Ventura, Sunta Maria, Paso Robles, Lompoc and other small towns. . . I honestly believe that the people will never again see such a flight of Band-tailed Pigeons. In Norlhoff it is the largest they have ever seen, and the birds evidently hung arnund until they were simply shot out.

An unusual concentration of the pigeons from the whole Pacific toast region into a district easily reached by hunters gave exceptional opportumity for the infliction of the slaughter above recounted. This weak feature in the pigeon's mode of life becomes apparent when conditions of restricted food supply force it into localities where its survival depends upon the sanity of humting regulations.

The ability of the Band-tailed Pigeon to maintain itself even in moderate numbers is due to many factors, among which the following are important. The birds repair to mountainous forested regions for the breeding season; they nest in widely separated localities and rarely if ever in colonies: they are secretive and give few if any clues to the location of their nests; and during the winter months when they are as a rule widely distributed in the foothills and valleys of the state, they do not occur regularly in the same places in successive years.

The fire-year closed season which began in 1913 was entirely satisfactory in that it allowed the birds to begin to recuperate from the disastrous effects of the 1912 slaughter. If, in 1918, after the termination of the close season, a shooting season is to be permitted, the 
daily, weekly, and possible seasonal bag limit should be closely restricted and absohtely no sale of this bird permitted. With proper care the Band-tailed Pigeon may be perpetuated as an important item in the game resonres of California ; it rests almost entirely with the people of this state to decide whether or not this end will be realized.

\section{Western Mourning Dove}

\section{Zemaidura macromra marginclla (Woothouse)}

Other xAnes-Dove: ('ommon Dove: Wild Dove; Cooing Dove; Rain Dove; Carolina Dove: Carolina Turtle Dove; Turtle Dove; Zenaidura macroura carolincusis; Zenaidura carolinensis; Columba carolinensis; Ectopistes carolinensis; Zenaidura macroura.

Description-Adu't male: Front and sides of head light yellowish brown; top and back of head bhish slate; chin pale huffy or whitish; small spot below ear, iridescent dark blue; upper eyelid dusky, lower one yellow; bill black; jris brown; hind neck grayish brown, with broad area at side showing pinkish purple iridescence; rest of upper surface chiefly olive lrown, a few of the tertials marked near ends with large black patches; tail elongated and pointed; long central pair of tail feathers in color like back; next outer pair bluish gray crossed near end by a black hand; the rest dark bluish gray (black below) near base, succected by black cross l,and, near end, and brodly tipped with white; ontermost tail feather showing white onter web; onter surface of elosed wing (coverts) like hack, becoming bluish gray at edge of wing; flight feathers chiefly bluish gray, but becoming brownish on tips and inner margins; lining of wing and axillars, ashy blue; under surface of flight feathers dull brown: throat and whole breast, pale pinkish brown; rest of under surface light yellowish brown, palest on under tail coverts; sides pale ashy like like lining of wing; feet lake red. Adult female: Like male but with iridescent markings somewhat reduced: bluish slate on head replaced largely by brown: throat and breast chiefly pale buffy brown. Males: Total length 12.00-12.75 inches (305-324 mm.) (ten specimens); folked wing 5.78-6.13 (146.8-155.6); bill $0.49-0.57$ (12.5-14.5); tarsus $0.77-0.87$ (19.5-22.0) (ten specimens); weight $4.28 \mathrm{oz} .(121 \mathrm{gm}$ ) (one specimen). Females: Total length 11.2.5-12.00 (286-305) (three specimens); folded wing 5.40-5.82 (137.0-147.9); bill 0.49-0.55 (12.5-14.0); tarsus 0.77-0.84 (19.6-21.4) (ten specimens); weight $3.98 \mathrm{oz}$. (105.1 gm.) (one sprecimen); all from California. Juvenile plamage: Similar to adult male, but with colors much duller and iridescence wanting; feathers of upper surface lightly tipled with white: clin white; top of hearl and ear region flecked with dusky; erlge of wing scaled with whitish; breast drab, with lighter feather-tippings.

MARKS FOR FIELD IDENTIFTCATION-Moderate size (ilecidedly smaller than domestic pigeon), eonspicuously pointed and white margined tail (fig. 59), prate yellowish or pinkish brown under suface, and lack of white on wing. The momrnful cooing note, and the whistling produed as the bird takes flight, are also distinctive.

VoICE-A series of foul mellow, yet far-reaching motes, ah-eoo-roo-cro, repeated at irregular intervals.

NEST-On the gromul, or in husles or tres's, somotimes as high as forty feet above the gromed, hut ustally six to eight feet up: a loose, flat structure, of 

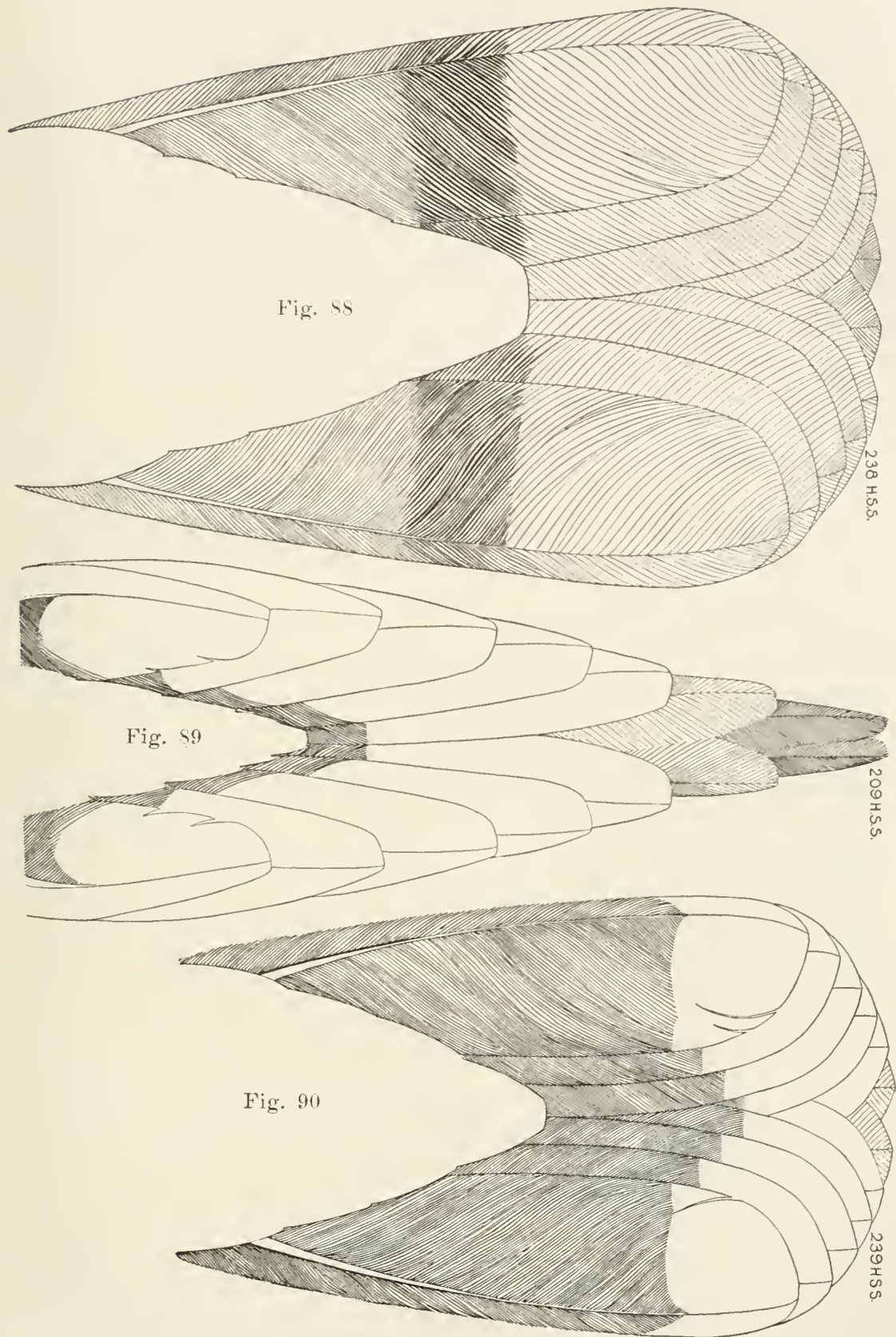

Fig. 88. Lower surface of tail of Band-tailed Pigeon. Natural size. Note nearly square end and lark band across midlle.

Fig. 89. Lower surface of tail of Western Mourning Dove. Natural size. Note wedge-shaped outline and white margins.

Fig. 90. Lower surface of tail of White-winged Dove. Natural size. Note nearly square end and white banil across end. 
sticks, rootlets and grass stems, earelessly arranged; when above ground usually situated on a horizontal branch or limb.

EGGS-Normally 2, elliptical in shape, measuring in inclies, 0.98 to 1.23 by 0.77 to 0.87 (in millimeters, 25.0 to 31.2 by 19.5 to 22.0 ), and averaging 1.07 by 0.83 (27.2 by 21.2) (thirteen sets, twenty-six eggs, from California); color white, unmarked, with a noticeable surface gloss.

General Distribution-Of the Mourning Dove, including the two north American subspecies: Breeds from British Columbia, Saskatchewan, Ontario, and southern Nova Scotia, south throughout the United States and Mexico, and locally in Lower California and Guatemala; winters from southern Oregon, southern Colorado, the Ohio Valley, and North Carolina sonth to Panama; casual in winter in the Middle States. Of the Western Mourning Dove (marginella): Western North America west of the Mississippi Valley, and in western Mexico (A. O. U. (heck-list, 1910, p. 149; A. O. U. Committee, 1912, p. 381).

Distribution in California-Abundant in summer, and breeds, throughout the lowlands of the state, occurring also in small numbers in the mountains through the lower portion of the yellow pine and Douglas fir belts (Transition life zone). Common in winter in the coastal district of southern California from the vieinity of Santa Barbara southward; also oecurs at that season in small numbers in the San Joaquin and Sacramento valleys to the head of the latter. Resident on all of the sonthern coastal islands.

The Western Mourning Dove, by one name or another, is probably known to more people in California than any other single species of game bird. It is found over very nearly the entire state, and usually in eonsiderable nmbers. Although present at all times of the year somewhere within our boundaries, it is mueh more abundant and more widely distributed in summer than in winter. During the nesting season the birds are found ehiefly in pairs, but, after the young are grown, old and young eongrogate in floeks and feed and roost together. It is then that dove hunters find their best sport. The birds have been hunted in California for many years, and still are: but in many of the eastern states they are now classed as nongame birds and protected by law. In California the nesting period of the dove has been found to inelude almost every month of the year, and on the basis of the argument that no shooting should be allowed when it is nesting, the arrangement of a proper hunting season has presented eonsiderable difficulty. Indeed, this and other eonsiderations, particularly its service as a destroyer of weed seeds, have quite properly raised the question whether we shonld continue to allow the dove to be shot as a game bird.*

* In the belief that the Mourning Dove merited more detailed cousideration than the data at hand made possible, a circular letter asking for local information on the species Was, at our request, sent out by the California Fish and Game Commission to its deputies. Replies were received from the following persons: San Diego, Webb Toms; Elsinore. J. H. Grger: Los Angeles, A. J. Stont: Santa Maria, H. J. Abels; Salinas, Frank Shook; Watson. ville, J. 11. Hill: San Jose, I. L. Koppel: Pleasanton, Karl Downing: Oakland, J. L. Bundock: Redwood Citr, T. F. Maloney: Valle.jo. W. H. Armstrong; Napa. W. J. Moore; Santa Rosa, IIenry Leneioni: IBig Pine, F. If. Ober: Fresno, S. L. N. Ellis: Dunlap, F. A. Bullard: Newman. J. E. Newsome; Columbia, G. F. Grant; Sutter Creek, F. S. Parke; Shingle, Encll Gray: Lonmis, C. A. Scroggs: Taylorsville, L. J. Warrent Sacramento George Neale: live Oak, E. D. Ricketts; Maxwell, S. J. Carpenter; Red Bluff, T. W. Birmingham; Susan. 
Ores much of the state the Mourning Dove is found throughont the year, but not at all times or in all loealities in the same numbers. During the summer months it is common over all of the lowland and foothill country, and oecurs in small number's in the lower past of the coniferous belt ('T'ransition life zone), thus ranging up into the mountains. It extends elear to the northwestern seacoast through the redwood belt. East of the Sierran divide it ranges up the mountains to fully \&,000 feet altitude (Mns. Vert. Zool.). It is found all over the dry deserts of southeastern California, as well as on all of the coastal islands. During the winter months it is well represented in the eoast distriet of southern California, and oeenrs also at that season in varying numbers in the San .Joaguin and Sacramento valleys. Nearer

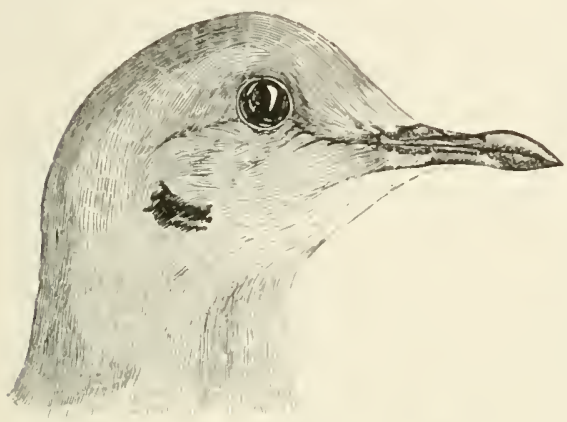

Fig. 91. Hearl of Western Mourning Dove. Natural size. the seaeoast small numbers are found in various localities north as far as Redwood City. Everywhere the number of wintering birds varies from year to year.

Our knowleclge of the migration of the Mourning Dove in California is ineomplete; this is due to a lack of observers, and also to the fact that in nany places small numbers of the birds remain through the winter which makes it diffenlt to determine the dates of arrival and cleparture of actual migrants. Belding (1890, p. 22) says that in 1886 it was first seen at Agua Caliente [Palm Springs], Riversid County, on Mareh $2 \bar{T}$, and beeame common there after April 1. At Mecea, Riverside County. the first in 1908 was noted Mareh 18 (Riehardson, MS). Stout (MS) says that about Los Angeles it is rare from Oetober to February, but beeomes eommon in March; and at Santa Maria, Santa Barbara County, where few are resident, the migrants arrive in April (Abels, MS). MeGregor (1901, p. 5) states that the dove arrives in the eoastal part of Santa Cruz County about April 1. In the vieinity of San Jose and Redwood City, and about San Franeisco Bay in general, it does not appear until late April or early May (Koppel, MS; Maloney, MS). The first for the season was seen at Olema, Marin County, on April 18 (1884), and at Nieasio on April 20 two years later; while at Hayward,

ville, F. P. Cadr; Weaverville, G. O. Laws; Weed, L. A. Streuher; Greenview, J. W. Harris; Crescent City, H. S. Preseott: Fort Bragg, C. R. Perkins: Eureka, E. P. Barnes.

In addition, copies of the letter were sent to, and replies received from the following ornithologists: John G. Tyler, Fresno: Leo Wiley, Palo Verde; and J. Eugene Law, Holly wood. To all of these persons the authors are grateful for their kindness in furnishing the information requested. Material used from these replies in the following cliscussion has been credited to the correspondents as MS (e.g., Toms, MS). 
Alameda County, it first appeared on April 23 (1885), and at Berkeley in the same year on April 30 (Belding, loc. cit.). In the e'ntral part of the state the migrant dove's arrive about the first of April, for example in the western part of Calaveras County (Roberts, MS), and at Loom is, Placer County (Scroggs, MS). At Sacramento, Neale (MS) says May 10 is the average date of arrival, while the birds are also late to arrive in the northern Sirras: Taylorsville, 3,500 feet altitude, I'lumas County, about May 1 (Warren, MS), and at Susanville, 4,200 feet altitnde, Lassen County, late April to micl-May (Cady, MS). On the northwest coast, at Crescent City, Del Norte County, Prescott (MS) reports that they do not appear until about Nay 1. East of the Sierran divide there are but two records of importance in this comnection. Lamb $(1912$, p. 35) says the dove becomes abundant near Daggett, in eastern San Bernardino Comnty, after May 1, while Ober (MS) states that it arrives in the ricinity of Big Pine, Inyo County, about the middle of May.

Direct evidence concerning the fall migration is difficult to obtain becanse of the iocal movement of the dores, from the valleys into the hills. This being almost eoincident with the opening of the hunting season, some persons believe it due to the frightening of the birds in the lowlands where shooting has been concentrated. Some approximate dates of departure are as follows: Crescent City, September 20 (Prescott, MS) ; Enreka, about September 1 (Barnes, MIS) ; Greenriew, Siskiyou Connty, micl-October (Harris, IIS); Weaverville, Trinity County, October (Laws, MIS) ; Red Bluff, ahout September 1 (Birmingham, MS) ; Susanville, Octobel' (Cady, MS) : Taylorsville, Plumas County, October 15 to 30 (Warren, MS) : Shingle, Eldorado county, September 15 (Gray, MS); Sutter Creek, mid-October to mid-November (Parke, MS); and Napa, Oetober (Moore, MS). About San Francisco Bay the birds depart from the vieinity of Oakland by the middle of September (Bundock, Ms'), and from Redwood City by the first of November (Maloner, MS') ; but in 1881 they were fairly (ommon at Burkeley on December 4 (Belling. 1890, p. 22). At more southerly stations, a marked dimimution in their numbers becomes apparent in Octoher.

The Monrning Dove is recognizable hy its comparatively small size, conspienously pointed and white-nargined tail, pale brown lower surface, and lack of white wing markings. Flom the Band-tailed l'igeon, it may be easily told by its much smaller size. pointed instead of square tail, and absence of white eollar on hind neck. From the White-winged Dove it may he distinguished by its slightly smallep size, pointed instead of square tail, and by the absence of white mankings on its wing. From the Mexican Gronnd Dove the DIourning Dore may be asily distinguished by its rery much larger size and pointed tail. 
This bird is essentially an inhabitant of open country, and is rarely if ever fomnd in thickly forested regions. It does, however, seck shelter in moderate growths of trees, such as willows and cottonwoods along stream courses, or the oaks and digger pines of the foothill eomutry. Sinee it feeds to a large extent mpon small plant seeds it is not limited to fertile regions, but is scattered far and wile over much of the desert country in the southeastern part of the state. Here the oceasional rains are followed by profuse crops of ammals which leave the gromid strewn with their seeds. In settled regions the birds are very often seen foraging along roadsides or in waste corners of fields.

Water is a prime requisite for the dove and regular visits are made to drinking places in the early morning and erening. Even in the desert eountry where feeding and drinking places aw often many miles apart, the birds make the journey between the two with remarkable regularity and directuess. Sometimes the only accessible water for miles is at a small isolated spring or seepage place, lut the birds find their way to it with apparent ease. Indeed, experiencerl travelers on the desert have asserted that when in seareh of water they have made use of this faeulty of the birds and followed their direct lines of flight with suecess. 'This essential habit, of visiting water holes, was formerly turned to advantage by Indians and market hunters, who secreted themselves in the vieinity and killed the birels in great numbers as they eame to drink.

Doves roost for the night both on the ground and in trees. A favorite pereh for the night is some leafless tree in the vieinity of a lrinking place. In illustration of their behavior in this respeet the instance may be cited of a flock on San Clemente Island, where at the time of observation "a chmp of seraggy cherry trees in the ravine a few rods north of the windmill seemed to be a regular roosting place. Just at dusk, every evening, the doves would arrive in pairs and settle in the trees until there were probably twenty or thirty. But they would leave in the morning by daylight ..." (Grimell, 1897, p. 13).

Mourning Doves are rarely seen singly. Usually they are noted in pairs and quite often in small flocks of a dozen or so. Sometimes the birds band into larger flocks numbering fifty or more; but this is only after the nesting season, when the young are fully grown, and the families have joined together. Thronghont most of the year, whether feeding in stubble fields or weed patehes, whether coming to drink or perehing in trees to roost for the night, the birds are as a rnle observed in pairs. This association in comples is so general as to give rise to the common belief that doves mate for life.

The call of this dove is a rather momrnful eooing, mellow but far- 
reaching in tone. It may be represented by the syllables: ah-coóroo-coo. Under favorable conditions the cooing may be heard for as much as half a mile. It is given most commonly in the spring and early summer months, and then at almost any time of day, even until late clusk. The notes are produced by the male, who is described as appearing quite active and cheerful despite the mournful character of his utteranees (Bendire, 1892, p. 140).

As a result of the equable climate of the state as a whole, the Mourning Dove here has an extremely long nesting season. Sixtysix definite records of the nesting of the species within the state are at hand (see table 19), the earliest being February 9 (1897) at San Gabriel, Los Angeles County, when a nest with slightly incubated eggs was found (Willett, 1912a, p. 44), and the latest, December 5 (1911) at Covina, Los Angeles County, when a heavily incubated set was discovered (Howell, 1912, pp. 73-74). Only the months of Oetober, November and January are lacking in the list. and it seems quite as probable that nesting may oceur during those months as during some of the others.

TABLE 19-Data Relative to the Nesting of the Western Mourning Dove in Califormia

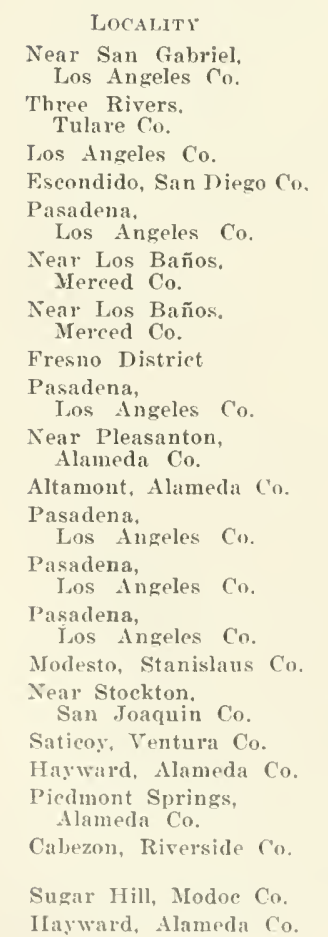

Nest Contexts AND CONDITION 2 eggs, incubation slight

Feb. $9, \quad 1897$

Feb. 27, 1902

Mar. 11, 1896

Mar. 15

Mar. 27, 1896

Mar. 28, 1912

Mar. 28,1912

Yar. 30, 1907

Mar. 30,1896

Mar. 31, 1915

Apr. 8, 1915

Apr. 15, 1892

Ipr. 18, 189.5

Apr. 25, 1895

Ар1. 29, 1913

May 6,1882

May 8, 1873

May 12, 1877

May 14, 1882

May 15,1908

May $20, \quad 1910$

May 20, 1878
2 eggs, slight

2 eggs, fresh

Eggs, fresh

$1 \mathrm{egg}$, fresh

2 eggs

$1 \mathrm{egg}$

2 half-grown squabs

2 eggs, incubation begun

2 eggs, about to hatch

2 eggs, incubated

2 eggs, incubation hegun

2 eggs, fresh

2 eggs

2 eggs, inculation one-half Mailliard coll

2 eggs, fresl

Nesting

Nesting

2 eggs

2 eggs, incubation

inder way

2 eggs

Testing
A CTHORITY

Willett, 1912a, p. 44

Dean, 1901, p. 111

Grinnell, 1898, p. 20

Sharp, 1907, p, 86 Grinnell, MS.

Beck, MS., in Mus. Vert. Zool.

Beek, MS., in

Mus. Vert. Zool.

Tyler, $1913 b, \mathrm{p}, 36$

Mus. Yert. Zool.

Bolander, 1915, p. 131

Bolander, 1915 , p. 131

Mus. Vert. Zool.

Mus. Vert. Zool.

Mus. Vert. Zool.

Mailliard coll.

Cooper, 1880, p. 251

Cooper, 1880, ¡. 251

Mrus. Vert. Zool.

Mus. Vert. Zool.

Mus. Vert. Zool.

Cooper, 1880, p. 251 
TABLE 19-(Continued)

LoCALITI

Hasward, Alameda Co.

Calaveras Creek,

Alameda Co.

Santa Cruz

Snow Creek. Riverside Co.

Iake Vallev. near Lake Tahoe

Jath rop. San Joaquin Co.

Snow Creek Riverside Co.

Near Lathrop, San Joaquin Co.

Hayward, Alameda Co

Colton.

San Bernardino Co.

Lathrop, San Joaquin Co.

Tathrop, San Joaquin Co.

Alameda Co.

Alameda Co.

Pasadena,

Los Angeles Co.

San Clemente Island

San Clemente Island

Pasadena,

Los Angeles Co.

Alameda Co.

3 miles east Coulterrille, Mariposa Co., 3,200 ft

3 miles east Coulterville, Mariposa Co., $3,200 \mathrm{ft}$.

Alturas, Modoc Co.

Alturas, Modoc Co.

Alturas, Modoc Co.

Sacramento

Eldorado Co.

Taylorville, Marin Co.

Palomar Mountain,

San Diego $\mathrm{Co}$.

Sacramento

Hayward, Alameda Co.

Santa Cruz Island

Hayward, Alameda Co.

Tulare Lake, Kings Co.

Pasadena,

Los Angeles Co.

Hayward, Alameda Co.

Cushenberty Springs,

San Bernardino Co.

Murphys, Calaveras Co.

Murphys, Calaveras Co.

Vallevista, Riverside Co.

Vallevista, Riverside Co.

Escondido, San Diego Co. Los Angeles Co.

Near Santa Monica,

Los Angeles Co.

Covina, Los Angeles Co.

\section{Nest CoNTexts}

AxD CoxpITION

May 23, 18852 eggs, fresh

May 23, $188122 \mathrm{eggs,}$ fresh

May 25, $1865 \quad$ Nesting

May 27, 1908 2 eggs

May 28, 19092 eggs, fresh

May 29, 19112 eggs

May 29, 1908 2 eggs, fresh

May. 30, 19112 squabs, partly fledged

May 30, 18872 eggs, fresh

May 30, 1907 2 eggs, probably fresh

June 1, $1911 \quad 2 \mathrm{eggs}$

June 1, 19112 eggs

June 3, $1899 \quad 2$ eggs, fresh

Jume 3, 18992 eggs, incubation begun

June 3, 18922 eggs, fresh

June 3, $1897 \quad 1$ egg, fresh

June 6, 18972 eggs, fresh

June 6, $1892 \quad 2$ eggs, slightly incubated

.Tune 6. $1899 \quad 2$ eggs, fresh

June $7,1915 \quad 1$ egg

June $7,1915 \quad 2$ eggs

Iune 9, 19102 eggs, fresh

June 9. 1910 2 eggs, fresh

June $9,1910 \quad 2$ eggs, fresh

June 11, 1867 2 eggs

June 11, $1898 \quad 2$ eggs, fresh

Iune 13, $1904 \quad 2$ eggs

June $15,1897 \quad 1$ squal

June 18, $1867 \quad 2$ eggs

June 18, 1878 Nesting

July $\quad$ T, $1912 \quad 1$ egg

July 12, 1881

July 30,1907

Aug. 1, 1895

Alug. 11, 1881

Ang. 11, 1905

Aug. 29, 1878

Aug. 29, 1878

Aug. 30, 1908

Aug. 30, 1908

Sept. 2,

Sept. 15, 1897

Sept. 22, 1894

Dec. 5, 1911
3 eggs, incubation two-thirds

Still breeding

$1 \mathrm{egg}$, fresh

2 eggs, incubation

begun

2 squabs

Eggs, nearly hatched

Eggs

Small squabs

Small squabs

Eggs, fresh

2 eggs, just hatching

2 eggs, fresh

2 eggs, incubation advanced

\section{AITHORITY}

Iailliard coll

Mailliard coll.

Cooper, 1880, p. 251

frinnell and Swarth, 1913 , p. 234

Ray. 1910 , p. 130

H. C. Bryant, MS.

Mus. Vert. Zool.

H. C. Bryant, MS.

Mailliard coll.

Hanna, 1907, p. 198

H. C. Bryant, MS.

H. C. Bryant, MS.

Mus. Vert. Zool.

Mus. Vert. Zool.

Mus. Vert. Zool.

Grinnell, 1897, p. 13

(trimmell, 1897, p. 13

Mus. Vert. Zool.

Mus. Vert. Zool.

storer, MS., in Mus. Tert. Zool.

Storer, MS., in Mus. Tert, Zool.

W. P. Taylor, MS., in Mus, Vert. Zool.

W. P. Tavlor, MS., in Mus. Vert. Zool.

W. P. Taylor, MS., in Mus. Vert. Zool.

Ridgway, 1877 , p. 597

Barlow and Price. 1901, p. 160

Mus. Vert. Zool.

McGregor, 1899 , p. 67

Ridgway, 1877, p. 597

Cooper, 1880, p. 251

Wright and Snyder,

1913 , p. 9

Mailliard coll.

Goldman, $1908 b$, p. 203

Grinnell, MS.

Mailliard coll.

Grinnell, 1908, p. 57

Belding, 1879 , p. 438

Belding, 1879 , p. 438

Grinnell and Swarth, 1913 , p. 234

Grinnell and Swarth. 1913, p. 234

Sharp, 1907, p. 86

frinnell, 1898 , p. 20

Willett, $1912 a$, p. 44

Howell, 1912, pp. 73-74 
The sixty-six recolds at hand (table 19) are distributed through the year as follows: 2 in February, 8 in Mareh, 5 in April, 17 in May, 20 in June, 3 in July, 7 in Angust, 3 in September, and 1 in December. Thirty-two of the sixty-six nestings were observed between May 20 and June 18, which period probably represents the height of the breeding season. It is also probable that relatively more nestings oceur in July than is here indieated. The report received from the Fish and Game Commission deputies would seem to show that the breeding season extends from February through October, with the height of the season

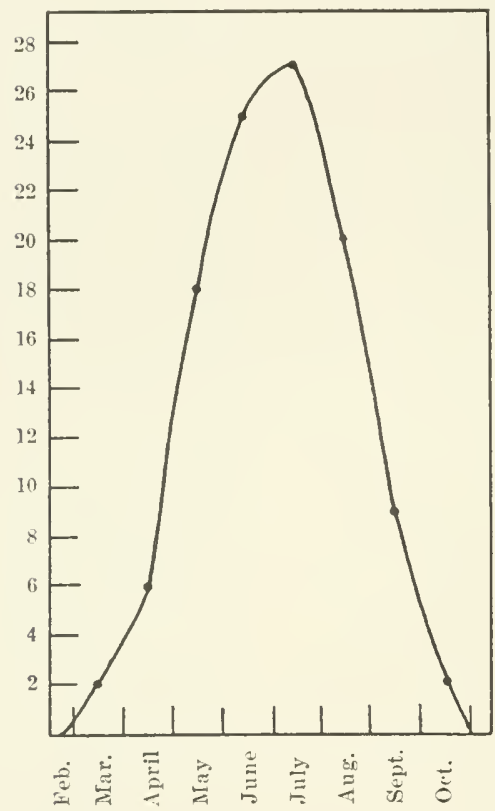

Fig. 92. Nesting season of the Western Mourning Dove in Califormia, according to opinions of deputies of the California Fish and Game Commission. in June and July; thus, in $31 \mathrm{re-}$ ports, 18 record nesting in May, 26 in June, 28 in July, and 21 in Angust, although in nine cases nesting is not recorded as continuing through the latter month. In 19 reports, five (four from the northwestrrn part of the state) record one brood, eleven record two broods and seven record three broods as obtaining either regularly or infrequently. Where stated, ground nests are reported commonest in eleven localities, and tree nests commonest in ten, but neither type seems to be altogether restricted to any particular part of the state. Probably the availability of sites and presence of enemies exereise some control upon the selection of any one kind of nest site.

The above lata bear upon the question as to when the hunting season can be opened, so as not to jeopardize exgs or squabs of nesting pairs of doves. The opening of the season for many past years has been either July 1 or July 15 , but even the latter of these dates is quite evidently too early. On the other hand, an occasional nesting as late as September wonld not seem to ns a valid warrant for deferring the begimning of the hmnting season (if the dove is not to receive total protection) until so late as October 1. especially in vicw of the departure of many migrant birds a month or more before that time. in the northern part of the state. If a miform date of opening throughont the state is to be adhered to, we believe that September 1 comes nearest to meeting the contingencies of the case. 
At the begimning of the breeding season, which is amnounced by the augmented cooing of the males, the flocks break up and the birds scatter out, earch pair ordinarily nesting by itself. At times, however, several couples may nest in such elose proximity to ear other as to suggest a colony ('Tyler', 1913b, pp. 35-37); but their behavior is quite different from that of strietly colonial birds. Nests are to be found in all sorts of loeations, and it is tifficult to infer any ehoice of situation on the basis of seclusion, protection from cnemies, or even proximity to foot or water. They are found on the bare open ground, on the banks of gullies, in low bushes, and at rarying elevations in trees, some having been noted as much as forty foet above the grommd. Probably six or eight feet would be an arerage leight for nests that are built ahove the surface of the ground. Whatever the location, the structure is erude, a mere platform of small sticks and grasses or roots, so loosely put together that in elevated nests the eggs may often be seen through the structure from below. Sometimes the deserted nests of other birks, as for example of the mockingbiret ('Tyler, loe. eit.), may be used, and sliginty adderl to: but this practice is not common.

Nests of the Mouming Dore rarely contain more or less than two "ggs. Tyler (loc. (cit.) states that after "examining hundreds of nests" he can only recall two in which the complement eleviated from that number. One contained three eggs, one of them being so different that he believed it to have been deposited by another female; the other held a single heavily ineubated egg in a remodeled mockingbird's nest. The umsual depth of the latter nest mate it mulikely that a second egg had been present and had rolled ont. A. K. Fisher (1893a, p. 33) states that at Lone Pine, Inyo County, a nest was found during the first part of June which contained three young.

According to Bendire (1892, p. 142), one day intervenes between the deposition of the first and seeond eggs, and the process of incubation is said to last for about two weeks. Our impression is that incubation is earried on by the female only. If a nest is approached the sitting bird may slip quietly off and fly away some distance; or. again, the "broken-wing" luse may be tried in its extremest manifestation. Probably, as with other birds, this ruse comes into use chiefly towards the end of the period of incubation.

The eggs are elliptical ovate, that is, more nearly equal-ended than those of the domestic hen, and are pure white in color, with a slight gloss. They vary considerably in size; thirteen sets (twenty-six eggs) in the Museum of Vertebrate Zoology measure in inches, 0.98 to 1.2: by 0.77 to 0.87 , and average 1.07 by 0.83 . The eggs of the Mourning Dove differ from those of the Band-tailed Pigeon in being decidedly smaller, about two-thirds as long and one-third the bulk. It is com- 
monly believed that two, and in some instances thrce, broods are raised in a season. There is no eonelusive evidence at hand to substantiate either this, or the eontention of some sportsmen that certain of the birds nest suceessively at high and then lower altitudes.

While in the nest the squabs are fed on material regurgitated by the parents, the so-ealled "pigeon's milk." Judd (1901, p. 431) reports that examination of five squabs of this species showed that their food comprised thirty per cent of entire seeds of plants and the balance consisted of irregular endosperm fragments of the same kinds of sceds. The plants represented are those species usually inchuded in the term "weed"; namely, oxalis, spurge, ragweed, sunflower, and pigeon grass. Adults collected during the same season had eaten all of the species of seeds identified in the food of the nestlings, as well as some others. 'The adults brood their young sometimes even after they are fully fledged. Although laying but two eggs the doves are remarkably successful in hatching them and rearing both squabs, and this together with the possibility that two broods are reared in a season may in part account for the dove's ability to maintain itself lespite the heavy slaughter during the hunting season.

An examination of the food of the Monruing Dove shows that weed seeds form the principal item of its diet thronghont the year. Beal (1904, pp. 6-7) in an examination of 237 stomachs of this bird from all parts of the country found that weed seeds comprised 64 per cent of the food for the year, and that the percentage did not vary greatly in different months. The remaining 32 per cent of vegetable food consisted of grains of various sorts (wheat, oats, barley, rye, buekwheat and corn), but of these the only grain taken in good condition, that is, apparently fresh, was wheat, which seemed to be preferred. By far the greater amount of this grain was waste, gleaned from stubble fields. Such grain has little or no value, and the amount taken by all the doves in California is negligible when the total amount of grain lost in harvesting is considered. The animal food taken by doves is chiefly insects, and constitutes less than one per cent of their total diet. It is probably for the most part taken aecidentally.

Enormous numbers of seeds are taken by doves. Three eounts were made by the Bureau of Biologieal Survey and showed 6.400, 7,500 and 9,200 seeds, respectively, in the stomachs and crops of three birds. A large percentage of the seeds taken are those of garden and farm weed pests. "In eertain parts of California the habit of feeding on the seeds of turkey mullein (Eremocarpus setigerus) is so well known that a botanist, on inquiring how he could collect some seeds of this plant, was advised to shoot a few doves and open their crops"' (T. S. Palmer, 1900, p. 17). All food material is gromnd into small fragments in the bird 's muscular gizzard: hence the dove is 
not instrumental in transporting the seeds of noxions weeds and other plants, as are many other birds that merely swallow the seeds or berries, dissolve off an outer nutritious eoating, and discharge them without affecting the powers of germination.

Oeeasionally doves have been killed by eating poisoned grain put out for horned larks where the latter were destroying grain (McAtee, 1905, p. 13). Serious complaint has been made here in California that poisoned grain put out for ground squirrels has killed numbers of doves (Bundock, MS). Some are probably killed each year by poisonous gases in the orange groves when the trees are being fumigated, as instaneed by Howell (1914, p. 55). Doves have natural

June July Aug. Sept. ()et. Nov. Dec. Ian. Feb. Mar. April May

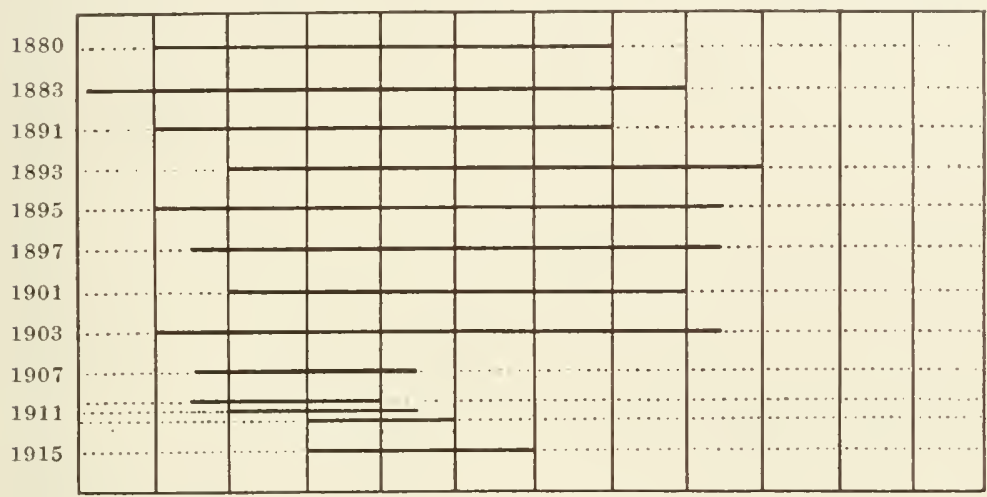

Fig. 93. Changes in the open season for hunting doves in California, from the time of the establishment of the first elose season in 1880 until 1915.

enemies, also. A. K. Fisher (1893b), as a result of the examination of 2,690 stomachs of hawks and owls taken all over the United States, found remains of doves in nime stomachs. But this is not a very large proportion as compared with 43 stomachs in which quail or grouse were found. In this eonnection, the relative numbers of doves to these other game birds ought to be taken into account, as well as their relative powers of flight. On the whole, doves are probably much more immune from natural enemies than are quail or grouse.

In a number of the eastern states, more particularly the northern ones (lying in the Transition life zone), the Mourming Dove is not, and has not, for many years, been considered a game bird; but, in the south, and here in the west, where a warmer climate favors the existence of the speeies in greater numbers, it has always been eonsidered fair game by sportsmen. In California, the first state-wide law protecting doves was passed in 1880 when the open season was 
made to extend from July 1 until Jammary 1, six months. Since that time there seems to have been eonstant dissatisfaction on the part of hunters in the different seetions of the state, with resulting readjustment of open and elosed seasons. There liave been no less than eleven different legislative enactments on the subject during the last thinty-five years. The changes in the law from time to time are indicated in the aecompanying chart (fig. 93).

The present (1915) law, which eonforms to the season under the Federal Migratory Bird Law passed in 1913, will be seen to be the most conservative of any yet enaeted in California. Two opposing conditions make the regulation of the dove season here extremely diffieult, namely, the late nesting, and the rather early migration in the northern part of the state. Birds in the region surrounding the head of the Saeramento Valley are nesting almost up to the time that they begin to leave for the south, so that if the hunters of this seetion are to be allowed to shoot the birds at all, the open season will have to include the latter part of the nesting period and be rather short at best. Opening the season on September 1 will not prevent shooting while some nesting is still in progress, yet it will allow the great majority of the young birds to be fully fledged before hunters take the field. A second chart (fig. 94) shows that the hunting season in California (1915) is a fair average as compared with the 21 other states that permit love shooting.

The number of dove hunters in California is simply enormous, and the wonder is that the birds have not been exterminated long ago. Mr. A. D. Ferguson, in charge of the Fresno Distriet of the California Fish and Game Commission, says (in Calif. Fish and Game Comm., 1914, p. 42):

In the season of 1913 , it is estimated that in Fresno County 4,000 gumners were out for doves on the opening day . . and. . . few it any of these people were disappointed in the day's bag. After the opening date doves could not be so readily secured. Apparently the surviving birds took refuge in the Sierra hills and in isolated sections of the sparsely inhabited west side of the valley. The spring of 1914, however, diselosed the presence of doves in their old breeding grounds in most satisfactory numbers.

Excessive shooting does undoubtedly have its effect, for in Los Angeles County Mr. George Willett states that the birds have been greatly reduced, and the same report eomes from Solano County. Agricultural derelopment in general may be said to favor the inerease of doves, and thus to some degree compensates for the reduction a aused hy hunting. Waste grain and other seeds furnish considerable food, while the inevitable growths of werds in neglected corners and fallow fiekls give further sustruance. The birds are notably adaptable in the choice of nesting sites, so that the planting of orehards. 
or on the other hand, the clearing of brush lands, does not affect them unfarorably.

In earlier years Mourning Doves furnished "a large amount of food to the Indians during the spring and summer. Before migration commences the Indians build rude huts of brush, grass, and weeds, in which to secrete themselves, near the springs and streams. Loopholes

June July Aug. Sept. ()ct. Nov. Dec. Jan. Feb. Mar. Apris Jay

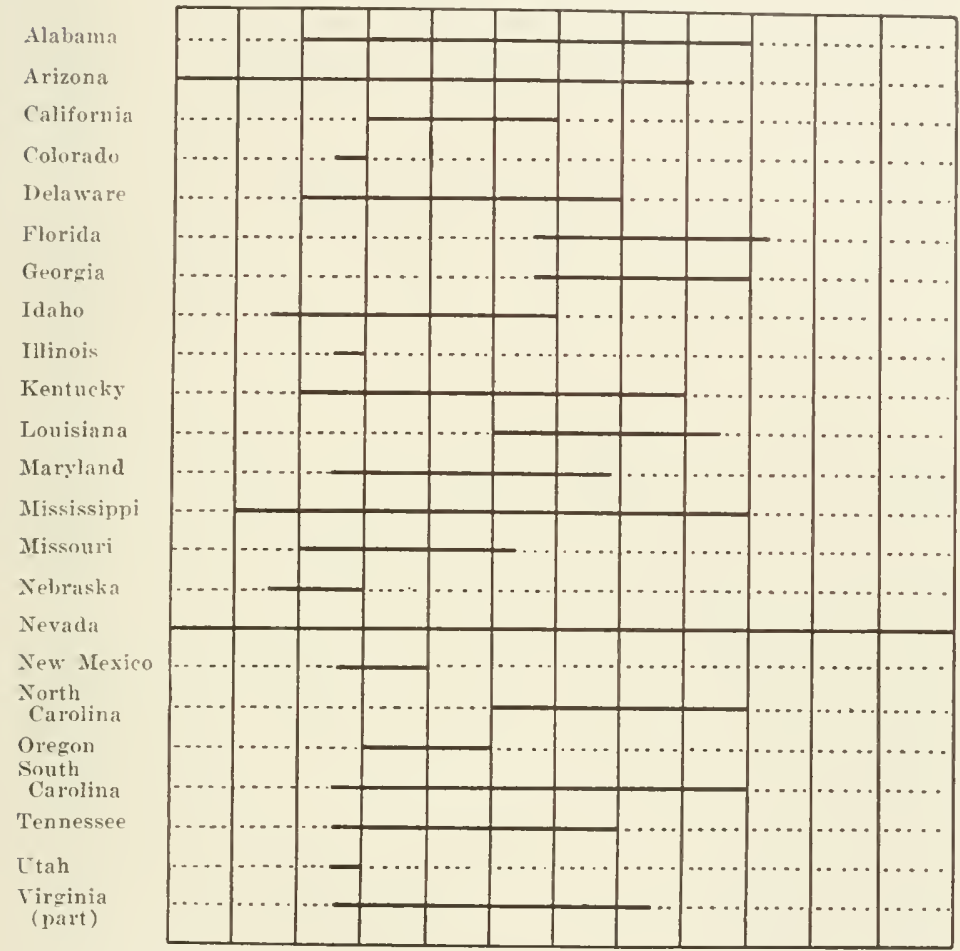

Fig. 94. Open season for hunting loves in states which allow these birds to be shot (1915).

are male on the sides toward the water, through which arrows are shot at the birds as they alight to drink" (A. K. Fisher, 1893a, p. 33).

In 1895-96, when doves were yet permitted to be sold in the markets, the records of the California Fish and Game Commission (Calif. Fish Comm., 1896, p. 40) show that 5,160 birds were received in San Francisco and Los Angeles from October to February, inclusive. Their value was quoted as slightly less than five cents apiece.

The dove population of California as a whole has decreased considerably during recent years. Trenty-two of our correspondents report decreases ranging from slight reductions to almost total extir- 
pation. five say that the dove population has remained constant, and four report that the birds have increased, although it is not stated whether this increase has reached former numbers or exceeded them. Nine of those reporting reduction in numbers attribute it to the increase in the efficiency of shotguns, and better modes of travel such as that afforded by the automobile; two eorrespondents, in the eentral coast district, state that doves have perished in large numbers by eating poisoned grain put out for the destruction of ground squirrels; while two others, in the northwestern part of the state, attribute the decrease to the work of predatory birds and mammals. Considerable diversity of opinion exists as to the means to be used in bringing the dove population back to normal; some of our correspondents believe that a closed season of a few years would suffice.

The matter of a proper open season is also diversely reported upon, ten persons deeming the three months beginning with September 1 satisfactory, while twelve recommend changes. Four recommend a later season, while four others would open it earlier, two even suggesting July 15 as an opening date! Happily this latter view of the situation is not shared by many : the majority believe that the Mourning Dove merits more consideration during the time that it is rearing its young than many hunters of the type of the two just mentioned are willing to grant it. In fact seven deputies recommend that the dove be entirely removed from the list of game species.

To sum up the situation, we find that the Mourning Dore is ralued by many sportsmen for its high qualities as an object of pursuit as well as article of food.* On the other hand very many persons urge that the Nouming Dove be once and for all removed from the list of game birds and be placed on the list of fully protected speeies. This dove is admired by many as an attractive feature in the wild life of the state; as an article of food it is of but small size; its forage habits are such that it is at least wholly harmless to agricultural interests, and a majority of bird students $\dagger$ claim for it a distinctly benefieent rôle as a destroyer of weed seeds; it is feared that decorease will continue in spite of restricted hunting season: and stress is laid on the extreme difficulty of arranging an open season which will permit hunting after the birds have finished nesting and yet before they have commeneed to migrate. It is diffieult to make a recommendation that is fair to all interests. If the dove shows no further

* Present information would seem to indieate that in most parts of the state under the restricted open season from September 1 to November 30 the dove will be able to hold its own, and thus continuc to sulserve the wishes of the hunter.

$\div$ The three authors coneerned in the preparation of this account of the Mourning Dore are disagreed as to the weight which should he given the evidence thus far available concerning the value of the bird to agriculture. Mr. Grinnell is unable to grant that valid proof has ret been presented establishing berond seientific question any practical or considerable service on the part of the dove to agriculture. On the other hand. Mr. Bryant and Mr. Storer are convineed that the evidence thus far adduced suffieiently proves that the dove is lighly beneficial to the farmer's interests. 
decrease, we see no practical reason why it should not be kept on the game list-with adequate restriction of hunting. But if the next few rears show notable diminution, the only fair thing will be for the sportsmen of the state entirely to relinquish their elaims on the species, and join heartily with birl-lovers in seeuring complete protection fol it.

\section{White-winged Dove}

\section{Melopelia asiatica trudeaui (Auclubon)}

OTHER NAMES-Sonora Dove; White-winged Wild Pigeon; Melopelie asiatica: Melapelia leucoptera.

Description-Adulls, brth seres: Top and hack of head and hind reck, dull grayish purple, most conspicuons in males; side of head, ashy brown; chin pearl gray, blending into pale brown of throat; streak below ear region black with reflections of deep blue and purple; side of neek ashy brown with bronzy green iridescence; "iris dark hazel; bill black; . . . bare orbital ring blue" (Brewster, 1883, [. 32); npler back light brown; lower back and rump, dull bluish gray ; upper tail coverts brownish gray, washed with blue; middle pair of tail feathers brown, darkest toward base; rest of tail feathers dark bluish gray above (and black beneath), becoming black subterminally (above), with broad white ends: male distinguishable from female in having somewhat longer tail with broader feathers and more white at ends; onter surface of closed wing (lesser and median coverts and tertials) light brown, continuous with back in tone; greater coverts bluish gray, with broad white outer margins and ends; primaries and their coverts black, the former narrowly margined with white; secondaries black, tipped narrowly with white; uncler surface of wing and axillars plain bluish gray; throat, fore-neek and breast, pale brown, changing gradually into light bluish gray on rest of under surface, palest on under tail coverts; legs [and fect?] "dull red" (Brewster, loc. eit.). Males: Total length 11.90-12.54 inches (302-318 mm.) (eight specimens from Arizona); folded wing 6.27-6.65 (159-169); bill along culmen $0.81-0.91(20.6-23.1)$; tarsus $0.95-1.04(24.0-26.3)$ (ten specimens from Arizond and California). Females: Total length 11.24-11.90 (285-302) (seven specimens from Arizona); folded wing 5.78-6.30 (147-160); bill along culmen 0.83-0.90 (21.0-22.8); tarsus 0.91-0.99 (23.0-25.1) (eight specimens from Arizona and California). Jucenile plumage: Similar to that of adult but generally paler, top of heal lacking purple tinge, streak below ear merely dusky, and chin bare of feathers.

MARKS FOR FIELD IDENTIFICATION-Medium size, this dove being smaller than either a Band-tailed or Domestic pigeon, but slightly larger than a Mourning Dove; a conspicuous white area on wing, forming a longitudinal streak when wing is closed and a distinct crescent when the wing is spread; tail square-ended, with a white band across end (fig. 90).

Volce-A frequently repeatel hoarse co-có-o-coh'-co-có-o (Gilman, 1911, p. 52; Grimnell, 1914b, p. 123).

NEsT-Placed most often in mesquite, but also in willows and other trees and shrubs; at varying heights from four to twenty-five feet (1.22-7.60 meters) though usually about ten feet (3.04 meters) above ground; a crude structure of twigs resembling that of the Mourning Dove but larger (Gilman, 1911, pp. 53-.54). 
Eggs-Usually 2, exceptionally 3, ovate in shape, measuring in inches, 1.0.i to $1.30 \mathrm{hy} 0.78$ to 0.95 (in millineters, 26.6 to 33.0 by 19.8 to 24.1 ), and averaging in two large series, 1.14 by 0.88 (28.9 by 22.4 ) and 1.17 by 0.88 (29.6 by 22.4 ) respectively; the color rangrs from white to cream (Davie, 1859, lp. 155-1.59), and the surface lacks the pearly luster seen in egas of the Monming Dove (Gilm:11, 1911, p. j4).

GENERAL DISTRIBUTION-Iower ('alifornia, "xtreme sontheastern Califormia, southern Arizona, sonthwestern New Mexico, southern Texas, and soutl tlurongh Mexico to Costa Rica; casual in Colorado aud recorded once from Washington (modified from A. O. U. Committee, 1912, p. 380).

Distrinution in California-summer visitant in moderate numbers along the Colorado River from The Needles sonth to the Mrxican boundary; recorded once as a straggler in western San Diego Connty. Arrives in late April.

The White-winged Dore, with a wide range in the sonther'n portion of our eontinent, barely reaches the extreme southeastern portion of California, in the valley of the Colorado River. Here it is a summer visitant in moderate numbers, arriving in the latter part of April (the 29th in 1910), and inhabiting ahmost exclusively the willow thickets along the river (Grimell, 1914b, p. 123), from the Mexican boumdary north at least to Thr Needles, San Bernardino County (Stephens, 1903, p. 77). A single individual taken ten miles west of Escondido, San Diego County, about September 25, 1911 (Dixon, 1912. p. 196) was doubtless a vagrant, and constitutes the only reord for ('aliformia outside the limited region above speeified. It has been reported from Twenty-nine Palms, on the Mohave Desert rast of Morongo Pass (Heller, 1901, p. 100), but not upon the best of evidence. Cooper (1877, p. 95) saw birds of this species in the markets of San Francisco; but, as suggested by him, there is a chance that ther were bronght in caged from Mexico.

From other members of the pigeon family occurring in California the White-winged Dove may be distinguished chiefly by the large white pateh on the wing. In addition it may be told from the Bandtailed Pigeon by its smaller size and white-tipped tail. from the Mourning Dove by its slightly larger size and squarish instead of pointed tail, and from the Mexiean Gromud Dove by its decidedly larger size, as well as by the presenee of much bluish gray in its coloration, and white tip on its tail.

Gilman, who has improved his excellent opportmities for olserving this speeies near Sacaton, Pinal County, Arizona, has written a very full account of it $(1911,1 p .52-54)$, from which we extract the following portions :

The White-winged Dove or Sonora Pigeon . . is migratory, arriving here about the 20th of April. Their coming is coineident with the ripening of the herries of the wild jujube. . upon which they feed greedily as long as the fruit lasts, consuming both ripe and green. . . The white color pattern shown 
when the bird is in flight is quite striking. When perched, the white on the wings is rather inconspicuous, but in motion it shows as two broad erescents, and the white ereseent-shaped bar across the tail, generally spreat a little in flying, adds greatly in produeing the striking effect.

From the day of their arrival in spring they set up a continual call which may be roughly described as Co-có-o-coh'-co-có-o. This call is heard in all direetions from morning till night and in such volume that it hecomes a sort of continuous bass hum, a baekground or sounding board for all the other bird songs and calls. It laeks the plaintive tone of the Mourning Dove eall, and to most people becomes a dreary, monotonous droning. . . .

Nesting begins soon after arrival in the spring and as only a slight platform is built for a nest, not much time is lost in eonstruction. The nest is praetically the same as that of the Mourning Dove though perhaps a little larger. .. They nest in a sort of scattered colony, and frequently two and three nests are seen in a large mesquite tree. In some favorel groves about every third big tree has one or more nests. Nuch of the nesting is done in May and June... The earliest late... for eggs was May 10, and at that time a great many new nests were seen. In 1908 and 1909 most of the nesting seemed to he done in May and June, but in 1910 the season rearlied well into July, as in that month $I$ found twenty-one nests containing eggs or young birds. . .

Nests are always, as far as my observation goes, placel in trees or shrubs at varying distances from the ground. The average height was ten feet and extremes ranged from four to twenty-five feet. The only nest as low as four feet was built in a mesquite tree and placed on top of an old Thrasher's nest. .. I found several others using old Cactus Wren's nests as founlation, and one had made use of a deserted Verdin's home.

The eggs are a little larger than those of the Mourning Dove and lack the pearly luster, the shell looking much like that of the tame pigeon's egg. T'wo is the usual number in a nest, but July $10 \mathrm{I}$ found a nest containing three partly incubated egcrs.

According to Davie (1889, pp. 158-159) the eggs are ovate in shape and measule 1.05 to $1.30 \mathrm{hy} 0.78$ to 0.95 , averaging $1.14 \mathrm{by}$ 0.88 and 1.17 by 0.88 in two large series, respectively. 'This author' also states that the shell color ranges from white to cream.

Continning, Gilman (loc. cit.) says that:

In choice of nesting sites the bird shows a decided preference for mesquite, as about 70 per cent of nests noted were in that plant. Ahout 20 per cent were in willows, and 3 per cent each in eottonwood, . . tree cholla, and . . screw-bean. ... The dove is usually very wild on the nest, flying off whenever approached as close as twenty-five feet. Rarely is the broken-wing play made, though I have seen a few mild attempts at it, and occasionally one will allow an approach as close as fifteen feet to the nest before taking flight.

In addition to the wheat, these doves feed on other grains and much weed seed. They are very fond of sorghum seed and large flocks gather on a field of this plant. The giant cactus . . furnishes them a large amount of food also. They may be seen on top of the great columns as soon as the first blossoms appear, thrusting their bills into the trumpet-shaped flowers, but whether for insects, pollen, or nectar was not learned. As soon as the fruit ripens, however, there is no doubt as to what they are seeking. Their actions 
are a sufficient index even without the tell-tale red stain aronud their mouths. They frequent the cactus groves as long as any fruit is left, flying a long distance to reach this delicacy.

The erop of a bird shot near Fort Yuma, California, May 5, 1910, contained 33 watermelon seeds and one muskmelon seed (Grinnell, $1914 b$, p. 123).

As soon as the young are grown both they and the parents congregate in large flocks and fly from feeding ground to watering place, thus affording a good chance at wing shooting. One evening in twenty minutes I counted orer $700 \mathrm{fly}$ past a bridge over a small irrigating canal. Along in August the big flocks begin to grow less, the birds probably seattering out and seeking feering grounds more distant from the breeding grounds. Toward the first of September they begin to thin ont in earnest and by the 15 th of the month very few are seen....

Beside the danger from gumer, the Cooper Hlawk is a menace, feeding often on the fat pigeon. I have seen a Marsh Hawk after a [wounded] White-wing . . . but do not think any hut wounded biris are ever attacket by this speeies (Gilman, loe. eit.).

In this bird, the gumner has a good test of his skill, as it flies rapidly, and, all things considered, is a fine game bird.

As the White-winged Dove is an essentially Mexiean speeies, it will probably never take an important rank among the game birds of California. Its restriction to the extreme southeaster'n portion of the state and its apparently late spring arrival and early fall departure limit its pursuit for sport to a very small number of hunters. Protection during the breeding season, and moderate hunting just previous to its departure, should ensure the persistence of this bird in its present numbers indefinitely.

\section{Mexican Ground Dove}

\section{Chaemepelia passerina pallescens Baird}

OTHER NAMES-Columbigullina passerina pallescens: Columbigallina passerinu: Chaemepelia passerina.

Description-Adult male: Forehead and sides of head, pale pinkish brown, continuous with tone of lower surface; top and hack of head, and hind neek, ehiefly bluish gray, with feather tippings of dusky, giving a decidedly sealed effect; chin and throat, pinkish white; bill "yellow... tipped with brown", (Baird, Brewer and Ridgway, 1874, III, p. 390); back, rump, upper tail coverts and central pair of tail feathers, uniform brown; outer tail feathers, slate gray at upper bases, broadly tipped with black at ends, entirely blackish brown ou under surfaces; outermost pair of tail feathers narrowly edged with white at ends; outer surface of elosed wing pale pinkish brown; greater coverts grayish pink: outer webs of primaries and outernost secondaries, blackish brown, their inner webs extensirely rich rusty brown, except for blackish tips; exposed tertials brown, like back, several of the eoverts and tertials bearing short, sharp streaks 
and spots of deep brown with blue and purple irideseence; whole under surface of wing and axillars, rich rusty hrown; throat and forepart of breast, pale pinkish brown, with half-concealed dusky feather centers and faintly darker feather tippings giving a sealed effect: rest of breast and forepart of belly plain pale pinkish brown, becoming nearly white on lower belly, and grading to gray on flanks and lower tail coverts; lower tail coverts tipped with dull white; legs and feet "yellow", (Baird, Brewer and Ridgway, loc. eit.). Adult female: Similar to adult male lut paler, lacking bluish slate on top) and back of head and neck (this being replaced by brown like back), breast pale drah rather than pinkish, and dark spots on outer surface of wing more brownish, and but slightly iridesceut. Males: Total length $6.62-6.87$ inches (168-174.5 mm.) (nine speeimens from Arizona); folded wing 3.25-3.56 (82.5-90.4); bill along euhnern 0.43-0.46 (11.011.7) ; tarsus 0.59-0.64 (15.0-16.2) (ten specimens from Arizona and ('alifornia). Females: Total length $6.56-6.87$ (166.5-174.5) (three specimens from Arizona); folded wing $3.24-3.42$ ( $92.2-86.7)$; bill along eulmen $0.43-0.47$ (11.0-12.0): tarsms $0.61-0.66$ (15.6-16.8) (eight specimens from Arizona and California). Tuxenile mumage: Similar to adult female but duller, the feathers of upper surface narrowly tipped with white or rusty, and feathers of breast with much paler centers.

MARKS FOR FIELD IDENTIFICATION-Smallest of the pigeon tribe oecurring in California; only about one-quarter the size of the Mourning Dove and but a trifle larger than an English Sparrow; general eoloration giving an effect of browness, without any eontrasting white areas; vivid rusty brown showing on vings in flight.

Vorce-A single long-drawn-ont $x^{\circ}(0)$, uttered at short intervals (Gilman, 1911, P. 54$)$.

NEST-In hushes or trees, at heights from two and one-lalf to twenty-five feet (0.76 to 7.6 meters) above ground; for a dove, fairly well constructed; of rootlets and small twigs, sometimes with a derided depression in the eenter (Gilman, 1911 , p. 5.5, writing from Arizona).

Egas-2, elliptical oval, measuring in inches, 0.79 to 0.91 by 0.63 to 0.69 (in millimeters, 20.0 to 23.0 by 16.0 to 17.5$)$, and averaging 0.8 .5 by 0.6 .5 ( 21.5 by 16.5) (fifty-four eggs in the Lnited States National Museum); in color pure white (Davie, 1900, p. 190).

Gexeral Distributiox-From Costa Rica north to middle southem Texas, southern Arizona, Lower California and extreme southeastern California; oceasional in western California nortl to San Franciseo (nodified from A. O. U. (heck-list, 1910, p. 150).

Distribution in CALiforia-Resident locally in small numbers in the extreme sontheastern corner of the state in the valley of the lower Colorado River; has cccurrel casually in the western part of the state at the following places: San Diego, Escondido and San Pasqual, San Diego County; Banning, Riverside County; San Gabriel, Los Angeles County; Monterey and Castroville, Montere County; Pescadero, San Mateo County; and San Francisco.

The Mexican Ground Dove is the smallest member of the pigeon family known to occur in California and, in fact, is among the smallest of its kind anywhere in the world. Its diminutive size would searcely. lead one to place it among the pigeons and doves, but its voice, habits and nesting, as well as its structure, all show it to be a member of that large and widely distributed family. 
Heretofore this species has been eonsidered to be of but casual oecurrence in California, but recent observations prove it to be regularly present locally in the extreme southeastern portion of the state along the lower Colorado River. Stephens (1903, p. 77 ) secured one of these birts on the California side of the river below Ehrenburg in August, 1902, while Ifowell and Tan Rossem (1915, p. 233) saw more than a dozen near Fort Y uma in Jamuary, 1913. More reeently, December 6 and 9, 1914, Leo Wiley (MS) saw birds of this speeies near Palo Verde, Imperial County, and eollecterl one on the first named date (specimen in Mus. Vert. Zool.): and in the following summer (1915) he found them breeding there in small numbers. Elsewhere in the state it has ocemred as follows: San Diego, November 10, 1915, one shot (Grey, 1916, 1. 83) : Escondido, San Diego County, June 29, 1915, one taken (Dixon, 1916, p. 84) ; San Pasqual, San Diego Comnty, one shot about 1900, and Banning, Riverside County, October, 1902, one taken (Willett, 1912a, p. 45); San Gabriel, Los Angeles Comnty, several shot a few years previous to 1870 (Baird, Brewer and Ridgway, 1874, III, p. 522); Monterey "taken' (ibid., p. 390) ; Castroville, Monterey County, one taken in June, 1913 (Silliman, 1915b, p. 207) : Pescadero, San Mateo County, one taken from flock of eleven, February 27, 1898 (Littlejohn, 1899, p. 73) ; and San Franeiseo, May, 1870, one killed (Baird, Brewer and Ridgway, 1874, III, p. 522). These are all irregular occurrences. 'vidently of birds wandering beyond the bounds of their normal habitat: so far as is known. such fortuitous dispersal has not led to the establishment of permanent colonies. Judging from the records already made, we may expect this dove to ocen from time to time at almost any place in the coastal region, north at least to San Francisco.

The Mexican Ground Dove is an easy speeies to identify. Its very sulall size-but slightly greater than that of an English Sparrow or Least Sandpiper-its general brown-appearing coloration, its square tail and the absence of any contrasted white markings easily separate it from all others of its family in the sonthwest. The Inea Dove of Arizona and Mexico, which may at some future date be found in California, is of somewhat greater size [total lengtl 8.00 inehes; folded wing $3.70-3.75$; tail 4.00-4.40, as compared with tail 2.60 to 2.80 in the Ground Dove (Ridgway, 1900, pp. 215, 216) ] and has eonspicuous white margins on the slightly rounded tail, and a definite scaled pattem of markings on the body feathers.

Of the Ground Dove in southern Alizona, Gilman (1911. Pr. 54-55) writes :

He might properly be called the "woo-woo bird," as his note is a single "woo"' long drawn out and uttered at short intervals. The somnd is very misleading, even to a greater extent than that of the Mourning Dove. The first time 
I heard it I started to eross a ten-acre field to search for the bird in some trees on the far side. I had gone but a few yards when the dove flew from a frnit tree about three rods away, where he had been the entire time.

These little doves are not very gregarious in this loeality, but that may be because they are present only during the breeding season. Three is the most I have seen in a group and that not often. Usually two are together, probably mates. They are rather quiet and the call is not heard often. . . They do not appear to go far from cultivatel fields, in fact I have never seen them out on the desert, as is the ease with the two larger loves [Mourning and Whitewinged]. They are most frequently seen near the river or along irrigating ranals, and nest in such locations...

The nesting season is late, as the earliest nest fomd was on July 7 and contained one half-grown young bird. This nest was in a pear tree and placed only two and a half feet from the ground.

Other nests were found as follows: July 16, two quarter-grown young; July 17, two half incubated eggs ; September 3, two half-grown roung; September 25, two eggs advanced in incubation: October 8 . two nearly fresh eggs. This latter set hatched on October 16, but the young were dead two days later.

Nests ranged from two and a half to twenty-five fect from the ground, with an average of ten feet. In regard to location, two were in cottonwoods, two in pear trees, one in a willow and two in the shrub Baceharis.

The nests are fairly well made for doves and are composed mostly of rootlets and small twigs. One nest rather more pretentious than usual was made of rootlets, grass stems and blades, leaf stems with veins attached, small twigs, horse hair and a few feathers. It was compact and fairly well made, with a decided cup in the center measuring nearly an inch deep, and two inches across from rim to rim. One was an old nest revamped, and another was merely a superstructure over an old Abert Towhee's nest. The rery late date before mentioned probably pertained to a second brood, as the nest was an old one re-lined, possibly a last year's nest, but more likely an earlier nest of the same year.

These doves are rather wild when on the nest and will not allow any familiarity. They rarely show any tendency to use the broken-wing tactics, though one did and made a most realistic performance of it. She fell from the nest when I was about eight feet distant and lay with quivering and beating wings. As I stepped closer she made ineffectual attempts to fly and fluttered along the ground at my feet just ont of reach. She kept this up for about fifty yards before taking to flight. I then went on about my business after ascertaining that the nest contained two newly hatehed young. Coming back an hour later, I scared her off the nest again and she repeated the performance but in a rather half-hearted way as though she did it from a sense of duty and rather doubted the efficacy of it (Gilman, loc. cit.).

Near Palo Verde, Imperial County. Leo Wiley (MS) found three or four pairs of Ground Doves nesting during the summer of 1915. One nest was situated five feet eight inches above the ground in a clump of mistletoe in a mesquite. A nest found by Bendire (1892, pp. 150-152) near Tueson, Arizona, May 30, 1873, measured four and one-half inches in diameter and was "almost perfectly flat." Other 
nests examined by lin were plaeed in both bushes and trees at heights from three to twenty-one feet above ground. He believed that these birds rear two and perhaps three broods in a season. despite the fact that the nesting season does not begin until the end of Nay. Inenbation lasts about fourteen days and both sexes take part in the work. The young are fed on small seeds and berries of different kinds, and grain when procurable. Gravel is takm in considerable quantities to assist in grinding np the seeds. Bendire belieres these birds mate for life.

Ground Doves are sometimes seen in the streets of towns and especially about corrals. Flocks of ten to twelve are commonest, but in the fall months as many as fifty may join together to feed on the ripe weed and grass seeds. During the winter months they are markedly fewer in numbers, and are then to be seen only in pairs.

Within California the Mexican Ground Dove will probably never be very abundant, although with the inerease of agrieulture in the extreme southeastern portion of the state the birds may be expeeted to appreeiably inerease in numbers. Their small size should, however, gain them protection from the gun of the hunter, who ean, for the present at least, find ample opportunity for sport among the larger game birds. 


\section{LITERATURE CITED}

ADAMS, E.

A

1900. Notes on the California Clapper Rail. Conilor, vol. 2, pp. 31-32, 1 fig. in text.

AlLeN, C. A.

1881. Collecting on the Pacific Coast. Ornithologist and Oologist, vol. 6, pp. 18-19.

American Ornithologists' Union Commitee.

1910. Check-list of North American birds, 3rd edition. (New York, American Ornithologists' Union), 430 pp., 2 maps.

1912. Sixteenth supplement to the American Ornithologists' Union rheeklist of North American birds. Auk, vol. 29, pp. 380-387.

Anderson, M. P., and Grinneli, J.

1903. Birds of the Siskiyou Mountains, California: a problem in distribution. Proc. Acad. Nat. Sei. Phila., 1903, pp. $4-15$.

Anderson, M. P., and Jeñins, H. O.

1903. A list of birds from the Santa Cruz Mountains, Califormia. Condor, vol. 5, pp. 153-155.

Anonymous.

1907. What will it be used for? Western Field, rol. 11, p. 208.

Anonymous [ $=$ C. F. Hodge].

1914. The Ruffed Grouse. How to rear this shy bird in eaptivity and some of its habits. Oregon Sportsman (Portland, Oregon), rol. 2, March, 1914, pp. 3-9, 4 figs. in text.

ANThoNT, A. W.

1896. Clangula hyemalis at San Diego, California. Ank, vol. 13, p. 172.

Askins, C.

1911. Speed of game birds. Outing, vol. 57, pp. 556-560, 2 figs in text.

Audubon, J. J.

1840-1844. The birds of America, from drawings made in the United States and their Territories. 7 vols. (Philadelphia, J. B. Chevalier), vol. V, 1842, pp. viii $+9-346$, pls. 281-350, several figs. in text; vol. VI, 1843, pp. viii $+9-457$, pls. $351-420$, several figs. in text.

BACON, S. E., Jr.

B

1892. Old Squaw (Clangula hiemalis). Ornithologist and Oologist, vol. 17, p. 45.

BAILEY, F. M.

1902. Handbook of birds of the western United States. (Boston, Houghton Mifflin Co.), pp. xe $+1+514,36$ pls., 601 figs. in text.

1915. Characteristic birds of the Dakota prairies. I. In the open grassland. Condor, vol. 17, pp. 173-179.

1916a. Characteristic birds of the Dakota prairies. IV. On the lakes. Condor, vol. 18, pp. $54-58$.

1916b. A populous shore. Condor, vol. 18, pp. 100-110. 
B.Ird, S. F., Brewer, T'. M., and RidGwax, R.

1874. A history of Nortl American birds. Land birds. 3 vols. (Boston, Little, Brown, and Co.), vol. III, pp. $6+560+$ xxviii, pls. lvii-lxiv, many figs, in text.

1884. The water birds of North America. 2 vols. (Boston, Little, Brown, and Co.), vol $1, p p$. $x i+537$; vol. 2 , pp. $6+552$, many figs. in text. [E vols. 12 and 13, Memoirs Museum of Comparative Zoology, IIarvard College.]

Baird, S. F., Cassin, J., and Lawrence, G. N.

1858. Birds. Pacific Railroad Reports, vol. 9, part 2, pp. lvi $+1+1005$.

BARLOW, C.

1893. Nesting of the Mallard Duck. Nidiologist, vol. 1, p. 38, 2 figs. in text.

Barlow, C., and Price, W. W.

1901. A list of the land birds of the Placerville-Lake Tahoe stage roal, Central Sierra Nevada Mountains, Cal. Condor, vol. 3, pp. 151-184, 11 figs. in text.

BARNHART, F. S.

1901. Evolution in the breeding habits of the Fulvous Tree Duck. Condor, rol. 3, pp. 67-68.

B.IRrows, W. B.

1912. Michigan bird life. (Michigan Agrieultural College, Ann Arbor, Mich.), Special Bulletin, Depts. Zool. and Physiol., Pp. xiv $+82 \cdot$, 70 pls., 152 figs. in text.

BARTSCH, [P.]

1901. Another instance of the Spotted Sandpiper (Actitis macularia) carrying its young. Osprey, vol. 5, pp. 143-144.

BEAL, F. E. L.

1904. Some common birds in their relation to agriculture. Revised edition. U. S. Dept. Agric., Farmers' Bulletin no. 54, 48 pp., 22 figs. in text.

1910. Birds of California in relation to the fruit industry. Part II. U. S. Dept. Agrie., Biological Survey, Bulletin no. 34, 96 pp., 6 pls.

Beск, R. H.

1907. Monterey Bay notes. Condor, vol. 9, p. 58.

1910. Water birds of the vicinity of Point Pinos, California. Proc. Calif. Acad. Sci., 4 th series, vol. 3 , pp. 57-72.

BELDING, L.

1879. A partial list of the birds of central California. Proe. U. S. National IIuseum, vol. 1, pp. 388-449.

1590. Land birls of the Pacific district. Calif. Acarl. Sci., Occasional Papers, no. 2, pl. $4+274$.

1891. Notices of some California birds. Zoe, vol. 2, pp. 97-100.

1892a. Geese which oceur in California. Zoe, rol. 3, pp. 96-101.

1592b. Food of the grouse and Mountain Quail of central California. Zoe, rol. 3, p). $232-234$.

1892c. On Numenius borealis in California. Zoe, vol. 3, p. 257.

1903. The fall migration of Oreortyx pictus plumiferns. Condor, vol. 5, p. 18.

1905. Plegadis guarana at Stockton, Cal. Condor, vol. 7, p. 112.

Bexplre, C.

1878. Notes on some of the birds found in southeastern Oregon, particularly in the rieinity of Camp Harney, from November, 1874, to January, 1877. Proc. Bost. Soe. Nat. Ilist., vol. 19, 1p). 109-149.

1892. Life listories of North Ameriean birds, with special reference to their breeding luabits and eggs. .. Smithsonian Contributions to Knowledge, rol. $28, \mathrm{pp} . \mathrm{x}+446,12$ pls. 
BENT, 1. C.

1901. Nesting habits of the Anatidae in North Dakota. Auk, vol. 18, pp. 328-336, pls. IV-VT.

1902. Nesting habits of the Anatidae in North Dakota. Auk, vol. 19, pp. 1-12, pls. II-IV; pp. 165-174, pls. V-V'T.

1907 a. The Marbled Godwit on its breeding grounds. Auk, vol. 24, pp. 160167 , pl. III.

1907b. Summer birds of southwestern Saskatchewan. Auk, vol: 24, pp. 407430 , pls. XVII-XX.

BetTeN, H. L.

1904. Snipe shooting. Western Field, vol. 4, pp. $265-270,5$ figs. in text.

BISHOP, L. B.

1900. Birds of the Inkon region, with notes on other species. U. S. Dept. Agric., Div. Biol. Surv., N. Amer. Fauna no. 19, pp. 47-96.

1905. Notes on a small collection of California birds with description of an apparently unrecognized race of Hutton's Vireo. Condor, vol. 7, pp. 141-143.

BLAKE, E. W., Jr.

1887. Summer birds of Santa Cruz Island, California. Auk, vol. 4, 1). $328-330$.

Bliss, W. D.

1893. Wilson 's Thalarope breeding in Califormia. /oe, vol, 4, p. 226.

BOLANDER. L.

1906. Whistling Swans. Condor, vol. 8, p. 7j.

1907. Birds observed from IIarysville to Grass Valley. Condor, vol. 9, pp. $22-27$.

1915. Early spring notes from west-central Califormia. Condor, vol. 17, p. 131.

BOND, F.

1900. A nuptial performance of the Sage Cock. Iuk, vol. 17, pp. 325-327, pl. XII.

Bowles, J. H.

1911. Notes extending the range of certain birds on the Pacifie slope. Auk, vol. 28, PP. 169-178.

Bowles, J. H., and Howell, A. B.

1912. The shore birds of Santa Barbara. Condor, vol. 14, pp. 5-11, figs. 1-4.

Breninger, G. F.

1897. An unusual nesting site. Osprey, vol. 1, p. 122.

BREWER, T. M.

1879. The Rocky Mountain Golden-eye (Bucepliala islandica). Bull. Nuttall Orn. Clul), vol. 4, pp. 148-152.

Brewster, W.

1879. Deseriptions of the first plumage in various species of North American birds. V. Bull. Nuttall Orn. Clul, rol. 4, pp. 39-46.

1881. Recent occurrence of Baird's Sandpiper (Tringa bairdi) in Maine. Bull. Nuttall Orn. Club, vol. 6, pl. 60-61.

1883. On a collection of lirds lately made by Mr. F. Stephens in Arizona. Bull. Nuttall Orn. Club, vol. 8, pp. 21-36.

1891. A study of Florida Gallinules, with some notes on a nest found at Cambridge, Massachusetts. Auk, vol. 8, pp. 1-7. 
1900. Notes on the breeding habits of the Ameriean Golden-eyed Duck or Whistler (Clangula clangula amerieana). Auk. vol. 17, pl. 207-216, pls. VI-VIT.

1902 a. Birds of the eaje region of Lower California. Bull. Mus. Comp. \%ool., Harvard College, rol. 41 , pp. 1-241, 1 map.

$1902 b$. Voices of a New England marsh. Bird-Lore, vol. 4, pp. 43-56, 7 figs. in text.

1907. Notes on the Black Rail of California. Auk, vol. 24, pp. 20.j-210.

1911. Courtship of the Ameriean Golden-eye or Whistler (Clangula clangula americana). Condor, vol. 13, pp. 22-30, fig. 15.

Brooks, A.

1899a. The Pintail. Recreation, vol. 11, p. 19, 1 fig. in text.

1899b. The Ringbill Duck. Recreation, vol. 11, p. 350, 1 fig. in text.

1903. Notes on the birls of the Cariboo District, British Columbia. Auk, vol. 20, pp. $277-284$, pl. X.

BRowN, H.

1906. The Water Turkey and Tree Dneks near Tneson, Arizona. Auk, vol. 23, pp. 217-218.

Bryar, W. A.

1903. A Turnstone (Arenaria interpres) taken in the mid-Paeific. Ank, vol. 20 , pp. $210-211$.

BrTANT, H. C.

1913. The results of some miscellaneons stomaeh examinations. Condor, vol. 15, pp. 92-93.

1914a. Birds as destroyers of grasshoppers in California. Auk, vol. 31, pp. 168-177, 4 tables.

1914b. More records of the Emperor Goose in California. Condor, vol, 16, p. 92.

1914e. Occurrence of the Black-bellied Tree-duck in California. Condor, vol. 16, p. 94.

1914d. The Eastern Sea Brant in California. Condor, vol. 16, p. 183.

1914e. A survey of the breeding grounds of dueks in California in 1914. Condor, vol. 16, pp. 217-239, figs. 62-70.

1915a. Another record of the occurrence of the Emperor Goose in California. Condor, vol. 17, pp. 58-59.

$1915 \mathrm{~b}$. Two records of the nesting of the Wilson Snipe in California. California Fish and Game (San Franciseo, Cal.), vol. 1, pp. 76-77.

1915e. Nesting of the Sora and Virginia Rail in Alameda County. Calif. Fish and Gane (San Franciseo, Cal.), rol. 1, p. 194.

1915\%. Crude oil-a trap for birds. Califomia Fish and Game (San Franciseo, Cal.), vol. 1, p. 184.

1915e. At the end of the migration season. ('alifornia Fish and Game (San Franciseo, Cal.), vol. 1, pp. 192-194.

1916. Habits and food of the Roadmmner in Califomia. Univ. Calif. Publ. Zool., vol. 17, pp. 21-58, pls. 1-4, 2 figs. in text.

BRIANT, W. E.

1880. Totes on the habits of Rallus obsoletus, with a deseription of its eggs. Bull. Nuttall Orn. Club, vol. 5, pp. 124-125.

1886. Additions to California avifuuna. Forest \& Strean, vol. 26, p. 426.

1887a. Piranga rubriceps and Tringa fuscicollis in California. Auk, vol. 4, p). 78-79.

1s57\%. Unusual nesting sites. I. Bull. Calif. Acal. Sci., vol. 2. p]) 451-454.

1888. Birds and eggs from the Farallon Islands. Proe. Calif. Acarl. Sei., 2 d series, vol. 1, pp. $25-50$.

1889. A catalogue of the birds of Lower California, Mexieo. Proc. C'alif. Aear. Sei., 2d series, vol. 2, pp. 237-320, 1 map. 
1890. An ornitlological retrospect. Zoe, rol. 1, pp. 289-293.

1891. Notices of certain Californian birds. Zoe, vol. 2, p. 128.

1893a. Notes on the food of birds. I. Zoe, vol. 4, pp. 54-58.

1893b. Occurrence of Clangula hyemalis in California. Zoe, vol. 3, p. 363.

BURNETT, L. E.

1905. The Sage Grouse, Centrocereus urophasianus. Condor, vol. 7, pp. 102$105,1 \mathrm{fig}$. in text.

BURT, H. C.

1911. An early spring trip to Anacapa Island. Condor, vol. 13, pp. 164-167, fig. 47 .

\section{California Fisil Comaissioners.}

\section{C}

1894. Thirteenth biennial report of the State Board of Fish Commissioners of the State of California for the years 1893-1894. (Sacramento, State Printing Office), 143 pp., illustrated.

1896. Fourteenth biennial report ... 1895-1896. Ibid., 108 pp., illustrated. 1900a. Fifteenth biennial report . . 1897-1898. Ibid., 75 pp., illustrated.

1900b. Sixteenth biennial report . . 1899-1900. Ibid., 45 pp.

1902. Seventeenth biennial report . . 1901-1902. Ibid., 76 pp., illustrated. 1904. Eighteenth biennial report . . . 1903-1904. Ibid., 112 pp., illustrated. 1907. Nineteentl biennial report . . 1905-1906. Ibid., 112 pp., illustrated. 1910. Twenty-first biennial report ... 1909-1910. Ibid., 72 pp., illustrated.

California Fisit and Game Commissioners.

1913. State of California Fish and Game Commission twenty-second biennial report for the years 1910-1912. (Sacramento, State Printing Office), $80 \mathrm{pp}$., illastrated.

1914. Twenty-third biennial report . . . 1912-1914. Ibid., 166 pp., illustrated.

Cameron, E. S.

1907. The birds of Custer and Dawson counties, Montana. Auk, vol. 24, pp. 241-270, pls. V-XII, pp. 389-406, pls. xv-xvi.

CARriger, H. W.

1899. The Yellow Rail and Saw-Whet Owl in Sonoma Co., Cal. Bull. Cooper Orn. Club, vol. 1, pp. 72-73.

CAssin, J.

1862. Catalogue of birds collected by the United States North Pacific Surveying and Exploring Expedition, in command of Capt. John Rodgers, United States Nary, with notes and deseriptions of new species. Proc. Acad. Nat. Sei. Plilia., 1862, pp. 312-328.

CAton, J. D.

1887. The origin of a small race of turkeys. American Naturalist, vol. 21, pp. $350-354$.

Chambers, W. L.

1901. Curious nest of Anna's Hummingbird. Condor, vol. 3, p. 105.

1904. The Snowy Plover. Condor, vol. 6, pp. 139-140.

1912. Who will save the Band-tailed Pigeon? Condor, vol. 14, p. 108.

1914. Hooded Merganser near Los Angeles. Condor, vol. 16, p. 92.

Chapman, F. M.

1905. The feeding habits of the Northern Phalarope. Bird-Lore, vol. T, pp. 273-274, 2 figs. in text.

1908. Camps and cruises of an ornithologist. (New York, D. Appleton and Co.), pp. xvi $+432,250$ illus.

1912. Handbook of birds of eastern North America. (New York, D. Apple. ton and Co.), pp. xxix $+530,24$ pls., 136 figs. in text. 
[CHilds, J. L.]

1907. Eggs of the Santa Catalina Partridge (Lophortyx catalinensis. Grinnell). The Warbler (Floral Park, N. Y.), vol. 3, p. 1.

CLARK, A. H.

1910. The birds collected and observed during the cruise of the United States Fisheries Steamer "Albatross"' in the North Pacific Ocean, and in the Bering, Okhotsk, Japan, and Eastern seas, from April to Decenber, 1906. Proc. U. S. National Museum, vol. 38, pp. 25-74.

Clark, P. G.

1905. In favored San Joaquin. Western Field, vol. 6, pp. 110-112, 5 figs. in text.

Clark, F. C.

1913. Preliminary report upon the disease occurring among the ducks of the southern San Joaquin Valley during the fall of 1913. Condor, vol. 15 , pp. $214-226$, figs. $66-77$.

COALE, H. K.

1915. The present status of the Trumpeter Swan (Olor buccinator). Auk, vol. 32 , pp. $82-90$, pls. VII-X.

COHEN, D. A.

1896. California Department [Red Phalaropes killed by flying against wires]. Osprey, vol. 1, pp. 1t-15.

Cooke, W. W.

1906. Distribution and migration of North American ducks, geese, and swans. U. S. Dept. Agric., Biol. Surv., Bull. no. 26, 90 pp.

1910. Distribution and migration of North American shorebirds. U. S. Dept. Agric., Biol. Surv., Bull. no. 35, 100 pp., 4 pls.

1913. Distribution and migration of North American herons and their allies. U. S. Dept. Agric., Biol. Surv., Bnll. no. 45, 70 pp., 21 figs. (maps) in text.

1914. Distribution and migration of North American rails and their allies. U. S. Dept. Agric., Bull. no. 128, 50 pp., 19 figs. (maps) in text.

COOPER, J. G.

1868. Some recent additions to the fauna of California. Proc. Calif. Acad. Sci., vol. 4, pp. 3-13.

1869. The naturalist in California. American Naturalist, vol. 3, pp. 182-189.

1870a. Ornithology of California. Vol. I. Land birds. (Cambridge, Mass., Geol. Surv. Calif.), pp. xi +592 , many figs. in text.

1870b. The famna of California and its geographical distribution. Proc. Calif. Acad. Sei., vol. 4, pp. 61-81.

1877. On seventy-five doubtful west-coast birds. Bull. Nuttall Orn. Club, vol. 2 , pp. $88-97$.

1880. On the migrations and nesting habits of west-coast birds. Proc. U. S. National Museum, vol. 2, pp. 241-251.

1886. The 'Water birds of North America'-a few corections. Auk, vol. 3, pp. 124-126.

1887. Additions to the birds of Ventura Connty, California. Auk, vol. 4, pp. $85-9.4$.

Cooper, J. G., and RidgwiY, R.

1586. The 'Water birds of North America'-explanations. Auk, vol. 3, pp. 401-404.

Cooper, J. G., and Suckler, G.

1859. The natural history of Washington Territory, with much relating to Minnesota, Nebraska, Kansas, Oregon, and California ... (New York, Bailliere Bros.), pp. $x+8+399,62$ pls., 1 map. 
Coues, E.

1869. Sea-side homes: and what lived in them. American Naturalist, vol. 3, pp. $337-349$.

1874. Birds of the Northwest: a hand-book of the ornithology of the region drained by the Missouri River and its tribntaries. U. S. Geol. Surv. of the Territories, Misc. Publ., no. 3, pp. xi +791 .

Crosbr, F. H.

1912. The gamy valley quail. California's contribution to American gamebirds an elusive and interesting little fellow. Onting, vol. 60, pp. 309-313.

Cumans, E. S.

1888. The habits of California quail. Onting, vol. 12, pp. 50-56, 7 figs. in text.

DAgGetT, F. S.

D

1901. Stragglers in southern California. Condor, vol. 3, p. 15.

1903. Wood Ibis in southern California. Condor, vol. 5, pp. 18-19.

DAVIE, O.

1889. Nests and eggs of North American birds. 4th edition (Columbus, Ohio, Hahn and Adair), pp. $10+455+$ xii, 13 pls.

1900. Nests and eggs of North American birds. 5th edition (Philadelphia, David MeKay), pp. $8+509+15+$ xii, frontisp., 5 pls., numerous figs. in text.

DAWSON, W. L.

1909. The birds of Washington. 2 vols. (Seattle, The Oecidental Publishing (o.), vol. I, pp. xv $+1+1-458$; rol. II, pp. iii $+459-997$, numerons full-page (inserted) plates and over 300 text illustrations.

1911. Inother fortnight on the Farallones. Condor, vol. 13, pp. 171-183, figs. $49-\tilde{5} 4$.

1912. Recent Santa Barbara records. Condor, vol. 14, pp. 223-224.

1913a. A glimpse of Surf-birds. Condor, vol. 15, pp. 5-8, figs. 1-6.

1913b. Identification by camera. Condor, vol. 15, pp. 204-205, figs. 57-58.

1915. Limicoline laggards at Santa Barbara. Condor, vol. 17, p. 207.

1916. A personal supplement to the distributional list of the birds of California. Condor, vol. 18, pp. 22-30.

DEAN, W. F.

1904. A few notes on bird life at Three Rivers, Tulare Co., Cal. Condor, vol. 6 , pp. 110-111.

DiRks, W. 亡..

1916. Green-winger Teal nesting in Alameda County. Calif. Fish and Game (San Francisco, Cal.), vol. 2, p. 46.

Dixox, J,

1906. Land birds of San Onofre, California. Condor, vol. 8, pp. 91-98.

1912. White-minged Dove in the San Diegan district. Condor, rol. 14, p. 196.

1916. Mexican Ground Dove, Western Grasshopper Sparrow, and California Cuckoo at Escondido, San Diego County, California. Condor, vol. 18, pp. $83-84$.

Dresser, H. E.

1902-1903. A manual of Palaearetic birds. (London, published by the author), pp. vii $+15+922$, 2 pls.

1904. On the late Dr. Walter's ornithological researches in the Tainyr Peninsula. Ibis, 8 th series, vol. 4, pp. 228-235.

DwIGHT, J., Jr.

1904. Occurrence of the Knot (Tringa canutus) at San Diego, California. Auk, vol. 21, pp. 78-79. 
EAtox, E. H.

1910. Birds of New York. (Albany University of the State of New York), New York State Museum, Memoir 12, Part 1, 501 pp., 42 pls., numerous tables of local occurrence and mmumbered figs. in text.

Eifrig, C. W. G.

1905. Ornithological results of the Canadian 'Neptune' Expedition to Hudson Bay and northward, 1903-1904. Ank, vol. 22, pp. 233-241.

ELio'T, D. G.

1895. North Ameriean shore birds. (New York, Francis P. Harper), pl. xvi + 17-268, 74 unmumberes pls.

EMerson, W. O.

1885. Californian Clapper Rail (Rallus obsoletus). Ornithologist and Oologist, vol. 10, pp. 142-143.

1900. Oceurrence of American White Pelican and the Ameriean Arocet at Haywards, Cal. Condor, vol. 2, p. 34.

1901. Nesting of Spatula elypeata. Condor, vol. 3, p. 116.

1904. Destruction of birds by wires. Condor, vol. 6, pp. 37-38.

Evermann, B. W.

1886. A list of the hirds observed in Ventura County, California. Ank, vol. 3, pp. 86-94, 179-186.

FEILDEN, H. W.

1877. List of birds observed in Smitl Somud and in the Polar Basin Inring the Aretic Expedition of 1875-76. Ibis, 4th series, vol. 1, pp. 401-412.

FFILNER, J.

1865. Exploration in Upper California in 1860, nnder the auspices of the Smithsonian Institution. Anmual Report Snithsonian Institution, 1864, Pp. $421-430$.

F'ERT, J. F.

1908. Notes from the diary of a maturalist in northern California. Condor, vol. 10,1 l. $30-44,2$ figs. in text.

FEUdGe, J. B.

1903. The Wood Ibis near San Bernardino. Condor, vol. 5, 1) 79.

Field, G. W., Grainas, G. H., and Adans, W. C.

1914. Special report of the Board of Commissioners on Fisheries amd Game, under Chapter 70 of the Resolves of 1913 , relating to the habits of those birds commonly known as pheasants. Commonwealth of Massaclinsetts, House [Document] no. 2049, January, 1914, $14 \mathrm{pp}$.

Fisher, $₫$. K.

1893a. Report on the ornithology of the Death Valley Expedition of 1891, comprising notes on the birds observed in sonthern California, southern Nevada, and parts of Arizona and Utalı. U. S. Dept. Agrie., Div. Orn. and Mamm., N. Amer. Fauma no. 7, pp. 7-158.

$1893 \mathrm{~b}$. The hawks and owls of the United States in their relation to agrieulture. U. S. Dept. Agric., Div. Orn. and Mamm., Bull. no. 3, 210 pp., 26 pls.

Fislier, W. II.

1902a. A trip to Mono Lake, ormithologieal and oflerwise. Condor, vol. 4, pI. 1-11, 11 figs. in text.

1902b. The redwood belt of northwestern Califoria. II. Land birds. Condor, rol. 4, pp. 131-135.

1904. Aythya collaris in San Mateo Co., California. Condor, vol. 6, p. 25. 
Forbush, E. H.

1912. A history of the game birds, wild-fowl and shore birds of Massachusetts and adjacent states. (Boston, Massachusetts State Board of Agriculture), pp. xvi $+1+622$, frontispiece, 36 pls., numerous cuts and 26 figs. in text.

1913. Useful birds and their protection. 4th edition (Boston, Massachusetts State Board of Agriculture), pp. $\mathbf{x x}+451$, frontispiece, 60 pls., 171 figs. in text.

1916. The natural enemies of birds. Massachusetts State Board of Agrienlture, Economic Biology-Bulletin no. 3, 59 pp., illustrated.

Foster, H. E.

1915. Whistling Swans in the Sacramento Valley. California Fisl and Game (San Franciseo, Cal.), vol. 1, p. 132.

Fowler, F. H.

1903. Stray notes from southern Arizona. Condor, vol. J, ly. 68-71.

Gallowar, J. C.

G

1895. A half-hour with Wilson's Snipe. Nidiologist, vol. 2, p. 86.

G.MIBEL, W.

1849. Remarks on the birds observed in Upper California, with deseriptions of new species. Jour. Acad. Nat. Sci. Phila., 2nd series, vol. 1, pp. 25-56, 215-229, pls. VIII-IX.

G.AYLORD, H. A.

1899. Spring migration of 1896 in the San Gabriel Valley. Bull. Cooper Orn. Club, vol. 1, pp. 7-8.

Gilmax, M. F.

1903. More about the Band-tailed Pigeon (Columba fasciata). Condor, vol. 5, pp. 134-135.

1907. The Gamlel Partridge in California. Condor, vol. 9, pp. 148-149.

1911. Doves on the Pima Reservation. Condor, vol. 13, pp. 51-56.

Goldanis, E. A.

1908a. The Green-winged Teal (Nettion carolinensis) breeding in California. Condor, vol. 10 , p. 129.

19086. Summer birds of the Tulare Lake region. Condor, vol. 10, pp. 200-205.

Goss, N. S.

18.91. History of the birds of Kansas. (Topeka, Kans., Geo. W. Crane \& (o.), pp. $692+1,35$ pls.

GreY, H.

1915. Bird notes from British Columbia and sonthern California. Condor, vol. 17, p. 59 .

1916. Mexiean Gromnd Dove at San Diego. Conrlor, vol. 18, p. 83.

GrixnelL, J.

1897. Report on the birds recorded during a visit to the islands of Santa Barbara, San Nicolas and San Clemente, in the spring of 1897. Pasadena Academy of Sciences, Publication no. I, 26 plp.

1898. Birds of the Pacific slope of Los Angeles County. Pasadena Academy of Sciences, Publication no. II, $52 \mathrm{pp}$.

1900. Birds of the Kotzebue Sound Region, Alaska. Cooper Ornithological Club, Pacific Coast Avifauna no. 1, pp. $6+80,1$ map.

1902a. Check-list of California birds. Cooper Ornithological Club, Pacific Coast Avifauna no. 3, 98 pp., 2 colorel maps. 
1902b. The Wilson Plover in Califormia. Auk, vol. 19, P. 197.

1904a. Midwinter birds at Palm Springs, California. Condor, vol. 6, pl. 40-45.

1904b. European Widgeon in southern California. Auk, vol. 21, pp. 383-384.

1905. Summer birds of Mount Pinos, California. Aık, rol, 22, pp. 378-391.

1906a. The Catalina Island Quail. Ank, vol. 23, PT. 262-265.

1906b. The Woor Duck in southern California. Condor, vol. 8, p. 29.

1908. The biota of the San Bernardino Mountains. Unir. Calif. Publ. Zool., vol. 5, pl. 1-170, pls. 1-24.

1909 . Two waders of note from Santa Catalina Island. Condor, vol. 11, 1. 139.

1909b. Birds and mammals of the 1907 Alexander Expedition to southeastern Alaska. The Birds. Univ. Calif. Publ. Zool., vol. 5, pp. 181-244.

1910. Birds of the 1908 Alexander Alaska Expedition with a note on the avifaunal relationships of the Prince William Sound district. [Tniv. Calif. Publ. Zool., vol. 5, pp. 361-428, pls. 32-34, 9 figs. in text.

1913. The outlook for eonserving the Band-tailed Pigeon as a game bird of California. Condor, vol. 15, pp. 25-40, fig. 7 (map).

1914a. A second list of the birds of the Berkeley campus. Condor, vol. 16, 1). 28-40.

1914b. An account of the mammals and birds of the lower Colorario Valley with especial reference to the distributional problems presented Univ. Calif. Publ. Zool., vol. 12, pp. 51-294, pls. 3-13, 9 figs. in text.

1975. A listrihutional list of the birds of California. Cooper Ornitholog. ieal Club, Pacific Coast Avifamna no. 11, 217 pp, 3 pls.

Grinnei.I, . ., and Swarth, H. S.

1913. An aceount of the birds and mammals of the San Jacinto area of sonthern California. Univ. Calif. Puhl. Zool., vol. 10, pp. 197-406, pls. 6-10, 3 figs. in text.

IIAL.I, H. M., and HaLL, C. C.

\section{$\mathrm{H}$}

1912. A Tosemite flora (San Franeisco, Paul Flder \& Co.), pp. vii + 282, 11 pls. (unmumberef), 170 figs. (unnumbered) in text.

HanNa, W. C.

1907. Notes from Colton, California. Conilor, vol. 9, p. 198.

HAYNES. W. B.

1900. The Old Squaw Duek. Wilson Bulletin, vol. 12, no. 32, pp. 12-13.

НЕАTH, H.

1915. Birds olserved on Forrester Tsland. Alaska, during the summer of 1913. Conitor, vol. 17, pp. 20-41, figs. 10-18.

Hedperly, E. I,

1912a. The spring season opens. Western Field, vol. 19, pl. 485-491.

1912b. A month's shonting in review. Western Field, vol, 20, pp. 44-59.

1912r. Valley Quail in eaptivity. Western Field, vol. 19, 1. 309.

HEERMANN, A. T,

1859. Report upon lirds collected on the Snrvey. Pacifie Railroar Reports, vol. 10 , part $6, n 0.2, \mathrm{pp}, 29-80,7$ pls.

HELI,ER, E.

1901. Notes on some little-known hirds of soutlern California. Coudor, vol. 3, p. 100. 
Hexshaw, H. W.

1576. Report on the ornithologr of the portions of California visited during the field-season of 1575 by H. W. Henshaw. Ann. Rep. upon the Geog. Surv. west of the 100th Meridian, in California, Nevada, Utal, Colorado, Wyoming, New Mexico, Arizona, and Montana. Appendix HS of Appendix JJ, pp. 224-278.

1850 a. The King Eider (Somateria spectabilis) on the Californian Coast. Bull. Nuttall Orn. Club, vol. 5, p. 189.

1s50b. Ornithological report from observations and collections made in portions of California. Nevada, and Oregon, by Assistant H. W. Henshaw. Ann. Rep. Geog. Surv. West 100th Meridian by George M. Wheeler; Appenclix L of Appendix OO of Ann. Rep. of Chief of Engineers for 1879 , pp. 282-335.

19S3. Instance of semilomestication of California Quail. Bull. Nuttall Orn. Club, vol. S. pp. 184-185.

Hrxman, B. C.

1903. On southern marshes. Nestern Field, rol. 2, p. 179.

HOLTERHOFF, G.

1584. Eskimo Curlew at San Diego, Cal. Auk, vol. 1, p. 393.

1555. The Glossy Ibis and Arocet at San Diego, Cal. Auk, rol. 2, pp. $311-312$.

Hoover, T. J.

1599. The gopler snake as a lespoiler of quails' nests. Bull. Cooper Orn. Club, vol. 1, p. 75.

HORNADAY, W. T.

1913. Our vanishing wild life (New York. New York Zoological Society), $\mathrm{xv}+1-411$ pl., numerous illustrations and maps.

HowELL, A. B.

1912. Unusual nesting date of Mourning Dove. Condor, vol. 14, pp. 73-74.

1914. Destruction of birds in California by fumigation of trees. Condor, vol. 16 , pp. $54-56$.

1915. California Pine Grosbeak in Mono County, and other notes. Condor, vol. 17 , p. 206.

Howell, A. B., and VAN Rossem, A.

1915. Additional observations on the birds of the lower Colorado Valley in California. Condor, vol. 17, pp. 232-234.

HuEx, L. M.

1913. With the Band-tailed Pigeon in San Diego County. Condor, vol. 15, pp. 151-153.

1916. The Farallon Rails of San Diego County. Condor, vol. 18, pp. 58-62, figs. $23-26$.

Huntington, D. W.

1897. The Sage Grouse. Osprey, vol. 2, pl. 17-18, 2 figs. in text.

1911. Our feathered game. A handbook of the North American game birds (New York, Charles Seribner's Sons), pp. xii $+396,29$ pls.

INGERSOLL, A. M.

\section{I}

1884. The Ruddy Duck and its nests. Ornithologist and Oologist, vol. 9, pp. 15-16.

1895. Wilson's Plover in California. Nidiologist, vol. 2, p. 87.

1909. The only known breeding ground of Creciscus coturniculus. Condor, vol. 11, pp. 123-127, 2 figs. in text. 
JENKINS, H. O.

\section{$\mathbf{J}$}

1906. A list of birds collected between Monterey and San Simeon in the coast range of California. Condor, vol. 8, pp. 122-130, 1 map.

JEWETT, S. G.

1914. Bird notes from Netarts Bay, Oregon. Condor, vol. 16, pp. 107-11j, figs. 34-38.

Јов, Н. К.

1899. Some observations on the Anatidae of North Dakota. Auk, vol. 16, pp. 161-165.

1915. Propagation of upland game-birds. (New York, National Association of Audubon Societies), Bull. no. 2, pp. 33-71, illustrated.

JUDD, S. D.

1901. The food of nestling birds. U. S. Dept. Agric., Yearbook, 1900, pp. 411-436, pls. xlix-liii, figs. 48-56.

1905. The Bobwhite and other quails of the United States in their economic relations. U. S. Dept. Agric., Bur. Biol. Surv., Bull. 21, 66 pp., 2 pls., 10 figs. in text.

KAEDING, H. B.

$\mathbf{K}$

1898a. [Note on occurrence of Black Rail in Alameda County, Cal.] Osprey, vol. 2 , p. 70 .

1898b. A summer in the Sierra Nevadas. Osprey, vol. 2, pp. 77-79.

1905. Birds from the west coast of Lower California and adjacent islands. Condor, vol. 7, pp. 105-111, 134-138.

KEEeler, C. A.

1892. On the natural history of the Farallon Islands. Birds. Zoe, vol. 3, pp. 154-165, pls. XVIII-XXI.

KELLOGG, L.

1911. A collection of winter birds from Trinity and Shasta counties, California. Condor, vol. 13, pp. 118-121.

1916. Report upon mammals and birds found in portions of Trinity, Siskiyou and Shasta counties, California. Univ. Calif. Publ. Zool., vol. 12, pp. 335-398, pls. 15-18, 1 fig. in text.

KeLls, W. L.

1895. The Black Turnstone. Nidiologist, vol. 2, p. 64 .

KENNERLY, C. B. R.

1859. Report on birds collected on the ronte. Pacific Railroad Reports, vol. 10, part 6, no. 3, pp. 19-35, 11 pls.

KEYES, C. R.

1905. Some bird notes from the central Sicrus. Condor, vol. 7, pp. 13-17, $42-43$.

КосH, F. W.

1893. Nesting of Gambel's Quail in the Colorado Desert. Ornithologist and Oologist, vol. 18, pp. 90-91.

LAMR, C. C.

\section{$\mathbf{L}$}

1909. The Knot in sonthern California. Condor, vol. 11, p. 208.

1912. Birds of a Mohave Desert oasis. Condor, vol. 14; pp. 32-40.

LAMB, C., and Howeli, A. B.

1913. Notes from Buena Vista Lake anıl Fort Tejon. Condor, vol. 1J, pp. $115-120$. 
LAw, J. E.

1912a. Wood Ibis near Long Beach. Condor, vol. 14, p. 41 .

1912b. The American Merganser at Lake Tahoe. Condor, vol. 14, pp. 41-42.

1914. Accidents to Spotted Sandpipers. Condor, vol. 16, p. 93.

LintoN, C. B.

1908a. Dafila aeuta breeding at Buena Vista Lake, Kern Co., California. Condor, rol. 10, p. 50 .

1908b. Notes from Santa Cruz Island. Condor, vol. 10, pp. 124-129.

1908c. Notes from Buena Vista Lake, May 20 to June 16, 1907. Condor, vol. 10, pp. 196-198.

1909. Further notes from San Clemente Island. Condor, vol. 11, pp. 193-194.

LITTLEJOHN, C.

1899. Three recorls for San Mateo Co., Cal. Bull. Cooper Orn. Club, vol. 1, p. 73.

1912. Rare takes for San Mateo County, California. Condor, vol. 14, p. 41 .

Loomis, L. M.

1895. California water birds. No. I. Monterey and vicinity from the middle of June to the end of August. Proc. Calif. Acad. Sci., 2nd series, vol. 5, pp. 177-224, pl. XIX.

1900. California water birds. No. V. Vicinity of Monterey in May and early Junc. Proc. Calif. Acad. Sci., $3 \mathrm{rcl}$ series, zoology, rol. 2, pp. $349-363$.

1901. The Oldsquaw at San Franciseo. Auk, vol. 18, p. 105.

MCATEE, W. L.

1905. The Horned Larks and their relation to agriculture. U. S. Dept. Agric., Biol. Surv., Bull. no. 23, 37 pp., 2 pls., 13 figs.

1911a. Our vanishing shorebirds. T. S. Dept. Agric., Bur. Biol. Surv., Cire. no. 79,9 pp., 3 figs. in text.

1911b. Three important wild duck foods. U. S. Dept, Agric., Bur. Biol. Surv., Circ. no. 81, 19 pp., 19 figs. in text.

1914. Five important wild duck foods. U. S. Dept. Agric., Bull. no. 58, 19 pp., 16 figs. in text.

McAtee, W. L., and Beal, F. E. L.

1912. Some common game, aquatic, and rapacious birds in relation to man. U. S. Dept. Agric., Farmers' Bulletin no. 497, 30 pp., 14 figs. in text.

MacFarlane, R.

1891. Notes on and list of birds and eggs collected in Axctic America, 18611866. Proc. U. S. National Museum, vol. 14, pp. 413-446.

1905. Notes on mammals collected and observed in the northern Mackenzic River district, northwest territories of Canada, with remarks on explorers and explorations of the far north. Proc. U. S. National Museum, vol. 28, pp. 673-764, pls. XXX-XXXIV, 2 figs. in text.

MCGregor, R. C.

1896. Cahto birds. Nidologist, vol. 3 , pp. $129-130,148$; vol. 4 , p. 8.

1898. Phalaropes. Notes on the occurrence of the Red and Northern Phalaropes at Santa Cruz, Cal. Osprey, vol. 2, pp. 87-88, 3 figs. in text.

1899. Some summer birds of Palamar Mountains, from the notes of $J$. Maurice Hatch. Bull. Cooper Orn. Club, vol. 1, pp. 67-68.

1901. A list of the land birds of Santa Cruz County, California. Cooper Ornithological Club, Pacific Coast Avifauna no. 2, pp. 6 + 22.

1906. Birds observed in the Krenitizin Islands, Alaska. Condor, vol. 8, pp. 114-122, 1 map. 
MACKAY, G. H.

1891a. The habits of the Golden Plover (Charadrius dominicus) in Massachusetts. Ank, vol. 8, pp. 17-24.

18916. The scoters (Oidcmia americana, $O$. deglandi, and $O$. perspioillata) in New England. Auk, vol. 8, pp. 279-290.

1892a. Habits of the Black-bellied Plover (Charadrius squatarola) in Massachusetts. Auk, vol. 9, pp. 143-152.

1892b. Habits of the Hudsonian Curlew in Massachusetts. Auk, vol. 9, pp. $345-352$.

1893. Observations on the Knot (Tringa canutus). Auk, vol. 10, pp. 25-35.

Macoun, J., and Macoun, J. M.

1909. Catalogue of Canadian birds. (Canada Dept. Mines, Geol. Surv. Branch), pp. viui $+761+$ xviii.

\section{Mailliard, J.}

1898. Baird's Sandpiper (Tringa bairdii) on the California coast. Ank, vol. 15, p. 51 .

1900. Breeding of Agelaius tricolor in Madera Co., Cal. Condor, vol. 2, pp. $122-124$.

1901. 'Two interesting stragglers for Marin Co., Cal. Condor, vol. 3, p. 16. 1902a. The parasite question again. Condor, vol. 4, p. 19.

1902b. Clangula hiemalis in Marin County, Cal. Condor, vol. 4, p. 46.

1904. A few records supplementary to Grinnell's check-list of California birds. Condor, vol. 6, pp. 14-16.

1911. Odds and ends. Condor, vol. 13, pp. 49-51.

1912. Breeding of the Band-tailed Pigeon in Marin County, California. Condor, vol. 14, p. 194.

1914. New breeding records for California. Condor, rol. 16, p. 261.

1915. Seaup Ducks breeding in Golden Gate Park, San Franciseo. Condor, vol. 17, p. 235.

Mailliard, J. W.

1912. Call note of the female California Quail. Condor, rol. 14, p. 73.

1916. The Old-squaw in west-central California. Condor, vol. 18, p. 8.5.

Manniche, A. L. V.

1910. The terrestrial mammals and birds of northeast Greenland. Biological observations. Danmark-Ekspeditionen til Grønlands, Nordostkyst 1906-1908, Bind V, nr.1, 2 + 1-200 pp., pls. I-VII, figs. 1-23.

Merrian, C. H.

1899. Results of a biological survey of Mount Shasta, northern California. U. S. Dept. Agric., Div. Biol. Surv., N. Amer. Fauna no. 16, 179 pp., 5 pls., 46 figs.

Merrian, F. A. [See also Bailer, F. M.]

1896. Notes on some of the birds of southern Califormia. Auk, vol. 13, pp. 115-124.

Merrill, J. C.

1878. Notes on the ornithology of southern Texas, being a list of birds observed in the vicinity of Fort Brown, Texas, from February, 1876 , to June, 1878. Proc. U. S. National Museum, vol. 1, pp. 118-173.

1888. Notes on the birds of Fort Klamath, Oregon. With remarks on certain speeies by William Brewster. Auk, rol. 5, pp. 139-146, 251-262. $357-366$.

Millais, J. G.

1902. The natural history of British surface-feeding dneks (London, Longmans, Green and Co.), pp. xiv $+107,6$ photogravures, 41 colored (numbered) and 25 uncolored (unnumbered) pls. 
MILLER, L.

1893. Notes from Riverside, Cal. Ornithologist and Oologist, vol. 18, p. 104.

MOORE, R. T.

1912. The Least Sandpiper during the nesting season in the Magdalen Islanıl. Auk, vol. 29, pp. 210-233, pls. xiii-xiv, 1 fig. in text.

Morcom, G. F.

1887. Notes on the birds of southern California and south-western Arizona. Bull. Ridgway Orm. Club. no. 2, pp. 36-57.

MortiMer, D.

1890. Notes on habits of a few birds of Orange County, Florida. Ank, vol. 7 , pp. $337-343$.

Muir, J.

1901. Our national parks. (Boston, Houghton, Mifflin and Co.), pp. $10+370$, 12 illus. (pls. and maps).

Mulier, C. S.

1916. Occurrence of Emperor Goose in northern California. Condor, vol. 18, p. 32 .

Muller, C. and J.

1912. Christmas bird census: Marysville, Cal. Bird-Lole, vol. 14, p. 43.

Murpoch, J.

1885. In Report of the International Polar Expedition to Point Barrow, Alaska. (Washington, Govt. Printing Office), 695 pp., numerous illus., plates and text figs., numbered in part. Pt. IV. Natural History. II. Birds, pp. 104-128, 2 unnumbered pls.

NEALE, G.

1915. The California Valley Quail and introduced game birds. California Fish and Game (San Francisco, Cal.), vol. 1, pp. 153-155.

1916. Coyote eats duck's eggs. Califormia Fish and Game (San Francisco, (Cal.), vol. 2, p. 161 .

NeLson, E. W.

1875. Notes on birds observed in portions of Utah, Nevada, and California. Proc. Boston Soc. Nat. Hist., vol. 17, pp. 338-365.

1877. A contribution to the biography of Wilson's Phalarope. Bull. Nuttall Orn. Club, vol. 2, pp. 38-43.

1880. An afternoon in the vicinity of St. Michael's, Alaska. Bull. Nuttall Orn. Club, vol. 5, pp. 33-36.

1881. Habits of the Black Brant in the vicinity of St. Michaels, Alaska. Bull. Nuttall Orn. Club, vol. 6, pp. 131-138.

1887. Birds of Alaska, with a partial bibliography of Alaskan ornithology. Report upon natural history collections made in Alaska between the years 1877 and 1881. Arctic Series Publ., Signal Service, U. S. Army, no. 3, pp. 19-226, pls. I-XII.

NEWBERRY, J. S.

1857. Report upon the birds. Pacific Railroad Reports, vol. 6, part 4, no. 2, chapter 2, pp. 73-110, 2 pls.

NordhoFf, C. B.

1902. February water birds of Elsinore Lake, California. Auk, vol. 19, pp. 212-214. 
OSBURN, P. I.

\section{o}

1911a. Notes on two birds from Santa Catalina Island, California. Condor, rol. 13, p. 76 .

1911b. The Yellow Rail in southern California. Condor, vol. 13, p. 108.

OsGOOD, W. H.

1904. A biological reconnaissance of the base of the Alaska Peninsula. U.S. Dept. Agric., Div. Biol. Surv., N. Amer. Fauna no. 24, 86 pp., 7 pls.

1907. Probable breeding of the Wandering Tattler in the interior of Alaska. Ank, vol. 24, p. 340 .

1909. Biologieal investigations in Alaska and Yukon Territory. U. S. Dept. Agric., Bur. Biol. Surv., N. Amer. Fauna no. 30, 96 pp., 5 pls., 2 figs. in text.

PALMer, T. S.

P

1889. Notes on the occurrence of Fregata aquila, Clangula hyemalis, and Oceanodroma furcata on the coast of northern California. Proc. Calif. Acad. Sei., $2 d$ series, vol. 2, pp. 87-88.

1900. Legislation for the protection of birds other than game birds. U. S. Dept. Agric., Div. Biol. Surv., Bull. no. 12, 94 pp., 2 pls., 8 figs.

Palmer, T. S., and Oldys, H.

1904. Importation of game hirds and eggs for propagation. U. S. Dept. Agric., Farmers' Bulletin no. 197, 27 pp., 1 fig.

PALMER, W.

1899. The avifauna of the Pribilof Islands. The Fur Seals and Fur Seal Islands of the North Pacific Ocean. (Washington, Govt. Printing Office), part III, pp. $355-431$, pls. TXXVIII-XLI.

PAYNE, H. T.

1908. Game birds of the Pacific. First paper-quail. Sunset Magazine

(San Francisco, Cal., Southern Pacific Co.), vol. 21, pp. 325-335,

7 figs. in text. Second paper-turkeys, grouse and pheasants. Ibid., pp. 442-451, 6 figs. in text. Third paper-the river and fresh water ducks. Ibid., pp. 507-514, 7 figs. in text. Fourth paper-the bay and sea ducks. Ibid.. pp. 643-651, 10 figs. in text. Fifth paper-geese, brant and swans. Ibid., pp. 767-774, 6 figs. in text. Sixth paper-the waders, shore birds, pigeons and doves. Ibid., vol. 22 (1909), pp. 65-73, 7 figs. in text.

Philipp, P. B.

1910. Annotated list of hirds observed [in the Carolinas]. Auk. vol. 27, pp. 312-322.

Pierce, W. M.

1913. Nesting of the Band-tailed Pigeon. Condor, vol. 15, p. 227.

1914. Occurrence of the Yellow Rail in sonthern California. Condor, vol. 16, p. 182 .

Pierce, C. C., and Clegg, M. T.

1916. The effect of strychnine sulphate on California Valley Quail. California Fish and Game (San Francisco, Cal.), vol. 2, pp. 11-13.

RAY. M. S.

\section{R}

1900. Notes on some unusual sets of eggs. Condor, vol. 2, p. 126.

1901. Birds about Lake Tahoe. Osprey, vol. 5, pp. 115-117, 3 figs. in text. 
1902. Rambles about my old home. Osprey, u. s., vol. 1, pp. 23-26.

1903. A list of water birds of Lake Valley, central Sierra Nevada Mountains, California. Condor, vol. 5, pp. 47-49, 1 fig. in text.

1905. A third trip to the High Sierras. Auk, vol. 22, pp. 363-371.

1910. Late spring in Lake Valley. Condor, vol. 12, pp. 128-132, figs. 41, 4..

1911. Some August notes for Lake Valley. Condor, vol. 13, p. 108.

1912a. Nesting of the Canada Goose at Lake Tahoe. Condor, vol. 14, pp. $67-72$, figs. $23-26$.

1912b. A journey to the Star Lake country and other notes from the Tahoe region. Condor, vol. 14, pp. 142-147, figs. 59-61.

1913. Some further notes from the Tahoe region. Condor, vol. 15, pp. 111-115, figs. 36-37.

1914. Some discoveries in the forest at Fyffe. Condor, vol. 16, pp. 57-70, figs. $25-32$.

REED, C. A.

1904. North Anerican birds eggs. (New York, Doubleday, l'age and Co.), pp. $10+356$, numerous photographic illus.

1912. American game birds. (Garden City, N. Y., Doubleday, Page and Co.), 64 pp., numerous colored illus.

RHOADS, S. N.

1893. The birds observed in British Columbia and Washington during spring and summer, 1892. Proc. Acad. Nat. Sci. Phila., 1893, pp. 21-65.

RicH, W. H.

1907. Feathered game of the northeast. (New York, Tlomas Y. Crowell and Co.), pp. xvi $+432,86$ pls. (unmumbered).

Richmond, C. W.

1916. An early record of American Scoter in California. Condor, vol. 18, p. 83.

RIDGWAY, R.

1877. Ornithology. U. S. Geological Exploration of the Fortieth Parallel. Part III. pp. 303-669.

1880. A catalogue of the birds of North America. Proc. U. S. National Museum, rol. 3, pp. 163-246.

1887. A manual of North American birds. (Philadelphia, J. B. Lippincott Co.), pp. xi $+631,124$ pls.

1900. A manual of North American birds. 4th edition (Philadelphia, J. B. Lippincott Co.), pp. xiii $+653,124$ pls.

RoBERTS, T. S.

1880. Breeding of Fuligula collaris in southeastern Minnesota, and a description of its nest and eggs. Bull. Nuttall Orn. Club, vol. 5, p. 61.

RoBERTSON, H.

1899. Nesting notes from Los Angeles, Cal. Bull. Cooper Orn. Club, vol. 1, p. 94.

SALVADORI, T.

1895. Catalogue of the Chenomorphae (Palamedeae, Phoenicopteri, Anseres), Crypturi and Ratitae in the collection of the British Museum. (London, Printed by order of the Trustees), pp. XV + 636, 19 pls. [ = vol. XXVII, Catalogue of birds in the British Museum].

SAMPson, W. B.

1901. An exceptional set of eggs of the Wood Duck. Condor, vol. 3, p. 95. 
SANDYS, E.

1902. The Wood Duck and its shooting. Outing, vol. 41, Jp. 163-171, 5 figs. in text.

SANFord, L. C., Brshor, L. B., and VAN DYKe, T. S.

1903. The water-fowl family. (New York, The Macmillan Co.), pp. ix +598 , frontisp., 19 unmumbered pls.

SAUNDERS, H.

1899. An illustrated manual of British birds. (London, Gurney and Jackson), pp. $\mathrm{i}+\mathrm{xl}+776,3$ colored maps, 384 figs. in text.

Scineider, F. A.

1893. Nesting of the cimmamon teal. Nidiologist, vol. 1, pp. 20-22, $1 \mathrm{fig}$. in text.

Sitarp, C. S.

1903. The Band-tailed Pigeon in San Diego County. Condor, vol. 5, p. 16.

1906. Unusual breeding records at Escondido. Condor, vol. 8, p. 75.

1907. The breeding birds of Escondido. Condor, vol. 9, pp. 84-91.

SiIARPE, R. B.

1896. Catalogue of the Limicolae in the collection of the Britisl Museum. (London, Printed by order of the Trustees), pp. xii $+794,7$ pls., numerous text figs., some numbered [ = vol. XXIV, Catalogue of birds in the British Museum].

SHAW, W. T.

1908. The China or Denny Pheasant in Oregon with notes on the native grouse of the Pacific Northwest. (Philadelphia, J. B. Lippineott Co.), $10+11-24$ pp., 15 pls. (1 colored).

SHELdoN, H. H.

1907. A collecting trip by wagon to Eagle Lake, Sierra Nevada Monntains. Condor, vol. 9, pp. 185-191.

SHIELDS, A. M.

1894. Nesting of White-faced Glossy Ibis. Nidiologist, vol. 1, pp. 108-109.

1899. Nesting of the Fulvous Tree Duck. Bull. Cooper Orn. Club, vol. 1, p. 9-11.

SiInN, C. H.

1890. Shooting in California. Outing, vol. 15, P. 464.

Silliman, O. P.

1915a. Range of the California Clapper Rail. Condor, vol. 17, p. 201.

1915b. Another Mexican Ground Dove for California, and other notes. Condor, vol. 17, p. 207.

Sillow AY, P. M.

1900. Notes on the Long-billed Curlew. Condor, vol. 2, pp. 79-82.

Simpson, G. M.

1914. Pheasant farming. Oregon Fish and Game Commission, Bulletin 110. 2, 50 pp., numerous illustrations.

SKIRM, J.

1884. List of birds of Santa Cruz, Cal. Ornithologist and Oologist, vol. 9, pp. 149-150.

Squires, IV. A.

1915. Nesting of wild ducks near San Francisco. Condor, vol. 17, pp. 234-235. 
Stearns, W. A., and Coues, E.

1883. New England bird life. 2 vols. (Boston, Lee and Shepard), vol. 2, pp. $2+409,88$ figs. in text.

StePHens, F.

1903. Bird notes from castern California and western Arizona. Condor, rol. 5 , pp. $7 \bar{j}-78,100-10 \overline{\text {. }}$.

1904. The Roscate Spoonbill in California. Condor, vol. 6, p. 139.

1909. Notes on the California Black Rail. Condor, vol. 11, pp. 47-49.

1913. Early nesting of the Band-tailed Pigcon. Condor, vol. 15, p. 129.

\section{STILLHUNTER.}

1907. South coast shooting. 1X. The Band-tailed Pigeon. Western Field, rol. 11, pp. 200-202.

STONE, W.

1900. Report on the birds and mammals collected by the MeTlhenny Expedi-

tion to Pt. Barrow, Alaska. Proc. Acad. Nat. Sei. l'lila., 1900, pp. $4-49$.

STORER, T. I.

1915. Additional records of the California Clapper Rail and Red Phalarope in California. Condor, vol. 17, p. 98.

Streator, C. P.

1886. List of birls observed in the vieinity of Santa Barbara, Cal., duriug the year 1885. Ornithologist and Oologist, vol. 11, pp. 51-52, 66-67, 89-90, 107.

1858. Notes on the birds of the Santa Barbara Islants. Ornithologist and Oologist, vol. 13, pp. 52-54.

Strong, R. M.

1912. Some observations on the life history of the Red-breasted Merganser, Mergus serrator, Linn. Auk, vol. 29, pp. 479-488, pls. XXI-XXIII.

Sivartir, H. S.

1900. Avifauna of a 100-acre ranch. Condor, vol. 2, pp. 14-16, 37-41.

1910. Miscellaneous reeords from southern California and Arizona. Condor, vol. 12 , Pp. 107-110.

1911. Birds and mammals of the 1909 Alexander Alaska expedition. Unir. Calif. Publ. Zool., vol. 7, pp. 9-172, pls. 1-6, 3 figs. in text.

1912. Report on a collection of birds and mammals from Vancouver Island. Univ. Calif. Publ. Zool., vol. 10, pp. 1-124, pls. 1-4.

1913a. The supposed occurrence of the Blue Goose in California. Condor, vol. 15, p. 43.

1913b. A study of a collection of geese of the Branta canadensis group from the San Joaquin Valley, California. Univ. Calif. Publ. Zool., vol. 12, pp. 1-24, pls. 1-2, 8 figs. in text.

SwEN K, M. H.

1915. The Eskimo Curlew and its disappearanee. Proc. Nebraska Ornithologists' Union, vol. 6, part 2, pp. 25-44.

TAYLOR, H. R.

$\mathbf{T}$

1885. California oologieal notes. Ornithologist and Oologist, vol. 10, pl). 141-142.

1894. Among the California Clapper Rail. Nidiologist, vol. 1, pp. 15.3-15.5, 1 fig. in text.

1897. Californian notes. Niclologist, vol. 4, p. 110.

1898. The Black Rail in eaptivity. Osprey, vol. 2, pp. 79-80. 
TAYLOR, W. P.

1912. Field notes on amphibians, reptiles and birds of northern Humboldt County, Nevada. Unir. Calif. Publ. Zool., vol. 7, pp. 319-436, pls. $7-12$.

Thompson, C. S.

1901a. Further tape worm observations. Condor, vol, 3, p. 15.

1901b. Notes from San Luis Obispo Co., Cal. Condor, vol. 3, p. 17.

THURBER, E. C.

1896. Southern California bird notes. Auk, vol. 13, p. 265.

TORREY, B.

1909a. The Blue-winged Teal at Santa Barbara. Condor, vol. 11, pp. 173-174.

1909b. The Ruddy Turnstone at Santa Barbara. Condor, vol. 11, p. 174.

1909c. The Golden Plover at Coronado. Condor, vol. 11, p. 207.

1910a. The Peetoral Sandpiper at Santa Barbara. Condor, vol. 12, pp. 44-45.

1910b. Unexpected birds at Santa Barbara in the summer of 1910. Condor, vol. 12, p. 204.

1913. Field-days in California. (Boston, Houghton, Mifflin Co.), pp. $12+235$, frontisp. and 8 unnumbered pls.

Townsend, C. H.

1886. Four rare birds in northern California: Yellow Rail, Emperor Goose, European Widgeon, and Sabine's Rufferl Grouse. Auk, vol. 3, pp. $490-491$.

1887. Field-notes on the mammals, birds and reptiles of northern California. Proc. U. S. National Museum, vol. 10, pp. 159-241, pl. V, 4 figs. in text.

TOWNSEND, C. W.

1910. The courtships of Golden-eye and Eider ducks. Auk, vol, 27, pp. $177-181$

1911. The courtship and migration of the Red-breasted Merganser (Mergus serrator). Auk, vol. 28, pp. 341-345.

1916. The courtship of the Merganser, Mallard, Black Duck, Baldpate, Wood Duck and Bufflehead. Auk, vol. 33, pp. 9-17.

TYLER, J. G.

1913a. Notes on some Fresno County birds. Condor, vol. 15, pp. 16-19.

1913b. Some birds of the Fresno distriet, California. Cooper Ornithological Club, Paeifie Coast Avifauna no. 9, $114 \mathrm{np}$.

Van Denburgh, J.

1899. Notes on some birds of Santa Clara County, Califomia. Proc. Amer. Philos. Soc., vol. 38, pp. 157-180.

VAN DYKE, T. S.

1890. The quails of California. Outing, vol. 15, pp. 460-464.

1892. The Valley Quail of California. Outing, vol. 19, pp. 485-488.

1904. When the Graywings come. Onting, vol. 43, pp. 667-672, 5 figs. in text.

1908. Liveliest of the birds. The Valley Quail of California which ehallenges keenest marksmanship and eleverest dogs. Outing, rol. 53, pp. $375-381$.

TAN ROSSEN, A.

1911. Winter birds of the Salton Sea region. Condor, vol. 13, pp. 129-137.

1914. Notes from the San Bernardino Mountains. Condor, vol. 16, pp. $145-146$.

VEITCH, T. W.

1912. The season in the north. Western Field, vol. 20, pp. 11-14, 2 figs. in text. 
WALL, F.

1893. Gambel's Partriıge at San Bernardino, California. Auk, vol 10. p. 204.

1915. Notes from San Bernardino, California. Condor, vol. 17, p. 59.

WARREN, E. R.

1912. Some north-central ("olorado bird notes. Condor, vol. 14, pp. 81-104, figs. $29-41$.

WESTERFELD, C.

1916. Game conditions in Great Britain vs. conditions in California. California Fish and Game (San Franciseo, Cal.), vol. 2, pp. 1-10, fig. 1.

WETMORE, A.

1915. Mortality among waterfowl around Great Salt Lake, Utal. U. S. Dept. Agric., Bull. no. 217, 10 lp., 3 pls.

WickershaM, C. W.

1902. Sickle-billed Curlew. Auk, vol. 19, 1'l. 353 \$5ti.

Wicks, M. L., Jr.

1893. Nesting of the Florida Gallinule (Gallinula galcata) near Los Angeles, Cal. Zoe, vol. 3, p. 363.

1897. Partuership nesting of Valley Partridge and Lomg-tailed Chat. Ank, vol. $14, \mathrm{p}, 404$.

WIDMANN, O.

1895. The Brown Creeper nesting in the cypress swamps of sontleastern Missouri. Auk, vol. 12, Pए. $350-3.55$.

WILDER, H. E.

1916. Some distributional notes on California biris. Conclor, vol. 18, pp. $127-128$

WILLARD, F. C.

1912. A week afield in sonthern Arizona. Condor, vol. 14, 1m. 53-63, figs. 13-19.

1916. Nesting of the Band-tailed Pigeon in southern Arizona. Condor, vol. 18 , pp. $110-112$, fig. 34 .

WILLETT, G.

1906. The Southern California Clapper Rail breeding on fresh water. Condor, vol. 8, p. 151.

1908. Summer birds of the upper Salinas Valley and adjacent foothills. Condor, vol. 10, pls. 137-139.

1909. Bird notes from the coast of San Luis Obispo County. Condor, vol. 11, pp. $185-187$.

1910. A summer trip to the northern Santa Barbara Islands. Condor, vol. 12, pp. $170-174$.

1911. Blue-winged Teal in southern California. Condor, vol. 13, p. 76.

1912a. Birds of the Pacific slope of southern Califomia. Cooper Orn. Club, Pacific Coast Avifauna no. 7, 122 pp.

1912b. Some 1912 spring notes from sonthern California. Condor, vol. 14, pp. $194-195$.

Wille'Tr, G., and JAr, A.

1911. May notes from San Jacinto Lake. Condor, rol. 13, 1'l1. 156-160, figs. $43-45$. 
Williais, J. J.

1902. A study of bird songs. II. Condor, vol, 4, pp. 65-68.

1903. On the use of sentinels by Valley Quail. Condor, vol, 5, pl. 146-1+8, $1 \mathrm{fig}$. in text.

WOODCOCK, A. R.

1902. Ammotated list of the birds of Oregon. Oregon Agricultural Experinent Station, Bull. 68, pp. $117+1,1$ pl.

WRight, H., and SNYDER, G. K.

1913. Birds observed in the summer of 1912 among the Santa Barbara Islanits. Condor, vol. 15 , pp. $86-92$, figs. $24-25$. 


\section{INDEX}

\section{A}

Acelinatization, 29, 34, 40, 43 .

Actitis macularia, 431-43\%.

Actohlromas bairdi, 373 .

maculata, 368 . minutilla, 376 .

Aegialeus semipalmatus, 469.

Aegialites rantianus nivosus, 473 .

Aegialitis alexandrina nirosa, 473. asiaticus var, montanus, 481 . ('antiana, 473 . montana, 481 . nivosa, $4 \pi 3-478$ semipalmata, 469-473. vocifera, $46 \%$. wilsonia, 479 .

Aix sponsa, 140-146.

Ajaia a jaja, 262-266.

A jaja rosea, 262.

Alexanrler, Annie M., iii, iv.

Allen, Albert H., iv.

Anas americana, 106 . boschas, 92 . rarolinensis, 113. rerca, 119. r.anoptera, 123. liscors, 120. ohseura, 101. jellelope, 111. platyrhynehos, 92-101. rubripes, 94, 101-10? strepera, 103 .

Anser albatus, 210. albifrons, 218, 219. albifrons albifrons, 219 . albifrons gambeli, 218-929. ervtluropus, 218. gambeli, 218. butchinsi, 230. hyperboreus, 210. rossi, 215.

Aphriza virgata, $485-489$.

Arenaria interpres, $366,489$. interpres morinella, 489-493. melanocephala, 493-497. morinella, 489 .

Arocet, $15,74,33 \%-344,345,346,347$, $349,350,448$.

American, 337.

California, 337.

Avoset, American, 337.

A ythya affinis, $159,166$.

americana, 146 .

collaris, 164.

erythrocephala, 146.

marila, 156.

marila nearetica, 156 .

vallisneria, 150 .

\section{B}

Badlè, W. F., 14.5.

Barlger, M. C., 523, 527.

Bailer, Florence M., 20s, 429, 537

Bailey, V'ernon, 428.

Palljiate, 71, 105, 106-111, 112, 113 , 190.

Bartramia longicauda, $497-430$.

Bastian, W. H., 9.

Beck, Rollo H., 3, 110, 133, 138, 195, $200,213,219,224,228,232,247$, $258,271,278,310,326,342,345$, $360,364,383,359,394,397,399$, $401,403,404,407,440,454,457$, $467,478,483,485,501,594$.

Becker, M., 12

Beetle-hearl, 452, 454.

Belling, I,yman, :3, 90, 95, 96, 106 , $108,112,115,116,118,119,139$, $144,152,161,165,167,169,175$, $183,188,189,191,206,207,211$, $213,215,216,217,219.224,230$, $235,238,247,254,255,261,270$, $271,273,274,276,278,294,297$, $304,308,210,315,321,328,339$, $346,352,255,360,378,383,384$, $385,389,401,403,409,418,433$, $435,436,439,451,471,483,485$, 487.

Bernicla Irenta, 237.

canadensis, 222.

gambeli, 218.

hutchinsi, 230.

leucoparia, 234.

nigricans, 237.

Bioletti, F. T., 531.

Birl, Beach, 391, 392.

Bow-fin, 320.

Bow-heal, 328.

Lawyer, 340.

Townsend's Surf, 485.

Whirligig, 329.

Woo-woo, 608.

Black-breast, 454 .

Black-hear, 164.

Big, 156 .

Greater, 156

Little, 159.

Black-jack, 10, 12, 14, 156, 159, 164.

Blinds, shooting, 25.

Blue-bill, 7, 10, 24, 157, 159. 161, 162, $163,173$.

Big, 156

Little, 161.

Blue-stocking, 337.

Blue-wing, 122, 123, 125.

Bob-white, 37, 38, 41, 58, 533, 534 
Bonasa sabinii, 55.

umbetlus, 552 .

umbellus sabini, .652-.558.

Bowl, Aubrey. iv.

Brant, 13, 219, 230, 23:, 236, 239.

Blark, 9, 237, 2:38, 240.

Black Sea, 56, 59, 60, 71, 23\%-241, $242,244,245$

Biown, 234.

Eastern Sea, 71, 211-24?.

Sea, $22:, 237$.

White, $210,211$.

Branta bernicla glancogastra, 241P49.

ranadensis ranadensis, 222-229.

"anarlensis hutchinsi, 230-234.

*anarlensis minima, 2.34-9.36.

canadensis occidentalis, 222, 225.

hutehinsi var. lencoparia, 234 .

minima, 234.

uigricans, $237-241,242$.

Breeding of game, 50-54.

Broat-bill, 156, 159 .

Brooks, Allan, iv.

Brown, Clante R., 560 .

Bryant. Harold C., iii, iv. 5, 15, 126, $127,147,149,247,270,298,318$, $341,348,349,360,383,403,422$, $507,509,521,523,565,595,602$.

Bryant, II. L., 9.

Bryant, Walter E., 304, 370.

Bicephala albeola, 177.

americana, 167.

("langula, 167.

clangula var. americana, 167. islandica, 17 ?

Buffle-head, 49, 73, 169, 1\%

Bull, C. C., 188 .

Bull-head, 452, 454, 45s

Bull hunting, 11, 12, 222.

Butterball, 177, 178, 180 .

King, 177.

('ackler, 234.

Carly, Frank P., 223, 561, 592.

Calico-back, 489

Calitris arenaria, 391.

leucophaea, 391-396.

Callipepla californica, 514, 5:3.

"aliformica vallicola, 514.

gambeli, 538 .

gambeli descrticola, 5.3.

picta, 504, 513 .

('a11, 9, 150, 151, 155.

Canace obscura, 544 .

Canvasback, $7,10,11,13,14,24,26$, $49,72,100,110,118,139,147$. $148,149,15 \cap-155,162,165,166$, $167,206$.

Carriger, Henry W. 285, 311, 317, $507,508,525$.

Caton, J. D., 36.

Catoptrophorus semipalmatus, +16 . semipalnatus inopnatus, $416-422$. ('avalier, Sianish, 246.

('entrocereus urophasianus, .764-7i??

('liachalaca, 36 .

('hamepelia passerina, 606 . jasserina pallescens, 606-610.

('lispman, Frank M., 334.

('larallins cantianus, 473 . rantianus nivosus, 473 .

lominicus, 460 .

dominicus dominicus, 458-463.

helveticus, 452 .

montanus, 481 .

s(juatarola, $: 366.452$.

virginiacus, 458

vociferus, 463.

('haritonetta albeola, 17y-181.

('hanlelasmus streperus, 103-106.

('hecker-belly, 218.

Checker-breast, 218, 219.

Chen albatus, 210.

hyperhorens hyperboreus, 210-21.5. hyperboreus nivalis, 210. rossi, 215-21\%.

t'hicken, l'rairie, 56, 57, 55, 5.58, 560 561 .

Chloroenas fasciata fasciata, 575 .

Christie, N. R., 421 .

Clangula albeola, 177 . americana, 167.

rlangula americana, $16 \%-1 \% 3$. glancion americana. 167. hyemalis, 181.

islandica, $173-176$

Clarke. Frank C. 145.

Clay, C. Irrin, 7, 9, 258, 262.

Climate, as bearing on introduction, 41.

('ock-of-the-plains, 564.

Colinus vilginianus, 37.

Columba cauolinensis, 5\&9. fasciata fasciata, $5 \% 5-588$. monilis, 575.

Colmmbigallina passerina, 606. passerina pallescens, 606 .

('ooper, James Cr., 6.

(oot. 152, 207, 208, 291, 312, .13, 314, :15. $316,318,319$

Ser. 201.

White-winged, 197.

Copperhead, 167.

Cosmonetta histrionica, 156 .

Coturnicous noveboracensis, 301-304.

Coturnix japoniea, 38.

Crane, Little Brown, 61. 74, 273-279, $280,281,282$

Sandhill, 61. 74, 273, 274, 275, 276, 278, 979-98?.

Whooping, 61. 274 .

r'perisers cotimionlus, 301-309. jamaicensis, 304 .

r'rmopluilus fuliearius, 320 .

(virlew, 56, 58, 59, 60.

Blark 269, 270, 438, 440 .

Bronze, 269.

Brown, 4 ise. 
Eskimo, $446,447,448$.

Ilulsonian, 66, 75, 396, 398, 405, $419,438,440,445-459,498,499$, $502,503$.

Jack, $445,446$.

Long-billel, 18, 75, 396, :998, 418, $438-445,446,445,451$.

l'ink, 262.

Short-billed, 445 .

Sickle-billed, 438, 439.

Straight-billed, 396,397 .

White, 337 .

Curve-bill, $435,439$.

Cyguus americanus, 256.

lucceinator, 253.

Darlily-long-legs, 4:38, 4:39.

Dafila acuta, 134-139. caurlacnta, 134.

Daggett, Frank S., 378.

Dawson, W. Leon, iv, 249, 250, 345, 348 .

Decoys, 23.

Decrease of game and its aauses, 618.

Demlragapus tuliginosus, 544 .

obseurus. $54 t$.

obseurns fuliginosus, 544, 5.5\%.

obsenus sierrae, 511-55\%.

Dendrocygna autumalis, 25/1-2.5.3.

bicolor, 246-251.

fulva, 246.

Denny, Juilge O. N., :31.

Disease, duck and quail, 17, 18, 43, 46,52 .

Dirks, W. N., 96, 137.

Dixon, Joseph, 21, 330, 426, 433, 528. $532,551$.

Dove, $56,58,59,60,588,597$.

Carolina, 595.

Carolina Turtle, 58s.

Common, 588 .

Cooing, 588 .

Ground, 608, 609, 610 .

Inea, 608 .

Mexican Ground, 75, 579, 592, 604. $606-610$.

Mourning, 3, 6, 15, 16, 48, 579, 550, $581,590,591,592,593,594,597$, $598,599,601,602,603,604,605$ $607,609$.

Rain, 588.

Sonora, 60:?.

Tuitle, 588.

Western Mourning, 78, .88-603.

White-winged, 7s, 580, 589, 592 . $603-606,609$.

Wild, 588.

Dowitıher, Long-billed, 76, 35.3, 358$363,364,365,366,367,399,405$, $410,419,441$.

Duck, Black, 71,92,94, 95, 99, 100 , 101-102, 195.
Black Surf, 197.

Dipper, 205.

Dusky, 101, $10^{2}$

Fish, 79, 83, 84.

Fool, 150.

Gray, 13, 14, 57, 103, 104.

Greater Scaup, 72, 156-159, 160, $161,164$.

Harlequin, 73, 182, 184, 186-191.

Lesser Scaup, 49, 72, 157, 159-163.

Long-legger, 251.

Long-tailed, 181.

Mallard, 57.

Mandarin, 141.

Mexican, 246.

Muscovy, 100.

Oyster, 89.

Raft, $156,159$.

Red-Jiearled, 146.

Ring-bill, 165.

Ring-neckerl, 18, 72, 147, 148, 157, $159,164-16 \%$.

Rudily, 73, 153, 178, 20.5-210, 249.

Scauj, $149,157,167$.

Spirit, 177.

Spooubill, 131.

Summer, 57, 140.

surf, 201.

Velvet, 197, 198.

Will, 92.

Woorl, 7, 9, 14, 15, 56, 57, 61, 71, $90,91,99,101,110-146,150$ $167,171$.

Dumlin, 381, 353.

American, :381, 383.

Duprey, H. F., 233.

E

E.tolistes rarolinensis, 588.

Eider, 2:39.

King, $73,192-194$.

Emerson, W. Otto, 248, 521.

Empire Gun Club, 10, 24.

Enemies of game birds, 19-22.

Ereunetes manri, 386-390.

occidentalis, 386 .

petrificatus, 386 .

jusillus, 386 .

pusilus occidentalis, 386.

Erismatura doninicensis, 205 . jamaicensis, 20.5-210. rubila, 205.

Eurromias montanus, 481

F

Fair, Paul J., 96, 126, 131, 132, 250, 294.

Faleinellus cayanensis, 269.

Ferguson, Andiew D., 8.

Fewher, Otto, 242.

Fiebig, Charles, 112.

Fischer, Eugene J., 222.

Foorls for dueks, 25, 51, 52, 53 . 
Fry, Walter, 37.

Fuertes, Louis Agassiz, iv.

Fuliea americana, 313-319.

Fuligula affinis, 159.

rollaris, 164 .

ferina americana, 146.

marila, 156.

mariloides, 159.

vallisneria, 150 .

Fulix affinis, 159 .

('ollaris, 164.

marila, 156.

\section{G}

Garlwall, 10, 56, 71, 93, 100, 103-106, $108,128,190$.

Garlwell, 57, 10:.

Gallinago delicata, 350-358.

melia, 350 .

media wilsoni, 350 .

wilsoni, 350 .

Gallimula chloropus galeata, 309 . galeata, 30.9-313.

Gallinule, 60, 310, 311, 312, 313 .

Florida, 74, 309-313, 314, 317.

Gambetta flavipes, $40 \mathrm{~s}$. melanolenca, 401.

Game, breeding of, $50-54$.

Came birds of California, key to, $6 \%-$ $\approx 8$.

Game listriets, 55.

farms, $46-47$.

laws, 55-61.

Garrot, Rocky Mountain, 173.

Gerber, W. E., 31, $\because 5$.

Giffori, Edward W., 152, 161, 454.

Gilman, Mr. French, 571.

Flaucionetta rlangula americana, 167.

islandica, 172

Glossary of special terms used, $62-65$.

Gollwit, 365, 396, 395 .

American Bar-tailed, 396.

Great Marbled, 396.

Marbled, 75, 396-401, 419, 438, $440,441,448$.

Golden-eye, 49, 147, 148, 169, 170 , $172,173,177$.

American, $73,167-17.3,174,175$. 176.

Barrow, 73, 168, 169, 1\%3-1\%6, 179.

Rocky Mountain, 173.

Goosander, 79.

Goose, American White-fronter, 70 , 218-222.

Beach, 243.

Blue, 211.

Big Mexican, 222.

Cackling. 70, 215, 216, 223, 224, 225, 227, 231, 234-236.

Canada, $7,49,70,211,212,219$. 229-229, 230, 231, 234, 235, 238.

China, $215,216$.
Finferol, 70, 219, 22?, 234, 239, 2.4.3-2.46.

Eskimo, 237.

Grav, 9, 218, 219, 221, 229, 2:0.

Greater Snow, 211.

Honker, 60, 229.

Hutrhius, 70, 221, 223, 224, 225, 227, 230-234, 235, 236, 23s.

l.anghing, 218, 220 .

Lesser Canada, 230.

Lesser Snow, 70, 210-215, 216, 217.

Little Squeaking, 234.

Mexican, 222.

Ross, 210, 211, 217, 219, 235.

Ross Snow, 70, 215-217, 235.

Sea, 320, 329.

Snow, 219.

Tule, 219.

White, 8, 9, 12, 13, 210, 211, 21?, 214 .

White-cheeked, 220, 225, 230.

White-frouterl, 211, 219, 221, 245.

White-hearler, 24.3.

Grass-bild, 371.

Greenhearl, 92, 94, 95.

Greell-wing, 11:, 111, 115, 117, 11s, 123.

Grey, Неnrт, 7, 9.

Frimell, Elizabetl, 49.

Grimnell, Joseph, 2, 5, 25s, 270, 27 , $281,360,383,403,420,424,435$. $439,453,454,457,491,500,509$, $521,524,532,549,569,595,594$, 595,602

Grouse, 57, 58, 60.

Blue, 544, 546 .

Columbian Sharp-tailes, 2, 9, 18, $77,256,554,558-564.572$.

Dusky, 544, 545, 546, 553, 554.

Oregon, 552.

Oregon Ruffed, 77, 5.52-5.58, 561.

Ruffei, 48, 553, 554, 555, 556, 55\%, 558.

Pine, 544, 546.

Prairie Sharp-tailed, 562.

Sage, 564, 565.

Sharp-tailed, 56, 57, 558, 560, .761. $563,566,567$

Sierra, 77, 544-552 553, 5.5, .56, $559,561$.

Sootr, 77, 544,546,549, 5.50, 556. 561.

Southern Sharp-tailed, 558.

Grus americana, 274.

('anallensis, 2\%3-279.

canarlensis mexicama, 279.

mexicana, 273, 979-282.

Gun clubs in California, 23-2s.

\section{H}

Haematolus ater, 498.

bachmani, 498-50\%.

frazari, $.509-509$.

niger, 498 . 
palliatus, 502 .

townsendi, 498.

Hall, Charles L., 497.

Hammond, L. IV., 48.

Harelda glacialis, 181.

hyemalis, $181-186$.

Hawks as enemies of game birils, 20-21.

Helodromas solitarins cinnamomeus, $411-416$.

Hən, Marsh, 58.

Prairie, 563.

Henshaw, Judge F. W., 116, 226.

Heron, Great Blne, 275.

Herron, R. B., 263.

Heteractitis incana, 492-497.

Heteropygia bairdi, 373 .

Heteroscelus incanus, 422.

Hill, J. H., 33.

Himantopus mexicanns, 3.4-350. nigricollis, 344 .

History of attempts to introduce nonnative game birds into California, $29-44$.

History of game-hird legislation in California, 55-61.

Histrionieus histrionivus, 186-191. minutus, 186.

torquatus, 186.

Honker, 13, 222, 223, 229.

Little, 230.

Medinm-sized, 230.

Howell, A. Brazier, iv, 383, 407, 424, $433,457,487,491$.

Hubbard, Samuel, Jr., 7, 159, 173, 288.

Hunter, 222.

Hunter, Joseph S., 13, 34, 145, 271.

\section{I}

This, 56, 58, 59, 60, 273.

White-faced Glossy, 73, 266, 269273, 438, 440 .

Wood, 73, 263, 264, 266-269.

Ibis mexicanus, 269 .

ordi, 269.

thalassinus, 269 .

Ingersoll, Albert M., 105, 132, 149, $207,208,306,307,311,480,582$, 584.

Introduction, 1-5.

Introduction of game birds, 99-44.

\section{J}

Jack, 445.

.Tackson, A., 145.

Jay, Antonin, 582.

Jordan, R., Jr., 531.

\section{K}

Kalmbach, E. R., 444.

Kellogg, Louise, 436.
Key to game birls of California, $67-78$

Killilee, 463.

Killleer, 16, 76, 292, 293, 297, 369, $370,375,382,410,423,424,428$, $432,436,453,455,459,460,463-$ $469,470,471,472,474,475,479$, $482,483,486,487,490,494,495$, 501.

Knot, 76, 323, 361, 363-368, 411.

Kolpel, I. L., 33, 591.

Kreeker, 371.

Krtka, Theotore, 49.

Lane, T. M., 7.

Law, J. Eugene, 523, 524, 525, 527, 591.

Laws relating to game, 55-61.

Lawyer, 344, 345.

Lead-back, 383 .

Legislation relating to game birds in California, 55-61.

Lelande, Harry J., 100, 150, 50 s.

Limonites minutilla, 376 .

Limosa felloa, 396-401.

Literature eitesl, 611-632.

Littlejohn, Chase, 49, 113, 162, 581, 582.

Lobefoot, 326, 328 .

Lobipes hyperboreus, 326. lobatus, 326-3.32.

Long-bill, 44l, 443, 445.

Long-shanks, 344, 345.

Loomis, Leverett M., 193.

Lophoilytes cucullatus, 89-91.

Lophortyx californica, 514.

californica brumescens, 5.37.

ealifornica californica, 515,537 .

californica catalinensis, 515, 517, $537-5.38$.

ealifornica vallicola, .514-537

catalinensis, 537.

elegans, 39.

gambeli, 39, 538-544.

Lueddemann, Frieda, iv.

Lute, Auna M., 557.

\section{M}

Macomber, King, 36

MacDonald, James, A., Jr., 275.

Macrorhamphus griseus, 358 . griseus scolopaceus, 358-363. scolopaceus, 358.

Mailliard, Josenh, 90, 96, 1.31, 141, $143,144,145,187,190,284,292$, $334,355$.

Mailliard, Joseph anıl Joln W., 2, $91,96,105,132,135,137,207$, $272,284,286,339,346,348,360$, $383,385,418,433,477.491,507$, $523,525,594,595$.

Mallard, 9, 10, 11, 13, 14, 47, 49, 52, 
$53,56,57,62,71,81,92-101,102$, $103,104,105,106,108,110,118$, $125,133,136,138,139,149,150$, $151,153,154,155,162$.

Black, 101.

('hinese, 313.

Gray, 92.

Klondike, 197

Mammals as enemies of game hirks, 21.

Mareca americana, 106-111. penelope, 106, 111-11.3.

Marila affinis, 159-163. americana, 146-150. collaris, $164-16 \%$. marila, $156-\vec{\imath} .59$. valisineria, $150-15.5$.

Marlin,.Common, 396 . Rerl, 396.

Marsh-hen, 58, 283.

Salt-water, 283.

Martin, W. T., 534.

Mr.Lean, Donald D., 294, 295.

Measurements, method of taking, 66 .

Meissner, Charles D., 560 .

Melanetta velvetina, 197.

Meleagris gallopavo, 36 .

Melopelia asiatica, 603.

asiatica trudeaui, $6 \cap 3-606$. leucoptera, 603.

Merganser, American, 70, $79-84,85$. $86,88,91$

Hooded, 63, 70, 89-91, 178.

Red-breasted, $70,79,81,83,84-88$.

Merganser americanus, 79 . serrator, 84.

Mergus americanus, $79-84$. eucullatus, 89 . merganser americanus, 79. serrator, $82,83,84-88$.

Merritt, Ralph P., 12.

Moreom, G. Frean, 2, 403.

Mud-hen, ]5, 47, 60, 74, 149, 283, 309, $310,311,313-319$.

Rerl-billerl, 309 .

Mulphy, Robert C., 348, 349.

Mreteria americana, 266-269.

\section{N}

Neale, George, 35, 38, 145, 355, 592.

Nettion carolinense, 113-118. carolinensis, 119. crecca, 119-120.

Non-mative game birls in California, 29-44.

Numenius americaus, 438-14.5. americanus americanus, 438. horealis, 447.

hulsonicus, 445-459. longirostris, 438 .

Nyroca americana, 146 . erythrocephala, 146. ferina, 146. valisneria, 150.
Ober, E. H., 565, 569, 570, 592.

Ochthorlromus wilsonius wilsonius, 479-481.

Oidemia americana, 194-19\%. deglandi, 197-201.

fusca, 197.

lerspicillata, 201-204.

verspicillata var, trowbridgei, 201.

Old-squaw, 73, 181-186, 187.

Olor buecinator, 253-256. columbianus, 256-262.

Oreortyx jicta, 504.

licta confinis, 504.

victa picta, 504, 505, 508, 512, 51.2514.

picta plumifera, 50.1-513, 514 .

Ortygops noveboracensis, 301.

Ortyx californica, 5]4, 537. picta, 504, 513.

plumifera, 504

Ottmer, F. H., 113.

Oxyechus vociferus vociferus, $463-$ 469.

Oyster-catcher, 494, 501.

American, 502.

Bachman, 498.

Black, 77, 498-50., 50:.

Frazar, 77, 499, 502-503.

Pied, 502.

Townsend's, 498

\section{P}

Pale-belly, 454.

Partridge, 57, 58, 59.

California, 5]4, 537 .

English, 58.

European, 35.

Gambel, 528.

Hungarian, 32, 35, 36, 46 .

Mountain, 505, 513.

Plumed, 504, 517.

Valley, 514.

T'ayne, H. T., 39

Perlioecetes columbianus, 558. phasianellus columbianus, 558-561.

Peep, 376, 377, 381, 386, 390.

Pelidna alpina americana, 381 . alpina sakhalina, 381-386. americana, 381 .

Pelionetta perspicillata, 201 . trowbridgei, 201.

Perdix californiea, 514. perdix, 35.

Peyton, Laurence G., 523, 524, 527.

Phalarope, Gray, 320, 321.

Nortlern, 15, 75, 321, 322, 325, 3263.3., 410.

Reil, 21, 74, 320-326, 327, 328, 329, 331,365 .

Wilson, 75, 329, 33.8-3.3\%, 436.

Phalaropus fulicarius, $320-326$. hyperboreus, 326. 
lobatus, 326 .

tricolor, 332 .

wilsoni, 332 .

l'hasianus torquatus, $30,5 \% 9-5 \% 5$.

Pheasant, Bohemian, 34.

Chind, 572.

Chinese Ring-nerked, 32.

Copper, 34.

Denny, 572 .

Erglish, 30, 31, 32, 34, 35, 35.

Golden, 34.

Lady Amherst, 34.

Mongolian, 32, 58.

Reeves, 34.

Ring-neckerl, 22, 29, 30, 31, 32, 33, $34,35,41,46,47,77,579-5 \%$.

Silver, 34,51 .

Swinhoe, 34.

Wood, 552.

Philacte eanavica, 243- 16 .

Pierce, Wright M., 523, 528.

Pigeon, Band-taileil, 9, 16, 49, 56, 61, $78,5 \% 5-588,589,592,597,60 \%$, 604

Blue, 575.

Domestic, 576, 579, 588, 60:3.

Mono Lake, 326, 328 .

Passenger, 2?, 577, 581.

Sonora, 604

White-winged Will, 60:

Wil $1,61,144,575,58:$.

Pignies, 376,386 .

Pinioning birds, 53.

Pintail, 49, 52, 71, 94, 95, 100, 105, $109,110,125,128,133.131-139$, $157,205,246$.

Pisoloia bairuli, $373-376$.

maeulata, $368-373$.

minutilla, $3 \approx 6-381$

Platalea ajaja, 262.

Platea mexicana, 262

Plegadis guarauna, 269-973.

Plover, 58, 59, 60.

American Golilen, 76, 366, 455, 456. $458-463$.

Black-bellied, $64,75,366,419,15 \Omega-$ $458,460,462,483$.

Black-breasted, $60,452$.

Candlestick, 416.

Field, 427, 429.

Golden, 60, 365, 457, 460, 46] , 463 . 483.

Kentish, 473.

Killdeer, 463.

Mountain, 18, 77, 302, $471,181-18.5$.

Prairie, 482.

Rerl-legged, 489.

Ring, 469, 471.

Ring-necked, 375.

Rocky Mountain, 481.

Ruldy, 391.

Semipalmated, 76, 469-4\%3, 475 .

Semipalmated Ring, 469.

Snowy, 77, $265,378,389,436,470$, $471,472,473-478,480$.
Swiss, 452 .

Tpland, 76, 197-430.

Whistling Field, 452, 454.

Wilson, $77,470,471,475$, 479-481.

P'luvialis virginiaca, 458 .

l'oehard, 146.

Porlasoeys montanus, 481-18.j.

Poisoning, 16.

Porzana carolina, 996-301.

coturniculus, 304 .

jamaicensis, 304.

jamaicensis coturniculus, 304.

Preserves, game, 23, 24.

1'ropagation of game biris, 4.j- 54 .

l'tarmigan, 40.

I'teroeyanea coeruleata, 12?. discors, $12:$

l'il's, 386 .

\section{Q}

Quail, 6, 10, 16, 51, 57, 58, 58.7.

Arizona, 5:38.

Bob-white, 58, 59, 516, 569.

Brown-backeil Valley, 514.

California, 5, 21, 78, 508, 515, 516. $518,520,522,524,527,530,532$ $533,534,536,53 \%$

Catalina lslanil, 5, 78, 515, 516, $53 \%-5.38$.

Chinese, 3s, is.

Crested, 514.

Desert, 39, 46, 56, 59, 60, 75, 515. $517,518,538-54$.

Eastern, 5s.

Elegant, $39,41$.

Gambel, 39, 41, 515, 517. 5.88, 5.89, 543.

Helmet, 514 .

Mountain, 46, 45, 56, 58, 59, 60, 63, $78,501-513,514,515,517$.

Paintel, 77, 504, 507, 51.3-514.

Plumer, 504, 505.

San Peilro, 504.

Topknot, 514.

Tufter, 514

Valler, 3, 5, 17, 20, 22, 39, 46, 48, $56,58,59,60,78,296.504,505$. $506,508,509,510,513,514-53 \%$, $538,539,540,541,543.544,574$.

Querquedula carolinensis, 113.

evanoptera, 123-199.

ifiscors, 120-123.

\section{R}

Rail, 58, 59, 3ti2.

Bangs, 289.

Black, 297, 298, 302, 305, 307, 308.

California Black, 74, 303, 3n4-3n9.

California Clapper, 74, 983-289. $290,291,293$.

Carolina, 296, 299, 300, 308.

Clapper, 9, 288, 249, 290, 291, 292, 296,297

Common, 296. 
Eastern Black, 304, 307.

Farallon, 304.

King, 283 .

Light-footed, 74, 283, 285, 289-291.

San Mateo, 283.

So1 a, 15, 74, 293, 996-301, 303, 307, 308.

Southern California Clapper, 289.

sweetwater, 291.

Virginia, 15, 74, 283, 284, 291-296, $297,298,299,301,303$.

Yellow, 74, 292, 293, 297, 29S, 30130.4 .

Rallus, elegans, 283.

elegaus var. obsoletus, 29:3.

levipes, 289-291.

olssoletus, 283-289.

virginianus, 291-296.

Ray, Milton S., 523, 524.

Rearing game biris, 52, 53.

Reclamation, its effect on game, 15.

Recurviostra americana, $337-344$. occirlentalis, 337.

Redhead, 9, 13, 14, 18, 49, 56, 57, 72 , $101,146-150,151,152,153,164$, $165,166,167,249$

Reviolkls, L. R., 477.

Rlyyacophilus solitarius, 411.

Richards, W. W., 25, 51, 145.

Richarison, Charles H., 35:2, 385, 397, $424,591$.

Ring-bill, 164, 167.

Ring-neek, 156, 162, 164, 165, 167.

Roadrunner as enemy of quail, 22.

Robin, as game, 56, 58 .

Rirdily, 9, 209.

Rynchaspis rlypeata, 129.

\section{$\mathrm{S}$}

Sage-cork, 564 .

Sage-hem, 48, 56, 57, 58, 59, 60, 77, $554,559,560,561,564-5 \% 2$.

Sale of game, $12,13,14$.

Sauderling, 77, 391-396, 475.

Sandpiper, Baird, 76, 370, 371, 373$3 \approx 6,384,393$

Bartramian, 427, 429 .

Black-bellied, 381, 383.

I.east, $15,76,305,371,375,376-$ 381, 384, 387, 389, 390, 393, 419, $424,431,474,475,608$.

Little, 376.

Peptoral, 76, 368-373, 375, 410.

Red-backed, 15, 76, 366, 380, 381$386,391,393$.

Sanderling, 391 .

Semipalmated, 388.

Solitary, $410,413,414,415,416$, $4: 31$.

Spotter, 76, 412, 414, 415, 431-437.

Western, 15, 76, 371, 375, 378, 379, $380,384,386-390,393,424,431$, 475 .

Western Solitary, 76, 335, 411-416.
Sawbill, 79, 81, 83, St, 169 .

Seaup, 110, 147, 149, 156.

Grcater, 157, 158, 159, 160, 161, $162,165,167,187,206$.

Lesser, 156, 157, 159, 160, 161, 162 . $163,164,166$.

Schacflle, Ernest, 3.

Sehneiker, William, 535.

Srolopax grisea, $35 \mathrm{~S}$.

noveboracensis, 358 .

wilsoni, 350.

Sroter, 192, 193, 195

American, 73, 194-19\%.

Black, 194.

Surf, 73, 196, 201-204

White-wingell, 72, 196, 197-201, 203.

Scooter, 195.

Scott, J. Walter, 12.

Sea-goose, 326.

Senuett, George B., 458.

Settlement of the comntry, its effect on game, 15.

Sharp, Clarence S., 522, 525, 527, 52s.

Sharp-tail, 559, 560, 561, 563 .

Columbia, 558.

Sheblev, W. H., 31, S3.

Shelriake, 79, 81, 8s.

Hoorled, s9.

Red-l)reasted, 84.

Shelton, Alfred C., 304.

Shepherd, Vernon, 102, 244, 252.

Shook, Henry, 49.

Shoveller, $47,49,71,100,128,129$ 134, 136, 13S, 182.

Shuftler, 156.

Sickle-bill, 438, 439 .

Skelton, A. E., 513, 534.

Skinner, R. W., 51.

Sknnk-head, 201.

Smith, Franklin J., 112, 187, 195, 242, 490.

Snakes as destroyers of quail's eggs, 22.

Snipe, 10, 56, 58, 59 .

American, 350.

Black-breasted, 3.83.

Bull-head, 481.

Checkerea, 489 .

Curve-billed, 44.5.

linglish, 350 .

Gray, 358.

1 rish, 337.

Jack, 60, 344, 350, 352, 35९, :360, 371,376 .

Neerlle-billed, 332, 334.

Rell-breasterl, 358, 363, 365.

Robin, 363,365 .

Stone, 401.

Surf, 391.

Wilson, 59, 60, 75, 3.50-358, 3.59 $361,364,371,381,407,411,467$.

Yellow, 337.

Somateria spectabilis, $192-194$. 
Nora, $292,294,297,295,299,301$.

South Southerly, 181.

Spatter, 205.

Spatterer, 205, 206.

Siatula clypeata, 129-134.

Siperkle-belly, 218, 219.

Sipeckle-breast, 21S, 219.

Spike-bill, 396.

sioonbill, 11, 13, 14, 24, 57, 129, 131. 264 .

Roseate, 73, 262-266.

Spoonie, 10, 129, 131.

Sprig, 10, 13, 14, 24, 26, 118, 134, 13.5, 139.

Sprigtail, 134, 205.

Squatarola helvetica, 452 . squatarola, $452-458$.

Squealer, 246.

Squires, Walter A., 207.

Steganopus tricolor, 332-33\%.

Stephens, Frank, 96, 291, 360, 392, $487,506$.

Stilt, $341,345,346,347,349,350,448$. Black-necked, $15,74,338,340,343$, $344-350,399,405$.

Strepsilas interpres, 489. melanocephalus, 493.

virgata, 485.

Storer, Tracy I., iii, 5, 378, 383, 420, $436,437,439,457,509,545,548$, 595,602 .

Surf-bird, 75, 424, $485-489,494$.

Swan, 59.

American, 256.

Trumpeter, 18, 69, 253-256, 257. 259, 261, 262.

Whistling, 69, 253, 254, 255, 256262.

Swarth, Harry S., 2, 3, 378, 418, 532, $541,549,586$.

Symphemia semipalmata, 416 .

semipalmata inornata, 416 .

semipalmata speculifera, 416.

\section{$\mathrm{T}$}

Tantalus loculator, 263, 266.

Tattler, 401, 403 .

Lesser, 410.

Solitary, 411, 413.

Tell-tale, 401 .

Wandering, 76, 405, 428-48\%, 455, 4S8, 494.

Yellow-shanks, 408.

Taylor, Walter P., 3, 126, 418, 421, $440,441,549,595$.

Teal, 10, 13, 14, 49, 57, 110, 118, 153.

American Green-winged, 113.

Blue-winged, 57, 72, 114, 115, 116 , 120-123, 124, 125, 132.

Cinnamon, 47, 56, 57, 72, 100, 104 , $113,114,116,117,118,121,122$, 123-129, 132, 147, 270.

Common, 113.

European, 72, 114, 116, 119-190.
Green-wingerl, 26, 63, 72, 91, 113$118,119,120,121,122.125,128$, 136.

Refl-breasted, 12:3, 124.

Western Blue-wing, 123.

White-facel, 120, 122 .

Teeter, 4:31.

Teeter-tail, $431,432$.

Tell-tale, 401, 403 .

Greater, 403 .

Lesser, 410.

Tetrao "alifornseus, 5:37.

columbianus, 558 .

obseurus, 544 .

phasianellus, 558.

sabini, 552.

urophasianus, 564

Tevis, Lansing, 281.

Tilt, 344

Tip-u1, 99, 431, 432.

Toms, W., 159, 163.

Totanus flavijes, $408-411$.

incanus, 422

macularius, 431.

melanoleueus, 401-40\%.

semipalmatus, 416.

solitarius, 411.

solitarius cinnamomeus, 411 .

Tree-rluck, 247, 250, 251, 252.

Black-bellierl, 71, 246, $251-253$.

Brown, 246.

Fulvous, 71, 149, 246-951, 252.

Fulvous-bellied, 246 .

Tringa alpina, $325,381$.

alpina var. americana, 381 .

alpina pacifica, 366,381 .

arenaria, 391

bairdi, 373 .

canutus, 363-368.

fuscicollis, 370 .

maculata, 368 .

minutilla, 376 .

pacifica, 351 .

semipalmata, 386.

wilsonii, 376.

Tringoides macularius, 431.

Turkey, Water, 266, 269.

IVild, 36, 37, 40, 46, 58, 143.

Turnstone, 366, 375, 419, 486, 487, $491,492$.

Black, 21, 75, 491, 493-497.

Common, 492, 493.

Ruddy, 75, 489-493,494, 495 .

Tyler, John G., 342, 345, 346, 347 , $348,349,433,471,521,523,524$, 527,591 .

Tympanuchus americauns, 561 .

\section{U}

Unglish, W. E., 7, 9.

\section{V}

Van Slyke, W. E., 36. 


\section{W}

Wanzer, H., 251.

Water-hen, 283.

Wavy, White, 211.

Whale-bird, 320 .

When-bird, 438, 439.

Wheeler, Roswell S., 141, 143.

Whistler, 167, 169, 170, 171, 172, 173.

Whistle-wing, 167.

Wirtgeon, 7, 10, 13, 14, 26, 106, 108, $118,136$.

American, 106, 108, 113.

European, 71, 107, 111-113.

Red-headed, 111, 112, 113.

Wildeat as enemy of game birils, 21 .

Willer, Harry E., 363.

Wiley, Leo, 126, 263, 269, 540, 541, $591,608,609$.

Willet, 416.

Eastern, 419.
Western, 75, 398, 405, 416-492, 441,443 .

Willett, George, $397,470,600$.

Wiretail, 205, 206.

Woolloock, 35\%.

Wythe, Margaret W., iv, 525.

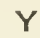

Yellow-legs, 60, 21s, 408, 424.

Greater, 75, 401-407, 408, 409, 410. t11, 419 .

Lesser, 76, 402, 404, 108-111.

Little, 408.

Summer, 408, 409.

Yellow-shanks, Greater, 401.

Yelper, 234.

Zenaidura carolinensis, 588.

macroura, 588 .

macroura carolinensis, $58 \mathrm{~s}$.

macroura marginella, 588-603. 







